

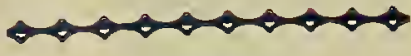

surols 'səureiq!I

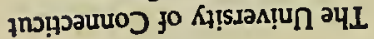

-วIEว ЧมโM

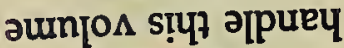
วิEว/d 


\section{Digitized by the Internet Archive}

in 2009 with funding from Boston Library Consortium Member Libraries 

-

- 

DEPARTIENT OF THE INTERIOR

\title{
MONOGR APHS
}

OF THE

\section{United States Geological Survey}

\author{
VOLUME XXIX
}

W A SHINGTON

GOVERNMRT PRINTING OFFICE

1898 
6958. 
UNITED STATES GEOLOGICAL SURVEY

CHARLES D. WALCOTT, DIRECTOR

\section{GEOLOGY}

\section{oF \\ OLD HAMPSHIRE COUNTY, MASSACHUSETTS \\ COMPRISING}

FRANKLIN, HAMPSHIRE, AND HAMPDEN COUNTIES

BY

BENJAMIN KENDALL EMERSON

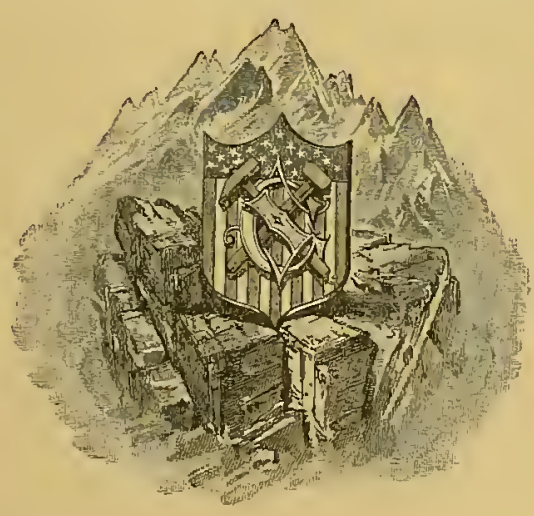

W A SHINGTON

GOVERNMENT PRINTING OFFICE 1898 



\section{CONTENTS.}

Page.

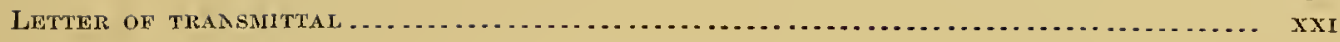

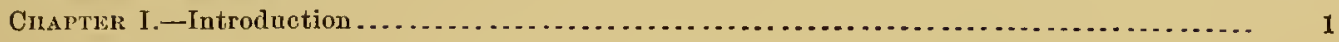

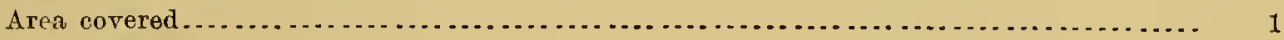

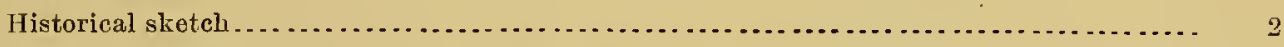

Chapter II.-Topography . ................................................... 8

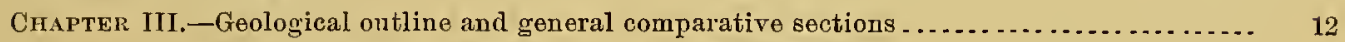

General comparative section of rocks in Massachusetts ..................... 16

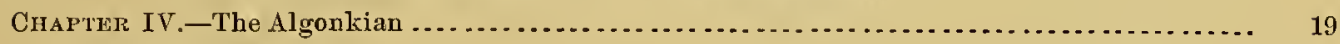

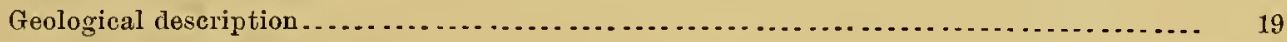

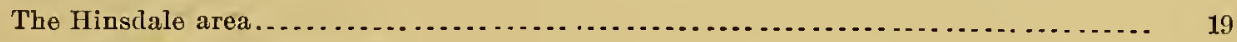

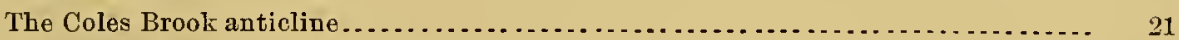

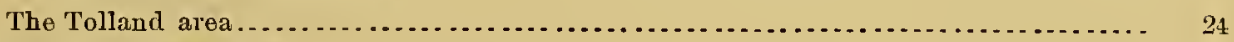

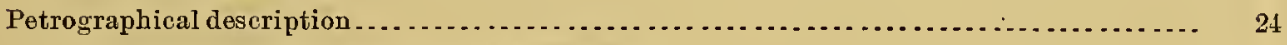

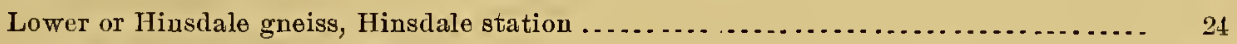

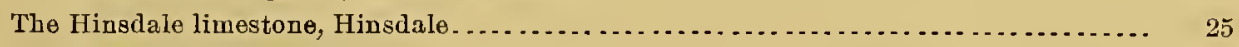

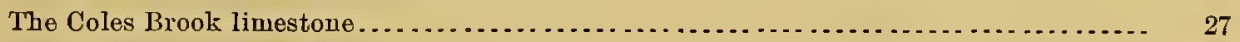

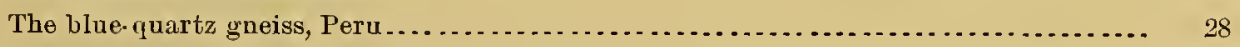

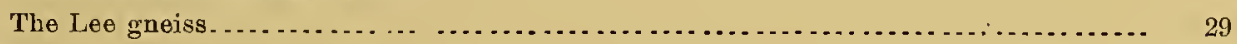

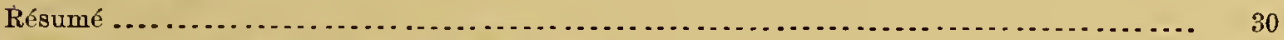

Chapter V.-The Lower Cambrian gueisses.................. 31

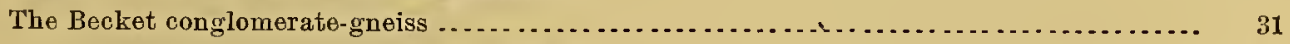

Coutact upou the Washington gneiss below ................................ 31

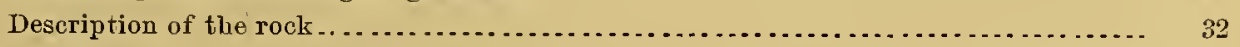

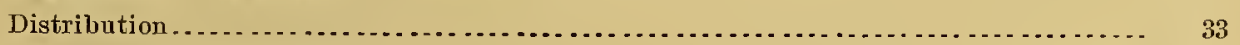

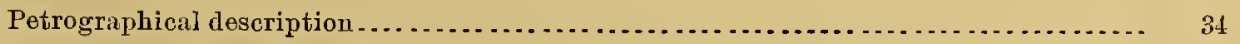

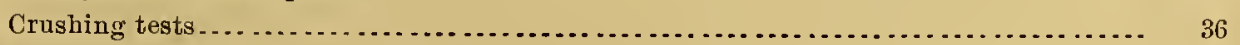

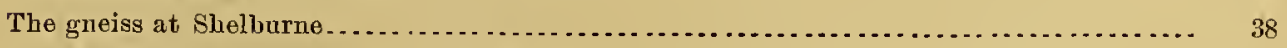

The Mlonson gneiss and associated rocks .................................... 41

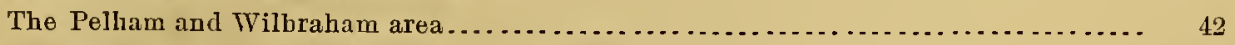

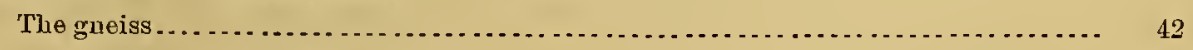

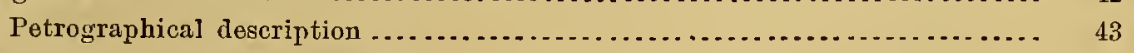

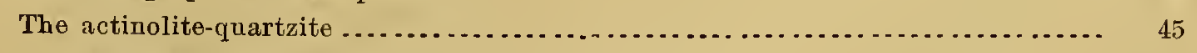

Petrographical description ........................................ ${ }_{46}$ 
Chapter V.-The Lower Cambrian gneisses-Continued.

Page.

The Monson gueiss-Continued.

The Polham and Wilbraham area-Continued.

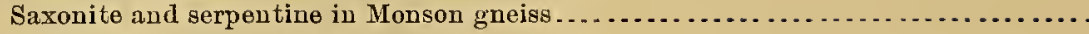

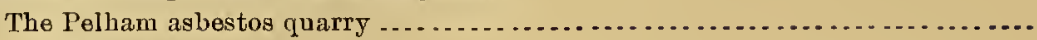

Petrographical description ......................................

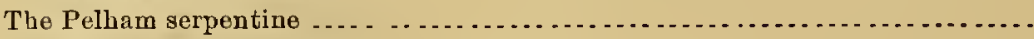

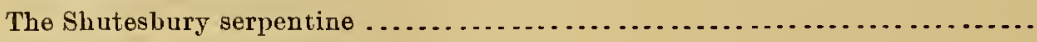

The New Salem serpentine....................................... 55

'The Orange and Monsou area............................................ 56

General deseription................................................... 57

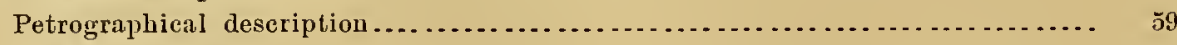

The Ionson quarry . ... . . . . . . . .

Strength of the IIonson gneiss...................................... 63

Conglomerate structure of the Monson gneiss and sudden expansion of the rock

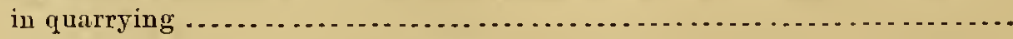

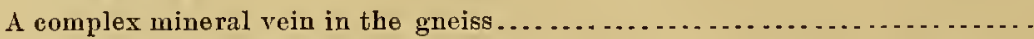

Chapter VI.-Lower Silurian sericite-schists and amphibolites on the west side of the valley-

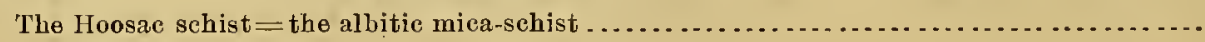

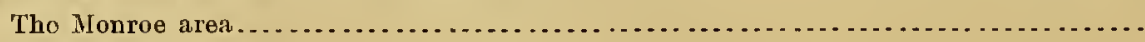

The Middlefield area................................................... 70

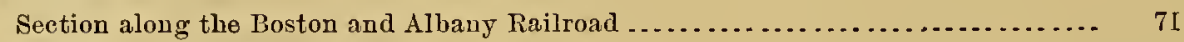

Relation to the Becket gneiss........................................ 72

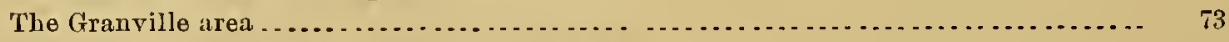

Hornblendic bands in the albitic mica-schist . . . . . . . . . . .

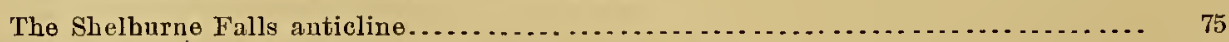

The Rowe schist $=$ the lower sericite- or hydromica-sehist $\ldots \ldots \ldots \ldots \ldots \ldots \ldots \ldots \ldots \ldots \ldots$

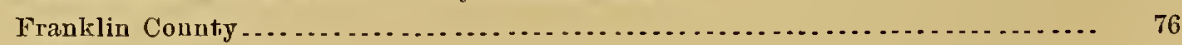

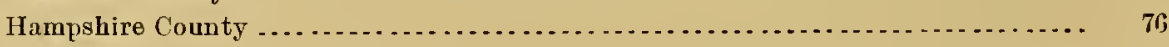

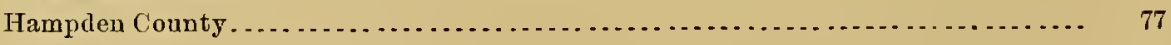

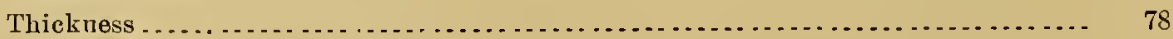

The Chester amphibolite and serpentines . .................................... 78

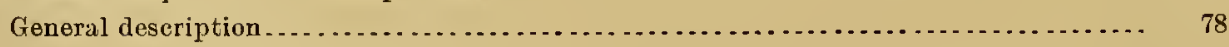

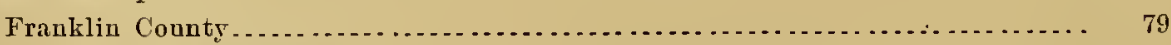

The Rowe serpentine. . . . . . . . . .

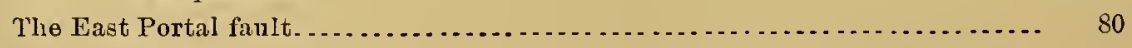

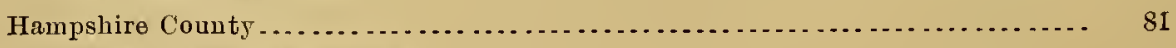

The Middlefield serpentiue....................................... 81

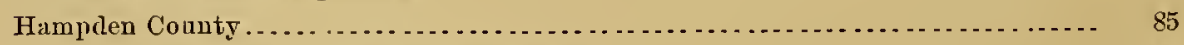

The Chester amphilolite and serpentine............................ 85

The Blandford serpentines and pyroxenite .......................... 85

The Granville and Rirsell enstatite-serpentines....................... $\quad 90$

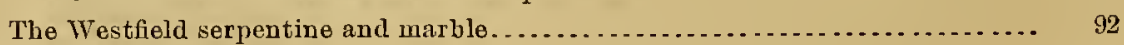

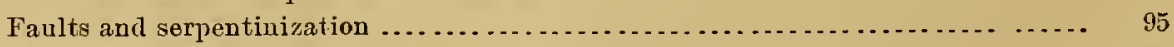

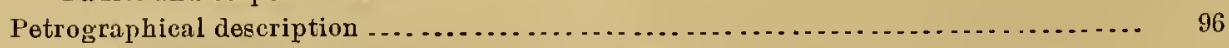

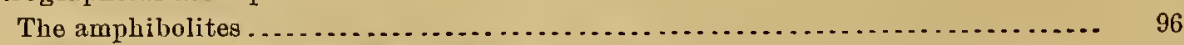

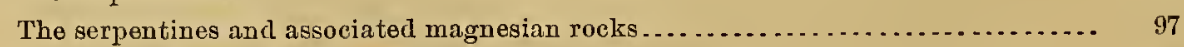

Bladed serpentine; antigorite- (or bastite-) serpentine ................ 98 
Cuarter VI.-I Lower Silurian sericite-srhists anel amphibolites on the west side of the valley-

Continued.

Tho Chester amphilolite and serpentines-Continued.

Petrographical description-Continued.

The serpentines and associated magnesian rocks-Continned.

Olivine- and enstatite-serpentine ................................. 101

Résumé ................................................... 114

Table of analyses of serpentines ................................... 116

The Chester emery bed................................................. 117

History of discovery and working of the bed............................ 117

A description of the emery mine of Chester, Hampden County, Massachusetts, by

Charies Upham Shepard.

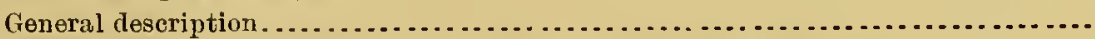

Association and paragenesis of the ninerals of the emery vein .................

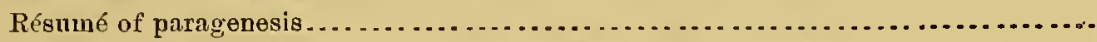

General explanation and correlation of the Chester amphibolite series..............

Original condition of the enstatite-serpentine and limostone complex ................

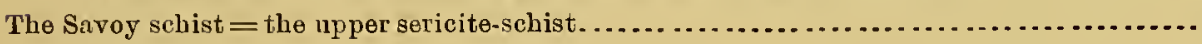

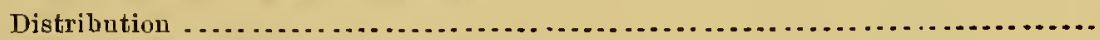

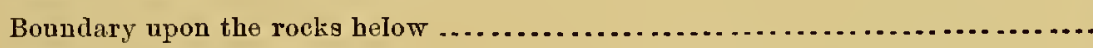

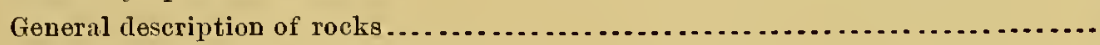

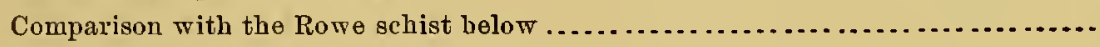

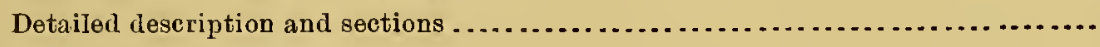

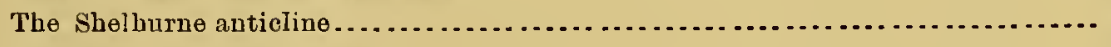

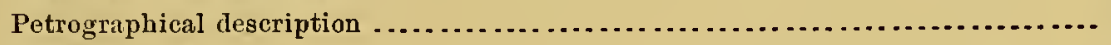

Intrusive rocks . . . . . . . . . . .

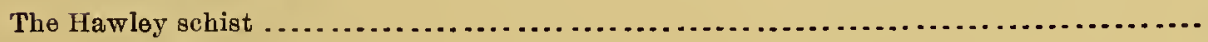

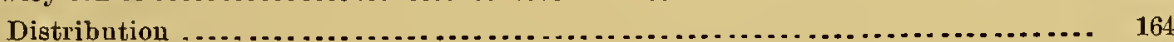

Detailed description ................................................ 164

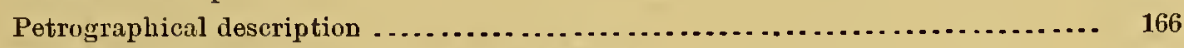

The possible igneous origiu of the Hawley schist . . . . . .

MincraI deposits .................................................. 170

The pyrite beds ................................................ 170

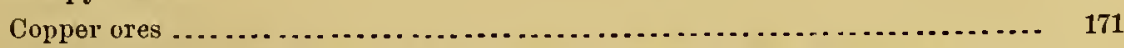

The great Hawley fault and the magnetite and hematite deposits, the rhodonite and rho-

dochrosite beds, and the garnet-schist or coticulc . ........................... 171

The Gosheil anticline..................................................... 175

Chapter VII.-The graphitic mica-schist series on the west side of the valley .............. 177

The Goshen schists or flage............................................. 177

General description ..................................................... 177

Uncouformable contact on the rocks below; outliers in the Hawley schist........... 179

Petrographicnl description............................................ 181

The Conway sohists, or the corrugated mica-schists $\ldots \ldots \ldots \ldots \ldots \ldots \ldots \ldots \ldots \ldots \ldots \ldots \ldots . \ldots \ldots$

General description .................................................... 183

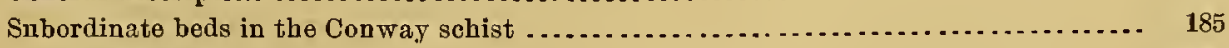

The gneiss heds...................................................... 185

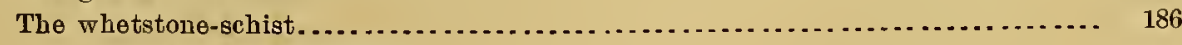

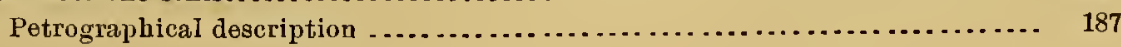


Chapter VII.-The graphitic mica-schist series on the west side of the valley-Continued. Page.

The Conway schists, or the corrugated mica-schists-Continued.

Subordinate beds in the Conway schist-Continued.

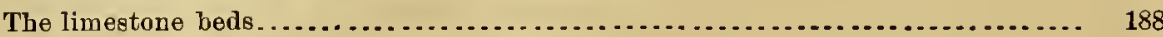

The amphibolite beds .................................................. 189

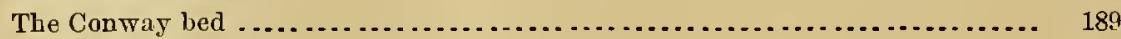

The Whately bed ............................................... 190

The Whitmores Ferry bed ........................................... 190

Petrographical description of limestone and amphibolite; the limestones, the auvils, passage of limestone into amphibolite.........................

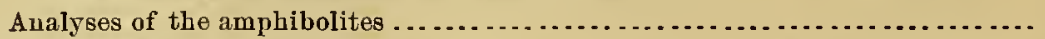

Projection of the limestone and amphibolite of the Conway schist through the Leyden argillite in Whately ............................................ 196

Contact metamorphism of the limestoue by granitite; argentine............... 197

Cleavage in the Conway sehists ......................................... 199

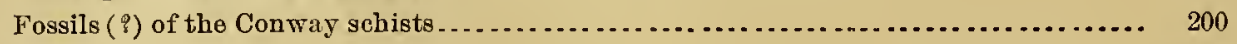

The Leydeu argillite ...................................................... 201

Description ....................................................... 201

Qnartzite in the argillite ............................................ 202

Petrographical description ........................................... 202

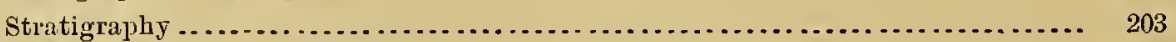

Boundary on the Conway schists ........................................ 203

Argillite on the western border of the "graphitic mica-schist" (Goshen schist).... 204

Relative age of the Conway schist and the Leyden argillite ................... 204

Contact metamorphism of the Leyden argillite bordering the tonalite of Hatfield.. 205

The sericite-gneiss ............................................ 206

The chiastolite-schist. .............................................. 209

Crapter VIII. -The bands of Silurian sebists on the east side of the valley ............... 211

The Northfield semisyncline ............................................... 212

General description. ................................................... 212

The Gulf road sections............................................ 213

Sectious north and south of the old Warwick road .......................... 215

Pegmatite dikes and minerals ....................................... 216

The Wendell branch syncline ............................................... 217

The Leverett-Amherst area................................................. 218

The amphibolite and mica-schist series along the east side of the Connecticut basin from

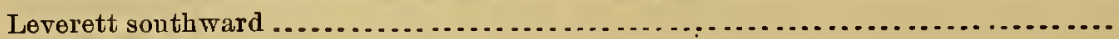

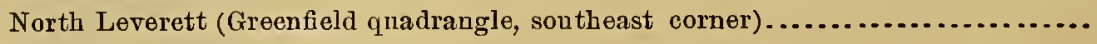

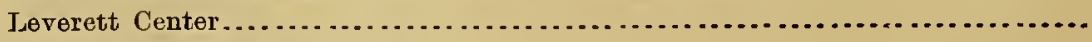

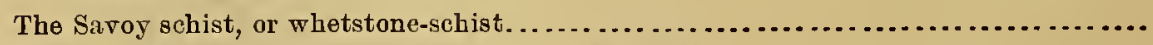

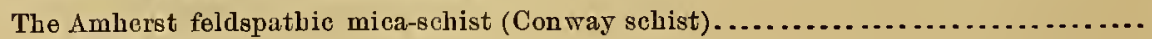

Leverett . . . . . . ..................................................

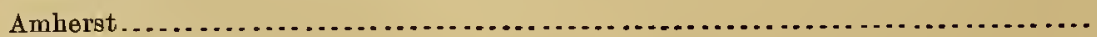

The Pelbam-Shutesbury syncline ........................................ 225

The great central syncline................................................. 227

Warwick and Orange.................................................... 227

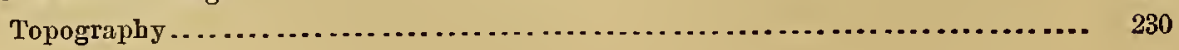


CinpTE1: V111,-The bands of Siluriau sehists on the east side of the valley-Continued.

The great "entral syuclium-Continuerl.

South Orango and New Salem ........................................ 230

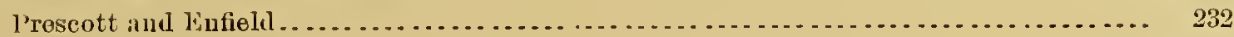

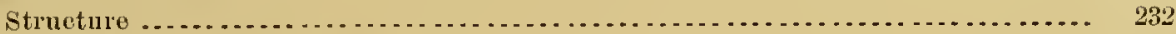

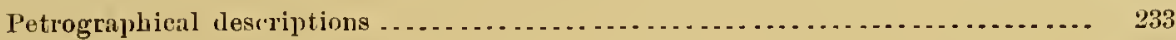

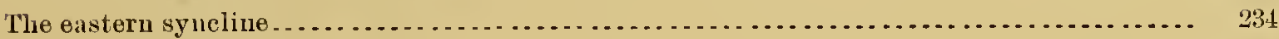

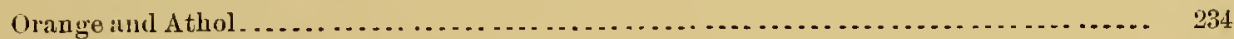

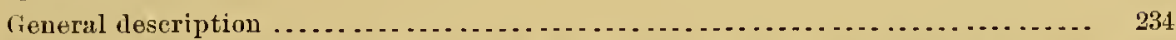

Metamorphism of the amphibolite band as it is involved in the granitite of the

Athol batholite, and its later change to stentite...................... 236

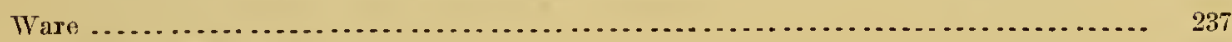

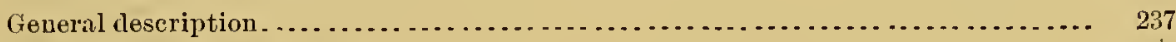

Petrographical description . .......................................... 238

The Hard wick gneiss ................................................... 239

Petrographical description ......................................... 240

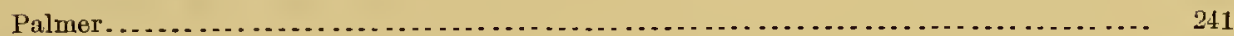

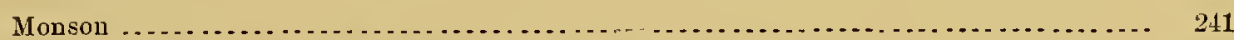

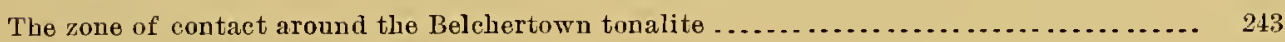

The pyroxenic amphiholites ............................................ 243

The fibrolite-schist inclusions.......................................... 246

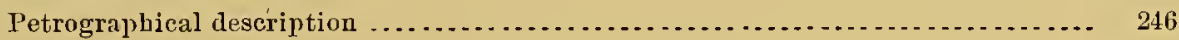

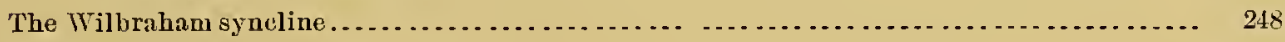

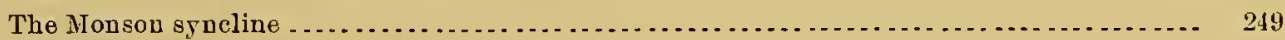

The East Greenwich-Enfield syncline................................... 251

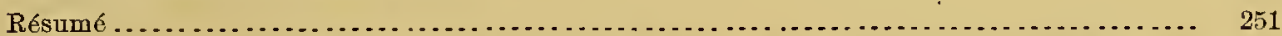

Argument for the identity of the schist series east of the Connecticut with those on the west

The passage eastward into the Brimfield fibrolite-schist...................... 252

Chapter IX.-The Bernardston series of Upper Devonian rocks....................... 253

Literature . . . . . . . .

History . . . . . . . . .

Upper Devonian age of the Bernardston fossils............................... 259

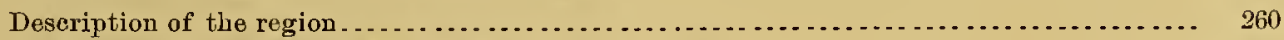

The relation of the Bernardston series to the argillite .............................. 261

The Williams farm section; the fossiliferous limestone; proof that the whole series is

Deronian ........................................................... 262

Description of the range from Bernardston to South Vernon........................ 272

The feldspathic quartzite .................................................. 282

The Bernardston series east of the Connecticut . . . . . . .

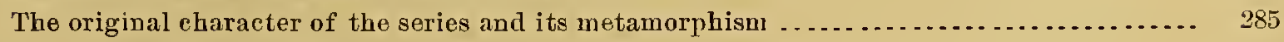

Petrographical description ............................................... 287

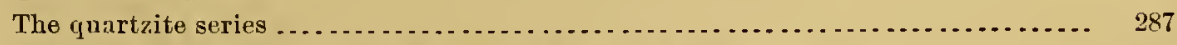

Amphibolite associated with the limestone in the gneissoid quartzite $\ldots . . . . . . .2 \quad 290$

The mica and amplibolite series ....................................... 291

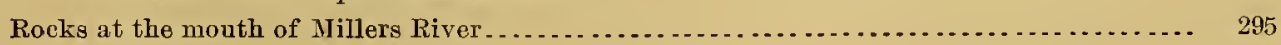


Page.

Chapter X.-The amphibolites described in the preceding chapters ..................... 300

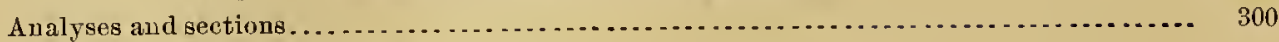

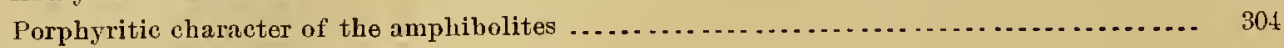

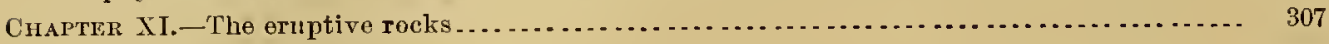

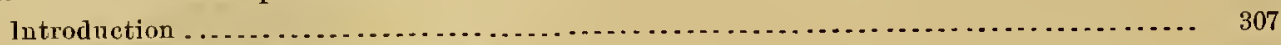

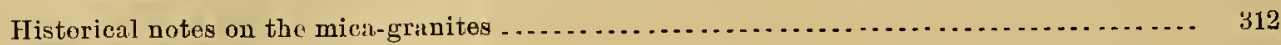

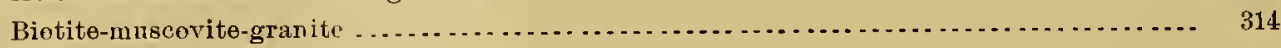

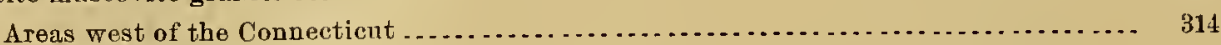

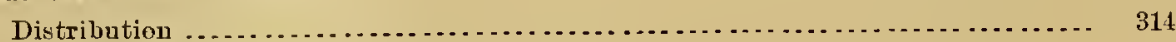

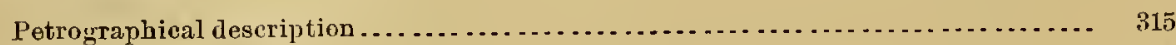

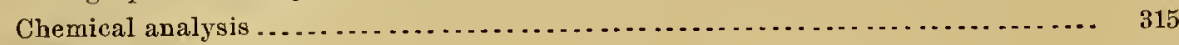

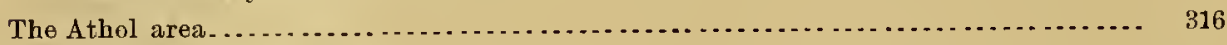

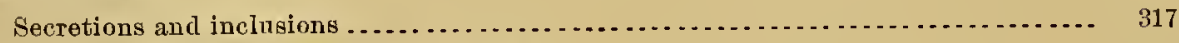

rbo Harlwick gneissoid granite and granitite ............................. 317

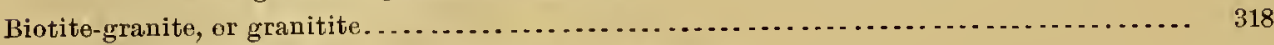

Contact metamorphism of the granitite and schists ............................ 318

The Middlefield porphyritic granitite. . . . . . . . . .

The Coy's Hill porphyritic granitite ........................................ 319

Deseription and distribution ........................................... 319

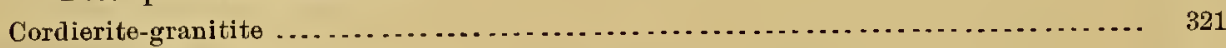

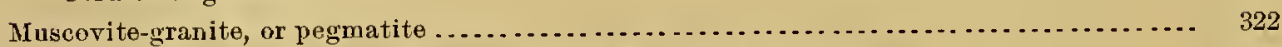

Probable extreme modification of the pegmatite by crnshing .................. 323

Albitic granite and pegmatite dikes containing rare minerals . ....................... 323

Distrilıtion and description ............................................. 321

The great tourmaline-spodnmene dike ................................... 324

Dikes in Goshen ..................................................... 326

Dikes in Chester, Blandford, and Hnntington ............................ 327

Dikes east of the Connecticut. ........................................ 327

Garnet in pegmatite with complex paramorphic border of zoisite-hematite, epidote-

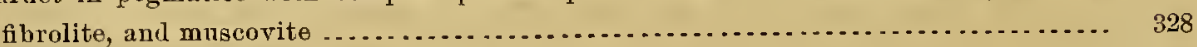

The crushing of minerals in the albitic granite ............................... 329

Hydrothermal changes in the albitic granite veins........................... 329

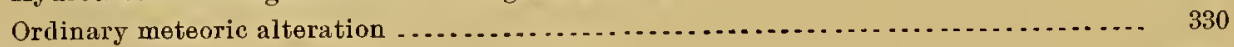

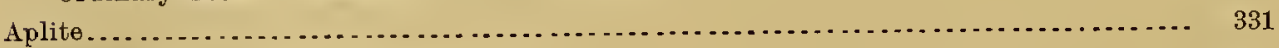

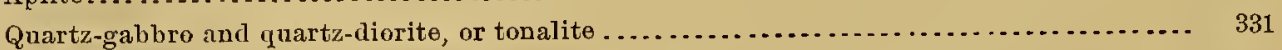

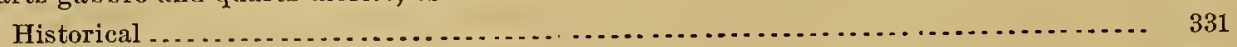

Basic secretious: Hitcheock"s suggestion of the theory of "schlierengünge" ....... 331

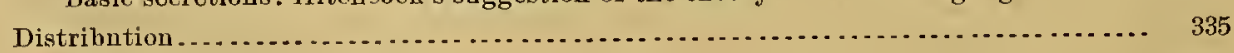

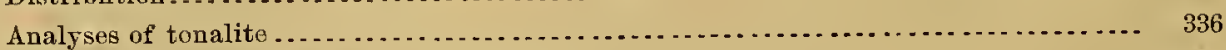

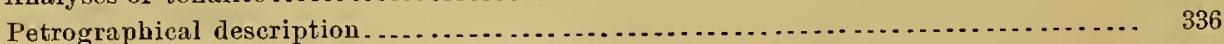

The crushing and alteration of the tonalite aleng the Pelham fault................ 339

Petrographical description of the altered tonalite ......................... 341

Diorite....

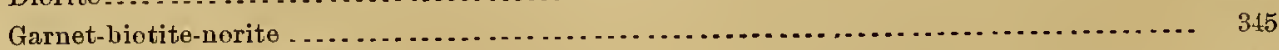

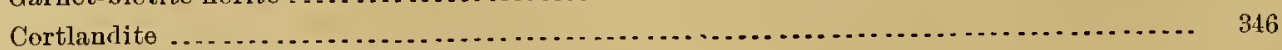

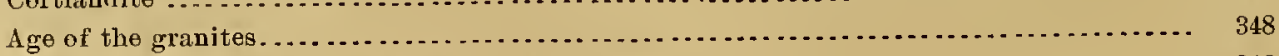

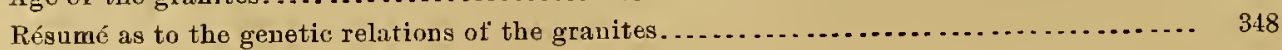

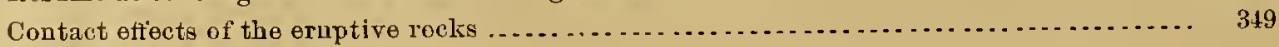




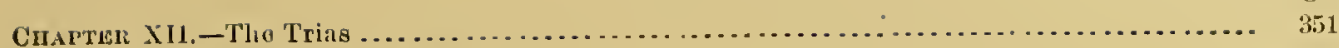

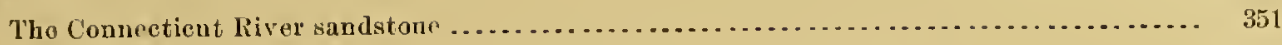

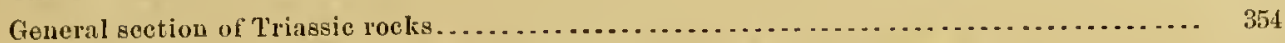

Tho Sugar Loaf arkose, or tho foldsprathic sandstone and conglomerat $\ldots . . . . . . . . . . .354$

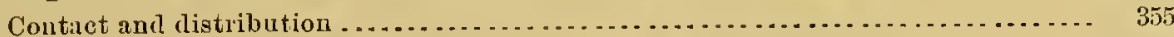

The Monnt Toby conglomerate, or tho slate and quartzite couglomerate . . . . . . . . . 358

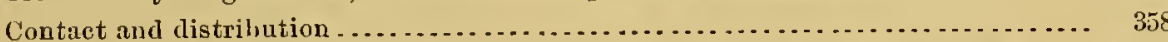

The outerops of crystalline rocks in the midst of the Mount Toby conglomerate ... 361

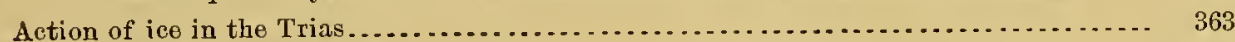

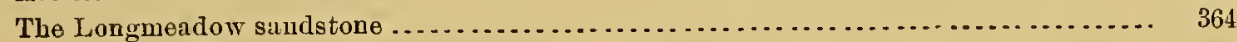

Fragments of white trap without augite in the sandstone above the Holyoke sheet. 365

Disturbances in the sandstones and inclusions of trap fragments just below the

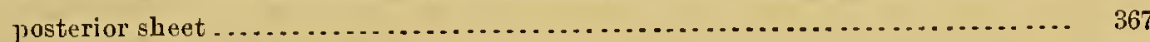

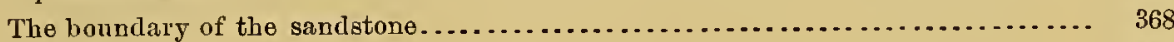

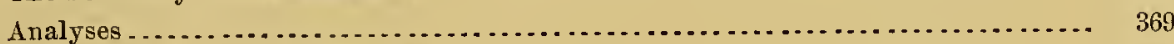

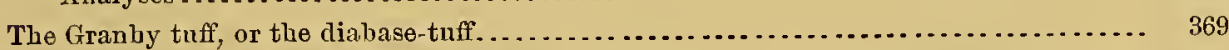

The Chicopee shale, or the calcareous shale. ............................... 370

The continuation of the State-line fanlt in a crushed band at the Holyoke dam and the

sccondars minerals found in the fissnres . . . . . . . . . . . . . . . . . . . . . . . .

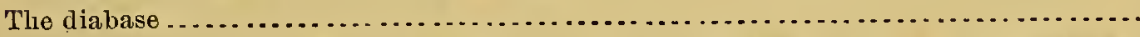

The formation of the basin aud the distribntion of the sediments by strong tidal currents..

The possible connection of the foot tracks with the trap sheets....................

Artesian wells

Psendomorphs of calcite and dolomite atter hopper-sbaped cnbes of salt. . . . . . . . . . . . .

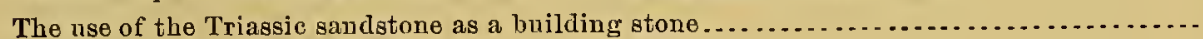

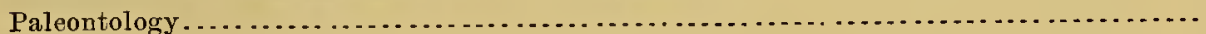

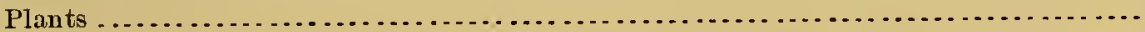

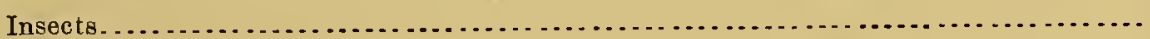

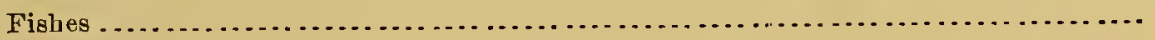

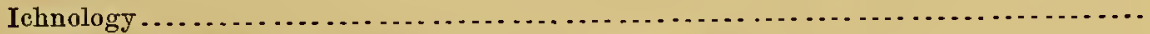

Recent progress in Iclınology, by C. H. Hitcheock . . . . . . . . . . . . . . . . . . .

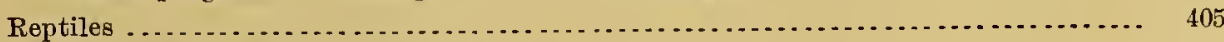

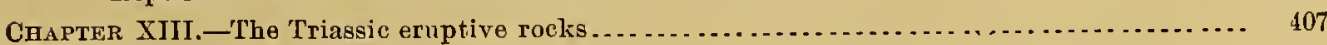

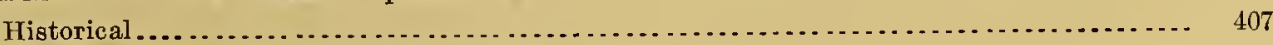

The three epochs of ermptive activity ; genernl account. . . . . . . . . . . . . . . . . . . . . 410

Diabase dikes and stocks in the gneiss east of the Trias . . . . . . . . . . . . . . . . . . .

A microscopical diabase dike from Pelbam, and olivine and glass-bearing dikes from

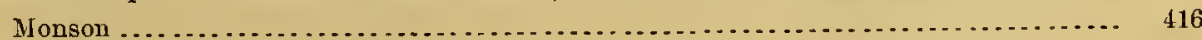

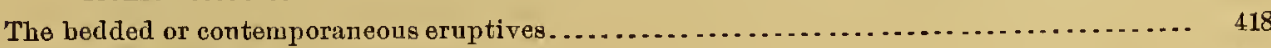

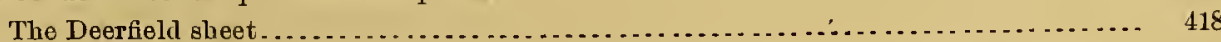

Contact on the saudstone below; the underrolling of the crust and the alteration of the diabase by heated waters to a pitchstone-breccia and a cliopside-plagioclase rock

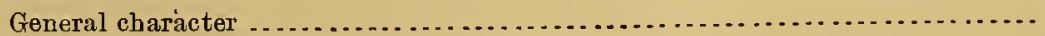

Greenfield quarry exposures and contacts . . . . . . . . . . . . . . . . . . . . . .

Petrographical description . . . . . . . . . . . . . . . . . . . . . . . . . . . .

Diabase-pitchstone 
Chapter XIII.--The Triassic eruptive rocks-Continued.

The bedded and contemporanens eruptives-Continued.

The Deerfield sheet-Continued.

Contact on the sandstone below, etc-Continued.

Petrographical description-Continued.

Anygdaloidal sindstone ........................................

Contact material............................................. 436

Lithophysæ ................................................ 436

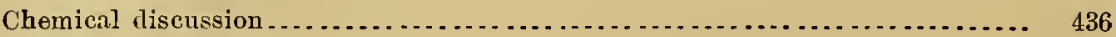

Origin of the glass and minerals.................................... 437

Contact of the sandstone npon the diabase............................. 439

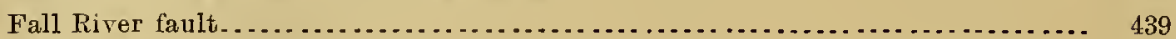

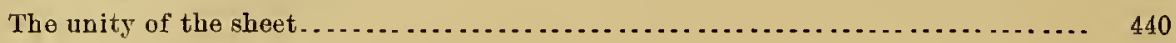

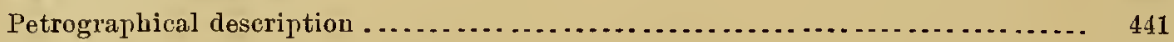

Paragenesis of secondary minerals.................................... 444

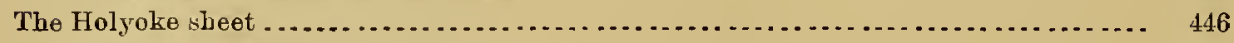

The faults at Mount Tom and sonthward................................... 449

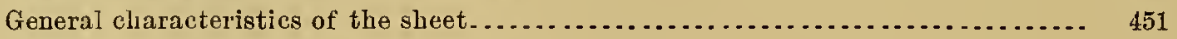

Normal contacts of diabase on sandstone.............................. 452

Contacts of underrolled diabase inclusions of limestone .................... 452

Petrographical ilescription .......................................... 453

Normal contact of the sandstone on the diabase ......................... 455

Contacts of sanilstone on diabase which is kneader full of limestone and shale..... 456

Section of trap fillell with limestone fragments on the Westfield-Holyoke Railroad.- $\quad 456$

Magnatic differentiation .......................................... 459

Origin of the clay and marl deposits. ................................. 459

On the muderrolling of the solidified surface of the trap ................... 460

Petrographical description of the normal diabase ....................... 461

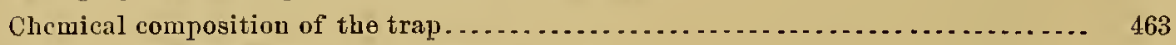

The upper or posterior sheet and its feeding dikes.......................... 461

The great widening of the trap area and the feerling throat beneath . ............ 467

Sills intruded in the sandstones below the posterior sheet.................... 469

Delaney's quarry, near the north line of Holyoke........................... 470

The Roaring Brook fault and the disappearance of the posterior sbeet.......... 473

The blending of the tuff with the surface of the posterior bed................. 474

A tuffaceous sandstone containing white trap ........................... 474

The posterior dike across Hampden County............................. 475

The Talcott sheet....................................................... 476

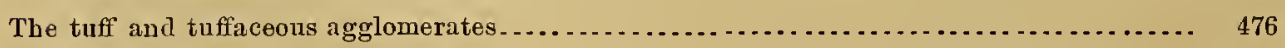

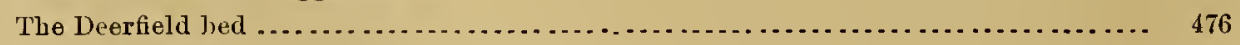

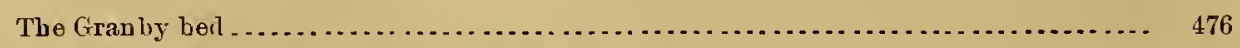

The isolated mass of tuff north of the seventh core........................... 47.9

Source of the material of the tuff bed ................................... 480

A hollow bomb from Delaney's quarry, Northampton ........................ 480

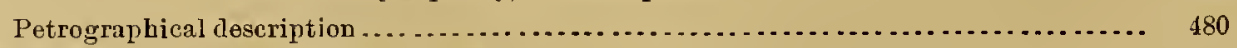

The newer serics of cores and short dikes. ................................... 481 
Chapter XIIl.-The l'riassic ernptive roeks-Continned.

The newer series of cores and short dikes-Continued.

Belchertown .......................................................... 481

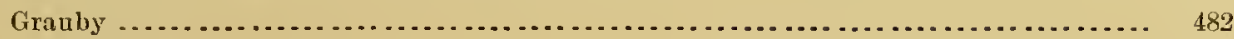

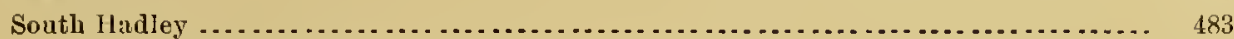

The ninth core of dialuase, with granitic inclusions....................... 483

Petrographical description......................................... 484

The eleventh or Black Rock core.......................................... 489

Petrographical description .......................................... 492

Northaupton. ......................................................... 494

Sumnary of the bistory of the Connecticut River sandstone . . . . . . . . . . . . . . . . . 495

The use of the trap as road material .......................................... 500

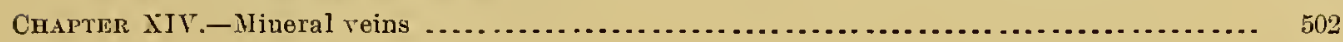

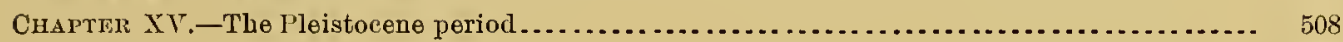

Literature .... . . . . . .

The interval between the Triassic and the Glacial period ......................... 508

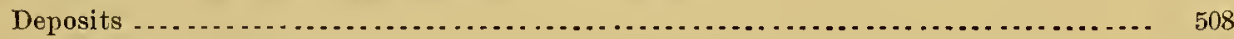

Pre-Glacial weathering ................................................. 509

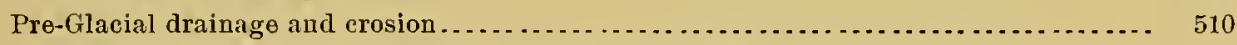

Pre-Glacial course of the Connecticut and its tributaries ........................ 513

Character and amount of the erosion during later Mesozoic time as compared with that

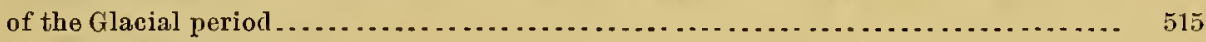

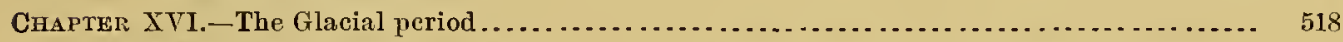

The present rock surface and the amount of Glacial and post-Glacial material on the same.. 518

Glacial grooves and strix............................................... 522

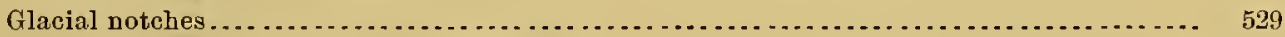

Pseudo-glacial striw on Devoniau argillites . . . . . . . . . . . . . . . . . . .

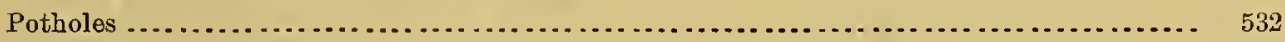

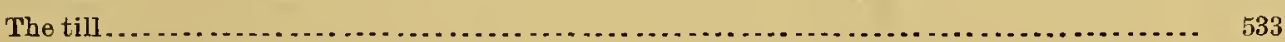

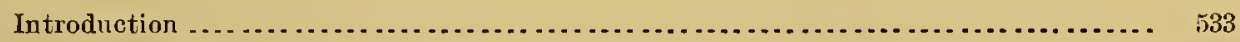

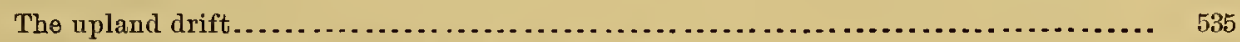

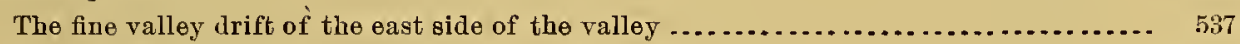

The coarse valley drift............................................ 541

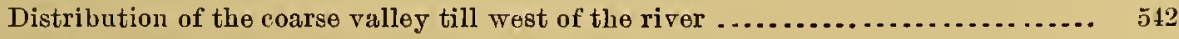

Drumlins........................................................... 543

Moraines and bowlder trains......................................... 519

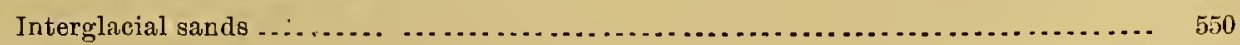

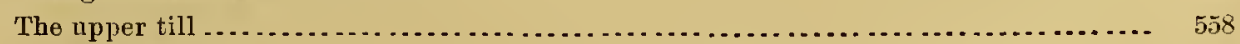

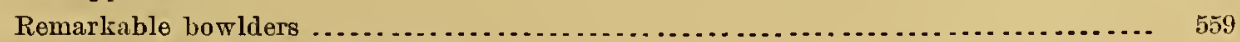

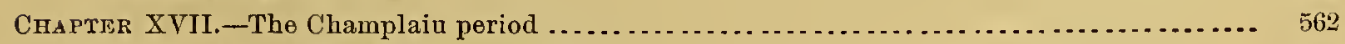

Glacial lakes east of the Connecticut River ................................... 562

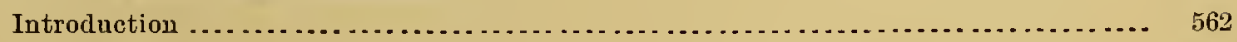

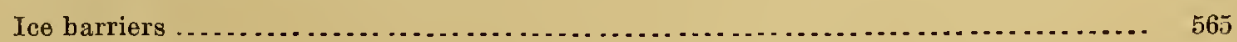

The Brimfield Lake ................................................... 565

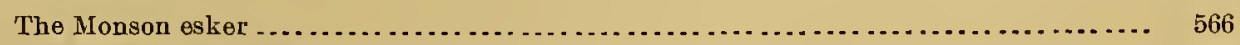

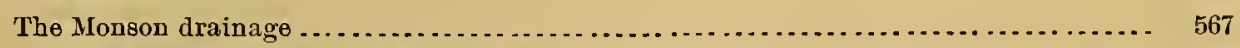

The eastern Palmer and Monson Lake................................. 567 
Chapter XVII.-The Champlain period-Continued. Page. Glacial lakes east of the Connecticnt River-Contiuued.

The Ellis Mills drainage .............................................. 569

The Paluer Lake..................................................... 569

The Ware and Swift River lakes ......................................... $\quad 569$

The Chicopee River drainage ......................................... 575

The Belchertown Lake.............................................. 575

The Pelham Lake and esker ........................................... 578

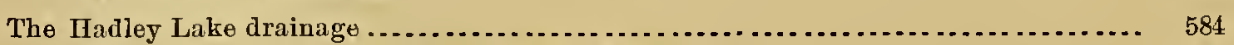

The Leverett Lake and the Notch east of Mount Toby ...................... 584

The Locks Pond Lake ..................................................... 586

Notches through the Holyoke range and the range north of Moody Corners............ 586

The Granby Road Lake............................................ 587

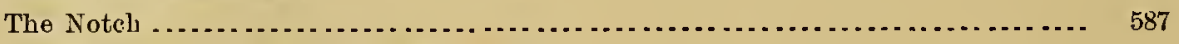

The low place and Moody Corners Lake................................... 587

The Pelham River and the "Moraine Terrace" sands along the eastern valley side, just above the level of the high terrace ........................................ 588

The Sunuy Valley Lake ............................................ 592

The sands along the west side of Mount Tom Range and in the Westfield basin

above the level of the hight terrace .................................... 592

Chapter XVIII.-The Champlain period (Continued) .............................. 593

Glacial lakes west of the Connecticut River.................................. 593

The Granville Lake ...................................................... 593

The North Granville Lake . . . . . . . . . . . . .

The Westhampton Lake ............................................... 594

The williamsburg Lake ................................................ 595

The Beaver Brook Lake above Leeds ..................................... 595

The Deerfield River lakes .................................................. 595

The Deerfield River and its tributaries on the north......................... 597

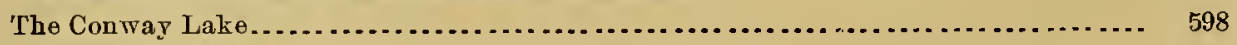

The Bear River Lake .................................................... 600

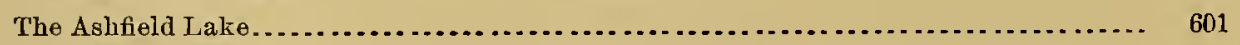

The Buckland Lake ...................................................... 602

The last important halting place of the ice front across the basin of the Deerfield River. 604

Glacial lakes north of the Deerfield River................................. 604

High level deltas. ........................................................ 605

The character of the terraced flood deposits of the Westfield River . ............... 607

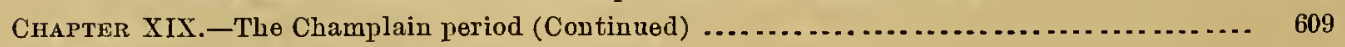

The Connecticut River lakes . . . . . . . . . . . . . . . . . . .

Introduction ............................................................ 609

Detailed description of the flood deposits in the Montague basin. .................. 615

The northern lobe of the lake ......................................... 616

The Bennetts Brook plain, or moraine terrace ............................ 617

The extension of the flood gravels westward through the Bernardston Pass........ 619

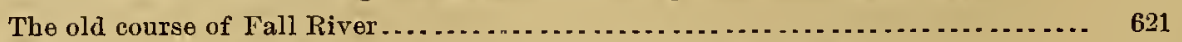

The bench on the east side of the river in Northfield and Erving................. 622

The Millers River delta; the canyon and old course of the Connecticut.......... 625 
Chapter XIX.-The Champlain period-Continued.

The Counecticut liver lakes-Continued.

'Tho lladley Lake.

'The north end of the lake in Greenfield and the ehannel of connection with the main valley

The Green River glacier.

The Factory Village channel

The high terrice plains in the south of Grenfield and the uorth of Jeerfida

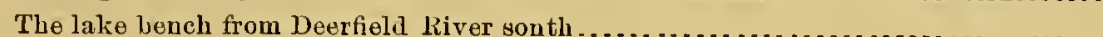

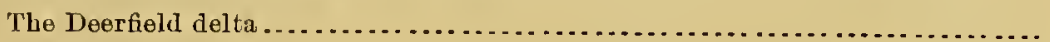

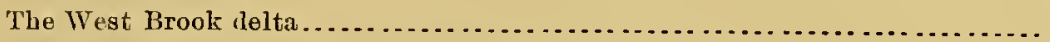

The Mill River delta in Northampton ................................

The lake bench ou the east side of Hadley Lake in Leverett and Amherst ......... The delta of Cushmans Brook at North Amlerst and the isolation of the East Street basin in Amherst

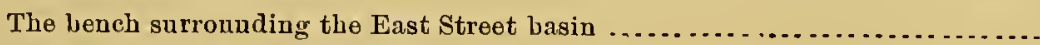

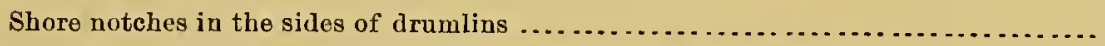

The high terrace or bench along the west side of the Amherst ridge...........

The bench aronnd Mount Warner .

The bench along the yorth slope of the Mount Holyoke and Mount Tom range......

The Westield plain

The greater elevation of the terraces in the Westfield than in the Springfield Lake; possible western elevation

Geology of Westfield and vicinity, by J. S. Diller

The "gorge terrace" of Dry Brook Hill in the north part of Sonth Hadley ........ . 661

The high terrace of the west side of the river from the Holyoke notch southward .. 662

The similarity of the Belchertown noteh to the notch east of Mount Toby ......... 663

The moraine across the southern part of the Granby plain .................... 661

Kettle holes and the old bed of the Connecticut........................... 661

Kettle holes and the structure of the high-terrace sands; their origin from the melting of ice heneath the terrace gravels ...................................... 665

Lake bottoms . ........................................................ 672

The Montague Lake ............................................... 672

The Hadley Lake ................................................. 673

The Springfield Lake................................................ 677

Detailed sections of terraces and lake bottoms, showing several advances of the ice front.

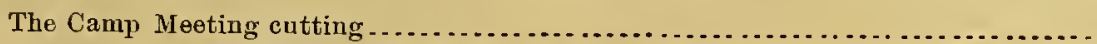

Section of clays in Hatfield, showing great disturbance and pressnre cleavage.....

The Wapping cutting

Chapter XX.-The Champlain period (Continned)

The Champlain clay

Introduction .

The Montague Lake

The Hadley Lake. . . . . . . . . . .

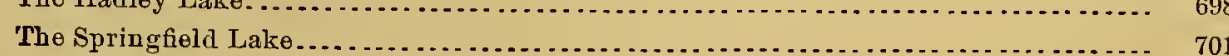

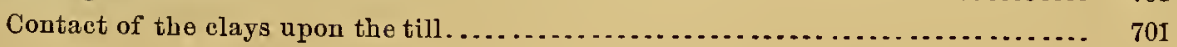


Chapter XX.-The Champlain period-Continued.

The Champlain clays-Continued.

The Springtield Lake--Continued.

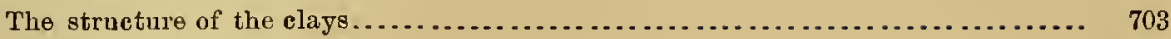

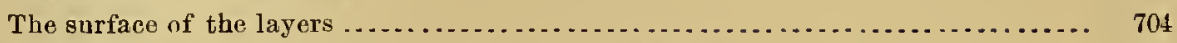

The lateral passage of the clays into the high terrace sands................... 705

The passage of the clays into the sands above ............................ 705

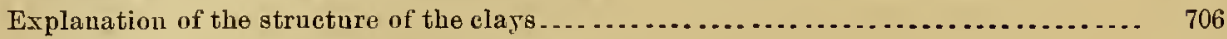

The time oecupierl in the deposition of the clays. ............................... 707

Action of icebergs and floes upon the clays................................... 707

Secondary structures in the clays. ....................................... 709

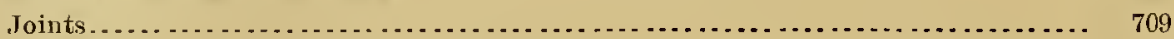

Concretions ......................................................... 711

Fossils of the (hamplain clays . ....................................... 718

Chapter XXI.-The terraces of the Connecticnt and the modern deposits................ 722

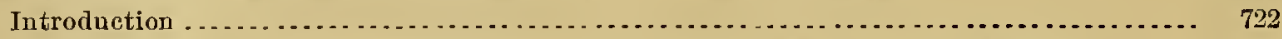

The intermediate terrace and harrier at Lily Pond in Gill; an abandoned waterfall....... 724

The low-level terraces and flood plain of the Connecticut in the basin of the Montague Lake. 725

The later terraces or meadows of the Connecticut in the Hadley Lake................ 726

The structure of the terraces ........................................... 727

The river sands................................................... 727

The muck sands . . . . . ............................................... 728

The peat deposits and the plant remains ............................... 728

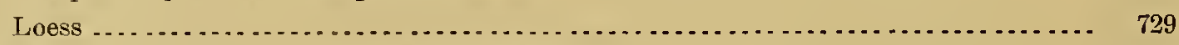

The terraces of the Connecticut in the Springfield basin .......................... 729

The incomplete terraces as illustrations of the stages in the growth of terraces ........... 731

On the oscillations of the Connecticnt from its earliest position . . . . . . . . . . . . . . . . ... 733

The oxhows of the Connecticut............................................ 734

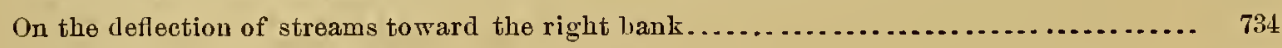

River terraces around a receding waterfall ........................................ 735

The terraces of tributaries.... . . . . . .

An old oxbow of Fort River ............................................ 737

Fossils of the terrace period . . . . .

The Pleistocene beetles of Fort River, Massachusetts, by S. H. Scudder............. 740

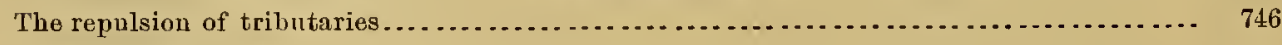

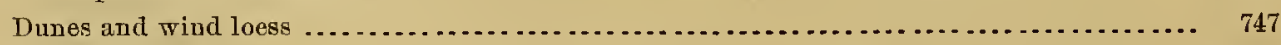

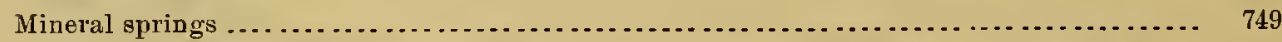

Thick modern fissure deposits of quartz surrounding roots in the base of the Holyoke trap

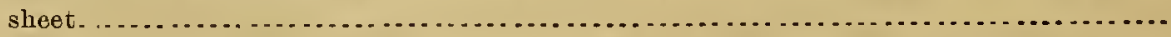

Chapter XXII.-Supplement to the author's mineral lexicon of Franklin, Hampshire, and

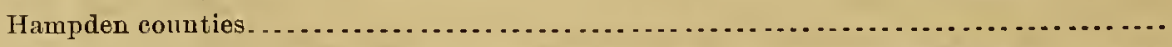

CHAPTER XXIII.-Chronological list of publications on the geology and mineralogy of Frank-

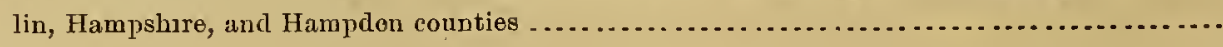

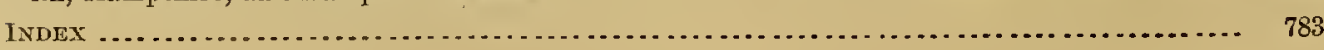




\section{ILLUSTRATIONS.}

PLATE I. Coign of Williston Hall at Amuerst College, showing conglomerate-gneiss from the Hlonson «

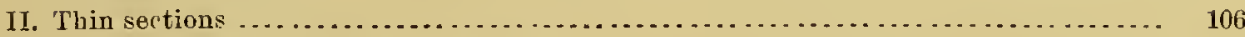

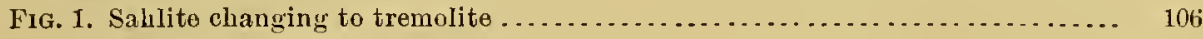

2. Dolomite changing to serpentine.............................. 106

3. Eustatite crystal altered to serpentine, cut parillel to $(001) \ldots \ldots \ldots \ldots \ldots . .106$

4. Garnet, with complex border, from pegmatite.................... 106

III. Thin sections..................................................... 208

FIG. 1. Leyden argillite changed to chiastolite sclust in contact on tonalite........ 208

2. Corlierite twins, froil cordierite-granite ........................ 208

3. Diorite, trom Packards Mountain, Prescott ......................... 208

4. Contact of diabase-amygdaloid and clayey limestone.................. 208

IV. Map of the Devonian rocks of the Bernardston series aud of the fanlted syncline of Silurian schist in Northfield Mountain ................................. 260

V. Sections of amphibolites derived from limestone .......................... 302

VI. Sections of amphibolites probably derired from limestone . . . . . . . . . . . . . . . 306

VII. Tourmaline dendrites in granite, Leerls . . . . . . . . . . . . . . . . . . . . . . . . 316

VIII. Vertical wall of diabase at the cuarry for road material in the east of Greenfield .... 424

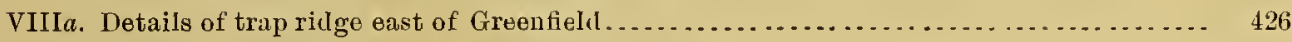

VIII $b$. Inclusion of mud in mper surface of trap sheet . . . . . . . . . . . . . . . . . . . . 498

VIIIc. Thiu sections of material from Greenfield and Mericten "ash bed" ................ 430

IX. Geological map and sections of the Mount Holyoke-Monnt Tom rauge, with the posterior cliabase sheets, the tuff, and the rolcauie cores...................... 446

$\mathrm{X}$. Batterson's quarry, in north part of South Hadley, showing veneering of sandstone

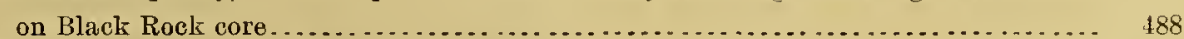

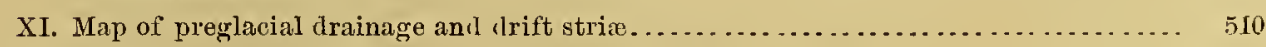

XII. Sections in Amherst Honse cellar, showing interglacial berls . . . . . . . . . . . . . . . 550

XIII. The great serpent esker in PeIham . . . . . . . . . . . . . . . . . . . . . . . . 578

XIV. Diagram of the lake-shore and lake bottom profiles of the Comeeticut jakes........ 656

XV. Sections at the Camp Heeting entting, on the north Iine of Northamptow, showing the

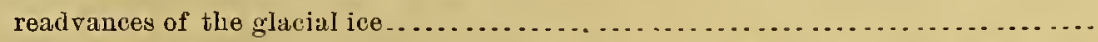

XVI. Surface of ice-contorted elay, smoothly cut with a knife, east of J. Ryau's house, Hatfield

XVII. Joints and faults in laminated clay, produced by the weight of the ice svii

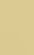

6

\section{8}

\section{8} 602

6

6

4

28

30

\section{0}

78

56


PL. XVIII. The Wapping and Camp Meeting cuttings $\ldots \ldots \ldots \ldots \ldots \ldots \ldots \ldots \ldots \ldots \ldots \ldots \ldots \ldots \ldots \ldots \ldots \ldots$
FIG. 1. Section of tine-grainer contorted sands at the Wapping cutting on the

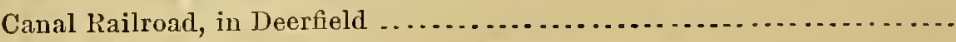

2. Section on the west side of the Camp Neeting cutting .................

3. Detail from peint above $\hat{x}_{\dot{x}}$ on Plate XV, helew fourth ice-worn surface......

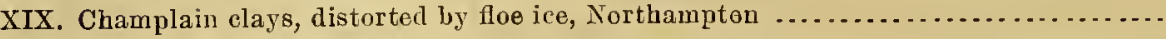

XX. Calcareous concretiens with worm tracks, Champlain clays, Hadley and Nerthampton.

XXI. Profile of the Cenuecticut River from Vernon, Vermont, to Hartford, Connecticut,

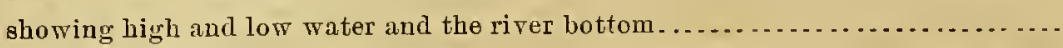

XXII. View across the Connecticut River, showing the notches formed by the river at the Lily Pond, in Gill, and its escape aronnd The Narrows .....................

XXIII. Pleistocene beetles of Fort Rirer, Massachusetts; S. H. Sendder . . . . . . . . . . . . ....

XXIV. Geolegical sections along liues I to $I V$, d]awn on the northwestern portion of the

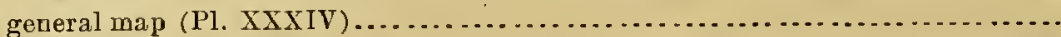

XXV. Geelogical sections aloug lines V to VIII, drawu on the western pertion of the general map (Pl. XXXIV)

XXVI. Geological sections along lines IX te XII, drawn on the southwestern portion of the

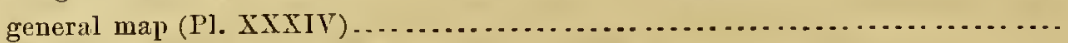

XXVII. Geological sections along lines XIII to XVI, drawn on the northeru pertion of the

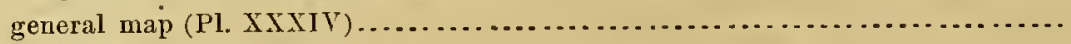

XXVIII. Geological sectiens aleng lines XVIl to XIX, drawu on the central portion of the

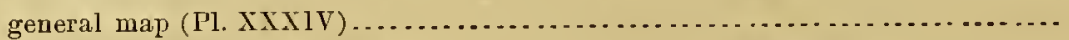

XXIX. Feelogical sections along lines XX to XXIII, drawn on the seuthern portion of the

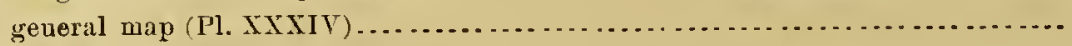

XXX. Geological sections along lines XXIV to XXVII, drawu on the northeastern portion

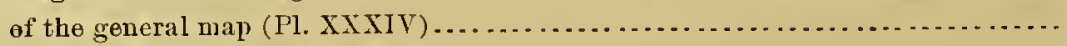

XXXI. Geelogical sections along lines XXVIII to XXXII, drawn ou the eastern pertion of the general maj (Pl. XXXIV) .....................................

XXXII. Geological sections along lines XXXIII to XXXVI, drawn ou the sontheastern por-

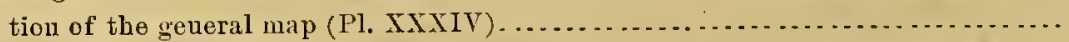

XXXIII. "Anvils," forinel by the nucqual erosion of blecks of impure limestoue (plate

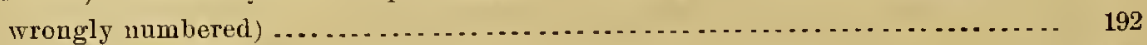

XXXIV. Geolegical map of Frankliu, Hampshire, and Hamplen conuties ............. In pocket

XXXV. Map of the surface geology ........................................ In pocket

FIG. 1. Algonkian section at Coles Broek...................................... 22

2. Detailed section of the limestone at Coles Broek............................ 23

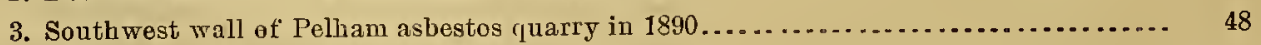

4. West wall of Pelham ashestos qnarry .................................... 49

5. Section at Osbern's soapstone quarry, Blandford ............................. 87

6. Map of emery veins in epidete-amphibolite at north end of bed on the bank of the

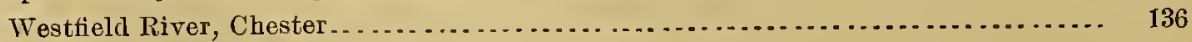

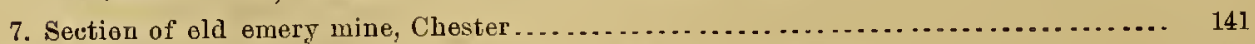

8. Stellate marble; Westfield Marble Company's quarry, Russell................... 152

9. Plan ef altered dikes and quartz veins in chlorite-schist, Charlemont . ............ 169

10. Conterted layer of garuetifereus quartzite (coticnle), from mine on l'orge Hill, Hawley.. 174

11. Map showing the protrusion of the limestene of the Couway schist through the Leyden

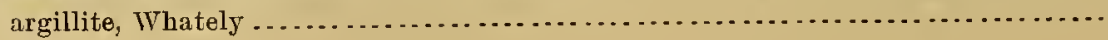




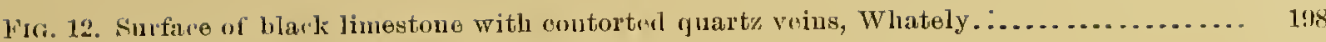

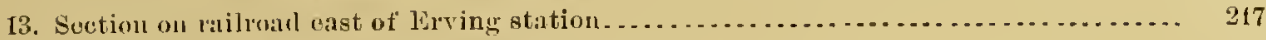

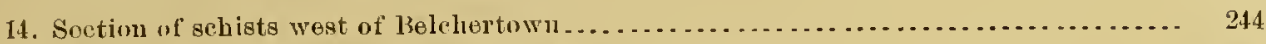

15. Mlap of llevonian rocks on the Williams firm, Bernariston.................... 263

16. Sortiou of l)evouian rocks from the Williams firmhouse 250 rods uorth west......... . 264

17. Sectim of the Williams firm quarry .................................... 264

18. Section at north oud of limestone, Willinus furm ........................... 266

19. Section across Beruardston series on Purple blind roal, Reruarilston ................ 278

20. Sketch milp of rocks near the mouth of Millers liver, Lwing ................. 295

21. Sketch of rocks at mouth of Miller's River, looking northeast from B, fig. 20......... 295

22. Section on east bank of the Connecticut above mouth of Millcrs River, at $\Lambda$, fig. $20 \ldots \quad 296$

23. Section at the Holyoke dam, showing the passage of a fanlt throngh the sliales........ 371

24. Thin sections of sand and glass breccia from the base of the freenfiell sheet at the

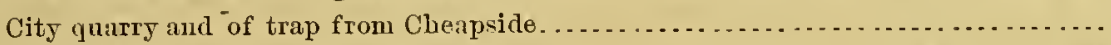

25. View of the posterior trap sheet and its feeding dike at Little Mountain, in Forest

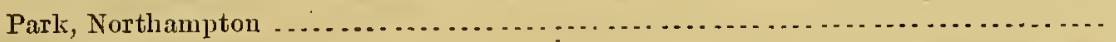

26. Section of Delaney's quarry on the Connecticut River Railroar in Northampton, near

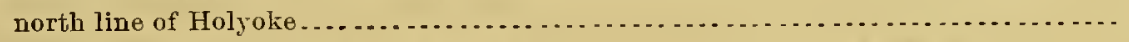

27. Section of contact of Black Rock plug and tho Mount Holyoke rliabase bed..........

28. Holjoke noteb from Hadley mearlow; pre-Glacial rock terraces . . . . . . . . . . . . . . . ...

29. Glacial groove ou compaet diabase, Prospert Honse, Monut Holyoke .... . . . . . . . . . ...

30. East slope of a large glaciated groove behind the bowliug alley on Mount Holyoke....

31. Section showing the strice on the surface of sandstone coutinued on the surface of the

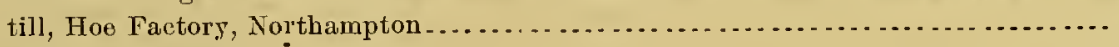

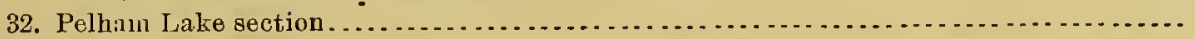

33. Section of terminal moraine covered by high-level flood gravels of Westfield River, at Russell

34. Sand bowlders, in terminal moraine, crushed by the ice while frozen . . . . . . . . ......

35. Section throngh the eroded front of the great delta at IJontagne City ...............

36. Sectiou of the Green River delta at north end of Green River basin ..................

37. Section of the shore beds of Hadley Lake sonth of College Hill, Amberst ..............

38. Enlarged section of the south side of the cutting shown in fig. 37..................

39. Detail of elay layer crumpled by the current, from fig. 38 . . . . . . . . . . . . . . . . . . .

40. Sections south of Millers Falls station, showing kettle-holns formed by ice melting

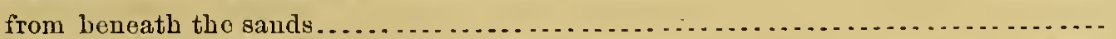

41. Section sonth of Millers Falls, showing kettle-hole formed by ice stranded on the sur-

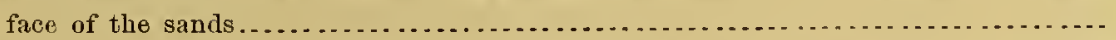

42. Section of north half of kettle-hole below Dwight's station, Belchertowu .............

43. Section at the south eucl of North Pond, Belchertown, showing part of a kettle-hole at the north end and of an erosion slope at tlie sonth end .......................

44. Section of kame sands at the north eurl of the "big fill," south of Inight's ..........

45. Block of frozen "pink sand," showing fine system of joints . . . . . . . . . . . . . . . .

46. Pharyngeal bone of a fish, from the Champlain clay, Holyolie . . . . . . . . . . . . . . . . . .

47. Sketch of the point of the Northampton meadow from Mount Holyoks. showing that the mearlow is a composite of many islands .............................. 726

48. An old oxbow of Fort River cut by the Connecticut below Hadley ................. 737 



\title{
LETTER OF TRANSMITTAL.
}

\author{
Anherst College, \\ Amherst, Mass., March 4, 1995.
}

SIR : I have the honor to transmit herewith the manuscript of a geological description of the three counties in Massachusetts through which the Connecticut River runs, and which include nearly the whole of that portion of its drainage area which lies within the limits of the State.

The studies here presented began in 1873. The results were offered to the United States Geological Survey in 1887, and were accepted at that time. A small portion of the area has since been reexamined, under the direction of the Survey, and the map has been extended a little beyond the limits of the State north and south, to cover the whole of the area represented on the topographic sheets employed. In this work I have been assisted by Mr. William Orr, jr, of Springfield, who has mapped part of the limestone and amphibolite bands of the Conway schist, and by Mr. Frederick B. Peck, who traced the western boundary of the Shelburne anticline and worked ou the southem border of the area mapped on the Granville sheet.

As the work was mostly done before the appearance of the topographic maps issued by the Survey, many allusions to names found upon county atlas maps remain.

Very respectfully, your obedient servant,

B. K. Emerson,

Geologist.

Hon. Charles D. Walcott,

Director United States Geological Survey. 



\title{
GEOLOGY OF OLD HAMPSHIRE COUNTY, MASSACHUSETTS, COH- PRISING FRANKLIN, HAMPSHIRE, AND HAMPDEN COUNTIES.
}

\author{
By Benjamin Kendall Emerson, \\ Professor of Geology in Amherst College.
}

\section{H A P T E R I.}

\section{INTRODUCTION.}

AREA COVERED.

Old Hampshire County, which formerly stretched across the State of Massachusetts between Berkshire on the west and Worcester on the east, has been less fortunate than these and has lost Franklin County on the north and Hampden on the south. Amherst lies in the center of this area, and hence it has come about that for many years the region has been the field of my geological studies.

The rocks strike north and south and run quite across New England and beyond, so some artificial limits had to be chosen in these directions, and the limits of the State were as convenient as any. On the east and west, the area lying between the plateau of Worcester County on the east and the full development of the Berkshire Hills country on the west possesses a good degree of geological unity, the Cambrian gneiss of its eastern and western boundaries being almost certainly continuous beneath the whole area and supporting several series of schistose rocks, which culminate in the Bernardston highly metamorphosed but fossiliferous beds of Devonian age. The area includes, also, the northern half of the Triassic terrane, which reaches nearly to the north line of the State, while the sudden widening of the valley of the Connecticut just at this northern point, with the lowering MON $\mathrm{XX1X}-1$ 
of its borders, occasions a much greater degree of complexity in its postGlacial deposits, the great series of Glacial lakes on its eastern side being just within the limits of the State, and the division of the valley into two portions by the sandstone and trap ranges from Mount Tom southward being wholly confined within the same limits. So that the area has given me a section of sufficient length for my purpose in those rocks which are of great extent meridionally, and a goodly number of problems of which all the factors are within its limits.

\section{HISTORICAL SIKETCH.}

While many a quaint and appreciative remark may be gathered from the records of the explorers and early settlers of the Connecticut Valley concerning the great natural beauty of the new country, I have after much search found nothing which had refereuce to its geological structure. Considering the little that was then known, even among the learned, concerning geology, we do not wouder at this. It is more a matter of regret that they so generally failed to retain the Indian names of the prominent landmarks, or to replace them by significant or euphonions substitutes. Except the name of the Connecticut ${ }^{1}$ itself, I know of few Indian names retained from the beginning in their proper application, and but few descriptive and appropriate names which have come down to us from the fathers. Among these are "The Notch" and "The Low Place" in the Holyoke range, and "Sugar Loaf," named, I doubt not, by the Hadley farmers who rowed over to mow the Hatfield meadow, whence its conical shape is most striking and suggestive.

It is true that in late times the names Agawam and Chicopee have been applied to towns, Mittineague and Willimansett to villages, while in a few cases the Indian names of brooks seem to date far back, as Chicopee, Quinebaug, Quabang, and Scantic rivers, Pecowsick and Watchaug brooks, and Massasoit Pond. President Hitchcock attempted to baptize several of our peaks with Indian names; i. e., Nonatuck, Norwottuck, transferred from the Northampton Meadows to the peak overlooking them, and Metawampe, from the name of an Indian who deeded the region to the whites. With

${ }^{1}$ Quin ui tnk=long tidal river: Coll. Conn. Hist. Soc., Vol. II, p. 8. Quou eh ti cut=the long river: Trumbull Hist. Conu., Vol. 1, p. 32. 
these exceptions the Indian names of the region have largely passed into the possession of hotels and manufacturing' companies. 'There is, on the other liand, a great poverty of names for all the natural features of the comntry, "mownt" and "hill," "brook" and "river," serving rather indiscriminately for all elevations and streams. One longs for the rich vocabulary of Spain and Scotland. Again, the names given are often trivial and constantly repeated. All the larger streams have an east, west, and middle branch, and I remember hearing one brook called the "West Branch of the Middle Branch of the Westfield River." There are several "Swift" rivers, "Roaring" brooks, "Muddy" brooks, and eleven "Mill" rivers (and brooks) within the limits of the three counties.

The early settlers had little appreciation of the natural beauties of the landscape, or they would not have offended the poetical ear of President Hitchcock by naming our finest peaks Mount Toby and Bull Hill, and have left so many striking objects unnamed entirely. Certain peculiarities of nomenclature have grown up in the valley, as the naming of mountain gorges "gutters" (e. g., Running Gutter in Hatfield and Rattlesnake Gutter" in Leverett), of alluvial bottoms "meadows" (Hadley Meadows), and of deep narrow valleys "gulfs" (Gulf road in Northfield).

In 1810 Prof. Benjamin Silliman, of Yale College, visited the lead mine in Southampton at the request of the proprietors and drew up a report for their use. This does not seem to have been printed by them separately, but was published by the anthor the same year in the second number of Bruce's Mineralogical Journal, in which also a paper descriptive of some of the minerals found at the mine was published, from the pen of Dr. William Meade.

The publication of Cleaveland's Mineralogy (1816) and of the first volume of Silliman's Journal (1818), and the influence of Amos Eaton in Albany, mark the beginning of a strong movement toward the study of mineralogy and geology in New England. The first articles of Edward Hitchcock ${ }^{1}$ appear in these years, one of them, "with a sketch by Mrs. Hitchcock," marking the beginning of a scientific partnership which was to last so long, and which has made this region classic ground for the geologist. From this time on for a half century nearly all that became known conp. 617 .

${ }_{7}^{1}$ Obituary : Proc. Am. Acad. Arts Sci., Boston, Vol.VI, p. 291 ; Hist. Conn. Valley, $\overline{1879,} \overline{\text { Vol. II, }}$ 
cerning the geology of the Connecticut Valley was discovered by him, and the whole body of knowledge on the subject was systematized in his successive reports. So frequent mention will be made of his work in the following pages, and its progress may be followed so fully in the Chronological List, in Chapter XXIII, that special mention may be omitted here and attention called to the many physicians, teachers, and laymen who became enthusiastic mineralogists and scoured the hills so thoroughly that it is now exceedingly rare that one finds a new locality for minerals within these bounds. Prominent among these was Dr. David Hunt, of Northampton, to whom President Hitchcock acknowledges great obligation for assistance in mineralogy as early as 1818, and of whom Amos Eaton said that he had every mineral in this part of the State at his call. ${ }^{1}$

Dr. Jacob Porter, of Cummington; Emerson Davis, principal of the Academy of Westfield; Dr. William Atwater, of Westfield; Simeon Colton, of Monson, and Dr. Ebenezer Emmons, ${ }^{2}$ of Chester, who commenced his scientific work here, were among the professional men who pursued mineralogy with great energy, and the last of this band of men, Mr. W. Morris Dwight, died in extreme old age in Williamsburg only a few years ago.

Prof. Amos Eaton, Dr. George Gibbs, Prof. Chester Dewey, and Prof. J. T. Webster extended their studies over this region from without, so that already in $1825 \mathrm{Mr}$. A. O. Hubbard, writing from Yale in commendation of Mr. Hitchcock's "excellent description of the Connecticut Valley," says the region "is becoming, or rather has already become, the rallying point of all the mineralogists in Massachusetts."

There appeared in Silliman's Journal for 1827 an article on the lead mines and veins of Hampshire County by Mr. Alanson Nash. Prof. C. U. Shepard was then assisting in the publication of this journal, and he once describerl to me the difficulty he had in deciphering the crabbed script of the author and in bending his sentences to the common rules of grammar. Little knowledge of the distribution of the lead veins has been added, however, to what is contained in that article, and several of the veins described by him I have not been able to find, though I do not doubt their existence. He was the forerunner of a great body of natural prospectorsmen without learning, books, or assistance, who, from a strong love of the

\footnotetext{
${ }^{1}$ Index, 1820.

${ }^{2}$ Sketch of life, by J. B. Perry: Proc. Boston Soc. Nat. Hist., Vol. XII, 1. 214 ; also by Jules Marcon: Am. Geologist, Vol. VII, p. 1, with tine portrait.
} 
quest, roamed over the hills hunting for minerals, and became as acute and skillful in the search as their neighbors did in hunting and fishing. I do not know that Mr. Nash was a cobbler, but I suspect so, for I have found both here and in Europe that, perhaps from the intermittent character of their employment, men of this trade are exceptionally apt to develop the taste for collecting minerals.

Of the long list of these men who have forwarded mineralogy in an nnambitious way I will mention only Mr. B. Hosford, of Springfield, who, at the suggestion of Professor Shepard, first dissected one of the Lancaster chiastolites, which was figured in Dana's Mineralogy, and whose study of the salt crystals in Westfield I have reported in Bulletin No. 126 of the United States Geological Survey, and Mr. William Newell, of Pelham, long time cobbler in Amherst. Students long before and after my time in college will remember his love of minerals and his reticence concerning his "localities." There was a pint of fine amethysts in the collection at Amherst which he had gathered from the gravels of Amethyst Brook. If they had been solid gold they would have poorly paid him for the time spent in searching for them; being amethysts, however, they satisfied him much better.

The first mineral from Hampshire County to receive notice abroad was the albite of Chesterfield (cleavelandite), which, as kieselspath, was described by Hausmann in 1817. The first article on minerals from this area by Professor Shepard appeared in 1824, beginning a half century of work as profitable for the advance of mineralogy in this region as that of President Hitchcock was for the progress of geology.

The halting places in the history of the geology of the valley are the dates of the publication of the principal works of President Hitchcock, as follows :

1818. Remarks on Geology of a Section of Massachusetts. This was followed by a period of collecting minerals and recording their localities, and by the beginnings of geological work, especially by Prof. Amos Eaton.

1823. Sketch of Geology of the Region of the River Connecticut. This was succeeded by a continuation of the collecting and recording period.

1833. Report on Geology of Massachusetts.

1835. Report on Geology of Massachusetts, second edition. This was followed by the most interesting episode in the history of the geology of the Connecticut, the discovery and description of the very numerous and 
perfect Triassic tracks found up and down the valley, with which discovery the names of Dexter Marsh, ${ }^{1}$ Dr. James Deane, ${ }^{2}$ and Dr. Roswell Field ${ }^{3}$ were also comnected. Previous to the year $1884 \mathrm{I}$ was for a long time accustomed to arrange the successive senior classes of Amherst College on the lawn before the house of Dr. Field, in Gill, and the old man would come out and give the boys a lecture on the "true theory of bird tracks," claiming, and I think with justice, that he first discovered the quadrupedal character of the animals which made the tracks.

1841. Final Report upon the Geology of the State. This summarized the geology of the region to date, adding, however, very little to the report of 1835 , while the discussion of the "bird tracks" went on vigorously until, in 1844, the Report on Ichnology brought together all that was known on the subject, with abundant illustrations-indeed, vastly increased what was before known, though it did not close the subject, since articles descriptive and controversial continued to flow from the pens of all those mentioned above, as well as more elaborate works from the two sons of President Hitchcock, while the last scientific article published by the President himself (1863) was concerning New Facts and Conclusions Respecting the Fossil Footmarks in the Connecticut River Valley.

1860. Illustrations of Surface Geology. With this, one of the pioneer works in a field which has since become most popular, the great work of President Hitchcock on the geology of the Connecticut closed.

1863. Reminiscences of Amherst College. This book contains an aftermath of opinion on the geology near Amherst.

I may here mention, in conclusion, several persons who have advanced the science of mineralogy in the region, or at least have gathered valuable collections for the use of other. MIr. James T. Ames, proprietor of the well-known foundries at Chicopee, was led, perhaps from his comnection with the Chester emery bed, to gather a collection very valuable for the illustration of the local mineralogy; and Dr. H. T. Lucas, ${ }^{4}$ who had a large share in the discovery of the enery at Chester, has been identified with the exploitation of this and many other mining properties in Hampshire County for many years. Mr. M. A. Brown, formerly of Northfield, has done very useful work in exploring the mineralogy of eastern Franklin

${ }^{1}$ For sketch of his life see History of the Connecticnt Valley, Vol. II, p. 585.

${ }^{2}$ Ibia., p. 520.

'Ibid., p. 576.

${ }^{4}$ Ibid., Vol. I, p. 1064. 
Comty. Mr. Oliver M. Clapp, ${ }^{1}$ of Amherst, recently deceased, was an ardent collector during his long life. The finest collection for the illustration of the local mineralogy, excepting, of course, the great collection of Professor Shepard, was that made by Mr. Josiah D. Clark, for a long time a teacher in Brooklyn, but a native of Northampton, who watched carefully the progress of the work at the last opening of the Loudville mine, during the war, and secured very abundant and wholly unique suites of all the rare things found there, as well as valuable material from all other localities of western Massachusetts. He sold his collection at an exceptionally low price to Smith College, from a desire that it might remain entire and in Northampton.

The burning of the great Shepard mineral collection in Walker Hall of Amherst College in 1882 may stand as a next and sad epoch in the history of mineralogy in the Connecticut Valley, a loss in many ways irreparable, for the rich store of material for the illustration of the local mineralogy can never be wholly replaced. Fortunately Professor Shepard had published largely concerning this material, and I had taken quite full notes of almost all the collection, which have been incorporated in the following report.

In December, 1887, the collections made by Professor Shepard after the sale of his collection to Amherst College were presented in his name to the college by his son, Dr. C. U. Shepard, of Charleston, South Carolina, and this goes far toward restoring the monument to his memory, and very far toward filling out the local collections at Amherst, which should be, of course, unsurpassed for the region in the center of which the college is situated.

It is proper to call attention to the fact that the list of publications upon the geology and mineralogy of the State (Chapter XXIII), in which I have included those upon topography, is the true history of the progress of these studies here during the present century, and that in the preceding pages I have purposed only to emphasize some names that would otherwise be overlooked, and to indicate some salient points in the history which seemed to me to deserve mention. 


\section{H A P TER II.}

\section{TOPOGRAPHY.}

The great central platean of Worcester County, averaging about 1,000 feet above the sea, lowers a little toward the west, and is accented as it passes into the area under consideration by deep north-south longitudinal valleys, the streans here taking for long distances a north-south course, and it is cut deeply by two great transverse valleys-those of the Millers and Chicopee rivers-which gather all the drainage from the east. With this modification the platean is continued westward until its border forms the eastern edge of the Connecticut Valley.

- The rim of the valley on its west side is the border of a similar broken plateau of about the same height, deeply cut by longitudinal valleys whose waters also reach the Connecticut by two transverse valleys-those of the Deerfield and Westfield (or Agawam) rivers-which are farther south than the corresponding valleys on the east, each by about the same distance. The plateau rises along the western portion of the three counties into the Berkshire Hills. It will be noted that the Connecticut Valley includes about all of the broad, low area underlain by Triassic rocks.

These two plateaus were probably once parts of a continuous plain that extended across the Connecticut and other valleys far beyond the limits of the area studied. This plain was formed by erosive agencies which degraded the rocks nearly to sea level. It seems to have been well established by Professor Davis that this degradation took place during the Cretaceous period, and that a later Tertiary elevation enabled the streams to cut down their valleys and clean out the wide lowlands in the soft rocks that border the Comnecticut and the eastern branches of the Swift River in Enfield. The peaks and ridges of more resistant rock that rise in these lowlands still reach almost to the level of the old plains, and are remnants of it. 
Of the longitudinal valleys the most peculiar is the basin in Greenwich and linfield, in the eastern portion of the region, in which the branches of the Swift River join and move sonthward. It is a broad, low, sand plain, studded with isolated, high, rocky islands and stretching from north to south through these towns. The streams enter and leave it by narrow channels, while the plain continues south through Ware, and was once, I suspect, continuous with the deep, straight valley which extends through the middle of Monson and on into the valley of the Willimantic; and it was in its middle part (in Palmer) clogged up with till during the Glacial period, so that the Swift River, which on this supposition formerly ran southward across Palmer and Monson into the Housatonic, has in postGlacial time found its way westward, breaking through the side of the basin to join the Connecticut. If this be so it explains at once why the basin is so disproportionate to the size of the present river, and why it is on all sides walled in by high ground, except the narrow gorge by which the Swift River escapes from it. It also explains the very straight Monson Valley, in the middle of which, just at the State line, the waters run south to the Willimantic and north to the Quabaug at Palmer.

The Connecticut Valley stretches across the center of the area from north to sonth, with a width of about $1 \frac{1}{12}$ miles at the north, which increases to $8 \frac{1}{2}$ miles opposite Greenfield, $10_{4}^{3}$ miles opposite Amherst, and averages 15 miles in the southern portion of the State. It is divided lengthwise into two portions of about equal width by the remnants of the red sandstone and the long trap ridges of Deerfield Mountain and the Holyoke range; and, except the short canyons of the tro western tributaries, the only breaks in this dividing wall are at its north end in Bernardston and in the long distance opposite Amherst, between Sugar Loaf and Mount Holyoke. Post-Glacial deposits occupy the full width of the Connecticut Valley in great complexity and beauty.

From the northern line of the State the eastern border of the valley, sloping rapidly to the bottom, runs nearly due south across the State, notched sharply by the gorges of the Millers and Chicopee rivers, and rarely opening out into a rounded high-lying valley, as in Pelham, opposite Amherst, or breaking down into an elevated plateau, as in Belchertown.

On the west the high ground crosses the State line but a little way back from the river, and for a few miles the valley preserves the same narrow limits 
and simple character which mark its more northern course. The crystalline rocks are then set back 7 miles to the west, along the northern border of Greenfield, and the rocky boundary thence goes sonth, with sharp eastward slope, notched only by the Deerfield gorge, to be again set back by about the same amount along the north of Northampton. It then runs south again, interrupted only by the Westfield River, to and beyond the south line of the State.

On both sides the brooks and the roads (which usually follow the brooks) come down sharply from the uplands, and railroads can enter and leave the valley only by the four tributaries mentioned above.

Just south of where the westem boundary first turns westward, in Greenfield, a great block of red sandstone hills, occupying the whole town of Gill, separates the valley into two parts, the river occupying the eastern portion and the narrow, high Bernardston Pass connecting it with the north end of the western portion. From the southwest corner of this mass the Deerfield trap sheet runs southward, forming Deerfield Mountain, its vertical western scarp making the eastem boundary of the western lateral valley, which preserves its width southwardly through Deerfield, while east of it the valley of the Connecticut proper expands into the Montagne basin, the ridge being much narrower than the block of hills in Gill, which makes the northern border of this basin. On the south the great mass of Mount Toby shuts in this Montague basin, the river passing in a narrow valley between it and the south end of the Deerfield range, which ends abruptly with Sugar Loaf, into the much broader Hadley basin, while a deep, narrow valley around the east side of Mount Toby also connects the two. By the breaking down of the Deerfield range the Deerfield Valley opens widely into the broad Hadley basin, which here has the full width of the Comnecticut Valley, 14 miles, between the crystalline borders on the east and west, though Mount Warner, a mass of crystalline rocks, stands midway to partly continue the barnier.

Sonth of Amherst the Holyoke range rises abruptly athwart the valley, leaving a narrow passage on the east into the Springfield basin, like that around the east end of Mount Toby, while it is broken through for the escape of the river just as the latter comes through a narrow passage between Mount Toby and Sugar Loaf on its entrance to the basin.

The Holyoke range extends south along the western border of the 
Springtield basin, while its steep western slope is the eastern boundary of a lateral valley, similar in size and position to the Deerfield Valley, of which, indeed, it may be looked upon as the continuation, and this valley extends across Southampton and Southwick and, as the Farmington Valley, is contimuous to the Sound.

The Springfield basin is also continued beyond the limits of the State, and, though contracted at the Enfield Falls, is not terminated until it reaches the narrows at Middletown, Connecticut.

On the east the longitudinal valleys, especially the Enfield Valley, are largely due to the folding of bands of newer and harder schists down into the gneiss and the subsequent deeper erosion of the latter. On the west, where the whole area is occupied by closely folded schists, one can only rarely see any connection between the valleys and the durability of the bottom rocks.

The topography of the northwest portion of Franklin County is, however, very plainly influenced by its stratigraphy. The Deerfield River, on entering the State, runs southward with the strike of the Hoosac schist. It then bends and cuts across this strike at right angles, and then turns southwest again with the strike, and repeats this zigzag several times, and at last, reaching the great fault at the portal, it turns sharply east across the sericite-schists. All the orographic lines in Rowe-the mountain ridges and the intervening valleys-are for the same reason directed southwest, parallel to the abnormal strike of the rocks thereabout. The deep depression in which Shelburne Falls lies is plainly the result of the great quaquaversal by which the gneiss is here exposed, and is the expression of its lesser durability.

Across the western half of Hampshire and Hampden counties the drainage is southeast, and is only in a minor degree controlled by the northsouth structure of the rocks. The east branch of the Westfield River flows from Cummington south to its mouth with the strike, curving around the Goshen anticline, and its gorge above West Chesterfield Hollow and the gorge of the Westfield Little River are the wildest in the State. 


\section{OH A P TER III.}

\section{GEOLOGICAL OUTLINE AND GENERAL COMPARATIVE SECTIONS.}

A long series of Archean outcrops runs from north to south across the western portion of the high ground between the Housatonic and the Connecticut valleys, and barely enters the western border of the area here described. This high ground is the continuation of the Green Mountain range across Massachusetts. Cambrian conglomerate-gneisses (Becket gneiss) wrap around these patches of Archean, graduate westward into the Stockbridge limestone, and dip eastward beneath the great sericite-schist series, which may be placed parallel to the Berkshire and Greylock schists on the west. These highly metamorphosed and much foliated sericiteschists stand vertical in appressed folds for a long distance eastward and then go beneath the extensive graphitic schist series, coming up farther east in anticlines from beneatl the latter. A remarkable band of amplibolites, with enstatite-bearing limestones and enstatite, pyroxene, and olivine rocks, all largely changed to serpentine, and with emery, runs down the middle of the sericite-schists. It seems to me possibly the equivalent of the Bellowspipe limestone of Greylock; and the Bolton limestone, farther east, is upon about the same horizon. The upper series of graphitic schists (the Goshen and the Conway schists) is less metamorphosed, and shows much of the original lamination, though masked by cleavage and foliation. It contains many beds of limestone in every stage of change to amphibolite. It is a graphitic muscovite-schist, abounding in garnet, staurolite, and transverse spangles of biotite. It graduates into the corrugated and cleaved Leyden argillite (phyllite) along the eastern border of the elevated 
area defined above, and upon it rests, at the lower level of the Comnecticut Valley, the complex Bernardston series-conglomerates, quartzites, limestone, mici- and homblende-schists, and gneiss-which is proved by the presence of many fossils to belong in the Upper Devonian.

A complex series of faults, with much westward overthrusting, bounds the elevated area on the west. A series of echeloned faults also drops the bottom rocks of the Connecticut Valley on the east and makes the elevated area a "horst" and the valley bottoms "gräben," in the nomenclature of Suess. ${ }^{1}$.

A great stock of tonalite, or quartz-diorite, occupies the eastern border of the area and encroaches on the Comnecticut Valley. This has come up through the thick Whately amphibolite bed. It graduates westwardly into the granitite, or biotite-granite. This has emerged in the region of the broad Whately limestone bed. This is followed outwardly by a great group of dikes, of every size, of granite or muscovite-biotite-granite. This is in the region of the muscovite-schists without limestone. Each of these rocks seems thus to be distinctly influenced in its chemical constitution by the rocks it has penetrated and dissolved. On the periphery are great quartz veins, and the remarkable tourmaline- and cleavelandite-bearing dikes, with minerals containing rare elements.

Farther west all the sericite-schists and Cambrian gueisses are free from later igneous rocks except the great isolated granitite dike in Middlefield.

The valley of the Connecticut may in a general way be called a broad syncline, so far as the crystalline rocks are concerned. It is rather a broad area of greater crushing and disturbance, which has favored greater erosion, and over its bottom the crystalline rocks lie often horizontal or in small anticlines and synclines, while on its borders they dip toward the center, often with high angles. In attempting to trace the history of the valley, it will perhaps always be impossible to assign their proper weight to the erosive agencies mentioned above in comparison with another agency which has been of prime importance in the formation of the valley. I mean that which has produced the great fanlts and the sinking of the areas between the faults. The principal southwest- 
by-south fault, which appears so plainly on the map, forming the eastern boundary of the valley across Northfield and Montague, is probably prolonged in the Holyoke range fissure from Mount Tom southward. From a point north of Mount Toby a fault branches from the main one and is continued down the east side of the valley, a series of great fanlts running south by east at the eastern border of the valley; and much the same seems true of the western side, and especially the two settingsback of the valley border seem due to the two east-west faults. How far the valley bottom has been depressed between these faults I can not determine, but the great thickness of the red sandstone, as shown by artesian wells, would indicate that the sinking must have been considerable after, and perhaps during and before, the deposition of the Trias.

The region is thus a great "graben"-a band of country sunk between parallel faults; and the great Greenwich-Enfield basin has, at least in part, the same character, though here erosion has been the more important agent, and in its northward extension into New Salem and Orange the sole agent.

In both pre-Triassic and Triassic time the Connecticut Valley has been a region of extensive faulting and the pre-Triassic faulting extends considerably east of the present bottom of the basin, especially in the Northfield region.

All the rocks of the area west of the Comnecticut reappear in the eastern region. The Bernardston rocks are present only in a few outcrops in Northfield and farther south, while the Leyden argillite appears in the south bank of the Connecticut just below the mouth of Millers River, and seems to run down the valley beneath the Trias and to appear west of the pond in the center of Leverett. It is also represented lithologically in the center of the middle syncline in Monson.

The salient features of the eastern area are-

(1) The eruptive rocks, consisting of $(a)$ the great block of diallagegranite, or tonalite, and quartz-gabbro in Belchertown and the surrounding towns, around which the crystalline rocks are thrown into great confusion; (b) the block of diorite in New Salem and Prescott, which seems to have produced very little confusion in the surrounding rocks; $(c)$ The Coy's Hill porphyritic granitite; $(d)$ the large granite areas in Leverett and Amherst. 
(*) The Monsm gneiss.-The great platean of Cambrian gneiss which, starting in Northfield, runs through Wendell, Shutesbury, and Pelhimn, and ends against the Belchertown tonalite, furnishes the key to the structure of the region. It is another "lorst"-a great area of ancient crystalline rocks bounded by faults outside which the ground has everywhere sunk away. It is, moreover, a region of very gentle dips, unlike the western lill country. The rocks, horizontal in the center, dip slightly toward the borders on the east and west. It is bounded by north-south faults on either side, which extend wholly or nearly across the State. These faults are lines or bands of extreme crushing, and outside them the rocks have been compressed in sharp folds, as if they had been thrust against the unyielding shoulders of the great "horst." The normal Monson gneiss is, however, the ordinary biotite-gneiss. One of the faults mentioned rtins at the foot of the high grounds along the east border of the broad Connecticut Valley, from Northfield south, through the notches at the east foot of Mount Toby and at the east end of the Holyoke range, and so on through Granby and Wilbraham. As noticed above, this fault forms also the eastern boundary of the Connecticut Valley "graben." The other fault runs in a corresponding position, along the east border of the valley of the west branch of the Swift River, through Wendell, New Salem, Prescott, and Enfield. The fanlts are marked by great crushing of the rocks, by the development of curious. "fault rocks"-bastard granites and green and buff hornstones-and by the cementation of the crushed rocks by comby vein quartz and specular iron. Within the "horst" the Monson gneiss contains a thick bed of a fine-grained actinolite-quartzite or at times fine biotite-quartzite or biotite-gneiss.

(3) The schists.-Outside these faults the upper schists are present in the same series as west of the river, viz: (a) A feldspathic mica-schist or twomica-gueiss, at times a quartzite or quartz-conglomerate, is the equivalent of the feldspathic mica-schist or Hoosac schists and the lower sericite-schist or Rowe schists of the west side. This is named after the more persistent and important bed of the western area, the Rowe schist. (b) A hornblendeschist=the Chester amplibolite. (c) A micaceous quartzite, very generally 
containing a hydrated mica or a green chloritic mineral, which is at times certainly derived from garnet; or the series is developed as a whetstoneschist-that is, as a thin-bedded, finely biotitic, arenaceous quartzite. It is the upper sericite-schist, or Savoy schist. (d) A mica-schist, in great thickness at times, exactly like the finely corrugated biotite-spangled garnetschist of Conway and Goshen, as in Northfield Mountain, on the ShutesburyNew Salem line, and in Monson. Usually it is a coarse, barren, muscovitebiotite-schist, like most of the Conway schist, but always without limestone, which seems to be replaced by homblende-schists. It is the equivalent of the Goshen schist and the Conway schist. It is named after the more important member and the one it most resembles-the Conway schist.

Instead of appearing in broad areas, succeeding each other from west to east-i. e., from below up, as they do in the western hills-the schists appear here in sharply compressed synclines which run across the State, disjointed by faults and thrown into confusion by the presence of eruptive rocks. Four such great synclines can be traced across the State, within the limits of the three river counties, though their identity is disguised by the fact that metamorphic changes superinduced upon original variations in composition have varied greatly both in kind and degree. One may especially adduce the fibrolitization which has progressively affected the mica-schist from west to east and from north to south.

For the reasons given above it will be more convenient to follow a geographical rather than a geological order in the discussion of the eastern schists and to take up the different synclines in succession.

GENERAC COMPARATIVE SECTION OF ROCKS IN MASSACHUSETTS.

In the first columu of the accompanying general section I have placed the section for northwestern Massachusetts, as determined by the labors of Professors Pumpelly, Dale, and Wolff, ${ }^{1}$ though they must not be held responsible for the exact parallelism here attempted. The distinction between the Becket conglomerate-gneiss below and the Cheshire quartzite can not here be always maintained, and the quartzite graduates both laterally and vertically into the limestone.

The area east of the Connecticut and extending slightly into Worcester

1 Geology of the Green Mountains in Massachusetts: Mon. U. S. Geol. Survey, Vol. XXIII, 1894. 
Comnty forms a strong contrast to that west of the river, and is an area of trinsition to the much simpler structure of Worcester Comnty. Metanorplism and the part taken by post-Carboniferous eruptives increase regularly eastward. Such rocks are wanting in the first column and in the westem half of the comntry covered by the second. In the eastern half of the latter the granites begin and rapidly become important; in the second other rocks are associated, and in the area of the last column they cover more than half the surface. In a column devoted to the Massachusetts coast region eluptive rocks would be still more predominant.

General section showing correlation of rocks in Massachusetts.

[The names given in the eecond and third columns are those used in this monograph, Those in the fourth column will be ueed in a forthcoming memoir on the geology of Worcester County.]

\begin{tabular}{|c|c|c|c|c|}
\hline & $\begin{array}{l}\text { Taconic Range and } \\
\text { Housatonic Valley. }\end{array}$ & $\begin{array}{l}\text { Berkshire Hills and } \\
\text { Connecticut Valley. }\end{array}$ & $\begin{array}{c}\text { East of Connecticut } \\
\text { River. }\end{array}$ & Worcester County. \\
\hline 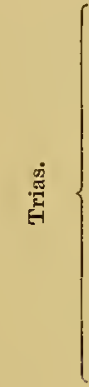 & & $\begin{array}{l}\text { Black Rock diabase } \\
\text { (intrusire). } \\
\text { Chicopee shale. } \\
\text { Longmeadow sand. } \\
\text { stone. } \\
\text { Granby tuff. } \\
\text { Monnt Holyoke dia. } \\
\text { baee (iuterbedded). } \\
\text { Sugar Loaf arkose. } \\
\text { Mount Toby conglom. } \\
\text { erate. } \\
\text { Unconformity. }\end{array}$ & $\begin{array}{l}\text { The whole Triaesic } \\
\text { series is repeated } \\
\text { east of the river. }\end{array}$ & \\
\hline 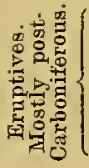 & & $\begin{array}{c}\text { Granite. Granitite. } \\
\text { Pegmatite. Albitic } \\
\text { granite. Tonalite. }\end{array}$ & $\begin{array}{l}\text { Granite. Granitite. } \\
\text { Pegmatite. Albitic } \\
\text { granite. Tonalite. } \\
\text { Diorite. Diabase. } \\
\text { Cortlandite. }\end{array}$ & $\begin{array}{l}\text { Grauite. Granitite. } \\
\text { Pegmatite. Albitic } \\
\text { granite. Tonalite. } \\
\text { Diabase. Olivine- } \\
\text { gabbro. Wehrlite. }\end{array}$ \\
\hline 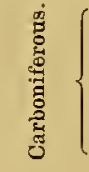 & & & & $\begin{array}{l}\text { Worcester argillite } \\
\text { (phyllite). } \\
\text { Harvard conglomer- } \\
\text { ate. } \\
\text { Worcester quartzite. }\end{array}$ \\
\hline 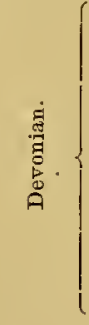 & & $\begin{array}{l}\text { Beruardston mica- } \\
\text { schist. } \\
\text { Bernardston amphib- } \\
\text { olite. } \\
\text { Bernardston quartz. } \\
\text { ite. } \\
\text { Bernardston lime- } \\
\text { stone. } \\
\text { Vernon gneiss. } \\
\text { Unconformity. }\end{array}$ & $\begin{array}{l}\text { Bernardston mica. } \\
\text { schist. } \\
\text { Bernardston quartz. } \\
\text { ite. }\end{array}$ & - \\
\hline
\end{tabular}


General section showing correlation of rocks in Massachusetts-Continued.

\begin{tabular}{|c|c|c|c|c|}
\hline & $\begin{array}{l}\text { Taconic Range and } \\
\text { Housatonic Valley. }\end{array}$ & $\begin{array}{l}\text { Berkshire Hills and } \\
\text { Conuecticut Valley. }\end{array}$ & $\begin{array}{c}\text { East of Connecticut } \\
\text { River. }\end{array}$ & Worcester County. \\
\hline 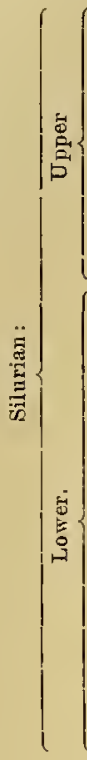 & $\begin{array}{l}\text { Greylock echist. } \\
\text { Bellowspipe li me - } \\
\text { stone. } \\
\text { Berkshure schist. } \\
\text { Stockbridge } 1 \mathrm{ime} \text { - } \\
\text { stone. }\end{array}$ & 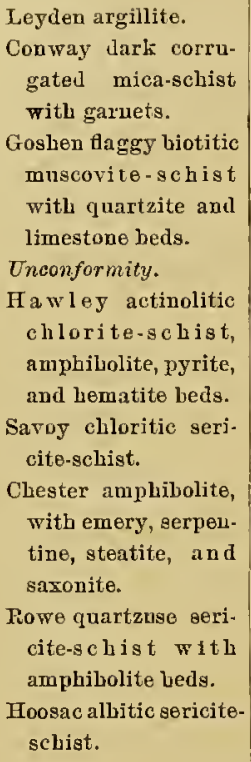 & $\begin{array}{l}\text { Savoy schist. } \\
\text { Chester amphibolite. } \\
\text { Rowe flaggy ochist. }\end{array}$ & $\begin{array}{l}\text { Paxton whetotone- } \\
\text { schist. } \\
\text { (Changes east of the } \\
\text { Carboniferous into } \\
\text { Bolton gneiss, in- } \\
\text { cluding Boltonlime- } \\
\text { atone.) }\end{array}$ \\
\hline 总 & $\begin{array}{l}\text { Stockhridge lime- } \\
\text { stone, lower part. } \\
\text { Vermont formation } \\
\text { (quartzite and } \\
\text { gneiss). }\end{array}$ & $\begin{array}{l}\text { Cheshire white gran- } \\
\text { ular quartzite. } \\
\text { Becket white con- } \\
\text { glomerate-gueiss. } \\
\text { Uncunformity. }\end{array}$ & $\begin{array}{l}\text { Pelhan quartzite. } \\
\text { Monson conglomerate- } \\
\text { gneiss. }\end{array}$ & $\begin{array}{l}\text { Grafton quartzite and } \\
\text { conglomerate. } \\
\text { Sutton gueiss. }\end{array}$ \\
\hline हू. & $\begin{array}{l}\text { Stamford gneiss (por- } \\
\text { phyritic gneis s } \\
\text { with blue quartz). }\end{array}$ & $\begin{array}{l}\text { Wasliugton blue } \\
\text { quartz-gnsiss. } \\
\text { Tyringham stretched } \\
\text { biotite-gneiss. } \\
\text { EastLeoblack biotite- } \\
\text { bornblende-gneiss. } \\
\text { Hinsdale coarse chon- } \\
\text { drodite-limestone. } \\
\text { Hinsdale granitoid } \\
\text { gneiss. }\end{array}$ & & Northbrjdge gneiss. \\
\hline
\end{tabular}




\section{H A P T E R I V.}

\section{THE ALGONKIAN. ${ }^{1}$}

GEOLOGICAL DESCRIPTION.

THE HINSDALE AREA.?

Before my work had extended to the western border of the region covered by this study, my attention was called, in the winter of 1882 , by Prof. J. D. Dana, to two interesting ontcrops of undoubted Archean rocks in Hinsdale, a gneiss and a limestone containing chondrodite and a peculiar peach-blossom-colored mica, determined by him to be probably rhodochrome. Althongh these localities lie beyond the western border of the river counties, the same rock extends into the southwest corner of Middlefield, and Professor Dana's discovery was very acceptable to me as furnishing a possible base to work from in the complex region under examination.

The two localities in question are at the first cutting west of the railroad station in Hinsdale and at the first cutting south of the railroad station in Washington, and as they give a much fuller exhibition of the series than the limited portion of the same which enters Middlefield, they are made in the main the basis of the description following.

The greater portion of the town of Hinsdale is occupied by an oval anticline, elongated north and south and overthrown to the west. This extends, much contracted, across Washington, and bending southeastward and narrowing still more it enters Middlefield and runs along the sonth line of the town to a point a mile beyond Becket station. The newer gneisses, all down the east side of the anticline, dip normally eastward away from the older, but here-that is, where the narrow band of Algonkian extends east along the Westfield River-a sharp east-west wrinkle forms in the newer gneiss, and the older gneiss buckles up through the newer.

${ }^{1}$ Azoic (Ljell), Eozoic (Dawson), Archæan, Dana.

${ }^{2}$ This will be described in detail in a monograph on the Archean of Berkshire County. 
Counting from below upward, the Algonkian rocks may be divided into four groups:

1. Hinsdale gneiss.-This is a group of gray biotite-gneisses, generally quite coarse and with the jet-black biotite in distinct, elongate patches, granitoid and yet well foliated. The broad, fresh cleavage surfaces of the feldspar are often strongly curved from pressure. These gneisses weather with exceptional rapidity and seem to be calcareous.

2. Hinsdale limestone.-The coarsely crystalline chondrodite-limestones form a concentric band around the older gneisses, marked by a series of abandoned limekilns, for the rock was economically important before the opening of the "Western Railroad."

3. Lee gneiss.-This is a heavy black hornblende- or hornblende-biotitegneiss.

4. Washington gneiss.-A broad band of rusty graphitic blue-quartz gneiss forms the outer circle of this Algonkian nucleus. It is in the main a biotite-gneiss, but with little mica, and rusty from the decomposition of hornblende, pyrite, pyrrhotite, and a ferruginous dolomite. In the whole circuit graphite is a never-failing accessory, especially in the npper portion. The graphite mine at Washington, except for the size of some of the constituents, suggests the Ticonderoga graphite mines. Very coarse calcite, graphite in broad, thin, hexagonal plates, coarse white sahlite, large green pyroxene and hornblende masses, groups of finely terminated pistachiogreen pyroxenes, brown sphene, and garnets, followed paragenetically by coarse calcite with phlogopite, and this by quartz, are some of the points of resemblance.

Another equally persistent and characteristic constituent of these gneisses is a blue quartz in flat laminæ 1 to $3^{\mathrm{mm}}$. in thickness, which has often so deep a tint of rich purplish blue as to furnish beantiful cabinet specimens, and is so abundant as to form more than three-fourths of the mass of the rock.

Everywhere in the outer circuit of the Algonkian rocks a band having the above peculiarities lies below the lowest beds of the Cambrian conglomerate-gneiss, viz, blue quartz formed in place, disseminated graphite, beds of the heavy black hornblende-gneiss, and a general abundance of hornblende and a very general rustiness, all associated with intervening bands of a common biotite-gneiss. 
From the Walshington station the older gneiss narrows and nccupies the silles and bottom of the narrow canyon, which continues toward becket station. The canyon, caused by the projection of this narrow lobe of the ohler rocks, is one of the most curions and interesting topographic features of the region. The lesser capacity of resistance to erosion of the older gneisses and limestones has caused the broad depression in which Hinsdale lies, and the southward projection of the same rocks has determined the long, narrow canyon in which the waters of the Westfield River, gathering in Washington, flow southward, thus providing the only chance for railway communication between the Comnecticut and Housatonic valleys. At Becket station, south of the river, everything is newer gneiss. Just north, in the village, appear the hornblende beds of the upper Algonkian band, and following the road north to the pasture overlooking the village, one finds abundant outcrops of the blue-quartz gneiss and the contact on the conglomerate-gueiss striking southeast and dipping northeast-that is, in the normal relation to each other. This allows them-the older gneissesto appear in a band on the north side of the brook, which band seems to contract and come to its apex just at the point where the railroad enters Middlefield, so that thence southeastward it appears to be wholly wanting at the surface, or is perhaps only concealed in the bed of the river. It however makes its presence below manifest by a continuation eastward along the river of the overturned anticline without the core of exposed Algonkian, until, at the junction of Coles Brook with the river, the Algonkian chondrodite-limestone, accompanied by heavy dark gneiss, buckles irregularly up through the conglomerate-gneisses.

THE COLES BROOK ANTICLINE.

Just a mile northwest of Bancroft station, Middlefield, the Boston and Albany Railroad cuts off a loop of the Westfield River, and Coles Brook enters this loop. The railroad runs in a deep cut a long distance before reaching this loop, and the cut continues through the loop and most of the way to the station. At bridge 143 the Cambrian white or conglomerate gneiss in synclinal posture mounts up on the older gneiss, which I have called the East Lee or black gneiss from its large development just above the limestone in the Lee-Tyringham region. It is especially contorted and cut by pegmatite at the junction, and consists of a great thickness of a 
wavy-bedded gneiss of fine grain and almost black from the abundance of the black biotite. (See fig. 1.) Contorted white veins one-fourth inch to 2

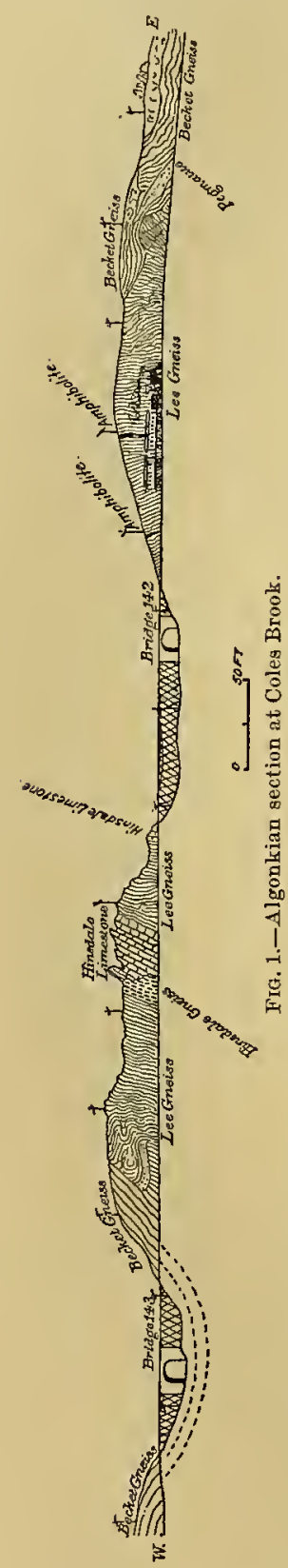
inches wide run through the rock, high up in the cutting, with most tortnous course, and on the south side I could recognize the spot whence came a great block which has long lain in front of the geological museum at Amherst and whose origin I had been unable to learn. These "veins" are formed by the expulsion of the biotite from their area, the white quartz-feldspar mass being continnous within and without their limits.

The black gneiss abuts, apparently by a fault, certainly by a wholly abrupt transition, upon a band of the coarse white, almost micaless, Hinsdale gneiss, 23 feet wide below, but narrowing above. This is followed by a bed of white, thin-bedded, highly crystalline chondrodite-limestone, with thin films of serpentine, forming a beautiful verd antique, which is separated by 108 feet of the same black Lee gneiss from a second band of a similar limestone, of which only 29.5 feet are exposed. This is followed in the brook bed at bridge 142, and on through the cutting, by a large mass of the dark gneiss, carrying beds of hornblende-schist, until we come, at the fourth telegraph pole from bridge 142, upon the fine unconformity where the conglomerate-gneisses mount upon the dark Lee gneiss.

Between this point and the Bancroft station the cuttings expose a long extent of contorted and twisted rocks, where the beds swing round from horizontal to vertical within a few feet. Gradually a low dip eastward predominates, and this becomes steeper, and a band of hormblendegneiss 10 feet wide sets in, and at the eighth telegraph pole from the station, just at the signal honse, a boss of coarse actinolitic rock derived from the older limestone protrudes. All east of the unconformity is Becket gneiss, except the few hornblende-gneiss masses and the lastmentioned boss of actinolitic rock, which are bronght just above the railroad level by the undulations of the Becket gneiss. 
The Coles Bronk anticline extends north into Middlefield more thim a mile and a half, following the brook bed for a lnundred rods. It is well exposed just south of Factory village, by the roadside, for a long distance south of the schoolhouse. Large bosses of the coarse linestone appear here, flanked on the west by the Lee lormblendic gneiss.

A still more instructive section is exposed halfway between the two localities mentioned above, where the road going west from Factory Brook up onto the high ground crosses the limestone near the site of H. Hawes's lonse (now destroyed). In the bare hill opposite this site the limestone and the green actinolitic rock derived from its alteration are abundantly

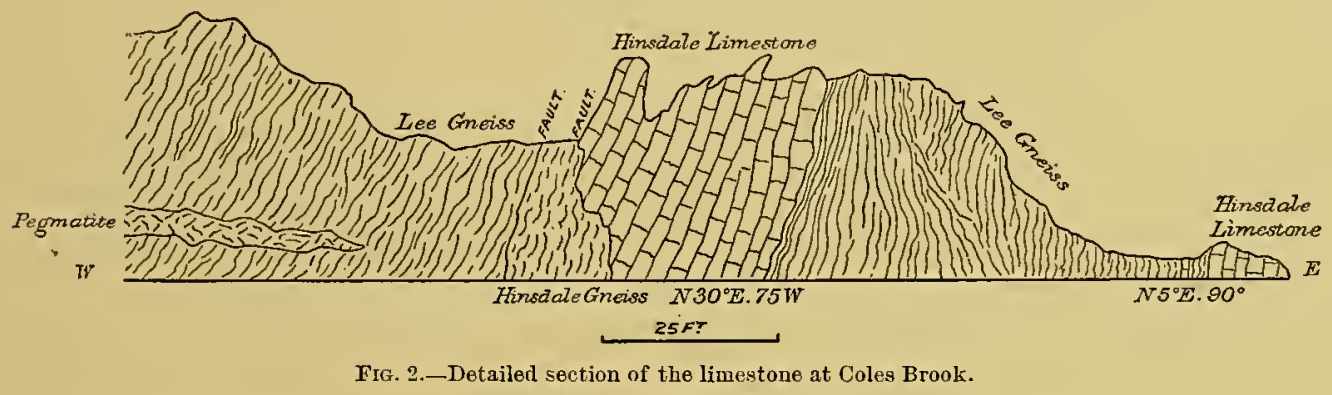

exposed in vertical strata, and the white Becket gneiss can be seen mantling over it in clear unconformity, starting with steep west dip on the west side of the hill, becoming horizontal on the top, and dipping easterly down the east side. The true bedding is in places replaced by a secondary vertical structure. A coarse, rusty muscovite-biotite-gneiss, with graphite and tourmaline in quite large prisms (the equivalent of the Washington gneiss farther west), accompanies the limestone on either side, extending east to the bend in the road and west to the house at the top of the hill. Just east of this is a bed of typical Becket gneiss. In the yard of the ruined house the mantle of the Becket gneiss is so nearly continuous that a boss of white limestone a foot wide projects from the ground, and only a few feet on either side the Becket gneiss dips away from it.

Interest attaches to the fact that the Becket gneiss is so strongly metamorphosed as to form a quarry stone of first quality only in a narrow band along either side of the limestone belt, as if the violent upthrust of the preCambrian rocks along this narrow axis had exerted an influence upon the Cambrian gneisses for some distance outward, producing in them a narked 
granitoid structure, which disappears insensibly as the beds recede from this center.

THE TOLLAND AREA.

A large ontcrop of Algonkian limestone occurs on the roadside in Riverton, Comnecticut, near the southwest corner of the Granville quadrangle, ${ }^{1}$ associated with a coarse fibrolitic two-mica-gneiss, which is characteristically Algonkian in the Sandisfield quadrangle, next west of this, where it is a variant of the blue-quartz gneiss. This fibrolite-gneiss enter's the Granville quadrangle at its southwest corner and runs north by east, in a tapering syncline, to a point north of Black Pond in Tolland.

The rocks often resemble coarse mica-schists, and are scarcely distinguishable from the coarse schists and schistose gneisses on the horizon of the Hoosac and Rowe schists, which lie next east of the Becket gneiss, except that they contain fibrolite and lie beneath the Cambrian gneisses, and in the next quadrangle west can be traced into undoubted connection with the blue-quartz gneisses and the chondroditic limestones.

East of the middle of the town of Tolland, at O. E. Slocum's, ${ }^{2}$ is a great quantity of large bowlders of a peculiar coarse hormblendic gneiss, often brecciated, with black hornblende, colorless quartz, and orthoclase. Some masses are medium-grained, some coarse, with holmblendes 4 to 5 inches long and 1 inch square at base. This rock is mentioned by President Hitchcock, but I could not find it in place. It probably was derived from the Algonkian anticline to the west.

\section{PETROGRAPHICAL DESCRIPTION.}

\section{LOWER OR HINSDALE GNEISS, HINSDALE STATION.}

The coarse gueiss just above ${ }^{3}$ the limestone is granitoid in texture, and contains in abundance a fresh black biotite in large scales, which in its upper layer's are aggregated into concretionary masses, flattened-ont lenticnlar nodules made up wholly of fine scales of biotite and epidote. These

1 The four-cornered division of the earth's surface represented on one of the sheets of the Topographic Atlas of the United States is called a quadrangle.

${ }_{2}$ The manuscript of this work was mostly completed before the atlas sheets of the United States Geological Survey were issued, and the citation of names refer to those upon the county atlases of F. W. Beers.

- ${ }^{3}$ Stratigraphically below, as the rocks are overturned. 
nodnles are placed in lamination plines abont $30^{\mathrm{mm} .}$ apart, the interspace, except for rare thin films of the same, being made up of a dead-white mixture of much feldspar and little quartz, mostly fine grained, but with here and there large curved cleavage faces of orthoclase exposer. It contains pyrite in small pentagonal dodecalıedrons and submicroseopic zircons of dark clove-brown color. Under the microscope the rock is much dusted with minute inclusions which give it an opaque white appearance. The quartz contains a few short, straight, black microlites, unlike the long rutile needles of the granites. The trains of cavities are very abundant, and often run through several grains of quartz, suggesting crushing. The orthoclase shows all stages of decomposition into epidote. At the beginuing the epidote gathers in small crystals in the two cleavage planes. The microcline is filled with the same short, black microlites as the quartz, and shows most beautiful microcline structure. The only place where a rock of this type appears in the old Hampshire County area is in the coarse mass which adjoins the Coles Brook limestone on the west. It contains, as does the pre-Cambrian gneiss of the Tyringham Valley farther south, a white orthoclase in large cleavage plates, which exhibits a rich blue opalescence.

\section{THE HINSDALE LIMESTONE, HINSDALE.}

Fifty rods west of Hinsdale station the limestone occur's with an exposed thickness of 25 feet (the top not seen) and dips $30^{\circ}$ E. Eight hundred and thirty feet farther west, at a stone mill, a gray epidotic gneiss occurs, with strike $30^{\circ} \mathrm{S}$. and dip $65^{\circ} \mathrm{E}$.

The limestone is a white to pink, rather coarse (grains $3-5^{\mathrm{mm}}$ ), highly crystalline rock, with a certain translucency in the grains which distinguishes it immediately from all the other limestones of western Massachusetts and allies it to the limestones of the Adirondacks. It carries coccolite, phlogopite, biotite, actinolite, chondrodite, pyrite, and magnetite. Generally the coccolite or the chondrodite, or both, are so abundantly and evenly scattered through the mass that it deserves the name coccolitic limestone or chondroditic limestone, and the accessory minerals are so arranged as to give the mass a distinct foliation, especially when the chondrodite and biotite predominate. 
An analysis performed in the laboratory of Amherst College by $\mathrm{Mr}$. F. H. Fitts gave the following results:

Analysis of Hinsdale limestone.

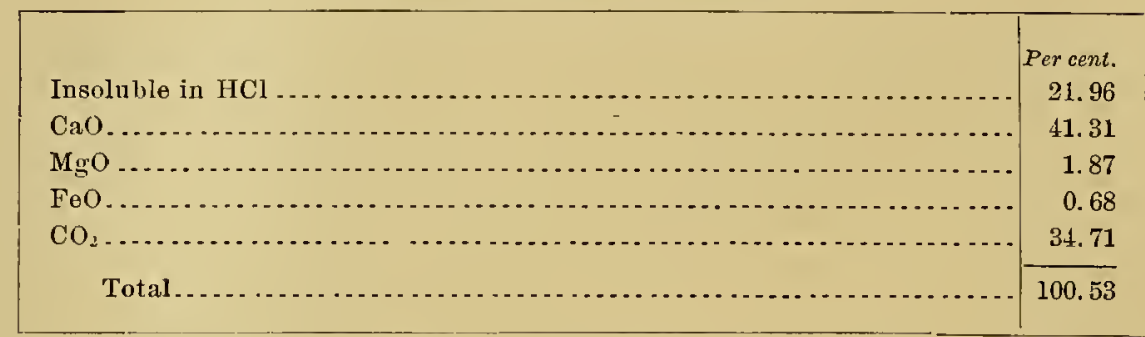

The chondrodite is disseminated through the rock in yellow patches elongate and parallel to one another, and as it in places changes into black patches by the admixture with it of a green mica and magnetite the resemblance to the boltonite from Bolton, Massachusetts, is striking, especially in specimens of the latter which are changing to serpentine. In large masses it is a rich deep-red, like the chondrodite from the Tilly Foster mine. Under the microscope the patches of the mineral are seen to be made up.of crysalline grains fresh and free from inclusions, and enwrapped by scales of at pale-green micaceons mineral, withont any indication that the one mineral has been derived from the other. The mineral shows strong dichroism, honey-yellow to deep red-brown. Toward the surface of the ledge the chondrodite weathers to a honey-yellow opaque mass.

The phlogopite is in small, thick crystals with rounded borders, having exactly the same bronzy color as the phlogopite from Templeton, Canada. Its crystals are generally surrounded by a band of scales of greenish-gray biotite. Both minerals are fresh, and there is no indication of a transition of one to the other. The mineral is optically negative and has the same axial angle as the Templeton phlogopite.

The biotite is disseminated in black scales through some parts of the rocks; at times as isolated crystals with rounded contours; at times bordering the phlogopite in greenish-gray, matted scales, or the chondrodite in thinner, deeper-green scales. All these occurrences are nearly uniaxial and negative.

The pyroxene occurs in dark-green grains of coccolite scattered through the limestone and in small, stout, limpid emerald-green prisms in the pink variety of the rock.

The magnetite and pyrite are in small crystals and crystalline grains, 
the former often associated with the chondrodite, the latter always in small complex (1)ystals.

\section{THE COLES BROOK LIMESTONE.}

The limestones of this locality are first noted by President Hitchcock in his Final Report ${ }^{1}$ as occurring in the west part of Middlefield on Pontoosne turnpike and on the railroad at the montih of Coles Brook and 1 mile east. Botli beds are said to extend south into Becket, one, the easterly (?), appearing in the sontheastern part of the town, on the "Billy Messinger" farm; also 2 miles farther south, on the old Becket turupike. It is a more or less crystalline, white, impure magnesian limestone. A delicate variety of serpentine is mixed with the limestone, forming a beautiful rerd antique, and in the south of Becket tremolite, talc, and titanite occur in it.

The following analyses are given: ${ }^{2}$

\section{Anulyses of Coles Brook limestone.}

[No 1, Coles Brook; No. 2, 1 mile east of Coles Brook $(\alpha)$; No. 3, Becket, sontheastern part; No. 4, Blandford.]

\begin{tabular}{|c|c|c|c|c|}
\hline & 1. & 2. & 3. & t. \\
\hline $\mathrm{CaCO}_{3} \ldots \ldots \ldots \ldots \ldots \ldots$ & 56.25 & 88.02 & 58.31 & 51.66 \\
\hline $\mathrm{MgCO}_{3} \ldots \ldots \ldots \ldots$ & 31.56 & 9.91 & 28.61 & 39.48 \\
\hline $\mathrm{Fe}_{2} \mathrm{O}_{3} \ldots \ldots \ldots \ldots \ldots \ldots$ & 1. 12 & 0.15 & 1.24 & 0.91 \\
\hline $\mathrm{SiO}_{2} \ldots \ldots \ldots \ldots$ & 11.07 & 1.92 & 11.84 & 7.95 \\
\hline & 100.00 & 100.00 & 100.00 & 100.00 \\
\hline Sp. gr... & 2.78 & 2.71 & 2.82 & 2.77 \\
\hline
\end{tabular}

$\alpha$ This locality, 1 mile east of Coles Brook, can not be located. The analysis contains so little magnesinm and eilicon that $I$ suppose the specimen came from a bowlder of the Stockbridge marble.

I have added the analysis of a limestone fiom Blandford from the same table, which proves to be a bowlder, doubtless from the Becket locality, and, like it, contains tremolite and talc. These large bowlders occur abundantly, and the one which is noted in the 1841 report as a ledge of limestone, in the northwest portion of the town of Blandford, was found to be a bowlder by Mr. S. A. Bartholomew, who used it and many others in his limekiln and traced them northwest to the outcrops in Becket. The microscopic description of the Hinsdale station limestones given above will apply wholly to these, and the change of chondrodite into the serpentine may be followed better here. The former rock is, however, coarser, and the 
included minerals are in larger individuals, and so better fitted for mineralogical study.

THE BLUE-QUARTZ GNEISS, PERU. 1

This is a rusty, fine-grained gneiss, with little mica (biotite), in distant flat sheets of small scales, and with greasy blue quartz in grains and flat plates 1 to $3^{\mathrm{mm}}$ thick, which often coalesce into parallel layers of considerable extent. These layers are plainly secondary infiltrations in a fine-granular ground which has the aspect of a fine sandstone or quartzite. Under the microscope this ground proves to be an exceedingly fine-grained mixture of quartz, orthoclase, microline, and, in abundance, minute scales of muscovite, and it is such a structure as may have been produced by the crushing. of a granite and the change of most of its feldspar into muscovite.

The blue quartz contains a few minute broken rutile needles, rarely cavities containing small, rapidly moving bubbles, and many sheets of very fine pores or grains of some mineral. These are rudely parallel. There are a few distant fissures. A fragment heated for a long time with the bellows blowpipe retained its color without perceptible change. It shows, with plane-polarized light, small traces of undulatory polarization, and the whole of each of the bands of the blue quartz, lowever large, polarizes as a single individual. The sections were cut at right angles to the foliation, but with what direction in that plane I do not know. It is interesting that in each case they are cut at right angles to the optical axis, and the slide can be moved from one end to another of the blue-quartz bands-1-2 ${ }^{\mathrm{mm}}$ wide, $15^{\mathrm{mm}}$ long-and the optical figure remains sharply defined, regular, and unchanged, which would seem to militate against the explanation of the color as due to strain.

It is, however, a very remarkable fact that these slides still show the lavender color distinctly with transmitted light when examined with the lens or the eye alone, in spite of the fact that it is of so pale and dilute a character that one would not expect to see it in so thin a film. Moreover, narrow bands, at times branching, run across the colored layers, in which the color is wholly wanting; and these bands, when examined in polarized light, are made up of a fine mosaic of quartz fragments. It is thus plain that the blue color is due to the state of tension in which the quartz is held, and disappears when this tension is relieved by rupture across the mass. 


\section{THE LEE GNEISS.}

Amphibolite from Washington. ${ }^{1} \quad$ Black, fine-grained, ristinctly bedderl rock. Nicroscopic hornblende abundant in small, thin plates, of medium absorption and pleochroism. $\quad \mathfrak{b}=\mathfrak{b}>\mathfrak{a} ; \mathrm{c}=$ pale indigo; $\mathfrak{b}=0$ live; $\mathfrak{a}=$ pale ocher. Menaccanite in large, shapeless masses, with broad border of lencoxene, abundant; little biotite.

The common feldspathic mosaic forming the groundmass of the rock is so covered up by the hornblende blades and of so fine grain that it is not possible to determine the variety of plagioclase which is present. There is not the slightest trace of cleavage or twinning, and thus there is small ground to suppose the rock to have been greatly influenced by shearing forces. At the same time, the separate rounded or polygonal grains of which the mosaic is composed show quite uniformly, when examined with planepolarized light, a form of undulatory polarization which I have called in the following notes concentric polarization. A single grain becomes black, first at the border, and the darkening advances regularly toward the center, and it sometimes requires a rotation of $45^{\circ}$ to render the whole fragment dark. At times such a fragment is cracked into several parts without disturbing the regularity of the above process.

In the absence of cleavage and twinning it is not possible to think of this as a result of strain from the external forces which have deformed the rock. It also is without the banded zonal arrangement which usually accompanies changes of chemical composition, and where a distinct crystal has been broken up into such a mosaic the fragments show this peculiarity in a striking mamner. It is a structure characteristic of the whole series of amphibolites described in the following pages, and especially of several forms which are certainly derived from limestones. This amphibolite preserves no residual structures pointing to an eruptive origin. It is a long, interbedded stratum, parallel with and near to the Hinsdale limestone, and it is a distinct associate of this rock and reappears with it in the Coles Brook band. It occurs also as a continuation of the limestone seen on the Alderman farm in Becket, where in one place the limestone is changed into white tremoliteschist for 7 feet in from the contact and in another into black amphibolite. It is also seen at the interesting outcrop in Middlefield described above;

${ }^{1}$ C. F. Lyman's pasture, east of the graphite mine. 
and the same is true throughout Berkshire County. ${ }^{1}$ I think it probable that the rock was derived from an impure limestone, but must leave its origin in doubt, because no lithological criteria can be found that will distinguish amphibolites derived from lavas or tuffs and those derived from impure limestones. In the succeeding sections treating of the amphibolites, to which reference may be made (see Chapter X), only those from the east of the river in Leverett have shown distinct residual characteristics peculiar to eruptives and comparable to those found in the altered eruptives of the Baltimore (Maryland) area and of several foreign localities.

\section{RÉSUMÉ.}

These oldest gneisses are coarse, often very coarse, often granitoid, and the cleavage surfaces of the large microclines are strongly curved. Allanite is very generally distributed, at times abundant.

The chondrodite-phlogopite-limestones are characteristic.

The upper gneisses, often strongly foliated, are marked by the universal distribution of graphite, at times so abundant as to tempt mining, and by the abundance of the peculiar blue quartz, of hornblende, and of iron rust. Allanite is even more abundant here.

${ }^{1}$ Professor Kemp has recently called attention to the fact that similar black hornbleudic rocks are constant attendants of the pre-Cambrian limestones of the Adirondacks, fringing the beds both above and below. Geol. Moriah and Westport: Bull. N. Y. State Museum, Vol. III, 1895, p. 329. 


\section{H A P T E R V. \\ THE LOWER CAMBRIAN GNEISSES. \\ THE BECKET CONGLOMERATE-GNEISS.}

This gneiss skirts the western border of Hampshire and Hampden counties, inclosing narrow strips of Algonkian rocks in Middlefield and Tolland, and stretches westward across the first two tiers of towns in Berkshire County, around many pre-Cambrian areas, to enter into most complex and obscure relations to the Stockbridge limestone and associated rocks of westeru Berkshire. It is thus much more amply developed beyond the boundaries of the river counties than within them, and I have for convenience given it a name from the town in Berkshire where it may be best studied. It rests upon the older gneiss in great beds of highly altered quartz-conglomerate, as at the Hoosac Tunnel central shaft and at the Dalton Clubhouse, and graduates in its upper portion into the Cheshire quartzites, so largely used for glass-making. The rock is unconformable upon the lower series.

With many exceptions, especially where it folds round the older rock, as given in detail below, the strike is the prevailing one of the region, varying but little from north and south, and the dips are high.

\section{CONTACT UPON THE WASHINGTON GNEISS BELOW.}

As it passes down the eastern side of the area of older rock in Hinsdale it dips away from it with some irregularity, which is confined to the immediate vicinity of the contact; farther away it regains the normal northsouth strike and a dip which varies but little from verticality for long distances. As it swings around the southern end of the underlying gneiss it dips away from it with low angles, changing from east through south to west, and it is at the same time so far affected by the strong east-west compression which has molded the whole region that it is thrown into a series of subordinate folds with axes radiating outward and pitching from the old gneiss, which has thus assumed the rôle of a foreign and more resistant 
body during the later folding of the newer gneiss. This is well seen along the railroad from above Becket to Bancroft station, in Middlefield, where one passes four principal anticlines with their intervening synclines, as well as many subordinate flexures, all pitching sonthward.

\section{DESCRIPTION OF THE ROCK.}

The prevailing rock is a rather fine-grained biotite-gneiss, always in some degree friable and breaking crisply, and without the extremely firm texture of the older series. Sometimes it is, while seemingly quite fresh, so softly saccharoidal as to crumble under the pressure of the fingers, and again so brittle that a blow of the hammer will punch a square hole in the middle of a thin slab without cracking it. It shows clear gray shades, dependent for their depth upon the amount of the biotite present, which is in clear black to dark-brown scales, both the feldspar and the quartz being colorless, limpid, and much fissured. It contains very few accessory minerals and only small and mimportant veins of coarse granite. It varies from a very thin-fissile rock-"scaly," the quarrymen call it-to a finegrained granitoid-gneiss, furnishing a quarry stone of the first quality, equal to anytling in New England for all kinds of monumental work.

It is best exposed for study along the Boston and Albany Railroad below Becket station, and a brief description of this section will give a good view of the range of variation in the rock, although it must be noted that the section is not taken at right angles to the dip, and that it contains several repetitions of the same strata, as the folds around the older gneiss are traversed.

From Becket station east to the Middlefield line the older, rusty, preCanbrian gneiss with small segregaterl granite veins continues, passing three bridges, and changes here immediately into a light-colored, fine-grained granitoid gneiss, which continues a long distance to the next (fourth) bridge, becoming gradually bedded. The change takes place across the strike, and the rock dips $70^{\circ} \mathrm{E}$.; the passage being apparently from lower to higher beds. A little farther, east of the next (fifth) bridge, and thus still higher up, a stratum of thin and wavy bedded muscovite-gneiss occurs, which is quite exceptional so far east in this series. Then for a long distance a "scaly" biotite-gneiss, often subporplyyritic and rusting from the abundance of the pyrite which is disseminated through it, runs on in great 
folds, the general strike coinciding with the course of the railroad, until the large quirries on the north side of the road are reached. These were rorked in 1887 by the Clark Hill Granite Company, Mr. J. H. Adams, of Dalton, being the principal owner.

1 am indebted to the superintendent, Mr. Hopkins, of Becket, who opened some of the first quarries in the region, for much information concerning the working of the quarry. Besides supplying much rough stone to the railroad and shipping many paving stones to Holyoke and other cities, this quarry furnishes a fine, light-colored granite of medium grain, obtainable in large blocks and suitable for all the uses of architecture, and a finergrained, darker stone of very even grain, which, if it can be quarried in as large blocks as the bed promises from surface indications, will be very valuable as a monumental stone and for all the finer classes of work for which granite is employed where its somewhat somber shade, when polished, is not objectionable. The "granite" extends far north into Clark Hill, on the south slope of which these quarries extend for a long distance, parallel to. the railroad, and crosses the river to the south into Becket, where also are quarries. Some small segregated veins and lenses of pegmatite cut the rock at the quarry.

The bedding of the granitoid gneiss of the quarry can be clearly seen, and is nearly horizontal, corresponding with the more plainly foliated rock adjacent, along the railroad, which seems certainly to grade into the quarry rock.

Between the next two bridges is again a great development of the same granitoid gneiss, followed by a thin, flat-bedded gneiss, banded in gray and reddish layers. Another band of the fine-grained granitoid gneiss separates this in the western entrance of the Coles Brook cut from the heavy, dark gneisses of the Algonkian. (See section, fig. 1, p. 22.)

\section{DISTRIBUTION.}

The rocks of this series occupy the western part of Middlefield, which is in Hampshire County, but beyond the limit of the map, and stretch across Becket, which is in Berkshire County. The broad band of workable granitoid gneiss seems to be continuous across the whole length of Becket, and it is used extensively by the Chester Granite Company, which obtains its materials from quarries in the eastern part of Becket, not far south of the MON XXIX- 3 
road running west from Chester station. This company has already put upon the market a large quantity of stone of the first quality. The rock is, when polished, a clear, dark gray-too dark for many purposes-and when left with a rongh surface is almost white, producing a marked contrast where the two kinds of surface are juxtaposed. The "sap" of the stone in the quarry is thin and white, showing it to be very durable, and the pyrite, which exists in small grains, seems not to be subject to oxidation, unlike that in the thin-bedded portions of the same rock. If it shall prove equally changeless in the worked surfaces after long exposure, the deposit is of great importance, as flawless blocks of the largest dimensions can be obtained, and the extent of the quarry rock is very great.

The gneiss enters the area of the map again at the northwest comer of Blandford and extends, with similar characteristics, down the western side of the town, widening to the east so as to occupy the whole width of Tolland and half that of Granville.

Following the band across Blandford, one finds it supper portion, nearest the mica-schist, to be everywliere thin-fissile, rusty, contorted, and more or less shot through by granitic veins; and where it widens out to the south the increased area seems to be occupied by these upper thin-fissile biotitegneisses and worthless rocks, and west of Tolland the granitoid gneiss either passes down or has run out entirely.

In some places in Tolland the rock approaches so closely the most feldspathic variety of the next series-at the blacksmith shop in the village even containing large garnets-that I have questioned whether one or more folds of this series are not included in the older gneisses.

It extends south into Connecticut as the western part of Percival's K 2, ${ }^{1}$ from which, on the east, the mica-schist is not separated. Far to the east the same gueiss rises again from beneath the hydromica-schists east of South Mountain, in the southern portion of Granville. It is here a granitoid gneiss of the common type, which extends southward into Connecticut, and is marked I 2 upon Percival's map.

PETROGRAPHICAL DESCRIPTION.

1. Granitoid gneiss from Clark Hill quarries, Middlefield. "Finest quan'y stone." 
A fine-grained biotite-granitoid gneiss of gray color, with shade of brown. The deep-brown biotite is scattered through a fresh colorless mixture of quartz and feldspar. Titanite is so abundant as almost to deserve place as an essential constituent. The lens shows a wholly even-grained, very dusty mass.

Under the microscope the quartz is characterized by the small number of inclusions it contains, rarely fluid pores with large, slow-moving bubbles in the largest grains. The long rutile needles are wholly absent; stont, flat muscovite microlites occur. Orthoclase appears in large, clear grains. Microcline is the most abundant and the most recent feldspathic constituent.

Biotite in deep greenish-brown, jagged grains fits itself to all the other constituents, and so is of later formation.

Muscovite appears in small quantity under the microscope.

Titanite appears in large, well-formed crystals, wine-yellow, and in abundant smaller, irregular-clustered grains.

Minute zircons, highly refractive, elongate, with rounded outlines, are not rare.

Magnetite and titanic iron are wholly absent.

2. Granitoid gneiss from Clark Hill quarries, Middlefield. Coarse quarry stone.

A medium-grained, light-gray muscovite-biotite-granitoid gneiss, whose clearer color, as compared with the preceding, is produced by the increase in the size of grain of the other constituents, while the mica does not increase in size or quantity. The lens shows larger, limpid grains scattered in a disconnected, granular, dusty, and micaceous groundmass, which is identical with the whole mass of the preceding variety.

The quartz rarely includes rutile needles, and contains, especially in the larger grains, sheets of pores, often negative crystals, a few with large motionless or slow-moving bubbles.

The orthoclase is in subporphyritic masses, rendered turbid, as usual, by an opaque white substance (kaolin?), which also occurs as an exquisite dendritic growth thrust out among the fissures between the quartz grains and appearing black by transmitted and silvery white by reflected light.

In one quadrangular section of orthoclase cut about parallel to $\infty \mathrm{P} \infty$ 
(010) a great number of sheets of fluid pores with moving bubbles appear, arranged part parallel to $0 \mathrm{P}(001)$ and part parallel to $\infty \mathrm{P}(110)$.

Microcline is abundant, with microperthitic structure.

A plagioclase near albite occurs.

The biotite is deep red-brown.

Muscovite appears abundantly, in microscopic scales.

Titanite is very abundant in congeries of grains, in one or two cases inclosing a grain of menaccanite.

Zircon appears in regular square prisms P (111) $\infty \mathrm{P}(110)$, colorless.

3. Granitoid gneiss, Becket. The best quarry stone of the Chester Granite Company.

Of slightly coarser grain than the best stone at the Clark Hill quarry, and of clear gray color-a muscovite-biotite-gneiss. The lens shows larger limpid grains in a porphyritic granular groundmass, which contains all the biotite and is somewhat dusty.

The larger grains are mostly quartz, without rutile needles, and with minute fluid inclusions showing motionless bubbles of elongate shapes.

Orthoclase occurs in rare, large grains, much dusted.

Microcline is in secondary growths cementing a great number of grains together. It is very fresh.

Plagioclase is rather rare.

The biotite is deep greenish-brown.

Titanite is visible with a lens, but is present in only small quantity in the slide.

No zircon or magnetite occurs.

\section{CRUSHING TESTS.}

Prof. J. F. Kemp has given ${ }^{1}$ some valuable facts in regard to the granite quarried by the Hudson and Chester Granite Company at Becket, Massachusetts. He says:

" $A \mathrm{n}$ analysis, which is the mean of two closely agreeing duplicates, was made by Prof. L. M. Dennis, of Cornell University, and the soda is given by difference, because in the $\mathrm{NH}_{4} \mathrm{Cl}$ and $\mathrm{CaCO}_{3}$ used in the determination of the alkalies some sodium was shown by the spectroscope. 
Analysis of granite from quarries at Becket, Massachusetts.

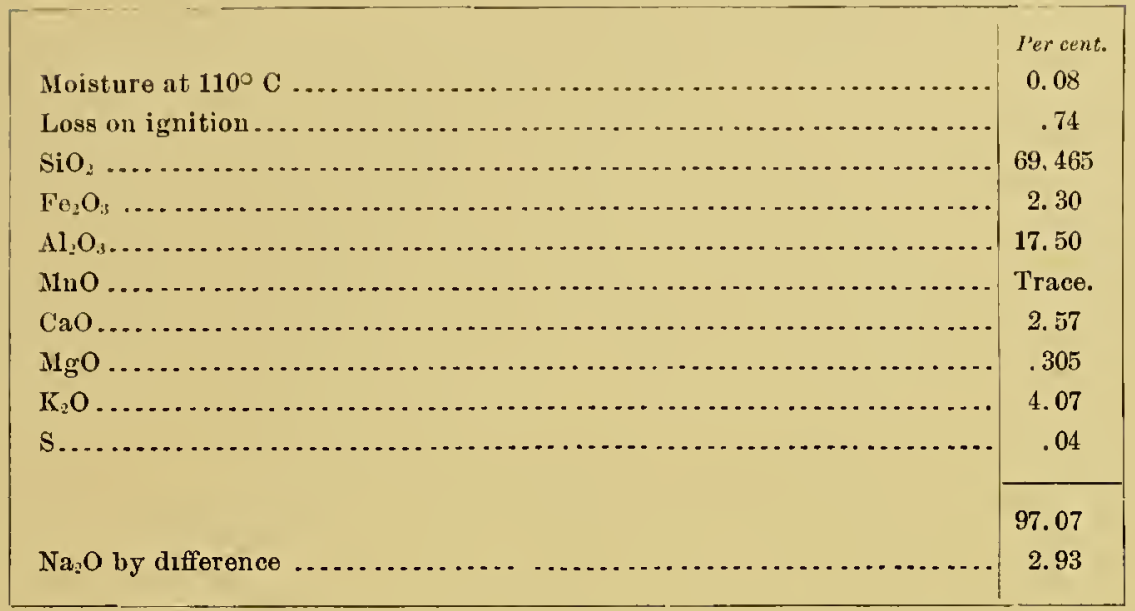

"Crushing tests were made on five sample cubes with the Emory testing machine in the School of Mines, and as preparatory to this the specific gravity was found on four cubes at 2.688, 2.687, 2.684, and 2.688. After three weeks' soaking these cubes absorbed water, respectively, 0.0021, $0.0021,0.00224$, and 0.0026 per cent. The cubes were first ground and polished so that the faces next the jaws of the crusher were parallel within a limit of error of 0.005 inch. The cushion employed between the cubes and the jaws was blotting paper. The crushing tests gave the following results:

Crushing tests of granite from quarries at Beeket, Massaehusetts.

\begin{tabular}{|c|c|c|c|c|c|}
\hline . & I. & II. & III. & IV. & v. \\
\hline Height..................... inches... & 2.033 & 1.983 & 2.059 & 2.011 & 2.009 \\
\hline Breadth ................... inches... & 2.0 & 2.13 & 2.02 & 1.97 & 2.03 \\
\hline Thickness................. inches.. & 2.1 & 1.99 & 2.03 & 2.03 & 2.03 \\
\hline Area...................... sq. inches.. & 4.2 & 4.23 & 4.1 & 4.0 & 4.12 \\
\hline Maximnm compression .... pounds .. & 113,200 & 122,000 & 106,000 & 101,400 & 108,700 \\
\hline Crushing strength .... per sq. inch... & 26,952 & 28,841 & 25,853 & 25,350 & 26,383 \\
\hline
\end{tabular}

"The cubes exploded without previous cracking. This strength is exceptionally high, as the general lun of granite is far less. It does not, however, equal the elæolite-syenite of Little Rock, Arkansas, which was tested by the late J. Francis Williams (see Annual Report of Arkansas State Geologist, 
1890, Vol. II), where results of over 30,000 pounds were obtained; but it is far beyond the requirements of building.

"Cubes of the rock were also boiled in acid. One which was thus treated for five hours in boiling dilute $\mathrm{HCl}(1$ part $\mathrm{HCl}$ of specific gravity 1.20 to 20 parts $\mathrm{H}_{2} \mathrm{O}$ ) lost 0.59 per cent in weight. A second cube treated in the same way in boiling dilute $\mathrm{H}_{2} \mathrm{SO}_{4}\left(1\right.$ part $\mathrm{H}_{2} \mathrm{SO}_{4}$ of specific gravity 1.84 to 20 parts $\mathrm{H}_{2} \mathrm{O}$ ) gave a loss of 0.48 per cent. Both these results indicate a great resistance to natural solvents. Two large cubes were placed in a muffle and maintained at a bright red for half an hour. One was allowed to cool just below redness and then plunged in cold water. It caused one crack that extended half through. The other cube was allowed to cool slowly in the air, and showed a thin external crumbling layer. When these results are compared with somewhat similar tests of other granites, as set forth by Mr. G. P. Merrill in his valuable work, Stones for Construction and Ornament, and with others in Vol. I of the Final Report of the Geological Survey of Mimiesota, and others by Dr. A. W. Jackson in the recent annual reports of the State mineralogist of California, it appears that the Chester ${ }^{1}$ stone endured well."

\section{THE GNEISS AT SHELBURNE.}

The oval area of gneiss on the Deerfield River, at Shelburne Falls, has long attracted attention as a very striking illustration of erosion. ${ }^{2}$ It is a regular quaquaversal. The gueisses in the center of the area are in the main horizontal, though much contorted. Toward the borders they dip under a bed of hornblende-schist, which frames them beautifully, and this schist in turu dips outward on all sides beneath the mica-schists, and these dip outward also, with gradually increasing inclination.

The erosion which wore throngh the newer beds domed over the gneiss has cut more rapidly into it, so that the gneiss occupies now the bottom of a deep circular basin and rises high up the sides of the surrounding hills, where it is capped by the newer beds. This basin is cut across by the Deerfield River and its tributary, the North River.

The rock is very largely a biotite-gneiss of medium grain, granitoid and light-gray, as at the quarry by the railroad on the western boundary of the

${ }^{1}$ This should be Becket; the quarries of the eompany are in Becket and the workshops in Chester.

${ }^{2}$ E. Hitcheock. "Ten thousand feet of verticil thickuess have disappeared." Elementary Geolows; 1860, p. 121. 
outcrop. llere it is not to be distinguished from the Becket or Monson gneiss. Under the microscope it is so fresh that the quartz and feldspar are scarcely visible without polarizer. Below the falls the gneiss is greatly dislocated, and many varieties alternate in much confusion. A white biotite-granitoid gneiss is followed conformably by a similar but thin-bedded rock. These are faulted against a greenish gneiss containing many intermixed fragments of schist, and against this rests the contorted hornblendegneiss which furnished the beautiful bowlder now adorning the vestibule of the geological museum at Amherst, which was figured by President Hitcheock. ${ }^{1}$ The rock is made up of thin bands of a very hornblendic gneiss, alternating with equally thin bands of a white gneiss, and the whole folded with a remarkable complexity. On the south side of the stream the black hornblende rock rests upon the biotite-gneiss exactly as it does on the top of Bald Mountain (now called Massaemet), and it is not impossible that the deep basin has been formed by a sinking of its bottom about 1,200 feet. Bald Mountain is the eastern border of the basin.

Toward the southwest of the area the rock is a thin-bedded biotitehornblende-gneiss with few garnets and with pyrite.

At the contact under the bridge on the road to Charlemont the rock is a rather fine-grained, thin-fissile biotite-gneiss, with few red garnets and some thick, compact quartzose beds. Above this is a very cortorted hornblende-gneiss. On the road south from Shelburne Falls along the east side of the river, and near the south border of the gneiss, the latter wraps around a great mass of horublende-schist, as if it were a granite rather than a gneiss.

It is with some reserve that I identify this gneiss with the Becket and Monson gneisses. The gray gneiss can not be distinguished from the upper portion of the Monson gneiss, except that it is not "stretched." The thinbedded hornblendic gneiss in many ways suggests the idea that it is developed from the homblende-schists which surround and once capped the gneiss, and it is unlike the hornblendic layers in the Monson gneiss. I have been brought to weigh these matters with care because of a more serious difficulty. At the Goshen anticline, next south, the calciferous mica-schists are broken through, and we have the normal section in descending order:

1. Corrugated schists=Conway schist.
2. Flags=Goshen schist.
3. Chloritic and hornblende-schists=Hawley schist.

${ }^{1}$ E. Hitchcock, Elementary Geology, 1860, p. 26. 
Going west across Goshen and Cummington, we find the same series repeated and carried still lower, thus:

4. The upper sericite-schist=Rowe schist.

5. The hornblende-serpentine band=Chester amphibolite.

6. The lower sericite-schist=Savoy schist.

7. The feldspathic mica-schist=Hoosac schist.

8. The Becket gneiss.

Now in the Shelburne anticline one passes directly from the corrugated schists (1) to the gneiss (8), with only the intervention of a single hornblende band, often not more than 50 feet thick, and this bed thus replaces the Goshen flags and the whole sericite-schist series.

It is true that the first bed of limestone above the hornblende-schist is white and slightly actinolitic, but it has a border of hard, black hornblendegarnet rock, so characteristic of the limestones of the Conway schist. An inspection of the map will show that the normal succession of the beds occurs across Shelburne exactly as across the towns north or south of the Shelburne gneiss, from which one is inclined to hesitate between three suppositions: (1) That the Shelburne rocks are the sericite-schist (4 to 6 above) grown feldspathic; (2) that all the berds of the flagstone and sericite-schist series, so abundantly developed just to the west, have thinned ont to the east, so that they are represented only by the thin hornblende band; and (3) that the granitoid gneiss is an intrusive rock grown gneissoid by pressure. I am inclined to accept the second supposition, as the hornblende-schist is almost certainly the continuation of the Hawley schist, and one may assume that the gneisses formed an island larger than the present exposure during the deposition of the sericite-schists and the flagstones. The diminished thickness of these two series east of the Connecticut harmonizes with this assumption. The coloring adopted on the map accords with this hypothesis.

Contacts.-Going south along the west side of the river into Conway, 20 rods north of L. W. and B. A. Andrews's house, one passes for a long distance over a thick-bedded, white biotite-gneiss, and finds this changing, in the hillside west of the road, into a thin-bedded hornblende-biotite-schist with garnets and pyrites.

The transition is sudden to the hornblende-schist above, and the two rocks are not separated by any fissure, but are welded together intimately. The schist is a thin-bedded hornblende-schist with few garnets, black, 
lustrous, with some beds, gneissoid and some marked by the absence of hormblende from spots which appear like porphyritic feldspars but are composed of a gramular feldspathic mass. At the top of the homblendeschist the contact is also visible, and the change is sudden into a rather coarse, slightly rusty, gray muscovite-schist with few gamets.

Directly across the river, back of J. Dole's house, the rather coarse white gneiss is followed immediately by an arenaceous hornblende-schist, gneissoid as before, and this is separated from the mica-schist above by a small mineral vein.

\section{THE MONSON GNEISS AND ASSOCLATED ROCKS.}

Amos Eaton says, ${ }^{1}$ referring to the gneiss range east of the river: "This range evidently passes under the Connecticut River, accompanying the granite and covered by other strata, and rises with it on the western side," and I have, myself, no hesitation in associating the bands of gneiss which cross the State east of the Connecticut with the Becket gneiss on the west of the river, on both lithological and stratigraphical grounds. They are, however, nowhere known to come into visible contact, and in default of this final proof of their identity I may consult convenience and give this rock also a separate name and treatment. It is the $\mathrm{C} 4$ of Percival. ${ }^{2}$ Beginning north of the great bend of the Connecticut, opposite Middletown, it runs north, and in a quarry at Portland, to which I was kindly guided by Prof. William North Rice, of Middletown, it is so exactly like its continuation farther north that in hand specimens and in mass it could not be distinguished from the products of the quarries of Monson or Pelham. It enters the State from the south in two narrow bands, separated by newer rocks, and the eastern band is limited on the east by the deep sand-filling of the central valley of Monson.

The two bands of this rock, separated by an infolded complex of homblende- and mica-schists, and bounded also on the west by a repetition of the latter, may be followed across Monson and Wilbraham into Palmer. Here they are all twisted together in extreme metamorphism to form the hornblendic border of the intrusive tonalite (syenite, Hitchcock), from which they extricate themselves in the latitude of Belchertown village, 
and the gneiss then extends continuously across the State to Northfield, where it is partly covered by newer rocks before reaching the State line. The eastern band runs north to Orange, where it disappears completely within the limits of Massachusetts.

On returning to the study of the Monson gneisses, after long experience with the change of the Cambrian conglomerates into the white gneisses in the Berkshire Hills, the traces of the same change struck me in the stretched gneisses of Monson and Pelham. The traces of pebbles nay now and then be clearly seen, and I present a reproduction of a photograph of the northeast corner of Walker Hall, one of the buildings of Amherst College, which shows this clearly (Pl. I, p. 64). The rock is from Monson, and in 1890 a great wall of conglomerate was exposed in the quarry just north of the trap dike, but it was all quarried away in 1892. In many cases the flat patches of lighter color and of long elliptical shape which appear on the cleaved foliation faces of the gneiss seem to be the remains of pebbles wholly flattened out into films, as was suggested by President Hitchcock in his remarkable investigation of distorted pebbles. ${ }^{1}$

THE PELHAM AND WILBRAHAM AREA.

THE GNEISS.

The broad anticline of this area enters the towns of Northfield and Warwick from New Hampshire, and though its surface is at first covered in part by isolated areas of newer rocks, it soon expands to a greater width than any other gueiss in the counties, and maintains this width nearly across the State, interrupted by the protrusion of the Belchertown tonalite.

It is in Northfield a fine quarry stone, especially marked on foliation faces by small squarish blotches of jet-black hornblende, and it continues to be good quarry stone in large part clear across the State. It differs curiously from the other areas in that it is, across the central portion of the State, a broad anticline with all its central portions almost horizontal and at the edges bending down quite sharply beneath the newer rocks. A further distinction of this area is found in the presence of a great bed of an actinolite-quartzite, which will be specially described, and in the presence of three great intrusions of an olivine-enstatite rock, which, with its complex contact phenomena, will be also the subject of a separate chapter.

${ }^{1}$ Geology of Vermont, Vol. I, 1861, p. 28. 
To the south the rock is coarser than in the other areas, and in contact with the great mass of the Belchertown tonalite is considerably altered.

In Wilbraham its attitude is nearly vertical, and it forms the core of an anticline which is slightly overturned to the east, as the dips are high to the west.

At Power's mine, in Greenwich, on the high hill overlooking the honse of S. B. Estey, considerable blasting has been done upon a vein of coarsely granular magnetite, containing much coarse red garnet and pyrite-an entirely worthless deposit.

petrographical description.

1. Granitoid gneiss from Massachusetts Agricultural College quarry, Pelham. This may be taken as a type of the Monson gneiss.

A very clear, fresh, gray, stretched biotite-gneiss. It is a most crisp and friable stone, showing no trace of decomposition, the fresh black biotite appearing in the mixture of limpid quartz and feldspar.

Titanite is an abundant constituent, and rarely a trace of epidote appears in the neighborhood of the biotite. The lens shows the jet-black biotite scattered in an almost limpid granular mass, with faint trace of porphyritic structure and slight nacreous dusting. Under the microscope the quartz shows swarms of minute inclusions, with groups of larger cavities having moving bubbles. One grain alone was filled with long rutile needles, and this had a slightly reddish shade.

Orthoclase occurs in larger erystals than the other constitnents and includes rounded quartz grains. It is quite abundant.

Microcline is abundant and of late formation, erystallized out so as to cement a great number of quartz grains.

Albite occurs rarely.

The biotite is in separate black scales, and with the lens is seen to be abundant, much notcherl and often extended to include several quartz grains.

Titanite is in angular grains of the same size as the other constituents, and in distinct crystals, pale greenish-brown exteriorly and deep redbrown in the interior, the boundary between the two colors being generally distinct, but in one case a red-brown crystal is inclosed by a pale-yellow one, the two being of common orientation and the outer bounded by fewer faces. 
Zircon is quite regularly disseminated in colorless to pale-yellow crystals one-fifth to one-tenth the size of the other constituents and regularly crystallized in stout prisms, some almost cubical. The forms $\mathrm{P}, 2 \mathrm{P} 2, \infty \mathrm{P} \infty$ could be seen in one crystal. It is included in all the other constituents.

Magnetite is absent.

2. Biotite-gneiss from Bassett's quarry, Northfield.

A fine quarry gneiss, light-gray. On the foliation faces distant, squarish, thin plates of hornblende make the rock appear as if ink-spattered. The feldspar appears as glassy as the quartz, which is common in all these gneisses, though it shows traces of change into muscovite under the microscope.

There are present orthoclase, microcline, and albite; a fragment of the latter gave extinction $+15^{\circ}$ on $\infty \mathrm{P} \infty$, and the triclinic feldspar in all these gneisses give commonly an extinction of $+4^{\circ}$ on either side of the twinning sutures on $0 \mathrm{P}$. Fine minute zircons are present, but no titanite.

3. Hornblende-gneiss from southwest Shutesbury, opposite W. Thresher's, adjoining trap dike. It is a sandy-granular rock of very fine and even grain, and of very dark-gray color. It is a rock quite common in the Monson gneiss, and found also in the Becket gneiss, in the northeast of Tolland. It becomes much more abundant in the eastern area, in its southern extension into Connecticut, where it is Percival's $\mathrm{C} 3^{1}$ in its eastern portion.

Microscopical character: The background is made up of little quartz, little albite (extinction $6^{\circ}$ on either side twinning lines), and much limpid orthoclase, without eleavage, and determined only by its positive biaxial character.

The abundant hornblende molds and incloses the other constituents; it shows peculiar basal cleavage in fine, close, straight lines. Its absorption and pleochroism are exceedingly strong $\mathfrak{c}>\mathfrak{b}>\mathfrak{a} . \quad \mathfrak{z}=$ deep blue; $\mathfrak{t}=$ deep olive; $a=b r i g h t$ yellow; much deep-green biotite and large light-red garnet, many plates of tremolite, much black and red ore, and a single group of leucoxene grains.

4. Biotite-gneiss from east foot of Mount Hygeia, upper quarry. A white gneiss, making heavy beds above the normal gneiss of Pelham, differing from it by the small amount of black biotite in distant scales and the abundance of small red garnets.

The quartz contains no rutile needles, and is in rounded grains that 
suggest water-wear. These are cemented by newly deposited quartz and fehlopar. It contains cavities, which are often negative crystals with very large, motionless bubbles, and other long trains of cavities, showing in great numbers smaller bubbles in rapid motion, not affected by being: heated to $70^{\circ} \mathrm{C}$.

Orthoclase predominates. Albite and microcline are present. Biotite occurs in deep brownish-green scales. There is little muscovite.

A single square prism of deep-red rutile was seen in the slide.

Zircons are rare. Single large grains of menaccanite were seen, changing to leucoxene.

\section{THE ACTINOLITE.QUARTZITE.}

The central portion of the Pelham gneiss area presents two peculiarities as compared with the other similar areas, viz, the series of olivineenstatite rocks and the great quartzite beds here described.

The biotite of the gneiss disappears at a certain level and reappears again as suddenly, leaving a great bed, perhaps 300 feet thick, between two beds of the Monson gneiss which can not be distinguished from each other. The intervening quartzite bed varies from a fine-grained quartzite to an equally fine-grained quartz-feldspar mass, with needles of tremolite or pale grass-green actinolite, just visible to the eye, scattered through the mass. It becomes at times a more distinctly bedded rock, and almost continuous films of the same pale-green actinolite appear on the foliation faces. Small garnets are quite commonly disseminated, and at times distant, minute scales of an amber mica replace the actinolite.

Distribution.-The outcrop of the rock is quite peculiar and depends upon the great flatness of the dome of the gneiss syncline in Pelham. The bed is exposed by the double scalping of the undulating surface of this syncline, and appears, therefore, in one closed ring in Shutesbury and in a loop open to the south in Pelham.

Beginning in the northwest corner of Belchertown, it rums north along the eastern slope of the Pelham range, passing just east of Pelham postoffice and just west of the poor farm, and continues north through the center of Shutesbury and a little beyond it; then it turns sharply southwest, and its dip, which had been low east, becomes resterly. It then runs southwest into Pelham again and ends in the high peak of Hygeia. Its 
extension is shifted more than a mile eastward to the waterworks dam by a fault, and it continues from this point southwardly, passing east of the "asbestos mine."

The other great area occupies the eastern portion of Leverett, is cut off on the north by a fault at the Rattlesnake Gutter, and projects southwardly across Shutesbury into the western portion of Pelham, where it ends under Mount Hygeia, approaching near the other band.

PETROGRAPHICAL DESCRIPTION.

1. Actinolite-tremolite-gneiss from Northfield, east of R. H. Minot's, and adjoining the great north-south fault. A greenish-gray, stretched, ligniform rock, the abundant needles just visible to the eye. In a fresh, granular quartz-orthoclase base the abundant parallel needles of pale-green actinolite and tremolite appear. They show a delicate, close prismatic cleavage, distant, strong basal parting, and strong absorption and pleochroism. Green and brown biotite are abundant, and there is much magnetite.

This is the only occurrence of the rock in the western portion of the Pelham area, and it is soon cut off on one side by the fault and on the other by granite.

2. Micaceous quartzite from Pratts Corner, southwest Shutesbury. In a white, fine-grained, only subgranular quartz mass are scattered small, rounded, red scales of biotite. No feldspar.

Under the microscope the quartz mass shows only rarely a fissure, and is so homogeneous, colorless, and free from foreign bodies that it is invisible in common light. With crossed nicols it shows a most complex mosaic of interlaced grains

The red scales of biotite are all in parallel planes, and inclose zircons which are surrounded by a marked deep-brown pleochroic border. The zircons are also scattered through the quartz in fine crystals. Red-brown, stout rutile prisnis occur surrounded by a granular, colorless leucoxene.

3. Actinolite-quartzite from north side of brook and about 100 feet east of the dam of the Amherst waterworks in Pelham. To the eye the rock is like a fine-grained, white sandstone or crisp, friable quartzite, with scattered needles of pale-green to almost colorless actinolite. The lens rarely detects a grain of feldspar. It is whiter and contains less actinolite than the Mount Hygeia rock, but is closely like it. Under the microscope 
the fresh granular quartz is free from fluid pores and acicular microlites. Felelspar is not distinguishable.

'The nearly colorless actinolites are parallel, and contain large, rounded grains, common also in the quartz, which are strongly refringent and polarize brilliantly; they may be zircon. Other grains clustered along the actinolite crystals seem to be epidote.

4. Actinolite-quartzite from east bluff of Mount Hygeia, Pelham. A granular quartz, white and of medium grain, with parallel needles of colorless to aquamarine actinolite.

In the granular quartz ground the actinolite needles are irregularly arranged; here and there is a scale of biotite. There are large zircons and microlites inclosed in quartz and actinolite; also grains of titanite.

SAXONITE AND SERPENTINE IN MONSON GNEISS.

THE PELham ASBESTOS QUARRY.

This locality has been long known as furnishing large masses of a hard asbestos, and the mineral has been extensively quarried.

Its interest from a mineralogical point of view was greatly increased by the discovery in 1869 , by Mr. A. B. Kittredge, of corundum in hard nodules in the biotite, which occurs there in great abundance. Later, Professor Shepard, observing the difficult fusibility of the "asbestos," analyzed it and found it to have the composition of brouzite, but gave it the wholly superfluous name asbestite. He also analyzed a tough, black, granular mineral which occurs in large masses in the deeper parts of the several excavations and found it to have the composition of olivine, but named it pelhamine, a name equally superfuous, as the mineral is optically as well as chemically identical with olivine, and its black color is due to disseminated magnetite and chromite.

The pits by which the bed is exposed are scattered for a distance along an eastward-sloping hillside, and as the dip is $40^{\circ} \mathrm{W}$, while the strike of the inclosing Monson gneiss is due north, the lenticular mass is exposed by erosion in a plane at right angles to its dip, giving a length of about 200 feet and a greatest thickness of 40 feet.

This is a great lens or short dike-probably an old voleanic core-of the highly basic igneous rock saxonite, in the highly acid conglomerate 
gneiss; and during the strong metamorphism which has transformed the conglomerate into a gneiss, the saxonite has been largely changed into anthophyllite, and, what is of higher interest, a broad selvage - a "reaction rim" on a grand scale-has formed by the mutual influence of the basic core and the acid surrounding. This selvage consists largely of minerals containing little or no silica-apatite, corundum, magnetite, tourmaline, anorthite, and biotite. It wraps around the saxonite with great irregularity, often folding deeply into its mass.

Measured downward from the hanging wall, the mass is greatly decomposed for a depth of from 3 to 12 feet, and as the pits have been sunk in this decomposed portion and work stopped as the hard unaltered rock was

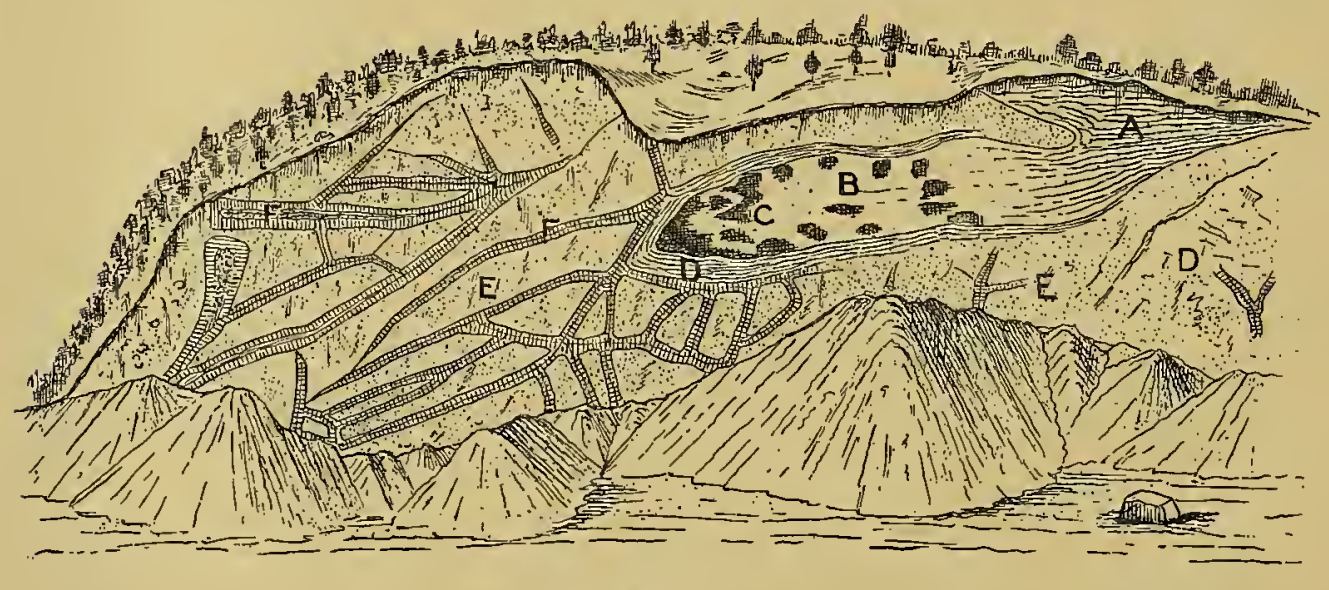

$$
8 F ?
$$

FIG. 3.-Southwest wall of Pelham aebestos quarry in 1890. A, Pelham gneise; B, anorthite rock; C, black tourmaline maseee; $\mathbf{D}$, biotite laser; $\mathbf{D}^{\prime}$, vermicnlite lajer (vermicnlite and steatite from biotite and actinolite); E, saxonite; F, anthophyllite derived from earonite.

approached, attention has been directed almost entirely to this decomposed portion, which will be discussed a little later. The pits everywhere disclose at the bottom the black rock, which consists of granular olivine, chromite, magnetite, and bronzite (saxonite), without admixture of any other minerals, and of this rock the whole intruded mass originally consisted.

At the top of the wall in the large central cutting the contact of the superincumbent gneiss upon the olivine rock can be well studied, and it is very peculiar. (Fig. 3.) The gneiss penetrates the olivine rock in a great club-shaped apophysis, the lamination of the gneiss being first bent down 
toward the latter and then somewhat confused, but distinctly traceable fau into it and dying out gradually by the slow diwiplpearance of the biotite and (1nistz, nutil the whole of the great projection is made up of a mass of snow-white, extremely fine-granular, massive anorthite, carrying toward its borclers a large quantity of black tourmaline in great irregular bunches, which, at the apex of the mass, affords blocks of pure, coarsely erystalline tourmaline over 2 feet across. The fluorine of the biotite las gone into the tourmaline. Many small crystals of allanite are shot through the anorthite, and when broken across the latter mineral shows the usmal puckered surface radiating from the allanite.

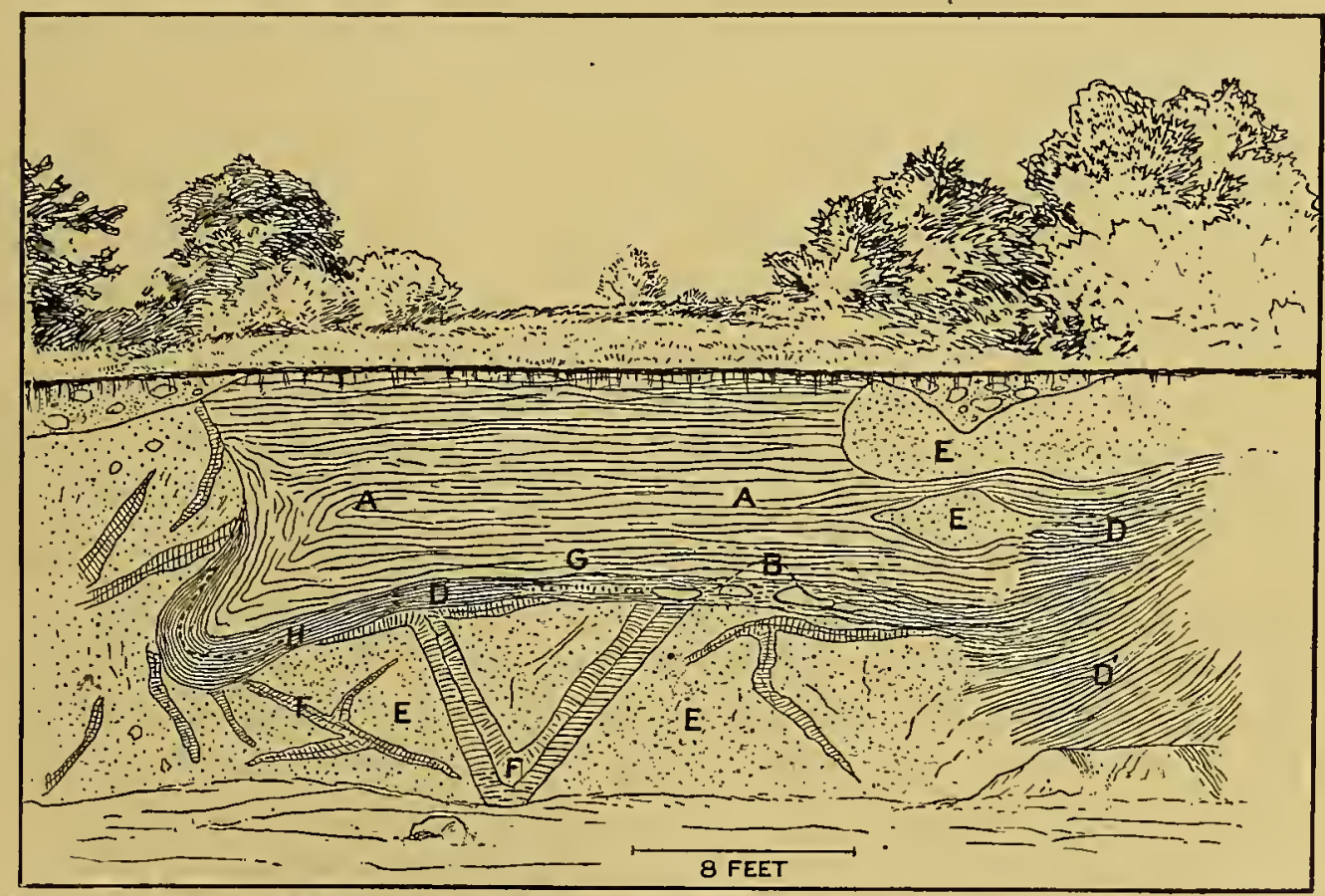

Fig. 4.-Test wall of Pelham asbestos quarry=right half of fig. 3, quarried deeper. Letters as in fig. 3. G, corundum nodules; $\mathbf{H}$, apatite.

The tourmaline breaks into large imperfect erystals, often 8 to 12 inches long, and in cavities shows terminations always with broad $0 \mathrm{P}$ planes. It contains, in cavities between crystals, zoisite, apatite, and beautiful geniculate twins of rutile, together with perfect apatites alone in other cavities and in the mass itself. Under the microscope it often shows an exquisite micropegmatitic intergrowth with the anorthite, the latter taking the place of the quartz in graphic granite, while the tourmaline is extinMON XxIx -4 
guished as a single individual over broad surfaces and in large disconnected reticulate portions. At the line of contact of the tourmaline and the anorthite many microscopic deep-red rutiles occur.

This anorthite projection, which is a thickened part of the outer layer of the "reaction rim," is separated from the olivine rock by a thick band of a deep bronze-colored biotite in large scales, which is wrapped around and extends beyond this projection. As it separates the gneiss at the north end of the bed from the olivine rock, it may very probably be a continuous layer around the latter. Nothing can be seen of the lower contact.

This biotite band, usually 4 to 8 inches thick, reaches in places a thickness of nearly 4 feet, and incloses hard nodules of a blackish-green matted hornblende and of the finest emerald-green parallel-fibered actinolite, and other similar nodules which contain large, imperfect crystals of gray corundum with central spots and streaks of rich sapphire-blue (see fig. 4), which are wrapped in a greenish chloritic mineral of large axial angle and marked pleochroism, probably clinochlore. Still other nodules contain large friable masses of a fine grass-green actinolite.

It is interesting to note how the extremely basic character of the olivine rock is continued outward in the biotite-corundum rock and beyond in the anorthite-tourmaline rock, and to observe how uniform this collocation of minerals is in all parts of the world-a subject to which I recur after describing the Chester emery bed (Chapter VI).

The broad border of decomposition products of the olivine rock mentioned above is of the highest interest, and for its understanding reference may be made to the accompanying fig. 3 (p. 48). Between the biotite (D) and the unchanged olivine ( $\mathrm{E}$ ) is a layer, generally about 3 feet thick, which, nearer the outcrop (at the left of the figure), is 13 feet thick, and consists of olivine changed in part to a pale-yellow, friable, granular villarsite, and in part to an earthy mass of ochery appearance. Through this runs an irregularly anastomosing network of veins of fibrous anthophyllite (F), which reach at times a thickness of 8 inches, at times run out to extreme thinness and disappear. They are for the most part made up of a woody mass of fibers, which are placed at right angles to the walls of the vein and meet on a suture at the center. In the thicker veins the visibly fibrous portion exists only a few inches from the walls on either side, and the central portion is made up of a compact, woody 
mass, splitting in a direction at right angles to the walls, and pearl-gray when not blackened by manganese.

More rarely the vein filling is completely asbestiforn and the fibers cross the vein from side to side; very often they are all bent somewhat to one side or the other as they approach the wall, being compressed by their own growtl.

In other parts of the excavation these veins have swollen to much greater width, and great ligniform masses, 20 to 30 inches in length, have been excavated. This is the "asbestos" of the quarry, and many hundred tons have been excavated and sold for grinding into paint and for asbestos papers. The resemblance of this structure to the well-known microscopic olivine network is extremely striking, and it would seem difficult to avoid the conclusion that the anthophyllite here must be of secondary origin and a derivative from the olivine, probably under conditions of considerable pressure and heat, and therefore at an early period in the history of the changes which the deposit has undergone. Its exact resemblance to the transverse fibrous rein fillings of calcite, gypsum, and chrysotile will hardly admit for it any essentially different explanation.

The anthophyllite occurs also in large, rather coarse-matted fibers. It polarizes very brilliantly and is quite fresh and limpid, the gray color being due to fine magnetite dust.

At the northern excavation and at the large opening there are sparingly disseminated in the fresh olivine rock squarish plates, $\frac{1}{4}$ to $\frac{1}{2}$ inch across, of a pale bronzy enstatite or bronzite, making an ordinary olivine-enstatite rock. This is a primary bronzite.

Masses of a bright emerald-green actinolite in matted fibrous arrangement of the single crystals were produced from the large opening, but their relations to the other minerals can not now be observed. At a new excavation made during the year 1883, near the south end of the bed, a long band of this mineral was struck just below the drift, and resting upon the thick decomposition layer of anthophyllite, in the midst of which several thin layers of the actinolite also appeared.

The biotite containing nodules of the dark-green hornblende here also folded deep into the saxonite, as at the large cutting. The anthophyllite layer was followed in the bottom of the excavation by the usual black, undecomposed olivine rock. The biotite has also been attacked on a large 
scale by a decomposition which has resulted in the formation of a mass of soft, greasy scales of rermiculite $\left(\mathrm{D}^{\prime}\right.$ fig. 4$)$, which, when boiled with sulphuric acid, yields a residue of white scales of pure silica. This has been named pelhamite by Prof. J. P. Cooke, and thus the town of Pelham has lent its name to two equally poor minerals.

1. Saxonite, or olivine-enstatite rock (pelhamine, Shepard). This is a very fresh mixture of olivine and enstatite, both dusted through with black ore, largely chromite. It is a dull-black rock of very great toughness. The olivine grains hare often many crystalline faces. The enstatite is in rare, small plates, with parallel sides and irregular ends, and with a fine wavy lamination, which is often marked by lines of black ore generally concentrated in some part of the plate, especially the center. Although nearly colorless or pale bronzy in common light, it has marked pleochroism. It is plainly rhombic, and grades into the asbestiform decomposition product in veins running throngh the section. The distant, strongly marked transverse cleavage so common in enstatite is wanting.

2. Secondary asbestiform anthophyllite occurs in the altered saxonite in clear gray masses parallel or matted fibrous, in the former case so finegrained as to resemble silicified wood, in the latter made up of a mass of short needles without radiated structure. It has very harsh feel. With a leus it seems to be entirely fresh, transparent, and colorless, the gray color being due to disseminated magnetite, which is visible, and may be removed from the powder by a magnet.

Under the microscope it presents a mass of colorless needles and blades with delicate longitndinal striation, which breaks off here and there against a transverse cleavage. The needles are broken across by a distant fracture not exactly at right angles to the length. Long, fine, straight needles, breaking up at times into a row of grains, are present, and though not very abundant, are concentrated more in the center; they appear black, but at times red with high powers. In erystals cut across the blades the form and cleavage of hornblende can be detected, and I was able to separate and measure one needle, obtaining $55.30^{\circ}$. They polarize brilliantly, and always strictly as rhombic crystals, and this is the case with the silky asbestos.

3. The plagioclase-feldspars of the contact zone. Professor Shepard analyzed the two varieties of massive triclinic feldspar found in the great 
apophysis penetrating the saxonite: (1) the white sacelaroidal portion forming its extremity and nearest to the olivine; (b) the bluish-white, coarsergrained portion which formed the neck of the mass and passed into the gneiss. For the former he fomd the composition of anorthite, and for the latter that of andesite. The latter portion, as it approaches the common gueiss, is less pure than the other, containing much biotite, but with the microseope the characters of anorthite were presented clearly by both varieties; here and there, however, the larger crystals were very distinct and were clearly andesite. The mass is like the feldspar accompanying the "fringe rock" of the Chester emery bed.

The portion called andesite by Shepard is compact to fine-grauular, translucent, bluish-white, fresh-looking, showing slight flesh color from the abundance of small disseminated biotite crystals, and having seams and irregular masses of black tommaline scattered through it. Occurring largely in the latter, and more sparingly disseminated in the feldspar, are minute crystals of zircon:

The anorthite grains are often almost entirely single individuals; here and there a few very fine distant twin laminx are interposed, but these rum out in a short distance, and in many cases the whole surface is covered by distant laminæ lying at right angles to each other. The maximm extinction was $31^{\circ}$ to $34^{\circ}$.

Under the microscope the feldspar shows through a lacelike network of brightly polarizing films or raveled-out seales of muscovite, and this increases nutil in slides cut from seemingly quite fresh material the feldspar can scarcely be distinguished in the mat of mica scales.

The biotite is optically miaxial, and is often decomposed wholly or in part, the sides being dissolved into a congeries of colorless scales, or the change attacking one or several of the lamina and proceeding quite across the specimen; and much of the new mineral has wandered out and surrounds the biotite crystals in large spots, which, with reflected light, are seen to surround the remnant of the original crystal like a growth of glistening. white mold, and these white spots are visible to the eye all over the slide.

The zircons are white, with a faint tinge of red and a high adimantine luster, or deep amber color to pale red by reflected and reddish olive-green by transmitted light. The white erystals are most regularly-formed, long, square prisms with sharp termination $\mathrm{P}$ and $3 \mathrm{P}$, and apparently $3 \mathrm{P} 3$. The 
red crystals show at times a sharp prismatic cleavage, being often very irregular lobed masses and often very regular crystals with shining faces.

The andesite (Shepard's type) crystals are about 20 by 10 by $10^{\mathrm{mm}}$, not bounded by distinct faces, but embedded in a granular, compact mass of anorthite, translucent and bluish-white, with many small scales of biotite intermixed. Sections cut parallel to $0 \mathrm{P}, \infty \mathrm{P} \check{\infty}$, and $\infty \mathrm{P} \infty$ were much decomposed and impregnated with seales of muscovite, placed principally in the planes of principal cleavage and in especially large plates parallel to $\infty \mathrm{P} \check{\infty}$. It is polysynthetically twinned parallel to $\infty \mathrm{P} \check{\infty}$ in broad continuous plates of equal width; extinction on $\infty \mathrm{P} \check{\infty},-13^{\circ}$ to $-14^{\circ}$; on $0 \mathrm{P},-4^{\circ}$ to $-5^{\circ}$, agreeing thus exactly with andesite

4. Serpentine from Pelham, about 100 yards west of the "asbestos", mine. Dull black-green serpentine, changed an inch deep into white talc and showing deep in the interior "phæstine"-like aggregations of talc, from alteration of the bronzite.

Slides cut- $(a)$ from the outer talc layer, $(b)$. from the layer of transition, $(c)$ from the interior deep-green serpentine-showed:

(a) A mass of wavy talc scales containing remains of bronzite, with long jet-black hairs, slightly curved, placed parallel to the vertical axis of the bronzite and ending on the mass of talc scales into which the mineral is decomposed; $(b)$ a matted mass of actinolite fibers of pale-green color, very strongly dichroic; $(c)$ a mass of actinolite fibers and talc scales, with small portions of serpentine and in places with grains showing the olivine network, the whole having the ontward aspect of a common serpentine.

The specimens labeled "Black serpentine and talc, Pelham, Mass.," No. 132, in the Massachusetts State Survey collection of President Hitchcock, is from the above locality.

5. Epidote-gneiss from Pelham; asbestos quarry. An even, fine- or medium-grained mixture of flesh-colored orthoclase, gray quartz, and bright pistachio-green biotite, with small black grains of tourmaline.

Under the microscope the epidote is scattered in long crystals exactly like the plagioclase in a diabase. Minute veins are entirely filled with epidote; only orthoclase is present as a feldspathic constituent, and around nuclei of this broad bands of epidote needles are arranged parallel to the former cleavage planes or outlines of the feldspar, showing the nucleus to be only a remnant of a larger crystal. 
THF PULIAM SERPENTINE.

About 325 feet west of the asbestos mine, on a small flat which interrupts the western slope of the hill on the eastern side of which the mine is sitnated, a great boss of serpentine rises through the till, and a little south of it a second, of which it can only be said that they occur within the limits of the Monson gneiss. The rock is a deep dull-green, opaque when wet, and containing chromite in some abundance. Over a large portion of its surface it is changed for some distance inward into a white talc, and as this change follows the surface of the rock it is plainly a change of the serpentine into talc since the erosion of the Glacial period.

THE SHUTESBURY SERPENTINE.

A second locality identical with the "asbestos". mine in Pelham occurs a mile south of the village of Shutesbury, in a pasture south of the house of C. Leonard. Fragments, some of large size, lie over the surface in a space a few yards square, turned up by plowing. One large mass of rusty-brown, half-decomposed olivine rock, shot through by white antlophyllite fibers and full of chromite, is not to be distinguished from similar masses at the Pelham locality. The fibrous asbestiform and woody varieties of anthophyllite are repeated here also, and masses of a green chloritic mineral occur. The deposit is surromded on all sides by outcrops of the Monson gneiss, but its exact relation and size can not be determined.

THE NEW SALEM SERPENTINE.

This locality is situated on the west slope of Rattlesnake Hill, about 300 yards northeast of $A$. A. Haskell's house. The country rock is a rather coarse biotite-granitoid gneiss, striking north-sonth and dipping $90^{\circ}$. The old rligging is covered, and no contacts can be seen. The olivine rock is at most 50 feet wide and may be 150 feet long. The nearest ontcrops of the gneiss are wholly normal and do not betray the presence of the foreign body. This is apparently a lenticular mass, its greatest diameter coinciding with the strike. The greater portion of the rock taken out is deep dullblack olivine, with small glistening scales of a micaceous mineral, apparently clinochlore. The rock weathers to a pale isabella-yellow from the removal of the black ore and the hydration of the olivine. Associated with it in some quantity is a fine fibrous light-gray anthophyllite, largely altered to an imperfect steatite. I was guided to the spot by an aged man 
who had owned the land for more than half a century, and I asked him how the rock had been discovered in the thick woods. He told me that when he was a small boy his father had cleared the hillside, a desolate slope consisting largely of uncovered ledges, and his older brother, while harrowing in oats on the spot, noticed that the harrow teeth made no noise over one portion of the ledge, but gouged deeply into the rock. He therenpon took a large piece of the rock home and put it into the fire, but conld not melt it. His pyrognostic experiments do not seem to have proceeded much further, but long after, about thirty-five years ago, the owners dng a deep trench into the mass, dumping a great quantity over the bluff, but did not find anything of value for use as soapstone, only a small portion of the rock having completed the change to steatite.

\section{THE ORANGE AND MONSON AREA.}

This band of gneiss extends nearly across the State as a narrow anticline, and near its north line in Orange the axis of the anticline dips down northwardly beneath the fibrolite-schists. Because it yields more readily to erosion, the gneiss occupies the bottom of a deep amphitheater open to the south, its bottom deepest outwardly, just at the foot of the sharp, high schist hills beneatl which it sinks. At its northern end the gneiss is quite granitoid and much disturbed by small intrusions of pegmatite. Around Orange village it is a fine quarry stone. Much of it is a dark biotite-hornblende-gneiss, much a lighter gneiss containing angular fragments of the darker variety, and very tortnous.

At the railroad east of Orange village the light-colored granitic gneiss folds around great fragments, or groups of fragments, of the dark hornblendegneiss, which have been but slightly moved and cemented by the lighter gneiss. In this it resembles the Shelburne Falls gneiss. Two east-west faults, 17 feet apart, here include a much darker and more hornblendic gneiss. It contains prehnite and stilbite in fissmres. All down its western border in Orange its contact with the schists above is more like that of an eruptive with an overlying sedimentary than like that between two sedimentary beds. At L. Mayo's it is rery granitic and is intermixed with the lower schists in a confused way. In the village of Orange, betrveen IIain and High streets, it is in direct contact with the hormblende-schist, and it continnes in contact with the schist across into New Salem. In this 
town and across Greenwich and linfield-that is, for 20 miles south-it forms the botton of a very peculiar, deep valley, in the center of which lise strunge, isolated peaks which have in some unexplained way escaped the general erosion.

Continuing sonth across Ware and Palner, the grneiss band narrows sonewhat and the valley is interrupted, though this is in part only apparent, being due to the filling of the valley by the abundant glacial-lake deposits in this latitude. Farther south the valley reestablishes itself in Monson and continues far beyond the limits of the map (Pl. XXXIV).

Across Orange the newer rocks dip toward the gneiss from all sides, forming a fan structure. Across the remaining area it forms the center of a closely appressed anticline, slightly overturned to the east, as the dips are all $70^{\circ}-80^{\circ} \mathrm{W}$.

GENERAL DESCRIPTION.

The Monson gneiss is a clear-gray, friable biotite-gneiss, in mass made up of small angular grains of quartz and orthoclase, equally limpid and colorless, and so loosely joined that there are many interstices, and one can sometimes rub a fragment into powder between the fingers. Scattered through this aggregate are grains of shining black mica, whose parallel arrangement produces the more or less clearly marked foliation visible upon cross fracture and the equally marked "stretching" seen upon the foliation face. The foliation is produced by the concentration of the black biotite in bands which have between them long linear or elliptical spaces that appear white upon the gray ground, and in which the knots of feldspar mostly occur when the rock becomes subporphyritic. The stretching is manifested upon the foliation faces by the greater concentration of the biotite along broad, imperfectly marked parallel bands; and oftentimes when by incipient decomposition the feldspar has been rendered opaque white or flesh-colored it is seen to have the same linear parallel arrangement. This structure often obtrudes itself more readily upon the attention than the foliation itself. There is, however, little or no greater tendeney in the quarry slabs to split parallel to this structural feature, and blocks are frequently gotten out with the "stretching" ruming diagonally across their broad faces.

'The biotite, although so important for' the color and structure of the rock, is present in rather inconsiderable amomit. 
There are also here and there in the mass, and especially upon the foliation faces, squarish spots of a black hornblende, generally from half an inch to an inch across, but at times forming great lustrous masses larger than one's fist, and in other places concentrating in distinct strata-often accompanied by a trace of copper-to so great an extent as to form a black homblendic gneiss, as in the western side of the Monson quarry and for a long distance north and south. This bed does not, however, so differentiate itself from the remainder of the gneiss that I thought it desirable to separate it upon the map.

Titanite is a very generally distributed constituent of the rock, in honey- to straw-yellow crystals, flat, often well formed, and reaching a size of from 2 to $5^{\mathrm{mm}}$.

Pistachio- to oil-green epidote in grains is aggregated with the biotite, and especially with the hornblende, making a loose border to the squarish plates of the latter. Garnet and magnetite occur in small grains. A palegreen pyroxene appears rarely in large, stout prisms embedded in the rock.

The narrow, white interrupted planes which express the foliation are structure planes and not planes of separation of the rock, and the latter planes are at times so closely approached as to divide the rock into thin plates (about 4 inches thick), whereby it becomes "scaly" (the local quarrymen's term) and useless as a building stone. In other places the latter planes separate more widely, furnishing thick banks of excellent quarry stone. The blotching with homblende, or with large roundish masses of white feldspar, and the amount and parallel arrangement of the biotite may vary in all these structural varieties, forming two types of special importance. On the one side, by the great increase of the feldspar nodules, a strongly marked "augen-gneiss" is formed, which is the "subporphyritic" gneiss of Percival, the "glandulous gneiss" of E. Hitchcock, ${ }^{2}$ and which differs decidedly from the porphyritic gneissoid granite of Worcester County, for that is a complete granite with porphyritic carlsbad twins, while here the feldspar is in roundish masses with no approach to crystallographic ontline and not twinned. On the other hand, by the sinking of all the constituents to the same size and by the more uniform arrangement of the biotite, a fine-grained granitoid rock results, like the best at the Monson quarry, though it is nowhere so completely granitoid as at the Middlefield and Becket quarries. 


\section{PETROGRAPHICAL DESCRIPTION,}

As the type of the Monson gneiss the rock of Flynt's quarry at Monson is naturally taken for detailed description, and for this purpose fine specimens of the two rarieties which served for the analyses quoted on page 62 were kindly furnished me by the proprietor of the quarry, Mr. W. N. Flynt, and form the material of the following description:

(a) The darker variety is a rather dark pure-gray granitoid rock of medium and very even grain. The quartz and orthoclase are almost equally colorless and glassy, so that they are not easily distinguished; the latter is disseminated in a certain small porphyritic way, so as to show many shining facets upon freshly broken surfaces. The black constituent is present in small quantity, but from the transhucency of the other constituents it gives a quite dark color to the mass. It is this translucency which canses the marked distinctions between the dark polished and the white pounded surface. The black constituent is a lustrous black biotite, greenish-brown or bright emerald-green by transmitted light. It is arranged with very imperfect parallelism, and yet is somewhat concentrated along certain lamination planes, although not joined into membranes, and this alone gives the rock its gneissoid texture. Seen edgewise, it resembles hornblende, but I have not detected this mineral in the present variety. Wine-yellow grains of titanite are associated with it, and rarely grains of a light-red garnet. Plagioclase could not be detected.

The biotite is often changed to a bright-green chlorite, and parallel therewith is an abundant development of hematite in isolated, regular hexagonal plates or elongated congeries. A few deep-green prisms of tourmaline occur, short, stout, and hemimorphic.

(b) The lighter variety is characterized by a somewhat coarser grain. The black constituent is almost equally biotite and magnetite. It is, however, much less abundant and so arranged in the cleavage planes that transverse to these the rock is nottled with white elongate spots from which it is absent.

The important distinction between the two is in tle fact that museovite in thin, membranous patches is quite abundant upon the lamination planes of this variety. This is an exception to the rule that muscovite is absent from the Becket and Monson gneiss in the three river counties and characteristic of the next formation above. 
The quartz is often inclosed in the orthoclase in wholly rounded grains. It contains great swarms of cavities of large dimensions and the most distorted shapes, often spun out into long capillary tubes, which sometimes connect distant cavities. Often these appear empty; often they contain a fluid with large, motionless bubble; sometimes they appear to contain two fluids, with moving bubble; sometimes, also, they are negative crystals, witl very large bubbles. Rutile needles occur rarely in the quartz. The orthoclase is in large crystals intergrown with albite. The plagioclase extinguishes at $25^{\circ}$ to $28^{\circ}$, is optically negative, and is a lime-sodafeldspar near anorthite. Large grains are free from multiple twinning, except near the borders, where it is caused by pressure.

The change of feldspar to muscovite is of great beauty. Often every other lamina of a triclinic feldspar is changed to a mass of fine nacreous scales, the intervening laminx being unchanged.

The biotite is red-brown, rarely green, and then associated with bexagonal scales of hematite. Zircon occurs in small, highly refringent prisms. Garnet is in hyacintl-red grains and dodecahedra, inclosing smaller dodecahedral crystals or cavities. There is no magnetite, menaccanite, or titanite.

Résumé.-Friable, light-gray, medium to fine grained biotite-gneisses, which, beyond the boundaries of the county, show abundant evidence of their derivation from conglomerates, of which traces are not wanting within the boundaries of the three counties along the western border, but fail almost entirely in the three eastern areas. They are contrasted with the older gneiss by the failure of all the peculiarities enumerated at the close of the last chapter (p. 30) and marked by the abundance of titanite in pale, flat crystals, both macroscopically and microscopically present. 'This mineral is very rare in the older gneisses, except in or near limestone, and it occurs there in larger and more sharply defined crystals.

Beds of hornblende-schist are almost always absent. Important beds of a fine actinolite-quartzite and of olivine-chromite-enstatite rock, with fine contact phenomena, characterize the Pelham area.

THE MONSON QUARRY.

The following account, copied from the Springfield Republican of May 9,1884 , and verified as to its accuracy, may find a place here, giving, 
as it does, a detailed listory of the nost important quary in westem Massachusetts:

"W. N. Flynt \& Co.'s granite quarries, situated a mile north of the village of Momson, on a spur track of the New London Railroad, were first opened eighty years ago by agents of the United States Government, who took from there stone for the foundation of the Springfield armory. In 1825 Rufus Flynt put four or five men at work in the quarry to supply the local market, and the front of the Chicopee Bank building in this city was soon afterwards built of this stone. Since 1836 W. N. Flynt, son of Rufus Flynt, has had charge of the work, and has greatly enlarged the business, until at present the yearly output of stone is 20,000 to 30,000 tons, valued at $\$ 150,000$ or $\$ 200,000$. In 188728,700 tons were produced, and in 1888 33,460 tons.

"The quarry land owned by the company amounts to 500 acres, all underlain by granite, only a small part of which, however, has yet been worked. The stone lies in horizontal layers from 1 to 12 feet thick, and wedges are mainly depended upon for getting out even the largest masses of rock, powder being used only to lift the loosened layer from its bed. The largest single piece which has yet been taken out was 354 feet long; 11 wide, and 4 high, and 1,104 wedges were used in detaching it.

"The present workings are on the slope of a hill, and although 75 feet below the crest of the hill, are above the surrounding country, so that water gives no trouble and the rock is the more easily handled. From March to December about 100 quarrymen and 40 stone dressers are employed, and during the winter an almost equal force is kept at work. Last year (1883) 28,403 tons of granite were shipped, and in all branches of the work between 600 and 700 men were employed.

"Specimens of the Flynts' workmanship are shown in the Monson Library, costing $\$ 35,000$, and in a memorial hall now being constructed at a cost of $\$ 30,000$, in both of which the light and dark varieties of granite yielded by the quarries are artistically blended.

"The Church of St. Francis Xavier, in New York City, was also built of this stone, as were also the Walker Hall and the stone churches in Amherst." 
The following letter is also published by the kind permission of Mr. Flynt:

\section{Massadhuset's Institute of Technologx,}

Messrs. W. N. Flynt \& Co.

February 14, 1881.

GENTLEMEN: The two sorts of Monson granite which were sent to us have been carefully averaged, and several analyses of each have been made, with the following results:

\begin{tabular}{|c|c|c|}
\hline & Light. & Dark. \\
\hline Silica........... & 73.47 & 69.35 \\
\hline Alumina.................. & 15.07 & 18.83 \\
\hline Mlagnetic oxide of iron ........... & 1.15 & 2.00 \\
\hline Lime $\ldots \ldots \ldots \ldots \ldots$ & 4.48 & 5.94 \\
\hline Magnesia. . & .12 & 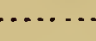 \\
\hline Soda $\ldots \ldots \ldots \ldots \ldots \ldots \ldots \ldots$ & 5.59 & 3.78 \\
\hline 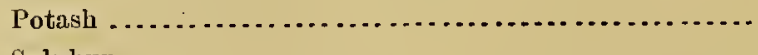 & .38 & \\
\hline $\begin{array}{l}\text { Sulphur } \\
\text { Copper } \ldots \ldots \ldots\end{array}$ & $\begin{array}{l}\text { Trace. } \\
\text { Trace. }\end{array}$ & \\
\hline & 100.26 & 99.90 \\
\hline
\end{tabular}

In this granite-mica is replaced by hornblende, ${ }^{1}$ as in the Quincy and Rockport granites. Such stones are much less affected by chemical agents than those which contain mica.

The percentage of the alkalies, potash and soda, has much to do with the power of resisting atmospheric influences. The amount of alkali in both specimens is uncommonly small for granites. The sum is less in the dark-colored one, because that contains a much larger proportion of the black hornblende, which probably is free from alkali. The potash and soda come from the feldspathic ingredient of the mixed minerals. This part seems to correspond nearly to andesite rather than to ordinary potash-feldspar.

We have in Hull's Treatise on Building and Ornamental Stones the analyses of thirteen European granites, which show, respectively, as the sum of the potash and soda: $6.74,7.27,6.16,7.91,7.74,7.98,8.61,9.67,7.46,5.63,7.40,5.82,9.00$ per cent, while the Monson granite shows 5.97 and 3.78. So far as the alkalies are concerned, the dark is superior to all of the thirteen, and the light is better than all except the twelfth, which was from Mont Blanc, and the tenth, which was from Meineckenberg.

The iron in the Monson granites is in the form of magnetic oxide, which is unchangeable. Were it in the form of pyrites it would be liable to oxidize and would give rusty stains on long exposure.

1 This is a mistake, as the black constituent of the specimens analyzed, which were submitted to me for study, was biotite. The alkali determination given above differs greatly from that given for the Becket gneiss and from the results of microscopical examination, which indicate the presence of potash-feldspar. 
As far as we may judge from the chemical and mineralogical composition, these Monson granites should remain practically unchanged for an indefinite length of time, since those coustitnents which favor disintegration are present in unusually small proportion.

Yours, truly,

JOHN M. ORDWAY, Professor Industrial Chemistry.

STRENGTH OF THE MONSON GNEISS.

Interesting data concerning the strength and durability of the Monson granite are given by Mr. A. P. Merrill. A block 7.6 by 7.4 inches, placed with the bedding horizontal, was crushed by a weight of 15,390 pounds to the square inch, and one 6 by 6.1 inches, with the bedding vertical, was crushed by a weight of 12,720 pounds to the square inch. ${ }^{1}$ These results may be compared with those given for the Becket rock on page 36 .

CONGLOMERATE STRUCTURE IN THE MONSON GNEISS, AND SUDDEN EXPANSION OF TIE ROCK IN QUARRYING.

The trimmings of Williston Hall, one of the buildings of Amherst College, was made of rock from the Monson quarries. I had been familiar with the buildings since my college days, and I was startled, two years ago, upon observing distinct traces of pebbles in the blocks forming the coign on the northeast corner, especially in those between 8 and 12 feet from the ground. Pl. I, coign of Williston Hall, Amherst College, represents these blocks, and is copied from a photograph. A little later I discovered traces of the same structure in the quarry at Monson, in a portion of the rock 6 or 8 feet square, near the surface of the ledge, and a rod north of the trap dike that intersects the quarry. I took a photograph of the wall, and the next year found the whole quarried away and secured a photograph of one large block which had recently been blasted from the spot. These pebbles were uniformly compressed, so that they were of a flattened egg-shape; the shortest diameter, about an inch or an inch and a half, was east and west; the next, 2 inches, was north and south, and the longest, nearly 3 to 4 inches, was vertical. The foliation here stands nearly vertical and strikes north and south; the gneiss lies in the core of a close-pressed anticline, and the pebbles have been flattened in the foliation plane by an east-west

${ }^{1}$ Stones for Building and Decoration, New York, 1891, p. 406. 
force and were able to expand but slightly in the north-sonth direction because of the resistance of the adjacent rock. They have been extended almost entirely in the vertical direction, but as this motion took place against the great weight of the superincumbent rock, there was a strong expansive stress or resistance in the north-south direction, and it is this tendency to expansion, still stored in the gneiss, which would seem to explain the sudden north-south elongation of blocks of the rock when they are quarried. These most remarkable phenomena have been described fully by Professor Niles. ${ }^{1}$

The face of the quary looks westerly, and horizontal joint pilanes are utilized in quarrying. Except for these planes the rock is remarkably free from joints. Slabs 3 to 5 feet in thickness and 10 feet wide from east to west, and of very great length from north to south, are split off by a long line of wedges, and while one end of the rock still retains its connection with the ledge the other expands so that the halves of the drill holes fail to match. In one case, in 1869, a block 4 feet thick, 11 feet wide, and 354 feet long was split by the use of nearly 1,200 wedges. As the block was followed up from the attached end the halves of the drill holes soon ceased to match exactly, and this increased witl regularity to the other end, where the elongation amounted to an inch and a half. Many such cases have occurred at all seasons and times of the day. Several were carefully studied by Professor Niles, and I have myself seen one most striking case. Where a long line of wedges was put in about 6 feet back from the quarry face, and before the cross channel was cut at the south end of the proposed block, the crack started of itself and ran beyond the line of the wedges for a long distance to the north, while at the south end it soon left the line of the wedges and went west, and ran out to the quarry face, and the expansion then caused the block to project at the south end westerly over the face of the quarry. As much as 10,000 tons of rock have been quarried out by a single fissure.

In the same way the expansion causes the horizontal sheets of the rock to rise, often quite suddenly, in considerable anticlines, with the arch as much as 50 feet long and the rise 3 or 4 inches. These anticlines form sometimes with explosive violence, throwing large fragments of the rock more than 2 feet from their original position. The large area of shattererl rock produces the impression of a small but violent earthquake. The explosions

\footnotetext{
${ }^{1}$ Proc. Boston Soc. Nat. Hist., Vol. XIV, p. 80; VoI. XVI, p. 41; Vol. XVIII, p. 272; and Proc. Am. Assoc. Adv. Sei., Vol. XXII, part 2, p. 156.
} 


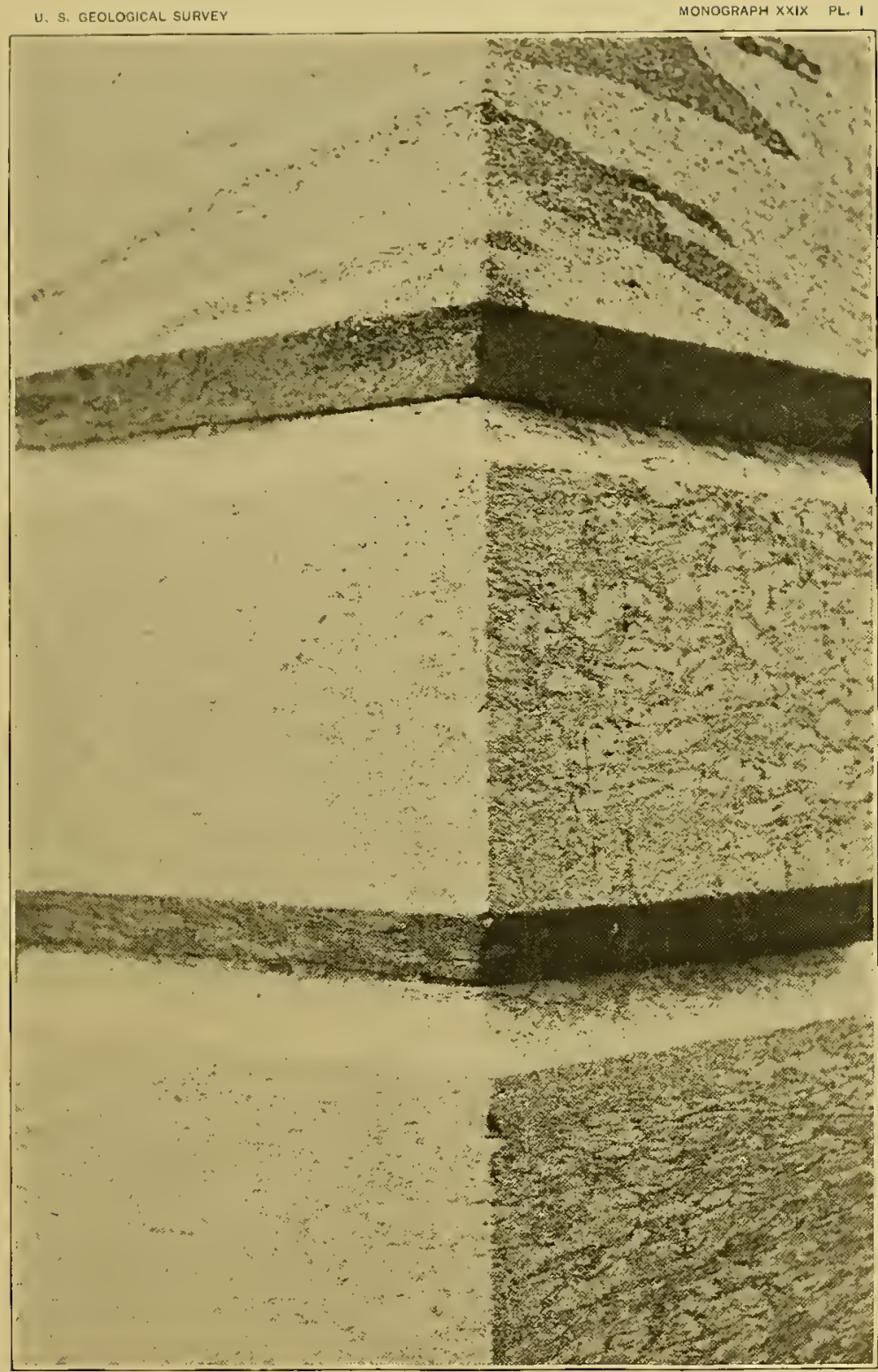

NORTHEAST COIGN OF WILLISTON HALL, AMHERST COLLEGE.

Showing the Cambrian conglomerate-gneiss from the Monson quarry, with traces of pebbles, and shear zones darkened by excess of biotite. (The pebbles are much more distirct in the photograph than in the reploduction, especially at the left.) 

are likened by the miners to the firing of a blast, and have been heard a mile away from the quarry.

Professor Niles explains the phenomena here described as the result of a force of compression acting from north to south. This would be a later exertion of the sane mountain-making force which, acting from east to west, has folded the rocks in meridional ridges. I know of no independent evidence of the replacement of the east-west force by a later north-south compression. The changes of level in the Glacial period, and along our coast in later ages, seem to come under a different category.

The rock is certainly in a state of elastic compression in a north-sonth direction at present, while the last traceable dynamic change it has undergone was the strong east-west pressure which crushed its pebbles into flat disks and cansed them to be so greatly stretched in the vertical direction. In the resolution of this force some portion of its north-south component seems to have been stored in the rock as an elastic stress which expresses itself in expansion when the surrounding masses are removed.

A COMPLEX MINERAL VEIN OF THE GNEISS.

A curious vein occurs in the northwest corner of the Monson quarry, adjacent to the region where the gneiss is highly hornblendic. The earliest filling of the vein was a matted mixture of pale-green, fine-fibrous actinolite, granular to short-bladed epidote, clinochlore, magnetite in octahedra, a little quartz, and colorless prehnite in thin, flat blades of the form 0 (001), $\infty \mathrm{P} \infty(010), \infty \mathrm{P} \infty(100), \infty(110)$, flattened on 0 and elongate parallel to the short axis. They are very minute, but were determined crystallographically by fixing the position of the optical axes. This ends with a downy surface of thin, colorless prehnite blades, and a second series begins with calcite in fine, transparent, cleavable masses, followed by rich-green prehnite in rosettes and sheaf-like forms, upon which is a final generation of calcite in distinct crystals - the rhombohedron $R$ with its edges replaced by a scalenohedron.

In other parts of the vein this is followed by laumontite, at first intergrown with the prehnite and then resting upon it. It is in fine, large crystals and coarse-granular crystalline aggregates of pink-white color. The series is closed by a leek-green hornstone, which fills the vein and envelops the laumonite. 


\section{CH A P T E R VT.}

\section{THE LOWER SILURIAN SERICITE-SCHISTS AND AMPHIBO- LITES ON THE WEST SIDE OF THE VALLEY.}

\section{THE HOOSAC SCHIST $=$ THE ALBITIC MICA-SCHIST. ${ }^{1}$}

Next east of and next above the Becket gneiss a continuous band of feldspathic mica-schist, often sericitic, crosses the State, and the irregular western boundaries of the counties here studied include three portions thereof within Monroe, Middlefield, and Blandford, while a loop of the same rock is brought up in the Granville anticline.

The bed has so decidedly the habit of a mica-schist and is so closely associated with the mica-schist next above that $I$ have chosen the name "albitic mica-schist" rather than gneiss for it. At its northern extremity, however, the amount of feldspar increases and the rock becomes a gneiss, porphyritic with small crystals of albite. It is shown below that this is the Green Mountain gneiss of Adams. At the base of this formation a dark, highly garnetiferous mica-schist forms the passage bed from the Becket gneiss to the main portion of the series. The latter has the habit of a mica-schist, although it is generally quite feldspathic. The small, rounded crystals of albite scattered porphyritically in the mass have often in crystallizing cemented several grains of quartz together. Both micas are present, and the rock is generally quite dark from the abundant biotite. It shares with the following formation the greasy feel from the hydration of its muscovite. Where it crosses the Boston and Albany Railroad the basal garnetiferous schist has disappeared, and the whole series is from the base up a light-gray, quartzose sericite-schist, porphyritic with many small, rounded albite crystals, which often cement the quartz grains. 
THE MONROE AREA.

Prof. (:. B. Adlans introduced the name Green Mountain gneiss for the gneiss of the Green Mountain range in Vermont, in lis first report, ${ }^{1}$ but without definition or detail. The name occurs in his enumeration of the primary rocks, between talcose slate and gneiss proper, and he remarks that in and south of Mount Holly the gneiss replaces more or less the talcose slate.

In the second report of Professor Adams ${ }^{2}$ is a letter from President Hitchcock, who calls attention to the fact that the broad band of gneiss which makes the axis of the Green Mountains across Vermont seems in Massachusetts to be replaced suddenly by mica-slate, and fears an appearance of discrepancy between the maps of the two surveys if the gneiss is made to 'mm up to the sonth line of Vermont. He expresses the belief that the rocks change on the strike in the neighborhood of the State line, and adds that much of the rock is halfway between gneiss and mica-slate.

In his own final report on the geology of Vermont ${ }^{3}$ President Hitchcock says that Professor Adams gave the above name to distinguish from true gneiss this range of gneiss, which is characterized by a deficiency of feldspar, so that the rock is often mica-schist, or at the best feldspathic mica-schist.

On a later page ${ }^{4}$ reference is made to the sudden change of the Green Mountain gneiss into the gneiss and mica-schist of the Hoosac range, and this change is explained thus:

1. The mica-schist of Hoosac Mountain and the gneiss of the Green Monntains belong to the same formation, and the Massachusetts stratum of mica-schist becomes gneiss extremely near the State line by the addition of a little feldspar. It is a case of the metamorphism of one rock into another.

2. There is a narrowing of the formations very near the State line. Both the gneiss formation and the mica-schist curve to the westward, so that in Massachusetts the mica-schist and gneiss are narrower than in Vermont.

It will be seen below that the Green Mountain gneiss in Heath and Monroe dips beneath and does not pass into the mica-schist of the Hoosac range.

\footnotetext{
${ }^{1}$ First Ann. Rept. Geology of Vermont, 1845, p. 62.

2 Second Ann. Rept. Geology of Vermont, 1846, p. 248.

3 Rept. Geology of Vermont, Vol. I, 1861, p. 454.

${ }^{4}$ Ibid., p. 462.
} 
In a later section, signed specially by President Hitcheock, ${ }^{1}$ this is said :

On the south line of Massachusetts almost the whole breadth of the range, not less than 20 miles, is tolerably well characterized gneiss. Yet as we pass northerly on the line of strike along the eastern margin the gneiss is rapidly succeeded by mica and talcose schist, and the gneiss becomes so pinched up as to form a mere wedge before we get across the State; and it is doubtful whether the mica-schist does not absolutely cut off the gneiss ere we reach the north line. We incline to the opinion, however, that a narrow belt of Green Mountain gneiss does extend across the whole State.

In accordance with this opinion, a band of gneiss is represented in the section through Hoosac Mountain on the line of the tumnel and occupying its middle third. ${ }^{2}$

These furtlier details are given concerning the gneiss along the north border of the State:

The eastern part of this range as it first appears in Vermont is a very distiuct gneiss. . . . It lies much to the east of the Green Mountains. . . . That which forms the axis of the Green Mountains in the southeast part of Stamford is scarcely distinguishable from mica-schist. . . . In the village of Stamford and at Hartwellville the gneiss almost passes into quartz rock. . . .

In Whitingham and Readsboro there is a large amount of dolomite and saccharoid limestone present in the gueiss in the form of beds. The gueiss west of Deerfield River in Readsboro is rather peculiar. It is a very coarse, greenish, massive rock, sometimes containing multitudes of garnets and blotches of what resembles clay slate. Most of the course of Deerfield River in Vermont lies in the trough of a synclinal. Hence the strata of gneiss in a part of their course, as in Wilmington, are nearly horizontal. ${ }^{3}$

Distribution.-An inspection of the map will show that the Hoosac schist extends farther east here (at the north) than farther south, and that its upper boundary is more irregular. Entering the town of Rowe from Vermont, the upper boundary goes southwest across that town, crosses the Deerfield River at the northwest corner of Florida, and, bending in a great semicircle open to the north, it leaves the county across the west line of Monroe, so that nearly the whole of this town is underlain by this rock in a broad anticline, with north-south axis and sharp southward pitch.

North of the tunnel entrance, at the last house on the river road before the Monroe line is reached, the Hoosac schist is abundantly exposed behind the house and 800 feet south of the line, while about the same distance farther south the overlying Rowe schist occurs. 'The latter is a much 
crumpled magnetite-hearing muscorite-schist (the mica often hydrated), with an abundance of the characteristic chlorite.

The Hoosac schist appears in its usnal development as a small porphyritic mica-schist or angen-gneiss It very closely resembles the Rowe schist above, except (1) that it is darker and (2) that there are developed in large numbers between the folia small, rounded grains of feldspar 2 to $3^{\text {mm }}$ across, so that the rock may be called a feldspathic hydromica- or sericite-schist. It contains the same chlorite as the rock above, though in greatly lessened quantity. It thus differs decidedly from the granitoid gneiss of Becket and Shelburne. Its feldspars have been determined by Dr. J. E. Wolff to be albite, though as a rule they lack the triclinic striation on cleavage faces. The Hoosac and Rowe schists both strike N. $80^{\circ}$ E. and dip S. $60^{\circ}$ at this point, so that the former dips beneath the latter.

Going west, the boundary closely follows Mill Brook, arching round to the northwest, and crosses the road to Florida, just south of where this brook crosses it, with a strike of $\mathrm{N} .30^{\circ} \mathrm{W}$., the Hoosac schist dipping $65^{\circ} \mathrm{S}$. beneath the Rowe schist. Still following the curvature of the brook, the Hoosac schist strikes east-west south of C. Stafford's sawmill and dips $30^{\circ} \mathrm{S}$. beneath the Rowe schist, and the beds continue in this posture to the west line of the town. Both the Hoosac and the Rowe schists are quite uniform in character along this line.

From the point of starting on the Deerfield River, the boundary bends around to the northeast, crossing the road from Monroe to Rowe just south of the second brook-crossing and north of J. F. Brown's, with a strike of $40^{\circ} \mathrm{E}$., the gueiss dipping $40^{\circ} \mathrm{SE}$. beneath the schist. The Hoosac is here a dark, subporphyritic, gneissoid biotite-mica-schist. Farther on it swings round to rm N. $20^{\circ} \mathrm{E}$. and dips $20^{\circ} \mathrm{E}$. and crosses the town line with the most westerly of the roads from Rowe into Vermont, far to the west of the point where upon the Vermont map the corresponding boundary is made to cross the State line. The boundary is well defined in Massachusetts, and especially well exposed where it crosses the Monroe-Rowe road in a ravine visible to the east from the road. One sees to the left (northwest) the whole hillside made up of the subporphyritic gneiss (Hoosac), to the right a dark, rusty, barren mica-schist (Rowe).

The boundary of the Hoosac schist upon the Becket gneiss below is found far beyond the border of the county to the west, and Dr. J. E. Wolff 
was so kind as to guide me to it. Just south of where the tumnel crosses the west line of Florida the Becket gneiss wraps around the Archean nuclens of Hoosac Mountain and the feldspathic mica-schist wraps around the Becket gneiss, and Dr. Wolff called my attention to the fact that the mica-schist is at base a rather dark garnetiferous mica-schist.

Thickness.-I have not been able to form an opinion concerning the thickness of the Hoosac schists from this region. They are cut across in the Hoosac Tumel and are 7,000 feet thick measured horizontally, and this with a mean dip of $35^{\circ}$ would give 4,000 feet for their thickness, but it is not certain that the section is free from repetitions or faults.

THE MIDDLEFIELD AREA.

The band of Hoosac schist continues from the point where it leaves Momroe, in Franklin County, a little east of south across Berkshire County to the point where it enters Middlefield, in Hampshire Connty; and in all this distance (24 miles) I have found the bed to maintain its character unchanged. There is a garnetiferous mica-schist stratum at the base, and above this a heavy bed of a feldspathic mica-schist fairly well deserving this name, as it is not so albitic as that in Monroe. It changes everywhere rather suddenly into the stratum above, the change consisting only in the disappearance of the porphyritic albites and part of the mica, the rocks being otherwise alike.

In both the mica is very extensively hydrated and greasy to the feel, and the rocks have beeu called talcose schists, talcoid schists, and, lastly, hydromica- or sericite-schists. It is generally barren, but in some bands is garnetiferous. The garnets are uniformly quite large -12 to $15^{\mathrm{mm}}$ may be an average-and are widely scattered through large beds of the rock, not often massed together in a single layer, as in the calciferous micaschist. They are almost always trapezohedia, while in the last-mentioned schist they are rhombic dodecahedra. They are often surrounded by a layer of chlorite, which has sometimes wholly replaced the garnet, and scattered bunches and scales of the same green mineral appear everywhere on the cleavage surfaces of the schists, distinguishing this and the Rowe, Savoy, and Hawley schists from all others in the series. The micaceous minerals are generally present in but small quantity, and much of the rock could be described as a micaceous quartz-schist. 
As it blends sonthwardly with the Rowe schist, which becomes feldspathic, and as it is here also doubled by its reappearance in East Granville, the whole of its southern portion was associated with the gneiss below by President Hitcheock, ${ }^{1}$ thongh in his first publication he suggests doubtfully "the passage of the mica-schists into gneiss along the line of strike," and reiterates the idea more decidedly in the first report on the geology of Massachusetts. ${ }^{2} \mathrm{He}$ continues, however, to color his map in accordance with the lithological character of the rock, representing the gneiss as a broad wedge, tapering northward, and the mica-schist as a wedge of about equal size, tapering southward and scarcely reaching the south line of the State. Prof. C. H. Hitcheock, from a study of the data given by his father, and of Percival's report, has in part corrected this in a map published in Walling's Atlas of the State of Massachusetts. ${ }^{3}$

\section{SECTION ALONG THE BOSTON AND ALBANY RAILROAD.}

The variety presented by the schist from below upward is well illustrated by a continuation of the section along the railroad from the point reached upon page 32. Just east of Bancroft station, where Factory Brook joins the Westfield River, the lowest bank of Hoosac schist rests upon the granitoid Becket gneiss with clear unconformity. It is a welldefined liydromica-schist, light-gray, quartzose and thin-fissile, but porphyritic with an abundance of small albite crystals, which are of rounded outline and are filled with the quartz grains in the midst of which they have formed.

Twenty rods east, at the beginning of the cutting, the green-spotted lhydromica-schist carries large, fine garnets $(\infty 0)$, and alternates through the cut with sandy gneissoid layers-layers which are gneiss in composition, but of an arenaceous texture, like that of the Devonian feldspathic quartzites described later from Bernardston, rather than that of the older gneisses. The appearance of the rock is as if a later development of feldspar and mica in a sandstone had transformed the rock into a gneiss which retains a sandy texture very different from that of the lower gneisses, where the constituents are closely interwoven.

On passing the second bridge the hydromica-schist, still feldspathic, is

1 Geology of the Conuecticut: Am. Jour. Sci., 1st series, Vol. VI, 1828, p. 19

${ }^{2}$ Geology of Massachusetts, 1835, p. 332.

${ }^{3}$ Boston, 1871. 
filled with flattened lenses, placed with the bedding, of quartz and of quartz and feldspar; and from this point the road runs for nearly a mile through an almost continuous cutting of the light-gray, flat-bedded hydromicaschists belonging to the next series-the Rowe schists, which are without accessory minerals of any kind and preserve a monotonous uniformity. The dip is nearly vertical, and the section line is nearly at right angles to the strike.

\section{RELATION TO THE BECKET GNEISS.}

It has been already stated that at the brook junction east of Bancroft station the change from the compact, flesh-colored, granitoid gneiss of the Becket series below to the porphyritic hydromica-schist is abrupt: 'The contact between the two is exposed for a good distance and is a fissure, the rocks not being welded together, and the discordance in strike is considerable and in dip very large. There is certainly unconformity and probably faulting at this point, but the nearness of the point to the area where the Becket gneiss is so irregularly wrapped around the southern end of the Hinsdale gneiss, and the fact that the Becket gneiss is peculiarly irregular in structure clear up to the junction, make it possible that this unconformity is only local, and at all events deprive it of a decisive weight in settling the question of real unconformity. The junction can be well followed north from the railroad to the center of Middlefield, and the series retains exactly its character, showing a great development of feldspathic hydromica-schists and imperfect, sandy gneisses, and above these a much greater mass of barren, gray, and green-blotched schists, belonging to the Rowe schists. The transition between the two series-the gneiss and the feldspathic schist-is best studied between the village and the Fair Grounds in Middlefield Center.

Just below the point where the roads join at M. Smith's, south of the Fair Grounds, the Rowe hydromica-schist, while retaining exactly its dip and strike (strike N. $10^{\circ} \mathrm{E}$., dip $70^{\circ}$ to $80^{\circ}$ E.), its flat-fissile, schistose appearance, its gray surface spotted with green, and the multitude of small corrugated and twisted quartz lenses, becomes indistinctly porphyritic, the feldspar here and there cementing together a group of sand grains. As one goes lower (i. e., westerly) this alternates many times in thick and thin beds with the common hydromica-schist, often chloritic, until the beds which strike through the Fair Grounds become a quite well-characterized 
gneiss, but still filled with the small tortuous quartz veins, and differing from the Becket gneiss below by the presence of two micas, the muscovite being the prevailing variety. In the village itself, but a few rods farther west, the true Becket gneiss appears and occupies all the region westward with exactly the same strike and the same high dip, and though the exact line of contact is not exposed, there is nothing to suggest unconformity. Everything here points to a gradual passage of the gneiss up into the hydromica-schist. On the other hand, the rocks here all stand vertical side by side and have been subjected to the greatest compression, and the traces of an unconformity of considerable importance may well be masked.

However, going south from the railroad across Becket, Blandford, and Tolland, along the winding junction line of the two formations, one finds marked evidence of a considerable unconformity, in that while the newer formation conforms in strike to the undulations of the boundary line, dipping away from it to the east, the strike of the older is in all this distance uniformly $\mathrm{N} .40^{\circ}$ to $45^{\circ}$ E., almost at right angles to the boundary, and thus to the strike of the newer rocks.

I conclude that the unconformity between the two formations is general, and that the feldspathic character of the lower half of this formation is due to its derivation from the older gneisses, against which it rests in the form of a coarser, feldspathic material, while the upper portion was a more arenaceous sediment, largely deprived of its alkaline constituents, and this conclusion seems to me strengthened by the study of the same junction on the east side of the Comnecticut.

THE GRANVILLE AREA.

This area comprises Blandford, Tolland, and Granville, in Hampden County, and Hartland and Gramby in Connecticut.

Sonth of the railroad section given above, along the south line of Middlefield, the feldspathic mica-schist continues across Becket in Berkshire County to its sontheast corner, and there it enters the Granville quadrangle at its northwest corner, and at the same time Hampden County. Its relations, especially to the Rowe schist above, can best be studied on the road west from Chester, where the pale greenish-gray hydromica-schist (Rowe schist) succeeds the homblende-schist as one goes west from the Emery mine, and is well exposed at the iron watering trough. Just beyond the first 
bridge in Becket the gray, garnetiferons, feldspathic mica-schist sets in and continues to the sawmill, where the Becket gneiss appears in a large quarry. Still farther south, in the west corner of Blandford, the Rowe schist narrows and occupies only the width of the North Neadow Pond, but is still a welldefined band of sericite-schist, while the Honsac schist retains its width and appears in the high hills west of North Blandford.

Two miles farther south, at Blair Pond, the rock from the Becket gneiss below to the hormblende-serpentine band above, and including thus both the Hoosac and Rowe schists, is a rather coarse mica-schist, not sericitic, but quite feldspathic, and in places abounding in staurolite crystals. The country begins in this latitude to abound in granite stocks and swarms of dikes, and the feldspathic character of the schists seems to depend largely on an impregnation from this granite, and the feldspathic constituent is arranged in flat blotches on the foliation faces, rather than in abuudant small porphyritic crystals, as is the ease farther north. The lithological distinctuess of the Hoosac schists and the Rowe schists disappears, from the loss of the hydrated mica in the upper bed and of the porphyritic albite in the lower, and I have not tried to separate the two beds in the Granville quadrangle.

By the development of three anticlines in these schists, in the two onter of which the Becket gneiss comes to the surface, and by the troughing out of the hornblende-schists in the intervening synclines, this complex expands eastwardly to cover the whole of the Granville quadrangle, wrapping around the separate area of gneiss in East Granville and Granby. (See map, Pl. XXXIV.)

Granite continnes abundant, and the rock becomes in the whole southern portion of the Granville quadrangle a very coarse muscovite-biotiteschist, showing on foliation faces continnous films of large mnscovite plates, or muscovite and biotite regularly intergrown, with, at times, feldspar or pegmatitic quartz-feldspar masses in the interstices, in place of the usual granular quartz. Toward the base of this complex on its western border, and in better developinent aronnd the Granville gneiss, is a rock of very attractive appearance. It is a white, gneissoid rock of rather coarse grain. In the limpid, granular quartz mass the rather distant scales of silvery muscovite, pale-red biotite, and pyrite are compressed into perfect parallelism, so that on foliation faces a very bright, silvery luster occurs. Considerable well- 
striated plagioclase appears in limpil grains in the gramular quarty gromml, and the rock is the gneissoid development of the allitic Hoosac schists, whose places it takes, though it did not seem comstant enough to furnish a basis for the division of the rock in mapping.

HORNBLENHIC BANDS IN THE ALBITIC MICA-SCHIST.

Along the eastem portion of the area, on the east slope of Sodom Monntain, in Granville, bands of nodules of a pale-green actinolite-grarnet rock occur, of a type which, so far as I have observed, has always been derived from limestone.

On the west slope of the same mountain is a narrow band of flat, fissile, garnetiferous homblende-schist of gneissoid structure. The hornblende is in black, shining grains, and the mass of the rock is black, but is closely spotted with round; whitish spots $4-6^{\mathrm{mm}}$ in cross-section, in which the hornblende is in larger crystals but much less abundant. Farther south the same rock contains garnets of the same size and arrangement as the whiter spots, so that it seems the hornblende may have been kept out of these spaces by garnets which have since disappeared, to give place to a later development of larger crystals of hornblende.

THE SHELBURNE FALLS ANTICLINE.

Nearly everywhere around the Shelburne Falls anticline hornblendeschist seems to rest directly upon the gneiss, and in several places it can be seen to do so, but on the west side, near J. W. Whitney's, there occurs just below the homblende-schist a white quartzite containing distant scales of biotite, magnetite octahedra, and rutile needles. This may be taken as a possible remnant of the hydromica-schist series. (See section 3 of the Hawley section sheet, Pl. XXIV.)

Accessory minerals.-Excepting garnet, which occurs locally in the greatest abundance in large crystals $\left(12-20^{\mathrm{mm}}\right)$, generally witl trapezohedral form, the formation is very poor in accessory minerals.

Staurolite accurs in quite good crystals, in both forms of twinning, on the road west of Blair's pond, in Blandford.

Cyanite appears in gray crystals just where the formation crosses the State line on the south, and near the south line of Blandford on the West Granville road. 
THE ROWE SCHIST = THE LOWER SERICITE- OR HYDROMICA-SCHIST.

For two-thirds of the way across the State, starting from the north, the stratum between the albitic mica-schist below and the interrupted hornblende-serpentine band (the Chester amphibolite) is a thick but extremely monotonous bed; and as for the purpose of working out the architecture of the region every valid distinction needs to be utilized, I have marked this bed separately from the Hoosac schist as far south across the State as practicable. It is the rock of the first 7,000 feet of the Hoosac Tunnel. In Hampden County, as already indicated, it becomes feldspathic, and can not be easily distinguished from the band below, as it is followed south from that region.

FRANKLIN COUNTY.

The schist enters Franklin County from the south, across the line between the east portal of the tunnel and the great serpentine deposit at E. King's, nearly a mile east, and, with ligh dips to the southeast, bends around the south end of the Green Mountain gneiss, and extends, with a width of a mile, northeast into Vermont.

At the tumnel portal and east to the serpentine it is a very quartzose, pale-green, hydromica-schist, stretched so that it has often a ligniform structure. It contains a few garnets, trapezohedra, and many flattened lenses of quartz, which rarely contain dolomite.

Followed northeast, where it crosses the Rowe-Monroe road it is very chloritic in its upper portion, and at the base is a dark, rusty mica-schist, resembling the Conway schist.

A thin section was cut from the rock 4,000 feet from the east portal of the tumnel; it is a light-gray, schistose rock of greasy feel, a true sericiteschist, from whose powder the magnet removes much magnetite. It slows under the microscope a mosaic of fine quartz grains, dusted with magnetite and wrapped around with muscovite and pale-green chlorite scales.

HAMPSHIRE COUNTY.

As the Rowe schist crosses Middlefield it has the same monotonous character. It is, however, more garnetiferous, and the garnets are very generally chlorite-bordered, and on foliation faces blotches of chlorite appear mixed witl the hydrated mica. 
It is best studied in the continution of the section along the Boston and Albany Raihorad, begiming at the point reached on page 72 , at the second bridge east of Middlefield station. There is from this point a nearly continuous entting for almost a mile through these light-green, quartzy sericite-schists, here wholly barren and monotonous.

Just beyond the fourth bridge many beds of a flat-fissile, epidotic amphibolite and of sericite-schist are exposed, as follows, eastward from the bridge:

Section of Rowe schist containing amphibolite.

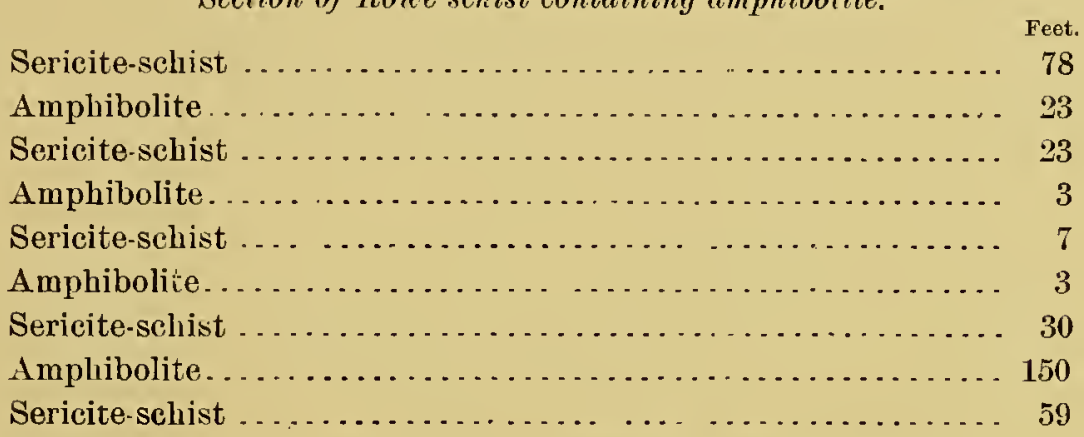

The same rock extends, poorly exposed, with a single small band of amphibolite to the Chester amphibolite at the Chester line; whole thickness, 820 feet.

This is the first case where any amphibolite occurs below the Chester amphibolite, and it is here that the remarkable overfolding or overcrushing of the vertical beds of thin-fissile amphibolite occur, which has been figured by President Hitchcock, who refers it to crushing by ice. ${ }^{1}$

\section{HAMPDEN COUNTY}

The rock is best studied along the Chester-Becket road, westward from the Chester emery mine, where much rock cutting has been done to protect the highway from the mountain brook along which it rums. It is a soft, greasy sericite-schist, often becoming very quartzose and then of firmer: texture. It enters the Granville quadrangle (and at the same time Hampden County) at its northwest corner, and continues with a width of half a mile to the pond at North Blandford. Two miles farther south, as noted in the description of the Hoosac schists, the whole area across from the Becket gneiss to the Chester amphibolite is biotitic and feldspathic and not marked 
by hydrated mica. As the intervening area is almost wholly covered, the line is drawn upon the map with much doubt.

\section{THICKNESS.}

The section gone over from the Middlefield station to the top of the series at the Chester line is, measured directly across the strike, 6,970 feet, which, with an average dip of nearly $80^{\circ}$, would give a thickness for the series of 6,897 feet, provided there be no repetitions from close folding or secondary structure simulating bedding-a thing one would be very unwilling to admit. This includes, it will be noticed, the two beds between the Becket gneiss and the big hornblende bed; that is, the Hoosac and Rowe schists.

\section{THE CIIESTER AMPHHBOLITE AND SERPENTINES.}

The albitic mica-schist and the lower sericite-schist already described, the hornblendic band which is separately discussed in this chapter, and the upper sericite-schist and the chloritic schist next to be treated (that is, the Hoosac schists to the Hawley schists, inclusive) are certainly one conformable series of beds, and form a group well demarcated from all above and below. The correlation of the strata has been attended with great difficulty, owing in large part to the fact that southward along the line of strike the hydration of the mica becomes less, and at last becomes inappreciable, while the chlorite also disappears and the feldspar increases in quantity, so that what in Hampshire Comty is well-characterized hydromica and chloritic schist becomes in Hampden feldspathic mica-schist, or even quite wellmarked gneiss. ${ }^{1}$

I have therefore found the broad band of amphibolite, associated abundantly with serpentine and talc, althongh interrupted, to form an exceedingly useful horizon clear across the State. Carrying as it does the unique emery vein at Chester, it is also of great interest in itself.

\section{GENERAL DESCRIPTION.}

The amphibolite is a dark-green rock, either flat thin-fissile or ligniform, and rarely massive. It is almost always epidotic. Aloug its easterm (that is, its former upper) surface at various points occur great masses of serpentine or serpentine and steatite (the latter above the serpentine), or rarely

${ }^{1}$ This change is caused by the great quantity of grauite in and south of Blandford, from which the schists are greatly soaked with feldspar. 
of steatite alone. These lenticular masses have eaten their way into the amphibulite for various distances, and it is suggestive that they always appear along the upper surface of the amphibolite, or on the upper surface of separate bands where, as is often the case, the latter rock does not occupy the whole space assigned to it on the map, but las intercalated subordinate layers of sericite-schist.

The Chester emery bed occupies the same position along the eastern border of the amphibolite. The character of the serpentine bands which accompany the amphibolite changes in Blandford. At Osborn's quarry is a bed of sallite-serpentine, one of olivine-serpentine, and the first of a series of enstatite-serpentines, which, as the bed is followed, becomes of greater relative importance and gradually almost replaces the amphibolite and is itself at last almost replaced by coarse dolomitic limestone.

The band is in its whole extent conformable with the sericite-schists and runs across the country with dip rarying very little from $90^{\circ}$ and in strike conforming to the winding of the schists.

\section{FRANKLIN COUNTY. \\ THE ROWE SERPENTINE.}

In the northern portion of the State the band enters the town of Rowe from Vermont, exactly at its northeast corner, and extends southwest across the town as a heavy bed, 10 to 20 rods wide, of a black, thick-bedded, epidotic amphibolite. It seems to be continued far north to the important actinolite bed at Newfane. It is well exposed at the bottom of the hill soutl of the house of J. Streeter, jr., and rums about a mile west of Rowe Center, where, 49 rods northeast of A. C. Bliss's, it carries on its east border a heary bed of steatite (bed No. $1^{1}$ ), which is very hard and chloritic. From this point it takes the same curve as the Deerfield River to the west, and forms the crest of a ridge until, at J. C. Cressy's, it crosses the road running down to Hoosac Tumel. It is here 30 rods wide, is very fine-grained, black schist in its western portion, and on the east is an epidotic quartz-hornblende-schist, and there are one or two other bands a few rods east in the hydromicaschist. It continues down the hill, and where it cuts across a sharp bend in the road it changes suddenly almost entirely into serpentine and steatite (bed No. 2), only 7 feet of the amphibolite remaining on the western border.

\footnotetext{
1 For convenience of reference I have numbered the beds of steatite and serpentine described in this section.
} 
Here the following section is exposed, from below upward, i. e., from west to east:

Section at Rove serpentine quarry.

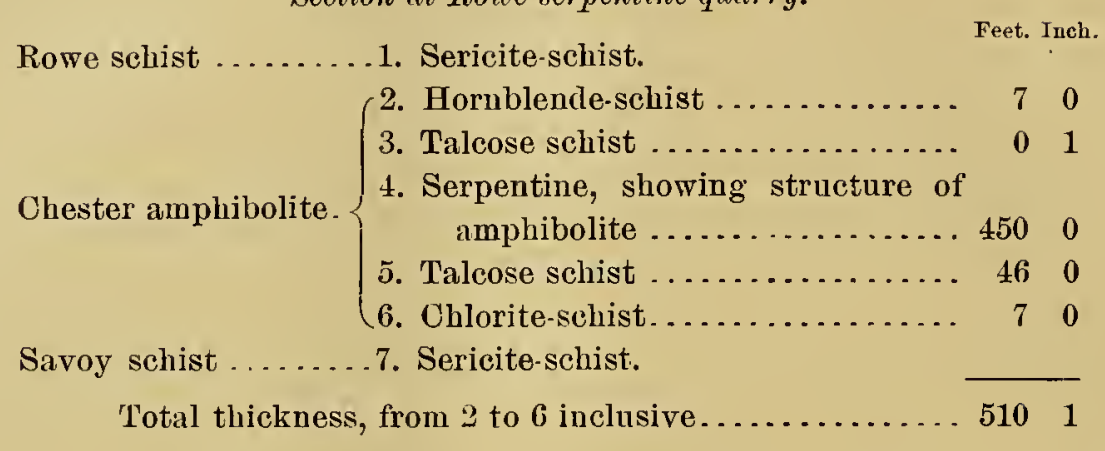

No. 4 is a serpentine altered from amphibolite; 3 and 5 are masses of schistose talc, representing a further stage of the alteration. It abounds in dolomite. It has been extensively quarried, but the large buildings erected for working it are abandoned.

\section{THE EAST PORTAL FAULT.}

The series maintains a width of about 30 rods down to a point 100 feet abnve the Deerfield River, and the continuation of the band can not be found across the river on the south; but it is shifted a mile to the west, to Mount Serpentine, by an important fault running in the bed of the Westfield River at this point. It is thus carried beyond the limit of Franklin County, but as it is still within the Hawley quadrangle its further course is traced to the point where it enters Worthington, in Hampshire County.

The steep mountain rising west of Rice's tavern, at the east portal of Hoosac Tumnel, and easily distinguished from the others that surround the valley by its bare precipitous walls, is Mount Serpentine, and is a great mass of the rock which has given it its name. Its north face seems to be the face of the fault here described; its east wall appears to be formed by the peeling off of the vertical schist from the massive serpentine.

The mountains as seen from the valley are projections of the plateau, notched by the successive brook gorges; and taking the road running up southwest from Rice's tavern, one finds at the first brook-crossing a magnificent bowlder of serpentine, and can climb by this brook to the serpentine overhead. By following the road to the first house, and then going 50 rods west, one comes on the serpentine, after passing a band of 
amphibolite 6 rods wide and 10 rods of swampy ground, probably in whole or part underlain by steatite (bed No. 3). Then comes the darkgreen serpentine, which is here 35 rods wide, and it is followed immediately by black, thin-fissile amphibolite. This is so clearly a repetition of the series at the soapstone quarry given above that a fault, substantially as shown on the map, is quite certainly present.

Where the berls cross the road to the sonth they are covered, and continue so as far south as I could penetrate in this wilderness.

At latitude $42^{\circ} 35_{3}^{2}$, longitude $72^{\circ} 55_{4}^{3 \prime}$, the amphibolite appears again, and the line of boundary is drawn approximately from the strike between these points, as the amphibolite conld not be found and the sericite-schists above and below the amplibolite are hardly distinguishable. Indeed, at the cross-roads a mile north of the last locality the sericite-schist is almost continuously exposed, but careful search failed to disclose any amphibolite.

From the last locality the amphibolite makes a bend to the east and cuts across the sharp curve in the road next south. On entering the Chesterfield quadrangle, the amplibolite, where it crosses the road near Swift River, in Windsor, is changed to steatite (bed No. 4), and at Jordansville the schist is well exposed in the brook southwest of the village.

HAMPSHIRE COUNTY.

THE MIDDLEFIELD SERPENTINE.

Reentering the county, the amphibolite appears just west of the village of West Worthington, and can be traced thence southward. At H. Smith's, in the northwest of Middlefield, it has on the east a fine deposit of serpentine (bed No. 5), bordered on the east by talc. Along the east side of a band of the common amphibolite rests a mass of dark-green serpentine, and next east a great mass of steatite, often carrying large nodules of the finest dolomite surrounded by delicate-green tale, and on the east sericite-schist folds around the great boss of steatite, as if it had been present-or, rather, as if the rock of which it has been formed had been present-as a foreign and resistant body during the compression of the schists. The steatite is here 66 feet wide, and it furmishes the best material in its upper half. It is opened in a quarry 41 feet wide and 82 feet long, and is separated from the amphibolite opposite the quarry by only 16 feet of covered space; so MON XXIX- 
here the serpentine can have at most only this thickness, though it swells a few yards north to treble this thickness at the expense of the steatite, which runs on north for a distance of 492 feet, with a thickness of 10 feet, and enlarges again into a pocket of harder soapstone.

The deposit extends southward across the road, and is then opened again in a large quarry on the land of Mr. Howard. The New York Metropolitan Company has quarried 200 tous, paying a royalty of 50 cents a ton, and the material was ground at a mill in the valley to the east. About as much more had been gotten out earlier, but no work was in progress at the time of my visit (1877). This is a type of all the serpentine and talc depositsa lenticular mass of serpentine replacing the amphibolite in its upper layers, and, as it were, eating into its mass and suggesting strongly that it has been formed at the expense of the schist and itself changed later for a varying distance downward into talc.

In a recent interview published in the Springfield Republican, ${ }^{1}$ the discovery by Dr. H. S. Lucas of another bed of emery, or the continuation to the north of the Chester bed, is announced. It is at a point a mile east of Middlefield and a mile and a half nearly due north of Chester, on land of Frank Smith, and the land has been purchased by Dr. Lueas. It is associated with hornblende-schist, as is the Chester bed, and is quite certainly the continuation of this bed northward. The specimens from the new locality shown me by Dr. Lucas contain grains of blue corundum.

Southward on the strike the outcrops are not abundant, but they are sufficient to show that the amphibolite is probably interrupted for a considerable distance, though it may be continued as a narrow band, somewhat shifted by faults. Two miles sontheast of the cheese factory it appears again in great force, and immediately to the east of it the serpentine (bed No. 6) appears in still greater force. The two expand rapidly to a width of 200 rods and run as a prominent range of hills over the town line into Chester, dropping down suddenly to the brink of the Westfield River. On the east and west the vertical sericite-schists, $200 \mathrm{rods}$ apart, inclose this great double bed of amplibolite and serpentine, and are continuous across the river to the south, and the western half of the bed, the amphibolite, also continues across, its eastern half, the serpentine, being replaced by amphibolite in the bed of the river. The boundary between the two, which may

2 "Another vein of corundum:" Spriugfield Republican, December 12, 1895. 
be found just opposite a shoddy mill near the river, runs in a great eurve $\mathrm{N} .30^{\circ} \mathrm{W}$, so that the serpentine encroaches still more on the amphibolite and at last occupies nearly its whole width. An inspection of the map (Pl. XXXIV) shows that the course of the river, where it separates serpentine and amphibolite, is in sonthward continuation of this curve, and that the serpentine is lodged as a great lens, a mile and a half long and nearly a half mile wide, in the amphibolite. The boundary line between the two runs up the hillside in a narrow gorge, its bottom everywhere encumbered with bowlders, and the amphibolite and serpentine could not be found nearer each other than 10 feet. At that distance there was no trace of transition from one into the other. Search was made for the boundary between the serpentine and the sericite-schist on the east for a mile north through the dense woods, but they could not anywhere be found in actual contact. The contact line was, however, a straight one, following the line of strike of the schist, while the schist, ordinarily a very flat-fissile rock, was for all this distance, and, indeed, for the full length of the serpentine lens, and in a thickness of above 350 feet, thrown into the most extreme contortions and twistings, the like of which I have hardly seen among any of the rocks of the region. This I take to be another indication of the formation of the serpentine before the final folding of the region. It is likewise interesting that along this line the serpentine was in many places, and it seemed continuously, separated from the sericite-schists above by a thin layer of amphibolite, and the serpentine, when traced to within a single foot of this, was complete serpentine. The mass of the latter would seem to be, then, strictly speaking, inclosed in the amphibolite.

As already noted by President Hitcheock, this serpentine mass shows abundant sigus of stratification, and I may add that this not only agrees with the dip and strike of the adjoining amphibolite, but shows closer agreement still with the latter, extending to the exact thickness of the laminæ, the angles and distance of the jointing, etc.; and further, that this structure is one brought out in the serpentine again only by the action of atmospheric agents, below the surface the serpentime appearing wholly compact. The serpentine is the common rather light oil-green variety, and, especially where a fine splintery fracture is developed, it has a dry grayish-green color. It weathers to a deep red brown, and the great ragged hill, bare of vegetation and covered with an almost unbroken layer of immense bowlders 
upheaved by frost, is a very striking object, suggesting immediately the idea of igneous action.

I visited the place once when, after heavy rains, the fine brook which runs down from the high ground in a great gorge lined with bowlders of the weathered serpentine, and the succession of beautiful waterfalls, derived a peculiar charm from their setting in the warm browns and greens of the rugged serpentine masses.

The serpentine locally is rich in chromite, and a considerable excavation made in mining for it exists in the woods near the southeast extremity of the bed. Small veins of precious serpentine, much picrolite, and crusts of hydromagnesite of some thickness occur. It also furnished to Dr. Emmons the well-known pseudomorphs of serpentine after chrysolite, formerly called serpentine after quartz, or hampshirite, the exact locality of which I have not been able to recover, ${ }^{1}$ and was doubtless the origin of the large masses of yellow chalcedony found in Chester by the same geologist. These psendomorphs are large, distinct crystals more than an inch long. They are sixsided prisms terminated by six faces which have some resemblance to the ending of a quartz crystal, in which two opposite faces predominate, but giving the angles of chrysolite. They are covered by a straw-yellow, secondary serpentine of a compact but slightly radiate-fibrous structure (picrosmine); it is homogeneous and almost apolar under the microscope. An analysis was made for me by Miss Helen P. Cook, of the chemical department in Smith College.

Analysis of pseudomorphs of serpentine.

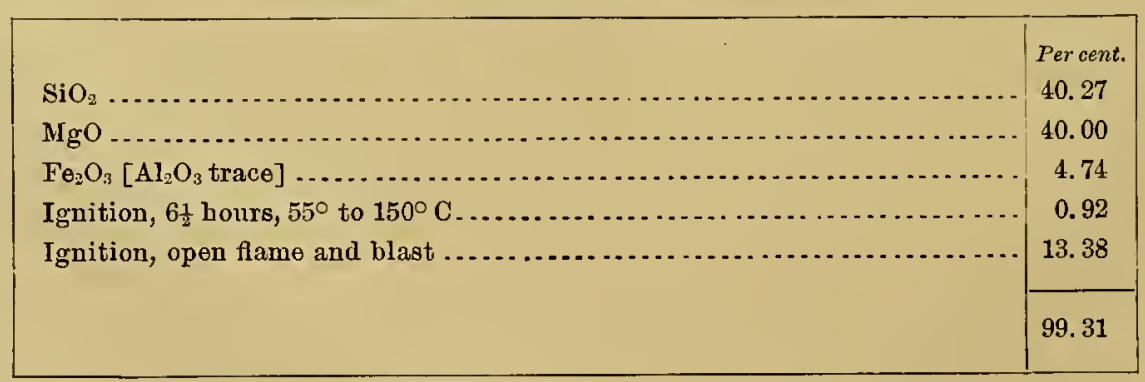

Secondary shrinkage joints in serpentine.-The detached blocks of the serpentine have often suffered secondary decomposition, so common with

\footnotetext{
1 These are fully described and figured, and the proof of their derivation from chrysolite is given, in A mineralogical lexicon: Bull. U. S. Geol. Survey No. 126, 1895, pp. 92, 146, under "Hampshirite."
} 
serpentine, to a depth of 10-15 $5^{\mathrm{mm}}$, accompanied with loss of color, hardness, and volume; and as a result of this last the surface is often covered with a fine system of regular shrinkage joints, one set of straiglit fissures about $20^{\text {mum }}$ apart being cut by another at an oblique angle, the latter about $50^{\mathrm{nm}}$ apart. In places the blocks have all separated from the underlying unchanged mass and lie loosely upon it.

\section{HAMPDEN COUNTY.}

THE CHESTER AMPHIBOLITE AND SERPENTINE.

Following the heavy hornblende band across Chester, where it forms in the north the high, sharp ridge called Gobble Mountain, and in the south the still higher Round Mountain, one finds in the higher part of the first hill a considerable deposit of serpentine (bed No. 7), situated, like the others, at the upper surface of the hornblende, but offering nothing peculiar. Fartler south, in the bottom of the brook gorge between these hills, at the old emery mine, is another deposit (bed No. 8), which is at a level of several hundred feet below the other.

The excavations at the mine exposed the following section from east to west across the vertical strata:

Section at the old emery mine near Chester.

Savoy schist. . . . . . . . Sericite-schist.

Chester amphibolite. $\left\{\begin{array}{lr}\text { Steatite inclosing a few small serpen- } & \multicolumn{1}{c}{\text { Feet. }} \\ \text { tine nodules } \ldots \ldots \ldots \ldots \ldots \ldots \ldots & 4-16 \\ \text { Emery and magnetite bed } \ldots \ldots \ldots . & 6 \frac{1}{2}-10 \\ \text { Fringe rock . . } \ldots \ldots \ldots \ldots 1 \text { inch to } & 10 \\ \text { Hornblende-schist. } & \end{array}\right.$

The small nodules of serpentine, often as large as one's hand, are isolated in the mass of the talc and are permeated by veins of the same material, and doubtless represent the original material from which the talc was formed. The serpentine is the usual variety, dark-green when wet, but, partly from its fine splintery fracture, gray-green when dry. Another variety is rich olive-green, and carries much malachite.

The talc is pale-green, foliated for the most part, and often crowded with dolomite crystals.

THE BLANDFORD SERPENTINES AND PYROXENITE.

The heavy hornblende bed continues with undiminished width across Chester, and is much covered by drift as it crosses into Blandford, where it is 
again well exposed. Northwest of S. A. Bartholomew's house, at his soapstone quarry, some layers of mica-schist are intercalated in the amphibolite. The quarry, from which much soapstone (bed No. 9) has been taken for grinding, is inclosed in walls of chloritic mica-schist, and lies in the prolongation of a bed of the ordinary amphibolite, which is exposed just north of the opening.

There is exposed in the north end of the excavation a layer, 1 foot thick, of light-green talc with scattered needles of actinolite, and east of this, one (the same thickness) of a green, soft, scaly chlorite, with here and there larger plates of clinochlore with very divergent optical axes, and magnetite octahedra. Farther south, in the bottom of the quarry, it can be seen that the steatite bed widens rapidly southward to 10 feet, and a mass of light-green fibrous actinolite appears, from which the whole steatite mass seems to have been derived, as it still retains the radiated and matted acicular structure of the actinolite.

A few rods south of the steatite quarry, and just west of the village of North Blandford, is the great mass of serpentine (bed No. 10) marked upon Walling's map of the county as "The Crater." The name is said to have originated with Dr. Hitchcock, when he thought the rounded, isolated mass, with a large cavity in its center, proof of the volcanic origin of serpentine. It seems to me not improbable that the cavity in question may be an artificial excavation, and it is certain that in early times considerable digging was done there for chromite. It is an oval mass, 328 feet long and 200 feet wide. On the west is a stratum of amphibolite 20 feet thick, which strikes north-sonth along the side and wraps round the north end until it strikes N. $28^{\circ} \mathrm{E}$. This seems to indicate that the change to serpentine took place before the final compression of the rock, or that the original rock was different and less compressible than the amphibolite. Below is the sericiteschist. The serpentine from this locality is easily distinguished from any other by its compactness, its black-gray color, the abundance of disseminated magnetite, and the nickel-green crust from weathering.

Along the strike of the rocks southeast by south the ground is much covered and no further outcrops have been found, though the region has been thoroughly searched in prospecting for emery, until the Osborn soapstone quarry is reached; but several bowlders reported to me by Mr. Bartholomew, viz, serpentine west of the north end of Blair's pond, and soapstone northwest of Pebble's brook, and also west of the Blair's pond road, indicate other deposits in the intervening space. 
The Osborn soapstone quarry lies west of the house of Mr. W. H. Griswold. Passing west over a few rods of sericite-schist, with two granite dikes and a thick stratum of serpentine, and more schist, all with strike N. $40^{\circ}$ W., dip $45^{\circ}$ E., one comes upon a bed (No. 11) of black serpentine 50 feet thick, which can be followed south a considerable distance along the line of strike and ends abruptly against chlorite-schist along a line at right angles to the strike.

It is also underlain by the chlorite-schist, and following the line of strike of this south a few yards, across covered ground, one comes upon the large quarries of a soapstone which has completely the structure of the coarse radiated actinolite from which it has been derived, and fresh and partly altered masses of the latter are also abundant, together with large

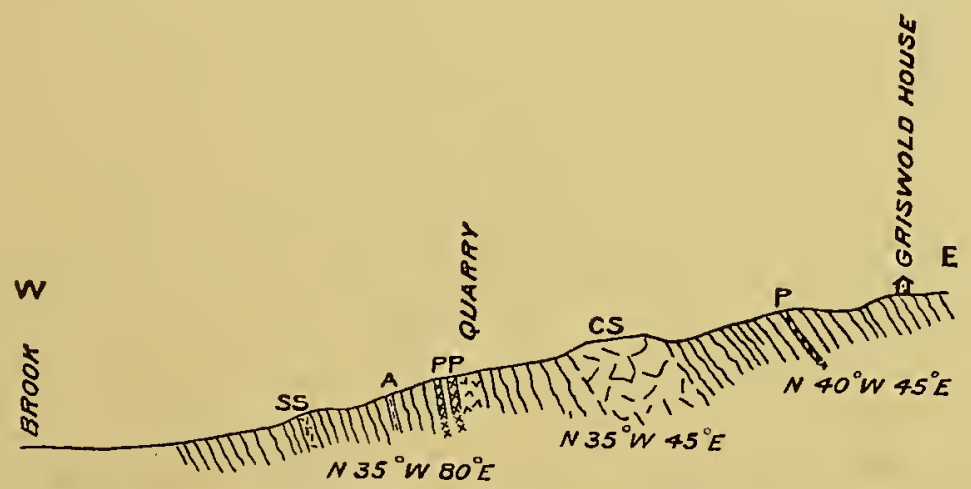

FIG. 5.-Section at Osborn soapstone quarry, Blandford. S S=Sahlite-serpentine; $\mathrm{S}=$ Steatite and enstatite-serpentine; $\mathrm{O}=$ Olivine-serpentine; $\mathrm{A}=$ Amphibolite; $\mathrm{P}=$ Pegmatite; conntry rock= sericite-schist.

masses of coarsely foliated chlorite-a clinochlore with very wide optical angle. The steatite bed is separated by a thin stratum ( 1 inch) of black mica and ene of equal thickness of heavy black hornblende-magnetite rock from a dike of granite.

A small brook runs from this point west through the woods, down over sericite-schist, to the bottom of the valley, where it cuts a great bed of peculiar, streaky, black to gray serpentine (SS; bed No. 12), derived from a very coarse-grained pyroxenite or sahlite rock, which still shows cleavage faces $20-30^{\mathrm{mm}}$ square. This bed seems to have been overlooked before, and it is doubtless the source of many of the bowlders found in the southeastern part of the town.

The old quarry has been opened during the past summer (1895) quite extensively with improved machinery. The whole width of the steatite 
bed has been exposed and a deep trench blasted through the schists to the west for drainage. The following section is now exposed (fig. 5, p. 87): Commencing at the bottom of the hill to the west, one climbs up 15 rods over coarse chloritic sericite-schists abounding in large quartz lenses and quartz-filled garnets sometimes an inch across. The schists dip $80^{\circ} \mathrm{E}$. At 50 feet above the meadow the lower bed of coarse, rudely bedded, black serpentinous rock appears (SS). It shows broad, black, lustrous cleavage surfaces of much-altered sahlite, and no specimens could be found where this mineral was still unchanged, such as were procured in the bed of the brook at the former visit. These cleavage surfaces make up the whole surface, or are somewhat separated and the interstices filled with white calcite and magnetite and shot through with tremolite.

An analysis of the least-altered forms of this rock, which still retains enough of the unaltered sahlite to enable one to make out its optical constants, gives the complete formula of serpentine, and is interesting as showing, as do all the other rocks of the series, a constant content of nickel and chromium. The analysis was made by Dr. W. F. Hillebrand.

Analysis of serpentine from Osborn's soapstone quarry, Blandford, Massachusetts.

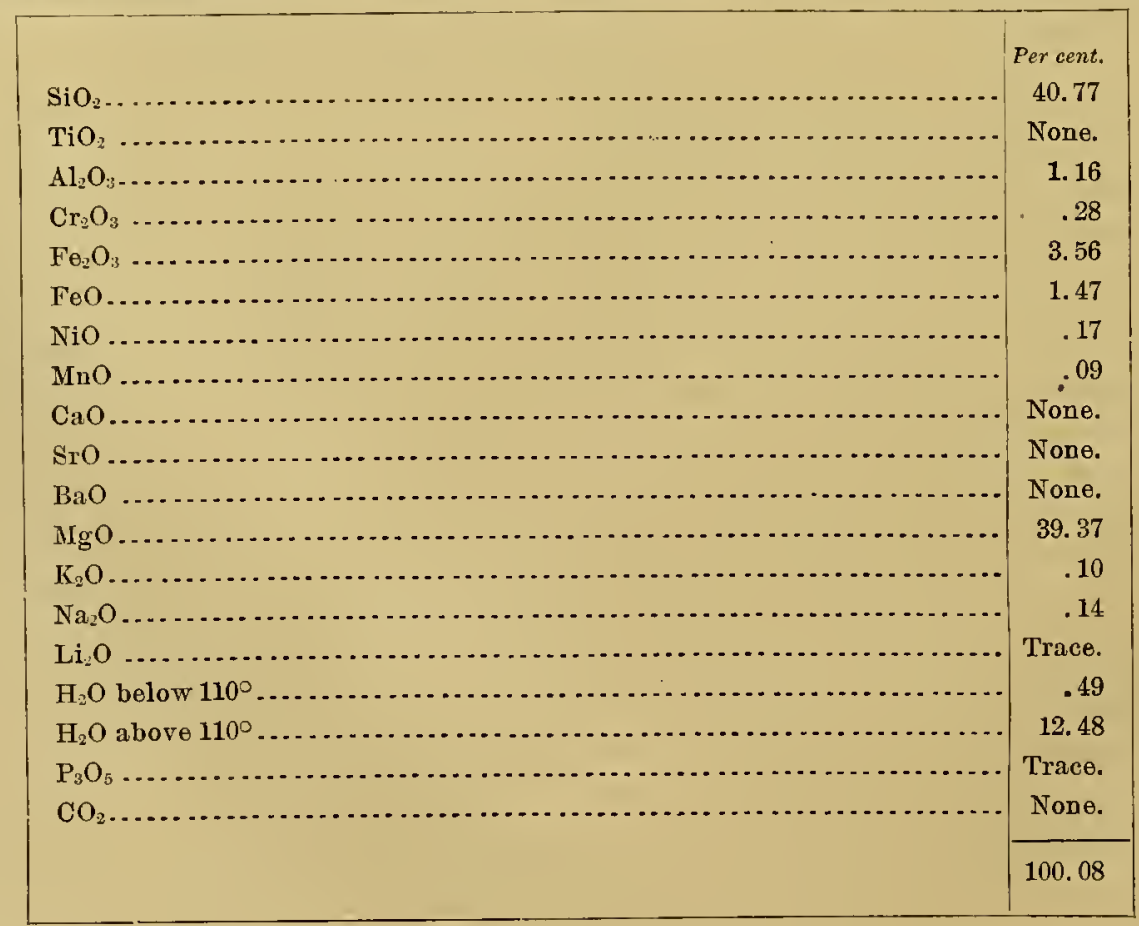


Next east is a bed, 150 feet thick, of finer-grained chloritic sericiteschist, without garnets, and containing a subordinate bed of jet-black, flatberded amphibolite (A), which is made up almost wholly of shining-black needles, the laryer porphyritic in a netwrork of the smaller. Eight feet of coarse pegmatite are followed by the same thickness of schist, and this by 12 feet of pegmatite, which is separated by a thin layer of reddish schist from the soapstone (S), which is 50 feet thick. On the west border is a thick bed of coarse tourmaline in a matted mass of large clinochlore, with a 6 -inch bed of coarse biotite adjacent. The eastern selvage is of coarse transverse chlorite in broad plates, which is often crushed to schist.

The outer sheets of the main soapstone bed are of coarse, matted tremolite, often radiated and plumose, and more or less changed to talc. In the eastern portion of the soapstone bed is a 10-inch layer of fine actinolite, and at the border these actinolite needles change directly into tremolite.

The central third of the steatite bed consists of black enstatiteserpentine, more or less tremolitic and partly changed to steatite, but still quite hard. This is the first bed of this enstatite rock met with, and it becomes increasingly important as the series is traced southward. Layers of an apple-green serpentine fill fissures in this mass. The superintendent informed me that a 2 -foot layer of a black amphibolite, exactly like that described above, ran through the soapstone parallel with the strike in a part of the quarry which was under water. The vein of steatite makes a sharp bend of $90^{\circ}$ to the east, and bends directly back $90^{\circ}$ to the north, and along the east side, where the latter bend is effected, the eastern schist wraps irregularly over the steatite and around a white albite lens, which is enclosed in a thin layer of black, coarse lomblende rock. This bend explains the cutting off of the bed of black serpentine mentioned above, and shows that beyond this sudden fault-like bend the band is less altered to steatite. Indeed, the steatitic alterations may be due to local disturbance, as the development of serpentine farther north seems to be caused by faults.

The next eastern bed is a reddish, quartzose, fine-grained biotite-schist 150 feet thick. This is followed up the hillside by 150 feet of a massive, darkgreen serpentine (OS), which at the base shows much half-changed olivine in granular masses, separated by a later tremolitic growth, followed by talc, all of which is beautifully shown under the microscope. This is the only 
trace of olivine that has been found west of the river, except the Middlefield psendomorphs mentioned above.

A bed of pegmatite a rod wide separates the serpentine from schist, which continues up the hill 412 feet to the Griswold house.

THE GRANVILLE AND RUSSELL ENSTATITE-SERPENTINES.

From the section north of Borden Brook, in the south of Blandford, where the hornblendic complex is made up of several amphibolite beds altemating with beds of sericite-schist, the series continues due sonth into Granville, and is for a short distance interrupted by pegmatite, but attains in Liberty Hill a thickness of 1,237 feet of clear, black amphibolite without interlaminated mica beds. It curves east and then west and retains this great width for a mile, and continues southwest as two bands of amphibolite, each about 15 feet wide. These soon run ont southward, and no trace of them could be found in the well-exposed bluffs east of West Hartland. Where it bends most easterly it contains the heavy bed of steatite (bed No. 13) a mile southwest of West Granville, at the bottom of the bluff east of E. Williams's house. Here some work has been done upon a deposit of steatite, which has been derived from a bed of fine, radiated tremolite; it still retains the structure, and part of it the hardness, of hornblende, and therefore the bed is not a promising one to work. Many bowlders of the black enstatite-serpentine occur near Mr. Williams's house, which must come from another bed of the rock near at hand, as the two rocks seem to be connected genetically, since the tremolite is exactly like that found with the serpentine of the next locality. Just after crossing the State line and Hnbbard Brook the amphibolite band carries a bed of black enstatiteserpentine (bed No. 14), of which about 5 or 6 feet is exposed.

On the sontheast flank of Liberty Hill, in West Granville, a branch of the amphibolite separates from the main bed, as mentioned above, and, bending round sharply, runs north with much diminished thickness, not exceeding 6 feet, to a point west of East Granville, where it bends north again and carries the remarkable bed of enstatite-serpentine (bed No. 15) which occurs in a densely wooded swamp 100 rods east of the house of J. Downey. A ridge 20 feet wide and rising 24 feet is exposed for a considerable distance, and, as usual, the serpentine is associated with amphibolite. It is a black serpentine, made up of crystals an inch square on the end and more than 2 
inches long, pseudomorph after enstatite, and it carries considerable dolomite disseminated, which does not effervesce with HCl. Traced northward a few rods it becomes a compact, gray, thin-bedded tremolite-schist, which lies in contact with an equally thin-berdled, white crystalline limestone which effervesces readily. Southward it is found in many bowlders around the cemetery, and here the limestone contains very fine specimens of a richgreen actinolite, and it crops out farther south on Trumble Brook. The band can be traced north from Downey's, by the abundant bowlders of the black serpentine, to the pasture back of H. Cooley's. The overlying rock in the Cooley pasture is a coarse muscovite-biotite-schist, carrying much cyanite in flat, colorless blades 1 to $1 \frac{1}{2}$ inches long, but 20 feet of covered space, possibly occupied by amphibolite, separates it from the serpentine. The serpentine bed (bed No. 16) is abont 50 feet thick, and is exposed 175 feet in length. Over the weathered surfaces of the ledge the great enstatite crystals project in a close network. These crystals are great plates onehalf to 1 inch in thickness, 3 to 4 inches wide, and in average 6 inches long, while some measure 14 inches in length. They are now changed to a dnll-black serpentine, but still retain the lustrons enstatite cleavage. In the narrow meshes between these large plates is a rather coarse-granular, limpid dolomite, dusted with small magnetite octahedra and broad plates of colorless to oil-green talc. The band can be traced northwest from this point by many large bowlders, and another locality occurs where the rock appears in place southwest of the point where "Wildeat road" bends sonth. Bowlders of the same rock occur northwest, in the bed of the Westfield Little River, at the great bend a mile below "Pothole Rock." From this point no traces of the bed have been found along the line of boundary drawn across Russell to the Atwater ledge, except where this line crosses a little-nsed road, not on the map, which runs west from the sharp bend in the road a mile above Atwater's to meet the dotted road. Careful search has been made in the intervening, heavily wooded country, and the presence of the rock as a continuous band is indicated by the abundant large bowlders strewn over the country for miles sontheast. The next outcrop is the one mentioned above as Atwater's (bed No. 17), from the extensive exposure in the high hill 1 mile N. $30^{\circ} \mathrm{W}$. of the house of F. B. Atwater, in the south corner of Russell and overlooking the Westfield plain. It was quarried quite extensively by Mr. Atwater's father as "black marble." The bed is 
exposed with a width of about 53 feet, when it is cut off by granite. It shows distinct foliation, and is bordered on the west by a biotite-hornblendeschist, which becomes in places a distinct gneiss. It is a black serpentine abounding in the green foliated bastite to which the name marmolite has been given.

THE WESTFIELD SERPENTINE AND MARBLE,

The next outcrop of the serpentine is south of this point, across the Little River, in the western edge of Westfield (bed No. 18). It has been opened by the owners, the Westfield Marble and Sandstone Company, and reported upon during the last year (1895) by Prof. W. O. Crosby, who considers the deposit valuable for verd-antique marble. He reports the following section from east to west, with explanations:

\section{Section in the western edge of Westfield.}

1. Vein of coarse granite (pegmatite)............... Feet. ${ }_{10}$

2. Soapstone and serpentine, with partings of mica-schist and veins of pegmatite .................... 15 to 20

3. Massive serpentinic marble (verd antique), with large crystals .............................. 15 to 20

4. White marble, with thin layers or partings of serpentinic

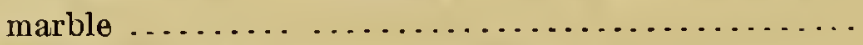

5. Banded serpentinic marble, consisting of very thin alternating layers of white marble and serpentine....... 15 to 20

6. Shaly serpentine and marble and banded serpentinic marble................................ 20

7. Massive black and green serpentine ............. $\quad 50$

8. Soapstone and serpentine, concealed............. 10

9. Fibrolitic ${ }^{1}$ mica-schist and granite............... trace.

The most interesting and valuable bed in this series is the verd-antique marble (No. 3). This is a very solid bed, and of fairly uniform character, considering the coarse structure of the marble. The serpentine, which has evidently resulted from the alteration of actinolite, is in the form of sleuder crystals from 1 to 3 inches in length, lying at all angles in a matrix of white crystalline limestone. Near the east side of the bed the structure is finer and somewhat banded, as in bed No. 5. This verd-antique marble is a striking and, so far as I know, nnique stone, of ornamental character; and I can see no reason why it should not give satisfaction in use. Although it would, I am confident, prove serviceable in exterior work, it is to be especially recommended for interior work. It is susceptible of a good and lasting polish, and this, together with its nnique, breccia-like structure, should insure a demand for the stone when it is properly brought before the public. It is probable 
that at a somewhat greater depth bed No. 4 , which could be very easily worked with No. 3, would yield some good white marble. A part of the banded marble in beds 5 and 6 is of a decidedly ornamental character and well adapted for some kinds of decorative work.

At the north end of the quarry a dike of granite cuts off the strata, and although there are indieations that the marble continues beyoud it, this has not been proved. So far as known, the marble is entirely wanting north of the river. South of the quarry the marble beds, although not actually exposed, are quite certainly continnous for 200 to 300 feet, when they are again cut off' by a mass of granite.

The quarry, to which I was guided by Professor Crosby, is situated in the extreme western part of Westfield, and is reached by leaving the electric cars at the crossroads east of the old Atwater place and going three-quarters of a mile south, passing two houses south of the Little River bridge, and going west by a field road, which runs northwest about a half mile to a point 380 feet above the sea and overlooking the valley of Little River.

The quarry throws much light on the problem of the origin of the enstatite beds. It contains three distinct beds of first importaince:

The first, the "black marble," like that of the old Atwater quarry, is a black enstatite rock of coarse grain and wholly massive structure and slightly bronzy luster (the enstatite cleavage showing in faces one-half inch in width by 2 to 4 inches in length), now in various stages of serpentinous change, and mottled with foliated masses of bastite (marmolite), derived from the enstatite, which are of high luster and rich apple-green color.

The second bed is a black spotted marble-a white or grayish, rather coarsely crystalline, magnesian limestone-containing much shining tremolite, effervescing moderately with strong hydrochloric acid, and spotted with elongate crystals of the same black altered enstatite, one-quarter to one-half inch wide and 2 to 6 inches long. These make a very regular reticulate or open network over the prevailing white surface of the marble, forming a remarkable rock. At times black squares of the mineral, with lighter and less changed centers, are interspersed with the narrower rods, and the latter radiate from the centers and sides of these squares with some regularity, and connect them into a stellate pattern (see fig. 8, p. 152). Again the squares may wholly replace the rods.

These two beds are of massive structure and furnish large blocks, which take a fine polish and promise to be of economic importance.

The third bed, which connects the other two, is a thin, flat-foliated, pale-green to white marble, with films and flat small lenses of pale-green 
to rich dark oil-green precious serpentine. The surfaces show at times narrow bands and squares of serpentine with centers of straw-yellow and borders of oil-green color, which form an attractive verd antique, plainly the last identifiable stage of the flattened-out enstatites that the rock formerly contained. It is further clear that this central portion never contained so much enstatite as the border beds.

The country rock to the west is a coarse muscovite-biotite-schist, with few garnets and a great abundance of coarse-bladed gray cyanite, which stands out in reticulated surfaces on the weathered slabs and will furnish interesting cabinet specimens. They can be obtained in abundance by following the path along the serpentine bed south to the first wood road and then going up west along the wood road to a prominent ledge on the south of the road.

Here also the foliation faces of the coarse schist contain rounded and flattened disks, 1 to $1 \frac{1}{2}$ inches long, which suggest pebbles. Rarely one can be seen by its cleavage to be in part feldspar, but most are a quartzbiotite mixture. Also, to the west of the south opening made by the company, which is reached by going up a wood road from a miner's shanty, the schist shows rounded and somewhat oval, white surface forms, which strongly suggest the trace of pebbles, but they are not distinguishable in the midst of the coarse schist when it is freshly broken. The rocks stand vertical, but I suppose these western schists to be older than the serpentine. The cyanite follows the serpentine and amphibolite for many miles across Granville, and in Barkhamsted, Connecticut, furnishes the finest cabinet specimens.

The cyanite-schists are succeeded from west to east by the following beds:

Section at the main mine.

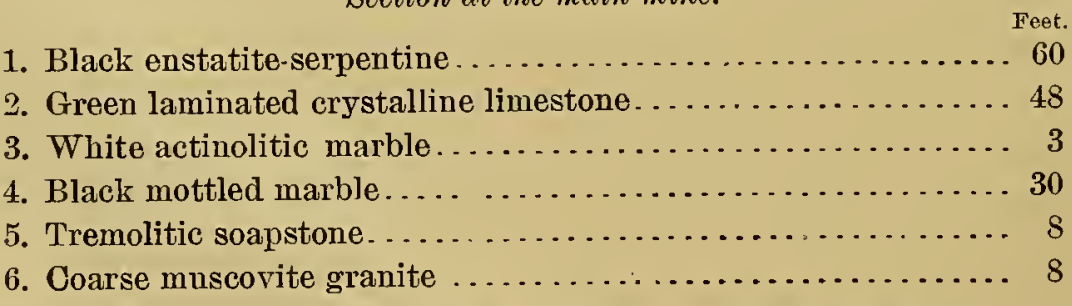

The eastern comntry rock is not here exposed, as the high terrace gravels cover the area to the east. It is a schist like that on the west, but without cyanite. A band of rich-green actinolite three-fourths of an inch wide runs across both of the principal bands of the quarry. 
'The soapstone lats been worked by the Indians. Half-made pots are still to be seen on the surface, and an Indian arrow was found, on blasting, 12 feet down in a narrow crevice in the limestone.

To the north of the quarry the bed of grinite cuts off the serpentine band, but it reappears after an interruption of a rod.

Followed a few rods south, the western contact of the bed is exposed by digging. It is a thick bed of rich-green, coarse-radiated actinolite mixed with biotite, and the wall on the left is granite with some plagioclastic fringe rock containing biotite and tommaline. Nearly the whole thickness of the bed here is black serpentine, but Professor Crosby pointed out to me a continuous valley, generally quite swampy, which may be occupied by the limestone and caused by its solution.

At the southeru outcrop mentioned above (and at several other places) a black, flat amphibolite accompanies the serpentine on the east, but does not seem to be in great force. Here the radiated tremolitic character of the soapstone is specially manifest. It forms a heavy bed on the east, followed westerly by a thin-foliated verd antique, made of bands of blackish-green serpentine and white marble, with about 20 feet of the black serpentine to the west before the schist is reached.

Farther south the rock crops out in the bed of Westfield Little River (bed No. 19), and in Westfield (bed No. 20) north of the Granville road, near the west border of the New Red sandsone; ${ }^{1}$ south of this road it crops out in the hill back of S. Drake's house (bed No. 21), where it is very coarsegrained, exactly like the East Granville locality, and from the weathering out of the calcite, which fills the interstices, it is very rough-surfaced; and, finally, it is seen in the bottom (bed No. 22) of Munn's brook, near the line between Granville and Southwick. It is in place where the brook emerges from its gorge in the hills. The prevailing rock is a black enstatite-serpentine; amphibolite is subordinate. The line of strike then carries the bed beneath the sands of the Westfield plain and it is not seen farther south.

\section{FAULTS AND SERPENTINIZATION.}

The great Hoosac fault displaces the rocks a mile on either side of the Deerfield River, below its bend at the mouth of the Hoosac Tunnel. It seems possible that this fault plane had a determining influence in the great devel- 
opment of serpentine from the homblende-schist bed, since this extensive development of serpentine extends north and south from this fissure, and the fault perhaps aided the work by bringing to the bed for great depths an abundance of water, and may have further intervened by localizing the earthquake forces, which may have shattered the rocks for a distance on either side of the fissure, thus aiding the chemical activity of the water. The sharp bend of the stream and its long course parallel to the direction of the fault show that the fault early controlled the direction of the river, and it probably did this because the softened rock was more easily eroded.

The next large area of serpeutine-and these two areas are vastly larger than the others-is in Middlefield, in the only other large transverse valley in the State. Here, also, I have mapped a fault in the valley bottom, and it seems probable that here also the fanlt may have had something to do with the hydration of the hornblende to serpentine, as well as with the position of the transverse valley. I have noted also a sharp bend, which is almost a fault, at the Osborn quarry. The other serpentine and steatite deposits are comparatively unimportant in size, or show trace of olivine and enstatite. 'This relation did not attract my attention until the field work was ended, or ${ }^{\bullet}$ other similar coincidences might have been detected.

\section{PETROGRAPHICAL DESCRIPTION.}

THE AMPHIBOLITES.

1. Epidotic amphibolite.-Blandford; North Blandford road at watering trongh. Typical jet-black, fissile schist, the shining hornblende needles just visible to the eye. Drusy surfaces of epidote and adularia upon fissures.

Under the microscope the abundant hornblendes appear as broad plates with strongest extinction and pleochroism; $\mathfrak{e}>\mathfrak{b}>\mathfrak{x}, \mathfrak{c}=$ blue-green, $\mathrm{k}=$ olive, $\mathrm{a}=$ yellow. Extinction, $22^{\circ} 30^{\prime}$. Interspersed everywhere among the hornblende needles are abundant grains of pistachio-green epidote. There is a sparing groundmass of. rounded, untwinned albite grains, showing positive bisectrix. Magnetite is abundant, but no lencoxene. Rutile occurs in the feldspar.

2. Feldspathic amphibolite.-Blandford; Osborn's soapstone quarry, at west junction of soapstone bed and granite. (See p. 87.) From a thin bed of black, very heavy feldspathic amphibolite, $20-30^{\mathrm{mm}}$ wide, with fringe of coarse, black transverse biotite $10^{\mathrm{mm}}$ wide adjoining granite, and therefore 
carrying orthoclase. With the microscope hornblende in broad plates with strongest pleochroism and absorption; $\mathfrak{c}>\boldsymbol{b}>a, \mathfrak{c}=$ deep blue, $\mathfrak{b}=$ deep olive, $x=$ straw yellow. Extinction $17^{\circ} 30^{\prime}$.

Orthoclase is abundant; plagioclase ocem's with extinction $24^{\circ}$. Little magnetite and no lencoxene. Epidote is abundant.

3. Amphibolite-Chester; cutting near railroad station on the west. (See Pl. VI, fig. 4, and p. 160.) A finely banded rock; internupted sheets of white feldspar grains rather distantly placed in ground of jet-black hornblende needles of high luster, all parallel to the common direction of the stretching.

Under the microscope, stout, long blades of very deep-green hormblende, with distant basal partings and almost no prismatic cleavage visible, slow the strongest pleochroism and absorption I have ever seen, the formula for which is the same as in the last case. Between the bands of these stout blades a coarse, limpid mosaic of plagioclase grains occmrs, and very little magnetite appears in the slide. The plagioclase is an oligoclase with positive bisectrix and extinction at $+9^{\circ}$ to the trace of the basal cleavage on M [010].

THE SERPENTINES AND ASSOCIATED MAGNESIAN ROCKS.

In the long hornblende-serpentine band which stretches across the State from Rowe to Granville, looping back in the last town so as to be repeated three times in an east-west line, the serpentines and associated rocks present a great variety, both as to present status and as to origin, and one can distinguish hornblende-serpentines, pyroxene-serpentines, enstatiteserpentines, and olivine-serpentines.

There are associated with these serpentines beds of clinochlore, tremolite, actinolite, corundum, magnetite, steatite, tale, and, in smaller quantity, deweylite, dolomite, magnesite, chromite, chalcedony, picrosmine, diaclasite, bastite, and "phæstine."

Of these the first five represent in general the results of other lines of change than that which has ended in serpentine, or at times a stage antecedent to the change into the latter mineral.

The talc and steatite can be traced back to tremolite or actinolite with or without the intervention of a serpentine stage, or, the purer talc especially, to serpentine of any origin; the secondary dolomite, magnesite, magnetite, Mron, $\mathrm{xxrx} \longrightarrow 7$ 
chromite, and chalcedony are surplus products of the serpentinous change. Deweylite and picrosmine are, as it were, special varieties of the main product, while diaclasite, bastite, and "phæstine" (or marmolite) are derived directly from enstatite. Of course remains of original calcite, dolonite, magnesite, pyroxene, epidote, and olivine also appear.

BLADED SERPENTINE; ANTIGORITE- (OR BASTITE-) SERPENTINE.

1. Serpentine with dolomite-Rowe, Massachusetts. Large bed at E. King's, east of the tumnel, p. 79. Compact, even-grained, splintery fracture, dark-gray, with trace of green on fractured or sawed surface, deep oil-green to light apple-green on polished or wetted surface; very translucent in splinters; abundant grains of pyrite and magnetite scattered through the mass. Dr. A.J Hopkins detected chromium in small amount; for analysis, see p. 116.

Slides show with pocket lens little magnetite, and preserve a uniform pale-green color, even when ground extremely thin.

Under the nicroscope is seen a network of interlaced serpentine blades of unusual range in size, the smaller elongate, irregularly outlined as usual, rhombic, and polarizing with bluish-white color; the larger broad, flat plates, with straight, longitudinal cleavage lines, polarizing white of the first order at border and deepening to yellow at center, the largest filling quarter of the field $(\times 70)$ and deepening in color, through yellow to bright magenta. These serpentine plates are sometimes arranged radially, showing a black cross; at other times they are arranged apparently according to the cleavage of a former mineral, and are accompanied by black rod-like microlites in the same direction.

Another mineral, talc, appears in small veins and broad irregular patches, as well as replacing to various depths certain laminæ in the broad bastite plates. It gives an aggregate polarization in bright, softly blended colors, with wavy and sharp zigzag outlines. Leucoxene occurs, surrounding the black ore. Dolomite appears at times in regular rhombohedra, and is generally in rounded grains, often with only faint traces of cleavage and always without trace of twimning,

2. Serpentine.-Chester. From the large Middlefield-Chester bed, at brook-crossing on Chester road near the base of the mass. (See p. 81.) Dull-black, with shade of brown; same color when wet; conchoidal fracture; massive. 
With a lens the slide sliows patches of separated grains of a yellowish, shining mineral, and between these patches run broad veins of the amorphons greenish serpentine and many magnetite grains.

Under the microscope the broad veins break up into a mass of very fine bluish-white blades, and the same lie among and separate the brightly polarizing grains, not after the manner of the olivine network, but so that the grains seem to be scattered and woven into the mass of needles as foreign bodies, a single needle often lying lengthwise in a crevice between grains. They are exactly like the grains of epidote in the epidotic amplibolites. Large tracts of these grains polarize together and show a single axis with rings of color. The colors are also not so bright as olivine usually is, and it is probable that the mineral is epidote.

3. Serpentine.-Chester. From the upper portion of the same bed, at its south end on Chester-Middlefield road. Rock shows original bedding in laminæ $20-25^{\mathrm{mm}}$ thick, and fine intricate jointing, the latter structure brought out by weathering, while the rock still cleaves along the planes of the first structure and shows on these planes a brownish-gray, shining surface and a texture that is suggestive of the mica membranes of the sericite-schists above, rather than of the hornblerde-schists, in the continuation of which it lies. The rock breaks with a harsh, fine-splintery fracture, is of rather light greenish-gray color, translucent and mottled with black when wet.

With lens the section shows, beside the large masses of magnetite, wavy lines of fine grains of magnetite $3_{3}^{2 \mathrm{~mm}}$ apart, which run out and are replaced by others. These are seen, in sections transverse to the bedding, to be determined by the cleavage planes mentioned above, and represent the original fine foliation of the rock.

The mineral shows under the microscope broad bands of fiber set transversely, and many large areas of disconnected epidote grains, all polarizing together.

4. Serpentine.-Chester. From the same bed at the north line of Cliester, $3 \frac{1}{2}$ feet from npper surface of serpentine bed and contact of sericiteschist. Slaty rock, dark-gray, dull yellowish-green and translucent when wet, with reddish-gray sheen on cleavage surface, as if from mica.

The slide shows no large grains of ore, only fine magnetite dust arranged in lines running in various directions, and no unchanged grains of any primary crystalline mineral. 
Under the microscope very fine serpentine needles appear arranged with a certain parallelism over broad surfaces, a structure inherited from the foliation; in some places they are larger, arranged irregularly, and, being thicker, show bright colors.

Veins of chrysotile occur, with a certain portion of the transverse needles replaced by magnetite. For analysis, see page 116.

5. Serpentine nodule in talc.-Old emery mine, Chester. Light-gray with shade of green; pale-green, translucent when wet; very fine-splintery fracture, producing a whitish surface, as if dusted with fine grains. The slide is pale-green, shows large grains of iron ore, and bristles with magnetite dust arranged along cleavage laminæ. Many spots of dolomite are visible with lens.

Under the microscope it is seen to be made up wholly of a network of fine serpentine blades, without any arrangement significant of the primary mineral from which they were derived.

6. Serpentine.-Chester. Another interesting serpentine occurs at the emery mine. A pale apple-green to oil-green rock, translucent, with shining luster, and having entirely the aspect of an indurated steatite; $\mathrm{H}=2.5$. It breaks into thin, shaly fragments, bounded by wavy, slickensided surfaces, caused by pressure, and resembles deweylite. It has, however, specific gravity 2.51, and under the microscope has the structure of a platy serpentine and polarizes in white to yellow of the first order, and it is decomposed by hydrochloric acid.

The serpentines thus far described, with the exception of those from the base of the large Middlefield bed, are characterized in greater or less degree by the following peculiarities:

(a) A harsh, splintery fracture.

(b) Secondary magnetite wanting or unimportant, and where present arranged often in long, wavy lines of the original lamination, as proved by the cutting of slides at right angles to this lamination visible on weathered surfaces of the rock.

$(c)$ As a consequence of $(b)$, a great degree of translucency in the rock when wet or polished, while the succeeding enstatite-serpentines are very generally black and opaque when moistened.

(d) The mass of the rock is made up of distinctly polarizing serpentine (antigorite) in bladed crystals, which stand in relation to the splintery fracture; and there is lack, at least nearly complete, of an amorphous serpentine substance and of chrysotile. 
(e) The abundant grains of a brightly polarizing, granular mineral seem to be sometimes epidote inherited from the amphibolite, sometimes titanite formed around grains of menaccanite which have wholly disappeared, while no trace of olivine can be detected.

The stratigraphical indications are thus reinforced by the lithological study, and the conclusion is rendered probable that these serpentines are in large part derived from the amphibolites with which they are associated. The lack of any direct proof of the presence of olivine is, however, very far from proof that it was wholly absent from these beds. Indeed, this mineral is so closely connected with the formation of serpentine in so many cases that one may suspect its former presence here, and the observations of Kalkowsky ${ }^{1}$ on the presence of olivine in hornblende-schists led me to search for it in the schists adjacent to these beds, but without avail. These rocks plainly also resemble Von Drasche's ${ }^{2}$ serpentine-like rocks (now called antigorite-serpentines), and can be easily distinguished from the olivine-serpentines. I have not, however, found any certain trace of diallage in them, and the minerals which are present separate them quite distinctly from those described by him.

OLIVINE- AND WNSTATITE-SERPENTINE.

\%. "Serpentine, Chester."-XIII, No. 53, Massachusetts Survey Collection. Rock dull-black, black when wet; many large grains of magnetite. The rock weathers superficially to carbonate.

With lens the slide is pale-green, and shows the secondary magnetite occupying planes of lamination and a fine system of joint planes nearly at right angles to these and very regular.

Under the microscope an olivine network, inclosing in one slide fragments of unchanged olivine, in another lacking these altogether, runs through the slide withont being influenced at all by the lamination and joint planes mentioned above.

This network runs through a base of nonpolarizing serpentine. I am not able to locate this specimen, but suspect that it comes from the base of the large Middlefield-Chester bed, or from the smaller bed upon the top of North Mountain.

Serpentine.- "The Crater," North Blandford. The rock of the crater is easily distinguished both macroscopically and microscopically from that

${ }_{1}^{1}$ Die Gneissformation des Eulengebirges. p 37 ; Tschermaks mineral. Mittheil., 1871, p. 1 .

${ }^{2}$ Ueber Serpentin und Serpentinähnliche Testeine: Tschermaks mineral. Mitthril., 1871, p. 1. 
of any other locality in the range. It is dark-gray, scarcely shaded with green, spotted full of primary magnetite in large grains, and weathering uniformly throngh light green to fawn color. It is very compact and tough and much jointed. A qualitative analysis detects about 1 per cent of chromium in the specimen from which slides were cut (Dr. A. J. Hopkins).

With the lens the slide shows no trace of magnetite dust, but is frosted all over with shining grains of a yellowish-white crystalline mineral.

Under the microscope the ground is a confused tangle of bluish-white, rhombic needles of extreme fineness, and the shining grains, polarizing brightly, are scattered in it so much like foreign grains that I suspected the slide to have been badly cleaned of the cormulum used in polishing, and cut new ones carefully, but with the same result. The mineral polarizes with about the brightness of pyroxene; the angular grains are fresh to the edge and show no cleavage; some of the larger show a single axis with rings of color. It does not gelatinize with hydrochloric acid. For analysis, see page 116 .

8. Olivine-serpentine.-Osborn's soapstone quarry, Blandford. Eastern bed. (See fig. 5 and page 87.)

Except one specimen from Chester, whose exact location is not known to me (Massachusetts Survey Collection, XIII, No. 53, described on p. 101), this is the only bed in the long series of ontcrops west of the river which contains olivine in abundance. In all the beds hitherto mentioned its occurrence conld at best be rendered only probable, though I lave little doubt that it was formerly present in many cases. In all the beds discnssed below the absence or rarity of olivine is equally certain, and the derivation of the serpentine from pyroxenite or coarse enstatite rock is quite clear. Indeed, much of the rock is so little changed that it could be as properly called enstatite rock as serpentine.

The great mass of the rock where freshest is dull-black, opaque when wet, with the marked shining, greasy luster characteristic of those serpentines which still contain olivine in abundance. It gelatinizes abundantly with acid, and the solution contains magnesium and iron, with trace of calcium.

A layer of surface decomposition of a drab or grayish olive-green color and $10-20^{\mathrm{mm}}$ thick covers the surface, and is sharply demarcated from the black interior. It is cansed largely by the removal of the black ore, and the rock within its limits has much more the look of ordinary olivine than in the 
black center. The weathered layer is distinctly softer, and althongh the change to serpentine is not more advanced than in the interior, the olivine fragments polarize much less brilliantly than in the black portion. They may be referred to villarsite.

In both the interior and the weatleered crust necur distantly seattered spherules, about $10^{\mathrm{mm}}$ across, of a finely radiated tremolite-asbestos. They are not bounded by a true spherical surface outwardly, but long, delicate needles, just visible with a strong lens, project far beyond the average surface. The impression is very strong that these latter are, as it were, feeler's thrust forward into the mass from a center of alteration.

Many of the spheres are changed wholly or partly into talc, the change starting at the center and following up the other to the periphery, and, especially in the onter layer, resulting in the entire ehange of the spherule into talc; and as the steatite bed into which the serpentine grades has the same radiated fibrons texture, it has apparently been derived from the latter after the same manner.

These radiated tufts bear also some resemblance to the radiated asbestos zone surrounding the garnets of the Saxon "garnet-serpentines," described by Dathe, ${ }^{1}$ though here no garnet eenter can be observed, and the radiating mineral is mnch coarser than would accord with the description of the Saxon oceurrence. Indeed, garnet, so abundant in the next higher formation, is here curiously absent from the amphibolites and associated rocks elear across the State.

Slides of the freshest black portion of the rock appear under the lens to be made up of angular grains of olivine, often quite complete erystals, without admixture of anything else except a black ore arranger in rudely parallel, interrupted lines. The bleached outer layer shows nothing different, except that the black ore is removed and the whole soaked full of iron rust.

Under the microscope the slides show the finest olivine network; the broad meshes of ehrysotile are beantifully developed and ocenpy about a third of the area. The olivine is without inelusions, exeept small chromite octahedra, and rarely long series of straight, black needles, which are arranged parallel to the vertical axis and at right angles to the length of the series with the regularity of a micrometer, except that some lines are 'Olivinfels, Serpentı, and Eklogit des sachischen Granulitgebietes: Nenes Jahrbuch, 1876, p. 225. 
prolonged far beyond the others. Highly magnified, they are reddish and translucent. In other portions of the slide the characteristic enstatiteserpentine occurs, with exactly the structure of fig. 3 , Pl. II.

In the onter, bleached layer the lines of magnetite dust in the suture of the chrysotile bands have disappeared and in the form of limonite have soaked through the fibrous chrysotile. With further process of change the latter loses its fibrous character, and every trace of the origin from olivine disappears. At times also the olivine grains here retain their position in the clurysotile network and their appearance, but lave lost their bright colors of polarization. The change of the olivine to tremolite seems to be of earlier date, and has often advanced to the replacement of nearly all the olivine. It appears to have occurred earlier than and independently of the superficial weathering, becanse the tremolite is found in equal abundance in the fresh interior and in the weathered surface.

Where the olivine is weathered, as in specimens taken from large bowlders on the West Granville road, just where the glacial currents would carry material from this bed, the specimens are not distinguishable from corresponding specimens from the Pelham and Shutesbury beds (see p. 47), aud I had expected confidently to find the fibrous mineral to be anthophyllite, and indeed its powder gives fragments which for the most part extinguish longitudinally, but at times other fragments extinguish with an angle of $11^{\circ}$ to $15^{\circ}$ to the length, and show a single optical axis placed laterally, exactly as in hornblende.

A cleavage parallel to $\infty \mathrm{P} \infty(100)$ seems to be unusually well developed, and most fragments rest upon it and so extinguish longitudinally, but show only one axis, as in hornblende. It is to be noted that this is from a unique bed lying east of the main hornblendic band. (See p. 89.)

9. Pyroxene-serpentine.-Lowest bed, near Osborn's quarry. (Fig. 5, p. 87.) The lowest bed at the margin of the north-south brook in the woods below Osborn's quarry attracted my attention immediately as something quite unlike any other rock connected with the serpentine series, to which it manifestly belonged; indeed, unlike any rock with which I was acquainted.

The weathered surface is for the most part rough and warty, dirty white, and covered with shining scales of talc. In some places this layer, $5-10^{\mathrm{mm}}$ thick, is covered by a white, powdery layer of magnesite. 


\section{PLATE II.}




\section{PLA TE II.}

\section{THIN SECTIONS}

FIG. 1.-Sahlite changing into tremolite; the latter beginning to change into serpentiue. From the lower bed at Osborn's soapstone quarry, Blaudford. $\times 47$. See pp. $87,104$.

FIG. 2.-Dolomite changing to serpentiue. Granville. $\times 28$. See p. 110.

Fig. 3.-Enstatite crystal altered to serpentine, cut parallel to (001). Drawn with polarized light and with the light bands placed at $45^{\circ}$ to the plane of polarization. $\times 60$. See p. 110 .

FIG. 4.-Garnet, with complex border; from pegmatite. Northfield. $\times 14$. See p. 328 .

106 

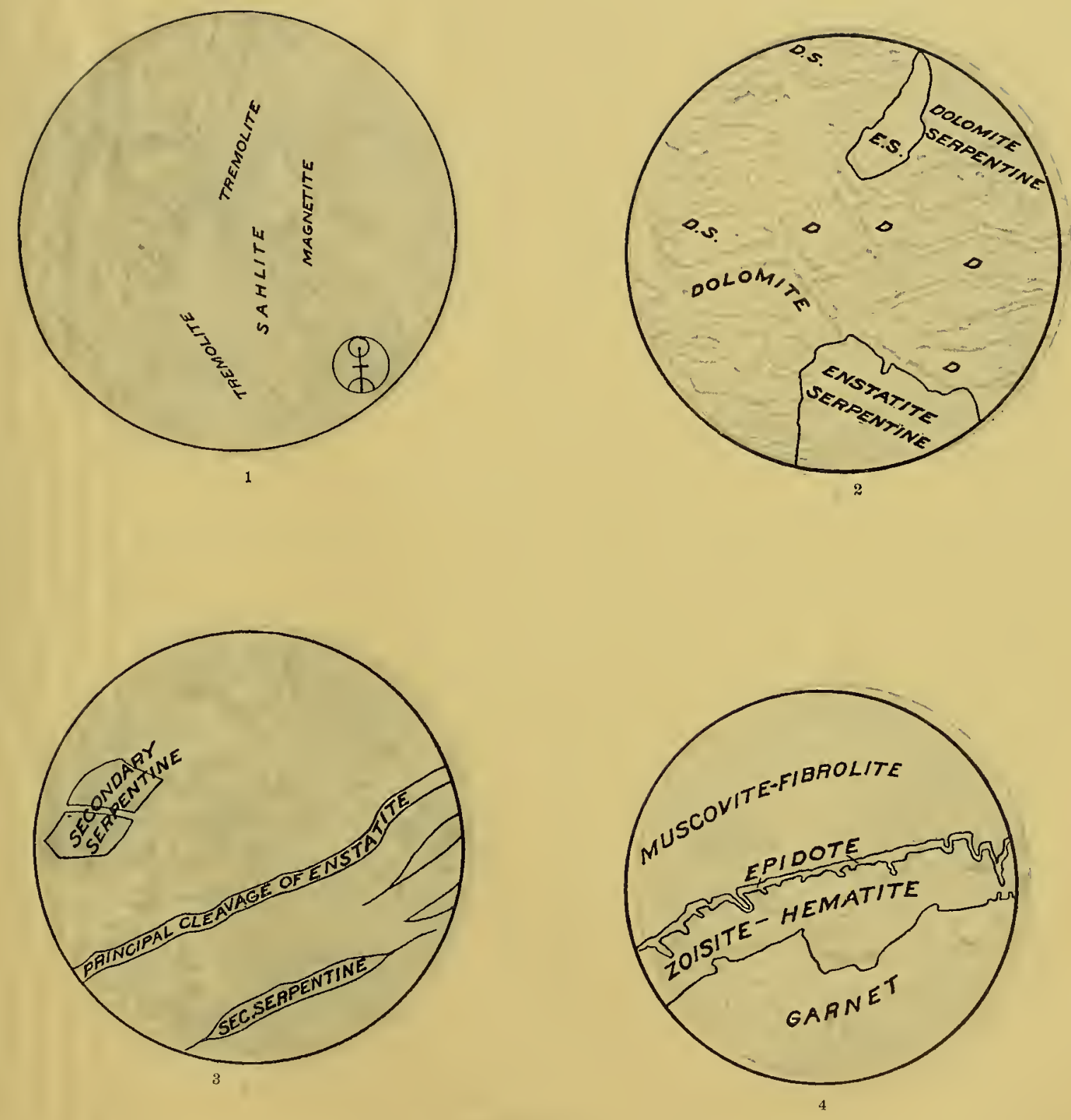

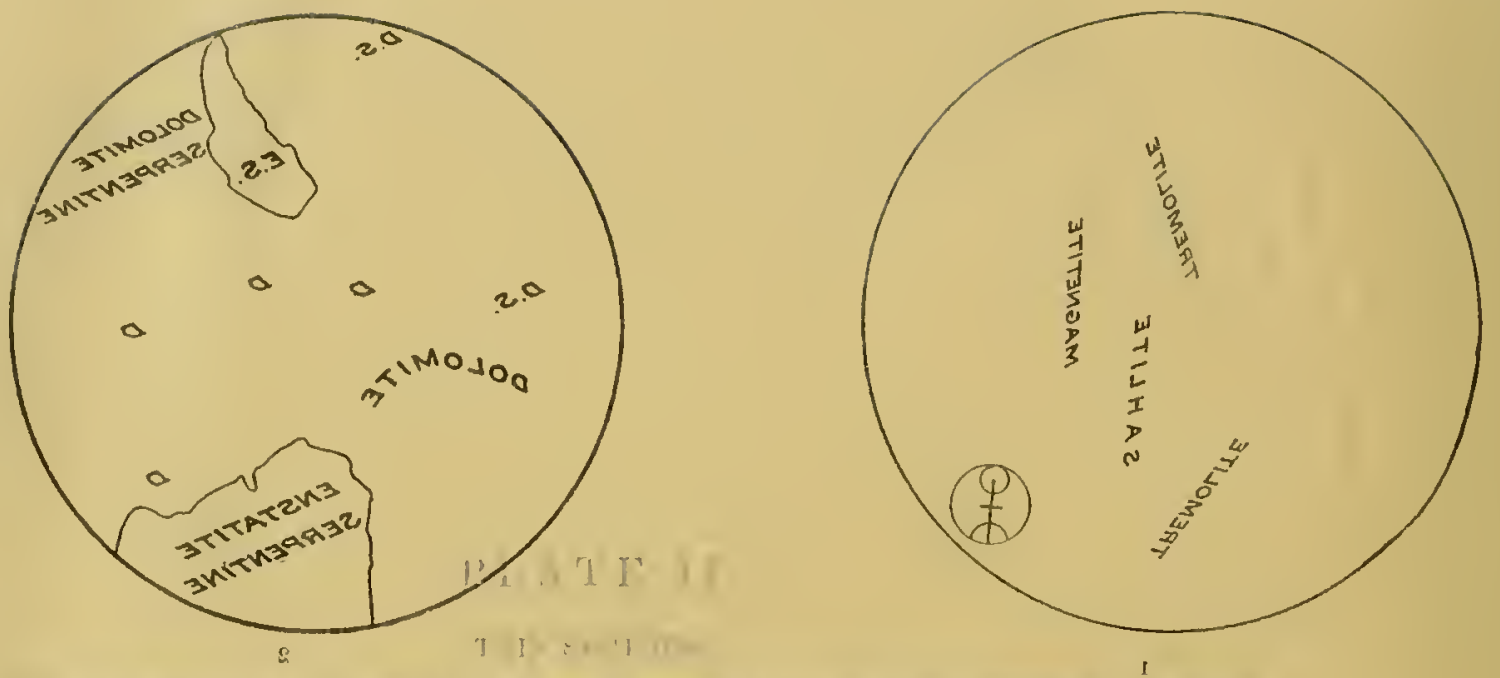

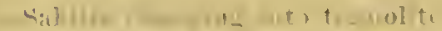

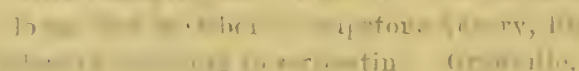

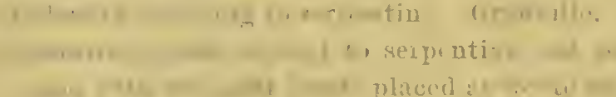
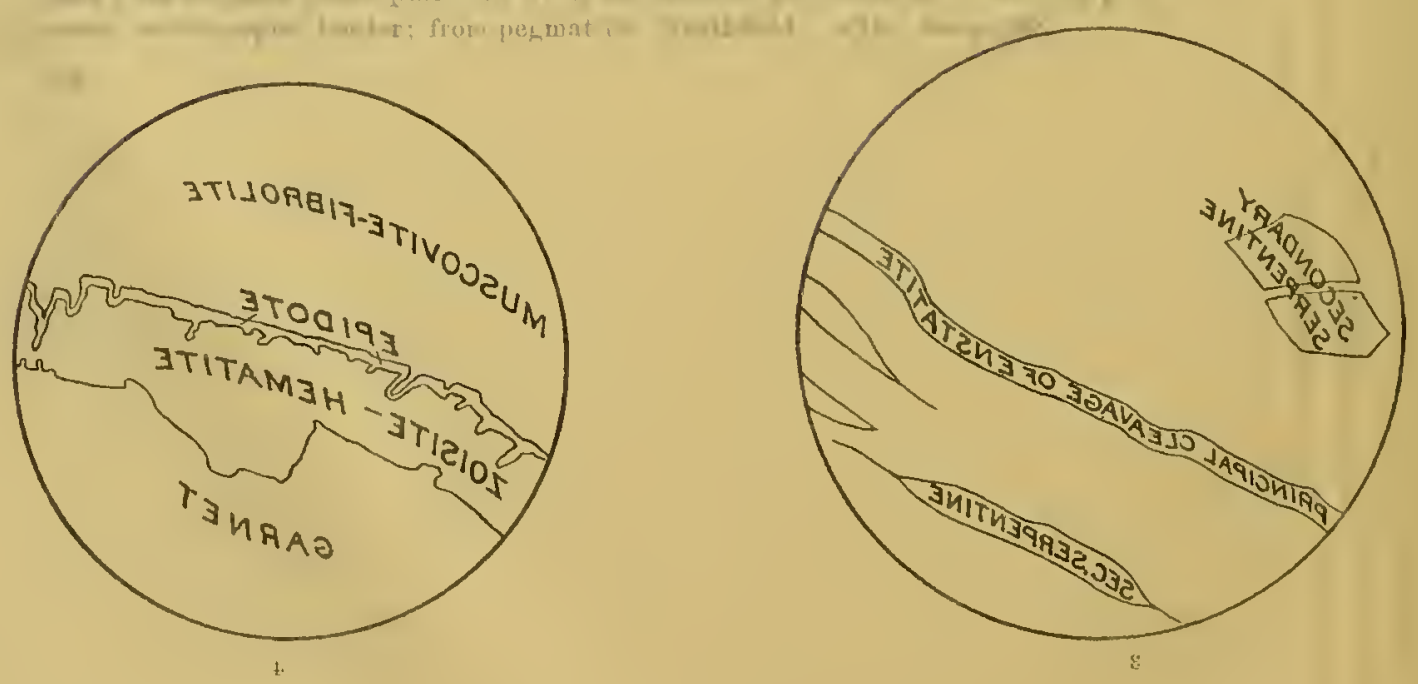

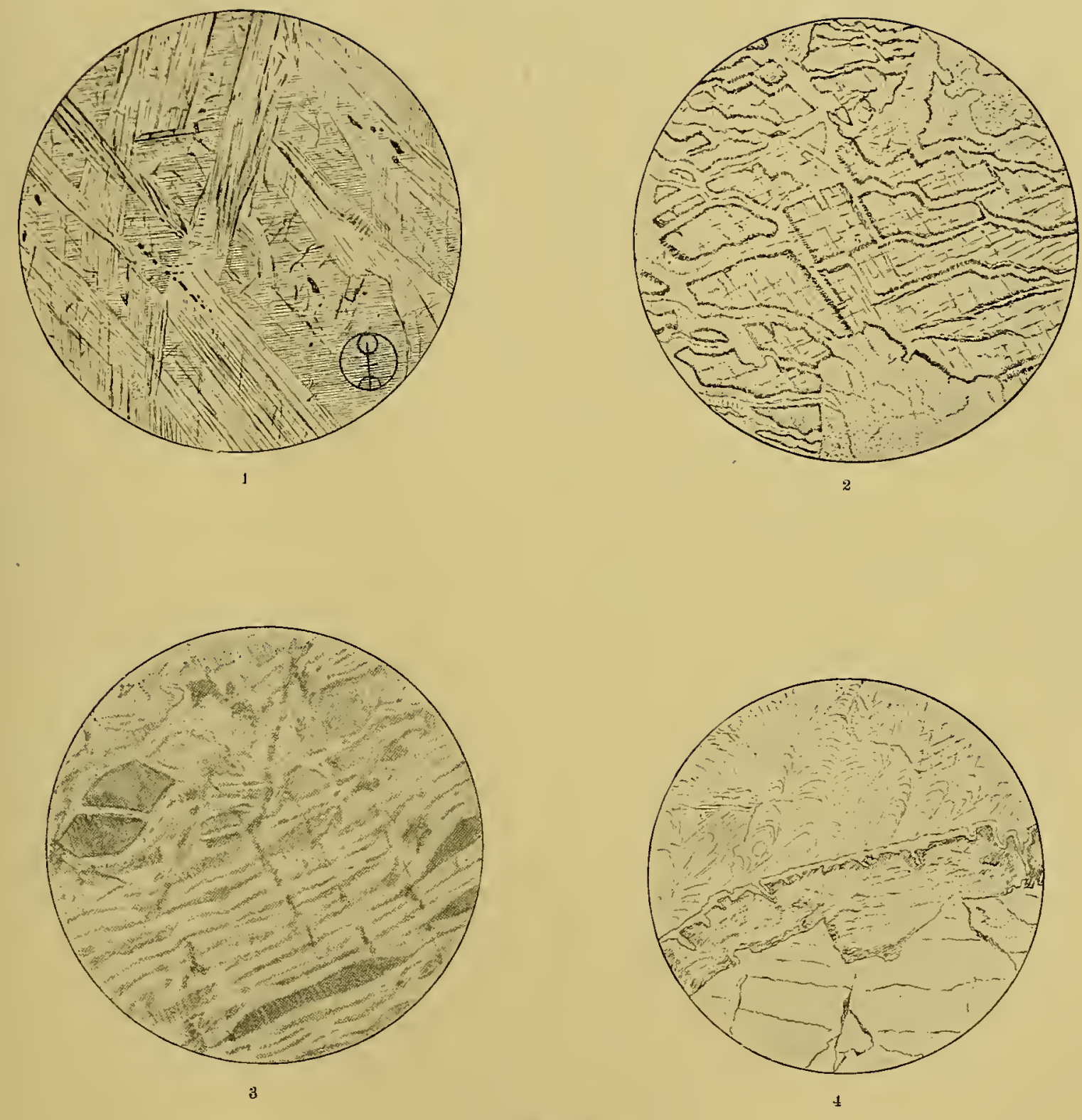

THIN SECTIONS 

'The interior is a dark oil-green, flecked with white or yellow; opaque black when wet, and with pecnlial greasy luster reflected from large cleavage surfaces, which run throngh the whole mass. These surfaces reach a size of $20 x+0^{\text {mu }}$, have a pearly luster, and are, in many cases where the rock is deeply weathered, bleached to an isabella-yellow or changed to an white mass like kanolin. They are covered with an acute-angled network from a second cleavage, like that of lornblende, but more acute, and a satiny" sheen runs over the face from the presence of fine tremolite needles, arranged parallel to this cleavage and gradually encroaching upon the original mineral, which proves upon microseopical stndy to be sahlite. Slices cut parallel to the perfect parting (see fig. 1, Pl. II), which proves to be $0 \mathrm{P}(001)$, show a fine, regular network of tremolite needles, which polarize witl an obliquity of about $15^{\circ}$ and coincide in position with the acute cleavage of the original mineral mentioned above. Where this secondary tremolite has not come to occupy the whole space the meshes are oceupied by a colorless sallite, showing in traces an interrupted prismatic cleavage and a delicate lineation parallel to $\infty \mathrm{P} \infty(100)$, with traces of a second at right angles to this. In the figure this fine lineation is of necessity too coarsely represented, it being visible only with high power, and it is given specially to show the extent of the mehanged sahlite. The latter polarizes with extreme brilliancy, and characteristic sudden changes of tint appear over its surface, arising from the brittleness of the thin lamine due to the very easy parting on $0 \mathrm{P}(001)$, which renders it difficult to polish it to a true surface.

The mineral is positive, and the optical axial plane is at riglit angles to the fine lineation-i. e., is in $\infty \mathrm{P}$ ó (010)—and a single axis appears, and this plane bisects the acute angle of the tremolite network, which measures about $54^{\circ}$. This would make the cleavage, which lias determined the position of the tremolite fibers, approximate to $\infty \mathrm{P} 2$ (120), the counterpart of $\infty$ P 2 (210)-the prism of hornblende when reckoned upon the pyroxene axes. An examination of the Bolton (Massaclusetts) sahlite shows that distinct traces of the same cleavage existed in fresh specimens. Here, as is not unusual, it is rendered much more distinct in the process of decomposition.

In slices cut at right angles to the perfect basal clearage or parting the strong equidistant lines of separation are the marked feature, and these lines quite far apart are the seat of most advanced change. 
The perfect sahlite cleavage is also retained after the change to serpentine is far advanced, and shines out when the piece is held in a particular position as single faces luster-mottled with small opaque spots of serpentine. In the process of change, black iron ores in rods and lines of dots appear in the interstices of the tremolite needles, as well as in the prismatic and pinacoidal cleavage of the sahlite; and after the serpentinous change (which commences in the transverse cleavages of the tremolite and advances in a network somewhat like that in olivine) has completely transformed the whole into a confusedly polarizing mass, the acute-angled network is as clearly marked in ordinary light as before by the black lines, and in places traces of the rectangular pyroxenic cleavages can also be seen.

In the most completely changed portions blades of actinolite, either later formed than the tremolite or more resistant than it, show marked pleochroism for so nearly colorless a mineral-pale blue-green to ocher-yellow.

10. Enstatite-serpentine and steatite-CHartland, Connecticut, just south of the town line, where the road from West Granville to Hartland crosses Hubbard Brook. On passing 100 feet up the slope southwest of the bridge the black enstatite-serpentine occurs in force. It is of finer grain than the other beds to the north, with which it otherwise agrees exactly, and it is largely changed to steatite.

11. Tremolite rock and enstatite-serpentine.-J. Downey, Granville. Following a wood road east into the densely wooded swamp from a point just north of the house of Mr. J. Downey, I came upon a very interesting outcrop, which represents the first occurrence of serpentine upon the amplibolite band, where, after turning north, it swings around the gneiss of Granville.

Along east of a band of the common amplibolite there crops out a low ridge of limestone, at times quite pure, light-gray, and thin-fissile, but taking more and more very fine tremolite into its composition, until it comes to be a flat-fissile, pale-green tremolite-schist, almost as finegrained as nephrite, which it somewhat resembles. It polarizes brilliantly, has extinction in maximum $27^{\circ}$, and shows a few straight, black microlites and a few large grains, also visible to the eye, of a black magnetic ore. It gives on analysis only traces of $\mathrm{Al}_{2} \mathrm{O}_{3}, \mathrm{FeO}$, and $\mathrm{CaO}$, and is an almost pure silicate of magnesia.

South of this there are no exposures for a short distance, and in the strike of the tremolite rock rises a great kuob of enstatite rock. It is a 
coarse, ragged rock, mide up of (rystals of enstatite, often $10 \times 6 \times 4^{\mathrm{cm}}$ in size; and no otler original constitnent can be detected except dolomite, which is inclosed in large, rounder grains in the freshest enstatite. Indeed, in much of the mass the whole is marle up of the large, imperfect, interlaced prisms. These are thickly coated by a greenish-gray talc-like product of decomposition, which also penetrates in thick layers along the perfect cleavage until the whole is changed into bastite and ultimately into talc. Where the change is more advanced, great sheets and remnants of the bastite, gray-green in color, lie in a mass of black serpentine, or in a mixture of this and a yellow dolomite. Often, however, the enstatite rock seems to degenerate into a talc-like mass withont any trace of serpentine, and the masses of black serpentine and dolomite may have originally contained some other mineral besides the enstatite, though I could obtain no proof of this.

Under the microscope the enstatite, cut parallel to the perfect cleavage, shows in the freshest portions only a few black microlites, but it is much cut up by a network of yellow serpentine; and here large octahedra of magnetite appear. With convergent light it polarizes in bright colors, and, of course, shows no axes, and on moving the slide spaces are found which show the axes as in diaclasite, accompanied with bright colors, and these parts are not distinguishable in ordinary light from the unchanged enstatite. Moving the slide a little farther, one sees the axes as in bastite and in paler colors, and in common light these parts have the appearance of serpentine. The divergence of the optical axes is very small for the bastite, certainly less than $30^{\circ}$. Embedded also in the black serpentine are, rarely, large scales of a deep-green clinochlore, with divergence of the optical angles of about $10^{\circ}$.

By the roadside near the cemetery, sonthwest of the last locality, are found bowlders of all the rarieties of rock mentioned from this outcrop, and several others of interest which seem also to come from this place, although this can not be made certain. One great mass of limestone is in places banded in dull black, from the large amount of magnetite in the limestone. It shows also, under the microscope, a large number of fine actinolite needles and rarely a grain of coccolite, and this piece is so exactly, in other parts, like the tremolitic limestone found in place north of the serpentine knob that it is scarcely possible that one can err in assigning to them the same 
origin. It contains, however, bands several centimeters broad of darkgreen, matted, fibrous actinolite.

Associated with this in another large bowlder is an entirely distinct limestone, a white, coarse, granular calcite, all the grains showing with the lens abundant twin striation, while the limestone mentioned above is too fine-grained to allow its structure in this respect to be seen, and under the microscope it is not twinned at all. It must be calcite, however, as it effervesces freely with cold acid. In the limestone now described a distinct stratification is effected by the interposition of fibrous masses of emeraldgreen actinolite upon the foliation planes, and in the midst of the granular calcite fine grains of coccolite and magnetite occur.

12. "Dolomite-serpentine, Granville."-XIII, No. 26, Massachusetts Survey Collection; Pl. II, fig. 2. This is a black serpentine, containing much white to greenish, granular dolomite, and is identical with the bowlders described above from near the cemetery in Granville. Remnants of the gray-green enstatite in every stage of change to phæstine appear, and prove, under the microscope, identical with those described above, and the traces of enstatite structure can also be distinctly seen in the completed serpentine.

The most interesting change here is that of the dolomite into chrysotile, many stages of the Eozoou structure being beautifully represented.

The slide (Pl. II, fig. 2.) shows a network of yellow serpentine, amorphous in common light, running though the dolomite and generally following the cleavage. The dolomite network appears where the carbonate las wholly disappeared. The dolomite fragments are surrounded by a quite broad, dark band, consisting of short, stout rods of the unchanged dolomite which project into the serpentine.

The dolomite shows exceptional absorption, and this dark band absorbs and extinguishes with it. Outside this band the serpentine veins polarize with wavy extinction and low colors, and show the most delicate fibrous structure, with central suture.

13. Enstatite-serpentine.-H. Cooley, Granville (Pl. II, fig. 3). The section cut parallel to the base of the large crystals of enstatite changed into serpentine shows a series of bands which appear in pairs separated by a narrow line of magnetite. These are the light bands seen in the figure, and broad surfaces could have been selected where these bands were more closely parallel than in the one drawn. The drawing was made with crossed nicols, 
In a considerable number of thin sections the enstatite structure was found everywhere strongly marked by broad, distant, granular bands of black ore, with very numerous straight, narrow lines made up of rods and grains of the same black ore and running at right angles to the broad bands. No trace of enstatite could be found unchanged, and the broad apple-green plates, which are often quoted as marmolite, from these localities had passed for the most part beyond the bastite stage into a network of serpentine needles, in which isolated bastite plates still remain.

Irregular grains and large patches of carbonate, much corroded and polarizing with a soft amber color, with faint irised border, occur everywhere; also miscroscopic veins of satin spar, sometimes insinuated in large number between successive plates of the bastite.

No trace of olivine structure could be discovered in any of the slides from this locality; and in the localities described later, where the rock is less changed, it could be seen that all of the rock exposed was made up of large enstatite crystals so closely apposed that there could have been at best only a trace of olivine present; and on the broad cleavage surfaces of the enstatite no trace of included olivine grains could be seen. The structure in the completed serpentine was everywhere the rectangular network, as characteristic of the enstatite-serpentine as the olivine network is of the latter mineral. It is beautifully illustrated by Dr. Wadsworth in pl. 7, fig. 2, of his Lithological Studies, ${ }^{1}$ from a specimen obtained "four miles from Westfield Center, Westfield, Massachusetts." This must have come from the Atrvater ledge, which is just 4 miles west of Westfield village, but lies across the line in Russell. As the rock from which the serpentine was derived was a nearly or quite pure enstatite rock, Dr. Wadsworth's assignment of it to the peridotites can not be accepted.

16. "Light-green, compact serpentine.-Russell." XIII, No. 25, Massachusetts Survey Collection. This is a superficial layer a few millimeters in thickness, which also runs in veins into the black serpentine, and is superficially covered by a rusty white layer. It is probably from the surface of the above bed. It presents under the microscope a tremolitic structure throughout-radiated, fibrous, a late stage of the clange into serpentine.

1\%. "Serpentine (bowlder).-Russell." XIII, No. 50, Massachusetts Survey Collection. This is certainly an erratic derived from the great bed 
in Middlefielel, and probably found in the valley of the Westfield in the north part of Russell.

18. "Black serpentine, tale, actinolite.-Westfield." XIII, No. 24, IIassachusetts Survey Collection. Subgranular, dull black, very little talc, lerived from enstatite.

The actinolite mentioned above is in part enstatite partially changed to bastite, in part fine radiating tufts of tremolite, green from the background of serpentine. The rock is traversed by veins of snow-white, fibrous calcite $20-30^{\mathrm{mm}}$ long and $2^{\mathrm{mm}}$ wide, with satiny transverse fibers and central suture.

It shows under the microscope large masses of unchanged pyroxene with coarse $\infty \mathrm{P}$ cleavage, and long, black microlites, often crossing each other rectangularly in three directions. It changes outwardly into coarse, radiated, fibrous tremolite (cleavage $124^{\circ}$ ), which is altered along prismatic and transverse cleavage into serpentine.

19. "Serpentine and calcite-Westfield." XIII, Nos. 27, 28, 29, 30, Massachusetts Survey Collection. The first two are wanting in the collection. No. 29 is a contact piece of dolomite, with light-green and strawcolored serpentine running out into it from a mass of oil-green serpentine with fine, broad veins of chrysotile and many characteristic eozoonal structures. It shows beautifully every stage of the change of dolomite into a colorless, almost perfectly amorphous serpentine, showing no needles and only faint patches of color with crossed nicols, and in many cases these serpentine grains retain perfectly the cleavage and the repeated twinning planes of the dolomite.

No. 30 is a white, bedded limestone with distant, thin partings of serpentine, probably originally an actinolitic limestone. Traces of hornblende with extinction $14^{\circ}$ could be seen.

20. "Massive garnet.-Westfield." XIII, No. 40, Massachusetts Survey Collection.-This is a granular mixture of quartz, garnet, and pyroxene, and can have been introduced here only as one of the rocks bordering upon the Atwater serpentine bed.

21. "Compact scapolite (?).-Westfield." XIII, No. 32, Massachusetts Survey Collection.-A bluish-white, translucent, partly sparry, partly cryptocrystalline mass, showing the distinct, very fine, triclinic striation of a plagioclase, exactly like that associated with the serpentine at the Chester emery mine and at the Pelham asbestos quarry.

MON XXIX- 8 
22. Enstatite-serpentine.-Westfield. Prolonging the line of the Atwater bed in Russell southward, it is found that many large bowlders occur where it crosses the road to Granville, and farther south an immense block lies in the woods on the hill back of $\mathbf{S}$. Drake's house, in the west parish of Westfield, which is made up of very large enstatite crystals in every stage of change to bastite, and the whole mass is exactly like that described above at J. Downey's, in West Granville.

Farther soutll, along Munn's brook, where it cuts a deep gorge in Sodom Momntain, at the lead of the gorge, near the house of H. H. Purchase, and at the mouth of the same, are many great bowlders of a similar black serpentine with large crystals of enstatite changing or changed into bastite or white talc. All these occurrences, to this last by Munn's brook, are so similar that a single description of slides cut from the great bowlder at H. H. Purchase's, Granville, may serve for them all, and this occurrence is so like that near J. Downey's, in West Granville, that the description can be brief, as I shall note only the important differences.

Slides of the freshest enstatite show a reddish-yellow color and polarize brilliantly. Some of them contain very abundantly the stout, straight black rods; in others they are as rare as in the former locality. Magnesite in rounded grains and distinct rhombohedra is found abundantly in the freshest enstatite, apparently as a primary constituent. A qualitative examination determined the absence of calcium. With cold hydrochloric acid fragments of the serpentine presented no change; with boiling acid there was a long-continued effervescence, and there remained an interlaced mass of altered enstative crystals.

23. "Diallage in serpentine.-Sodom Mountain." XIII, No. 48, Massachusetts Survey Collection. The specimen is wanting in the collection at Amherst, but it must have come from one of the latter localities along the gorge of Munn's brook, through Sodom Mountain, and must have been an enstatite and not a diallage rock, the latter mineral not occurring in the serpentine range.

RÉSUMte.

In the long line of outcrops from Zoar to North Blandford the serpentine is characterized by deep oil-green colors, marked translucence, and freedom from secondary magnetite. It is composed of fine serpentine blades mingled with softly irised films of talc, and still contains the scattered grains 
of highly reflactive epidote, which have passed unchanged from the parent rock, and often show traces of its stratification. It wonld seem, then, to have been derived from the common epidotic homblende-schist (amphibolite) with which it is associated. In a great number of slides no trace of olivine or enstatite, or of the structures characteristic of these minerals, conld be detected except in the bowlders from Chester (Massachusetts Survey Collection, XIII, No. 53), whose exact locality can not be determined, and those from the base of the large Middlefield bed, from which place the Chester bowlder may have come. The presence of so large masses of chromite and of nickel requires explanation, and indicates that some parts of these beds were once chrysolitic. The specimen labeled XIII, No. 43, of the Massachusetts Survey Collection, from Chester, probably from the south end of the large Middlefield bed, where is an old "mine" of this ore, is a mass of chromite $50^{\mathrm{mm}}$ on a side. Moreover, the discovery that the so-called quartz psendomorphs from the Middlefield bed are serpentine pseudomorphs after olivine ${ }^{1}$ must receive consideration in this connection. They are, however, large, perfectly terminated crystals, some of which have broken off from the walls of the cavity to which they were attached, and they can not be taken as normal idiomorphic constituents of an ultra basic eruptive. They are better explained as fissure minerals in a crystalline limestone, like the Snarum crystals.

I conclude, therefore, that nearly all of these serpentines are derived from the amphibolites, and find the stratigraphical evidence in this direction strengthened by the lithological evidence.

Osborn's quarry at Blandford is a dividing point between the translucent hornblende-serpentines on the north and the black enstatite-serpentines on the south. To the east of the central steatite bed, which is quarried, is the isolated and unique olivine-serpentine bed; to the west is the equally peculiar sahlite-serpentine bed.

The black serpentine and dolomite mass which forms the center and least changed portion of the central steatite bed is the first of a series of such deposits which locally replace the amphibolite in its further progress south. They are rare and subordinate to amphibolite in the broadened portion of the bed across West Granville, but after the bed has bent northward at East Granville they increase in relative importance and are associated with 
considerable beds of white crystalline limestone, dolomite, and tremolite schist, and in the further prolongation of the bed across Russell and Westfield the enstatite-serpentines and the half-altered beds of very coarse enstatite rock associated with great beds of crystalline limestone become entirely predominant. The black, fissile amphibolites accompany the enstatite-serpentine beds to the end.

The presence of dolomite as an original constituent, both as inclusions in the unchanged enstatite and in the interstices of the enstatite rock, as well as in great beds, indicates the derivation of the whole series from large beds of dolomitic limestone. The subject is summarized on page 147, after the description of the emery bed.

Below is given a table of all the analyses of serpentines known to me from this area. The material used in the analyses 1 to 6 was furnished by the author, and, excepting 2 and 9 , great care was taken to detect all the rarer constituents, especially nickel, cobalt, and chromium.

\section{Analyses of serpentines.}

[Nos. 1, 3, 5,6, and 8, by Mr. George Steiger, in the laboratory of the United States Geological Surrey; No. 3, by Miss H. P. Cook, instructor in chemistry in Smith College; No. 9, by Prof. C. U. Shepard; No. 2, by Melville, quoted from Dana's Manual, p. 672; Nos. 4, 7, and 11, by Dr. W. F. Hillebrand, of the United States Geological Survey.]

\begin{tabular}{|c|c|c|c|c|c|c|c|c|c|c|c|}
\hline & 1. & 2. & 3. & 4. & 5. & 6. & 7. & 8. & 9. & 10. & 11. \\
\hline $\mathrm{SiO}_{2}$ & 40.42 & 44.22 & 40.27 & 38.62 & 39.14 & 33.87 & 40.77 & 37.82 & 44.16 & 36.94 & 54.04 \\
\hline Tic & None. & & & None. & None. & None. & None. & Trace. & & Trace. & None. \\
\hline $\mathrm{Al}_{2} \mathrm{O}_{3}$ & 1.86 & .53 & & .35 & 1.18 & .77 & 1.16 & .61 & & .50 & .52 \\
\hline $\mathrm{Fe}_{2} \mathrm{C}$ & 2.75 & 6.61 & & 3.44 & 4.46 & 2.81 & 3.56 & 7.92 & & 6.04 & 1.51 \\
\hline $\mathrm{FeO}$ & 4.27 & & & 3.99 & 3.14 & 4.25 & 1.47 & 1.15 & 7.05 & 1.94 & 3.90 \\
\hline $\mathrm{FeS}$ & .43 & & & & & & & & & $\cdots$ & $\ldots$ \\
\hline $\mathrm{Cr}_{2} \mathrm{O}_{3}$ & .28 & & & .39 & .33 & .38 & .28 & .19 & & .33 & .14 \\
\hline $\mathrm{NiO}$ & .53 & & . & .21 & .47 & 33 & .17 & .45 & & .40 & .23 \\
\hline $\mathrm{CoO}$ & Trace. & & & $\cdots$ & Trace. & & $\{\ldots . . .$. & .05 & .. & None. & ...... \\
\hline Mn & Trace. & $\cdots$ & & .10 & None. & .04 & .09 & 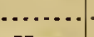 & $\cdots$ & Trace. & .11 \\
\hline $\mathrm{CaO}$ & .66 & $\cdots$ & .. & .40 & None. & None. & None. & None. & & None. & None. \\
\hline $\mathrm{Ba}$ & None. & ........ & $\cdots \cdot$ & ........ & None. & None. & $\ldots$ & None. & $\cdots$ & None. & None. \\
\hline $\operatorname{MgC}$ & 35.95 & 37.54 & 40 & 40.61 & 41.45 & 38.57 & 39.37 & 37.94 & 37.44 & 38.35 & 34.40 \\
\hline $\mathrm{K}_{2} \dot{\mathrm{O}}$ & 16 & & & .08 & Non & Non & .10 & Cra & & None & \\
\hline $\mathrm{Na}_{2} \mathrm{O}$ & & & & .10 & INOUE, & Avone & .14 & L Tace & & Node & .08 \\
\hline $\mathrm{Li}_{2} \mathrm{O}$ & .... & & & Trace. & & & Trace. & & & & \\
\hline $\mathrm{H}_{2} \mathrm{O}-$ & .21 & .36 & .69 & .36 & .34 & .38 & .49 & .75 & & .71 & .70 \\
\hline $\mathrm{H}_{2} \mathrm{O}+100$ & 10.51 & 11.26 & 13.61 & 10.91 & 9.48 & 7.00 & 12.48 & 12.50 & 11 & 12.07 & 3. 07 \\
\hline $\mathrm{SO}_{3} \ldots$ & Trace. & c....... & …..... & .......... & None. & .20 & $\cdots$ & $\cdots$ & & .20 & ....... \\
\hline $\mathrm{P}_{2} \mathrm{O}_{5} \ldots \ldots \ldots \ldots$ & Trace. & - & $\ldots$. & Trace. & .02 & Trace. & Trace. & Trace. & & Trace. & None. \\
\hline \multirow[t]{2}{*}{$\mathrm{CO}_{2} \ldots \ldots \ldots$} & 1.44 & ....- & $\cdots$ & .52 & None. & 10.82 & None: & 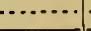 & & 1.85 & 1.32 \\
\hline & 99.47 & 100.52 & 100.31 & 100.08 & 100.01 & 99.42 & 100.08 & 99.38 & 99. 65 & 99.33 & 100.02 \\
\hline
\end{tabular}

No. 1. Rich, dark-green serpentine. Rowe. Quarry near R. King's.

No. 2. Pierolite. Florida.

No. 3. Straw-sellow, fibrous eerpentine, glazed, enveloping olivine psendomorphs. Middefield. From the specimen figured in Bull. U. S. Geol. Survey No. 126, Pl. I. 
No. 4. Normal dark-green, elightly ofly eerpentine, from tho ceutor of the large Mliddlofield bod, taken from whore tho road oroeses the Choster-Middlofiold lino.

No. 5. Black.groon eorpentine, weathering to pale niokel-greon, with much chromite. North Ilandford. From "The Crater."

No. 6. Gray, splintery eerpentino onveluped in talc. Chester. From the east wall of the old mine.

No. 7. Serpentino from the low or bed at Osborn'e quarry, Blandford, which etill rotaine tho cleavage of eahlite and in places cunsidorablo remuants of the mineral.

No. 8. Fnstatite changed to erpentine. Granville. H. Cooley's.

No. 9. Black serpentino with luastite. Ruesell.

No. 10. Black serpentine containing marmolite (hastite). Russell. Atwater'e quarry.

No. 11. Slightly altered, nearly colorless enetatite, from Downey'e, in Granville; added for comparison.

The constant content of nickel, cobalt, and chromium in all these analyses where it has been searched for is very interesting and may be taken as an indication of the eruptive origin of the whole series, which would, however, involve the derivation of large beds of white crystalline limestones, both dolomitic and quite purely calcareous, from the same basal eruptive rocks.

\section{THE CHESTER EMERY BED.}

\section{HISTORY OF DISOOVERY AND WORKING OF THE BED.}

Not the least interesting element in the peculiar geology of the western part of Chester is the great magnetite-emery bed which lies along the upper (eastern) line of junction of the homblende-schist with the sericiteschist and extends from the Westfield (better Agawam) River southward nearly to the south line of the town and nearly as far as the great hornblendic band retains its maximum thickness.

The history of the discovery of this bed has often been told, and deserves to be retold. The eredit of the discovery and its first announcement belongs to Dr. C. T. Jackson. I remember how Professor Shepard, when taking my college class through the cabinets in 1865, stopped at the old State geological collection made by President Hitchcock during his survey of Massachusetts, and took down the specimen of magnetite collected from the Chester bed and pointed out to us the emery which it contained, to show us how near Dr. Hitchcock had been to numbering this among his many discoveries. Dr. Hitchcock had described several beds of magnetite for the first time in his final report. ${ }^{1}$ They were located in the western part of Chester, in hornblende-schist, and none of them exceeded 1 foot in width.

For the next events in the history of the locality I must have recourse 
to the "Biographical Sketch" of Dr. Herman S. Lucas, of Chester, inserted at the end of the town history of Chester." From the well-known manner in which this book was compiled, and from internal evidence in the sketch itself, one is led to attribute to it somewhat of an autobiographical character. The paragraphs bearing upon the history of the emery beds are as follows:

But perhaps the most remarkable event in his career was the discovery of what was for some time supposed to be a vast deposit of iron ore in the mountains around Chester. This occurred in 1856, and arrangements were at once made for the opening and working of the mine; and in the course of about one year 1,200 tons of mineral were taken out and transported to the furnaces of Stockbridge, Lenox, and Hudson.

The financial erisis of 1857 compelled a discontinuance of the business, and it was not renewed until 1863. In the last-mentioned year, in company with his brother, John E. Lucas, and Henry D. Wilcox, he resumed the business. A blast furnace and forge were erected in Chester and the manufacture of iron was commenced, bnt the ore proved somewhat intractable and the results were not satisfactory. In the meantime the Doctor made a more thorough examination of the mineral, and on the 6th of September, 1864, discovered that it contained a large percentage of emery, a mineral hitherto nearly unknown in the United States; in fact, this is believed to have been its first discovery in America.

Coming at a time when the country was engaged in a terrible war with internal enemies, the discovery was doubly valuable. Heretofore the emery used in this country had been imported from the Turkish dominions, and as the English and French Goverments had a monopoly of the mines near Smyrna, in Asia Minor, and on the Greek island of Naxos, in the archipelago, the United States Government was debarred from procuring its necessary supply, except nnder unusual difficulties. In this dilemma the Chester emery was utilized and the Government works were supplied from it for a considerable time.

This mineral had repeatedly been examined by various scientific gentlemen, and specimens were placed in the collections at Amherst College and in that made by Professor Hitch cock for the State and labeled magnetite.

In 1868 Dr. Lucas, with Messrs. Charles Alden and H. D. Wilcox, formed what was known as the Hampden Emery Company, and erected a mill on the river below Chester village for the manufacture of emery.

In 1874 questions touching the ownership of the mines involved the Doctor in litigation, which necessitated a change in his business, and from that time he has obtained his mineral mostly from the Turkish mines.

The Doctor continued iu business in his own name until May 1, 1878, when Nathan Harwood became associated with him.

The importance of this discovery is well illustrated by the remark of a great English statesman, that "The discovery of an emery mine was of more value than that of many gold mines."

\footnotetext{
${ }^{1}$ History of the Connecticut in Massachnsetts, vol. 2, p. 1064; Lewis H. Evert, Philadelphia, 1879.
} 
I think that one may hazard the conjecture that the last sentence in the above was quoted from menory, and thus rather imperfectly, from the opening sentence of the article cited next below, though there is no other indication that the biographer of Dr. Lucas was acquainted with the part taken by Dr. Jackson in the discovery of emery at Chester. It will be well, therefore, to let the acconnt of the matter given by Dr. Jackson himself follow: ${ }^{1}$

It has been said in England that "a good mine of emery is worth more to a manufacturing people than many mines of gold." Such being the case, it affords me great pleasure to be able to announce the discovery of an inexhaustible bed of the best emery in the world in the middle of the State of Massachusetts, in Chester, Hanpden County, quite near to the Western Railroad, which, with its ramifications, leads to the largest armories and manufactories of metallic articles in this and the adjacent States.

For more than two years the existence of important beds of magnetic iron ore, originally discovered by Dr. H. S. Lucas, has been known, and endeavors were made by that gentleman to organize a company for the purpose of smelting these ores. In consequence of this agitation I was employed by John B. Taft, esq., on the 19th of October, 1863, to examine the locality and to make report of my results to him.

On examiuation of my specimeus of minerals after returning to Boston, and my notes for sectional profiles of the rocky strata containing the iron ore, I found that the minerals margarite and chloritoid, in talcose, hornblende, and mica slate rocks, indicated the occurrence of emery, the association of the rocks and minerals being identical with conditions known to exist in the localities of emery in Asia Minor.

I therefore called the attention of the owners of the property to these facts, and directed that search be made for emery, and that every mineral resembling it should be sent to me for examination. Little attention was paid to this prediction at the time, nor until I had invited $\mathrm{Dl}^{2}$. Lucas, who resides in Chester, by personal represen. tations and solicitations, to make the required search, the characters of emery being fully described to him.

On his return to Chester he soon learned that the miners were complaining of the great hardness of the supposed iron ore, and that no less than forty drills were dulled in boring a single hole for blasting. He then sent me pieces of this hard rock, in the belief that it was the emery I had predicted. On examination it was found to scratch quartz and topaz readily and to have all the properties of emery. A chemical analysis proved it to be identical with the emery of Naxos.

The owners, resident in Boston, being notified of this discovery, went with me to the locality on the 11th of October last, when a full exploration of the premises was made. There are several large beds of rich magnetic iron ore at this locality, and the emery being magnetic (as it always is) has caused it to be mistakell for magnetic iron ore, and many tons of it had been smelted with the carbonate of iron and hematite in

1 Discovery of Emery in Chester, Massachusetts, by Charles T. Jackson, M. D., Geologist and State Assayer: Am. Jour. Sci., 2d series, Vol. XXXIX, May, 1865, p. 87. 
the Berkshire County iron furnaces without a suspicion, notwithstanding its refractory nature, that the ore was emery, with only a small admixture of iron ore.

The mineralogical and geological data of the article are quoted under "Emery" in the Mineralogical Lexicon covering the field of this monograph ${ }^{1}$ and under the general description of the vein (p. 135). The conclusion of the article is as follows:

It may be proper to add that John B. Taft, esq., of Boston, in belialf of his associates, owners of the emery mine, has the sole management of the business connected with the mine.

I would express my obligations to Mr. J. L. Smith for the valuable information contained in his articles on the emery of Asia Minor and on the associated minerals of the emery localities published in Vols. $\mathrm{X}$ and $\mathrm{XI}$ of this journal; also to Dr. H.S. Lucas, of Chester, for kind assistance in the field. ${ }^{1}$

It seems thus that the veins became known to Dr. Hitchcock between 1835 and 1841, and that Dr. Lucas, who, as an ardent student of the mineralogy of his native town, was doubtless acquainted with Dr. Hitchcock's published work, examined the beds, became convinced of their economic value and began work upon them in 1856. He renewed his work in 1863 , but as an iron indnstry it did not prove profitable, and the property passed into the hands of a Boston company represented by Mr. John B. Taft, and in which Dr. Lucas was interested.

Largely, perhaps, on account of the refractory nature of the ore, Dr. Jackson was employed to examine the mine, and, relying upon the earlier investigations of J. Lawrence Smith, predicted the occurrence of emery from the associated minerals and urged Dr. Lucas to search for it.

In the meantime the miners had practically discovered the emery, much to their sorrow, and I have been iuformed by two who worked in the mine at the time that they were well persuaded that the brown mineral was what dulled their tools and were accustomed to call it emery. Armed with this practical and scientific information, Dr. Lucas investigated the ore anew, determined the emery, and sent the specimens to Dr. Jackson, upon which he made his mineralogical tests and, most important of all, his chemical analyses. ${ }^{2}$

${ }^{1}$ Bull. U. S. Geol. Survey No. 126, under "Cornndum."

${ }^{2}$ In a recent report of an interview with Dr. Lucas (Springfield Republican, "Another vein of corundum," December 12, 1895) the history of the discovery is repeated much poore nearly in accordance with the account of the matter I have given than with the biographical sketch quoted 
This gave rise to the emery mining, and, in 1868 , to the formation of the Hampden Emery Company, in which Dr. Lucas, Mr. S. A. Bartholomew, of Blandford, and Dr. Jackson were interested. A few years later this company deeded, in apparent good faith, what they supposed to be the main vein, of which they had previously bought the mining right, to the Chester Iron Company, afterward the Chester Enery Company, a stock company controlled by Mr. James T. Ames, of Chicopee, Massachusetts, of the Ames Manufacturing Company.

The older company deeded "commencing in the middle of the vein of iron ore and running at right angles to the same 5 rods, thence parallel to the same to its south end, thence 10 rods at right angles to the same, thence parallel to the same to the north end, thence 5 rods at right angles to the same to the place of beginning, being about 4 acres." The new company went to work upon its purchase, while the old company continued to work upon a vein farther west, which it still held. In a short time it was found that the new company was working upon a line of bowlders derived doubtless from the true deposit to the west, upon which the old company was still working vigorously.

Thereupon arose an important lawsuit, the Chester Company claiming the true vein, while the old company claimed that a blunder had been made by all parties, and that the attempt to apply the deed to the western vein would give 7 acres instead of 4 . After protracted litigation the case was decided for the purchasers, and the vein came into the hands of the Chester Company and was worked by it, extensive buildings being erected and expensive machinery obtained. In 1879 thirty-five men were employed and 210 tons of emery were produced, valued at $\$ 20,000{ }^{1}$

The mine was worked apparently without much profit, since in 1883 , after the death of $\mathrm{Mr}$. Ames, the whole property, said to have cost above $\$ 80,000$, was purchased by Dr. Lucas for a sum reported to be about $\$ 12,000$.

On the adverse issue of the lawsuit Dr. Lucas had, with customary energy, turned his attention to the Naxos emery, and curiously, from the

above. Dr. Lucas here claims to have discovered the omery in 1864; it is said that the miners "could make very little headway against the rocks, which, they told Dr. Lucas, were so hard that they could not keep their tools sharp;" that Dr. Jackson told Dr. Lucas that the margarite was sometimes found with emery, and "it was this that gave Dr. Lucas his clew." .

${ }^{1}$ Hist. Conn. Valley, Vol. II, p. 1063. 
fact that the crude emery could be entered free while the manufactured article was highly taxed, and from the further fact that sailing vessels trading with the Mediterranean were compelled to return in ballast and were thus willing to deliver the crude emery in New York with little or no charge for freight, he was able to create a lucrative indnstry. Latterly his supplies have been drawn principally from the Southern States.

In 1883 no work was in progress except at the nortl mine, where six men were employed, and during the year even this work was stopped. In 1890 the old mine was reopened and has since been worked continuously, and the working has reopened the area where the fine diaspore occurs. In 1894 an adit was driven into the hill on the north side of the road along. the eastern wall of the vein.

In 1865 Prof. C. U. Shepard published a report upon the mine, ${ }^{1}$ mainly mineralogical, but containing notes on the geology of the vein. The report was published in such form that it is not now obtainable, and it seems to me desirable that it be published in full in this place.

a Description of the Emery Mine of Chester, Hampden County, Mass.

U. S. A., By Charles Upham Shepard, Massachusetts, professor of Natural History in Amherst College. (Printed by Taylor \& Francis, Red Lion Court, Fleet street, London, 1865.)

\section{CORRECTION.}

The statement in this report respecting the suggestion of Dr. Lawrence Smith was based upou a misapprehension of the facts.

The whole credit of the emery discovery at Chester is dne to Dr. C. T. Jackson, who made a personal examination of the locality with reference to the iron ore, and from his knowledge of the minerals associated with emery inferred the existence of that mineral in this locality and advised an examination for the purpose of ascertaining whether it did not exist there. Dr. Jackson, among other sources from whence he had derived information on the general subject, had in his possession the articles of Dr. Smith on the emery of Asia Minor and on the associated minerals, published in Vols. $\mathrm{X}$ and XI of the American Jomrnal of Science. But Dr. Smith had no knowledge of the Chester mine or minerals until after the published reports of the discovery of the emery by Dr. Jackson.

Boston, November 7, 1865.

Charles Upham Shepard.

'A Description of the Emery Mine of Chester, Hampden County, Massachusetts. 16 pages. London. 


\section{EMTRY MINE.}

The discovery of this mine so recently as the antunn of $\mathbf{1 8 6 4}$ within the boundaries of the State of Massachusetts, where so much attention has been given to Inineralogy and geology, seems somewhat singular; the more so, perhaps, as its occurrence is so near the machine shops and armories in which the consumption of emery is very considerable. Among the reasons of its delayed discovery may be adduced its situation in a mountainons and thinly inhabited section, which until recently has attracted bnt little scientific or economic notice. Emery, noreover, being itself rich in iron and largely associated with magnetic iron ore (magnetite), is extremely liable to be confounded with the latter substance, and this was the case with it at Chester, whence about 1,000 tons were raised for iron making before its true nature was ascertained. The discovery wonld probably have been still longer deferred but for the happy suggestion of Prof. J. Lawrence Smith, ${ }^{1}$ that the occurrence of the margarite at Chester should lead to a direct search for emery, this mineral being one of the invariable concomitants of that highly important substance. This suggestion was at once successfully acted upon by Dr. Lucas and N. O. Sawyer, esq.

The mine is situated nearly in the center of the Green Mountain chain as it traverses the western border of the State, at a point not far from halfway between the Connecticut and Hudson rivers. It is included in the metamorphic series of rocks, here consisting of vast breadths of gneiss and mica-slate, with considerable interpolations of talcose slate and serpentine. The general direction of the stratification is N. $20^{\circ}$ E. and S. 200 W., the relation to the horizon varying from vertical to a dip of from $75^{\circ}$ to $80^{\circ}$, sometimes east, sometimes west.

The immediate vicinity of the mine presents a succession of lengthened rocky swells with rather precipitous sides, having summits between 750 and 1,000 feet above the level of the principal streams by which the hills are traversed. The longer axis of the elevations generally coincides with the direction of the strata.

The emery vein traverses in an nubroken line the crests of two of these adjoining mountains and scarcely deviates as a whole from the magnetic meridian. Each mountaiu is estimated to have a length of 2 miles, thus giving 4 miles extent to the metalliferous stratum, for such it may truly be called, cousisting, as it does, so largely of the metals iron and alumininm. The Westfield River, here a small stream of about 4 rods in width, flows directly across the northern end of the vein, while a branch of the same river, having half its size, separates the two mountains and very nearly divides the vein into two equal portions. The height of each mountain is estimated at 750 feet.

The emery vein, whose average width may be taken as 4 feet, is sitnated near the junction of the great gneiss formation constituting the western flank of the mountains, with the mica-slate forming their eastern slope. To spenk more exactly, however, it lies just within the gueiss, having thronghont a layer of this rock from 4 to 10 feet in thickness for its eastern wall. Nor does the mica-slate advance quite up to this outsicle layer of the gneiss, but, in place thereof, an extensive intrusion of

1 To Dr. Smith we are indebted for the first scientific survey of tho emery mines of the Grecian Arehipelago and Asia Minor. 
the talcose slate occurs, having an average thickuess of 20 feet on the South Mountain and widening out on the North Mountain to a breadth of nearly 200 feet as it reaches the terminus of the vein in the bed of the Westfield River.

The gneiss, more especially in the vicinity of the vein, is a very peculiar rock. It abounds in thick seams of a coarse-grained very black and shining hornblende, and where this is not found it is much veined and penetrated by epidote. The stratification is much contorted also, and when the surface of the formation happens to be weathered or water-worn its basseting edges strikingly resemble in color some of the serpentine marbles. It is also noticeable that in it quartz is everywhere singularly deficient. Traces of a white calcareous spar (calcite) are now and then visible upon the joints of the gueiss, with occasional specks of yellow copper, together with malachite stains, but no corundum, emery, or magnetite particles bave thus far been detected as constituents of the gneiss itself. It is quite otherwise, however, with the talcky rock exterior to the wall of gueiss, for that formation in all its different varieties of talcose slate, soapstone, chloritic aggregates (with included seam of indianite), talcky dolomite, etc., which together constitute the stratum separating the gneiss from the mica-slate, contain here and there disseminated grains of either emery, corundum, or magnetite, but, like the gneiss again, are strikingly free from quartz or uncombined silica in any of its forms. Indeed, this generally abundant substance is altogether.wanting, not only in the emery vein, but in the talcose formations constituting its easteru boundary. It makes its appearance, however, in abundance in the mica-slate as soon as the talcose rocks are passed, showing itself not only as the usual constituent of the slate, but in more or less continuous seams from a few inches thick np to above 6 inches and sometimes a foot in width. Where the seams are thin and discontinuous the included masses thin out at each end before disappearing, the sharp edges being curved in opposite directions so as to form frequent white patches upou the surface of the rock in the shape of the letter S. ${ }^{1}$

Corundum and emery (the former consisting of pure alumina and the latter of the same earth in combination with the protoxide of iron), have been found hitherto almost exclusively in carbonate of lime (marble or saccharoidal limestone), from the substance of which as a mediun or vehicle free from silica they were precipitated in erystals, nodular masses, or veins. Here, however, carbonate of lime is wanting (if we except a partial development of impure dolomite in one place at the top of the South Mountain); but a parent rock or menstruum for the formation of corundum aud emery is supplied in a talcose slate series equally deficient in free silica, this being a compound which, if coexistent with alumina and protoxide of iron, would seem to be incompatible with the formatiou of either corundum or emery, inasmnch as uuder the play of the ordinary chemical affinities, several very different species would be more likely to result."

${ }^{1}$ It is in the principal veins of this white quartz that very large crystals of ilmenite (washingtonite) were found at one spot within a mile from the northern end of the voin.

${ }^{2}$ An analogous abejance of quartz characterizes the aluminous group of the spinels, the occurrence of which is much restricted to timestone and talcose slate; and since alumina is rarely abuudant, even in granular limestone and talcose slate, we appear to have an explanation of the general scarcity of the corundom and spinel species in the mineral kingdom. 
particles not excecling in size those of certain varieties of steel or fine-grained cast iron. The firacture is effected with the greatest dilliculty, and takes place as readily in one direction as another. The surface, moreover, has an exceedingly hard feel. Its color is a darker brown than that of the preceding varieties. It also presents in some specimens a faint violet-bIne tarnish. It has often been mistaken for magnetite, though its harshness of feel and very diffienlt frangibility easily distinguish its masses from that ore. It has a tendency to ocenr throughout the vein in wedge-shaped, contorted masses, as well as in elliptical balls of all sizes, from a few pounds weight up to a hundred pounds.

(d.) Emery magnetite.-This is a massive magnetite containing a variable intermixture of emery. It closely resembles magnetite, but it is distinguished by its superior hardness, its purplish tarnish, and more difficult frangibility. It does not appear to be abundant, though it is often liable to be met with throughout the course of the vein.

(e) Stony emery.-This in general is the chloritoidal rock or substance of the vein in places where it is not replaced by one of the preceding varieties. It is a slaty, tough, greenish-gray, rather heavy aggregate, containing everywhere fine-grained emery in proportions varying between 10 and 20 per cent. Other minerals also are present occasionally, such as tourmaline, epidote, margarite, ottrelite, magnetite, etc. A variety of stony emery in thin, highly contorted, schistose layers enveloping the compact emery frequently presents itself. Its color is a delicate greenish white, and it is often interlaminated by seams of pinkish margarite-the entire aggregate being, nevertheless, rich in emery.

\section{Magnetite.}

Next in abundance among the constituents of the vein stands the present species, that richest and most precious of all the ores of iron. Its composition being so strictly accordant with that of emery, their joint occurrence would, on chemical grounds, be looked for almost as a matter of course. Like the emery itself, it here occurs massive, thin-veined, granular, and dissemiuated. The massive variety is found perfectly pure and unmixed, having a structure between the coarse-grained (shot ore) of the Lake Champlain region and the fine-grained, compact ore of Franconia and Dannemora, Sweden. It sometimes exhibits in the fracture a slightly purplish tint not observable in any other magnetite with which $I$ am acquainted. It is also a shade blacker than most magnetites. It is wholly free from pyrites and all traces of rust, and consequently is bright and fresh in luster throughout. It is magnetic with polarity, but does not give rise to examples of the native magnet. It presents itself in considerable quantity at several places on the course of the vein. For example, at the top of the North Mountain it constitutes a continuous seam from 10 to 15 inches thick in a chloritoidal vien, itself 4 or 5 feet wide, and made up of the disseminated variety, presently to be mentioned. This vein of maguctite forks off from the great emery vein on its eastern side at an angle of about $30^{\circ}$ and then pursues its course between the talcose slate strata, within which it has already been opened for 
10 or 12 yards, having an easterly dip of $70^{\circ}$; and thence continues for an undetermined distance, the surface of the ground not yet having been cleared of loose rocks and of trees in such a manner as to define ${ }^{\circ}$ its extent. This branch vein has already been sunk upon at this spot to a depth of 25 feet. Little or wo emery is present. A mass of at least 10 tons weight of the massive variety of magnetite lies loose in the wood (with which the northern slope of the mountain is covered), 600 feet on the direct course of this vein and near to an opening of what seems to be its direct continuation. The product of the latter excavation, however, is not the present massive variety of ore, but this agaiu occurs in quantity at the openiug quite at the summit of the South Mountain, forming a part of the great emery vein which there for a distance of several rods widens out to at least 15 feet. It here occurs in a series of several more or less interrupted seams, often affording masses 6 or 8 inches thick and quite pure, thongh in immediate proximity to the emery.

The massive magnetite passes into the thin-veined where the seams are half an inch and less in thickness, traversing the corundophilite or chloritoidal mineral, among whose particles are frequent chinks or cavities constitnting a very fissile opeu rock. When these seams or veins become much broken or interrupted we have what may be called the disseminated variety. All three coexist in the same vein and often graduate iusensibly to each other, the ore itself being in each variety eutirely identical.

The stony magnetite exists in other places, and is disseminated in smaller graius through a firmer gangue, identical in character with that constituting the stony emery. It is well seen at a place above referred to, where a vein has been worked upon 600 feet to the north of the summit of the North Mountain, and whence 50 tons of ore have been raised for the furnace. It here exists in the proportions of 50 to 60 per cent thronghout the vein, which is 3 feet wide. As the vein is free from emery, it may prove to be a prolongation of that bearing magnetite at the top of the mountain.

Dr. Jackson has detected the presence of titaninm in the emery of Chester, rendering it probable that it will also be found in the accompanying magnetite. Should this prove to be the case, it will only be in mere traces, and will probably increase the valne of the ore for iron making. It is quite certain that all the compounds, both of sulphur and phosphorus, are entirely wanting throughout the formation.

\section{Corundum.}

This species consists of the well-known pure anhydrous alumina, and is rare even in mines of emery. It is nevertheless occasionally found in those of Turkey, occurring in the form of thin seams, small grains (often of a blue color), and rarely in crystals diffused through the emery stone. It occurs rarely also at Chester, but thus far has been met with only in seams or veins one-half or three-quarters of an inch thick, though exhibiting a surface of nearly a square foot. It is grayish white, highly crystalline, like that from the Carnatic. The seams occur in the granular and compact emery. 
To complete this general description of the locality it may not be deemed superflnons to ald the interesting geological fact that in two places the surface of the enery vein (near the snmmit of each monntain), for a distance of several rods in each ease, has been decply grooved and smoothed by glacial action. That the friction prodncing this effect must have been enormous is apparent from the size and depth of the channels, no less than from the initial hardness of the mineral worn away; and that it could not have been the result of running water is demonstrated by recurring to the example of river action in the Westfield River upon another portion of the same rein, where no such smoothing effect has been prodnced; but in place we have merely an eroded, pitted surface from which the coarse crystalline particles of the hard omery are left projecting, precisely as garuet and staurotide are seen on merely weathered faces of mica-slate.

Passing now from the geological features of the region we enter upoll a brief notice of the vein itself and its mineralogical contents. The principal gangue or matrix may be said to be chloritoidal. It can not properly be called chlorite slate or even chloritic trap, inasmuch as the green chloritoidal mineral it contains is considerably removed in character from the species chlorite. This opinion is based not so mnch npon its wanting the color and argillaceous odor of chlorite as upon the consideration that where crystallized it is found to be harder and heavier than that mineral and further differs from it by containing less magnesia and more alumina and protoxide of iron than belong to chlorite. In fact, it is much nearer to corundophilite, a mineral thus named by me from its being the almost constant attendant of corundum. It is not certain, however, that true chlorite is absolutely wanting in the vein, or at least in the contiguous talcose slate, and inasmuch as masonite and ottrelite, varieties of the species chloritoid, are often present, I shall generally speak of the gangue or vein stone as chloritoidal rock.

\section{MiNeRALS IN THE VEIN.}

\section{EMERY.}

Not a little confusion has hitherto prevailed as to the mineralogical and chemical nature of this substance. A common opinion has been that it is a mechanical mixture of corundum and magnetite, while some have imagined it to be a triple componnd of alumina and the two oxides of iron. Dr. Jackson, in view of his own analyses of emery, conceives it to be a combination only of alumina and the protoxide of iron. ${ }^{1}$

He found-

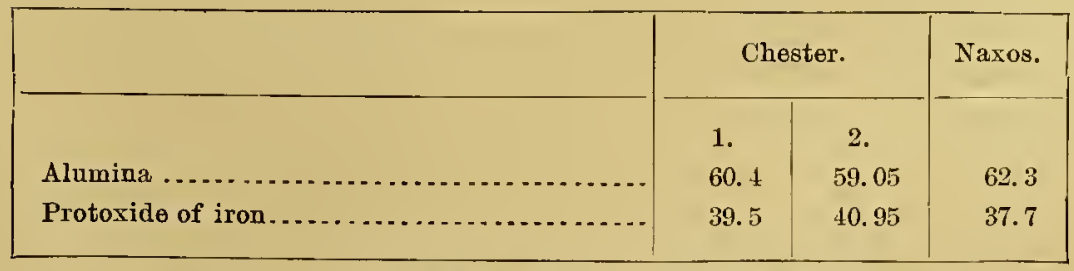

${ }^{1}$ See Am. Jour. Sci., 2d series, Vol. XXXIX, January, 1865. 
and he suggested that it be considered a distinct species in place of being included as a variety under corundum. ${ }^{1}$ His conclusion would obviously be acquiesced in were it not for the strong resemblance in strix and cleavage between the emery and common corundum, making it impossible for us to separate the substances erystallographically from one another. It would, however, be singular if two minerals differing so widely in their other physical qualities should be specifically identical.

Nothing like a perfect crystal of emery has yet been found at the mine, but it is quite remarkable that the mineral is here generally coarsely massive or in large separate individuals, often of the size of kernels of Indian corn (maize), whose cleavage is perfect, and which present on their planes the delicate strix so characteristic of adamantine spar from the Carnatic. The color, moreover, is perfectly uniform, a reddish-browu with a faint coppery luster. Its specific gravity is superior to that of corundum by nearly five-tenths, while its power of abrading, as accurately determined in the Turkish aud Grecian varieties by Dr. J. L. Smith, is less than half that of the sapphire, though in all its varieties, and especially that of Chester, its scratching power or true hardness is sufficient to scratch topaz. It is constantly magnetic.

In chemical composition the Chester emery is equally uniform, and in constitu. tion may be considered strictly isomorphous with the magnetite, which species indeed coexist in the same vein or in closely contiguous offshoots therefrom. Supposing alumina to have replaced the peroxide of iron (ferrous acid), we then have instead of ferrite of iron (magnetite), the aluminate of the same base (emery), the chemical expression of the first being $\dot{F} \mathrm{e}$, that of the second $\dot{F} \mathrm{H} \ddot{4}$.

The composition of emery in 100 parts, being deduced from this formula, gives a composition scarcely different from the results of actual analysis. Its percentage of metallic iron is therefore a fraction over 29 . It hence becomes apparent how natural was the mistake of regarding it as an ore of iron.

Several varieties of emery at Chester, growing out of the size of particles, their mode of aggregation, and mixture of other minerals require to be pointed out.

(a) Granular emery.-This occurs in flattened grains, from the size of kernels of Indian corn down to that of peppercorns, disseminated through corundophilite. The grains rarely touch each other and are distributed throngh the rather open green mineral, with their flat faces parallel to the foliation of the gangue. Hence this variety cleaves without difficulty into slaty fragments a few inches in thickness. It also breaks crosswise without much difficulty. The pure emery forms from one-half to three-fifths the bulk of the aggregate.

(b) Veined emery.-This variety arises from the occasional contact and partial union of the individuals (by their edges mostly) of the preceding variety. The veins are much interrupted and are rarely above half an inch thick. The granular and veined varieties sometimes pass into each other.

(c) Compact emery. - This variety, though not absolutely compact in the mineralogical sense, is nevertheless a very close, fine-grained mineral in its structure, the

\footnotetext{
1 Sbould it hereafter be found proper to separate emery from corundum the name of emerite might not be an unsuitable designation for the new species.- [SHRPARD.]
} 
4. Diaspore.

This is hydrated alumina, perhaps the most strictly characteristic accompaniment of emery in the Grecian Archipelago and Turkey. It occurs at Chester precisely as in those regions, viz, in needle-shaped crystals and bladed masses, chiefly upon the closs joints of the emery blocks, though sometimes embedded (in compressed round masses) quite within its snbstance. It is generally colorless, thongh sometimes of a jinkish or violet tint. Perfect crystals of the usual form are not wanting where the usual open spaces existin the inasses. Crystals also of corundophilite and very rarely of brookite are found embedded in it.

\section{Margarite.}

Scarcely less characteristic of emery, and also of corundum, is the present mineral, a species whose general aspect snggests that of mica, from which it differs in possessing a greater hardness and a lower dose of silica with a corresponding increase of alnmina added to an almost total absence of either of the alkalis. ${ }^{1}$ The margarite presents itself frequently and with a richness of crystallization and color nowhere else known. It is always in near proximity to the purest masses of emery-sometimes traversing it in veins, at others coating, more or less perfectly, large and small rounded masses of it with layers an inch or more in thickness. The laminæ of the margarite are arranged transversely in respect to the direction of the seams, i. e., they stand at right angles to the walls of the veins. Sometimes an open space exists in the middle of the margarite seam, when the mineral exhibits very rarely regularly terminated crystals with which also crystals of corundophilite are associated. Emery grains are likewise to be detected everywhere among the margarite. Its color is almost universally of a pinkish tint. In a few instances, however, where it occurs in detached scales mixed up with a yellowish epidote in the massive emery, it assumes a grayish color and might be mistaken for ordinary mica, a species which I have nowhere recognized in the formation.

\section{Ottrelite (Masonite, Chloritoid).}

This species belongs to the same mineralogical group as the preceding, but differs from it in many physical properties no less than in chemical composition. It is in disseminated scales of a blackish-green color, whose breadth is rarely more than a quarter of an inch. They present considerable resemblance to mica where seen on weathered surfaces of the vein or on open joints of the rock, but are easily distinguished by their greater hardness and want of elasticity. It is chiefly confiued to the stony emery. In composition it differs considerably from the margarite, having above 20 per cent of protoxide of iron, together with 6 per cent of water, and stands in relation to mica somewhat as emery does to corundum.

${ }_{1}$ This nonalkaline feature of the contents of the vein, together also with the paucity of silica, seem to be essential conditions of all the emery veins. It is curious to remark how completely all the other micas, as well as the feldspars, with the exception of the indianite, itself not abundaut, are excluded from the formation.

$$
\text { MON XXIX—9 }
$$




\section{CoRUndophilite.}

The present mineral has not yet been fully analyzed. An imperfect examination made of a few grains of it found along with the sapphire of Buncombe, North Carolina, lead to the conclusion that, like ottrelite, it is a silicate of alumina and protoxide of iron, but with little lime and magnesia. Des Cloizeaux has described it as one of the micaceous minerals, but it rather appears to belong to the clinochlore gronp. Its crystallization is near to mica and its hardness is between 2 and 3 . Its laminæ are inelastic and almost brittle. In color and in the arrangement of its particles, even when giving rise to a slate, as it often does, it does not resemble the well-known mineral chlorite. It is of all others the most abundant gangue mineral of the purer varieties of both emery and magnetite.

\section{INDiANite.}

Exterior to its vein, on its eastern side and a few feet within the talcose slate, at a place on the South Mountain near the smaller Westfield River, runs a layer or stratum from 6 inches to 2 feet in thickness, called by the workmen " the fringe rock." It consists of a soft, columnar miueral, but it is difficult to say whether it is chlorite or corundophilite, or whether it may not be a mechanical mixture of the two. The columns or fibers, if such they can be called, are perpendicular to the sides of the vein and are made up of superimposed scales of the mineral. The columns have been renclered tortuons and wavy by lateral pressure. Through the middle of this stratum runs, with occasional interruptions, a vein of indianite varying from 2 to 10 inches in thickness. The mineral is massive, finely granular, of a yellowish color, and contains . grains of corundum, whereby it is easily capable of scratching quartz.

\section{Tourmaline.}

'This is also a highly prevalent mineral throughout the entire course of the vein, though perhaps most abundant on the North Mountain. It is more frequent near the sides of the vein, though at some places it is interlaminated through its entire mass, showing itself on the cleavage surfaces. The crystals are often several inches long and from one-fifth to three-fourths of an inch in diameter, being arranged in fascicular and radiating groups with their longer axes conforming to the stratification of the rock. The crystals are usually six-sided prisms with smooth surfaces, but always lacking regular terminations. Their color is brownish black.

\section{EPIDOTE.}

Though not abundant, it is nevertheless frequently observed, especially in the vein on both sides of the smaller Westfield River, near the mill. It is in light yellowish-green crystals, 1 or 2 inches long by one-eighth to one-fifth of an inch in diameter, the crystals being arranged parallel to the lamination of the vein and being often associated with grayish scales of margarite, ottrelite, and with emery. A beautiful radiated pistachio-green epidote, accompanied by diaspore, has also been observed in the same vicinity coating the cross joints of the vein rock. 
11. WASHingtonite (ILMENITE).

This species is rarely met with in black foliated, much-curved laminæ betwixt the double seams of margarite. On the whole, however, its occnrrence is very limited compared with that in the adjoining mica-slate, to which reference has already been made.

\section{BROOKITE.}

Only a few crystals of this rare titanic acid have thus far been noticed, and these were found in close connectiou with diaspore.

\section{Chalcopyrite (Yhllow Copper ORe).}

But few grains of this ore have been seen. It was found, like the washingtonite, in margarite, and also upon the joints of the gneiss near the emery vein-in the latter case attended sometimes by stains of malachite.

The foregoing are all the species thus far found as proper to the vein, with the exception of two apparently rare instances-one in small browu and copper-colored prisms somewhat resembling tyrite, the other in orange-colored specks (slightly decomposed) upon the joints of the emery, and sometimes disseminated through the chlorital gangue, both of which await examination.

Outside of the vein with the talcose slate, besides the sparsely diffused grains of emery and magnetite, a greenish-white laminar talc in thin seams occurs sometimes, penetrated by a greenish yellow actinolite. But the most important mineral economically is that modification of the talcose slate recognized under considerable variations of character as soapstone. It is here found in immense quantity at several points on the course of the vein, but nowhere, perhaps, in a more promising condition for being wrought than near the works upon the South Mountain. It here quarries with much facility in virtue of the natural joints by which it comes out in blocks of from 4 to 6 feet superficially, with a thickness of at least 1 foot, often 2 or more feet. It has the further recommendation of being free from those foreign minerals so frequently interfering with its easy division into slabs in the process of sawing.

It is a point of some importance to notice the correspondence between the minerals enumerated in this paper and those described by Prof. J. Lawrence Smith in his report ${ }^{\mathrm{I}}$ as occurring at the Turkish and Grecian localities of emery. He concludes his account of these with the following observations : "I do not risk much in saying that the hydrate of alumina (diaspore), as well as the silicates emerylite (margarite), chloritoid, and tourmaline, and the ores of iron (magnetite) aud titaniferous iron (ilmenite), will be found almost everywhere with the emery and cormndum."

It will also occur to the chemical geologist and mineralogist that we are now furnished with an explanation of the unfreqnency of the cornndum and spinel families of minerals, since their formation presupposes the existence of alumina, not only in excess, but attended by the absence of silica; while for the formation of emery there

'See Am. Jonr. Sci., 2d series, Vol. XI, January, 1851. 
is demanded the same unusual chemical conditions, accompanied by the abundant presence of protoxide of iron.

The contrast between the conditions of emery at the only two regions of its known occurrence grows ont of the difference in the parent rock or originating formation. It is saccharoidal limestone (white marble) in Asia and talcose slate in America; for although the emery vein at Chester is situated just within the limits of the gneiss, it can scarcely be doubted, since the emery and magnetite are both found in the slate and neither in the gneiss, that these minerals originated in the former at a period, of course, when the strata were horizontal and the talcose slate was uppermost.

\section{Conclusion.}

The preceding statements afford the fullest view I am able to present of the emery mine at Chester as the result of several days of diligent examination of the locality and surrounding region. The vein, thongh fully traced and secured by its present proprietors for the distance of 4 miles, has not been opened except at comparatively few points; but the workings have beell sufficiently extensive to demonstrate the perfectly inexhanstible supply of the emery, not to say also of the magnetite and soapstone. The vein, moreover, following as it does the crests of two precipitous mountains, and holding a vertical position with a width of 3 to 5 feet within well defined walls throughont, presents facilities for exploration that must be obvious to everyone. Experience has not yet been sufficient to determine what will be the cost of raising either the emery or the magnetite; but it may be stated that many hundred tons of both have been mined at a cost not exceeding $\$ 2$ per ton, and it is confidently believed that, when the most advantageous localities for working have been decided upon, a reduction of this charge may be effected. The fact that the mine is capable of being worked for generations without incurring the smallest expense in freeing it from water is a consideration of much importance; while a further advantage to the property arises from the fact that the smaller Westfield River bisects the vein midway of its length where the North and South Mountains come together. Already valuable use is made of this water power in extensive mills here erected for crushing the emery and splitting the soapstone, and a further use may be made of the same stream for the erection of iron works to any extent desired.

The Albany and Boston Railroad passes within a quarter of a mile of these mills-the road from there to the depot being level, or at most having only the descent of the stream. The distance (going east) to Springfield, on the Connecticut River, is 30 miles, and the road to that place is crossed at Westfield, two-thirds of the way thither, by a north-and-south road, whereby the coast at New Haven can be struck at a distance of 62 miles, thus affording by the Hudson River another connection with New York City, as well as the entire region of the West. Indeed, it is easy for anyone, with a map of the United States before him, to assure himself that the Chester mine is situated at the very focus of our system of railroad communication, as well as of the manufacturing industry of the country. 
The quantity of manufactured emery at present annually consumed in the United States is over 1,000 tous, and the consnmption is rapidly ou the increase. This supply has hitherto been derived in part from London and partly from Alden's manufactory at Ashland, near Framingham, Massachusetts, which establishment has imported the crude stone direct from Smyrna, though it is now beginning to derive its material from Chester.

The estimation in which the American product is held is sufficently vouched for in the following certificates, coming as they do from sources of the highest respectability. The letters are addressed to J. B. Taft, esq., of Boston, who is trustee for the parties in interest to the property:

Office of Master Armorer, U. S. Armory, Springfield, Massachusetts, November 16, 1864.

DEAR SIR: The samples of emery sent here for trial have been tested and decided to be superexcellent. The tost has been made without the slightest knowledge of its character by either Mr. Chamberlain or the men.

The Nos. 46 and 70 are not of the right grade, but the eveuness of all the numbers and their cutting qualities can not be equaled by any Turkish or American emery.

Yours, truly,

JoHN B. TAFT, Esq.

$$
\text { (Signed) E. S. Allin, M. A. }
$$

Boston, Massachusetrs, December 1, 1864.

We are very much pleased with the emery you left with us to tr.v. We find it far superior to anything we have heretofore used. We have bought the best that we could possibly find for years, without regard to price, and we find by actual experiment that yours will do one-third more work than the best London emery. We have made a very careful experiment, and can give a more particular report if necessary. If you can supply us with the fine grades to compare with the samples left, you can have all our orders as soon as we use what stock we have on hand.

Very respectfully,

$$
\text { (Signed) Hassam Bros., }
$$
Makers of Fine Cutlery and Surgical Instruments, 116 Washington Street, Boston.

JonN B. TAFT, Esq.

CHICOPEe, April 20, 1865.

Dear SIR: The two packages of emery, as samples, Nos. 46 and 70, were received and tried-the 46 on a lead wheel for cutting out grooves of blades and the 70 on a leather-covered wheel for shaping the large grooves of saber blades. Either test requires good emery to do the work successfully. We had not the means of making a comparative test, but the best thing $I$ can suy for it is that the workmen would use no other kind if they could have emery like the sample. This is of the very best quality we have had an opportunity to use.

$$
\text { Yours, very truly, } \quad \text { (Signed) JAS. T. Alıes. }
$$

J. B. TAFT, Esq.

Mixling SHOP, April 25, 1865.

SIR: The following is a report on the relative qualities of American and English emery, No. 70, as tested in this department. We have given it three different trials. The number of wheels set with emery at each trial was 12,6 with American and 6 with English. The wheels used for the first trial were reversed for second trial, those being set with English emery in second trial that were used with American in first trial, and vice versa.

You will please notice the work as performed by different men with the sume emery. 
Tests of American and English emery.

\begin{tabular}{|c|c|c|c|c|c|c|c|c|c|c|c|c|}
\hline \multirow{3}{*}{ Workmen. } & \multicolumn{4}{|c|}{ First trial. } & \multicolumn{4}{|c|}{ Second trial. } & \multicolumn{4}{|c|}{ Third trial. } \\
\hline & \multicolumn{2}{|c|}{ Whasls. } & \multicolumn{2}{|c|}{ Bayonets. } & \multicolumn{2}{|c|}{ Wheels. } & \multicolumn{2}{|c|}{ Bayonets. } & \multicolumn{2}{|c|}{ Wheels. } & \multicolumn{2}{|c|}{ Bayonets. } \\
\hline & Am. & Eng. & Am. & Eng. & Am. & Eng. & Am. & Eng. & Am. & Eng. & Am. & Eng. \\
\hline J. H. Wade.... & 2 & 2 & 38 & 18 & 2 & 2 & 23 & 25 & 2 & 2 & 35 & 36 \\
\hline H. Eldridge . ........... & 2 & 2 & 45 & 24 & 2 & 2 & 31 & 52 & 2 & 2 & 32 & 47 \\
\hline H. E. Foster.... & 2 & 2 & 24 & 25 & 2 & 2 & 33 & 42 & 2 & 2 & 68 & 55 \\
\hline Total ... & 6 & 6 & 107 & 67 & 6 & 6 & 87 & 119 & 6 & 6 & 135 & 138 \\
\hline
\end{tabular}

RECAPITULATION.

\begin{tabular}{|c|c|c|}
\hline Recapitulation. & $\begin{array}{l}\text { Whole } \\
\text { number of } \\
\text { wheels. }\end{array}$ & $\begin{array}{l}\text { Bayonets } \\
\text { polishod. }\end{array}$ \\
\hline American ........... & 18 & 328 \\
\hline 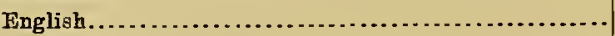 & 18 & 329 \\
\hline
\end{tabular}

Yours, respectfully,

(Signed) W. G. Chamberlais, Foreman.

[Indorsement.]

Respectfully referred to Mr. Taft for his information.

(Signed)

T. T. S. LAIDLEY, Major of Ordnance.

U. S. ARMort, Springfield Milling Shop, April 27, 1865.

SIR: The following is a report on the result of an experiment made in this department on American and English emery, No. 70:

\begin{tabular}{|c|c|c|c|c|c|c|}
\hline & \multicolumn{2}{|c|}{ Butt platss. } & \multicolumn{4}{|c|}{ Bayonets. } \\
\hline & $\begin{array}{l}\text { No. of } \\
\text { wheols. }\end{array}$ & $\begin{array}{c}\text { Tangs } \\
\text { of butt } \\
\text { plates } \\
\text { polisher. }\end{array}$ & $\begin{array}{l}\text { No. of } \\
\text { whegls. }\end{array}$ & $\begin{array}{c}\text { Bayonst } \\
\text { backs } \\
\text { poliøbed. }\end{array}$ & $\begin{array}{l}\text { No. of } \\
\text { wheols. }\end{array}$ & $\begin{array}{l}\text { Bayonet } \\
\text { fronts } \\
\text { polished. }\end{array}$ \\
\hline Amsrican ........ & 4 & 256 & 5 & 223 & 5 & 253 \\
\hline 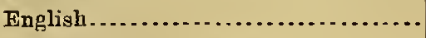 & 4 & 211 & 5 & 225 & 5 & 250 \\
\hline
\end{tabular}

A quantity of Nos. 80 and 90 American emery is desirable for further experiments. Very respectfully,

(Signed)

W. G. Chamberiain, Foreman.

[Indorsemont.]

Respectfully forwarded to Mr. Taft for his information. Several workmen this morning asked for the American emery to put on their wheels. This is the best indication of its quality. Please send as soon as possible some of Nos. 80 and 90 .

(Signed) T. T. S. LAIDLEY, Major of Ordnance. 
There would appear to be one quality in the Chester emery particularly recommending it over the Asiatic variety. It is this, the foreign emery is liable to oxidation, while the American is not, it remaining bright and clean after being moistened and exposed to air. The damage by oxidation is not only a partial loss of hardness, but the coating of the particles by rust interferes materially with their adhesion to the wheel; consequently a wheel charged with the American emery best retains its charge and accomplishes the most abrasion. That this is a well-ascertained difference between the substances from the two localities is apparent from the invariably rusted appearance of the crude stone coming from the East, whereas the produce of the Chester mine and even the loose stones lying about the vicinity betray not the slightest tendeney to oxidation. I am informed also by Mr. Alden, the emery manufacturer at Framingham, that he has long been aware of a 2 per cent gain in weight to his manufactured Naxos emery-an increase which under the circumstances may fairly be ascribed to the fixation of atmospheric oxygen in the production of iron rust. It is singular, indeed, that the same mineral, though from different localities, should not exhibit the same phenomenon when subjected to similar conditions; but numerous examples of other minerals are familiar to the mineralogists, presenting the same capricious instability of constitution.

London, 21 Norfolk street, Strand, 1865.

GENERAL DESCRIPTION.

The Westfield River (the Agawam) runs east across the strike until, entering the northwest corner of Chester, it swings round the north end of the broad hornblende band already described, forming the boundary between this and the Middlefield serpentine, and running south through the township nearly with the strike, it occupies a somewhat wider valley, in which is the village of Chester. This valley is excavated in the softer sericite-schists, and the greater durability of the vertical hornblende-schists (amphibolite) finds expression in the sharp ridge of the North Mountainor Gobble Hill, as it is called with less euphony by the inhabitants-which, seen from north or south, rises like a tower and is a prominent landmark. A small brook coming in from the west in a deep, narrow valley separates it from the South Mountain, which rises to greater height, but is more rounded and falls away southward to the common level of the high ground in Blandford.

The great height of these hills, about 750 feet above the village, 1,583 and 1,797 feet above the sea, is due, as said above, to the amphibolite band, and to the south, where this breaks up into several beds intercalated with sericite-schist, the ground falls off. 
Starting at the north end of the great amphibolite bed and at or near its junction with the sericite-schist on the east-that is, I suppose, its former upper surface-the first exposure of the emery, and the most interesting one offered for study at present, occurs in a ledge projecting into the Agawam River on its left bank near the most northerly railroad bridge over the river in Chester, north of L. Otis's house.

Fig. 6 represents this reef, which projects into the river, where the wear of high water keeps a fresh surface suitable for study.

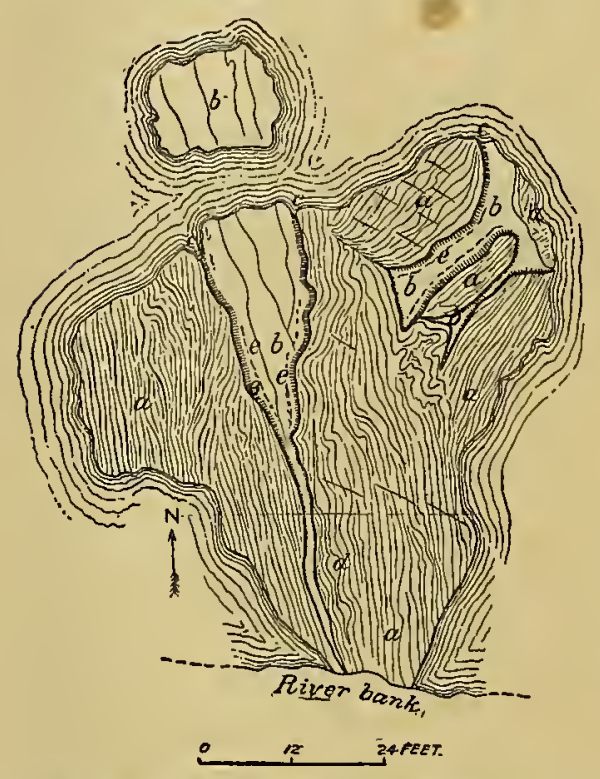

Fis. 6.-Map of emery veins in epidote-amphibolite at north end of bed on the bank of the Weetfield River,Ches. ter. $a$, Epidote-amphibolite; $b$, magnetite-emery beds; $c$, biotite fringe rock; $d$, quartz veins; $e$, tourmaline.

The country rock is an epidotic amphibolite (a), contorted and thinlaminated. The tortuous lines in the drawing represent the foliation, and along the western side of the principal vein, so far as it retains its greater thickness, the laminæ bend around, often quite sharply, so as to end abruptly against the emery vein, the lamination being at times continued through the "fringe rock" (c). On the west of the narrowed portion of the vein, as well as along the whole eastern side of the same, the lamination of the schist accommodates itself quite accurately to the irregular boundary of the vein.

Around the smaller vein to the east the structure of the schist is still more complex, and in part, especially in the small mass which is wholly inclosed in the vein, the lamination is entirely obliterated, and filaments from the vein are spun out into the schist until they become as thin as a knife blade.

A heavy vein of white quartz $(d)$ runs parallel to the main vein in its contracted portion, at a distance from it of 1 to 2 feet, and bunches out several times to a width of a foot or more.

The emery vein $(b)$ where it comes out from the bank is scarcely a foot wide and is growing thinner. It expands northerly, at first quite 
suddenly and then more gradually, to 12 feet, and appears again in the river in an isolated rock with a somervhat greater widtl.

The customary "fringe rock" (c) borders the vein on both sides from an inch to a foot wide, the width being rudely proportioned to the width of the emery rein. It is a soft schist, made up wholly of biotite.

The emery vein is a cliloritic magnetite containing in abundance bronze-colored grains of emery, and, along the borders of the thicker portion of the main vein and of the eastern vein, a considerable quantity of brownblack tourmaline in delicate stellate forms $(e)$.

This extreme contortion of the amphibolite is rare in the region, and $I$ may call to mind that, following the line of strike across the river from this point, one comes directly upon the line of junction of the serpentine (which has replaced the amphibolite) and the sericite-schist, and that the latter is also contorted to an equally extreme degree.

From the outcrop upon the river bank one follows the vein southward up through a notch in the mountain, where, about 800 feet south, it has been opened and some iron ore taken out, and then up along the eastem slope of the mountain, just under the crest, to the new mine, about a mile north of the village, where alone work was in progress in 1883 .

The part of the vein rich in emery was about 1 to 3 feet wide where I saw it, and the corundum was regularly disseminated porphyritically in rich bronze-colored crystals $5-15^{\mathrm{mm}}$ across, affording a very rich ore. The soft, green chloritic "fringe rock" was developed in great force and cuts the emery bed in the bottom of the opening as a heavy horizontal cross-vein. It was filled with bright fresh cubes of pyrite and crystals of tourmaline $10-30^{\mathrm{mm}} \operatorname{long}$ and $2-3^{\mathrm{mm}}$ in diameter, which were all regular hexagonal prisms, with rather dull unstriated sides. They are often radiated and fasciculate.

With a lens slides of the rock show wavy bands of a pale-salmon color, which alternate with bands and lenticular patches of bright green. The former are very fine fibrous, and show the aggregate polarization of talc. The latter is in coarser scales, often radiate, and they polarize from green to black. They have low absorption and pleochroism: $\mathfrak{c}=$ pale blue-green; $\hat{b}=$ same; $a=$ bright yellow; extinction inclined $8^{\circ}$ from the cleavage.

Magnetite is abundant; also deep-brown grains of chromite, the former often interlaminated with chlorite. The tourmaline is in sharp hexagons; 
$\omega=$ black, $\varepsilon=$ deep prussian-blue, with black border. Sharply refringent grains of titanite, with dark border surrounding them, occur in the chlorite. The opening was otherwise poor in the usual accessory minerals of the vein, only traces of margarite occurring. Here also a branch vein runs off to the east and the mica-schist is greatly contorted.

Going south toward the old mine in the valley, one passes, about a third of the way on, the large abandoned Sackett mine, opened about 50 feet on the vein, which is here about 12 feet wide and has been extensively worked for magnetite. The thin "fringe rock" can be seen attached to the hornblende-schist on the west wall of the opening over a broad surface. In the magnetite only a limited amount of emery is visible, and no other minerals could be found. Dr. Jackson says:

On the North Mountain the emery is more largely crystalline and less mixed with magnetic iron; it is more like corundum, but still contains the combined protoxyd of iron, characteristic of true emery.

Three large beds of rich magnetic iron ore, distinct from the ore accompanying the emery, occur, the ore yielding $54_{4}^{1}$ per cent of metallic iron. This ore is mined and is smelted into bar iron by forge fires, and is also sold to mix with the hematites and carbonates of iron at the Lenox and Stockbridge furnaces.

The next opening on the vein is at the foot of North Mountain, north of the Becket road and directly opposite to the main works. (See fig. 7, p. 141.) Here, at the head of a small ravine, an adit was driven in 500 feet during 1893, and brought out a great quantity of the fringe rock, filled with beautiful rosettes of the hexagonal tourmaline. Of the further continuation of the vein across the brook and up the north face of South Mountain Dr. Jackson writes as follows:

The principal bed of emery is seen at the immediate base of the South Mountain, where it is 4 feet wide and cuts through the mountain near its summit at an angle of $70^{\circ}$ inclination, or dip, to the eastward. Its course is N. $20^{\circ} \mathrm{E}$., S. $20^{\circ} \mathrm{W}$., and its known extent 4 miles. Near the summit of the mountain the bed expands to more than 10 feet in width, and in some places is even 17 feet wide.

The alteruations of rock in two sections are as follows, beginning to the eastward [that is, at the top]:

1. $a$, Mica-slate; $b, 15$ feet soapstone or talcose rock; $c, 2$ feet crystallized talc; $d$, talcose slate; $e, 1$ foot granular quartz; $f$, chlorite slate; $g, 4$ feet emery; $h$, chloritoid and margarite; $i$, magnetic iron ore; $j$, hornblende rock highly crystalline.

2. a, Mica-slate; $b, 6$ feet magnetic iron ore; $c$, talcose slate; $d, 6 \frac{1}{2}$ feet magnetic iron ore; $e$, chloric slate; $f$, hornblende rock, crystallized; $g, 7$ feet emery, chloritoid, and margarite; $h$, magnetic iron ore; $i$, lornblenle rock. 
The elevation of the npper onterop of this bed above the immediate base of the mountaiu is 750 feet. There are remarkable rounded masses of pure emery 3 feet in diameter in this bed entirely invested with a coat of rose-colored margarite and a thick layer of bright green chloritoid, the investing coat being from half an ineh to 2 inches in thiekness. It is fonnd extremely diffieult to break np these masses of solid emery, drilling holes in them being very slow and laborious, and no grip ean be had on their roumded sides by the sledge. A heavy drop hammer will be required to break them to pieces, or they may be eracked by fire if heat does not injure the emery.

The first of the two sections given by Dr. Jackson and quoted above refers to the old mine on the brook between the two mountains.

The talc on the east has a thickness of from 5 to 15 feet. Much of it is very pure, lightish-green, schistose talc. Much of it also carries disseminated dolomite, often removed and leaving rusty holes. In places it is a dark leek-green, compact talc.

Scattered through the talc are remnants, up to a foot in diameter, of the serpentine from which the talc has doubtless been derived. These nodules are rounded and pass outwardly by gradual transition into the talc, and veins of the latter mineral also penetrate the serpentine. Large masses of foliated talc could be obtained pure, but of inferior color-a very pale green.

The next band upon Dr. Jackson's section, "chlorite slate," is the usual chloritic or corundophilitic "fringe rock," which is here specially well developed upon the eastern side (where it contains the oligoclase bed next described) as well as upon the western.

The corundophilite, in plates often $20^{\mathrm{mm}}$ broad, is placed with considerable regularity at right angles to its planes of contact with the oligoclase in layers which reach $40^{\mathrm{mm}}$ thickness on each side of the latter. It often penetrates the emery vein in sheets, filling fissures, and thus often inclosing on all sides blocks of the ore, and in cracks not wholly filled develops excellent crystals, upon which rest margarite in the finest foliated sheets and diaspore in thick masses of interlaced blades and in separate crystals of great perfection associated with fine needles of rntile. The cormulophilite is further disseminated more or less through the mass of the magnetite-emery aggregate, and where this aggregate lessens in quantity its place is taken by a white to pink colored granular margarite, forming a schistose rock, for which Professor Shepard proposes the name corundophilite-schist. ${ }^{1}$

Where the cortundophilite wholly disappear's there results an interesting 
stratum of white to reddish, fine-grained, saccharoidal oligoclase, which was very pure and very persistent, although nowhere reaching great thickness.

Prof. C. U. Shepard first called this mineral a "rose-colored amphodelite assaciated with the diaspore," ${ }^{1}$ and later described the bed in question:

A vein of indianite many inches thick is found near the tumnel on the South Mountain, running for many rods through the chloritic rock on the east side of the emery vein (exterior to the gneissoid wall). Small particles of crystalline corundum are diffused through the indianite. ${ }^{2}$

In his report he adds only that it is 2 to 10 inches thick, massive, finegranular, yellowish. ${ }^{3}$

In a second report Dr. C. T. Jackson writes:

The portion of the rock originally mistaken by me for granular quartzite, and called indianite by Shepard, proves on analysis to be andesine, although it is harder than stated in the books, scratching quartz crystal readily. It is very compact, finegranular in texture, and has $G=2.586, \mathrm{H}=7.5$, the color slightly greenish white. I obtained for its composition:

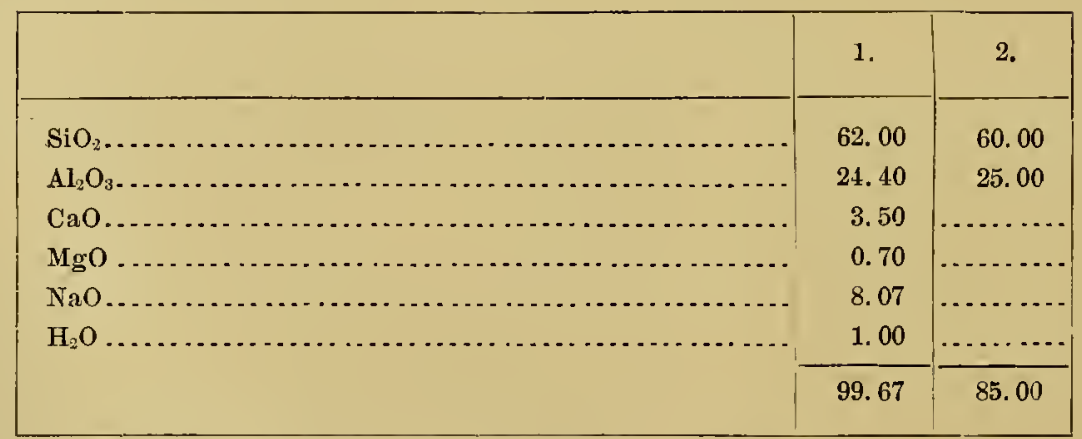

In No. 2 there was a trace of oxide of iron not weighable.

This fringed feldspar bed can not now be observed at the mine, nor can specimens of it be obtained there. Fortunately a large mass, representing the whole thickness of the bed, with the green fringe rock attached on both sides, is preserved in the geological collection at Amherst. It is a gift of Mr. J. T. Ames. The feldspar is 12 inches wide and the green fringe rock 3 and 4 inches wide on the two sides, respectively.

\footnotetext{
${ }^{1}$ Am. Jour. Sci., 2 d series, Vol. XL, 1865, p. 112.

${ }^{2}$ Ibid., p. 123.

${ }^{3}$ Report Chester Emery Mine, 1868, p. 11.
} 
A study of thin slides of the rock is given in Bulletin 126 of the Uniterl States Geological Survey, under "Oligoclase."

The width of the emery bed is given as 4 feet by Dr. Jackson in his first article quoted above; in his second ${ }^{1}$ he writes:

The emery vein eularges as it goes in, and from 4 feet has already widened to 7 feet $S$ inches of solid emery of the best quality. The adit is now extended 260 feet.

In a limited portion of the working in the lowest shaft (see fig. 7, below) the rock carries diaspore in large quantity and of the finest color, especially the isolated crystals resting in open fissures upon and partly

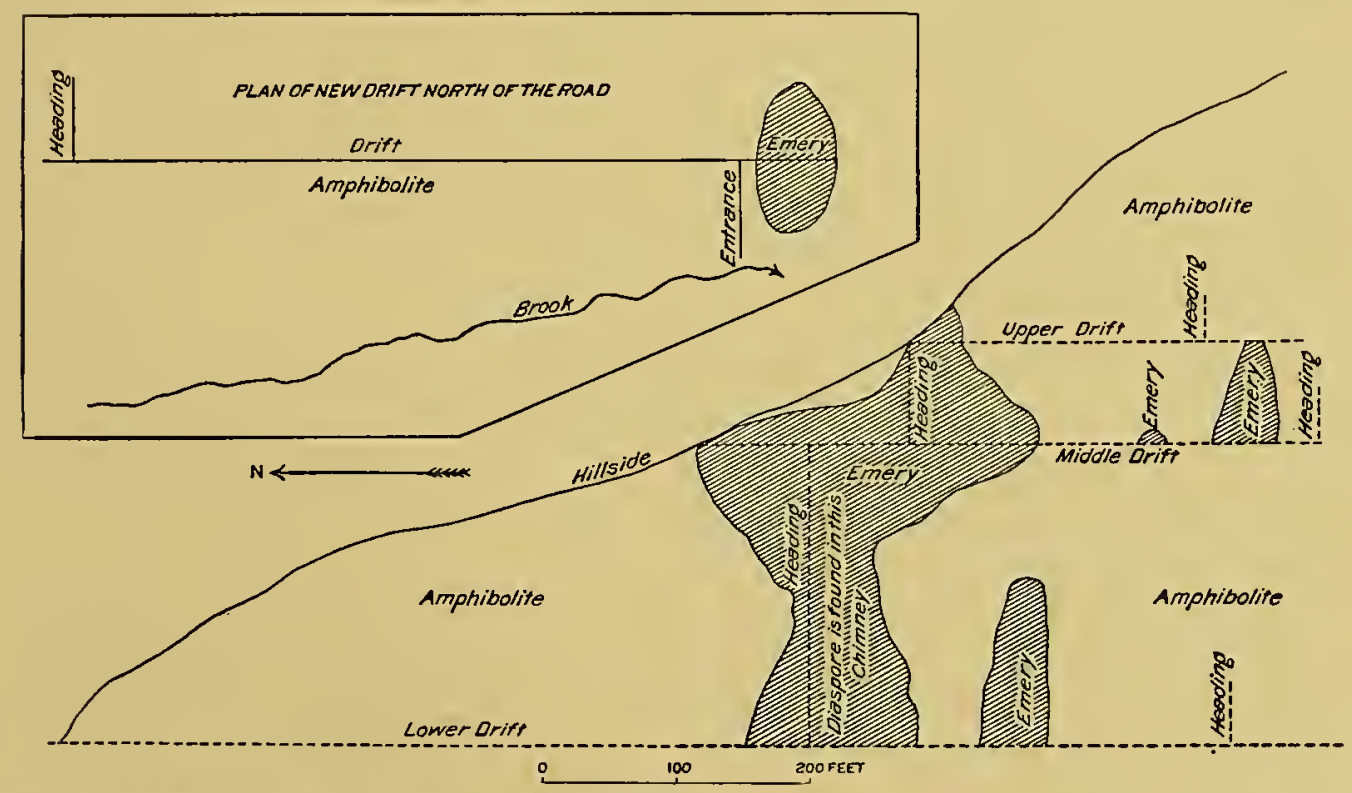

Fra. 7.-Section of old emery mine, Chester. Section of the main mine south of the road and plan of the new mine north of the road. All drifts are in amphibolite except where emery is indicated.

inclosed in crystals of corundophilite and shot through and overgrown with delicate needles of rutile; and radiated crystals of epidote and rarely of brookite $^{2}$ were of exceptional beauty, both of form and color. The diaspore presented square prisms $25-30^{\mathrm{mm}}$ in length, finely terminated, of rich violettinted hair-brown color. It occurs also in compressed, rounded masses quite within the substance of the emery. ${ }^{3}$

I am indebted to Mr. Judson Thomas, superintendent of the emery

${ }^{1}$ Am. Jour. Sci., 2 d series, Vol. XLII, 1866, p. 107.

${ }^{2}$ Shepard's Report Emery Mine, 1865, p. 12.

${ }^{3}$ Ibid, 1865 . 
mine, for a section of the underground work at the old mine south of the mill, and a plan of the new opening directly opposite and north of the brook. (See fig. 7.) It will be seen that the magnetite-emery vein is not continuous, but lies in separate lenticular masses or chimneys-"pots," as they are locally called.

Sontherly the outcrop of the emery bed rises rapidly to the top of South Mountain and has been opened at several points. About 650 feet south of the point where the road to the Melvin mine crosses the bed an opening shows chloritic magnetite, without visible emery and talc, with brown spar on the east, proving that the talcose stratum is very persistent.

At the Melvin mine, the most southerly point to which the bed has been traced, the ore has been removed in an open working about 130 feet on the strike and 35 to 40 feet in depth, to the full width of the bed, which is $6 \frac{1}{2}$ feet wide at the north end and opens out for a distance of 33 feet to a width of 16 feet, and then contracts again southward to a width of nearly 10 feet.

The ore is mostly a chloritic magnetite with few accessory minerals, margarite of rare beanty being the only interesting occurrence. A little tourmaline is present. The epidotic amphibolite appears in a thin band on the east of the emery bed, separating it from the sericite-schist farther east, and on the west the same amphibolite adjoins the bed and makes up the whole western half of the mountain.

The soft chloritic "fringe rock" bounds the ore for a distance and then runs behind a layer of homblende $2 \frac{1}{2}$ inches thick. Farther south, at the Bartholomew soapstone quarry in the north of Blandford, and at the Osborn soapstone quarry, the same chloritic "fringe rock" occurs, and at the latter place, adjoining the main soapstone bed on the west, a layer of magnetite about 1 incli thick occurs, which I thought at one time to contain emery, but I was not able to confirm this on further investigation.

Taking, however, the known limits of the bed, there is "in sight" a very great quantity of magnetite and emery-extending a length of about 4 miles and a depth of about 750 feet above the water level of the brook, and having an estimated average thickness of 4 feet. Nevertheless, it must be admitted that the exploitation of the deposit has been of much more scientific than pecuniary profit, and that it has not realized the sanguine expectations of the early promoters. 
ASSOCIATION AND PARAGENESIS OF THE MINERALS OF THE EMERY VEIN.

The magnetite, which, when pure, is very fine-grained, compactmassive, with peculiar purple tint, becomes mixed with emery in gradually increasing proportions - the "emery-magnetite" of Professor Shepard's classification. The emery increases until a harsh, rough-surfaced mass is formed, in which the coppery-brown corundum crystals are abundantly disseminated, like the feldspar in a porphyry. There is also a passage, by the gradual increase of the corundophilite from the magnetite, into the "corundophilite-schist" of Professor Shepard. The thin sections of the latter rock show, however, no corundum, but abundant octahedra of magnetite, and I have been unable to convince myself of the existence of anything corresponding to the "stony emery" of Professor Shepard. Also thin sections of the "fringe rock" show only magnetite. The pure magnetite is at times beautifully jointed. In one piece three systems of joints, about $20^{\mathrm{mm}}$ apart, break up the mass into rhombohedra with about the angles of calcite, and the parts are slightly slipped on each other and recemented. Further, quite large irregular cavities in the chloritic magnetite have fine blades of the corundophilite prolonged freely into them from the mass of the rock.

In another mass the "compact emery" is brecciated; angular pieces about $30-50^{\mathrm{mm}}$ across are separated $20-30^{\mathrm{mm}}$ from each other and the interspace is filled with fine, scaly coruudophilite. In other cases, as mentioned by Dr. Jackson, large rounded masses of the tough emery are wrapped around on all sides by a schistose aggregate of corundophilite and margarite.

Again, as mentioned above, a great cross vein of the compact chlorite rock, carrying much tourmaline and pyrite, cuts directly across the vein at the north mine.

In one piece the light-pink and green schist is firmly joined to a mass of magnetite, with its laminæ at right angles to the plane of junction.

In many cavities and open cross-joint fissures the surface is covered by a thick layer-separated from the subjacent rock by a distinct suture, and plainly of later formation under circumstances different from those described above-of 'large, stout, six-sided crystals of cortudophilite, all placed with their vertical axes parallel to the surface, but taking any direction in this plane, and terminated above by black striated faces of the 
prismatic zone. Delicate needles of bright-red rutile penetrate this crust or rest upon it. Broad, warped sheets of menaccanite also are implanted in or planted upon the corundophilite, while epidote, margarite, and diaspore, though generally somewhat intermingled with the chloritic basal layer, find their principal development later. The epidote, which is rare, fills cavities with an open network of yellowish-green needles. The diaspore, in the limited portion of the vein in which it was found, sometimes filled fissures $50-60^{\mathrm{mm}}$ across with a mass of pink blades irregularly arranged.

The margarite, while it sometimes rests on and in the chloritic layer, with its base parallel to the surface, more commonly arranges itself in compact masses of broad plates at right angles to the surface of the joint plane, and rests on the chlorite, and two such sheets often meet in the center of the fissure with a central suture, and this fills the whole cavity. The "fringe rock," generally a compact corundophilite with abundant radiating hexagonal prisms of brown-black tourmaline, belongs to this second stage.

Calcite is sometimes found between the diaspore and the corundophilite, though its most abundant development occurs later, and menaccanite occurs also in the central suture, between the seams of margarite, in much curved laminæ. Chalcopyrite is noted by Professor Shepard in margarite, and brookite embedded in diaspore. Parallel with this second stage in its earlier portion, or perhaps even earlier, may be placed the rare secondary veins of grayish-white corundum, which reach a thickness in the magnetite of $15-20^{\mathrm{mm}}$ and show single cleavage faces across the whole width of the vein. I have not found these so associated with other minerals as to exactly fix their agẹ. Other veins in the compact magnetite, $5-10^{\mathrm{mm}}$ wide, appear at first sight to be almost entirely calcite, but on dissolving this away the following paragenesis appears:

(1) Corundophilite resting on the magnetite, $1-4^{\mathrm{mm}}$ wide, in tapering hexagonal crystals, mingled with (2) rutile in its upper portion. The rutile in long, hair-brown, shining, striated needles, often bent and twisted, often sagenite-like, in groups of deeply grooved needles. This is followed by (3) a layer of corundum, partly colorless, partly a most beautiful sapphire-blue or pale pink, crystallized in flat plates, which are very acute rhombohedra, with one pair of faces developed greatly in excess of the others, as is indicated by the fact that, laid on the broadest face, the ring system appears, with convergent polarized light, very eccentrically placed. This layer 
reaches a thickness of $12^{\mathrm{mu}}$. This is at times follower by (4) disapore, which crystallizes aromil the blades of cormndum.

In some veins the whole series is closed (5) by an abundant development of margarite; in others by a layer of calcite (6), up into which the thin, knife-like blades of the corundun project, graphic-granite-like, and on etching away the calcite delicate parallel threads of the corundum appear, with blades of cormudophilite attached to them or floating freely in the calcite, as well as a beautiful lacework of rutile needles crossing at $60^{\circ}$ and $120^{\circ}$. It is in these veins that the coruudophilite changes into the pale-green amesite of Shepard.

Another vein, $15^{\mathrm{mm}}$ across, shows the following interesting paragenesis begimning with the walls of cortundophilite-schist on either side:

(a) A thiu, silvery layer of maroarodite in transwillimeters.

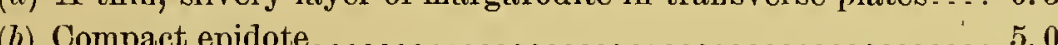

(b) Compact epidote............................ 5.0

(c) Bright flesh.colored plagioclase (oligoclase) ............ 2.0

(d) Mixture of last with fibrous erystalline epidote .......... 7.0

(e) Transparent square plates of diaspore in pockets along the central suture ............................... 3.0

A third generation of minerals, plainly of much later origin, closes the series. This consists of layers of specular iron $(f)$ in small rosettes of bright scales, upon which aragonite $(g)$ occurs in rosettes of long, thick blades, $35-40^{\mathrm{mm}}$ across, in small tufts, and in thick, grannlar, sugary, white crusts, with some pyrite and chalcopyrite, and finally the whole is often covered with a layer $(h)$ of small wine-colored rhombohedra of calcite, $\frac{5}{4} \mathrm{~J}$, and films of malachite.

It seems to me most probable that the emery-magnetite vein was originally a deposit of limonite which was formed by the replacement of limestone, and into which, as in the Berkshire County limonites, alumina was carried by infiltrating solutions and deposited as allophane and gibbsite. The subsequent metamorphism of the bed, although it may well have been intimately connected with the extremely violent mechanical forces to which the strata have been subjected, was largely completed before these forces had ceased their activity, as is shown by the jointing and brecciation of the magnetite and emery, and by this metamorphism were formed maguetite and corundum, and, so far as silica sufficed, the very basic corundophilite $\left(\mathrm{SiO}_{2} 24, \mathrm{Al}_{2} \mathrm{O}_{3} 25.9, \mathrm{FeO} 14.8, \mathrm{MgO} 22.7, \mathrm{H}_{2} \mathrm{O} 11.9\right)$. The heary stratum MON XXIX-10 
of magnesian rocks which covers the emery bed seems to lave been the source of the magnesia in this mineral. The less altered ferruginous limestone below was changed into the epidotic amphibolite.

While thus magnetite, emery, and corundophilite form the first generation of minerals of the bed, the latter mineral continued to be formed or reformed in the abundant fissures produced by the continned intestinal movements of the mass, cementing the breccias and forming thick crossveins with a fine-grained chloritic mass, at times closely resembling an aphanitic hormblende rock, and in this form abundantly associated with tourmalines (always in regular six-sided prisms), with epidote and pyrite. In a third and more quiet stadium the corundophilite formed incrusting layers upon the free surfaces of fissures, made up often of congeries of broad, vertical plates terminated above in well-defined faces, and associated with rutile, brookite, menaccanite, calcite, diaspore, margarite, and epidote.

This stadium is closely parallel to the customary secondary fissure deposits of the associated rocks, especially the hornblende-schists, which consist usually of prochlorite, menaccanite, rutile, calcite, and epidote, and is peculiar only in the substitution of corundophilite for the ordinary chlorite and in the presence of the satellites of enery, diaspore, and margarite.

The fourth and final stadium in the development of the minerals of the vein seems to be quite distinct from and later than the preceding and to indicate the presence of steam or heated and gradually cooling waters in a new set of fissures which cut across the older diaspore-margarite veins, and thus prove the later appearance of the new series of minerals. The succession-specular iron, aragonite, calcite-clearly indicates at first steam or hot water for the formation of the first and second, and a transition to cooler water for the formation of the last. The sudden appearance of the calcic carbonate in considerable abundance is also interesting. Calcium is wholly wanting in the first and second stadia defined above. A trace of calcite and epidote in small amount, together with margarite, represents altogether but a small quantity of this element in the third stadium, while here the carbonate makes up the greater portion of the new series and may have been introduced from without, possibly set free by decomposition of the hornblende in its change into serpentine. 
RÉSUMF́ OF P'ALAGENESIS.

1. Limonite, gibbsite, allophane.

2. Magnetite, emery, disseminated corundophilite.

3. Corundophilite in veins, tourmaline, pyrite, epidote, cormundum in veins, oligoclase.

4. Corundophilite in incrusting layers, diaspore, margarite, rutile, epidote, clalcopyrite, menaccanite.

5. Diaspore, margarite, menaccanite, brookite, calcite.

6. Specular iron, aragonite, calcite, malachite.

GENERAL EXPLANATION AND CORRELATION OF THE CHESTER AMPHIBOLITE SERIES.

I desire to bring together here the reasons which lead me to conclude that this series was originally a more or less impure ferruginous dolomitic limestone, and to consider also the residual facts which favor the opinion that these rocks were derived from basic and ultrabasic eruptives.

I have attempted to trace the enstatite-serpentine and the limestone beds of the sonthern part of the range back from their present to their earliest clearly demonstrable condition, in a series of sections following, which have special application to the newly opened and most interesting quarry of the Westfield Marble Company (see page 92), but which are equally true of all the range north to Blandford.

ORIGINAL CONDITION OF THE ENSTATITE-SERPEN'TINE AND LINES'TONE COMPLEX.

1. The steatitization.-The alteration of the abundant tremolite beds, or those of actinolite which do not contain a large per cent of iron, to tale is cornmon and easily understood. This is the latest change of the beds concerned, except simple solution of the limestones and the coating of fissures with iron rust.

The fibrous-radiate structure of nearly all the steatite beds may be assumed to be proof that they are altered tremolite and actinolite beds.

There has often been an intermediate serpentine stage, and serpentine of all kinds has changed into talc. This is sometimes a very modern change. I have observed cases where it was in considerable part postGlacial.

2. The serpentinization.-The alteration of the magnesian mineral enstatite, as well as of the olivine, pyroxene, dolomite, and actinolite, into 
serpentine is also a process not requiring special consideration at this place, as it has been demonstrated in a preceding chapter that the serpentine still contains traces of unchanged enstatite, or of the other original mineral in the case of the corresponding serpentine. The bastite formation in the black rock is a part of the same process.

3. The tremolitization.-The alterations by hydration mentioned above were subsequent to the change of the limestone at the Westfield quarry, for several feet inward on its eastern margin, into a quite pure, matted and radiated tremolite, and subsequent to the partial cliange of the whole thickness of the limestone bed into the same tremolite, which is later than the formation of the enstatite, since its needles end against the enstatite crystals.

The band of actinolite which cuts across the main quarry, and the broad actinolite selvage on the west wall farther south, in the same way cut across both limestone and enstatite, and are plainly of later formation, nearly contemporaneous with the tremolite, and formed, like it, by the action of heated siliceous solutions, lere ferruginous and there not, which have been infiltrated from the schistose walls. The same alteration appears at many places farther north in the limestone. On the Alderman place in Becket there lias just been uncovered a wall of pre-Cambrian limestone, where the limestone, for about the same distance in, is changed in the same way into a mass of matted tremolite fibers.

4. The shearing.-The peculiar bed at the quarry, and the one which promises to be of the most economic importance, is the central band of the foliated serpentine marble, which seems to me plainly formed by the shearing of a rock like the black spotted marble forming now the eastern band. The former enstatite has been wholly changed to serpentine, often to an oilgreen precious serpentine, but every stage of the change can be seen, from that in which the black enstatite is crushed into black bands between layers of limestone, only a few bronzy cleavage surfaces remaining, to that in which the long, narrow bands and spots of the rich green serpentine, with their lighter centers, are the last remnants of the black serpentinized enstatites with their gray centers.

5. The formation of the enstatite. - The bed is thus traced back to a condition when it consisted of about a hundred feet of a white crystalline limestone mottled with enstatite crystals, and an adjoining bed to the west, 60 feet thick, of a massive rock consisting almost wholly of the same coarse 
crystals of enstatite, of about the same size and proportions, and with, as the result proverl, the same tendency to serpentinization. I may say that transverse sections of crystals, from both the massive and the implanted forms, show the prismatic and two pinacoidal cleavages of enstatite, marked with great regularity by bands of black nnagnetite dust, even when the whole mass is completely changerl to serpentine.

(a) The formation of the enstatite in the limestone is not due to dynamic metamorphism.

A shearing of the central band of limestone, which has promoted the complete destruction of the enstatite and caused the thin foliation, is very manifest. No one can, however, examine a cubical block of the black mottled marble, where the long rods of enstatite run in all directions without crushing, bending, faulting, or fibrous development, and avoid the conclusion that the mass was free from internal movements during and since their formation. The same must be true of the coarse enstatite rock, found elservhere, made up of long interlaced crystals. They must, then, have been formed since the erection of the beds into their present vertical position and during their penetration by the abundant granite dikes which cut them.

(b) The development of enstatite in the limestone, and of the cyanite in the schists, coincides geographically with the spread of the great granite batholites.

The Chester series-amphibolites, serpentines, pyroxenites, enstatite rock, serpentinic and dolomitic limestones, and steatites-can be traced from the Hoosac Tunnel across the State, and in great loops across Granville, to its disappearance south of Munn's brook. The granitic intrusions extend westward across Granville and Blandford, and are wanting in the neighborhood of the band farther north. Where they are present the intenser metamorphism of the schists is indicated by their coarser crystallization, the lack of sericite, and the great abundance of cyanite, which of all the purely aluminous silicates indicates the strongest metamorphic agencies.

The development of enstatite in the limestone is also coincident with the presence of the granite, and represents a stronger metamorphism of the dolomite dependent upon its influence, and the most northerly appearance of the enstatite and coarse pyroxenite is at Osborn's quarry in Blandford, just where the western boundary of the granitic area leaves the line of the 
Chester series to run northeast. North of this point the rocks of the series cease to be influenced by the granitic metamorphism which followed the dynamic metamorphism in the rocks farther southeast, and consist entirely of amphibolites, partly altered to serpentines, and tremolites changed to steatite, while the inclosing feldspathic rocks change at the same place into sericite-schists.

(c) The enstatite of the black serpentine west of the limestone and that in the limestone must have had the same origin.

The two occurrences are identical in physical peculiarities, size, shape, cleavage, huster, and tendency to serpentinization, and under the microscope I find no difference in them. There is no more reason for giving them a different explanation than in the case of the separate wernerite crystals in the Bolton limestone and the massive wernerite rock which forms the border of the crystalline limestone on the granite, or the white pyroxenes scattered in the Canaan limestone and the compact canaanite into which it graduates, or the bladed tremolite regularly disseminated in the Lee marble and the compact tremolite rock which is associated with it.

In all these cases it is recognized that the bladed crystals have grown in the limestone much as the bladed cyanites have grown in the quartzose mica-schist adjacent to our serpentine, and that the only further assumption needed to explain the corresponding-massive rocks is that the silicate has in each case replaced all the carbonate, or that the solutions which brought the silica into the limestone have removed the surplus of the carbonate. It seems to me that the natural explanation here is that the massive enstatite rock is simply the result of carrying the process which has formed the enstatites in the dolomite a step farther to the almost complete replacement of the latter; and, indeed, within what we have called the limestone, every stage can be traced from pure limestone to a rock nine-tenths enstatite. rock.

(d) The enstatite not necessarily a proof of eruptive origin of the

I know of no eruptive rock made up exclusively of coarse, long-bladed enstatite, but I have studied several beds of such character among the crystalline schists.

I have collected the large, smooth-faced, altered enstatite crystals in Norway, and they seemed to lave formed as attached crystals, projecting into free spaces in crystalline limestone, rather than as constituents of 
ermptive rock. Also the enstatite rock, an 1 have seen it at the Tilly Foster mine, is a nember of a highly metamorphosed crystalline-sehist series. It resembles quite closely what the Wustfield rock may lave been, but is finergrained.

It is to be further remarked that the massive structure of the black serpentine is not a characteristic indicating, necessarily, an ernptive origin, since the rock is made up of elongated square prisms, often 3 to 8 inches long, interlaced, and with calcite in the interspaces. It is like the massireness of the Bolton rock, or the canaanite. The black color also is wholly the product of serpentinization, as the freshest enstatite is everywhere translucent and pale-gray.

(e) I therefore conclude that the rock was once a bed considerably thicker than the present one, and consisted of a somewhat ferruginous dolomite, which was permeated by heated siliceous solutions, set in motion by the large granite batholites, upon their intrusion into their present positions.

The ferruginous enstatite (the serpentine derived from it contains 8 to 9 per cent of iron) was formed by the reaction of these solutions with the magnesinm of the carbonate, and the resulting carbonated waters may have promoted the solution and removal of a part of the unaltered calcinm carbonate, and this may have been the condition necessary to the formation of the pure enstatite rock of the west wall, which differs only in the almost complete absence of the calcite. The analogy of the wernerite-limestone, the camanite-limestone, and the tremolite-limestone, and of the corresponding massive silicate, nearly free from carbonate, seems to me complete for the explanation of the enstatite-limestone, and of the massive enstatite of the western border of the Westfield quarry and the similar: beds farther north. Indeed, the change of the limestone at this locality into tremolite, for a certain distance in, along the eastern border, and the partial change into tremolite throughout, seems not essentially different from the earlier change, for a greater distance inward, into enstatite.

The idea that the black serpentine at the Westfield quary is an altered dike rock, and that the marble only is an altered sedimentary limestone, I can not entertain for a moment. The identity of the black prisms in the limestone with the black prisms which are interlaced to form the massive rock seems to me fatal to this theory, especially when we consider those parts of the limestone which are nearly all composed of the black rods. 
That the enstatite can have passed from the western enstatite rock into

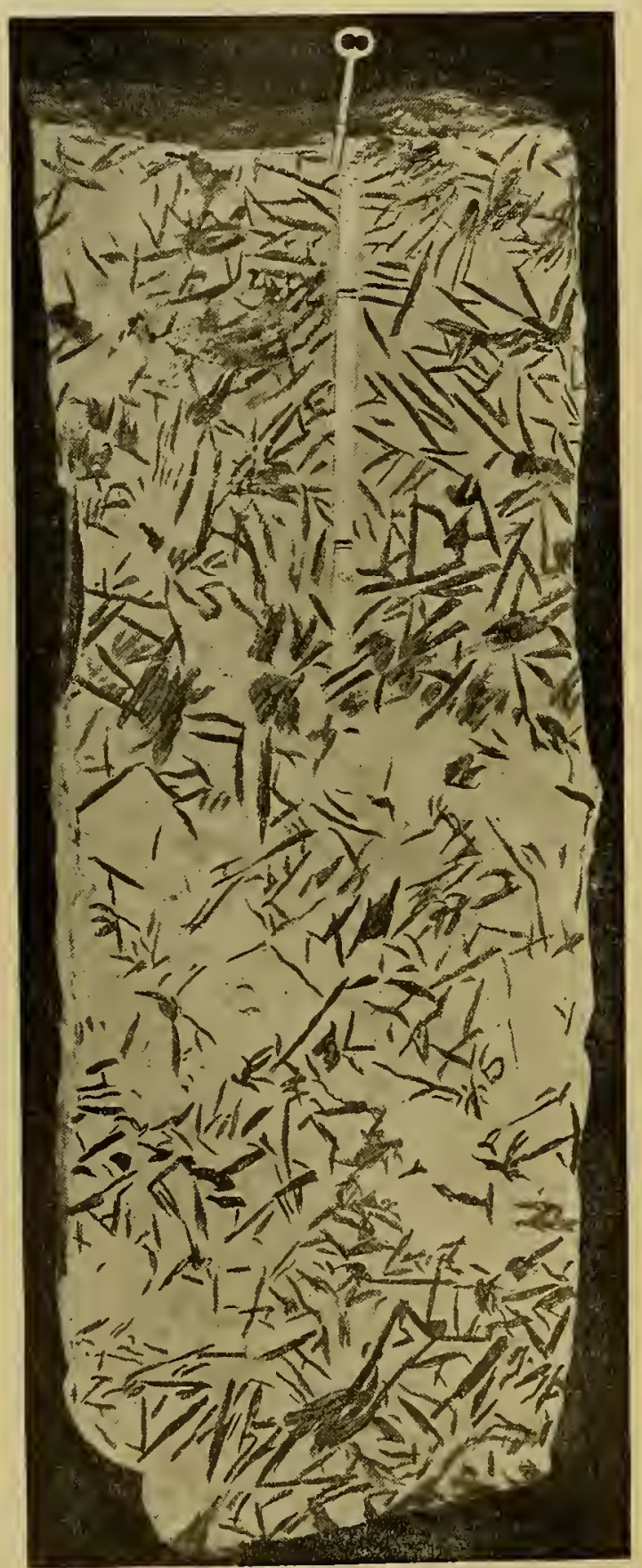

the limestone is improbable, for the fifty feet nearest to the enstatite rock contain much less of the enstatite than do the next thirty.

At Downey's the white limestone is free from enstatite, and the contact with the enstatite rock is covered in the swamp. At Munn's brook the enstatite-limestone mixture is less in amount, and the enstatite so predominates that I tried to explain the whole by assuming that the black serpentine (or enstatite rock) was an igneous rock, and that the serpentine-calcite mixture (which in altered surface specimens could not be studied so well as in the fresh masses opened in the Westfield quarry) was derived from the ermptive rock by the removal of some allotriomorphic constituent and the interstitial development of a later secondary calcite in its place. A single look at the great blocks of the black spotted marble in the quarry will prevent one from deriving this homdred feet of limestone from any alteration of an enuptive like that from which the black bed may have 
heen derived, and will compel one to hold to the independence of the two, if one will not acept their commor derivation from a dolonite.

6. Derization of the black, thin-fissile amphibolites from the limestones.If the stejs by which the black serpentine has been traced backward in the preceding sections be valid, a goodly portion of the series for 20 miles from the Westfield end, and in places its whole thickness, was originally a dolomitic limestone. Associated with this black serpentine series, in gradually increasing quantity as we go north, is the black, or dark-green, amphibolite, made of a matted network of actinolite needles in an albite mosaic. The two series are closely joined in all this distance; they replace each other along dip and strike, and if the amphibolite be an altered eruptive it must have been intuded by a kind of preestablished harmony, so as to fit itself to the limestone exactly through this long distance, without showing any eruptive relations to it or preserving now any eruptive rock texture.

'Therefore, as in the case of the same amphibolites which in the same way attach themselves to the pre-Cambrian limestones throughout their whole extent in Berkshire County (see p. 29), I conclude that these rocks are, in the main, derivatives of an impure argillaceous limestone, and I extend this conclusion to the long range of amphibolite which goes north from Blandford across the State, interrupted only by areas of serpentine derived from the alteration of the amphibolites. The residual facts which point to the eruptive origin of some part of the series are the constant presence of chromium and nickel in the serpentine from several localities, as indicated in the table of analyses on page 116, and the close agreement in composition and structure of the dark amphibolites with rocks which have been proved to be derived from basic eruptives.

In relation to the first point, it is very probable that olivine-bearing rocks may be present in the serpentine masses north of the Blandford and Middlefield olivine occurrences, though long search in the field and the study of many sections has compelled me to refer all these beds to the category of translucent hornblendic serpentine. In these great areas of serpentine much may have been overlooked, as sections conld not be cut from every part. The presence of these assumed olivine rocks may have been the initiating cause of a serpentinization which extended far beyond the rock in which it started. Further, an inspection of the table of analyses shows that the enstatite and sahlite, minerals which have certainly formed 
in the limestone, have a constant content of chromium and nickel. I think we may therefore assume that these elements have been concentrated from extremely dilute solutions in and by the limestone, being derived perhaps from the olivine rocks, and that they do not necessarily indicate that all the minerals which now contain them were of eruptive origin.

As to the other point, I find it very difficult to establish any certain criteria to distinguish amphibolites derived from the complete alteration of basic eruptives, or their tuffs, and those derived from argillaceous limestones, and I have illustrated the difficulty in the series of figures on Pls. V and VI. Where all residual structures are obliterated two rocks may become indistinguishable. It is a question mainly of the actinolite network and the limpid and untwinned albite mosaic of the amphibolite. The actinolite may have either origin, and every stage may be observed from tremolite-schists certainly metamorphic to actinolite schists. In several cases I have found the albite mosaic closely like the untwinned albite growth of the adjacent albitic schists, for which no one would suggest a connection with eruptives; and that such a mosaic may readily form also from the action of heated solutions on a diabase is slown by its occurrence in the red Triassic trap, described in Chapter XIII. It is rather a question of the easy formation and solubility of albite or other plagioclase than of any necessary connection with a basic eruptive.

7. Formation of the Chester emery.-The Chester emery may have been formed by the replacement of a portion of the limestone bed. Just as great beds of limonite with gibbsite and allophane have formed, by replacement, at the surface of the Stockbridge limestone, in Berkshire County, and of the Bernardston limestone described below, so the formation of such a bed at the surface of the former Chester limestone would explain the magnetiteemery bed which now caps the Chester amphibolite.

Metamorphic agencies have changed the limonite into magnetite, while the hydrated alumina compounds have become corundum, and continued alteration has, as is usual with corundum, produced many interesting minerals.

The tourmaline can not be taken as a fumarole mineral of the olivine rock, since, as it surrounds the emery bed in great quantity, and is not found in association with the olivine rocks, it would tend to prove the emery bed 
to be an igneous rock, rather than the olivine bed. The tourmaline is, as it contains much magnetite, a very late-formed mineral in the fringe rock, which is itself a late product of metamorphism. This association of the emery bed with limestone may point to a similarity of origin for this bed and the beds of Naxos, which are thin sheets of emery in crystalline limestone associated with miea-schist and granite.

S. The great extent and constant horizon of the series a proof of its sedimentury origin.-Above and below the Chester amphibolite series are highly tilted sericite-schists of great thickness, often very quartzose, which were doubtless once sandstones, of about the same age as the Berkshire and Greylock schists.

The Chester series is conformable with these, and where it loops up to the north it forms a compressed syncline, pitching to the north, and east of this another, more open syncline, pitching southerly. It has the aspect of a sedimentary series, and not that of an intrusive body, and its complexity and great length indicate its origin by sedimentation. I have followed it more than 60 miles in Massachusetts and found it an almost uninterrupted band of amphibolite, often breaking up into several beds, with thin interposed sericite-schists; and it extends a great distance north and south, across Vermont and Connecticut, and can be followed far east into Worcester County at a constant horizon.

I conclude, then, that the Chester series represents an eastward expansion of the limestones of the Silurian sea which deposited the Stockbridge and Bellowspipe limestone in Berkshire, and that it may be tentatively paralleled with the latter bed. Some very basic igneous rocks may have been associated with it in this, its shoreward, extension, and along its central part its upper surface was, at a later time, replaced locally by limonite.

The Bolton limestone in Worcester Connty occupied about the same horizon, and has in places changed into actinolite-schists and developed in large quantity boltonite, which is almost a variety of olivine, and is in places changed into black serpentine, forming a rock exactly like the Westfield quarry stone. The black prisms of altered boltonite scattered in the white limestones reproduce on a slightly smaller scale the black rods of enstatite' in the latter rock. 
THE SAVOY SCIMST-THE UPPER SERICITE-SCHYST.

DISTRIBUTION.

A broad band of sericite-sclist enters the State from Vermont across the eastern half of Rowe and the whole of Heath, and as it crosses Charlemont it extends over into Berkshire County. It occupies the western half of Hawley, Plainfield, and Cummington, where, much narrowed, it comes again wholly within the limit of Hampshire County.

It runs south in a narrow band, 1 to 2 miles wide, of nearly vertical strata or of strata with high easterly dip, across Middlefield, Chester, and Blandford, and in the latter town expands broadly eastward across this town and Russell, attaining a width of above 7 miles. It divides and wraps around the Hoosac schist below, and extends south across Granville in two bands in the east and west parts of this town, on either side of and dipping away from the older formation. The East Granville gneiss thus forms the nucleus of an anticline having its axis inclined to the north, so that the Hoosac and Rowe schists and the Chester amphibolite, and finally the Savoy schist, appear in succession on either flank. On the east the succession can not be followed higher, as the Savoy schist, which forms the long ridge of Sodom Mountain, has at its foot the sandstones of the Trias, covered mostly by the Glacial and post-Giacial beds. On the west the Savoy schist is a closely folded syncline, bounded by the amphibolite band (Chester) on either side, and doubly looped to include Liberty Hill and Sweetman Mountain, and running out to the south before reaching the State line. (See map, Pl. XXXIV.)

On the north, where it broadens out so suddenly in folding round the north end of the anticline, it dips under the Goshen spangled mica-schist, and the axis of the anticline is continued northward beneath the latter, and by an upward undulation brings up the Savoy schist in an interesting fanlted quaquaversal in the middle of Goshen, and again, farther north, brings up once more by a stronger upward curve the underlying Canbrian gneiss at Shelburne Falls.

\section{BOUNDARY UPON THE ROCKS BELOW.}

Where the Chester amphibolite band is present in force as a single massive bed, as across Rowe, Chester, and Granville, the transition between the two is very sudden. 
Across Blandforl, where the beds are much covered, and where, while many beds of sericite-schist intervene in the Chester amphibolite, the predominant rock is lormblende-schist, the boundary is less clear, and here, on the one hand, hornblendic bands appear in abundance all through the liydromica-schist series, and on the other the intercalated schists mentioned above are identical with the schists of the upper series; but this boundary is of somewhat subordinate importance, and the Chester amphibolite already described, although fully deserving separate treatment, both from its importance as a horizon and from the geological interest of its varions members, is quite closely allied to the present series, and the most important boundary line lies at the base of the latter. Around the Granville anticline and north of Middlefield, where the amphibolite band narrows and is interrupted, the boundary is drawn with less but still with very satisfactory accuracy.

GENERAL DESCRIPTION OF ROCKS.

The prevailing rock is a muscovite-schist of medium to coarse grain, with varying but always considerable content of mica, and as this inineral is very generally hydrated the whole series was for a long time called talcose schist, from the soapy feel of the softened mica. The rock is of a light-gray or greenish-gray color, and both carbonaceous and ferruginous matter in such form as to darken the rock are very generally absent-a general mark of distinction between this and the subsequent formation.

Almandine garnct is very generally but very irregularly present, often crowding the strata for great thickness and often wholly wanting. The forms 202 (211); 202 (211), $\infty 0$ (110); and $\infty 0$ (110) appear. The garnets frequently reach large size-25-35 $5^{\mathrm{mm}}$-and in several places, especially in Chester, afford fine cabinet specimens. They are often changed to the center into chlorite, and this mineral also often appears in scales, especially stretched in long lines along the cleavage faces of the rock, giving the schist a greenist tint, and so far increases at the expense of the mica as to become a chlorite-schist.

The sericite-schist further carries white, sugary sandstone beds shot throngh with long, flat crystals of black hornblende, which forms a striking rock in the cutting nearest the Chester station and appears abundantly farther south in Blandford. This increases at the expense of the other 
constituents until a hornblende-schist is formed, made up of jet-black needles of hornblende and a little quartz and albite, which differs from the heavy bert of amphibolite below in its deeper color, the lack of visible epidote, and its more friable texture. Scattered through the series, however, are other beds of hornblende-schist which do not materially differ from the basal bed.

A light-green pyroxenite, more or less calcareous, forms small beds of a tough, massive rock at various points throughout the whole extent of the formation. This rock was noted by President Hitchcock under the name augitic gneiss.

At its southern extremity, in Granville and Russell, the beds become, as an exception, somewhat feldspathic, and biotite and cyanite associate themselves with the muscovite. In the railroad cuts east of Russell station occur beds of a rather coarse schist in which, on the lamination faces, the bright black biotite is intergrown with the muscovite, the latter surrounding the former, and the basal cleavages being common.

\section{COMPARISON WITH THE ROWE SCHIST BELOW.}

The two formations agree in the prevalence of muscovite-schists, and the hydration of the mica is a phenomenon common in the older series, notably where the Chester-Becket road crosses the torw line and northward across the State, and then a rock exactly like the prevalent one in the higher series results. The feldspathic character of the lower series is not at all projected into the other, and the green tint of the upper beds due to chlorite and to the intercalated bands of hornblende and chlorite-schist differentiate the two abundantly. Stratigraphically there is no trace of any break between the two, and as there is, as already described, a wellmarked break between the Hoosac feldspathic mica-schist and the Becket gneiss below, and a probable one at the top of the Savoy schist, the Hoosac, Rowe, and Savoy schists are more nearly allied to one another than is any one of these to the adjoining series above and below.

\section{DETAILED DESCRIPTION AND SECTIONS.}

The facies of the formation changes greatly from north to sonth. At its sonthern extremity the two arms which pass through Granville are made up of a coarse two-mica, slightly feldspathic schist, rusty, and over large areas barren of accessory minerals, and much cut up in many 
places by reins and irregular patches of coarse granite. It sometimes abounds in coarse eyanite blades.

In Sodom Mountain, in East Granville, the same rock prevails. Unimportant bands of hornblende-schist oceur, and a bed of the pale-green calcareous pyroxenite, very probably an altered impure limestone bed, was observed by Presirlent Hitchcock ${ }^{1}$ and catalogued as angitic mica-slate. The rock here very closely resembles the Amherst rusty feldspathic micasehist.

Northward through Blandford the rock gradually ceases to contain biotite and feldspar as constant and important constituents, becomes gray and more siliceous, and the muscovite is generally hydrated. It is much corrugated in this area, and doubtless contains many subordinate folds and great flutings, which could in some cases be traced for considerable distances, and to which I devoted much labor, but without reaching results which conld be entered upon the map.

If from Granville we go north throngh Russell, east of Blandford, and thus through the eastern half of the broad expansion of the formation, we find that the Granville feldspathic facies persists much farther north and would seem to belong to the lower portion of the series here discussed. Northward it is, nearly to the Westfield River, a coarse, rusty muscoviteschist, often biotitic, often a little feldspathic, and, indeed, may be called a coarse membranous gneiss, the continuons folia or membranes of mica being separated by thick sheets and lenses of quartz with a little feldspar.

As before (see p. 85), a somewhat detailed description is given of the development of the series along the Westfield River, which in Chester rmus down across this series, making an acute angle with the strike, and then, crossing the southward prolongation of the Conway mica-schist, again enters this formation and runs for a long distance through Huntington and Russell, across the head of the eastern anticline.

In Chester the rock is already a chloritic sericite-schist, of a type which continues a long way north; flat, thin-fissile into plates $10-15^{\mathrm{mm}}$ thick, with the micaceous minerals concentrated mostly on the lamination planes; uniformly light-gray with a shade of green from the presence of scales of chlorite mixed with the muscovite, and these can be detected with the microscope when they are not visible to the eye; at other places this 
increases and the cleavage surfaces are mottled by large aggregations of the green mineral. The thickness of the plates is made up of highly crystalline quartz, at times fused into a complete vein quartz and carrying garnets and pyrites, often in large quantities. It is frequently also wholly barren over broad areas.

To the east of the great serpentine bed in the north of Chester the rock is gnarled and contorted in a most marvelous manner; the quartz laminæ branch out and grow thin in rapid alternations, and many small quartz veins run in all directions. This holds for a half mile eastward, until, on the first road rumning north, the corrugation lessens suddenly and disappears, and the schist takes the normal form described above.

Several beds of amphibolite, 7 to 12 feet thick, are interposed in the schist, and the transition from one to the other is in all cases very sudden.

The succession of the beds next above is well shown in the second cutting north of Chester station, and the section is given in detail to show the rapid and repeated alternations of nicaceons and horublendic strata. The section runs from below npward:

Section north of Chester station.

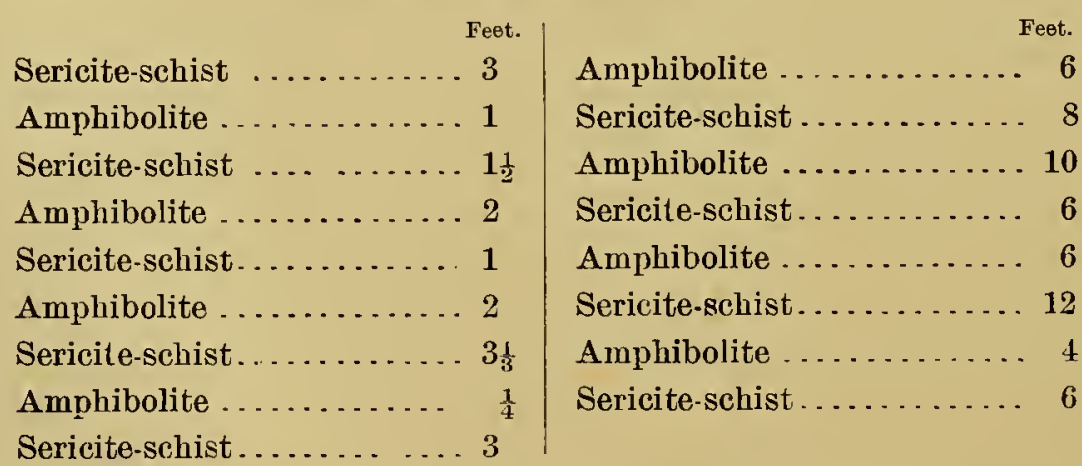

A very short distance separates this section from the cutting nearest the station, representing the strata next above those just described. This cutting exposes 217 feet, and in this distance are 23 beds, from 1 to 20 feet in thickness, of alternating sericite and amphibolite. (See Pl. VI, fig. 4, p. 306.) Many of the sericite-schist layers contain in abundance large, distant garnets in every stage of change to chlorite.

Following the line eastward from the station to the junction with the Conway mica-schist the greenish-gray sericite-schist in this upper portion, 
almost free from amphibolite, is flat-bedded and presents a rather monotonous area of vertical beds, with strike varying little from the meridian.

North of Chester the series occupies a position on either side of the line between Middlefield and Worthington, being about half in each of these towns, exposed on the slopes of one of the most characteristic deep $V$-shaped longitudinal valleys so common in the Berkshire Hills.

The ficies of the series has clanged greatly, and starting from its base at the serpentine and soapstone bed at Harold Snith's, in the north part of Middlefield, which is plainly the continuation of the great bed in the south of this town, instead of the interminable alternation of sericite-schist and hornblende-schist beds noted above in Chester, one crosses a great thickness of the vertical sericite-schists, often very quartzose, often garnetiferons, but without much hornblende until the top of the series is reached. Through the whole length of the town of Worthington the conditions are remarkably uniform, and the section along the road from Peru to Worthington Center may be given as a sample of the whole distance.

At the cemetery, 160 feet east of the Pern line, the Becket gneiss gives place to the Hoosac albitic mica-schist, coarse, corrugated, rusty, and carrying at times large garnets, and just before the bed of the Middle Branch of the Westfield River is reached a layer 115 feet thick of a bright-green, fissile chlorite-schist appears at the base of the present series and replaces the usual serpentine and hornblende bed-the Chester amphibolite.

Up the sharp hillside eastward, near the house of W. Starkweather, the beds, as made out along the road and for a long distance north and south, are of coarsely corrugated sericite-schist, often a quartz-schist with films of hydrated mica, and rarely a band of soft, deep-green, slaty chlorite-schist, the whole dipping $90^{\circ}$ and aggregating 720 feet.

- East of this house the same schists, often very quartzose, continue and carry five beds of horublende-schist, 3 to 10 feet thick. The whole series is 3,280 feet thick.

North, across Plainfield and Hawley, a great mass of barren, monotonons quartzose sericite-schists expand to a considerable width and occupy the almost inaccessible hill region drained by the Cold River They preserve this habit where they are deeply cut by the Deerfield River, from Hoosac Tunnel to Zoar. Rarely a hornblendic bed appears near the base. MON XXIX-11 
They impress themselves strongly on the topography as they bend northeast from Zoar, in Adams Mountain, but preserve their uniform habit to the State line.

THE SHELBURNE ANTICLINE.

This anticline is distinguished strongly from the more southern one by the absence of the sericite-schist, the calciferous mica-schist being separated from the gneiss by only a band of hornblendic rock of no great thickness, with merely a suggestion of the Rowe schist below.

PETROGRAPHICAL DESCRIPTION.

Mica-schist from near School No. 6, Charlemont. Rather coarse, lightgray rock, with shining muscovite scales and distant large garnets.

Feldspar can be seen rarely with the lens. One piece gave extinction $+15^{\circ} 30^{\prime}$ in the plane of $\infty \mathrm{P} \infty(010)$ when measured from the edge M t, and was therefore albite. Another gave extinction $+2^{\circ} 30^{\prime}$, and was therefore oligoclase $\left(\mathrm{Ab}_{2} \mathrm{An}_{1}\right)$.

The feldspar is present in small amount. The garnets are crowded with impurities and polarize distinctly.

Garnetiferous sericite-schist from Chester. Railroad cutting west of station. A pale greenish-gray rock, with greasy continuous films of hydrated muscovite between thin layers of rather coarse-granular quartz, full of pale-red garnets.

Under the microscope the angularly granular quartz abounds in rounded grains of magnetite, and these two minerals fill the garnets, magnetite being more abundant in the garnet than outside. The muscovite is in twisted films and radiates in broad plates from the garnets. The latter send out abundant amoeboid processes among the quartz grains.

Beautiful triangular and doubly terminated tourmalines of greenishbrown color show exquisite absorption-deep crimson at one end, shadiing to emerald-green at the other, or to the middle, when the green shades into smoke-brown at the other end. They are thus miniature reproductions of beautiful crystals from Paris, Maine. On rotation the colors change places. A few bright-green chlorite scales appear. The order of formation is: magnetite, tourmaline, quartz, garnet, chlorite, muscovite, while the quartz lias formed and re-formed and some of the present grains inclose all the other constituents. 
All the pyoxene rocks described below are plainly altered limestone beds in the schist, and, though common, never reach large dimensions.

I'yroxene-schist fiom Meath. No. 203, Massachusetts Survey Collection. "Angite mic:a-schist." Lalrge, pale-green pyroxenes, with irregular outlines, inclosing many quartz veins, and placed in a coarse-gramular quartz mass, with mucl biotite and magnetite.

I'yroxenic limestone from Sodom Mountain, Southwick. No. 202, Massa(husetts Survey Collection. "Angitic miea-slate." Gives abundant effervescence in cold $\mathrm{HCl}$, which is renewed on heating. A thin layer of ealcareous coccolite between two layers of quartz, the whole inclosed in mica-schist.

The slide slows the pale-green pyroxene changing into a white asbestos.

Pyroxenic limestone from Russell; railroad cut, east of station and just west of G. Frost's. A layer 3 feet thick, of a very tough, fine-grained, reddish rock, showing muel caleite, garnet, pyrite, and titanite. In the slide sahlite is abundant, actinolite rare.

\section{INTRUSIVE ROCKS.}

In its southern portion, through Granville, many pegmatite or coarse muscovite-granite veins and masses penetrate the schist, especially in Sodom Mountain, and the same is true in a lesser degree through Blandford, where, near Mr: Osborn's, the fine rose qnartz veins are associated with coarse granite in this series, and in the south edge of the village, where the deeply rotted beds have been much quarried for kaolin. Farther north, across Chester, Middlefield, and Worthington, these coarse granitic vein stones are almost or altogether wanting.

In the east of Middlefield, and wholly isolated, an enormous dike of porphyritic granitite runs north and south nearly the whole length of the town, with a width in places of 1,300 feet. It is a rock not unlike the New Hampshire "porphyritie gneisses," but the feldspars are somewhat smaller, $10-15^{\mathrm{mm}}$ in lengtl. Farther nortl granite is wanting.

\section{THE H.IWLEY SCHIST.}

This would have been called by Percival, in his quaint but very effective nomenclature, "a ferromagnesian formation." The most prevalent rock is a dark-green, soft, chloritic sehist, generally crowded with porphyritic 
crystals of brown ankerite, which are usually in grains a fraction of an inch across, but at times are perfect rhombohedra, more than an inch in size.

The quartzose, pale-green muscovite or sericite-schist, common in the formation below, appears here also, but it is usually spotted, especially on the cleavage faces, with groups of long blades of black horublende, often 6 inches in length, which are radiated on the foliation faces of the schist from a central area, after the fashion of a sheaf of wheat, from which circumstance President Hitchcock named the mineral fasciculite. Although the name has passed into the list of synonyms, I have found it useful as a designation of the sericite- and chlorite-schists in which these hornblende blades, often in sheafs, appear as quasiporphyritic inclusions which have the habit of a somewhat constant accessory, rather than of an essential constituent, of the rock in question. There are thus fasciculite-chlorite-schists and fasciculite-sericite-schists; but this rery generally disseminated horublende has been ignored in mapping, and the large amphibolite beds which are represented on the map are black, purely hornblendic schists, free from any visible micaceous mineral. This general distribution of hornblende distinguishes the Hawley formation or series from the beds wlich precede and follow it, wherein, outside of the amphibolite beds, hornblende is very rare and for the most part wanting altogether. None of the hornblendic bands in this series show any tendency to serpentinization.

\section{DISTRIBUTION.}

The baud enters from the southwest corner of Halifax, Vermont, with a width of a mile, and begins at the Davis mine to widen, crossing the Deerfield River with a width of 3 miles. It goes across Hawley with this width, and is bounded on the west by a great fault. As it enters Plainfield the Gosheu schists begin to overlap it rapidly, and it crosses this town, Cummington, and Worthington with a width of half a mile. As it enters Chester a second overlap of the Goshen schist cuts it off entirely. Farther south no series possessing its lithological peculiarities and richness in iron can be found.

\section{DETAILED DESCRIPTION.}

The whole eastern slope of the deep valley that separates Middlefield and Worthington is underlain by the rocks of this series, and the large garnets, superficially changed to chlorite, and the slabs of fasciculite furnish many attractive specimens for the cabinet. 
In eontinuation eastward of the section of the Savoy schist given on page 161, one finds that the barren Savoy schist is followed by a great development of amphibolite (1,640 feet thick), the upper half made up almost entirely of this rock, the lower part containing some unimportant beds of sericite-schist and biotite-schist, and layers of a coarse, yellow sericiteschist with "fasciculite," and all grading into amphibolite. The prevailing rocks are: ( $($ ) a dark-brown hornblende- (cummingtonite-) schist, with very fine lamination, which is brought out more distinctly by weathering; (b) a gray, micaceous hornblende-schist; $(c)$ layers of very fissile chlorite-schist. This is followed by a series ( 656 feet thick) of thin-fissile, very fine-grained, friable, dark-gray mica-schists, made up almost wholly of muscovite, and without accessories; this band can be followed clear across the town of Worthington and lies beneath the undoubted flaggy schists of the next series (Goshen), to which I have usually, but with some hesitation, referred it. The whole thickness is 2,296 feet.

The above distances are approximate, being measured along a nearly straight east-west road, the strata being vertical and striking north and south. Across Cummington the beds abound in fasciculite, chlorite, and scattered grains of ankerite, or of rust spots which mark the removal of the latter.

Fifty rods east of A. W. Brown's sawmill, near the west village, these sericite-schists with fasciculite and ankerite are followed on the east by thin-bedded, light, sandy mica-schists, and these by a thin bed of porphyritic amphibolite, above which are 50 rods of graphitic pimpled schists, which one must associate with the Goshen mica-schist; then comes a 2-foot layer of amphibolite, and then the Goshen mica-schist continues eastwarl. This is the beginning of a new peculiarity, at the boundary between the two series, which continues and grows more marked northward-a heavy bed of amphibolite near the top of this series, another equally heavy, but of different habit, occurring near the bottom of the higher series, and both increasing in thickness northwardly. Across Plainfield and Hawley the conditions remain unchanged. The main bed of amphibolite at the top of the Hawley series grows thicker, and is, I doubt not, more continuous than can be made out from the outcrops in this drift-covered region. Other beds of amphibolite occur lower down, and the beds carrying chlorite, fasciculite, and ankerite increase, so that, measured across the middle of Hawley, they occupy a full half of the width of the town, and the series is here at its widest. 
This is well seen in going east from the Hawley iron mine. West of the ore bed the rock is the common quartzose sericite-schist (Savoy). The ore bed itself is a hematite-schist (itabirite), made up of beantifully corrugated scales of micaceous hematite, which can be followed on the strike more than a mile. The pure hematite reaches scarcely a foot in thickness. Inchuding the quartz-hematite-schist the visible thickness was not above 3 feet, but from the width of the open workings of the bed, now filled with water, the thickness would seem to have been in places more than twice as much.

Going east down the long hillside, and with the dip of the steeply inclined beds, one finds a great thickness of chloritic schists, so abounding in yellow ankerite in grains that the latter mineral often makes more than half its mass, and near the surface, where it is weathered out, the rock is often a friable mass, somewhat rusty. At the foot of the hill is a great development of amphibolite, and much of the sericite-schist abounds in the sheaf-like hornblende aggregates or fasciculite, and this description holds true clear across the town to the upper boundary of this series. North through Charlemont and Rowe to the State line great beds of chlorite-schist, often dolomitic, and of hornblende-schist, sometimes with calcite, abound (as just west of Charlemont station), and the sericite-schist itself is often a fasciculite-schist.

\section{PETROGRAPIICAL DESCRIPTION.}

The jet-black, thin-fissile hornblende-schists of this series do not materially differ from those found below. Two specimens were chosen for special microseopical examination, and one of these has also been analyzed.

Porphyritic epidote-amphibolite from northeast of E. Gleason's, Heath (see Pl.VI, fig. 3, p. 306). A dull-black, fissile rock made up of matted needles visible to the eye, doubly porphyritic, with black, stout hornblendes and long, rectangular, white plagioclase crystals with greasy luster from the abundant epidote inclusions. With common light the stout hornblende sections show a peculiar dichroism. The basal sections are of a yellow color, similar to that shown by the same sections with polarized light vibrating parallel to $a$, and the longitudinal sections a green like that seen parallel to $c$. They have a clear border, but the center is so full of inclusions as to give a mosaic of brilliant color. Small hornblendes, epidote, biotite, and ankerite abound. The hornblendes are twinned, with extinction $21^{\circ}$ on either side of the suture, and show strong absorption colors: $\mathfrak{c}=b$ lne, $\mathfrak{b}=$ olive-green, 
$a=$ bright yellow, $b>c>a$. The colorless phenocrysts are small, single twins of albite, extinguishing at about $2^{\circ}$ on either side the center. With : lens they are seen to be frosted full of small grains of epidote, and scales, alpharently of muscovite. With polarized light these make a mosaic of such brilliant color that only a trace of the polarization of the feldspar is visible. In a section parallel to $\infty \mathrm{P} \propto$ (100) al negative obtuse bisectrix was observed. The large rhombs of ankerite with rust-marked cleavage appear everywhere. Magnetite is abundant in small, rounded grains withont alteration products. The background is a mosaic of small, short horublende blades and magnetite, epidote, and feldspar grains. It forms most beantiful microscopic slides.

Black, fissile amphibolite from Worthington, west of G. Sherman's. Nearly all a network of large blades of horublende, with finely marked prismatic cleavage This has medium pleochroism and the formula $\mathfrak{x}=$ blue-green, $\mathfrak{b}=$ yellow-green, $\mathfrak{a}=$ yellow: $\mathfrak{c}>\mathfrak{b}>\mathfrak{a}$. Titanite and apparently zircon appear.

The analysis of this rock was made by Mr. L. G. Eakins.

Analysis of amphibolite from Worthington.

\begin{tabular}{|c|c|}
\hline $\mathrm{S}_{2} \ldots$ & $\begin{array}{c}\text { Per ecent. } \\
48.53\end{array}$ \\
\hline $\mathrm{TiO}_{2} \ldots$ & .51 \\
\hline $\mathrm{Al}_{2} \mathrm{O}_{3} \ldots \ldots \ldots \ldots \ldots \ldots \ldots$ & 16. 35 \\
\hline $\mathrm{Fe}_{2} \mathrm{O}_{3} \ldots \ldots \ldots \ldots \ldots$ & 2.03 \\
\hline $\mathrm{FeO} \ldots . . .$. & 10.52 \\
\hline $\mathrm{MnO} \ldots$ & .17 \\
\hline $\mathrm{BaO} \ldots \ldots \ldots \ldots$ & trace \\
\hline $\mathrm{CaO} \ldots \ldots \ldots \ldots \ldots \ldots$ & 9.83 \\
\hline $\mathrm{MgO} \ldots .$. & 9.71 \\
\hline $\mathrm{K}_{2} \mathrm{O} \ldots$ & .32 \\
\hline $\mathrm{Na}_{2} \mathrm{O}$ & 1.36 \\
\hline $\mathrm{H}_{2} \mathrm{O} \ldots \ldots \ldots \ldots$ & 1.7 \\
\hline \multirow{2}{*}{ 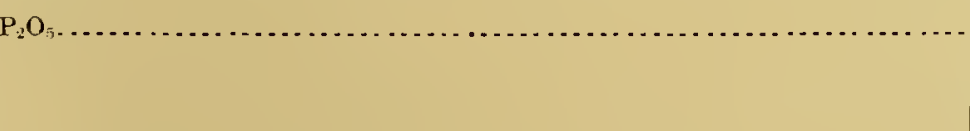 } & .07 \\
\hline & 100. 19 \\
\hline
\end{tabular}

The Heath amphibolite bed.--Across Heath from north to soutl, within the border of the Goshen schist, runs a band, standing nearly vertical and 
50 rods wide, of a dull, dark-gray, slightly greenish amphibolite, thin-fissile and highly porphyritic. It closely resembles the Guilford band in its wider portion across Vermont, west of Brattleboro, where the latter is porphyritic. The porphyritic spots are due to feldspar, which excludes the hornblende, but is itself full of impurities, especially biotite. The latter is wanting in the main mass. It lies near the western border of the Goshen schist and passes through the railroad cut east of Charlemont station. The upper amphibolite bed of the Hawley schist is at times porphyritic, and I lave assumed that this Heath bed was a repetition of that upfolded throngh the Goshen schist. The small content of lime and magnesia may be thought to militate against this assignment and indicate a relationship to the Guilford and Whately bands, which occur in the Goshen schist far to the east, and this is perhaps the best assignment of the bed.

An analysis of the rock has been made by Mr. L. G. Eakins, from a specimen taken from near W. M. Sanford's:

Analysis of Heath amphibolite.

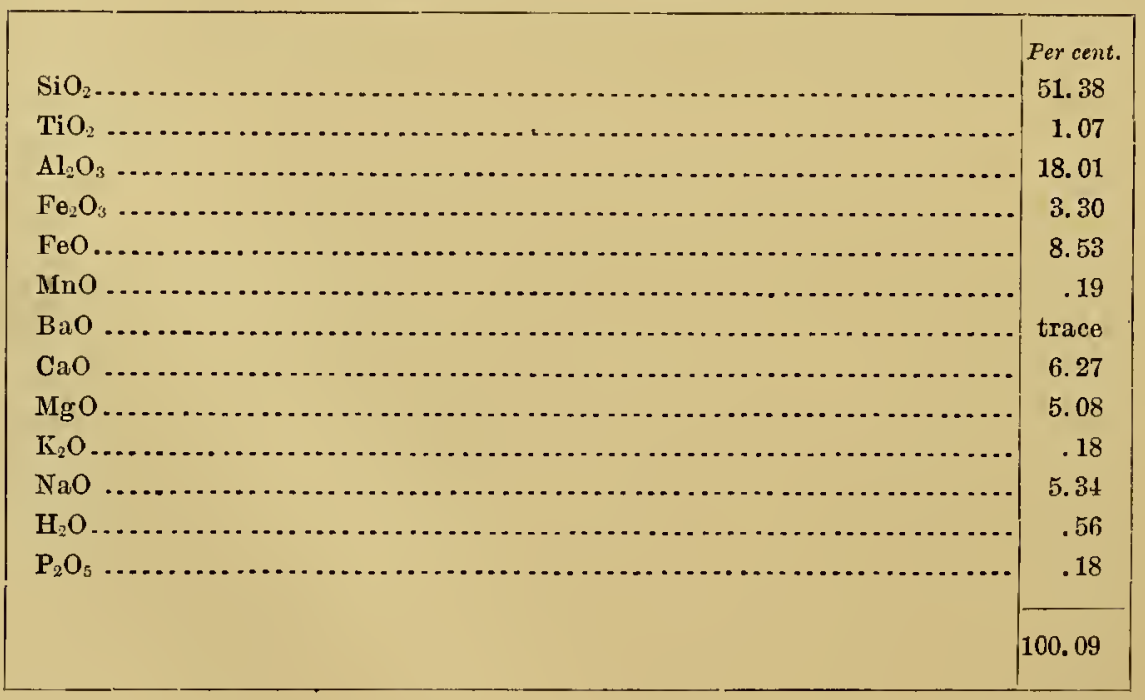

The white gneiss. - A single curions band of white, thick-bedded gneiss runs down through the middle of the Hawley schist area. It passes through the southwest corner of Halifax, Vermont, and can be well studied on the high lill south of the road. It is a very prominent bed on the road going 
up to the Davis mine, where, a mile below the mine, a crosssoarl tums off to the enst. It las blue quartz, single twinned feldspars, and very little biotite, and is 60 feet thick.

\section{THE POSSIPLE IGNEOUS ORIGIN OF THE HAWLEY SCHIST.}

The theory that a ferromagnesian formation like the present may be in whole or part of igneous origin is very attractive, and I know of no sedimentary series which could be more easily transformed by wholly intelligible metamorphic processes into the present one than the Triassic beds of the Holyoke range, with their interbedded traps, tuffs, and ferruginous sandstones, to which respectively the amphibolites, chloritic schists, and fasciculate sericite-schists can be compared. There remains now no distinctively eruptive structure in these beds. The pseudo-porphyritic character of the amphibolites proves to be caused by the exclusion from the white spots of the black hornblende needles by a secondary feldspar growth, now more or less saussuritic, so that the white feldspar ground appears. A single very strik-

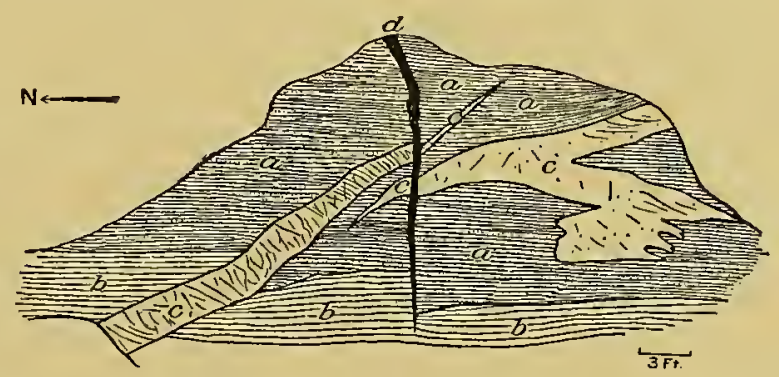

Fig. 9.-Plan of altered dikes and quartz veins in chlorite-schist, Charlemont. $a$, ankerite-chlorite-schist; $b$, sandy muscovite-gneiss; $c$, altered dikes, now green ankerite-chlorite-schist; $d$, blue-quartz reins.

ing occurrence, looking like a small dike branching across the bedding, occurs in Charlemont (fig. 9), going up over the bare rocks west of A. P. Maxwell's (now Vincent's), a mile north of the village, to the highest rocky bluff visible in the woods from the lonse. On the east is the common soft ankerite-chlorite-schist $(a)$, and a sharp boundary line separates this from a white feldspathic muscovite-schist or gneiss of sandy texture $(b)$ Distinct dikes $(c)$ of ankerite-chlorite-schist of slightly different texture from the country rock (a) appear in the latter and run out into the white gneiss, branching and expanding into irregular forms. The country rock is distinctly faulted by the dike, and a later fault cuts across the whole and throws it, and this is filled with vein quartz $(d)$. There is a distiuct foliation in the dike, which is in part parallel to that of the country rock and in part divergent therefrom, as indicated in the figure. 
MINERAL DEPOSITS.

THE PYRITE BEDS.

Toward the north, to some extent in Hawley, but more abundantly north of the Deerfield River, lenticular beds and impregnations of pyrite occur, currying' a small percentage of chalcopyrite. 'The success of the Davis mine in Rowe has greatly stimulated the search for similar deposits and their exploitation. Much time and money seem to have been fruitlessly expended, and often by those who could ill afford it, without, so far as $I$ could learn, consultation with any person competent to advise upon such matters.

Many considerable beds have been opened, but none have proved remmerative except the Daris mine, near the east line of Rowe. This is a great lens, lying with sericite-schist as its western (foot) wall, and on the east chlorite-schist, which is soon replaced by sericite-schist. The strike is N. $30^{\circ} \mathrm{E}$., the $\operatorname{dip} 70^{\circ} \mathrm{E}$. The bed has been opened for 700 feet on the strike and to a depth of 425 feet. On the north it swells in a short distance from 6 feet to 24 feet and maintains this thickness nearly to the south end. It is an enormous mass of almost pure, coarse-granular, slining yellow pyrite, with some chalcopyrite, blende, garnets, and gahnite-the two latter fine and rare. I am indebted to the proprietor, Mr. H. J. Davis, for the facts concerning the workings of the mine up to the summer of 1892. It is supplied with the most approved appliances of every kind. A little village has sprung up in this desolate corner of a decaying town, and much taste and energy were manifest everywhere. A new post-office (Davis) has been created, and surveys were being made for a narrow-gange road from the mine to Charlemont. Everything thus indicates that the mine is successful to a degree exceptional in the history of mining in Massachusetts.

In 1892 the greatest depth of No 1 shaft was 501 feet; greatest length of adits, 998 feet; total depth of all shafts, 621 feet; whole length of adits, 5,989 feet; greatest width of the vein, 61 feet. Total product of mine to January 1, 1892, 334,552 tons

Considerable work has also beeil done on Rice's brook, a mile above Charlemont village, and an engine has been set up, but the enterprise did not prove remunerative.

The most abundant and promising deposit after the Davis mine is in 
the high bhuffis orertooking the road eant of M. V. Cressy's "second pasture," where for a long clistance along the strike, in an area 20 rods in width, the chlorite-schist is crowded with pyrite in lirge, rough-faced cubes two-thirds of an inch across. One linyer nearly a foot thick has been opened.

$$
\text { COPPER ORES. }
$$

The pyrite beds usually carry a small percentage of chalcopyrite. Copper is said to have been mined in a small way nortluwest of $\mathrm{M}$. Stetson's and northeast of P. Packard's, in Plainfield. In an opening made by II. V. Cressy in the pasture north of II. Baker's, where the sericiteschist is much impregnated with granitic material, bornite is quite abundantly disseminated in small grains, partly changed to malachite; and farther north in Charlemont, back of the louse of G. Veber, on a blind road running north from the river road, bornite appears in masses an inch across.

THE GREAT HAWLEY FAULT AND TIE MAGNETITE AND HEMATITE DEPOSITS, THE RHODONITE AND RHODOCIROSITE BEDS, AND THE GARNET-SCHIST OR COTICULE.

The mineral rhodonite has been found for many years in large bowlders in Cummington, near the Bryant homestead, and it has, in fact, been called cummingtonite from that circumstance. Within a year or two statements have appeared in print to the effect that the ledge from which the bowlders had been derived had been found on the Bryant road in Cummington. On investigating the trenches I found that they did not reach any ledge there at all, and taking the direction of the glacial stria I soon found the ledge $2 \frac{1}{2}$ miles distant to the northwest, in Plainfield.

On the road running north, up the hill from West Cummington, at the house of T: Williams, now occupied by Henry C. Packard, about 35 rods south of the house and 10 rods west, a garnetiferous sericite-schist (Savoy schist) on the west abuts against the chlorite-ankerite-schist on the east, and a band 8 rods wide is filled with veins of quartz, quartz and magnetite, and quartz and rhodonite. Some of the latter are 3 feet wide, of the finest and deepest color, often blackened at the surface. All the varieties found in the bowlders on the Bryant road in Cummington can be found in place here. The line between the two has the direction of the glacial strix of the region, and this locality is doubtless the source of all the Cummington 
rhodonite. Much mining was done here in 1848 , but it was abandoned because of the California gold excitement. By following the road north a mile and a half to a point where it turns sharp east, measuring 60 rods south from this bend, and going 10 rods east into the open field, one comes to another opening on a vein or group of veins 10 feet wide, mostly quartzrhodonite veins, the unaltered rock faintly pink and the whole greatly blackened by oxidation. These two openings are called, locally, the manganese mines. They mark the line of a great fault, which runs south through the area of iron-manganese in Hawley. An inspection of the map will show that the amphibolite bands coming south are cut off witl an acute angle against this fault, and the contrast of the highly ferruginous ankeritechlorite-schists (Hawley schist) on the east and the barren quartzose sericite-schists (Savoy schist) is everywhere very striking.

Across Forge Hill, in West Hawley, this contact line bends considerably to the east, but the crushed band, largely filled with quartz veins, more or less ferruginous, is so wide here that I have represented the state of things by doubling the fault line across this area. I was guided the whole length of the iron deposits on Forge Hill, sonth of the old Hawley mine, by MIr. M. V. Cressy, who owns most of the land and has examined the country for iron more carefully than anyone else. At the most southern opening marked on the map, and the one where the dipping needle was most affected, the schist was impregnated with magnetite for a thickness of 12 feet in the digging, and about 2 feet of this would pass as a lean ore. From this point the vein or veins can be followed north for a long distance, and opposite the south end of the amphibolite band and in the line of the straight fault marked on the map considerable digging has been done and the magnetite, here exceptionally abundant, is accompanied by much fleshcolored quartzite, apparently colored by rhodonite and rhodochrosite. The schist is full of magnetite for many rods to the east, and a well-marked hematite vein occurs here, with the quartz-rhodonite mixture accompanying it. About 10 rods south of this the epidotic amphibolite comes to an end and the ankerite-chlorite-schist abuts against the quartz-sericite-schist. The vein can be followed north by disseminater ore to the Cressy "second pasture," a mile south of the old mine. Here a deep shaft has been sumk on the vein at the junction of the two rocks and masses of pure magnetite were lying at its mouth, and the accompanying vein quartz here and along 
a line a few feet east was pink from the intermixture of rhodonite and rhodochrosite. Ilmenite and fluorite also ocem here in quartz veins near the point where, a few rods west up the hillside, a new shaft has been sunk and has exposed much beautiful corrugated hematite-schist.

A half mile farther north on the vein, at Mr. Cressy's "first pasture," the excavations have so exposed the vein as to throw much light upon its character and origin. 'The following section is exposed, commencing on the east:

\section{Section in West Harley.}

1. Dark-green ankerite-chlorite-schist (Hawley schist).

2. Compact vein quartz, tinted flesh-color from rhodonite, or rusted to deep brown and black; vertically color-banded, and with very regular rhombic jointing, 3 feet.

3. Solid, rusty, granular magnetite, 3-6 inches.

4. Granular quartz full of white quartz veins, carrying ilmenite, which seems to be the sericite-schist crushed, deprived of its mica, and recemented, 18 feet.

5. Sericite-schist fnll of scales of hematite replacing the mica and fine-granular rhodonite, 4 feet.

6. Sericite-schist (Savoy schist).

Everything indicates the crushing of a wide body of the rock and the deposition of magnetite along the main fissure, while manganese was carried far out from the fissure into the crushed rock, with much vein quartz and ilmenite; and still farther away from the main fissure, and perhaps at a lower temperature, hematite replaced the mica of the schist.

The old Hawley mine, a half mile farther north, is sunk on a vein r'unning $\mathrm{N} .10^{\circ} \mathrm{E}$. and dipping about $80^{\circ} \mathrm{E}$. This vein is situated in the sericite-schist, 5 rods west of the junction of this schist and the ankeritechlorite-schist, from whose abundant store of iron the vein was doubtless filled when the mountain-making movements opened the fissures and stimulated the chemical activity of the heated waters. The mine was much worked many years ago, and though the shaft was filled, the deep open workings have remained open and have furnished the many elegant specimens of the "micaceous iron" from Hawley found in all cabinets.

This is the ore in the upper portion of the vein, and has been opened for 80 or 90 feet south from the shaft, which is 50 feet in depth, with a maximum thickness under 2 feet. A cross-cut of 10 feet cuts two more narrow veins. It is a well-foliated rock, generally finely corrugated, and 
made up almost entirely of small, shining scales of hematite. I think it is a pseudomorph after the sericite-schist in which it is intercalated.

Below, the vein changes into a firm, compact magnetite, which is often interlaminated with the quartz-rhodonite mixture.

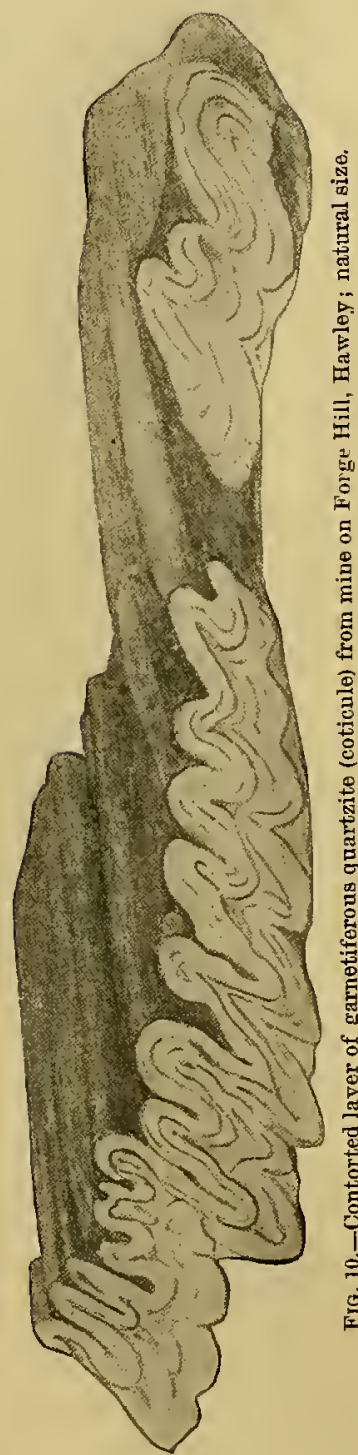
The mine has been recently (1891) opened by Mr. Ferd. S. Ruttmann with improved appliances.

The flesh-colored quartzite, plainly colored by manganese, which occurs as a veinstone on Forge Hill and south all along the vein, has the aspect of a common granular quartzite, but under the microscope its appearance is very striking. The slide looks exactly as if a layer of half-dried blood corpuscles were spread upon it. They average $.05^{\mathrm{mm}}$ across, but vary from half to double this size. They are flattened and circular, but not always entirely regular, have darker centers, and are of reddish color. They are completely apolar, but have at times a polarizing grain at center. Some of them are complete trapezohedra, and they are manganesian garnets. A few grains of quartz and a rare scale of chlorite complete the slide. This description is of the rock at Forge Hill.

From the mine on Cressy's land, on the south, the grains are much smaller, $.016^{\mathrm{mm}}$. There is a little more quartz, otherwise they are the same. The rock is thus a coticule or quartz-garnet rock, tinted flesh-color by manganese, and is a product of the same heated waters which have filled the vein with hematite.

It is at times marvelously contorted, as illustrated by fig 10 , taken from a band at the mine on Forge Hill. 'This in appearance is a tine-grained, pink sandstone. The folds are so nearly sheared apart that a piece falls asunder easily in coarse bars, and the whole surface is frosted over witl specular iron. Few traces of the iron can be found farther north, but south of the point where the fault line is made to terminate, 
up the steep hill, I have found, at the abrupt transition between the chloriteschists and the sericite-schists, signs of the continuation of the fault, in the inpreguation of the rock with fermginuous quartz veins.

An interesting vein occurs in the deep, picturesque gorge below $C$. Colby's mill, near the town honse in Hawley. It is a vein, 14 feet thick, of quartz with much hematite disseminated, and tinted flesh-color from manganese. There has been some work done here in opening the vein.

Another rein occurs here on the hillside east of M. V Cressy's house. 'This rock is impregnated with hematite, and great masses of interlaced epidote crystals occur here. It has been tested with a diamond drill to the depth of 100 feet.

On the south face of the high hill a mile and a half north of Charlemont station is a bed of magnetite 6 feet wide, which was worked a little over forty years ago. It is for the most part very quartzose, except 1 to 3 inches at the center, and lies in the fasciculite-sericite-schist.

\section{THE GOSHEN ANTICLINE.}

On the line between Chesterfield and Goshen, and stretching east nearly to the center of the latter town, is a most interesting outcrop of the rocks of this series, isolated, and surrounded on all sides by the newer formation. It is a broad oval, with its long axis parallel with the meridian, and the beds are arranged as a quaquaversal or short anticline, with high dips on the east and low ones on the west, and with a fault crack along the crest having a considerable upthrow on its west side From the friable nature of the rocks this anticline is sunk by erosion into a peculiar, deep, oval valley, which separates the two towns and in which Burnell's pond lies The area is framed in its whole circumference by a bed of fine-grained, light-gray granitoid gneiss abont 50 feet thick, which I have assigned to the upper series.

Commencing at the north end of the series, just west of W. J. Ball's house, the rock is a white, friable, granular schist, containing a shining black biotite on the distant lamination faces and very large, scattered garnets, and varying from a quartz-schist to an almost quartzless biotite-schist.

Farther west the same biotite-schist becomes hornblendic, like the "fasciculite"-schist, and is replaced by a black amphibolite. The same schists are continued down the lower (eastern) portion of the western wing 
of the eroded anticline. At A. and R. Hawk's house, farther south, around the south end of Burnell's pond and on the east side of the fanlt, the rock is a coarse, light-gray sericite-schist, very micaceous and tinged with green from the scales of chlorite mingled with the mica. This schist is somewhat feldspathic, and it carries subordinate intercalated beds of gneiss, bedded granite, and quartzite. In the upper portion of the western side of Burnell's pond, and overlooking it as a high bluff, an interesting bed stretches north and south, which is wanting upon the other side of the fanlt. This is a layer in the sericite-schist 30 feet thick, the upper part a very coarse, rusty rock, made up of the brown cummingtonite in broad, radiated, interlaced blades matted around deep-red garnets 1 to 2 inches across. There is much pyrite disseminated in the rock. In its lower portion the rock is made up of a ragged mass full of large garnets and separate nodules of quartz and feldspar, with coarse mica layers wrapped around them. This grades below into the gray sericite-schist, as also above; and in quartz veins in the schist, immediately above, the finest cyanite is found. 


\section{OH A P TER VII.}

\section{THE GRAPHITIC MICA-SCHIST SERIES ON THE WEST SIDE OF THE VALLEY.}

\section{THE GOSHEN SCHISTS OR FLAGS.}

The Goshen schist includes the lower portion of the "calcareomica slate" of Prof. C. B. Adams, or the "calciferous mica-schist" of the Second Vermont Survey. 'The second name is objectionable, becanse it is used in England for a subdivision of the Carboniferous and in America for a subdivision of the Silurian; and in the uncertainty concerning the age of the beds here described mistakes have arisen, and it has been supposed that the name carried with it an implication that the rocks were Lower Silurian. Moreover, the name as usually employed would indicate that calcite was an accessory constitnent of the rock, and not that beds of limestone were intercalated at wide distances in the series. This latter is the case, and in central Massachusetts they are so widely separated that generally only two or three thin beds occur in a towaship, and in the lower subdivision here to be described they are almost wholly wanting. The limestone grows far more abundant northward across Vermont.

\section{GENERAL DESCRIPTION}

I have taken as a type for description the broad band of flags which surrounds the oval of sericite-schist in Goshen, upon which all the flagstone quarries of this town are situated. The rock is a flat-fissile, arenaceous muscovite-schist, splitting quite regularly into flags 2 to 3 inches thick and of the largest size. It is of clear gray to rather dark-gray color, from a constant content of graphite. It shows shining flat cleavage surfaces pimpled with small garnets $(\infty 0)$. Staurolite, eyanite, and beds of limestone are rare or wanting. 
The ascending section is (1) sericite-schist, (2) flags, (3) corrugated schist, which is met with in going out on any radius from the Goshen anticline; and these three beds are found exactly repeated in inverse order in the west of Worthington; that is, on reaching the corrugated schists (3), one keeps on west across them and passes a syncline, and west of Worthington village comes upon the flaggy schists (2) exactly as in Goshen, followed farther westward by the same hornblendic sericite-schists (1). The Goshen schist is here a true flagstone, splitting into thin slabs with smooth faces. It shows rarely staurolites embedded on the cleavage faces, on which appear also the garnets and the cross-sections of the very elongate biotite spangles.

The mass of the schist is here a gray muscovite-schist, very fine-grained, in many layers showing no free quartz when examined with the lens, in others showing much quartz in flattened lenses made up of grains of white quartz, around which the membranes of muscovite fold. The quartzose layers are 2 to 5 inches thick, and alternate regularly with more micaceous layers, so that here cleavage and lamination coincide.

This band is sharply differentiated from the corrugated schist above, and on the map (Pl. XXXIV) the boundary is exactly laid down across Worthington southwardly, and except where the till is an obstruction, across Chester to the river. South of this, as it swings around the south end of the syncline, it is involved in the general corrugation and can not be accurately bounded. It has already grown narrow, and can be clearly defined at Salmon Falls, on the Westfield River, but in the intermediate spaces the absence of limestone and a less amount of graphite and other accessories are the only guide. Indeed, the distinction is a comparatively unimportant one, but from the great extent of these graphitic schists it is needful to search out any recognizable stratigraphical distinctions in order to unravel their structure, and to retain these distinctions, when otherwise unimportant, in order to express this cartographically.

Northward from Worthington the flags widen across Cummington and Plainfield. Northwest of Cummington they are finely developed-an alternation of more or less quartzose layers with intervening more micaceous and garnetiferous layers; the latter, an inch wide and 3 inches apart, preserves an original alternation of more sandy and more clayey layers.

The widening continues across Ashfield. At C. and B. Hawes's, 4-inch sand layers, a foot apart, appear in the dark, garnetiferous spangled schists. 
Across Hawley we find the same lead-gray, flat flags, garnetiferous where micaceous, biotite-spangled where arenaceons, without quartz veins and withont staurolite. 'The litter mineral is henceforth absent as one goes across Charlemont and Coleraine, while otherwise the rock continues unchanged.

\section{UNCONFORMABLE CONTACT ON THE ROCKS BELOW. OUTLIERS IN THE HAWLEY SCHIST.}

At Salmon Falls in Russell, and at E. Clark's in Montgomery, the change from the light sericite-schists to the graphitic garnet-bearing schists is sudden. In Chester the contact is exposed at the falls high up on a branch of Sanderson Brook, visible from the road over the mountain. It is just at the north edge of the Granville quadrangle. The brook comes down over the vertical, flat, flaggy beds of the sericite-schist from the west; and 30 feet above its mouth, at a 2 -foot granite dike, the change is sudden to the highly corrugated black schists, very fine-grained and biotitic, but with little spangling. These schists effervesce with acid, and the transition is abrupt. A considerable unconformity is probably present, although the black schists are crushed into apparent conformity with the older flaggy schists.

The next place where this contact can be conveniently studied is in the open valley of the Westfield River, $1 \frac{1}{2}$ miles sontheast of Chester, at the end of a blind road which crosses the river and railroad just west of the mouth of Abbott's brook. The Savoy schist is hornblendic just north of E. Smith's house, at the end of the road, then follows the ordinary sericiteschist on the east, and the great development of amphibolite common farther north is wanting The junction begins just west of and runs up a small gully in a walnut grove above and northeast of the house of E. Smith. There is about 3 feet of fine granite at the junction, and for 2 rods east of the junction the Goshen schist is much corrugated and wavy, and nearly horizontal bands of what seems the original bedding run to meet the vertical Savoy schist. The Goshen schist is dark-gray, garnet-bearing, and spangled, and 3 rods east, across the gully, it lias the vertical posture and northerly strike common to all the region.

Across Worthington the boundary is well defined and is well exposed on all the roads leading down to the Middle Branch of Westfield River. Above 
the heavy bed of hornblende-schist is a layer of thin-bedded, soft, dark, crumbly schist, made up mostly of muscovite, and almost wholly barren, showing rarely a large, shapeless garnet. This is 40 rods wide, and is perhaps best assigned to the sericite-schist, though on the map it is colored with the upper bed. The change above is abrupt into the garnet- and staurolite-bearing flags.

The doubtful border layer mentioned above continues north across Cummington; and on the road to West Cummington, south of Deer Hill, the dolomitic fasciculite-schist (Hawley series) appears at L. Packard's, with amphibolite on the east of it, and just east of this amphibolite is a black, fine-grained, graphitic schist, pimpled with garnets, which is the base of the Goshen schist and the continuation of the doubtful layer mentioned above; and directly east of this again is a thin amphibolite layer, which is a repetition of the Hawley beds, followed immediately by the light-gray Goshen flags. Across Hawley and Plainfield the junction is nowhere well exposed.

At the first cut east of the Charlemont railroad station the same graphitic, thin-fissile slate occurs just above and to the east of the highest hornblendic bed of the Hawley schist, and is followed above by the Goshen flags, with the intervention here also of a bed of amphibolite, and this curious boundary continues diagonally across Heath from the mills west of the center to the northeast corner. An important change takes place here which indicates the unconformity between the two formations. The bed of porphyritic amphibolite near the top of the sericite-schist is continuous clear across the town of Heath, and a little above this the light-gray, quartzy fasciculite-sericite-schist (Hawley) comes in on the east with gradually increasing width and is succeeded a little farther east by a very plumbaginons, friable slate, in which I searched a long time for fossils. This bed has been dug for plumbago near J. D. Tinkham's, and it is well exposed at J. Loveridge's, in the northeast corner of the town. It grows wider as it goes north, and develops into well-characterized Goshen flags, and is plainly an outlier of these rocks embedded in the Hawley schists.

East of this bed the band of porphyritic amphibolite which was mentioned above in the Cummington and the Charlemont section widens and becomes across the whole of Heath 820 feet wide. This structure is well brought out upon the geological map and the sections accompanying it. (See map, Pl. XXXIV.) 
At $J$. Barber's, in Plainfield, is another very interesting outlier of the Goshen schist. (See map, Pl. XXXIV, region west of South Fawley, and section 4 on Pl. XXIV) It is a dark-spangled, garnetiferous muscoviteschist, and appears across the brook south of the house and strikes N. $25^{\circ} \mathrm{E}$ beneath the house in a broad band. The dark schists thus come in contact with different beds of the older rock as they go north in a way that indicates the presence of an unconformity of some consequence, and the relations of these upper schists to the Shelburne anticline can best be explained by the assumption of an unconformity between them.

\section{PETROGRAPHICAL DESCRIPTION.}

Garnetiferous musconite-schist from J Hawke's quarry, northwest of Goshen Center The rock is a fine-grained, even-bedded schist, mueh used for flagging, lead-gray and arenaceous, and is pimpled with garnets and spangled very abundautly by transversely placed scales of black biotite, as is the case with the Bernardston schists (see page 291). The background under the microscope is a colorless mixture of quartz grains and muscovite so fresh and clear that quite thick slides become transparent and the dark-gray color is seen to be due to the coaly grains. The garnets and the biotite are much larger and more abundant than in the newer schists.

The biotite, which has been called adamsite, phyllite, and ottrelite, but which shows all the optical properties of a biotite (meroxene), is in stout, thick, black crystals, the optical axes only slightly separated, but yet more than in the biotite of the newer schists.

The garnets are very curiously and regularly filled with quartz inclusions of two sizes, arranged differently, and every crystal is the close counterpart of every other. The larger inclusions have exactly the range of shapes of the fluid cavities in quartz. They are often rounded, frequently having the shape of a quartz crystal, and are arranged, closely crowded, in triangular planes resting upon the edges of the dodecahedron and meeting at the center. They thus divide the crystal into the twelve segments demanded by the theory of the lower symmetry of garnet, but under crossed nicols every portion of each crystal is perfectly black except where the quartz inclusions shine through.

The second group of inclusions starts at the surface of an ideally perfect dodecahedron, an eighth of the way in from the surface of the crystal, 
leaving this outer band quite limpid, and extends about halfway toward the center, the granules being largest at the surface and diminishing regularly to extreme minuteness and arranged in lines normal to the crystal faces. They are crowded so densely that they give the crystal the appearance of some hauyne or nosean sections, and by reflected light the red of the center is gradually diluted almost to white at the outer edge, and then framed by the deep red of the outer, clear border.

The quartz crystals are $0.15-0.20^{\mathrm{mm}}$ in size, the larger inclusions $0.02-0.03^{\mathrm{mm}}$ and the smaller $0.01-0.006^{\mathrm{mm}}$. The causes or forces which brought out this peculiar structure must have operated throughout the rock with great uniformity; must have risen in intensity to a maximum and then ceased suddenly, and have been followed by a period when the crystals increased without interpositions of quartz. At the last stage the crystals were built out only at the edges, these being advanced in the sections in bastions, often of great regularity. This is figured in Bulletin No 126, under "Garnet."

Stamrolite is a regular miscroscopic ingredient, often quite abundant where it is wholly wanting macroscopically It occurs in single wineyellow crystals, not often well formed, and is so loaded with large elongate and club-shaped quartz inclusions that three-fourths of a surface is often occupied by the latter. Here, also, an outer band is free therefrom, though not uniformly so, as in the garnet.

The biotite, which is usually quite pure, is of later origin and includes garnet and staurolite, and has also an outer clear border. There are thus indications of two times of metamorphism. One may perhaps be connected with the folding of the rocks and the other with the later intrusion of the great granite masses.

Biotite-gneiss from the crossroad to Buck Hill, Blandford; in Goshen schist. A fine-grained, yellowish rock, with abundant biotite scattered in a sandy quartz-feldspar mass.

Under the microscope the quartz, in grains coated with limonite, seems to be clastic. The rows of pores do not run from one to the other, and are not parallel. Rutile trichites are absent. The feldspar, mostly orthoclase, is in grains also coated with limonite, which are at times seemingly increased in size outside this coating. Rarely a grain of microcline or plagioclase appears. The biotite, black and fresh, molds the other constituents. There is no trace of any other constituent, and the rock is as monotonous under 
the microscope as it is in the field, and may be called a bastard gneiss or a feldspathic sandstone grown biotitic by metanorphism.

Crunitoil biotite-gneiss from near the great pegmatite dike at the south end of South street, Chesterfield; from a thick stratum, conformably interbedded in the spangled mica-schist near its base. It bears a close resemblance to the Becket gueiss.

A light-gray, fine-grained, biotite granitoid gneiss, the scanty biotite scales rounded or hexagonal, separate, and at times deep-red under the lens. The quartz and feldspar are colorless; the latter is glassy, often showing strie. Under the microscope it is remarkably and unexpectedly fresh, only here and there is a muscovite growth accenting the twinning of a plagioclase It is, furthermore, very unlike the Becket gneiss, with which it agrees macroscopically.

The quartz shows primary grains marked out by iron rust and secondary quartz in lobed, interlocked masses. The abundant traces of water pores generally contain globules, but these are of small size and only rarely show motion They are unaffected by heat The quartz contains in considerable abundance the rutile (?) trichites.

The orthoclase is generally in carlsbad twins, and shows the most remarkable wavy extinction. Microcline is well represented. The plagioclase shorws an extinction of $10^{\circ}$ and $4^{\circ}$ on each side the twinning plane. The biotite is wholly unlike that in the Becket gneiss, and resembles closely the biotite of the mica-schists, with which it is associated. It is bright brownish-red, with strong dichroism and no tendency to change into green forms It shows parallel intergrowth with muscovite, and is surrounded at times with a band of muscovite scales. It incloses apatite.

Muscovite appears only microscopically, and besides its association with biotite shows at times a beautiful microplumose structure.

Apatite occurs in great abundance. Opaque iron ore, titanite, rutile, and zircon are wholly wanting.

THE CONWAY SCIISTS, OR THE CORRUGATED MITA-SCHISTS. GENERAL DESCRIPTION.

This widely extended formation (the upper portion of the calciferous mica-schist) is a dark-gray to black, quite highly graphitic muscovite-schist, so sharply corrngated that the foliation surfaces are often wholly lost in a 
crumpled ligniform structure. The whole is often also largely contorted and full of white quartz veins. It is of such fine grain that the separate mica scales are just visible.

It is very generally a "spangled schist," oval or elongate biotite crystals being set transversely to the bedding, and over considerable area all parallel to a common plane, which seems always to be the plane normal to the direction of pressure at the time the crystals were deposited

Garnet and staurolite are usually abundant, especially in the southern half of the area. In Cummington they become rare, and north of this town the staurolite disappears almost entirely, coincidently with the disappearance of the great granite masses. There is often an interlamination of more and less sandy layers, and in this case the more sandy layers lose the fine corrugation described above, but retain the spangles of transverse mica.

Toward the east, where the mica-schist is entangled in the great masses of granite in Williamsburg and Westhampton, it largely loses the fine regular corrugation in an extreme and irregular twisting and contortion, and it becomes of much coarser grain and barren of all accessory minerals except a few garnets.

The cliffs just south of the locality for colored tourmaline on the old Weeks farm in Goshen (now Barras farm) are composed of a typical black, coarse, spangled, corrugated muscovite-schist.

I have chosen Conway as the general type of this series because it was there first studied by President Hitchcock, and because it is there most calciferous and best shows the whole range of variety of the series.

Throngh Russell, Blandford, Montgomery, and Huntington gray cyanite is a common constituent. In the next tier of towns, Worthington and Chesterfield, it is not so common, but occurs in finer specimens of rich blue color. It is here not so regularly disseminated in the rock as farther south, but is in veins of coarse quartz, at times associated with apatite.

In the same latitude, in Goshen and Williamsburg, zoisite is quite common, and zoisite, cyanite, and staurolite disappear from the continuation of these beds north across Franklin County, parallel with the increase in the amount of limestone, though bowlders of zoisite abound in Shelbume.

As a quite exceptional occurrence a large area of the schist on the hill north of Anson Johnson's mill, on the Worthington-Chesterfield line, and not near any granite, is full of small black needles of tourmaline. 
Across Franklin County the rock is a rusty, contorted, dark-gray micaschist, with few garnets, rarely or never spangled with biotite, much twisted and full of quartz veins, and abounding in black graphitic and biotitic limestone beds, often very impure. The ledges present, as a whole, a most uninvitingly lagged and dark, rusty appearance. The rock is folded into a series of closely appressed folds in the broad area over which it extends, and it is not possible to umravel them and lay them down separately upon the map.

\section{SUBORDINATE BEDS IN THE CONWAY SCHIST.}

THE GNEISS BEDS.

There are in several places in the dark schists light-colored beds of a fine-grained gneiss or feldspathic quartzite. The transition from the one rock to the other is very sharp, and in the strong folding the rocks have undergone the gneissoid beds are found in attitudes relative to the schists which suggest an intrusive origin of the former. The small phenocrysts of feldspar often show twin striation and quite regular outline, and the latter is true of the quartz and the red-brown mica. The groundmass is so fine as to give the whole the aspect of a trachyte, but with a strong lens it is seen to be sandy rather than felsitic, and in thin section it is seen to be $a$ ' finely granular clastic mass, nearly all of small and rounded quartz grains, with much clayey dust, and clear traces of the enlargement of quartz grains and the later growth of the small feldspars and mica scales

The most marked bed crosses the road a few rods west of the house of $\mathrm{R} A$. Gates in northwest Leyden. It is 13 rods wide, runs a long way north and south with the strike, is generally regularly intercalated in the inclosing schists, but in places irregularly thrust into them, and is accompanied by small parallel beds, a foot or less in width, which seem like offshoots of the main bed.

It also occurs in Whately, just west of the village, and near the houses of G. Cowan (where the bed is 1.2 feet wide) and Mrs. M. Taylor, and in Chesterfield opposite the schoolhouse on the Clark road.

There were apparently sudden transitions from the coaly clays to a fine calcareous sand, which have allowed the development of the small porphyritic lime feldspars and only a very small quantity of dark mica. 
THE WHETSTONE-SCHIST.

This rock is a fine but very even- and sharp-grained, almost massive sandstone, with small scales of a deep-brown biotite, notched and irregular, and often inclosing grains of the quartz scattered distantly but very regularly in it. The biotite was of course formed where it now is, but the quartz grains seem to be pretty purely clastic.

It occurs in distinct beds in the mica-schist, often of considerable thickness-33 to 262 feet. It generally grades into the mica-schist by increase of the size and change in the position of the biotite, and often by the appearance of garnet and staurolite.

It occurs most abundantly in Chesterfield and Worthington, where the beds run for long distances with the strike, and where I spent much time in tracing them out, hoping to get useful material for the study of the structure of the mica-schist. I have put them down on the map just as I found them, letting them end where the outcrop ends, and not generally connecting fragments unless it was quite certain they were continuous. In many cases one can see on the map that disconnected portions are probably continuous. In many cases the common schists were found after an interval in exact contimuation of the whetstone. In a few cases this could be proved to be caused by small faults; farther north in Franklin County and east in the granitic area these beds are less distinct or wanting, with one notable exception detailed below.

The rock called whetstone in this section is not, of course, everywhere suitable for whetstones, though portions of the beds may be of the right texture for this purpose; indeed, these beds have been quarried for whetstone for many years. Good quarries are found on the south slopes of the spodumene hill in Hnntington; the best at B. Shaw's in Cummington. They are called Quinnebang stones, and I was interested to find them selling for 50 cents apiece, as the best stones obtainable, at a hardware store in Brattleboro, Vermont.

Officers of the Pike Manufacturing Company, which owns quarries in Cummington and which controls the manufacture for a large part of New England, state that the founder of their business, Isaac Pike, operated quarries at Cummington about the year 1830. These quarries are not being worked at present (1892), though in the past they have sometimes produced 
firom 1,000 to 2,000 gross of scythe stones per annum. A new quarry, which is still worked, was opened in 1888 in Cummington. ${ }^{\text {it Hitcheock }}{ }^{2}$ reports in 1832 that mica-slate is quarried in lárge quantities in Norwich (now Huntington).

The most remarkable band of this sort is encountered on the river road from Shelburne to Greenfield. The road where it runs farthest south, in Deerfield, crosses the band, which is here 300 feet wide, and its eastern outcrop is near a small schoolhouse. The next road north, which enters Shelbume from the northwest corner of Deerfield, crosses the same band with the same width, and it seems to make the whole flank of Arthurs Seat. It is a flat-fissile, fine-grained, light-gray, micaceous quartzite with a shade of red, which changes on weathering to pale green, and which recalls the sericite-schist. East of it, on the last-mentioned road, is a black garnetbearing and biotite-bearing schist, exactly like the upper bed of the Conway schist at contact on the Leyden argillite farther north.

Another interesting outcrop of the whetstone-schist is the band in Whately between the great hornblende band and the argillite. This is in places somewhat more micaceous and carries four thin limestone beds. The same bed comes out through the conglomerate of Mount Toby at Whitmores Ferry, in Sunderland. (See page 361.)

PETROGRAPHICAL DESCRIPTION.

Opposite school on road to Clarke towmaline ledge, Chesterfield. Under the microscope the whetstone is a mass of angular quartz grains, manifestly clastic, with distant, regularly disseminated flakes of biotite with irregular outlines conditioned by the surounding quartz grains.

Pale-green muscovite occurs in elongate scales. There is little coaly matter and the magnet shows no nugnetite. A few stout elongated prisms with cross cleavage and rounded ends may be andalusite.

Cummington, B. Shaw's quarry. Best quarry stone. Like the above, but of darker color, finer, and more even grained. Under the microscope: clastic quartz, more biotite, less muscovite, and much more coaly matter; no magnetite.

\footnotetext{
${ }^{1}$ L. S. Griswold, Whetstones and the novaculites of Arkausas: Geol. Survey of Arkansas, 1892, pp. 24,73 .

${ }^{2}$ Geol. Mass., 1832, p. 23.
} 
THE LIMESTONE BEDS.

Before the introduction of railroads these beds of impure limestone were of great importance, and they are fully treated by President Hitcheock in all his works on the geology of the region. They are black, graphitic and biotitic limestones, not often above 30 feet in thickness. The bed west of Coleraine village and that in Whately are the thickest. They have been mapped for me with great care by Mr. William Orr, jr., of Springfield.

They increase in number toward the north and toward the east, and are most abundant in Ashfield, Conway, and Coleraine, and they continue right up to the Leyden argillite, in which they are wanting.

In the southern tier of towns 'occupied by these schists two very narnow beds appear in Montgomery; in the next tier to the north none were found. In the next a few unimportant beds occur in Goshen. In the next tier they are abundant in Conway, etc., as detailed above.

These limestone bands are generally capped above and below by a thin layer, 3 to 4 inches tlick, of a black, compact, quartz-liormblende rock, often studded with well-formed black garnets $(\infty 0)$, which are commonly called melanite, but which are a common red, lime-iron garnet, colored black by carbon. These bauds have been formed at the expense of the limestone, and often one finds beds where the limestone has been altered entirely; and where a bed thims out to 6 or 8 inches it becomes wholly hornblendic. The mica in the limestone is arranged in rude spherical concretions of the size of a walnut, and these two structures explain (a) the curious "anvils"-the columnar and mushroom forms on square pedestals, which are so common in the limestone region-and $(b)$ the rough, warty surface of these peculiar forms and of the weathered limestone everywhere.

The process of the formation of these anvils is as follows (see Pl. XXXIII): Jointing separates a square block of the limestone, with its caps of amphibolite. The latter is more resistant, and weathering eats deeply into the limestone, forming anvils, stools, or, where only one band of amphibolite is preserved, columnar forms, warty from the projections of the mica concretions. They are found most commonly in swampy places, where the solution of the limestoue has been farored.

President Hitchcock made many analyses of the limestone, which are 
summarized below, exchding several from bowlders of the Hinsdale and Stockbridge limestones:

Analyses of limestones.

\begin{tabular}{|c|c|c|c|c|c|c|c|}
\hline Date. & Loenlity. & $\begin{array}{l}\text { No. in cata- } \\
\text { lorue of } \\
\text { state col. } \\
\text { lection. }\end{array}$ & Sp. gr. & $\mathrm{CaCO}_{3}$ & $\mathrm{MgSiO}_{z}$ & $\mathrm{SiO}_{2}$ & $\mathrm{Fe}_{2} \mathrm{O}_{3}$ \\
\hline $1832 \ldots$ & Whately, purest....... & & $\cdots$ & 78.00 & & & \\
\hline $1832 \ldots$ & Whately, poorest...... & ......... & $\ldots .$. & 67.00 & & & \\
\hline $1832 \ldots$ & Conway line, compact. & $\ldots$. & & 58.00 & & & \\
\hline $1833 \ldots$ & Whately .............. & & $\cdots$ & 76.00 & & & \\
\hline $1835 \ldots$ & Southampton.......... & (....... & ...... & 45.00 & & & \\
\hline $1835 \ldots$ & Williamsburg bowlder. & ... & $\ldots$ & 63.00 & & & \\
\hline $1838 \ldots$ & Sonthampton......... & -.. & 2.93 & 38.4 & & & \\
\hline $1838 \ldots$ & 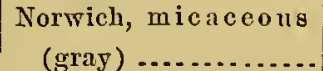 & 188 & 2.79 & 53.8 & & & \\
\hline 1841. & $\begin{array}{l}\text { Whately, crystalline } \\
\text { (gray) ................... }\end{array}$ & 459 & 2. 72 & 66.00 & & 34.00 & \\
\hline $1841 \ldots$ & Whatel $y$.............. & 1916 & 2. 72 & 64.66 & 5.01 & 28. 79 & 1.54 \\
\hline $1841 \ldots$ & $\begin{array}{l}\text { Norwich, micaceous } \\
\text { (gray) }\end{array}$ & 2503 & 2.79 & 53.80 & & 46.20 & \\
\hline $1841 \ldots$ & Ashfield, micaceous.... & 1920 & ........ & 64.85 & 1. 60 & 50.00 & 1.55 \\
\hline $1841 \ldots$ & .... do. & 1921 & (n) & 45.13 & 3.50 & 48.57 & 2. 70 \\
\hline
\end{tabular}

THE AMPHIBOLITE BEDS.

THE CONWAY BED.

The geological maps of Vermont and Massachusetts represent a very broad band of hornblende-schist crossing Guilford, Vermont, and Leyden and Shelburne, Massachusetts. This I could not understand, as I could find only a narrow band crossing Shelburne. Later, my assistant, Mr. William Orr, jr., traced the bed carefully across the Greenfield quadrangle and found that it widens in the southwest corner of Guilford so as to cover a half mile in area and attains a possible thickness of 2,000 feet. It narrows rapidly at West Hollow Brook, and seems then to be interrupted for 3 miles to a point $1 \frac{1}{2}$ miles east of Coleraine Center. From this point it is continuous south for 11 miles to a point a mile east of Conway. It is best studied in Brimstone Hill, in Shelburne, where it is 10 rods wide, and a few rods west of the Conway railroad station. It is generally a shining black, thin-bedded rock, but at times the content of hornblende lessens and the rock becomes gray. In its continuation northward in Vermont it becomes porphyritic 
and resembles the Heath band in the Goshen schist. As it crosses Shelburne and Conway it resembles the Shelburne Falls and East Charlemont band, though lacking the abundance of pyrite in the latter (see PI. VI, fig. 2).

THE WHATELY BED.

The other and more important band of amphibolite comes out from beneath the sands of the valley in Whately with a width greater than that of the former band at its widest, and runs with increasing width southwest across this town and into Williamsburg, to abut against the great block of granite in that town.

In massing the evidence for the batholitic character of this granite I have, on page 310 , mentioned the series of isolated patches of the schist found for many miles as inclusions in the granite along an area extending southwest in the line of strike of the bed across Roberts and Sawmill hills, in the north part of Northampton, and parallel with the similar inclusions of limestone and mica-schist. Several of these are marked on the map. It is very singular that if the line of this series of inclusions of the hornblendeschist be continued south still farther it would cross the site of the Loudville lead mine. This gives a curious interest to the following extract:

Serpentine occurs at 723 feet from the entrance of the adit at Loudville (Southampton), containing very red quartz embedded in various directions. It is very compact and.mostly green. Here it is but 3 feet thick. About 670 feet is beautiful green soapstone. ${ }^{1}$

There are, so far as I know, no specimens extant of the rocks mentioned, and the adit has been closed many years.

The fact that the hornblendic rock here discussed shows elsewhere no tendency to change to serpentine or talc lessens the probability that they are the same, and I have been disposed to refer this occurrence to the older serpentine connected with the Chester amphibolite.

THE WHTMORES FERRY BED.

Far out in the middle of the Triassic area, where the western foot of Mount Toby meets the Connecticut River, is a remarkable outcrop of amphibolite and whetstone-schist, projecting through the Mount Toby conglomerate in a most unexpected way. The proofs of the identity of the amphibolite with the Whately bed are given in the petrographical descrip-

${ }^{1}$ Amos Eaton: Am. Jour. Sci., 1st series, Vol. I, 1818, p. 137. 
tion following, and the curions relations' of the bed to the base of the Triassic are discussed in Chapter XII, under the head of "'The Mount Toby conglomerate:"

PETROGRAPUICAL DESCRIPTION OF LIMESTONE AND AMPHIBOLITE. THE LIMESTONES. THE ANVILS. THI PASSAGE OF LIMESTONE INTO AMPHBOLITE.

(a) Carbonaceous limestone from Whately. From the mass at the bridge west of the village, thrust up through the argillite (described on p: 196); a dark-gray, nearly black, compact, traplike rock, weathering deeply to a red-brown, porous and friable mass.

Under the microscope it is seen to be a granular mixture of quartz and calcite, the latter often multiple-twinned, and the whole darkened by coaly matter in fine grains. In this groundmass are developed varying quantities of muscovite and biotite, the latter more loaded with coal dust than the general mass, indicating early crystallization, when the whole was more coaly.

(b) Micaceous protuberances on the limestone anvils from Goshen (?). (See Pl. XXXIII.) This section was cut from a small warty protuberance, an inch across, from the central limestone portion of an "anvil," which stands in front of the geological building at Amherst, to determine the cause of the regular projections on the weathered surfaces of the limestone portion of the "anvils." On the fresh surface the projections appeared exactly like the rest of the limestone. Under the microscope there proved to be in them considerable accumulations of a greenish muscovite, with here and there a few scales of red biotite. The muscovite was filled with needles of rutile. There was also considerable feebly pleochroic hornblende in notched plates.

(c) Base of same anvil. This seems to have been a passage bed from the sandstone to the limestone. It is nearly 4 inches thick, and is made up of a green, fibrous, matted hornblende, filled with quartz grains which are in part rounded and apparently original, in part turberculous and cansed by secondary infiltration, and in part in scales so sharply angular that they may have been crushed in place. Very many of these quartz grains are crowded with coal dust in the center and are clear outside, indicating secondary enlargement, and the same is true of the large hornblendes. A few muchcorroded grains of calcite remain. There are also grains and well-formed 
crystals of titanite, wine-yellow and colorless, in considerable number, which sometimes contain grains of black ore, thick prisms of rutile, often with dark border, rust, and a little coaly matter. The centers of the hornblende blades are often red-brown, the outside green, and they seem sometimes to be built up around plates of biotite, but more often the color shades off indefinitely at the edges, and is peculiar to the hornblende. The hornblende has weak pleochroism $\mathfrak{c}>\mathfrak{b}>a ; \mathfrak{c}=$ green, $\mathfrak{b}=$ olive, $\mathfrak{a}=$ yellow.

The large white porphyritic spots, $2-3^{\mathrm{mm}}$ across, are so loaded with opaque white dust, muscovite scales, etc., that it is generally only possible to make out a mosaic of untwinned feldspar and quartz grains, and, in the absence of cleavage and twinning, to make sure that the mineral is in part biaxial. In one large grain, cut parallel to $M(010)$, an optical axis emerged at the lower left-hand border, indicating anorthite, and where twinning occurred the extinction angle was very large, giving the same indication.

(d) Rim of a similar "anvil" from Plainfield. (In the collection of Amherst College. See Pl. V, fig. 1, p. 302, for sectioni.) In the matted, green, fibrous hornblende, greatly darkened by rust and coal dust, are many scales of a greenish mica, garnets with the same radial inclusions as in the West Chesterfield schist (p. 182), curions long red prisms of rutile, matted fine white needles with longitudinal extinction, apparently zoisite, and a fine plagioclase, extinction $26^{\circ}$, loaded with coal dust, but with clear border. In other cases sections cut at right angles to both cleavages gave an extinction of $38^{\circ}$ to $45^{\circ}$, indicating a very basic feldspar

It is significant, as connecting these beds with the porphyritic amphibolites, that rounded clear spots of impure plagioclase appear, from which all the dark constituents are excluded.

The slides of black hornblende-schist or amphibolite last described, cut from the thin plates of the rock which borders the limestone beds, and which have manifestly been derived from the limestone, furnish abundant proof that some amphibolite beds may originate from limestone.

The thin beds of amphibolite of exactly similar habit with the above and found in the Conway schists have clearly the same origin, the change having reached the center of the former limestone from each side. These beds have commonly a thickness of 6 inches to 1 foot.

(e) The amphibolite at the brook crossing in Whately. (See Pl. V, fig. 3, 


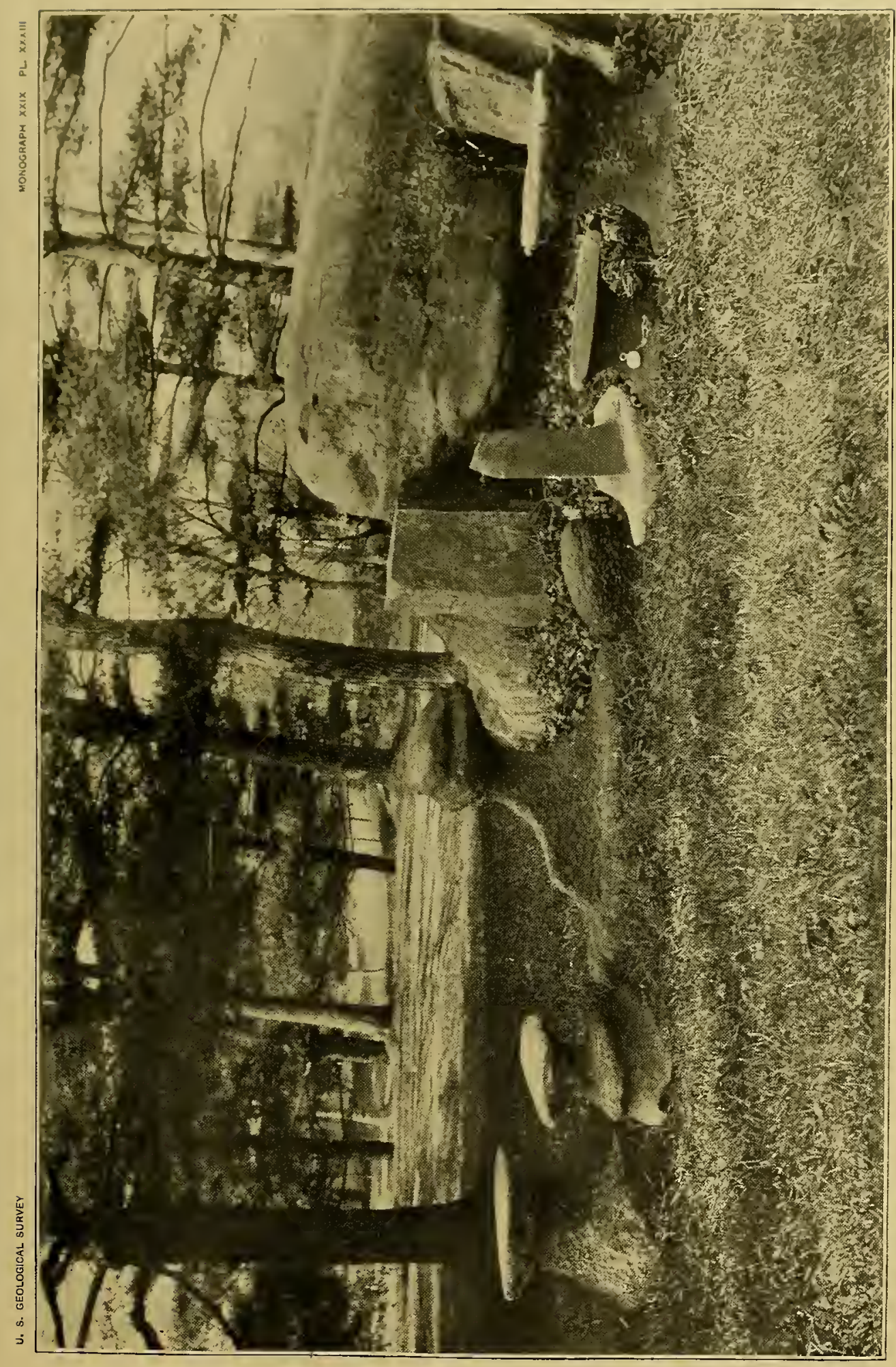

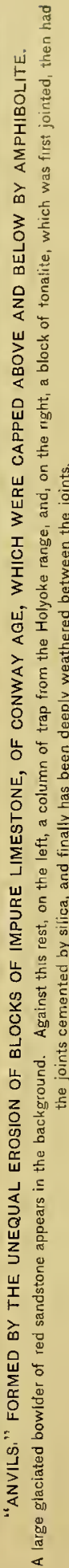



p. 302, for section.) The amphibolite at the brook crossing is thrust forcibly up through the argillite, together with the black Conway limestone, as described on page 196. It shows in many ways a transition between the narrow bands of homblendic rock which form selvages to the limestone beds, as described above, and the larger bed which is the subject of the next chapter.

It is a dull, dark-green, massive rock, which shows with a lens the usual interlacing network of actinolite blades, with rare open white spots composed of a granular feldspar, nuch changed to mica The feldspar is optically positive and has extinction $+6 \frac{1}{2}^{\circ}$ on $M(010)$, and so is an oligoclase.

The hornblende is peculiar in two ways. It has a brown center and grades through green to colorless at the ends of the blades The brown is like the cummingtonite found in the Conway schists farther west. It has low absorption colors. The brown shows $c=$ greenish brown, $\mathrm{b}=$ redbrown, $a=$ pale brown; the green, $c=$ blue-green, $b=$ pale green, $a=$ pale yellow: $\mathfrak{r}>\mathfrak{b}=\mathfrak{a}$. The blades are fibrous and often twinned, and give extinction $14^{\circ}$ to $17^{\circ}$.

The second peculiarity of the hornblende blades is that the brown centers often show dark-brown bands situated in the basal parting and sending out long, straight needles in both directions parallel to the vertical axis, which makes them look like combs with teeth directed both ways. These straight needles are also abundant everywhere in the hornblende and in the feldspars and seem to be rutile. A "hof" surrounds the larger comblike accumulations and dims their outline

Other hornblendes are built up around red biotites filled with coaly matter. A few grains of calcite occur, and the black ore grains show no trace of lencoxene.

This agrees so nearly with the calcite-derived amphibolite described above that one must assign to it the same origin. Its close association with the limestone strengthens this conclusion. It is, however, not certain that this bed is part of the large bed next described, though highly probable.

$(f)$ The great Whately amphibolite. This bed, which extends as a broad band across Whately and Williamsburg, is for the most part a very finegrained, black, fissile rock, and in sections cut from the north end of the bed the hornblende is present in a network of long blades with strong MON $\operatorname{xxTx}-13$ 
absorption and pleochroism; extinction, $16^{\circ} 30^{\prime}$. These lie in a mosaic of untwinned feldspar grains. Menaccanite and leucoxene are abundant, and in slides from the south end of the bed in Williamsburg (south of P. M. Gillett's) each grain of menaccanite is surrounded by a single crystal of leucoxene, and these often have the regular wedge-shape of titante.

East of C. Bardwell's the rock abounds with white spots which prove to be a quartz-feldspar mosaic, greatly crowded with many impurities, but with clear borders. The hornblende is in sheafs and bundles of fine fibers, which partly coalesce into stout crystals, so that the transverse parting runs across the bundle and the center polarizes as a single individual. The central portion of these large crystals is full of coaly particles. Pleochroism and absorption are weak. Biotite and rarely a congeries of grains of leucoxene occur. This occurrence agrees clearly with the hornblendeschist derived from the calcite beds described above, and I assign this origin to all the hornblendic beds in the Conway schist, particularly as limestone is abundant and all other traces of basic eruptives are wanting.

All these rocks share with the accompanying micaceous schist the peculiarity that the centers of the larger phenocrysts are full of coaly matter or fine quartz grains, indicating that both have together passed through two stages in the metamorphic process.

This peculiarity is wanting in the similar amphibolites of the Bernardston series (see p. 291), with which I would compare these rocks. The latter series, though of later age geologically, is more metamorphosed and differs in the more abundant development of the clear mosaic of untwinned plagioclase, but in no other way. They have the same field relations, the amphibolite being always interbedded in the schists. They have the same abundant actinolitic hornblende, biotite, ilmenite with leucoxene, rutile with dark border, and basic plagioclase, and range from massive to slaty varieties.

At Mrs. M. Taylor's, in Whately, the rock is fine-grained and thin-fissile. Its long, thin hornblende needles have low absorption and pleochroism, and lie in a feldspar mosaic. A great number of titanite grains inclose one or more grains of black ore. For section, see Pl. VI, fig. 1, p. 306.

(g) The Whitmores Ferry amphibolite. At Whitmores Ferry, in North Sunderland, in the midst of the Triassic shales, arises an outcrop of a dark 
amphibolite, easily mistaken for the bituminous shale, and exactly resembling the above amphibolite, especially in having the highly refringent grains, each inclosing one or more rounded grains of a dark ore, which is here slightly brownish. The agreement, macroscopic and microscopic, is so perfect, and the rock is chemically so nearly identical with the Guilford band of amphibolite in the Conway schist farther north, as shown by the analyses below, that one can not doubt that the Whately amphibolite is continued in the line of its strike northeast beneath the sandstone to the Whitmores Ferry outcrop. ${ }^{1}$ The association with whetstone-schist in both places strengthens the probability of their identity.

The agreement of the three analyses given below is sufficiently close to strengthen the opinion maintained above that all these hornblendic rocks have been derived from limestone beds.

(h) The Guilford band. (For section, see Pl. VI, fig. 2, p. 306). An inspection of the map (Pl. XXXIV) will show this extensive bed, beginning in Conway and running continuously across the northern half of the State and widening suddenly as it crosses into Vermont. Its stratigraphical relations do not preclude the supposition that it may be a great dike. Lithologically it is like many beds of the Chester and Hawley series. Its cleavage surfaces show many black hornblende needles of high luster in a mat of finer needles. Its hornblende crystals are not filled with grains of coal or earlier constituents, as are the other Conway beds, and also the Bernardston beds. The most marked peculiarity of this band is the presence in the slide of many deep red-brown rutiles clustering around black ore grains. The feldspar seems to be albite, with which the content of soda agrees.

ANALYSES OF THE AMPHIBOLITES.

I. Guilford, Vermont. Shining-black, thin-bedded amphibolite.

II. Whitmores Ferry, Sunderland. Outcrop in the midst of the Trias. Very fine-grained, dull-black, shaly amplibolite.

III. Goshen. Base of largest "anvil," from which slides described above (p. 191) were taken. A quartz-hornblende rock, formed by the alteration of the limestone by reaction of solutions derived from the inclosing schists. For general discussion of analyses see page 300 . 
Analyses of the amphibolites, by L. G. Eakins.

\begin{tabular}{|c|c|c|c|}
\hline & I. & II. & III. \\
\hline $\mathrm{SiO}_{2}$ & 49.16 & 49.86 & 55.64 \\
\hline $\mathrm{TiO}_{2} . . . .$. & 1.03 & 1.58 & .50 \\
\hline $\mathrm{Al}_{2} \mathrm{O}, \ldots .$. & 16.43 & 15.50 & 16.27 \\
\hline $\mathrm{Cr}_{2} \mathrm{O}, \ldots$ & trace & & \\
\hline $\mathrm{Fe}_{2} \mathrm{O}_{3} \ldots \ldots$ & 3.92 & 2.99 & 1.22 \\
\hline $\mathrm{FeO} \ldots \ldots$. & 7. 19 & $\begin{array}{r}8.01 \\
07\end{array}$ & $\begin{array}{r}7.20 \\
98\end{array}$ \\
\hline …........ & .23 & $\begin{array}{r}.07 \\
\operatorname{trace}\end{array}$ & .28 \\
\hline $\mathrm{BaO}-\ldots \ldots \ldots+\ldots$ & .02 & $\begin{array}{r}\text { trace } \\
8.89\end{array}$ & 9.23 \\
\hline $\mathrm{CaO}$ & 8.19 & 7. 79 & 5.58 \\
\hline $\begin{array}{l}\mathrm{MgO} \\
\mathrm{K}_{2} \mathrm{O}\end{array}$ & .41 & .72 & .19 \\
\hline $\mathrm{Na}_{2} \mathrm{O} \ldots \ldots \ldots \ldots$ & 3.70 & 3.26 & .91 \\
\hline $\mathrm{H}_{2} \mathrm{O}$ & .45 & 1.51 & 3.11 \\
\hline \multirow[t]{2}{*}{$\mathrm{P}_{2} \mathrm{O}_{5} \ldots \ldots \ldots \ldots \ldots \ldots \ldots$} & .16 & .11 & .23 \\
\hline & 100. 10 & 100.29 & 100.36 \\
\hline
\end{tabular}

PROJECTION OF THE LIMESTONE AND AMPHIBOLITE OF THE CONWAY SCHIST THROUGH THE LEYDEN ARGILLITE IN WHATELY.

Following the road west from the hotel in Whately, one comes in a few steps upon a bridge over a small brook, and to the north across the brook a fresh surface has been exposed in the bluff by blasting. An inspection of the wall reveals small spots of pyrite as the. probable cause of the blasting, and, what is of greater interest, one soon finds that a small boss of the black limestone and the amphibolite of the Conway series, both of which are in place a considerable distance to the west, has been here thrust up through the argillite with great force. The argillite dips away from the limestone on both sides and mantles round its end, as shown in fig. 11.

A few rods up the brook, on the other side of the road, several similar bucklings of the limestone and hornblende rock up through the argillite may be seen. This shows, of course, that the Conway mica-schists are carried far beneath the argillite and thus are older than it. The amphibolite and the limestone are identical with those farther west in the Conway schist and are described above. As an indication of the force with which the limestone was thrust up through the newer rock, there follows a 
description of a vein of hard, vitreous quartz 7 inches in width, which runs across the face of the limestone; it is represented in fig. 12, p. 198.

The large vein is twisted and the limestone is kneaded into the compact quartz and drawn out into long filaments carried down into the center of the vein and pinched off in it, and the smaller veins are contorted still more remarkably. The limestone has received a marked fluidal structure in the apophyses, which penetrate the quartz throughout its whole mass in curving bands, which fit themselves with more or less success to the complex surface of the vein. Under the microscope the limestone shows all stages in the development of a cleavage by slipping caused by the pressure (Ausweichungsclivage of Heim. ${ }^{1}$ ). Portions of a thin section cut at right angles to the cleavage plane break up into a series of very long, thin wedges, placed with their cutting edges pointing alternately in opposite directions. Each wedge shows a fluidal structure, expressed by the bending of the lines of coal

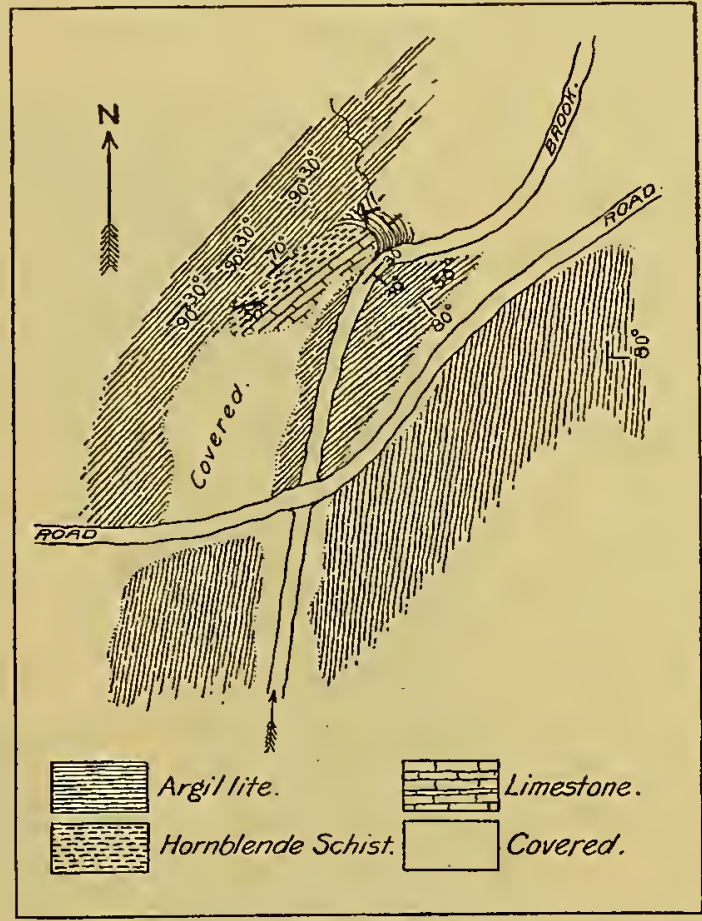

Frg. 11.- Map showing the protrusion of the limestone of the Conway schist through the Leyden argillite. Whately. particles toward its head. This slipping of the wedges alternately to right and left concentrates the coaly particles somewhat along the boundaries of the wedges, by which they themselves become more distinctly defined, and at last confluent into a new plane, marked at once by a cleavage and a color banding.

CONTACT METAMORPHISM OF THE LIMESTONE BY GRANITITE. ARGENTINE.

A very interesting exposure occur's on the river road from Leeds to Haydenville, near the junction of the biotite-granite (granitite) and the muscovite-granite. The former is very confusedly melted into the 
remnants of mica-schist which occur as inclusions in the great granite mass, and at one point appears a grayish-white, massive, fine-grained rock which proves under the microscope to be a labradorite-pyroxene-calcite rock. Treated with acid, it leaves a glassy, friable mass, in which scales of graphite and needles of bright-green actinolite are visible.

Under the microscope it shows an abundance of calcite, multiple twinned; labradorite, extinction $14^{\circ}$, often doubly twinned; and large color-

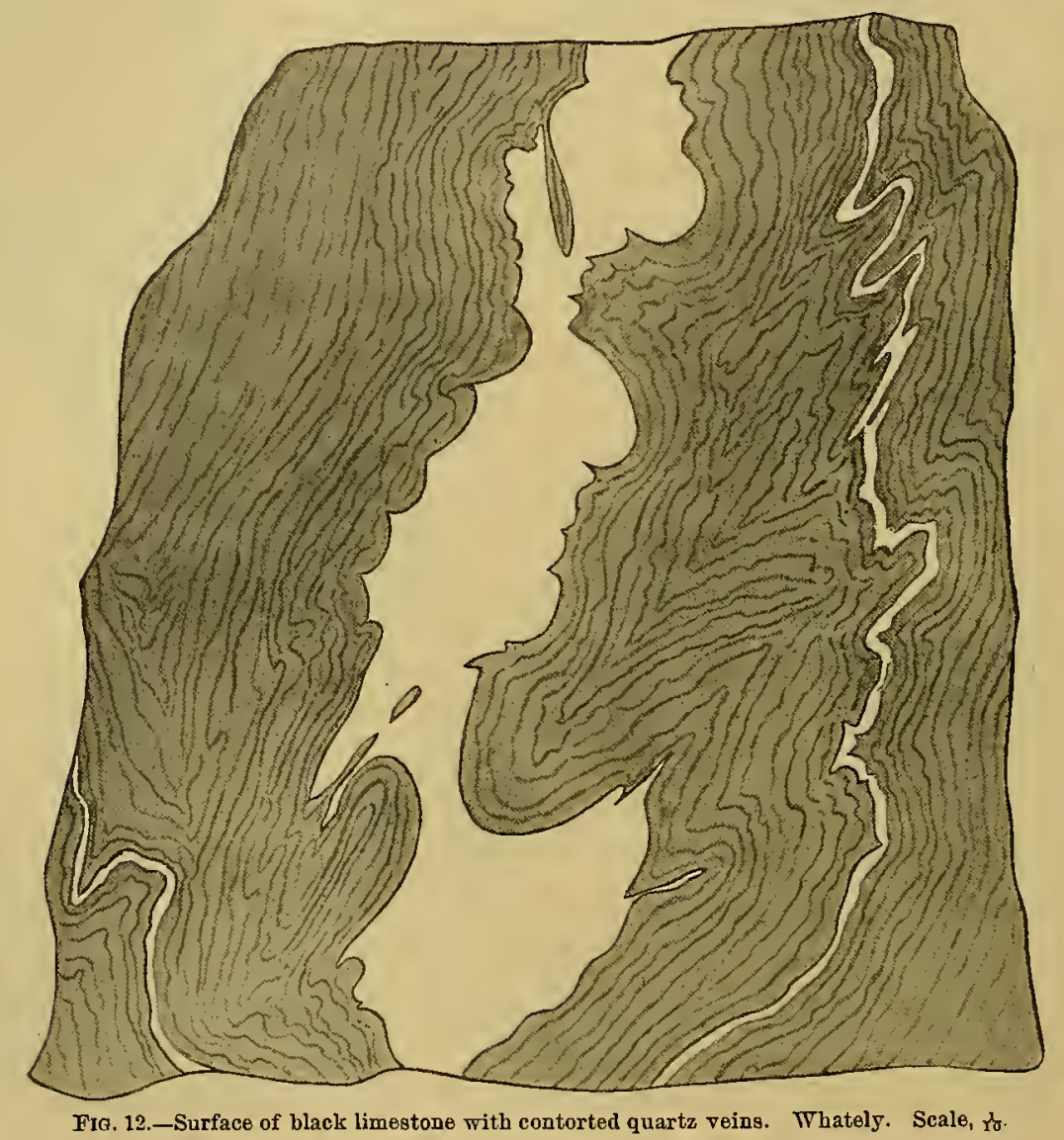

less pieces of pyroxene, extinction $41^{\circ}$, inclosing many grains of the other constituents. Rounded grains of titanite occur. This may be referred to the graphitic limestone of the Conway mica-schist altered by the granite, and this, in connection with the long distance across the granite area that one can follow the hornblende-schist (see p 190), leads one to conclude that the mica-schist fragments in the granitic area in Williamsburg are also remnants of the Conway schist, and that the "argentine" occurrence in the midst of 
the granite still farther south, on the Westhampton line, is another remnant of the same limestone from the Conway schist which formerly mantled over the granite. The inclusion is still partly micaceous limestone.

\section{CLEAVAGE IN THE CONWAY SCHISTS.}

In the flags, or Goshen schists, the original lamination seems to be generally preserved. In the Conway schists a distinction can be made between the eastern half of the schists in the granitic area, where the impregnation of granite and quartz and the great contortion leave one at times in doubt as to the origin of the foliated structure, and the western or lower portion, where the fine crenulation or corrugation produces a ligniform structure in which strike remains distinct but dip becomes quite uncertain.

Without searching far one can generally find a banding of coarser and finer material-a bed of limestone or whetstone-schist-and then generally will find the foliation to agree with the original lamination. This is beautifully seen at the dam in Huntington village. Standing at a distance, the laminæ, from 2 to 14 inches in width (average 6 inches), are each bounded by a black band at the bottom, 2 to 3 inches wide, which shades off above into the lighter portion, the whole making exactly the impression of a laminated sandstone, the lower part of each being fine-grained and clayey, the upper part coarse and sandy. On inspection the lower portion is found to be dark from the abundance of garnet, biotite, staurolite, and cyanite, while the light portion is sandy and contains only scattered garnets.

What seemed at a distance to be true was doubtless once true, and the lower portion of each layer, being argillaceous, has given rise to the aluminous minerals wanting in the sandy portion of the layer. A part of the dark color also depends upon the fact that the new-formed minerals have often inclosed much coaly matter that might otherwise have been carried off.

At other places precisely the same structure enables one to detect a well-developed cleavage. This is the case along the western of the two roads going south from Chesterfield Center, and on the east-west road a mile south of the village.

This is finely illustrated also along the east side of the road going south from Stevens's mills, in Worthington, in a field abounding in most beautiful roches montonnées. The rock is a dark, corrugated mica-schist. The

\footnotetext{
'See "Argentine" in Mineralogical Lexicon: Bull. U. S. Geol. Survey No. 126, 1895, p. 43.
} 
lamination is marked by alternations in color, in bands 1 to 6 inches thick, exactly as described above. A dike of tourmaline-granite coincides in position with this structure; strike N., dip $70^{\circ}-80^{\circ} \mathrm{E}$.

The cleavage is indicated by a bedding which comes out by weathering, and along which alone the rock splits easily, and membranes of mica are developed. This strikes N. $40^{\circ}$ E. and dips $25^{\circ}-30 \mathrm{~W}$. There is in this last structure a cleavage clianging into a foliation.

In general cleavage is subordinate in these schists, and usually where it occurs the strike of the primary and secondary structures very nearly coincide.

\section{FOSSILS (?) OF THE CONWAY SCHISTS.}

In many places cavities coated with rust are found in the quartzose and slightly calciferous beds in the schists, which I have no doubt represent fossils, but which, in every case that has come to my knowledge, are so poorly preserved that it is possible to explain them as due to the removal by solution of some mineral, possibly calcite. The mode of occurrence suggests, however, that a large number of small, flat bivalve shells, $5-25^{\mathrm{mm}}$ long, were deposited, all lying flatwise and about equidistant in the sands which have now become the whetstone-schists. In a bowlder found on the railroad in Worthington these cavities were flattened, nearly round, $5-7^{\mathrm{mm}}$ long.

West of E. B. Drake's, in the northwest part of Chesterfield, the cavities are about $15-25^{\mathrm{mm}}$ long, flattened oval, and in many cases two such impressions lie side by side joined by a straight line, strongly suggesting the opened valves of a leperditia like $L$. baltica. They are flat, rust-covered cavities, and in one fresher part of the rock are represented by darker spots, all arranged parallel to the bedding plane of the rock, and having the same shape as the cavities. These dark-gray spots seem to be only spots in the sandstone. They effervesce much more abundantly than the rest of the rock, and seem to be flattened concretionary patches of a calcite darkened by carbon.

At the Clarke tourmaline ledge an exactly similar occurrence is found, only the cavities are a little larger.

At B. Shaw's whetstone quarry, in Cummington, is a bed of the whetstone about $15^{\mathrm{mm}}$ thick, full of closely approximated tubular cavities $2-3^{\mathrm{mm}}$ 
in diameter and parallel, which suggest scolithus, but which are parallel to the bedling.

All these specimens were submitted to Mr. C. D. Walcott and other paleontologists, but they conld not decide that any of them were certainly of organic origin.

\section{THE LEIDEN ARGILLITE.}

DESCRIP'IION.

The rock is in its whole extent of uniform texture and structure-a dark-gray and very fine-grained slate with glistening cleavage surfaces, dull-black when broken across the ends, and generally crumpled and corrugated to the extreme of complexity. It is remarkably barren of all accessory minerals, and this has been taken as a characteristic to distinguish it from the Conway schists, though in places small garnets and biotite scales are scattered sparingly over its cleavage surfaces. Slaty cleavage is developed in it in every degree. Thin sandy layers often show the original bedding after the rock has been crumpled up into sharp folds and the cleavage perfectly developed ontside these layers, and the rock can still be separated along these into thick plates fluted and folded in the sharpest curves, and at the ends of the plates the slaty cleavage is seen to cut across the slab and to divide it into thin, flat laminæ regardless of its convolutions. Moreover, the importance of the shearing force in the developinent of cleavage can often be beautifully seen, the fine, close-set and equidistant corrugations becoming sharper and changing from folds into faults, and the elements between these faults being flattened out, with some degree of flow of the material, into the cleavage plates.

A remarkable block found (not in place) at the outcrop nearest and to the west of the lower quartzite of the Williams farm in Bernardston may find mention here. A mass of chlorite-slate 3 inches wide cuts across the argillite exactly like a dike. It is bounded by parallel planes and is sharply demarcated from the aryillite, and while both are cleaved perfectly at right angles to the plane of the dike, the plane of cleavage in the green schist makes a small angle with that of the argillite. One can not well avoid surmising that a small diabase dike has been here very curiously metamorphosed, but the microscope shows only matted chlorite and muscovite scales, quartz, and geniculate rutiles, the latter visible also with the lens. 
The argillite is characterized by a great abundance of quartz nodules and bosses, often of great size, which, though not wanting in the Bernardston series, are there comparatively unimportant.

On the road from Greenfield to Charlemont, above Fall River bridge, the argillite is a fine-cleaved roofing slate for a long distance by the roadside, almost as fine a slate as that at the Guilford quaries in the town next north in Vermont.

\section{QUARTZITE IN THE ARGILLITE.}

On the road north from Bernardston, at C. Cushmore's, is a heavy layer of a dark, thick-bedded quartzite about 33 feet thick, and a little farther north, at I. K. Brown's, is a crumpled, thin-bedded quartzite.

Just over the State line to the north, near the Guilford slate quarries, the argillite is replaced by a fine-grained quartzite, which President Hitchcock called a novaculite-schist and found to be a quarter of a mile thick. ${ }^{1}$

\section{PETROGRAPHICAL DESCRIPTION.}

The mass of rock is made up of minute, elongate, brightly polarizing muscovite microlites, often raveled out at the ends and with wavy sides, in an amorphous background. Clay-slate needles are only doubtfully present. Stout elongate forms, opaque by transmitted and curdled white by reflected light, seem to be leucoxene derived from menaccanite. Magnetite and calcite are wanting. There is much coaly matter in swarms of black dots, and rarely a biotite scale placed in the plane of cleavage. Often a strongly marked pseudo-fluidal structure, expressed by the position of the elongate muscovite crystals, indicates clearly the mode in which pressure has produced this cleavage.

Microscopically the rock is thus a very fine-grained, argillitic micaschist or phyllite, and it differs much from the true argillites, e. g., the cleaved slates of Snowden, Wales, or the slates of Hoosick Falls, New York, with which I have compared it. I have followed custom in applying the name argillite to the band of rock, somewhat in a geological sense.

The rock sometimes contains small garnets in considerable number, and these are often changed wholly or partly into small white balls of kaolin, or kaolin and hematite. The kaolin was infusible and gave blue color with 
cobalt, and no reaction for potash. The mass of kaolin does not quite fill the cavities. These occur north of the Devonian limestone in Bernardston.

\section{STRATIGRAPHY.}

The rock is crushed into sharp folds and finely corrugated, and where sandy layers are wanting the primary structure may be replaced wholly by the cleavage; in other places it is brecciated and thrown into confusion. Everywhere the strike and dip vary suddenly and within wide limits. About N. $20^{\circ}$ E. may be the average strike, and $60^{\circ} \mathrm{E}$. the average dip.

A comparison of hand specimens, and especially of sections of the three rocks, shows that the "argillite," while a distinct mica-schist, is far less thoroughly metamorphosed than the schists in the Helderberg series, and from this criterion alone one would consider it the newest rock in the whole area. That it is newer than the mica-schists to the west and older than the Helderberg series seems to me in the highest degree probable, and also that the two older groups are Paleozoic; but I can find no very convincing ground for their assignment to a definite horizon in the Paleozoic.

\section{BOUNDARY ON THE CONWAY SCHISTS.}

At Beaver Meadow, in the northeast corner of Leyden, one finds the point of contact just at the foot of the mill dam. The black, barren argillite has strike north to south, dip $70^{\circ}-80^{\circ}$ E., all the way up from Fall River, a mile east, and often shows true cleavage. Here several thin, rusty beds appear, and quite suddenly the rock becomes slightly coarser and full of very small spangles and transverse crystals of biotite; and three thin beds of black limestone occur in quick succession. The boundary is best drawn at the first bed of limestone, just at the dam, but for 300 feet below the rock is black, fine-grained, finely double-corrugated, and differs mainly in the minute mica spangling from the argillite lower down the brook, and for a little way above this limestone much of the rock can scarcely be distinguished from the argillite. It is, however, a little coarser, rusty on cleavage faces, and spangled on transverse fractures. It is thus a rather gradual transition, and President Hitchcock was often in doubt about the existence of any boundary whatever.

Exactly the same transition occurs between the two beds at all places 
where the boundary can be studied. At the base of the argillite one finds minute spangles of mica; a few feet below comes limestone, and then the rock quickly grows coarser, mica-spangled, and garnetiferous. This is well seen toward the south end of the boundary line, in the southeast corner of Coleraine, near the house of D. Nelson.

In the Whately area the transition is almost exactly the same, but a heavy band of white quartz marks for a long distance the exact boundary, and there is probably a fault there. I have found nothing along this boundary which would suggest the existence of unconformity between the two beds.

ARGILLITE IN THE WESTERN BORDER OF THE "GRAPHITIC MICA-SCHIST"

(GOSHEN SCHIST).

An inspection of the map of the Vermont survey of 1861 shows a broad band of argillite, bordered on the west by Devonian limestone, extending south from Lake Memphremagog, and thinuing south and disappearing midway the State.

Along the west border of the Goshen schists, where they enter Massachusetts, in Heath, is a band of thin, black slate that looks exactly like the metamorphosed Carboniferous slate from Worcester, and which seems to be the continuation of the Memphremagog slate. Farther south it is indistinguishable from the ordinary Goshen schists, except across Worthington, where a band, 50 rods wide at the base of the schists, is a fine-grained, barren, flat-fissile schist, unlike the garnetiferous schist above and the hornblende-schist below. These beds are described in some detail in following down the western border of the Groshen schist (see page 179). I have treated them as the base of the Groshen schists, and think this the most probable view. There is no satisfactory reason for identifying the two argillites. The western seems inconstant, and does not appear in the Goshen anticline.

RELATIVE AGE OF THE CONWAY SCHIST AND THE LEYDEN ARGILLITE.

An examination of the comparative sections on page 258 will show that the first discrepancy of importance there indicated is in regard to the relative positions of these two series, the argillite being regarded as the lower and assigned to the Huronian by Professor Hitchcock. 
The Leyden argillite, as it runs north through Vermont, borders and everywhere rests upon the Conway schist, where they are not vertical. ${ }^{1}$ In the discussion of the argillite in the Vermont survey it is placed, withont hesitation, above the schist; indeed, is still associated with the limestone and assigned to the Devonian. ${ }^{2}$ In the Geology of New Hampshire, Professor Hitcheock has shown that the "calciferous mica-schist" dips beneath the argillite clear across the State.

The much more pronounced metamorphism of the schists, the abundance of great granite veins containing rare minerals, as well as the long series of minerals found in the schists themselves, may be contrasted with the barremness and low degree of metamorphism of the argillite as indicating that the schist is the older rock. The microscopic description of the two rocks may be compared from this point of view.

'The locality at the brook west of Whately village (see page 196) is also a decisive one in reference to the question of the relations of the two rocks under consideration. That the triangular area of argillite occurring here is a continuation of that in the Bernardston area is quite certain, in view of their complete identity, and has not been doubted by anyone; and that the black limestone, with its border of hornblende rock, is the common limestone of the lower formation is equally clear; but the latter is here thrust up throngh the argillite in a knob, like a button through a buttonhole, and the argillite mantles around it and dips away from it on all sides, and this is far out in the middle of the argillite, showing that the latter is underlain by the Conway mica-schist, which dips under it on the west. The relations of the two are indicated upon the sketch map (fig. 11, p. 197). A few rods farther south, and on the opposite side of the road, the limestone again buckles up twice through the argillite.

\section{CONTACT METAMORPHISM OF THE LEYDEN ARGILLITE BORDERING THE TONALITE OH' HATFIELD.}

A band about 1,300 feet wide, bordering the tonalite on the west, commencing in the woods west of the school south of Whately village and extending southwest across Hatfield to its southwest corner, shows on the exact contact a narrow band of green sericite-gneiss, and outside this a 
very broad band of chiastolite-schists, grading through pimpled schists into the ordinary slate.

The argillite is itself, in its normal condition, a highly crystalline rock, approaching the mica-schists and widely removed from the more normal "argillite," like that of Hoosick Falls, New York. Much of it is pimpled on cleavage surfaces and comparable with the knotenglimmerschiefer of the Germans.

THE SERICITE-GNEISS. .

This rock may be best studied above West Brook village, on the south line of Whately. In the pasture just north of F. Bardwell's the contact of the two rocks can be followed for a long distance, and the argillite extends in a long point south into the granite; and farther south, in the line of continuation of this point, are several masses of the argillite wholly surrounded by tonalite. The southern of these rises in a vertical wall just east of a small pond in the pasture, and here the exact contact can be studied. The specimens described below were taken from this place.

The rock at contact is a true sericite-gneiss. The foliation faces have a dull-green, serpentine-like surface, slickensided and with greasy feel. Broken transversely the thick sericite layers fold around small, white feldspar grains; other layers run into white quartzite on one side and into a more micaceous and less feldspathic rock on the other. Both varieties resemble exactly the Taunus sericite rocks and are unlike the sericite or hydromicaschists of the west border of the county, where the mica scales are much more distinct.

Under the microscope the fine-matted felt of a micaceous mineral (sericite) makes a background in which are scattered many wisps of green chlorite; bright, highly refracting, rounded grains exactly resemble zircon, and large, almost wholly decomposed feldspars. The latter are wholly opaque by transmitted light and rusty white by reflected light, and often show regular eight-sided crystalline cross-sections. When very thin and very highly magnified these sections allow the light to pass through in thin, distant, parallel slits, arranged at times at right angles, at times at an angle approaching that of the prismatic cleavage in feldspar. This seems to come from thin bands of the feldspar still undecomposed. The zircon. contains large bubbles. 


\section{PLATE III.}




\section{PLATE III.}

FIG. 1.-Leyden argillite changed to chiastolite-schist in contact on tonalite. Only the black cross of the cbiastolite remains. The crystals have been changed into a mass of muscovite scales inclosing many staurotite crystals. Belmont, Hatfield. $\times 7$. Natural light. (See p. 209.)

Fig. 2.-Sections of $t$ wins of cordierite from cordierite-granite. Brimfield. $\times 20$. Drawn with crossed nicols. (See p. 321.)

Fig 3.-Diorite from north end of Packards Monntain, Prescott. $\times 25$. Natural light. (See p. 342.)

Fig. 4.-Contact of diabase-amygdaloid and clayey limestone, from the upper surface of the Holyoke sheet. The curving of the layers of the fine mud as it flowed into the open steam holes can be scen on the left. The large cavity was clogged by a trap fragment and afterwards filled by infiltrated calcite. Rounded drops of the mud and rouuded holes filled by infiltration can be seen in the trap C. Dibbles, South Holyoke. $\times 28 . \quad$ (See p. 456.) 

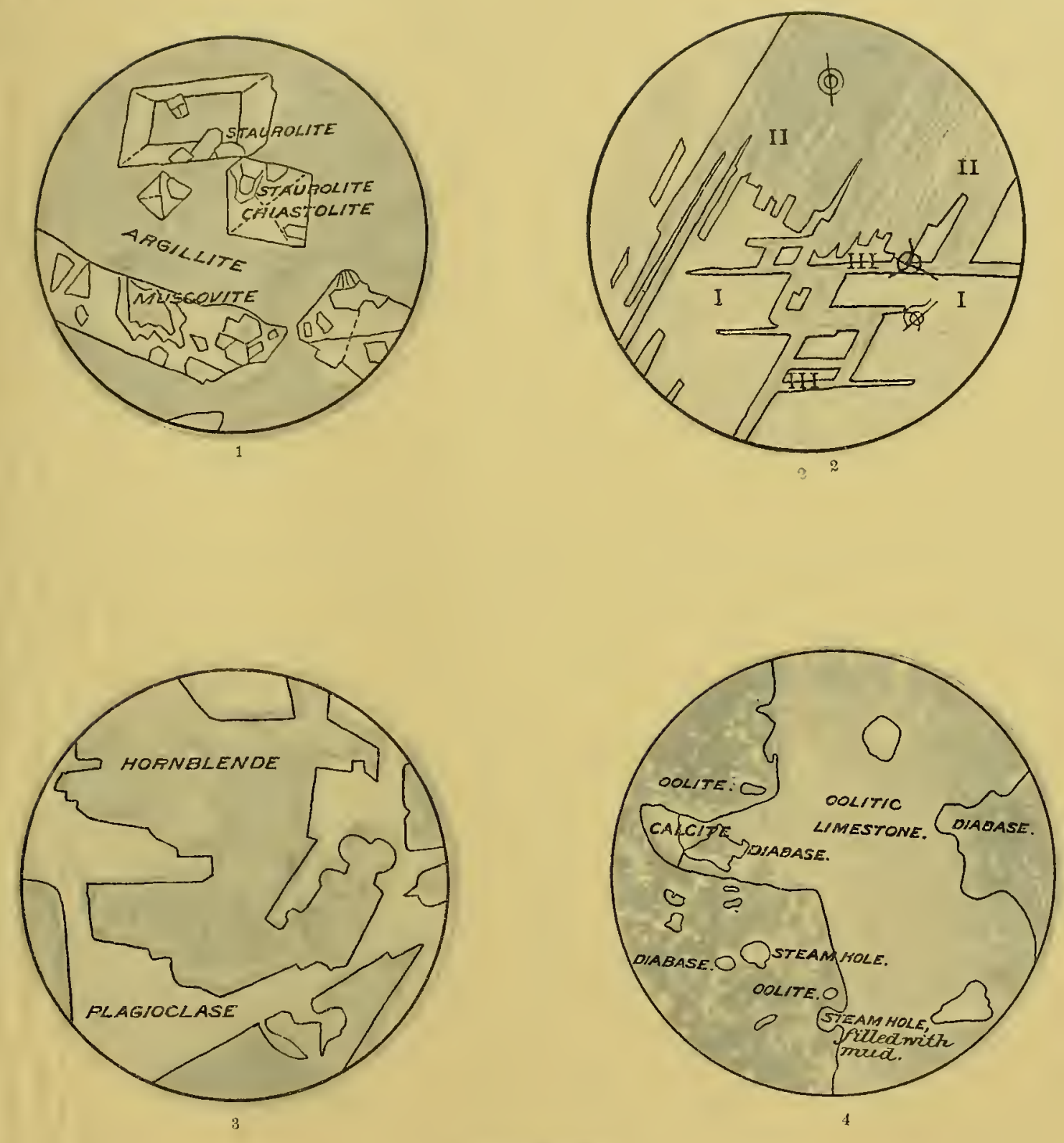

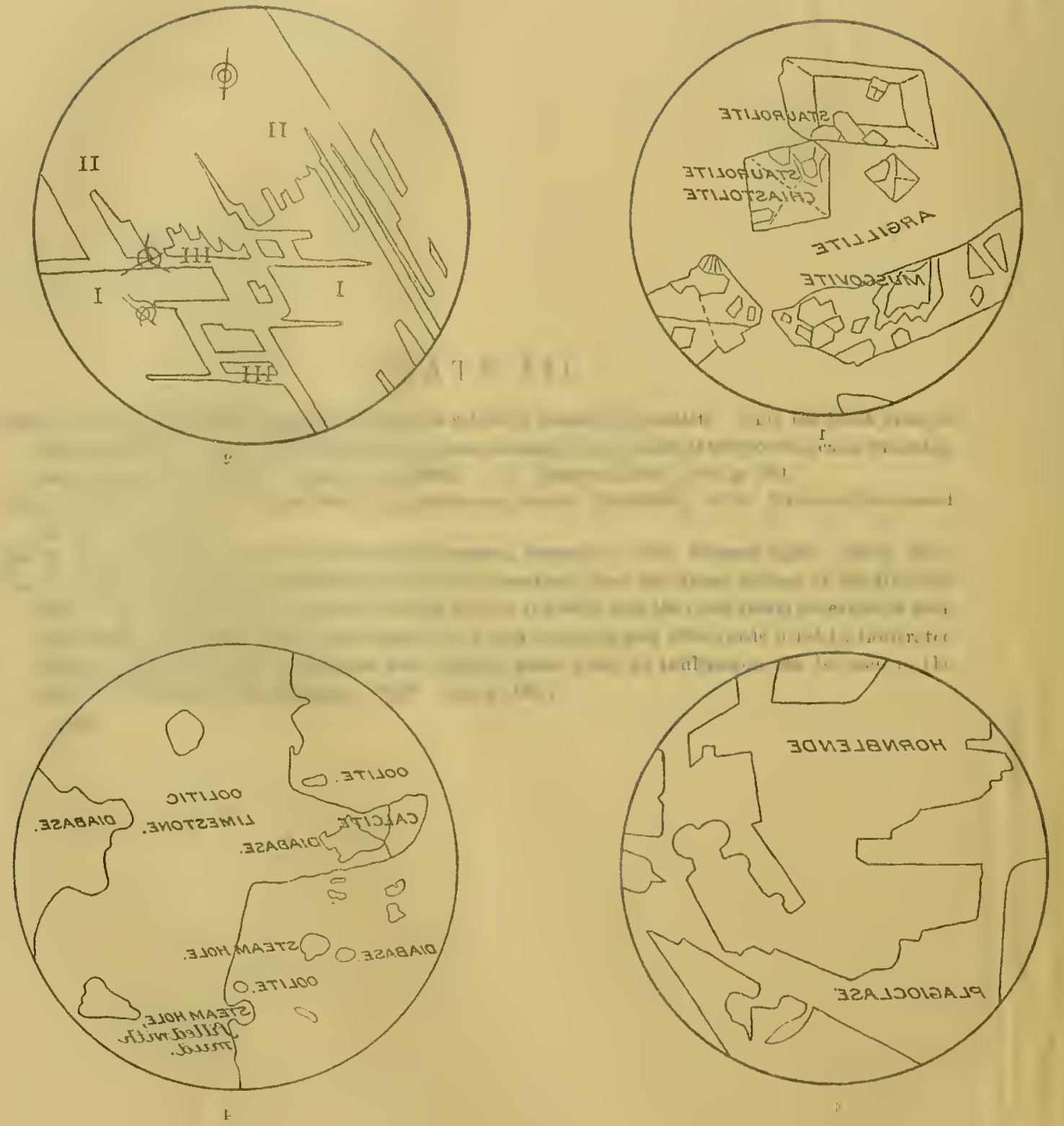

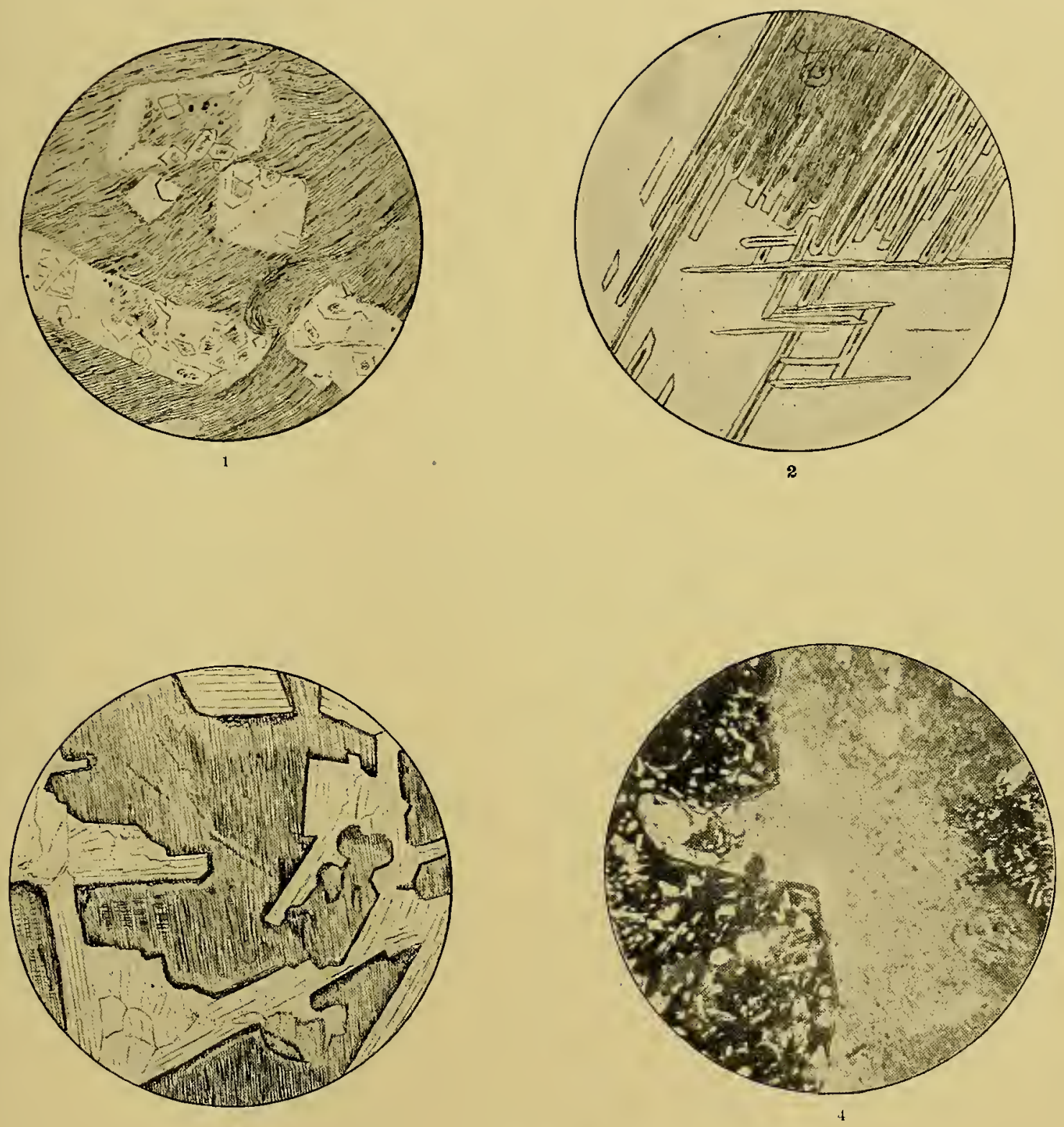

THIN SECTIONS. 

Besides these exomorphic effects of the contact, the tonalite shows distinctly an endomorphic influence of the schist upon itself. It is finer gritined than usual, though it is granular to the eye, and the deep fleshred feldspar stands out on a background green from the abundance of chlorite. It is rudely foliated, and the foliation surfaces are dull-green, like the schist itself, and in transverse sections the microscope reveals thin, wary layers, winding in between thick layers of the feldspathic material, which seem to be made up of the sericitic matter from the schist crowded into tlie fissures.

The main mass of the argillite followed north from the contact retains all the complex contortions common in the rock, but it is soaked full of quartz, or quartz and feldspar, the parallel bands being in some cases separated as much as $30^{\mathrm{mm}}$ by the intrusion of these new constituents. There is also much coarse muscovite, and the rock is in places greatly brecciated. When it is followed farther north small staurolites appear and the next band is reached.

Going a short distance west along the road to the bridge over West Brook, and then south 165 feet along the brook, one finds a fine contact of the argillite and the tonalite exposed. The rock is here more arenaceous, and is indurated to a hornfels.

THE CHIASTOLITE-SCHIST.

This rock (see fig. 1, Pl. III.) may be studied most conveniently on the southeast slope of Belmont-a great symmetrical drumlin, bare of trees, in the northwest cormer of Hatfield. The original bedding of the rock is here clearly marked by bands of sandstone about an inch wide, separated by argillite layers of twice this thickness. The whole is extremely contorted, and the well-marked cleavage oversprings the sandy layers in almost every case. The original clay layers are now a fine, dark-gray mica-schist, to which one would hardly still apply the name argillite, and in some places it is coarsely muscovitic. The schist is full of chiastolite crystals, square prisms about $4^{\mathrm{mm}}$ wide and $40^{\mathrm{mm}}$ long, enfolded in the layers of the schist, as is usulal with this mineral. These are now uniformly changed into a shining-white muscovite in matted scales (with traces of the black cross everywhere remaining), in which small andalusite crystals occur so abundantly as often to occupy half the space. They are in stout prisms nearly MON XXIX- -14 
a millimeter across, often twinned and well terminated, of red-brown color, and with shining faces. They project in every direction into the muscovite, and have been plainly manufactured from the material of the chiastolite by some second metamorphism. The muscovite gave deep blue with cobalt, and a purple flame when fused with gypsum, and fused with difficulty to a white enamel. It gave the axial divergence of muscovite. The staurolite, measured with reflecting goniometer, gave $\infty \mathrm{P} \wedge \infty \mathrm{P}=129^{\circ}$. $\infty \mathrm{P} \wedge$ $\infty \mathrm{P} . \breve{\infty}=115^{\circ} 11^{\prime}$, and twins after $\frac{3}{2} \mathrm{P} \breve{\infty}$, could be determiried optically under the microscope.

The andalusite crystals are orange-yellow under the microscope, but a central portion with boundaries parallel to the surface, even when that surface is plainly one of fracture, is colorless in most cases and has a soft, slightly wavy striation, which a high power shows to be dne to the presence of an immense number of stont tubular bodies, slightly reddish, with rounded ends, often slightly twisted and varying in diameter; at times, indeed, passing into formless bodies. They are so numerous as to give the rock a spongy appearance, and are parallel to one another and to the vertical axis of the staurolite. They are $0.025^{\mathrm{mm}} \mathrm{long}, 0.005^{\mathrm{mm}}$ across. Being placed parallel to the axis of the inclosing mineral, they extinguish with it; but in diagonal position the larger ones show color for themselves, and they are probably quartz. Many sections of the stanrolite are broken up into separate fields from twinning, and the rods have a separate direction in each of these fields. ${ }^{1}$

The rock contains, also, groups of small garnets. It is a biotitemuscovite-schist. In a quartz-muscovite background many long-notched blades of a dark-brown biotite and much coaly matter are arranged in a pseudo-fluidal structure and wrap around the chiastolite crystals.

'Lassaulx, Ueber Staurolite: Tschermaks mineral. Mittheil., Vol. III, 1872, p. 173, pl. 3. Compare the uncolored figures where the rods are stouter and more distant than here. 


\section{CH A P T E R VIII.}

\section{THE BANDS OF SILURIAN SCHISTS ON THE EAST SIDE OF THE VALLEY.}

As noted in the geological ontline and the generalized section in Chapter III, the representatives of the Silurian series from the Hoosac schists to the Conway schists are present east of the river in several narrow synclinal bands resting in the Monson gneiss, which are most conveniently described in geographical rather than geological order. The series is greatly simplified and is divisible into only four or five members-a muscovitic or serieitic and biotitic quartzite below; next a band of hornblendeschist (amphibolite); above this a thin-bedded biotitic quartz-schist, which I have called the whetstone-schist, as it is much quarried for scythestones; then a garnetiferous and graphitic schist. These are, respectively, referred to the Rowe schist, the Chester amphibolite, the Savoy schist, and the Conway schist of the western side of the valley. Along the eastern border of the region the series is still more simplified by the disappearance of the hornblende-schist, and the lower bed, which includes the Rowe and Savoy schists, is developed across Worcester County as a monotonous, thinbedded micaceous quartzite which I have named the Paxton whetstone-schist, while the upper bed, the Conway schist, grows more metamorphosed eastwardly and southerly and becomes rusty, strongly fibrolitic, coarsely graphitic, and in places feldspathic. This I have named the Brimfield schist in Worcester County.

I lave, then, to describe the following areas (see geological map, BI. XXXIV):

1. The Northfield semisyncline.

2. The Wendell branch syncline.

3. The Leverett-Amherst area. 
4. The Pelham-Shutesbury syncline.

5. The great central syncline.

6. The eastem syucline.

7. The zone of contact and disturbance around the Belchertown toualite.

8. The Wilbraham syucline.

9. The Monson syncline.

10. The East Greenwich-Enfield syncline.

\section{THE NORTHFIELD SEMISYNCLINE.}

For a loug time it seemed to me probable that the rocks at the mouth of Millers River (see p. 295) and those here under discussion were a coutinuation of the Beruardston series, and thus of known age; and because of the importance of the question I have studied these areas with great care and describe them in somewhat greater detail than usual, and compare them with the Bernardston series, in order that the grounds for accepting or rejecting the correlation suggested above may be clearly seen. The fold here described lies along the east liue of Northfield, in the Warwick quadrangle.

The comparison of this series with the Silurian beds west of the river forms the first step in the correlation of the beds east and west of the river. The gneiss $a$ in the sections below (p. 213) is identical with the Becket gueiss. The beds $b$ and $c$ are close lithological representatives of the Rowe schist. The bed $d$ agrees well with the Chester amphibolite. The whetstone-schist $e$ is closely like the Savoy quartzose schist, while the bed $f$ is the exact counterpart of the Conway schist in all its peculiarities, even to the presence of spodumene and cleavelandite dikes.

\section{GENERAL DESCRIPTION.}

The rocks were first compressed into a great syncline in the Monson gneiss, the axis of the syncline pitching to the north, and then a north-south fault occurred along this axis, and the rocks on the east were upheaved by about the thickness of the series $(1,890$ feet), and so far eroded that ouly a remuant of the lowest bed remains on the eastern half. Then several transverse faults cut across the beds, and one is notable from the amount of drag which the beds on the north side of it have suffered at their south 
emls trom frietion anainst the wall of the fiult on the soutly; for an inspeetion of the map will show that to the north of this transverse fault the strike of all the beds bends from a north-sonth direction round to an easterly direction. It is remarkable, also, that to the north of this fault all the beds of the western flank of the syncline, as well as the remnant of the eastern flank, are inverted and now dip uniformly to the west.

The topography of the region is to an exceptional degree dependent upon its geological structure. Each of these transverse faults is now the gorge of a brook.

The upper beds of the series-the Conway mica-schists-are the most resistant to erosion, and form the high hills, which are pushed forward or recede as the block of mica-schist of which each is made is pushed forward or back by the faulting. The amphibolite is more rapidly eroded, and it forms a deep furrow across the town, in which runs what is appropriately caller the Gulf road, the word gulf being used in this sense in several places in western Massachusetts. The basal quartzite is also resistant and mantles over the gneiss of Brush and Crag mountains in sharp, angular ridges, which can be seen and recognized so far off as the station at Millers Falls as peculiar and not like the forms of the gneiss. The Gulf road mentioned above rums south from Northfield to Erving, at the east base of Brush and Crag mountains, and continues a long way on the hornblende-schist of this series, and here the whole may be best studied.

\section{'THE GULF ROAD SECTIONS.}

Two miles south on this road a side road goes up onto the mountain westerly to the house of Mrs. J. Robbins, and a little farther south a similar blind road runs east to the house of R. H. Minot. The whole series is well exposed along this line, and it is described in the following section, beginning at the west enrl:

The granitoid biotite-gneiss (a), which makes the mass of Brush Mountain, forms the base of the section. It is the northern portion of the large Pelham area of the Monson (Cambrian) gneiss. The line of boundary between the basal quartzite (the Rowe schist) and this gneiss runs beneath the Robbins house, making a large curve to the east, and the two rocks are unconformable. This is shown by the fact that the gneiss has strike $\mathrm{N}$. $40^{\circ}-50^{\circ} \mathrm{W}$., dip $25^{\circ}-35^{\circ} \mathrm{E}$, while the quartzite above has strike N. $15^{\circ} \mathrm{W}$., 
dip $10^{\circ}-15^{\circ} \mathrm{E}$; and as one goes east from the boundary down the steep hill and across the quartzite the dip of this latter rock increases gradually to $45^{\circ}$, showing that the quartzite mantles orer the gneiss. The quartzite $(b)$ is here quite micaceous, the mica being, as usual, a shining-white muscovite, or often a sericite. In places coarse patches of biotite scales also occur. Southward along the crest of the hill this bed is in one place distinctly conglomeratic, pebbles of quartz about an inch across and much flattened by the compression of the rocks, making up the mass of the rock in a great vertical cliff looking west. West of C. T. Swan's, where the 1,200-foot contour crosses the road, 200 rods sonth of the Robbins honse, on the mountain crest, it is a very vitreous quartzite, resembling an aggregation of the quartz nodules in common mica-schist. Some beds here also abound in a shiningwhite mica, and others carry a little biotite. The thickness opposite C. T. Swan's house is 575 feet. 'This is followed by a very coarse, wavy, very micaceous, often sericitic, gamet-bearing schist of white color $(c)$. It is 40 feet thick on the Robbins road; in the section opposite C. T. Swan's honse, 65 feet. (b) and (c) are the equivalents of the Rowe schist.

The amphibolite $(d)$, or the Chester amphibolite, is a greenish-black rock of fine grain, separating into thin plates which have a ligniform structure from the perfect "stretching" of the rock. It is usually of even grain and free from all accessories. Nodules of albite and ilmenite occur rarely. It is, on the Robbins section, about 500 feet thick; on the Swan section, 330 feet.

The whetstone-schist (e), or the Savoy schist, is a gray, arenaceous biotite-schist or micaceous quartzite. The biotite is in thin scales, not concentrated upon foliation planes, but scattered sparingly and evenly through the rock. Near the top, at R. H. Minot's house, is a very rusty layer full of coarse garnet and homblende. In the Swan section its thickness is 612 feet.

Then follows a coarse muscovite-schist $(f)$, often very micaceous. It is affected by both a fine corrugation of the foliation surfaces and a general twisting and contortion of the folia themselves. It is graphitic and abounds in garnets and staurolite, the latter especially abundant toward the base. Its thickness in the Swan section is 354 feet, but here the whole thickness is not present because of the fanlt; a little farther south, opposite the schoolhouse, it is 445 feet. This is identical with the Conway schist. 
In the Swan section continued east along the Minot road the finult and the contact of the mica-schist $(f)$, dipping $30^{\circ} \mathrm{E}$., with the basal quartzite dipping $15^{\circ} \mathrm{W}$, am be clearly seen. The latter is here largely a twomica-gneiss of arenaceous structure, with shining-white niuscovite.

In the section opposite School No. 10, where the road branches a little way sonth of Swan's house, a bed of granite 8 feet thick occupies the place of the fault, and to the east of it is a thick-bedded quartzite, which at top becomes a coarse, white, sandy muscovite-schist with wavy folia and carrying garnets. The whole has a thickness of 307 feet, and represents the basal quartzite $(b)$ and a little of the mica-schist $(c)$ above it. It belong. to the eastern flank of the syncline, and is brought up by a fault whose throw must be at least equal to the thickness of the strata $c$ to $e$, or 1,890 feet. The western flank of the syncline dips normally E. $30^{\circ}-35^{\circ}$, while the remnant of the eastern flank is overturned upon the mica-schist and dips easterly against a great dike of pegmatite.

\section{SECTIONS NORTH AND SOUTH OF THE OLD WARWICK ROAD.}

The mica-schist $(f)$ continues north as a high ridge which terminates in the prominent hill south of G. Alexander's, called locally Tom Field's hill, whose crest and western slope are underlain by the corrugated schists, while the fault runs along just east of the highest part of the hill. The schists sink down northwardly to the east-west fault which follows closely the line of the old Warwick road, upon which A. Moore's house stands.

North of this fanlt the main longitudinal fault is continued north with little or no interruption, passing just east of A. Moore's liouse, but the whole series of schists, which forms the western half of the anticline and which has been already described, is overturned so that it dips everywhere $50^{\circ}-70^{\circ}$ to the west. This continues to the next road on the north, the present Northfield-Warwick road, and all the members of the series are unchanged except the bed of rusty garnet-hornblende rock at the Hinot honse, which becomes a persistent and thick bed of hornolende-schist in the upper portion of the whetstone-schist. Another fuult cuts off the southwest portion of this area, and this part is placed in normal relation to the north end of the gneiss area to the southwest, striking east and west, and dipping north away from the gneiss.

The next transverse fanlt to the north follows the Northfield-Warwick 
road already mentioned. To the north of this line the whole series of the schists is moved horizontally to the west for a considerable distance, dragging upon the fault so that the strata bend around from the normal north-south direction to a direction due east at the fault. The series maintains, however, the inverted position and constant westerly strikes of the portion sonth of this fault.

The explanation of this complex system of faults seems to be that the great Pelham gneiss mass on the west ends just where the first of these tranverse faults appears, while to the east of the great north-south fault an equally high gneiss area extends north across the whole town of Warwick. When the east-west compression acted on these beds they were on the south of the first transverse fault, supported by the north end of the Pelham gneiss in Brush Mountain, while on the north, finding firm support only at a lower level, they were thrust westward and overturned.

\section{PEGMATITE DIKES AND MINERALS.}

A curious point of resemblance between the Conway schists of the west side of the county and the same schists in this section-the upper beds $(f)$ of the series-is the appearance of large granite dikes carrying spodumene, cleavelandite, tourmaline, columbite, and beryl. One great dike of this character appears in the yard of M. A. Brown, on the Winchester road and just over the town line in Vermont, and is there filled with poor crystals of spodumene. On the top of Strowbridge Hill, a half mile south, I found the same dike, or its successor on the line of strike, filled with cleavelandite and a little tourmaline; and the same distance again to the south along the line of strike is the fine columbite locality discovered by Mr. M. A. Brown. This may be reached by following the lane back of L. A. Moody's house, east through the woods nearly to the War'wick road. Farther south, on the Minot section, the same coarse granites carry immense beryls, and just where the beds cross the town line to the south the granite abounds in spodumene.

This is one of those curious and inexplicable matters of paragenesis, and it derives its problematical character from the fact that the pegmatites cutting all the other beds are wholly wanting in those minerals containing rare elements, except those penetrating the comparatively recent Conway schist, which at distant localities on both sides of the Conmecticut River carries them abundantly. 
TIIS WWNIEIA IBRANCII STNCLINE.

In the southwest corner of Warwick, at Harris's pond, a subordinate syncline branches off from the great central syncline next to be describerl. It is directed first west, bends round south in Barber's hill, in which it passes throngh a corner of Erving, and crosses the river and extends south into Wendell, where it ends abruptly against a fault.

At the point where it branches, west of Barber's pond, the uppermost bed in the syucline is a dark, graphitic mica-schist (Conway) with abundant transverse biotite and with many staurolites and small garnets. It is thus exactly like the corresponding uppermost beds $(f)$ in the Northfield syncline already described, and so forms an important link in the chain of evidence in favor of the identity of the series I am here describing with the similar series across the Connecticut Valley, with which I have associated it.

There is a fine section of the beds of this series exposed in the railroad

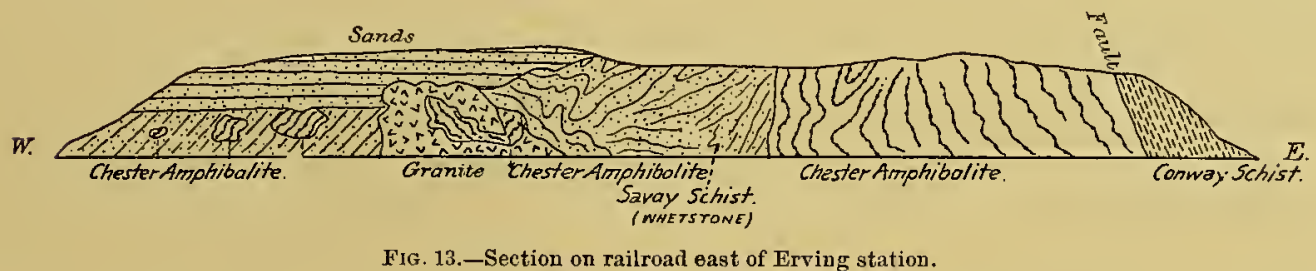

cutting east of Erving and opposite the piano factory (fig. 13), though the beds are thrown into such confusion that no conclusions can be drawn concerning their sequence.

Entering the cutting from the west, several large outcrops of amphibolite appear through the sands, and just beyond is a great boss of granite curiously molded together with amphibolite, which is changed to biotiteschist at its contact with the granite, which carries upon its back a great mass of a gray whetstone-schist extremely contorted. This is followed by a great body of amphibolite, in places much contorted. It contains albite and calcite in veins, and nodules of epidote often $15^{\mathrm{cm}}$ long. To the east this is followed by a coarse, gray mica-schist with garnets $(\infty 0)$ and small staurolites.

All these beds resemble closely the corresponding ones of the Northfield section, which ends just north of this point, and this serves to comnect the two and unite both with the western area. It serves also to illustrate 
the extreme complexity which characterizes these beds in their progress south through Wendell until they are cut off by the fault east of Wendell Center.

This may be well studied by going up the Osgood Brook road and turning onto the high hill north of S. Stevens's honse. Everywhere the beds are thrown into great confusion and filled with granite dikes, so that the representation on the map, though the result of much work, gives only a general view of the main facts. The whole southern portion of the area is underlain by whetstone-schist, which has been quarried here for scythestones, and for this reason the hill is locally called Whetstone Hill.

\section{'THE IEVERETT-AMHERS'T AREA.}

THE AMPHIBOLITE AND MICA-SCHIST SERIES ALONG THE EAST SIDE OF THE CONNECTICUT BASIN FROM LEVERETT SOUTHWARD.

The bottom of the Connecticut Basin, as the area of transition between the closely folded rocks with vertical dips on the west and the undulating, almost horizontal gneisses on the east, is underlain by a broad band of extremely disturbed rocks, faulted, soaked full of granite and quartz veins, and, especially along a line extending quite across the State and situated at the immediate foot of the eastern platean, most thoronghly crushed, brecciated, slickensided, and filled with veins of bematite, albite, quartz, and epidote, or mineral veins of the "baryta-lead formation."

It is just along this line of maximum disturbance that a series of rocks which forms a repetition of those described in Northfield (p. 212) runs south from the mouth of Millers River at the great bend of the Connecticut.

The same succession-feldspathic quartzite, or two-mica-gneiss $(b),{ }^{1}$ amphibolite $(d)$, whetstone-schist $(e)$, and spangled mica-schist $(f)$-can be made out, but with difficulty, and all the members are nuch altered and thrown into great confusion, so that the assignments made upon the map, though the result of long study, are given with much hesitation.

For convenience the amphibolite and the quartzose bands, the quartzite below and the whetstone-schist above, are described together, while the equivalent of the spangled or Conway mica-schist-the Amherst feldspathic mica-schist-is discussed apart.

${ }^{1}$ The italic letters $a-f$ refer to section given on pp. 213-214. 


\section{NORTII LEVERETT (GREENHIELI) QUAIRANGLE, SOUTHEAST CORNER).}

Still firther south, and just south of the railmad crossing over Locks Pond Brook, the series appears in Stoddard Hill and forms a narrow band running south between the grneiss and the red sandstone. It is largely cut by granite, which has replaced it over great areas, and this rock shows often the preculiar structure adverted to in the description of the Millers River section (p. 295). The materials, of a very coarse pegmatite, form a distinctly foliated mass from the parallel arrangement of the large muscovite scales, and agree in dip and strike with the surrounding schists. It seenı also, where it comes in contact with the different beds of the series, to have absorbed large quintities of their material into its mass, being near the amphibolite a fine two-mica-granite of coarse but very even texture, as above the cemetery in Leverett, and finer-grained, more quartzose, and almost free from mica in the neighborhood of the quartzite, as north of the cemetery in North Amherst. Furthermore, the granite seems to have assumed a schistose character where it has intruded itself into the place of the more schistose members of the series, as if by a kind of pseudomorphism it had inherited their structure.

The series in Leverett is divided into two portions by an exceptionally large mass of granite. The northem portion presents a section from east to west as follows: (a) Monson gneiss, (b) basal quartzite, $(c)$ mica-schist, $b$ and $c$ together representing the Rowe schist, $(d)$ Chester amphibolite, (e) granite, here occupying the position of the whetstone (Savoy) schist, $(f)$ spangled or Conway mica-schist-all dipping westward from the gneiss. East of E. G. Reynolds' the quartzite is feldspathic and like the Bernardston upper quartzite. The mica-schist $(c)$ and the amphibolite $(d)$ agree completely with the corresponding beds of the Northfield section. In Stoddard Hill, 325 feet east of the railroad, the latter is a coarse hornblende-schist, in places very biotitic, in places massive.

The mica-schist $(f)$, which I identify with the Conway mica-schist, is the first outcrop we meet, going south, of a rock which, from its expansion across Amberst, I have called the Amherst feldspathic mica-schist. Its appearance here in the same position as the Conway mica-schist of Northfield is one of the reasons for identifying the whole mass with the rock so named across the river. The subject is fully discussed on page 222 . 
The rock here is a coarse, very rusty, garnetiferous and feldspathic mica-schist. It is surrounded by granite, and floats, as it were, in it, and is largely injected with granite veins, which at times so greatly predominate that one must describe the area as occupied by granite containing parallel filaments and thin sheets of schist. The latter do, nevertheless, preserve the dip and strike of the main mass, while the granite has also its constant rude dip and strike in the same sense as if the process had here been carried a step farther, and the granite, being injected into and opening out the laminx of the schists and cooling between them, had retained a lamination from them after they had been wholly or almost wholly absorbed into its mass.

The schists agree so closely with the Conway mica-schist where it comes into the granitic areas on the west of the river, directly opposite, that I have no hesitation in following the stratigraphical indications and associating them together.

\section{LEVERETT CENTER.}

South west of the great mass of granite another long strip of the rocks of the series runs from A. Field's, on the road east of Momnt Toby, southeast through Leverett Center and Sonth Leverett and on into Shutesbury, to end in Mount Boreas at Adams Mills.

Just above Leverett Center the gneiss is notched into it by a series of faults. The amphibolite runs down the eastern border of the strip. It is for the most part a thin-fissile rock, often stretched and ligniform, of darkgreen color, made up of magnetite, feldspar, and lornblende, the latter in elongate needles, and all parallel to one another and to the line of stretching. It is at times, as south of A. Field's, a tremolite-schist. The mineral is in short, stout prisms, without feldspar, quartz, or ore. Rarely the lower micaschist (c) appears between it and the gneiss, but the whole series is in the greatest confusion and is also largely covered by till and sand.

THE SAVOY SCHIST, OR WHETSTONE-SCHIST.

The center, and by far the larger portion of the series, is taken up by an arenaceous rock, slightly micaceous, and at times slightly hornblendic, which is at times crushed to pieces and jointed and cut by many quartz and specular iron veins, the rock itself being thoroughly silicified and rendered compact and hornstone-like. It is often exactly like the corresponding 
stratum in the Northfield Mountain. It abounds often in a green, chloritic: mineral, and along the road east of Mount Toby it is abundantly brecciated and cemented by hematite.

Mlong the east side of Mount Toby the whetstone-sehist appears in the bise of the mountain. Its first outerop is just south of the Mount Toby station, and it can be followed from this point sonth to the first brook, where the contact of the Mount Toby conglomerate upon the whetstone is 40 feet above the railroad ( 436 feet above sea level), and on to the second brook, where the contact is 12 feet above the railroad. This greatly lessens the probable thickness of the conglomerate of Mount Toby.

In the extreme northeastern corner of Amherst there is by the roadside a small ontcrop of thin-fissile, stretched hornblende-schist in the whetstone, exactly resembling that found in the Northfield section. It can be traced northwest past the brook-crossing east of A. Adams's louse, and comnects with the bed at Leverett Center. It is a beantiful rock under the microscope. The perfectly parallel horublende blades have the strong pleochroism and absorption of the Chester amplibolite, large, rounded grains of magnetite are frequent, and the whole is placed in a background of untwinned feldspar grains. An analysis of the rock by Mr. L. G. Eakins is given below:

Analysis of hornblende-schist from Amherst.

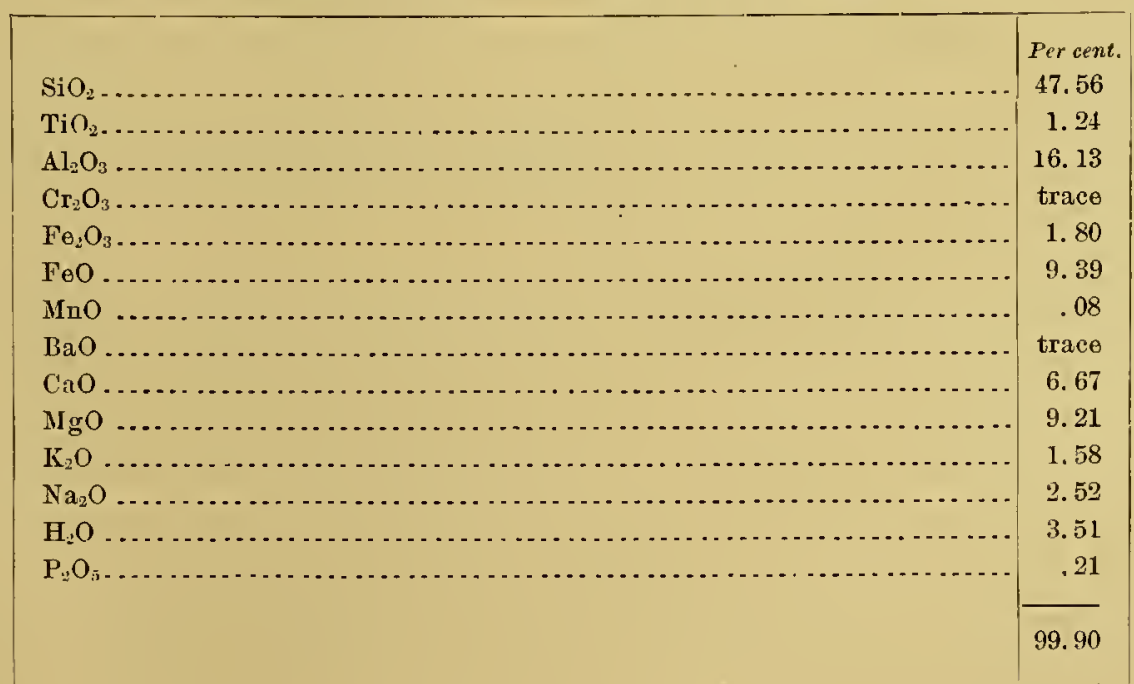


THE AMHERST FELDSPATHIC MICA-SCHIST (CONWAY SCHIST).

LEVERETT.

West of the band of whetstone-schist in South Leverett begins the broad area covered by the Amherst feldspathic mica-schist and granite in inextricable confusion. It is in this northern portion so purely granite, and the shreds of schist are so impregnated with granitic material, that I have marked but a small portion as schist upon the map.

AMHERST,

The Conway mica-schist of the western side of the Connecticut Valley, where it approaches the great masses of granite from Williamsburg to Montgomery, can be seen along both dip and strike to become more coarsely crystalline and feldspathic, while the plumbaginous material disappears or crystallizes into graphite and thus colors the rock less. The garnet and stanrolite also disappear in large measure, and a rock results closely comparable to that which underlies the towns of Amherst and Hadley

Furthermore, the same mica-schist in Horse Mountain, on the western line of Hatfield, dips west and formerly mantled over the hornblendegranite at its eastern foot. It is here not greatly different from much of the Amherst rock, and I assume that it reappears in the nearest outcrops on the east of the river in Mount Warner, where it forms a much-disturbed syncline, and then extends across Amherst, on its eastern border dipping west-that is, away from the hormblendic band which underlies it, and which I have already traced across Pelham.

Starting thus from the exact lithological identity of the Conway micaschist of Northfield on the east and that of Coleraine directly opposite, west of the Connecticut, I have shown that the coarse mica-schists of the northwest of Leverett occupy the same stratigraphical position as the Conway schist in Northfield, and then have traced the Leverett schists southward into continuity with the Amherst schist. The latter is then shown to be identical with the altered representative of the Conway schist on the west of the river just opposite, and the same parallelism can be proved clear across the State. 
It remains to discuss the rock itself and see how far it still shows points of resemblance to the calciferous mica-schists.

The rock appears in Mount Warner, in an area north of South Amherst, beneath the till in the ridge from Amherst village to North Amherst, and in the rocky region along the north line of the town and extending wer into Leverett. It is everywhere greatly cut by granite dikes and thoroughly impreguated with granitic material, especially in the latter area, where it exists only as shreds in an almost continuous expanse of granite. This is clearly the eastern border of the great granite area which lias its center in Williamsburg, on the west of the valley, and extends thence east beneath the Trias and finds its eastern border closely coincident with the Conway mica-schist in which it has its whole development.

Description.-The rock is in composition a gneiss, in texture a coarse schist, so that $\mathrm{D}_{1}$. Hitcheock sometimes gave it one name and sometimes the other. It varies from a coarse muscovite-schist, made up almost wholly of mica in large scales, to a schistose gneiss, at times containing large rounded masses of fine microcline. It is always rusty, and very generally contains pyrite, so that the water from several wells along the western border of Amherst, when low, curdles milk and gives strong reaction for sulphuric acid, and in new openings fissures of the rock are covered with fine sheets of pyrite of very recent origin.

Along the western edge of the ridge, appearing in my well on the Northampton road, and in that of President H. H. Goodell farther north, as also in Mount Warner, is a band the lamination surfaces of which are spangled with large, rounded, equidistant plates of silvery muscovite filled with fine radiated needles of fibrolite, a peculiarity which appears on a much more extensive scale in the more easterly bands of the mica-schist. This fibrolite occurs where the road over Mount Warner rounds a rocky spur at the southwest corner of the mountain, and this is the most western appearance of fibrolite in the schists.

In excavations at the north end of Prospect street, in the hill east of North Amherst railroad station, and in the large outcrop near South Amherst, there are intercalated beds of an eclogite-like rock, a massive quartz-garnethornblende rock containing shining scales of graphite. The garnet is lightred, and is intimately mixed with the quartz to form a groundmass which the hornblende penetrates in stont, parallel rods, transverse to the bedding, 
of such size and arrangement that, on weathering, the rock presents very closely the appearance of a scolithus sandstone, and I tried for a long time to persuade myself that this was the case. I am uow inclined to connect these beds with the beds of tough hornblende rock carrying black garnet which appear in the Conway schists, either alone or as a selvage to the beds of black limestone, as both have the same composition-quartz, garnet, hornblende, and graphite. The hornblende changes often to serpentine.

A very similar rock appears on the eastern border of the tonalite in Hatfield (near the lonse of J. Glasner), and is probably a product of the contact action of the latter upon a limestone bed of the Conway schist. The exposures are not sufficient to make its relations clear.

Correlation of Amherst schist.-As a feldspathic mica-schist the rock resembles the feldspathic varieties of the Conway schist on the west side of the valley, especially in its southern extension, as about Russell. In this assignment $I$ have been infuenced by stratigraphical considerations, by the very general content of graphite, by the common traces of ealcite, by the probable derivation of the eclogite-like rock from bands of arenaceons limestone like those common in the calciferous mica-schist, and by the fact that these Amherst schists closely resemble the calciferous mica-schist immediately opposite, in Williamsburg, where it is most influenced by the granite and develops into a fibrolite-schist like the neighboring bands of the same schists on the east.

Minerals in the Amherst schists.-Apart from the baryta-lead veins, described under mineral veins in Chapter XIV, there have occurred the following minerals in the schists:

(1) Essonite and graphite; west slope of Monnt Warner.

(2) Heulandite in perfect, deep-red crystals, with rosettes of a rewly formed pyrite; head of Prospect street, Amherst, and at the college grove well with pyrophyllite. $\infty \mathrm{P} \infty$ (010), - $2 \mathrm{P} \bar{\infty}(201), 2 \mathrm{P} \bar{\infty}(\overline{2} 01), 0 \mathrm{P}$ (001), $\infty$ P (110).

(3) Pyrophyllite after feldspar, fibrolite, and biotite.

In a well at the northwest corner of the college grove the rock was a biotite-schist, much impregnated with granite, which swells to lenses of the coarsest pegmatite many feet in length. Associated with these granite lenses are layers and large masses, which often run off into veins across the schists, of a granitoid mixture of quartz, little feldspar, and much green biotite 
(arely brown) in large seales which are completely filled with radiating tutts of fibrolite.

The schists contain graphite abumlantly disseminated in small scales, often hexagonal, and some layer's are finely colored masses of purple, almost amethystine garnet, pyrite and apatite in distinet erystals.

The orthoclase of the granite is now in every stage of change into an amor phons mineral; $\mathrm{H}=1$; color, pale momtain-green to deep olive-green, or light to dark wax-yellow. The yellow is translucent on edges, and this increases in water. In the flame the green mineral rapidly becomes white. The yellow variety becomes flesh-colored, like a decomposed feld-spar. Both give a fine blue with cobalt, and fuse at 3 to 4 to white enamel. The fibrolite is also often attacked in the same way, the change proceeding from the centers of radiation of the needles, which are first beaded with browner spots, showing aggregate polarization, and then wholly changed, and at last involving the biotite also, while the garnet is the last to be affected. The quartz clears up under the blowpipe and effervesces with soda.

The quartz, throngh all the adjoining schist and granite, is of the same waxy luster as the amorphous mineral, and has become brittle $(H=4)$, and gives with cobalt a beautiful, filmy, superficial blue, deeper in spots.

The change seems to be initiated by the decomposition of the pyrite, and it seems possible that the curious appearance of the quartz is due to hydrofluoric acid set free from the micas during their decomposition, but it is at times a deeper change into an aluminous silicate.

The topographical surroundings of this interesting locality are such as to render it probable that the Trias conglomerate was barely planed off from its surface during the Glacial period, so that it is a remnant of an ancient and peculiar form of decomposition which took place beneath the couglomerate.

\section{THE PELHAM-SHUTESBURT SYNCLINE.}

Across Pelham the great block of Monson gneiss ( $a$ ) which occupies the whole town is nearly horizontal, with low dip to the east on the east side and to the west on the west side. On the east side of this extremely flat anticline we have, commencing with the central (that is, the lowest) beds at the quarries in the center of Pelham, the true friable subporphyritic MON XXIX-15 
biotite-gneisses (a); then, at and just east of East Pelham, the actinolite quartzite; then a second narrow band of the biotite-gneiss $(a)$; then a broad band of the nuscovite- $(b)$ and hornblende- $(d)$ schist here discussed; and finally, at top, a recurrence of the true biotite-gneiss $(a){ }^{1}$

On the east the series dips with so small an angle and so regularly eastward, and the members can be seen passing under each other so normally, that it is very difficult to avoid the conclusion that they are in regular succession and that all are a part of the Monson gneiss series, and this was at first my opinion. On the other hand, the series bears in several particulars strong resemblance to the mica-schists and amphibolite as developed to the east in New Salem.

As one goes down the long hill east from Pelham Center, after reaching the first road turuing south, one finds many outcrops of a thin-fissile, quartzose two-mica-gneiss, which varies from a thin-fissile quartzite with much coarse muscovite spread upon the rather distant foliation faces to a fissile biotite-gneiss with muscovite distributed as above, or, finally, a shining-white, purely muscovite-gneiss, or-and this last comes to be the prevailing rock going either north or sonth-a very coarse, rather rusty muscovite-biotite-gneiss or schist. This agrees closely with the basal beds $(b)$ of the other section. Slight traces of the hornblendic rock $(d)$ occur down this slope, but northward, across Purgee's brook, a heavy bed of the hormblendic rock $(d)$ appears in the bluff north of D. Shore's house.

The series can be followed from this section south 5 miles to a point west of Enfield Center and north 5 miles across Pelham and Shutesbury into Wendell, maintaining a width of about a mile, which, from the low dip and its position on a hillside sloping with the dip, does not represent a great thickness In all this distance the rock is everywhere cut by great granite dikes or is greatly impregnated with granite, so that many beds seem like purely granitic (pegmatitic) material made schistose by pressure.

Above the amplibolite $(d)$ in the above section and near D. Shore's house a coarse mica-schist full of large garnets represents the Savoy schist $(e)$, and following the river road north from this point any section carried across the hills to the west would give the same succession until, in the extreme northeast corner of Pelham, one finds these upper schists dipping apparently beneath the heavy-bedded Monson gneiss, but separated from it, I suppose,

${ }^{1}$ The italic letters refer to sections given on pp. 213-214. 
by a fiult which the exposures did not permit me to demonstrate. This continnes north into Shntesbury, where the whole series is cut by a transverse fanlt, along which trap has been erupted in several places. North of this point the series seems to be a regular overturned syncline. The bed above the :mphibolite $(d)$ appearing in the center is a thin-bedded quartzite (b) with few coarse muscovite scales, but it soon runs out, as does the amphibolite, while a narrow band of the coarse muscovite-schist $(e)$ runs a long way morth, past the mineral springs and far into Wendell.

Followed south the three beds already described soon dip beneath a dark mica-schist containing much biotite and, at school No. 6 in Enfield, many small needles of dark-brown tourmaline and a little feldspar. This I have referred to the Conway schist $(f)$.

This series runs S. $15^{\circ}$ E., and so abuts with very acute angle upon the fanlt which runs along the east side of the valley of Swift River Branch. It is, if my interpretation as given upon the map be true, a syncline overturned to the west, and to the south of the transverse fault near the north line of Pelham is further affected by a longitudinal fault which eliminates part of the east flank of the fold.

\section{THE GREAT CENTRAL SYNCLINE.}

This enters the State from New Hampshire, occupying the whole eastern half of the town of Warwick and extending eastward into Royalston a mile beyond the limits of the area shown on the map (Pl. XXXIV).

West of Tullyville, in the apex of the town of Orange, it divides, sending off an eastern branch (see p. 234), and itself extends south with diminished width.

\section{WARWICK AND ORANGE.}

The western quartzites and amphibolites.-For a long distance south the syncline consists of a broad area of mica-schists, having on either side a narrow border of the quartzite beds (b) below, which separate the schists from the Monson gneiss on the east and on the west. Where they enter the State in the eastern hillside above Sunny Valley, in the northern part of War'wick, the basal bed is a white, shining muscovite-quartzite, often gneissoid, and south of Warwick village it is a coarse, gneissoid quartzite, containing much chlorite and magnetite. 
The amphibolite $(d)$ is a thin-fissile, often epidotic, persistent bed, not of great thickness, which on Mount Grace contains a beautiful radiated tourmaline, common in collections.

The upper quartzite bed $(\dot{e})$ is developed as a light, sandy biotite-schist (= whetstone-schist) for a long distance east of the road east of Sunny Valley. Northeast of Warwick Center it is a thin-bedded quartzite, exactly like the Bernardston quartzite. It is generally a gray whetstone-schist.

These three beds dip east beneath, and form a narrow border to, the great area of mica-schist $(f)$, which has a width eastward of nearly 4 miles.

Structure.-The lower beds dip east beneath the mica-schist. The latter strikes north-south and has high and irregular dips, being crumpled up into a mass from which one can gain no idea of its real thickness.

The lower beds run south normally until, opposite Mount Grace, they are thrown into great confusion. An east-west fault runs through the north brow of the mountain and far east. South of this and on the slope east of Mount Grace the lower beds are greatly crumpled, while Mount Grace itself is formed by the westward projection and folding of these three beds, and traces of this disturbance are seen all through the village of Warwick, the rocks being so crumpled that the amphibolite runs south in three long bands to Hasting's pond. On this bend north of the pond a vein of coarse epidote-garnet rock with fine quartz crystals is found

Farther on the lower beds regain their regular posture and run south to Harris's pond, in the southwest corner of the town, where the Wendell anticline, already described (p. 217), branches off. A little to the east a minor fold brings up the amphibolite $(d)$ through the mica-schist $(f)$, and on either side of it the whetstone-schist $(e)$, in a narrow anticline which rums down Brush Valley, crosses the river east of West Orange and continues south, ending in the west part of Orange.

The eastern border of quartzites and amphibolites.-At the east side of Prospect street, in Orange, the amphibolite $(d)$ rests directly against the Monson gneiss, with steep eastward dip, as if it went under the latter. This "fan structure" is common all around the Orange basin.

The beds below the amphibolite are fanlted out of sight-north and south-for a long distance. The latter is reduced to a small thickness here, perhaps 30 feet; and the upper quartzite $(e)$ is still more reduced, being here a compact quartzite; a mile nortl it is a fine-grained micaceous quartzite. 
The central fibrolitic micu-schists (the Comway sehists).-These are dark, rusty, contorted muscovite-biotite-schists, at times spangled with transverse biotite. They contain garnets, often in large numbers, of small size ind of the form $\infty \mathrm{O}$ (110). Staurolite appears rather rarely, but at localities seattered over all the area, especially on the west, where the Wendell syncline branches off; and across to the east, where the road north from Tullyville crosses the town line, the rock is a rather coarse mica-schist, the matrix made up of fine scales of shining-white muscovite, but largely darkened by graphite and by large blotches of biotite. It contains garnets and large single staurolites, together with fibrolite.

Fibrolite in the mica-sclists. - This mineral occurs in the mica-schist a mile northeast of Warwick Center, south of the house of Rev. J. Goldsbury. If a line be drawn southeast from this point to the apex of Orange, at the locality just mentioned, above Tullyville, it will mark approximately the northern border of the abundant occurrence of the mineral in the schists. If another line be drawn south from the same point it will mark the western boundary of the occurrence of fibrolite through Warwick and Orange. From these boundaries it gradually increases in amount southwardly and eastwardly, but the increase is more marked toward the east than toward the south, so that the eastern syncline from its beginning in Tullyville is marked by a maximum of the mineral, which continues clear across the State. It is not abundant in Warwick, nor southward in the central syncline liere described, throngl Orange. The transition is indicated on the map ( $\mathrm{Pl}$. XXXIV) by allowing the Conway schist color to grade into the Brimfield fibrolite-schist color without drawing a boundary line across the strike. This is the most important illustration of the passage of the Conway schist into the Brimfield fibrolite-schist.

To the east of the center of the area of mica-schist occurs a band of amphibolite, generally porphyritic in appearance, the structure being due to the absence of horublende from spots which thus appear white. In this amplibolite band is much iron, especially a lialf mile west of the point where the Warwick-Orange road crosses the town line. Here a small amount of mining work has been done. The mine is opened 2 rods on the "vein" and 10 feet deep. The "vein" is a vertical bed of quartz-garnet rock, very ferruginous, 1 foot wide at north end and 3 feet wide at south end, with a central layer of very compact, pure magnetite 4 to 6 inches thick. 


\section{TOPOGRAPHY}

The mica-schist, when set on edge, is usually the more durable rock, and appears in the row of hills_-Mallards Hill, Beech Iill, Pitts Hill, Fall Hill-which sharply border the gneiss depression of North Orange; and where the central anticline brings up the amphibolite and whetstone it produces the "Brush Valley," and the mica-schists, divaricating on the west from the main body, formed the long ridge of Barbers Hill. At the same time the quartzites, sharply folded and compacted with granite, rise high above the level of these hills in Mount Grace. On the other hand, in the next anticline to the east the "Big Tully Mountain," made of granite, rises to a peak which dominates the whole region. The Swift River fault runs between these two basins, and some comparatively modern elevation may explain the discrepancy.

\section{SOUTH ORANGE AND NEW SALEM.}

The western border.-The western-border beds cross the river east of West Orange and go south down the west line of Orange, crossing the corner of Wendell and continuing south along the New Salem-Shutesbury line, where they become involved in the West Branch fault.

The following section across the middle of this town line, from the schoolhouse in the west edge of Shutesbury, gives the succession of all the strata, including the mica-schist:

\section{Section in Shutesbury.}

Feet.

1. Monson gneiss $(a)$

2. Granular, micaceous quartzite (Rowe) (b) ............ 100

3. Amphibolite (Chester) (d) . . ..................... 100

4. Rusty, contorted, chloritic sericite-schist (Savoy) (e) ....... 325

5. Amphibolite . . . . . . . . . . . . . . . . . . . . . 16

6. Dark-gray, spangled mica-schist (Conway) $\left(f^{\prime}\right) \ldots \ldots \ldots \ldots$.

The latter bed is graphitic, garnet-bearing, contains transverse biotite scales, and is identical with the Conway schists. It includes a single bed of thin-fissile quartzite, consisting of a limpid quartz like that of a mineral vein.

This border series seems to meet the fault line at a very acute angle, so that in the hill just north of Cooleyville the lower member of the section above is cut out and the amphibolite $(d)$ abuts against the 
Monson gneiss (it). The latter indurated the former and shattered it, and a heary bed of granitie finlt rock (flesh-colored binary granite) is interposed. Just south of Cooleyville, at the last house before the road crosses the Prescott line, is an interesting section: Below is Monson gneiss ( $($ ) , flat-foliated but thick-bedded, regularly spotted by grains of black hornblende, and looking like a granite-porphyry, being much more compact and less granular than nsual, and plainly influenced by the fault. The great fault up the hillside is marked by about 25 feet of a granitic fault rock, at times a fleshcolored binary granite, at times a hornstone of similar color or green, at times a flesh-colored chloritic gneiss in structure-all these crushed and recrushed and again cemented. Then comes about 10 or 15 feet of amphibolite $(d)$, also wholly crushed, and above this a buff quartzite, perhaps 20 feet thick, followed by a great thickness of bedded gneissoid rock, granular and rusty, and with its micaceous mineral wholly decomposed, which is apparently identical with the chloritic sericite-schist $(e)$ of the last section but one. It repeats exactly the corresponding members of the section north of Cooleyville, and this shows that nearly all the amphibolite has here been cut off on the fault.

The eastern border beds.-At Orange Center the border beds are compressed against the gneiss and overturned, the lowest bed wholly concealed, the others greatly thinned. Just south of the river in Walnut Hill all these beds reappear in force and in duplicate in a remarkable subordinate anticline, best understood by inspection of the map (Pl. XXXIV).

The whole center of the hill is made up of the lower member, here a fine-grained, thin-fissile, two-mica gneissoid quartzite $(b)$, with garnets. This is flanked on either side by amphibolite $(d)$, then by a micaceous quartzite $(e)$, then by the mica-schist $(f)$, which is on the east side fibrolitic.

The narrow syncline which separates this anticline from the gneiss on the east dies out southward and, a little over the south line of Orange, lets the basal member of the series come in contact with the Monson gneiss in a normal manner, and it continues thus across New Salem as a broad band of two-mica quartzose gneiss.

The mica-schist.-This has been described in the section above as a true graphitic, spangled Conway schist. This is its character only in a narrow band along the New Salem-Shntesbury line, which runs out before reaching the latitude of Cooleyville on the south, and which on the north 
soon merges into the coarser, less graphitic, rusty, garnetiferous schists common farther north.

Around New Salem Center it is greatly cut by granite and carries several bands of amphibolite, and bowlders of a pyroxene-garnet rock occur, which indicate the former presence of limestone. All this area of the schist, except as mentioned above, lies to the west of the line already given as the boundary of the occurrence of fibrolite, and this mineral was not observed at all in New Salem; but the band of mica-schist which runs down from New Salem village carries this mineral soon after it passes over into Prescott.

Structure-An inspection of the map will show that the band crosses the north line of New Salem, after disengaging itself from the Walnut Hill anticline, as a simple syncline, and continues thus to the middle of the town, where an upfolding of the whetstone-schists $(\dot{e})$ separates the micaschists $(f)$ into two parts, and a little farther south this upfolding brings up also the amphibolite $(d)$, which runs down to the east of the large diorite area and seems to end upon an eastward prolongation of the great Pelham cross-fault, and I have so represented it.

The western and broader portion into which the mica-schist $(f)$ is thus divided contracts rapidly and sends a narrow lobe down west of the diorite mass into Prescott, where it ends. All these irregularities stand in relation to this great mass of diorite, as appears plainly from an inspection of the map, and prove that it was present passively during the upfolding of the rocks, preventing the continuance southward of the regular syncline in New Salem already described. Indeed, a further irregularity appears east of the north end of this diorite mass, in that the three lower members of the series disappear, and the mica-schists can be for a long distance seen resting directly upon the gneiss to the east.

\section{PRESCOTT AND ENFIELD.}

\section{STRUCTURE.}

Across Prescott the band continues unchanged. It is bordered on the east and the west by faults which separate it from the Monson gneiss (a) and conceal the two lower beds. The surface is thus mostly occupied by the whetstone-schists (e-Savoy schist), the amphibolite $(d)$ coming up 
throngh these near their western border, and a broad band of the micaschists $(f)$ separating them from the gneiss on the east.

As they pass into Entield both these funlts become less effective On the west the Monson gueiss is no longer bronght up to form the western border of the band of schists, but these are permitted to come into normal relations with the Pelham band beneath the sands of the West Branch, the two forming a double syncline of much regularity. The fault, however, seems to continue due sonth across the whetstone-schists, directly toward Enfield rillage, and it is marked north of this village by a line of crushed rock full of comby quartz, which runs down west of the amphibolite and between the two roads rumning north from the village, near the house of $J$ Thayer. On the east the amphibolite $(d)$ appears again, and toward the southern part of Enfield the Rowe two-mica-gneiss (b) also comes up from below the latter.

At this point the band comes under the influence of the Belchertown tonalite and passes dow் its eastern border, through Ware and Palmer, greatly fanlted and metamorphosed, so that its description is connected with the discussion of the contact metamorphism effected by the tonalite (p. 243).

South of this it becomes the West Monson syncline, which is more naturally associated with the other bands east and west of it and is discussed in a later section of this chapter (p. 249).

\section{PETROGRAPHICAL DESCRIPTIONS.}

The basal bed of the series (Rowe) is wanting through nearly the whole area. Where it reappears, in the south part of Enfield and Ware, it is a coarse muscovite-gneiss, as in Pelham. The amphibolite requires no special description. The whetstone-schist (Savoy), usually a gray whetstone, becomes in North Prescott, near H. Stetson's, a flat-fissile sericiteschist with large garnets $\left(15-20^{\mathrm{mm}}\right)$, which change externally into coarse chlorite. It corresponds exactly with the same rock west of the river-the typical Savoy sericite-schist-with which it is here paralleled. Farther south, near A. Gilbert's, it becomes a suow-white quartzite divided by very broad, whitish (sericite) films.

In Enfield, north of School No. 4, it is the same as above, but very greatly contorted. In the south of Enfield, on the east flank of Quabin Mountain, it appears in great force as a snow-white, granular quartzite, 
with few distant films of white muscovite, which was recommended by President Hitchcock as a firestone for furnaces.

Farther south, in Palmer (north of G Keith's), it is again a greatly crumpled, white, granular quartzite with distant sericite films; and still farther south, on the west flank of the high hill above Thorndike (north of C. Kalliher's), it is a curious white sericite- or hydromica-schist; broad, continuous wavy sheets of pea-green hydrated mica inclose flattened, nodular masses of friable quartz resembling loaf sugar.

The band of mica-schist $(f)$ which, starting at New Salem Center, runs down the east side of Prescott, becomes gradually more fibrolitic and extends across Enfield, Ware, and Palmer as a rusty, graphitic, corrugated schist, generally coarse and carrying few garnets. The fibrolite remains very fine and is not abundant, and the "augen" of transparent feldspar found in the next band to the east are wanting.

\section{THE EASTERN SYNCLINE.}

\section{ORANGE AND ATHOL.}

GENERAL DESCRIPTION.

Where it branches from the broad central syncline in the northeast corner of Orange and crosses the town the band of the schist forms a high ridge looking down upon the granite basin of the Tully brooks on the east and upon the gneiss basin of Orange Center on the west. It is a closed syncline with a subordinate central anticline, all slightly overturned toward the east. Along the western slope the western wing of the syncline is abundantly exposed. The center and eastern wings are almost continuously laid bare along the road which forms the boundary between Orange and Athol and on its continuation toward Athol.

The Monson gneiss, which appears low down on the western slope opposite J. Worrick's, is a stretched, slightly epidotic biotite-gneiss. It is subporphyritic by the development of shapeless, opaque, white feldspar clumps.

Next above is a heavy bed, occupying the whole hillside, of a rather coarse porphyritic gneiss, or augen-gneiss, which over a large area is not very different from the lower gneiss on superficial examination. When studied carefully, however, it is found to be very different. The feldspar, instead of being opaque, has a moonstone-like transparency, which con- 
tinues to be a characteristic of the gneissoid members of this fibrolitic series clear ancoss the State. The feldspar's are also often in regularly shaped carlsbad twins. The rock is a complete angen-gneiss.

Continuous micaceous filuns or sheets of varying thickness, while in general parallel to one another, wind in and out and inclose the quartz-feldspar nodules or the larger porphyritic crystals, and these sheets are thin lityer's of a strongly fibrolitic biotite-muscovite-schist, which can be traced in one direction to where it is lost in thin films in local granitic masses and in the other to where the sheets coalesce in heavy beds of slightly feldspathic fibrolite-schist. Corresponding with the stronger metamorphism, the fibrolite is unusually coarse for the region, occurring in distinct transparent needles and not in the fine-fibrous bucholzite.

I have little doubt that this is a case of extreme granitic impregnation and regular insinuation of the granitic material between the opened laminæ of the schist subsequent to its formation as a schist, and that the rock is the representative of the layer between the biotite-gneiss ( $a$-Monson gneiss) and the amphibolite $(d)$ in the other bands, where it is so often developed as a two-mica-gneiss. The band is here about 820 feet thick. It is thus placed as the equivalent of the Rowe schist, thongh the development of fibrolite in these lower beds is exceptional.

Next above comes the amphibolite, very coarsely crystalline and porphyritic in its lower band and carrying beds of a finely matted, fibrous, dull, dark-gray hornblende rock. It is about 650 feet thick.

Intercalated with the amphibolite and forming a thin bed above it is a rusty, very arenaceous biotite-schist of rather fine grain, which lacks fissility but agrees quite well with the whetstone-schist of the Northfield series.

Above this comes a great thickness of the coarse, very rusty muscovite-biotite-schists, in places very fibrolitic, the fine-fibrous mineral (fazerkiesel, bucholzite) occurring in films or in regularly disseminated porphyritic blotches, whose shape and arrangement are so like those of the blotches of muscovite common in these schists as to suggest the derivation of the fibrolite from the muscovite. Two things are certain, that the fibrolite is closely associated with the muscovite, and that its amount increases with the increasing intensity of the metamorphism, as is best seen in the abundance and large size of the mineral in the contact ring of the tonalite in Belchertown. 
In the center of the area the amphibolite is brought up along the south line of the town, as it seems to me, by a minor fold. It may be traced north nearly to North Orange. On the east of the anticline the amphibolite appears in force at the third bend after passing the site of the old fort on the road to Athol.

The beds above the amphibolite, which represent the whetstone-schist, are a fine-grained biotite-quartzite, having some resemblance to very finegrained varieties of the lower gneiss. Northward along the eastern border the lower beds are everywhere covered by the broad gravels of the valley.

METAMORPHISM OF THE AMPHIBOLITE BAND AS IT IS INVOLVED IN THE GRANITITE OF THE ATHOL BATHOLITE, AND ITS LATER CHANGE TO STEATITE.

The great bed of amphibolite which occurs east of Athol, and which is in one place changed to steatite, can be followed a long way N. $20^{\circ} \mathrm{W}$., and after disappearing for a distance beneath the sands it appears again in the southwest shoulder of Tullys Mountain, east of North Orange, crosses the great granitite mass like a bridge, and is continued beyond in the schists, changing with their strike to the northeast. It mounts the steep granite mountain side with a width of about 40 rods, and is well exposed by the workings of the soapstone quarry. The adjoining granitite is a fine-grained biotite-granite, containing rarely large crystals of magnetite and a little allanite. It shows a slight banding parallel to the contact with the schist, and sends offshoots into the latter

At the quarry the contact for a long distance runs athwart the folia of the schists, and their twisted ends abut against the granitite and are parted by it. The great mass of the hornblende-schist is changed into a coarse, shining, dark-brown, massive gedrite ${ }^{1}$ rock, containing small, fresh plagioclase grains, and abounding in small, sharp cubes of pyrite with truncated corners, or a more friable dark-green aggregate of actinolite needles. In part, especially near the borders, the rock retains the banded appearance which it has beyond the limits of the granitite. All the contact phenomena are those of an eruptive rock upon a schist. In several places the massive gedrite rock is further changed, in bands running about N. $70^{\circ} \mathrm{E}$., into a dark-green soapstone abounding in white dolomite, talc, and a green chloritic mineral. In some places there are, over broad surfaces, plates of clinochlore

1 For description and analysis see "Gedrite" in A mineralogical lexicon : Bull. U. S. Geol. Survey No. 126,1895, p. 86 . By mistake the nineral is assigned to Warwick instead of Orange. 
several inches arross. The steatite did not appear to be, either in character or amount, of economic importance. 'This seems to be a case similar to many I have stndiert among the great granite ovals in Massachusetts, where the igneous rock has forced its way upward through the eompressed sehists, dissolving or parting them in its progress, so that the present erosion surfice often presents an appearance as if the great separate floes of the schist had floated upon the granite while still held in orientation with the surrounding schists. They bear testimony to the continuity of the overlying schists which once covered the granite and projected into it, and they owe their common dip and strike to this former comnection.

WARE.

GENERAL DESCRIPTION.

The eastern band of schists leaves the county at the south line of Orange, and, traversing Worcester County for a long distance, reenters the area of the map in Ware and crosses Palmer and Monson. The fourfold division of the schists, which has been persistent over so large an area, and which seems to be somewhat less distinct at the beginning of this band in Orange, here fails entirely. It is reduced to a twofold division of amphibolites below, resting directly upon the Monson gneiss, and a great volume of fibrolitic mica-schists, the lower portion of which may represent the whetstone-schist, but in which no persistent lithological distinetions can be established.

On the map I have given to this band a color resembling that given to the Conway mica-schist, since in Orange and Warwick the gradual passage of schists which are lithologically and stratigraphically the representative of this terrane into these fibrolite-schists can be clearly followed, and the lessening of the number of distinct bands above the amphibolite seems to be effected mainly by the suppression of the whetstone-schist or its merging with the hornblende-schist, with which it seems more intimately comnected than with the upper bed, rather than by its becoming lithologically like this upper bed-that is, like the Conway mica-schist.

Across Ware the amphibolite can be followed with apparent continuity (it is, of course, much covered by loose deposits), bordering the fibroliteschists on either side and separating it from the Monson gneiss below It presents no peculiarities of interest. 
The fibrolite-schists are deep-brown biotite-schists, in which the redbrown shade of the biotite is very characteristic. A fine, silky fibrolite is very abundant. Deep-red garnets are common, and it is largely due to their ready decomposition that the schists have always at surface a very rusty appearance. Nodular masses of a perfectly fresh and limpid moonstone, often $20-30^{\mathrm{mm}}$ across, and generally consisting each of a single untwinned crystal, appear at times abundantly in the schists, whose layers wrap round the nodules so that they seem like pebbles. They are often surrounded by a border of sugary, white, granular feldspar, plainly formed by the crushing of the large central mass and the slight displacement of the fragments produced. This displacement becomes at times considerable in the direction of the bedding; and the granular material is drawn out in tails forming complete "augen," which, with their center's of orthoclase as limpid as calcite, stand out in marked contrast with the deep red-brown of the schist. They inclose occasionally garuet and graphite, but I do not recall an iuclusion of fibrolite. Graphite in minute scales is everywhere present in the rock and is at times quite abundant.

\section{PETROGRAIHICAL DESCRIPTION.}

Mica-schist from Ware. In the bluff near the contact of mica-schist on hornblende-schist, 175 rods southwest of B. Bond's house, is seen a black, fine-grained schist with wavy, shining lamination surface, which may almost be called an argillite, with rarely deep-red garnets and large porphyritic spots of white feldspar.

In section the dark color is seen to be due partly to trains of coaly matter, but more to the dark color of the biotite scales, which are dark olive-green in thin plates.

The garnets are apolar and without inclusions. The feldspar is orthoclase, with no trace of microcline. The rock is very interesting from the pseudofluidal structure developed by the gradual growth of the orthoclase in the mass. The centers are large, rounded or quadrangular masses of feldspar, showing at times very faint undulose extinction. At either end are grouped a congeries of intergrown grains varionsly arranged optically, and tapering away to form with the central pieces "augen," around which trains the mica-scales curve. Outside these other bands of feldspar grains appear, and converge in either direction to meet and inclose the central band of mica scales. Outside this another band of mica scales widens out 
to include the whole, and this is sometimes repeated several times on one or both sides of the center, showing a gradual growtl of the feldspar within the mass of the mica-schist. There was first the formation of the large central mass and its welding with a layer of the mica scales at its surface (scattered scales of the sane mica occur within the large feldspars), and liter the addition of other granular layers of feldspar ontside the first, each retaining in contact with its outer surface a film of the mica scales. Each feldspar layer luas possibly some relation to a stage in the folding process of the rock, by which straius were set up within it and localized at the surface of the feldspar grains, so that growth of new feldspar at that place was made possible.

\section{THE HARDWICK GNEISS.}

In a communication to the Geological Society of America as New York in $1889^{1} \mathrm{I}$ described briefly the great bands of granite which cross the State as batholites of igneous rock, melted up along great synclines of the compressed schists, and stated that the Cambrian biotite-gneisses, which are sometimes finely granitoid from recrystallization, could scarcely be distinguished from these granites made schistose by crushing, and I held the Barre and Orange bands in reserve, as their relations to the gneisses and to the granites were so evenly balanced that I could not decide in which category to place them. A more exteuded study of the band across Massachusetts and New Hampshire has convinced me that it must be put with the intrusive bands, as it shares so many of the characteristics of the latter. It is intruded as a broad band in the fibrolite-schists, while if it were the Monson gneiss in normal relation to these schists in the core of an anticline it would be separated from them on either side by amphibolite and whetstone-schist, as is the case in the anticlines next east and west. Now, the northeru end of the next easteru band-the Orange band-is the counterpart of the northeru end of this mass. The shape is the same; the rocks are in places scarcely distinguishable; but the newer rocks seem to mantle rom the Orange area as around a core of gneiss, and the band can be traced continuously south into mion with the Palmer-Monson area, where the interbedded quartzites and conglomerates prove the mass to be a Cam-

${ }^{1}$ Porphyritic and gneissoid granites in Massachusetts: BnIl. Geol. Soc. Am., Vol. I, 1890, p. 559. The name Barre granite used here has been changed above to Hardwick grauite to prevent confusion with the well-known granite of Barre, Vermont. 
brian gneiss. I am thus constrained to leave the Orange band with the gneisses and to assign the Hardwick band to the granites, in spite of their resemblances. The latter band widens as it goes north, and crosses the State line with the whole width of the country between Royalston and Winchendon, and ends with the characteristic blunt point north of Fitzwilliam; and the line of the syncline continued passes under Monadnock, and the granites possibly continue along this line, beneath the mountain, and have caused the large development of andalusite in its schists, as they have on the border of the Princeton band and in the center of the Worcester slates. Only its southern, narrowed end enters the territory under review, in Ware, and runs down the eastern portion of the Palmer quadrangle. Across the whole State the narrower western portion of this band is a very dark granitite-generally dark from excess of black biotite, more rarely by the presence of jet-black hornblende. The eastern portion is an excellent biotite-muscovite-granite, like that of Fitzwilliam. The darker portion is well exposed in the railroad cut at Gilbertville, and is described below. Where the Coys Hill granitite crosses it it carries large "angen" of adularia, like the adjoining schists. It is thus older than the post-Carboniferous granites.

The rock may be studied best along the road running east from South Monson and neair the east line of the town. At L. Bradway's it resembles a good typical Monson gneiss, as also at B. Brook's. At T. Sutleff's a black granular hornblende-granite, a dark biotite-granite with amber feldspar, and a granulite full of shining-white fibrolite occur on this terrane. Such fibrolite always appears to have been dissolved in granite, being derived from the adjacent fibrolite-schists.

\section{PETROGRAPHICAL DESCRIPTION.}

At the first cutting on the Central Railroad northeast of Gilbertville station, 17 feet east of a pegmatite dike, occurs a rather fine-grained granite, nearly black from the abundance of biotite and magnetite, and of slightly subporphyritic aspect from the presence of disseminated scales of biotite, or groups of scales $3-4^{\mathrm{mm}}$ across.

Under the microscope it is a wholly fresh, highly crystalline granitoid rock. On a background of closely interlaced grains of orthoclase and plagioclase an abundance of biotite, magnetite, and epidote appears. Quartz is wholly or almost wholly wanting, and there is no trace of microcline. The 
older constituents are apatite, magnetite, zircon, rutile; the newer, biotite, ortlurelase, albite, epidote, pyrite. Apatite is very abundant, as is also magnetite: pyrite is rare. The abundant biotite shows the richest absorption colors.

A large crystal of albite contains many small, sharp plates of biotite parallel to $0 \mathrm{P}(001)$ and $\infty \mathrm{P} \infty(010)$, and the section is so exactly parallel to $\infty \mathrm{P} \infty(100)$ that these plates are both presented edgewise to the eye. It extinguishes the light at $22^{\circ}$ and $23^{\circ}$ with the twinning plane, while the mica plates make with each other an angle of $94^{\circ}$. It is also crowded with minute black rutile (?) microlites, which are broken up to an unusual extent into short rods, or often into long, rigid rows of black dots parallel to $0 \mathrm{P}$ (001) and $\infty \mathbf{P} \propto(010)$, and in other directions as well. The epidote usually associated with the magnetite shows striking absorption-a =colorless, $\mathrm{br}=$ pale mountain green, $\mathfrak{c}=$ salmon color. The zircon is in small, rounded, limpid grains, with rounded liquid inclosures, or many large elongate, stout prisms with several constrictions and centrally densely dusted with black grains. This agrees closely with the type of zircon occurring in the gneisses as determined by K. de Kroustchoff. ${ }^{1}$

\section{PALMER.}

Across this town the western band of amphibolite is broad and well marked; it commences where the town line runs north nearly to the Ware River, and contimues south to Fentonville, being well exposed west of E. Shorley's in the middle of its length. The eastern band is wanting.

The mica-schist extends across this town with less width than it has through Ware. The great east-west fault through the south of Ware, on the south of which the rocks are thrust far to the westward against the granite, seems to account for this. The schists in the northern half of the town are dark, rusty, fine-grained biotite-schists, in which fibrolite is exceptionally rare, but it sets in again abundantly in the southern part of the town.

\section{MONSON.}

The same series crosses Monson, forming the crest of East Hill and Moulton Hill, and crosses the State line east of Cedar Swamp Hill. It is 
well exposed in a section continued a mile east from the town farm, or east from South Monson, past the house of T. K. Beckwith.

After passing over the Monson gueiss and the amphibolite one comes upon a band of gray, fine-grained, thin-fissile gneiss containing garnets, which represents the whetstone-schist, but is so thin that it is not separately represented upon the map. It contains a small amount of fibrolite in the finest needles.

Just above it is a dark, fine-grained mica-schist, full of small garnets and spangled with transverse biotite that exactly resembles the Conway mica-schist, except that it contains fibrolite.

On the next road south, in the roadside by S. Blodgett's, the rock is a very striking one. It was originally an arenaceous band in the mica-schist, like the whetstone layers in the Conway mica-schist ou the west of the river. It has now assumed the chocolate-brown color of the rest of the rock, and is full of fibrolite needles that wind with an excellent initation of a fluidal structure around porphyritic masses of feldspar or garnet, which reach a diameter of $25-30^{\mathrm{mm}}$, and very closely imitate pebbles. They are well rounded, but consist in each case of a single crystal.

The feldspar is a perfectly fresh and slightly opalescent moonstone, regularly penetrated by blades of plagioclase so exceedingly fine that, except with thin plates and very high powers, it seems to be an orthoclase of ideal purity. These rounded masses are bounded by a sugary, granular border of white feldspar, clearly produced by the crushing of the central mass, and I have nowhere seen the cataclase structure more beantifully developed.

The average rock of this band across Monson is a rusty, chocolatebrown biotite-schist, everywhere abundantly fibrolitic and graphitic, and very generally carrying garnets. Occasionally it is chauged into a gneiss, as described above, by the development of the porphyritic feldspars, but this seems so plainly a modification of the mica-schist during folding, by the warping open of cavities which became filled with feldspar, that I have not separated it upon the map.

On the east of the mica-schist only traces of amphibolite could be found along the line of separation of the schist and the band of gneiss still farther east, and this could not be given on the nap without great exaggeration. 
TIE ZONL OF CONTACT AROUND TIIE BELCHERTOWN TONALITE.

THE PYROXENIC AMPHIBOLITES.

An inspection of the map will show that the crystalline rocks are thrown off on all sides from the flanks of the great Belchertown "batholite," and that great sheets of the same rest on the tonalite far ont in the center of the mass. These are of the varieties most characteristic of intense contact metamorphism-coarse fibrolite- and pyroxene-schists, epidosites, and highlly silicified gneisses and quartzites.

The zone of crushing following the foothills through Leverett, Pellam, and Belchertown passes directly through this contact border and materially increases the difficulty of identification and correlation of the beds with their equivalents elsewhere.

It is not possible to distinguish between the beds below and those above the amphibolite, since the quartzite becomes heavily loaded with biotite, forming a fissile gneiss, which I have found all around the mass and have in my notes called the Baggs Hill gneiss, from its abundant development in this hill in Granby near the Belchertown line. As soon as it approaches the granite mass the amphibolite becomes pyroxenic, as at Kelleys Crossing and on south down the west side of the mass, while the Conway schists become coarse fibrolite-gneiss and epidosite.

The band of amphibolite which was traced through Leverett to Adams's mills reappears between the two Belchertown ponds and wraps around the south end of the Pelham gneiss, uniting the Leverett-Amherst area and the Pelham-Shutesbury syncline, and extending across Belchertown Center with great width because of the disturbing influence of the tonalite. It is much shattered, and swarms with small aplitic dikes from the tonalite.

A sahlite-amphibolite appears at the point where the road from Amherst to Belchertown crosses the railroad-in the new cutting of the Massachusetts Central Railroad-and a short distance farther south in the cutting of the New London and Northem Railroad at the next crossing (Kelleys Crossing).

Here the rock is a coarse amphibolite of dark-green color, made up almost wholly of broad, interlacing plates of hornblende. It is much cut by dikes of a flesh-colored granite (aplite) containing little mica, which send small veins through it in all directions, recementing the brecciated mass. 
Bordering these on all sides, in a width from one-half inch to 2 inches, the homblende is changed into a much lighter green sahlite, plainly a contact product. At the south outcrop a band of the pyroxene rock much wider occurs, which is not in visible relation to the granite.

The schist is in places rendered gneissoid by the intrusion of sheets and small irregular aggregations of flesh-colored granular feldspar, which can at times be distinctly traced back into connection with the granite.

Followed south along the road the rock becomes again a chloritic hornblende-gneiss, and just beyond and east of its southern outcrop appears a band of quartzite and mica-schist, which is exposed in the cuts of the two railroads and seems to overlie the hornblendic rock, as indicated in the section and described below. (See fig. 14.)

In the roadside 165 feet below J. Squire's and in the cuttings of both the railroads above (east of) his house occurs a flat, thin-fissile, feldspathic

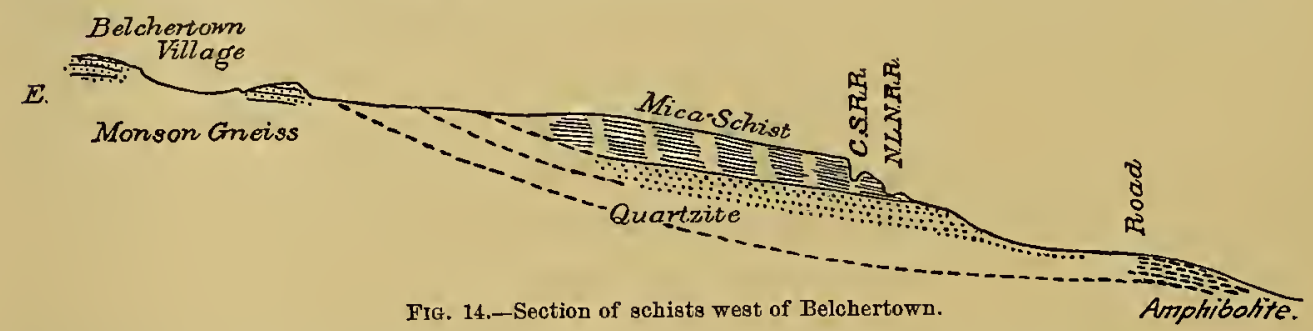

mica-schist of dark greenish-gray color and so full of small cubes of pyrite that it is deeply decomposed. Dikes of coarse pegmatite from 1 to 25 feet wide cut through it, and they also contain pyrite and are kaolinized to great deptl. The mica-schist is 10 feet thick.

Below this is a thin-bedded, light-gray quartzite, sliglttly biotitic on cleavage faces. It is nuch fissured, and filled with combs of quartz, films of hematite, and calcite, and slickensided. Below this, on the west side of the road, is a massive, crumbling amphibolite, which seems to underlie the quartzite. The section is here sufficiently undisturbed to show the amphibolite in normal relation to the npper beds.

Along the road farther south, in the field east of T. S. Haskel's, is an outcrop of a coarse sahlite-amphibolite, like that at Kelleys Crossing, which joins Monson gneiss on the east and is cut off by a great granite vein upon the south. It is still coarser than that farther north, and the pyroxene crystals are larger. It furnished the material for the microscopical description of the rock below. It is a massive, friable, granular mass of 
green pyroxene grains, with here and there a great black homblende crystal appearing porplyyitically in the mass, its shining surfaces luster-mottled by many grains of the pale-green pyroxene, which are here better erystallized and smaller than in the main mass. The pyroxene is colorless, without pinacoidal eleavage or inclusions of any kind.

This is the rock that was called angitic syenite by President Hitehrock, and slides were ent from the specimen in the survey collection (XVIII, 92). The rock contains large leek-green erystals of pyroxene, large black hornblendes, and a scanty granular groundmass of plagioclase.

In slides the dark-green hornblende, which is at times brown centrally, is luster-mottled on its broad cleavage surfaces with pyroxene, which is faintly reddish, of high refraction and coarse cleavage. The large pyroxenes are intergrown with irregular portions of hornblende with the axes $a$ and $b$ of the two minerals parallel. In sections normal to $b$ the cleavage lines coincide and a revolution of $17^{\circ}$ to $19^{\circ}$ brings the hornblende to extinetion, and of $43^{\circ}$ in the same direction, the pyroxene. The two minerals are so interwoven that they give almost an aggregate polarization. Small, brown octahedra appear in the hornblende. In general the amphibolite is not made pyroxenic, but is only crushed and filled with quartz veins. It is the usual flat-fissile, dark, fine-fibrous rock.

Samples from an artesian well, bored on the grounds of Mr. Myron P. Walker, in the center of Belchertown, taken at the depths indicated, gave the following results:

Record of an artesian-woll boring in Belchertown.

80 to 100 feet, pegmatite.

115 feet, granite, with little amphibolite.

130 feet, granite, with little amphibolite.

145 feet, granite.

160 feet, granite.

175 feet, yellow granite, with much muscovite.

190 feet, gray granite, with amphibolite.

205 feet, gray granite, muscovite, and amphibolite.

220 feet, gray granite, muscovite, and amphibolite.

249 feet, much coarse biotite.

Still farther south, on the west slope of Baggs Hill, in Granby, appear dark greenish-gray, membranous, feldspathic mica-schists, associated with a quartzite which is at times blackish, at times greenish, and abounds in quartz erystals and pyrite. 
THE FIBROLITE-SCHIST INCLUSIONS.

The most instructive occurrence to prove the eruptive character of the tonalite and to illustrate its contact phenomena is found in the broad sheet of coarse fibrolite-schist which runs two miles southwest from "Slab City," in the east of Belchertown, to end at the house of V.H. Pease. In the middle of the road that runs along its sonthern border at the western Clongh house-this and the Pease honse being the only ones on this road-at a watering trough, a brook crosses the road, coming down over the rocks, and 30 feet above the road one sees the contact of the tonalite and the schists above it, and at the trough the quartzite appears as a gramlar quartzepidote rock. The bright yellow-green epidote is in rounded erystals, each surrounded by a white spot, from which the iron has gone to supply the epidote crystal.

At the northeast end of the inclusion, at G. Robinson's, a dark biotite schistose gneiss, like that found at Baggs Hill, dips normally under the fibrolite-schist. The biotite is black, with a shade of green, and makes continuous films through the granular quartz mass. Below this gneiss are beds of a thin-fissile, slightly micaceous quartzite.

This fixes the position of the fibrolite-schist as the equivalent of the upper mica-schist, as does the fact that it lies in continuation of the micaschists in Eufield, and the latter are the only beds sufficiently argillaceous to have furnished material for so much aluminous silicate. These same mica-schists grade eastward into fibrolite-schist and continne across Worcester County, but they are rarely so coarse as here.

PETROGRAPHICAL DESCRIPTION.

Fibrolite-chloritz-schist, from bowlder in cutting on Massachusetts Central Railroad, South Belchertown, but coming donbtless from the contact zone of the granite; a stretched gneiss-like rock of gray color, with shade of green and showing much fibrolite.

Under the microscope radiated fibrous tufts of a green, chloritic mineral inclose much graphite in notched plates, and this chlorite is associated with an abundance of large garnet grains free from the same inclusions, and these together frame large grains of quartz full of rutile needles. The quartz polarizes as a mass of grains and is plainly secondary. The fibrolite is abundantly woven through the whole. 
1.4brolite-biotite-schist, from south end of the main belt of schist in the granite. 'This is a coarse schist, showing an abundance of muscovite and biotite, rusty, and containing large spots of garnet and coarse fibrolite blades, often $3-5^{\text {mum }}$ widle.

'The nicroseope shows many black scales, part of which are blood-red specular iron, and part seem to be graphite, as they are grown together in long lines and have rounded outlines. There are many rutile needles in the quartz.

Garnet-staurolite rock, from large bowlder in the first eutting of the Massachusetts Central Railroad south of Belchertown, and coming doubtless from the band of fibrolite rock to the north. This rock represents the extreme of metamorphism reached by the rocks bordering the granite. It is a highly crystalline rock of medium grain. Large patches of garnet and quartz and much biotite are visible to the eye, and the lens detects much staurolite, graphite, and a few shining surfaces of fibrolite.

Under the microscope nearly half the surface is occupied by staurolite; the garnet patches are seen to be made up of congeries of small grains, and these two separate quite widely the quartz patches, which are crowded with fibrolite and rutile microlites and are thus plainly secondary quartz. All these minerals include plates of graphite scales-single or grown together in long series.

Epidote rock, from Belchertown. This is an interesting product of the contact metamorphism of the tonalite upon the schist. It occurs at the watering trough near the house of $\mathrm{J}$. Clough, in the southeast part of Belchertown. The rock has a mottled look; a white groundmass winds among rounded spots of a dark yellowish-green color, made up of biotite and epidote. The rock grades into biotite-gneiss.

The epidote is the most abundant constituent, and with a strong lens one can make out the fresh, shining, model-like crystals, regularly disseminated, and semiopaque centrally. With the microscope they are seen to be filled with grains of quartz, of elongate, irregular shapes, and very large in proportion to their host, which crowd the central portion and radiate outward. It contains, also, chlorite scales. Biotite, regularly disseminated and strongly dichroic, molds itself to the epidote, as does the rare quartz. Apatite occurs in regular crystals, forming pleochroic rings in the biotite. 
All the constituents are perfectly fresh and almost entirely free from fluid inclusions and microlites, and the absence of these, as also of zircon, rutile, garnets, and iron ore, is remarkable.

Hand specimens are on one side biotite-gneiss, on the other epidosite, and the two seem normally interlaminated; but the latter must be of later and very different origin, and may be in effect a vein stone, in which, perhaps, the chlorite scales are remnants of the earlier rock, which has been almost wholly resorbed to make place for the new minerals.

THE WILBRAHAM SYNCLINE.

South of the deep transverse valley of the Quabang and its continnation in the Chicopee River, the simplicity of the geology is as marked as is the complexity of the region north of the same valley. Three great synclines of the schists run south across the towns named above, forming as many high ridges. The Wilbraham syncline looks down on the sands of the Connecticut Valley on the west and upon the deep gneiss-bottomed valley of East Wilbraham on the east, and across this valley rises the West Mountain of Monson, made up of a second syncline of the same rocks and looking down on the deeper and narrower Monson Valley, which is underlain by the same gneiss. Across this valley on the east the third syncline rises to form East Mountain, which is bordered on the east by a less strongly marked and yet distinet valley, underlain by a third repetition of the Monson gneiss and, followed farther east, by the Brimfield gneissoid micaschists, forming a fourth syncline. (See sections, Pl. XXXII, and map, Pl. XXXIV.)

The Wilbraham syncline is concealed in its western half beneath the Triassic sandstones, which rest against the western foot of the ridge, and the slope of the ridge on the west is so steep that it is probable that the fault, so well marked farther north, is continued at its base, and that the rocks have sunk to form the broad Connecticut Valley. It is a closed fold, slightly overturned to the west, and its rocks closely resemble the corresponding beds on the west of the Conmecticut Valley in Granville.

The gneissoid quartzite or muscovitic gneiss, the equivalent of the Rowe schist, which usually intervenes between the Monson gneiss and the hornblendic beds, seems to be wanting here, and the hornblendic beds rest directly on the white biotite-gneiss. The upper beds of this gneiss are very fine-grained and magnetitic and probably represent the Rowe schist, but 
no boundary could be drawn below to separate it from the MLonson gneiss proper.

The hornblende-schist (Chester amphibolite) is a jet-black rock, satiny on the surface from the effect of the great number of fine needles of hornblende which make up nearly its whole mass. The whetstone-schist (the equivalent of the Savoy schist) is at gray, granular, friable quartzite, varying from thin-fissile to massive, often a shining muscovite-quartzite, or abounding in distant flakes of chlorite. It is covered on the western flank of the syncline until the range crosses into Connecticut, when it appears on the west flank of Perkins Mountain.

The Conway mica-schist is a coarse, light-gray muscovite-schist, generally barren, but carrying at times a few garnets. Along its westem base it is much crumpled and silicified, as if from the influence of the fault.

On passing into Connecticut the regularity of the syncline is interrupted. The amphibolite band which forms the ridge of Pine Mountain, Rattlesnake Hill, and Perkins Mountain, in Somers, is suddenly cut off in the south shoulder of Perkins Mountain by the gneiss. The latter rock, which up to this point has dipped a little north of west, here swings around sharply, dipping steeply north and northeast, so as to cut off the whole series up to the mica-schist, and, reversing its direction, it runs south again, dipping normally beneath the Conway schist, of course with a fault boundary.

\section{THE MONSON SYNCLINE.}

The west Monson syncline is a perfectly symmetrical closed fold of the schistose series in the gneiss, and its character will be understood by comparing the detailed section below with the cross-sections on Pl. XXXII. The section given below commences with the older rock-the Monson gneisson the east, at a point 1,830 feet east of the sharp turn in the road at the house of A. Bliss, jr., a mile northwest of Peaked Mountain, and runs west:

a. ${ }^{1}$ Monson gneiss.

b. Rowe schist. Gneissoid quartzite, with very little feldspar, muscovite, and a green mica or chlorite, with beds of gray biotite-quartzite, chlorite-schist, and hornblende-schist appearing a little farther north, opposite the honse of J. Burley; 361 feet.

d. Chester amphibolite. Epidotic quartz-hornblende-schist, thin-bedded above and changing into chlorite-schist; 459 feet.

e. Savoy schist. Chloritic mica-schist, with subordinate beds of muscovitegneiss, changing above into arenaceous mica-schist (whetstone-schist) and still higher 
into quartzite and quartzose sericite-schist, with pale-greeu hydrated muscovite and large distant garuets; 3,791 feet.

$f$. Conway schist. A coarse, lead-gray, barren mica-schist occupies about half the thickness of this bed and is succeeded above by a corrugated mica-schist of fine grain, very dark, from the large amount of graphite in it, and abounding iu small garnets ( $\infty$ P) and dark red-browu biotite, set transversely to the bedding; 1,188 feet.

The similarity of this series to the corresponding one across the Connecticut Valley is striking. Each subdivision between the Becket gneiss and the Leyden argillite is represented, though with diminished thickness. The Saroy schist $(e)$ is well exposed in the first cutting west of the Palmer station on the Boston and Albany Railroad. Here there is trace, apparently, of a corrugation of the quartzite, upon which the vertical foliation may be superinduced as a secondary structure. This would throw doubt upon the thickness given above. Following the Somers turnpike a mile and a half west from the south end of State-line Pond, in Connecticut, at the south end of the long ridge of Peaked Mountain one comes upon the finest quartzconglomerate in the Rowe schist. It is in a great ridge on the north side of the road, at a ruined house northwest of the schoolhouse.

The mica-schist $(f)$, the central portion of which agrees strikingly with the. Conway schists clear across the town, is best studied where the road from Palmer to Hampden crosses it, a mile nortluwest of Flynt's quarry. The uppermost beds are so fine-grained and plumbaginons that they recall the Leyden argillite, and this is exactly the horizon at which it should occur.

If the section be continued westward it repeats itself exactly in inverse order, though liere the amphibolite is very generally porphyritic in appearance-a structure which is due usually to the absence of homblende from small spots regularly disseminated, so that the whole granular groundmass shows; but many bowlders of the rock found in the sonthwest corner of Monson are of fine, porphyritic diorite-schist with fresh, poorly cleaving feldspars in close-set, rounded grains.

It seems to me probable that a narrow fragment of rocks of this series starts east of Flynt's quarry, near the "rock house," and extends north through Bunyan Mountain, either fanlted down into the center of the anticline or brought there by a subordinate downward fold of the schist which formerly mantled over the gneiss. It was of too limited extent to find place upon the map. 


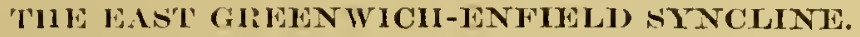

A narrow symcline comes out from beneath the sands east of Greenwich village and near the east line of Greenwich. Traces of it appear to the north, mostly covered by sind, along the roadside east of Warner's pond. It makes the high hill which extends down the east line of Greenwich and Enfield, and is well exposed along the road running east from Enfield. Here, near W. N. Avery's, the fibrolite-schist is a nearly pure bucholzite, in thick layers, in a fine-grained feldspathic quartzite without brown mica, graphite, or garnet. As it lies inmediately above the amphibolite it occupies the position of the whetstone-schist. The center of the series is occupied by the rusty mica-schist, while on the west there is a dull-greenish graphitegarnet-muscovite-schist and a granulite with its garnets bordered by green, and both these beds indicate the presence of the basal beds below the amphibolite, but not in thickness sufficient to be put upon the map. In Ware this terrane is well exposed between the town farm and the schoolhouse to the west.

It is shifted to the west by the great fault in the south of Ware, and across Palmer it forms the high Pattaquattic Hill and the range of high ground south across the town. On the south flank of this hill, northwest of J. Carrigan's, the black mica-schists are locally so crowded with the large rounded "angen" of feldspar that the separated folia of the schist, $2-5^{\mathrm{mm}}$ thick, wind in and out among the latter and occupy not more than a fourth of the space in a cross-section of the rock.

In Palmer it can best be studied along the road ruming east from the Center, and its first branch to the northward, especially in the hill east of B. Olney's. Here a distinct band of quartzite appears above the amphibolite. It runs out soon after reaching Monson.

\section{RÉSUMÉ. \\ ARGUMENT FOR THE IDENTITY OF THE SCHIST SERIES EAST OF THE CONNECTICUT WITH THOSE ON THE WEST.}

In the north of the State the beds in the first band east of the river agree most closely with the corresponding beds west of the river, and some of them, as the Conway schists, agree exactly in a multitude of characters. Southward the strata change greatly, but in the latitude of Amherst the 
corresponding strata east and west of the river still resemble each other closely. Farther south the beds revert to the types prevalent in the northern part of the State, but with many minor peculiarities, and still the resemblance is close, bed for bed, between those on the east and those on the west of the river.

THE PASSAGE EASTWARD INTO THE BRIMFIELD FIBROLITE-SCHIST.

On the north of Warwick the Conway schists agree exactly with those in the Northfield syncline next west, and thus with the type west of the river. As the beds are traced south along the strike they gradually become fibrolitic, and the same change takes place slowly across the strike as one goes eastward into higher beds.

Because of the abundance of granite, metamorphism is more pronounced in the central part of the State, and here fibrolite occurs in the schists all the way to the Connecticut. Again, where the nonfibrolitic Conway schist passes out over the Belchertown tonalite it becomes most coarsely fibrolitic. Finally, as the beds are followed still farther east across Worcester County the great increase of granite promotes a corresponding increase of fibrolite in the highly aluminous Conway schists, and they are named for convenience the Brimfield schists. 


\section{H A P T E R I X.}

\section{THE BERNARDSTON SERIES OF UPPER DEVONIAN ROCKS.}

\section{CITERATURE.}

1. 1819. E. Hitchcock. Geology of a section of Massachusetts on Connecticut River, ete. Am. Jour. Sci., 1st series, Vol. I, p. 105.

2. 1823. E. Hitchcock. Geology, etc., of the regions contiguons to the Connecticut River, with map. Ibid., Vol. VI, p. 1.

3. 1825. E. Hitchcock. Same article, separate publication.

4. 1832. E. Hitcheock. Report on the Geology of Massachusetts. Part I, Economic Geology, with map. Ibid., Vol. XXII, p. 1.

5. 1833. E. Hitcheock. Report on the Geology, ete., of Massachusetts, with atlas.

6. 1835. E. Hitchcock. Report on the Geology of Mássachnsetts. 2d edition, 702 pp.; map.

7. 1841. E. Hitchcock. Final Report on the Geology of Massachusetts. $831 \mathrm{pp}$; map.

8. 1844. E. Hitchcock. Explanation of the newly colored map of Massachusetts. $22 \mathrm{pp}$.

9. 1844. E. Hitchcock. Geological map of Massachusetts, on same sheet as the Borden Trigonometrical Survey Map.

10. 1851. E. Hitchcock. On the geological age of the clay slate of the Connecticut River Valley. Proc. Am. Assoc. Adv. Soc., Vol. VI, p. 298.

11. 1858. E. Hitchcock. Geological map of Franklin County, on Walling's wall map of Franklin County.

12. 1861. E. Hitchcock and C. H. Hitcheock. Report on Geology of Vermont. Vol. I, p. 447; Vol. II, p. 598.

13. 1870. C. H. Hitchcock. The Geology of Vermont, in the Geology of Northern New England.

14. 1871. C. H. Hitchcock. Geological map of Massachusetts, in Walling's Atlas of the State. Boston.

15. 1873. J. D. Dana. On rocks of the Helderberg era in the valley of the Connecticut; the kinds including staurolite slate, hornblende rocks, gneiss, mica-schists, etc., besides fossiliferous limestone. Am. Jour. Sci., $3 d$ series, Vol. VI, p. 339. 
16. 1877. C. H. Hitcheock. Note upon the Connecticut Valley Helderberg. Ibid., Vol. XIII, p. 313.

17. 1877. C. H. Hitcheock. The Geology of New Hampshire. Vol. II, p. 428, with map and sections.

18. 1877. J. D. Dana. Note on the Helderberg formation of Bernardston, Massachusetts, and Vernon, Vermont. Am. Jour. Sci., 3d series, Vol. XIV, p. 379.

19. 1883. R. P. Whitfield. Observations on the fossils of the metamol'phic rocks of Bernardston, Miassachusetts. Ibid., Vol. XXV, p. 368.

20. 1890. Ben K. Emerson, A description of the Bernardston series of metamorphic Upper Devonian rocks. Ibid., Vol. XL, pp. 263, 362.

\section{IIISTORY.}

1819. "Argillite sometimes alternating with mica-slate, siliceous slate," "undoubtedly primitive." Almost perpendicular, inclining a few degrees to the west. $\left(1,{ }^{1}\right.$ p. 105 . $)$ The hormblende-schist of this series is associated with the Triassic "greenstone." (1, p. 109.)

1823. Extends from Leyden, north to Rockingham, Vermont; occurs again at Woodbridge, Connecticut; often tortuous and slightly undulating, especially when passing by imperceptible changes into mica-slate. It embraces numerous beds and "tuberculous masses" of white quartz. It also alternates with mica-slate, and a peculiar coarse limestone forms beds in the argillite. The map separates the argillite from the mica-slate on the west by a continuous band of limestone and extends it eastwardly to include all the mica-schists which have been associated with the Bernardston limestone in later time, while the mica-schists on the eastern side of the river are associated with the mica-slate west of the argillite. (2, p. 36.)

The hormblende rock is separated as primitive greenistone in the north of Gill and south of West Northfield. (2, p. 31.)

1832. The limestone and magnetite beds which had been worked forty or fifty years before, but had produced poor iron, are described briefly in their economic aspect but without geological data. (4, p. 27.) It was supposed to form a bed in the argillite. Compares it in valne with a gold or silver mine.

1833. Fossils discovered in the limestone and figured (6, atlas, pl. 14, p. 47); and the limestone, though not seen in contact, supposed to lie unconformably upon the argillite. The quartz rock lying above the limestone,

${ }_{1}^{1}$ The numbers 1, 2, 3, etc., refer to the numbers above under the head of Literature. 
but not seen in contact, is noted. The complex foldings of the argillite are describerl and figured. (6, pp. 289, 295.) Concludes that the encrinal limestome is newer than the argillaceous slate.

18+1. Doubts are expressed as to the encrinal character of the fossils. The relations of the argillite, limestone, and quartzite described as before. $(\bar{\tau}, 1 \mathrm{p} .54,556,560$.

1851. Because of the discovery of an upper stratum of slate (the upper schist described below) beneath which the limestone passes, it is decided that the whole of the argillite together with all the series to the top of the upper schist of the section on page 258 is Devonian, in accordance with the determination of the crinoids by Prof. James Hall, who thought them to be of the age of the Onondaga limestone. (10, p. 298.)

1858. Bermardston and West Northfield are divided about equally by a north-south line between argillaceous slate on the west and hornblendeschist on the east, with the number for mica-slate entered on the area of the latter; but not subdivided from the rest. Limestone and iron ore marked. (11.)

1861. While the preceding history has dealt entirely with the work of President E. Hitchcock, I understand, though it is not distinctly stated in the chapter in question, that the report of the Vermont survey was based upon the studies of Prof. C. H. Hitcheock, and I have so indicated above

Under the heading "Upper Helderberg Limestone" is given the best section yet published of the rocks in question, containing every bed of importance except one, and indeed one bed, D, a clay-slate immediately above the limestone, which does not exist. All the beds from the argillite up are made conformable, but no other indication is given in the chapter as to how much of the series is assigned to the age indicated in the heading. The upper quartzite (that is, the quartzite east of the limestone on the Williams farm) is suspected to rest unconformably upon the argillite in Vernon, the intervening members being absent, and on page 598 of $\mathrm{Vol}$. II this quartz rock, with the gneiss into which it grades, is assigned to the Devonian age, from its identity with the upper quartzite of the Williams farm section. Attention is called to the fact that an upper schist resting upon the quartzite-it is described as a "distinct clay-slate, thicker-bedded and harder than most clay-slates" - is not elsewhere seen resting upon the quartzite. This I have not found to be true. (12, Vol. I, p. 447; Vol. II, p. 598.) 
1870. Prof. C. H. Hitchcock classes the argillite as Upper Silurian, and the Bernardston series is "doubtfully referred to the Devonian." "Both above and below are quartzites not of great thickness, and also slates." $(13$, p. 4.)

1873. Prof. J. D. Dana pronounced the argillite to be an older formation lying unconformably below the other members of the series, as supposed by E. Hitchcock in 1833 for the argillite in relation to the limestone-an opinion receded from on the discovery of an upper band of slate-and by C. H. Hitcheock in 1861 for the overlying quartzite. From the close resemblance of the mica-schist and quartzite on the other side of the Fall River Valley to that on the Williams farm, he assignis to the age of the Helderberg these and the new rocks associated with them, viz, staurolite, mica-schist, hornblende rock, and feldspathic quartzite, which comes at last closely to resemble true gneiss.

He concluded that the Coos group of Professor Hitchcock, if correctly traced out, was the continuation northward across New Hampshire of the Helderberg rocks, and that the two bands of hornblende rocks marked upon Prof. F. Hitchcock's geological map of Massachusetts as extending across the latter State, with their continuation southward in Connecticut, as described by Percival, where they pass beneath the New Red sandstone near Middletown, and emerge again west of New Haven, were possibly to be assigned to the same horizon.

1877. In 1877 Professor Hitchcock, first in abstract in the American Journal (16), and later in the Geology of New Hampshire (17), gave the result of a new investigation of the region in question, which diverges in a remarkable degree from his own and his father's conclusions and from those of Professor Dana. Accepting the conclusion of the latter that the argillite is an older and unconformable bed beneath the strata in question, he claims that the limestone "does not certainly dip beneath the quartzite," but "may be a remnant of a once extensive deposit covering both the other formations mentioned, and what remains is in an inverted position," and thus is newer than all the other rocks of the region. This decided change of opinion caused a discrepancy in the volume already cited, as, in the earlier part, the series is stated to consist of several thonsand feet of quartzite, limestones, schists, etc., and probably hornblende-schists. p. 18.) 
In his matured conclusions (17, p. $428 \mathrm{ff}$ ) the gneissoid rocks which in the Vermont report are stated to appear to pass imperceptibly into the quartzites, and to rest invariably upon them, and therefore to be newer (12, Vol. Il, p. 598), are classified as Bethlehem gneiss, and thms assigned to the Laurentian. The band of this gneissoid rock crossing the State line west of South Vemon is marked on the map (17, Pl. XVIII) as Bethlehem, but in the atlas to the same volume, prepared later, it is colored as Coos quartzite, but left in the section at the foot of the sheet as gneiss.

The hornblende-schist is next described, and its extension sonthward through Gill pointed out, and it is referred to the same horizon as the Shelburne Falls, Massachusetts, band, and both are assigned on the scale of colors of the map to a position below the Huronian. The argillite is described as Cambrian clay-slate-that is, as Primordial Silurian.

The remainder of the series on both sides of Fall River and east of the Connecticut through Northfield-quartzite, mica-schist, and stauroliteslate-is assigned to the Coos group, and this is placed, in the stratigraphical column at the end of the book, beneath the calciferous mica-schist, and to the whole is given a position in the Paleozoic series above the Cambrian and below the Lower Helderberg.

Professor' Hitchcock calls attention to one very important matter-the absence of staurolite, hornblende rocks, and feldspathic quartzite from the Villiams farm section, and their presence, with the absence of limestone, on the other side of the narrow Fall River Valley. In his final column of the rocks of the State $(17$, p. 674) a thickness of 500 feet is assigned to the Helderberg, which is not clear if only the limestone is to be assigned to that age.

During the same summer I visited this region with Professor Dana and we went over the ground between Bernardston and South Vernon together, examining the Williams farm section carefully. I then called his attention to the lower stratum of schist beneath the limestone, and soon after detected fossils in the quartzite over the latter. These we found to be quite abundant. On his return Professor Dana gave the results of this examination and controverted the conclusions of Professor Hitcheock in a somewhat polemical paper (18), giving in some detail the earlier opinions of the latter, and deciding that, since the quartzite was both fossiliferous and conformable upon the limestone, the two could not be brought into their MON $\mathrm{XxIX}-17$ 
present position by faulting or inversion, and since the schist occurs both below and above the limestone in apparent conformity, one or other of the beds must be newer than the latter.

Both of the members of the Coos group being thus proved to be of the same age as the limestone-the quartzite by containing fossils and the schist by conformity with the latter and with the limestone-numerous examples of visible and conformable conjunction of the hornblende-schist and gneiss with both the mica-schist and the quartzite in the area between Bernardston and South Vernon are given, together with instances of the passage of the one rock into the other, in proof that these rocks are there all of Helderberg age.

Order of succession of rocks in the Bernardston region.

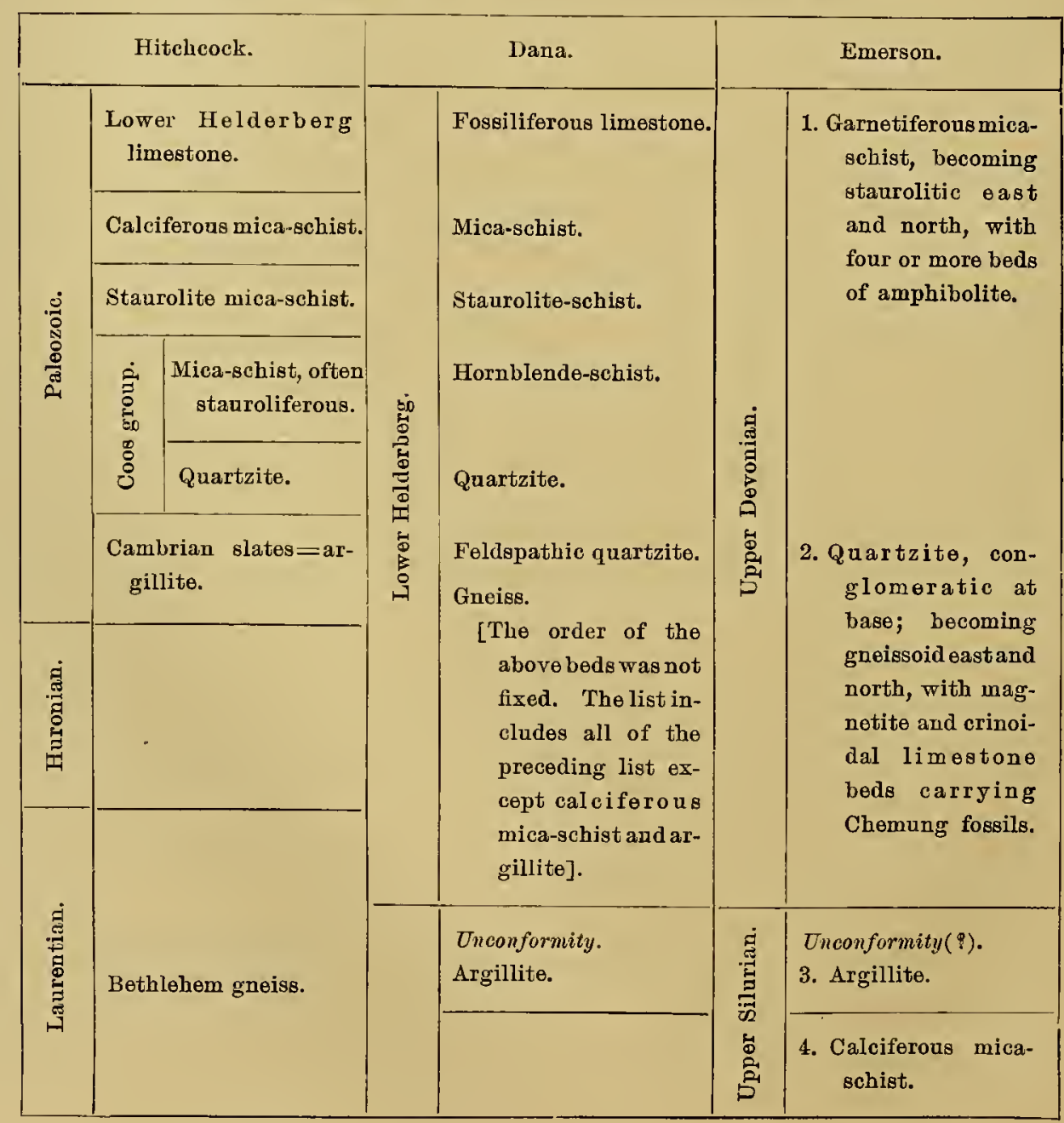


Profesor 1)ana says (18, p. 381, note) that Professor Hitchcock's "later conchusions have been influenced by his faith in the lithological test of geological age and his unbelief in the existence of gneisslike metamorphic rocks of later date than the Cambrian;" which I can not think wholly just, since the latter, upon his atlas map, classes the wholly gneisslike band upou the north line of the State and the quartzite, together with the staurolite-schist-indeed, all the rocks in question except the hornblende-schistwith the Coos group, and places this among the Paleozoic rocks in his final scheme at the end of the Geology of New Hampshire, Vol. II. The discrepancies are, however, sufficiently great between the interpretations of the two authors, and I have placed in parallel columns their views and ny own of the true order of succession of the rocks in the area in question. See also the section on page 285 .

1883. Mr. Whitfield (19) concludes, from an examination of the fossils, that the limestones may be Middle Silurian; the shales (i. e., the thin-bedded, rusty quartzite immediately above the limestone) were most probably Middle Devonian.

1890. The results reached by the writer were prolished in the American Journal of Science (20); but as several errors unfortunately escaped his notice, the substance of the article is reproduced below in a corrected form.

\section{THE UPPER DEVONLAN AGE OF THE BERNARDSTON FOSSILS.}

Prof. John Mason Clarke has been so kind as to reexamine the fossils, and as he is familiar with the locality his conclusions may be considered as settling the age of the series with a large degree of probability. All the fossils of the upper bed of shaly quartzite occur also in the upper part of the the limestone, and it is not possible to separate this continuous limestone mass.

Professor Clarke writes me as follows (January 28, 1895):

The impressions left by the fossils are so distorted, obscure, and closely packed together that a little imagination can construe them into species of all sorts of ages, but I feel reasonably secure of the following points:

First. The prevaleuce of a large spirifer, with moderately strong dental plates, like S. granulosus Conr. of the Hamilton group, or S. disjunctus Sow. of the Chemung.

Second. The presence of Microdon, probably abundant among the distortions, but recognized in a single instance. The species is uncertain, may be Hamilton, Ithaca, or Chemung. 
Third. A well-defined Palæoneilo, with coarse surface striæ (I obscured the impression somewhat by taking a squeeze from it). There are species throughout the Middle and lower Upper Devonian of a similar character.

Fourth. Well-defined Camarotcechias, like Rhynchonella sappho and $R$. congregata, too obscure for specific identification.

Fifth. A recognizable fragment of a large Actinopteria.

Sixth. The "tricircled encrinite" of Eaton and Vanuxem. Though only a crinoid column, this is, 1 think, the safest horizon-marker visible; at least its association with the other fossils mentioned helps to a close approximation to the age of the fauna. Its stout calcareous body has often preserved it from the distortions which have wrecked the associated fossils, and its characteristic expression as it occurs in the lower Chemung and Ithaca beds is well reproduced here.

Thus I believe we are justified in assuming this fauna from the shaly quartzites to be of Upper Devonian age; no change from the old conclusion, but a better fortified opinion.

\section{DESCRIPTION OF THE REGION.}

The terrace sands of the Connecticut River are narrow upon its western side, where the river crosses the State line, and they continue with little increase of width for 4 miles southwesterly, and then, as they enter Bernardston, their boundary upon the older rocks turns abruptly west and runs for 7 miles a little south of west, past the village of Bermardston and along the north line of Greenfield. (See Pl. IV.) Bernardston village stands just in the middle of this line and at the mouth of a narrow valley, up which a lobe of the alluvial sands reaches northwardly for nearly 2 miles. On the west this valley is bounded by the high ridge of West Mountain, made up of the contorted argillite, which stretches in a narrow band far north across Vermont and disappears below the river sands on the north line of Greenfield, appearing again only in the limited outcrop just west of the village of Whately, 15 miles farther south, and in one newly discovered at the mouth of Mill River. Everywhere the slope of West Mountain shows only the black argillite, except in a single band back of the house of Mr. F. Williams, a mile north of the village, where, apparently resting upon the argillite, occurs the fossiliferous series. The section has a width going up the hillside on the line of dip of only 3,445 feet. The outcrops of the argillite to the north and south show that there can be only a very limited amount of the newer series preserved upon the hillside, while the heary accumulation of till generally prevents one's seeing its limits or its contact 
4

2 



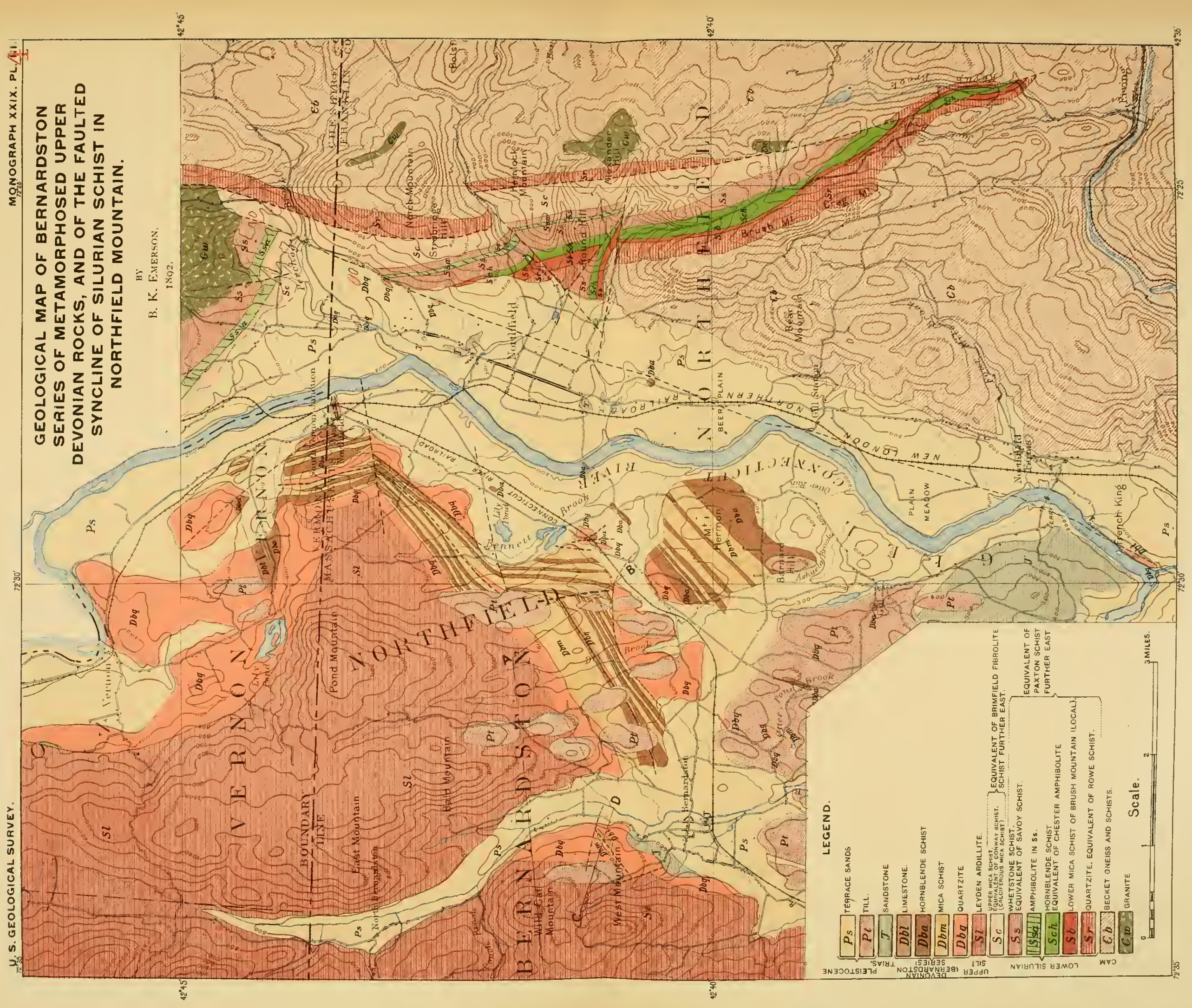



upon the rock below. It approaches the argillite quite closely upon the west, and in the line of strike can not be more than 9,850 feet long. Over aganinst West Mountain on the east, across the narrow valley of Fall River, rises a range of hills, bounded on the sonth and east by the terrace sands, which is composed of a similar series of rocks in similar succession. The principal clifference between the two is that on the east a dark homblende rock, often massive, takes its place in the series, wlile the limestone and magnetite beds of the typical section are present only in traces or in altered form, and all the other members are somewhat more metamorphosed.

Staurolite here occurs in the schists, feldspar crystals and biotite in the quartzites, and they are thrown into complex folds and greatly faulted. They lie, in fact, along the center of the great syncline of the Connecticut Valley, which is an area of maximum disturbance of the rocks quite across the State. These discrepancies become less important when it is noticed that hornblende exists in considerable quantity directly above the Williams farm limestone, and the second bed of the same limestone in South Vernon is encased in hornblende-schist, and several of the hornblende-schist beds can be proved to be altered limestone beds.

Across the river in Northfield the white saccharoidal quartzite extends to the base of Northfield Mountain, and is there bounded by a north-south fault, while only a single outcrop of schist is exposed.

\section{THE RELATION OF THE BERNARDSTON SERIES TO THE ARGILLTTE.}

It was originally assumed by President Hitchcock that the argillite and the schists of this series were conformable. Prof. J. D. Dana, ${ }^{1}$ finding the argillite about a half mile west of the limestone to lave a much higher dip, decided that they were unconformable to and much older than the upper series, and this conclnsion was accepted by Prof. C. H. Hitchcock. ${ }^{2}$ In tracing the distribution of the quartzite, $I$ lave given five localities where the boundary of the quartzite and argillite is well exposed (p. 273), and I could increase the number, and in each case there is apparent conformity and a uniform passage from the common argillite into argillite witl minute garnets and minute biotite spangles, fine-grained black quartzite grading

\footnotetext{
${ }^{1}$ Am. Jour. Sci., Vol. VI, 3d series, 1872, p. 343.

${ }^{2}$ Geol. New Hampshire, Vol. II, 1887, p. 433.
} 
into coarser quartzite, and conglomerate. The argillite is extremely corrugated and often cleaved, and observations of dip a rod from the contact are of no value in settling a question like this.

THE WIILTAMS FARM SECTION. THE FOSSULIFEROUS IIMESTONE. PROOF THAT THE WHOLE SERIES IS DEVONIAN.

The long band of the recks of the Bernardston series along the lower slope of West Mountain has been brought into its present position by extensive dislocations, and is plainly cut off by two transverse faults which run approximately in the brook gorge north of the limestone and in the larger gorge of Fox's brook half a mile south. The area between, containing the fossiliferous limestone, is the one here described. (See Pl. IV and fig. 15.)

Passing up the hillside back of Mr. Williams's barn, the first bed and the upper one on the section (fig. 16, p. 264) is a dark muscovite-schist (1), which is exposed in a single small quarry and separated by a depression which runs with the strike, and which I have assumed in the section to be occupied by the same schists and to have been formed by their erosion. The outcrops are almost continuons across the quartzite (2) and the limestone (4) which follows to the second outcrop of schist, where a similar depression separates the latter from the second band of quartzite, which I have in like manner supposed to be occupied by this schist.

Section of the Williams farm rocks.

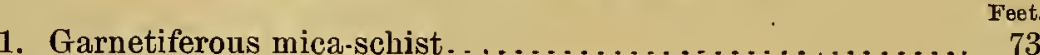

2. Micaceous quartzite and conglomerate............. 443

3. Magnetite, maximum . . . . . . . . . . . . . . . . . . . . . $3 \frac{1}{3}$

4. Limestone............................... $19 \frac{1}{2}$ Quartzite concealed beneath the limestone (?). Fuult.

$1^{\prime}$. Mica-schist . . . . . . . . . . . . . . . . . . . . 115

$2^{\prime}$. Quartzite and conglomerate, if conformable with the micaschist . ........................... 656

Argillite.

(The beds below the fault are a repetition of those above.)

The argillite (fig. 16, west end).-Beginning nearly a mile northwest of the Williams house, and just north of the point where the road over West Mountain bends sharply west, a long ridge of the typical, excessively con- 
torted argillite extends northerly. Listwand, a drumlin conceals its contact with the nower rock. It is probably a conformable contact of the argillite and the runtzite; as I have found it so everywhere in the region.

The western outcrop of the mica-schist $\left(1^{\prime}\right)$.-Where the series outcrops for the first time after crossing the drumlin a small area of the mica-schist of this series has recently cone to my notice. It is a garnetiferous mica-schist,

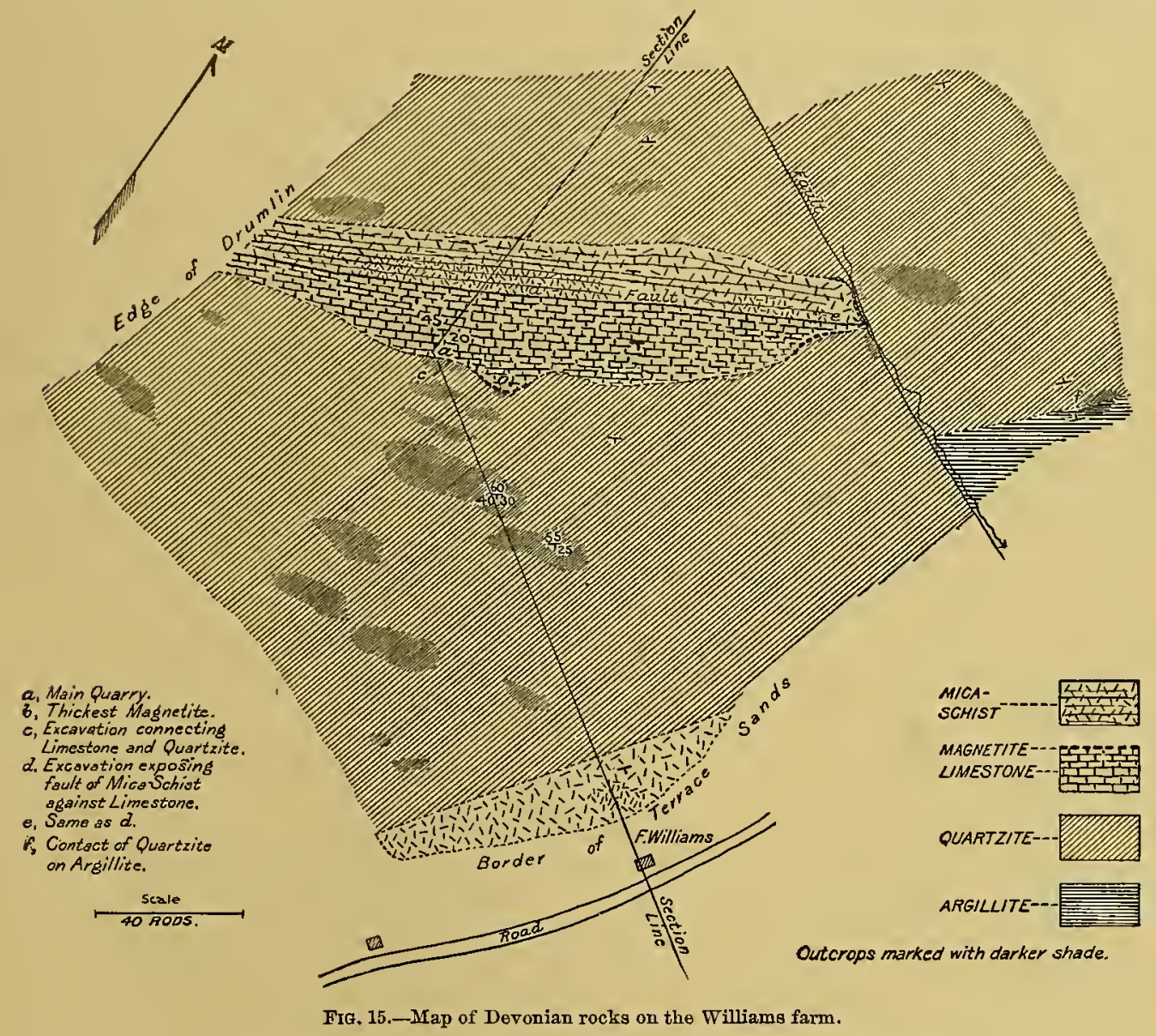

like the more eastern outcrops, and it lies plainly in a small syncline of the quartzite 10 rods south of the western end of a row of great chestnuts which crown the hill.

The western exposures of the quartzite $\left(2^{\prime}\right)$.- The discovery of the schist just described makes plain the structure of these quartzite ontcrops with their western dip. As the schist is in a small syncline, the quartzite makes a corresponding anticline on the east of this outcrop of the mica-schist. The 
rock is dark-gray quartzite, at times a conglomerate, weathering very rough, with strike and dip very irregular and uncertain, with many slight slips and crushings--indeed, often completely brecciated and recemented with limpid quartz. Locally it passes into a black siliceous slate by the microscopical development of biotite and the accumulations of coaly matter. A

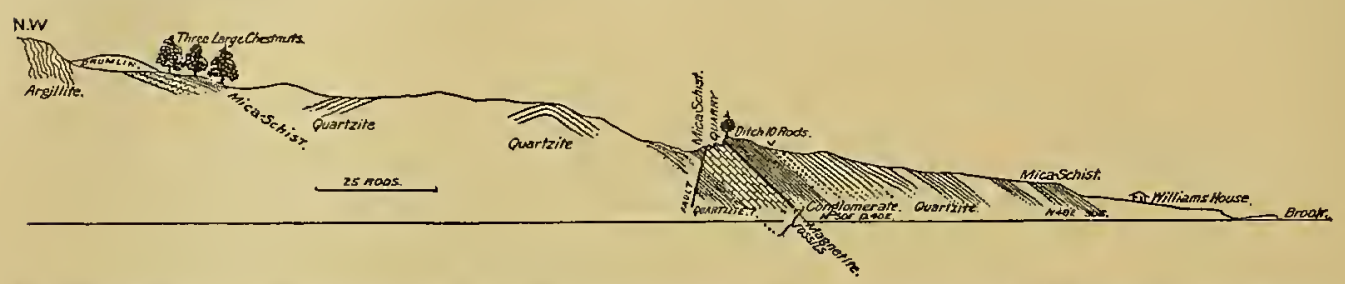

FIG. 16.- Section of Devonian roeks from the Williams farmhouse 250 rods northwest to the sharp bend in the road orer West Mountain, along the section line on map, fig. 15.

few scales of the former mineral can be seen with the lens. Up the hillside from the limestone along the line of dip, two small ledges of the rock appear, as may be seen from the section, widely separated from each other and from the rocks above and below.

It is not difficult to find among the less crushed portions of each ledge

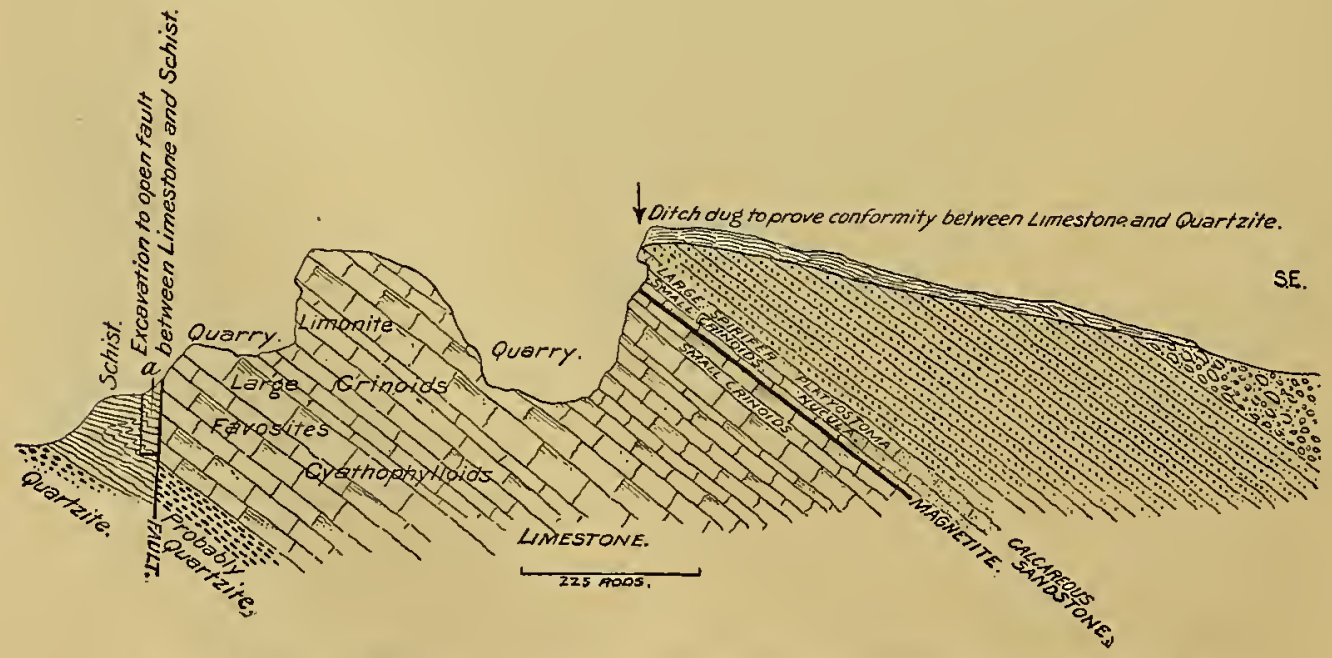

Fra. 17.-Section of the Williams farm quarry; an enlargement of the center of fig. 16, at $a$ of fig. 15.

pieces which agree exactly with the quartzite above the limestone, especially that which outcrops a few meters above the latter, and its peculiar appearance is largely due to crushing and infiltration of quartz. The same result 
is reached by eximining the quartzite ledges along the strike north and soutl from this point and comparing them with the "upper quartzite."

The mict-schist west of the limestone (1').-This rock, like that east of and above the himestone ( 1 of tho section) is a dark, even-bedded muscorite-schist, so fine-gramed as to be almost indistinguishable from the evenberkderl varieties of the argillite below, with its glistening surface pitted here and there by minute hollows from which small red dodecahedral garnets have fallen out. It is abundantly marked by small bodies, which appear much like minute altered chiastolites barely visible to the oye. It occurs only at the bottom of the slope just west of the line of excavations for limestone. (See "Petrographical description," No. 14, p. 291.)

Fault between the schist and the limestone (d, fig. 15).-The bed last described apparently dips $25^{\circ}-35^{\circ} \mathrm{E}$. under the limestone, with the strike N. $70^{\circ}$ E. But just opposite and northwest of the largest excavation in the limestone, under a small apple tree, where the schist seemed certainly to go under the limestone, and where Professor Dana and I once dug down and followed it for 6 inches under the limestone, I had excavations made at a later time, having doubted the reality of the apparent conformable superposition because the bed of limestone rested on the schist with abrupt transition and total want of continuity. I found the two rocks to be faulted against each other, the wall of the limestone bending under for a few inches and then going down vertically, and the schists, so flat in the exposures below, were here crumpled up sharply and ground into shapeless masses against the limestone. I followed the fault down nearly 4 feet without finding the bottom of the limestone, but mingled in the crushed schist I found fragments of the chloritic rock which lies in the limestone and is exposed in the bluff to the north (fig. 18). At a later date I had further excavation made, uncovering the northern bluff, where also the micaschist approached the limestone at its northern end, and I exposed here a zigzag fault line between the schist on the west and the black magnetitepyrite-chlorite-limestone, and below this between the schist and the white limestone itself ( $e$, fig. 15). The fanlt plane is nearly vertical. The relation of the beds at this point are made plain by fig. 18 (p. 266).

The limestone.-The limestone, which forms the center of interest of the section, is exposed in many old pits, extending from the bluff overlooking the brook to the largest opening overhung by birches, where the rock is 
most fossiliferous; and the line of outcrops is continued by more seattered openings farther southwest. It extends in all abont 407 feet from northeast to sonthwest-that is, along the line of strike. It is for the most part a coarsely crystalline, saccharoidal limestone, at times so coarse that cleavage pieces of calcite 3 inches across can be obtained from it. Below, it is in thick beds, with stratification mostly obliterated, while the upper portion for about $6 \frac{1}{2}$ feet is thin-bedded, finer-grained, and micaceous. The rock contains some pyrite, which, with the more abnndant deposit of the same in the bottom of the quartzite, has been the source of the great amount of porous limonite which fills broad veins and great cavernons spaces in the limestone. Its modern formation is attested by the rootlets, changed into limonite, inclosed in it.

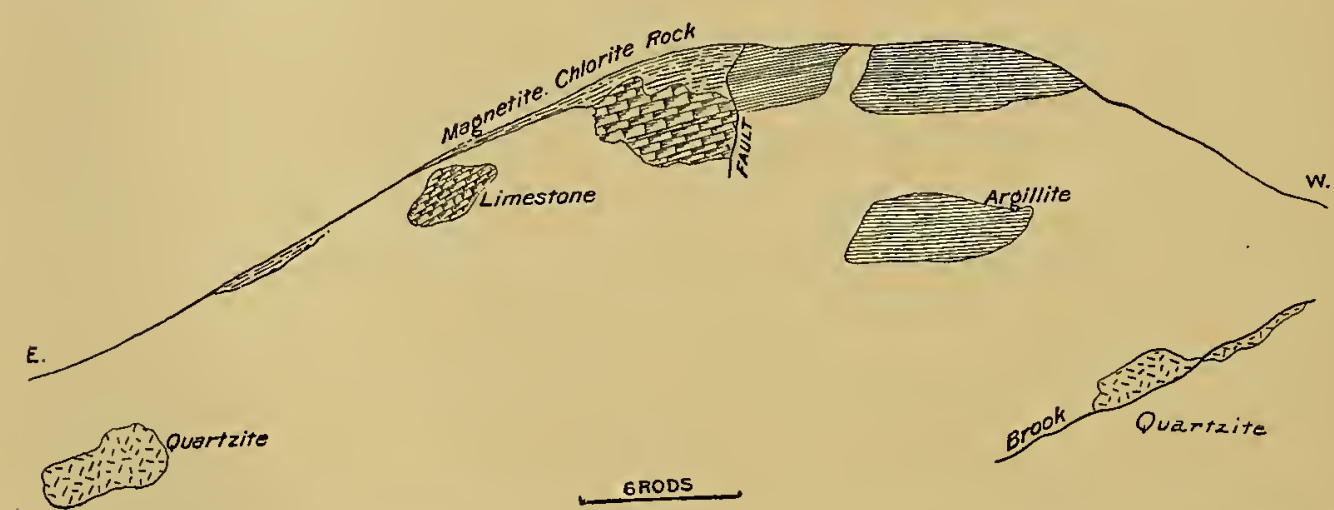

FIG. 18.-Section at north end of limestone, Williame farm. The two lower ontcrope of quartzite are separated from the rest of the section by an east.west fault.

To turn over a mass of coarsely crystalline marble and find the weathered surface covered with crinoid stems or corals makes a strange impression upon one. In masses showing no trace of fossils these are brought ont equally well in thin sections, and I have even observed a fragment of the shell of a brachiopod preserving the punctate structure, the pores agreeing closely in position and measurement with those of modern genera.

In the section, fig. 17, all the fossils known are assigned to their proper horizon, so far as possible. I would especially note the fact, to which my attention was first called by Prof. J. M. Clarke, that the line of division between the two paleontological horizons represented falls well 
down in the limestone, and that the upper 3 feet of the latter is thin-bedded and lacks the forms found below, while it carries the peculiar annulate crinoid stems found also very abundantly in the quartzite above.

The shaly limestone is in places much fissured, and is cemented at times with veins, one-fifth to two-fifths of an inch wide, of a completely granitoid mixture of quartz and muscovite, the plates of the latter extending quite across the vein, while the cemented rock still shorrs abundant crinoid stems. The limestone contains: $\mathrm{CaCO}_{2}, 98.38 ; \mathrm{Fe}_{2} \mathrm{O}_{3}, 0.62$; $\mathrm{SiO}_{2}, 1.00$.

The marnetite bed.-In the largest opening under the main group of birches the limestone for the upper 3 inches is impregnated with magnetite, and the quartzite above this is fossiliferous. Fifty feet north the ferruginous horizon swells out to a thickness of $3 \frac{1}{2}$ feet, and is here represented by a bed of porous limonite. At the same distance farther north it is a bed of finegrained magnetite, often pyritous, in one place garnetiferous, and 3 feet thick. It is of limited extent, but furnishes blocks of ore not to be distinguished from Laurentian magnetites. Analysis indicates phosphorus as well as sulphur.

A little farther north, where the base of the quartzite is exposed over the thickest magnetite, it is a dark-gray quartz-schist, abounding in pyrite, much crushed, and having the fissures covered with small, fresh rosettes of gypsum crystals and with drusy crusts of a mineral of earlier formation, now much decomposed, which seems to be prehnite; but owing to the small size of the erystals (one-fifth of an inch) and their altered state they could not be certainly determined. 'The form of the crystals is peculiar. It is as if each were made up of half a dozen long, square prisms, bounded above by a dome and placed side by side, producing a form like a section of a thick saw blade or the milled edge of a coin.

At the point where the magnetite is thickest- $3 \frac{1}{2}$ feet-I exposed, by digging, its contact with the limestone below and with the quartzite above, and found it to pass gradually into the white limestone below and to grade above into a layer, 1 inch thick, of a compact, grayishblack rock, rusting red and glistening under the lens with fine biotite. Under the microscope it proved to be a granular limestone. (See "Petrographical description," Nos. 8 and 10, p. 289.) The rock grades into the black pyritous quartzite above; all the beds are so entirely 
continuous and undisturbed that it is impossible to think of faulting or any irregularity at the junction any more than at the opening farther south under the birches, where the junction is equally undisturbed. The paleontological evidence reenforces the stratigraphical for the continuity of the limestone and the quartzite. At its northern end, overhanging the brook in the most northerly digging, the magnetite layer is a black magnetite-pyrite-chlorite rock. (Fig 18, and e, fig. 15). This rock which caps the limestone contains amplibole, biotite, chlorite, a little pyrite, magnetite, and hematite, and an amorphous mineral resembling serpentine. The biotite is very dark-colored in basal sections, and in places changes into chlorite and passes at the edges into the serpentine-like mineral. In the larger part of the section the latter has a fibrous structure, with the fibers, grouped into large, elongate patches, at times radiate, and the whole resembles a fine hornblende-schist. It is of oil-green color, shows only in patches a trace of dichroism, and with polarized light there is a faint predominance of extinction at about $3^{\circ}$ from the long axis of the fibrous groups, which proceeds from the whole group; and this is overlain, as it were, by the aggregate polarization of the fine scales and needles of the serpentine-like mineral. An analysis made for me by Mr. G. H. Corey, of the class of ' 88 in Amherst College, gave: $\mathrm{SiO}_{2}, 42.56 ; \mathrm{Fe}_{2} \mathrm{O}_{3}, 44.25$; $\mathrm{CaO}$, $13.11=99.92$. The absence of magnesia from this analysis is puzzling, as the product of decomposition of the hornblende resembles serpentine strongly. It is possible that a highly ferruginous amphibole has developed in the magnetite-calcite bed, and that this has changed into a ferruginous mineral allied to chloropal.

The eastern bed of quartzite (2).-Under the birches, as presented in the section (fig. 17), $3 \frac{1}{4}$ feet of a thin, evenly laminated, light-gray quartz-schist caps the limestone and is very rusty, especially at the base, and porous from the amount of pyrite and calcite that has been removed. Two-thirds the way up a layer of about 4 inches thickness is crowded with flattened and distorted casts of brachiopods and of annulate crinoid stems. A large spirifer with septa like $S$. disjuncta is very abundant. Traces also of Rhynchonella and Orthis are common, of Nucula and Platyostoma rare, and the ringed crinoid stems are again very common. The fossiliferous part of the bed is of very limited lateral extent, and I could trace it only about 10 feet.

The next outcrop, 150 feet east and about 6 feet above the bed just described, is a hard, gray, quartzose conglomerate, with white, flattened quartz 
pebbles one-hilf to 1 inch across. Under the microscope the rock is seen to be male up of angular grains with large cavities filled with water, containing spherienl, highly refringent globules with moving bubbles. It carries also curbonaceous natter in globules, magnetite, pyrite, a little hornblende, and muscovite, the latter forming the partings between the pebbles. It resembles much more closely the highly altered quartzite described above (p. 263) than it does the rest of the quartzite above and below it. The quartzite continues very compact, vitreous, and unevenly bedded for 66 feet down the lill, and in its upper portion carries garnets. It then becomes thin-laninated, separating into layers about $1 \frac{1}{4}$ inches thick, which are in fresh cross-section white to bluish, vitreous quartz, and the surface of the plates is coated with muscovite. It is finely jointed and the surfaces of the broad plates are somewhat warped, giving varying dips. Higher up it is cut by great veins of quartz, and in the last outcrop before reaching the easter'n outcrop of mica-schist it is again a compact quartzose conglomerate. The strike of the rock averages $\mathrm{N}$. $60^{\circ}$ E., but varies between N. $25^{\circ}$ E. and N. $70^{\circ} \mathrm{E}$. The dip is generally $30^{\circ}-35^{\circ}$ E., but varies from $25^{\circ}-50^{\circ}$. At the large quarry a single surface 10 feet square gave $25^{\circ}$ above and $42^{\circ}$ below. (See "Petrographical description," No. 9, p. 289.)

Conformity of the limestone and the overlying quarzite.-Since the limestone, the magnetite baud, and the ferruginous quartzites immediately overlying the latter are visibly conformable and all contain the same fossils, as several times indicated above, there remained in this direction only one question unanswered, namely, What is the relation of the series exposed in the large quarry at the birches and mentioned in the last paragraph to the quartz-conglomerate with flattened pebbles, exposed 150 feet to the east, and thus to the whole mass of the eastern quartzite? The latter seems much more metamorphosed than the quartzite at the quarry, and it might be urged that a fault intervened between the two. On the other hand, the conglomerate is typical of that extending from this point northeast to South Vernon and thence north nearly to Brattleboro, and the exact proof of their conformity would greatly enlarge the value of the limestone for fixing the age of the rocks. For this reason I had pits dug 10 feet apart from the top of the rusty quartzite to the nearest outcrop of the conglomerate to the east, and found the quartzite apparently continuous and no indication of any fault between the two. 
As this did not wholly settle the question, I had a trench dug exposing the ledge the whole distance from the fossiliferous quartzite to the conglomerate. It exposed a continuous surface of the black shaly quartzite for 154 feet and conglomerate for 10 feet, with strike N. $50^{\circ}$ E., dip $40^{\circ}$ E.; each layer dipped conformably beneath the succeeding one, and all were fused together into a continuous stratum, and the possibility of any fault was wholly excluded. (See fig. 16, p. 264, and $c$, fig. 15, p. 263.)

The upper outcrop of the mica-schist (1). -This outcrop occurs 164 feet east from the uppermost outcrop of the quartzite, in a single small ridge 131 feet long and 66 feet wide, with strike N. $48^{\circ}$ E. $\left(41^{\circ}-50^{\circ}\right)$ and dip $30^{\circ}$ E. $\left(25^{\circ}-34^{\circ}\right)$. (Fig. 16, east end, and fig. 15.)

It is a dark-gray, fissile muscovite-schist splitting into thin slabs. Its surfaces are pimpled with small garnets and biotite crystals, or pitted by the cavities left when the crystals remained in the adjoining slab of schist; and it carries abundantly small, dark-brown biotite crystals-long prisms with rounded angles 1.5 by $2.5^{\mathrm{mm}}$, placed generally with their broad cleavage face at a large angle to the bedding plane of the rock, and therefore visible only as dull-black lines on the latter plane, but as shining-black scales when the slab is broken across. In tracing the same rock across the valley it was observed that the great majority of the scales' lie with their flat surface normal to the line of strike and with the longer diagonals, here greatly elongated, parallel to each other and in the same plane with the dip-a phenomenon entirely comparable with the "stretching" of gneiss, and indicating a pressure and an incipient structure at a large angle to the present foliation.

Microscopically the rock shows exactly the same scaly, coal-dusted mass, consisting largely of muscovite plates irregularly bounded, as does the schist $\left(1^{\prime}\right)$ adjoining the limestone ( $d$, fig. 16), only on a slightly larger scale. The biotite crystals are also bordered in the same way by a layer of larger and purer muscovite scales, but not so constantly, nor is the layer so broad and regular. This produces the forms which on the surface of the rocks look like minute chiastolites.

The only microscopical distinction between the schists is in the somewhat larger size of the constituents and a slightly greater clearness of crystalline texture in the uppor, so that one can affirm more certainly the absence of any clayey matter. (See "Petrographical description," No. 15, 
p. 292.) Macroscopically the upper schist is somewhat thicker bedded and of more meven surface. A lens is hardly needed to see the muscovite scales on the surfice of the slabs, and the biotite and garnet are conspicuons and abundant accessories, instead of being only minute and, in the case of garmet, rare.

The syncline north of the brook in the Williams pasture.-(See north part of map, fig. 15, p. 263.) Within the area just described the rocks dip mostly to the east, while north of the brook the structure is decidedly different. A section east and west through the woods shows a great syncline of the quartzite in the argillite.

Following down the brook from the limestone to where the woods end, and then skirting the latter for a few rods north to where the first wood road enters them, a little way in and at the first outcrop on the south side of the road one comes upon a well-exposed contact of the argillite beneath and the quartzite above; strike N. $20^{\circ} \mathrm{E}$., dip $20^{\circ} \mathrm{W}$.; the - argillite flat-fissile, with few chloritized garnets; the quartzite a dark-gray indurated sandstone, becoming coarser higher up. The two beds seem to be plainly conformable. The argillite can be followed north to a point in the bluff opposite C. Frary's house, and has a uniform westerly dip beneath the quartzite, and on the west of the latter the argillite is found dipping easterly beneath it, though the junction is covered. I imagine this syncline is cut off on the north by a fault along the bed of Fall River, but the rocks are covered here. Directly opposite the limestone across the brook to the north the quartzite contains dodecahedral garnets one-half inch across, bordered by chlorite.

The outerop along Fox Brook south of the Williams section.-On the road over West Mountain, behind the first house after leaving the village, there is seen from the road a bare bluff of blue till, and below this is an outcrop in the brook of Triassic sandstone. Twenty rods above this the quartzite rests conformably upon the argillite, which contains a few garnets just below the junction. It strikes $\mathrm{N} .60^{\circ}$ E., and dips $20^{\circ} \mathrm{E}$., and the boundary is thus pushed east by the whole width of the Williams section, though the fault which separates them can not be exactly located. 


\section{DESCRIPTION OF THE RANGE FRON BERNARDSTON TO SOUTH} VERNON.

Directly opposite the Williams farm and 200 rods distant, on the east side of Fall River, begins a range of low hills which run northeast between the two towns named above. This range of hills is backed on the northwest by a much higher range of argillite hills-Bald Mountain and Pond Mountain - and is bounded on the sontheast by the high terrace sands, through which one large area and many smaller islands of the rocks of the Bernardston series emerge. I have called this the West Northfield range, from the town in which it for the most part lies. The road running along the east side of Fall River skirts the range at its western end, and the main road from Bernardston to South Vernon borders it on the south and east, while the roads which branch from the latter and cross the range are named from some resident upon each, as given in Beers's atlas and as marked on the map, Pl. IV.

The mapping of this area was difficult, both because the rocks are thrown into great confusion, many beds being in places echeloned so that the local strike regularly disagrees with the general run of the bands, and because of the presence of several large drumlins which effectually conceal the underlying rock. The intervening areas are, however, so entirely free from drift up to the very foot of these hills that, were it not heavily wooded, the region would furnish abundant outcrops, and, as it is, the fragments on the surface can be safely used to determine the rock below. The series wraps around the argillite and uniformly dips away from it, generally at low angles, at first south, and then for a long distance southeast; then it swings sharply round, crossing the State line with dips a little east of north, making thus a great bend to the westward as it crosses the town of Vernon. I have not been able to prove the existence of folds or overturns, and the present position of the beds seems to be best explained as the result of very extensive faulting.

The argillite. - I have assigned to the argillite the broad area marked "Coos" upon Professor Hitchcock's map (17, Atlas), to which he also assigns the slates of the Bernardston series, because I have found that the boundary between it and the argillite to the west as given upon that map has no justification in any physical change in the character of the rock where it is drawn, and the argillite can be traced unchanged up to and dipping beneath 
the quartzite next described. It is true that minute scattered garnets and rery small stancolites are found sparingly in the rock in some places in this area, and these seem to have been relied upon by Professor Hitchcock in making the assignment of the rocks to the Coos; but the same garnets ean be found at times in the undoubted argillite in West Mountain, and these and the same minute staurolites occur in the center of the Whately argillite, and both the minerals are very different from their representatives in the Coos group. Both in macroscopical and microscopical structure the rock remains quite constant up to the quartzite, and in its finer grain, its darker color, its excessive contortions, and its abundant and large quartz veins it is well distinguished from the slates of the higher series.

The very remarkable projection of the argillite into the basal quartzite in Vernon, in the northwest corner of the Warwick quadrangle, is very clearly made out on the ground and is very interesting. (See map, Pl. IV.) It is well exposed on the high, bare hill north of the last house in West Northfield (M. Merrill's). The argillite dips everywhere outwardly under' the quartzite, and is greatly contorted and crushed and filled with quartz veins and combs.

The basal quartzite and conglomerate.-The position and extent of the basal quartzite gave the first clue to the complex stratigraphic arrangement of the series in its eastward continuation. Beginning at the point already described (page 272), opposite the Williams farm and east of the road to East Mountain (back of "Mrs. Haley's" on the old atlas map), with a strike due east, it has bent round to N. $65^{\circ} \mathrm{E}$. before it goes under the massive drumlin which lies east of the river, and on its emergence it is abundantly exposed with the same strike along the southern of the two northwest roads mentioned above, west of Dry Brook, especially south of A. G. Chapin's house. Taking the direction of this road across the valley of Dry Brook, it can be followed readily, with the same strike and low southeast dip, and physically mehanged, through the chestnut woods northwest of the end of Purple's blind road, east of Dry Brook. It crosses the first north-south road in Northfield at a point where a loop of the brook is cut by the road, and gradually bearing round to the north it passes the State line with a strike $\mathrm{N} .10^{\circ} \mathrm{W}$. It then makes a great sweep to the east, turns sharply on itself, goes south across the State line for a little way, and then swings round to the north at the foot of the high ground and continues northerly. MON XX1X-18 
Back of Mrs. Haley's, mentioned above, the rock is an obscurely bedded conglomerate of quartz pebbles in a dark ground containing much slaty material. The conglomerate here toward its base is exactly like the same rock west of the limestone on the Williams farm, and I have no doubt that they were formerly connected across the valley. Higher up the rock is a'pudding-stone, with rounded quartz pebbles up to 4 inches in length, but mostly 1 inch long; the abundant quartz sand and ground which wraps around them cleaves into thick layers coated with muscovite scales and iron rust, so exactly like the upper quartzite of the Williams farm, especially the conglomerate layer, that it is difficult to avoid the conclusion that they are parts of a single stratum. Calculated upon its average dip of $20^{\circ}$ the thickness of the bed is 400 feet, which is only a rough approximation.

In the field south of A. G. Chapin's house is an interesting outcrop. The rock is here jointed with almost mathematical accuracy into acute rhombs, the joint planes passing through the quartz and quartzite pebbles, and the latter are finely compressed and indented one by another. The rock here carries garnets one-fifth of an inch across. It is unchanged across Dry Brook for a long distance to the northeast, when it crosses the last road; but once over the range, at a point where the brook makes a loop across the road (near J. M. Pickett's), the pebbles are flattened out into thin disks resembling the small lenses of quartz common in crystalline rocks, making it possible that they are of secondary origin-a possibility which does not extend to the range described above. In the woods southwest of this point the rock in some beds is in appearance a fine-grained biotite-gneiss, with large garnets surrounded by a broad, annular, white space, in which the biotite is wanting, the iron being concentrated in the garnets. Farther north in the band the pebbles grow smaller, and where it crosses the State line it is at base a thin-bedded biotitic quartzite; higher up, a muscovitic quartzite. In some layers the muscovite becomes abundant and wraps around pencils of quartz, so that the rock obtains a rude columnar or ligniform structure. It has here an apparent thickness of 350 feet.

At the point already mentioned on the grist mill road (at J. M. Pickett's), where the brook makes a short loop across the road, at the south bridge, is a fine section in a high bluff west from the bridge. The conglomerate strikes N. $45^{\circ}$ E. and grades downward through 50 feet of 
quartzite into fine, nicaceous quartzite, and this into flat argillite with minute transverse biotites. The whole is well exposed and planinly conformable. Its dip increases from $22^{\circ}$ at the south end to $45^{\circ}$ at the north end, where the upper portion of the bed has this high dip, while the lower portion runs up on the argillite with the low dip of $20^{\circ}$. It thus folds around and dips away from a great promontory of the argillite; and it is blackened in many places by a remnant of the argillitic material.

All this is well exposed just north of the last house before the State line is reached (at M. Merrill's), and the argillite where it is nipped by the sharply bending quartzite is greatly crushed and filled with quartz combs. This boundary crosses the next road north-the old Bernardston-Vernon road-at a small abandoned house (two houses below the schoolhouse) where the brook comes nearest the road. Just behind this house, in the side of the brook, is exposed a most interesting junction of the conglomerate upon the argillite. Commencing at a ruined dam perhaps 15 rods from the house, we find typical argillite, which changes through a few feet of spangled schist into thin-fissile, black, muscovite-quartzite with some thicker, highly erystalline layers, and this grades into a highly muscovitic, very vitreous quartzite, which is at one place a conglomerate of rounded quartz pebbles 2 to 4 inches long. This is where the water falls over a reef 3 to 4 feet high, 2 rods below a wooden bridge. Immediately below is a bed of heavy hornblende rock, massive, in places showing a reticulated structure. Masses of this rock built into the piers of a wrecked bridge just behind the house show pebbles and contain also much green mica, often quite coarse; it resembles the more gneissoid rock found over the South Vernon plain to the river, and classed by Professor Hitchcock as Bethlehem gneiss. The series strikes N. $55^{\circ} \mathrm{W}$. and dips $45^{\circ} \mathrm{E}$. The outcrop is continuous and shows a gradual passage through a spangled argillite and fine-grained quartzite into conglomerate, often coarsely garnetiferous, the change being effected within 50 feet and showing no trace of unconformity. Many masses of a thin-fissile, pyritous magnetite occur here, but the bed could not be found in place. The magnetite, green mica, and hornblende rock suggest a repetition in the quartzite of a limestone band, perhaps on the same horizon as the Williams farm bed.

East of the boundary line just described, across Vernon to the river, the whole area is underlain by the basal quartzite except where the West 
Northfield schist series extends across the State line west of the village of South Vernon and where, across the brook, it rises in the hill back of S. Titus's, at which place the road to the Lily Pond branches from the Brattleboro road. The quartzite dips for the most part to the east except east of the Lily Pond, where a minor fold of considerable size occurs, caused. by the sharp bend on the State line, and here the beds dip south. Followed eastward it becomes more and more feldspathic and the muscovite is largely replaced by biotite, forming a completely gneissoid rock. It is here not distinguishable from the felclspathic quartzite occurring east of the West Northfield series, and described on page 282. (See "Petrographical description:" Nos. 1-4, p. 287.)

The Vernon limestone.-On the Lily Pond road, above mentioned, and just east of E. G. Scott's house, occurs a band of limestone. It is a coarsegranular limestone, highly crystalline, of light color, containing some garnet, hornblende, and green mica. It contains what seem to be distinct traces of corals and crinoids, and in every way closely resembles the Bernardston bed, with which I identify it without hesitation. Especially do the weathered surfaces show a peculiar, conglomerate-like structure common at Bernardston. Large, rounded fragments of a fine-grained, white limestone are cemented by a coarser and more highly crystalline limestone; the latter in large amount, as if the rock had been brecciated by pressure and the fragments then rounded by percolating waters and recemented. This bed is exposed about 30 rods, and may have a thickness of as many feet, but its boundaries are not well exposed. Toward the west it grades on the strike into a calcareous homblende-schist, and above that, to the south, through an actinolite-quartzite into a quartzite abounding in large garinets and blotches of a greenish mica, while below it passes into a very coarse, thick bed of hornblende-schist. (See "Petrographical description," Nos. 11-13, p. 290.) The whole series is inclosed in the gneissoid quartzite. This limestone is considered by Prof. C. H. Hitchcock to be an Archean limestone in Bethlehem gneiss. ${ }^{1}$

The mica-schist and hornblendic beds.-Resting on the basal quartzite and dipping from it with low angle to the south, southeast, and east successively, as it folds around conformably with it in the long distance from Bernardston to South Vernon, is a broad area of mica-schist with several bands-probably 
five-of horublende rock, a massive amphibolite, and a central baud of gneissoil quartzite. From the mequal rigidity of these rocks they are thrown into great confusion, and from the similarity of the rock in the separate bands the tracing of them is very difficult. As they are placed upon the malp a greater regularity appears than exists in the field, many bands being male up of the slightly shifted portions of what was originally one, and many minor faults being of necessity neglected.

In general the schist is in its lower portions finer-grained and more slaty, with small development of the transverse mica, without staurolite, and with quite small garnets, becoming above coarser, of rougher surface, and knotted with large staurolites.

At the south end, nearest the Williams farm, along the road east of Fall River and northeast of Bernardston village, the basal quartzite dips beneath a very fine-grained, flat-fissile mica-slate, which dips $20^{\circ}$ in the direction S. $10^{\circ}$ E., its surface sparsely pimpled with small garnets, but being without other accessories and closely like the western schist $\left(1^{\prime}\right)$ of the Williams farn section. A local bed of a dark, pyritous quartzite, slightly hornblendic, is marked in this band of schist, but could not be followed far east.

The lowest bed of amphibolite is followed by a second band of micaslate exactly like the first, which widens in outcrop easterly and passes with the same dip and strike beneath a massive, dark-gray to greenish-black amphibolite, greatly jointed, and this is exposed in a broad area nearly down to the main road running east from Bernardston and extending east to the house of S. J. Green, 100 rods west of the locality mentioned by Professor Dana. ${ }^{1}$ It contains a central band of dark limestone, at times a foot thick. The amphibolite is capped by a thin layer, never more than 3 feet thick, of a shining-white, arenaceous mica-schist, with scattered scales of biotite, and a similar layer was found to cap a similar hornblende rock in so great a number of instances between this point and South Vernon that it attracted particular attention. This white layer was found to pass in every case up into the common dark-gray mica-schist, and to differ from it only in the entire absence of coaly matter and magnetite; and it seems possible that the former may have been discharged by the ferruginons matter of the hornblendic band adjacent; that is, the organic matter may have been employed to reduce

${ }^{1}$ Am. Jour. Sei., 3d series, Vol. VI, 1873, p. 342. 
the iron oxides to the soluble form in which they were concentrated in the limestone bands as a preliminary. to their change to amphibolite. It is,

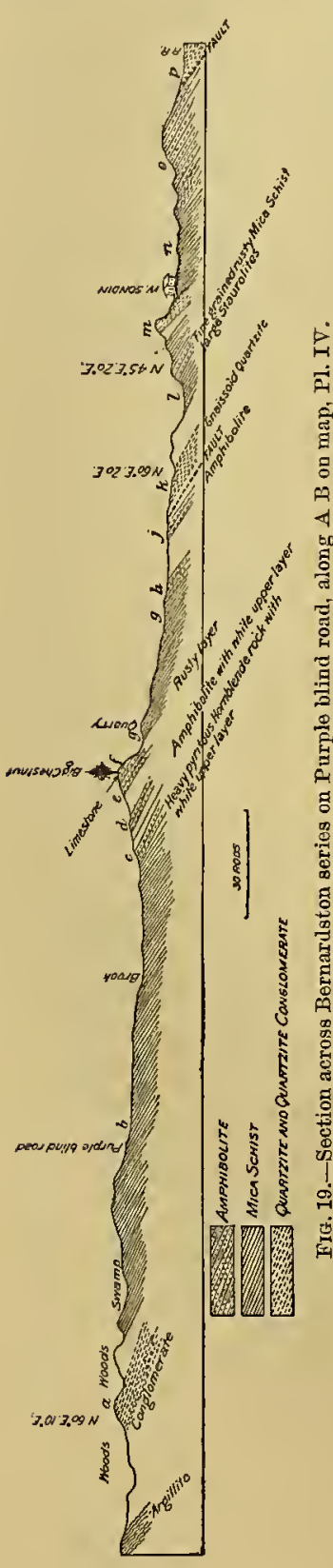
however, wanting below the hornblendic bands, which rest directly on the dark-gray and finer mica-schist. This makes it probable that none of the homblendic bands are overturned, though overturn may possibly have preceded the final metamorphism.

In places the passage of the amphibolite into the mica-schist is by alternate bands and thin lenses of the two rock varieties, and the passage beds may be 3 or 4 feet thick. This is more like the passing of one sedimentary layer into another than like the contact of an eruptive on a schist.

The schists of the area just described are cut off, going eastward, by a great drumlin, though the quartzite can be followed by its north end. Beyond, one finds sections which expose the whole thickness of the schists and amphibolite bands.

They are best studied in the area east of the Purple blind road (see map, Pl. IV, and fig. 19 for section, and "Petrographical description," Nos. 16-21, p. 293), where, commencing in the chestnut woods northeast of the end of the road, at the basal conglomerate ( $a$, fig. 19), we pass south over a broad area of the lowest mica-schist (b), broad because of the low dip, and come upon the lowest amphibolite (c), a band about 13 feet thick, here, as always, quite ferruginous and pyritous. Fifty feet beyond there is a second bed of the hornblendic rock (d) like the first, and both are capped by the white mica-schist layer described above. Farther on 66 feet, at the top of the ridge, near a large chestnut tree conspicuous in the open field, there is a third, rudely foliated layer of amphibolite (e), thicker than the others. This is capped by a bed 3 feet thick of a rusty limestone $(f)$, carrying abundantly cinnamon-colored garnet in large, shapeless masses and light-green pyroxene, and by a thin band of quartzite. The three 
beds of amphibolite mentioned are represented as one on the map, as they are near together, and the mortherly slope on which they appear approximates their outcrops still more. A long slope follows, with scanty outcrops of mica-schist (y), still fine-grained and without stanrolite, but with one sulall bed of :mphibolite (h), and at its foot streceeds a heavy bed of hormblendic rock, about 66 feet thick, which, by the quite abundant development of feldspar, is in large part a complete quartz-diorite-schist (i). Except for the appearance of feldspar in small, irregular, white spots, it does not deviate from the usual type of the hornblendic rock of the area. It is followed almost immediately, though the exact contact could not be found, by a bed, about 50 feet thick, of a fine-grained granitoid quartzite $(k)$. This is, indeed, in its whole extent a complete granitoid gneiss, never fissile, and faintly foliated only by the parallel arrangement of the biotite, or wholly lacking this even, and becoming a fine-grained, tough, granitelike rock, largely feldspathic and with many striated feldspar cleavage surfaces and light gray from the small amount of the biotite. It can be followed for a long distance, breaking off against a fault in the northeast direction and going southwest across Dry Brook. Its place between the two heavy hornblendic bands then seems to be taken by a very finegrained, massive quartz rock, with abundant fine scales of muscovite and with large, round plates of biotite set at every angle. It appears again farther northeast, at the last road across the range, and can be followed thence continuously over the high hill west of South Vemon station and across the plain in Vernon, trending here directly toward the point where the road to Vernon goes beneath the railroad. It is unlike the basal quartzconglomerate on the west and the feldspathic quartzite-to be described-on the east, and, conforming in dip and strike with the mica-schist and making all the curves with it, it seemed to me for a long time that it must be looked upon as a separate band in the mica-schist and could not well be derived, by folding or faulting, from the other quartzite. On noting, however, that all the beds grow more metamorphosed and more feldspathic as they go east, and that in nearly every case the eastern bands of quartzite are brought up by faulting and can be proved to be the same as the basal quartzite, it has seemed to me most probable that this band has been brought up in the same way and is identical with the basal quartzite. It is lithologically transitional between the quartzose conglomerates farther west and the feldspathic quartzites farther east. 
This interpretation reduced the number of the homblendic bands in the schists to 4 or 5 , in place of 8 or 9 , and this makes the structure of the whole region much more intelligible.

On the section line the quartzite band is followed by a heavy bed (100 feet) of a dark-gray mica-schist (l), much coarser than the beds below and carrying abundantly transversely placed biotite, small garnets, and large staurolite crystals, the latter in single crystals and in twins according to both the common laws. This greater coarseness of the texture and the great abundance of staurolite in the upper beds of the mica-schist are the rule through the whole length of the range, and militate against any attempt to make out repetitions in the series now gone over. This band contains one bed, and is capped by another heavy bed, of massive amphibolite. $(m)$, 65 to 80 feet thick, which rises in a prominent ridge overlooking an isolated house (W. Soudin's), and is followed by one more repetition of mica-schist $(n)$ and by a great bed and one or more smaller beds of schistose amphibolite $(0)$ before a fault is reached. Beyond this a broad area of feldspathic quartzite $(p)$-to be described later-continues to the railroad at the northwest conner of Gill. If the section is extended across Grass Hill to the Connecticut River it cuts first a broad continuation of this upper quartzite, followed by a complete repetition of the mica-schist series with five hornblendic bands, one feldspathic, the eastern sloping down the hillside from the Mount Hermon School buildings to the river, and thus covering a large area.

Sections carried across the area any where from the quartzite base southeastward give substantially the same succession as that detailed above, only for a distance east of this line there is a longitudinal fault and a repetition of the beds; so that, starting from the same point as the one chosen for the beginning of that line and going directly east to the sawmill on the South Vernou road, one passes nine distinct hornblende bands, and in almost every case each band is found capped by the whitish schist described above. Also along the State line and for a distance north and south, either by the thimning of the beds of mica-schist or by the slipping of the hormblendic bands over them, the latter are usually approximated, the three bands below the middle band of the quartzite coming into close proximity to one another and to the basal quartzite. The latter is separated by a broad mica-schist valley from a prominent hornblende-rock ridge just in the east edge of the 
wook looking down on South Vernon, which is subdivided by only very thin layers of schist. Still farther east, in the large pasture above the South Vemon Hotel, the beds are gruatly faulted, as indicited upon the map. ILere pseudonorphs-biotite after staurolite-occur and show well-formed twins, and a tourmaline granite containing coarse blue orthoclase cuts the schist and makes it gneissoid.

It illustrates the abundant fanlting of the region that at the two short railroad cuts in these beds there are in each case two marked faults, bringing quite distant beds into contact. Just south of the South Vernon station nearly horizontal mica-schist is faulted on the north against a dike-like block of massive amphibolite about 33 feet wide, and on the south an equally distinct east-west fault line separates the latter rock from the feldspathic quartzite, also nearly horizontal. At the next cutting, 3 miles farther. south, near where the road crosses the railroad, one band of the massive amphibolite is pushed over another, and the quartzite over both, so that they have a common dip of $25^{\circ}, \mathrm{S} .65^{\circ} \mathrm{E}$; but the fault planes are distinctly visible, and both the hornblende-rock bands are capped by the whitish schist layer which marks their transition into the common micaschist.

The type of the amphibolite or hornblende rock as seen in the area described above and in many bands stretching across the country to South Vernon-a type from which there is little variation-is a dark-gray to black, fine-grained, wholly massive rock, resembling so exactly, especially in its jointing, an intrusive diorite that it was connected with the Mesozoic diabase in the first work of President Hitchcock, and at its occurrence at the South Vernon station, where it is faulted between mica-schist and quartzite, it was called trap by so experienced an observer as Prof. C. H. Hitcheock, in his latest work on the area. ${ }^{1}$ The hornblende is generally arranged in radiated fibrous tufts just visible with the lens, which aid in giving the rock its great toughness. It is not prone to weathering and stands up generally in long ridges, the schists having been considerably lowered on either side of it, but at the railroad cutting in South Vernon the fissures were coated with an abundant deposit of calcite and pyrite. (See "Petrographical description," Nos. 17-20, p. 293.) 
Becanse of its position in the hollows between the hornblendic ridges the mica-schist, which really occupies more of the surface than the former, seems on casual inspection to be of subordinate extent and importance.

The thickness of the beds, calculated on the average dip of $22^{\circ}$, is: quartzite, 350 feet; mica-schist, 370 feet; hornblende rock, 508 feet; which is certainly far too large judging from the long line of outcrops farther northeast, and it is probable that each is partially repeated several times by cross fanlts.

I have elsewhere suggested that amphibolite beds of this type are generally derived from limestone, and in fact the hornblende bands are still locally quite rich in carbonates. At the locality first described above, just east of Fall River, the broad amphibolite band contains layers of limestone an inch thick; and farther northeast, at a large chestnut tree east of the end of the Purple blind road, there occurs in the same association a bed nearly a meter thick of impure limestone carrying garnet and pyroxene. The development of hornblende at the upper surface of the crinoidal bed has been detailed above, and the large development of hornblende in the quartzite surrounding the limestone in South Vernon points in the same direction.

\section{THE FELDSPATHIC QUARTZTTE.}

Reserving the question of the identity of this rock with the basal conglomerate, I may first call attention to its curions distribution as shown on the map, Pl. IV. It occupies a broad area along the eastern border of the schist series described above, everywhere dips away from it to the eastward with apparent conformity, and makes the same folds with it all the way from the State line south to the point where the main South VernonBernardston road crosses the railroad, even swinging round to a north-south strike with the schists. Beyoud this point it occupies a broad area stretching from the railroad across to the Purple blind road, east of Dry Brook, and is plainly separated from the schists on the north by a curvilinear fault. Thence it continues in a broad band sontheastward a long distance and can be followed in scattered outcrops across the sand plains into the town of Gill. Beyond Dry Brook it seems to regain its conformity with the schists. Across the narrow neck by which the West Northfield sands join those of Bernardston the same quartzite reappears in the northwest shoulder 
of Gratss Hill, and is appinently continuous nuler the sands with the larger area west of the raihoul. It dips under the hormblende rock to the east.

It is everywhere a fine-grained, light-gray, fissile quartzite, with small, fresh felelspar crystals porphyritically disseminated in it, often quite abumdiuntly. 'These reach $1-2^{\mathrm{mm}}$ in cross-section, and are often, but not always, striated. They are nuch larger than the quartz grains, and often have sharp crystalline outlines. (See "Petrographical description," Nos. 6 and 7, pp. 28s-289.)

In the area south of the great fault at the Purple blind road, and far west from this area, the rock is marked by an abundance of grains of lavender quartz included in it, which appear to have come from the pre-Cambrian gneiss of the Green Mountains, as I have found it characteristic of the Washington gneiss in western Massachusetts. Muscovite, so abundant in the lower quartzite, is wholly wanting; rarely a small amount of biotite in fine scales, or, at one outcrop, of hornblende in scattered needles, appears.

The dips of the rocks and of the slates below are so low, and, with the strikes, vary so rapidly and irregularly within narrow limits, that I am left in slight doubt as to the exact conformity of the two for any long distance. Along the line of junction for 2 miles north or south from the northern road over the range no contact of the two could be found, but in the whole distance they seem to be exactly conformable and to have shared all minor disturbances; for instance, although the rocks are tilted so that they strike N. $65^{\circ}$ E. and dip $40^{\circ} \mathrm{SE}$., they have also been subjected to an eastwest thrust, as is seen on a large scale farther south, so that small portions placed irregularly among the rest have a north-south strike, which is shared by both the schists and the quartzite.

The basal conglomerate, often blackened by argillitic material, is a rock of very different habit from this fine-grained, biotitic, feldspathic quartzite; but the description above given of the passage of the beds across Vernon indicates that the former passes into the latter eastward beneath the schists, and is then brought up by a fault along the easterm base of the schist series and in places thrust over the latter in apparent conformity. The fault line must be an exceedingly tortuous one, and the Mount Hernon series, on the east of this line, must be a repetition of the West Northfield series. The former series stretches from Otter Pond Brook, in Gill, to Mount Hermon, and contains the same succession of mica-schists and 
amphibolite. The southern band of the latter rock has a broad lateral extent, becanse its dip coincides with the slope of the hill.

THE BERNARDSTON SERIES EAST OF THE CONNECTICUT.

The adjoining area east of the river in Northfield is unfortunately so covered by the terrace sands that only few outcrops appear. I think that the rocks of the Bernardston series find their eastern limit, through the whole length of Northfield, Erving, and Montague, at the foot of the high ground which bounds the Connecticnt Valley on the east; that it ends without any marked shore deposits, but with great crushing of the fine quartzite, probably on a fault of great magnitude and extent; and, finally, that the quartzite-schists and amphibolite, which succeed to the east in the Northfield hills, though presenting some points of similarity with the Bernardston rocks, are to be associated rather with the series which lies west of the argillite and which is presumably older.

The quartzite in Northfield.-North of this village a porphyritic quartzite identical with the eastern band in the West Northfield range crops out along the eastern edge of the high terrace sands, but is immediately followed on the east by an older series, mentioned above. It is much brecciated, and abundantly cemented by hematite. It appears also in the brook bottoms; and just over the line in Winchester a shaft has been sunk a hundred feet in it for lead, which appears very sparingly in narrow, interrupted fissures a few millimeters wide, associated with barite and fluorite in equally small quantities, and at the bottom containing beautiful diuses of pale-yellow, saddle-shaped dolomite crystals. Below the surface the quartzite is snowwhite, but otherwise unchanged. The rock is a hard, white, saccharoidal sandstone, regularly porphyritic, with small, clear feldspars in stout rectangular cross-sections, for the most part striated and plainly of secondary growth, since they inclose sand grains. It is here everywhere massive. (See "Petrographical description," No. 5, p. 288.) Outcrops are seen in all brook beds in the northern part of the town, and it approaches nearest to the older series in a lane running east from the L. A. Moody homestead and along the Winchester road. It is here greatly brecciated and full of quartz and hematite veins. On the east of the boundary line several bands of the older series abut obliquely against this line, so that the quartzite on the west rests in manifest discordance, due either to unconformity or to faulting of the quartzite against the older series. 
The micr-schist in Northfield. - East of the river only a single limited outerop of mica-schist occur's, laalf a mile below the village, just opposite Grass Fill and 200 rods fiom the nearest outcrop of hornblende rock on the west side of the river. It agrees in texture with the lowest beds of sehist on the west of the Connecticut, is fine-grained, and carries ferw accessories. It abounds in flattened cavities, which seem to be the obscure traces of fossil shells, but they are wholly indeterminable, if, indeed, they be of organic origin at all. Upon the joint faces are abundant weathered crystals of a flesh-colored zeolite, apparently chabazite. The exact locality is by the brook crossing at a mill pond near the house of $A$. Billings.

\section{THE ORIGINAL CILARACTER OF THE SERIES AND ITS ALETAMORPHISM.}

The section below seems to me to represent the succession of the beds under consideration, the newest above.

Bedls of the Bernarlston series.

Upper Devonian:
1. Mica-schist.
2. Amphibolite.
3. Mica-schist.
4. Amphibolite.
5. Mica-schist.
6. Amphibolite.
7. Mica-schist.
8. Quartzite.
9. Amphibolite and magnetite, local, derived from the
Quartzite series... limestone.
10. Limestone, with fossils.
11. Amphibolite, derived from the limestone.
Upper Silurian :
12. Quartzite-conglomerate.
13. Leyden argillite.
14. Conway mica-schist.

Originally heavy beds of shale (13) were followed by a great series of feldspathic sandstones and conglomerates (12-8), which contained a band of crinoidal limestone, with here and there a local development of iron ore near its surface. Above this was an extensive series of shales $(7-1)$ with several intercalated beds of impure limestone. The first series has changed into a crumpled and cleaved phyllite, to which the name argillite has been for a long time applied. The second series has passed through all the 
changes to a gneiss so complete that Professor Hitcheock insists on associating it with the Bethlehem gneiss-quartzite with flattened pebbles, muscovite-quartzite, biotite-quartzite, feldspathic quartzite, often porphyritic, and complete biotite-gneiss, often becoming chloritic from superficial change.

The limestone has become most coarsely crystalline and the lime and iron have been carried far out into the quartzites above and below, to form amphibolites and complex hornblende-chlorite-pyrite rocks. The iron ore forms a bed of magnetite or a magnetite rock, probably precipitated as limonite at the surface of the limestone in the earlier stages of change, and then metamorphosed to magnetite later.

The upper series is changed to complete mica-schists, spangled with transverse biotite crystals, often loaded with garnets and staurolites, while the limestone beds are changed from the surface toward the center into amphibolite beds, abstracting the iron from an adjacent band of the shales.

The dips are all to the east and the beds are several times repeated by monoclinal faulting, and with each reappearance of the quartzite it is finergrained and more feldspathic.

The series has a slight pitch to the south, so that in Vernon the whole upper series tapers northward and disappears; and then in going eastward from the argillite we pass from the more quartzose conglomerates through muscovite- and biotite-quartzite to complete gneisses, as in the successive reappearances farther south.

The most abundant and characteristic fossils are Chemung with several Hamilton forms, so that the limestone, magnetite, and the base of the quartzite above the limestone may be placed with certainty near the base of the Chemung. That the whole series must go together is, I think, clear from the map and the preceding discussion. The suggestion of Professor Hitchcock that the limestone was bounded on both sides by faults ${ }^{1}$ proves true for the west side, but it is not true for the east side, and the important deduction made by him that the limestone was much newer than all the surrounding rocks is also disproved. ${ }^{2}$

'Am. Jour. Sei., 3d series, Vol. XIII, 1877, p. 315.

${ }^{2}$ Professor Hitehcock informs ine by letter of November 22, 1890, that he did not speals of two faults, as implied above, but held that the limestone was newer than the quartzite and infolded in it. A reference to the article above cited proves that no mention is made of faults, and I am at a loss to explain how I came to refer this opinion to Professor Hitcheock when the above paragraph was printed by me in the American Journal of Science in October, 1890, p. 374. That the limestone is newer than the quartzite is, however, clearly untenable. 
The argillite, though the oldest rock, is least metamorphosed; it is crumpled and cleaved with dull surfaces and is full of coal grains and kilolin, in its most eastern exposures showing minute pustules on its slaty surfaces, and at last developing garnet and biotite in sone abundance. In the western exposures of the Beruardston mica-schist series kaolin could scarcely be detected, and biotite, garnet, and staurolite were quite abundant but almost microscopic, while farther east the surfaces show clearly the muscovite sheen and the above accessories are abundant and large. In the Conway mica-schist, which lies below the argillite, the separate muscovite scales are clearly visible to the eye, and the same accessories occur still larger and with a very different and much more complex structure.

\section{PETROGRAPHICAL DESCRIPTION.}

THE QUARTZITE SERIES.

1. Micaceous quartzite from South Vernon, roadside east of Lily Pond, near the town line. A rather thin-foliated and somewhat fine-grained gneissoid rock, the broad and abundant films of a green micaceous mineral separating the white, fine-granular quartzose ground. This is the Bethlehem gneiss of Prof. C. H. Hitchcock.' In section the quartz ground is plainly clastic. The abundant scales of biotite are rarely brown at center, but mostly changed to green; and are much stretched, wrinkled, and raveled ont.

2. Another specimen from the same region, but nearer Lily Pond, has much more the aspect of a quartzite, but with the lens abundant fresh secondary grains of feldspar can be seen among the quartz grains, with many small garnets, octahedra of magnetite, needles of tremolite, and, in the foliation plane, scales of deep-green biotite. In section the quartz ground is plainly clastic, the feldspars secondary, inclosing many quartz grains.

3. A specimen from the roadside near the outlet of the same pond is a similar rock, showing here and there large blotches of green mica scales In section the fine clastic quartz ground contains many magnetite and garnet grains, fine filaments of tremolite with weak dichroism, biotite with very strong dichioism, yellow and very dark olive-green, the latter rarely changing to a light-green chlorite.

4. A specimen taken from a branch in the road between Lily Pond and the limestone (north of $\mathrm{E}$. Tylor's) is of less granular texture than the 
others and less foliated. It has been both more thoronghly crushed and more completely cemented by infiltrated quartz. In section it shows strikingly the effect of this crushing and cementation. The quartz ground is plainly clastic and like that of the other three specimens, but many secondary grains have grown into the interstices between the other grains, and the biotite crystals have rubbed out into thin scales, twisted and raveled out completely and, except in rare cases in the center of the larger fragments, changed from brown to green.

5. The quartzite east of the Connecticut, along Perchee Brook and at Rowe's mine, on the north line of Northfield A white, fine-grained, massive quartzite, friable to compact, containing galena, barite, fluor, pyrite, and dolomite in the abundant fissures. It resembles loaf sugar.

Under the microscope this is made up of clastic grains of quartz, among which the perfectly fresh and often idiomorphic feldspars, just visible to the eye as shining porphyritic spots, are plainly of secondary origin, being limpid at center and outwardly crowded full of inclosed quartz grains like those ontside. These are sometimes single crystals, sometimes polysynthetic, but usually formed of two individuals with observed extinctions $2^{\circ}$, $5^{\circ}$, and $16^{\circ}$ on either side the suture in different individuals. Most of these are carlsbad twins of orthoclase, and one section gave extinction of $21^{\circ}$, being cut parallel to M, exactly as in fig. 216 of Rosenbusch. ${ }^{1}$ Many grains of magnetite occur.

6. The middle ontcrop of gneissoid quartzite, east of the north end of the Purple blind road, Bernardston. A light-gray, fine-grained rock, almost massive, but with faint parallel structure from films of biotite. It has wholly the appearance of a fine-grained, gray gueiss; contains quartz, biotite, an untwinned feldspar, muscovite, lencoxene.

This shows under the microscope a completely granular; clastic mass of minute, rounded quartz grains. In this the rectangular and elongate sections of feldspar are plainly of later growth, inclosing often rounded quartz grains in large numbers, especially toward the outer portion. These feldspar sections are plainly visible with lens, are very fresh and clearly idiomorphic, and dotted often with the contained quartz grains.

The red biotite is also notched at the edges, from contact with quartz grains, and incloses many of the latter. It is constantly associated with the

${ }^{1}$ Mic. Phys., 1892, under Orthoulase, p. 633. 
lencoxene. There are many carlsbad twins and one very distinct ease of secomblary growth of a rounded grain of feldspar.

7. A fine-grinined, pepper-and-salt gneiss, slightly more granitoid and feldspathic thin the above, from West Northfield, on section west from South Vernon fair grounds, interrupting second homblendic band. It contiins the same constituents, together with grains of plagioclase, with the extinction uniformly $3 \frac{1}{2}-4^{\circ}$ on either side of the twimning plane. The orthoclase is more abundant, larger, wholly xenomorphic, and never twinned; it cements many quartz grains together. Leucoxene grains contain centers of ilmenite, and many grains of black ore appear.

8. Micaceous limestone from Willians farm, just above the magnetite bed at the opening where it is thickest. A black, compact roek, rusting red and glistening under the lens with fine biotite scales.

Under the microscope this is a granular limestone composed of subangular, equal-sided grains of calcite, many polysynthetically twinned. Biotite is regularly disseminated through the mass without being orientated to any plane, much as it is in the whetstone-schist, to which rock the one under examination bears a close resemblance in its microscopical appearance. This biotite is of so deep absorption that basal sections are wholly opaque except at the thinnest edge of the section, and then greenish-brown. A single crystal of homblende and a little magnetite and rust appear: An arm piece of a crinoid was seen, and fragments of the punctate shell of a brachiopod, in which the centrally expanded center of the pores can be detected.

9. Biotite-quartz-schist from Williams farm, at bluff overlooking brook at north end of limestone and directly overlying the latter where excavation was made to expose the fault. A rusty, thin-bedded, dark biotite-schist with much biotite appearing in the granular quartz mass and minnte, white, square needles on foliation faces; no effervescence.

In section a granular clastic quartz ground rum through by veins of secondary granular quartz with grains larger than those in the mass, the whole swarming with flakes and shreds of dark-brown biotite much notched at the edges. Menaccanite surrounded by leucoxene, pyrite, and the problematical needles. These are long needles with longitudinal and transverse cleavage and longitudinal extinction; refraction strong. They are redbrown, with faint pleochroism down the center and bordered by a narrow MON XXIX -19 
area colorless or faintly flesh-colored. This border is interrupted as if of later and irregular growth on the sharply defined brown prism, but is of the same optical orientation as the latter. It seems to me to be rutile coated with lencoxene.

10. Hornblendic limestone; from upper surface of the magnetite at the opening north of the large quary, Williams farm, Bernardston, and thus directly above the main limestone. An impure limestone, effervescing abundantly; dull, mottled, blackish-gray, glistening with cleavage faces of minute hornblende crystals, rusting deep brown.

In the thin section a colorless ground appears, with few magnetite grains and many hormblende needles, often aggregated into compound crystals of considerable size, and changing in small amount to chlorite. The hornblende is also often fasciculate and in feathery groups, and shows very weak pleochroism. The ground consists of much twinned calcite grains, with some quartz and feldspar.

AMPHIBOLITE ASSOCIATED WITH THE LIMESTONE IN THE GNEISSOID QUARTZITE.

11. Amphibolite from South Vernon limestone locality. Immediately adjoining the limestone on the north is a coarse hornblende rock, darkgreen with blotches of white, consisting of a granular quartz-feldspar mass, and carrying in fissures minute attached plagioclase crystals.

In sections the large hornblendes are almost free from color and pleochroism and are composed of groups of needles, sometimes fasciculate, sometimes gathered into large, well-outlined individuals, and entirely undecomposed. There is only a trace of effervescence and that is confined to the hornblende.

12. Amphibolite from South Vernon, south of road at E. G. Scott's, opposite the limestone. A greenish-gray, fissile rock, resembling a finegrained gneiss. The lens shows many fresh cleavage surfaces of plagioclase and pale "luster-mottled" hornblende.

In section the large hornblendes inclose many grains of plagioclase, rutile, and magnetite; they show marked dichroism; $\mathfrak{h}>\mathfrak{c}>a ; \mathfrak{c}=$ emerald green, $\mathfrak{b}=$ olive, $\mathfrak{a}=$ yellow; extinction at $21^{\circ}$. Leucoxene is in aggregates of grains nearly colorless or with red-brown centers; rutile occurs in square prisms. Fine, large, pale-reddish titanite crystals show positive bisectrix and axial figure parallel to $\infty \mathrm{P} \dot{\infty}$. The whole colorless background is made up of limpid granular plagioclase, often twinned but more often free 
from twimning or cleavge, and then showing the strongest concentric extinction. Extinction in twimner plates, $14^{\circ}-34^{\circ}$. Quartz is scarcely present.

13. Amphibolite from South Vernon, 10 rods north of limestone at E. G. Scott's. A thin-fissile, greenish-graly rock, showing with lens many scales of black biotite and rarely a sharply defined, light-brown prism of epidote.

In section nearly the whole field is covered by a tangled network of hornblende blarles which show quite marked pleochroism. The colorless background is for the nost part feldspar, rarely showing twin striation, and, as so often happens in these hornblende schists, wholly fresh and without cleavage. Many scalarifor'm or coraloidal groups of lencoxene occur, rarely with a trace of black ore at center, but each separate crystalline grain itself red-brown at center and colorless superficially. No other ore occurs.

\section{THE IICA AND AMPHIBOLITE SERIES.}

14. Mica-schist from Bernardston, Williams farm, from the bed of schist west of the limestone. A dark-gray to black, very fine-grained, evenbedded slate, with its glistening surface pitted here and there by hemispherical hollows, from which small red dodecahedral garnets have fallen and marked by minute white spots of shining muscovite scales just visible to the eye, which often appear in fine double lines sharply parallel to each other and inclosing a narrow dark center. They appear thus like minute chiastolites.

Under the microscope the rock shows a fine, scaly, colorless ground, dusted abundantly with coaly matter, and with polarized light showing in abundance minute muscovite scales and needles. These are embedded in a ground which shows agrogegate polarization and is partly apolar and apparently opal. Kaolin could not be retected, nor "clay-slate needles." The much fissured garnets have often a black boundary, from the accumulation of the coaly matter expelled from the space they occupy, and within this a broad decomposition band of chlorite in twisted scales, which often extends nearly to the center of the crystal. They contain large grains of quartz irregularly arranged.

The centers of the minute chiastolite-like forms mentioned above prove to be small, very impure, transversely placed biotites with flat sides and raveled ends, having on each of their long sides bands, broader than themselves, of clear muscovite scales placed at right angles to the broad faces of 
the biotite against which they rest. The large amount of coaly matter in the centers of the biotites indicates that the rock was more carbonaceous when the biotite was formed than at present. The biotite incloses garnet, which was thus first formed, and the muscovite has also folded round the garnets, forming small cups from which they fall, and has also, as above, arranged itself symmetrically to the biotite, and is thus shown to have been third in order of appearance. Leucoxene appears in yellowish-white grains more rarely than in the argillite.

Staurolite appears in some abundance in stout, shapeless masses nearly large enough to be seen with a lens-red-brown by reflected light, nearly opaque by transmitted light. They polarize distinctly, showing in the thinnest places a mosaic of bright red and blue, indicating twinning, and also traces of the square and prismatic sections of single crystals. Some crystals giving the proper angles of staurolite are white by reflected light, from decomposition, and this I have seen macroscopically in the schists around Vernou. Here the staurolite was removed in every degree from the network of quartz, until only a few browu grains remained, and at last only a cellular network of white quartz.

15. Mica-schist from above, and east of the quartzite, Williams farm. A dark-gray, fissile muscovite-schist, with pimpled surface of somewhat coarser grain than the preceding.

The ground is exactly the same colorless, scaly, coal-dusted mass as in the lower schist, and presents with polarized light exactly the same appearance upon a slightly larger scale. It differs by the development of the transversely placed biotite into quite large crystals, visible to the eye when the rock is broken across the bedding, and these crystals form most of the pustules which rise on the cleavage surface of the plates. They are bounded on the basal planes, as in the lower schist, by a line of larger muscovite plates, but this is not at all so constant as in the former case. Scales of muscovite are often intercalated in the biotite with magnetite and pyrite. The mineral is a true biotite (meroxene), with $\rho<v$ and small divergence of the optical axis. Limpid dodecadral garnets, magnetite, and pyrite also occur.

Microscopic stamrolites, single crystals with $\infty \mathrm{P}, \infty \mathrm{P} \check{\infty}$, and $0 \mathrm{P}$ measuring $\infty \mathrm{P} \wedge \infty \mathrm{P}=115^{\circ}, \infty \mathrm{P} \wedge \infty \mathrm{P} \breve{\infty}=112^{\circ}$, are quite common. They are very impure and nearly opaqne, sometimes crushed and the parts separated. They are nearly white by reflected light. Some slides show 
in abundance grains of an opraque black ore, often partly changed to opacque white. 'There are other' grains of an opacue yellowish-white naterial of the same shipe and size. These are apparently menaccanite and lencoxene.

'The only distinguishing characteristics to separate the present and the preceding rock are the somewhat coarser texture of the ground in the former, the larger size of the transverse biotite, and the somewhat more perfect crystallization of the stanrolite and garnet. They nay well have derived their material from the same source and have been subjected to almost precisely the same influences during netamorphism.

The above descriptions were written for the two rocks when it was supposed that the western schist dipped below the limestone, while the eastem rested upon the quartzite above, and the rocks were studied in the hope of finding some peculiarity by which they conld be separately traced. They are now believed to be part of the same stratum, and the detailed descriptions above attest their lithological identity.

16. Mica-schist from Purple's quarry. A dark-gray, fissile, garnetiferous muscovite-schist, differing from the upper schist of the Willians farm only in the greater abundance of garnet.

In a ground of muscovite seales abundantly strewn with coaly matter occur many garnets inclosing scales of muscovite and bounded by a decomposition layer of chlorite in scales parallel to the side. The strongly dichroic biotite plates, much dusted with coaly matter, are bounded on $0 \mathrm{P}$ by broad layers of vertical muscovite scales, which in one place inclose a layer of fresh orthoclase.

17. Massive amphibolite from Bernardston, east of village, and just east of J. Nelson's, the first house on the road turning north after passing the Fall River bridge. Dark-gray, jointed, massive rock in heavy bed, associated with thin ber of limestone. Effervesces abundantly with cold hydrochloric acid, especially around the wisps of hornblende, and shows then with the lens hornblende, biotite, magnetite, and plagioclase. II uch magnetite removed from the powder by the magnet. The microscope shows few scattered wisps of hornblende needles, groups of grains of black ore not associated with lencoxene. The hornblende shows weak absorption and pleochroism.

18. Massive amphibolite from Bernardston, north of R. Park's, locality C cited by Professor Dana $(14,342$ ). (See Pl. V, fig. 3, for section.) A massive, black, fine-grained, diorite-like rock. The microscope shows the rock 
to be made up of long, interlaced, crystalline blades of horublende running in every direction and inclosing a great number of feldspar grains. The horublende has extinction $=27^{\circ}$ and is strongly pleochroic; $\mathfrak{x}=$ mountain green, $a$ and $b=$ yellow; one grain of plagioclase, extinction $20^{\circ}$ on each side of the twinning plane. Many sections from specimens taken from the varions beds between this point and South Vernon show precisely the same structure, but generally contain grains of menaccanite surrounded by leucoxene.

19. Amphibolite from West Northfield, from large outcrop rising above the terrace sands east of the Bernardston-South Vernon road at the point where the road branches off to the ferry. A jet-black, schistose amphibolite, the shining-black hornblende needles being arranged parallel to the foliation plane, but in every direction in that plane.

20. Amphibolite from West Northfield, at first branching of the road west of Northfield ferry. A fine-grained, black rock, the fine black needles arranged as in the last case. These two rocks resemble more closely the older amplibolite of Northfield Mountain east of the river than the tough, matted, fibrous, massive rock of the West Northfield range described above. (In the Northfield Mountain rock, however, the stretching is complete and the rock thin-fissile, and the hornblende needles are all closely parallel to one another. It is porphyritic, has the usual medium absorption and pleochroism, $c=$ blue-green, $b=$ olive, $a=$ honey-yellow; extinction $19^{\circ}$.) Under the microscope the needles are grouped in parallel or almost parallel bundles to form large crystals, which resemble the large blades of the range to the west, described above. The fine, fresh needles are often well terminated, the pleochroism strongly marked; $\mathfrak{c}=$ deep mountain green, $b=o l i v e$ green, $a=$ yellow. Beautifully complex, large reticulated groups of magnetite crystals occur, and with polarized light the colorless background breaks up into a fine-granular plagioclase aggregate. The lighter spots show the usual untwinned plagioclase mosaic. The grains show the usual concentric extinction; the rounded or angular centers extinguish in one position, and the darkening goes outward to the surface with continued rotation.

21. Limestone; Bernardston, northeast of N. W. Purple's honse (now abandoned), on the Purple blind road. Layers of white grauular limestone up to $15^{\mathrm{mm}}$ thick, in green, compact hornblende rock. 
Under the microscope grains of chuartz appear seattered in a very finc-grained mass of phmose homblende. Bands of ealcite run throngh this, mate up of several hayers, with mucls acicular homblende developed in it. The calcite grains are polysynthetic. The hornblende is partly deromposed into a bright-green, apolin serpentinous mineral.

\section{ROCKS AT THE MOUTH OF MILLERS RIVER.}

Sonthward from Northfield the Triassic sandstones border the river on the west and older gneisses approach it on the east, and the first exposures

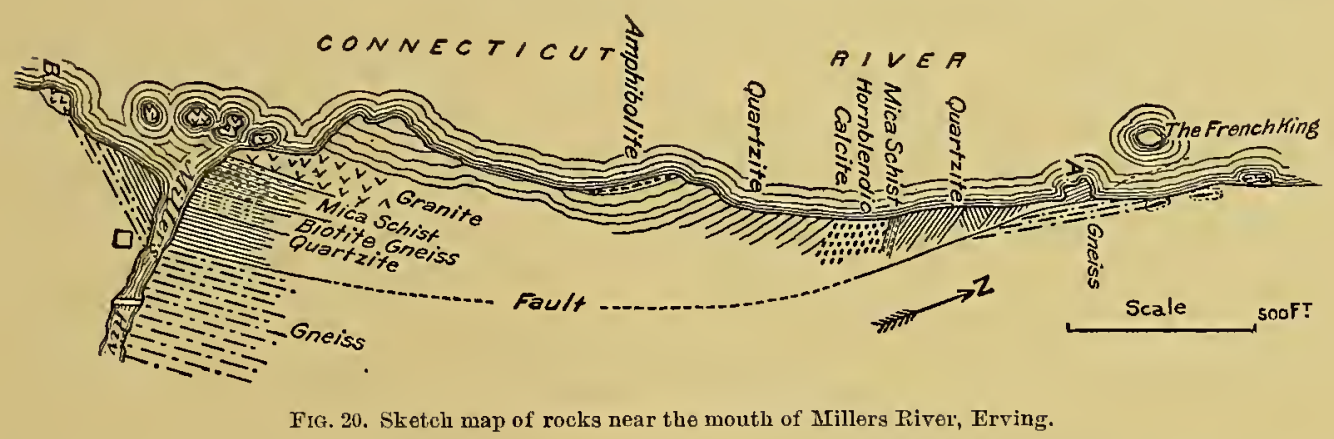

which can be compared with the Bernardston series appear in the east bank of the Connecticut 5 miles below Grass Hill and just above the month of Millers River (figs. 20-22). Here, for nearly a mile, there is an

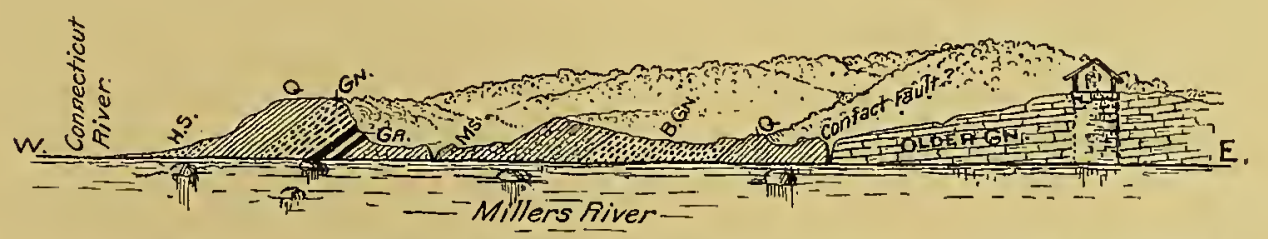

FIG. 21. Sketeh of rocks at wouth of Millers River, looking northeast from B on map, fig. 20. Scale, 1:2000. H. S.= hornblende-sehists; Q.=quartzite; GN.=gneiss; GR.=granite; M. S.=mica-schist; B. GN.=biotite-gneiss; OLDER GN.=-Monson Cambrian gneiss.

unbroken exposure of rocks of great interest, which I have associated with the Bernardston series, at times with much confidence and at times very doubtfully. It becomes, in fact, a question how far the original sediments may have been different from proximity to the gneiss instead of the argillite, and how far, also, the immediate presence of the gneiss during the thorough metamorphism of the sediments in question may have condnced 
to a result different from that reached where the underlying mass was a nonfeldspathic schist. I am inclined to give great weight, perhaps the greatest weight, to the occurrence of the same succession in beds of abont the same thickness-quartzite, mica-schist, limestone-the latter changing into hormblende rock, and to the tracing of the beds into such close proximity rather than to the exact texture of the beds themselves. The following description will emphasize the differences in the latter regard:

Below the fall at the mouth of Millers River, and on the north bank of the latter, at a small crevice in the cliff, a fault is plainly seen (fig. 21), the biotite-hornblende-gneiss which formed the apron of the dam dipping $10^{\circ} \mathrm{W}$, against a flinty quartzite which dips $40^{\circ} \mathrm{W}$. Following the

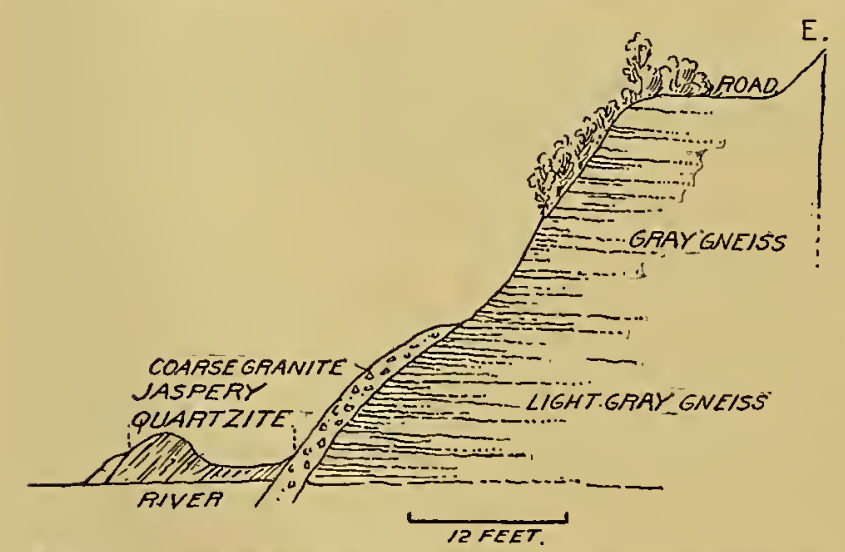

F1G. 22.-Section on east bank of Connecticnt River above mouth of Millers River at A on sketch map, fig. 20.

E. outcrop along the river to its north end, at a point 164 feet south of "The French King," " we find a marked promontoryan island except at low water-of the same jaspery quartzite, with high westerly dip, which is separated by a narrow dike of coarse granite from the much older horizontal

Becket gneisses which crop out in the bank of the river and continue for a long distance north. The unconformity is indicated in the above figure (fig. 22). The rock at the promontory is a very peculiar quartzite, very thin-laminated and corrugated like the grain of guarled oak. Layers, which sometimes swell to $10^{\mathrm{mm}}$, of black, flinty quartz, wavy and interrupted, alternate with bands of white to oil-green, compact quartz, prodncing a structure which resembles the banding of some eruptive rocks more than ordinary bedding. The rock can be followed south for 500 feet along the bank. The ribboned quartzite changes into a coarse mixture of bhe, greasy quartz

${ }^{1}$ A great bowlder of Triassic conglomerate which lies in the middle of the river at the head of the rapids, and derives its name, according to tradition, from the fact that the bateaux of the French and Indians, during the French wars, were stopped here by the rapids, and one adventurous Frenchman pressed on to this rock and broke a bottle of wine over it, claiming the country in the name of the French King. 
and feldspar, rery rusty and carrying pyrite and galena, and rarely nuscovite in broad seales. Going 33 feet along the strike, one fincls the rock (hamging to a massive, dark leek-green lornstone, which continues a long distance, becones in places black, and assmmes a small colummar structure, and at last returus to the coarse mixture of quartz, flesh-colored orthoclase, and muscovite, the latter often in plates about an inch across-the whole coarsely but distinctly bedded in laminæ 1 to 2 inches thick.

This is succeeded in ascending order by a well-developed, coarse muscovite-schist 13 feet thick, which dips beneath a bed of very siliceous limestone about 40 feet thick, very rusty externally, in the interior white to flesh-colored at base, but soon becoming dark-green to black above, and very horublendic. In places it is a pure amphibolite, but it is generally mottled with white calcite. It is cut by two dikes, 3 to 7 feet thick, of coarse granite. Then begins a great bed which seems to rest upon the hornblende-calcite rock, but the exposure leaves this indistinct. This bed begins at base as a greenish, apparently calciferous quartzite (it rusts deeply), and makes the mass which projects into the Connecticut at a point just north of the mouth of Millers River. At base some parts are conglomeratic, quartz pebbles one-half to 1 inch long occurring. This rusty layer is about 20 feet thick. Then a thin layer of amphibolite, like the other, caps the quartzite for a short distance (72 feet) along the water's edge, and the latter rock, the quartzite, runs on in great undulations for 656 feet toward Millers River, its average strike agreeing closely with the course of the Connecticut at that point (S. $60^{\circ} \mathrm{W}$.) and its dip being $42^{\circ} \mathrm{W}$. The high, bare cliffs give almost umbroken exposures between the two exposures of the fanlt at the extremities of the section, and leave the stratigraphy uncertain at only one point. The upper quartzite is thin-fissile in its upper layers, bluish at times, and repeating all the flinty varieties seen at "The French King" (16 feet). At the great point just north of the mouth of Millers River, where the shore-line swings round to the east as one passes up the bank of the latter stream, this grades below into a perfect feldspathic gneiss of medium grain, with a little greenish mica (20 feet), which passes below into coarse granitic gneiss or a gneiss breaking in laminæ nearly an inch thick but composed of the coarse orthoclase and large muscovite scales of a common coarse granite. The muscovite scales are often an inch broad, and are generally in the plane of foliation ( 30 feet). 
This stratum is followed below, just at the junction of the rivers, by a heavy bed of a very coarse, very micaceous muscovite-schist. This mica-schist incloses a great number of lenses of coarse granite, its laminæ separating to inclose them, and the strike of the rocks continues closely parallel to the course of the Connecticut. This stratum passes beneath the water at the place of junction of the two rivers, and the granite lenses rise in twelre small islands which stretch across the month of Millers River (105 feet).

The mica-schist changes suddenly below into a dark, much-jointed and yet fissile biotite-gneiss. The biotite is bronze-colored, but green superficially. 'This is followed finally by the basal quartzite, containing at first bands of coarsely feldspathic quartzite with scattered red garnets like those common in granite, and broad flakes of muscovite, and witl quite large granite lenses. Below it is for the most part a green to flesh-colored, compact quartzite with feldspathic and biotitic layers, and resembling closely that at the north end of the exposure at "The French King," and faulted, as already detailed, against the older gneiss just below the bridge over Millers River. (See fig. 21, p. 295.)

The order from the fanlt upward is, thus, at both ends: (1) quartzite, (2) mica-schist, (3) amplibolite and limestone; and it is cloubtful whether the order continues upward, (4) rusty quartzite, (5) amphibolite, or whether the two upper are repetitions of the lower members of the series.

Crossing Millers River, the fanlt line runs through the high Mine Hill west of the village of Millers Falls, and, especially the band of schist and gneiss impregnated with granitic material, makes the crest of the hill. This band is greatly brecciated and its fissures are filled with magnetite, which has suggested the name, while on the western slope a greenish compact quartzite or hornstone caps the feldspathic beds.

Southward across the Montague plain all the ontcrops are to the east of the line of junction of the two formations, and thus lie in the older gneiss, until, on the southern border of the great sand plain and just northeast of the village of Montague, there occurs a great mass of the same gray to pale-green, greatly-jointed and brecciated quartzite, quite massive and hornstone-like in texture. A few rods to the east, across the railroad, the older gneiss rises above the sands, dipping beneath the quartzite. South and west everything is covered by the Triassic sandstones, but on the north 
fice of the hill west of Montague a coarse gneiss showing traces of congolonterate structure rises out of these sindstones and is most nearly allied to the coarrere rocks at the mouth of Millers River, with which I have asso(iated it on the map. (See p. 362.)

Along the tault line northward from the nouth of Millers River across Northfield, the older gneisses rise firm beneath the sands in many places up to, but not beyond, the line of the fault, while the few outcrops of the Bernindston series approach the same line on the west until, opposite Northfield village, in L. A. Moody's lane, the Devonian quartzite, identical with that west of the river on the Willians farm, here greatly breceiated and its fissures filled with hematite, approaches very near to the older rocks, and the same thing is true northward along the road which skirts the mountain to and beyond the State line, where the fault enters the older rocks, as shown on the map, Pl. XXXIV.

The quartzite, greatly brecciated, and veined with hematite, can be traced in several places into near proximity to the older series. It is a finegrained rock which shows no signs of derivation from the varying nembers of the older series against which it successively rests. It fails to conform to them in dip and strike, and these facts, combined with its thorough brecciation along this whole line, make it probable that the Bernardston series is bounded on the east by the extended fault which has been traced north and south from Millers River. 


\section{H A P T E R X. \\ THE AMPHIBOLITES DESCRIBED IN THE PRECEDING CHAPTERS.}

\section{ANALYSES AND SECTIONS.}

I have in the preceding chapters described a great variety of amphibolites, and have assigned most of them with more or less confidence to the list of altered sedimentary rocks. Forms which are associated with basic eruptive rocks or retain any traces of the structure of those rocks I have classed with eruptive rocks. Varieties which form selvages to limestone beds, or are in every way closely associated with limestones and interbedded with the schists in which they occur, I have considered to be derivatives from impure limestones. Without recapitulation, I may call attention to the discussion of the amphibolites associated with Algonkian limestones, on pages 29-30, and of the origin of the Chester amphibolite, on pages 147-155, and to the description of the amphibolites of the Hawley series, on pages 166-169, and of those nore certainly derived from limestones in the Conway schist, on pages 189-196, and in the Bermardston series, on pages 275-282, 290-294, 297. I bring together here for comparison all the analyses of amplibolites from the region, and a series of sections commencing with forms which are certainly sedimentary and ending with those concerning whose origin there will be difference of opinion. A curious porphyritic structure which is common in the amphibolites is also briefly discussed.

I have described many beds of amphibolite that may, with more or less certainty, be derived from limestone. I have perhaps given too much weight to this mode of derivation, and may have included beds of igneous origin. It is very striking how small the chemical variation is in rocks differing widely in age, habit, and probable origin, and the close agreement of all these analyses with that of an average disbase will not escape atten- 


\section{PLATE V.}




\section{PLA TE V. \\ SECTIONS OF AMPHIBOLITES DERIVED FROM LIMESTONES.}

Silurian and Devonian age. Drawn with lower nicols to show the pleochroism of the hornblende. The upper nicol is used to bring out the ontlines of the colorless mosaic. The plane of polarization is parallel to the long side of the plate. The hornblende crystals are generally full of colorless grains like those of the ground. All show remnants of calcite. $\times 20$.

FiG. 1.-Calcareous garnet-amphibolite. Conway schist, Plainfield. From the base of the large "anvil," figured in Pl. XXXIII and deseribed on page 191, and formed by the metamorphism of the impure limestone which still makes the shaft of the anvil. The rock has the aspect of a coarse hornblende-schist, but effervesces with acid. The coarser-grained portion of the colorless mosaic is clastic, identical with that of the adjacent mica-schist, and the garnets have the same symmetrical arrangement of the coaly impurities. The finer part of the colorless ground is plagioclase. One large grain is marked by triclinic striation and most of it is crushed. The biaxial character of many grains could be determined. Extinction 37\%, indicating anorthite. The ragged hornblende plates inclose many colorless grains, generally quartz or calcite, but sometimes small colorless zircons with deep halos of darker color. The dull portions, heavily dusted with carbon grains, are remnants of corroded calcite. Swarms of leucoxene grains surround ilmenite. (See Analysis I, p. 303.)

FIG. 2.-Amphibolite. Whately. From bridge west of the Whately Hotel. A black, massive amphibolite; forming portion of limestone bed in Conway schist and folded into argillite. The long hornblende blades are often centrally brown, with colorless ends, and loaded with trausverse black bands which send out comb-like teeth parallel to the vertical axis. There is some biotite. Red rutile surrounds black ore, and small colorless zircons (?) appear, surrounded by dark halos. There is a mosaic of feldspar without twinning and generally without cleavage. (See pp. 192, 196.)

Fig. 3.-Amphibolite. Bernardston, near R. Park's. From the Devonian Bernardston series. A black, massive rock, made of broad, stout, interlaced blades of hornblende. These blades grade into radiate tufts of hornhlende needles. The hornblende crystals inclose many colorless grains, often of branching and irregular forms, resembling the grains of titanite which surround some of the black ore masses in the slide. Some of the grains of the colorless mosaic are twinned and have generally the small extinction angle of albite. Others show secondary growths around rounded centers. One fine fibrous and punctate fragment seems to be organic, resembling a brachiopod shell. It is too small to show in the drawing. (See Analysis VII, p. 303, and comparative discussion, p. 275.)

FIG. 4.-Garnet-graphite-amphibolite. Bowlder from Leverett, but coming with great probability from one of the coarser Bernardston beds or from the great Guilford bed in the Conway schist, figured on Pl. VI (fig. 2). A complete block of massive amphibolite. The stout interlacing blades of hornblende contain in their meshes little granular mosaic, which decomposes readily and gives a beautiful surface. The fresh surface effervesces. A few garnets appear. The striking peculiarity, indicating the derivation of the rock from a graphitic limestone, is that the surface of very many of the hornblende crystals show shining scales of graphite, which only rarely appear in the photograph. $\times \frac{1}{2}$. 


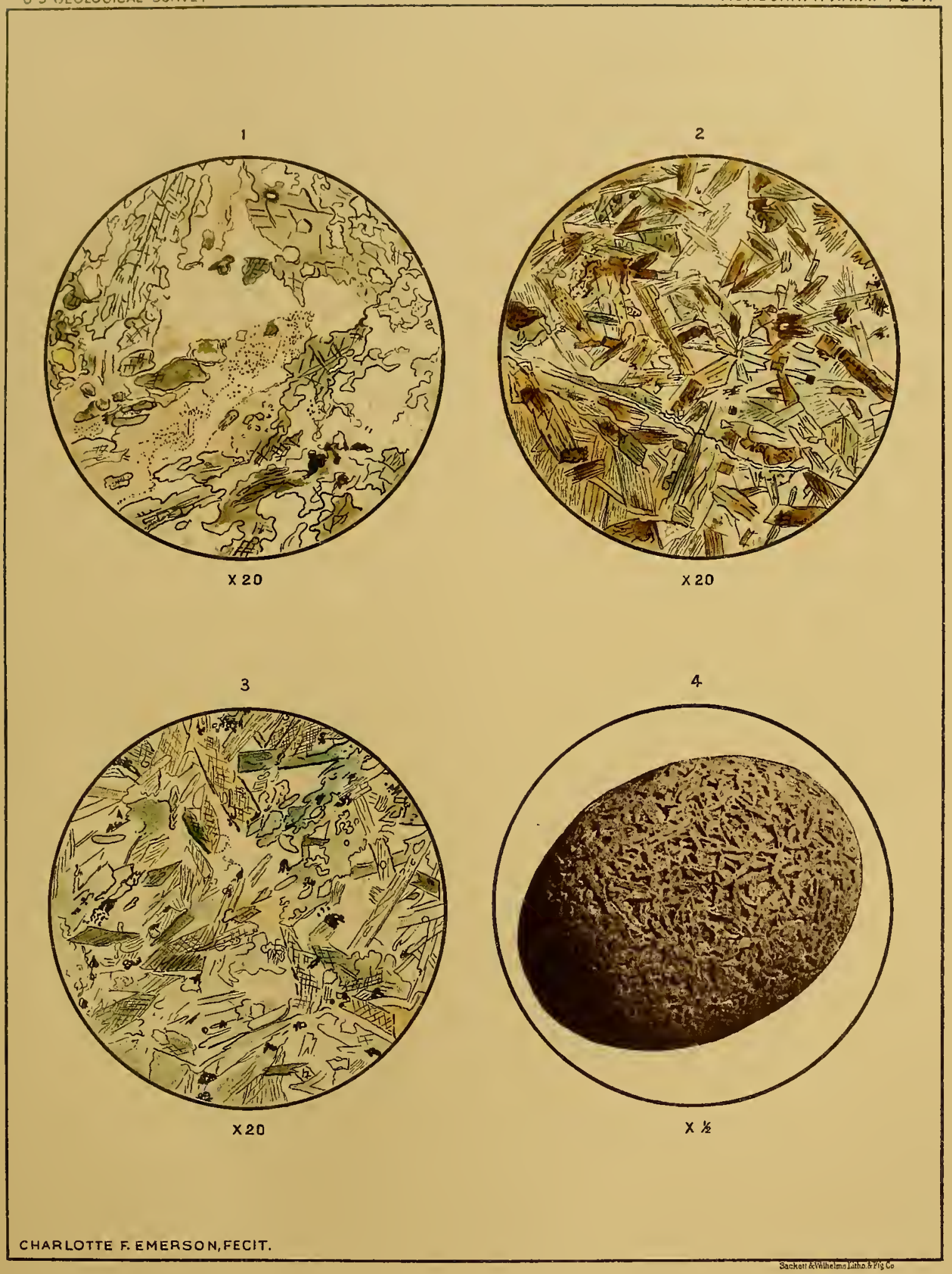



tion. No. IX is, however, certainly, and Nos. I, IV, and $V$ are almost certainly, lerived from limestone. There is therefore no reason from the chemical side why they should not all be so derived.

Analyses of the amphibolites described in the preceding chapters.

[Analyst, L. G. Eakius. $]$

\begin{tabular}{|c|c|c|c|c|c|c|c|c|c|}
\hline & 1. & II. & III. & IV. & V. & VI. & VII. & VIII. & IX. \\
\hline $\mathrm{SiO}_{2}$. & 51.38 & 45.48 & 51.56 & 49.86 & 49.16 & 48.53 & 51.72 & 47.56 & 55.64 \\
\hline $\mathrm{TiO}_{2}$. & 1. 07 & .77 & 1.97 & 1.58 & 1.03 & .51 & 1.39 & 1.24 & .50 \\
\hline $\mathrm{Al}_{2} \mathrm{O}_{3}$. & 18.01 & 19. 43 & 14.82 & 15.50 & 16.43 & 113.35 & 16.51 & 16.13 & 16.27 \\
\hline $\mathrm{Cr}=\mathrm{C}$ & ......... & trace & $\cdots .$. & $\cdots$ & trace & $\cdots$ & $\cdots$ & trace & \\
\hline $\mathrm{Fe}_{3}$ & 3.30 & .13 & 4.30 & 2.99 & 3.92 & 2.03 & 1.72 & 1.80 & 1. 22 \\
\hline $\mathrm{Fer}$ & 8.53 & 6.58 & 7.21 & 8.01 & 7.19 & 10.52 & 9.56 & 9.39 & 7.20 \\
\hline 1110 & .19 & trace & trace & .07 & .23 & .17 & trace & .08 & .28 \\
\hline $\mathrm{BaO}$ & trace & .01 & trace & trace & .02 & trace & trace & $\operatorname{trace}$ & . \\
\hline $\mathrm{CaO}$. & 6.27 & 10.66 & 7.09 & 8.89 & 9.21 & 9.83 & 8.89 & 6.67 & 9.23 \\
\hline $\mathrm{MgO}$ & 5.08 & 11.08 & 7.36 & 7.79 & 8.19 & 9.71 & 6.58 & $9.2 \mathrm{I}$ & 5.58 \\
\hline $\mathrm{K}_{2} \mathrm{O}$ & .18 & .11 & .17 & .72 & $.4 \mathrm{I}$ & .32 & .34 & 1.58 & .19 \\
\hline $\mathrm{Na}$ & 5.34 & 2. 28 & 4.21 & 3.26 & 3.70 & 1. 36 & $2.7 t$ & 2.52 & .91 \\
\hline H & .56 & 3.17 & 1. 47 & 1.51 & .45 & .79 & .51 & 3.51 & 3.11 \\
\hline $\mathrm{P}_{2} \mathrm{O}$ & .18 & .14 & .09 & .11 & 16 & .07 & .23 & .21 & .23 \\
\hline \multirow[t]{2}{*}{$\mathrm{CO}_{2} \ldots$} & …… & .20 & $\cdots$ & $\cdots$ & 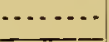 & 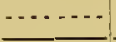 & ....... & …. & …. \\
\hline & 100.09 & 100.04 & 100.25 & 100.29 & 100.10 & 100.19 & 100.19 & 99.90 & 00.36 \\
\hline
\end{tabular}

I. Heath; W. M. Sanford's. Porphyritic amphibolite in Goshen schist.

II. New Salem. Amphibolite associated with steatite.

III. Leverett; gothic house east of village. Massivo, coarse, altered diabase.

IV. Whitmores Ferry; Sunderland. Thin, shaly, aphanitic amphibolite of Conway age projecting through Triassic sandstone.

V. Guilford, Vermont; shining-black, flaggy amphibolite; long bed in Conway schist.

VI. Worthington; in Hawley schist; nearly pure, matted, black hornblende needles.

VII. Bernardston; R. Park's. Black, heary, massive hornblende rock. Devonian.

VIII. South Leverett. Ligniform, deep-green amphibolite.

IX. Goshen; base of the "anvil" formed by solution of the block of impure limestone, and thus eertainly derived from limestone of Conway age. (See p. 191.)

In the accompanying plates (Pls. V, VI) I have brought together types of all the amphibolites described in the preceding chapters for comparison with the table of analyses given abore. The sẹctions on $\mathrm{Pl} . \mathrm{V}$ are certainly derived from limestone. The first two sections on Pl. VI have probably the same origin. The third section, from the Hawley schist, and the fourth, which is from a bed adjacent to the great Chester amphibolite, are of uncertain origin. 
PORPHTRITIC CHARACTER OF THE AMPPHBOLITES.

The hornblendic bands of the Beruardston series are often pseudo-porphyritic, especially west of the Mount Hermon School. This structure is widely distributed in older amphibolites from the Hawley to the Conway series, botlı inclusive, especially in the Guilford and Heath amphibolites and the large upper band of the Hawley schist (see p. 166). It reappears again in the Conway schists in Granville, and is seen in the most striking form in South Monson (see p. 249). The dark surface of the rock is interrupted by white spots $2-10^{\mathrm{mm}}$ in length, more or less angular and of somewhat uniform size. A quite close inispection will often leave the impression that they are forned simply by the expulsion of the hornblende needles from the area, and are a portion of the gramular base of the rock, but a bright light will show at times the flash of a common cleavage over the whole or half of the surface.

With polarized light the same effect is produced. A simple mosaic of feldspar grains appears, but by using a very low power it can generally be seen that the gromndmass is held together by a single large feldspar growth, so crowded with foreign bodies that it can hardly be separated.

I compare these feldspar growths to those described on page 287 in the Bernardston quartzites, or the small porphyritic albite crystals in the Hoosac schists, and consider them the earlier generation (as compared with the hornblende needles) in their present position. They often include minerals of early growth, as biotite and dolomite (which are now wanting in other parts of the rock), as well as the common groundmass, and have by their early presence prevented the iron-bearing mineral from occupying their place. They are now often sanssuritic, made up wholly or largely of highly refringent epidote, or zoisite grains, very possibly as the result of a paramorphic change at the time of the development of the hormblende.

The whole process is one more intelligible as occurring in a calcareous red sandstone than in a metamorphosed diabase, and it is very common in the amphibolites, which occur in thin, extended, conformable sheets, grade more or less into limestone, and show no tendency to form serpentine and steatite, and it is wanting in the gabbro-like beds and in the great Chester amphibolite, which is associated with olivine and enstatite rocks, serpentine, steatite, and emery, and which may thus be derived, at least partly, from beds of distinctly eruptive origin. 


\section{PLATE VI.}




\section{PLATE VI.}

\section{SECTIONS OF AMPHIBOLITES PROBABLY DERIVED FROM IMPURE LIMESTONES.}

Silurian. Drawn with lower nicols to show pleochroism. The upper nicol is used to bring out the outlines of the grains in the colorless mosaic. The plane of polarization is parallel to the long side of the plate. The hornblende grains are generally free from grains of the plagioclase. $\times 20$.

FIG. 1.-Magnetite-amphibolite. Conway schist, Whately. From the north end of the large band near house of Mrs. M. Taylor. A black, slaty rock, easily mistaken for a black shale. A rock of very fine and even grain. Many of the ore grains are surrounded by small groups of titanite grains, many grains of which are scattered evenly in the whole field. A narrow vein filled with large and long plagioclase grains. like the ground, crosses the slide. (See Analysis IV, p. 303, and for description p. 194.)

FIG. 2.-Rutile-epidote-amphibolite. South line of Guilford, Vermont. A shining-black schist, slightly larger needles, black and lustrous, appearing among the others. A limpid granular mosaic, in small quantity, no multiple twinning, rarely cleavage, one probable determination of albite. Hornblende ragged-bordered, but without inclosures, with strong pleochroism and cleavage. Much deep-red brown rutile clustering around black ore grains. Considerable paleyellow epidote. (See Analysis V, p. 303, and for description p. 195.)

FIG. 3.-Epidote-amphibolite. Hawley series. Heath, near E. Gleason's. With large porphyritic hornblendes and feldspars. A fine-grained, limpid feldspar mosaic, thick set with minute but quite well-formed hornblende and rounded epidote grains. The large hornblendes show remarkably strong pleachroism when viewed with a lens without the intervention of nicols, and twinning. both of which properties are indicated in the figure. They are centrally filled with minute foreign bodies. The feldspar crystals are centraily filled with highly refringent, slightly yellow grains of epidote, and the same are scattered through the ground. The distinctly bounded feldspar crystals are mostly broken into a mosaic. One shows trace of carlsbad twinning, but no cleavage or multiple twinning can be seen. The abundant grains of magnetite show no trace of change. The red grains are much rusted ankerite. (See p. 166.)

FIG. 4.-Amphibolite. Chester. From the cut nearest to the station. A black rock banded with white layers, which are thin and interrupted, the mass of the rock made of shining, jet-black needles just visible to the eye. Under the microscope the rock is very fresh, the hornblendes are in long, ragged-ended, parallel blades with few inclusions and strong pleochroism. Extinction 210. The coarse, limpid ground mosaic is made up of quartz and albite grains, polarizing brilliantly and hardly distinguishable from one another, except that the quartz gives the black cross and the feldspar is positive and biaxial. This mosaic resembles exactly that of the adjacent sericite-schist. There is no trace of any other mineral except these three. (See pp. $97,160$. 


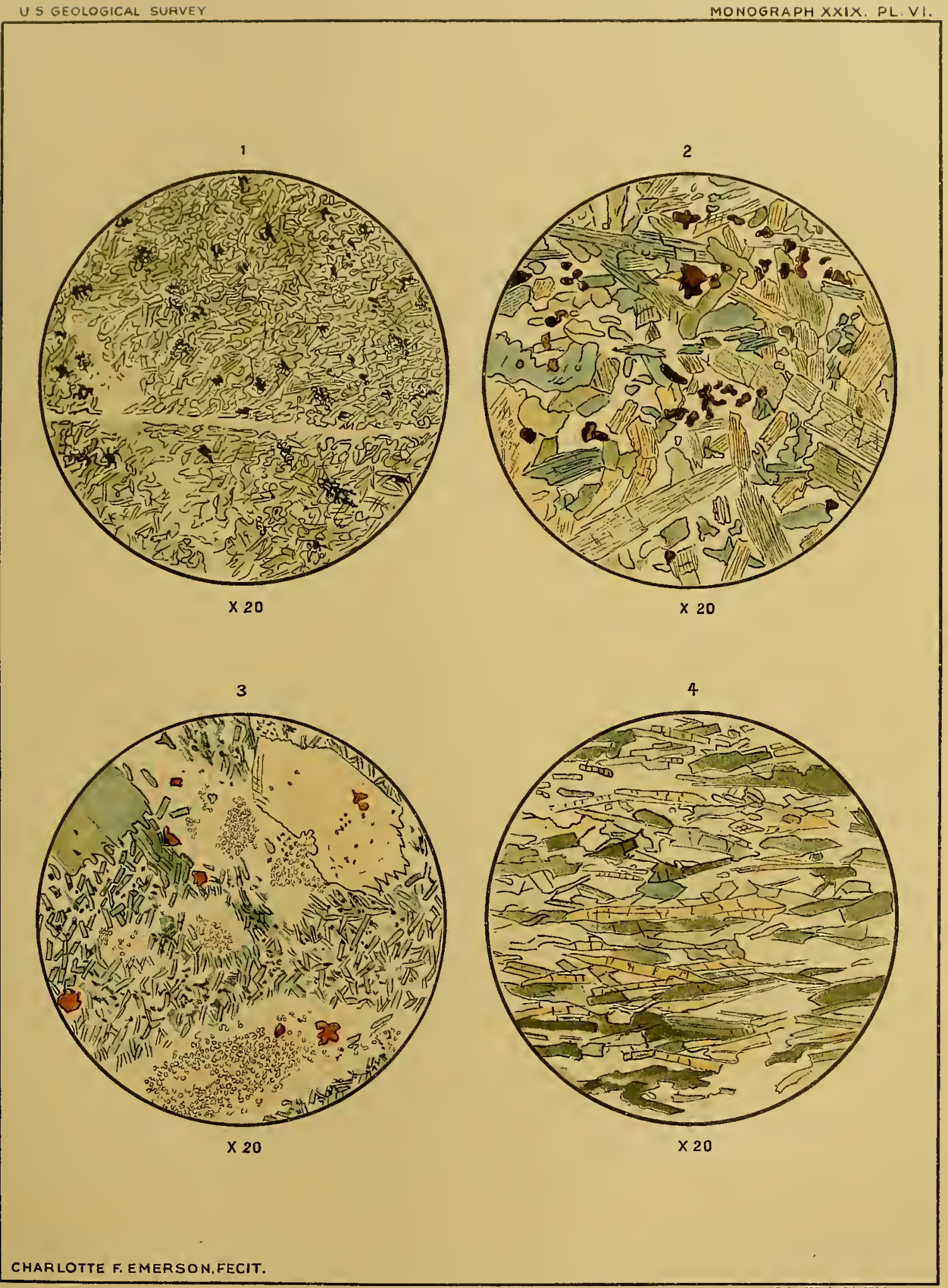

AMPHIBOLITES 


\section{H A P T E R XI.}

\section{THE ERUPTIVE ROCKS.}

\section{INTRODUCTION.}

The species of igneous rocks occurring within the area of the crystalline sehists are:

1. Granite, in the strict sense, or biotite-muscovite-granite, the most widely distributed.

2. Granitite, or biotite-granite, generally porphyritic.

3. Pegmatite, or muscovite-granite.

4. Albitic granite in secondary veins in the pegmatite, remarkable for their content of rare elements.

5. Aplite.

6. Quartz-gabbro.

7. Tonalite, or quartz-diorite, wholly or in part derived from No. 7, and with it forming the syenite of President Hitchcock.

8. Diorite.

9. Diabase.

10. Cortlandite.

Within a square twenty-five miles on a side, with Northampton at its center and its eastern line along the foothills on the east side of the broad Connecticut Valley, in Belchertown and Pelham, the country consists for the most part of large areas of granitic rocks of the above types. Where schists cross the region they are contorterl and granite-impregnated, and rest upon the granite in separate sheets, often of small size, or narrow bands, and all, down to the smaller fragments, retain their dip and strike, even when surrounded on all sides by the massive rock.

A large portion of the area outined above lies beneath the sands and sandstones of the Connecticut Valley, and the line of Triassic eruptions 
bisects it from north to south, so that the great depression of the valley seems to be connected with these ancient granitic intrusions.

Outside the area defined above granite dikes are few and small, the only large ones being the Middlefield and Coys Hill dikes. Topographically, and in the interest of cartographic work, they may be divided into four groups: (a) the great stocks and dikes of muscovite-granite, with their accompanying swarms of smaller dikes, the whole surrounding the groups $b$ and $c$ below; $(b)$ the extended central areas of quartz-gabbro and tonalite (syenite of President Hitchcock), which are without accompanying dikes; (c) the biotite-muscovite-granite, which occupies great areas topographically as well as lithologically intermediate between the other two, and is with difficulty separated from the former ( $a$ ) becanse it is itself cut by an enormous number of veins of muscovite-granite, or pegmatite, not distinguishable from that of the group $a$ itself, so that it could often as well be assigned to the one as to the other on the map; $(d)$ the porphyritic biotite-granites, which are widely separated from the above group.

At the two opposite corners of the granitic region are two great squarish masses of quartz-hornblende rocks (tonalite), which send out no dikes, and which have produced a much more intense contact metamorphism than the mica-granites.

The Hatfield tonalite area is immediately succeeded on the west by a fine-grained biotite-granite almost like the Monson gneiss, but which from the beginning carries a small, constant quantity of muscovite. To the west it soon begins to be cut by pegmatite dikes, and at the Mill River in Leeds, a mile west, their number is already considerable. In the next mile west the belt of granite which stretches from Loudville to Williamsburg has, as it were, a substratum of the fine-grained biotite- (or two-mica-) granite, but so cut up by successive generations of the coarser muscovitegranite that it almost disappears beside the latter.

Then still farther west and south, and on much higher ground, the great rounded granite stocks, which stretch from Montgomery to Conway and rise to form some of the highest hills on our western horizonPomeroy Mountain, in West Hampton, and Moores Mill, in Goshen-are desolate regions of a coarse muscovite-granite, rarely slashed by great blades of biotite, in which one finds here and there large areas or, as on the top of Moores Mill, an isolated block of the fine-grained biotite-granite. 
$\mathrm{Up}_{\mathrm{p}}$ to this point the description covers an area of mbroken granitic rocks of various types, superficially separated by shallow bridges of sehist. Like the roots of a great tree inverted, there radiate from this central mass numberless rlikes of every size, the connection being proved in many cases and probable in all. These dikes are of two kinds, the fine and uniform grained biotite- (or two-mica-) granites or granitite, and the coarse to very course muscovite-granite veins-pegmatite. The former are generally, the latter sometimes, interbedded in the schists for long distances. Toward the periphery of the area the pegmatite dikes carry secondary veins of albitic granite with many rare minerals. Within the area cut by the dikes and surrounding it in a broad halo the country rock is filled with quartz veins and peginatite lenses of every size, derived, I doubt not, from the granite.

On the eastern side of the river there stretches north from the Belchertown tonalite ("syenite") area a region where the schists are so crowded with pegmatite veins that they (the schists) sink into unimportance. This continues across Amherst, and in Leverett is followed by a large area of almost unbroken granite.

The discovery and description of the peculiar type of eruptive masses to which the name "laccolites" ${ }^{\text {h }}$ has been given by Gilbert-great mushroomlike bodies of lava thrust up into the bedded rock to a certain level and then, expanding into a cake-like mass between the beds, pushing up the superincumbent strata into a low dome, but not reaching the surface-suggested to E. Suess ${ }^{2}$ the name "batholites" for the similar but more extensive masses of granite which occupy a position in the crystalline schists analogous to that of the laccolites in the newer rocks. It is in this connection that the observation of Hitchcock is interesting, that the great masses of granite seem to be set free by the denudation of the schists above them, and the furthier observation-which I have had occasion to make repeatedly-that where the schists are so cut up by the interlacing granite dikes that the latter make up far the greater portion of the surface, and even where long isolated sheets stand vertical or nearly so in the great granite masses, the prevalent strike and dip of the surrounding schists are strictly maintained, indicating

${ }^{1}$ G. K. Gilbert, Rept. Geol. Henry Mountains. A. C. Peale, On a peculiar type of eruptive monntains in Colorado: Bull. U. S. Geol. and Geog. Surv. Terr., No. 3, p. 551 . F. M. Endlich, Eruptive rocks of Colorado: Tenth Ann. Rept. U. S. Geol. and Geog. Surv. Terr., p. 199.

? E. Suess, Das Antlitz der Erde, p. 219. 
that they are downward projections of the roof of the batholite, which has been removed just to their average plane of junction. Such a great batholite is well seen in Mount Tekoa, in Montgomery. To one standing on the high ground on the west hine of Westfield and looking north the contrast of the white granite and the black schist is strongly marked. On the right the great dome of granite makes the sky-line. To the left its curved surface passes down beneath the mass of the schists of Mount Tekoa. The latter at first mantle up over the dome conformably, and higher up end very obliquely on the contact plane, and are greatly corrugated and cut by many large dikes sent off from the main mass.

Again, these schists and their limestones, entangled in the granite, have been subjecterl to the same kind and degree of contact metamorphism as the broad band surronnding them. The schists became feldspathic and the limestones coarsely crystalline, as described under the head of the Conway mica-schist, page 197 , while the hornblende-schists became pyroxenic (as described on p. 243) or feldspathic with or without the development of pyroxene. I look upon the larger masses as great granitic reservoirs ${ }^{2}$ which have partly forced and partly melted their way up through the schists to the place where they are found, absorbing much of the material of the latter in their progress and sending upward and outward a complex radiating network of dikes.

I consider the two great stocks of "tonalite" described below to be partially denuded domes of these great granite batholites, which have melted so much of the gneiss and hornblende-schist into their mass that their composition has been greatly changed, but which, penetrated more dẹeply, would change to ordinary granite.

Two bands of hornblende-schist may be traced right up to the Belchertown stock on the south, and reappear again with their attendant beds upon the north, and a single very thick bed can be followed up to the Hatfield bed on the north, and in traces dipping toward it along its western side.

The homblende-schist west of Belchertown village, cut by numerous dikes of granite, becomes impregnated with feldspar, and its fragments have their hornblende largely changed to green pyroxene for a foot from the contact plane (this at Kellys Crossing), and farther south beds of augitic

${ }^{1}$ See J. W. Judd, The ancient volcanoes of the Hebrides: Jour. Geol. Soc. London, Vol. XXX, 1874 , pp. 220-300. 
granite nearly 4 feet thick border the larger granite veins, or are interealated in the amphibolite, and at last the whole greatly resembles the "syenite"-here a diallage-biotite-gabbro.

'The eastern hormblendic band eomes south as a sharp synclinal fold of hornblende-schist, embracing a band of mica-schist, and becomes changed to resemble the tonalite, while the inclosed schist continues far south into the tonalite, metamorphosed into a highly crystalline fibrolite-schist.

On the west side of the river broad bands of homblende-schist and limestone can be traced to contact with the tonalite, and isolated fragments appear on the latter across its whole length. Farther west, beyond the influence of the hornblende-schist, the tonalite changes to biotite-granite, and still farther west to muscovite-granite. Biotite-granite becomes the prevailing rock of the batholites, where they are contained in the Conway garnetiferous schists.

Two circumstances are very peculiar in the distribution of the rock. The first is the barrenness of the great central masses as compared with the richness in minerals of the smaller bordering dikes; the other, the degree to which the granite is confined to the mica-schist and avoids the gneiss which bounds it east and west and in all probability underlies it. This association is so marked that when a narrow strip of the Conway mica-schist appears east of the river in Northfield there are associated with it dikes of pegmatite having secondary veins of albitic granite carrying cleavelandite, spodumene, columbite, and beryl.

The western line of Pelham and its prolongation northward and southward through Leverett and Belchertown is the eastern boundary of the disturbed area, and in the gneiss east of it granite dikes are few and unimportant, rarely, as at the Monson quarry, carrying garnet and beryl.

I have given much thought to those theories which would trace the granite down to the subjacent gneiss which, entirely melted, is supposed to have been "extravasated" into the subjacent rocks; but I find no good reason for inferring any intimate relation between the gneisses of the region and the pegmatite. Many chemical and microscopical peculiarities of the gneiss militate against that relation, such as the large content of quartz, calcium, and iron and the small content of potassium, the uniform distribution of biotite and titanite, and the absence of tourmaline and muscovite.

Further (exception being made of the small secondary veins with 
their abundant minerals), the notion that any considerable portion of the pegmatite is "endogenous"-i. e., is a granite veinstone of aqueons originis met by its enormous amount in comparison with the schists from which it is supposed to be derived, and the fact that it has plainly conduced to the enrichment of the schists by rendering them feldspathic and abundantly quartz-veined rather than to their impoverishment. At the same time, the appearance of the granites solely in the mica-schist area is a fact for which I have no explanation, except that the granites have come up along the axes of the larger synclines.

\section{HISTORICAL NOTES ON THE MUCA-GRANITES.}

1819. E. Hitchcock. Geology of Deerfield, ete. Am. Jour. Sci., 1st series, vol. 1, p. 106.

1820. A. Eaton. Index, p. 95.

18ミ3. E. Hitcheock. Geology of the Connecticut River. Am. Jour. Sci., 1st series, vol. 6, p. 18.

1824. C. Dewey. Geology of Berkshire County, etc. Ibid., vol, 8, p. 4.

1824. E. Emmons. Notice of localities. Ibid., p. 250.

1827. A. Nash. Lead mines of Hampshire County. Ibid., vol. 12, pp. 238-258.

1828. E. Hitchcock. Mineral localities. Ibid., vol. 14, 1. 219.

1833. E. Hitchcock. Geology of Massachusetts, p. 465.

1835. E. Hitcheock. Ibid., No. 17, p. 473.

1841. E. Hitchcock. Ibid., Final Report, p. 682.

1855. E. Emmons. American Geology, p. 64.

1866. C. U. Shepard. Am. Jour. Sci., $2 d$ series, vol. 42, p. 248.

1876. W. O. Crosby. Report on Geological Map of Massachusetts, pp. 30, 38.

1879. A. A. Julien. Spodumene and its alterations. Annals N. Y. Acad. Sci., vol. 1, p. 346.

In $1819^{1}$ President Hitchcock mentions the granite as extending from Southampton to Hatfield, with veins of lead ore-not distinguishing the Hatfield "syenite."

In 1820 Eaton uses the term "the Northampton Range," and notes the direction and extent of the lead vein from Montgomery to Leverett as proof of the continuity of the above range of granite. He also notes the three granite veins, with tourmaline, in Goshen and Chesterfield.

In 1823 President Hitchcock designates the granitic area extending

${ }^{1}$ The year number may serve as reference number to the article cited above. 
from Southimpton through Williamsburg "the Sonthampton granite," and considers it "in original fundamental deposit of this rock." He says:

I would here snggest whether the mica-slate of this region that contains beds of granite may not be a newer formation reposing immediately upon that granitic nuclens which probably forms the basis rock in New England. And wherever this mica-slate and upper granite is worn away or there is a projection in the nucleus the basis rock may appear.

He describes further the Amherst-Leverett range of granite, extending it to the mouth of Millers River. The granite veins abundantly cutting across all the other rocks of the region are discussed and figured. These, as, for example, the main body of the great Chesterfield tourmaline-bearing vein, "are doubtless contemporaneons-that is, such as were consolidated at the same time with the rocks they traverse"-a curious idea, based, I presume, on the fact that the Chesterfield dike is interbedded in its schists with apparent conformity.

Graphic granite in Deerfield and Goshen, porphyritic granite in a range five or six miles long in Chester (which is a mistake for Middlefield), on authority of Dr. Emmons, and "pseudomorphous granite" are described. The latter is a coarse pegmatite, in which thin blades of biotite of the size and shape of the blade of a dinner-knife penetrate the rock in every direction and meet at every angle, but never intersect.

In 1824 Dewey correctly locates the great Middlefield porphyritic granite vein, doubtless on the anthority of Emmons, and the latter describes and figures many veins in Chester.

In 1827 Nash notes that often in ascending a mountain mica-slate forms the base, granite the apex, and that the great masses of granite are wholly destitute of minerals, and only the veins in mica-slate contain these.

In 1833 President Hitchcock gives a very complete and very clear description of granite, restricting it to the variety without hornblende, illustrating its complex relations to the mica-slate by forty-eight figures, enumerating the minerals contained in it, and giving a long argument in favor of its eruptivity. He says: "Upon the whole, the granite lies remarkably low in respect to other rocks, and one can not avoid the inference when he examines its situation, in almost all cases, that the abrasion of the stratified rocks may have brought the granite to light."

In 1835, and again in 1841, he publishes the same description with 
scarcely any change, except to call attention to the remarkably complex system of veins at Great Falls, in Russell. He recurs as follows to the idea quoted above: "And I have sometimes inquired whether, if the whole surface were denuded as deep as that part occupied by granite, we should not find this rock spreading over a great part of the State."

In $1876 \mathrm{~W}$. O. Crosby calls the granites of western Massachusetts "exotic montalban granites, whitish or gray, seldom red or greenish, as the Huronian granite is always micaceous, seldom hornblendic," and yet in the next section he classes the "syenite," which is generally reddish or greenish, and hornblendic, with the montalban granite. I am not certain that I understand this classification. He says further: "The Williamsburg granite represents, I conceive, the extension southward of the Shelburne anticlinal, only carried a step farther to produce the extravasated granite." An inspection of the map will show that the Groshen anticline is the continuation of that at Shelburne. There is no anticlinal structure connected with the Williamsburg granite and mica-schist.

In 1879 Julien publishes a most valuable article on the minerals of the granite veins related to spodumene, containing much concerning the secondary veins themselves which I have incorporated in my own description beyond.

\section{BIOTITE-MUSCOVITE-GRANITE.}

AREAS WEST OF THE CONNECTICUT.

Characteristic for this rock is its fine, even grain. Biotite, the prevailing mica, is scattered in small, separate, jet-black scales in a fresh, bluish-white mixture of quartz and feldspar. This gives it a deceptive similarity to the granitic forms of the Becket gneiss, from which it is distinguished by its greater firmness and by a small, constant content of muscovite. It resembles the granite of Concord, New Hampshire. It may be best studied at the quarries east of Florence. In its finest varieties, as at the Loudville mine, it is almost a petrosilex; in its coarsest, as at the quarries above, the grains reach $2-3^{\mathrm{mm}}$. It is wholly wanting on the east side of the river, around the Belchertown tonalite, which is in immediate proximity to the Monson gneiss.

\section{DISTRIBUTION.}

Just east of the Florence quarries, and extending from the house of Mrs. Haley to that of W. N. Moore, this granite adjoins the tonalite. In all 
this distance the exact contact is covered, but the rocks can be studied at points a few feet from it, and the change from the one rock to the other seems to be quite abrupt.

From this boundary it extends westward to the Mill River, and it is abundantly exposed along the road beside the river from Leeds to Williamsbury. As already indicated, it is found to be more and more replaced by dikes of pegmatite as one goes out to the border of the area and up to the ligher levels.

It makes always the impression that it was the original rock, and that the pegmatite was injected into it at a later time, perhaps only slightly later: Around the periphery of the area its dikes are very abundant in Goshen and Chesterfield, and less so in Conway and Blandford. Its dikes are so uniformly interbedded in the schist around the Goshen anticline that I for a long time mapped it as gneiss, until at the south end of South street in Chesterfield, near C. Damon's, I found it cutting across the beds of the schist. In these dikes it is of 'a little finer grain and more friable than in the main stocks.

\section{PETROGRAPHICAL DESCRIPTION.}

In the middle quarry west of Moore's and east of Florence it is medium-grained, very fresh biotite-granite, with little muscovite, very feldspathic, and showing abundant triclinic striation. The quartz is rare and occurs in rounded grains, as if resorbed. It contains fluid cavities in enormous quantity, of grotesque forms and in large sheets, often with bubbles, some moving rapidly, some slowly, and some being statiouary. They contain water and carbon dioxide. Large, rigid needles of rutile also occur. The feldspar, mostly triclinic, is centrally decomposed into a brown, opaque mass of kaolin scales. The narrow, fresh border seems almost as if it were a secondary growth. Extinction, $18^{\circ}$ on either side. Orthoclase and microcline are also present, but in small quantity, and the large amount of plagioclase allies it to the tonalite.

\section{CHEMICAL ANALYSIS.}

Analysis I, following, was made by Mr. L. G. Eakins from a specimen of the best quarry stone of coarser grain from Moore's quarry, Florence, from which also the slides were cut. It is remarkable how exactly this analysis agrees with that of the lighter variety of the Monson gneiss, 
with which variety this rock agrees most closely. I have repeated, for comparison, the analysis of the Monson rock (II):

Analyses of granite from Florence and gneiss from Monson.

\begin{tabular}{|c|c|c|}
\hline & I. & II. \\
\hline $\mathrm{SiO}_{2} \ldots \ldots \ldots \ldots \ldots \ldots \ldots$ & 73.27 & 73.47 \\
\hline 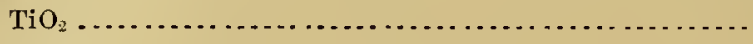 & .10 & $\ldots$ \\
\hline $\mathrm{Al}_{2} \mathrm{O}_{3} \ldots \ldots \ldots \ldots \ldots \ldots \ldots \ldots \ldots \ldots \ldots \ldots \ldots$ & 15.51 & 15.07 \\
\hline 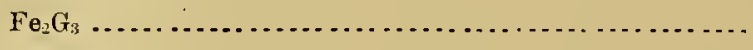 & .33 & 1.15 \\
\hline $\mathrm{F}_{\theta 0} \ldots \ldots \ldots \ldots \ldots \ldots$ & 1.14 & $\int 1.20$ \\
\hline $\mathrm{MnO} \ldots \ldots \ldots . . . . . . .$. & Trace. & ......... \\
\hline 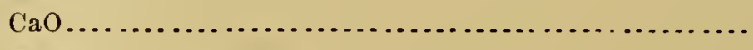 & 2.74 & 4.48 \\
\hline $\operatorname{Mgo} \ldots \ldots \ldots \ldots$ & .15 & .12 \\
\hline 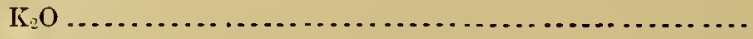 & 1.66 & .38 \\
\hline 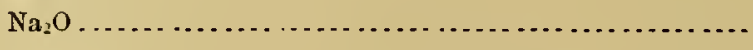 & 4.79 & 5.59 \\
\hline 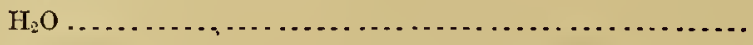 & .68 & \\
\hline $\mathrm{T}_{2} \mathrm{O}_{5} \ldots \ldots \ldots$ & Trace. & .... \\
\hline . & .......... & Trace. \\
\hline $\mathrm{Cu} \ldots \ldots \ldots \ldots \ldots \ldots$ & ......... & Trace. \\
\hline Total. & 100.37 & 100.26 \\
\hline
\end{tabular}

TOURMALINE DENDRITE ON THE SURFACE OF A. BLOCK OF GRANITE FROM LEEDS.

On the surface of a block of the light-gray granite quarried at Leeds is a layer, one-eighth of an inch thick, which differs greatly from the mass of the granite. The latter is a clear, gray granite of medium grain whose mica is mostly a jet-black biotite. The thin layer is a slightly coarser muscovite-granite, and over a large surface beautiful dendritic growths of jet-black tourmaline have formed. (Pl. VII.)

It is clear that boracic-acid emanations have passed through a fissure in the newly formed granite, and have promoted at once the formation of tourmaline and the replacement of the biotite of the granite by muscovite.

THE ATHOL AREA.

This enters the county only in the east portion of Orange, east of the west brauch of Tully Brook, and the boundary is continued northward across the west portion of Royalston. The granite, from more rapid erosion, forms a steep valley, out of which rise the steep-sided Big Tully and Little 


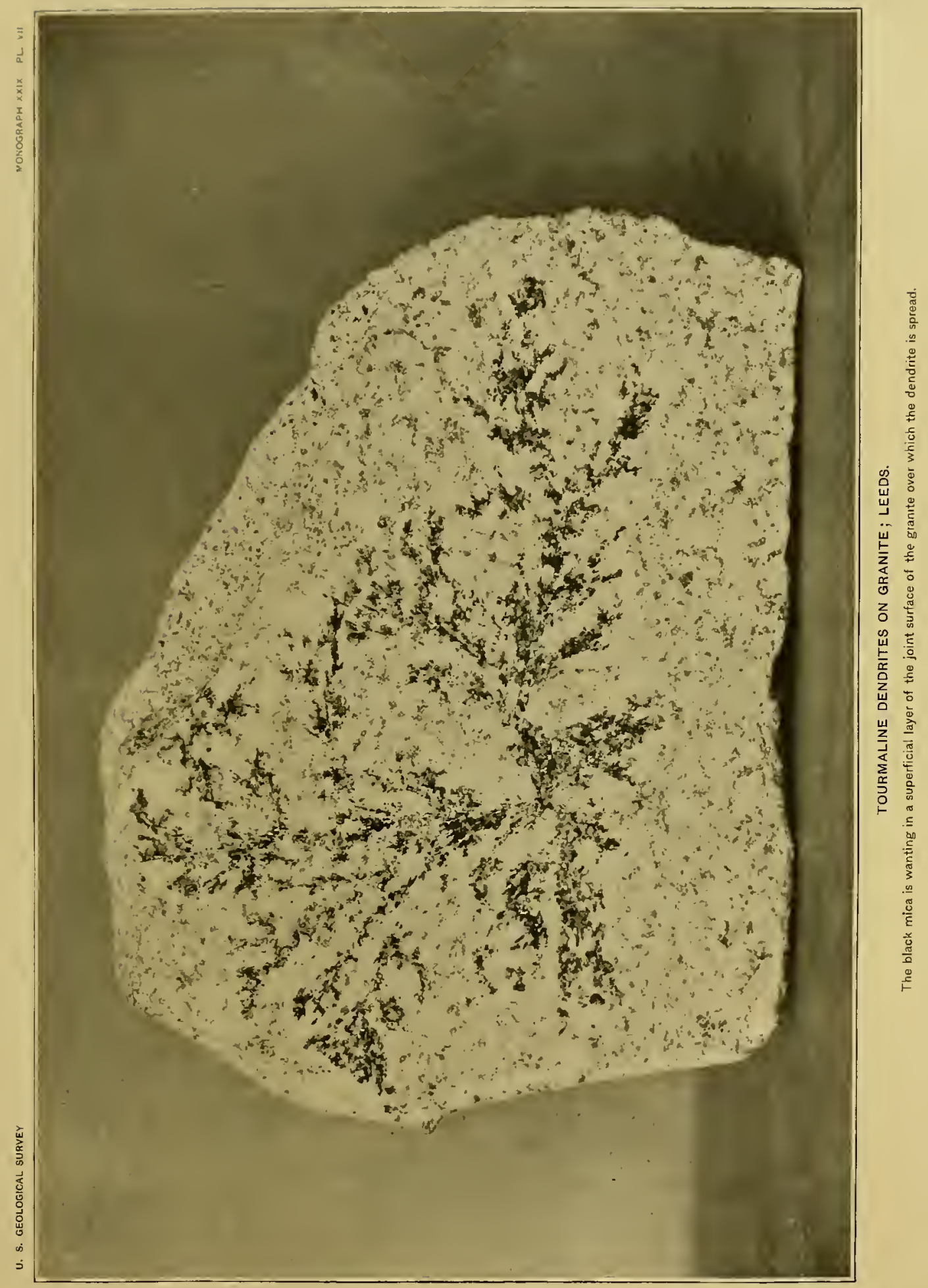



Tully mountains. The drainage established itself toward the sides of the basin and left these mountains in its center, as in the Orange-Enfield basin. The result is that the contacts with the schists are everywhere concealed beneath the brook deposits, and farther north by the till.

From the lighest ground on the road north from North Orange a fine view is obtained of the deep basin, with the white granite showing in the flanks of the Tully Mountains and all the ground above the sand level a "felsenmeer" of great woolsack bowlders of granite, while the bold hill in the extreme northeast of Orange shows by its jagged ridges of rust-brown rock that it is made up of the ligher fibrolite-schists.

The rock is the same almost purely biotitic granite as in the other bands, in the northern portion beautifully "stretched" and slightly garnetiferous. Along the side of Little Tully Mountain the biotite is mingled with epidote in porphyritic blotches.

\section{SECRETIONS AND INCLUSIONS.}

I have described below (p. 332) the black biotitic secretions which occur in the tonalite on either side of the river, and which resemble exactly those found in this granite. They are formed by the accumulation of biotite around centers. Other inclusions are more or less angular, and are finergrained and less micaceous than their host, or coarser-grained and black from excess of biotite and hornblende. These seem to be portions of the rock itself which have solidified before the rest and have been broken up and floated to their present position, with more or less re-solution.

There is in the first Massachusetts survey collection one specimen from Whately which contains a true inclusion of a foreign rock-a highly pyritous muscovite-schist.

THE HARDWICK GNEISSOID GRANITE AND GRANITITE.

Reference may be made to the section in Chapter VIII having the above caption for a preliminary description of this rock (p. 239). It covers a much greater area in Worcester County than here, and its relations will be more fully discussed in a memoir on the geology of that county. The rock could have been described with perhaps greater propriety in this chapter than with the Brimfield schists.

The Coys Hill granitite seems to me somewhat older than the other 
granites of this section, as it is more clearly affected by the last foldings, and it cuts the Brimfield schist and the Hardwick granite-gneiss. The latter is thus materially older than the other granites, and more nearly contemporaneous with the Brimfield. schist, in which I suppose it to have been intruded before the final folding of the series, and with which I have therefore described it.

\section{BIOTITE-GRANITE, OR GRANITITE.}

Within the central granite area I have found but one dike of a purely biotite-granite, an exceptionally fresh, coarse, subporphyritic rock with white orthoclase, much plagioclase, and amber quartz. It occurs 820 feet west of the outlet of Burnell's pond in Chesterfield.

The granite described above-that extending west from the tonalite through Florence, and that around Williamsburg-is often in hand specimens a purely biotitic rock; but it generally contains at least a small amonnt of muscovite. This muscovite has always in the freshest rock the character of an original component, and is so regularly present that I have classed these rocks as two-mica-granites.

CONTACT METAMORPHISM OF THE GRANITITE AND SCHISTS.

The granitite is a highly feldspathic rock, and it has had great influeuce npon the rocks bordering it on either side.

The rusty fibrolite-schists become garnetiferous gneisses, porphyritic with a great number of rounded masses of clear, fresh, transparent orthoclase, which oi ten furnish good moonstones, and were formerly quoted as adularia from brimfield and Sturbridge. They appear also in the dark Hardwick granite, where the porphyritic granitite approaches it, and they continue to appear in the fibrolite-gneiss far south of the most southern point to which the granitite can be traced, across Brimfield and Monson, as if they marked its subterranean continuation. They are often crushed at the border into a fine, sugary mosaic, and this cataclase structure is at times continued clear to the center.

THE MIDDLEFIELD PORPHYRITIC GRANITITE.

The great dike of granite in Middlefield, about 6 miles long, is widely separated from all other ontcrops, and is unlike all the other masses of 
granite in the region. It is purely a biotite-granite, small-porphyritie in all its central portions. The feldspars are about three-fourths of an inch long, rarely show earlsbad twinning, and are microcline without albite bauds. A few rounded spots, apparently of albite, break the continuity of the clearage surface. These feldspar crystals are at times bounded by a layer of secondary muscovite plates, and this is the only appearance of muscovite in the granite.

The biotite is aggregated in groups of rather dull-black plates, with epidote, garnet, and rarely white apatite needles accompanying it. The yellowish-white background is a somewhat friable mixture of much granular orthoclase and little bluish quartz, which is characterized by the presence of small, elongate cavities. At the border the porphyritic feldspars and the biotite aggregates disappear, and the friable ground with small distant spots of biotite and the small cavities remain unchanged.

\section{THE COYS HILL PORPHYRITIC GRANITITE.}

\section{DESCRIPTION AND DISTRIBUTION.}

The Middlefield dike on the west of the area is matched by this still larger dike on the extreme eastern border. It begins in Winchendon, and runs south 25 miles across Phillipston, Barre, New Braintree, West Brookfield, and Warren before it enters the Palmer quadrangle at its nortliwest corner, and ends in Brimfield. Its whole length is 33 miles; its average width is one-half mile. Only the portion in the Palmer quadrangle is here studied. It is a highly feldspathic, very coarse-porphyritic, garnetiferous granitite, which presents almost everywhere a distinct gneissoid structure from the parallel arrangement of the large feldspars. It is proved to be an intruded rock by the fact that it runs for 20 miles in the Brimfield fibrolite-gneiss; then, just as it enters the Palmer quadrangle, it crosses very obliquely the Hardwick black granite, and enters the eastern band of fibrolite-gneiss. This is further proved by the fact that where it sends a great lobe into the western fibrolite-gneiss the boundary between the two is a broad sigmoid curve, having a general east-west direction, while the granitite on the north and the rusty fibrolite-gneiss on the south of this line have the same foliation structure, which strikes N. $25^{\circ}$ E. and dips $60^{\circ}-70^{\circ}$ 
west with great uniformity, and thus cuts directly across the boundary between the two rocks at every angle. The sudden disappearance of graphite, pyrite, and fibrolite, and rustiness and the great increase of feldspar, separate it from the Brimfield gneisss.

This gneissoid structure, furthermore, distinguishes this dike from the other granites of the region and indicates for it a greater age. The other granites have often been injected into the vertical foliation planes of the schists after these had been completely formed, and do not show any trace of having been subjected to the pressures which have given these structures to the schists, while here the granitite and the schists have been subjected to the same compression.

A crushing of the feldspars occurs in the bordering portions of the granitite itself, and is well shown where, across the brook north of Fentonville, in Brimfield, the western boundary runs up the mountain side. Here the large feldspars are only slightly rounded and the sugary border of crushed feldspar still retains the angular boundary of the former crystal. The change increases until only the transparent centers remain, and this causes a marked whitening of the whole rock and ends with the formation of a light-gray, granular granitite, hardly to be distinguished from the Monson gneiss. This forms a selvage to the dike a hundred feet wide near H. Sherman's, a mile southwest of West Warren, and a large quarry has been opened upon the same rock on the west slope of Colonels Mountain, in the northeast corner of Palmer.

The rock can well be described by supposing the large porphyritic carlsbad twins which are scattered through the rusty fibrolite-schist of East Monson and Sturbridge to develop so abundantly that a complete augengneiss should result, the biotite and the garnet remaining the same as in the fibrolite-schist, and only the fibrolite, graphite, and pyrite disappearing, which they do almost uniformly. I have been thus led at times to consider this rock an extreme of the granitic impregnation which has affected the fibrolite-schists in this region, and not an intruded plutonic rock pure and simple. A granite dike 33 miles long and only 2,500 feet wide is rather anomalous, especially in a region where the granites are in great blocks of a wholly different type. We are here, however, at a point where the type changes. Farther east porphyritic granitites are very common. 
CORDIERITE-GRANITITE.

At Brimfield, in the roadside near the north line of the town, is a coarse granitic rock made up almost wholly of grumular feldspar, in which linge, rounded crystals of the same are embedded. In both forms the feldspar is largely transparent. Thin films of biotite, mostly changed to r.hlorite, are shot through with tufts of fine fibrolite. Garnets and flakes of graplite are irregularly disseminated. Large, granular inasses of nearly black, fresh cordierite occur, which are at times amethystine.

The feldspar proves to be almost wholly microcline, with finest microperthitic structure (which is the cause of the moonstone luster) and with crushed borders, and it contains unusually large and well-defined zircons. The quartz contains many long, curved rutile needles.

The cordierite is exceptionally fresh; rarely there spreads in fissures a delicate, feathery growth of limonite, and the mineral is altered for a small distance into a yellow, serpentine-like mass having aggregate polarization. It contains in great numbers regular hexagonal plates of hematite, placed in two planes at right angles to each other.

Interposed lamine occur at times in twin positions. (See fig. 2, Pl. III.) There are two sets, making an angle of about $61^{\circ}$ with each other. They are long, rigidly straight and parallel, narrow plates, sometimes slightly tapering or truncated at the end by an oblique plane.

Sometimes a broad untwinned area sends a great number of these thin bands far into the untwinned area of another crystal.

At times the bands interlace and include many diamond-shaped fields of the host. They are unlike plagioclase bands in that they are surrouncled in polarized light by a white band. This is because the plane of boundary runs obliquely to the plane of the section, and the complementary colors of two parts nentralize each other. The fibrolite runs up, branching and rebranching like a plant, and at the end of each branch bright-green plates of ehlorite are attached like leaves. In some cases it seems as if the square prism of the fibrolite were changed to chlorite.

In fig. 2 of Pl. III the unshaded portion shows the axial figure of the first crystal (I) eccentrically. as indicated. This crystal was large, and from a second, smaller crystalline portion (II) blades generally rigidly straight and with straight boundaries were sent ont into (I). These plates MON XX1X-21 
are bounded by sides of the prism $\infty \mathrm{P}$, which is the twinning plane. They show a single axial ring, and the axial plane makes an angle of $48^{\circ}$ with that of (I), instead of $60^{\circ} 50^{\prime}$, as would be the case if they were cut parallel to 0 P. The other crystal (III) is represented by a series of blades which make an angle of $61^{\circ}$ with the first series. They are also bounded by $\infty \mathrm{P}$, which is the twiuning plane, and their optical axial plane makes an angle of $58^{\circ}$ on the other side of (I). The figure is drawn with crossed nicols and with the crystal (II) at the point of extinction.

\section{MUSCOVITE-GRANite, OR PEGMATITE.}

One may omit any detailed description of a rock so well known. It is a granular mixture of quartz, muscovite, and a potash-feldspar mostly microcline, or orthoclase more or less mixed with microcline, and veined with albite; generally coarse-grainerl, and often very coarse-a giant granite with its feldspars several inches on a side and its mica a foot or more across. Its greater masses and its smaller dikes are almost wholly barren of any accessory minerals. In its dikes of medium or larger size several minerals-as beryl, biotite, tourmaline, garuet-occur sporadically, and much more rarely "secondary veins" of foliated albite contain these and others of the rarest minerals in greatest beanty and profusion.

The great masses which stretch from Montgomery to Conway and the many dikes which go out from them, the great mass southeast of Mount Toby in Leverett and the nortl of Amherst, and the dikes extending thence south throngh Amherst and Belchertown are the main outcrops of this rock.

These dikes have been extensively worked in Blandford and Huntington for mica, feldspar, and quartz, especially upon the property of the Pontoosic Flint Mills, in the north part of Blandford. There is opened liere one of the most beautiful veins of giant granite in the county. The upper and the lower walls are occupied by a selvage 2 to 3 feet wide of the coarsest muscovite, which projects inward with crystals a foot square, mingled with feldspar. There follows above and below a layer 1 to 2 feet wide of great feldspars a foot on a side, which projects freely inward. The center, 2 to 5 feet wide, is of clear, smoky quartz, and in one direction the whole vein changes to quartz.

These veins are very rare in the tonalite, but going out from these into the granites they increase gradually in number and at last swarm in 
soveral generations and of every size until the original granite almost disappears, ant they appear in great numbers also far beyond the great granite stocks, in the sehists.

While muservite is so rare as to be alnost an accessory in the granitite, biotite is not wholly wanting here, but appear's always with the distinct habit of an accessory, in great blades touching each other so as to form a rude cellular structure. This was called psendomorphons granite by IItcheock.

IROBABLE EXTREME MIODIFICATION OF THF PEGMATI'LE BY CRUSHING.

The North Amlerst granite. -This is a peculiar rock, appearing in the hills southeast and west of North Amherst station, and again at the foot of the west slope of the Pelham ridge east of D. Hawley's, beside a brook.

It has at times a quite marked foliation (almost certainly a secondary structure), distant planes being thickly covered with quite coarse muscovitebiotite films, while in cross-section it appears wholly free from mica and has a subporphyritic look. Opaque, subangular portions of feldspar or quartz-feldspar are scattered quite distantly in a highly crystalline and continnous quartz mass which seems a secondary constituent cementing the brecciated fragments of a highly feldspathic granite from which most of the homblende or biotite has been removed during the violent changes the rock has undergone.

In thin section a few twisted fragments of mucl altered biotite appear. The feldspars are brown with alteration products-rust, kaolin, and muscovite-and rarely determinable; more plagioclase can be made out with the lens in the mass than under the microscope in thin section. The grains are much cracked and crushed, and show undulatory extinction and wavy twin laminæ. Everything accords with its position along the main fault area marked by strong crushing.

\section{ALBITIC GRANITE AND PEGMATITE DIKES CONTAINING RARE MINERAIS.}

It is a remarkable fact that the rare elements appear only in pegmatite dikes on the extreme periphery of the great granite area, and that they are not found in the biotite-granite or within the great central region of granite. This is enforced by the list of localities below, and may be brought into 
casual connection with fumarole activity, using the term in a wide sense, and indicates that the pegmatite dikes were the later products in the complex series of granitic types present in the region. It has some analogy with the fumarole products accompanying the trap eruptions in which, as I have described (p. 423), albite, clearly water-deposited, rests on delessite in amygdaloid cavities, as do also datolite, axinite, and rarely tournalineboracic acid minerals. The cleavelandite, which is a variety of albite, and abundant tommaline match the minerals named above, but the analogy does not extend to the rarer elements.

\section{DISTRIBUTION AND DESCRIPTION.}

Because of several peculiarities in the separate occurrences, I have given below a description of each, commencing at the northwest and going around the area by the south.

\section{THE GREAT TOURMALINE-SPODUMENE DIKE.}

Macomber's spodumene ledge, Clarke's tourmaline ledge, the West Chesterfield Hollow, and the well-known Wahnut Hill spodumene ledges (the last in what is now Huntington, the others in Chesterfield) are all portions of one continuous or nearly continuous, vertical, interbedded dike of coarse pegmatite, which is fanlted and its south lalf thrown east at West Chesterfield Hollow.

\section{A. A. Julien ${ }^{1}$ says:}

At Macomber's ledge the coarse orthoclase granite of the main vein contains films of margarodite and few imperfect green beryls, while in the secondary vein the succession seems to have been, first, quartz, muscovite, granular albite, tourmaline, and spodumene; then cleavelandite, quartz, manganese, garnet, and zircou; and, finally, smoky quartz with green aud blue tourmaline. The larger crystals of most of these minerals penetrate through all the layers and their growth seems to have been continuons.

At Clarke's ledge the main granite vein is of the same general constitution as at Macomber's, rarely showing a few large beryls. In the secondary vein no spodnmene occurs, but the snccession is in the same order. First, on either wall a saccharoidal albitic granite, with little quartz and mica and a few scattered, imperfect black tourmalines and garnets, then coarse cleavelandite, with blue, green, red, and rarely brown tourmaline, and small quantities of the rarer minerals, microlite, columbite, cassiterite, zircon, cookeite, lepidolite; all these, especially the tourmaline, increase in quantity toward the center of the vein, which is filled up by an irregular sheet of smoky quartz.

${ }^{1}$ Sporlnmene and its alterations: Annals N. Y. Acad. Sci., Vol. I, p. 351. 
Here the schists have beon worn away fiom the main dike, which stands up in a vertical wall 33 feet high. In many places a veneering of schist renains attached, and when it is removed the impression of the schist is sharp and alear on the surface of the pegmatite. The layer of schist against which the pegmatite rests shows no signs of its influence, thus differing fiom the schist in contact with the albitic granite at the Barrus farm, described below, where the contact metamorphism is pronounced and the granite and schist are fused together.

The secondary vein, as described above, is seen high up on the face of the vertical side of the main dike, and seems to we to have been deposited in a vertical transverse fissure in the latter, which fissure extends from the east face only abont halfway across the dike and to an intermediate distance up and down. This fissure seems to have been formed in the newly consolidated peginatite and to have been filled by a magma of peculiar composition, much hydrated, rather than by a simple solution. Thus, commencing with this tonalite and ending with the quartz veins, I suppose there is an unbroken series from igneous fusion to aqueous solution.

At Chesterfield Hollow the granite of the main vein is of the usual character, but shows no beryl and little mica. The successive deposition of minerals in the secondary vein is, first, orthoclase in huge crystals, large plates of muscovite, sometimes 6 to 10 inches in diameter, and grayish-white quartz. Within this comes an irregular mass of a coarse albitic granite, with green muscovite, spodumene, greenish-white beryl in masses sometimes 10 to 25 ponuds in weight, and a zircon rich in uranium in minnte double pyramids rarely three-sixteenths of an inch in diameter. Usually this albitic granite passes gradually into a mixture of quartz and cleavelandite in bunches of snow-white plates inclosing less muscovitemanganese garnets in large and abundant but imperfectly erystalline grains, zircon, spodumene, and yellowish-white beryl in irregular masses.

Finally the core of the vein consists of an irregular sheet of smoky quartz, penetrated by long prisms of spodumene, green beryl in small and good crystals, muscovite in hexagonal plates, often well crystallized and np to 2 or 3 inches across, as well as in sheets, scattered scales and wavy films which in part seem to be altered to margarodite, columbite, and zircon in rare but perfect crystals. This snecession of minerals in the secondary vein is not as regular as might be inferred from the foregoing description, in which it is intended to indicate only the general tendency toward a definite arrangement.

At Walnut Hill, in Huntington, the material of the main vein is similar to that of the preceding locality. In the secondary vein the rich deposit was found to be a very coarse albitic granite, rich in black tonrmaline in huge masses, muscovite, and garnet; then followed cleavelandite, white quartz, and spodumene in the 
well-known fine crystals associated with black and blue tourmaline, triphylite, crytolite, garnet, apatite, muscovite, and greenish-white beryl, and the central sheet of smoky white quartz received the terminations of the spodumene crystals, together with a little beryl, moscovite, and cyrtolite. ${ }^{1}$

\section{DIKES IN GOSHEN.}

The first dike in Goshen, that on the Mamning farm, west of the Ashfield road, near the north line of the town, can not be well studied, as only discomnected masses can be obtained and the boundaries of the dike are not visible.

The veinstone consists of a coarse aggregate of albite, indicolite, garuet, and spodumeue, whose crowded and imperfectly outlned grains indicate a more rapid crystallization than in the other localities.

At the Barras vein, a mile to the west, the mass of the vein seems to be represeuted in place by a coarse aggregation of white quartz, orthoclase, and muscovite, and occasionally greenish beryl, accompanied in places by a contiguous vein of reddish-white quartz, while the seattered bowlders of albitic granite appear to be fragments of a central band or secondary vein whose slow crystallization is suggested by the beautifnl aggregate of snow-white cleavelandite and grayish-white quartz which forms the matrix of the rarer minerals. Of these the most abundant are the spodumene, mostly in rectangular prismatic masses up to 18 inches in leugth, and tourmaline in black, green, or blue-black (indicolite), generally massive, but sometimes in good crystals. Less commonly were found beryl, green and white (goshenite), in grains or sometimes fairly crystallized, with good terminations, garnet, rose-colored muscovite, and, still more rarely, columbite and cassiterite in minute crystals. Apparently there has been also in parts of the vein a final deposition of masses of smoky quarts enveloping smaller crystals of these minerals, but particularly of green beryl and indicolite. ${ }^{2}$

Here the secondary vein came in part in contact with the country rock, and the latter, which is a whetstone-schist just at the contact, has been for several inches (at least 4) fully impreguated with silica, albite, and tourmaline in fine, black needles.

Halfway between the Manning and the Barus ledges, by the roadside, south of J. B. Taylor's, much blasting has been done recently (1889) by Mr. Barrus for spodmmene. It was proposed to export the mineral for the manufacture of lithium. The spodumene is abundant in poorly bounded crystals and coarse crystalline aggregates associated with little tourmaline,

${ }^{1}$ A. A. Julieu, Spodumene and its alterations: Aunals N. Y. Acad Sci., Vol. I, p. 351.

${ }^{2}$ A. A. Julien, ibid., p. 350. 
gannet, and muscovite. The three localities last mentioned lie in a line, trending about $\mathrm{N}$. $70^{\circ} \mathrm{W}$., and may be parts of one vein.

A new lacality diseovered by me is in a pegmatite ledge a mile sonth of the Barms ledge and overlooking Lily Pond. Here prismatic psendomorphs of coarse muscovite after spodumene, 2 meles long, ocenr in limited number:

III. DIKES IN UHISTER, BLANDFORD, AND HUNTINGTON.

The locality mentioned by E. Emmons ${ }^{1}$ as oceurring a mile north of Chester village was stated by him to contain spodumene, smoky quartz, muscovite, cleavelandite, and indicolite. This ledge I was not able to find. Mr. A. A. Julien seems to have had better success, but to have found no spodumene there. ${ }^{2}$ Not far from this locality the granite veins have furnished large and perfect manganesian garnets.

Farther sonth, on the northeast line of Blandford, a very coarse pegmatite, much quarried for mica, quartz, and feldspar, the property of the Pontoosic Flint Mills (see page 322), has furnished beryls of great size, the largest as big as a powder keg, with large garnets. A granite in the churchyard in Blandford also carries beryl. Just south of the first house on the Westfield-Russell road after entering Russell the pegmatite abounds in manganesian garnets of large size and great perfection, which are found in every cabinet.

IV. DIKES EAST OF THE CONNECTICUT.

On the other side of the area the small pegmatite veins at the Monson quarry have furnished very fine beryls and many manganesian garnets. The finest bluish-white cleavelandite occurs in New Salem. In Northfield, where the Gulf road crosses the south line, large beryls occur in the pegmatite, and farther north, a mile west of the Moody homestead, is the interesting locality of columbite in a pegmatite vein in the mica-schists, and a mile north on the strike of the schists is a secondary vein of the fine radiate-foliate cleavelandite of very considerable size, exactly like the Goshen-Chesterfield schists, in which I conld find no other minerals. Still farther north, on the strike and therefore in the same schists, is a

${ }^{1}$ Am. Jour. Sci., 1st series, Vol. VIII, 2824, p. 243.

${ }^{2}$ A. A. Julien, Spodumene and its alterations: Annals N. Y. Acad. Sci., Vol. I, p. 221. 
pegmatite vein abounding in albite and spodumene and closely resembling the occurrence at the Manning farm, described above (see p. 326). This lies just across the north line of Northfield, near the house of M. A. Brown, on the Winchester road.

\section{GARNET IN PEGMATITE WITH COMPLEX PARAMORPHIC BORDER OF ZOISITE- HEMATITE, EPIDOTE-FIBROLITE, AND MUSCOVITE.}

In the coarse inuscovite-granite that occurs on the Gulf road in the sonthern part of Northfield and cuts the Goshen mica-schist which farther east becomes fibrolitic and is called the Brimfield schist, several interesting garnets have been recently discovered by Mr. C. H. Webster. (Pl. II, fig. 4.) They are nearly an inch across, of deep-red color and of trapezohedral form, with a narrow dark-red band surrounding them which is in places spotted with green. Ontside this is an opaque white border, $3-7^{\mathrm{mm}}$ broad, which looks like saussurite.

The garnet under the microscope is evenly cleaved and almost free from inclusions. There are a few rounded blebs of the quartz-muscovite mixture or of the zoisite-bematite mixture which is found in the border.

This border layer is largely composed of zoisite in stout grains, which shows low polarization colors, high refraction, a divergence of optical axes of $45^{\circ}$, and is optically positive. The hematite is deep-red to black, and occupies regular and close cleavage fissures in the zoisite, often so regular as to recall the cross-section of a tabulate coral. This layer is joined to the garnet by a suture, which is very intricate, so that lobes of the two minerals penetrate deeply into each other and rounded blebs of the zoisite are cut off in the garnet. While thus intricately joined interiorly, the zoisite mixture forms exteriorly quite smooth crystal faces for the garnet.

Outside this first layer is a delicate and very thin layer of green epidote, which folds into every irregularity of the last layer and extends continuously over all the surface of the latter and around all inclosed portions of the same. It has rather moderate absorption and extinguishes in proper relation to the cleavages for epidote. The outer layer is a mass of muscovite blades felted with a fine-fibrous mass of fibrolite needles arranged in beautiful plumose and tufted groups in a general way radially to the surface of the garnet. 
THE CRUSHING OF MINERALS IN THE ALBITIC GRANITE.

In fle summer of 1885 the pegmatite dike on Walnut IIill, in Huntington, wals reopened for me by Mr. Frank L. Nason. The spodumene 'rystals obtained were large-larger than most of those obtained previonsly. They were clear-gray, without the shade of flesh-color of those before ohtained, and were covered with dendrites, which also penetrated everywhere into the perfect cleavage. Several fine twins occurred, but for the most part they were not well terminated. The largest erystal was 28 by $7 \frac{1}{2}$ by $3 \frac{1}{2}$ inches. The crystals bear abundant evidence of the violent pressure to which they lave been subjected since their formation, several large, perfectly terminated crystals a foot long being several times obliquely sheared off and the parts slipped one-eighth to one-fourth of an inch and recemented; and the largest crystal, whose dimensions are given above, is broken across or sharply folded into "monoclinal flexures" more than forty times. Other large crystals are bent over as much as $45^{\circ}$ in a great curve, one sharply a full $90^{\circ}$, and without a crack. ${ }^{1}$

The feldspar (nicrocline) occurs in masses as large as one's head, often in part green. The cleavelandite is not distinguishable from that of Chesterfield. Tourmaline appears in large, rude, black crystals. Granular masses of honey-yellow manganesian garnet (intermixed with feldspar) as large as an egg have by their decomposition furnished the material for the abundant dendrites. These latter masses are at times punched into the great spodumenes as if these had been plastic as wax.

There is in the collection at Amherst a crystal of tourmaline from the Clarke ledge, once figured by President Hitchcock, ${ }^{2}$ which is broken across fifteen times and the parts moved into a position en échelon and recemented by quartz, and I have a crystal of beryl from Huntington similarly affected.

HYDROTHERMAL CHANGES IN THE ALBITIC GRANITE VEINS.

Pseutomorphs.-Julien has described a most interesting series of pseudomorphs in these dikes, produced by alkaline (mainly sodic) silicate solutions, by which spodumene is changed into cymatolite, killinite, albitic granite, muscovite, albite, and quartz, the lithia being replaced by the other

"For figures of these erystals see Minerological Lexicon, under "Spodumene": Bull. U. S. Geol. Survey No. 126, 1895, p. 159.

E. Hitcheock, Geol. Mass., p. 702. 
alkalies. Inmediately afterwards Brush and Dana proved the cymatolite to be a mixture of albite and muscovite formed from the spodumene with the intervention of a lithia- nepheline (encryptite), and made it probable that the killinite was mainly hydrated muscovite, and thus the series of pseudomorphs is reduced to one type, namely, spodumene changed to albitic granite, whereby, from the gradual suppression of any one or two of the constituents, forms made up of either quartz, mica, albite, or mica and albite result. Psendomorphs a yard in length and nearly a foot across are made up of a coarse mixture in various proportions of albite, muscovite, and quartz, with manganese, garnet, zircon, beryl, etc., occasionally interposed, and we may add also microcline.

\section{ORDINARY METEORIC ALTERATION.}

By ordinary carbonated waters there has been a gradual removal of a part of the lithia and more soluble protoxides, almost universal, with the consequent effect upon the physical characteristics of the mineral shown by the loss of weight, lnster, greenish color, and translucency.

The zircons have absorbed water and lost part of their uranium, which has separated as antunite, torbernite, and, by a further decomposition, uranocher. The garnets afford ocher and pyrolusite in dendritic films.

The triphylite by absorption of water and higher oxidation of some constitnents has assumed its present altered form, so that only rarely do small blue nuclei of the unaltered mineral remain.

The spodumene and cymatolite both at last degenerate into clayey material, sometimes pink and allied to kaolin or montmorrillonite. ${ }^{1}$

The kaolin beds at Blandford village illustrate on a large scale the results of the agencies deseribed in the last section. Great beds of coarse granite in every stage of alteration are exposed in the diggings; in some parts the feldspars are only softened and made friable, in others they are pure soft kaolin, and the mica-schist which is tangled among the big veins is rotted to a soft, rnsty earth. All the fissures in the altered mass are blackened by deposits of manganese oxide. It is quite certain that this deep-seated alteration of the granite is mainly pre-Glacial and owes its preservation to its position on the sontheastern slope of the hill npon which the village is built. The material has been used extensively at Russell for the manufacture of brick of fine quality and tile, but recently the buildings have been destroyed by fire. 


\section{APII'T'L:}

Conse pegmatite dikes are rare in the tonalite areas. Their place is taken by aplite dikes, which in many places are very abundant in the tomalite, but are always very narrow. The rock is a fine-grained quartzfeldipir mixture, almost without hornblende or mica. Two miles north of Leyden Center a road runs west down to Green River. Following this road a half mile west, one reaches a place where it bends sharply south around a projecting spur of rock. A dikelike mass which has in part the aspect of an aplite and in part that of a quartz-porphyry crosses the road at this point. It is 13 rods wide, and stands vertical in the Conway schist and strikes north with it. The dike ends in the bluffs to the south, but can be followed a long way north. It is a pale-gray, rather smallporphyritic rock, and is the only rock of this type in the area. I lave sometimes thought it an exceptionally massive arkose-gneiss.

\section{QUARTZ-GABBRO AND QUARTZ-DIORITE, OR TONALITE.}

The syenite of President Hitchcock seems to me to have been originally a quartz-diallage rock, but it is now for the larger part a homblendic rock; indeed, west of the river the presence of diallage can only rarely be rendered certain. The low percentage of silica and the almost complete absence of orthoclase exclude it from the syenites.

\section{HISTORICAL}

BASIC SECRETIONS: HITCHCOCK'S SUGGESTION OF THE THEORY OF "SCHLIERENG̈̈NGE."

In 1819 President Hitchcock mentions "syenite" as the prevalent rock along the Connecticut on the east side-a statement scarcely correct-and notes that the proportion of hornblende is rather small and that mica is often present. "Porphyritic syenite is common in this quarter and steatite occurs in its eastern part." The first statement is afterwards retracted, and the second I can not explain. ${ }^{1}$

In 1823 the same author describes the rock more fully from its two localities, Whately and Belchertown. He notes first the interesting fact that in coming from the westward across Northampton "one passes over the most decided granite until he comes within 4 or 5 miles of the rillage. 
He will then find the texture of the rock to be finer, and in some instances it contains a portion of hornblende, while the proportion of quartz is diminished somewhat and the feldspar frequently becomes red. Coming nearer Northampton, however, we find the hornblende more and more abundant until we arrive at the eastern edge of the range, where we find a rock containing little else than feldspar and hornblende."

He notes the abundant veins of granite in the brook 2 miles south of the chureh in Whately, and the many minute fanlts of the rock and its peculiar conglomerated character. "The rock here contains numerous embedded masses of other primitive rocks, as gneiss, mica-slate, quartz, hornblende, and a finer kind of syenite, all almost uniformly rounded."

He mentions a third locality of syenite west of the road, a mile north of the village of Whately, associated with "greenstone-slate nearly allied to homblende-slate, and unstratified primitive greenstone. It consists of nearly equal proportions of feldspar and hornblende-the former white and compact or very finely granular, entirely destitute of foliated structure or pearly luster." ${ }^{1}$ A study of this rock in thin section shows it to be an amphibolite. The white spots of supposed feldspar are parts of the finely gramular ground mass, which are free from green homblende, and it is not different from the other beds of amphibolite named above, with which it is associatecl. (See p. 191.)

In the Reports of $1833^{2}$ and 1835 an extended account of the rock is given, which is reprinted almost verbatim in the Report of $1841,{ }^{3}$ with the suppression of a single very suggestive theory.

He describes the rock as a quaternary compound of feldspar, hornblende, quartz, and mica. He describes the "conglomerated sienite" of Whately in detail:

It is in fact a real conglomerate, and in some places the nodules are so numerous that it has very much the appearance of the coarse pudding-stones of the newer rocks. The nodules vary in size from the diameter of half an inch to that of 6 or 8 inches. They are not smoothed, like the pebbles in the more recent conglomerates, by mechanical attrition, but they appear like masses of rocks that have been partly melted down by heat. Upou the whole, I think I have ascertained the presence of hornblendeslate, mica-slate, and quartz rock in these nodules. When the rock is broken they are knocked out without difficulty, like the pebbles of a common conglomerate.

${ }^{1}$ Geology of Connecticut River: Aw. Jour. Sci., 1st series, Vol. YI, p. 29.

${ }^{2}$ Rept. Geology of Massachusetts, p. 463

'Ibid., p. 668. 
The inclusions may have been rounded by slow solntion in the melted maknini, this solution attacking corners and edges most rapidly. That the inclusing rock is an igneous rock is certain from its microscopical character and its contact effect. That the pebble-like masses are true foreign "inclusions" does seem probable from their lithological variety and difference from the inclosing rock. They closely resemble pebbles rounded by water, but so many eases of snch inclusions rounded by melting (as granite in lamprophyre and quartz in varions magmas) have been described that this may be the explanation. ${ }^{1}$

I am, however, more inclined to consider them secretions in the mass of the rock itself, as they seem to belong wholly to two types which occur commonly in this way. The one is a coarse, black hornblende-biotite aggregate, such as is often seen in small masses anywhere in the rock. Slides of this showed it to agree with these concretionary masses, and not with any amphibolite known as an independent rock in the region. The other is a fine-grained granite or elrite, like that so common in the veins that cut the rock abundantly. Both these rocks seem to have separated from the magma, to have been accumulated here in unusual amount, and to have been rounded by resorption according to the methods discussed in the articles cited above.

The locality where these forms are found is at the upper dam at West Brook, on the north line of Hatfield.

A third most interesting variety of the syenite is described as follows:

Augitic syenite.-The presence of hornblende in this variety and the absence of mica have led me to call it augitic syenite rather than augitic granite, although in position it is associated with granite. There are two varieties. The first is composed of black hornblende, greenish angite, and yellowish feldspar, all the ingredients except the feldspar exhlbiting a very distinct and lively crystallization. This variety occurs in the northern part of Belchertown. The other variety, which I have fonnd only in bowlders in Amherst, consists of angite and feldspar, the former being so arranged in the latter as to present the appearance of letters. ${ }^{2}$

He insists, further, on the low level occupied by the syenite in the valley and upou its columnar structure, and describes in considerable detail the segregated veins which occur so abundantly. He presents a

${ }^{I}$ See, for several citations, R. Pohlman, Euschliisse von Granit in Lamprophyr: Neues Jahrbuch fïr Mineral. etc., 1888, II, p. 87, and note on page 92.

${ }^{2}$ Thus is a contact modificatiou of the amphibolite bordering the granite and is described on p. 243. 
discussion of these last in the Report of 1833, suppressed in that of 1841 , which, as he develops it, has some resemblance to the theory of "schlierengänge," as developed by E. Reyer.

The greater part of the veins in our syenite consists of material foreign to the nature of the rock and introduced subsequently to its original production. I do not say subsequently to its consolidation, for it has appeared to me possible that while a molten mass of rock-say syenite-was in an incipient state of refrigeration matter of a similar kind still more intensely heated might have been injected into it, so as to form veins.

Other veins associated with faulting he refers to the filling of fissures formed in the solid rock.

Under the head "Mineral contents" he refers a mineral crystallizing in four-sided prisms to rutile. It is allanite. He mentions quartz erystals and "gashed quartz," quartz "full of thin fissures, as if made by random cuts of a knife," and explains it as due to the growth of quartz about some mineral now removed. This mineral was doubtless barite. The minerals of the Hatfield baryta mine are also enumerated. Under the head "Theoretical conclusions" the hypothesis is advanced that "the syenite was formed by the melting down of the lomblende-schist," and in proof of this he presents a rude diagram of the state of things at the north end of the syenite in Whately. In this diagram the syenite is represented as being succeeded to the north by hornblende-schist, the two being in contact and the bedding of the schist being continued in a rude stratification of the syenite. He adduces also the fact that the hornblende-schist on its western border, a mile north of the syenite, is massive, columnar, and feldspathic, and theorizes that there was here heat "sufficient for the production of feldspar, but not for its crystallization;" that with a greater degree of heat syenite would have been produced; with a still greater, the production of hornblende would have been impossible and granite would have resulted.

The diagram and description of the relations of the syenite and the hornblende-sehist in Whately are based upon a serious error of observation.

The hornblende-schist which outcrops in great force north and sonth of the south line of Whately is toward the north separated by argillite from the broak band of hornblende-granite with which the diagram connects it.

C. II. Hitcheock, in $1871,{ }^{1}$ elassed the rock as a Lamrentian gneiss.

'Explanation of geological map of United States, in Walling's Atlas of Massaehusetts. 
It is put as an "exotic M[ontalban granite" on the "centemnial may" of IV. O. Crosly, becanse it is micaceons as well as hornblendic and because it continins a center of true granite (according to President Hitcheock's map of 1844 ) in the southwest comer of Belehertown-a gromelless argument, since the grinnite in question is simply a great pegmatite dike which euts the tonalite.

\section{DISTRIBUTION.}

On the west side of the river the rock commences in Whately, a short distance sonthwest of the village, where it is seen in contact with the Leyden argillite, producing a marked contact metamorphism (p. 205), and rums south in a long, bare ridge ("The Rocks"), like a great dike, into Northampton, where it ends in Elizabeth Rock. It is 6 miles long and 2 miles wide. East, west, and south broad areas of sands and sandstones separate it from its neighbors. To the west of its south end it grades into a great area of biotite-granite identical with itself except in the absence of hornblende.

On the east side of the river a great squarish mass occupies the southwest portion of Belchertown, extending into Granby and Ludlow, its contacts, unfortunately, greatly obscured by the heavy post-Glacial sands. It is a great batholite and in many places strong contact metamorphism can be observed at its borders and in broad sheets of schists that float ont in the center of the great mass. (See p. 243.)

North from the northwest corner of the area of tonalite across Belchertown and Pelham, and so on north in the foothills, is a line of outcrops of much crushed rock which seem at times like amplibolite shot through by many small aplite veins and at times like the tonalite. The Shays flint is a peculiar facies of this rock which resembles a petrosilex. As it runs along the western border of Mount Hygeia it is quite gneissoid, but appears in Leverett in typical development as a beantiful dark-green granitoid rock shot through with epidote veins. Also, going north from the northeast corner of the Belchertown mass along the corresponding eastern foothills of the next valley to the east, across Prescott and New Salem, a similar line of tonalite ontcrops occurs, ending with the great block of diorite on the north line of Preseott. These are both lines of strong faulting and crnshing.

\footnotetext{
${ }^{1}$ Report on a Geological Map of Massachusetts, p. 31.
} 
ANALYSES OF TONALITE.

Analyses of the tonalite were made in the laboratory of Amherst College (1) by William Orr, jr., and (2) by F. H. Fitts. A third (3) was made by L. G. Eakins, of the United States Geological Survey:

Analyses of tomalite.

\begin{tabular}{|c|c|c|c|}
\hline & 1. & 2. & 3. \\
\hline $\mathrm{SiO}_{2} \ldots \ldots$. & 56.69 & 56.18 & 55.51 \\
\hline $\mathrm{TiO}_{2} \ldots \ldots \ldots \ldots \ldots \ldots \ldots \ldots \ldots \ldots \ldots \ldots \ldots \ldots$ & .62 & 1.60 & .91 \\
\hline $\mathrm{Al}_{2} \mathrm{O}_{3} \ldots \ldots \ldots \ldots \ldots \ldots$ & 15.48 & & 16.51 \\
\hline 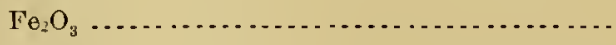 & 6.22 & $\int_{.}^{23.19}$ & 1.68 \\
\hline FeO & ..... & $\cdots$ & 4.57 \\
\hline MnO ............ & $\ldots$ & 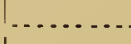 & .11 \\
\hline BaO............. & , & $\cdots$ & .02 \\
\hline $\mathrm{CaO} \ldots \ldots \ldots \ldots \ldots \ldots$ & 7.59 & 6. 49 & 6.73 \\
\hline $\mathrm{MgO}, \ldots \ldots \ldots$ & 6.53 & 6.53 & 6.73 \\
\hline $\mathrm{Na} \mathrm{O}$ & 3.41 & 3.40 & 3.19 \\
\hline $\mathrm{K}_{2} \mathrm{O} \ldots \ldots \ldots \ldots \ldots$ & 3.43 & 3.27 & 2.46 \\
\hline $\mathrm{H}_{2} \mathrm{O}$ & $\ldots \ldots$ & $\ldots . .$. & 1.53 \\
\hline \multirow[t]{2}{*}{ 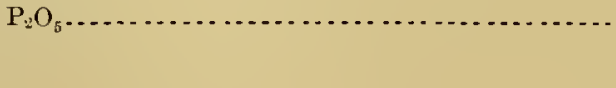 } & ......... & ......... & .17 \\
\hline & 99.97 & 100.26 & 100.12 \\
\hline
\end{tabular}

Analyses 1 and 2 were made from the same hand specimen of the slightly amethystine, fresh, medium-grained tonalite, which showed with the lens dark, bronzy diallage, and bright-green hornblende and amethystine quartz. The specimen came from just north of Three Rivers, in Belchertown. Analysis 3 was made from the beautiful epidotic-veined rock from the crossroads east of South Leverett, described on page 339, which was more altered than the others.

\section{PETROGRAPHICAL DESCRIPTION.}

Macroscopical.-The rock is a wholly granitoid, medium- to fine-grained and very even-grained mixture of quartz, orthoclase (?), plagioclase, biotite, and hornblende, the latter being at times replaced by a dark-bronze diallage in the Belchertown area, a mineral which occurs very rarely in the Hatfield region. The passage of diallage into hornblende can be well observed, and reasons will be given below for the assumption that the rock 
was originally erupted as a diallage-biotite-gabbro. It becomes aphanitic in places, but is never porphyritic or pegmatitic. It is a tough, compact rock not easily disintegrated, but weathering white. It is light-gray, often greenish, the two colored constituents rarely predominating, so as to give it a dark-graly shale, but often weathering so as to give it a greenish tint. In other cases the feldspar weathers red, and it always has a somewhat conpact appearance, the cleavage liardly appearing.

In the south of Belchertown a beantiful variety occurs abundantly. The quartz is amethystine, the diallage dark-bronze colored, the hornblende bright-green. Very generally the decomposition of the hornblende has furnished a large quantity of chlorite, which then gives a green shade to the rock.

Microscopical.-A description of the quartz-gabbro from South Belchertown specimens will be given first, as the least altered form of the rock. In thin sections the quartz shows fluid inclusions with moving bubbles. Long, fine, rigidly straight, opaque needles of rutile occur in great abundance, and are often divided into many widely and regularly separated parts, all perfectly aligned. The feldspar is nearly all triclinic, with extinction of adjacent bands at $12^{\circ}$ to $14^{\circ}$. Orthoclase could not be proved to be present. The diallage is in separate, quite well-formed crystals of palegreen color, but so loaded with the customary red and black inclusions as to give it a deep-brown color. In sections parallel to $\infty \mathrm{P} \infty(100)$ these are, in abundance, shape, and arrangement, exceedingly like the Labrador hypersthene, and the vertical striation is clearly developed. In sections parallel to $\infty \mathrm{P} \infty$ (010) the red plates are not nearly so much shortened parallel to the vertical axis as in the hypersthene, and are so abundant as nearly to obscure the green color of the diallage.

In one regular octagonal basal section, while the diallage cleavage is finely developed, and a cleavage less perfect and at right angles thereto is clearly seen, the prismatic cleavage is entirely wanting. In another twinned very clearly after the common pyroxene law, on $\infty \mathrm{P} \infty(100)$, all the three cleavages are developed, the $\infty \mathrm{P} \infty$ (100) cleavage being much the best. The freshest of these crystals are surrounded by a narrow zone of green, rounded plates of hornblende, in which the black inclusions remain, but the red do not.

MON XXIX-22 
In other crystals this change has proceeded in every degree until the crystal becomes wholly changed to a fibrous hornblende (uralite), in which the black inclusions of the diallage still remain, and indeed appear often to be considerably increased at the expense, it would seem, either of the red inclusions or of the diallage itself, and to possess in the hornblende a very distinct zonal arrangement. Furthermore, the hornblende itself is in most cases changed more or less into an aggregate of rounded green scales of chlorite, but slightly dichroic, which has in many cases eaten into the center of the hornblende in great patches, in others has surrounded it in a regular layer.

Finally, very peculiar and delicate plumose aggregations of elongate, round-ended scales of biotite are gathered in tufts at spots along the outside of the chlorite and attached to it, or a group of such tufts radiates from a center in which, in each case, remains of the green chlorite scales appear. The whole arrangement suggests very strongly the derivation of the biotite from the chloritic mineral parallel with the decomposition of the feldspar. In another case a flat patch of the green chlorite scales seems to change gradually into a mass of brown biotite scales, some of the small plates having the green color and weak pleochroism of chlorite at one end and the brown color and strong pleochroism of biotite at the other, and these latter pass into a single large biotite crystal, so that one can hardly avoid concluding that the biotite has been derived, in part at least, from the diallage through the hornblende and chlorite stages. The earliest stage may, of course, have been with diallage surrounded by biotite, and the change to chlorite may have proceeded both ways from the boundary.

Many slides cut from varions parts of the area show no remains of the diallage, but only the fibrous hornblende containing the zonally arranged black inclusions, and having chlorite and biotite arranged with regard to it exactly as in the slides where the diallage is present. We may thus conclude that the diallage was once widely and abundantly present in the rock.

Apatite occurs in exceptionally large crystals in the hornblende.

To the above description of the pyroxenic varieties are added some special notes upon the commoner and more altered biotite amphibole granite, or tonalite, and upon one or two rare varieties.

The quartz is everywhere distinctly subordinate to the feldspar, and molds the latter. At Elizabeth Rock, in the north of Northampton, it is 
very full of eavities with moving bubbles, many of the cavities containing water and carbon dioxide and a moving bubble of the latter.

The feldspar is uniformly very much more decomposed than the appentance of the rock would lead one to suspect. Sometimes the change is into kaolin, sometimes into muscovite. The change is always central, and at times a sharply defined diamond-shaped area of change occurs in a square crystal. This change is so general that it can only be determined that the feldspar is for the most part triclinic, with extinction at small angles.

The hornblende is often twinned, and extinguishes at high angle$19^{\circ}-21^{\circ}$.

Epidote, in minute groups in the chlorite, and titanite are abundant in the Whately bed.

Allanite is frequent, especially in the Hatfield bed, in crystals visible to the eye, and surrounded by the peculiar radiate puckering or splintery fracture common around this mineral. Under the microscope it is at times surrounded by epidote.

In the Hatfield mass the biotite is subordinate and the rock agrees exactly with the tonalite of the Tyrol. In Belchertown it is more biotitic. In the latter area, in the region around Three Rivers, the quartz is amethystine and contrasts beautifully with the green diallage. This variety shows under the microscope a beautiful granophyre structure. Farther east, in South Belchertown, large bowlders on the railroad show a coarsely porphyritic development of the biotite, each of the large scales being surrounded by a white border, and the quartz in this variety is violet, like the pre-Cambrian gneiss in the western portion of the State.

THE CRUSHING AND ALTERATION OF THE TONALITE ALONG THE PELHAM FAULT.

The outcrops of the tonalite which appear in the line of the great fault at the foot of the eastem plateau from Belchertown to Leverett are greatly altered by the movements which have taken place along that line. Following the road west from South Leverett to the point where an mused road goes east to the old cemetery, one finds a large ontcrop of a beantiful darkgreen chloritic tonalite, in which the reddish feldspar contrasts finely with the dark hornblende, and the contrast is heightened by a network of fine, 
dark-green, epidotic quartz veins. Between this and the Monson gneiss to the east the lower coarse mica-schist crops out. In thin section the feldspars are largely triclinic, and the constituents are larger and clearer than elsewhere in the series, but much crushed. The epidotes are especially large and well crystallized. Titanite, which is not wanting in the other sections, is especially abundant here. An analysis of this rock is given on page 336 .

The band is covered by heavy sands across Shutesbury, but reappears at "Mount Boreas," above Pratts Corner, and a mile east of the pond a mile south of South Leverett. The western half of the hill is made up of the whetstone-schist, so crushed that dip and strike can be determined with difficulty, and the eastern slope by an equally crushed quartzose amphibolite, while below, by the stream, is a tonalite which is somewhat gneissoid, and is doubtless the continuation of the ornate rock mentioned above, though from the greater amount and the colorlessness of the quartz and feldspar it has not its attractive appearance. This rock continues across Pelham in a narrow band resting in the foothills against the older gneiss and separated by a broad area of sands from the feldspathic mica-schist of the center of Amherst. It is a highly hornblendic granitoid gneiss, much intersected by epidotic quartz veins and often very chloritic.

The large mass of leek-green hornstone known locally as Shay's flint, ${ }^{1}$ from the tradition that it was used for flints during Shay's rebellion, was found on Amethyst Brook, in Pelham, just where this band crosses it. It was a bowlder, and its origin was unknown. Some years ago I found the same material in place where the band of hornblende-gneiss (altered tonalite) crosses the south line of Pelham. It forms beds in the latter sometimes as much as 20 feet thick, and at times crosses the bedding. It is a cryptocrystalline quartz, colored green by chlorite derived from the decomposing hornblende of the granite, passing from green to flesh color and weathering white and grading into ordinary gneiss, and it is a result of the thorough crushing and silicification to which the rock has been subjected. The veins colored by epidote are not essentially different from these, though they do not reach such large dimensions, and where the fissure is not entirely filled they show beautiful plane, polished surfaces of

${ }^{1}$ For the history of the rock, which has been called plasma, prase, and green hornstone, see under "Quartz," in A mineralogical lexicon: Bull. U. S. Geol. Survey No. 126, 1895, p. 135. 
the chalcedonic quartz, colored a light pistachio-green by epidote. 'These surfices are not "slickensides," but are as if varnished, and ane cansed by the crystallization of the fine-grained material. They are analogous to the smooth surface of botryoidal chalcedony or limonite.

A similar petrosiliceous variety occurs in Whately-a pale leek-green, subgranular mass, of hornstone-like appearance, with a few crushed muscovite plates. It shows no biotite or quartz. The luster is generally dull, but here and there the sheen of a feldspar cleavage appears, and this always shows triclinic striation. It appears at the Hatfield lead mine in thin layers on fissures. (XVIII, No. 57, in Massachusetts Survey Collection.)

\section{PETROGRAPHICAL DESCRIPTION OF THE ALTERED TONALITES.}

"Sliay's flint," Pellam, the typical rock. Under the microscope this shows a regularly mottled aggregate polarization which has some resemblance to clastic structure, but more to that of agate or chemically deposited quartz; and as it resembles exactly the purer parts and the veins of the same hornstone from Pellam, in situ, I have no doubt that it is chemically deposited silica, rendered impure by kaolin and a little green chlorite. It is in large part apolar, and therefore opal.

Tonalite, Pelham, west line north of S. Jewett's. Dark hornblende abundant, feldspar flesh-colored. In section very feldspathic, the feldspars (mostly triclinic) greatly kaolinized; all constituents reach the extreme of crushing - the hornblendes opened along cleavage planes; the feldspars crushed and parts moved; the twin striation greatly twisted, and the undulatory extinction greatly obscuring the twinning; hornblende shows $\mathfrak{c}=$ green, $\mathfrak{b}=$ olive, $\mathfrak{a}=$ yellow $; \mathfrak{c}=\mathfrak{k}>\mathfrak{a}$.

Green lornstone, like "Shay's flint," from locality where first found by me in place in Pelham, at S. Jewett's. This is a quartz mass, filled with scales like kaolin, which are opaque by transmitted and white by reflected light, and permeated by veins which have the same scattered scales. It resembles exactly, both with and without polarized light, the true "Shay's flint." Some slides show a beautiful microbrecciation from crushing. They contain magnetite and a little green chlorite. Under the polarizer there appear now and then larger, rounded, transparent grains, which may be 
the original quartz grains. The structure seems, lowever, in general much more like that of agate. It contains much opal.

Pelham, south line, 40 rods east of western road. A coarse, schistose, hornblende-gneiss; coarse, wavy cleavage surfaces of hornblende make up foliation faces, luster-mottled by rounded grains of fresh white feldspar, in which cleavage is feebly developed. In section the hornblende is in large, fresh plates, exactly like the few developed in the section last described; it shows deep colors, weak pleochroism, and is much cracked and twisted by pressure. The feldspar is very fresh, and shows a great variety of triclinic striation-very broad to very narrow bands with perfectly parallel sides, and tapering, interrupted, and offset bands; also ballds wavy and contorted by pressure and associated undulatory extinction. In one crystal, cut at right angles to $0 \mathrm{P}(001)$, all the laws of twinning are beautifully developed.

Belchertown, northwest corner, 40 rods east of R. Thayer's. A green granitoid rock of medium grain, mottled with flesh-red from decomposed feldspar; distinctly foliated. In section broad hornblendes much crushed, feldspars crushed, showing undulatory extinction, much kaolinized, many triclinic, with small extinction angle; much chlorite and epidote, the latter often with distinct erystal faces externally, but with rounded zonal structure internally, the spherical center extinguishing first and then successive zones in order to the surface, with revolution of $17^{\circ}$.

A little farther south, on same band, north of house of A. Goodale, the wholly crushed and altered rock is hornstone-like, with a dull mottling of greenish and flesh color: In section the bisilicate is almost wholly removed, and the quartz-plagioclase mass is wholly crushed, with wavy extinction and twisted twin laminæ. This is the south end of the "Shay's flint" band. Followed 40 rods east, its contact on Pelham gneiss is seen. There is a hornblende-biotite-gneiss for a rod at the contact, and the Pelham gneiss is full of granite dikes.

\section{DIORITE.}

North Prescott and New Salem.-A great oval area of diorite, 3 miles long from north to south and about a mile wide, lies across the line separating the above towns. It is a resistant rock, and makes the whole of Packards Mountain in the latter town. It is surrounded on all sides by the gneissoid quartzites, which dip uniformly to the west, undisturbed by the intrusive rock. On all sides as one approaches the mass the quartzite 
grows more gneissoid from contact influence, but this is not marked. The rock is nomally diak-gray or nearly black, with a shade of brown, and seems at first sight to be fine-grained; but when held to the light it is seen to be niade up of squarish surfaces, from a half to three-fourths of an inch across, of jet-black to dirk-green hornblende, rery beautifnlly lustermottled by fresh, white, striate, broad lath-shaped plagioclases, and showing rarely a grain of quartz, garnet, or a black ore.

It is in places bedded, and on the west, in the hill above Cooleyville, one traces the amphibolite into immediate proximity to the diorite, where it is thickened unusually, is massive, and greatly resembles the diorite. It may be a compacted and altered ash bed, associated with the eruptive rock. In the southwest portion of the mass, near A. Pierce's, in Prescott Hollow, the diorite is a coarse, white, feldspathic, slightly saussuritic rock, with only small, distant patches of a dark silicate, now changed to a mixture of actinolite and biotite.

The freshest material for microscopical study was obtained from a great bowlder on the north side of the road west from Prescott Center, near the last house in the village. (See Pl. III, fig. 3.) It presents a very attractive appearance under the microscope. A portion of a single hornblende crystal occupies the whole field, notched by the regular crystals of feldspar, which run in every direction. It shows a maximum extinction angle of $22^{\circ}$, and is therefore near labradorite. It is quite fresh, and full of acicular needles.

The hormblende is deep-green, extinction $20^{\circ}$, with slight pleochroism, $\mathfrak{c}=\mathfrak{b}<\mathfrak{a} ; \mathfrak{c}=$ blue, $\mathfrak{b}=$ olive-green, $\mathfrak{a}=$ yellow.

It is dusted full of a very fine black powder, in bands more or less dense, parallel to the cleavage, rendering wholly opaque the central parts of the lobes, into which the crystal is divided by the feldspars, while it shades off toward the border, where it is still more densely accumulated in a broad band bordering the feldspars. In places the central portions of the lobes are crowded by red-brown scales, placed largely at right angles to the bedding and resembling those found in bronzite. Cleavage pieces of the homblende measured with the reflecting goniometer gave $124^{\circ} 30^{\prime}$. Rarely a large pale-green pyroxene appears, with a border of hornblende; and menaccanite and red-brown rutile, with fine leucoxene borders, are present. 
In other slides, from near H. Winter's, the rock is greatly decomposed, the feldspars are mostly kaolinized, the hornblende is broken up into a network of actinolite and biotite, and only disconnected patches of the black opacite remain. Secondary quartz and calcite appear. One feldspar was shown, by the position of the optical axes, to be orthoclase. Here, and in sections from the south border, the plagioclase shows fine undulatory extinction. In the coarse white variety from A. Pierce's the feldspar is full of muscovite and the dark silicate is changed to an actinolite, with very strong transverse fissures. One feldspar, cut parallel to M $(\infty \mathrm{P} \nsim)$, showed extinction $-35^{\circ}-36^{\circ}$, with edge P M, indicating anorthite.

In fissures in the diorite beside the road near the old cemetery a large quantity of pure-white radiated prehnite occurred. It was proved, optically and by measurements under the microscope as well as by blowpipe tests, to belong to this species. ${ }^{1}$

Leverett Center.-North and south of the road east from this place to the point where this road turns south are outcrops of a massive rock which, although greatly decomposed, gives every indication of having been a diorite of the same type as that last described. With the lens the rock is seen to be composed of saussuritic feldspar and coarsely cleavable black hornblende, arranged with the texture of a gabbro. The feldspar is often included in separate grains in the hornblende, or rarely in pyroxene. Its feldspars are generally wholly kaolinized, but their shape and arrangement are exactly those of the Preseott rock. They show extinction of $12^{\circ}$ to $25^{\circ}$. The intervening hornblende is mostly changed into a matted mass of actinolite needles of weak pleochroism, or changed to serpentine, but does at times polarize together over a considerable area, and shows large patches of the black opacite, exactly as does the altered portion of the Prescott diorite. Masses of menaccanite surrounded by leucoxene are especially abundant, and the apatites are unusually large, $0.12^{\mathrm{mm}}$ across by $0.37^{\mathrm{mm}}$ long. The rock presents both the varieties described under the Prescott rock. Owing to the drift covering, its extent and relations can not be well made out.

${ }^{1}$ See under "Prehurte," in A mineralogical lexicon: Bull. U. S. Geol. Survey No. 126, 1895. 
An analysis of this rock from opposite a house of gothic architecture east of Leverett is given below. It was made by Mr. L. G. Eakins:

Analysis of diorite from Leverett.

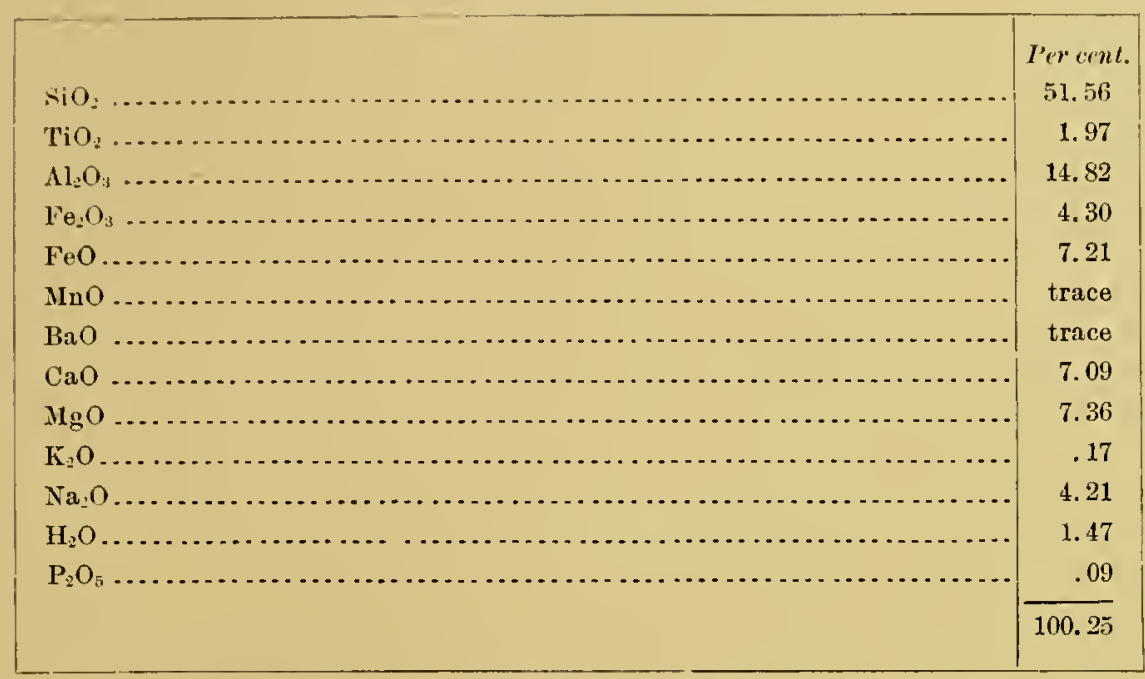

A wholly exceptional band of diorite occurs at the top of the whetstone in the hill west of A. Adams's, in the south of Leverett, and is continued to the west of the north end of the "Flat Hills" road in the northeast corner of Amherst. It is here, in a bed 325 feet wide, a dark, tough, massive diorite, much decomposed and associated with siliceous limestone.

Some of the amphibolites described in Chapter $\mathrm{X}$ as of doubtful origin may be altered diabases or diorites, and thus belong here.

\section{GARNET-BIOTITE-NORITE.}

The rock appears in a single isolated outcrop in the roadside near G. Peffer's house, in the village of Parksville, in Brimfield. It is a fresh, dark olive-green rock of granitic texture and slightly above medium grain. Large grains of deep-red garnet are quite abundant, and here and there a group of black biotite scales appears, often crumpled. Many shining cleavage surfaces of the feldspar occur which do not show striation, though the microscope shows all or nearly all of these grains to be multipletwinned.

The microscope shows the field to be almost wholly made up of a coarse, entirely fresh mosaic of xenomorphic and equidimensional feldspar, which has all the optical properties of a labradorite $\left(\mathrm{Al}_{1} \mathrm{An}_{1}\right)$, with broad twinning 
bands sometimes wanting or extending only a little way in, as if the rock were but slightly affected by pressure. It is sometimes crowded with fine black needles parallel to the axis $c$ and with swarms of brightly polarizing grains.

The garnet is fresl, without inclusions or polarization, and partly idiomorphic.

The biotite is in aggregates of long, brown blades, with the usual very strong absorption, sometimes accompanied by fine radiating wisps of muscovite. It is usually also associated with hypersthene, which is in stout prisms, often showing the flat end faces. It is pale-green, without inclusions, and shows, $\mathfrak{c}=$ ultramarine, $\mathfrak{b}=$ reddish yellow, $\mathfrak{a}=$ deep salmon color. Some crystals are altered at one end into a green, negative, micaceous mineral and change at the other into a brown-red serpentine.

The dark-colored constituents form a very small portion of the rock. The outlines of this occurrence can not be marle out as it rises through the sands of a post-Glacial lake. It is one of a series of isolated stocks of highly basic rocks, all very fresh and interesting for microscopical study, which run north near the eastern border of the map, but mostly ontside its limits in Worcester County, including picrite, olivine-gabbro, and wehrlite.

\section{CORTLANDITE.}

A single great mass of a brownish-black rock closely comparable to one of the commonest types of the Cortland series occurs in the center of the great tonalite area in the southwest corner of Belchertown, near $\mathrm{D}$. Griffin's. It is a hornblende-pyroxene-biotite-peridotite. 'The most striking peculiarity of the rock is that at times it breaks up into angular blocks with so great regularity that the fragments form rude rhombic dodecahedra with faces about 2 inches across, and the surfaces of these blocks are covered with a thin layer of brown-red biotite scales, approximately parallel and luster-mottled by grains of an emerald-green pyroxene. This peculiarity is still more strikingly illustrated in the Cortland rock, and the structure seems to replace a primary one, as in the deeper and fresher portions of the rock the biotite is seen to be gradually encroaching on broad surfaces of a dark hornblende wlich is finely luster-mottled with abundant rounded grains of olivine and pyroxene.

In the freshest slides the pale-brown, faintly pleochroic hornblende is luster-mottled by rounded masses of olivine and more angrular pyroxene of 
light color, strong prismatic eleavage and abundant twinning: The broad hornblende surtices are also replaced by an aggregate of the pyroxene grains, and thus passes inte the second type of the series. The normal decomposition is into tale, and broad bands centrally blackened by magnetite grains pass through the olivine and pyroxene alike.

The relation of the lnster-mottled hornblende to the biotite is less clear. It seems at first sight to be a superficial change, and the mica, now green and now brown, is developerl in the cleavage planes of the homblende. But as it is luster-mottled by all the other minerals with fresh borders, it was quite certainly formed originally by some change in conditions of cooling, and simultaneonsly with the hornblende. Perhaps it is to be looked at as a contact-metamorphic effect, brought about by the introduction of fluorine from without. There is associated with the normal rock a massive, friable, granular rock, made up of fibrous hornblende and bright emeraldgreen pyroxene, like that found on the western border of the homblendegranite. Enstatite occurs but rarely. Calcite is quite common, as soon as change sets in. Feldspar is wholly wanting.

An analysis of the finer-grained and fresher portion of the mass was made by Mr. L. G. Eakins :

Analysis of cortlandite from Belchertown.

\begin{tabular}{|c|c|}
\hline $\mathrm{SiO}_{2} \ldots \ldots \ldots \ldots \ldots$ & $\begin{array}{c}\text { Per cent. } \\
48.63\end{array}$ \\
\hline $\mathrm{TiO}_{2} \ldots .$. & .47 \\
\hline $\mathrm{Al}_{2} \mathrm{O}_{3} \ldots \ldots \ldots$. & 5.32 \\
\hline $\mathrm{Cr}_{2} \mathrm{O}_{3} \ldots \ldots \ldots \ldots \ldots \ldots$ & .36 \\
\hline $\mathrm{Fe}_{2} \mathrm{O}_{3}, \ldots \ldots \ldots \ldots \ldots$ & 2.91 \\
\hline $\mathrm{FeO} \ldots \ldots \ldots \ldots$ & 3.90 \\
\hline $\mathrm{MnO} . . . . . . . .$. & .12 \\
\hline $\mathrm{BaO} \ldots \ldots \ldots$. & trace \\
\hline $\mathrm{CaO} \ldots \ldots \ldots \ldots$ & 13.04 \\
\hline Mgo.................. & 21.79 \\
\hline $\mathrm{K}_{2} \mathrm{O} \ldots \ldots \ldots \ldots \ldots \ldots$ & .23 \\
\hline $\mathrm{Na}_{2} \mathrm{O} \ldots \ldots \ldots \ldots \ldots \ldots$ & .34 \\
\hline $\mathrm{H}_{2} \mathrm{O} \ldots \ldots \ldots$ & 2.81 \\
\hline $\mathrm{P}_{2} \mathrm{O}_{5}, \ldots$ & .21 \\
\hline \multirow[t]{2}{*}{ 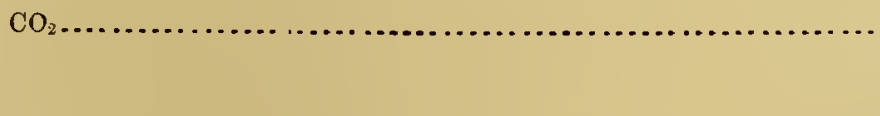 } & trace \\
\hline & 100.13 \\
\hline
\end{tabular}


AGE OF THE GRANITES.

The tonalite cuts the Leyden argillite, one of our newest rocks, in Hatfield. A porphyritic and a common granite dike cut the same argillite on the north line of the State, and 3 miles south quartz-muscovite veins in the Bernardston Devonian limestone seem to me to be the outermost filaments of the same granitic intrusion. The pegmatite cuts the tonalite. On the other hand, the way in which the dikes are intruded between the layers of the vertical schists would indicate that this intrusion occurred after their upfolding, while the way in which the tourmalines are broken in pieces and the great spodumene crystals are bent and many times fractured and faulted would indicate that some part of the folding has been done since they reached their present position. We may, then, consider the tonalite to be the oldest, the pegmatite and cortlandite the newest, and the whole series as of late Devonian or Carboniferous age. The porphyritic granitite seems to be older and to have been influenced more by the upfolding of the region, and the Hardwick granite is still older, as it is cut by the porphyritic granite of Coys Hill.

\section{RÉSUMÉ As TO THE GENETIC RELATIONS OF THE GRANITES.}

The two great masses of tonalite were the cores of two batholites, which came up at points on the two faults which border the great Connecticut. River depression.

From the northeast and northwest comers of the Belchertown mass extend the eastern Connecticut and the Swift River fault lines, along which narrow dikes and patches of the tonalite occur far to the north.

Unlike the above, the Hatfield tonalite is bordered outwardly in its western half by biotite-granite (granitite) and biotite-muscovite-granite, and then both are much cut up by later pegmatite dikes in several generations, which extend out into the surrounding country in a broad aureole, within and beyond which the schist is greatly impregnated with quartz and considerably more metamorphosed than outside their influence.

Toward the periphery the granite dikes carry rare minerals in great abundance and beauty, and these show two modes of occurrence. Beryl and large manganese-garnets occur irregularly in the muscovite-granite dikes of very coarse grain. Albite, tourmaline, and the minerals of the rare earths occur in secondary dikes of most puzzling character in the main 
pegmatite dikes. The eireunstances under which a crystal of spodumene a yard long and a foot thick could form in a great granite dike and then be replated by albitic granite containing zilcon, garnet, and beryl are difficult to imagine. It is, perhaps, possible to suppose that the latter minerals were included in the original crystal, and then the change by the action of heated alkaline solutions as made out by the anthors eited above (p. 344ff) seems satisfactory for the explanation of the main change into albitic granite.

It seems to me that the suecession made out above-(1) tonalite and granitite, (2) pegmatite, (3) albitic granite-was essentially a series of eruptions in which mineralizers took a gradually increasing part, and that aqueous agency proper began with the formation of cymatolite and the other remarkable pseudomorphs and the quartz veins.

\section{CONTACT EFFECTS OF THE ERUPTIVE ROCKS.}

These rocks penetrate highly crystalline schists and gneisses, and in general the contact effects are not marked. On the west side of the valley the complex spangled structure of the Conway schists disappears, the transverse biotite and gamets are wanting, and the rock is coarser-grained and feldspathic. On the east side it becomes a coarse fibrolite-gneiss. In the amphibolites and argillites the changes are more interesting. The broad band of chiastolite-schists derived from the Leyden argillite is described in connection with the description of these rocks. The others are discussed also in connection with the less altered rocks with which they are associated and from which they have been derived, as the purpose of this study has been to determine the sequence and proper association of the crystalline schists.

Around the border of the Belchertown tonalite, and to a less extent around the Hatfield area, are dark-green, friable, granular pyroxene rocks, which represent, apparently, an effect of contact metamorphism. (See p. 243.) Near the western border of the former mass, back of the house of T. S. Haskel, the rock appears near a great dike of pegmatite.

Also across the river, near the north end of the western exposure of the tonalite, occurs a biotite- and pyroxene-bearing rock, greenish-black and somewhat above medium grain. Abundant large scales of biotite give it a shining appearance, and the green granular pyroxene is often visible, and the microscope shows the finest regular cross-sections, with well- 
developed pinacoidal and prismatic cleavages, often twinned three and four fold after the usual law.

At the eastern foot of "The Rocks," in Hatfield, 400 feet west of D. Glasner's, there occurs a limited amount of a peculiar contact product of the tonalite. It is a compact, quartzlike, massive rock, red, mottled with green. The reddish parts are a granular quartz mass, full of small red garnets; the green parts are patches of a pale-green hornblende, with grains of magnetite, and crystallizing so as to include many grains of the other constituents.

Under the microscope the quartz is full of sheets of granitic fluid cavities, rarely with moving bubbles, and is without microlites. Feldspar is represented by opaque white grains, changed wholly into a parallel fibrous mass of scales of muscovite. Garnet is in bright yellowish-red clustered grains. The hornblende often contains remnants of a pale-green, nondichroic pyroxene, extinction $37^{\circ}$, and showing basal cleavage. Beautiful tourmaline crystals appear, which are strongly dichroic, violet to black, several transparent and colorless, but with black heads, the rest colorless.

The fibrons hornblende runs through the mass in parallel elongate rods, so as to strongly recall a scolithus quartzite in which the tubes had been filled with actinolite. This is now mostly changed to a mixture of serpentine and calcite, which effervesces strongly with acid and leaves behind a fibrous white mass resembling tremolite, which seems to be fibrous quartz.

An entirely similar rock occnrs in Amherst at the north end of Prospect street, on the hillside east of North Amherst, and just north of South Amherst. At the first-named locality it is filled with bright spangles of graphite, and in all the other places it is associated with the highly metamorphosed and granite-soaked schists and appears to be a metamorphic rock, and in the Hatfield occurrence it may also be a result of contact metamorphism. I hoped for a long time to be able to prove it to contain scolithus.

It seems to have been formed as a contact product of one of the beds of limestone that occur in the Conway schists. 


\section{H A P T E R XII.}

\section{THE TRIAS. \\ THE CONNECTICUT RIVER SANDSTONE.}

The Connecticut River sandstones extend northward from the Sound, with a width of about 20 miles across Connecticut and Massachusetts to Nortlampton; there they contract to about 6 miles, and continue north with this width to Bemardston, where they contract to a mile in width, and soon end just north of the village of Northfield.

Their western boundary is everywhere coincident with the foot of the bluff of crystalline rocks bordering the valley, and the same is true of the eastem border from the south line of the State northward to the Belchertown ponds. In this-the larger portion of their boundary-the sandstones never extended much beyond their present limits, and show everywhere shore conglomerates resting against the schists and granites on which they were deposited.

In the remainder of the eastern boundary, from the ponds north to Mount Toby, the boundary of the sandstones has been carried by erosion far west from the old shore line-the line of the bluffs in Pelham bordering the valley on the east. From Mount Toby to the north line of the State the extremely coarse conglomerates which form the present eastern portion of the Trias must represent quite accurately the original eastern shore line, and the deep depression which now separates these bluffs of conglomerate from the escarpment of gneiss that forms the true border of the valley may have been in large part produced by the erosion of Paleozoic schists which crop out from beneath the Trias and occupy the bottom of this depression. This is the more probable since this coarse conglomerate is made up wholly

1 The name Newark was proposed by Prof. I. C. Russell in 1889 for the Triassic of the Atlantic Coast. Prof. C. H. Hitcheock supported the name "The Connecticut Sandstone Group" in Science, Vol. I, 1895, p. 74 . 
of these schists and argillites, and if it had extended across this depression ti would have covered the beds from which it must have derived its material. It would then have had the gneiss for its shore country, and the gneiss must have supplied a large part of its mass. On the contrary, these Pelham biotite-gneisses seem wholly wanting in the Mount Toby conglomerates, from which I conclude not only that the schists and argillites then filled this depression and furnished the conglomerates a border nearly on the present boundary of the latter, but that they then mantled eastward over the gneiss. This demands an unexpected amount of erosion during and since the Trias.

The artesian wells that have been bored along the line of the Connecticut with depths from 600 to 3,700 feet have never reached the bottom of the sandstone. (See p. 380.) If we add to this the height of the crystalline walls of the valley above the Connecticut, I think we may estimate the present depth of the Triassic trough at somewhat above a mile. Indeed, I shall show that the major portion of the material of the Triassic beds came from the immediate borders of the basin, and would thus add another considerable but unknown quantity to the maximum depth of this long and narrow trough. I think the maximum thickness of the Triassic beds therein, restoring the post-Triassic and especially the Glacial erosion, must have been considerably more than a mile.

I have elsewhere (see p. 13) discussed the system of faults bounding the block, or group of blocks, whose sinking formed this Yosemite-like Triassic valley, or "graben," to use the nomenclature of Eduard Suess, ${ }^{1}$ and their outer boundary can be closely followed on the new four-sheet map of Massachusetts by tracing the 500-foot contour line at the foot of the escarpment east and west of the Connecticut, though the fault lines lie generally a little lower-that is, nearer the river.

If this line be followed from the north line of the State just east of the Connecticut to the Belchertown ponds, and another line be drawn down the Connecticut to the mouth of Millers River and south to Mount Tom, it will include a long quadrangular area having its base at the northern foot of the Holyoke Range, which area was once deeply covered by the Trias, but has now been for the most part denuded of this covering. Over this area the crystalline substratum of the valley stands everywhere about 300

\footnotetext{
${ }^{1}$ E. Suess, Das Antlitz der Erde, p. 166.
} 
feet albove sea level, instead of 4,000 feet below, as in the remainder of the basin. This I call the Amherst area. Just west of this area, from Turner's Falls to Nortlampton, and south of it across Hampden County, this substritum has not been reached by borings from 600 to 3,700 feet. On this elevated substratum rest the great conglomerate masses of Mount Toby and Gill, rising several hundred feet above the adjacent plateau area on the east, from which they must have received their material.

It seems to me probable that this block, bounded by the Leverett fault on the east, the Mount Tom-Northfield fault on the west, and the Mount Holyoke faults on the soutl, has experienced a later movement of elevation in opposition to the prevailing sinking of the valley blocks, and that this explains its present elevation and the present height of Mount Toby.

This eastern border fault follows the line taken by the railroad east of Mount Toby; and on the east of the railroad the conglomerates occur at the railroad level, while on the west of the railroad the junction of the conglomerate on the old quartzites below is about 50 feet above the railroad; so the upthrow of the conglomerate along its eastern edge by this one fault must be 50 and may be nearly 100 feet.

The upthrow of the Hount Toby block on its western edge is also made probable by the following considerations:

The great Northfield fault, continuing south from the mouth of Millers River, seems to pass beneath the Connecticut between Mount Toby and Sngar Loaf. The flat top of Sugar Loaf in this exposed place seems to be due to the fact that the Deerfield trap sheet formerly capped it and has been removed by erosion (probably near the end of the Glacial period) so recently that the mesa form remains. The dip of the trap sheet in Mount Toby is $15^{\circ} \mathrm{E}$, and its distance from Sugar Loaf is 5,610 feet. With this dip it would be carried over Sugar Loaf, 936 feet above its summit. But the dip in Sugar Loaf is $8^{\circ} \mathrm{E}$., and, allowing the dip to ehange at the fault, that is, about midway between the present trap outcrop and the mesa top, the height of the trap sheet over Sugar Loaf, if there were no faulting, would be 575 feet, and this latter number would be near the true amount of the upthrow on the east sicle of the fault.

HoN XXIX -23 


\section{GENERAT SECTION OF TRIASSIC ROCKS.}

The Triassic rocks have been divided by the author in an earlier publication ${ }^{1}$ as follows:

1. The Sugar Loaf arkose; or the sandstone and conglomerate made up of the débris of granite.

2. The Mount Toby conglomerate; or the coarse conglomerate made up of large schist and quartzite pebbles.

These two numbers are, speaking generally, the west and east shore deposits.

3. The Longmeadow browustone; or the red sandstone generally marked by so-called fucoidal forms, which are probably concretions.

4. The Chicopee shale; or the calcareous red shale.

These two are the offshore and central beds of the series.

5. The Granby tuff; or the diabase-tuff.

6. The Holyoke and Deerfield diabase beds.

7. The Black rock volcanic necks and the posterior diabase beds.

The last three distinctions cover the fragmental, interbedded, and intrusive occurrences of the diabase, respectively; except that the posterior sheet is placed with the injected necks, with one of which it is directly connected.

THE SUGAR LOAF ARKOSE OR THE FELDSPATHIC SANDSTONE AND CONGLOMERATE.

This most persistent and abundant rock is a coarse, buff arkose made up largely of the slightly rounded and slightly weathered débris of a muscovitic granite. The average grain is about an eighth to a third of an inch, so that in a region of fine-grained rocks it would be called a conglomerate. It is slightly cemented by iron. It grades in one direction into a medium-grained, buff, micaceous sandstone, more commonly through coarse, pebbly arkose into a coarse conglomerate, in which the mass of the rock is the same coarse, unworn granitic débris and the larger constituents are large rounded pebbles-of granite when the rocks of the adjacent shore are granite. It is at times whitened over broad areas by the removal of the iron cement by organic agencies and the complete kaolinization of its feldspars to great depths. The red rock is first spotted with green from the reduction of the iron oxide, and then whitens as the protoxide salt is removed by solution.

${ }^{1}$ On the Triassic in Massachusetts: Bull. Geol. Soc. America, Vol 1I, 1891, p. 451. 
Offshore the rock is well but coarsely bedded; cross-bedding and coarse rippling are often well marked; bands of comminuted coaly matter from retted and disintegrated wood occur; but all sigms of abandonment by the water, as mul-cracks, tracks, etc., are wanting. It occupies a broad band commencing at the north end and rmuning down the west side of the valley, and expands to occupy the full width of the valley centrally across nearly the whole of Hampshire County. South of Mount Holyoke it branches, and across Hampden County occupies the east and west sides of the basin in broad bands.

\section{CONTACT AND DISTRIBUTION.}

Along the western side of the valley the contact of the shore beds and the schists is first seen in Bernardston, in the brook gulch just south of the Devonian limestone, and in the same pasture. Here there is a thin remnant of the conglomerate resting on the basset edges of the Devonian quartzite and mica-schist, and it is made up of a coarse red sandstone, full of large angular fragments of the rocks on which it rests. There is here scarcely more than a single layer of pebbles cemented to the edges of the schist.

On Fox Brook south of the road over West Mountain, in Bernardston, the very coarse arkose call be seen almost in contact with the schists, showing that almost from the beginning the strong northward tidal currents carried their granitic material even into this far northern portion of the basin. Skirting the base of the great argillite block of Leyden, south and west, the contact is everywhere covered until Leyden Glen, in the northwest corner of Greenfield, is reached. Here is a brook gorge of great natural beauty, affording an opportunity to study the extreme contortion of the argillite, as well as to see the contact of the Triassic beds upon the latter, the whole dissected out most beautifully by the erosion of three brooks. Just below the dam of a burnt mill, on the east side of the main brook, a small stream comes down over the argillite, here flat-berdded, with strike N. $10^{\circ} \mathrm{E}$, dip $90^{\circ}$, and has cut through a basal stratum of the Trias, which is plastered against the argillite, the plane of contact dipping $45^{\circ}$. The stratum is here made up of subangular masses, nearly an inch across, of the vein quartz derived from the argillite, and is quite uncemented. It is 1 to $1 \frac{1}{2}$ inches thick, and passes gradually up into a bed, 2 or 3 inches 
thick, containing many smaller pebbles of the white vein quartz in a deepred paste. This graduates into a deep chocolate-colored layer-a coarse, pebbly arkose-full of muscovite and feldspar, but with much vein quartz, and argillite also, and this continues upward across the brook, becoming lighter in color.

Eutering the gorge of the next tributary, 50 feet lower down on the same side, one finds that the brook has just eut down to the argillite, but traces of the basal conglomerate bed can be found resting nearly horizontally on the vertical slates for 245 feet up the brook. It is a striking rock, from the large white quartz pebbles in the bright-red sand. Above this, just at the entrance of the brook, is a fine bluff, and in it the basal bed grades through $3 \frac{1}{3}$ feet of fine red sandstone into a bed, 10 feet thick, of coarse buff arkose with two thin conglomerate layers, and above this is a bed, 10 to 12 feet thick, of a coarse conglomerate with pebbles an inch across; strike N. $70^{\circ} \mathrm{E}$., dip $15^{\circ} \mathrm{S}$. These are mostly well-rounded masses of the vein quartz from the argillite, also of gneiss, mica-schist, argillite, etc. These bowlders are often full of iron rust, a fact which may throw light upon the penetration of biotite into all the pebbles of the Cambrian gneisses of Berkshire. We see that the circumstances favoring the deposition of iron rust were present from the beginning, and that after a brief period (during which the waters advancing upon this sharp slope deposited only the angular quartz masses so generally abundant in the argillite, yet wanting just here, but which were transported only a little way) the strong tidal currents brought up from the south the granitic material of the Williamsburg area, and that there for a long time and for a considerable distance out into the valley by far the larger and the finer portion of the deposit was this far-traveled granite débris, while the coarser and more angular portion was vein quartz from the argillite. The black mud from the latter seems to have been swept away entirely and to have found no place of permanent deposit north of Holyoke.

The shore conglomerates are concealed by the Green River lake-beds south across Greenfield and the north of Deerfield, but opposite Pine Hill and the north part of Deerfield village the brooks coming down from the west cut through the heary sands of the high terrace and expose the Triassic beds nearly up to the conglomerates, especially in the brook south of J. F. Hartwell's and in the roadside running down into the valley near the Baptist church. 
The rock is everywhere a coarse pudding-stone, the large pebbles of vein quartz and sehist being derived from the adjacent bluffs of mica-schist and growing smaller and raver as one recedes from the bluff in going eastward, until in the Deerfield River they are mostly wanting, while the paste in which these large pebbles are embedded is a coarse arkose with much kaolinized feldspar and muscovite, which could not have been furnished by the dark schists that make the shore for miles north and sonth, but which have drifted up, as before indicated, from the south.

From this point on the arkose abuts against the western wall clear across the State. The exposures are poor, but the shoreward portion is an arkose-conglomerate with pebbles rarely larger than 8 inch cube. Thus, at Whately, in the roadside near the school south of the village, the arkose contains 8-inch pebbles of a coarse granite exactly like that of Williamsburg, in a mass of coarse granitic débris, while the adjacent argillite and tonalite are wanting.

The next place where the conglomerates are exposed near the junction is at Loudville, where the arkose is in coarse pebbles 2 to 3 inches across, and in the old adit the contact between the two was cut through. Here the feldspar grains are often soft kaolin.

In 1868 Amos Eaton described with great care the rocks of the Loudville adit. Begimning 800 feet from the mouth, vertical strata of graniteschist and serpentine continue for 134 feet east, toward the tunnel mouth. Then a "green granular aggregate" appear; which "begins to approach a horizontal position." This continues 66 feet and is followed by a "granulated schistose aggregate chiefly of quartz and mica."

At 480 feet a half-inch coal stratum appears and runs on to 300 feet, where it goes below the floor of the adit. The green aggregate is the first Triassic bed, and the sudden transition seems to indicate that the two are faulted against each other. The green color is probably due to the introduction of surface waters into the crushed band along the fault, which have reduced the iron oxide and discharged the red color. The sandstone dips east here, as the coal bed indicates.

The next contact of the conglomerate can be seen in Southampton, a mile south of Glendale, on the Great Mountain road. As usual, it is a granitic conglomerate, but its coarseness does not reach that of the eastern beds.

South of the mouth of Westfield River, across Westfield, Southwick, and into Connecticut, till rests against the bold, continuous bluff and con- 
ceals the shore conglomerates. This till stretches half across the Westfield Valley and extends a long way south, and, curiously, in the portion adjoining the bluff of crystalline rocks it is made up almost wholly of the arkose, while its thicker central portion is composed of coarse granitic materials.

The Triassic shore conglomerates are largely concealed. Only in one place (Mrs. S. Gillett's), near where the Granville road goes over Sodom Mountain, in the southwest portion of Southwick, is the rock seen in place, within 50 rods of the base of the bluff. It is lhere a coarse, flaggy arkose, the mass of the rock a coarse, buff, feldspathic sand, with a few far-traveled pebbles of quartz 1 to 3 inches long. Skirting the base of the bluff for miles the abundant fragments in the till show that this is the prevailing rock. It is often so well cemented and so little worn that it closely resembles a granite. Stretching east across Westfield and Southwick to the railroad the rock is uniformly a loosely cemented mass of unworn granitic débris, quite deep red in the interior, but bleached and kaolinized at the surface, and very often dug into for road material It is commonly more or less spotted with well-rounded and therefore far-traveled quartz and granite pebbles 1 to 4 inches across.

\section{THE MOUNT TOBY CONGLOMERATE, OR THE SLATE AND QUARTZITE CONGLOMERATE.}

This rock never anywhere sinks to the dimensions of a sandstone, but varies from a conglomerate with its coarse pebbles 2 inches long to one where the larger constituents are from 2 to 4 feet in length. The mass of the rock is very largely and often wholly made up of comminuted argillite, quartz-schist, and vein quartz, with the larger pebbles of the same material.

In many cases, as along the eastern slope of Mount Toby and in Gill, it deserves the name of a giant conglomerate, blocks from 1 to 2 feet long being stuck as closely as they can lie in a coarse gravel from which all sand has been washed. An arrangement of the constituents, often very partial, with their flat surfaces parallel to a common plane and a rude stratification in coarser and finer beds is the only structure. The rock occupies the east shore of the basin except in the central portion.

CONTACT AND DISTRIBUTION.

The most northern outcrop of the Trias occurs a half mile north of Northfield, where the Winchester road starts. It is a coarse conglomerate, which appears in continuous ontcrops west of the village street, and may 
be best studied in the fine roches montonnées in front of the church erected recently by Mr. I). L. Moody and along the brook near by, down a little wost to the gristmill. Here the pudding-stone contains pebbles of granite, quartzite, and amphibolite. One block of a flat, barren mica-schist was 2 feet long. The whole series comes from the escarpment of crystalline rocks directly east, and the great fault at the foot of this escarpment is about 100 rods east, and that represents the probable distance of the shore line. A mile firther south, at the south end of the village, the conglomerate contains pebbles of the peculiar coarse hornblende rock that crops out in the lower portion of the escarpment due east, and there only, which indicates that these conglomerates have spread thinly from the foot of the scarp less than a mile east, the spreading being due to a gradual transgression of the waters of the Triassic bay. The area just described seems to be now almost isolated by erosion, and from this point south to the mouth of Millers River the Connecticut may run wholly on crystalline rocks beneath the Champlain sands, and the narrow shelf between the river and the east-side escarpment of the valley has been stripped, largely, I have no doubt, by the ice of the shore deposits which once covered it.

The section at the mouth of Millers River is interesting and peculiar. The farthest bluff visible on the south side of the Connecticut to one standing at the mouth of the tributary is the coarse conglomerate of the Trias. To reach it one passes along the shore over a coarse muscovite-granite, rudely parallel and fissured by pressure, and comes at a small brook course upon an outcrop of the Leyden argillite and quartz-schist, wholly crushed and slickensided. This continues a few rods and is followed to the west by the conglomerate. This is the coarsest shore breccia, wholly derived from the adjacent argillite and showing no granitic material. Many blocks are 3 feet long; one was measured 43 inches long. The junction is not well exposed, but seems to be nearly vertical, and the whole region is one of intense crushing and faulting, though there is no indication of great throw.

The conglomerate is exposed along the river about 25 rods, only a part of its true thickness, and dips $40^{\circ} \mathrm{N}$. (strike N. $80^{\circ}$ E.) beneath the sandstone, a thin-bedded, gray, shaly rock, which for many rods is crushed into a mass of slickensided pencils. It also for a considerable distance has strike N. $80^{\circ}$ E., dip $30^{\circ} \mathrm{W}$, and then changes suddenly to strike N. $80^{\circ}$ W., dip $40^{\circ} \mathrm{S}$., and in a little distance one comes on a well-known "bird track" quarry. 
The conglomerates are concealed beneath the broad sand plains of Montague, but rise in the great mass of Mount Toby to their greatest height and their most extensive development. The steep walls of the deep gorge which borders this mountain on the east show sheer cliffs and enormous bowlders of the coarsest conglomerate, and high above the bottom of the valley, in the beds of Roaring Brook and of the next brook to the north, the contact of this conglomerate on an ancient quartzite can be seen.

This mountain is a slate-conglomerate from base to summit and from its eastern slopes west nearly to the Connecticut. High up on its western slope are two bands of fucoidal sandstone, which penetrate the mountain with slight eastward dip, and indicate two horizons at which a deepening of the water sent the finer sediment far east over the shoreward conglomerates. The high level (310 feet above the sea) at which the rocks of the South Leverett plain pass beneath the conglomerate, and the rising of the whetstone and amphibolite through it at Whitmores Ferry, show that the rock is not above a thousand feet thick.

From Mount Toby to Belchertown Pond the shore conglomerates are wholly removed by erosion. Some of the most interesting exposures of the shore conglomerates on the east side of the valley occur in Wilbraham. Just east of the academy, after passing a bend and slight rise in the road, one comes upon outcrops of a dull-brown, rotted conglomerate, so soft that it is dug into for road material. It is exposed along the south side of the road for 80 feet. Just to the east a highly indurated muscovitic quartzite, full of quartz veins and of dark color, rises sharply to form the eastern escarpment of the valley. The conglomerate rests against this and only a few feet of turf covers the line of junction. This is marked by a slight depression which crosses the road obliquely, east of which the ground rises rapidly and is covered by the large light-colored bowlders of the schist. All or nearly all of the pebbles of the conglomerate, 1 to 8 inches long, are from this schist.

A medium- to fine-grained red sandstone occurs west of the conglonerate and can be traced in the bed of the road right up to the conglomerate, where the two are seen only 2 or 3 feet apart, and the sandstone either runs under the conglomerate or the two abut by an irregular fault. The latter is by far the most probable, as the sandstone dips $15^{\circ} \mathrm{W}$., while the conglomerate is horizontal, and the transition would be very abrupt if the sandstone went underneath. 
Great ledges of the coarse rock streteh away south and have the abmornal attitude, strike N. $60^{\circ} \mathrm{W}$, dip $30^{\circ} \mathrm{N}$, thus making the existence of a fiult here the more probable. This is just the position of the main east fiult at the foot of the east scarp of the valley.

The exact contact of the two rocks may be seen in the bed of the brook which crosses the road just south of the village (south of J. Holman's), by following the brook east to the foot of the scarp. Here, resting on the black crushed and silicified schist, is a compact pudding-stone with abundant pebbles, about 4 inches long, of the schist in a ground of deep-red sandstone. We have here the combination of finer far-traveled and coarser local material, discussed more in detail below (p. 374). From this point heavy kame gravels cover all the shore deposits far into Connecticut.

THE OUTCROPS OF CRYSTALLINE ROCKS IN THE MIDST OF THE MOUNT TOBY CONGLOMERATES.

The Conway hornblende- and quartz-schists at Whitmores Ferry, in Sunderlancl.-I had long maintained that the conglomerate of Mount Toby could not be above 1,000 feet thick, and that it must have a base about 300 feet above the river, so that the discovery of large outcrops of the underlying masses in the heart of the Mount Toby conglomerates was very gratifying to me. It has proved very useful, as well in throwing light upon the distribution of the older rocks beneath the Trias as in accounting for the source of the materials of a large portion of the conglomerates and the extreme coarseness of those conglomerates at large distance from the old shore bluffs, which seemed to be the only source for them. Several of the rocks outcropping thus are unique and their presence in abundance in the conglomerate had long been a puzzle to me. Again, at certain points in the mountain far from the shore, the pebbles of the conglomerate swell suddenly to large size and maintain such size for a limited area around the central point. This has now enabled me to locate several outcrops of crystallines in the midst of the clastic rocks.

The first area discovered was the more interesting, as it forms the whole or part of the ledges over which the waters of the mill at Whitmores Ferry run, east of the road, while west of the road they pass over the black fish-bearing, shaly sandstores. The crystalline rock is here a black, finegrained and thin-bedded amphibolite, and that it has not been recognized as distinct from the black fish-bearing sandstone is not surprising. Upon 
the plateau above, just south of the mill pond, is a series of roches moutonnées, and an examination of these reveals a very interesting state of things.

The western well-smoothed ledge is at its north end a dark-green, very fine-grained amphibolite, striking north and standing vertical, full of wavy quartz veins and lenses placed with the bedding. The whole is little jointed, but a few feet along the surface the traces of jointing increase in distinctness, and farther south become slightly opened planes, and then traces of motion of the fragments are seen, and infiltrated sand now indurated in the joints. This disturbance increases slowly until all the fragments are thrown into confusion, but one can see how they may be moved back into their places. Three rods from the beginning the whole is a breccia of large plates of the parent rock; at 10 rods one begins to see foreign pebbles-quartz and gneiss--and for a mile south the amphibolite pebbles can be found in abundance. East of the amphibolite, which is perhaps 10 rods wide, is a band of light-gray, fine-grained, thin- and flat-laminated quartz-schist (whetstone), and still farther east is a second adjoining bed of the fine-grained amphibolite. The first bed forms the face of the bluff, and the water pours over it, and it can be examined along the path up to the dam. All these show, southward, a full repetition of all that has been described for the first band, and the quartz-schist is more abundant in the conglomerate and more characteristic of it than any other rock. For the age and microscopic character of these rocks, see page 196 .

The Bernardston gneiss of the hill west of Montague.-On the northern slope of this hill, near the honse of H. H. Taylor (now burned), with its center at the branching of the road at the most northerly loop of the 320foot contour on the map, is a large outcrop of a spotted, thin- and wavybeddled gneiss, with a greenish, greasy sheen of its mica, which slows traces of pebbles and agrees with the South Vernon gneiss modification of the Bernardston quartzite. It is a large outcrop, as the ice has planed the conglomerate off from the whole north face of the hill, and its similar position to that of Mount Warner, in the Amherst basin, is interesting. This was a great hill in the Trias, and furnished material in large amount as the waters rose over it. To the north the Triassic rock grows rapidly finer, but the long exposures in the bed of the stream at the foot of the 
hill, a lumulied rods north, are a coarse, pebbly simdstone, derived almost wholly from this peenlial rock.

All around the south borker of the grneiss the outerops of the junction are very fine, and one can seo the ledge nudisturberl, passing gradnally throngh the stages described above at Whitmores Ferry until, at a distance of a tew rods, a coarse conglomerate is formed, in which I measmed one egg-shaped block 47 inches long; and in tìe whole hill to the sonth for miles the large glacial bowlder's of this rock are so abundant that I searched specially for an outcrop of the older rock, and found it here. The conglomerates are thrown off in all directions from this mass, and in the brook dip $30^{\circ}$ E., away from the hill. The gneiss bowlders weather more rapidly than the fine paste, and form great holes in the conglomerate.

At the most northern point in the south wood road, on Mount Toby, is probably another similar outcrop, as pebbles 40 to 45 inches occur, and 3 rods east of the east end of this road is another outcrop of a fine granite protruded through the conglomerate.

Breccia at North Amherst-Just east of the North Amherst railroad station, in a pasture a few rods southeast of the point where the road turns south, and at the Golden Gate dam, a half mile east, occurs a coarse, rusty breccia of gneiss pebbles and quartz and feldspar grains.

In one slide a large pebble of an even-bedded biotite-gneiss is embedded in finer material. In another many rounded grains of a fine-grained gneiss, often cracked and distorted, appear in a clastic paste. This has in many places the appearance of a coarse conglomerate distorted by pressure, and I was at one time inclined to consider it a portion of the mica-schist, gneiss, and granite crushed in place, recemented, and much weathered. In places it is shot through with calcite veins.

As soon as I had studied the contact of the Triassic conglomerate on the gneiss at the exposure west of Montagne Center, I was struck by the similarity of the two, as well as by the resemblance of this occurrence to that at the Williams farm, at Bernardston. It seems, then, to be the contact layer of the Triassic conglomerate on the granite.

\section{ACTION OF ICE IN THE TRIAS.}

All these contacts present peculiarities which strongly suggest the presence of ice during the formation of the coarse breccias, especially the Whitmores Ferry beds. It is very hard to understand how the large 
angular blocks can have been moved from their place and camried horizontally southward, as they have been, without the intervention of shore ice. In a valnable résumé of the evidence bearing upon the question of the existence of Triassic glaciers Professor Russell ${ }^{1}$ has expressed his conclusion as follows:

The absence of glacial records seems to warrant the conclusion that glaciers did not enter the basins in which the Newark rocks were deposited. It does not follow, however, that the Appalachiaus were not occupied by local glaciers. The suggestion that these mountains were higher in the Newark period than now and were covered with perennial snow while the adjacent lands enjoyed a mild climate, seems an attractive and very possible hypothesis, but definite evidence as to its verity has not been obtained.

With this conclusion I agree, as I have, after much searching, found no decisive proof of the advance of glacier's into the Triassic basiu, but much that suggests the presence of shore ice.

THE LONGMEADOW SANDSTONE.

This, the well-known building stone, is a deep-red sandstone of rather coarse grain, usually quite quartzose and with abundant cement of hematite. Both the Sugar Loaf arkose and the Mount Toby conglomerate, but more commonly the latter, grade into this rock. It is generally subsequent to the first outflows of trap, but both in Greenfield and in Agawam underlies in part the Deerfield and Holyoke traps, respectively. Round or slightly flattened rods of sandstone one-fonrth to onehalf inch across, often transverse to the bedding, often interlacerl, are everywhere abundant and characteristic, and at times the whole mass of the sandstone is made up of these problematical forms, commonly called fucoids. They seem to me to be ferruginous concretions formed in the sand by ironbearing solutions derived from the diabase. They are so uniformly present in the beds of this subdivision that they have almost the value of a characteristic fossil, and I have fallen into the habit of calling the rock the fucoidal sandstone. Mud-cracks, rain-drops, glazed and curdled surfaces, tracks, and all indications of short and frequent emersion from the water are very abundant.

The rock appears in an isolated area in the region around Greenfield, and occupies the center of the basin from the tuff beds in South Hadley southward. It is well exposed at the quarry near Mr. E H. Lyman's house,

${ }^{1}$ Correlation Papers, The Newark System: Bull. U. S. Geol. Survey No. 8.j, 1892, p. 53. 
the first house south of Titans Pier, in South Hadley, and contains here many curions inclusions of angular, flat pieces of a buff indurated clay, which have been formed by the drying, cracking, and warping of a clay hed exposed at low tide, and then the sweeping of the angular fragments into their present position in the sand. It contains also scales of graphite in considerable number, and this continues south to Holyoke in the sandstone and the tuff. The "fucoids" are especially abundant in Springfield.

Forty rods north of the above quarry, at the west end of the sandstone bluff which overhangs the brook, and about 18 feet above the water of the brook, which here runs on the Holyoke trap, there are many angular fragments of limestone up to an inch in length. It is a coarse, crystalline limestone, containing much tremolite, and more rarely plagioclase and wernerite.

This rock and the coarse scales of graphite came probably from the Archean area about the headwaters of the Westfield River, and after entering the basin were drifted northeast, with the prevailing current, to their present situation, though there is a nearer and much more abundant source for the graphite in the Brimfield schists to the east, and this schist carries also thin beds of limestone with coccolite and garnet.

FRAGMENTS OF WHITE TRAP WITHOUT AUGITE IN THE SANDSTONE ABOVE THE HOLYOKE SHEET.

A tuffaceous agglomerate occur's in the second sandstone of the Holyoke range, containing a colorless, wholly feldspathic trap.

The great sheet of trap which forms Mount Holyoke flowed out quietly and was immediately covered by fine calcareous mud in the central parts and by coarser sands nearer the borders of the basin. I had supposed that it remained covered during all the subsequent time of Triassic deposition, and contributed nothing except by ferruginous solutions to the sandstones that cover it. Recently my students in geology from the senior class of 1896 at Amherst discovered an interesting deposit of tuff between the Forest Park, or Little Mountain, plug and Mount Tom. It lies in the bed of the brook which, flowing north between the main and posterior sheets, crosses the railroad at the burnt mill north of Smiths Ferry. The bed occuirs near the headwaters of the brook, below a bridge, and is exposed for about 18 rods. It is a rather coarse, dark-greenish 
sandstone, with many quartz, muscovite, and graphite grains and scales visible to the eye. It is thick-bedded or massive, changing suddenly from the thin-bedded sandstoue. Its full thickness is not exposed. It is very calcareous, and I think it possible that it may be the bed of limestone marked near here by President Hitchcock on his maps, which I have not before found so far north.

In this calcareous sandstone are small rootlike concretionary bodies, which appear in the rusted rock as minute tubes rarely branching. They reach one-half inch in length, and at most one-eighth inch in diameter. In the fresh rock they appear as white calcareous bodies, with a trace of longitudinal fibrous structure, remotely suggesting a minute branching chætetes.

In this sandstone are many wholly angular fragments, from 1 to 4 inches loug, of a volcanic rock, which may often make up a quarter of the mass of the whole bed. In fresh fracture it is a white or light-gray, finegrained rock, with exactly the look of a somewhat siliceous limestone spotted with small grains of pyrite. Weathering or careful study with the lens brings out the fact that the rock is amygdaloidal, with small cavities, mostly spherical, which are filled with calcite or pyrite, or both, and rarely the reflection of a minute twinned plagioclase lath can be seen in the solid rock. In a thin slide it is found to be a diabase considerably altered, but preserving a close resemblance in many particulars to the Mount Holyoke trap, but more to the abnormal red trap from Cheapside. (See p. 431.) It has the same distant feathery groups of larger plagioclase of first consolidation $\left(0.8^{\mathrm{min}} \mathrm{long}\right)$, just visible to the eye and containing rounded inclusions of glassy magma, and these lie in an ophitic network of plagioclase laths of two sizes, the one in quite stout rods, $0.4^{\mathrm{mn}}$ long, which are scattered abundantly in a reticulate or stellate ground consisting of very fine needles of plagioclase, $0.03-0.04^{\mathrm{mm}}$ long. Both the finer feldspars are distinctly fibrous, a structure which is caused by lines and rows of minute grains of a dark ore, which is doubtless limonite, and was originally hematite, as in the Cheapside trap. This makes up almost the whole content of iron in the rock, as only one uncertain augite grain could be detected. There is no magnetite or chloritic decomposition product except a trace of an amorphous green constituent in the amygdules.

To cornplete the resemblance to the Cheapside rock; the small round cavities are lined by a secondary growth of fresh albite in well-shaped 
twinned erystals .03 to $04^{\mathrm{mm}}$ long, maximum extinction $17^{\circ}$. When the alcite is dissolved they appear perfectly limpid and fresh, and often show the marked undulatory extinction characteristic of aqueous albite. One of the larger feldspars of first consolidation, cut paralled to MI (010), showed the optical figure almost central, with the axial plane at $103^{\circ}$ to the vertical axis of the crystal, thus having all the characteristics of albite. The smaller feldspars are more basic. All the constituent feldspars are dusted with kaolin, but their properties can be made out clearly. The rock may have been bleached somewhat by acid waters and the iron may be now present in the pyrite, but when the calcite is dissolved with acid the rock seems little decomposed, and it is of the same character throughout the compact mass from surface to center.

It must, therefore, have differed materially from the Cheapside trap when fresh, although more like it than any other variety in the Trias. The large amount of calcite in the bed indicates a considerable body of lava as its origin. The wholly angular character of the fragments was due to an explosive eruption not far distant. I have little doubt that the focus of this ertuption is to the east, along the old main fissure, concealed by the masses of the Forest Park phig and the newer sandstones.

DISTURBANCES IN THE SANDSTONES AND INCLUSIONS OF TRAP FRAGMENTS JUST BELOW THE POSTERIOR SHEET.

Where the western lobe of sandstone passes down between the areas of trap which extend north from the region of the Little Mountain core the dark-gray sandstone, at a horizon just below the posterior sheet, is much contorted, bands of the sandstone being tivisted into sharp zigzags in a few inches. It makes the impression of some local disturbing force acting before the hardening of the sand to rock, like the "wallows" in the sandstone at Turners Falls, formed by the crowded tracks of the great reptiles. At other localities along the western part of the eastern lobe of sandstone which projects into the trap area this disturbed layer is covered by several feet of undisturbed, flat-bedded sandstone, the disturbed sandstone gradnating rapidly into the undisturbed rock and showing the contortion to have been produced before the deposition of the latter. There are a few small anticlines in the rocks at this place which are easily distinguished from the structure in question. The band is the more interesting because it contains angular fragments, 6 inches long, of the common black trap, 
like that of the Holyoke range, together with small fragments of a white rock, like the white trap described above (see p. 365), but not showing pyrite or porous texture. I associate these disturbances, and similar ones that appear beneath the posterior sheet as far north as the latter can be traced, with the bed of white trap described above. They possibly represent the border of an explosive eruption of limited extent, whose tuffs may have locally loaded the muddy floor of the estuary so as to have produced the crumpling of the beds, but the ontcrops are insufficient to give the whole history of the deposit.

It may be noted that the small sills which appear a few feet below the posterior sheet 90 rods north and 150 rods south of this area greatly contort the sandstones, and the disturbances here noted may be due to the same cause.

THE BOUNDARY OF THE LONGMEADOW SANDSTONE.

The northern boundary of the sandstone, in Gill, is very complicated, because here at the northern, narrowed end of the central sand flats the feldspathic gravel at times projected far out over the sands from the west and the slate gravels from the east. The area of the sandstone narrows as one goes down in the beds, so that in their undisturbed state the central sandstone graduated east, west, and north into the two conglomerates, with many intercalated lobes; and now that they are tilted and faulted one finds many sudden changes from the straight, sudden fault boundaries to the complex, lobed line of passage of sandstone into conglomerate. Especially marked is the narrow band of fine, deep-red, shaly sandstone which rests upon the trap and follows it north nearly to the fault in the latter on the Turners Falls road. This suddenly-appearing and exceptionally fine-grained bed seems due to the shallowing and obstructing of the bay by the ontpouring of the trap.

Because of the prevalent easterly dip of the rocks the boundaries of the sandstones upon the arkose present along their western border the normal relations, and the arkose passes regularly below the sandstone. Along the eastem border of the northern basin the sandstone dips beneath the conglomerate, and it is proved to pass far beneath the upper beds of the conglomerate, because it is twice brought up by faults and repeated upon the western slope of Mount Toby, once at the 500- and once at the 700-foot contour, as seen in the sectional view of the mountain on the section sheet 
(Pl. XXVIII). 'This indicates that after the deposition of the major portion of the conglomerates and the extension of the sand flats far to the east there was a tilting of the beds, which gave them a slight eastward dip and deepened the eastem channel so that the eastern current was strengthened and the slate-conglomerates passed by a broad transgression west over the sands.

\section{ANALYSES.}

The rock of the Kibbe quarry, of East Longmeadow, has been analyzed by Prof. C. F. Chandler, of New York; that of the Worcester quarry and of the Maynard quarry by the Worcester Polytechnic Institute.

Analysis of the roclis of the Kibbe $(I)$, Worcester $(I I)$, and Maynard $(I I I)$ quarries.

\begin{tabular}{|c|c|c|c|}
\hline & I. & II. & III. \\
\hline Silica $\ldots . . . \ldots \ldots \ldots$ & $\begin{array}{c}\text { Per cent. } \\
81.38\end{array}$ & $\begin{array}{c}\text { Per cent. } \\
88.89\end{array}$ & $\begin{array}{c}\text { Per cent. } \\
79.38\end{array}$ \\
\hline Alnmina $\ldots \ldots \ldots \ldots \ldots \ldots \ldots \ldots$ & 9.44 & 5.95 & 8.75 \\
\hline 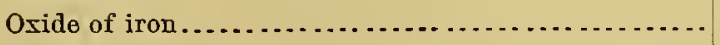 & 3.54 & 1.79 & 2.43 \\
\hline 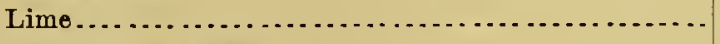 & .76 & .27 & 2.57 \\
\hline 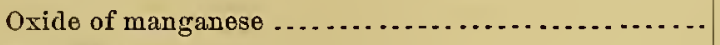 & .11 & ......... & .......... \\
\hline 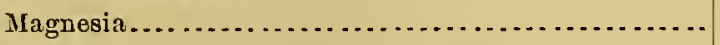 & .28 & ......... & ......... \\
\hline 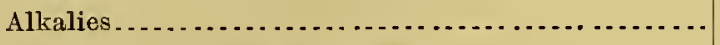 & …..... & .86 & 4.08 \\
\hline \multirow[t]{2}{*}{ 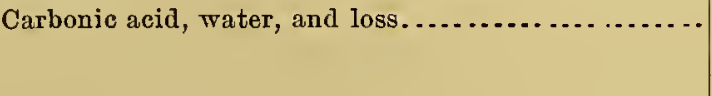 } & 4.49 & 1.83 & 2.79 \\
\hline & 100.00 & 99.59 & 100.00 \\
\hline
\end{tabular}

The amount of alrmina shows that there is probably considerable feldspar in the rock, and that some part of the loss is alkali.

THE GRANBY TUFF, OR THE DIABASE-TUFF.

This bed is the most distinct geological unit of the series. It is made up of diabase ash, lapilli, and bombs. It grows finer in any section from bottom to top and from west to east. West of the Connecticut it is made up of coarse material, with many masses as large as one's head. South of The Notch it consists of fine lapilli, and farther east it is a consolidated ash bed. It always contains some granitic material, often only muscovite scales. The transition from sandstone to tuff is sudden, and the tuff rests on arkose from the east end to the river, and then on fucoidal sandstone. It graduates npward imperceptibly into the fucoidal sandstone, and while the main trap sheets made no impression on the sediments, the tuff furnished abundance of iron and lime to all the upper beds. It is described in detail in Chapter XIII, in connection with the description of the volcanic rocks. MON XXIX-24 
THE CHICOPEE SHALE, OR THE CALCAREOUS SHALE.

All the bluffs in the city of Holyoke, especially the long railroad cut, are made up of a gray shale which varies into a paper-thin red sandstone, in which rarely a bed a foot thick can be quarried. It always effervesces abundantly with acid; many beds are full of nodular concretions of clayey limestone, and at times these coalesce, cementing thick beds of the clay into water-lime.

The rod-shaped concretions which have been called fucoids are wanting, but all the marks of frequent recession of the water, as mud-cracks, raindrops, and ripple-marks, are present. The rock abounds in casts of gypsum and of salt crystals. It extends fiom Holyoke southward, occupying the central portion of the basin, and is bounded on either side by the Longmeadow sandstone.

The large quantity of hematite and of iron- and lime-carbonate would seem to have been derived from the subjacent trap and trap-tuff.

THE CONTINUATION OF THE STATE-LINE FAULT IN A CRUSHED BAND AT HOLYOKE DAM, AND THE SECONDARY MINERALS FOUND IN THE FISSURES. ${ }^{1}$

During the building of the new dam at Holyoke, the shales of the area below the present dam were accessible for a long time, and a deep trench was blasted from the foot of the dam halfway to the bridge below, which exposed an exceptionally crushed, folded, and faulted band in the shales (fig. 23).

The section begins in midstream at the foot of the dam and extends 60 rods east toward the bridge. For 11 rods the rock is a red sandstone of medium to fine grain, which rums in easy undulations and has a slight dip north, or from the observer. A compact bed of different color from that of the rest indicates a fault at the middle and end of this part of the section. This is followed by a fine, brittle, calcareous shale-a slightly indurated mud rock, at times massive, at times banded, generally dark-gray, but often of a bright red; some of the bands are a buff water-lime. This is strongly folded, jointed, and contorted, and in several places one or two rads wide crushed completely, so that all structure is gone, and after being thrown out on the bank the rock slakes under the influence of the weather and crumbles to powder in a few days.

${ }^{1}$ For further discussion of State-line fault, see the section "The Holyoke Sheet," p. 446. 
At the east end of the section the red sandstone reappears for a few rods, with the normal low dip, to the east and no twisting of the beds

On cxannining my maps I found that the State-line fanlt, which 1 had located where it crossed the two trap ranges, and hard not been able to follow farther north beneath the great sand plains of Holyoke, would cross the Connecticut just at the place of the section. I have therefore prolonged this fault so as to make it include the central shale of the section, and consider this an area of crushing at the passage of the fiult. The throw of the fault does not seem to be great, and it is probable that the shale is an upper member dropped in between the sandstone beds and strongly crushed.

The shales contain impressions of hopper-shaped salt crystals, cubical cavities, variously distorted, from which salt has been removed, and angular cavities 3 inches by $\frac{1}{3}$ inch in cross-section and 1 inch deep, from which some mineral, probably barite, has been removed. Many shrinkage cracks, often forming complex networks and broad stellate forms, are filled with white calcite.

At a much later time the abundant fissures, formed by the crushing of the rock, were filled by a more complex series of minerals. The oldest is siderite, which coats broad surfaces with fine crystals often a third of an inch across, ranging in color from a yellowish gray to a rich reddish yellow, and as they have the faces $\mathrm{R}$ and $\infty \mathrm{R} 2$ equally developed they simulate dodecahedra and suggest cinnamon garnets. Before the completion of their growth flat blades of gypsum formed upon them, which have since been removed. They were followed by a curious acicular growth of barite-parallel groups of straight, doubly serrate needles formed of minute rhombic prisms $(0 \mathrm{P}, \infty \mathrm{P})$ just touching by the acute angles and having the axis $\mathrm{b}$ common. These are superficially inclosed in the siderite and project from it in a common direction.

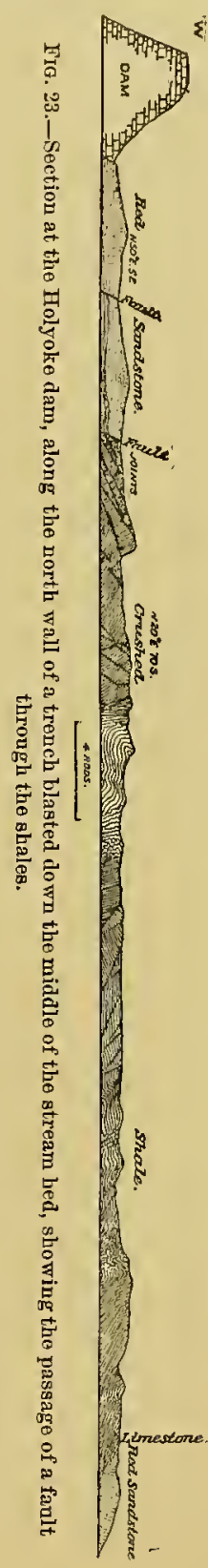

The specimens are beautifully frosted by a growth of small white calcites, $\mathrm{R} 3, \infty \mathrm{R},-\frac{5}{4} \mathrm{R},-2 \mathrm{R}$, with rounded apex or coated by a layer of 
brittle anthracite whose rounded surfaces indicate that it came into the fissure as a bitumen, but which gives a yellow flame for an instant only and then burns with extreme slowness.

This is often coated by a layer of pyrites of very modern growth. Where the same beds are crossed by the Chicopee River the red shales contain broad seams of a pink, transversely fibrous calcite, and in the bed of the Westfield River, in West Springfield, all the occurrences detailed above are repeated and the curious salt pseudomorphs described on page $\mathbf{3 8 9}$ are also found.

THE DIABASE.

The great Deerfield and Holyoke diabase beds and the posterior or Talcott bed fall into this series, but lie partly intercalated in each of the above members and partly on their borders. They are described in Chapter XIII.

The series of newer volcanic cores, of which the Black Rock may be taken as the type, close the list of Triassic deposits. They are specially described near the end of Chapter XIII.

\section{THE FORMLATION OF THE BASIN AND THE DISTRIBUTION OF THE} SEDIMENTS BY STRONG TIDAL CURRENTS.

The rocks which have been described are not chronologically successive in the order given, or in any order, but are synchronous facies, dependent for their variety on the varying character of the shore rocks from which they were derived, on the strength and direction of the tidal currents by which they were carried, and on the varying distance from shore and the varying depth of water in which they were deposited. The last is a most important element. Because of the great depth of the western portion of the basin and the abundance of granite along the western shore, the advancing waters may have begun to deposit the arkose here a little earlier than the other varieties, but very soon must have come in contact with the argillites and schists of the eastern border, and the development of the arkose and that of the conglomerate were then strictly synchronous. As the waters rose and attained greater width the central portion of the basin was occupied by a deposit of offshore sands-the Longmeadow or fucoidal sandstones-and when the maximum width was reached the middle portion of the sandstones sank to the fine-grained sand and mud beds which have become the central Chicopee shales. 
The coarser beds are not so well fitted to retain marks of exposure, but the false betding and the ripple-marking, together with the lack of indications of exposure, convince me that during the earlier portions of the Trias the waters were deeper, and of such depth as to render the strong currents most effective, and that later the broad basin became so shallow that the currents were effective only where concentrated in their shoreward portions, while over the broad central and shallower flats, regularly abandoned by the tide, conflicting currents carried only fine material.

An inspection of the detailed geological map of the Appalachian chain makes it very plain that the sonthward trend of the main structure lines across New England must have made a great sigmoid curve to the west in sympathy witl the same curves in the more western chains across the Middle States, and that a great post-Carboniferous sinking must lave depressed an extended block south of an east-west line running north of Long Island, thus producing the "Rias Coast" ${ }^{1}$ of southern New England and admitting the sea into the deep fjordlike bay of the Connecticut River Trias. The development of the fault system which borders this bay and has produced it may have been an attendant upon the larger movement, but it is quite clear that the depression of the bottom of the basin was, in part at least, synchronous with the accumulation of the Triassic sands, and in part of later date.

It is difficult to assign the correct value to this cause, the sinking of the bottom of the basin, as another valid cause is recognizable which worked to the same end, namely, the great Triassic transgression. While the above statements present the true explanation of the formation of the Triassic basin-that it is a narrow fault-bounded and sunken block-the presence of a large number of isolated sandstone and conglomerate masses along the Atlantic Coast indicates a general positive motion of the waters over the land along the whole coast-one of those general "transgressious" the importance of which has been so ably enforced by Suess-as the true explanation of the gradual advance of the waters into the basin.

I have now collected abundant evidence that the waters in their slow transgression across the bottom and up the sides of the basin found a great store of material for their work in the results of the secular disinte-

${ }^{1}$ A coast line which truncates mountain ehains about at right angles to their trend: Suess, Das Antlitz der Erde. 
gration of the rocks (as insisted upon recently by Professor Pumpelly and applied by him to a more ancient transgression), ${ }^{1}$ especially the vast amount of granitic débris, which has been swept into its place so rapidly that, although carried many miles across the valley, it is so angular that it seems to be still at the base of the granite ledge from which it was derived.

I have been further led to look with some hope upon the theories concerning former high tides and strong tidal currents which have been so eloquently expounded by the astronomer, Sir Robert Ball, ${ }^{2}$ for it is beyond question that the sediments were spread by tidal currents which passed north up the west side of the valley and down the east side, and with a force greater than I can find anywhere described for modern currents. The proof of this is presented here in abstract, but many details are given in the description of the different rocks in the last chapter.

Along the middle portion of the westem border-lands of the Triassic basin is a very great development of granites, abundantly muscovitic, and the schists down to the southern line abound in these dikes, which plainly extend eastward far beneath the border of the Trias. Now, all along this line the Trias is made up at the shore-line of a granitic conglomerate which, as it extends far out into the valley and up in the series, graduates through coarse to fine arkose.

In the northern half of the State the western border-country is of black schists and argillites, but the arkose sweeps up along this shore for more than 20 miles, scarcely darkened by any admixture of the black schists, but where it is coarse containing many large, well-rounded pebbles of the vein quartz from the schists. Here it is plain that the immediate shore wash has rounded the quartz pebbles, and that they have then been carried outward by the undertow and forward diagonally by the sweep of the tidal current, while the mass of the material came from much farther south.

The same thing is clear along the eastern side of the valley. The materials derived from each of the rocks that formed the ancient shore are carried far south of the area occupied by the respective rock. At the north end the peculiar crystalline rocks of the Northfield hills form the slate-conglomerates at their foot and are carried far south. And

${ }^{1}$ Secular rock disintegration: Am. Jour. Sci., $3 d$ series, Vol. XVII, 1879, p. 133. The relation of secular rock disintegration to certain transitional crystalline schists: Bull. Geol. Soc. America, Vol. II, 1891, p. 209.

${ }^{2}$ A glimpse through the corridors of time: Natnre, Vol. XXV, p. 79. 
they, with the equally peculiar rocks which are disclosed by erosion in the midst of the conglomerates of Mount Toby, are carried south over the granites of the eastern shore, and the arkose derived from these granites at last takes their place and is itself continued south at the foot of the slate bluffs of Wilbraham, where it slowly gives place to a slate-conglomerate. Where the basin is narrow these two rocks-the arkose on the west and the conglomerate on the east-meet and blend in an interdigitating boundary. When the basin widens they separate to include broad areas of sandstones and shales, representing the sand and mud flats which intervened between the strong current which moved up the west side and that which passed down the east side of the basin.

I have elsewhere (p. 353) described the Mornt Toby conglomerate as resting upon a pedestal of crystalline rocks whose surface is nearly 400 feet above the sea. This pedestal is continued south as the great ridge upon which Amherst is built. The presence of this ridge and the consequent shallowness of the waters explain the fact that the arkose extending south from the ridge expands entirely across the valley and contains from its eastern border clear to the Mount Tom station in the center of the basin angular pebbles of granite, often as large as one's fist.

Wherever I have examined the cross-bedding it tells the same story as to the direction of the currents; as in the bluffs of Mount Tom, and especially in a fine island of arkose in the northwest bend of the Deerfield River (which is interesting as having more than sixty potholes cut in its surface by the strong high-water current of the present river, which passes over it), where the beautiful cross-bedding is plainly directed northerly.

President Hitchcock presents the matured results of his long studies of the Trias in the introduction to the Ichnology of Massachusetts (1857), wherein he gives the details of four sections across the sandstones, in which he obtained the following thickness:

Thickness of the Triassic sandstones at different localities.

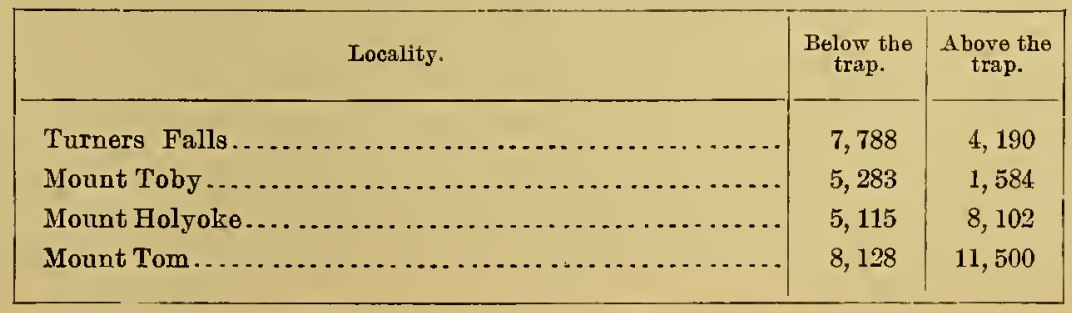


He was not satisfied with these numbers, as they seemed excessive; and he gives consideration to original deposition on an incline and to faulting as explanations, and rejects both, effectively disproving the first and remarking concerning the second that he had been unable to find any considerable faults, such as the theory wonld demand. Accordingly he considered the general easterly dip to indicate that there was a uniform progression from older to newer beds in passing from west to east and made a threefold division-(1) the sandstones below the trap, (2) the sandstones above the trap, and (3) the conglomerates of Mount Toby, the latter being the newer.

More favorable exposures and more detailed mapping have revealed many faults, and I feel sure that many more remain concealed.

Along the eastern side of Mount Toby the coarse conglomerate rests in normal unconformity upon the old quartzite, and instead of being newer than the fine-grained sandstones (the distinctions I have made of arkose and red fucoidal sandstone agree in the main, though not exactly, with the above distinctions, sandstone below the trap and sandstove above the trap), it is certainly older than these, and, as an eastern-shore deposit, is to be placed parallel with the arkose which forms the shore deposit along the western side of the estuary. As I have indicated elsewhere that the waters spread over this portion of the basin somewhat after the time of their advent in the western portion of the basin, I should not place them parallel to the base of the arkose on the west, but rather to its middle and upper portions, and should place the main continuous mass of the red sandstones and shales which, beginning in South Hadley, extend broadly southward in the central portion of the basin as in part later than both. They are largely the tidal mud flats of a shoaled-up and contracted estuary which must have had high tides like the Bay of Fundy.

The dips are certainly for the most part easterly, but this is commonly overstated. Across Hatfield they are largely westerly. In Mount Toby they are nearly horizontal. East of Turners Falls and in the Holyoke range they swing round to south. In Hampden County they are very low and rarely observable in the eastern portion. With these dips and with the repeated monoclinal faulting the boundaries, if we could draw them accurately, would often be sharply serrate, but hindered by the uniform character of the rocks of the series, and more by the thick cover of till, one can draw only approximate boundaries. 
I have been greatly interested in the hypothesis which has been advancer and exponnded with so much aeuteness hy Prof. W. M. Davis ${ }^{1}$ in explanation of the monocliual faulting, and applied so fully to the sonthward extension of this area across Comecticut, and I have permitted myself to be guided by it as far as possible. This has been, however, rather permissive than compulsory in this region, for, as just seen, the easterly dips are only slightly in the ascendency. All the strongest dips are to the south, as in the Holyoke range, in Gill and northern Montague, or northwest in central Montague. In several cases submerged peaks and bosses of crystalline rocks have thrown off the sandstones in various directions and have plainly acted rather as resistant masses against which the sandstones have been crowded irregularly than as masses whose own deep-seated compression has produced a monoclinal fanlting in which the sandstones have passively shared. Thus at the mouth of Millers River the rocks have been crushed and faulted against a great mass of most rigid quartzite, and dip strongly west, and a little farther west change suddenly to high south dips, and to the west of Montague village the great mass of uncovered gneissoid conglomerate throws off the sandstones to the northeast. It would thus seem that in all its northern portion the valley is too narrow and tortuous and its bottom too irregular and too much broken through by later intrusive plugs of trap to allow of the regular development of this structure. The southern, broader portion of the valley in Massachusetts is too much covered to exhibit fully the system of the faults.

At the north end of the basin the boundary extending southwestward from the Connecticut is plainly a boundary of erosion, and the conglomerates extended formerly much farther than at present. Indeed, it leaves the impression that the basin was a strait, extending northward into another sea.

An inspection of the map will show that the whole width of the Trias across the north of Gill is of conglomerate, equally divided between the arkose on the west and the slate-conglomerate on the east. The boundary is a narrow, transitional band, rather than a line, but is very distinct. From Bernardston across to the boundary the rock is pure granitic débris; near this line slate pebbles begin to appear, rounded and far-traveled, and soon the finer material comes to be also wholly of comminuted slate and

${ }^{1}$ Am, Jour. Sci., $3 d$ series, Vol. XXIV, p. 347; Vol. XXXII, p. 342. Bull. Mus. Comp. Zool. Harvard Coll, geol. series, Vol. II, p. 99. 
quartz, and continues thus across to the river. The granitic material on the west has been brought from 20 miles south, the slaty material from Vernon and Northfield to the northeast, and the two currents pass each other well established, with plenty of room to move in, and do not show any indication that they are located near the head of a narrow bay.

The behavior of the great overflow trap sheets is instructive as indicating the character of the bottom over an extended area at a given time. The Deerfield bed is an overflcw, as is proved by the beautiful ropy surface at Turners Falls. That it flowed over the muddy bottom of the bay is indicated by the kneading together of trap and shale in Greenfield (see p. 419). It rests on the Mount Toby conglomerate from Gill Center nearly to Fall River, then on fucoidal sandstone and shale to Deerfield, then on arkose to the Connecticut, and on the Mount Toby conglomerate to the sonth end of Mount Toby. It had little influence upon the later rocks, and is covered by the same rocks as those which lie beneath it, except that the boundary of the fucoidal sandstone and the Mount Toby conglomerate is shifted to the north by an amount equivalent to the thickness of the trap.

The same is true of the Holyoke bed. The same buff arkose that precedes its advent also rests upon it, and does not receive the smallest influence from the abundant iron in the trap, as it was immediately covered by the strong currents. It continues to rest on the arkose to Holyoke, and from there to the south line of the State rests upon the fucoidal sandstone and the shale. All these rock types thus formed portions of the bottom of the basin at the same time.

The shallowing of the basin effected by the outflow of the great mass of trap made itself manifest in the transfer of the boundary of the arkose and sandstone far to the north. That is, it shallowed the waters so that along the central axis of the valley the finer-grained sandstones characteristic of the shallower central area extended much farther north. This strengthens the impression that one gets from the signs of repeated emergence from the water, so abundant in the sandstones, and their absence from the arkose, viz, that the sandstone was deposited in shallower water and laid bare at low tide. That the arkose and calcareous shales were deposited at the same time is further shown by the fact that from Titans Pier, where the Holyoke trap sheet crosses the Connecticut, nearly to the Westfield River, about ten miles, the trap, which here everywhere rests 
directly on the coarse arkose, is filled with fragments of the fine-grained shales and dove-colored limestones which were in place as part of the bottom far to the east or southeast. This shows that the fissure was situated east or southeast of the present outcrop, and that the trap broke through and flowed out, first over the mud flats and then over the coarse granitic débris lying westward. The greater thickness of the trap sheet in just this portion of its length, viz, in Mount Tom, may be because the trap sheet extended into the deeper shoreward portion of the basin-that occupied by the western, northward-moving current.

\section{THE POSSIBLE CONNECTION OF THE FOOT-TRACKS WITH THE TRAP SHEETS.}

It is furthermore interesting to observe that all the famous localities of tracks are far out in the center of the ancient bay, in sandstones that rest directly upon the back of the broad trap sheets, and not very high up above the upper surface of the trap.

Above both the Deerfield and the Holyoke trap sheet the area within which these tracks occur is approximately identical with the area overspread by the trap sheet, and it seems to me quite probable that the shallowing of those broad central areas of the bay 300 to 400 feet by the great trap sheets may have produced the peculiar surfaces just between tides, on whose sand and mud flats the reptiles walked and the raindrops made their marks. The iron which was soon set free from the decomposing lavas below permeated the muds and, besides giving them their red color, cemented them with unusual rapidity, and so favored the very remarkable preservation of the tracks, as the preparation of the broad central intertidal mud flats favored their production.

There are more than 20,000 tracks in the Amherst collection, perhaps as many more in that of Yale, and again as many more in other collections, and it is hard to say how many have been destroyed for every one in the collections. There is, therefore, something quite exceptional to be explained in the vast number of these tracks which are found in this very limited space. There is a slight possibility that the heat of these great trap sheets may have promoted rapid consolidation of the sand layers by which they were quickly covered. 


\section{ARTESIAN WELLS.}

WELL AT TURNERS FALLS.

Artesian well of Montague Paper Company, Turners Falls, just west of the south end of the dam. Samples at Amherst College. For analysis of water see Chapter XXI. The rock lies very near the surface and 25 feet below the top of the dam. The figures indicate distance in feet from the surface of the rock.

Record of artesian-uell boring at Turners Falls.

\begin{tabular}{|c|c|}
\hline Kind of roek. & Feet. \\
\hline 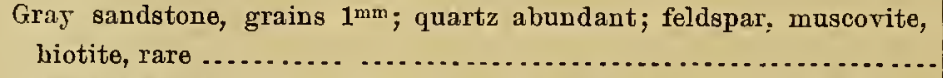 & 15 \\
\hline 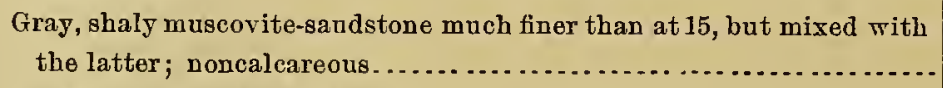 & 18 \\
\hline 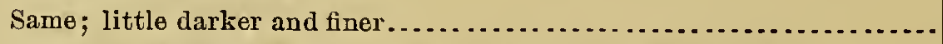 & 23 \\
\hline White sandstone, grains 1 to $4^{\mathrm{mm}}$; quartz, muscovite, biotite ..... & 24 \\
\hline 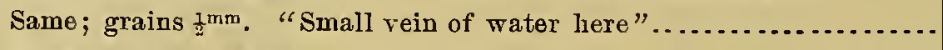 & 26 \\
\hline 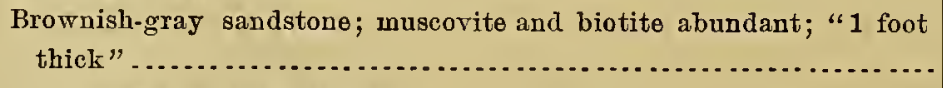 & 32 \\
\hline Gray, micaceoue, shaly sandstone; "1 foot thick" ................. & 33 \\
\hline 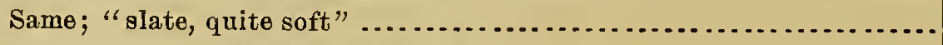 & 34 \\
\hline Dark-gray, micaceous, shaly sandstone...................... & 50 \\
\hline Browuish-gray, micaceous, shaly sandstone ................... & 54 \\
\hline Light-gray, micaceous, shaly sandstone; "struck water here" .... & 56 \\
\hline Gray, micaceous quartz-sandstone, grains 1 to $4^{\mathrm{mm}} \ldots .$. & 60 \\
\hline Gray, shaly sandstone $\ldots . . . . . . . . . . . . . . .$. & 66 \\
\hline 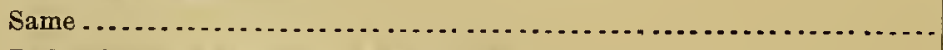 & 68 \\
\hline 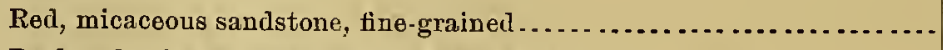 & 72 \\
\hline Dark-red, micaceous saudstone, fine-grained $\ldots \ldots \ldots \ldots \ldots . . . . . .$. & 80 \\
\hline 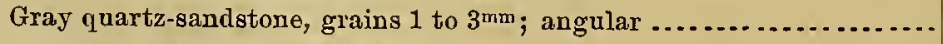 & 85 \\
\hline 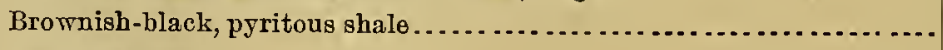 & 94 \\
\hline Dark-gray shale $\ldots \ldots \ldots \ldots \ldots \ldots \ldots \ldots \ldots$ & 106 \\
\hline 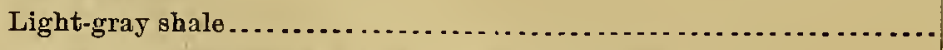 & 110 \\
\hline White quartz-sandstone, grains 1 to $2^{\mathrm{mm}}$; little muscovite...... & 120 \\
\hline 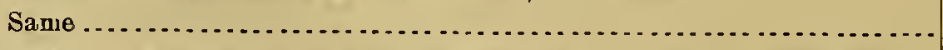 & 125 \\
\hline Buff quartz-sandstone, grains 1 to $6^{\mathrm{mm}}$; well rounded; "water here"... & 133 \\
\hline Clear-gray quartz-muscovite-sandstoue, grains 1 to $6^{\mathrm{mm}} \ldots \ldots . .$. & 140 \\
\hline Light-chocolate quartz-muscovite-sandstone, grains 1 to $6^{\mathrm{mm}} \ldots \ldots \ldots \ldots$ & 150 \\
\hline Dark-brown quartz-muscovite-sandstone, grains 1 to $6^{\mathrm{mm}}$; shaly $\ldots$. & 200 \\
\hline Same.................. & 225 \\
\hline Same.........$\ldots \ldots \ldots \ldots$ & 260 \\
\hline Same .... & 275 \\
\hline
\end{tabular}


Record of artesian-well boring at Turners Falls-Continued.

\begin{tabular}{|c|c|}
\hline Kind of roek. & Feet. \\
\hline Sano.... & 290 \\
\hline 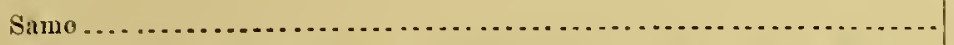 & 320 \\
\hline Bright brick-red quartz-muscovite-sandstoue, grains 1 to $6^{\mathrm{mm}}$; shaly... & 340 \\
\hline Dark-brown, shaly sandstone, very micaceous ................ & 360 \\
\hline Bright-red, shaly quartz-muscovite-sandstone, grains 1 to $6^{\mathrm{mm}} \ldots$ & 390 \\
\hline 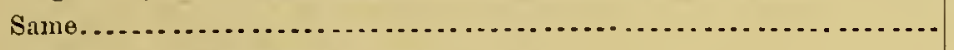 & 400 \\
\hline 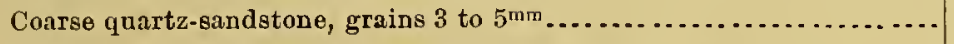 & 420 \\
\hline Bright-red quartz-muscovite-sandstone, grains 1 to $2^{\mathrm{mm}} \ldots \ldots$ & 440 \\
\hline 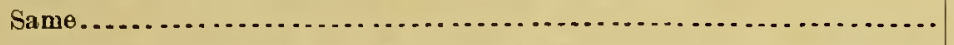 & 460 \\
\hline $\begin{array}{l}\text { Pale-green chloritized diabase, larger lath-shaped twinned plagioclase } \\
\text { grains } 1 \text { by } 1 \text { to } 3^{\mathrm{mm}} \text {; augite wholly changed to chlorite; magnetite } \\
\text { octahedra. The microscope shows much feldspar in two generations; }\end{array}$ & \\
\hline $\begin{array}{l}\text { Same. The pyroxene shows under the microscope nearly colorless } \\
\text { center and good cleavage; yellow-green border and poor cleavage... }\end{array}$ & 610 \\
\hline 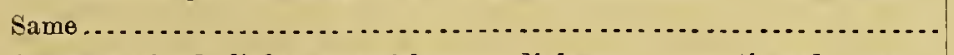 & 617 \\
\hline $\begin{array}{l}\text { Coarse-grained, light greenish-gray diabase, copper-tinged; many } \\
\text { grouped magnetite octahedra. Under the microscope the pyroxene } \\
\text { is fresh, green, and much twinned } \ldots \ldots \ldots \ldots \ldots \ldots \ldots \ldots \ldots \ldots \ldots \ldots \ldots\end{array}$ & 640 \\
\hline Dark-red quartz-muscovite-sandstone, grains 1 to $6^{\mathrm{mm}}$; shaly ......... & 670 \\
\hline Light-gray quartz-muscovite-sandstone, grains 1 to $6^{\mathrm{mm}}$; shaly ....... & 690 \\
\hline Red quartz-muscovite-sandstone, grains 1 to $6^{\mathrm{mm}}$; shaly .............. & 700 \\
\hline Light-gray quartz-sandstone, grains $\frac{1}{3} \mathrm{~mm}$; well rounded .............. & 705 \\
\hline Brown-gray quartz-muscovite-sandstone, grains 1 to $2^{\mathrm{mm}} . . . . .$. & 708 \\
\hline Dark-red quartz-muscovite-sandstone, grains 1 to $4^{\mathrm{mm}} \ldots$. & 710 \\
\hline 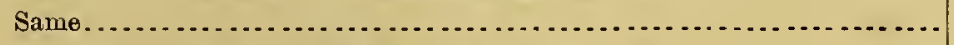 & 738 \\
\hline Gray quartz-muscovite-sandstone, graius 1 to $5^{\mathrm{mm}} \ldots \ldots \ldots \ldots \ldots \ldots$ & 795 \\
\hline Reddish-gray quartz-muscovite-sandstone, grains 1 to $5^{\mathrm{mnt}} \ldots \ldots$ & 800 \\
\hline Coarse, buff quartz-muscovite-sandstone, grains 1 to $5^{\mathrm{mm}} \ldots \ldots \ldots \ldots .$. & 810 \\
\hline Dark-red quartz-muscovite-sandstone, grains 1 to $5^{\mathrm{mm}} . \ldots . . . . . . . .$. & 865 \\
\hline Red, shaly quartz-muscovite-sandstone, grains 1 to $6^{\mathrm{mm}} \ldots . . . . . . .$. & 875 \\
\hline
\end{tabular}

WELL AT SOUTH HADLEY.

Artesian well at Mount Holyoke College, South Hadley. Samples at Mount Holyoke and Amherst colleges. Samples all calcareous, very finely pulverized, so that structure could be only partly made out. 
Record of artesian-uell boring at South Hadley.

\begin{tabular}{|c|c|}
\hline Kind of rock. & Feet. \\
\hline Fine buff sand........ & 25 \\
\hline Same.............. Terrace sands . & 30 \\
\hline Very fine buffi saud... & 40 \\
\hline Rather fine-grained, light-red, micaceous sandstone, mnscovitjc.... & 50 \\
\hline Same, but much mixed with saud................ & 60 \\
\hline Light-red, fine-grained, muscovitic saudstone....... & 70 \\
\hline Same...................................... & 80 \\
\hline Same............................ & 90 \\
\hline Red, fine-grained, muscovitic sandstone ............ & 160 \\
\hline Dark-gray, shaly, muscovitic sandstone................ & 110 \\
\hline Red, very fine-grained, muscovitic sandstone................ & 120 \\
\hline Brick-red, very fine-grained, muscovitic sandstone............ & 130 \\
\hline Same...... . . & 140 \\
\hline Same................................. & 150 \\
\hline Gray, very fine-graiued, muscovitic sandstone..... & 160 \\
\hline Dark-gray shale............................. & 170 \\
\hline Same.......................... & 180 \\
\hline Brick-r'ed shale........................... & 190 \\
\hline Brick-red, shaly, muscovitic saudstone.......... & 200 \\
\hline 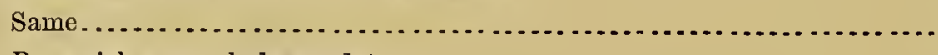 & 210 \\
\hline Brownish-gray, shaly saudstone. ................. & 220 \\
\hline Dark-gray, shaly sandstone ...................... & 230 \\
\hline Same. . . . . . & 240 \\
\hline 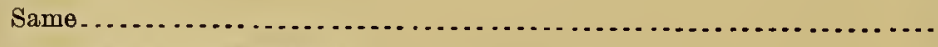 & 250 \\
\hline Pale-buff, shaly sandstoue ........................ & 260 \\
\hline Chocolate-colored, fine-grained, micaceons sandstone ......... & 270 \\
\hline 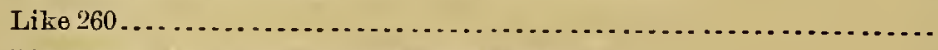 & 280 \\
\hline Light-gray, fine-grained, micaceous sandstone......... & 290 \\
\hline Dark-gray shale ..................................... & 300 \\
\hline Same. & 310 \\
\hline Same. & 320 \\
\hline Reddish-gray, fine-grained, micaceous sandstone............... & 330 \\
\hline Dark-gray, fine-grained, micaceous saudstone.................. & 340 \\
\hline 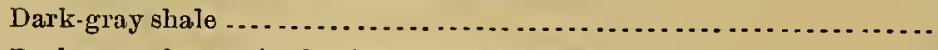 & 350 \\
\hline Dark-gray, fine-gr'ained, micaceous sandstone................ & 360 \\
\hline 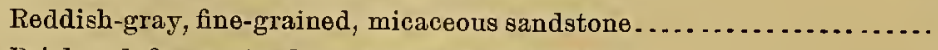 & 370 \\
\hline Brick-red, fine-grained, micaceous sandstone ........... & 380 \\
\hline 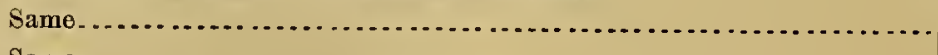 & 400 \\
\hline Same. & 410 \\
\hline Gray, fine-grained, micaceons sandstone ........... & 420 \\
\hline Light-gray, fine-grained, biotitic sandstone.................. & 430 \\
\hline Brick-red, muscovitic sandstone .......................... & 440 \\
\hline Same............................. & 450 \\
\hline
\end{tabular}


WELL A'T HOLYOKE.

Artesian well of Parsons Paper Company, at Holyoke; near west end of dam; October, 188t. E. IV. Chapin, superintendent. The samples in this series were especially clean, and the method of boring favored the production of large fragments. All the samples are very fine, and the distinction drawn between shale and sandstone is a very close one. The specimens were curefully bottled and labeled with depth and date, and given to the Amherst College cabinet by Mr. Chapin.

Record of artesian-vell boring at Holyoke.

\begin{tabular}{|c|c|}
\hline Kind of rock. & Fobt. \\
\hline Sand, etc. (not reported) & 0 \\
\hline 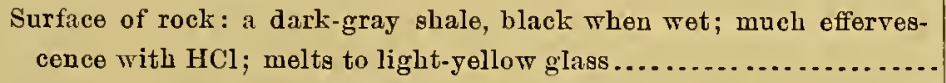 & 85 \\
\hline Same black ohale; small drusy surfaces of calcite crystals, apparently & \\
\hline$R^{3}$ with odges cut by $-2 R$ and apex by $-\frac{1}{2} R \ldots \ldots \ldots \ldots \ldots \ldots \ldots$ & 102 \\
\hline Fine sandstone, dark chocolate-brown, slightly calcareons, micaceous .. & 113 \\
\hline 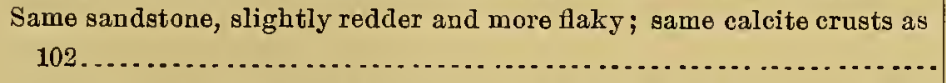 & 115 \\
\hline $\begin{array}{l}\text { Same very fine, micaceous sandstone, dirk-gray; some grains colorless; } \\
\text { sandstone with biotite and muscovite scales....................... }\end{array}$ & 130 \\
\hline Fine, light-gray, micaceous sandstone; abundant calcareous cement... & 132 \\
\hline 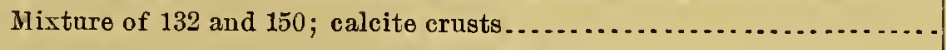 & 140 \\
\hline Dark-gray shale; calcareous, pyritous grains ................ & 150 \\
\hline 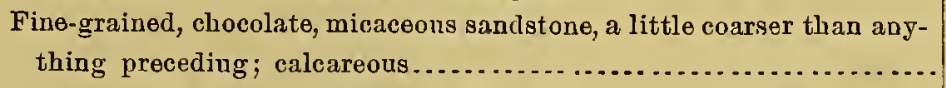 & 160 \\
\hline 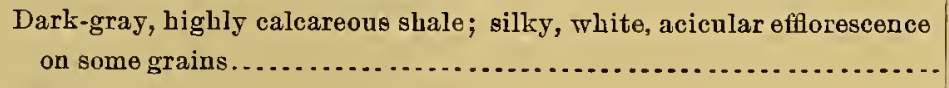 & 164 \\
\hline 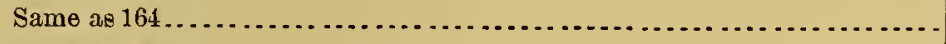 & 176 \\
\hline 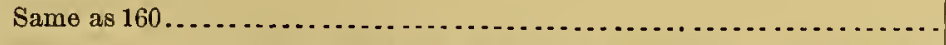 & 190 \\
\hline 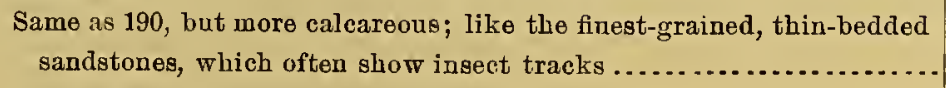 & 200 \\
\hline 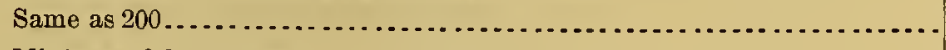 & 215 \\
\hline 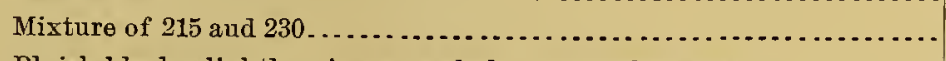 & 223 \\
\hline Bluish-black, slightl 5 micaceous shale; very calcareous ..... & 230 \\
\hline Dark-gray, micaceous and pyritous shale....... & 235 \\
\hline Fine, black, calcareous shale................ & 240 \\
\hline Same as $240 \ldots \ldots \ldots \ldots \ldots \ldots . . . . . .$. & 244 \\
\hline Dark-gray, calcareous shale............... & 255 \\
\hline 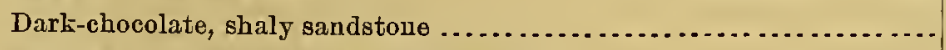 & 260 \\
\hline 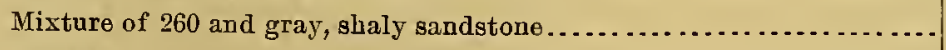 & 270 \\
\hline 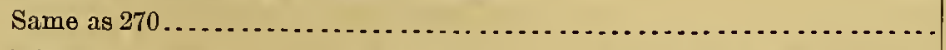 & 280 \\
\hline $\begin{array}{l}\text { Mixture of dark- and light-gray shale; many grains show efflorescence } \\
\text { of iron } . . . \ldots \ldots \ldots \ldots \ldots \ldots \ldots \ldots \ldots \ldots \ldots \ldots \ldots \ldots \ldots \ldots \ldots \ldots\end{array}$ & 285 \\
\hline
\end{tabular}


Record of artesian-well boring at Holyoke-Continued.

\begin{tabular}{|c|c|}
\hline Kind of rock. & Feot. \\
\hline 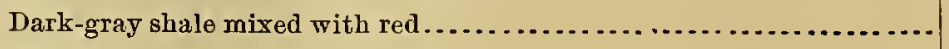 & 290 \\
\hline 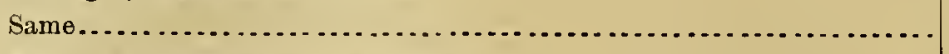 & 300 \\
\hline 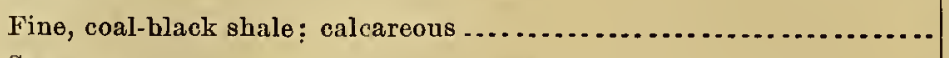 & 308 \\
\hline 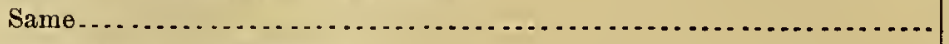 & 318 \\
\hline 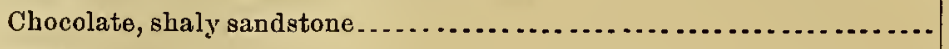 & 330 \\
\hline Same....... & 338 \\
\hline Dark-gray shale. . . . . . . . . . & 347 \\
\hline 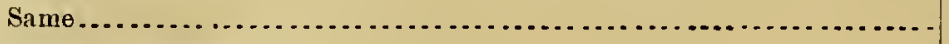 & 355 \\
\hline 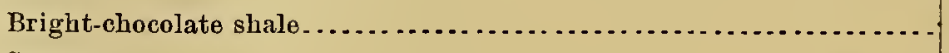 & 360 \\
\hline Same........................ & 365 \\
\hline 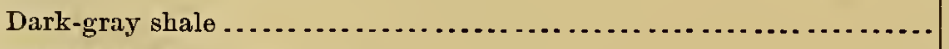 & 375 \\
\hline Black shale.... . . . . . . . . . . . . . & 380 \\
\hline 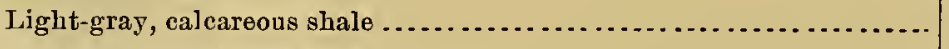 & 385 \\
\hline 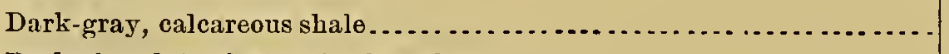 & 390 \\
\hline 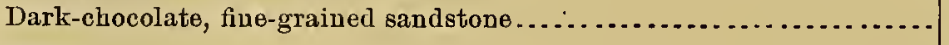 & 400 \\
\hline 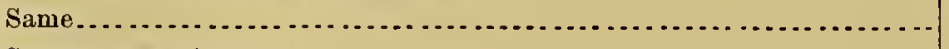 & 408 \\
\hline 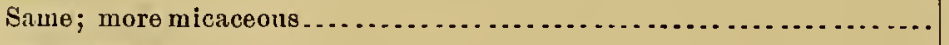 & 420 \\
\hline Black shale........ & 435 \\
\hline 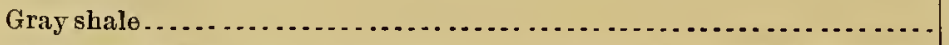 & 440 \\
\hline Dark-gray shale with layer of light-buff, highly calcareous sandstone.. & 460 \\
\hline Dark-chocolate, shaly sandstone ................ & 472 \\
\hline 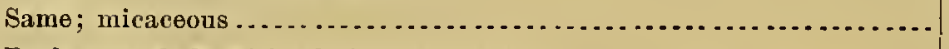 & 475 \\
\hline 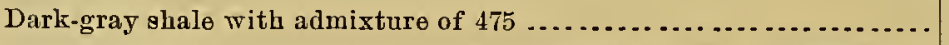 & 485 \\
\hline Dark-gray shale; layers of fine-grained, light-gray, micaceous sandstone. & 490 \\
\hline Dark-gray shale; micaceous and only slightly calcareous ..... ....... & 500 \\
\hline 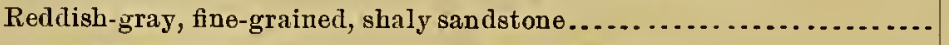 & 505 \\
\hline Chocolate-colored, fine-grained, muscovitic sandstone . . . . . . . . . . . . & 510 \\
\hline
\end{tabular}

Parsons Paper Company, Holyoke, Mass. A separate partial series from the same well as the last. Samples deposited in collection at Amherst College.

Record of artesian-well boring at Holyoke.

\begin{tabular}{|c|c|}
\hline Kind of rock. & Feet. \\
\hline Red-brown, fine-grained, marly sandstone, very ferruginous........ & 250 \\
\hline 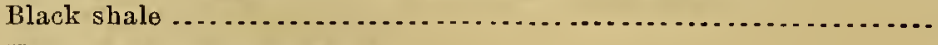 & 365 \\
\hline 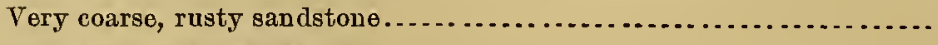 & 400 \\
\hline 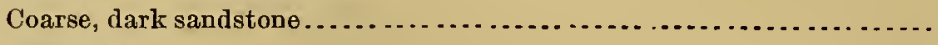 & 420 \\
\hline Same, granitic................... & 425 \\
\hline Black shale. . . . . . . . . . . . . & 435 \\
\hline Same............................ & 445 \\
\hline Dark-brown sandstone ..... & 455 \\
\hline
\end{tabular}


Record of artesian-zell boring at IIolyole-Continued.

\begin{tabular}{|c|c|}
\hline Kind of rock. & Feet. \\
\hline 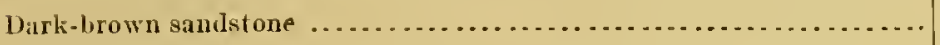 & 460 \\
\hline 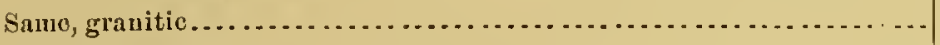 & 480 \\
\hline Forruginous marl . . . . . . . . . . . . . . . . . . . . . . . . . . . . . . . . . . & 490 \\
\hline 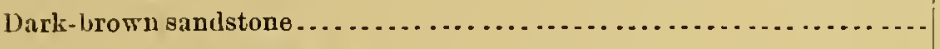 & 500 \\
\hline 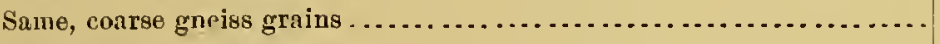 & 530 \\
\hline 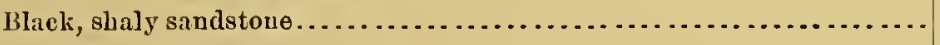 & 565 \\
\hline Dark-gray, shaly sandstone. . . . . . . . . . . . . . . . . . . . . . . . . & 570 \\
\hline 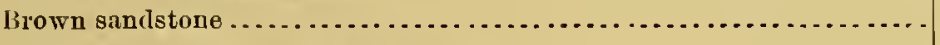 & 590 \\
\hline 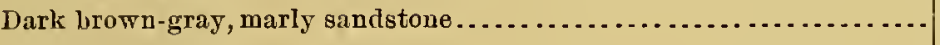 & 615 \\
\hline 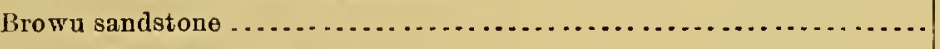 & 645 \\
\hline 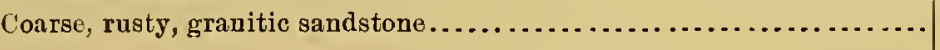 & 685 \\
\hline
\end{tabular}

WELL AT NORTHAMPTON.

Northampton, at Belding's silk mill, south of the railroad station. Commenced in 1885. Depth, 3,700 feet; mouth of well, 125 feet above sea level. In New Red sandstone. Samples furnished by the borers of the well and deposited in the Amherst College collection.

Record of artesian-well boring at Northampton.

[Abloreviations: q, quartz; f, feldspar; m, muscovite; b, biotite; g, garuet.]

\begin{tabular}{|c|c|c|}
\hline Kind of rock. & $\begin{array}{c}\text { A rerage } \\
\text { grain, in } \\
\text { millimeters. }\end{array}$ & Feet. \\
\hline Sand ......... & & 0 \\
\hline 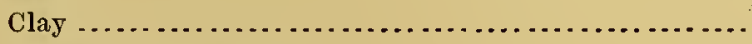 & & 140 \\
\hline Red sand (probably till) $\ldots \ldots \ldots \ldots \ldots$ & $\cdot 1$ & 150 \\
\hline Red sandstone, borings $\ldots \ldots \ldots \ldots \ldots$ & . . & 535 \\
\hline 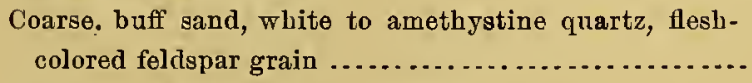 & $1 \frac{1}{2}$ & 682 \\
\hline Similar, but finer and more rounded grains....... & $\frac{1}{2}$ & 692 \\
\hline Same....... & $\frac{1}{3}$ to $1 \frac{1}{2}$ & 710 \\
\hline Same; few scales muscovite and hornblende ........... & $\frac{1}{2}$ to $1 \frac{1}{2}$ & 730 \\
\hline 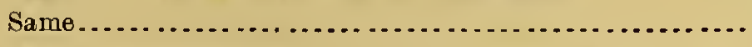 & $\frac{1}{2}$ to $1 \frac{1}{2}$ & 750 \\
\hline $\begin{array}{l}\text { Same; many grains deep red-brown from rust covering, } \\
\text { whicb has been usually worn off by the attrition of the } \\
\text { drill } \ldots \ldots \ldots \ldots \ldots \ldots \ldots \ldots \ldots \ldots \ldots \ldots \ldots \ldots \ldots \ldots \ldots \ldots \ldots \ldots \ldots\end{array}$ & $\frac{1}{2}$ to $1 \frac{1}{3}$ & 780 \\
\hline 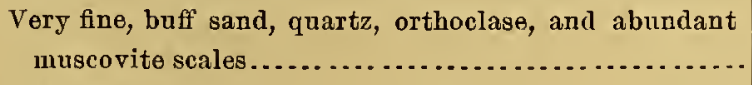 & to $1 \frac{1}{3}$ & 910 \\
\hline Like $730 \ldots \ldots \ldots \ldots \ldots \ldots \ldots \ldots$ & $\cdots$ & 930 \\
\hline 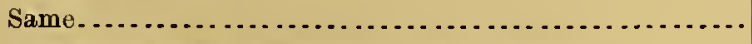 & & 950 \\
\hline Buff sands, quartz, feldspar, little muscovite........... & $\frac{1}{2}$ & 970 \\
\hline
\end{tabular}

MON $\mathrm{XX1X}-25$ 
Record of artesian-well boring at Northampton-Continued. [Abbreviations: $q$, quartz; f, feldspar; $m$, muscovite; b, biotite; g, garnet.]

\begin{tabular}{|c|c|c|}
\hline Kind of rork. & $\begin{array}{c}\text { Arerage } \\
\text { grain, in } \\
\text { millimeters. }\end{array}$ & Feet. \\
\hline Buff sands, quartz, feldspar, little muscovite........... & 1 & 990 \\
\hline 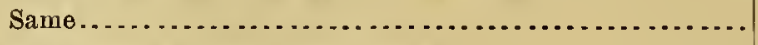 & 1 & 1,010 \\
\hline 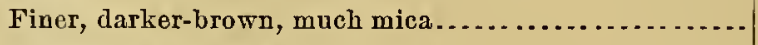 & $\frac{1}{4}$ & 1,030 \\
\hline Coarser, light-buff, granitic, q.f.m................. & $1 \frac{1}{2}$ to 2 & 1,050 \\
\hline 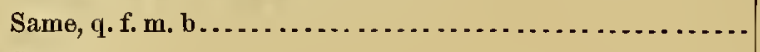 & $1 \frac{1}{2}$ to 2 & 1,070 \\
\hline 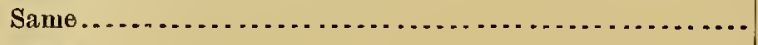 & $1 \frac{1}{2}$ to 2 & 1,090 \\
\hline 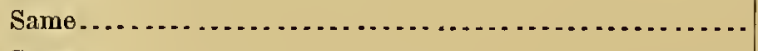 & $\frac{1}{2}$ to $1 \frac{\pi}{2}$ & $1, \mathbf{1 1 0}$ \\
\hline 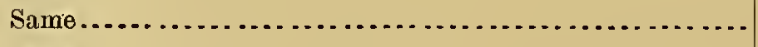 & $\frac{1}{2}$ to $1 \frac{1}{2}$ & 1,130 \\
\hline 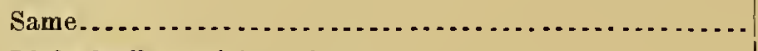 & $\frac{1}{2}$ to $1 \frac{1}{2}$ & 1,150 \\
\hline 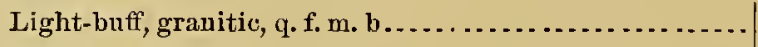 & 1 & 1,170 \\
\hline 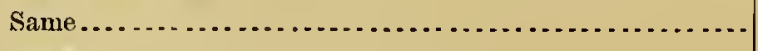 & 1 & 1,190 \\
\hline 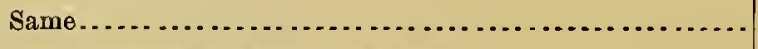 & 1 & 1,210 \\
\hline 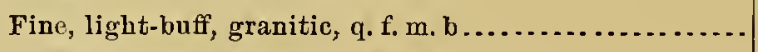 & $\frac{1}{2}$ & 1,230 \\
\hline Fine, light-buff, granitic, q.f.m. b. ; coal............. & $\frac{1}{2}$ & 1,250 \\
\hline 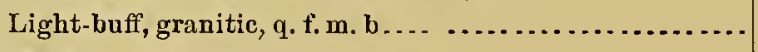 & 1 & 1,270 \\
\hline 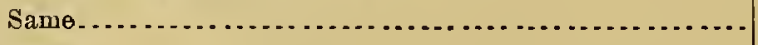 & $\frac{1}{2}$ & 1,310 \\
\hline 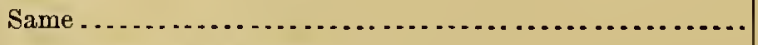 & to 1 & 1,330 \\
\hline Fiue, light-buff, granitic, q.f. m.b................. & $\frac{1}{2}$ & 1,350 \\
\hline 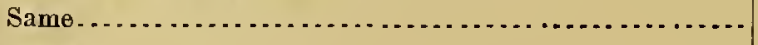 & $\frac{1}{2}$ to 2 & 1,370 \\
\hline Same. . . . . . . . . & $\frac{1}{2}$ to 2 & 1,390 \\
\hline Same. . . . ......... & $\frac{7}{2}$ to 1 & 1,420 \\
\hline 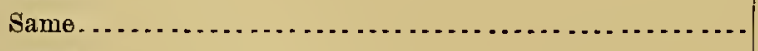 & $\frac{1}{2}$ to 1 & 1,440 \\
\hline 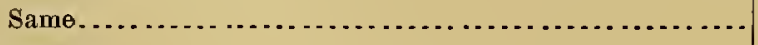 & $\frac{1}{2}$ to 2 & 1,460 \\
\hline 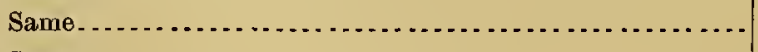 & $\frac{1}{2}$ to 2 & 1,490 \\
\hline 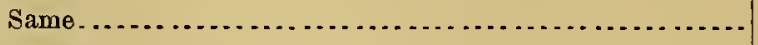 & $\frac{1}{2}$ to 2 & 1,510 \\
\hline 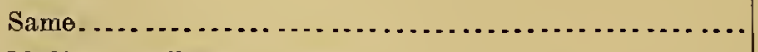 & $\frac{1}{2}$ to 2 & 1,530 \\
\hline 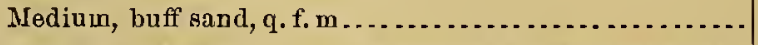 & $\frac{1}{2}$ to 1 & $\mathbf{1}, 550$ \\
\hline Medium, buff sand, ๆ. f. m.; few worn grains black slate.. & $\frac{1}{2}$ to 1 & $\mathbf{1}, 5 \mathbf{7 0}$ \\
\hline 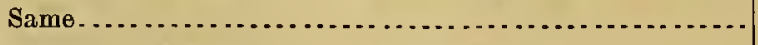 & $\frac{1}{2}$ to 1 & 1,590 \\
\hline Medium, buff sand, q. f. m.; white slate................. & $\frac{1}{2}$ to 1 & 1,610 \\
\hline 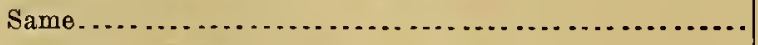 & $\frac{1}{2}$ to 1 & 1,630 \\
\hline Medium, buff saud, q. f. m.; black slate................. & $\frac{1}{2}$ to 1 & $\mathbf{1}, 650$ \\
\hline 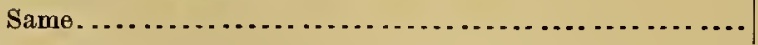 & $\frac{1}{2}$ to 1 & $\mathbf{1}, 670$ \\
\hline 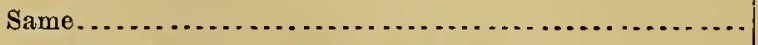 & $\frac{1}{2}$ to 1 & 1,690 \\
\hline Coarse, buff sand, q. f.m.; black slate................ & 1 to 3 & $\mathbf{1}, 695$ \\
\hline Medium, buff sand, q. f. m. ; garnet, slate.............. & $\frac{1}{2}$ to 1 & 1,710 \\
\hline 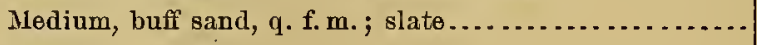 & $\frac{1}{2}$ to 1 & 1,730 \\
\hline Medium, buff saud, q. f. m. b. ; slate.................. & $\frac{1}{2}$ to 1 & 1,750 \\
\hline 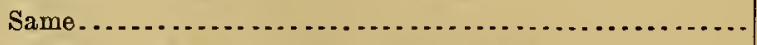 & $\frac{1}{2}$ to 1 & 1,770 \\
\hline Medium, buff sand, q.f.m. b. ; slate trace.............. & $\frac{1}{2}$ to 1 & 1,790 \\
\hline 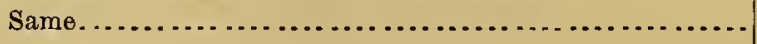 & $\frac{1}{2}$ to 1 & 1,810 \\
\hline
\end{tabular}


Resord of artesian-well boring at Northampton-Continued.

[Abbreviations: q, quartz; f, feldspar; m, muscovite; b, biotite ; g, garnet.]

\begin{tabular}{|c|c|c|}
\hline Kind of rock. & $\begin{array}{c}\text { Average } \\
\text { grain, in } \\
\text { millimeters. }\end{array}$ & Feet. \\
\hline Merlium, buff sand, q. f. m. b. ; garnet.................. & $\frac{1}{2}$ to 1 & 1,830 \\
\hline Mediuru, buff sand, q. f. m. b. ; garnet, slate trace......... & $\frac{1}{2}$ to 1 & 1,850 \\
\hline Same...................... & $\frac{1}{2}$ to 1 & 1,870 \\
\hline Same. ..................... & $\frac{1}{2}$ to 1 & 1,900 \\
\hline Medium, buff sand, q. f. m. b. ; slate trace............... & $\frac{7}{2}$ to 1 & 1,920 \\
\hline Same.................. & $\frac{1}{2}$ to 2 & 1,940 \\
\hline Same.................... & $\frac{1}{2}$ to 2 & 1,960 \\
\hline 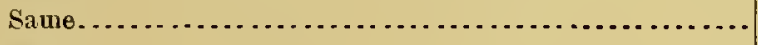 & $\frac{1}{2}$ to 2 & 1,980 \\
\hline Same..................... & $\frac{1}{2}$ to 2 & 2,020 \\
\hline 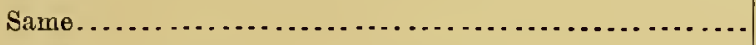 & $\frac{1}{2}$ to 2 & 2,030 \\
\hline 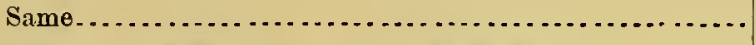 & $\frac{7}{2}$ to 1 & 2,040 \\
\hline Medium, louff sand, q. f. m. b.; magnetite.............. & $\frac{7}{2}$ to 1 & 2,060 \\
\hline Medium, buff sand, q. f.m. b.; slate trace................ & $\frac{1}{2}$ to 1 & 2,100 \\
\hline Same...................... & $\frac{7}{2}$ to 1 & 2,120 \\
\hline Same. . . . . . . . . . . . . . . & $\frac{1}{2}$ to 1 & 2,130 \\
\hline Same................... & $\frac{1}{2}$ to 1 & 2,140 \\
\hline 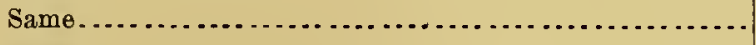 & $\frac{7}{2}$ to 1 & 2,150 \\
\hline 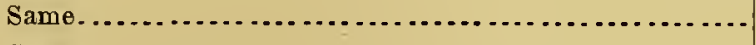 & $\frac{1}{2}$ to 1 & 2,160 \\
\hline 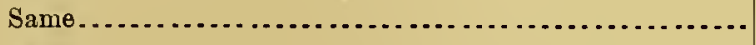 & $\frac{1}{2}$ to 1 & 2,170 \\
\hline 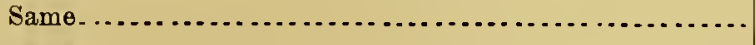 & $\frac{3}{2}$ to 1 & 2,180 \\
\hline 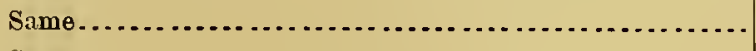 & $\frac{7}{2}$ to 1 & 2,190 \\
\hline 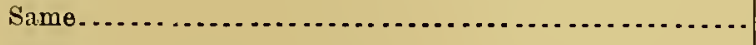 & $\frac{1}{2}$ to 1 & 2,200 \\
\hline 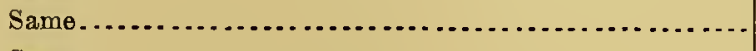 & $\frac{1}{2}$ to 1 & 2,210 \\
\hline 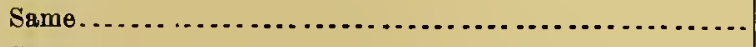 & $\frac{1}{2}$ to 1 & 2,220 \\
\hline 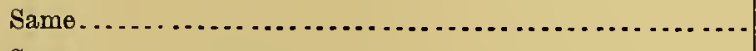 & $\frac{1}{2}$ to 1 & 2,230 \\
\hline 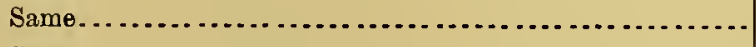 & $\frac{1}{2}$ to 1 & 2,240 \\
\hline 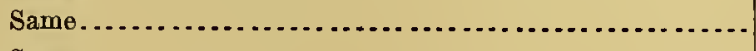 & $\frac{1}{2}$ to 1 & 2,250 \\
\hline 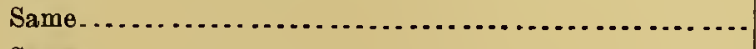 & $\frac{1}{2}$ to 1 & 2,260 \\
\hline Same. . . . . . . . . . . . & $\frac{1}{2}$ to 1 & 2,270 \\
\hline Same.................. & $\frac{1}{2}$ to 1 & 2,280 \\
\hline Same.................. & $\frac{1}{2}$ to 1 & 2,290 \\
\hline Same..................... & $\frac{7}{3}$ to 1 & 2,300 \\
\hline Same............. & I to 1 & 2,310 \\
\hline Same.............. & $\frac{1}{2}$ to 1 & 2,320 \\
\hline Same.............. & $\frac{1}{2}$ to 1 & 2,230 \\
\hline Same . . . . . . . & $\frac{7}{3}$ to 1 & 2,340 \\
\hline Medium, buff sand, q. f. m . . . . . . . . . . . . . . . & 学 to 1 & 2,350 \\
\hline Same....................... & to 1 & 2,360 \\
\hline Same...................... & $\frac{1}{2}$ to 1 & 2,370 \\
\hline Coarse, brown sand, q. f. m........... & 1 to 5 & 2,380 \\
\hline 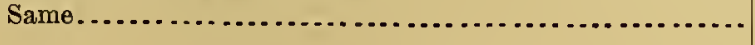 & 1 to 3 & 2,400 \\
\hline
\end{tabular}


Record of artesian-well boring at Northampton-Continned.

[Abbreviations: q, quartz; f, feldspar ; m, muscovite; b, biotite; g, garnet.]

\begin{tabular}{|c|c|c|}
\hline Kind of rock. & $\mid \begin{array}{c}\text { A rerage } \\
\text { grain, in } \\
\text { millimeters. }\end{array}$ & Feet. \\
\hline Coarse, brown sand, q. f. m.......... & 1 to 2 & 2,410 \\
\hline Same...................... & 1 to 3 & 2,420 \\
\hline 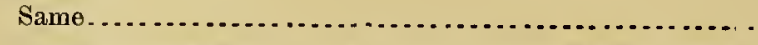 & 1 to 3 & 2,430 \\
\hline $\begin{array}{l}\text { Coarse, brown sand, q. f. m., } 1 \text { grain } 10^{\mathrm{mm}} \text {; second piece, } \\
\text { deep-red, fine, micaceous sandstone.................... }\end{array}$ & 1 to 3 & 2,440 \\
\hline Coarse, brown sand, q. f. m...... . & 1 to 3 & 2,450 \\
\hline Medium, brown sand, q. f. m............. & 1 to 2 & 2,460 \\
\hline Same $\ldots \ldots \ldots \ldots \ldots$ & 1 to 2 & 2,470 \\
\hline Fine, buff sand, q. f. m............ & $\frac{1}{2}$ to 1 & 2,480 \\
\hline Medium, red sand, q. f. m............. & 1 to 2 & 2,490 \\
\hline Medium, reddish sand, q.f. m.......... & 1 to 2 & 2,500 \\
\hline Same............. & 1 to 2 & 2,510 \\
\hline Same............. & 1 to 2 & 2,520 \\
\hline Same.................... & 1 to 2 & 2,530 \\
\hline Same................... & 1 to 2 & 2,540 \\
\hline Same $\ldots \ldots \ldots \ldots \ldots \ldots \ldots \ldots \ldots$ & 1 to 2 & 2,550 \\
\hline Medium, buff sand, q. f. m............... & 1 to 2 & 2,560 \\
\hline 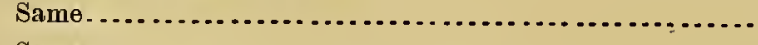 & 1 to 2 & 2,570 \\
\hline 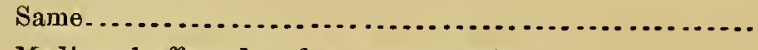 & 1 to 2 & 2,580 \\
\hline Medium, buff sand, q.f. m. ; more rusty ............... & ............. & ........ \\
\hline Medium, brown sand, q. f. m. ; more rusty ............... & 1 to 2 & 2,754 \\
\hline Fine, brown sand, q. f. m. ; more rusty .................... & $\frac{1}{2}$ to 1 & 2,770 \\
\hline Same.............................. & $\frac{1}{2}$ to 1 & 2,774 \\
\hline Medium, buff sand, q. f. m...... . & 1 to 2 & 2,826 \\
\hline Medium, buff sand, q.f. m................ & 1 to 2 & 2,851 \\
\hline Same........................................... & 1 to 2 & 2,872 \\
\hline Same..................... & 1 to 2 & 2,901 \\
\hline Fiue, brown sand, q. f. m............... & $\frac{1}{2}$ to 1 & 2,933 \\
\hline Same................................... & $\frac{1}{2}$ to 1 & 3,024 \\
\hline Same....... & …- $\frac{1}{2}$ & 3,100 \\
\hline Same........................ & $\frac{1}{4}$ to $\frac{7}{2}$ & 3,260 \\
\hline 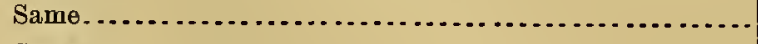 & $\frac{1}{4}$ to $\frac{7}{2}$ & 3,250 \\
\hline $\operatorname{Sam} \theta, \ldots \ldots \ldots \ldots \ldots \ldots \ldots$ & $\frac{1}{4}$ to $\frac{1}{2}$ & 3,300 \\
\hline Same................................. & $\frac{1}{4}$ to $\frac{1}{3}$ & 3,350 \\
\hline Medium, brown sand, q. f. m......... & 1 to $2 \frac{1}{2}$ & 3,500 \\
\hline Same.$\ldots \ldots \ldots \ldots \ldots$ & 1 to 2 & 3,525 \\
\hline Same & 1 to 2 & 3,536 \\
\hline Same $\ldots \ldots \ldots \ldots \ldots \ldots \ldots$ & 1 to 2 & 3,550 \\
\hline 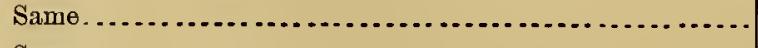 & 1 to 2 & 3,650 \\
\hline Same $\ldots \ldots \ldots \ldots \ldots \ldots \ldots \ldots$ & $\frac{1}{2}$ to 1 & 3,675 \\
\hline Same $\ldots \ldots \ldots \ldots \ldots \ldots \ldots \ldots \ldots \ldots \ldots \ldots$ & $\frac{1}{2}$ to 1 & 3,700 \\
\hline
\end{tabular}


WELL ON WESTPIELD LITTLE RIVER SOUTH OF WESTFIELD.

Artesian well at Crane Brothers' paper mill, on Westfield Little River, south of Westfield; bored by Daniel Dull, New York. Sunk 1,110 feet in conglomerate; unsuccessful and now closed up. A soft, black, pulverulent layer reported.

\section{PSEUDOMORPHS OF CALCITE AND DOLOMTE AFTER HOPPER- SHAPED CUBES OF SAIT.}

It has been reported for many years that chiastolites occurred in the sandstone in West Springfield. but I can not find that anything has been published upon the subject.

Specimens containing small white crosses of about the size of ordinary chiastolites and having some resemblance to them were brought to me some years ago by a student, who informed me that they were discovered by Mr. B. Hosford, of Springfield. These specimens were lost in the fire which destroyed the Shepard collection. Later, through the kindness of Mr. J. S. Diller, I received another specimen with permission to sacrifice it, and $I$ had several slides cut from it. It shows white squares and triangles on a black ground of fine-grained, shaly, bituminous sandstone, but this gronud is not marked off from the rest of the surface of the sandstone by any square or round boundary representing the cross-section of a prismatic crystal in which the white lines should be diagonal, so that the resemblance to chiastolite is only superficial. These slides are fignred in the Mineralogical Lexicon ${ }^{1}$ of the three counties.

On touching the white areas with acid an abundant effervescence occurred, and under the microscope they proved to be made up of calcite, quite white and coarsely granular down the central portion of the bands and very finely granular and gathered in minute rounded concretions just visible with the lens on either side of these central bands, the concretions grouped with more or less of the dark material of the sandstone intervening, so as to give the whole a brownish shade. The calcite was not confined to these bands, but impregnated large portions of the sandstone, so that, when polished, parts where there was no calcite remained dull and other patches took a fine polish. It is plain that cubical crystals of salt

2 Bull. U. S. Geol Survey No. 126, 1895, under "Salt." 
with excavated hopper-shaped faces had been embedded in the mud, dissolved out, and their place taken by the calcite, which has largely impregnated the sandstone, but which shows the white color only where it occupied the cavities of the salt hoppers.

The locality as given me by Mr. Diller is along the south bank of the Westfield River, in West Springfield, near the water's edge, and just below the large dam some distance above (west of) West Springfield village.

Later a specimen was found at Holyoke, near the west end of the railroad bridge, and is now in the Smith College collection. It is larger and much more delicate than the Westfield specimens. It is figured and described in detail in the Mineral Lexicon. ${ }^{1}$ The piece must have come from a very short distance northwest, and I lave observed single hopper-shaped casts in the shale at the cutting within the city of Holyoke, and similar forms on the shale at Ashley's pond, farther west, and at many other localities in the shale. In 1895 a large share of the finest specimens collected by Mr. Hosford came into iny possession-the best piece of all through the kindness of his daughter. This is a finely ice-polished slab of black shale, covered with small white figures, three or four to the square inch, in great variety, formed by the various cross-sections of single and aggregated cubes, whose faces were excavated into hopper shapes to various depths. Three-rayed, fourrayed, and six-rayed forms were most common. The center of each ray, marking the trace of the six planes which connect the cube edges, is generally very dark, so that it stands out against the white calcite, and where the faces are only slightly excavated, so that the calcite is now nearly a square, the resemblance to a chiastolite is striking. This darker band is calcite colored by petroleum or coaly matter, and in some cases it is a quite wide band of pure asphaltum.

It would seem that the solution of the salt and its replacement by white calcite progressed slowly from the outside at a low temperature. At the last the central band of salt was removed and calcite took its place when somewhat more elevated temperature prevailed, so that bituminous matters were distilled into the empty spaces along with the last calcite. In other specimens cubes are found with only slightly excavated faces, which are made of quite coarsely crystalline calcite, irregularly colored by bitumen. Other pieces have slickensided faces, with surfaces of fine-fibrous graphite 
(which is remarkable, as there is here no other trace of marked heat action), together with veins of coarse-fibrous calcite, grains of galena, and filuns of gyjsum. Other cubes are flat-faced, but a little elongate, and made of fine-grained ealcite. At times the rays are broadly bordered by delicate feathery growtls of white limestone, which shows a fine, concretionary, almost oolitic strueture under the microseope.

The thin-bedded rusty sandstone from the island at Turners Falls, which contains the ferruginous concretions, contains also remarkable salt psendomorphs-skeleton cubes with each bar nearly an inch long. The interspaces are now filled with limonite, which was doubtless at first an iron carbonate.

THE USE OF THE TRLASIC SANDSTONE AS A BUILDING STONE.

The Sugar Loaf arkose is somewhat used for rude masonry, such as embankments, walls, bridge piers, ete. The large quarry on the northwest shoulder of Mount Tom furnished the stone for the piers of the railroad bridge over the Connecticut River at Northampton, and had been long worked for similar purposes. The rock is too coarse for architectural use; if it were not its light color would make it very valuable.

The Longmeadow sandstone, under the name "brownstone," has been for a long time in high repute as a building stone of the greatest value, and it has been exported to great distances and employed upon the most expensive buildings. The report Mineral Resonrces of the United States for $1890^{1}$ states that the sandstone produced in Massachnsetts during that year was valued at $\$ 649,097$, and of this amount $\$ 563,179$ was furnisled by Hampden County, and came from the quarries extending south from Sixteen Acres, in Springfield, to East Longmeadow.

'The following, copied from an article in the Springfield Republican of May $9, \mathbf{1 8 8 4}$, and verified by me in all important particulars, gives a good account of the industry at that date:

The Norcross Brothers are the largest shippers of stone from East Long. meadow, having last year loaded 115,000 cubic feet of brownstone for bulding purposes on about 900 freight cars. In addition to this amount, 35,000 cubic feet was qnarried during the year, but kept in the yard to furnish winter work for the stonecutters. Two quarries, located within a mile of the East Longmearlow depot, the Saulsbury and Kibbe, furuish all but a small part of the product and give 
employment to about 200 men for a greater portion of the year. There is also a third, yielding a finer-grained, harder stone, which occurs, however, in a thinner stratum and at greater depths below the soil, so that it is now used ouly on special orders. All the stone is brownish-red in color, cloes not flake on exposure to the weather, is free from stratification, and eveuly hard throughout-that from the Kibbe having a somewhat richer red bue than the others. The quarries are located on nearly flat ground, and the sandstone croppings are over 10 feet thick, with" a dip toward the southeast of about 10 degrees. As the line of the dip is followed the stone becomes finer in texture and harder, aud the stratum also thickens, until, when covered by 20 feet of soil, it forms a layer from 20 to 30 feet through Above the stone is found a mass of slaty brownstone, and below it is the same material, although explorations indicate the existence of another stratum of good rock at a small distance below the first. But little powder is used in quarrying, most of the work being done with picks and wedges. Blocks weighing in the rough from 5 to 6 tons are frequently taken ont and sometimes shipped uncut, and one block of 12 tons weight has been snccessfully quarried and raised. Water canses much trouble and expense, and in the Saulsbury workings a steam pump, throwing 60 gallons a minute, is employed for an average of twelve hours a day to keep down the flow from springs and surface drainage. The quarry work lasts from Aprll to December, and during the winter months a force of laborers is employed in stripping the rock and removing the soil and waste to old workings. About half of the stone quarried is dressed before shipment.

The firm is now using Longmeadow stone either iu solid walls or as trimmings on the following contracts: The Union Theological Seminary, a four-story 200 by 125 foot building, on Park avenue, New York, which will cost $\$ 300,000$ when finished in May: the St. James Episcopal Church, to cost $\$ 125,000$, and cover a space of 120 by 72 feet on Madison avenue, New York; the Jefferson Physical Laboratory for Harvard College, a four-story building, 70 by 212 feet, with the peculiarity that in portions of it no iron, even in the form of nails, will be used on account of pos. sible magnetic action; for the University of Vermont, at Burlington, a library building of Kibbe saudstone, to cost $\$ 100,000$; on Eighth street, St. Louis, Missouri, an eight-story 64 by 130 foot building, to cost $\$ 225,000$, for the use of the Turuer Real Estate and Building Association; at Lawrenceville, New Jersey, eight bullings, to cost $\$ 325,000$, for the Lawrenceville Academy. The Norcross Brothers quarry three shades of stone, the trade names by which they are kuown being "Maynard," a bright-red stone; "Kibbe," a dark-red; and "Worcester," a brown.

There are a number of Springfield men interested in getting ont stone for buildings, and the East Lougmeadow quarry of James \& Marra, of this city, lies near the Norcross Brothers works, and the stone obtained from it much resembles the Kibbe rock in quality, although of a slightly lighter color. The quarry was first worked about sixty years ago by a man named Sanlsbury, but only small amounts of stone were taken out until it passed into the hands of Nathaniel Billings In 1882 the present owners bought the property of him, and have since added to 
it, nutil they now own 174 acres of goor stone land and two morr fruarres, both of which hive been opened, but are now nuworked. In the Billings workings the rock was 20 feet thick where tirst quarried, bnt by following its dip of about 10 degrees to the sontheast the owners tind it increased to 40 feet of unstratified and little seamed stone. Abont 20 feet of earth cover the layer of stone at present worled, and below it is fonnd a deposit of soft, shaly rock. Water is a troublesome feature of this quarry, and a steam jump is kept at work much of the time. During nine months 85 men are employed aronud the works, 10 of whom are stonecutters; the same firm keeps 25 cutters at work in the Franklin street yard in Springfield. About 100,000 cubic feet of rock was shippen from the quarry last year, and nearly halt of this amonnt was dressed before it was sent away. The largest contracts for stone either completed within a year or now being finished are: All order for 20,000 feet for Judge Tree's louse in Chicago, Illinois; for the Union League Clubhouse, Ohicago, 35,000 feet, and for the Second Congregational Chureh, Holyoke, 35,000 feet.

The Spriugfield quarry, located within the city limits, 4 miles ont on the Hanpulen road, owned by W. \& E. W. Pease, was first worked in 1882, and lies on a tract of 30 acres, bought from John Rockford. The leclge first quarried was 20 feet thick at the croppings and of fine quality browustone, but at a few feet below the surface a large spring was struck, which made operations too expensive. In the second opening two ledges, each 12 and 14 feet thick and separated by a layer of shaly stone, are worked, and 20 feet of sand is at present removed to get at the deposit, which dips toward the southeast at an angle of about 30 degrees. Water has not yet proved troublesome. About 50 men are employed, and last year nearly 100,000 feet of stoue was shipped over the New England Road, mainly to the eastern part of this State. The Palmer depot and the new Taftsville mill are conspicuous examples of buildings trimmed with stone from this quarry.

The Carlisle Stone Company owns a brownstone quarry not far from Sixteen Acres, and last year employed 26 men and shipped to Boston by way of the Indian Orchard depot 25,000 cnbic feet of rock, of which only a small proportion was dressed. A tract of 60 acres, including the present quarry, which was first worked four years ago, was bought by the company in 1881, and the stone obtained since that time has been of fine quality, although of a lighter red color than Longmeadow stone. The stratum is 18 feet thick, dips about 15 degees to the east, and is covereil by 12 feet of sand and 2 feet of hardpan. No shaly rock is found, but flinty bowlders occur, and water causes considerable trouble in the spring months.

M. A. Glymn works a quarry at East Longmeadow, abont a mile north of the depot, and obtains a fine quality of brownstone, which he sells undressed to several New Eugland dealers. The Glynn quarry was opened ten or twelve years ago, but was worked only a little. It was bought, with 7 acres of land, by the present owner a year ago from the Enfield Shakers. The rock is covered by 5 feet of earth, without hardpan or shaly material, and is of uncertain thickness, having been worked only to a depth of $\mathbf{1 6}$ feet as jet. Water is not troublesome. Last year 8 quarrymen were employerl and 12,000 cubie feet of stone were sold. 
Mr. George P. Merrill ${ }^{1}$ gives the following data: Price per cubic foot, $\$ 1$ to $\$ 2$; cost of pointing, 10 to 15 cents; ax-hammering, 30 cents. An extra price is charged for blocks of more than 25 cubic feet. Strength of the sandstone per square inch, $8,945,8,812$.

The stone sells now (1893) for 50 to 70 cents per cubic foot delivered at the station, while the Berea stone sells for $\$ 1$ per foot delivered in Springfield.

\section{PALEONTOLOGY.}

In the following section I have given, by means of the synonymy, the history of opinion concerning each species known to me, and each locality where the species has been found.

I have not, however, given special attention to the foot-tracks, and present only the latest list of species prepared by Professor Hitchcock.

\section{PLANTS.}

\section{Halymenites shepardi E. Hitchcock.}

1833. Fucoides sp. E. Hitchcock. Geol. Mass., p. 233, pl. 13, figs. 38, 39 .

1835. Same.

1841. Fucoides shepardi E. Hitehcock. Geol. Mass., Final Rept., p. 455, fig. 95.

These forms occur so abondantly throughout the central areas of fine-grained sandstones and shales that I have often called these the fucoidal sandstones. The best locality, in addition to those mentioned below, is at the water shops in Springfield. I append Hitchcock's description, premising that branching is not so rare as it would indicate. Bands of the sandstone several feet thick are at times filled evenly full of these rods, and intervening bands are empty, as at the mouth of Fall River:

This relic varies in size from one-tenth of an inch to an inch in diameter. More commonly it runs through the rock in a direction correspouding to that of the laminre, in which case it is considerably flattened. Sometimes it passes obliquely throngh the layers, aud very commonly crosses them at right angles, in which last case it has a cylindrical form. It is rare to see a specimen of any considerable length that is not more or less curved, and I have never met with one that was branched at all. I have noticed specimeus a foot or more in length, and they may be much longer than this, since I have not met witk any large mass of rock containing them. The sandstone in which they are found is rather fine and quite soft and easily disintegrates. They occur near Hoyt's quarries, 1 mile west of the village of Deer- 
field, and also a few rods sonth of the county jail in Grcenfield, elose by the stage rond, and on the road to Bernardston, a wile north of the village of Greenfiedd.

The vegetable matter in these remains is wholly replaced by sandstone. By breaking the specimens transversely a curious structure is revealed. It may be described by saying that the eylinder is made np of convex layers of sandstone piled upon one another; and I observe that in the same rock all the specimens lave the convex sides of these layers in the same direction, so that on one side of the rock you will see numerons button-like protuberances and on the other side corresponding concavities. (No. 258.) But I do not know which side is nppermost in the rock, in situ. ${ }^{1}$

I allow the above to stand, although the forms now seem to me to be tubular ferruginous concretions, the result of the circulation of iron-bearing solutions in the sands. After forming the concretions the solutions have gone on to cement the intervening sand into a red sandstone.

Of the other figures presented in the Geology of Massachusetts in 1841 as plants, fig. 89 , p. 451 ; fig. 91 , p. 453 ; figs. 92 and 93, p. 454 ; and figs. 3 and 5 on pl. 28 (cited as 29 in the text) are dubious impressions, which are very common in the sandstones. Some may have been caused by fucoids; others, as fig. 3 , by the dragging of the roots or branches of floating trees rising and sinking with the waves. Fig. 94, p. 454, represents ferruginous concretions; fig. 1, pl. 28, is a track. For fig. 92, the name Fucoides connecticutensis is suggested on p. 453 .

\section{Clathropteris platyphyla Brongn.}

1841. "Peculiar vegetable relic," like a fern. E. Hitchcock, Geol. Mass., p. 452, fig. 90. Teste, E. Hitcheock, jr.

1854. C. rectiusculus. E. Hitchcock, jr. Description of a new species of Clathropteris, discovered in the Connecticut Valley sandstone. Am. Jour. Sci., 2d series, $\mathrm{XX}$, p. 22 ; figured in the text.

1858. C. rectiusculus. E. Hitcheock. Ichnology of Massachusetts. P]. V, fig. 1; Pl. VII, tig. 1.

1890. C. platyphylla Brongn. J. C. Newberry, Fossil Fishes and Fossil Plants of the Triassic Rocks of New Jersey and the Connecticut Valley: Mon. U. S. Geol. Survey, Vol. XIV, p. 94, Pl. XXII.

Locality: Bassett's quarry, on the west face of Mount Tom, in Easthampton, just below the Holyoke trap sheet, in coarse, buff arkose. The type specimen is in the museum of Williston Seminary, at Easthampton. A large series in the Amherst College cabinet, where are also specimens from the quarry of Roswell Field, in Gill; also from the banks of the

I E. Hiteheock, Geol. Mass., 1841, p. 456. 
Connecticut in Montague, 2 miles southwest of the latter place, as noticed by $\mathrm{E}$. Hitchcock in 1841 . The latter localities are a coarse, gray arkose. I am convinced, from an inspection of European specimens in the museum at Munich, of the identity of this species with C. platyphylla.

Dr. Newberry cites, also, Westfield, Massachusetts, Durham, Connecticut, and Newark and Milford, in New Jersey.

Macrotaniopteris magnifolia Schimper.

Small leaves for this species, about 3 inches long, and a little more cordate than the figures. In black shale; Turners Falls.

\section{MaCRot}

1843. Tceniopteris vitata. E. Hitchcock. Trans. Assn. Am. Geol.. Vol. I, p. 294.

From a bowlder of dark-gray sandstone on Mount Holyoke. The impression is nearly 2 feet long. I can not find the specimen in the Amherst collection. Similar large leaves occur in the north part of Montague, on the road going down to the bridge to Greenfield.

\section{Astrocarpus virginiensis Fontaine.}

A very poorly preserverl specimen of a large frond with strong rachis and long, straight pinnæe. On buff arkose, like that under Mount Tom, containing Clathropteris. From the collection of President Hitcheock, who said it came from the valley, but could not give the exact locality.

\section{Pachyphylum simile Newberry.}

1857. Walchia variabilis E. Emmons. American Geology, p. 108, fig. 76.

1890. Pachyphyllum simile Newberry. Fossil Fishes and Fossil Plants of the Triassic, p. 88, Pl. XXII, fig. 2.

Includes the larger and longer and sharper-leaved twigs of coniferous plants.

Locality: Tưrners Falls, in black shale.

\section{Pachyphyllum brevifolium Emmons sp.}

1823. Unknown relic. E. Hitchcock. Geology of Connecticut River. Am. Jour. Sci., 1st series, Vol. VI, p. 80, pl. 9, fig. 5 .

1832. Lycopodites sillimanni De la Beche. Manual of Geology, 2d ed., p. 419.

1841. Possibly a Voltzia. E. Hitcheock. Pl. 28 (eited 29), fig. 2.

1843. Possibly a voltzia. E. Hitchcock. Traus. Ass. Am. Geol., Vol. I, p. 294.

1857. Walchia brevifolia E. Emmons. American Geology, p. 108, figs. 74, 75. 
18is. Cone and twig. L. Hiteheock. Ichnology of Massachusetts, P'l. VII, fig. 2. 1890. Pachyphyllum hrevifolium Newberry. Fossil Fishes and Fossil Plants of the 'Triussic, Pl. XXII, figs. 3-3c.

The Is. sillimami is quoted above, from Hadley, Connnecticut, doubtless a mistake for Matssachusetts, and the plant was carried from here to Europe. It was described (1823) from the fish locality at Sunderland. It occurs at Turners Falls; and I have found it quite abundantly at the cut just sonth of the south line of Holyoke, below Holyoke dam, and at the adjacent cut on the railroad to Westfield; also in the northwest of Montague, where the road goes down the hill to Greenfield. Its small cypresslike twigs often spread over slabs 2 or 3 feet square. Its small cones, about an inch long, are figured in the last two works cited above.

\section{Schizoneura planicostata Rogers sp.}

1883. S. planieostata Fontaine. Older Mesozoic Flora of Virginia: Mon. U. S. Geol. Survey, Vol. VI, p. 14, Pl. I, fig. 1.

1890. S. planicostata, J. S. Newberry. Fossil Fishes and Fossil Plants of the Triassic, p. 87.

\section{Palisssya? sp.}

Many flattened fragments of branches or stalks of plants occur, especially in the arkose. These are transversely jointed, from shrinkage in the process of change to bituminous coal, and are faintly striated longitudinally. Larger trunks occur at times as cylinders of sandstone crossing the laminations of the sandstone, 12 to 20 inches in diameter.

President Hitchcock mentions stems of plants "converted into vesicular amygdaloid," and he figures a specimen from a bowlder in Amherst, which he evidently supposes came from the upper portion of the Greenfield trap sheet. ${ }^{2}$ Trunks of this kind are doubtfully referred to the above coniferous genus by Dr. Newberry. The specimen is a tapering, roughsurfaced rod, of rounded, cordate cross-section, 2 feet long, $2 \frac{1}{4}$ by $1 \frac{1}{4}$ inches at one end, and $1 \frac{3}{4}$ by 1 inch at the other.

The inclosing rock is a dark greenish-gray diabase, of the type of the freshest, medium-grained rock of the Deerfield bed.

The tube is made up of a slightly finer diabase, with steam cavities filled with delessite. There is no trace of tuff structure in the rock or in the slides of either portion. It is a case where a branch was enclosed in 
the liquid lava, burned, and the cavity immediately after filled with lava from above. I have collected such specimens at Kilauea. This rock came probably from near the sonth end of the Deerfield sheet, where the river crosses it, and where several amygdaloidal beds show that the sheet is nade up of a number of successive flows, one quickly following another.

\section{LOPERIA SIMPlex Newberry. ${ }^{1}$}

Professor Newberry has given this name to the plants whose stems appear commonly as simple cylinders about an inch across. They occur abundantly in Springfield, and were filled at one locality by a sand that differs from that which inclosed them by its freedom from mica scales and its pale-green color.

INSECTS.

Mormolucoides articulatus E. Hitchcock.

1858. M. articulatus E. Hitcheock. Ichuology of New England, pp. 7, 8, pl. 7, figs. 3, 4, with letter of Professor Dana.

1862. Palephemera medieva E. Hitchcock. Am. Jour. Sci., 2d series, Vol. XXXIII, p. 452.

1867. M. articulatus S. H. Scudder. Proc. Boston Soc. Nat. Hist., Vol. XI, p. 140; Greol. Mag., Vol. V, p. 218.

1871. M. articulatus A. Packard. Bull. Essex Inst., Vol. III, p. 1.

1886. $M$. articulatus S. H. Scudder. The Oldest Known Insect-Larva, from the Connecticut River Rocks. Mem. Bost. Soc. Nat. Hist., Vol, III, p. 431.

These remarkable forms were found in considerable numbers in the fine black shale at Turners Falls. A series of slabs containing each a great number of indviduals is preserved in the museum of Amlierst College. A full history and description of the species and abundant illustrations are given in the last article cited above.

Professor Dana first decided that the form was a neuropterous larva. Mr. Scudder and Professor Packard concluded that it was a coleopterous larva. In the last work Mr. Scudder returns to the first conclusion, that it is probably the larva of a sialidan neuropteron.

\section{FISHES.}

The monograph upon the fossil fishes of the Trias, ${ }^{2}$ by Dr. Newberry, should be consulted by anyone wishing to become acquainted with what

${ }^{1}$ Fossil Fishes and Fossil Plants of the Triassic: Mon. U. S. Geol. Survey, Vol. XIV, 1888, p. 93, Pl. XXV, figs. 1-3.

${ }^{2}$ Idem. 
is known concerning the fossil fishes of this region, and the numerous and accurate plates will enable him to determine the name and character of auy specimen found. Dr. Newberry says :

Fishes seem to be equally abundant in the Connecticut River basin. At Dur. ham, Connecticut, and Turners Falls, Massachusetts, they are particularly numerons and well preserved, while they have also been obtained at Mildletown, Sudluury, Chicopee, Amherst, and Hadleys Falls. ${ }^{1}$

In this list Sudbury must be changed to Sunderland, and Hadleys Falls to South Hadley Falls; and Amlerst nust be canceled, as only coarse arkose occurs in Amlerst, and no fishes have been found there.

At Turner's Falls, on the east bank of Fall River, a few rods above the bridge, at the southeast corner of the island, a few feet above the point where the dan abuts, and on the mainland directly north of this spot, in the line of strike at the foot of the bluffs and near the water's edge, many specimens can be obtained by digging in the black shales.

At Whitmores Ferry, Sunderland, in the north part of the town, in rocks exposed only at low water, numerous impressions may be found. Good specimens, carefully and skillfully developed, can be purchased of the owners of the mill adjacent. The slabs are left out during the winter and split by the frost, so as to expose the impressions of fishes to the best advantage.

Hadleys Falls, mentioned by Newberry, must, I think, be South Hadley Falls Canal, as fishes were found during the digging of this canal, and are now deposited in the musenm of Amherst College. The specimens from this locality do not seem to have been examined by Professor Newberry, as he does not cite any species from there. Those in the Amherst Musuem were by oversight not submitted to him.

Chicopee Falls has not afforded anything, so far as I know, for many years. The excavations made during the building of the dam and mills may have supplied the specimens which fell into the hands of Mr. Redfield, and furnished the material for the new species which Dr. Newberry has named for this torvn. There are no specimens from this place in the Amherst collection.

I have given below a list of the forms which have been identified in Massachusetts, and a word concerning the listory of the more interesting 
species. Excepting the rare form found at Chicopee, it will be seen that they are all referred to two ganoid genera, Ischypterus of Sir Phillip Egerton, which is characterized by the great strength of the fin rays, and Catopterus, distinguished by the posterior position of the dorsal fin.

Most of the specimens found belong to the two species Ischypterus tenuiceps and Catopterus gracilis.

Ischypterus ovatus. W. C. Redfield. Sunderland (Redfield), Turners Falls (Newberry).

Ischypterus marshii W. C. R. Sunderland (Redfield).

Ischypterus micropterus N. Sunderland.

Ischypterus tenuiceps Ag., sp. Turners Falls. Sunderland. Figured by E. Hitch cock. Geol. Mass., 1841, Vol. II, p. 459, PI. XXIX, figs. 1, 2.

Ischypterus macropterus W. C. R. Sunderland.

Ischypterns parvus W. O. R. Sunderland. Figured by Hitchcock. Geol. Mass., 1835, Atlas XIV, fig. 44, and 1841, Pl. XXIX, tig. 3.

Ischypterus latus J. H. R. Sunderland.

Ischypterus elegans. Sunderland.

Catopterus gracilis J. H. R. Sunderland.

Catopterus parvnlus W. C. R. Sunderland.

Acentrophorus chicopensis $\mathrm{N}$. Chicopee Falls.

\section{ICHNOLOGY.}

Since the publication of the Ichnology of Massachusetts and its Supplement, which President Hitchcock looked upon as closing the most original scientific investigation of his life, but little has been done to advance the knowledge of this the most peculiar contribution of the Connecticut Valley to geology, except what has been published by Prof. C. H. Hitchcock, who has kindly permitted me to print in this place a portion of an article upon the subject, containing his latest views upon the classification of these forms, from the proceedings of the Boston Society of Natural History, Vol. XXIV, 1889, p. 117. The article has been corrected by Professor Hitchcock (1892).

\section{Recent Progress in IChNologt.}

Ву С. Н. НІтснсоск.

The study of the Ichnozoa, or the animals that made the tracks, naturally divides itself into three parts: First, an examination of the ichnites themselves; second, the restorations of the animals from their bones, and third, comparisons of the 
impressions made by living animals with the Triassic imprints. I will at present speak only of the first.

Allow me to present, at the outset, a complete list of the Triassic Ichnozoa, arranged in convenient classes. It will not be needful to state the reasons why certain species of the Ichnology are iropped. The number, after several erasures, has increased frow 150 of the Ichnology to $170 .^{1}$

ICHNOZOA OI THE TRIAS.

Larsupial.

Cunichnoides marsupialoideus E. H.

Birds, Pachydactylous.

Brontozoum giganteum C. H. H. approximatum C. H. H. minusculum E. $\mathrm{H}$. divaricatum E. $\mathrm{H}$. tuberatum E. H. exsertum E. H. validum E. H. sillimanium E. H. Amblonyx gigantens (?) E. H.
Amblonyx lyellianus (\$) E. H. Grallator cursorius E. H. parallelus E. $\mathrm{H}$. tenuis E. H. gracilis C. H. H. cuneatus Barratt. formosus $\mathrm{E}$. $\mathrm{H}$.

Leptonyx lateralis E. H.

(?) Birds, Leptodactylous.

Argozoum redfieldianum (?) E. H. dispari-digitatum E. H.

Anomoepus major E. H. isodactylus C. H. H. intermedius $\mathrm{E}$. $\mathrm{H}$. curvatus E. H. minor E. $\mathrm{H}$. cuneatus C. H. H. minimus $\mathrm{E}$. $\mathrm{H}$. gracillimus C. H. H.

Gigantitherium caudatum E. H. minus E. $\mathrm{H}$.

Hyphepus fieldi E. H.

Corvipes lacertoideus E. H. Tarsodactylus expansus C. H. H. caudatus $\mathrm{E}$. $\mathrm{H}$.

Apatichnus crassus C. H. H. holyokensis C. H. H. circumagens $\mathrm{E}$. $\mathrm{H}$. bellus $\mathrm{E}$. $\mathrm{H}$.

Plesiornis quadrupes s. H. pilulatus E. H. rqualipes E. H. mirabilis E. H.
Argozoum pari-rligitatum E. H.

\section{Dinosaurs.}

Plesionnis giganteus C. H. H. n. sp. C. H. H.

Chimærichnus ingens C. H. H. barrattii E. H.

Anticheiropus hamatus E. H. pilulatus E. $\mathrm{H}$.

Platypterna deaniana E. H. tenuis $\mathrm{E}$. $\mathrm{H}$. delicatula E. H. recta $\mathbf{E}$. $\mathbf{H}$. varica $\mathrm{E} . \mathrm{H}$. digitigrada E. H.

Ornithopus gallinaceus E. H. gracilior E. H.

Tridentipes iugens E. H. elegans E. H. elegantior E. H. insignis $\mathrm{E}$. H. uncus (?) E. H.

Trihamus elegans E. H. magnus C. H. H.

${ }^{1}$ A catalogue of the Ichnozoa, as they were known in 1871, was prepared by me for Walling and. Gray's Official Atlas of Massachusetts.

MON XXIX-26 
Reptiles and Amphibia.

Polemarchus gigas E. H.

Plectropterna minitans E. H. gracilis E. H. angusta E. H. lineans $\mathbf{E} . \mathrm{H}$.

Triænopus leptodactylus E. H. Harpedactylus gracilis E. $\mathrm{H}$. gracilior E. H. crassus E. H. n. sp. C. H. H.

Xiphopeza triplex E. H.

Toxichnus inæqualis E. H. Orthodactylus floriferus E. H. iutrovergens E. H.

Otozoum moodii E. $\mathrm{H}$. caudatum C. H. H. parvum C. H. H.

Batrachoides nidificaus E. H. Palamopus clarki E. H.

Macropterna vulgaris E. H. divaricans $\mathrm{E}$. $\mathrm{H}$. gracilipes E. H.

Ancyropus heteroclitus E. H. Chelonoides incedens E. H. Helcura caudata E. H.

Grammepus erismatus E. H. Acanthichnus cursorius E. H. alternans $\mathrm{E} . \mathrm{H}$. alatus E. H. anguineus $\mathrm{E} . \mathrm{H}$. trilinearis E. $\mathrm{H}$. punctatus E. H. rectilinearis E. $\mathrm{H}$. divaricatus E. H. saltatorius $\mathrm{E} . \mathrm{H}$.

Bifurculipes laqueatus E. H. scolopendroideus $\mathrm{E} . \mathrm{H}$.

Orthodactylus linearis E. H. Antipus bifidus E. $\mathrm{H}$. flexiloquus E. H. Stenodactylus curvatus E. H. Arachnichnus dehiscens E. H. Isocampe strata E. H.

Typopus abnormis E. H. gracilis E. $\mathrm{H}$.

Anisichnus [C. H. H.] deweyanns E. H. gracilis E. H. gracilior E. H.

Comptichnus obesus E. H. n. sp. C. H. H.

Batrachians.

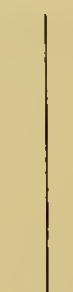

Cheirotheroides pilulatus E. H. Shepardia palmipes E. H.

Lagunculipes latns E. H.

Selenichnus falcatus E. H. breviusculus E. H.

Exocampe $\operatorname{arcta}$ E. H. ornata E. H. minima $\mathrm{E}, \mathrm{H}$.

Chelonians.

Helcura surgens E. H. anguinea $\mathrm{E}$. $\mathrm{H}$.

Amblypus dextratus E. H.

\section{Hexapod Arthropoda.}

Bifurculipes curvatus E. H. elachistotatus E. H.

Copeza triremis E. H.

propinquata $\mathbf{E}$. $\mathrm{H}$. punctata E. H. cruscularis E. H.

Hexapodichnus magnus E. H. horrens E. H.

Conopsoides larvalis E. H. curtus E. H.

Harpipes capillaris E. H. Sagittarius alternans E. H.

Inferior Arthropods, including larval forms and worms.

Harpagopus dubius E. H.

Stratipes latus E. H.

Hamipes didactylus E. H.

Saltator bipedatus E. H. caudatus E. H.

Halysichnus laqueatus E. H. tardigradus $\mathrm{E}$. $\mathrm{H}$.

Cunicularius retrahens E. H.
Spheripes larvalis E. H. magnus E. H.

Lunula obscura E. H.

Pterichnus centipes E. H.

Unisulcus marshi E. H. intermedius E. H. minutus E. H. magnus $\mathrm{C}$. H. H. 
Hollusea.

Bisulene undulatus E. II. Trisuleus Iaqqueatus li. H. Cochlea archimedea E. H.
Cocblichnus anguineus E. H. two n. sp.

Incerta sedis.

Ifoplichnus equıs E. H. polodrus E. H.

Nnigmichnus unultiformis E. H.
Grammichnus alpha E. H.

Ampelichuus sulcatus E. H.

Climacodichnus corrugatus E. H.

Of lower arthropods and worms there may be half a dozen new species and two new genera.

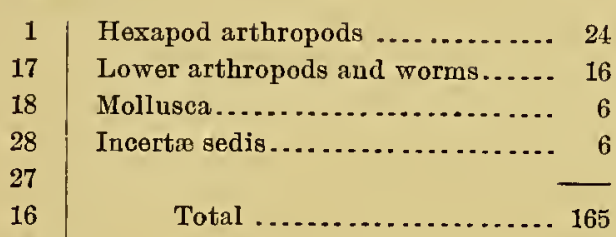

The class of Birds is still retained for convenience, although the bones found in the west seem to point to reptiles as most probably the animals thus designated. It is still a fact that such special reptilian characteristies as would be exhibited in walking are absent in the genera Brontozoum and Grallator, while those creatures called Dinosanrs are thus referred, either because of the marks of front feet, heels to the hind feet, or of tails. The bird group is also characterized by long legs, while most of the Dinosaurs had short legs, as indicated by their numerous steps. I do not change the reference of a group to Chelonians, though it is not satisfactory.

The Arthropoda are most likely to be referred to the lower classes; yet the presence of only 6 feet in the impressions leads us to speak of them as Hexapods. They may not be true insects, but Iarval forms, requiring further investigation before satisfactory references can be made out. Further statement of the reasons for referring various imprints to their lowly owners would involve a discussion of the third part of the subject, which can not be undertaken now. ${ }^{1}$

It will be proper to state a few facts about museums and localities before describing the new species.

\section{THE AMHERST MUSEUM.}

A few slabs have been added since 1865, and the arrangement of the rooms has not been changed since the printing of the catalogue. One slab shows a Brontozoum with two toes on one foot and three upon the other, as if the owner had lost a toe by

I Of modern authors, A. G. Nathorst has treated of the iuvertebrate tracks most fully in his Mémoire sur quelques traces d'animanx sans vertébré, etc., et de leir portée paléontologique, 1880. His bibliography notices several American anthors, but he has evidently not seen the Ichnology of Massachusetts. 
fighting or by accident. After the discovery of Apatichnus holyokensis, I was able to point out several illustrations of the new species at Amherst, which had been overlooked in the preparation of the Ichnology and Supplement.

MUSEUM AT SOUTH HADLEY.

The Mount Holyoke Seminary and College has taken great interest in Ichnology and possesses an admirable collection. Among the more important ones are the type specimens of Apatichnus holyokensis and of six or eight new species from Wethersfield Cove, besides Anomopus cuneatus and $A$. isodactylus from the Dickinson quarry at Sonth Hadley. The data for improved descriptions of Brontozoum divaricatum and Plectropterna elegans are present, as well as long rows of Otozoum moodii, Brontozoum giganteum, and $B$. approximatum. The slabs occupy a large room in the basement of the Lyman Williston Hall, while smaller specimens have been placed in the adjoining apartment.

The institution possesses several slabs from the Dickinson quarry, about a mile north from the buildings. These are composed of a hard sandstone which preserves the impressions and casts with unusual distinctness. The marks of the heels of the hind feet, the front feet, and the tails of Anomœus are very plentiful. About sixty species of Ichnozoa are placed upon these tables, and a careful description of every slab exists in the manuscript form.

This catalogue is like the one prepared by myself in 1865 for the Amherst collection and printed in the Supplement.

Of the above species, the Anigmichnus multiformis is certainly the marking of a drifting tree whose roots or branches trailed in lines strictly parallel along the bottom, these lines often changing to a row of dots or a moniliform line from the rising and sinking of the plant with the waves. These parallel lines cover a space several feet wide and could hardly be formed by any animal. Further, Professor Hitchcock has omitted a section of fish-tracks given in the Ichnology with a genus Ptilichnus, or "fintrack," thought by President Hitchcock to be the marks of the fins of fishes. The markings are very uncertain and may well be withdrawn from the list. I have, however, found in the collection many fine, thin slabs with a curious marking upon them, which bear the name "Aroid Plants, Sunderland" in President Hitchcock's writing, but about which he seems to have published nothing. The resemblance of these markings to the markings which would be made by the ventral fin spines of a fish drifting slowly backward, and by a few slight rapid strokes stemming the current at regular intervals, is certainly striking. 
REPTILES.

\section{MEgadactyluds Owen.}

Megadactylus polyzelus E. Hitcheock, jr.

18is. "Bones of a reptile." Jeffries Wyman. Ichnology of New England, p. 186. 1563. Megadactylus polyzelus. E. Hitchcock, jr. Supplement to Ichnology of New England, p. 39.

18i1. Megadactylus polyzelus. E. D. Cope. Synopsis of the extinct Reptilia and Aves of the Uniterl States: Trans. Am. Phil. Soc., Vol. IV, p. 122a, Pl. XIII.

1884. Amphisaurus (Megadactylus). O. C. Marsh. Am. Jour. Sci. Sup. XXVII, p. 338 .

1889. Anchisaurus. O. C. Marsh. Am. Jour. Sci. Sup. XXXVII, p. 331.

This rare and remarkable fossil has had a peculiar history. The bones were thrown out by a blast in excavating a well for the casting of a big gun at the water shops of the United States Armory, in the south part of Springfield, and only a part of the skeleton was preserved and presented to President Hitchcock. These bones were first studied by Jeffries Wyman, and determined by him to be those of a reptile. His letter contains many acute observations. He notes the hollowness of the bones, a peculiarity suggesting birds and pterodactyls, but decides against the reference of the bones to either of these. The unequal length of the toes suggests a jumping animal.

The bones were then carried to London by Dr. Edward Hitchcock and submitted to Prof. Richard Owen, who determined them to be those of a Saurian reptile, but added otherwise nothing to the diagnosis of Wyman. His one sentence concerning the bones is interesting. They belong to "a Saurian reptile with an unusually thin wall of bone in the limb bones, which, however, might have been occupied by unossified cartilage, as in the young crocodile and turtle; but if they were filled with oil or light marrow, it would point to a course of development toward pterodactyls or birds. The phrase is purely hypothetical, and I mean to express no more than a degree of resemblance, supposing marrow and not gristle to have filled the large cavities." Later, Dr. Hitcheock worked out the bones with a graver and named the animal in the article quoted.

The specimen was then carefully studied, figured, and described by 
Cope, who referred it to the Triassic Dinosauria and called special attention to the very peculiar ischium.

In 1876 I carried the bones to New Haven, where they were studied by Professors Huxley and Marsh, and casts of them were taken by the latter. Professor Huxley was inclined to think them.identical with one or other of two genera of reptiles found by Stutchbury in the Trias near Bristol, England, and preserved in the museum of that city-Paleosaurus and Thecodontosaurus-but because of some loss or change of labels it was not passible to tell which of the bones preserved in the museum should be called by the first of these names and which by the second. At a later time Professor Marsh gave a new name to the genus, as indicated in the synonymy above, and still later, finding that this name had been preoccupied, he gave the fossil another name.

The bones include a nearly perfect foot, the ischium, femur, caudal vertebræ, and many imperfect fragments. A few very imperfect fragments of the bones of a similar species were found earlier, and are preserved in the museum, but without locality; and I have found many imperfect fragments of bone in the indurated sandstone of the contact zone of the easternmost volcanic core in Belchertown. This induration has prevented the percolation of water, which has doubtless carried away many bones formerly embedded in these coarse sandstones. 


\section{CHA PTER XIII.}

\section{TRIASSIC ERUPTIVE ROCKS.}

\section{HISTORICAL.}

As early as 1815 President Hitchcock described the "Basaltick Columns" of Titan's Piazza in the first volume of the North American Review. ${ }^{1}$ He gave the "greenstone" only a word in the Geology of Deerfield," not distinguishing it from the hornblende-schist of West Northfield. It is described at some length in the Geology of the Connecticut ${ }^{3}$ as "secondary greenstone," without reference to its mineralogical constitution. He notes that it is more amygdaloidal in its upper portion, describes the contact of the upper sandstone on the trap in Sunderland and Deerfield, and interprets the fault at the mouth of Fall River, described below (p. 437), as a repetition of the trap.

In his earlier report upon the Geology of Massachusetts ${ }^{4}$ he gives a very full account of the "greenstone," touching upon its lithological peculiarities, its distribution, mineral contents, and origin, an account which has lost little of its value, and which, because of its great length, I shall only briefly summarize here, as the main points are cited beyond. He now considers the "greenstone" to be made up of feldspar and hornblende, and remarks that he has not met with a genuine and distinct dike of trap in the sandstone.

In the later edition of the above work (1835), and in the Final Report, ${ }^{5}$ the same account is reprinted almost verbatim, the only additional information given relating to the small dikes in the gneiss on the east of the sandstones. An inspection of the maps accompanying the above reports shows clearly that the trap was laid down most accurately on the map of 1823 ,

${ }^{1}$ Page 337.

${ }^{2}$ Am. Jour. Sci., 1st series, Vol. I, 1819, p. 105.

${ }^{3}$ Am. Jour. Sci., 1st series, Vol. VI, 1823, p. 44.

${ }^{4}$ Geol. of Mass., Amherst, 1833, p. 404.

${ }^{5}$ Geol. of Mass., Final Rept., Amberst, 1841, p. 640. 
especially as regards the Deerfield bed, and that with the poor maps and the small scale used the delineation became more and more inaccurate. Upon the map of 1844 the Mount Tom range is represented much more accurately, a posterior range is given in West Springfield, and three long patches of "trap tufa and tufaceous conglomerate" are laid down. Upon the map.in the Ichnology, 1857, a further advance is made by showing that the Holyoke range consists of two bands of trap with a narrow intervening band of sandstone. The section through Norwottock on the border of the above map is incorrectly colored to indicate three bands of trap; the southern band should receive the color of the "trap tufa." Furthermore, in all the copies of the work $I$ have seen the trap tufa has the same color as the crystalline rocks upon the borders of the map, while in the legend a deeper shade of the color is assigned to it. This error has perpetuated itself in a curious way. Upon the small geological map attached to the map of Hampshire County of H. F. Walling (1858) a pink band of crystalline rocks is made to run across from Belchertown to the river south of the Holyoke range. The map is said to be "by Edward Hitchcock." One may infer, I think, that he had very little to do with it.

In the small map appended to Reminiscences of Amherst College (1863), President Hitchcock gave his final results regarding the rocks in question. He now makes the Holyoke range a single broad area of trap extending east to overhang, with undiminished width, the northern of the Belchertown ponds, and lays down two great areas in Pelham, the one made out by coloring as trap the whole area between the two occurrences detailed below, and the other based upon the area of great bowlders east of Amethyst Brook.

The geological map of Prof. C. H. Hitchcock in Walling's Atlas of Massachusetts (1871) gives a posterior bed in the eastern half of the Holyoke range and the northern part of the Mount Tom range, presenting thus the best results of his father's work.

In 1875 Prof. E. S. Dana presented to the American Association the preliminary results of studies upon the Triassic diabases, undertaken by himself and Mr. G. W. Hawes, and in the same year Mr. Hawes printed a series of analyses of these rocks, including one from Mount Holyoke. Although in the main devoted to the Connecticut rocks, these studies reached results applicable to this area, viz: the greater freshness of the 
diabase from the gneiss, its composition of pyroxene and the triclinic feldspars labradorite and anorthite, and the rare presence of olivine. By comparison of the altered with the unaltered varieties, it was seen that this alteration has not been attended by further oxidation of the iron, and therefore could not have been accomplished by any surface action, since the oxidation of protoxide of iron is one of the clief causes of surface alteration, while in this case one mineral containing protoxide has been changer into another protoxide mineral. It would therefore seem certain that the alteration took place at the time of ejection, as had been urged by Professor Dana. ${ }^{1}$

Later, Mr. Hawes ${ }^{2}$ made a separation (by Thoulet's solution) and analysis of the feldspars in diabase from New Jersey, determining them to be labradorite and andesite. He further calculates, on the basis of analyses in his preceding paper, the mineral composition of the "West Rock dike" near New Haven, finding it to contain the feldspars anorthite, albite, and orthoclase, with augite, titanic iron, magnetite, and apatite.

Professor Dana, ${ }^{3}$ in a very pungent critique of this paper, objects that the anorthite came from a later transverse (east-west) dike in the West Rock dike, and so can not be combined with the gross analysis of the latter, as was done by Mr. Hawes.

In 1882 the author published a paper, mainly mineralogical, on the Deerfield dike ${ }^{4}$ in which the contact metamorphism on the sandstone below and the amygdaloidal character of the trap sheet in its upper portion and the unaltered condition of the sandstone above, which is molded into all the interstices of the trap, are adduced in support of the view that this trap body is a contemporaneous sheet and not a true dike.

The presence of a beantiful fault at the mouth of Fall River was noted. The proofs of its existence would seem to have been given with too much brevity, as they failed to convince the author of the paper to be mentioned next, and they will be given more fully in the sequel.

In the following year appeared a very valuable article, by Prof. W. M. Davis, ${ }^{5}$ on the "Triassic trap rocks of the eastern United States," spe-

${ }^{1}$ Am. Jour. Sci., 3d series, Vol. VI, p. 104.

${ }^{2}$ Proc. U. S. Nat. Mus., 1881, p. 129.

${ }^{3}$ Am. Jour. Sci., 3d series, Vol. XXII, p. 230.

${ }^{4}$ Am. Jour. Sci., 3 series, Vol. XXIV, 1882, p. 195.

${ }^{6}$ Bull. Comp. Zool. Harvard Coll., Vol. VII, p. 251. 
cially valuable because of the reproduction of all the sections and diagrams explaining earlier views of the structure of the trap ridges and of the full discussion of previons theories. Of the abundant original observations only two groups relate to the Massachusetts area-one to the Turners Falls, the other to the Mount Tom region. He considers part of the trap masses to be contemporaneous beds and part to be true dikes, but adduces only cases under the first category from Massachusetts. The Deerfield bed he makes to be three beds, echeloned one posterior to the other. I have found it to be a single bed, fanlted several times at the north end, as will be detailed below.

In 1892 the anthor pnblished a preliminary paper on the quarry ror road material at Greenfield and described the under-rolling of the trap and the formation of breccia-like beds. ${ }^{1}$

In the summer of 1896 the author presented a paper before the Geological Society of America entitled, "Diabase pitchstone and mud inclosures of the Triassic trap of New England." $\quad$ The paper explains the mamner in which water and mud, frothing up into the trap from the sea bottom over which it was flowing, produced pitchstone and shattered the mixture and recemented it with an aqueous deposit of albite and bisilicates. There was also described the sweeping of fine mud out over the surface of the Holyoke sheet by convection currents and its under-rolling to form the base of the bed.

\section{THE THREE EPOCHS OF ERUPTIVE ACTIVITY; GENERAL ACCOUNT.}

1. The rapid transgression of the Triassic waters over the area had spread a great thickness of coarse granitic débris when two fissures allowed the passage of great volumes of basic lava to form the Deerfield and Holyoke diabase sheets. Sedimentation went on nndisturbed. Generally the first layers spread on the surface of the sheets were the same or nearly the same as those on which the trap rests. In the Holyoke bed one can see in small degree the influence of the shallowing of the waters, and the beds above are of finer grain. The fissure for the Deerfield bed must have been beneath the present outcrop or the lava must have come from the dikes in the gneiss along the eastern border of the basin. The fissure of the

${ }^{1}$ Am. Jour. Sci., 3d series, Vol. XLVI, p. 146.

${ }^{2}$ Bull. Geol. Soc. America, Vol. VIII, 1897, pp. 59-96. 
Holyoke bed was probably a mile south and east of the present ontcrop, along the line of later trap intrusions. The beds slightly baked the sandstones below and are anygdaloidal and ropy-surfaced above. They often took up great quantities of the rock over which they flowed, and the fact and direction of flow are shown by the marked difference between these fragments and the subjacent rock. Much sedimentary material is in places kneaded into the surface layers of the trap-either before it became solid or in a breccia layer-and is then carried underneath by the under-rolling of the solid and yet plastic front of the advancing sheet.

2. A great core, representing a second epoch of volcanic activity, now forms Little Mountain, which lies between Mount Tom and the river below Smiths Ferry, and from it flowed a thin but double sheet south beyond the limit of the State and north at least to the river, a half mile south of the Holyoke gap.

3. Immediately following this came an explosive outburst which spread tuff south to Holyoke and east across the whole basin to Belchertown. East of the river this rests on arkose; west, on the upper trap sheet. Its masses are largest (3 feet in length) at Smiths Ferry and decrease slowly east and south.

The results of the last period of volcanic activity appear in a line of crater throats and short intrusive dikes extending from the river to the east edge of the basin, parallel to and a mile south of the Holyoke range. Two are of very large size and one is a diabase full of quartz and feldspar grains. They make a small angle with the tuff sheet, so that some lie south and some north of it and some penetrate it in whole or part.

\section{DIABASE DIKES AND STOCKS IN THE GNEISS EAST OF THE TRLAS.}

A series of small dikes appear in the gneiss east of and a short distance from the sandstones. I do not find reason to consider them continuous over so long a distance north and south as they would appear to be from Percival's excellent map of their distribution in Connecticut, nor does any trace of the similar western line of dikes marked by lim extend northward into Massachusetts.

They are typical diabases, much fresher and of finer grain than the large masses in the sandstones, but scarcely offering any appreciable distinction from the finer grades of the latter. On their borders, however, and in small 
dikes from a half inch to an inch across, which are at times abundant in the gneiss, they reach a degree of fineness never seen in the central dikes, and are in part or wholly made up of glass, and contain olivine, which allies them to the newer outflows in the main valley.

1. The most northerly of these dikes cuts gneissoid rocks on the east bank of the Connecticut, a few rods below the mouth of Millers River. The dike is about 3 feet wide and runs south from the water's edge and disappears in a short distance beneath the terrace sands. It is a compact, very fresh, dark-gray rock, with few porphyritic feldspars $1^{\mathrm{mm}}$ long and extinction $21^{\circ}$ on either side of the twinning suture, the smaller feldspar $0.12^{\mathrm{mm}}$, the light-yellow angite peculiarly granular and without crystalline outline. Magnetite is very abundant. This occurrence is cited by President Hitchcock in his first report, ${ }^{1}$ and incorrectly assigned to Erving in the Final Report. $^{2}$

2. The next dike is intruded along the bedding of the gneiss, in the vertical wall which forms the north bank of Millers River, east of the bridge in the village of Millers Falls. As the gneiss has a low dip to the west, the dike, which is about 7 feet wide, reaches the water's edge just west of the bridge, where its crossing the stream gave rise to the falls from which the village gets its name. The rock was not distinguishable in thin sections from that of the preceding occurrence.

3. The next outcrop was a knob of remarkably fresh ice-worn rock exposed in the cutting made in 1881 in the relocation of the railroad tracks a few rods south of the Millers Falls station. The diabase was exposed in a rounded ice-worn boss, 10 or 12 feet across, without contacts. A few yards to the east, and 2 yards lower, gneiss was exposed, in which rock the diabase was doubtless intruded.

4. President Hitchcock notes greenstone in Montague, on the west border of gneiss, 2 miles northeast of the meetinghouse. It separates in plates directed east and west and standing vertical. ${ }^{3}$ This locality is beside the railroad, a mile south of Millers Falls, south of J. Hannegan's house. A ridge 325 feet long, 82 feet wide, and 20-30 feet high runs N. $35^{\circ} \mathrm{E}$., surrounded by the terrace sands. The last three outcrops may form parts of one long dike.

\footnotetext{
${ }^{1}$ Geol. of Mass., 1835, p. 417.

${ }^{2}$ Ibid., 1841, p. 648.

${ }^{3}$ Geol. Mass., Final Report, 1811, p. 648.
} 
The above dikes near Millers Falls are of ideal freshness; very rarely one sees in a single large feldspar a slight contral clonding, like a delicate tleck of cotton. They are rather light-gray, extremely tough, and yet brittle as glass. The constituents are of exactly the average dimensions given in the general deseription of the diabase, page 438. The angite is yellow to amethystine, dichroic, and, although perfectly fresh, it appears, from the strong cleavage and abundant inclusions, only translucent, and looks in the slide as if a quintity of pulverized material had been spread over the network of feldspars. This enables one to distinguish it from other occurrences.

5. Across Montague and Leverett no other outcrops occur. In Pelham, on the sonth sicle of the Shutesbury road, west of where it crosses Amethyst Brook, a great outcrop of the same fine-grained diabase occurs in the actinolitic quartzite. It is a squarish mass about 82 by 130 feet, its longest diameter north and south. Following the stream up from this point to where a brook comes in from the north, one finds a great number of large bowlders of diabase in its bed, some of large size. There is probably a considerable bed in the pasture a few rods east of the junction of the brooks. Further, the fine amethysts which occur as rolled specimens in the bed of the brook probably indicate the presence of diabase here. A mile northeast also, in the deep brook gorge north of Ward's quarry, occur a great number of very large diabase bowlders, as well as much farther east in the eastern portion of the town, along the roads that run down from Pelham Center to the Swift River Valley.

6. If the line connecting the above outcrops in Pelham be prolonged N. $40^{\circ}$ E. into Shutesbury, it strikes a great outcrop of diabase at the point where it crosses the road going north from Pelham Center, opposite the honse of W. Thrasher. It is exposed with a length of 25 rods and a width of 75 feet, and runs N. $40^{\circ}$ E. It is a fine to very fine, very fresh diabase of the common structure, the finest-grained portion showing a globulitic groundmass as inclusion in the feldspars, and small olivines.

7. If the line be prolonged N. $40^{\circ}$ E. across to the river road, another ontcrop of diabase occurs on the hillside northwest of the house of $\mathrm{S}$. H. Stowell. An inspection of the map will show that all the above series of outcrops occur along a northeast fault which has opened the entrance to the upland basin of Pelham and caused the sharp southern slope of Mount Hygeia. 
8. Again, where the road east from Pelham post-office, halfway down the hill, turns from south to southeast, a large outcrop of trap occurs on the north side of the road.

9. Going about 115 rods on the first western road running south from the West Village of Pelham, and turning east into the woods, one finds an east-west vertical dike, at one place nearly 6 feet thick, but running west with a thickness of only 1 foot, which sends off many small branches into the gneiss, one of which furnished the material for the study on page 416 .

10. On Coys Hill, in the southeast part of Ware, north of the point wnere the road crosses the town line, a vertical dike of diabase occurs in the high bluff northeast of the road across the ravine. It is horizontally bedded, 50 feet wide, and can be followed a half mile south, first with strike N. $40^{\circ}$ E., then swinging round to N. $30^{\circ}$ E., when it crosses the town line into Worcester County. It is fine-grained and is beautifully exposed, with its attendant swarm of small dikes in the adjacent gneiss. It is now quarried for road material just east of the station, where it is 5 rods wide.

11. A great accumulation of bowlders of the aphanitic diabase in Belchertown, north of the schoolhouse, near E. Willis's, another near the center of Wales, and another in the northeast of Belchertown indicate in each case the proximity of an area of the rock covered by drift deposits.

12. About 650 feet east of the house of J. Bardwell, near the west line of Belchertown, occurs an isolated outcrop of trap, forming a hill of great, broken masses of the rock. It is about 33 by 100 feet, and gneiss occurs in the near vicinity on every side, though the immediate contact could not be observed. The rock is the dark bluish-gray aphanitic variety common in the gueiss.

13. Just south of Flint's quarry, in Monson, a heavy dike of trap is cut through by the quarry railroad. It can be followed but a short distance to the north, when it is cut off by a fault and offset to the east, and its continuation, with the evidence of the faulting, can be found in the sonth bluff of the ridge next east. From this point it can be followed northeast more than half a mile, till it disappears beneath the sands in the Monson Valley. It is about 410 feet wide. The small dike next described is apparently an offshoot from it, and the great number of trap bowlders found over the high ground in the east part of Monson are clearly derived from it, and their distribution makes it plain that the dike extends much farther northeast and southwest than can be seen. It is now quarried for road material. 
14. A vertical dike of black, fine-grained, horizontally jointed diabase runs east and west through the great quarry at Monson. It is nowhere more than 16 inches wide, and as it goes upward it has a curious warp to the soutl. It sends off many small dikes, which are specially discussed in the next section below (p. 416).

15. Farther south in Monson, in the crest of the bluff west of S. Macintosh's house, is a dike of similar rock, 50 feet wide, rumniug N. $65^{\circ} \mathrm{E}$., which can be traced for some distance in the face of the cliff, cutting the amphibolite.

16. Still farther south, on the east slope of Peaked Mountain, west of the house of J. Bliss, jr., occurs a dike of about equal size and of similar character. These dikes in Monson were already traced by Percival.

Trap bowlders are very abundant along the western slope of the high ground east of the central valley of Monson, from one end of the town to the other.

17. Another plug occurs just over the State line in Stafford. It runs N. $10^{\circ}$ E., is 60 rods long and 200 feet wide. It is high up on the east slope of the hill which lies across the brook west of where the HampdenStafford road crosses the State line. The slides show a trace of decomposition. The feldspars of first generation have broad bands with wavy extinction from strain; the second are very complex twins.

18. A mile S. $10^{\circ} \mathrm{W}$. of this, where the road from the State-line Pond to Somers rises to the top of a high hill, another dike is exposed just south of the road. The contact, in granite, is exposed on the west. The strike is N. $40^{\circ} \mathrm{E}$. It is 56 feet wide, 200 feet long, has steep slope on the north and a swamp on the south. The sections show unusually fresh and sharply and regularly outlined plagioclase of only one generation.

19. A third stock of trap occurs a half mile S. $10^{\circ} \mathrm{W}$. of this, which crosses the next east-west road. It is 45 rods long from north to south, 25 rods from east to west. The gneiss is continuously exposed around its east, north, and west sides. It is a compact, light-gray trap. In these sections the large plagioclase crystals of first consolidation have the central portion out nearly to the border changed into a cottony mass of plumose, micalike, elongate, ragged scales, while the clear border shows at one end a marked wavy extinction and the other end extinguishes sharply at $25^{\circ}$ on either side of the twinning suture. 'This is an unusual change to some micaceous or zeolitic mineral, instead of to kaolin. 
20. In the northeastern corner of the Palmer quadrangle a dike of the same fine-grained, dark-gray diabase was discovered by my assistant, Mr. C. S. Merrick. It is nearly a mile west of the point where the Boston and Albany Railroad leaves the quadrangle, and appears in the crest of the hill at the 900 -foot contour. ${ }^{1}$ It is about 100 feet wide and strikes N. $20^{\circ}$ E., and is plainly a part of the dike No. 10, which ean be traced north across Ware and New Braintree.

\section{A MICROSCOPIC DIABASE DIKE FROM PELHAM, AND OLIVINE AND GLASS- BEARING DIKES FROM MONSON.}

The two great diabase masses of the Triassic in Massachusetts, the Deerfield and the Holyoke dikes, are amygdaloidal at surface and aphanitic at base, but everywhere normally crystalline, and everywhere, even when seeming quite fresh, much decomposed. The series of sinaller dikes of the same rock, when run in the gneiss, parallel to and a few miles distant from the eastern border of the sandstone, which were traced across Connecticut and Massachusetts by Percival and Hitchcock, are in texture exactly similar to the former, showing a typical diabase texture, but always very much fresher. They often send off a great number of apophyses, which sink to very small dimensions and run out in all directions and to considerable distances through the gneiss, which, ordinarily very friable, is here so indurated that thin flakes can be broken off and slides prepared containing one or more of these minute dikes. An interesting slide of this character from Pelham contains a dike $0.9^{\mathrm{mm}}$ wide and $20^{\mathrm{mm}}$ long. It is a tachylyte, shading from dark gray at one side to jet black at the other, and under the microscope is a colorless glass loaded with a fine dust, apparently magnetite. The shading into black is due to the occurrence of this material in much greater quantity at one side of the dike, as if it had been formed horizontally and the magnetite had sunk to the bottom. The rest of the surface has a mottled look, like a miniature representation of a tiger's skin. This comes from the fact that minute angular fragments of quartz and feldspar, which are scattered through the mass, are surrounded by a halo of the same black dust, outside which a broad ring of the glass is comparatively clear. This gives the whole an apparent spherulitic structure, and this structure is really present and the glass is in a state of tension around the foreign grains, as 
is secu by the finet that the clear rings polarize feebly and slow traces of a black cross.

On the upper side, i. e., opposite the black border, the liquirl rock forced its way in several places between the grains of the bounding rock. In one place it flowed in with a width of $0.5^{\mathrm{mm}}$, showing a delicate fluirlal structure, the lines of black dust being drawn into a series of regular parabolas, exactly as in a diagram of the surface flow of a river around a curve. Another, narrower, runs far into the gneiss and passes lengthwise of a large biotite crystal in a gliding plane, with a width of $0.02 \mathrm{~mm}$.

The contact effects of the small dike on the gneiss are also interesting. Not only is the former filled with minute fragments of the inclosing rock, as already noted, but in places along the side is finely crushed and disturbed, and cemented again by eruptive material. Crystals of triclinic feldspar have their laminæ interrupted and echeloned by a series of fine faults, and in the immediate neighborhood of the dikes they were so influenced by heat that the laminæ, instead of being as usual (and as they are here farther away) perfectly straight and sharply defined in polarized light, become wavy and bend over into the direction of flow of the lava, and the bands of color pass gradually into each other.

In other cases, in a feldspar apparently fresh, on approaching extinction a band of black passes in from the border to the center and disappears.

The large biotite, through which the narrow vein passed, seemed entirely fresh, but in polarized light it was seen to be markedly affected, apparently by compression, so that it broke up into patches of color, arranged along the sides of the intruding vein. Smaller crystals of biotite were twisted, so as to show a brilliant aggregate polarization in long interwoven lines.

The large quartz grains, usually entirely uniform, were broken up into irregular patches of brilliant color, and showed marked undulatory extinction.

Specially fine cabinet specimens of the small dikes mentioned above ean be at times obtained from the Monson quarry-hand specimens of the light-gray gneiss, with three or four dikes narrower than one's finger crossing them, and at times bending round so sharply as to inclose a thin wedge of the gneiss, thimner even than the small dikes themselves.

From the aphanitic border of the largest dike there, which is only MON XXIX-27 
about a foot wide, I cut sections which showed, under the microscope, many porphyritic olivine erystals sharply outlined, some nearly fresh, but most well advanced in the change to serpentine. Some were penetrated by thick branching lobes of a brown glass, which in one case took up more than half the surface of the section of the crystal and was accompanied by two separate globules of the same glass with motionless bubbles. This is the first certain occurrence of olivine in the traps of the Connecticut Valley in Massachusetts, and this, with that mentioned on page 411, the first occurrences of a glassy modification of the rock. The position of the olivines and their large size suggest that they may have been formed at great depths and floated up to their present position.

Another of the minute dikes, $2^{\mathrm{mm}}$ wide, in the gneiss from Monson was cut. It had for part of its boundary a border of crushed gneiss, the triclinic feldspar showing mudulatory extinction, and the dike sent off into this a veinlet $0.1^{\mathrm{mm}}$ wide. It was of finely granular, devitrified tachylyte, with a lighter border one-third millimeter wide. The feldspars in it were from one-third to one thirty-eighth millimeter in length. The well-shaped olivines allowed measurement of $(021) \wedge(021)=98^{\circ}\left(\right.$ calculated $\left.99^{\circ} 06^{\prime}\right)$.

\section{THE BEDDED OR CONTEMPORANEOUS ERUPTIVES.}

THE DEERFIELD SHEET.

This, the most northern occurrence of ermptive rock in the Trias, begins near the northeastern border of the latter, back of C. M. Conant's honse, in the west edge of the village of Gill, and extends west by south past the house of $\mathrm{J}$. Blake, where it is slightly faulted and where it has a thickness of about 40 feet, which it maintains for a long distance. It is compact at base and slightly porous at surface, and has low southeast dip with the conglomerate in which it is intercalated. At its crossing of the Gill-Tumers Falls road it is again slightly faulted, and the bed was traced only to this fault in my previous study of it. ${ }^{1}$ It turns here and rmns down to the moutl of Fall River, where it is again faulted. It is moved about 165 feet to the west and an opening made, through which the Fall River reaches the Connecticut. From this point it runs down the west side of

${ }_{1}$ The Deerfield dike and its minerals: Am. Jour. Sci., 3d series, Vol. XXIV, 1882, p. 195. 
the Connecticut, though Greenfield and Decrfield, and, tuming ealstward, crosses the river and ends in Mount Toby. It is at first inclunled in the Longmeaduw sandstones, and continues south in them until, at its sonth end, it runs oft' into the conglomerate of Mount Toby.

It has thus the characteristic elongated $U$ shape which appears on a scale so much larger in the Holyoke range. It is worthy of note that the ligh westem border of the valley, which I shall elsewhere try to prove to have been caused by faulting, corresponds in direction with both these sheets, being set back in Greenfield and Northampton so as in each case to present a reentrant angle to the northwest corner of the trap ranges, with sides parallel to the corresponding portions of the ranges.

The bed is about 21 miles long, and where the Deerfield River breaks through it it is about 100 feet thick; at Fall River, 165 feet. Where it is cut by the artesian well of the Montague Paper Company (see p. 380) it was penetrated 110 feet, which, with the dip of $40^{\circ}$, would give a thickness of 84 feet.

CONTACT ON THE SANDSTONE BELOW; THE UNDER-ROLLING OF THE CRUST AND THE ALTERATION OF THE DIABASE BY HEATED WATERS TO A PITCHSTONEBRECCIA AND A DIOPSIDE-PLAGIOCLASE ROCK.

Going sonthward from the bridge over Fall River, one finds in the roadside, just before coming to the mouth of the stream, a contact of the diabase upon the sandstone below-a granitic sandstone, coarse to medium in grain, which is baked for an incl into a black hornstone and changed for a foot into a strong quartzite. The trap above is little affected.

Opposite Mrs. Gr. P. Heyward's, in Greenfield, and underneatl the lookont tower which stands on the crest of the trap ridge, a crushing machine has been set up to supply the city with road material. For a long distance the vertical wall has been cleared and a most interesting contact is exposed. (See Pl. VIII.)

Climbing up from the sand flats, over 60 feet of fucoidal sandstones with strike N. $10^{\circ} \mathrm{E}$. dip $40^{\circ} \mathrm{E}$., one finds, at the base of the great trap sheet and resting on the sandstone below, a layer 60 feet thick, made up of rounded and angular blocks of trap, of all sizes up to 3 feet thick, the whole mass penetrated by veins of fine red and black sandstone, often 6 inches 
thick, which branch upward for about 7 feet from the main mass of the sandstone and are full of small steam holes at the top.

A fine-grained and finely porous, reddish trap is continued downward from the compact trap above in all the interstices between the blocks, cementing them together in the same way that the sand below cements the larger blocks, and the two cements meet along a horizontal line. (See Pl. VIII. The person seen in the plate stands on the sandstone and touches this line with his finger:)

As the great mass of lava flowed over the bottom of the bay, its congealed and much fissured crust at the front of the flow, like an unrolling carpet, gradually passed beneath the advancing mass, and the nud rose up into all the fissures in the crust, while the heat baked it into a porous rock and the still liquid lava within oozed into the cracks above to meet the mud.

The above partial description of this most interesting locality was made at a time when the quarry had exposed only a portion of the surface to study. A more careful exannination of the place brought out these facts: The basal portion of the bed is made up of angular blocks of trap, and these blocks are often interlocked and a common structure passes from block to block, showing that it is the portion of a bed of trap in place and not a tuff or agglomerate of transported blocks. The blocks are of the common, rather coarse-grained trap of the sheet, but are distantly and coarsely vesicular, some of the spherical cavities being an inch across; and what is most striking, many of the blocks have rows of these cavities around their borders in whole or in part, and these cavities are tubular at times and closely set at right angles to the fissure which separates the block from its neighbor. At times two adjacent blocks have a similar arrangement of tubular cavities on either side of the crack. The arrangement of these tubes at the surface of the blocks shows that the slow expansion of the steam was effective after the mass had cracked into great blocks. Perhaps the increased heat from its under-rolling and penetration by the liquid lava may have been effective here. Moreover, some of the blocks surrounded by the finer trap are quite spherical, as if they had been partly remelted after being enveloped in this newer trap. Again, it is a very partial description of the upper portion of the wall to say that a finer trap has oozed down to meet the upcoming red sand and cemented the blocks of trap. There is a well-defined line 
about 7 feet above the sandstone along which the veins of red sand blend with in fine-grained, reddish material quite unlike the coarse blocks of trap, and this remblish material cements the blocks of earlier trap together for a ferv feet highter, and ligher up the blocks grow more distant and smaller and disappear in the mass of the newer material, which is cracked into small fragments, so that the whole closely resembles a tuff, but is not a tuff, if the idea of transportation of fragmental igneous material by air or water be essential to the definition of a tuff. It is a breccia of sand, trap fragments, and glass, produced by explosions of the water introduced with the mud. In places it loses the red color and becomes greenish. On examining the whole face of the cliff', it is seen that this tuff-like condition continues up half the height of the bed, and its upper boundary continues north and south for a long distance. This is visible in the plate.

A careful examination of the zone of contact of the sandstone veins and the newer trap shows the latter to be compact or finely porous, as contrasted with the blocks of trap, which are very coarse amygdaloidal.

The newer trap or glass-breccia is reddish, because it is an intimate mixture of trap and red sand, and for 20 feet up, as far as one can climb at the quarry, the mixture of the filaments of sand and trap are most intimate, and on a polished surface it is seen that the delicate anastomosing films of the trap penetrating the sand conld have reached their present position and condition only in a liquid state, while the thin layers of sand are as intimately mixed in the trap.

Under the microscope (see fig. 24, $A, B$, p. 422) the thicker portions of the sand filaments (left side of figures) in specimens taken about 20 feet from the base of the sheet are of the same texture exactly as in the broad intruded masses of sandstone below, but are blackened around their border by the canstic action of the adjacent lava, and as they grow thinner they become black across their entire width. This seems to be cansed by the coating of the sand grains with hematite derived from the iron of the red mud and recrystallized by the heated waters. These borders bristle outwardly also with beautiful hexagonal plates of blood-red hematite, and the same plates are found also in the sand and in the surrounding rock.

The second constituent of the rock is the trap, here in somewhat abnormal development. It is in small fragments and minute filaments, penetrating the sand in every way. It contains the large, angular, and 
well-formed plagioclase twins of earliest consolidation, which are, as usual, dusted with impurities, or decomposition products, and a few fine rods of later growth, and these constituents are entirely like those found in the normal trap. They are, however, not accompanied by magnetite and augite,
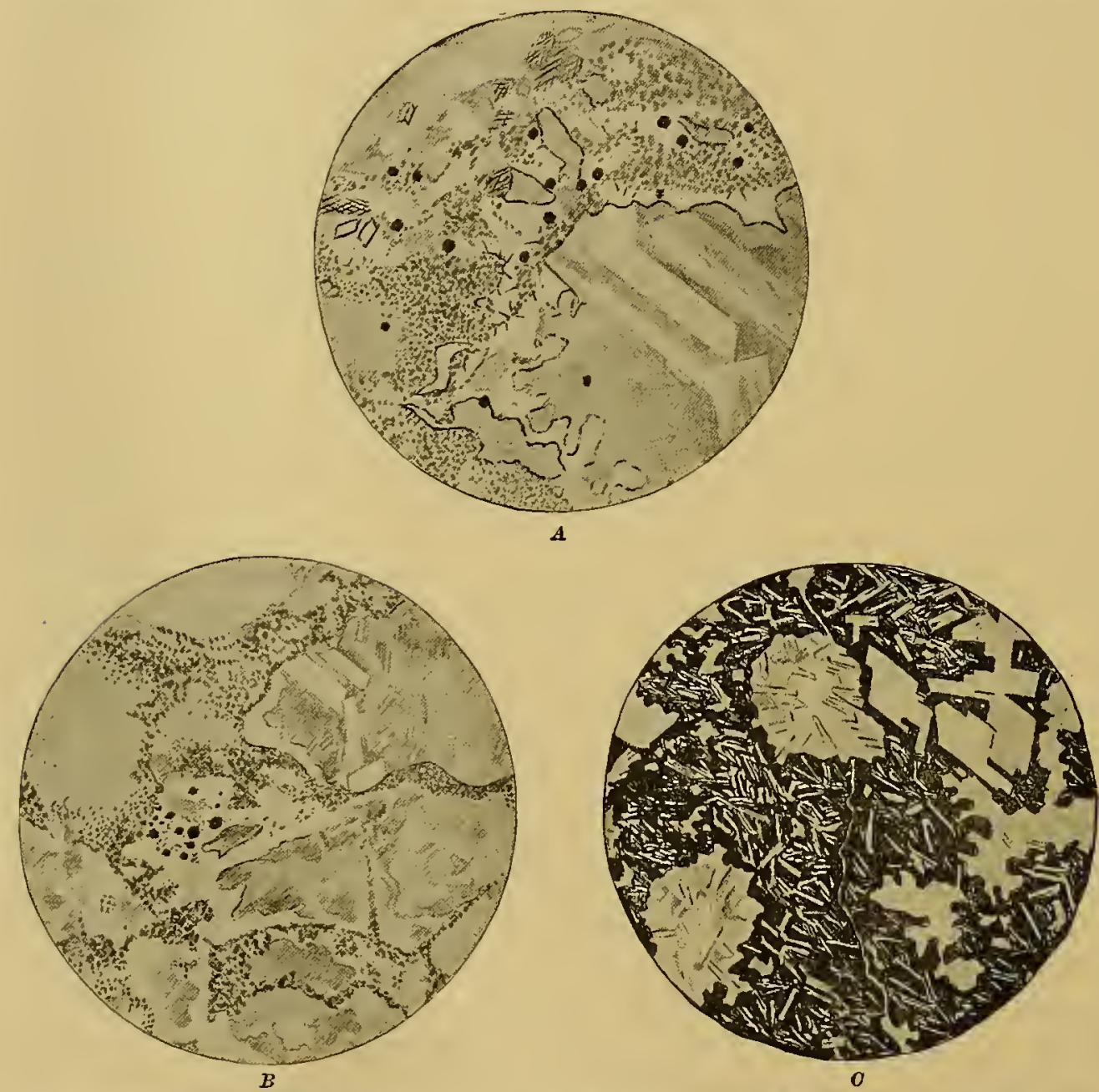

FIG. 24.-Thin sections of sand and glass breccia $(A, B)$ from the base of the Greenfield sheet at the city quarry and of trap $(C)$ from Cheapside. Drawn hy Charlotte F. Emerson. $A \times 30, B \times 85 . \quad O \times 30$.

as in the normal trap, but are included in an olive-green streaky and hardly differentiated magma, which is often thrust in among the sand grains where the feldspar can not follow. Large trap fragments appear at the right of $A$ and $B$.

The third constituent of the rock, and a most interesting one, is of aqueous or igneo-aqueous origin, it being plainly formed by the action 
of the waters of the mul on the heated lava under pressure. It appears as narrow limpid bands in $A$ and $B$, often interjected between the other "onstituents. It is malle up mostly of a clear feldspar, in blades and plates sereral times twimed, of very fresh appearance, and polarizing in bluish whites, with the strong, wavy or central extinction which characterizes the waterdeposited allites of the cavities of the red diopside-diabase of the dike at Cheapside (fig. 24,C). This feldspar is also closely like the ordinary plagioclase of the amphibolites and albitic schists of the metamorphic series farther west. There is also a pyroxenic mineral of a quite peculiar character associated with this feldspar, and like it plainly of secondary origin. It has extinction $a=$ emerald-green, $b=$ clove-brown to violet, $\mathfrak{c}=$ red-brown.

In this rock small groups of stont, colorless diopside erystals occur, often bristling on the surface of the sand filaments like the hematite (which is another constituent of this rock), and in one case a well-formed arrowheaded twin of this mineral was observed. The considerable development of the green pyroxenic mineral gives much of the tuff-like rock a green color and the appearance of being greatly weathered diabase, and this somewhat abnormal variety forms narrow and interrupted bands between the filaments of the red mud and small fragments of the trap. These latter have the primary and secondary feldspars weathered and inclosed in an olive-green groundmass. The hematite plates penetrate to the very center of these fragments.

The mud was thus most intimately blended with the liquid trap in which the lath-shaped feldspars had already been crystallized. It furuished water for the hydration of the groundmass into an olive-green unonpolarizing glass, and some of the same superheated water produced the abnormal igneo-aqueous deposit which unites the normal trap with the sand filaments.

Several years after the foregoing description was written I made a comparative study of the above occurrence and similar tuff-like beds in Meriden, Comnecticut, during which many slides were examined and an analysis of the glass at Meriden was made. This gave me much clearer ideas of the part taken by the water in forming and shattering the glass (which proves to be a basic pitchstone) to make the fine sand and trapbreccia mentioned above, in carrying up portions of the basal bed to become the bomblike masses, and in promoting the formation of a rock resembling a crystalline schist. I therefore reprint here the substance of 
this article, so far as it relates to the Greenfield bed, at the expense of a little repetition. ${ }^{1}$

The flow of the submarine lava bed seems here to have been unusually rapid, and the under-rolling to have been a somewhat subordinate phenomenon; still, the convection currents rising from the front of the bed seem to have generally chilled it, so that a somewhat thin layer of compact, heary, fine-grained trap was solidified and under-rolled to form a basal bed protecting the liquid mass above. When the sheet had advanced over the muddy bottom so far that the imprisoned vapors could not escape laterally, some slight and local disturbance broke up this basal layer more or less, the heat reached the water-soaked sand below, and steam and mud frothed up into the mass of the still liquid lava in great quantity, carrying many blocks of the basal bed. These abnormal conditions promoted the formation of unusual varieties of trap. The absorption of water caused the formation of much basic pitchstone, while repeated smothered explosions shattered and commingled the heterogeneons products.

GENERAL CHARACTER.

For a thickness of 30 to 70 feet and for a distance of several miles in the vicinity of Greenfield the basal portion of the trap sheet is a mixture of sand, fragments of various sandstones, fragments of various kinds of diabase-some witl glass base, some with hyalopilitic base, and some resembling andesites, all unlike the monotonous Triassic diabase-and abundant fragments of glass, all cemented by glass, and variously shattered and recemented, and the interstices filled by a water-deposited mixture of albite, diopside, calcite, ægirine-augite, and hematite.

The main mass of the trap sheet is normal and continuous above this confused mass, and in many places the basal portion of the sheet can be seen to be a continuous mass of trap beneath the breccia, so that the latter must have been formed in the midst of the sheet itself. The sheet is a normal, contemporaneous sheet, often showing a ropy flow structure at the surface.

GREENFIELD QUARRY EXPOSURES AND CONTACTS.

For a mile north of the quarry beneath the observation tower east of Greenfield one can walk along the line of contact of the trap on the 

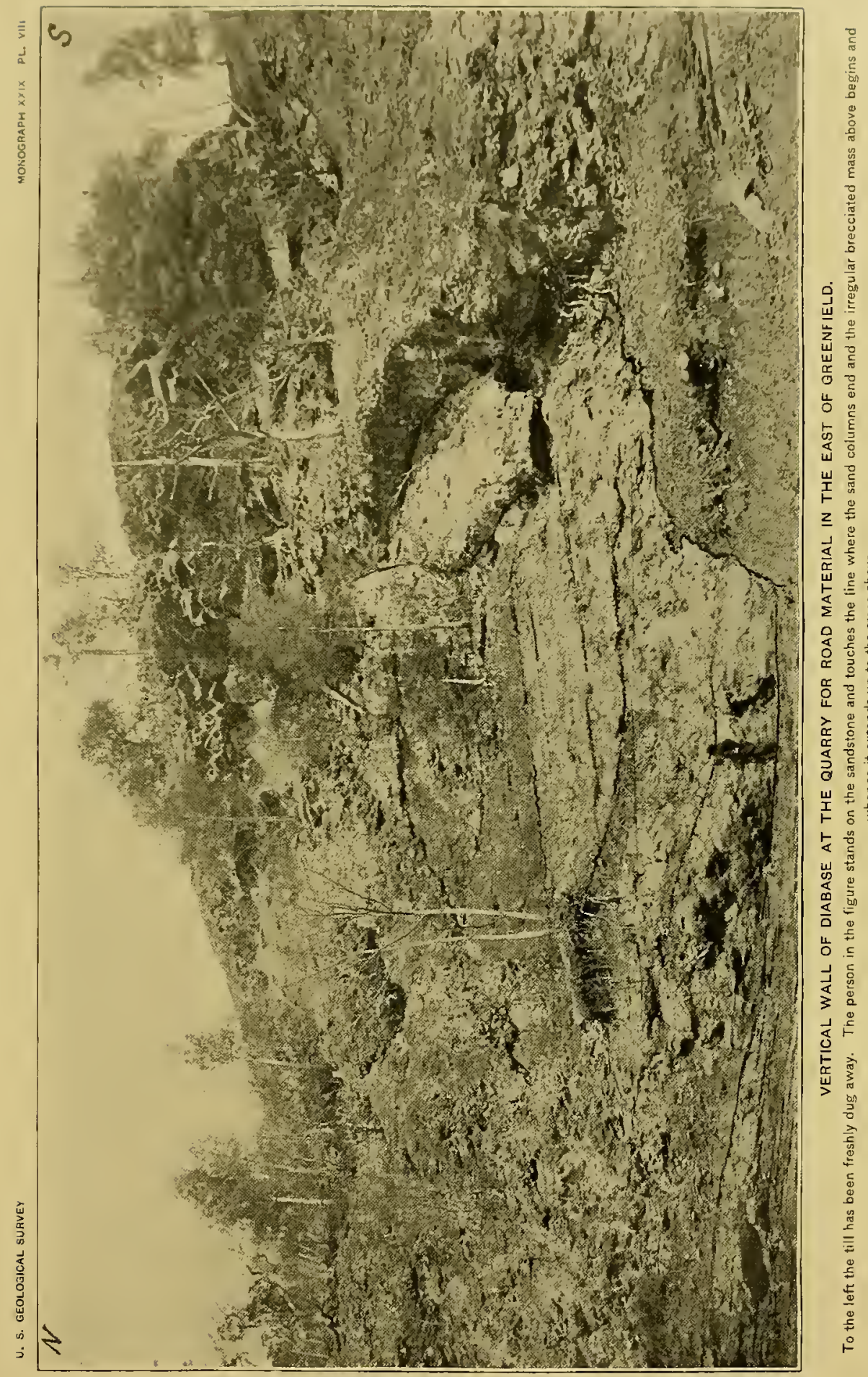

PLATE VIIIo. 


\section{P L A T E V I I I $a$.}

\section{DETAILS OF TRAP RIDGE EAST OF GREENFIELD.}

FIG. 1.-Photograph of the sonth face of a large bowlder at the foot of the cliff below the quarry. The rounded and angular blocks are trap, and they are inclosed in the sand and glass mixture, which often shows fluidal structure. Commencing to the right of the watch chain, which is to be seen in the lower left-hand corner of the picture, and continuing upward for twice the length of the chain is a series of four rounded blocks connected by narrow necks, and sending out narrow, angular lobes-forms which can not have resulted from explosions throwing masses of lava into the air. The effect of the pile of great round blocks with comparatively small amount of interstitial matter can only partly be given by the photograph. See page 431.

FIG. 2.-Enlargement of the part of fig. 1 which lies to the right of the wateh in the photograph. A bund of the sand and glass mixture exteuds across from the upper right corner and separates a large, rounded block above from a double block below, whose parts are joined by a narrow neck near the center, while the part to the right sends down a long, curved lobe into the breccia below. This shows one of the forms which can not have been "bombs" in the ordinary sense. See page 431 . 

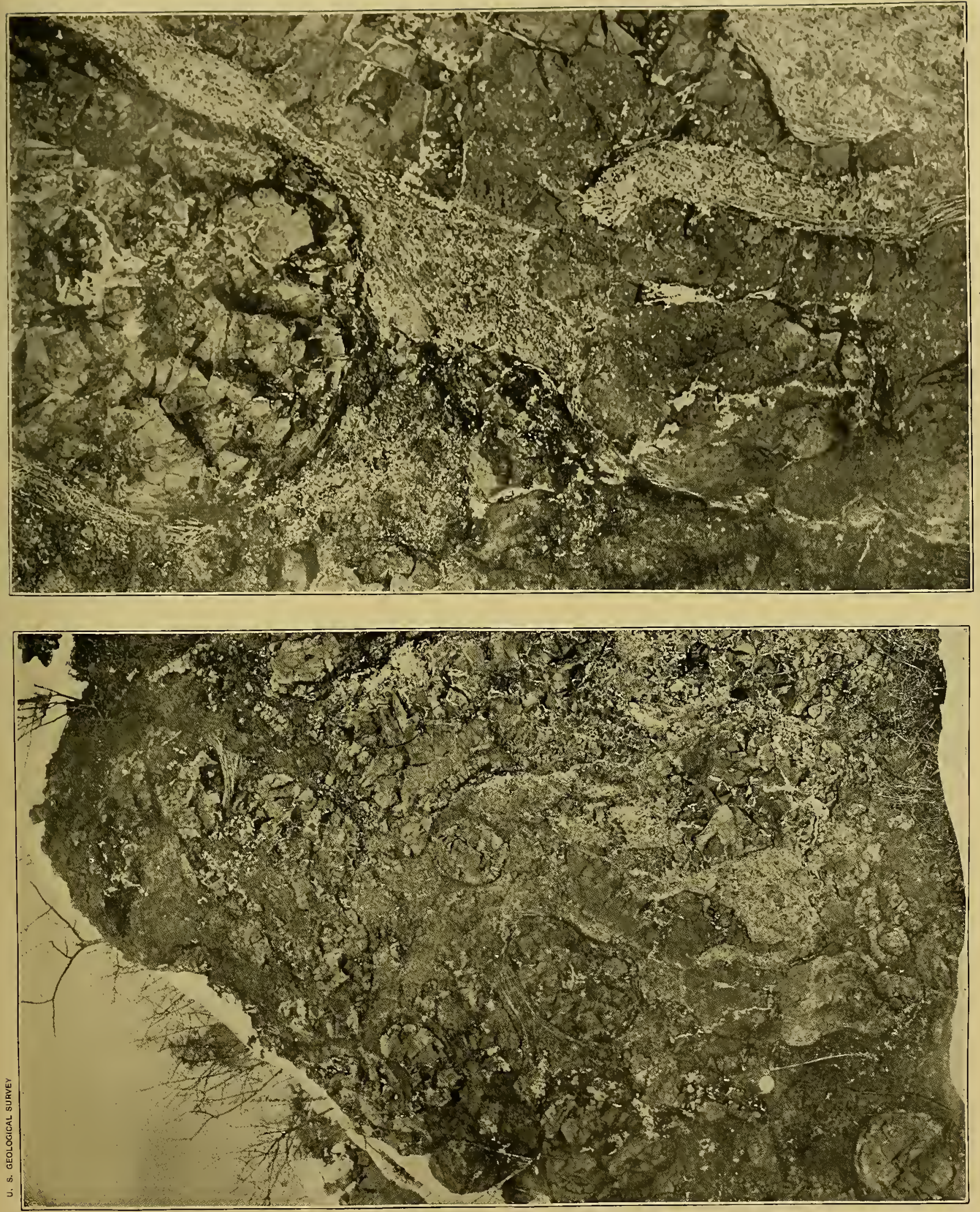

PLATE VIIIb. 


\section{P. LA TE VII Ib.}

INCLUSION OF MUD IN UPPER SURFACE OF TRAP SHEET.

FIG. 1.-A block of trap from the contact of a sheet of sandstone 12 feet long and a foot wicle which was included in the trap a few feet below and parallel with the surface. The lower surface of the specimen was in contact with the sandstone. The whitest spots are steam holes filled by secondary calcite. 'i'he trap is full of drops and lobate masses of the gray mud. From the north end of the east wall of the cnt. Dibbles Crossing, Holyoke. About twothirds natural size. From photograph. See page 456.

FIG. 2.-Polished surfaces of pieces from the south end of the cut, to show the intimate mixture of the shattered trap and the light-gray mud. The mud fills many of the steam boles in whole or part. Natural size. From photograph. See page 456. 

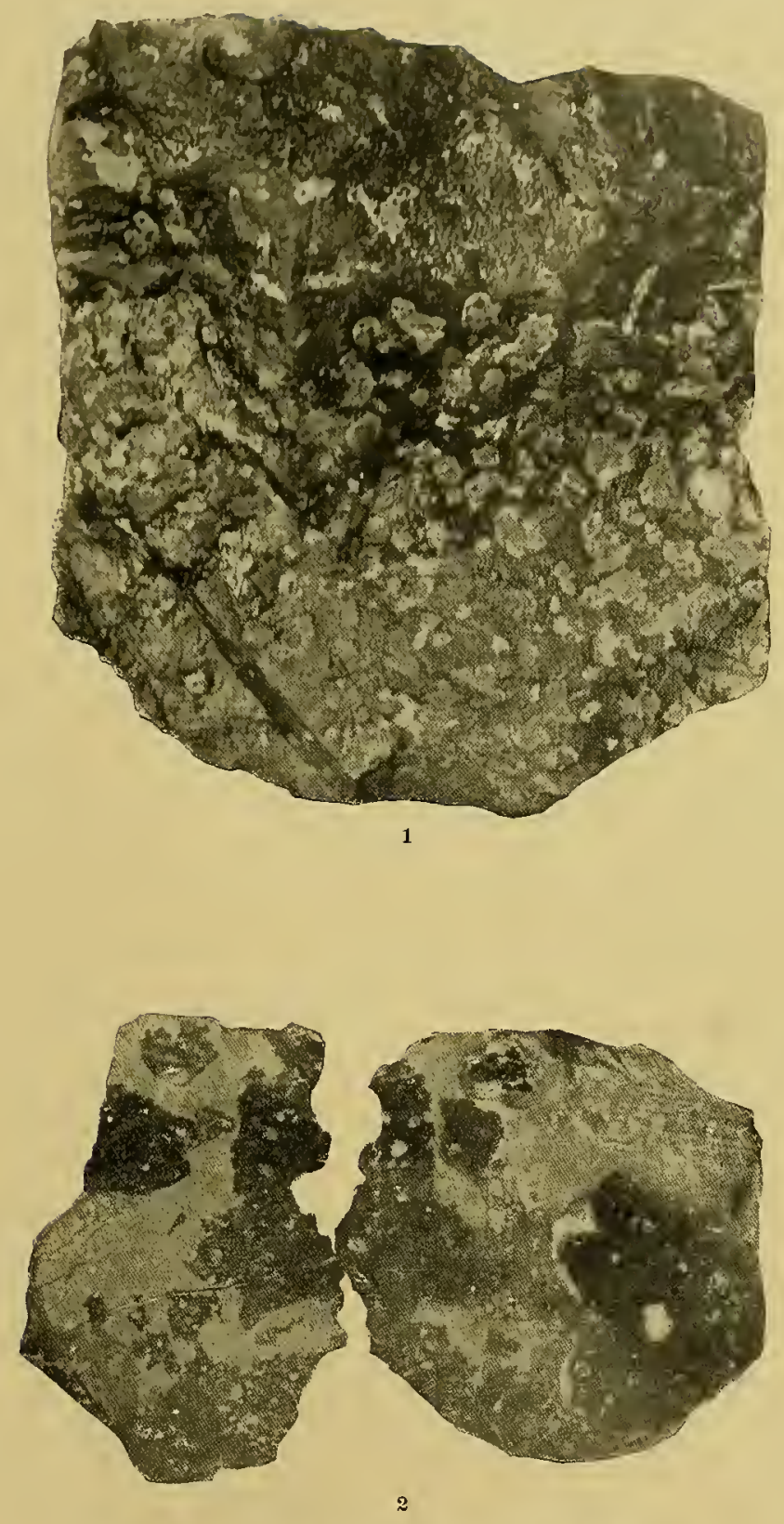

INCLUSION OF MUD IN UPPER SURFACE OF TRAP SHEET. 



\section{PLATE VII}




\section{P L A T E V. I I Ic.}

\section{THIN SECTIONS OF MIATERIAL FROM GREENFIELD AND MERIDEN “ASH BED."}

FIG. 1. - Red hematitic trap with secondary albite in perfect twinned crystals lining the interior of steam holes. Two large balf-filled cavities and three smaller ones, wholly filled, appear. The large porphyritic plagioclase to the right is mottled irom decomposition. Greenfield, near Cheapside Village, at the electric railroad cut. Sce page 442. Magnihed 20 times; crossed nicols.

FlG. 2.-The interstitial aqueous deposit of plagioclase (probably albite), diopside, and rgerineaugite. The plagioclase has a dusty, altered center, caused by an early change to calcite and a limpid exterior of later formation, which resembles the secondary plagioclase of fig. 1. The diopside is marked by strong boundaries and distaut cleavage. The iegerine-augite is in dark patches. The darker bordering portions are aitered to serpentine with development of clenvage. At the lower border patches of the black sand appear. At the top and right edge are isolated spherulites. Greenfield quarry, 20 feet above base of bed. See page 434. Magnified 35 times; crossed nicols.

FIG. 3.-Scoriaceous sandstone. The dark parts are the rusty sandstone, red in the interior of the bands, and blackened hy heat exteriorly. They show mud flow. The light parts are irregular, limpid, plagioclase grains. The mud has shrunk away at the top from a frst growth of this kind, leaving a thin film of black graius, and in the narrow space a more limpid, plagioclase growth occurs. In the center of the older growth is a highly refringent mineral (datolite?), showing a micropegmatitic structure with the plagioclase. See page 435. Greenfield, Cheapside cut. Magnified 20 times.

FIG. 4.-Greenish-brown glass with yellow borders, which are devitrified in series of small sphernlites with dark centers. The glass has been shattered, while the frigments were slightly plastic. The fragments are iu place in the slide, and the cavities are partly filled by a secondary water-deposited albite growth. See page 432. From Meriden "ash bed," near top on south path. Magnified 35 times.

FIG. 5.-Hyalopilitic diabase from the Meriden "ash bed." Base formed of tufted, feather5, and fasciculate groups of headed threarls. Large olivine at right, large angite full of glass inclusions on left. Contact of basal bed on glass breccia. See page 436 . Maguified 35 times. 

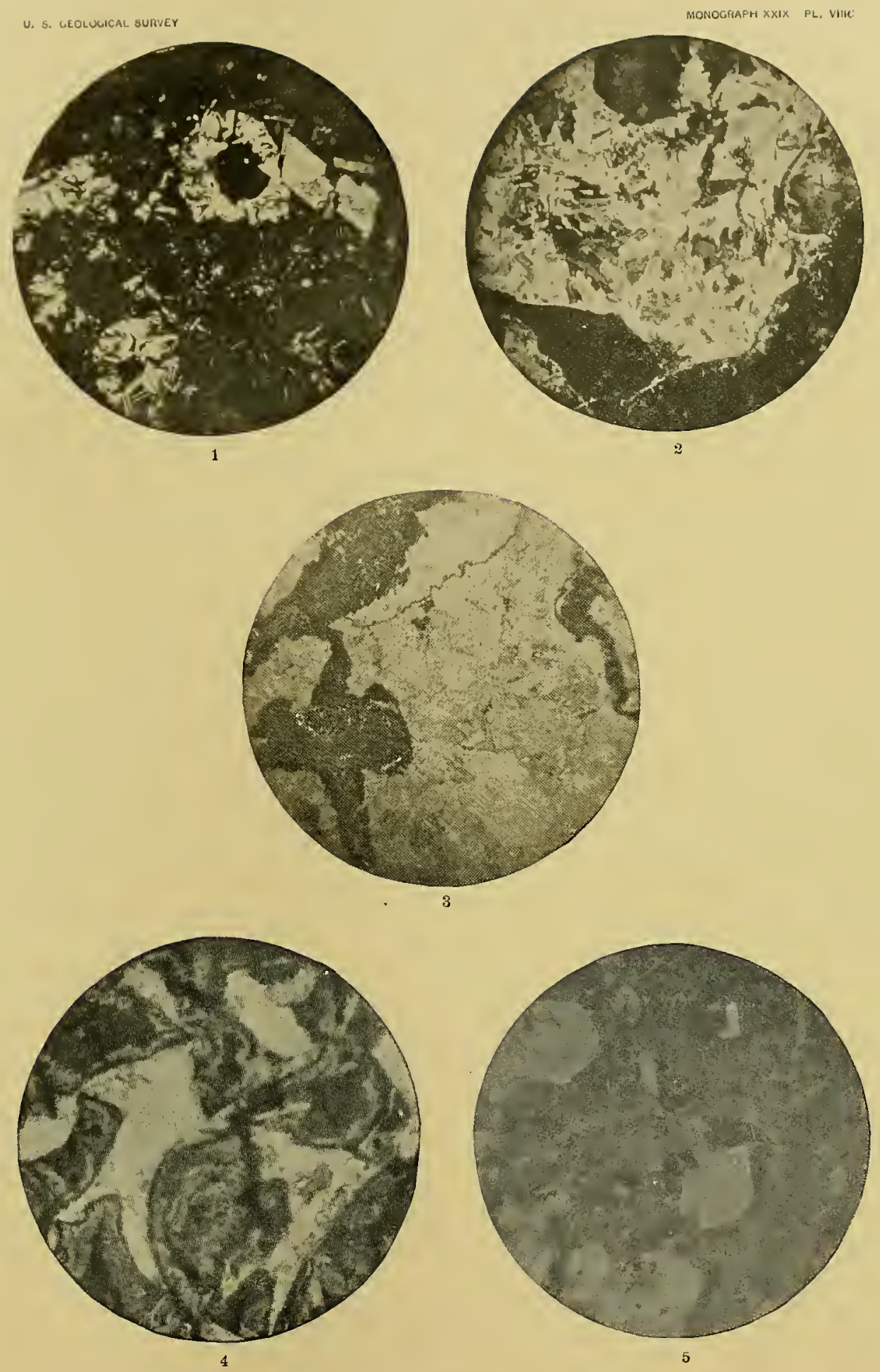

THIN SECTIONS OF MATERIAL FROM GREENFIELD AND MERIDEN "ASH BED." 

sandstome with the rertical wall of the trap rising above. Here there seems to have been no distinct basil bed, but the whole mass was conled nearly to the crystallizing point when the sand rose up into it at almost ergual intervals, and the streams of the sand and glass breccia formed by the water lise in great streaks or "schlieren," anastomose, and pass with Huidal structure around the great rounded blocks of the normal trap, which make somewhat more than half the wall.

At the quarry is a more distinct basal bed of trap 7 or 8 feet thick, more or less shattered and displaced, and the sand can be seen continuous with the underlying sandstones rising in rifts in this basal bed and frothing. out into a scoriaceous sandstone, where it meets and blends with the breccia inove. 'This breccia is 60 feet thick-a greenish mass of shattered glass and trap, full of filaments of red sand shining with hematite scales.

The rounded, bomblike masses of the compact and crystalline trap which are contained in this breccia grade superficially through hyalopilitic trap into the green glass, and while compact at center are toward the surface full of radiating steam pores. They seem to have been often carried aloft by the explosions into the still liquid glass, partially melted, and made superficially plastic by reheating, so that the steam has been able to struggle to the surface from the outer portion. Where they are large and angular they liave been carried but a little way from the base where they were formed; where they are small and spherical they are far-carried and much resorbed in the glass mass.

Among these blocks are many long sheets and rounded masses connected by narrow necks, which could not have been blown into the air and have fallen as common bombs. (See Pl. VIII $a$, p. 426.)

A little way north of the quarry one can climb up the whole face of the trap by a steep path, and 60 feet from the base can study the top of the breccia. Here are unusually large masses of sand frothed up into an amygdaloidal sandstone and filled with water-deposited silicates like the Cheapside rock (see Pl. VIII $c$, fig. 3), and above this the trap is normal and crystalline and full of steam holes for a few feet, and then grades into the common compact colunnar trap of the upper part of the sheet. ${ }^{1}$

\footnotetext{
1 In reporting my brief account of this case, Professor Dana has destroyed the meaning of the whole by an error. He says that the trap sheet rests on coarse sandstone-breccia 12 to 16 feet thick, instead of coarse trap-breccia. (Manual of Geology, 1895, footnote on p. 805.)
} 
PFTROGRAPHICAL DESCRIPTION.

DIABASE-PITCHSTONE.

The diabase-pitchstone in its purest form is a dark liver-brown pitchstone, dull-green or mottled brown and green by reflected light, and redbrown by transmitted light. It is often an apple-green glass with the same dichroism. It has resinous pitchstone luster, and so differs fron most tachylytes. The microscope shows a very minute, regular network of cracks, often developing into a perlitic structure around crystals and spherulites, which explains this luster. The deep-brown glass streaked with very deep brown is wholly amorphous and hardly to be distinguished from the Kilanea glass in common light, and, like it, it is not affected by acid. The phenocrysts are of similar size and distribution, but with polarized light the feldspar rods are always, and the large colorless pyroxenes sometimes, changed to granular calcite, easily removed by acid; the olivines, to fibrous serpentiue.

The fresh glass is full of small grains (cumulites), white by reflected light, red-brown by transmitted light, which are made of aggregates of minute grains (globulites). Even where the glass seems compact it often separates into small sheets and portions, showing minute curdled surfaces, and under the microscope the same wrinkled surfaces can be seen where small cavities have collapsed or where the fragments have flowed or have been drawn out in threads.

The glass has been shattered into angular fragments by sudden explosion while still able to flow under slow pressure. 'Each of the fragments is then bordered by a layer of even thickness of paler-brown and equally nonpolarizing glass-an effect of the heated waters on the iron content.

The larger fibrous spherulites in the glass are usually perfect circles or ovals, but they are sometimes distorted by flow or pressure. They are often bordered by several concentric bands of lighter and darker brownishgreen glass, each band having a concentric radiate structure. The central part is colorless and beantifully radiate-fibrous, showing perfect black cross. The fibers are optically positive and polarize like a plagioclase. They are not affected by boiling acid or alkali. Sometimes the centers are filled by a greenish granular mass, which scarcely polarizes, showing only scattered light points. The spherulites are often broken and found in parts in the breccia, and the layers separated and crushed, so that the glass seems full of fragments of eggshells. 
A fibrous devitrification sometimes affects all the fragments of a slide, each one being now a pale-yellow clevitrified glass of a finely tufted or fibrous structure radiating from many centers. The fibers have the same optical properties as do the spherulites. The inclosing glass is more granularly devitrified, polarizing in dots.

The glass sometimes undergoes a peculiar calcification, which seems to me rather a metanorphic change produced by the heated waters than a later decomposition by cold atmospheric waters. A fragment of glass will be redbrown at the center, pale-brown farther out, and perhaps colorless at its border; its angular boundaries will be sharply defined and the phenocrysts equably disseminated through the whole, and with common light the whole seems unchanged glass. It will, however, polarize in whole or part in broad patches of bright and softly blended colors and show everywhere the uniaxial figure of calcite. Acid removes it readily and leaves only a powdery remnant. 'The outer colorless part is generally devitrified in plumose patches or in series of minute fibrous globes in the greenish fiorous devitrified glass. The calcite disappears rapidly with acid, leaving an opaque-white granular residue, while the colorless ylass becomes opaquewhite in lines and streaks, showing a concealed fluidal structure.

It is noteworthy that among all the reactions carried out here so little quartz is set free. Under the influence of the heated and carbonated water the glass, rich in calcium and alkalies and poor in silica, tends to split into calcite and acid feldspars. This explains the formation of spherulites and the fibrous devitrification of the glass, with the abundant development of calcite.

GLASS-BRECCIA.

Under the microscope a fragment of the greenish tuff-like mass, taken 20 feet from the base of the bed, was composed as follows:

The first thing that attracted attention was the fine red sand, each grain being covered with iron rust. Where this was in thick masses it was still red in the interior, but on the exterior was black from the recrystallization of the iron rust by the caustic effect of the melted lava, in which it had been disseminated in threads and sheets. In the interstices between these dark sand portions many minute angular grains of diabase, like that found in the basal bed, were scattered. These had been broken up by an early explosion and carried up from the base with the sand. The whole had been MON XXIX-28 
cemented by an olive-green glass, containing a few crystals of plagioclase and scattered spherulites, penetrating among the sand grains and to the very center of sand areas, which would otherwise have been called sandstone fragments. The whole thus formed has been again shattered, and is now cemented by a hot-water deposit of albite, calcite, diopside, and æoirine-augite. Beautiful large hexagonal plates of hematite bristle over the trails of sand grains, and in all the other constituents except the basal trap fragments. Sometimes cavities of later formation are filled by radiating chalcedomic growths, with centers of calcite and ankerite and copper pyrite.

The water-deposited plagioclase (Pl. VIII $c$, fig. 2, p. 430, the colorless center) has the appearance and the optical character of the small but perfect albites (Pl. VIII $c$, fig. 1, and fig. 24, $C$, p. 422) which line the steam holes in many places in this bed, and often rest upon the earlier diabantite. These I have proved by optical and specific-gravity tests to be albite. ${ }^{1}$ It has also a curious resemblance to the albite of the "albitic" schists and amphibolites, and the whole mixture has some resemblance to a crystalline schist.

The ægirite-like mineral (Pl. VIIIc, fig. 2, the dark grains) is in shapeless grains and shows a strong prismatic cleavage like that of augite. It is intergrown with the feldspar, calcite, and diopside in such a way as to show that they were all deposited together. The absorption in this mineral is very strong: $a=$ deep blue-green, $b=$ violet to olive-brown, sometimes with shade of green, $\tilde{c}=$ brownish yellow. A single twin with an extinction of $38^{\circ}$ on either side of the suture was found, and the maximum of the blue-green absorption was also at $38^{\circ}$ on either side of the suture, and this blue absorption represented the greatest elasticity. The mineral has thus the negative ${ }^{2}$ sign and the strong absorption of æairite and the optical figure in the position of augite. It is therefore allied to the ægirineangite of Rosenbusch, but the absorption parallel to it is clear blue-green and not grass-green. Large patches of the mineral are changed to a yellowgreen serpentinons mineral, which under crossed nicols is almost black, but with seattered points of light.

\footnotetext{
${ }^{1}$ Mineralogical Lexicon, under "Albite": Bull. U. S. Geol. Survey No. 126, 1895.

${ }^{2}$ By an oversight the mineral is said to have the positive sign in the article cited, and the absorption color is given as blue. This is only true in some sections between a and $b$, which blend the blue, green, and violet.
} 
The diopside is in stout, small crystals or in long, stout prisms, sometimes broken. T'hey are enveloped by the ægirine-angite witlout common orientation.

One of the columns of sand rising from the sandstone and penetrating the basal bed at the Greenfield quarry expands 9 feet from the base, where it passes above the basal bed into the glass-breccia, and its central portion presents a scoriaceous appearance. It is a red sandstone filled with more or less rounded spots of a white silicate, which I have no doubt, from my examination of other similar cases, is mainly a granular plagioclase. The same thing is developed much more extensively at the top of the breccia, on the path going up over the cliff north of the quarry. Here for several feet in thickness the rock is a red sandstone closely filled with small cavities. The whole makes the impression of a rather coarse, red amygdaloid with white amygdules.

A still more attractive form of the same rock is found in the cut of the electric road at the Deerfield River, a mile south of Cheapside (see Pl. VIIIc, fig. 3). Here a light-red sand rock is filled with the fiesh white amygdules. Under the microscope the sandstone between the white fillings has a beautiful fluidal structure, thus heightening the resemblance to an amygdaloid. The cavities are superficially blackened by the recrystallization of the iron oxide. The white filling is mainly a fresh matted network of plagioclase blades, which shows distinct triclinic striation rather more frequently than is usual in this water-deposited feldspar. They are raggededged from interference due to rapid crystallization. In the center of the cavities is another mineral into which the feldspars penetrate with a micropegmatitic structure or which runs out among them. It polarizes with bright yellows, and I suspect it to be datolite, as a mineral with the high glassy luster of datolite can be seen with the lens in the centers of some cavities. It shows no cleavage, and it has a rough surface like olivine, which agrees with the liigh refractive index of datolite. Other slides of this occurrence showed a curious radiate-fibrous structure with coarsely beaded fibers and extinction up to $40^{\circ}$, and some smaller stout, square prisms with flat ends. They present all the peculiarities of wollastonite. Another peculiarity is that the cavities seem to have been filled with the mixture described above, after which the sand has shrunk away from the 
filling for a considerable distance along one or more sides, leaving a film of the black sand grains attached, and then a more limpid feldspar has grown in the narrow cavities thus formed.

CONTACT MATERIAL.

A slide cut within the porous outer portion of the trap from the contact of one of the bomblike masses of trap with the glass-breccia showed only a very feldspathic and vesicular diabase. Specimens cut from the fused border between the two showed a rock with the aspect of an augite-andesite. The well-shaped feldspars of two generations and the equally well-shaped olivines were inclosed in an opaque red-brown base, which in thinnest places revealed its hyalopilitic or fibrous structure. (Pl. VIIIc, fig. 5, p. 430.) Its outer surface had at times a rounded and lobed, fused surface, and just under the surface a single row of steam holes filled with silica, all indicating a superficial remelting.

LITHOPHYSA.

In one large specimen from near the base of the bed north of the quarry at Greenfield the breccia was full of well-formed lithophysæ a half inch to an inch and a half in diameter. The cavities were half filled with curdled masses of a lighter rock.

CHEMICAL DISCUSSION.

In his article on the lavas of the Sandwich Islands and other volcanic islands of the Pacific, ${ }^{1}$ Cohen states that all the basic glass found was anhydrous, and in general a basaltic pitchstone has not been described.

I have studied slides of many tachylytes, and only that of Ostheim, in Hessen, with its green superficial color and liver-brown interior color, resembles these glasses. I have not seen any analysis of this rock giving water determination. It is deeper brown than most of the glass here studied, and contains large, round, oval spherulites with still deeper color, with radiate structure, and drusy surface. The other basaltic obsidians quoted by Zirkel do not contain more than 2.75 per cent of water.

The following analysis of basic pitchstone from the Meriden "ash bed," by Mr. H. N. Stokes, of the United States Geological Survey, was made on a pure liver-brown glass identical with that here described. 
It hats specific gravity of 2.87 , and melts easily to a black magnetic and frothy glass.

Basic pitchstone from "ash bed" northeast of Meriden.

\begin{tabular}{|c|c|}
\hline & $\begin{array}{c}\text { Per cent. } \\
46.86\end{array}$ \\
\hline 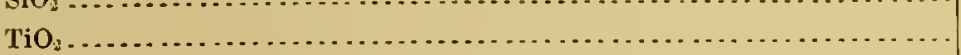 & 1.13 \\
\hline $\mathrm{CO}_{2} \ldots \ldots \ldots \ldots \ldots \ldots \ldots \ldots \ldots$ & 2. 19 \\
\hline $\mathrm{P}_{2} \mathrm{O}_{5} \ldots \ldots \ldots \ldots \ldots \ldots \ldots \ldots \ldots \ldots$ & .15 \\
\hline 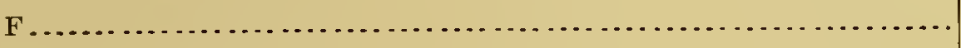 & trace \\
\hline $\mathrm{Al}_{2} \mathrm{O}_{3} \ldots \ldots \ldots \ldots \ldots \ldots \ldots \ldots \ldots$ & 13.96 \\
\hline $\mathrm{Fe}_{3} \mathrm{O}_{3} \ldots \ldots \ldots \ldots \ldots \ldots \ldots \ldots$ & 5.23 \\
\hline 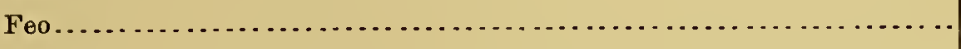 & 4. 67 \\
\hline 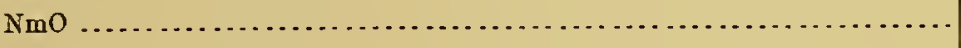 & trace \\
\hline 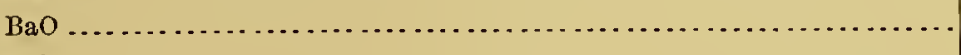 & .03 \\
\hline SrO........................... & trace \\
\hline $\mathrm{CaO}$ & 9.42 \\
\hline 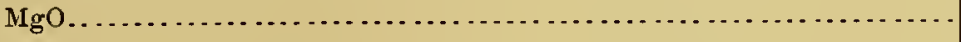 & 7.69 \\
\hline $\mathrm{K}_{2} \mathrm{O}$ & 2.02 \\
\hline $\mathrm{Na}_{2} \mathrm{O}$ & 1.85 \\
\hline 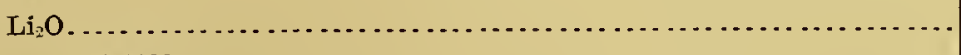 & trace \\
\hline $\mathrm{H}_{2} \mathrm{O}\left\{\begin{array}{l}\text { at } 110^{\circ} \ldots \ldots \ldots \ldots \ldots \\
\text { above } 110^{\circ} \ldots \ldots \ldots \ldots\end{array}\right.$ & $\begin{array}{l}1.29 \\
3.43\end{array}$ \\
\hline & 99.92 \\
\hline
\end{tabular}

ORIGIN OF THE GLASS AND MINERALS.

It remains to consider the cause of the extensive development of glass in the midst of the trap as a result of the introduction of water and sand in so great a quantity.

It might seem probable that the introduction of so much quartz would have permitted some solution, so that the glass, being more acid, would more easily take the vitreous form. The percentage of silica is, however, somewhat less than in the average of the diabase, and a study of a great number of slides failed to show any trace of quartz or tridymite, except in a late vein filled with coarse calcite and analcite. Slides boiled with concentrated HKO failed to show any change.

It is more probable that water has been absorbed in such quantity as to have contributed to the observed result. While obsidians are water-free, pearlstones average 3 per cent of water, and pitchstones 7 per cent, while the corresponding porphyries average only $1 \frac{1}{2}$ per cent.

It is remarkable, considering the quantity of water which must have 
been carried into the mass with the mud, that there is almost no trace of anygdaloidal development. Only one fragment of a trap inclosed with other's in a breccia contained small steam holes.

The collapsed cavities with wrinkled interiors and the absence of the common steam holes are explained by the absorption of the water by the magma, and this absorption explains the unusually large development of basic glass in connection with this exceptional occurrence. Above the compact and columnar trap which rests on this hydrated glass is the usual coarsely amygdaloidal surface layer of the trap, whose moisture seems to have no connection with this development at the base of the bed. It was, however, in this surface anygdaloid in the Deerfield bed that I found perfect secondary albite crystals resting on diabantite in the amygdules.

The great abundance of calcite and its intimate admixture with the other constituents are remarkable. I have elsewhere given reasons for thinking it in great part formed during the consolidation and cooling of the glass It is consonant with this that the feldspars formed during this cooling, especially those in the spherulites, are quite acid, while Hawes found very basic feldspars an abundant constituent of normal trap.

When these secondary feldspars are boiled with strong hydrochloric acid and treated with fuchsin there is no trace of decomposition, and the optical characters indicate a very acid feldspar. The $\mathrm{CO}_{2}$ brought into the mass by the waters from the coal-bearing sandstones below may have taken possession of a large portion of the $\mathrm{Ca}$, leaving the $\mathrm{Na}$ to go into the newly made feldspar.

The similarity of this aqueous feldspar to that in a metamorphic schist is remarkable, and it is interesting to find diopside and ægerine-augite and hematite formed with it, thus making a very peculiar crystalline schist in a very peculiar position.

It is again remarkable that diabantite and its serpentinous decomposition product are rare in these glasses and the associated traps. This militates against the idea that the penetration of the ground waters into the liquid trap is the cause of its chloritization.

The lava bed flowed over the muddy bottom quite rapidly, and the heated mud and water have frothed up into the still liquid mass, cansing an intimate blending of sand and lava for a thickness above the base of the bed of from 30 to 75 feet and for a distance, parallel to the advancing front of the sheet, of several miles. 
The sudden introduction of so linge a volume of water has caused the mass to cool as a sphernlitic glass with a minute crackling;, which gives it a pitchy luster and a large content of water (4.72 per cent), thus forming a basic pitchstone, which does not seem to have been described before.

As a further direct influence of the water on the lava, many abnormal forms of trap were made locally. The liquid mod rose in the liquid lava with many explosions, shattering the abnormal mixtures already solidified, aud blending them in still more complex mixtures while the newly solidified glass was still slightly plastic.

The whole is cemented by the remnant of the glass, or an aqueo-igneous stage follows the igneo-aqueous, and a more distinctly hot-water product, consisting of albite, diopside, hematite, calcite, and ægerine-angite, forms the cement. This glass-breccia is proved to be an integral portion of the trap sheet by the fact that there is a heavy basal bed of crystalline trap resting upon the sandstone, and the breccia grades downward into this bed, as it does also upward into the overlying crystalline trap which forms the major portion of the overflow. Sometimes this basal bed is shattered and its parts are carnied up into the glass and rounded and filled with superficial steam holes by remelting.

\section{CONTACT OF THE SANDSTONE UPON THE DLABASE.}

On either side of the mouth of Fall River, and for a mile south, continuous outcrop of the upper contact is visible at low water. The rather soft, deep-red, shaly sandstone is wholly unaltered and never included in the trap, while it folds around all small protuberances of what was, doubtless, the old ropy surface of a lava flow, its laminæ thickening in the bottom of the protuberances till they have evened up the surface of the ropy lava, and at times fragments of the traps are wholly included in the sand. The sand even fills the opened steam holes. Just north of the point where the wood road goes east from the Sunderland Hotel there is another fine contact of the sandstone on the trap, near its south end.

\section{FALL RIVER FAULT.}

On following down the trap from its north end to the Connecticnt, one finds that it halts abruptly at the water's edge east of the month of Fall River and faces an island of sandstone which lies just in its line of strike; but on following the bed up from the south, one discovers that it 
ends abruptly in a vertical, northward-facing wall 165 feet west of the termination of the northern portion already noted, and on the other side of Fall River.

We notice that the sandstone resting on the trap near the northern terminus of the west ridge is exactly the same soft, deep-red shale, and that it rests upon a trap with the same anygdaloidal texture and the same mineral contents as at the south terminus of the east ridge. At the same distance from this contact in either ridge the rock becomes suddenly filled with the same chopped-straw-like forms, which may be fucoids, or indusia of the insect found farther east in the sandstone, or, more probably, concretions; and measuring a second distance we find a thin bed of gray conglomerate interposed in the sandstones in both cases. The sandstone series thus agrees minutely on either side the line, and with the traps must have been faulted with the dip about 165 feet.

The rock is intercalated in the sandstone and dips eastward with it. It would seem to follow this direction only a little way before coming to the Fall River fault, as an artesian well sunk on the east bank of the river by the Montague Paper Company (see "Artesian wells," Chapter XII) went down 900 feet below the level of the dam, while immediately opposite on the west, and separated only by the width of the river (about 1,430 feet), the trap dips toward the well with an angle of $32^{\circ}$, which would make it appear in the well at 894 feet below the surface, whereas it does appear at 585 feet, making an upthrow on the east of the fault plane of 209 feet.

THE UNITY OF THE SHEET.

From its north end to a point just below the lower suspension bridge at Turners Falls, the trap ridge is an inconspicuous object seen from the surface of the high sands on the west, and here it is for a distance entirely covered by them. When it reemerges it has a greater width and has changed its direction to southerly. This is my interpretation of the facts at this point, and I find myself here again at variance with the conclusions of Professor Davis, cited above. It is certain that there is no proof that the trap from the south runs by the northern strip on the west, so that the latter could be called a posterior range to it. There is also no conclusive proof that the two parts of the dike are united under the sands. I think it most probable that they are. The two are lithologically identical, as are the sandstones above them, and the region abounds in faults. 
Southward the trap rises higher and continnes, with lofty, nearly vertical walls on the east and west, between the river and the town of Greenfield. President Hitcheock quotes "trap tuff" as constituting, a mile east of Greenfield, "a large portion of the ledge of greenstone, which is in places a liundred feet thick." This is the great pitchstone-breccia at the base of the bed described above.

Across the deep notch of the Deerfield River the sheet rises and thickens in Deerfield Mountain and looks down with vertical wall upon the village of Deerfield at its foot. It shows just east of the village the finest columns in the State, 2 to 3 feet in diameter, and in places distinctly curved. ${ }^{1}$

Farther south, just before crossing the river, the great sheet shows, from below upward, four horizons of heavy amygdaloids, indicating, doubtless, that it is a composite of as many great lava flows in this portion of its extent.

To the south, in Mount Toby, where it is thinner, it is amygdaloidal in nearly its whole thickness, while at its north end it is compact at base and heavily amygdaloidal in its upper portion.

\section{PETROGRAPHICAL DESCRIPTION.}

NORMAL DIABASE.

The rock is a typical diabase, ranging from aphanitic varieties to those where the white, flat feldspars are 2 to $4^{\mathrm{mm}}$ square, and from compact to very coarse amygdaloidal. The different veins are of very uniform texture and always in an advanced stage of decomposition, though appearing quite fresh; plagivclase, apparently of two species, augite, magnetite, and olivine are uniformly present. Apatite call not be detected.

The common plagioclase, probably labradorite, is always by far the most abundant constituent, and the angle of extinction of its long rodlike crystals is commonly $12^{\circ}$. Several varieties of the rock are subporphyritic by the development of white spots, made up of groups of stout erystals of a second triclinic feldspar, apparently distinet from the first, whose angle of extinction is $21^{\circ}$. Both feldspars are thoroughly decomposed, commonly from the center, and sometimes show only aggregate polarization.

The augitic constituent has for the most part gone over into a mixture of green and brown chloritic minerals, but here and there an exceptionally arge crystal remains in whole or in part intact. 
The rock at the new cutting south of the Deerfield River and southward is very fine-grained, breaking with conchoidal fracture, dark-gray and compact at the base of the dike, and there distinguished by an abundance of the well-known feathery aggregations of magnetite grains, while in the whole upper portion it is coarsely amygdaloidal, the amygdules filled commonly with diabantite, calcite, or both-when one penetrates below the deep layer of rusty scoriaceous rock from which all the secondary minerals have been removed-and here the magnetite is never arranged in feathery groups. At the old cutting on the other side of the Deerfield River, a few rods north, the rock becomes more granular in texture, and grayish- and reddish-white varieties occur, subporphyritic and abounding with flattened steam cavities, filled now with diabantite. These colors are arranged in layers, giving the rock an indistinct fluidal structure. These varieties continue northward and are exposed in great force for nearly a mile of fresh cuttings where the road from Greenfield to Turners Falls crosses the dike, and from the Suspension bridge, at the end of this road, along the river side for a mile north, to the mouth of Fall River and beyond. Through all this area prehnite and the products of its decomposition occupy the amygdaloidal cavities in very great quantity, accompanied everywhere by traces of copper minerals in place of calcite and chalcedony, which abound farther south. The masses of native copper found in the till must come from here.

The most interesting variety is a very coarse one, abundant on the Greenfield road, which coutrasts pleasantly with the somber gray of the prevailing types. Broad white plates of the feldspar stand out upon a dark-red background of decomposed augite, the whole sprinkled with amygdules of prehnite and diabantite. That this coarse variety is younger than the greenish-gray subporphyritic trap is clear from a large slab from the middle of the slope on the Greenfield road, showing a contact of the two, upon which the latter is cut off immediately and sharply and without change, while the former has a layer of deep-red, very fine-grained rock $15^{\mathrm{mm}}$ wide adjacent to the contact plane. It seems to me, however, to represent only a slight difference in age and to be probably a case of "schlieren," in the sense of E. Reyer. ${ }^{1}$

An exceptional rock occurs abundantly in bowlders on the south side of

1 Theorïtische Geologie, 1888, p. 80. 
the Deerfiell River, but I have not met it on the north or in place. It is a clear, light-gray rock, with roundish blotches of white, and it looks like a weathered lencitophyre. Under the microscope the blotches are seen to be malle up of aggregated stout crystals of plagioclase, and the rest of the mass between of rorlike plagioclase and magnetite, with almost no augite. The rare amygdules in this rock are filled with a fine silky, radiated mineral, apparently an altered prehnite resting upon diabantite, or more rarely lined with glassy crystals of albite, with datolite, pyrite, or globules of zincblende.

RED DIOPSIDE-DIABASE, WITH SECONDARY ALBITE.

Much of the basal part of the Deerfield bed just north of the Deerfield River is a peculiar rock, remarkably different from the usual monotonous trap of the region. It has been radically metamorphosed by hot water during its cooling. It is a fresh, fine-grained, brick-red rock, full of small cavities and scattered larger ones, both lined or filled with exquisite albite crystals large enough to be easily studied with a lens (fig. 24, C, p. 422). The feldspars "of first consolidation" in the body of the trap, which are near oligoclase, have been floated to their present place in delicate feathery groups. They retain their sharp crystal outlines and trace of cleavage and multiple twinning on two bands, but have been changed to a sericitic mass of subparallel scales and needles of two kinds, very minute needles polarizing in low colors $0.015^{\mathrm{mm}}$ long and $0.0003^{\mathrm{mm}}$ wide, and brightly polarizing scales $0.04^{\mathrm{mm}}$ long. They seem to be kaolin and mica.

The ordinary brown interstitial augite is wanting, but a few much twinned idiomorphic diopside crystals occur. The above minerals are free from the very abundant hematite which in grains and dendritic growths fill the second generation of feldspars and make most of the slide opaque, and which entirely replace the usual black ores and colored angites. The second generation of feldspars is often in sheaves of parallel fibers, one or more generally projecting far beyond the rest. They are heavily loaded with the red rust, but often have clear borders or the rust is in a cross occupying the diagonals to the square sections.

Many of the cavities are filled with a fresh albite mosaic, and this at times closely resembles the limpid feldspar mosaic of the amphibolites, being often without twinning and showing the same concentric polarization. This want of twinning is largely due to the development of the albite in 
mica-like scales with their M (010) faces arranged parallel to the section plane, so that they show no twinning, but give with convergent polarized light a negative bisectrix.

In some of the large cavities a broad-bladed mineral, probably barite, has formed in many separate and parallel plates, and all these have been coated with albite and then removed by solution. Chalcopyrite also appears in these cavities. There is no diabantite nor any trace of ordinary weathering in the slide; and it is probable that heated waters acting on a magma in which the first feldspars were floating have decomposed these, changed all the iron into hematite, thus preventing the formation of the dark augite and the black ores, and have then deposited the residumm of the feldspathic material in the steam holes. Specimens can be obtained where the trap has recently been blasted to make way for the electric road and the fragments dumped on the steep slope extending down to the Deerfield River.

The difference of the rock from the normal diabase is shown by order of crystallization of the constituents of this and of the normal diabase.

Diopside-diabase.

First plagioclase.

Diopside.

Hematite.

Second plagioclase.

Steam holes.

Third plagioclase.
Normal diabase.

Magnetite.
First plagioclase.
Second plagioclase.
Angite.
Steam holes.
Diabantite.

Magnetite.

First plagioclase.

Angite.

Diabautite.

It is interesting to see here the development of the sericitic growth and the albite mosaic without the formation of hornblende.

The rock here incloses fragments of fine sandstone exactly like those found at the Greenfield quarry about 3 miles north on the same dike, and, as there, it is greatly baked and fused with the trap. (See p. 419.)

\section{PARAGENESIS OF SECONDART MINERALS.}

During the summer of 1880 a heary cut was made through the trap on the south side of the Deerfield River for the extension of the Canal Railroad, which opened up veins carrying the usual trap minerals in great abundance and beauty. The veins run nearly vertical, with a thickness not above 4 inches, and they were exposed to a depth of 60 feet. Later a similar cutting along the north side of the stream and directly opposite afforded many large cavities filled with the finest transparent datolite of unusual size, but lacking 
wholly the variety shown on the south side. I have included a detailed study of these minerals in the Mineralogieal Lexicon, ${ }^{1}$ and give here-

1. The paragenesis of the stilbite-chabazite veins-

1. liadiated stilbite.

2. Chabazite.

3. Oalcite.

4. Pyrite; or
1. Prehnite.

2. Heulandite.

3. Prismatic stilbite.

4. Chabazite.

5. Calcite.

2. A general table of the paragenesis of the minerals found. The oldest is first, and the overlap of the words corresponds approximately to the overlap of the minerals:

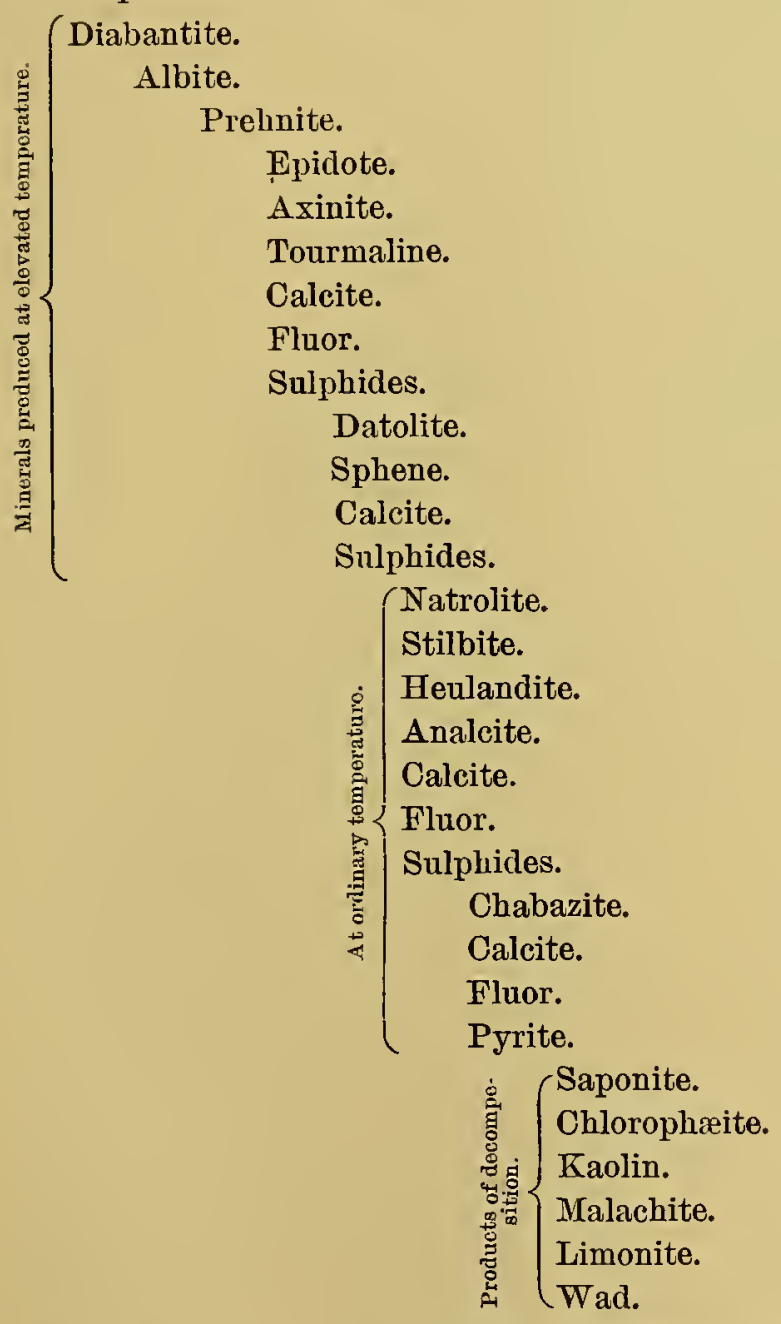

${ }^{1}$ Bull. U. S. Geol. Survey No. 126, 1895. 
THE HOLYOKE SHEET.

Situated a few miles below College Hill, Mount Holyoke has been for many years annually visited by me with my classes, and has been also assigned, part by part, to small groups of advanced students for their first essays in practical geological work. Many men who have devoted their lives to geology were of especial assistance to me in making out the structure of this rugged and heavily wooded area. ${ }^{1}$

The great sheet of diabase which makes through most of its leugth the crest of the Holyoke range is a contemporaneous flow resting upon the coarse granitic sandstone, which it bakes, and it is covered by exactly similar coarse, light-buff sandstone. (See Pl. IX.)

In the eastern end of the range the bluffs which overhang the Belchertown ponds contain no trap, and one must skirt the sandstone ridge for a long distance westward before coming to the first outcrop' of the volcanic rock. This emerges from the sands of the post-Glacial lake (in the roadside just east of H. and L. E. Upham's house) midway ou the north slope of the ridge.

Curiously, this easteru end of the sheet, where it disappears beneath the sauds, is directed northeast, while the south end of the great Deerfield bed in Mount Toby is directed southeast, toward the great core of diabase

${ }^{1}$ In 1894 Mr. Benjamin Smith Lyman published, in an article entitled "Some New Red uorizons" (Proc. Am. Puilos. Soc., Vol. XXXIlI, p. 192), "a conjectural map of the Connecticut and Massachusetts New Red." This map is said to bave been "compiled from Professor Emerson's map of the Massachusetts New Red," so far as the part here under discussion is concerned. On the same page (loc. cit., p. 202) it is stated that "the topography seemed to indicate clearly the necessity of reducing the extent of the trap, in some places very nuch," and "in Massachnsetts, too, near Mount Toby, and at the eastern end of Mount Holjoke, the topography seemed to require the changes that bare been made in the mapping of the trap." As a result, the trap is carried aloug the bare sandstone ridges to the Belclertown ponds and apparently doubled in a wholly inaccurate way, while the Deerfield berl is still more wrongly drawn. The whole shows clearly the incapacity of the gentleman to interpret topography in terms of geology. Again, the coarse conglomerates of Mount Toby, which my map shows to rest on all sides directly on the crystallines, is assigned to the "Grynnedd shales" and placed in the upper half of the series abore the "Norristown shales," to which a thickness of $6,100 \pm$ feet is assigned. All the fossils of the Trias are referred in an indefinite way to tho "Norristown shales"that is, to a horizon below the Mount Toby conglomerates, which is also wide of the facts. At the beginning of the article, in the midst of several pages of harsh criticism of uis predecessors, the author says of his attempt, "There is reason to hope that it may keep well within the not wholly unprecedented New Red proportions of 2 bushels of conjecture to 2 grains of fully ascertained fact." (Loc. cit., p. 193.) So far as Massachusetts is concerned, I think he has hardly kept within the proportions he had set himself, and this is the more surprising as the author is a native and nominal resident of Northampton, which is in sight of the rocks he has mapped so incorrectly. 
9 



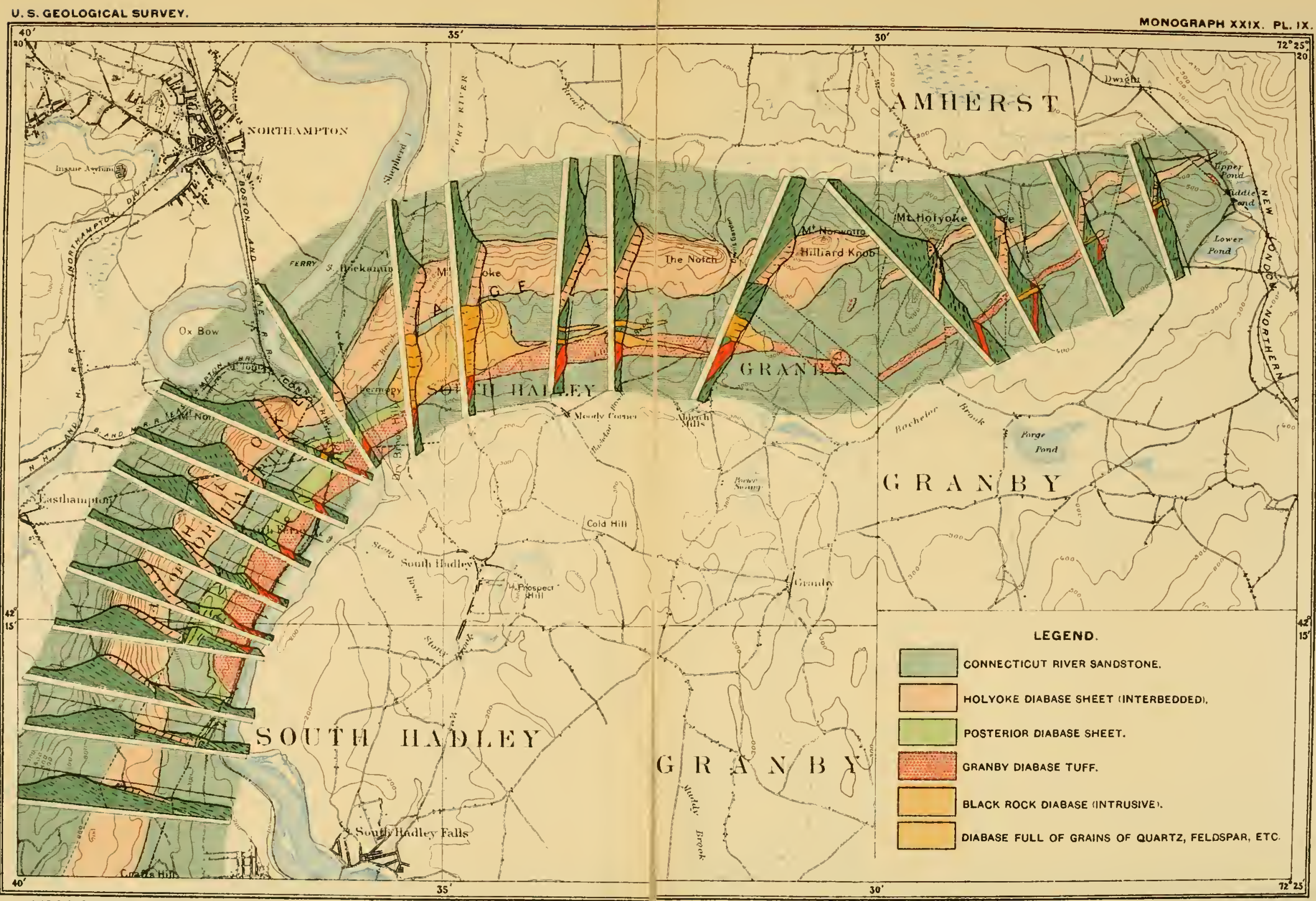

GEOLOGICAL MAP AND SECTIONS OF THE HOLYOKE AND POST ERIOR DIABASE SHEETS, THE TUFF, AND THE VOLCANIC CORES.

HV B. K. EME KSUN. 1892.

$\frac{1}{\text { Comtour Intor }}$ 

in Pelham, on Amethyst Brook. The slieet mounts the hillside obliquely towarl the west, and where it reaches the crest of the hill has at thickness of abont 260 feet, and where it crosses the first road, the Bay road, ruming to Belchertown, of about 370 feet. It presents only a low bluff to the north and dips sonth with an angle of $25^{\circ}$. It does not grow much thicker as it is followed west, nor does the bluff become more prominent until, having. passer the second road over the mountain, it rises to a much greater height in the long, flat-topped ridge which is so marked an object as seen from the north and which is locally called Long Mountain or Flat Top. The crest has had across Belchertown a height of 450 to 475 feet above the sea, but rises in Long Mountain to a height of 600 feet. This is explained in part by the thickening of the bed, which measures here 542 feet east of the Granby road, 612 feet at the eastern central, 770 feet at the center, and 824 feet at the western central part of the mountain. The last of these measurements was made carefully with a chain by Mr. W. E. Sanderson. It would seem that several undiscovered faults must have been crossed, as the number seems much too large.

This sudden elevation of Long Mountain is also partly explained by the faults which bound it on the east and west and present the edge of the sheet in this mountain at a better angle for resisting the southward movement of the ice. The fault on the east is beautifully marked, runs with the dip, and transfers the outcrop of the bed southward by just the amount of its width. The second fault is directed southwesterly, making a large angle with the dip, and on its eastern side the dips have more easting, so that the outcrop of the diabase extends southwestward for a long way and ends in a point far sonth of the main ridge. (See Pl. IX.)

Following the ridge a mile west one sees a sharp, heavily wooded, conical peak, locally called Rattlesnake Knob, which is the mext marked peak after leaving Long Mountain, and which is a quite exact imitation on a small scale of the next high peak to the west, namely, Norwottock or Hilliards Knob, the highest point on the ridge east of the Connecticut. To the east of the small cone is a deep, semicircular depression, exactly like one at the western foot of Long Mountain, and like it caused by a great fault. In both these depressions sandstone forms the crest of the ridge.

Both these faults run southwest, and between them an isolated section of the trap sheet, called Bishops Mountain, is placed, en échelon, running 
southwest far down behind the continuation of the bed, which, starting again in the small cone, Rattlesnake Knob, runs on westwardly through Norwottuck. Bishops Mountain is a ligh isolated ridge. ${ }^{1}$

This fault is, on the eastward face of the small cone, marked by an almost vertical wall, nearly a hundred feet high, and climbing this wall one finds midway a narrow shelf, composed of the sandstone resting against the trap. The sandstone is not baked, nor is the trap amygdaloidal, nor aphanitic, but of the grain usual to the central portion of the bed. It is, however, brecciated at the contact by crushing and recemented by silica, as can be seen by digging at the southeast corner of the narrow flat.

Westwardly the heavy vertical bluff continues, deeply notched at the "Notch" and the "Low Place," until, after presenting for several miles its vertical wall to the north, it sweeps down in a magnificent section, nearly at right angles to its dip, from the height on which the Holyoke House stands, past Titans Piazza with its fine columns, to Titans Pier, where it plunges beneath the waters of the Connecticut to rise on the west side of the river to the top of Nonotuck in a section which is the counterpart of that on the east.

The Notch is produced by erosion on a northwest-sontheast fault, with upthrow on the east, which causes the fine northeast bluff of Bear Mountain on the west of the notch road and the equally marked southwest bluff, which stretches away southeast on the southern aspect of the range east of the road.

That the Holyoke and Mount Tom beds are connected beneath the river admits of no doubt. As one stands below Titans Piazza, midway in the Mount Holyoke section, and looks across the river, the Mount Tom section opposite is seen to be the exact counterpart of the former, and from the two mountain houses which crown the crests of the ridges on either side of the river the massive beds sink down southwardly, and agree in the character of the sandstone beneath, in the amount of its baking by the bed, and in the character and thickness of the trap itself. The Holyoke ridge ends in Titans Pier, whose vertical walls rise 65 feet above the water, and at exactly the corresponding point on the opposite bank the trap appears and runs west in a heavy ridge across the low terrace flats and, turning, mounts up to the crest of Mount Nonotuck and forms the high continuous ridge to its culmination in Mount Tom. 
Secn from the west, a marked depression and eastward recession of a central section of the trap ridge is manifest, and as the smaller eastern bed was finely faulted at points opposite to the extremities of this section and the part between the faults moved east, these faults were prolonged westerly to explain the structure of the main bed, and I was able by later study to locate them quite exactly on the ground. The northern is very plainly marked in the western boundary of the main sheet, which bends sharply east in an acute angle.

\section{THE FAULTS AT MOUNT TOM AND SOUTHWARD.}

Viewed from the south, Mount Tom is a table mountain, liaving a nearly horizontal sheet of trap, 300 feet thick, resting upon a great pedestal of sandstone which rises about 900 feet above the sea, with vertical scarp on west, south, and east. At the foot of the eastern scarp a fault runs very obliquely to the course of the bed, about N. $35^{\circ} \mathrm{E}$., and on the west of this fault the mass is raised about 650 feet, so that if one stands on the road south of the mountain the trap seems to come to a sudden end in Mount Tom, but turning eastward one can traverse its whole width and can follow it thence south continuously across the State, and can trace the sandstone north in a sharp triangular projection sent in between the two sections of the trap by the displacement of the fault. This eastward-facing bluff of Mount Tom sinks northwardly; but where the fault crosses the river and makes the westward-facing bluff of Mount Holyoke the throw is about the same.

At Titans Piazza we have strike N. $85^{\circ}$ W., dip $22^{\circ}$ S., which would carry the base of the trap far below the level of the river at Titans Pier. Since, then, the lower contact appears at the water's edge at Titans Pier, another fault must pass to the east of this point, running between the pier and the piazza, with an upthrow on the west of about 625 feet.

The new Holyoke reservoir lies just across the north line of Holyoke in Northampton, and the wood road from its north end soon crosses a brook rumning north, and here the gray sandstone rests against the main sheet of trap, which is brecciated for several feet down and cemented by a fine, light-gray sand at the contact on the fault.

The slickensided fault-wall has been well exposed by the cut on the electric road just south of the lower station of the cable road onto Mount Tom; and about 5 rods south along the fault, where a small brook comes MON XXIX- 29 
down over the trap, above a small quarry, is an excellent exposure of the fault showing a marked brecciation of the adjacent beds.

The ridge reaches its culmination in Mount Tom because of the great ripthrow on the fault rumning at the eastem foot of the mountain, and not because of any thickening of the trap sheet there; it has a thickness of about 250 feet at Mount Nonotuck and about 300 at Mount Tom. It then sinks down to a comparatively low level, but continues south as an unbroken ridge, rising in Provens Mountain, in Agawam, to 625 feet, and running, with thickness not greatly diminished, to the south line of the State, and upon Percival's map of Connecticut it is prolonged without intermption to the south line of Simsbury.

Parallel to the Mount Tom fault run three others, farther south, which cross the trap ridge very obliquely; and, which is of more interest and importance, all four run parallel to the western rocky border of the basin. One forms a gap in the range in Holyoke through which passes the railroad which comnects this town with Westfield, and this I have called the Holyoke fault. The second forms the notch for the passage of the Westfield River, after which I have named it. The third determines a notch in the range at the point where it enters Connecticut, and I have referred to it as the State-line fault. ${ }^{1}$

These parallel faults divide the country into narrow orographic blocks which are tilted to the east, producing the uniform easterly dip; and, furthermore, each block seems to be raised vertically as compared with its neighbor to the east, a structure which seems most marked in the case of Mount Tom.

This produces a pattern in the boundary of the trap ridge on the map which is repeated at each fault. The western boundary of trap on sandstone below swings round in sickle shape to meet the fault, while the eastern boundary of sandstone on trap is transferred to the northeast along the fault line. Thus the ridges are slightly echeloned, ending in a high rounded bluff on the south, while the continuation of the ridge is to be found moved north and east and beginning in a sharp point.

As the fault lines run so nearly parallel to the trap itself, they form the boundary of the latter for long distances. This is recognizable on the east by the fact that where the sandstone rests normally on the trap the upper surface is very scoriaceous and full of inclusions; where the fault boundary

ISee pages 370, 476, for further discussion of State-line fault where it crosses the posterior dike and the river at the Holyoke dam. 
is present on this side, sandstone occur's in immediate proximity to compact trap for long distances. On the west, in many cases, if not in all, vertical blutt's :und "Devil's Gardens" of trap débris coincide with the fault boundaries of the trap along the uplifted edge of the blocks. The researches of von Koenen ${ }^{1}$ as to recent movements on such fault planes suggest the possibility thit many of these vertical trap bluffs may be the result of such recent movements. I think this consideration has sufficient force to deprive these vertical bluffs of any value as measures of the time since the disappearance of the ice, as I bave attempted to use them elserwhere. The effect of these faults is more manifest upon the narrow posterior bed. (See p. 473.)

The results regarding Triassic faulting are in accord with the very valuable discoveries of Prof. W. M. Davis in Connecticut (p. 377.) So far as the substratum beneatb the Triassic is regular and bas north-south strike, the faults agree therewith. Where, under the Mount Holyoke range, the substratum is a great granite massive and two great trap plugs further complicate matters, the fanlts are correspondingly irregular.

GENERAL CHARACTERISTICS OF THE SHEET.

At the east end the bed is amygdaloidal in almost its entire thickness, and greatly decomposed. This general decomposition of the whole mass is a striking characteristic of the whole bed, and even where it seems as fresh as possible, as where it was blasted through at the "Iron Gate" (Thermopylæ) for the passage of the riverside road to South Hadley, the microscope shows it to be deeply decomposed. It presents far less range and variety of texture than the Deerfield bed, being mostly aphanitic and showing only a faint porphyritic structure by the development of the earlier generation of feldspars to distinct visibility. Back of the Holyoke Mountain House and on Titans Pier it is exceptionally coarse-grained and gabbro-like in texture, the broad, flat, black sheets of pyroxene being often markedly warped and one-half inch in length. Unlike the newer traps, its fissures are cemented by quartz.

Following the sheet westward the amygdaloidal texture is confined to the upper portion of the bed, except where it is under-rolled, when a marked steam-hole structure takes its place at the base of the bed.

It is everywhere, after reaching its full thickness, rudely columnar, and at Titans Piazza the columns are of the largest size and in great perfection.

1 Jahrbuch K. preuss. geol. Landesanstait, 1886, p. 467. 
NORMAL CONTACTS OF DIABASE ON SANDSTONE.

East of the Bay road, the most easterly road crossing the Holyoke range, no direct contacts are visible. Pieces of the sandstone indurated by the trap have been found in the neighborhood of the lower contact.

At the northwest shoulder of Rattlesnake Knob-the conical hill east of Norwottuck, or Hilliards Knob-a very interesting contact is exposed. If one goes east from the fault which limits the trap at the east foot of the peak, and follows the contact as nearly as may be across the talus at the north foot of the peak to a point below and a few rods west of where the peak sinks down to the ridge which connects it with Norwottuck, one finds a vertical wall of the trap projecting over the sandstone where the contact is exposed. The diabase is fine-grained, and the dark-red sandstone is baked for 3 feet down to an unusual degree into a rock closely resembling a schalstein.

At the northwest corner of the sharp peak of Norwottuck, at the corner of a cleared field, a contact can be observed. The sandstone is indurated for a short distance.

The next point is more accessible, being to the west of and just over the Notch road at the north corner of the "Devils Garden," where the trap can be seen from the road below to be overhanging. Here the sandstone is coarse and is darkened and indurated to a complete quartzite for a foot down, and slightly vesicular.

There is another exposure on the south side of the north footpath to Mount Holyoke. ${ }^{1}$

The next place is just north of Titans Piazza, a place figured by President Hitcheock, ${ }^{2}$ and here the diabase is at its base very black and compact and full of vertical steam holes a foot or more long. The sandstone below is baked into a tough quartzite or hornfels for a foot down.

CONTACTS OF UNDER-ROLLED DIABASE CONTAINING INCLUSIONS OF LIMESTONE.

A remarkable wall of trap is exposed at low water of the river at the north foot of Titans Pier, just where the Hadley town line reaches the river, below a small cemetery. The contact is visible for 100 feet. The

'E. Hitchcock, Am. Jour. Sei., Ist series, Vol. XIII, 1828, p. 218.

${ }^{2}$ Final Report, Geol. Mass., 1841, p. 640. 
coarse-grained, rusty sandstone below is but slightly indurated, and for only a small distance. The diabase is aphanitic and full of steam holes for 13 feet up, and contains in great number angular fragments and long filaments of a drab, fine-grained, compact argillaceous limestone, up to 6 inches in length, together with fragments of a fine-grained micaceous sandstone. The two are often kneaded together, as if both had been plastic. The lower foot of the trap is quite free from inclusions, and the pores are here large, distant, and more like the cavities formed by the upward motion of the steam than by simple expansion.

Both these rocks are represented in the Chicopee shale, and this point is at the northern limit of this series. They are mulike the coarse sandstone on which the trap rests; so that it is not impossible that the trap may be slightly faulted upon the sandstone at this point.

This is the material which was classified by President Hitcheock as a variety of greenstone, under the title "indurated clay," and the locality given above is the only one cited. ${ }^{2}$

\section{PETROGRAPHICAL DESCRIPTION.}

Under the microscope the limestone is fine-grained, with many grains of quartz as well as of calcite. In a narrow, superficial layer, $\frac{1}{2} \mathrm{~mm}$ wide, at the contact of trap and limestone the limestone is recrystallized as a much coarser and purer calcite. Along one portion of this zone the cross sections of distinct, sharp scalenohedra appear, and these are now covered by a layer, $\frac{1}{10} \mathrm{~mm}$ thick, of a finely fibrous mineral. Rarely there oceurs in this zone a long blade with rounded end extinguishing longitudinally and inclosing rounded grains of calcite resembling those included in the Laurentian apatites. The mineral seems to be tremolite. The calcite scalenohedra rest on the diabase at the contact line, and project into the recrystallized zone of the calcite, where they are surrounded by the colorless fibrous layer (aragonite?), which is of constant thickness, and upon this rests a botryoidal layer of ankerite or siderite in simple rhombohedra, with rust marking the cleavage, and above this a coarsely crystalline calcite.

In the above section the diabase is typical and is unchanged up to the contact, and the recrystallized band gives no evidence of ligh temperature. In a second section, cut a few inches from the first, the results are quite different. There is no zone of coarser crystallization surrounding the 
limestone, but here and there a large crystal has developed porphyritically, enveloping the dusty ground in which it grew. In several cases five scalenohedra are joined at base to form a star. In one place is a round section, $4^{\mathrm{mm}}$ across, of coarsely granular and clear calcite without the dusty matter of the rest of the limestone, and with its large grains untwinned, which projects half into the limestone and half into the trap, as if the two had been plastic together and a steam hole had been formed at the border. Another oval body of the same size as the above is composed of the same clay-dusted granular limestone as the large fragment, but has a border of larger grains, and, while retaining its shape and individuality, is thrust a third of its length into the main mass, while two-thirds its length projects into the trap. It seems here also as if the large mass must have been plastic and impressed by the smaller one. The limestone fragment itself has straight sides and shows a distinct contact effect, its mass being slightly reddish, while a border $2^{\mathrm{mm}}$ broad is greenish and is separated from the reddish interior by a band of black cubes, apparently altered pyrite.

The endomorphic changes in the trap are much more marked than in the former case. A zone $2 \frac{1 \mathrm{~mm}}{2}$ wide is made up of a red-brown base in which the few and distant feldspars appear like windows. A broad, clear, brown halo surrounds each feldspar and an opaque brown mass fills the scanty interspaces. This gives the groundmass a curdled appearance. It contains beautifully sharp calcite crystals, scalenohedra and rhombohedra. With higher magnifying power the ground is resolved into a fine hyalopilitic groundmass made up of beaded threads $\frac{1}{800}$ to $\frac{1}{1200} \mathrm{~mm}$ across and $\frac{1}{30} \mathrm{~mm}$ long, radiating in tufts from the feldspars and showing aggregate polarization and black cross. It polarizes in blue colors. This felt of fine threads is beaded with a black dust to make the more opaque portion of the ground. This zone passes gradually into the normal diabase.

A contact of the trap with the sandstone below is exposed in the road leading up to the Nonotuck House, showing a distinct but not important induration of the sandstone. It contains the same inclusions of limestone.

The diabase at its contact with the sandstone below, at the northwest shoulder of the peak next southwest of the Nonotuck House, is for a height of 7 feet kneaded full of fragments of a fine-grained buff sandstone, and the trap itself is filled with dark-green amygdules. The sandstone effervesces only at its contact with the trap. The diabase is greatly decomposed, only 
the foldspars retaining their form. 'The amygdules consist of radiated diabantite, so fine-fibrous that it looks like an olive-green serpentine, and it scurcely polarizes. In it are grains and crystals of calcite, and, floating freely, many small fenthery albite groups, visible only with the microscope, and resembling those described (p. 443) from the cavities of the Deerfield diabase. They are in twins; extinction 6 to $9^{\circ}$ on each side of twinning suture. In one case the angle of extinction with the trace of $0 \mathrm{P}(001)$ measured on $\infty \mathrm{P} \breve{\infty}(010)$ was $+4^{\circ}$, indicating albite.

Also where the boundary of the trap swings farthest east at the south foot of this peak the base of the trap is full of angular fragments of dovecolored indurated clay, calcareous and having minute muscovite scales, and the two substances are molded together and the trap is amygdaloidal, as at the occurrence on the south line of Holyoke. Under the microscope secondary plagioclase rods like those in the diabantite cavities can be seen in this rock, and they are visible as shining lines with a lens. The trap at contact shows a distinct endomorphic change. The feldspar rods decrease in size and number and the magnetite grains increase until a black opaque border $2-3^{\mathrm{mm}}$ wide intervenes. In other places the trap is shattered and its fragments mingle witl the sedimentary matter (see p. 368). A further contact occurs just north of the Westfield-Holyoke highway, directly west of the town line. Here the baking of the sandstone is marked, but the trap above does not contain inclusions.

NORMAL CONTACT OF THE SANDSTONE ON THE DIABASE.

At all points where the upper contact could be seen the diabase is very amygdaloidal and is often finely filled with secondary calcite and zeolites. The sandstones rest upon the trap, filling irregularities, and not in the smallest degree indurated or 'in any way showing heat effects.

Dry Brook, which runs by Larrabee's quarry in the extreme north of South Hadley, flows for a long distance west along the back of the southward-sloping trap sheet, with sandstone for its lower (south) bank, and it affords the longest continuous section of the contact. Following it up eastward over the divide a similar valley runs east and continues to expose the same contact, and farther east it is shown in each brook gorge that comes down the south of the mountain. The amygdules are here filled with natrolite and calcite, and form beautiful objects under the microscope. 
The above description applies to all contacts from the east end of the bed to the Connecticut River and from the Westfield River to the south line of the State.

CONTACTS OF SANDSTONE ON DIABASE WHICH IS KNEADED FULL OF LIMESTONE AND SHALE.

Between the Comnecticut and Westfield rivers fine shales rest on the trap, and the upper surface of the latter is full of inclusions of limestone and shale. This can be seen just south of the station of the Mount Tom Electric Road, but it can be studied best at Dibbles Crossing on the south line of Holyoke, as described below.

SECTION OF TRAP FILLED WITH LIMESTONE FRAGMENTS ON THE WESTFIELDHOLYOKE RAILROAD.

At the first rock cuttings in the main trap sheet on the railroad near the south line of the towu of Holyoke the upper surface of the bed is exposed and is covered by thin-fissile argillaceous sandstones containing Pachyphyllum. For a distance on the strike (north-south) of 1,475 feet, and with the dip (east-west) of 200 feet, the upper portion of the bed, to a thickness of 6 to 12 feet, is so filled with fragments of the clayey limestone and sandstone that everywhere the two rocks are present in about equal quantity. The limestone is in small pieces, angular and little altered, or the pearl-gray fragments are molded and kneaded together with the trap. It is as if the trap, plastic from heat, were molded together with the marl, plastic from moisture. The trap is fine-amygdaloidal, the cavities filled with secondary calcite and diabantite. In the section figured on Pl. III, fig. 4 (p. 208), the trap is already solid; the mud flows into its minute cavities. When polished surfaces of the mass and thin sections are examined, the fact of the mutual molding of the two rocks is clearly established. (See Pl. VIII b, figs. 1,2 , p. 428 .)

With a lens the limestone is seen to be fine-oolitic, at times very distinctly so, with round grains 0.6 to $0.9^{\mathrm{mm}}$ in diameter and made up of finely granular material dusted with minute opaque grains. There is only rarely a trace of concentric structure. At times the amount of clay becomes considerable and the fragments are of a thin-laminated calcareous marlite. That this limestone was deposited in place and has molded the trap is 
entirely clear from an inspection of the figure, showing how it surrounds multitudes of the trap fragments and insinuates itself into all sorts of narrow and tortuous crevices. It can be seen where the muddy mass has flowed into steam holes broken into on the surface of the trap, and there is a distinct fluidal structure of partly concentric lines in the mass, each bending less deeply into the cavity than its forermmer. The limestone is in places brecciated by the internal motion and explosions of the mass, its fragments in part rounded by solution and recemented; it is homogeneous in every part, and shows no marked effects at the inmediate contact.

If it is clear that these fragments of trap have been molded in the oolitic mud, it is equally clear that this mud has been involved in the liquid trap. Indeed, the thin sections were made from a point in the wall of the great trap sheet exposed in the railroad cutting at least 10 feet below the surface and wholly included in the continuous mass. That the trap fragments were liquid when they came in contact with the limestone is shown by the endomorphic effects produced in the trap itself at the contact. There is generally a thin film of pure and transparent glass in contact with the limestone; then comes a border, 3 to $5^{\mathrm{mm}}$ wide, which is dense black from the amount of fine magnetite grains precipitated in a colorless ground and contains exceedingly minute feldspar needles. In the larger fragments the feldspars gradually enlarge toward the center and the magnetite diminishes until a normal trap results in which the larger generation of feldspars contains fine ramose glass inclusions, but in fragments less than $10^{\mathrm{mm}}$ in diameter the whole section is dense black. The small, round steam holes are much more abundant in these borders than farther within the normal trap.

Streams of the small rounded grains of limestone can be seen penetrating the trap, running into it for several millimeters. The grains are in great numbers, at first in contact with each other and without trace of intervening trap, and as the stream is followed inward the rounded grains separate and float freely in the trap. They are distinguished from the secondary steamhole fillings of crystalline calcite by being of finely granular material, often dusted with black trap grains. This black trap dust is abundant in places in the larger limestone masses and is an indication of the shattering of the liot trap by the oolitic mud. The true steam pores are filled with diabantite or calcite coarsely crystallized in transparent masses showing many twin laminæ. 
The marl and trap are often intimately mixed together like two nonmiscible fluids, and the dark-gray or red-brown trap and the pale-gray clay rock produce the effect of Castile soap. Long filaments and stringers and rows of bubbles of the clay go out very generally from the larger masses of the clay rock into the trap in a way explicable only on the assumption that a mass of muddy clay was thrust suddenly into the liquid trap. At the north end of the east wall of the cutting is a sheet of the clayey sandstone, which is about 12 feet long, a foot wide at the center, and tapering to nothing at the ends. Above and below this the trap is coarsely amygdaloidal, or rather abounding with rounded, beaded, and variously lobed eavities, which are filled with the gray mud. ${ }^{1}$ Some of the pores were left empty or only partly filled by the mud, and these are filled with white infiltrated calcite, making a striking contrast. In many cases it can be seen that the mud has risen from the stratified mass of the argillaceous rock to form and fill the cavities. That the bubble-like masses of mud have thus risen from this larger mass, and that they are regularly disseminated in the trap and are not simply the filling of superficial steam holes, can be clearly seen, and the trap can be chipped off and layer after layer of the gray drops seen to be isolated in the trap (see Pl. VIIIb, fig. 1, p. 428).

In one case there can be seen at the height of one's eye, at the south end of the west wall, a series of blocks filled with drops, and the mud mass from which they stream can be seen below, while now the mass containing these mud amygdules is itself shattered and its fragments cemented by more of the same mud (see Pl. VIIIb, fig. 2). In other places a thin, gray, laminated, sandy shale is confusedly mingled in the trap, its layers being greatly warped and twisted. Under the microscope the mixture can be seen to be still more intimate, and while there was often a complete emulsion of the two nonmiscible fluids there is only a slight chemical action discernible. Only a microscopic layer of recrystallized carbonates appears. $^{2}$

In other cases the whole wall has a coarse, conglomeratic look, rounded

\footnotetext{
1 The later infiltration of calcite has changed this mud iuto a massive gray rock exarstly like the claystones so common in the Champlain clays.

If anyone visits this most interesting locality, which is situated 4 miles from Holyoke, on the road to Westfield, he will find that the ridge running from the Dibble house sonth to the next house is cut by the railroad, showing the trap and the sandstone above. In the swale west of this small ridge is a fault, which can be seen in the brook directly behind the second house. West of this fault the series is repeated, and the broad surface of the trap for a mile north is filled with the foreign material.
} 
portions of the trap as large as a fist being wrapped around by thick flakes of the thin-fissile, sandy shale, as if balls of putty had been separated by being folded in thick wads of wet wrapping paper.

Above this intimate mixture a few angular fragments of scoria are inclosed for a foot or two in the thin-bedded sandstones. This layer can be followed north 10 miles wherever the upper surface of the trap is exposed.

Another contact of the sandstone upon the trap occurs on the Westfield-Holyoke highway, just where it crosses a brook, and this is the most southern point where the trap contains limestone inclusions at its surface.

President Hitchcock plainly refers to a further effect of the trap farther south on this line, in West Springfield, at a place which escaped my observation, when he speaks of the limestone in contact with the trap being converted to "tripoli" and in part made brittle as glass.

\section{MAGMATIN DIFFERENTIATION.}

Many fragments of the trap which were inclosed in the mud while still molten are bordered with black from the concentration of the iron in feathery groups of twinned octahedra of magnetite. This illustrates on a small scale a process which has been the subject of much study-the differentiation of a molten magma into a more basic portion, which seeks the cooled outer surface, and a more acid one, which remains at the center. When this process is carried to its limit the centers of the fragments become white and free from iron and iron-bearing minerals, and the fragments of white trap described on page 365 seem to have been thus formed. They are found only in this contact layer and in the sandstone immediately above it.

ORIGIN OF THE CLAY AND MLARL DEPOSITS.

It is hard to explain how, over a portion of the surface of the great sheet, so large a quantity of laminated marl can have been deposited and then become so regularly and deeply intermixed with the trap. It seems most probable that the central currents carried the mud out over the sheet while it was still moving, and filled its brecciated surface, and that the mud flakes sank down at times into the still-liquid trap in such quantity that they were merely indurated and cemented by the small quantity of the diabase. 
The thick trap sheets flowed out over the muddy bottom of the bay, and their heat produced strong upward convection currents and correspondingly strong indrafts from the sides, which carried muddy waters out over the surface of the trap while it was still flowing and covered it with a quantity of calcareous mud out of proportion to what would have been carried in the same time by the normal currents. I have seen sheets of newly solidified lava careen and slide beneath the liquid mass at Kilavea, and the sheets of mud and lava may have thus become variously mingled here, producing the results described above. The surface of the Holyoke trap sheet is filled with fine mud just as far north as the fine Chicopee shales extend; and farther north, where the sheet flowed over coarse gravel, nothing of the kind occurred, because the coarse gravel could not be thus carried out over the thick sheet.

\section{ON THE UNDER-ROLLING OF THE SOLIDIFIED SURFACE OF THE TRAP.}

The appearance of the same layer at the base of the trap sheet is explained by the under-rolling of the newly solidified surface of the sheet, as when a carpet is unrolled on the floor what was on top descends along the front and comes to lie inverted beneath.

Thus the porous mud-filled surface came to form, inverted, the base of the bed, and to rest, though filled with fine mand, upon the coarse sand onto whieh the sheet had advanced. ${ }^{1}$

${ }^{1}$ I have already reported very briefly npon this occnrrence (Am. Jonr. Sci., 3d series, Vol. XLIII, p. 147); too briefly, it would seem, as the facts given were wholly misunderstood and incorrectly quoted by Professor Dana and made to do dnty in proof of the laccolithic origin of the Monnt Tom trap sheet. In his Mannal of Geology, on page 805, he says: "The limestone had been torn off from a layer not visible in the section."

This was the very point I was trying to disprove, by showing both that there was no bed in the older rocks of the region from which any such material conld be derived and that the shapes of the inclusions were not snch as would be possible in solid rock torn off from the walls of the fissure throngh which the lava flowed, since it was in thin filaments and flowed in to fill all the open steam holes of the trap fragments.

On the next page, 806, he says: "A laccolithic origin and the abrasion of the underlying sandstone are indicated by the occurrence of breccia beneath the trap, and especially by the limestone chips in the lower part of the mass of the trap, and also over its upper surface, as described by Emerson. A bed of limestone was evidently divided by the advancing tongne of melted trap, part being left below and the rest ahove. As Emerson observes: "The facts prove that the heavy trap flowed over the sandstone, abrading and tearing it."

This was plainly quoted from a very dim recollection of the article in question. There is no brecia beneath the trap. The inclusions can not be called chips, and there is not the slightest evidence that the melted trap has split asunder a bed of solid limestone. I have not made, in the article cited or elsewhere, the observation quoted in the last sentence, since the facts all prove exactly the opposite. I know of no facts favoring a laccolithic origin of the Holyoke trap sheet. 
At every point where the surface of the trap sheet can be inspected, from where it crosses the Connecticut to where it crosses the Westfield-Holyoke Railroad, it has included a great number of fragments of marly limestone and indurated clay, and the trap and limestone are often knended together. Within the same limits the base of the trap repeats all the peculiarities of the surface. It is anygdaloidal for about the same thickness and in the same way; the same dove-colored limestone occurs blended with the trap in the same way; and the subjacent arkose is almost wholly unaffected by heat. The 300 feet of trap have not produced so much effect as is often seen upon the border of a 10-foot dike. This is best studied at the river's edge at the north foot of Titans Pier. On the other hand, where the molten surface of the trap sheet has come in contact with the sands of the sea bottom, as at Titans Piazza, 100 rods north, the trap is aphanitic at the contact, but pierced by great vertical steam holes, and the sandstone is greatly baked. It seems that the broad submarine trap sheet moved slowly westward, its incrusted surface being covered by a fine marly clay deposit which was in places desiccated and. molded together with the still plastic trap, and that the surface was carried forward to be rolled over the front and become the bottom along a length of about 10 miles. The limestone and marlite inclusions of the surface and base of the trap have been described in detail above and their identity established, and similar cases of under-rolling of the Deerfield dike and of the posterior dike have been given elsewhere. ${ }^{1}$

PETROGRAPHICAL DESCRIPTION OF THE NORMAL DIABASE.

GENERAL DESCRIPTION.

The rock is so monotonously uniform in all its characteristics that much repetition will be avoided by giving first a general description of the common type and then following this by a special discussion of the peculiarities of separate occurrences.

The rock from the "Iron Gate," or Thermopylæ, where a passage has been blasted through a projection of the Holyoke sheet for the river road to South Hadley, near 'Titans Pier, coming from near the middle of the sheet, is an especially fresh-looking variety, and may serve as the new type for general description. 
It is a dark-gray, almost aphanitic rock, with broad conchoidal fracture and without any tinge of red or brown in its color. It is faintly subporphyritic, and with a leus the scattered, minute, squarish feldspar cross sections appear, and at times a triclinic striation can be observed. At times, also, one detects a black cleavage surface of angite, but only with difficulty.

Under the microscope the rock is seen to be a typical diabase, the network of elongate feldspars inclosing the shapeless masses of augite. Two generations of feldspar, augite, magnetite, and apatite make up the constituents.

The larger feldspars of earlier generation are distantly scattered in the field in squarish crystals or crystal groups, and measure about a millimeter across, and this is by far the commonest size in all the slides I have examined. They often show indication of transportation, being broken, or showing undulatory extinction, or having an external band which extinguishes differently from the central. A delicate zonal structure is at times present, or the center is full of opaque grains and the outer -portion limpid. These latter structure forms are more commou in the dikes than in the two large beds. The twinning striation is often interrupted and distant, so that quite broad patches belong to a single individual. At the type locality these large crystals are exceptionally fresh for specimens out of the large trap beds. They are, however, largely decomposed into a mass of shapeless, brightly polarizing scales, apparently micaceous, while more commonly both the generations of feldspar are decomposed into a fibrous sanssuritic mass.

In a long series of observations of the extinction angle of porphyritic crystals from every part of the valley, more than half the angles obtained were about $31^{\circ}$. This would indicate strongly that the feldspar was anorthite, which would agree with the results obtained by Mr. Hawes (cited below, p. 464) in an analysis of the porphyritic crystals of a dike cutting West Rock in New Haven. I may recall, also, Hawes's suggestion that the more difficult fusibility of anorthite may favor its earlier crystallization.

The second generation of feldspar, which forms the latticework, is lath-shaped, often with ragged ends and notched and irregular sides, and averages $0.1^{\mathrm{mm}}$ in length, though it is subject to more fluctuation than the larger group. Its extinction angles vary from $12^{\circ}$ to $26^{\circ}$, which would best comport with the compasition of labradorite. The rock under special 
discussion is one of the freshest-looking in the valley, and yet it is sometimes impossible to find in a slide a single feldspar on which one can observe the extinction, so decomposed are they, and the series of which the extrenes are given above are taken from the whole length of the valley.

The angite is strictly subsequent to the lath-shaped feldspars and presents little that is specially noticeable, though oftentimes it is less decomposed than the feldspars. It differs thus in the large sheets from the diabase of the tuff above and of the newer dikes, where the augite is often porphyritic and contemporaneous with the earlier feldspars.

I have in many places noted olivine with a qnery; but on reviewing the whole series of slides I lave not been able to find either the unchanged mineral or any serpentine or hematite patches which would seem to have been derived from it at the locality under consideration or in either of the large trap sheets. In the dikes in the gneiss and in the newer dikes in the sandstones it occurs, and it may be wanting in the large beds only because of their advanced state of decomposition.

Magnetite is uniformly distributed, always rather but never very abundant, generally quite well crystallized. The delicate featherwork of beaded octahedra is especially abundant at the base of the great bed at the contact on sandstone just north of Titans Piazza.

Apatite, never abundant, is rarely to be detected except piereing magnetite.

There is no trace of groundmass discernible between the constituents; rounded or pear-shaped blebs of glass appear in the older feldspars. Cavities filled with diabantite, rust, calcite, and zeolites are not wanting, even in the wholly compact rock we have chosen for discussion, but they, are very minute. Sections from the upper surface of the dike where it is cut by Dry Brook in the northwest of South Hadley exhibit very beautiful amygdules, showing from without inward diabantite, calcite, and radiated natrolite.

CHEMICAL COMPOSITION.

In 1838 President Hitchcock analyzed the much decomposed and amygdaloidal trap from the east end of Mount Holyoke with the result shown in column 1. ${ }^{1}$ In 1875 Dr. G. W. Hawes published analyses of 
the compact trap from Mount Holyoke (columns 2 and 3), and a mean of the same (column 4$):^{1}$

Analyses of trap from Mount Holyoke.

\begin{tabular}{|c|c|c|c|c|}
\hline & 1. & 2. & 3. & 4. \\
\hline $\mathrm{SiO}_{2} \ldots \ldots \ldots \ldots \ldots \ldots \ldots \ldots \ldots$ & 53.70 & 52.70 & 52.65 & 52.68 \\
\hline $\mathrm{Al}_{2} \mathrm{O}_{3} \ldots \ldots \ldots \ldots \ldots \ldots \ldots \ldots \ldots$ & 13.00 & 14.11 & 14.17 & 14.14 \\
\hline $\mathrm{FeO} \ldots \ldots \ldots \ldots \ldots \ldots \ldots \ldots \ldots$ & .......... & 9.78. & 9.80 & 9.79 \\
\hline $\mathrm{Fe}_{2} \mathrm{O}_{3} \ldots \ldots \ldots \ldots \ldots \ldots \ldots \ldots \ldots \ldots$ & 21.00 & 1.87 & 2.03 & 1. 95 \\
\hline $\mathrm{MnO} \ldots \ldots \ldots \ldots \ldots \ldots \ldots \ldots \ldots$ & 0.19 & 0.45 & 0.44 & 0.44 \\
\hline $\mathrm{CaO} \ldots \ldots \ldots \ldots \ldots \ldots \ldots \ldots \ldots \ldots$ & 0.70 & 9.36 & 9.39 & 9.38 \\
\hline $\operatorname{MgO} \ldots \ldots \ldots \ldots \ldots \ldots \ldots$ & 0.15 & 6.42 & 6.35 & 6.38 \\
\hline $\mathrm{Na}_{2} \mathrm{O} \ldots \ldots \ldots \ldots \ldots \ldots \ldots \ldots$ & ......... & 2.54 & 2.57 & 2.56 \\
\hline $\mathrm{K}_{2} \mathrm{O} \ldots \ldots \ldots \ldots$ & ......... & 0.89 & 0.87 & 0.88 \\
\hline $\mathrm{H}_{2} \mathrm{O} \ldots \ldots \ldots \ldots \ldots \ldots \ldots$ & 8.50 & n..... & ..... & $\cdots$ \\
\hline s. and loss $\ldots \ldots \ldots \ldots \ldots \ldots \ldots \ldots$ & 2.76 & $\ldots .$. & & \\
\hline \multirow[t]{2}{*}{ Ig $\ldots \ldots \ldots \ldots \ldots \ldots$} & …....... & 1.61 & 1.58 & 1.60 \\
\hline & 100.00 & 99.73 & 99.85 & 99.80 \\
\hline
\end{tabular}

THE UPPER OR POSTERIOR SHEET AND ITS FEEDING DIKES.

This bed (see Pl. IX, p. 446) runs from a point on the Connecticut River about a mile below the Mount Tom station, parallel with and about a half mile east of the Holyoke range, to and beyond the south line of the State, while its great irregular feeding dike is about 2 miles soutl of Smiths Ferry and just east of Mount Tom, where on the map the outcrop swells out suddenly. It is locally known as Little Mountain, and forms the culminating point of Forest Park, to which the Electric Road runs from Springfield and Holyoke.

The trap sheet shows the low easterly dip of the sandstone, in which it lies at a horizon about 600 feet above the Holyoke bed, though north of Mount Tom the two beds seem to be much nearer because of the Mount Tom fault, which at the cut south of the Mount Tom Electric Railroad station brings them apparently within 30 feet of each other. The bed is thick, but does not seem to extend east of the Connecticut, where the tuff rests directly on the sandstone. Yet an inspection of the map may leave

${ }^{1}$ Am. Jour. Sci., 3d series, Vol. IX, 1875, p. 186.

${ }^{2}$ Called thus by Percival in The Geology of Connecticnt, because the trap ridges face west and subordinate ridges often appear before and behind the main one. 
the impression that it extends, at least in a frammentary way, far east. The long castern projection of the Black Rock plug (see Pl. IX, p. 446) and the one east, and the string of smaller phugs elongate east and west, seem to be parts of it. They are, however, true intrusions, and their elongation seems rather to indicate the existence of a common ancient and deep-seated tissure through which they lave been extruded. This is proved by the fact that they cut directly across the beds of the sandstone below the tuff, the tuff itself, and the sandstone above, while west of the river the tuff rests directly upon the posterior sheet.

The sheet appears first as a great reef projecting into the Connecticut a mile below Mount Tom station, its northern portion fine-grained and columnar, its southern coarse and in great blocks, and is doubtless continuous beneath the sand southwest to the interesting ontcrop at Lymans Crossing (the first crossing below Mount Tom station), where a wall of trap is exposed in the raihroad cut. The northern portion of the cut is rudely columnar trap, with an irregular surface dipping about $35^{\circ}$ SE. Resting upon this surface is a coarse trap agglomerate, consisting of blocks a foot across and a fine sandy paste, in which many flakes of graphite appear. This is the normal relation of the tuff to the posterior sheet for a long way south.

A rod south of this tuff is an outcrop of trap which, from its great freshness and cornpactness, and from its containing inclusions of coarse amygdaloid from the tuff, I associate with the Burnt Mill plug just south, which interrupts the sheet at this point. A few rods south of the crossing a brook crosses the road, and on it is the ruin of Aldrich's leather mill, burnt many years ago. The brook flows east along the course of a transverse fault, and at and below the dam can be seen very finely the outcrop of an intruded trap mass, which clearly cuts across the sandstones, bakes and twists them, and extends west along the north side of the mill pond. (See p. 494.)

South of the brook and the fault the outcrops are continuons, and the posterior sheet can be seen to be wholly independent of the core which crops out north of the stream at the dam. Commencing at the railroad culvert over the brook, the sandstone can be seen on the south side of the brook in contact with and beneath the trap of the posterior sheet and having the unusually steep dip of $60^{\circ} \mathrm{SE}$. beneath the trap because of the fault. From this point the sandstone can be followed along the south bank of the brook continuously, past the mill and the pond. It dips regularly to the southeast MON XXIX- 30 
beneath the trap (which has only slightly inchurated it), and thus separates it completely from the intrusive trap of the plug north of the brook.

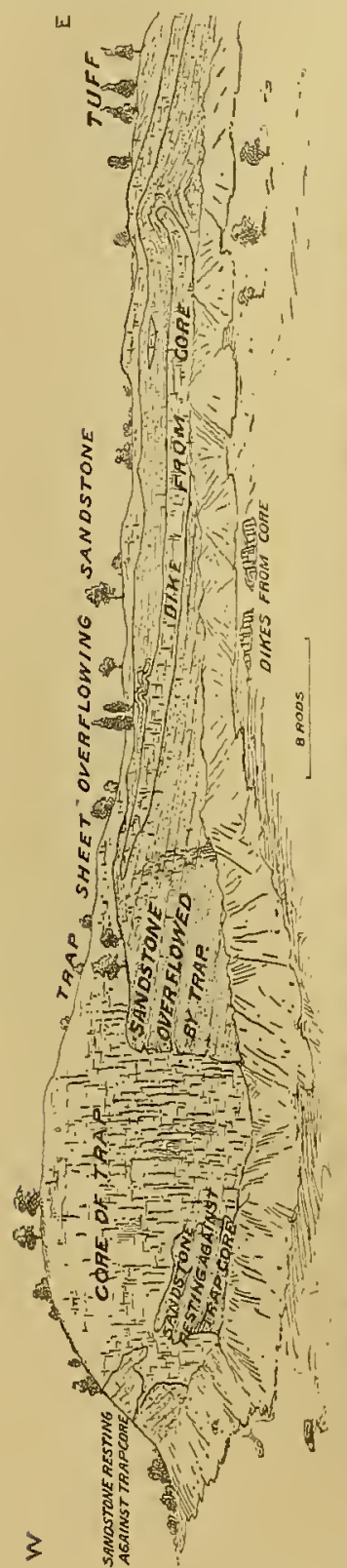

The removal of the mill and dam has improved the outcrop greatly and disclosed a quite sharp anticline of the sandstone beneath the trap in the south bank of the brook, which, as the dip of the sandstone is very low to the east, and the slope of the hill is in the same direction, has the effect to very greatly increase the width of the exposure of the trap, although the sheet is only 35 to 40 feet thick here.

The half of this anticline as formerly exposed seemed to show the trap resting directly on the basset edges of the sandstone beds, and this, taken with the mexplained greater width, made it seem probable that the trap lad broken throngh here. ${ }^{1}$ This anticline seems to canse the greater width of the trap outcrop sonth nearly to Sniths Ferry.

From the burnt mill the ontcrop of the upper bed extends southward as a prominent ridge just west of the river road and separated by a deep valley from the corresponding ridge of the HolyokeMonut Tom bed to the west. In the steep westward declivity of this ridge the contact of the trap on the sandstone beneath can be found in many places, and the sandstone is indurated for a small distance downward and rarely sends up a steam hole into the trap above. The trap is covered by the heavy tuff beds, which seem in the neighborhood of the burnt mill to be blended with the trap itself, as if it had fallen upon the latter while it was still molten, so that it is hard to mark the true boundary, but no trace of such blending could be detected in slides cnt for the purpose.

The narrowing of the trap upon the map is dne to the westward advance of the tuff upon it, by the elevation of the ridge, so that it ontcrops in the steep westward-facing bluff.

${ }^{1}$ F. Hitchcock, Geol. Mass., 1,35, 17. 424; 1811, p. 656. 
Jnst northrest of the smiths Ferry railmat station the trap is faulted slightly", the soutl side being moved a few rods westward, and in the low pliace in the ridge thus formed the sandstone approaches within 80 rodis of the railroatl.

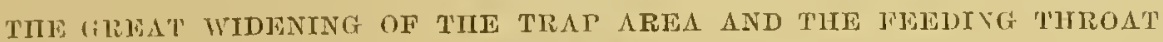
I3ENEATH.

A mile soutl of Smiths Ferry the trap widens to a triangular surface, a half mile on a side, and the ridge reaches its greatest height, rising westerly from the river to its crest in Little Mountain (now marked by the highest lookout tower in Forest Park) and sinking by a vertical wall to the ralley which separates it from the Mount Tom trap ridge. (See Pl. IX, p. 446, northeast of Mount Tom.) Along the western edge of the expanded area the thin trap sheet still rests normally on the sandstone, and on the eastern edge is covered by the tuff, and its great width is due to the fact that it dips with the slope of the hill east from its crest. In the deep inlets of sandstone running down into the trap from the north the latter can everywhere be seen to lie normally on the sandstone, with little baking, and along the border from this point around to the west the same conditions hold for a long way south, until one comes to the point where the wood road coming up from the reservoir crosses the brook and goes up onto Mount Tom, and where the posterior ridge itself rises to its greatest height in Little Mountain. At this point the face of the core is finely exposed for study, as indicated in fig. 25. The trap comes up from the depths with but a small portion (30 feet) of its width exposed, sending out great dikes into the sandstone north and south. The sonthern dike, starting with a width of 8 feet, was followed 50 feet.

North of the core a small dike is seen inclosed wholly in the sandstone, and a wide dike branches from the main mass and can be followed a long way north before it is concealed by the talus. At the surface the trap flows out over the sandstone, greatly indurating it, and becomes the sheet which we have followed from the north to this point. The whole is like a great toadstool; the stem is the core which forms Little Mountain. The west. ern and most of the southem part of the "umbrella" is broken off by erosion; the eastern part is the sheet dipping east beneath the tuff.

The exposed wall of trap shown on the left in the figure seems to be a 
portion of the western wall of the plug, just grazed by the Mount TomHolyoke fault, and from its point of contact with the sandstone on the north the boundary of the plug seems to run first north and then about east beneath the continuous area of trap. The southern half of its boundary can be much more closely located.

Continuing south from the south contact of the trap which forms part of the core and the sandstone in fig. 25 along the highest portion of the bluff, and turning ronnd the face of the high bluff at its south end where it overlooks the reservoir, one finds the sandstone to be only a thin veneering on the face of the walls of the great throat, and one can dig at the surface and see that the trap extends down behind the sandstone. The surface boundary of trap and sandstone is, along this line, almost the boundary of the core also, and erosion has spared little of the western half of the overflow. This boundary skirts the eastern vertical face of the bluff for a little way north, and as this bluff soon turns to face south, and runs east less steep and elevated, the surface boundary of trap and sandstone, turns and runs parallel with it, but not quite so near the edge of the bluff, and becomes the sonth boundary of the sheet as the latter extends east from the plug.

The baking of the sandstone from the point where the plug was first reached has been exceptionally marked, but along this wall it is more intense than anywhere else in the valley and can be clearly perceived 12 to 15 feet from the trap. Along the middle of this south wall, which continues east from the plug, near the top, a foot-wide dike of trap is intruded between the nearly horizontal layers of the sandstone beneath the sheet. It is unusnally decomposed, to a pistachio-green porons mass, with spheroidal structure.

About 20 feet below this a great horizontal dike or sill starts, just at the reentrant angle made by the sonthward projection of the high bluff-that is, just where the plug ends and the wall of sandstone facing sonth begins and seems to branch off from the main trap mass. It starts with a width of 2 feet and ruus down east, widening soon to 12 feet, and continnes with the bottom concealed, and at its end it bends up suddenly, with the sandstone on its back, into a vertical position. It is exposed about 150 feet and is very fine-grained, black, and horizontally fissured for 2 feet at surface, and is an exceptionally fresh, ringing, small-columnar rock in the center. It sends two narrow dikes, an inch to a few inches wide, up into the overlying sandstone. 
Theso pass upward in fissures for about a foot and then bend the unbroken liners of the sandstone above into an areh, forming minute laccoliths, and clearly indicating that the sill was injected under strong pressure.

SILLS INTRUDED IN THE SANDSTONLS BELOW THE POSTERIOR SHEET.

Besides the dikes and sills which penetrate the sandstones so abundantly in the immediate vicinity of the Little Mountain core, other small sills appear immediately beneath the posterior sheet at so great a distance that they can not be brought into very close connection with the core itself.

The most northern of these is N. $60^{\circ} \mathrm{W}$. of the Smiths Ferry station and about 6 feet below the top of the sandstone. There is a sill 2 feet wide which can be followed 20 feet, and 2 feet below this is another only 1 foot wide. The sandstone has strike N. $40^{\circ}$ E. and dip $22^{\circ} \mathrm{E}$.

About a mile south along the bluff, at a point S. $65^{\circ} \mathrm{W}$. of Smiths Ferry and west of the marked drumlin which conceals the tuff, a larger sill appears, 10 feet below the trap, which is 4 feet wide and 8 or 9 feet long. The sandstone is much disturbed beneath it.

Along the boundary of the sheet farther south no other sills are found in the sandstone below until the western border of the plug is reached and the very abundant dikes and sills appear around its western and southern side, which have been described and figured above.

There is a turnstile by the road, and steps going down to the railroad, a mile and a half below Smiths Ferry, and the field road southwest from here leads out over a ridge to an amphitheater, now called Forest Park, from which all the points here described are easily identified. The ridge is the continuation of the trap sheet southward. The beautiful horizontal 12 -foot sill described above (p. 468) is in the north wall at one's right, and if one crosses the basin to the next ridge overlooking the reservoir, and west of the terminus of the Electric Road, the high bluff of the plug projects south toward the point where one stands, and above the screes of trap fragments the sandstone veneering can be seen abutting against the trap in the thick woods.

Turning south from the east end of the 12-foot sill mentioned abore, on the sontheast of the plug, and going to the bottom of the basin near the brook, one finds a place where the sandstone is crushed into sharp folds a foot or two across and baked by the trap, which has penetrated it inegularly, but apparently only in small amount. 
Along the eastern margin of this basin the outcrop of the trap sheet is plainly visible, covered by tuff and marked at its base by a prominent talus. As it is followed sonth its boundary makes a great loop to the east, where the ridge is cut through by a brook, but rises again in a higher bluff south of the brook, now marked by a high trestlework lookout-tower. The contact on the sandstone below is everywhere normal-the compact trap rests on unbaked sandstone-until the boundary swings around the south end of this prominent hill to a point which rises sharply in a bluff 30 rods north of where Roaring Brook crosses the road. This is the brook that comes up from the south and bends sharply to enter the Connecticut sontheast of Mount Tom. Delaney's quarry, described below, is situated just south of its mouth, between the road and the railroad.

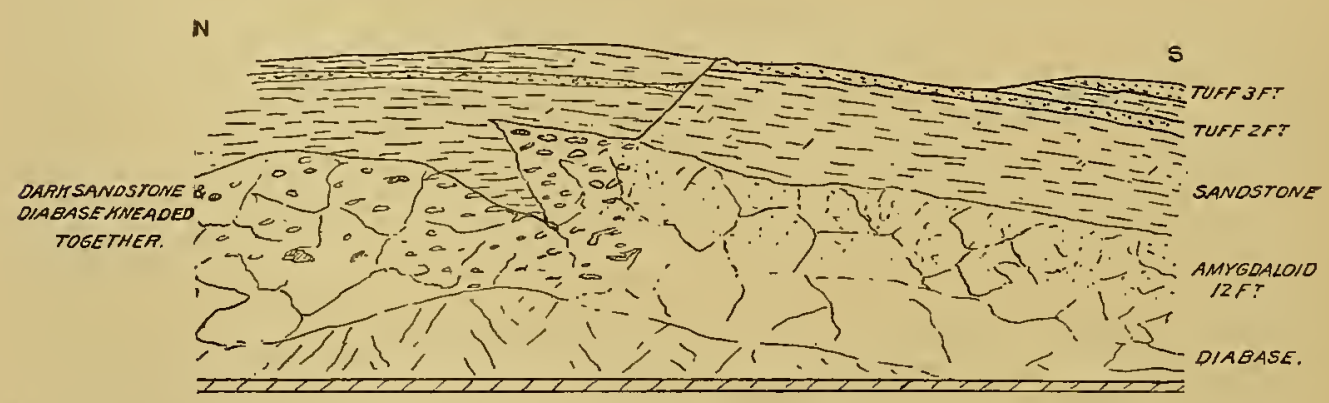

FIG. 26.-Section of Delaney's quarry, in Northampton, near the north line of Holyoke, on the Connecticnt River Railroad.

The base of the trap sheet in this bluff is scoriaceous and filled with sheets and filaments of limestone and shale exactly like the surface of the trap a few rods south at the quarry mentioned above, so that I am compelled to assume that a portion of the surface has here been under-rolled to make the base

The conditions here are so peculiar that they require detailed discussion, which may best begin with a detailed description of the quarry east of the fault, returning then unorth to the south bluff section, which can be best explained by a comparison with the conditions at the quary.

DELANEY'S QUARRY, NEAR THE NORTH LINE OF HOLYOKE.

This is a good example of a deeply submerged lava surface onto which much mud was washed while it was still plastic (see fig. 26). Many masses of the mud, varying from thin filaments a few inches long and a small 
fartion of an inch thick to broad layers, were washed onto the trap and sank into its mass, so that the upper 3 or 4 foet of the trap is knearked tull of the rark, compart shales, which have at times glazed and wrinkled surfaces as in the ordinary shale, especinlly at the south end of the quarry, and for 3 or + feet the trap and shale are kneaded together; shreds and broal plates of the dark-glay, thin-laminated shale are twisted and plicated in the black trip.

In sections thin tortuons layers of the shale can be secn in the trap, at times directly inclosed by the trap, at times a part or the whole of a film resting in the bottom of a steam hole, as if the moisture of the mud had furnished the steam to form a cavity too large for the mud to fill. The sandstone above wraps over the very irregular surface of the trap, which rises and falls 20 feet within the limits of the quarry and dips $17^{\circ} \mathrm{F}$. It fits itself also around smaller irregularities and separate blocks of the trap, and for several inches it is rery ferruginous and contains small, flat concretionary grains like the Clinton iron ore. The trap is fine-amygdaloidal for 12 feet down from the surface.

A north-south fault appears in the quarry with an upthrow of 4 feet on the east, $\operatorname{dip} 8^{\circ} \mathrm{E}$, and many strong slickensides appear parallel to this surface. In pockets along this zone of crushing occur datolite crystals of richer color and more brilliant luster than any found clsewhere in the State. They are described in the Mineralogical Appendix, Chapter XXII.

There were opened in 1892, near the north end of the quarry and a few feet back from the railhoad and 10 feet above its level, a series of pockets in the solid anygdaloidal trap, a foot or more below its surface, which were filled with the finest broad lamellar anhydrite, ${ }^{1}$ with some coarsely granular calcite near the borders. These pockets were small and irregular, never more than 3 inches thick and \pm inches long. Much very coarsely cleavable calcite appears also in fissures in the sandstone for a little distance above the trap, inclosing cavities from which gypsum has disappeared, and within the same limits broad fissures in the sandstone have their walls coated with thick layers of specular iron in drusy surfaces of fine plates, and much of the sandstone is cemented by shining scales of hematite. The sandstone over the trap has alternating

This is a most nuusual oceurrence of the mineral. It occurs rarely in the Monte Somma bombs. R. Brauns, Neues Jahrbuch fïr Min., 1894, p. 257. See Mineralogical lexicon: Bnll. 126. 
layers darkened by fine tuffaceous material. Twelve feet above the trap the coarse tuff begins to appear in the sandstone, and this is its most sonthern occurrence.

It seems to me probable that the mud was swept over the still plastic trap and sank into it to make the streaks of sandstone, and that the trap was thus frothed up to make the amygdaloidal and cavernous structure. The formation of the calcite, anhydrite, gypsum, and hematite all took place immediately after, under the influence of heated solutions from the still heated trap. The pyrite of the trap furnished the sulphuric acid for the anhydrite, and little calcite developed in the heated cavities of the trap and gypsum and much calcite in the cooler fissures in the sandstone, while abundant hematite and some magnetite impregnated the sands and formed the beautiful surfaces of specular iron.

In the bluff section to the north, mentioned on page 470 , the vertical south wall of the hill shows an exactly similar amygdaloidal band, about 12 feet thick, filled with wholly similar twisted sheets of sandstone and shale. Indeed, at one point a block of sandstone at least 3 feet thick and 10 feet long is half included in the trap and half projecting. It is twisted and baked gray and fissured all to pieces at the surface nearest the trap, and is reddish at the center. This porous band of the trap is, however, not, as in the quarry just south, the surface layer, but forms the base and is covered by about 20 feet of coarsely columnar compact trap in the vertical wall, and the thickness of the whole bed upon it is much greater. It can be seen to rest upon the fine-grained reddish sandstone below. It is very porous, especially around the included fragments, and this porosity runs out gradually in the compact trap above. One must put emphasis upon the fact that these are thin sheets and films of thin-bedded shale, often twisted in the lava and presenting shapes which can not possibly be explained as inclusions of a solidified sandstone torn off from the surface of the fissures up through which the lava passed.

One may imagine the lava flowing southeast from the great vent at Little Mountain, over the sand flats under several hundred feet of water, for the most part cased in solid lava and thus producing very little effect upon the ground over which it flowed and being very little influenced by the water. If, however, the crust were locally ruptured and the liquid lava came in large quantity into contact with the water, a violent uprush of 
steam and water might oecur, and an indraft of muldy water, which would suddenly coat the surface with fine, thin-laminated mud, and this would then be mingled with the plastic lava so as to produce veins like those seen in Cistile soap.

The current was here passing directly into the apex of the area of the Chicopee shale, and the fiagments in the trap are of exactly the sime character as this rock. - This mixed layer appear's in its normal position on the surface of the trap at the quary, and the heavy-bedded sandstones above show that they were very rapidly accumulated over the still heated trap by the abundance of specular iron that coats all their fissures. Here in the bluff the whole former surface of the trap is under-rolled and appears inverted upon the sandstone of the old sea bottom.

THE ROARING BROOK FAULT AND THE DISAPPEARANCE OF THE POSTERIOR SHEE'T.

The amygdaloidal surface of the trap, so well exposed at Delaney's quarry, can be followed continuously a few rods north in the bed of Roaring Brook. It is here more coarsely anygdaloidal and without inclusions and is covered by a thin bed of tuffaceous sandstone full of flat fragments of a white volcanic rock (see p. 474). Following up the brook across the road to a small waterfall on this amygdaloidal surface, with the saudstone forming the bank, one comes upon the first fault. At the foot of the fall is the scoriaceous surface. The trap over which the water plunges is compact, and here there is a fault with upthrow on the west which amounts nearly to the thickness of the trap sheet. A little west there is another fault in the same direction and throw, running about N. $20^{\circ}$ E., parallel with and a little west of the brook, which seems to have given the brook its direction, and which continues north along the east foot of the eastern bluff of the hill 30 rods north of the brook that contains the inverted section described above (p. 472) and crosses the next brook on the north 10 rods west of the road and of the broad surface covered with bird-tracks beside the road. It has the sandstone on the east and the tuff and trap on the west.

As the surface of the trap sheet is exposed in the bed of Roaring Brook, and as the base of the same sheet appears 30 feet higher in the hill 30 rods north, the aggregate throw of the faults is about 60 feet. 
From the bend in the brook the upper, highly scoriaceous surface of the trap can be followed north, along east of the fault line and behind the house standing north of the brook. The trap is very deeply rotted. It is a fine example, rare in this region, of a protected pre-Glacial surface. It falls apart now into a mass of spheroidal bodies made up of many very thin concentric layers, a result of rapid cooling. It is the same surface which just adjacent is loaded with shale.

On the other hand, going south up the brook from its bend, one finds it ruming on the trap near its base until one comes to its farthest outcrop near the Electric Road. Here the trap rests on the sandstone irregularly, partly upon its basset edges on the west side of the outcrop and partly mantling over to rest on the surface of the upper stratum toward the east. The fault must pass just to the west of this contact.

THE BLENDING OF THE TUFF WITH THE SURFACE OF THE POSTERIOR BED.

Beneath the northeastern pavilion in Forest Park (fig. 25, p. 466, near the east end) the surface of the posterior bed is full of angular fragments of a fine-grained trap, partly compact and partly porous, which are plainly foreign inclusions. They are, however, sometimes fused into continuity with the inclosing trap, as if they had fallen into the molten lava and had been themselves partly remelted. The inclosing trap has a mottled, red-brown, weathered surface, and is covered by small pimply knobs, which cause the mottled appearance, and it is so coarse-grained that the white feldspars can be easily seen. It is thus quite unlike the inclosed trap. The old surface of the trap sheet is filled in this way for a distance of 150 yards west, to the top of Little Momntain, and 600 yards north. This is quite the same thing as the mingling of mud with the surface of the same sheet just south, at Delaney's quarry, as described on page 470, and indicates that the ejected fragments fell upon the surface of the flowing lava here as the mud spread over it farther south.

A TUFFACEOUS SANDSTONE CONTAINING WHI'TE TRAP.

This curious rock appears just above the posterior bed on the north bank of Roaring Brook, a few rods east of the Northampton-Holyoke road and near the line between these towns. It is a sandstone containing many small, angular pieces of a white rock which effervesce freely and seem to be calcite. They prove to be a scoriaceous lava, now filled with secondary 


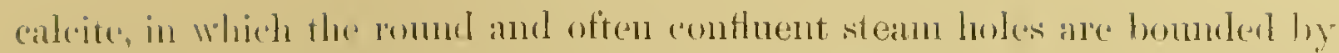
very thin walls, which alpear as black hines survounting the calcite filling and contain only twinned plagiodise rods. The sandstone also contains (rackled fingments of bottle-green glass in which rodlike crystals of plagio(liase of two sizes appear. The fragments are thus like the white trap found a mile firther north, on the brook north of the station of the Mount Trom Raihoad (see p. 365).

THE POSTERIOR DIKE ACROSS IIAMPTON 'OUNTY.

One can trace the trap for a short distance farther sonth, hardly to the town line, as everything is heavily covered with alluvinm. The bed then disappears and seems to be concealed for nearly 3 miles by the throw of the Holyoke fault. It reappears again on the roarl from Holyoke to Wright's pond, with a thickness of 33 feet, and can thence be traced southward to the excellent section made by the Holyoke and Westfield Railroad, where it is 120 feet thick and divided into two beds. The lower of these (resting on the fine red sandstone, dipping $15^{\circ} \mathrm{W}$., and not perceptibly altering it) is 53 feet thick, very coarse-columnar in its main mass, with 8 to 10 feet amygdaloidal above, while the upper bed rests directly upon the lower one and is amygdaloidal at its surface for 15 feet in thickness, and the whole is covered by a fine-grained red sandstone.

This thinning out toward the north may indicate that the bed is not continuous across the covered area; on the other hand, the double character of the bed is repeated as in the bed to the north. Sonth from the railroad crossing the bed appears as a continnous ridge, increasing in altitude until it reaches the Boston and Albany Railroad, where another fine section is exposed east of the Tatham station, which repeats almost exactly the railroad section described above.

Here gray and red shaly sandstones dip $25^{\circ} \mathrm{E}$. beneath the trap, and are distinctly baked for 2 feet and show a rust-filled columnar parting:

The lower bed is 32 feet thick, with about 10 feet finely amygdaloidal above and full of diabantite and calcite. The upper bed is massive and 44 feet is exposed. In it are four zones of crushing, 1 to 2 feet wide, with strike N. $10^{\circ} \mathrm{E}$., dip $70-80^{\circ} \mathrm{W}$., which indicate small faults of unknown throw.

Just above the mouth of the first brook entering Westfield River from the sonth, east of Provens Mountain, in Agawam, a massive ledge of the trap projects into the main stream, and the brook runs over the trap in a pretty 
waterfall where it crosses the road at J. Miller's house. This is directly in prolongation of the ridge north of the river, and there is no indication of any fault between these points. The bed is then lacking for 2 miles south because of the throw of the State-line fault, ${ }^{1}$ but reappears again at the house of A. Flower, and then follows the road closely S. $10^{\circ} \mathrm{W}$. to the State line and on across Suffield in Comnecticut. It rises as a low ridge above the sands, which conceal the contacts. The greatest thickness exposed was 62 feet.

THE TALCOTT SHEET.

This is the anterior sheet of Percival. It enters the Granville quadrangle at its southeast corner, in the town of Suffield, Comnecticut, and therefore appears on the map, but it does not cross the State line.

THE TUFH' AND TUFFACEOUS AGGLOMERATES.

THE DEERFIELD BED.

At the first outcrop on the Greenfield-Turners Falls road the rock is a complete "schalstein," a thin-bedded, dark-green rock, largely decomposed into a flaky chlorite, and abounding in grains of calcite and a reddish zeolite for the most part iron-stained prehnite. This bed seem to rest directly upon the trap and to have but limited extent.

THE GRANBY BED.

The coarse arkose or sandstones, consisting of slightly waterworn and sorted granitic materials, which dip beneath the great bed of diabase of the Holyoke range, are followed above the diabase by exactly similar beds of pale-buff arkose containing little iron and having a low dip south from the Mount Holyoke range and sontheast to east from the Mount Tom range.

This is followed by heavy beds of black tuff and tuffaceous sandstone, which vary from fine-grained volcanic sandstones to coarse breccias and agglomerates, and from rocks made up wholly of volcanic débris to such as contain fragments of granitic and gneissoid rocks, or in the finer-grained varieties contain the materials of granite, especially white mica on the lamination faces and grains of quartz in the mass of the rock. In other cases rounded masses of diabase are distantly scattered in deep-red sandstone.

This band begins opposite the east end of the diabase bed and half a mile south of it, and, attaining a surface width of 1,600 feet, runs west 
parallet to the diabane to and across the Comnecticut, and continues south parallel to the Hount 'Tom range to within a short distance of the IIolyoke town line.

It appear's first in the bluff orerlooking the northern of the Belchertowu ponds as a thin-bedded, rusty sandstone with grains of diabase. It strikes N. $100^{\circ} \mathrm{W}$. and dips west into the hill and beneath the sandstone, and has plainly been faulted into its present position, and received thus its unusual westward dip. It is wholly separated from the remainder of the bed.

Farther west, where the Bay road after crossing the diabase goes south toward Belchertown, the tuff does not outcrop, but in the fields west of this road abundant fragments occur by which it can be approximately traced, and soon it appears in a strong ridge which can be followed west to the next road. Here the tuff appears for a long distance north and south of the second house met after going south across the mountain into Granby (the house formerly occupied by A. Convere, now in ruins), and tracing it west it rums just south of a small diabase mass sonthwest of this house. It is an arkose containing in great number angular diabase fragments, some as large as a pea, and is cut off by a fault, which can be traced very clearly in the woods south of the diabase. Farther west it has been crossed at several points but not followed continuously through the densely wooded area to the next road, i. e., the main or Notch road, and it appears at the first branching of this road south of The Notch. The rounded rusty hummocks of the tuff are very conspicuous.

The rock is composed mainly of trap in small angular fragments which look like pitchstone and which consist of a diabase with semicrystalline base.

The tuff bed makes a small angle with the road rumning east from this point, and its exposures are found abundantly in the roadside until the road goes down onto the terrace sands. The outcrops of the tuff vary fion deepbrown, thin-bedded sandstones, which the microscope shows to be quartz sandstones impregnated with the finest dust of the trap, to agglomerates in which masses of trap a foot across appear, as in the woods just south of where the ninth volcanic core (see p. 483) crosses the road.

Farther east the tuff bed is cut off completely by the ninth core. The best exposures are where the bed is crossed by the wood road which runs north from Moody Corners, where the rusty tuff weathers into a pile of 
large spheres, and in the brown ledges visible from this road off to the south, whose ragged mass is made up of large angular pieces of the trap cemented by finer dust of the same material.

Here, in the north of South Hadley, the bed has great widthl, and across to the north, at the top of the fine cliffs of buff sandstome which orerhang the entrance to the brook gorge reached by H. White's wood road, just east of the school and at the highest point of the ridge, the base of the tuff and its junction with the underlying sandstone is instructively shown. In a rertical wall of the pale-buff sandstone the lower half is composed of the usual coarse granitic sand, and abore a large number of angular masses of the trap, of the size of one's fist and larger, are scattered at some distance from one another in the same buff sandstone, while a few feet higher up the rock is deep rusty-brown tuff.

These fragments are manifestly the first and farthest-thrown products of a distant explosion, as the perfectly classified material of the sandstone below and around the fragments indicates a current capable only of moving coarse sand before and during the time when these large angular masses were dropped here, to be followed by so great a supply of trap débris that the granitic sand almost disappears in it.

Still farther west, where the bed runs to a point on the south of the Black Rock dike, it is a loosely cemented. mass of trap grains, all of the size of large peas. From this point west to the Comecticut it is replaced by the Black Rock dike, and on the west of the river it appears in the cutting south of the point where the road crosses the railroad, below Mount Tom station (Lymans Crossing), as a coarse trap agglomerate resting directly on the trap, and except where it is interrupted by the leather-mill fault it appears in the roadside all the way to the Holyoke line. The blocks are a foot across, and in the fine-grained matrix a great number of graphite scales occur.

Just south of the cemetery north of Siniths Ferry, by the roadside, the great blocks of the trap, nearly 2 feet long, cemented by the finer fragments of the same material, can be seen to rest directly upon the surface of the coarse rusty sandstone, and to have sunk into its upper surface as they fell. Very little foreign material can be found here in the finer portion of the tuff, but it seems never wholly wanting, and the graphite and muscovite scales are never absent. 
Finther solth fine firsh exposines can he studied where the road and railinal come nearest togrether, and here the round blowk are a foot in dianeter. $\quad$ Ill along the listance we have traced, the tuff is in great thickness, and vecupies the whole distance between the posterior trap range and the terrace siluds adjoining the river, its rarying width of outcrop depending mpon the height to which it overhangs the trap. It is well exposed by the cuttinges of the raihnad.

The first reefs of sandstone containing foot-tracks appearing in the river are bromght up by a fault rmming N.25 E. (see p. 473), which cuts off the tuff, and sonth of this line where it appears in the quary by the railroad; near the Ilolyoke line the tuff has dwindled quite suddenly to three beds with a thickness of less than 3 feet each, inchded in the deep-red, fine sindstone, and lying 3 to 4 feet apart, the lowest layer 10 feet above the irregular surface of the trap, that thickness of sandstone having suddenly intervened.

President Hitchcock's descriptions of the tuff beds are full and clear. ${ }^{1}$ The several repetitions of the bed given by him south of Mount Holyoke are due to faulting. 'The occurence in West Springfield and the occurrences mentioned at the base of the main trap and on its surface, and the varieties described as "masses of red and gray sandstone embedded in a scoliaceous paste," are separately discusser on pages $453-460$ and 476 as cases of the inclusion of sedimentary material at the surface or base of the flowing sheets of trap.

THE ISOLATED MASA OF TUFF NORTH OF THE SEVENTH CORE.

A half mile north of the serenth core, described in the next section (p. 482), and a little more than a mile north of J. McGrath's honse and reached by a wood road from this house, in the deep woods in the north part of Granby, is a great isolated mass of the coarse rusty diabase-sandstone, which stands perhaps 12 feet high and rises like a great telescope upon a massive pedestal. The mass does not seem to be more than a rod square beneath the surface, and must have been dropped into the sandstones here by a fault, of which in the covered and heavily wooded region no other trace can be found. It shows that the tuff extended half a mile north of its present outcrop.

${ }^{1}$ 1844, Explanation of Geological Map; 1848, Am. Jour, Sci., 21 series, Vol. IY, p. 199. 
SOURCE OF THE MATERIAL OF THE TUFF BED.

The sections of the diabase from the tuff show varieties containing (1) much glass base, (2) well-developed porphyritic augites and olivines, (3) development of augite as early as the oldest feldspars, (4) inclusions of quartz grains, all peculiarities common in the newer dikes and not found in the older diabase of the Mount Holyoke bed. The nerver dikes lie along the same line with the tuff, and are punched up through it.

The description of the base of the bed given above indicates that an explosive eruption of diabase occurred somewhere along this line, which furnished the great mass of material whose length of outcrop is 10 miles and whose thickness is about 550 feet. The later dikes seem to have been driven up through this tuff bed, and, I think, lie along the line of the great fissure up throngh which the diabase of the Holyoke-Mount Tom bed comes.

It is just south of the ruined stone mill above Smiths Ferry that the tuff bed is thickest and the blocks in it are largest, and it contains many fragments 1 to 3 feet across. Their size diminishes southward; 1 mile south (R. Houston's) the fragments reach 8 inches; at 2 miles (P. Brenu's) 4 inches, and here the tuff has dwindled to three beds 3 feet thick, and the mass of the fragments are about an inch long, though above the upper bed distant rounded fragments 5 to 6 inches long appear in the sandstone. The place of eruption seems to have been somewhat, but not far, north of Smiths Ferry. It is interesting to trace the graphite found in the tuff and in the sandstone above it to its source, which must have been in the region of Sturbridge, 18 miles to the east, while the crystalline boundary on the west is only 9 miles.

HOLLOW BOMB FROM DELANEY'S OUARRY, NORTHAMPTON.

I dislodged from the tuff at this quarry a rounded bomb $1 \frac{3}{4}$ by 1 by 1 inch, with its center coarsely amygdaloidal, the cavities of such shape that they could have been formed only by steam and not by later weathering, and a border from $\frac{1}{2}$ to $\frac{1}{4}$ inch wide which was completely compact.

PETROGRAPHICAL DESCRIPTION.

The rock from large blocks in tuff from roadside south of Smiths Ferry, where the railhoad makes a deep cut in the tuff, is a typical diabase with decomposed feldspars; a brown glass, generally devitrified and filled 
with black dust, occupies the interstices. Large, fresh, porphyritic augites appear, which are often twimned; and small, very brightly polarizing grains seem to be olivine.

\section{TIE NEWER SERIES OF CORES AND SHORT DIKES.}

BELCHERTOWN.

THE FIRST VOLCANIC CORE.

This is situated about 150 rods sontheast of the east end of the Holyoke main sheet of trap and 2,100 feet N. $47^{\circ} \mathrm{E}$. of the house of H. Moody, on the Bay road in Belchertown. It is just south of the source of a brook and within the edge of the woorls, rising in a small knoll. On the north edge the contact with the sandstone is well seen, and the baking of the latter is unusually severe. The alteration has bardly begun to decrease in the width exposed-above 10 feet. The coarse red sandstone is baked into a hard, light-gray graywacke, its mica and feldspar grains having been so affected by the heat that they have been removed by later infiltration, leaving pores coated with rust. Still nearer the contact the sandstone contains many white compact masses, which are in part hollow tubes and seem to be bones of a reptile of about the same size as that found in the sandstone at Springfield. The rock is here rendered hard and impervious, and this has favored the preservation of the bones. The specimens contain lime phosphate.

The trap is fresh, very fine-grained, and shows few steam pores. Very thin, well-formed plagioclase crystals, flattened parallel to $\infty \mathrm{P} \infty$, and of the earlier and larger generation, are visible with the lens.

\section{THE SECOND CORE.}

The second of the series of old craters or volcanic throats is exposed in a row of low knolls in the field opposite the house of J. A. Barrett, where the Bay road has just crossed the mountain toward Belchertown village and near the western line of the same township. The exposure is only about 15 rods long by 3 rods wide, with strike N. $60^{\circ}$ E., and near at hand on all sides are abundant outcrops of conglomerate, which proves it to be an isolated deposit of limited extent. It agrees in all essentials with the rock of the newer intrusive dikes.

MON XXIX-31 
THE THIRD CORE.

This rises as a low knoll in the open field 80 rods S. $70^{\circ} \mathrm{W}$. of J. A. Barrett's and 10 rods north of a bluff of tuff. It is exposed with a width of 3 rods and a length of 5 rods. Its strike is N. $60^{\circ} \mathrm{E}$.

\section{GRANBY}

THE FOURTH CORE.

Where the Amlierst-Granby road passes over the range a single house (C. Harris's) stands on the west side. Eighty rods S. $65^{\circ}$ E. of this house, on a wood road at the south foot of a high conglomerate bluff, is a small, nearly circular outcrop of trap with the adjoining sandstone exceptionally altered on the contact. The coaly plant remains which it contains are largely changed into graphite.

\section{THE FIFTH CORE.}

In the field wost of the only other house on this road (A. Convere's) and about 30 rods $\mathrm{N} .10^{\circ} \mathrm{W}$. of the house is a ridge of the trap 8 rods wide, 25 rods long, running N. $50^{\circ}$ E. a few rods north of the tuff bed.

\section{THE SIXTH CORE.}

In the same field with the last and about 35 rods $\mathrm{S} .75^{\circ} \mathrm{W}$. fiom it is another high ridge, 14 rods wide and 30 rods long, having about the same direction of its longer axis, the same relation to the tuff bed, and the same fine-grained, dark-gray diabase without anygdaloid as have the other occurrences. Like them all, it bakes the sandstone strongly and seems to be wholly surrounded by the sandstone. It is more jointed and werthered than usual. About 5 rods southeast is a dike of the diabase 10 feet wide and about 5 rods long, which runs north and south parallel with a fault plane a little farther east. This is very probably an offshoot from the latter throat, but the junction is covered.

\section{THE SEVENTII CORE.}

About 200 rods north of J. McGrath's this plug occurs, at the eastern terminus of the band of diabase-tuff which crosses the Notch road and enters Granby from the west. This terminus is caused by the intersection of the tuff band by one of the main north-south faults which cross the trap ridge, and the small plug of trap came up just at this crossing. It 
is only 5 or 6 rorls in cross-section. The rock is black, fresh, compact, only the lirger and earlier generation of feldspars showing as fine lines with a strong lens. The few small cavities show a white, compact, fibrous zeolite.

Under the microscope the rock shows the usual structure, with the following peculiarities: The area surrounding the cavities is of much finer grain thun the remainder. The large feldspars are almost always made up of only two broad individuals. An interstitial groundmass exists in considerable quantity and decomposes to a red-brown mass. The cavities contain (1) calcite, (2) diabantite, (3) wavy interstratifications of diabantite and matrolite, (4) natrolite, (5) a red decomposition product of diabantite. The whole slide is full of the finest feathery groups of magnetite octahedra.

\section{THE EIGHTH CORE.}

One will find this large and interesting mass by starting from the southern boundary of the tuff, just across the brook south of the first branching of the road after passing The Notch. The sandstone rises in a low bluff facing north, and may be followed due east 100 rods across the field and through the woods to a deep, dry gorge running north. Following this up across the tuff, one comes upon the trap at the head of the gorge and can follow the line of contact very closely round in a great circle to the point of starting, and it is plain in several places that the trap has come up through the sandstone and is not a bed in it, and that it has come up on the line between the sandstone and the tuff, intruding partly on the area of the one and partly on that of the other. No amygdaloid was observed, and the diabase is very fresh, dark-gray with shade of brown, fine-grained, the earlier generation of feldspars being just visible to the eye, and their striation discernible with a strong lens.

The induration of the tuff was very marked on its contact with the diabase on the south side of the block. This would be the upper surface of the bed if it had been a contemporaneous flow, and in this case there would lave been no trace of baking of the adjacent tuff.

\section{SOUTH HADLEY.}

THE NINTM CORE; DIABASE WITH GRANITIC INCLUSIONS.

An inspection of the map will show the next, or Black Rock, core to consist of a great rounded mass which is situated south of the Holyoke House and sends off to the east a long tail-like dike. If this be followed 
east half a mile to a point beyond the Moody Corners wood road it will be seen to be bordered on the south by a rounded mass of diabase lithologically different from anything found elsewhere in the valley, and very peculiar. It has a long dike projecting to the east, and is thus paddle-shaped and rudely resembles the much larger Black Rock core. It is an aphanitic diabase, which is full of grains of quartz, microcline, orthoclase, etc.-so full that in breaking hand specimens from every ledge across its width, 650 feet, not one was found that did not contain many grains. It is as if the lava had broken up through unconsolidated sandstones or flowed over beds of sand, taking up a great quantity of the latter in its progress; and as the tuffs contain a certain quantity of the same granitic sand, and as this had often been relied on as a means of distinguishing the tuff from weathered outcrops of the trap in the field, a new difficulty was added, and weathered outcrops of this trap were with great difficulty distinguished. Indeed, in my first section across this area I was in great perplexity, and the peculiar pitchstonelike appearance of the rock, quite new in this region, added thereto. Still, I decided before cutting sections that the rock must be a lava and not a tuff.

PETROGRAPHICAL DESCRIPTION.

The specimens described here were taken on a section throngh the middle of the dike, where a wood road goes north a short distance east of Moody Corners and crosses the brook where a branch enters it. From this point the first outcrop of the trap is visible, and going north across a cleared area and then a short distance through the woods to a second cleared field one finds abundant exposures of the trap, and to the north long ridges of the sandstone appear. The first section was taken from the north cleared field, 23 feet south of north border of the diabase. It is a clear, black, aphanitic rock of unusual freshness and slightly pitchy luster, and contains in great quantity inclusions of granitic quartz, and rarely orthoclase, of the same size as the grains in the adjacent sandstone (up to $5^{\mathrm{mm}}$ ). As many as three or four to a square centimeter occur, and the lens shows many more of smaller size. Fragments of a glassy triclinic feldspar, perfectly fresh, and the larger groups of plagioclase of earlier consolidation are also visible. The quartz is colorless or slightly blue, of strong greasy luster; without fissures and with rounded outline, or much fissured and then yellowish. A single grain, $5^{\mathrm{mm}}$ square, was made up mostly of a flesh-colored feldspar, but nearly a quarter of its mass was of the same greasy, bluish quartz. 
A plate of the feldspar was isolaterl and gave the optical characters of orthoclise and was wholly untwinned.

The pocket lens shows grains and flat vein-like accunulations of a deep-rect, resin-like character:

The microscope reveals anorthite, labradorite, augite, fayalite, magnetite, hematite, and, as inclusions, quartz, orthoclase, microcline, albite, rutile, muscovite, and biotite, and fragments of granite and amphibolite. The texture of the rock is entirely unlike any other occurrence among the eruptives of the region. The original minerals enumerated appear as fresh as in a modern lava, distantly, often very distantly, scattered in a finely granular ground.

Anorthite.-The porphyritic feldspars of the first consolidation are often as much as $2^{\mathrm{mm}}$ across. They seem to me to have shot out rapidly in thin plates, which are often much bent and broken and the parts moved away from each other, showing what is otherwise proved below, that they were formed in the liquid magma and moved some distance in it before its entire consolidation. They are of glassy clearness, and show not the faintest trace of alteration. They are bounded by perfectly smooth crystal faces, except where deep angular or rounded offshoots of the groundmass extend into them. Inclusions of this groundmass are very abundant and variously arranged-at times collected in the center, at times in concentric lines marking old surfaces of the crystal, which often differ from the final form; at times quite regularly arranged in $I, T$, and $L$ shaped masses, conforming to the cleavage planes with great regularity, the masses being of quite uniform size. The crystals show lines of growth of great delicacy, which are curiously disturbed as they bend in to surround rounded projections of the groundmass which penetrate the crystal. Some of the broadest plates lie so that they show no twinning, indicating that they are broad by the large development $\infty \mathrm{P} \breve{c}$. The angie of extinction is $-36^{\circ}$ on either side the twinning plane, indicating anorthite.

Labradorite.-The feldspars of later consolidation, from $\frac{1}{3}^{\text {mam }}$ to the smallest dimensions, extinguish with an angle of $122^{\circ}$ on either side the twinning plane, and so are very probably labradorite. They affect the lath shape more than the anorthite does. The larger are, however, broad, with square ends; the smaller, narrow rods; and they are rarely in contact, so that the ophitic structure characteristic of the common diabase is wanting. 
The angite is also perfectly fresh, although the abundant inclusions, combined with the irregular cleavage, make it only imperfectly transparent. Separate crystals are bounded by perfect planes. An acute pyramid or dome appears with especial frequency. They are finely twinned, with the interposition of several very fine laminæ at the center, and nearly colorless.

In one portion of the field is a group of the largest feldspar crystals (described above) loosely interlaced, and in the interstices the angite has developed so as to fill the spaces and produce exactly the basaltic structure. Only where the meshes were not closed do the augites project ontward with terminal faces. If the crystallization had continued undisturbed it would have produced a rock having exactly the texture of a Tertiary basalt. As it is, it is plain that the delicate featherwork of feldspar plates was floated along in the magma and its crystallization arrested, and one can see that the formation of the basaltic structure does not necessarily depend upon the crystallization, first, of the feldspar in a network of bars, and then, second, of the augite in the interstices thus left, but rather upon the different methods of the crystallization of the two minerals simultaneously; the augite, having started a crystal in contact with a feldspar blade, tended to increase this to a large, stout crystal, while the feldspar, rapidly shooting out new blades, inclosed and bounded the augite on all sides, hindering the formation of crystal faces.

Hematite is quite abundant in the rock, blood-red, with botryoidal fibrous structure, showing the black cross abundantly, and aggregate polarization, and especially surrounding the inclusions of quartz and microcline. It also occurs, with blood-red color and fibrous structure, pseudomorph after olivine. The olivine form is sharp and clear, $2 \mathrm{P} \check{\infty}(021)=99^{\circ} 15^{\prime}$ (calculated $99^{\circ} 06^{\prime}$ ), and this sharp dome is combined with the prism. When traces of the original mineral remain they extinguish longitudinally. Irregular cracks run across the mineral as in olivine and bound separate fibrous masses, the fibers being at right angles to the fissures. I conclude that an olivine very rich in iron-a fayalite-lhas changed into hematite, more or less mixed with serpentine. The pseudomorphs are always surrounded by a whitish, semiopaque halo, probably from the silicic acid expelled from the primary mineral. Other similar forms are olive-green and polarize only in traces, and seem to be olivine changed to serpentine. They have also the white, opaque halo. Very rarely a rounded grain, which 
still polarizes brilliantly, is surromded by a broad layer of fibrous structure, the fiber's radiating and wholly anorphons.

Matymetite is ratre and in small grains only.

The gromulniss is made up of angular and romded grains $0.001-$ $0.005^{\mathrm{mm}}$ across, which ean at times be seen to be twins, and they seem to be, in part at least, angite, as they show an extinction at $42^{\circ}$. A specimen from the north edge of the dike has the large feldspars so filled by these minute angites that they occupy the whole space as closely as they do in the surrounding groundmass. Indeed, it appears as if a portion of the groundmass having a regular crystalline outline had been preserved intact fiom all decomposition, so that the interstices of the grains have not been filled with the fine dust of limonite, kaolin, etc., which renders the rest of the ground clouded. With polarized light the grains are seen to be optically orientated in the feldspar, as they extinguish together, and the feldspar bands can be distinctly seen shining through. The groundmass is for the most part the same in the portions included in the large feldspar crystals as outside, but some inclusions are red-brown and apparently glass. I can not detect with certainty any glass in the groundmass itself. The inclusions are plainly from granite: quartz with slreets of pores, some containing moving bubbles, and rutile needles, microcline, centrally decomposed albite with extinction angle $4^{\circ}$, and orthoclase. Fragments of granite with feldspars wholly altered, and of an amphibolite quite fresh and closely resembling the fine-grained rock at the northeast corner of Amlierst, also occur.

A specimen from the first cleared field north of the brook, externally like the last, shows both the feldspars and the augite perfectly fresh and colorless, sharply defined, and distantly scattered in the ground. There is so much hematite that it takes up a considerable portion of the surface. One quartz inclusion is surrounded by a colorless radiated fibrous layer, and outside this by a broad band of hematite. The hematite so often surrounds the foreign inclusions in a rock otherwise fresh that one is tempted to assume it to have been a cement covering the grains before their envelopment in the lava.

A great number of bodies are present having exactly the shape of olivine crystals and a bright-yellow or red color. The yellow scarcely polarizes at all, some few fibers or isolated spots showing faint color, and it seems to be a yellow serpentine pseudomorph. The red shows a peculiar 
aggregate or patchy polarization, and seems to be a hematite pseudomorph after olivine.

Another specimen from the vicinity of the last has a very different structure. In a granular groundmass $\left(0.01-0.02^{\mathrm{mm}}\right)$ there are regularly disseminated, well-formed octahedra of magnetite, visible with a lens in the slide, and abundant diabantite-filled cavities. Small lath-shaped plagioclases and augites are distantly scattered and inconspicuous. The rock resembles that of the dike from the house south of the ruined leather mill below Mount Tom station, on the west of the river.

The above descriptions had been written before I received the first accounts of Mr. Diller's discovery of quartz-basalt at the Cinder Cone, in California. On sending him fragments of the rock here described, he wrote that the quartz resembled closely that of the Cinder Cone, and was more abundant.

It will be seen from my own descriptions that the idea that the quartz was original in the rock had not occurred to me. It does certainly resemble the Cinder Cone quartz very closely, and it is hard to see how a great quantity of foreign sand could be included in an erupted dike, and especially how it could fail to bring with itself moisture enough to make the rock vesicular. The shapes of the grains and the high greasy luster are not like granite-quartz. I have not been able to verify my observation that the slides contain microcline and mica, as the slides are not now accessible, but the presence in the diabase, among many quartz grains, of a large fragment ( $5^{\mathrm{mm}}$ across) made up of quartz and orthoclase is certain. The quartz was exactly the same rounded, bluish, greasy quartz as the rest, and the flesh-colored feldspar gave the optical tests of orthoclase, so that I feel quite certain that the unusual constituents have come in as foreign inclusions.

The structures produced by the introduction of this large amount of foreign material into the liquid trap resemble those described from the Greenfield bed in Chapter XIII (p. 419), where the sand has risen up into this lava from below. This locality was studied many years ago, before the Greenfield and Holyoke beds were understood, and I can not say what modification of the above description might come from a new examination of the place with new light. The blue color of the quartz may be due to tension produced by heating, or the quartz may be derived from Algonkian blue-quartz gneiss. (See page 29.) 


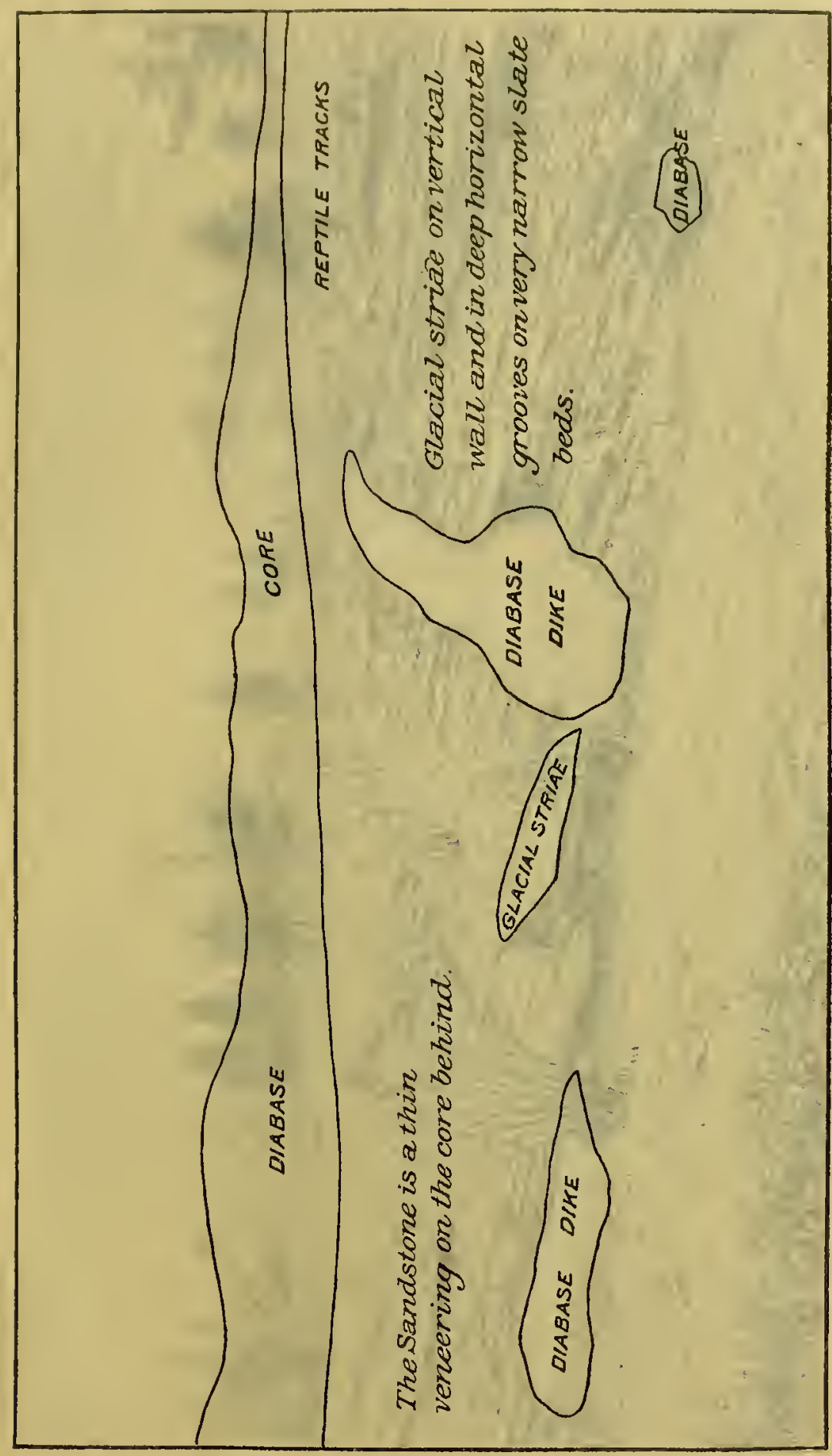




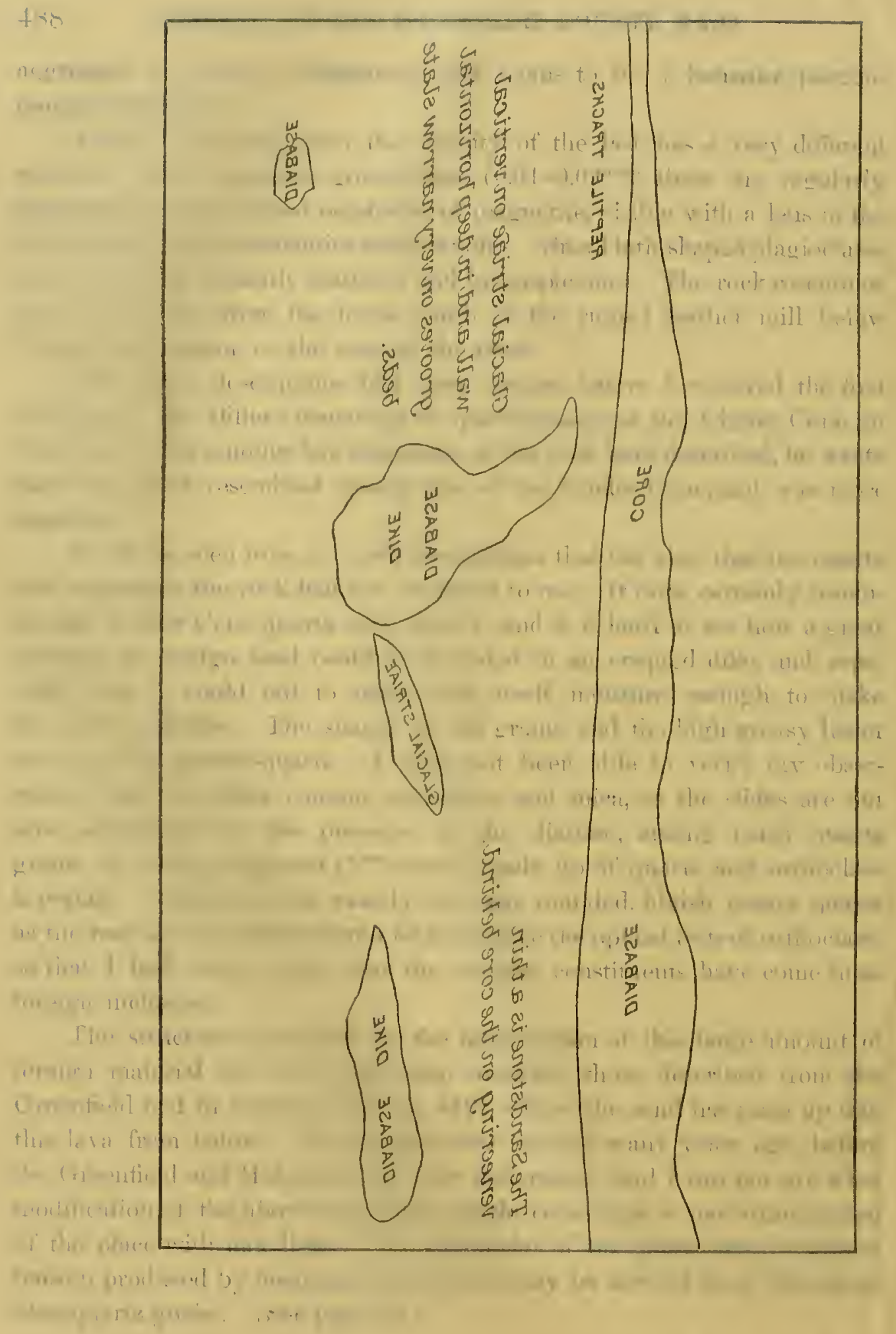




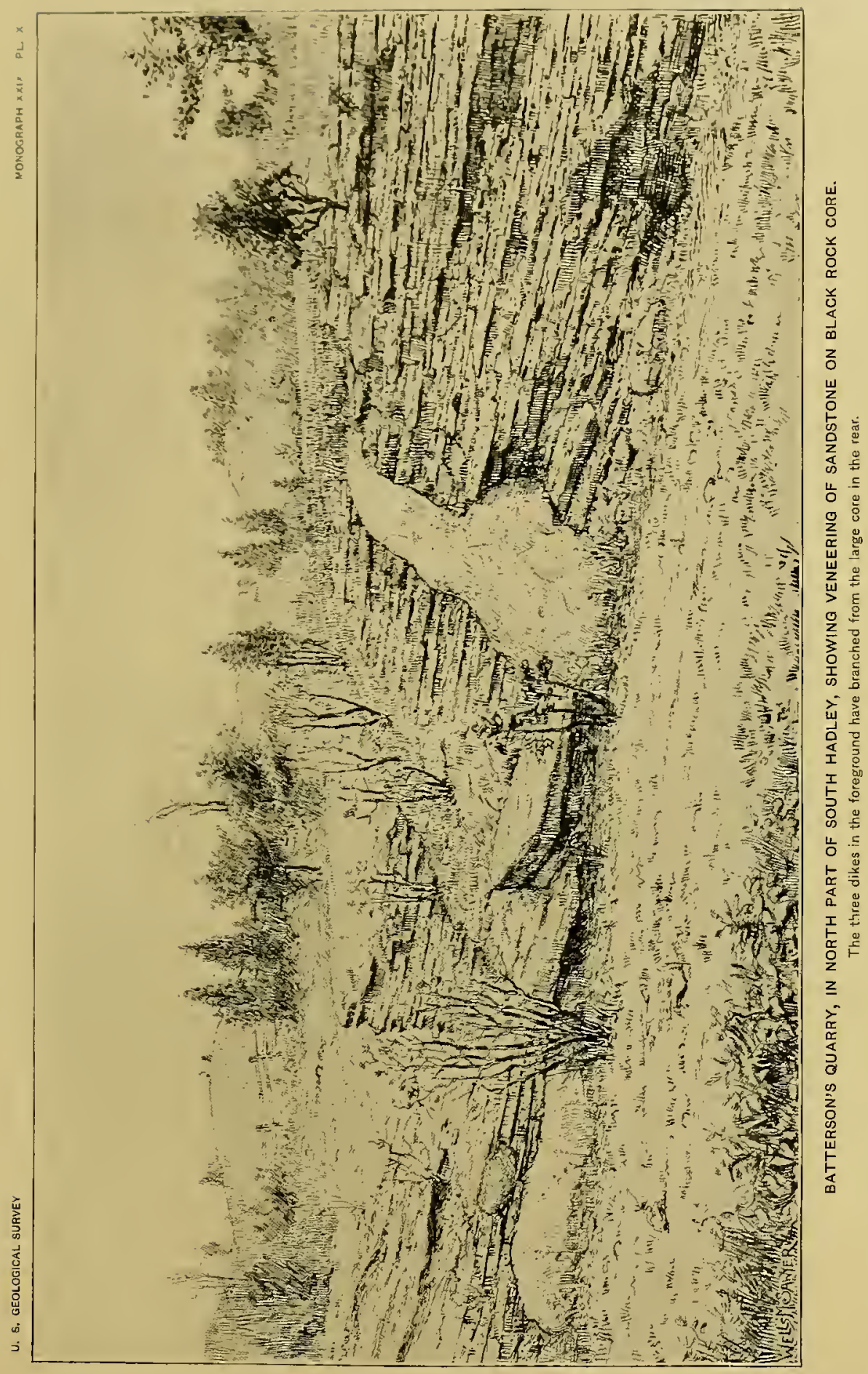



THE TENTH CORE.

The wood road that runs north into the mountain west of Moody Corners branches after crossing the eleventh trap mass, and the western branch in a few rods runs ont on the sands of the large Glacial lake described below. Here, at a pair of bars giving entrance to the field, near a small brook, begins a long outcrop of trap, which continues 50 rods west, forming the bluff which made the south shore of the lake. The coarse arkose surmounts it on the sonth, and it is by the downward pitch below the sands of this sandstone on the east and the west that the outcrop of the trap in those directions is limited, while the sands conceal its northern limit. Near its western end, where a stone wall runs across the sands, at the foot of a marked bluff, the sandstone resting on the trap can be seen to be well baked by it, and as the trap is wholly fine-grained and without steam holes it is plainly intrusive.

THE ELEVENTH OR BLACK ROCK CORE.

Looking southeast from the Mountain House, on the tọp of Mount Holyoke, one sees a prominent ridge of dark rock ruming parallel to the mountain-indeed, duplicating it on a smaller scale, repeating its easy southern slope and sharp northward-facing bluff and making with it the great sweeping curve. It differs radically from it in its origin, the larger deposit having been, as I have shown, a bed spread out over the subjacent sandstone, and this an injected dike cutting across the latter. (See Pl. IX, p. 446.) This bluff, as seen from the mountain, is called "The Black Rock," and I have chosen this name to designate the core, and also the whole series of the newer trap intrusions. Seen from the west side of the river above Smiths Ferry, it simulates exactly a volcano with sharp slopes and central depression.

The core is best studied at Batterson's quarry, in the northwest corner of South Hadley, near the last house (E. H. Lyman's) before the town line is reached. As seen in the accompanying view ( $\mathrm{Pl} . \mathrm{X}$ ), the nearly horizontal sandstones are a remnant resting with their edges against the diabase.

The latter not only cuts across the sandstone at this point, but sends into it apophyses of finer grain than the main mass, which have altered the sandstones in places for 4 feet from the contact and have fused themselves into firm union with the latter at their junction. The thin-bedded micaceous sandstones are delicately plicated by the intrnded trap. 
Following the vertical wall of the diabase north 335 feet from the quarry - a wall which is the contact surface against which the sandstones formerly rested-one comes upon a most interesting point, where this wall is continued as sandstone, a fine contact being exposed, and the boundary line of the diabase and sandstone goes into the hill at a right angle. Climbing to the top of the bluff, one can follow this contact east, the sandstone at a distance of 4 feet from the diabase being baked into a dark-blue, lornstone-like rock. When the boundary bends round from east to north the thin-fissile sandstones have the unusual position, strike N. $70^{\circ} \mathrm{W}$., dip $40^{\circ}$ E., being thus thrown off from the eruptive rock. Continuing, the boundary returns westwardly, and thus embraces a great projection of the

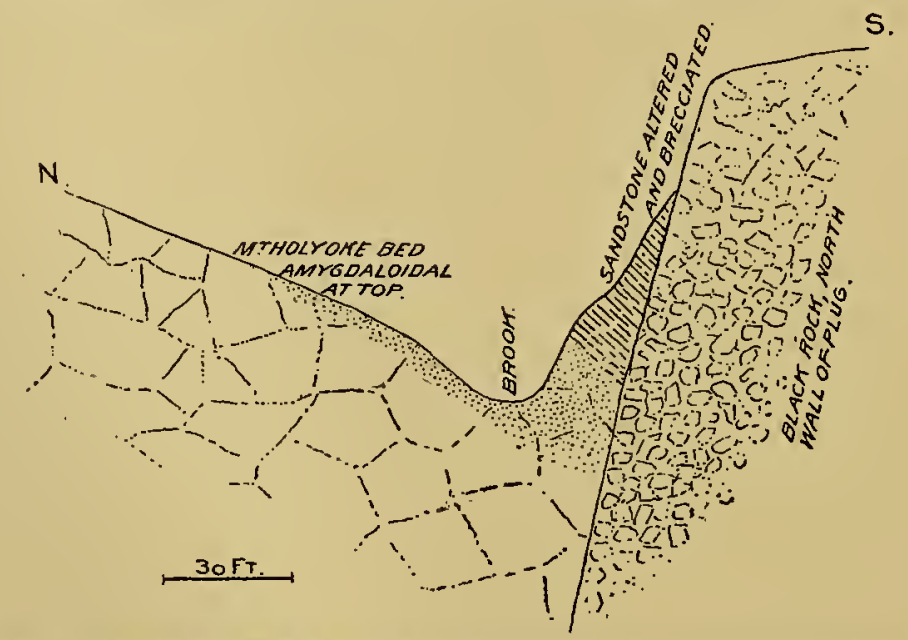

FiG. 27.-Section of contact of Black Rock plug and the Mount Holyoke diabase bed.

sandstone which extends far into the diabase, and then turns round to the east, parallel to the direction of the older bed.

For a long distance one can follow up the bed of Dry Brook running on the back of the older diabase, while its left (south) bank is a vertical wall of sandstone dipping southward and ending abruptly against the diabase of the Black Rock dike, as indicated in fig. 27.

At the point where the first outcrop of the sandstone on the brook appears, about 590 feet from the contact in the vertical wall last described, occurs a curious metamorphosed limestone-breccia, with garnet, near the base of the sandstone. This nearness of the two diabase bodies continues, and one goes east a long distance through a valley with its right or north side 
the harck of the main cliabase bed, rising gradually nortl to the Holyoke 11 une, its left or south side the vertical wall of the Black Rock dike, its face reneered to al rarying distance upward with the remains of the sandstone.

When one comes out where one can look down on the cleared sand flats of the post-Glacial lake mentioned above, one sees that the boundary of the Mount Molyoke bed contimes east, while that of the great crater swings round southeast and extends to the deep gorge of the little brook which drains the basin of the lake above mentioned, and has cut deeply throngh the diabase to enter Elmer Brook, just north of H. White's. The diabase continues to rise ligh and to carry a thin remnant of the sandstones in contact with its vertical face, which sandstone shows contact effects and can often be plainly seen to abut against and not to underlie the volcanic rock, toward which it dips. Where the boundary of the diabase runs southeast the sandstone preserved its east-west strike in the nnain, but in places dips toward the diabase with the abnormally high angle of $80^{\circ}$.

At the west end of the mass the diabase appears in the road at the Lyman house, and its westward extension is concealed by sands. This is also the case with its southern border. The outcrop at the point where Ehmers Brook crosses the road is so brecciated and its fissures are so filled with druses of small rhombohedra of hematite that it is probably near the southern contact.

On following the southern edge along to a point about north of the schoolhouse, where the road to South Hadley starts, it is seen that sandstones appear on the south of the trap, strike N. $65^{\circ}$ E., dip $15^{\circ} \mathrm{S}$ - -finegrained, calcareous sandstones, blue-black as if baked or loaded with volcanic ashes, and rusting slowly inwardly, like the diabase, and between them and the diabase is a band, apparently 10 to 15 feet wide, of the most perfect tuff, made up wholly of angular trap fragments of the size of a pea, with here and there one as large as an acorn, all greatly decomposed. The exact relation of the tuff to the other beds could not be made out.

The boundary can be closely followed eastward to the brook east of White's wood road, to which the northern boundary has already been followed. The exact contact can not be seen, but the dark rusting sandstones dip south away from the diabase, while the latter rock in the inmediate proximity to the contact ( 6 to 8 feet distant) is compact, coarsegrained, and not porous. 
Approaching the brook the boundary bends northeast, as that on the north side had bent sontheast, and down the slope to the brook the diabase is amygdaloidal where nearest the sandstone. The boundaries have approached each other so that in the deep side of the narrow brook gorge only a fourth of the width of the great mass appears, but this is well exposed, and a great tahus of fragments of a quite coarse diabase makes up the greater portion of its width. The bottom of this narrow gorge is covered with sand. In its opposite east wall one can trace from the south the sonthward-dipping tuffs, and from the north in fine cliffs the light-buff sandstones with the same dip, to where they approach the eastward continuation of the diabase; and althongh the contacts are covered, it can be pretty plainly seen that from both sides the sedimentary rocks abnt against the diabase. The latter is very fine-grained and has only a small fraction of the width it had on the other side of the gorge. This gorge is 1 mile northwest of Moody Comers.

Going east it cuts through the tuff, and where this is coarse and both are decomposed it is very difficult to separate them. In one place the diabase is quite coarse, light-colored, and greenish from the abundance of diabantite, like that just east of White's wood road, and like the rock of the Deerfield bed at the Deerfield Noteh. Followed still farther east, where it is crossed by the wood road north from Moody Corners, the diabase is on the north dark, fine-grained, and bounded on the north by sandstones which for a long distance east abut against the high wall of the diabase, as already described. Its boundary against the tuffs on the south is less clear. Where the road crosses, the distinctly columnar diabase rises in a ridge about 35 feet wide, and yet in this is a mass of tnff nearly a meter across, containing fragments of granite. To the south a narrow swamp separates it from a rock which seems to be a coarse volcanic agglomerate made up of angular fragments often 10 to 16 inches across, which in much-weathered exposures can hardly be distinguished from the normal diabase.

PETROGRAPHICAL DESCRIPTION.

1. A section taken from the second outcrop by the roadside going in from Mr. Lyman's house and Batterson's quarry is the typical gray diabase, not distinguishable by the lens from the Iron Gate rock taken as a type above (page 461), and the microscope reveals little distinction between the two, either in structure or stage of decomposition. Pyrite occurs in excep- 
tional abmulance. The feldspars are wholly decomposed and the rock is full of spots of diabantite.

2. In varions sections cut from specimens taken at different distances up to 3,300 feet from the edge of the dike no distinction could be observed, but in one taken from very near the center the augites were in large, distinct crystals, very abundant, and plainly anterior to the feldspars.

3. Slides taken from the south edge of the dike, where Elmers Brook finally leaves the trap, showed a large development of the finely granular groundmass (grains $0.005^{\mathrm{mm}}$ ) so common in the rock of the tenth dike.

4. Sections were cut from the long, narrow, eastward prolongation of the dike where the Moody Comers wood road crosses it and at its intersection by the two roads next east. They resemble the type closely. The augite is in the main subsequent to the feldspars, but is a little more distinctly individualized in long blades. Olivine changed to an olive-green serpentine and distinct traces of the unaltered mineral occur sparingly.

5. In sections cut from the edge of the small apophyses sent off by the main mass into the sandstone and exposed in Batterson's quarry, we get additional proof that the larger feldspars are of earlier consolidation. These porphyritic feldspars are of the common size, 1 to $2^{\mathrm{mm}}$ across, and are associated with deep-green, well-formed olivines in an extremely fine-grained groundmass, so that it seems that they had already separated out in the magma before its injection into the narrow fissure in the sandstone, in which it cooled so rapidly that the customary ophitic structure was not produced but was replaced by the semicrystalline development described below.

The main groundmass is a felted mass of finest fibers $0.0016^{\mathrm{mm}}$ across, quite possibly feldspar microlites, which are not rigidly straight, but wavy, often beaded, and are clearly margarites; generally, however, they polarize distinctly. These fibers have a radiated arrangement, which gives the whole groundmass a spherulitic structure. The fibers polarize sheafwise, although they are not parallel.

The presence of olivine in the fresh fine-grained diabase dikes in the granite, and especially in the minute dikes I have described (p. 416), as also its presence in the newer diabase of the volcanic plugs, particularly in that one which has been described as so full of quartz grains (p. 483), may seem, when contrasted with the absence of olivines in the great Deerfield and Holyoke beds, to indicate that the two former occurrences are to be 
associated together as of the same age and contrasted with the two latter and older occurrences; but olivine occurs in considerable abundance in the base of the Holyoke bed at the west foot of Provens Mountain in Westfield. It is strange, howerer, that where the inclusions of quartz are most abundant olivine is also most abundant.

\section{NORTHAMPTON}

THE TWELFTH OR BURNT MILL CORE.

Beneath the railroad bridge over the brook which crosses the railroad a mile above Smiths Ferry the contact of the sandstone dips steeply southeast beneath the posterior trap, and this contact can be followed, clearly exposed, along the south side of the brook beneath the road bridge and past the ruined leather mill, and along the south side of the mill pond. The couformable posterior trap bed extends southeast of this line. (See p. 465.) Just north of the brook and below the dam one sees the outerops of an intrusive dike or plug, which comes up apparently along a transverse fault that can be traced west across the mountain from this point. The trap cuts across the strata of sandstone that underlie the posterior trap bed at every angle, and adjacent to the north end of the dam bakes the sandstone for 6 or 8 feet, so that the line of contact between trap and sandstone is seen with difficulty.

A long ridge of the trap extends west along the northwest side of the pond, and appears also on its south side, and can be followed thence south for 20 rods. At the water's edge trap and sand are confusedly blended. In the bluff above, just south of the head of the pond, appears a well-marked fault. The posterior trap abuts on the sandstone. It is the continuation of the Mount Tom fault, and the newer trap comes up at the intersection of the two faults. A large part of the trap is fresh, compact, and breaks with sharp splintery fracture; a portion of the surface is crumbly and much weathered. This represents a part of the surface of the old laccolith.

The trap of the plug may be followed down the brook on its north side to the road, and just east of the road several offshoots from it appear on both sides of the brook. On the north is a 4-foot dike, on the south a 4-inch dike at the water's edge and a 1 -foot dike a few feet up. The latter continues under the road to the dam. A few rods farther east one comes upon the most southern of two outcrops of trap at the Lyman railroad crossing, which is doubtless the eastern edge of the plug, since it is com- 
posed of the same type of trap and contains as inclusions portions of coarsely amyrglaloidal trap, derived doubtless from the posterior trap sheet, or the tuff, through which it has been intruded.

THE SMITHS FERRY CORE.

Directly opposite the Smiths Ferry station and at the edge of the low terrace sands just south of the extensive dog kennels the tuff is interrupted by an area of trap, abont 6 rods on a side, which seems to be intruded throngh the tuff, since it has angular masses of the tuff 6 inches across included in its mass. It does not rise above the level of the tuff, as is usual with the more compact plug trap, and I at first considered it a portion of the surface of the posterior sheet exposed where the tuff had been worn through, but the inclusions of trap are foreign to the posterior sheet and the erosion of the old lake shore-line may have lowered the plug at this point. (See, however, page 474.)

CORE AT THE LLECTRIC RAILROAD CROSSING OF ROARING BROOK.

Where the Holyoke Electric Railroad track leaves the main road to go to Forest Park it crosses Roaring Brook. Just south of this crossing is a surface of trap, exposed by the excavations for the road, which is weathered and breaks up into spheres at the surface and rests on the sandstone in the brook just below. This is the south exposure of the posterior trap sheet. Just across the brook the railroad cutting exposes a splintery trap of fine grain and perfect freshness, which seems to be the sonthernmost of the small plugs accompanying the posterior sheet.

\section{SUMMARY OF HISTORY OF THE CONNECTICUT RIVER SANDSTONE.}

The mountain-making forces which folded up the Appalachian chains acted against the mass of the Archean rocks in the Adirondacks, as seen by the great curve which these chains make as they run southward beyond its influence. The outlines of the Connecticut Basin were laid in preDevonian time, since the Bernardston Devonian is bordered by shore conglomerates which coincide with the borders of the basin and the later limits of the Trias. The sinking of the great block south of the Connecticut shore-line, which broke this curve of the Appalachian chains, prepared the way, perhaps, for the second admission of the waters into this narrow channel, which in slape and position resembled the Bay of Fundy. 
The tides of this bay were on a scale which for a bay of this width have no counterpart at the present time. They passed strongly up the west side and down the east side, and were here reenforced by the prevailing west winds, so that they formed very coarse conglomerates on the east. The currents sweeping up the west side, past shores and over bottoms of coarse and deeply decomposed granites, swept granitic débris far north, over the area of black schists. Those passing south swept argillite and quartzite débris far south along the pegmatite shore-line of the east side, and the pegmatite material south along the tonalite and schist terrane, and only where the bay widened was there in its center an elaboration of quartz sand to form the brownstones. In the narrower parts of the bay the two shore conglomerates meet along a central suture, so to speak, and this ends so abruptly at the north end of the basin as to suggest that it extended much farther nortl and was perhaps a strait opening into a larger area to the north.

The network of faults which bounds and intersects this basin permitted the sinking of its bottom, in which movement the block from Amherst to Northfield participated in a much less degree than did the rest. In the great transgression which followed, the waters slowly rose upon the bottom and the slopes of the basin and found a great abundance of material ready for transportation and redistribution, because the rocks had become deeply disintegrated during the long period of emergence which was now brought to a close.

I lave examined both shores of the Bay of Fundy as well as the fiords of Norway and Scotland, and in comparison the work done here seems to me to indicate stronger currents, a larger amount of material, more rapid change of level of the sea, and more rapid deposition, than can be found in any modern examples. The sea seems to have risen over the flats and slopes of deeply softened rock more rapidly than it could remove the material, and therefore advanced without forming a fixed and deep-cut coast line. It often moved the softened débris in such large quantity to its present resting place that it is scarcely sorted or rounded even when quite coarse gravel. Indeed, the study of this Triassic transgression has thrown more light upon the ancient and more widespread Cambrian transgression (Chapter V) than I have gained from the examination of more modern instances.

It is very remarkable how entirely the finest clayey material was 
wholly removed from the basin during the deposition of beds of so great thickness. At a certain time in the midst of this rapid deposition came the great eruptions, apparently synchronous, of the Deerfield and Holyoke berls. The bottom of the bay at this time presented a surface covered in different parts by beds of every degree of coarseness along its borders and grading toward the center into finer beds, as is indicated by the character of the substratum on which the trap beds rest.

Along beneath the trap of the Holyoke range from west of Mount Ilolyoke to beyond Mount Tom much argillaceous limestone is inclosed in the trap at its base, and in Holyoke, at Ashley's pond, the same limestone occurs in the inchisions at the surface of the same trap sheet.

I explain the above structure by the under-rolling of the surface of the sheet. A limited amount of calcareous mud was washed by the strong convection currents onto the submerged surface of the advancing sheet (which was superficially solidified) and blended more or less with this surface, which by the continued advance of the mass became in part underrolled, like the surface of an unrolling carpet, thus protecting the sand below from baking, and bringing the highly vesicular trap loaded with limestone to the base of the bed. A similar structure occurs at the base of the trap sheet east of Greenfield, but not at its surface. This was caused by the frothing up of the muddy bottom into the liquid trap.

It is quite probable that these trap sheets were poured out through fissures-the Holyoke sheet through an east-west fissure passing beneath the line of small volcanic cores a mile south of the main outcrop of the main bed, and continuing as a north-south fissure passing through the same series of plugs west of the Connecticut. The focus of most intense and long-continued action was about a mile south of the point where the river cuts through the main ridge and where these fissures intersect. The Deerfield fissure can not be exactly located. It was beneath or east of the present outcrop, because artesian wells at Turners Falls cross the trap sheet just east of this outcrop, and there is no trace of intrusive trap west of the present western bluffs. Its focus was probably just east of Greenfield. These sheets produced no disturbance in the distribution of sediments and almost no tuffs, and the arkose which covers them is often buff and niearly free from iron and lime.

The sands which spread over the basin soon covered the great trap MON $\mathrm{xxIX}-32$ 
sheets, and then a second period of volcanic activity followed. The lava broke out at a point on the fissure through which the older lava had come, and flowed in a broad sheet down the bottom of the valley. The place where the lava came up is preserved in Little Mountain, east of Mount Tom, and the outerop of the lava sheet extends north and soutl from here, and has been described as the posterior sheet.

The next episode in the history, following immediately on this outflow of lava, was an explosive eruption of diabase forming the beds of tuff from the Belchertown ponds to Holyoke. The center of eruption seems to have been at the focus mentioned above, not far from Smiths Ferry, since the bombs there are a foot across and decrease in size in both directions. The tuffs produced a marked change in the fucoidal ${ }^{1}$ beds (the Longmeadow sandstone) above, into which they grade, as compared with the older beds beneath the tuff. By shallowing of the water the beds are rendered finer, and they are made deep-red and calcareous from the decomposition of the tuff. These red beds extend south from the lunate band of tuff, but this tuff only accelerated and intensified a process which extended far south beyond its influence, and which had its cause in the width of the basin, its shallowness, and the presence of northward currents along its west side and southward currents along its east side. These currents kept the sides of the basin deeper and made them a seat of coarser sedimentation, and between them was a central area of conflicting and shifting currents-a sort of Sargasso Sea, in which the finer fucoidal sandstones were deposited and so frequently exposed by the retreating tides that almost every part shows mud-cracks, rain-drops, tracks, thin films of coal, or some trace of exposure.

The northern or Montague basin reached only this stage, the broad development of the central fucoidal sandstones, and there was no tuff outburst or development of shales. In the wider southern or Springfield basin a central area of still greater quiet developed with the widening of the channel, in which at last marly sediments were retained within the area, marked by numerous salt psendomorphs, and in which a later circulation of the waters has concentrated the lime into bands of concretionary limestone.

1 These paragraphs were written when the rodlike markings in the "fucoidal" sandstones were supposed to be plant remains. I now think them to be concretions, as explained under "Plants," $p$. 395. There may thus be added to the effects of the impregnation with iron the abundant rod-shaped concretions which have been mistaken for plant remains and called "fucoids." 
The beds containing reptile tracks are almost without exception above the great trap sheets, and in most cases not very far above them vertically. Some of the localities situated far to the east have been brought up by fanlting. These central exposed mud flats seem to have been eaused by shallowing of the waters, which resulted from the flowing of the great sheet out over the bottom.

The present dips are the result of three actions difficult to separate:

(1) Deposition upon an inclined plane, especially that between the central shallower portion and the deeper portion on the border. This seems to be the case across Hatfield and Deerfield, on the western side of the basin, where the finer central beds dip slightly west toward the coarser beds near the shore, and across Sonth Hadley, Springfield, and farther south, where the finer central beds have a low dip eastward toward the shore beds. In these cases the beds have been moved but little since their deposition.

(2) A slight excess of sinking on the eastern side or an increment in the strength of the eastem currents, or both, by which the finer central beds were in their eastern portion encroached upon and covered by a broad transgression of the eastern conglomerates, so that all down the east side the fine-grained beds dip normally beneath the coarse.

(3) Later tilting, largely to the east, but bending to the south in the Holyoke range, and generally of the monoclinal type, the important exception being at the mouth of Millers River, where there is a great syncline whose axis pitches sharply a few degrees south of west. By this later monoclinal tilting the covered bed of fucoidal sandstone is brought up several times in the mass of Mount Toby.

A third period of volcanic activity occurred in the southern basin about the time of the close of sedimentation and the final tilting of the sandstones. Nearly a score of volcanoes formed a chain running from the Belchertown ponds first west to the Connecticut River and then south to Holyoke, apparently caused by the reopening of weak points along the great fissures which had supplied the material of the earlier sheet. One of these shows indications of having been a laccolith sending out a long fissure-filling in the sandstone. Another is diabase filled with granitic inclusions. The rest are small plugs.

The final tilting was much more severe in the northern portion of the 
basin, and has here a large component of north-south motion, and thus of east-west strikes. The limit of this severe action is the east-west fault marked by the line of craters just mentioned. Many baryta-lead veins in the sandstone and the crystalline rocks on its borders seem to have been formed at this period.

In his review of the question whether the rocks of the Connecticut Valley were deposited in a separate basin, as has been maintained in the preceding pages, or were connected across western Massachusetts and Connecticut and eastern New York with the New Jersey Triassic, which culminates in the Palisade range, Professor Russell ${ }^{1}$ still maintains the opinion he had advanced in earlier papers. The localities described in the preceding pages where coarse conglomerates and coarse, unworn arkose beds rest on the crystalline rocks along the western border, and the relation of these beds to the great granite areas directly west, make it quite certain that the upper end of the bay in Massachusetts had its western shore-line quite exactly at the present western border of the Triassic beds. These latter are mainly formed from botton to top of the coarse débris of muscovite-granites such as now form their western border, while if they had transgressed but a few miles westward they would have covered entirely all this coarse granite area, and there is no similar area from which the arkose could have been derived farther west, where the shore-line must have been.

\section{THE USE OF THE TRAP AS ROAD MATERIAL.}

It is well known that the trap furnishes the best material for road making, and as the legislature of Massacliusetts has wisely entered upon an extensive and carefully arranged scheme looking to the extension of macadamized roads throughout the State those places where the trap is found in large quantity and of good quality and near to railroads will be of economic value. The city of Springfield has for a long time worked a quarry at the point in Westfield where the Boston and Albany Railroad crosses the main or Holyoke trap sheet. Recently (1895) the Massachusetts Stone Crushing Company has established an extensive plant on the south side of the Deerfield River at Cheapside, with a capacity of about 100 tons per diem. The company has spur tracks to the Turners Falls branch of the Canal Railroad and can distribute its product readily by rail 
from Northampton or Greentield. This work is on the main Deerfield trap sheet. The Now England Trap Rock Company, of Westfield, has oprenerl another large quarry on the west line of West Springfield, on the Iolyoke-Westfield road, with a spur track to the railroad which comnects these towns. It has two large crushers with a capacity of 700 tons per diem, and can deliver the rock on the cars at 65 to 75 cents per ton. A crusher has also been set up at the west foot of Mount Tom, in Easthampton, which supplies this town with road material. It is directly under the most picturesque portion of the palisaded bluff, and although it is at present working in the trap talus, later the operations may seriously mar the north wall of the mountain. The great dike beside the spur track of the quarries of W. N. Flynt \& Co., in Monson, has been opened by that company, and will supply material of the very best quality.

The city of Northampton has for several years established its crushing works near the north line of the town and at a distance from railroarls, and works the Hatfield tonalite or hornblendic granite, which. is a partly decomposed rock, more brittle than the trap, and in many ways an inferior rock for road ballast. The city has access beside the road or railroad within its own limits to several better ledges than the one it works now. In 1897 the city of Ware opened a quarry on the Coys Hill dike on the mountain side east of the railroad station. The dike is here 5 rods wide, favorably situated for quarrying, and will furnish the best material in inexhaustible quantity.

The other localities where the rock occurs in good quantity and quality and convenient of access to the railroad are: Where the Fitchburg Railroad crosses the Deerfield trap sheet, on the north side of the Deerfield River and directly opposite to the present works; along the Connecticut River Railroad below Mount Tom station, especially at the first crossing, and at Delaney's quarry on the north line of Holyoke; at Tatham Cutting, in West Springfield; and finally, all the later volcanic cores marked on the map, and especially the dikes of the trap marked in the crystalline rocks on the east of the Triassic area, furnish a rock more fresh and firm than the trap of the main sheet.

West of the Triassic no beds of trap are found and the hornblendeschist of Chester or the Becket gneiss will be the best substitute for local use. 


\section{H A P T E R X I V.}

\section{MINERAL VEINS.}

The only mineral veins in the area are of the "baryta-lead formation," though in some of the fissures occupied by these veins there seems to have been an antecedent "fluorspar-calcite formation." Many of these veins seem to have been first filled with fluorspar and calcite and various ores. These are now scarcaly represented except by the many pseudomorphs of quartz after fluor and calcite. The circulating waters bearing silica first dissolved out or replaced the fluor and calcite. This forms the beginning of the second stage of vein filling, and the veins soon became quartz-barite-galena deposits, with chalcopyrite and sphalerite at times replacing the galena. It is quite possible that the fluorspar-calcite formation dates from the time of the post-Carboniferous folding, and entirely probable that the baryta-lead veins coincided with the folding of the Triassic rocks, since they occur both in the Triassic sandstones and in the older rocks.

All the minerals which occur in the veins mentioned above are described in detail in the author's Mineralogical Lexicon of the three counties $^{1}$ and in the supplement to the same in Chapter XXII of this monograph.

The other beds in which mining is done-the emery bed and the pyrite and hematite beds in the Hawley schist-are in the main contemporaneous beds, interstratified with the schists which contain them, and the workable ores were either originally present, as in the emery bed, or were formed largely by replacement of other beds, so that it has been more natural to discuss them in comnection with their country rock.

Westhampton; the Loudville vein.-On July 27, 1679, the little plantation of Nonotuck, now Northampton, held a town meeting and voted, "after much discourse and agitation," that the town have a general interest 
in a leat mine newly discovered within its limits. There is but one other entry on this subject in the early records of the town, viz:

At a legal meeting Oct. 16, 1679, they then having further Conference about the lead mine whieh Robert Lyman fonnd ont, they then voted that all such persons as rould join in the Carrying on of that design, Should meet on the 23d of this instant at Sun one hour high at night, and to them or to those persons that shall then appear the Town do hereby give up all their right in that mine lying about six miles off; at the west side of the Town.

It can not be learned what came of this vote, but bullets were cast from lead smelted here during the Revolution. ${ }^{1}$ The shaft was opened before 1769, and again in October, 1809 . It was reported upon by Benjamin Silliman in October, 1810, and the report was printed as an article in Bruce's American Mineralogical Journal." The shaft was then 60 feet deep, the adit 25 to 30 feet, and the vein was "a very magnificent one, 6 to 8 feet in diameter." In 1815 the adit was 726 feet; the shaft entering 500 feet from the mouth was 90 feet deep. ${ }^{3}$ In 1818 Amos Eaton described the rocks of the adit carefully. It was then 800 feet deep, 666 feet in sandstone, 134 feet in granite-schist and serpentine, containing veins carrying quartz, fluor, calcite, chalcopyrite, and one small vein of galena.. ${ }^{4}$ In 1823 the adit was 990 feet long and had cost $\$ 20,000$.

In 1827 druses containing more or less calcite crystallized among the crystals of quartz had occurred in the last 200 to 300 feet of the adit ${ }^{6}$ and a company opened a new mine with a drift on what was supposed to be the same vein 3 or 4 miles southwest; the vein being 6 inches to a foot wide. In the next year the vein was opened one-half mile north. ${ }^{7} \quad$ In 1832 President Hitchcock mentions with apparent regret that work had been stopped on the adit at 900 feet, largely because the price of lead had decreased greatly, from western competition, and expresses the belief that the vein would have been struck in a few feet. The mine was opened again in 1855 "with prospect of success."

The mine was again opened in about 1862 , and I remember visiting it

${ }^{1}$ Evert's History of the Connecticut Valley in Massachusetts, Vol. 1, 1879, p. 17.

2 Ibid., Vol. I, p. 63.

${ }^{3}$ E. Hitchcock: North American Review, Vol. I, p. 335.

"Amos Eaton: Am. Jour. Sci., 1st series, Vol. I, p. 137.

${ }^{5}$ E. Hitchcock: Am. Jour. Sci., 1st series, Vol. VI, p. 201.

${ }^{6}$ A. Nash, The lead mines of Hampshire County: Am. Jour. Sci., 1st series, Vol. XII, p. 258.

${ }^{7}$ E. Hitchcock: Am. Jour. Sci., 1st series, Vol. XIII, p. 218.

${ }^{8}$ E. Emmons, American Geology, p. 183. 
then, in my freshman year, and rowing the length of the adit. The Manhan Silver-Lead Company was formed, which erected extensive buildings and installed expensive machinery. I have been informed that the enterprise failed because of the fall in the price of lead at the close of the war, and that the machinery, costing about $\$ 60,000$, was sold to the Chester Emery Company for about $\$ 17,000$.

The vein produced lead with about $12 \frac{1}{2}$ ounces of silver per ton from galena. Sphalerite, chalcopyrite, pyrite, and bornite occurred more rarely; barite and quartz in abundant crystals was the gangue. As decomposition products, malachite appeared with wulfenite, cerussite, and anglesite, and the finest pyromorphite occurred. Psendomorphs after calcite and fluorite indicated the former more abundant presence of these gangue minerals.

The most interesting article that has been published on the lead veins of Hampshire was by a wholly self-tanght man, $\mathrm{Mr}$ A. Nash, and this seems to haxe been his only essay in authorship. Professor Shepard, who then did editorial work on the American Journal of Science, told me that it took much editing to make the paper intelligible. Much of what follows comes from that paper. ${ }^{1}$

Whately.-This vein is in the sonthwest part of the town, on the summit of a high mountain of granite. The vein is 3 to 4 feet wide; considerable galena occurs in a quartz gangue; the range and vein strike northeast. (Nash.) I have searched for this without success.

Whately.-In the northwest part of the town. The vein runs north and south. It has been traced 100 yards to the edge of Conway. The ends of the vein are in mica-schist; the middle is in granite; 6 to 7 feet wide. The gangue is quartz; the ore, galena only. (Hitchcock. ${ }^{2}$ ) Shows graphitic slickensides; crushed veins with quartz, calcite, and green fluor.

Conway.-Southeast part, 3 miles from meetinghouse, and southeast of the manganese vein. It contains quartz and galena. (Nash.) May be the same as the last.

Chesterfield.-A copper mine is put down on Nash's map east of the Lily Pond Brook, but not mentioned in the text.

Goshen.-Sixty rods east of Congregational meetinghouse; galena in crystallized masses of quartz on the ground; no vein seen. (Nash.)

${ }^{1}$ Am. Jour. Sci., 1st series, Vol. XII, p. 238; map.

${ }^{2}$ Am. Jour. Sci., lst series, Vol, VI, n. 204. 
Williumshury-Northeast part; vein not seen; large blocks of quarty oceur in great profusion in a range several rods wide and one-quarter of a mile long; the quarts is radiated and 'rich in galena and chalcopyrite. (Nash.)

Williamsburg.-Vein runs north west, then north, and then northeasterly into Whately; quartz partly green and amethystine with pyrolusite and galenil, which increases northerly. (Nash.)

Williamsburg.-Extending into Whately one-half mile east of the above. Contains galena and pyrolusite in quartz. (Nash.)

Williamsburg.-At northwest corner of Northampton, near the argentite locality (see Mineralogical Lexicon, ${ }^{1}$ under "Calcite"). It contains pseudomorphs of calcite and fluorspar; the vein extends down the brook one-third of a mile on the east side. (Nash.)

Shelburne.-North of J. Dole's, 1 mile west of Shelburne Center, at southeast border of gneiss on contact of homblende-schist and mica-schist; vein 2 feet wide, containing pyrite, galena, blende, malachite; runs N. $25^{\circ}$ E., dip $40^{\circ} \mathrm{E}$.

Greenfield.-At junction of diabase and upper sandstone, on the west bank of the Comnecticut, 100 rods below the mouth of Fall River. It goes north obliquely into the diabase and south across the sandstone in the river bed. The principal vein is 5 to 6 feet wide. It strikes north-south; dips $90^{\circ}$; malachite is common, the sulphuret is rare. There is a second vein about a mile below, and narrow veins with fine slickensides occur in other places between. (E. Hitcheock. ${ }^{2}$ )

Turners Falls. - West side of the island at the falls; strike north-south; dip $90^{\circ}$; produced fine large masses of chalcopyrite and much siderite; is in brecciated sandstone.

Hatfield.-Vein appears in the bluff of tonalite about 2 miles west of the town, 60 rods north of the road to Williansburg. It can be traced N. $60^{\circ}$ W. for about 30 rods. A slanting shaft has been sunk from the base of the bluff; the vein is 1 foot at surface and 3 feet at bottom. Farther west the vein has been opened about 20 feet deep; it is here 4 feet wide at surface and 8 feet at bottom. Back from the vein the tonalite seems very fresh, but under the microscope its feldspar is always much kaolinized. 
For several feet on the border and in the numerous "horses" it is changed to a plainly kaolinized white nica-granite, most or all the hornblende being removed. It contains rarely green fluor and calcite, $\mathrm{R}^{3},-\frac{1}{2} \mathrm{R}$, weathered to dull gray and both in every stage of change to hollow pseudomorphs of quartz. The main filling of the vein-following the above calcite-fluor stage-was quartz, itself covered by barite, which so abuts against the quartz with its prismatic faces that the latter seems to be the newer mineral, which is rarely the case. Galena, blende, pyrite, chalcopyrite are the ores. A second generation of calcite, $R, R^{3}$, occurs in the quartz. Cerussite, malachite, pyromorphite, limonite, and pyrolusite are the decomposition products.

Leverett.-One mile northwest of the meetinghouse, on land of Mr. Field, once considerably worked, but abandoned on account of its unpromising appearance. (Nash, 1827.) Was worked by a company organized in New York a few years ago, but did not pay. ${ }^{1}$ Strike north-south; dip $90^{\circ}$. (E. Hitchcock.) The vein is in mica-schist and granite. It is several feet wide, and contains galena, chalcopyrite in masses of the size of one's fist, blende in the best crystals obtained from any of the veins, aud pyrophyllite. The gangue is baryta. Hollow quartz psendomorphs after pyrophyllite occur.

Leverett.-South line, "White Rock quarry." Only few inches wide at surface, but widening below. Galena and chalcopyrite abundant at surface, but rare below; worked but few feet down, there 1 foot wide; nearly pure barite. (Nash.) Later a long adit was driven in, but eaved many years ago.

Leverett.-Cut south of railroad crossing next east of last mine; narrow veins of barite, with little galena.

Northampton.-At the quarry east of Florence, in Northampton (south of W. N. Moore's house), the biotite-muscovite-granite is cut by joints running N. $50^{\circ}$ E. and dipping $60^{\circ} \mathrm{N}$. These joints are about a foot apart and in this and in the next quarry to the east are often marked by fine slickensided surfaces. Between two of these fault planes a sheet of the granite is finely crushed and the parts recemented, producing a great crush fault which runs beyond the limits of the quarry in both directions. The fissures thus produced were occupied first by calcite, which is now present only in a few erystals coated with transparent cubes of fluor, but is further represented by negative erystals in barite and quartz. Barite followed the 
calcite and shot out through all the cavities in broad plates of extreme thimess. 'This was followed by an abundant deposition of quartz, both as drusy surfices and as pseudomorphs after calcite, and by barite. There is also an abundince of a chocolate-colored tabular quartz, slashed full of tissures fiom which the blades of barite have disappeared, which is a most perfect pseudomorph after the peculiar tabular form of calcite called argentine, which occurs also on the other border of the great granite area.

The quartz is followed by prehnite in broad surfaces of large crystals, simple or slightly rosetted. The prehnite was followed by laumontite in fine large crystals possessing the wholly peculiar form characteristic of this mineral, but now represented only by hollow incrustation psendomorphs in albite, which latter appear as minute, limpid, very characteristic twins. The whole forms thus a very peculiar but very clearly observed paragenesis.

Russell.-Mineral veins appear in the northwest part of Russell, showing drusy quartz and galena. ${ }^{1}$ Specimens are deposited in the Massachusetts State Survey collection made by E. Hitchcock.

Huntington.-Angel's mine, Norwich, now Huntington. Showing bleude in large masses and a beautiful drusy quartz pseudomorph after barite and calcite, ${ }^{2}$ according to the specimens in the survey collection.

${ }^{1}$ Cat. Agr. Museum, 1859. Rept. Agriculture Mass., Appendix, p. LXIX, No. XIX, 202, 203.

${ }^{2}$ Loc. cit., 300, 201, 204-211. 


\section{H A P T E R X V. \\ THE PLEISTOCENE PERIOD. \\ LITERATURE.}

1818. E. Hitchcock. Geology of Deerfield. Am. Jour. Sci., 1st series, Vol. II, p. 107.

1823. - Geology of Connecticut River. Ibid., Vol. VI, p. 80.

1827. A. Nash. Lead Mines, etc., of Hampshire County. Ibid., Vol. XII, p. 248.

1833. E. Hitchcock. Geology of Massachusetts, pp. 33, 135.

1835. - Geology of Massachusetts, 2d edition, p. 174.

1841. - - Geology of Massachusetts, Final Report, 40, pp. 306, 332, 357.

1850. - Proc. Am. Assoc. Adv. Sci., Vol. III, p. 155.

1852. —. Ibid., Vol. VI, p. 264.

1860. - Illustrations of Surface Geology. Smithsonian Contributions to Knowledge, Vol. IX, pp. 1-155. Also issued separately.

1863. - - Reminiscences of Amherst College, pp. 260, 311.

1871. J. D. Dana. On the Conuecticut River Valley Glacier. Am. Jour. Sci., 3d series, Vol. II, p. 233 . Vol. V, 1873, pp. 198, 217. Vol. X, 1875, pp. 180, 280, 353, 497. Vol. XII, 1876, p. 125. Vol. XXIII, 1882, p. 87. Vol. XXV, 1883, p. 440 . Also published separately.

1877. J. S. Diller. Westfield during the Champlain Period. Am. Jour. Sci., 3d series, Vol. XIII, p. 262.

1877. - Westfield Times and News Letter, Vol. XXXVII, Mareh 28, September 19.

THE INTERVAC BETWEEN THE TRIASSIC AND THE GLACIAL PERIOD.

DEPOSITS.

Within the area here under survey the materials for a reconstruction of the history of the later Mesozoic and the Tertiary are extremely scanty.

With the exception of a single trap talus beneath the lower till there are no known deposits left to represent these long ages. The excavations for the Turners Falls branch of the Canal Railroad were carried along the south side of the Deerfield River where the latter passes through the notch in the Deerfield range to reach the Connecticut, and exposed at a height of 
50 fect above the river a great talus of trap fiagments-a pre-Glacial "Devils Garden," as these desolate slopes were called by the fathersresting against the rertical will of trap, which here rises about 100 feet above the level of the stream. The talus was exposed for a length of 90 feet and for a height of 30 feet, and it apparently extends down to the level of the river, 50 feet below, but this was not observed. Covering this talus and extending up over the trap was a layer of very compact till, 30 feet thick, of reddish color, made up mostly of sandstone with few bowlders of mica-schist from the western hills and with none of trap. At least ninetenths of the bowlders, down to those not above 2 inches on a side, were finely striated-a quite unusual proportion.

A fresh vertical section of this till produced by caving was marked for a long distance by wavy lines of apparent bedding so perfect that at a distance I had supposed the beds to be the thin-laminated Champlain clays, but the lamination proved to be an unusually perfect pressure cleavage in the till, in planes dipping $60^{\circ}$ to $70^{\circ} \mathrm{NW}$., at right angles to the direction from which the ice was moving in the canyon, as marked by the striæ upon the trap immediately above. These data prove that the ice breasting the long westward-facing vertical wall of the Deerfield trap range was pressed into this notch in the range with exceptional force, from which we may deduce that the prevalent southward motion of the ice in the valley was due to its deflection from the normal northeast direction by the northsouth walls of the valley and of the divide ranges.

A further interesting deduction is that the notch of the Deerfield range is, in its present form, of pre-Glacial origin, and since the river flows throngh without exposing rock at bottom the gorge was then of even greater depth than at present. The Deerfield Indians affirmed that it was begun by a squaw with a clam shell.

One other deposit, probably of Tertiary age, is described with the "Camp Meeting cutting," near end of Chapter XIX. It is a thoroughly sorted, pink beach sand, and it appears below the glacial beds on the nortl line of Northampton.

PRE-GLACIAL WEATHERING.

The only important case of the preservation of any portion of the deeply decomposed surface rocks which must have characterized the country before the advent of the ice, as they are now characteristic of 
non-glaciated countries, is the great bed of kaolin preserved from the ice under the lee of the great hill on which Blandford is built (see p. 330). Another area is northwest of Roaring Brook bridge, on the south line of Northampton (p. 474).

PRE-GLACIAL DRAINAGE AND EROSION.

The above deduction concerning the age of the Deerfield notch may serve as an introduction to the discussion of the other similar notehes in the valley and of its pre-Glacial drainage and erosion. (See map, Pl. XI.) Not only does the Connecticut pass through a like notch in the Holyoke trap range near its highest point in a deep, short valley bordered by fine rock-cut terraces (fig. 28), while it conld have passed down the western lateral valley (see topography of the valley, p. 8) without rising more than 145 feet above its present height, but the Westfield and Farmington rivers also, like the Deerfield, after passing out of their gorges in the crystalline rocks, run across the low sand plains of the western lateral valley, make a

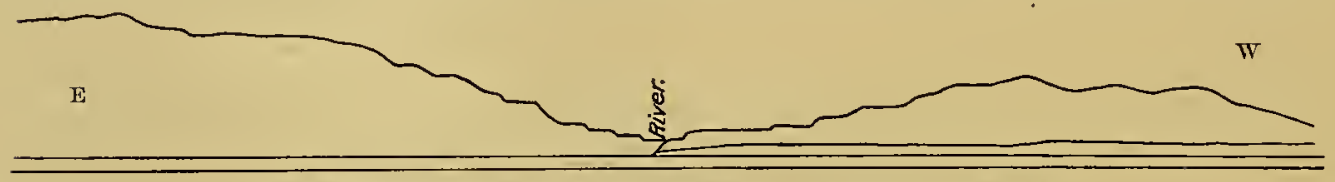

Fig. 28.-Holyoke notch from Hadley meadow; pre-Glaciàl rock terraces.

wide loop sonthward, and return to find in each case opposite the mouths of these gorges a notch in the high trap ridge through which they join the main stream, while in each case they could with a slight rise have passed sonthwardly across the sand plains, the Deerfield to join the Connecticut around the sonth of Sugar Loaf, the others to reach the Sound at New Haven. Indeed, this peculiarity of the valley system of the Connecticut early attracted the attention of President Hitchcock, who, after having described it with a sketch map in the Geology of the Conuecticut, ${ }^{1}$ writes in the Geology of Massachusetts (1841, p. 328):

The valleys through which the Connecticut and its tributaries flow are among the most remarkable in the State. The ordinary laws of physical geography seen here to be set at defiance, so much that a late ingenious writer doubted whether I had correctly represented the geology of the Connecticut because the course of the rivers and the direction of the mountain ridges were described as having so little correspondence with the rock formations.

${ }^{1}$ Am. Jour. Sci., Lst series, Vol. VI, 1823, p. 1. 



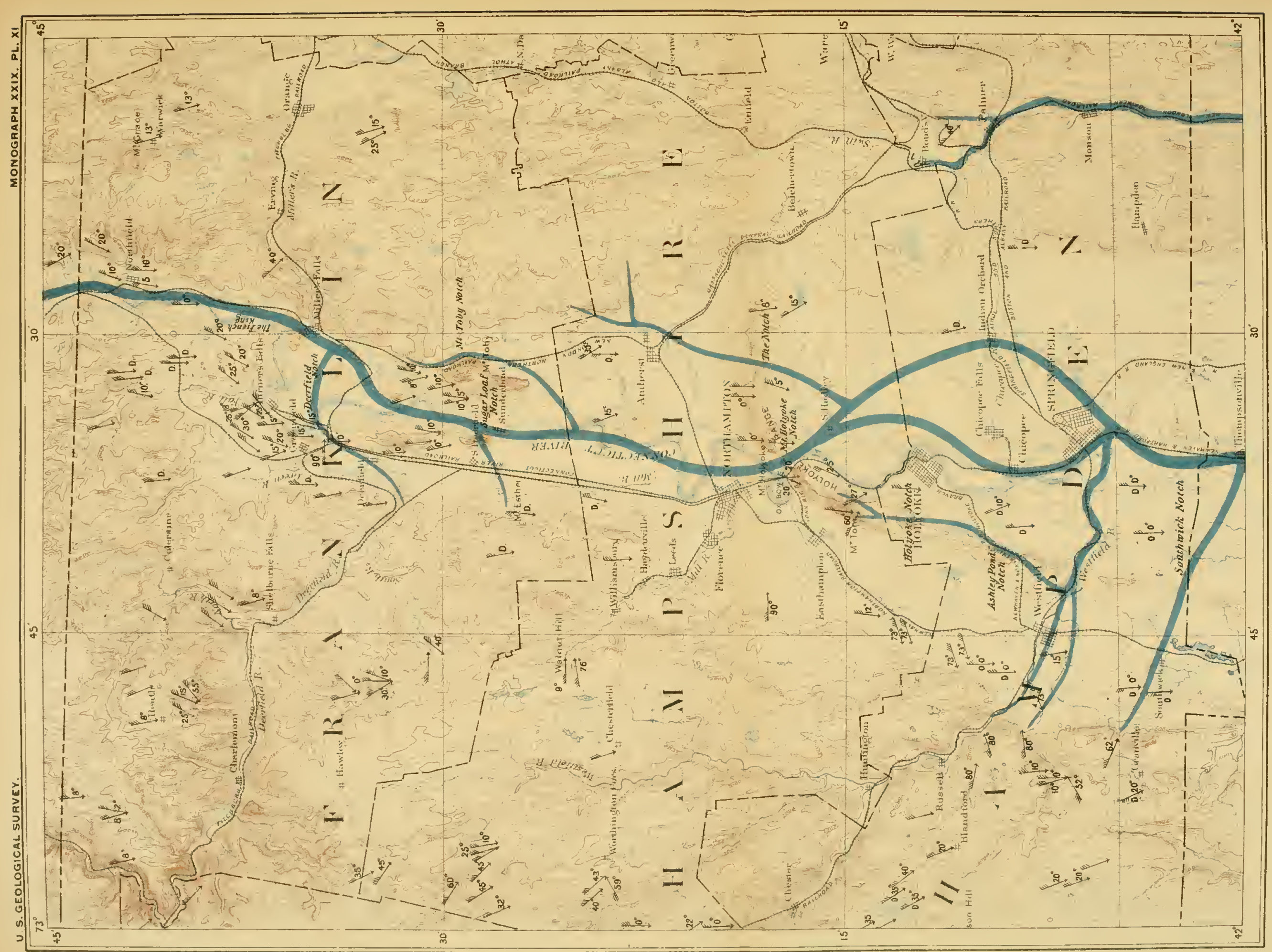



P'resident llitcheock draws the inference from the facts detailed above "that the Connecticut River did not excavate its own bed through these momitans, for had the barrier at Northampton been more than 134 feet above its present bed it must have emptied into the Sound at New Haven. We must seek some other canse, therefore, for the origin of the passage between Holyoke and Mount Tom." I draw the opposite conclusion, and believe the history of the erosion of the valley to have been as follows:

The streams occupied their present valleys in the crystalline rocks before and during the Triassic (at levels, of course, much higher than the present), and entered the Triassic estuary near where their gorges now end at the border of the sandstone. On the recession of the waters the Connecticut followed down the deepest line in the middle of the long bay and the tributaries took a direct course down the slope to this line of greatest depth to join the main river.

I imagine that the dislocation of the sandstones took place after this drainage was established, and so slowly that the streams were not seriously disturbed, but eut down through the sandstones till they reached the trap sheets, and then through these until the four gorges were carved.

Many facts point to the conclusion that these valleys were cut much deeper than the present bed of the river, and down, indeed, to or below the present level of the sea. Piles driven in clay at the Northampton bridge went 10 feet below sea level. The Belden artesian well, sonth of the Northampton station, struck rock 25 feet below sea level, and soundings showed the clays to have great depth beneath the main street crossing; these may represent an old course of the Mill River. Borings of the United States survey of the Connecticut River between Chicopee and Longmeadow were carried to points 19 and 21 feet above sea level and 43 feet below without meeting rock, and $1 \frac{1}{2}$ feet above sea level striking rock. ${ }^{1}$ In each of the four gorges here specially under discussion no rock appears in the stream beds. All the points cited above lie along the old channel, at places specially sheltered from glacial erosion.

From this one may conclude, in passing, that the falls along the Connecticut are located in portions of its course which do not coincide with this ancient one.

1T. G. Ellis, Report of survey of Connecticut River: Ex. Doc. 101, Forty-fifth Congress, second session, 1878, p. 122. 
Parallel with this deepening of the stream beds the unequal erosion of the whole area wore back the banks of the streams in easy slopes where they crosserl the soft sandstones, brought out the trap ridges in sharp relief, and left thus the short canyons or notches through these ridges.

Thus on the approach of the Glacial perior a surface had been reached which coincided much more closely with the present cultivated surface of the valley than with its present rocky floor, except along the western lateral valley - that is, the broad depression west of the trap ranges-and north of the Holyoke range, where the surface of the sandstones was then probably higher than the present surface of the later sands. Then came the Glacial ice, destroying the whole drainage system and removing an enormous quantity of the soft sandstone. Its work was favored and localized in two ways by the position of the trap ranges ruming down the middle of the valley. Where these ran nortl and south with bold westward-facing bluffs, as in the Deerfield and Mount Tom ranges, the ice coming from the northwest was deflected southward and scoured out the soft sandstone at the western foot of these ranges, and where the Holyoke range runs clear athwart the valley east and west the ice, by its recoil as it lifted over the range, plowed out the sandstone all along its northern base down to a level much lower than could have been well effected by ordinary aqueous erosion.

Thus the river chammels between the ends of the ravines in the crystalline rocks' and the notches in the trap ridges were obliterated because they were contained in the comparatively soft sandstone, and we have finally to seek the reason why the streams, upon the decrease of the floods which accompanied the retreat of the ice, in every case found their way again through their old notches instead of taking the more direct and natural course down the deep western lateral valley, from which the ice had removed the sandstone to so low a level. The broad river occupied then almost precisely the boundaries of the earlier Triassic estuary, and the tributaries entered it along the border of the western highlands.

Across Massachusetts the great river was, indeed, rather a series of lakes than a river, in that it was filled mainly from the sides by the great confluent deltas of its tributaries, which were pushed out to a distance proportionate to the importance of the stream that furnished each, while down its center clays and fine sands were deposited in less thickness. Thus it came about that the great body of sand delivered to the main stream by each tributary was spread diagonally across between the westeru hills and the divide ranges, 
and in somewhat larger proportions in the area just below the mouth of the tributary as a resultant of the transporting power of the main stream and the tributary, so that upon the lowering of the waters of the main stream and their retreat from the westem lateral valley each tributary found its way southward danmed up by its own delta deposits, and, ponding 'back behind them, flowed again through its old notch to join the diminished waters of the Connecticut. The heavy sands which fill up the lateral valley below each of these tributaries, from the western border across to the divide range, do in fact show, both by the derivation of their material and by their strueture, that they are the ancient deltas of these streams.

The thread of the current of the main stream, driven elear across toward the eastern foot of the divide range by the great delta of the Millers and Chicopee rivers, had continued to pass through $(a)$ the narrow passage between Deerfield Mountain and Mount Toby and $(b)$ the Holyoke noteh, two portions of its old ehannel, partly, perhaps, because these lay in the main artery of the pre-Glacial drainage, but more because they were out in the center of the lake, far from all lateral streams and their deposits, and on the recession of the waters the western or lateral valley was filled up to such a height by the Westfield River that the Connecticut was compelled to shrink down to this line and reoccupy its old noteh in the Holyoke range.

THE PRE-GLACIAL COURSE OF 'THE CONNECTICUT AND ITS TRIBUTARIES.

The pre-Glacial bed of the Connecticut across Massachusetts lay below the present sea level. (See map, Pl. XI, p. 510.) Hence, where the river passes over rocky bottoms with rapids and waterfalls it has been expelled from its pre-Glacial bed by Glacial and Champlain deposits. In each case the old bed of the stream is marked by a broad band of depressions in the high terrace sands-kettleholes-partly empty and partly water-filled. The ice seems to have persisted in the deep channel until it was covered by the flood sands and then to have melted to form the depressions. This is most marked south of Millers Falls across the Montague plain, in the great loop of Millers River and the succession of ponds extending southward, of which Lake Pleasant (its bottom about 67 feet below the plain) is the largest. From the State line to Northfield farms the river has regained its old bed. South of this point the great delta of Millers River crowded it 6 miles west to the foot of the trap ridge and MON XXIX_- 33 
compelled it to cut in the sandstone the French King gorge ${ }^{1}$ and the canyon of the Lily Pond.

The river regains its old bed in the passage between Monnt Toby and Sugar Loaf, where its fiue pre-Glacial rock-cut terraces which flank Momit Toby have received the name Sunderland Park, and its course across the Hattield-Northampton meadows is closely given on Pl. XI, p. 510. After its passage through the Holyoke noteh its conrse is nncertain, and there I give two alternatives on the map.

The reasons favoring the eastem course are that it lies along a line of deep depressions in the broad sand plain, and shows no rock outcrops where erosion has gone deepest. The reasons favoring the other course are that it passes over the borings of the Government surveys of the Connecticut River, one of which went 30 to 40 feet below sea level, and, like the other, is a line where the deepest erosion discloses no rock. (See "The Springfield Lake," in Chapter XIX.

It is certain that between the Holyoke notch and the latitnde of Springfield the river ran far east of its present comrse, because it now cuts throngh rock all the way from Mount Holyoke to the Holyoke Falls.

The justification for the course given the Deerfield River and the Westfield River has been presented above. An inspection of the map will suggest that the Deerfield River may have run southeast from its ravine through the finely rock-terraced notch between Sugar Loaf and North Sugar Loaf, and that its present notch in this range may have been cut by the Green River, but the drawing on the map represents the most probable status. The Sugar Loaf notch is not deep enough for the Deerfield River, which probably ran south of Sugar Loaf.

The notch which separates Sugar Loaf from North Sugar Loaf is plainly water-formed, and Whately Glen is its most probable upstream continuation among the crystalline rocks, as indicated on the map.

In the same way the main gap in the center of the Holyoke range, to which the name "Notch" is especially restricted in the valley, was the result of water erosion and was the site of a great waterfall before the Glacial period. It is deeply cut in the trap, with vertical walls, and its continuation in the sandstone immediately south of the trap sinks very suddenly to a mneh lower level, forming the Orchid Garden, celebrated among botanists. I think this notch was in contimnation of the "Freshman 
River:" It was temporarily reocenpied during the recession of the ice, receiving the overtlow of a Glacial lake which formed on the north flank of the Holyoke range, banked on the north by the ice of the Hadley basin.

There are two striking gorges in the west of the town of Holyoke, both entting the trap very obliquely, one occupied by Wrights Brook (which enters Hitchcocks Pond), while the Westfield and Holyoke Railroud passes through the other. These gorges seem to be portions of the bed of a stream that gathered on the east flank of Mount Tom and ran soutl into the Westfield River.

Another notch of unknown depth cuts the trap ridge just where it crosses the State line into Connecticut. This I have connected with the large brook which comes down from Sodom Mountain, in Granville, and have called it on the map the Sonthwick notch.

Though the evidence is much less clear, it seems probable that the narrow canyon skirting the east front of Mount Toby was cut by Locks Brook. Its bottom has now the shape of an abandoned water channel. It is probable that the portion of the channel of Locks Brook which ran in sandstone between the end of its gorge in the crystalline rocks and the beginning of the canyon was removed by ice erosion. At the end of the Glacial period the ice, halting in the Montague basin, deflected the brook again southward into this canyon.

THE CHARACTER AND AMOUNT OF EROSION DURING LATER MESOZOIC TIME AS COMPARED WITH THAT OF THE GLACIAL PERIOD.

From the preceding discussions of the crystalline rocks and the Triassic sandstones it is certain that the broad Connecticut Valley was an orographic feature of first importance formed in the crystalline rocks before the deposition of the sandstones, its borders coinciding elosely with the present boundaries of the latter. Prof. W. M. Davis ${ }^{1}$ has suggested that there may have been a pre-Triassic peneplain over this area. The places where the crystalline rocks break through the Trias are at such different levels in places very near one another that this is not probable.

This valley was then deeply filled by the sands of the Trias, indeed above and beyond the present lips of the basin, and has been since so thoroughly eroded a second time that only remnants of this filling remain. It seems quite certain that the walls of the valley during and at the close

${ }^{1}$ Bull. Geol. Soc. America, Vol. I1, 1, 549. .Jour. Geol., Vol. IV, p. 678. 
of the Trias were much higher than now or that the sandstones once extended much farther east and west.

Mount Toby, wholly made up of sandstone and conglomerate, is 1,275 feet above sea level (1,170 feet above the river), but to obtain its true height as a measure of the height of the Triassic at its maximum we must add a considerable but unknown amount for subaerial and glacial erosion. It is possible that we must subtract something also to offset the elevation of the mass during the disturbances which have tilted the rocks. I imagine it would be an overestimate of the latter movement if we should assume it to have been great enough to counterbalance the depression of the old surface by erosion. If, then, we take the present height of Mount Toby or Mount Tom as that of the sandstone at the close of its deposition and run a contour line at this level along the sides of the valley to obtain the original boundaries of the sandstones, on the assumption that the valley walls were then about their present height, this line would lie so far back from the present border of the sandstone and run into so many sheltered valleys that we should encounter greater difficulty in explaining why the sandstones are wholly absent from these broad areas on each side of their present limits than in assuming a very considerable degradation of the walls of the valley since it served as an estuary for the accumulation of the Triassic sediments. Indeed, we may say directly that the present border of the sandstones represents closely the old border of the estuary, because the coarse angular conglomerates and rudely sorted feldspathic sandstones cau have been transported but a very short distance, and, as their mineralogical character indicates, must have been derived largely from beds immediately adjacent, which would have been covered if the waters of the estuary had extended as far as the supposed contour line, and that, therefore, the crystalline border of the valley must have been sufficiently higher than now to form retaining walls for the accumulated Triassic gravels. Within these limits the coarse sandstone rose, as above indicated, to a height above that of Mount Toby, filling the whole valley to that level. The increased elevation may have amounted to many hundred feet.

It would be interesting to follow the course of the erosion by which the present ridges have been sculptured out of this mass and to divide the long quiet work of the waters in later Mesozoic and Tertiary times from the work of the harsher agencies of the Glacial period. 
I think it may be derluced from the facts given above that the greater portion of this erosion was performed by the first agent, but that the ice wore into the soft sandstone considerably, and in some places enornously; so thint, if the Pleistocene deposits were removed from the valley, the rocky floor below would bear small resemblance to the surface upon which the ice began to act. I inagine that the present surface of these latter deposits would much more nearly coincide therewith. Indeed, along all the west side of the valley from Deerfield to Southwick and beyond, and north of the Holyoke range, the sandstones may well have been considerably higher than the present cultivated surface of the valley. This is deduced from the consideration that if the present drainage represents closely the pre-Glacial, as shown above, the sandstone should rise by easy slopes from the streams and be highest in the areas between them, or in some way show an intelligible relation to them. But from this point of view the deep depression in the sandstone west of the trap ridge in Deerfield and north and west of the Holyoke range would render such a drainage impossible, and must be a later work, which can only have been done by the ice. This exceptional erosion of the ice depended largely upon the soft nature of the sandstones and the peculiar position of the trap ridges.

From the top of Mount Holyoke I have seen the valley fog rest against the hills east and west and, rising to my feet, spread, with a surface level as the sea, up and down the valley as far as the eye could reach. If it had risen a few hundred feet higher I believe its mass would have rudely equaled the pre-Glacial erosion of the Triassic, while I imagine the present Pleistocene deposits in the valley would scarcely equal the amount removed by the ice.

As for the crystalline rocks which flank the broad Connecticut Valley on either side, the fact that the newer crystallines are covered by the Trias in the bottom of the valley and yet are abundantly present in the coarse Triassic conglomerates, while the older Cambrian gneisses are broadly exposed on the east but are not represented in the adjoining Triassic conglomerates, shows that there has been large erosion over the eastern plateau since the Trias. The suggestion of Professor Pumpelly that secular disintegration may have deeply prepared these rocks for glacial erosion must be taken account of, and renders it impossible to assign to pre-Glacial and Glacial agencies their proper share of work. 


\section{H A P T E R XI.}

\section{THE GLACIAL PERIOD.}

THE PRESENT ROCK SURFACE AND THE AMOUNT OF GIACIAT AND POST-GLACIAJ, MATERIAL ON THE SANIE.

If the unconsolidated deposits-sands, clays, and gravels-were removed from the valley we should see a rocky floor, everywhere almost the exact surface upon which the ice last lay, except where, from the northward-facing cliffs of the Holyoke range, the frosts have since eaten into the much fissured trap and formed the talus of sharp fragments which rests against its base, and in limited areas where the streams flow on rocky beds.

The whole horizon would be unchanged. The high ridge which stretches south from Mount Toby, and upon which North Amherst, Amherst village, and South Amherst are built, would be little changed until, coming southward, we reached Mount Pleasant, the sonthern portion of which would be lowered to the level of the street at its western base, and College Hill, Mount Doma, and Castor and Pollux ${ }^{1}$ would also be absent. A ridge of rock would also stretch southward from Mount Warner, much below the present surface. The three depressions which, rumning nortl and soutl, bound these two ridges, would be much deepened, the East street depression by at least 50 feet; the middle one, separating the two rocky ridges, to an unknown depth; the western, in which the Connecticut now runs, to at least 110 feet below low water of that river, and thus down somewhat below the level of the sea. On the west of the river, in Northampton, the changes would be more extensive, as south of Elizabeth Rock and Roberts Hills and east of Loudville all the elevated comntry, Round Hill, the Hospital Hill, and the rest, would be removed, and the rock floor would be found everywhere down near or below the present level of the river, except along Mill River near the West street bridge. Under the Northampton meadows it may well be a hundred feet below the river level. I have already indicated the probable condition of the valley when the ice began to work upon it,

${ }^{1}$ Names given by President Hitcheock to drumlius south of College Grove and uorth aud south of Sonth Amherst.

518 
and the canse of the extreme inequality of its effects over different portions "1) the bisin is to be found primarily in the mequal resistance offered by the different rocks of which it is composed, and secondarily in the influence of the projecting masses of harder rock in deflecting the ice and shielding the softer rocks in their lee. Here the trap, so ensily dissected by the first, prover most able to resist the onset of the ice. The ridge of trap which makes the backbone of Deerfield Mountain survived after the sandstone hald been worn down on either side and protected the Sugar Loaf ${ }^{1}$ in its lee, and, with Hount Warner, farther south, projected into the ice as it wore deeply on their flanks. So Mount Toby, built of a conglomerate more durable than the sandstone beneath, and protected by Deerfield Mountain, stemmed the ice and sheltered the long ridge which runs south from it, so far that a fragment of the soft incoherent sandstone still lies along its eastern slope in Amherst village.

But the Holyoke range, coming up from the south, swings around eastward in a great curve, commencing at Mount Tom, and from Mount Holyoke on runs eastward to its end, and the great trap sheet which makes its strength is so placed as to present the maximum resistance to the ice moving from the north and northwest-that is, it dips everywhere as a continuous sheet from the crest of the ridge southward where the chain runs east and west, and as the ridge swings round to run southward the dip of the sheet swings round to the east. It received the pressure of the ice, then, as a $\log$ set to brace a falling building receives its weight. The ice, lifting over this sharp obstruction set right athwart its course, wore into it with great severity, and by its recoil as it raised its mass over the opposing range wore to a very exceptional depth in the area just in front of the latter, which had been filled with the soft sandstone, forming the broad, deep furrow which runs along the northern and western base of the range, beneath the Easthampton, Northampton, and Hadley meadors, and in the southern part of Amherst, in which furrow the three deep north-south depressions $I$ have described abore ended. ${ }^{2}$

${ }^{1}$ The table-mountain form of Sugar Loaf is probably due to a eapping of trap from the southward projection of the Deerfield trap sheet, whieh endured to near the elose of the Glacial period. It is ealled au "Eddy Peak" by Prof. J. D. Whitrey (1888); see bibliography in Chapter XXIII.

2It is an interesting faet that a line at the uorth foot of the east end of the Holyoke range forms a boundary north of which granite bowlders are abundant in the till, while south of this line they are rare. This is becunse the iee mass was greatly shattered as it lifted over the ridge, dropping ite bowlilers, while it eroded strongly on the erest; or it may represent the closing period when the seo wore over the Leverett granite aul halted at the north foot of the Holyoke range. 
It would be tedious to detail all the observations upon which this description of the present surface of the rocky substratum of the valley is based. One may trace on the map the crystalline rocks emerging from below the sandstones of Mount Toby and appearing at the surface in scattered outcrops southward to South Amherst, and the same thing may be seen, though less clearly, south of Mount Warner. At East street a well 50 feet below the lowest ground there failed to reach the ledge, and at the Northampton bridge piles were driven in the clays 110 feet below low water of the river without reaching bottom.

The most remarkable effect upon the present contour of the basin of this general erosion of the ice was in excavating hollows so deep and capacious that-especially where they lay aside from the direct line of the currents of the floods in the subsequent period-they have remained only partially filled to the present time, notably in the case of the East street valley and the southern part of the middle depression, which lies west of the village of South Amherst.

South of the Holyoke range the protecting influence of the ridge is as plainly seen as its agency in reenforcing the power of the ice on its north and west, and the sandstones stand much higher and appear abundantly above the surface of the later deposits and doubtless make a continuous substratum for the latter, while north and west, I imagine, the erosion over much of the deeply covered area must have cut down through the sandstones to the crystalline rocks below.

The low rock-floored valley bottom, everywhere nearly at and often much below the present river level, stretching across from the Pelham Hills to the western line of Northampton and broken only by the Anherst ridge and Mount Warner, not only sent a lobe southwardly through Easthampton, but another of exceptional depth up through the Deerfield Valley to the north line of that town, which was continued still farther north in a strange, narrow depression running up the west side of Greenfield and ending abruptly at its north line-a depression which was left unfilled in Champlain time.

North of Mount Toby the Montagne basin would be also largely increased toward the north by the removal of the drift. The immense sand desert between Millers Falls and Turners Falls and all the hills except one that rise above it would be removed, leaving a great depression, 
much of it below the present river level, with an ohl berl of the ('omecticut rumning down its middle and extending north firom Villers Falls to the State line with considerable increase of width. And the removal of the great swarm of drumlins which crowd the area west of the river in the northem portion of its course would materially affect the contours in Gill and Bernardston.

On the higher ground west of the valley the removal of the loose deposits woukd not so materially affect the surface except in the extreme west of Hampden County, and especially in Blandford, where over broar. areas the till reaches great thickness and rises in drumlins of the first magnitude.

East of the Connecticut Valley the same remark holds, except for eastern Hampden and southeastern Hampshire, where the removal of the heavy sands of the great series of Glacial lakes described beyond would greatly modify the surface and wonld probably show the deep GreenwichEnfield Valley to be continuous across Ware and thence, via the Beaver Brook and Ware River, to Thorndike, and thence straight south to Palmer station and on through the deep Monson. Valley and the narrow gorge of the Willimantic to the sea. (See map, Pl. XXXV.) The Ware River also seems then to have run directly sonth to Palmer to join the Swift River.

This basin stretching from Orange south across the State to its south line at Monson is peculiar in many ways. It is underlain by the Monson gneiss and widens and narrows with the width of this rock. While the broad band of this same rock which lies next west of this forms high ground, this forms a deep flat-bottomed valley, in the center of which rise high, isolated, dome-shaped hills of gneiss, which may have been preserver by a capping of the same quartz schists which form the ligh walls of the basin. The whole basin seems to be the result of deep disintegration of the gneiss. 
GLACIAL GROOVES AND STRI $A$.

(See map, Pl. XI, page 510.)

List of glacial grooves and strice in Franklin, Hampshire, and Hampden counties; bearings corrected.

[E. H.=F. Hitcheoek, Geology of Massachusetts, 1841, p. 387; Report on Certain Points in the Geology of Masøachusetts, 1853, House Dor. No. 39, pp. 34-44. B. K. E.= the present author.]

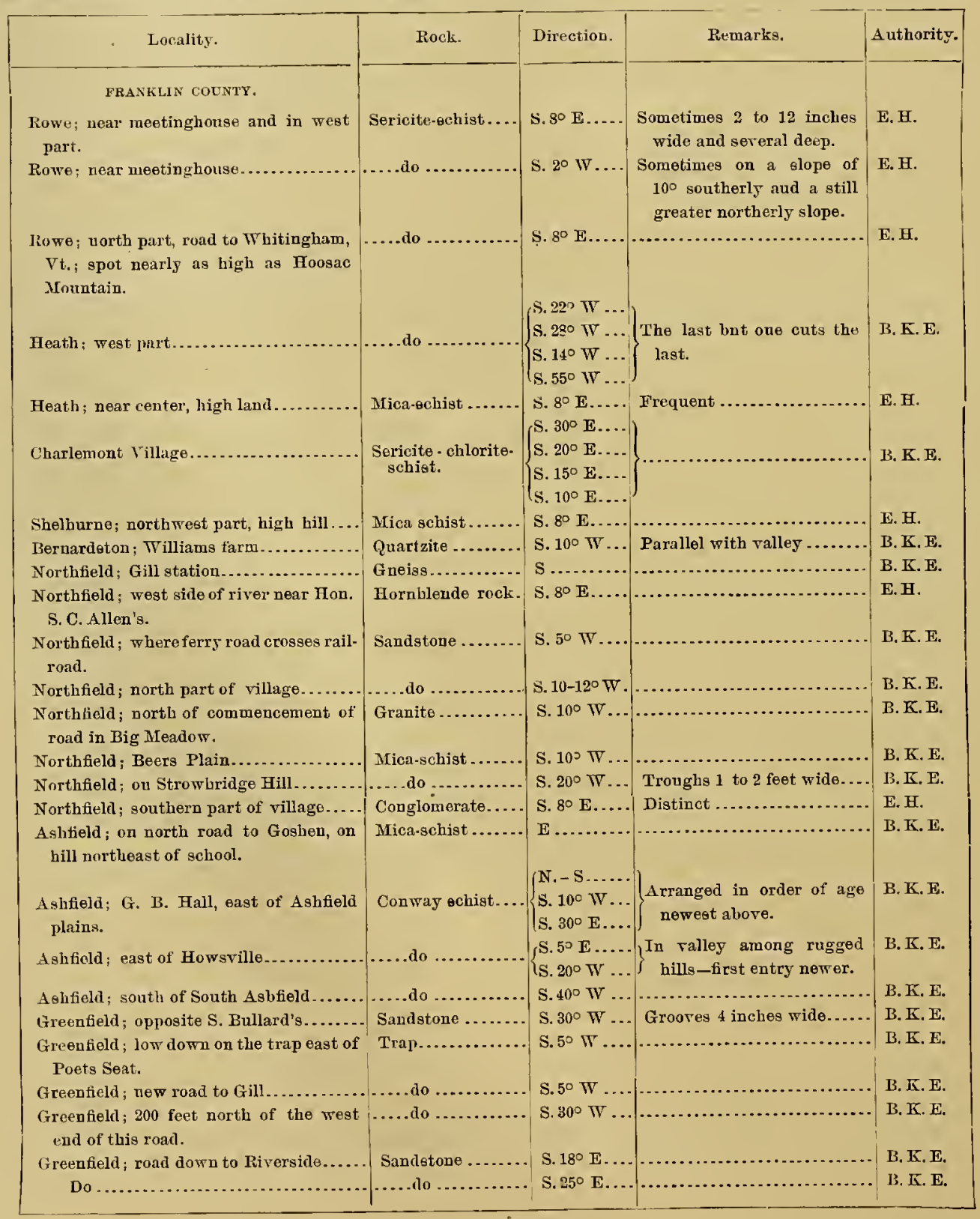


GLACLAL S'THIAE.

List of ylactal groores and striat, etc.-Continued.

\begin{tabular}{|c|c|c|c|c|}
\hline l.mulity". & Rock. & Direntioll. & Re'muarks. & Authority. \\
\hline \multicolumn{5}{|l|}{ FRANKLIN fOUNTY-continuot. } \\
\hline 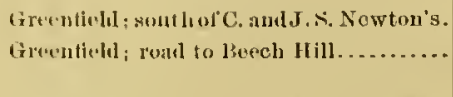 & Sandstone. & $\begin{array}{l}\text { S. } 30^{\circ} \mathrm{W} \\
\text { S. } 10^{\circ} \mathrm{E} \text {. }\end{array}$ & $\begin{array}{l}\text { Striae and gruoves } 3 \text { tect } \\
\text { wide, } 8 \text { inclies deep. }\end{array}$ & $\begin{array}{l}\text { I. K. E. } \\
\text { B. K. E. }\end{array}$ \\
\hline Greentield; north palt of Fecioral street. & ..... do . & S. $8^{\circ} \mathrm{E}$. & Very distinct . . . . . . . . & E. H. \\
\hline Greenfield; west of tactory villago...... & .....do do........... & S. $25^{\circ} \mathrm{W} .$. & 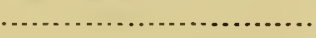 & B. K. E. \\
\hline $\begin{array}{l}\text { Greentield; onc-lialf mile northeast of } \\
\text { culer. }\end{array}$ & Sandstoce ........ & S. $8^{\circ} \mathrm{E} \ldots .$. & Very distinct ....... . & S. H. \\
\hline Gretntield ; sear mouth of Mlill Brook... & ..... do ............. & S. $15^{\circ} \mathrm{W} \ldots$ & 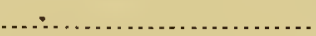 & B. K. E. \\
\hline Gill; school south of center............ & Conglomerate..... & S. $20^{\circ} \mathrm{W}$... & .......... & B. K. E. \\
\hline Gill ; 1 miles north of Lily Pond....... & .... do & S. $20^{\circ} \mathrm{W} \ldots$ & .......... & B. K. E. \\
\hline Gill; northwest of fiactory village....... & Sacdstoue ........ & S. $25^{\circ}$ W ... & & В. К. E. \\
\hline $\begin{array}{l}\text { Erving: under Dressers Mountaie on } \\
\text { sontl. }\end{array}$ & Greiss....... & S. $40^{\circ} \mathrm{E}$. & $\begin{array}{l}\text { In Miller's River Valley ont } \\
\text { of Connecticut Valley. }\end{array}$ & B. K. E. \\
\hline Warwick; southeast near iron-ore beds.. & Mica-schist... & S. $13^{\circ}$ E.... & $\begin{array}{l}\text { Sometines several feet wide } \\
\text { and a foot deep. }\end{array}$ & E. H. \\
\hline Now Saleu; 200 ruks south of academy. & . do & $\begin{cases}\text { S. } 15^{\circ} & \text { E.... } \\
\text { S. } 25^{\circ} & \text { E. . . }\end{cases}$ & Oe high gros & B. K. E. \\
\hline Warwick; near meetinghouse... & Horableede-echist & S. $13^{\circ}$ E.... & & E. H. \\
\hline $\begin{array}{l}\text { Deertield; south ead of trap nearest to } \\
\text { river. }\end{array}$ & Trap.............. & S. $10^{\circ} \mathrm{W} .$. & $\begin{array}{l}\text { East slope of Deerfielt } \\
\text { Monntain. }\end{array}$ & B. K. E. \\
\hline $\begin{array}{l}\text { Deerfield: wouth of gorge of Deerfietd } \\
\text { River. }\end{array}$ & Sandstone... & S. $15^{\circ} \mathrm{W} \ldots$ & In the Connecticut Valley.. & B. K. E. \\
\hline Deerfield; southeast part............... & Conglomerate..... & S. $8^{\circ} \mathrm{I}$ & & E. $\mathbf{H}$. \\
\hline Deertield; nortbwest part............... & Mica-schist ....... & S. $8 \circ \mathrm{E} . . .$. & & E. II. \\
\hline $\begin{array}{l}\text { Deerfield; gorge of Deerfield River is } \\
\text { trap range. }\end{array}$ & Trap......... & E...... & Finely preserved. & B. K. E. \\
\hline Doerfield; at west entrance of above gorge & Sandstone........ & S ....... & & B. K. E. \\
\hline Montague; sonthwest corner ............ & Conglomerate..... & S. $12 \circ$ E.... & ... & B. K. E. \\
\hline Montague; south part. . ................. & . .... do .............. & $\mid \begin{array}{r}\text { S. } 8^{\circ} \mathrm{E} \ldots \ldots \\
\text { (S. } 15^{\circ} \mathrm{E} . \ldots\end{array}$ & 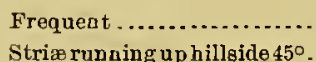 & E. H \\
\hline Greenfield : porthedge of city, S.J. Lyous & Sandstone & $\begin{cases}\text { S. } 5^{\circ} & \mathrm{W} \ldots \\
\text { S. } 20^{\circ} & \mathrm{WT}^{\top} \ldots\end{cases}$ & $\begin{array}{l}\text { Groove } 2 \text { feet wide. } \\
\text { Groove } 5 \text { feet wide, rising } \\
\text { slightly. }\end{array}$ & B. K. E. \\
\hline $\begin{array}{l}\text { Montague; road up to Turmers Falle from } \\
\text { lower suepension hridge. }\end{array}$ & .... do .. & S. $50^{\circ}$ W. & & B. K. E. \\
\hline $\begin{array}{l}\text { Suaderland; north beed of north wood } \\
\text { road onto Mount Tohy. }\end{array}$ & Conglomerate & $\left\{\begin{array}{l}\mathrm{S} .5^{\circ} \mathrm{W} . \\
\mathrm{S} .10^{\circ} \mathrm{E} .\end{array}\right.$ & & B. K. E. \\
\hline Sunderland; north part, near cave...... & .....do & S. $8^{\circ} \mathrm{W} \ldots$ & & E. H. \\
\hline Sucderlasd; aorthwest of cave.......... & & S. $10^{\circ} \mathrm{W}$. & & B. K. F. \\
\hline HAMPSHIRE COUNTY. & & & & \\
\hline Plainfield; south of S. Barton's.......... & Sericite-schist.... & S. $35^{\circ}$ E... & & B. K. E. \\
\hline Plainfield; northwest corner............. & Amphibolite...... & S. $35^{\circ}$ E... & & B. K. E. \\
\hline $\begin{array}{l}\text { Cummington; northwest corner, south of } \\
\text { Deer Hill. }\end{array}$ & Sericite-schist.... & S. $60^{\circ}$ E... & $\begin{array}{l}\text { In bottom of deep valley } \\
\text { ruaning S. } 60^{\circ} \mathrm{E} \text {. }\end{array}$ & B. K. E. \\
\hline Cumnington, Sehool No. 10 . & Conway schist.. & $\begin{cases}\text { S. } 10^{\circ} & \text { E.... } \\
\text { S. } 21^{\circ} & \text { E.... } \\
\text { S. } 45^{\circ} & \text { E.... }\end{cases}$ & & B. K. E. \\
\hline $\begin{array}{l}\text { Cummington end of blind road at } I \text {. } \\
\text { Farling's. }\end{array}$ & Se & $\left\{\begin{array}{l}\mathrm{S} .25^{\circ} \mathrm{E} . . . \\
\mathrm{S} .45^{\circ} \mathrm{E} \cdot \ldots\end{array}\right.$ & $\cdots$ & B. K. E. \\
\hline $\begin{array}{l}\text { Goshen; eoutheast part, deserted road } \\
\text { west of Hubhard's ledge. }\end{array}$ & Mica-schist.. & E $\ldots \ldots$ & $\begin{array}{l}\text { Moutoncé orer a broad sur- } \\
\text { fice. }\end{array}$ & B. K. E. \\
\hline
\end{tabular}


List of glacial grooves and strice, etc.-Continued.

\begin{tabular}{|c|c|c|c|c|}
\hline Locality. & Rock. & Direction. & Remarks. & Authority. \\
\hline HAMPSHIRE COUNTY-Continned. & & & & \\
\hline Goshen; farther south.......................... & Mica-schist ........ & S. $76^{\circ} \mathrm{W} .$. & $\begin{array}{l}\text { Both follow direction of val- } \\
\text { ley. }\end{array}$ & B.K. E. \\
\hline Worthington; west part................... & Sericite-schiot & S. $22^{\circ}$ E. . & 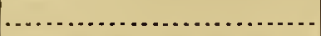 & E. H. \\
\hline $\begin{array}{l}\text { Worthington; west part, road to Middle- } \\
\text { field. }\end{array}$ & .....du .... & S. $22^{\circ} \mathrm{E}$. & 300 feet below top of hill.... & E.H. \\
\hline Worthington Center.................. & ..... do. & S. $40^{\circ}$ E.... & & B. K. E. \\
\hline Worthington; Stephers's mille.......... & .....do ....... & S. $50^{\circ}$ E.. & & B. K. E. \\
\hline Worthington; 1 mile north west of center. & ..... .do ....... & S. $65^{\circ}$ E... & 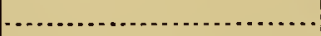 & B. K. E. \\
\hline $\begin{array}{l}\text { Worthington; first crossroads west of } \\
\text { center. }\end{array}$ & .... do ........ & S. $43^{\circ} \mathrm{E}$.. & & B. K. E. \\
\hline Worthington Center.................. & .... do ..... & S. $59^{\circ} \mathrm{W} .$. & & B. K. E. \\
\hline $\begin{array}{l}\text { Amheret; northeast spur of Monnt War- } \\
\text { ner. }\end{array}$ & Gneiss............ & S. $15 \circ \mathrm{E} \ldots$ & & B. K. E. \\
\hline $\begin{array}{l}\text { Amherst; roadside one-half mile north } \\
\text { of the site of President Clark's honse. }\end{array}$ & .....do & N. $50^{\circ} \mathrm{W}$. & & B.K. E. \\
\hline Amherst; northeast of center............ & Granite............ & S. $30^{\circ}$ E.... & & B. K. E. \\
\hline $\begin{array}{l}\text { Pelham; west alope of ridge } 1 \text { mile north } \\
\text { of Hrgeia. }\end{array}$ & Gueiss........... & S. $15^{\circ} \mathrm{W} .$. & & B. K. E. \\
\hline Middlefield; near meetinghouse......... & Sericite-schiat & S. $22^{\circ} \mathrm{E}$. & & E. H. \\
\hline Middlefield; one-half mile south......... & ....do do....... & $\mathbf{S} \ldots \ldots$ & & B. K. E. \\
\hline $\begin{array}{l}\text { Middlefield; east part, near soapstone } \\
\text { quarries. }\end{array}$ & ....do ............ & S ....... & & E. ㅍ. \\
\hline $\begin{array}{l}\text { Northampton; high upon road to Eyrie } \\
\text { Honse; Mount Nonotnck. }\end{array}$ & Arkose.. & S. $220 \mathrm{~W}$ & & B. K. E. \\
\hline $\begin{array}{l}\text { Northampton; Bouthwest corner Kings- } \\
\text { ley's mill. }\end{array}$ & Granite.... & F..... & Stoss side ohserved......... & E. H. \\
\hline $\begin{array}{l}\text { Northampton; at Eyrie House on top of } \\
\text { the mountain. }\end{array}$ & Trap. & S .. & & B. K. E. \\
\hline $\begin{array}{l}\text { Northampton; helow Smiths Ferry hird- } \\
\text { track locality. }\end{array}$ & Sandstone. & S. $25^{\circ} \mathrm{E}$. & & B. K. E. \\
\hline $\begin{array}{l}\text { Northampton; } 1 \text { mile south of mountain, } \\
125 \text { rods northwest of where road to } \\
\text { Westfield hranches. }\end{array}$ & Trap... & S. 60 & & B. K. E. \\
\hline Hadley; second peak west of Gap road.. & :...do... & S .. & $\begin{array}{l}\text { Groove } 2 \text { feet wide, } 4 \text { inches } \\
\text { deep. }\end{array}$ & B. K. E. \\
\hline Hadley; same peak, west fore knob ..... & .......... & $\mathbf{S}$ & $1 \frac{1}{2}$ feet wide $\ldots . . . . . .$. & B. K. E. \\
\hline $\begin{array}{l}\text { Hadley; same peak west of this and } 40 \\
\text { feet lower, straight pass } 15 \text { feet wide, } \\
\text { wholly smoothed and scratehed. }\end{array}$ & .....do ... & S ... & $\ldots$ & B. K. F. \\
\hline Hadley; Mount Holyoke House.... & $\ldots$ do & $\left\{\begin{array}{l}\mathrm{S} .5^{\circ} \mathrm{W} . \\
\mathrm{S} .2^{\circ} \mathrm{E} . .\end{array}\right.$ & See figs. 29,30, pp. 527,530 . & B.I. E. \\
\hline Granby; mouth of forge pond.. & Sandstone... & S. $15^{\circ}$ E.... & & B.K. E. \\
\hline Granby; north part $\ldots . . . . . . . . . .$. & .....do .............. & S. $8^{\circ}$ E..... & $\ldots$ & E. H. \\
\hline Granby ; Moody Corners................ & ..... do .............. & S.50 W.... & & B.K. E. \\
\hline Sonthampton; south of center......... & ..... do ............. & S. $73^{\circ}$ W... & 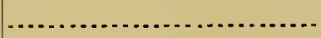 & E. H. \\
\hline Southampton : east of village ............ & Conglomerate..... & S. $12^{\circ} \mathrm{W} . .$. & & B. K.E. \\
\hline Easthampton; Mount Tom............. & Trap.............. & S. $8^{\circ} \mathbf{E} . .$. & $\ldots$ & E. H. \\
\hline $\begin{array}{l}\text { Easthampton; quarry, weot shoulder of } \\
\text { Mount Tom. }\end{array}$ & Conglomerate..... & S6. $0^{\circ} \mathrm{E} \ldots$ & $\ldots$ & B. K. E. \\
\hline Holyoke; south of Mount Tom......... & Sandetone & S. $60^{\circ}$ E... & & B. K. E. \\
\hline Belchertown; $42^{\circ} 20^{\prime}, 72^{\circ} 25^{\prime} \ldots$ & Tonalite..... & N. $80^{\circ}$ E... & & $\begin{array}{l}\text { G. H. Bar- } \\
\text { ton. }\end{array}$ \\
\hline
\end{tabular}


GLAOIAL STRIA.

List of glacial grooves and strice, ctc.-Continued.

\begin{tabular}{|c|c|c|c|c|}
\hline Lucality. & liock. & Direction. & Remarks. & Authority. \\
\hline HAMPUEN COUNTY. & & 1 & & \\
\hline $\begin{array}{l}\text { Chester: top of Round and of Gobble } \\
\text { hills }\end{array}$ & Emery ..... & S. $8^{\circ} \mathbf{E} ?$ & $\begin{array}{l}\text { Deoply groovod and } \\
\text { smoothed. }\end{array}$ & $\begin{array}{l}\text { C.U.Shop- } \\
\text { ard. }\end{array}$ \\
\hline $\begin{array}{l}\text { Blatudford; one-half mile north of meet- } \\
\text { ingliouse. }\end{array}$ & Sericite-schist & S. $8^{\circ} \mathrm{E}$ ?. & & E. H. \\
\hline $\begin{array}{l}\text { Blandford; North atreet, north of meet- } \\
\text { inghouse. }\end{array}$ & ......do ........ & S. $20^{\circ} \mathrm{E}$.. & & B. K. E. \\
\hline Blindford; Northetreet, Dng Hill....... & .....do ... & S. $35-40^{\circ} \mathrm{E}$ & & B. K. E. \\
\hline $\begin{array}{l}\text { Blandford; North street, farther north, } \\
\text { crotch in road. }\end{array}$ & ......do .... & S. $25-40^{\circ} \mathrm{E}$. & & B. K. E. \\
\hline Blandford; North street, near north line. & 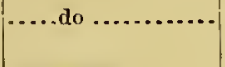 & S. $40^{\circ}$ E... & $\begin{array}{l}\text { Beautiful deep flntiugs, } 8 \text { to } \\
18 \text { inches across. }\end{array}$ & B. K. E. \\
\hline $\begin{array}{l}\text { Westfield; eonthwest from Cowle's } \\
\text { quarry, south of mouth of gorge of } \\
\text { Little Kiver. }\end{array}$ & Sandetone & S. $73^{\circ} \mathrm{W}$ & $\begin{array}{l}\text { (Drumlins here run eouth. } \\
\text { B. K. F.) }\end{array}$ & E. H. \\
\hline Westfield; west of village............... & Conglomerate... & S. $15^{\circ} \mathrm{W}$. & .. & B.K. E. \\
\hline West field; road to Holyoke.............. & Trap.............. & S. $30^{\circ}$ E... & & B. K. E. \\
\hline Westfield; south of West Farms......... & Sandstone ......... & S. $73^{\circ} \mathrm{W} .$. & (..................... & E. H. \\
\hline Palmer ; north of C. Kalliher's. . . ........ & Hornblende-schiet & S. $10^{\circ}$ E.... & - & B. K. E. \\
\hline Tolland; northeast of Noyes Pond....... & Gneist........... & S. $20^{\circ}$ E.... & & B. K. E. \\
\hline Tolland; south of month of Noyes Pond. & .... do ...... & S. $10^{\circ}$ E.... & . & B. K. E. \\
\hline Tolland; 6outh of Cranherry Pond ...... & 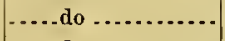 & S. $15^{\circ}$ E.... & & B. K. . \\
\hline $\begin{array}{l}\text { Granville; middle, } 1 \text { mile weet of meet- } \\
\text { inghouse. }\end{array}$ & .....do . & S. $22^{\circ}$ E.... & & E. H. \\
\hline $\begin{array}{l}\text { Granville; north part, mouth of deep } \\
\text { gorge in Sodor Mountain opening into } \\
\text { Connectient Valley in Sonthwick, near } \\
\text { weet end, near house of Mrs. Jones. }\end{array}$ & Miea-achist & S. $60^{\circ}$ E... & 630 feet above sea.. & E. H. \\
\hline Granville; east line, near Munns Brook.. & .....do .. & S. $62 \circ \mathrm{E} . .$. & $\begin{array}{l}\text { Thonght by Dr. Hitchcock } \\
\text { to have heen a local gla- } \\
\text { cier. }\end{array}$ & E. H. \\
\hline $\begin{array}{l}\text { Granville; } 2 \text { miles northwest of eaet } \\
\text { village, Blandford road. }\end{array}$ & ..... do & & 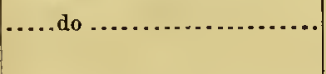 & I. H. \\
\hline 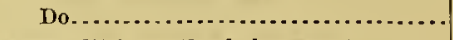 & .....do ...... & S. $52^{\circ}$ E.... & ..... do n........... & E. H. \\
\hline Same; little north of ahove spot......... & .....do ...... & S. 120 E.... & ( & E. H. \\
\hline Russell; south of Salmon Falls Mille.... & .....do & N. $80^{\circ}$ E... & $\begin{array}{l}\text { Thought by Dr. Hitchcock } \\
\text { to have been a local gla- } \\
\text { cier. }\end{array}$ & E. H. \\
\hline Russell; ip brook from falls............. & .....do.... & S. $80^{\circ}$ E... & .....do do.............. & E. H. \\
\hline $\begin{array}{l}\text { Russell; southwest, north bank Little } \\
\text { River, 1,100 feet above sea. }\end{array}$ & .....do .... & S. $8^{\circ}$ E.... & (.................... & F. H. \\
\hline $\begin{array}{l}\text { Russell; southwest, north hank Little } \\
\text { River, at mouth of gorge. }\end{array}$ & .....do .. & N. $80^{\circ}$ E.... & $\begin{array}{l}\text { Tlought by Dr. Hitchcock } \\
\text { to bave heen a local gla- } \\
\text { cier. }\end{array}$ & E. H. \\
\hline $\begin{array}{l}\text { A gawam and Suffeld, Conn.; one-half } \\
\text { mile east of east foot of trap ridge. }\end{array}$ & Sandetone... & S. $50^{\circ}$ W... & $\therefore$ & B. K. E. \\
\hline
\end{tabular}

On the map, PI. XI, p. 510, all the glacial striæ tabulated above are entered, together with some from the map in the Surface Geology of President Hitchcock. ${ }^{1}$ The latter are transferred as accurately as possible, and appear withont indication of the divergence from the meridian, as that is not 
given upon the original map. So far as the sonthern part of the State is concerned, this map is the same as the one accompanying the report of 1853 , cited above; but the strix with abnormal westerly direction, at Kingsley's mills, in the southwest corner of Northampton (sonthwest of Florence on the map of the 1853 report), are omitted from the later map. Hence we may suppose that President Hitchcock came to doubt the observation as to the stoss side being on the east. I have entered the striae with the probable direction-namely, east.

The map (Pl. XI) is very interesting as a composite of (1) the general direction of the ice across the area under consideration; (2) the simultaneous deflection of the ice at base in the long trough of the Connecticut Valley; (3) minor deflections around prominent obstructions and in gorges, also affecting only the base of the great ice sheet; (4) later deflections of frontal lobes of the ice by prominent valleys; (5) fanning out of frontal lobes.

(1) The normal direction is $\mathrm{S} .35-40^{\circ} \mathrm{E}$., and this is more regularly manifest beyond the confines of the map on the west.

(2) The influence of the Connecticut Valley in deflecting the ice southward seems felt for a considerable distance out over the western platean.

(3) The southward deflection in the valley is well exhibited and is most remarkable on the top of the Holyoke range.

(4) The local inflnence of the Greenfield and Deerfield trap ridges of the Cummington Valley and the Fall River and Deerfield River notches are well marked, producing in both the latter cases striæ at right angles within and withont the gorges. The same is seen at both ends of the Mount Tom range.

(5) The curions fanning out of the striæ north of Westfield, S. $73^{\circ} \mathrm{W}$. and S. $60^{\circ}$ E., seems to indicate a valley lobe of the ice extending south between Mount Tom and Mount Pomeroy to the west, and expanding to the south where the valley widens toward Westfield. A similar fanning out is indicated in the main Connecticut Valley by the direction $\mathrm{S} .50^{\circ} \mathrm{W}$. in Agawam and Suffield.

The sonthwesterly direction above Shelburne Falls and the easterly direction down all the valleys opening from the western highlands into the main valley were due to later lobes in the retreating ice front.

The most remarkable grooving and fluting is found along the whole crest of the Holyoke range on the hard trap. Near the Prospect House, 
on Homnt Holyoke, are some of the most remarkable groover I lave seen. One northeast of the honse, between the two iron boundary posts, is at the morth ond 2 feet wide and shallow, at the sonth end 1 foot wide and 8 inches deep. Several other grooves almost equally marked occur near this. Their direction is $\mathrm{S} .2^{\circ} \mathrm{E}$.

A curions groove (fig. 29) comes out from under the house on the southwest side and runs in a southwesterly direction. This is exposed best in the bottom of an unused reservoir, and can be traced for a length of 12 feet. It is about $2 \frac{1}{2}$ feet wide by 10 inches deep, the greatest deptl being at the east side, which is overhanging, being fluted regularly like a letter S. This seems to me to have been caused possibly by water running beneath the ice and to be a true "lapiaz," as they occur beneath the ice of the Alpine glaciers. It must, then, have been polished by the ice at a later time.

High up on the road to the Eyrie House, on Mount Nonotuck, deep strie run S. $22^{\circ} \mathrm{W}$., deflected westward in the direction of the Easthampton valley, while on the summit above broad, deep grooves abound, ruming

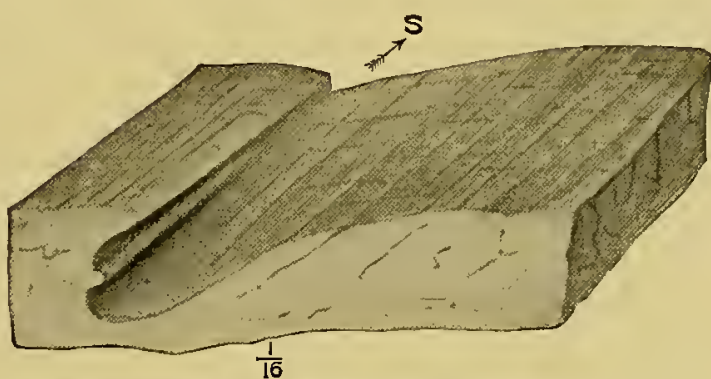

FIG. 29.-Glacial groove on compact diabase, Prospect House, Mount Holyoke. north and south. South of the Holyoke range, at Smiths Ferry, the striæ r'un S. $25^{\circ} \mathrm{W}$., on trap. At Batterson's sandstone quarry, south of Mount Holyoke, at E. H. Lyman's house, the fine-grained sandstone is grooved and fluted and scratched most beautifully over a broad surface (see Pl. X, p. 488). The ice met the vertical and overhanging face of the sandstone and fitted itself. so exactly to it that scratches and polishing occur on surfaces placed at all angles to the horizon, even upon the under side of projecting ridges. In the vertical westward-facing wall the basset edges of the horizontal sandstone beds are polished like glass, and one thin, softer, shaly bed is cut in deeply to form a long groove $10_{2}^{1}$ inches deep and only 3 inches wide at the mouth, but polished to the bottom, where it is but a half inch wide. The direction of the scratches is here very irregular, going to all points both in altitude and azimuth. The prevalent direction, however, over the broader, flatter surfaces is south. 
I hardly need call attention to the magnitude and the peculiar character of the force which has done this work, grinding down all the pebbles of a conglomerate, hard and soft alike, to a common level, as can be well seen on the road which goes over the north shoulder of Mount Toby just after leaving the Sunderland road, and cutting grooves in the trap, a rock so tough that one rarely attempts to drill a hole in it, preferring, when it is necessary to remove it, to do the work by building fires upon it and drenching the rock with water, by which means it is crumbled and slowly removed. Two men and a holder drill only 8 feet a day in trap. These grooves are of all dimensions, ranging from fine lines, visible only in oblique light with a lens, to broad troughs.

Even more striking is the polishing of the surface of the great emery vein in Chester, which for a distance of several rods near the summit of each mountain has been deeply grooved and polished by glacial action. That the friction producing this effect must have been enormous is apparent from the size and depth of the channels, and that it could not have been the result of running water is demonstrated by recurring to the example of river action in the Westfield River upon another portion of the same bed, where we have an eroded, pitted surface from which the coarse crystalline particles of the hard emery are left projecting. ${ }^{1}$

Another point deserving, perhaps, further consideration here is the great degree of irregularity in the direction of the striæ, since these give accurately the direction of the motion of the ice at the time they were made. For many of these differences of direction we may assume, as above, (p. 526) that they were variations in the direction of the motion of the ice at different times. For most we must assume that the great ice sheet was affected by the greater irregularities of the bottom over which it flowed, just as-to use the illustration given by Prof. J. D. Dana (to whom we owe this explanation and its application to the anomalous north-south direction of the ice in the Connecticut Valley) - a mass of pitch flowing down an inclined board upon which strips had been nailed at various angles to the line of inclination would in its under parts be deflected behind the strips and flow in the direction of the grooves thus produced. Ice, in short, thongh moving with extreme slowness, comports itself like a fluid and obeys the laws of hydraulics. Thus the line of motion for the great 
mass of the ice over Hampshire County was S. $35^{\circ}$ E., while the lowest portions in the broald depression of the Connecticut Valley moved with that valley from north to south, and even west of south along the Mount Tom range. While this explanation is surrounded with difficulties, it cloes explain in a very satisfactory way many peculiarities of the character and distribution of the till in the valley, as will be made clear in the next sections.

\section{GLACIAL NOTCHES.}

Another remarkable series of phenomena, which we may possibly refer, in whole or part, to the direct action of the ice upon the rocky floor over which it moved, is to be found in the succession of notches of varying depth which cut the Holyoke chain transversely in its east-west portion and give it the appearance of a sierra in miniature. One of these cuts the ridge to its base, forming the notch through which the river flows. Two cut down deep into the heart of the mountain, forming low cols, through the western of which the road runs. ${ }^{1}$ Others are shallower, and one may find a quite complete series connecting them with the ordinary glacial grooves and scratches. The larger notches are themselves scratched and polished, and the direction of the scratches coincides with the axis of the notches themselves.

Another circumstance harmonizes with the idea that they were formed by a force like that of moving ice, the direction of whose action was in great degree independent of the relative hardness and direction of the ridge. The Holyoke range lies like a blowpipe with the mouthpiece pointing south and the point directed east. So long as the chain runs east and west the grooves cross it at right angles, running, as did the ice in the valley, north and south, while as the ridge swings round from west to south the succeeding notches run parallel to the first and cut the chain more and more obliquely until the last coincides with the southward prolongation of the mountain and splits it; and one looking at the trap from the west-in Southampton or Easthampton, for instance-sees the almost vertical cliff of trap bounded above by a line which deviates little from horizontality, instead of the serrate sky line of the Holyoke range proper as seen from Amherst.

\footnotetext{
1This used to be called the East Crack, the deep notch just east of the Holyoke Mountain House being known as the West Crack, and there was once a road through this also; and the deepest depression between these was the Low Place.
}

MON XXIX -34 
This rule is not without exceptions, since the pass which separates Mount Tom from the next peak trends a little north of east, and the next passage north trends east and west. President Hitchcock argued as follows concerning the matter: ${ }^{1}$

If these notches had been determined by anything in direct relation with the trap of the monntain, the most probable cause would have been a fissuring of the bed of trap during its upheaval, and as this fissnring would have occurred most naturally at right angles to the axis of the chain, the fissures would have converged on a point south of the mountain, somewhere about the northwest corner of Lndlow.

So he concluded that if the first notches he noticed (those cutting at right angles) were caused by fissuring, those farther west would be also

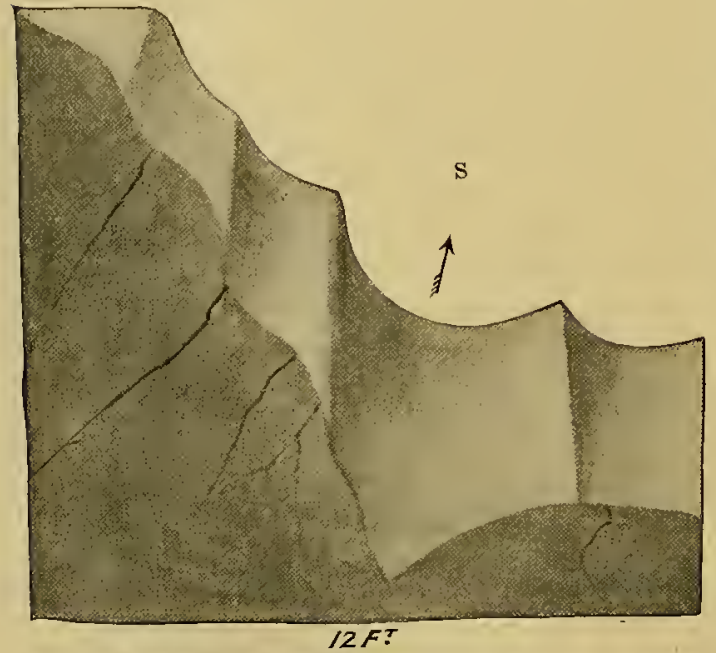

FIG. 30.-East slope of a large glaciated groove behind the bowling alley on Mount Holyoke. at right angles to the chain there and parallel with the dip there; and when he found this was not the case, he explained them as a strange result of the great northern diluvial current which did duty then in place of the ice current of more modern theories. ${ }^{1}$

The larger notches seem to have been caused by the system of faults which cut the range, and to have been enlarged by pre-Glacial streams (see Pl. XI, p. 510) in case of two or three of the deeper ones. Where, as is often the case, these faults fail to run north and south, the notches may have been remodeled by the ice and given a new direction, and the great number of smaller notches, all parallel with the direction of the ice, do not seem explicable as a result of water action, but rather as the work of the ice acting on the irregular rim of the trap sheet, which emphasized irregularities where this rim ran athwart the course of the ice, as in the Holyoke range, and smoothed them down where the rim ran with the ice, as in Mount Tom. 
'Thus if, after examining the marked grooves under and north of the Prospert llouse on Momut Holyoke, one goes a f'ew rods east to the groove, about 12 feet deep) and of equal width, just behind the borvling alley (see fig. 30), one will find it hard to draw the line between them. And if, after examining the grooves and strix on the second peak west of the noteh, one goes down west into the deep groove about 40 feet across, the similarity in direction and shape will be found very striking; and such cases are quite common.

IPEUDO-GLACIAI STRIA ON DEVONIAN ARGILLITES.

While examining the garnetiferous nica-schists at Purple's quarry, in the east part of Bernardston, I was attracted by a peculiar striation which occurred upori a broad, flat cleavage surface of the nearly horizontal slates and continued beneath the superincumbent beds. The surface in question was just at the north edge of the water which fills the abandoned quarry, and was certainly in place and nndisturbed, and I raised the slates which rested upon it and followed the striation beneath for a foot or more inward without seeing anything which suggested to me that these upper layers were not also in place and undisturbed.

Clear impressed lines, from those so fine as to be seen only with a lens up to those a millimeter in diameter, covered the broad, flat surfacein average about an inch apart-the larger showing a delicate longitudinal striation. These grooves vary in length between quite wide limits-1 to 6 inches. The larger number are straight, or nearly so; very many form easy open curves, single or double. Over most of the surface two distiuct systems, making an angle of $40^{\circ}$ with each other, were apparent, the one having the longer and finer lines and most of the long curving lines, the other being somewhat broader, shorter, and more rigidly parallel and straight. Their length varied very little from an inch, and they were often slightly gonged out at the end. On putting several parts together, so as to get a broad surface, the finer lines of the first system are seen to bend and continue in the second system.

The whole impression was quite like that of the rain-marks on a car window before and after starting. Faint traces of a third system at right angles to the first are also present. The direction in the rock was not taken, as the marks were supposed to be of mineral or organic origin; many of them strikingly resemble in size, curvature, etc., impressions of Graptolithus 
minutus. A suggestion of long needles of hornblende or chiastolite also occurred.

On further examination the minute garnets on the surface were found to be polished down and scratched like the rest. At one portion of the surface unmistakable glacial striæ were found adjoining the problematical grooves. That the marks were formed by movement of an upper layer of the slate on the underlying ledge seemed clear, and that the garnets fixed in the bottom of the upper moving stratum furnished the grooving tools. The change in the direction was caused by a change in the direction of the moving mass, some portion of the bottom becoming fixed and forming a pivot around which the rest revolved. That the mass was moved only a slight distance from its original position was also clear. Whether this motion was caused by glacial ice, by the expansion and contraction of the rock, or by earthquake action, I can not decide.

\section{POT-HOLES.}

President Hitchcock notes ${ }^{1}$ the absence of pot-holes among the results of the diluvial currents which were supposed to have originated the till and the glacial striæ, and concludes therefrom that these phenomena were not the work of rivers but of widespread currents without falls of much magnitude. He describes later a great series of pot-holes west of Shelburne Falls, on the road to Charlemont, in an old bed of the Deerfield River, 85 feet above the present stream, which may have belonged to a pre-Glacial bed of the river or may be of Glacial age.

Pot-holes occur, of course, along the channel of the Connecticut and its tributaries, in the former especially below its falls in the canyon formed by their recession, in the latter on the bottoms of the deep gorges they have cut through. the crystalline rocks.

Striking illustrations are to be seen in the Westfield River, at the Crescent Paper Mills, in the extreme north of Russell. Just below Russell station also a great dike of granite formerly obstructed the stream, but has been cut through, and here are many pot-holes. One interesting one was half removed as the stream cut down its bed, and the remaining half is still to be seen in the wall, about 10 feet above the water. It is regularly urn-shaped, with bent constricted neck, and is about $6 \frac{1}{2}$ feet deep. 
By far the fincst development of river pot-holes is in the almost inaccessible cunyon of the south branch of Westfield River, one of which is 25 foet deep and 20 by 10 feet at the mouth. 'They exist abundantly along the course of Deerfield River, in many cases ligh above the present level of the river, as noted by President Hitchcock. I connted more than 50 on a single reef of sandstone which projects into Deerfield River at the most northerly point reached by the stream bofore it turns toward its notch in the trap range. One is found by the road to the south side of Catamount Hill, in Colerain, 2 feet deep and $1 \frac{1}{4}$ feet wide.

The only pot-hole, however, which I can without hesitation assign to the Glacial period I found by the roadside under the steep souther'n face of Sugar Loaf, in South Deerfield. It is in red sandstone at a point 130 feet above sea, and is 2 feet deep and 2 feet wide. From its position it must have been formed during some phase of the Glacial period, as it lies apart from any probable stream bed, and the surface of the sandstone around it is striated. I have surmised that these usual accompaniments of glacial action, which we should especially expect to find in so irregular a region, may have been many times formed and again eroded and destroyed by the ice, and that this may be the origin of many of the spherical; ovoid, and flat-ellipsoidal pebbles of quartz which occur here in considerable numbers in the true till and which agree quite exactly in form with the polishing stones of a pot-hole. However, they may belong to a coarse-pebble beach of inter-Glacial age, synchronous with the pink sands described below.

TIIF TILI.

\section{INTRODUCTION.}

Pure ice moving over the country would by its thrust tear off projecting portions of the subjacent ledges, but could not alone polish and scratch the rocks as we find them now. The agents of this work were the stones themselves, which, torn from their places and frozen in the ice, transformed it into an immense rasp and increased its eroding power many fold. By the melting and freezing of the lower surface and by the slow intestinal motion, as well as by the sudden fissuring of the mass, its lower portion wonld become filled with a large and varying quantity of loose, rocky material.

Also, where, by secular decomposition, as indicated on page 374 , the rocks had become softened to great depth, the whole, soaked with water, 
might be frozen into a solid mass, and the snows gatliering on this, it might with little change become the base of the glacier and be moved on bodily Much of the same material was pushed along beneath the ice, its parts crushed and ground against each other, whereby all the softer rocks were soon reduced to an impalpable mud, the larger and the harder ones enduring longer, but all at last yielding to the same fate, unless, worked up into the ice itself or gathered in thick accumulations beneath it, they were shielded from the more violent action of its mass. The ice was, however, constantly providing itself with new material, and soon wore the fragments into the peculiar shapes so characteristic of glacial accumulations, three- and four-sided forms, with irregular ends more or less elongate as the rock was more or less schistose, the sides flat or broadly convex, joined by rounded edges and scratched in various directions.

These peculiar forms, called by the Germans "dreikantuer," are as characteristic of the till as graptolites of the Silurian. Thus the ice elaborated in immense quantity a peculiar subglacial material of varying but always characteristic composition, and spread it with unequal and sometimes with very considerable thickness upon the rocky surface. For the ice did not everywhere and always rest with its rasping surface upon the rock and grind into it without intermission. Over a given surface it might wear for a long time continuously, but by this means a new surface would be gradually produced, partly by the unequal force of the ice, partly from the varying hardness of the rock, and this would react upon the ice, producing slight variations in its subordinate currents, transferring its intenser action to another area and allowing it to deposit material over the first area. At a later time the maximum of eroding power might be transferred back to its former position and the accumulation so laboriously brought together would be again swept away. In this way one may explain some of the cases where the rock surface shows strix in two directions, for the local movement of the ice might be somewhat different at widely separated times.

Very commonly the ice heaped up its accumulations in the rear of some obstruction in a long ridge projecting from the obstructing rock in the direction in which the ice was moving, as the water arranges sands. At other places, especially in broad open portions of a valley, the ice molded its fine clayey moraine material into massive hills, called drumlins, rounded and 
elongate in the direction of its motion, like an inverted "anne. These one may compare with the bars of a river, and thus complete tho almost pertect parallel between the two.

The study of these deposits is very difficult (the hardest problems in the groolugical book are at the beginning and the end) becanse they often blend intricately with succeeding deposits and are largely concealed by them, and because they can be successfully studied only in fresh excavations. In a few days the exposure caves and sinks into a slope which often loses all its characteristic peculiarities of the deposit. For this reason the following descriptions have reference ahmost always to fresh exposures, and especially where the color or consistency of the bed is discussed the ruference is to a surface newly opened up and still moist.

The deposits of the basin which we may refer to the "moraine profonde" of the inland ice and which we may believe to have rested beneath the ice wholly completed in the form in which we now find them, at a time when the ice was so far thimed by melting that it lad ceased to advance and only awaited its final dissolution, may be divided into three groups of ouly local value, whose differences in structure depend in large degree upon their position in the valley or their altitude above it. These are the upland drift, the fine valley drift, and the coarse valley drift.

THE UPLAND DRIFT.

Using the old word drift (although it has somewhat gone out of fashion in late years, and although it contains always some reminiscences of earlier theories now wholly abandoned) for the explanation of the phenomena with which we are now occupied, we will take the section exposed by the ditch for the water main from the west village of Pelham eastiward to where the Shutesbury road branches off. In this exposure a face 1,300 feet long and 5 feet deep, 320 feet above sea, in many places showing the underlying rock, was open for study.

This mass is wholly free from clay or fine sand, and consists in the main of fragments of rock of various sizes up to 4 feet on a side, with a considerable preponderance of those about 1 foot in diameter. These bowlders are almost wholly local-that is, they consist of the ordinary Pelham gneiss upon which they rest-with very rarely a fragment of the compact trap which occurs a few rods north. 
A careful search of the material thrown out of the ditch revealed a single well-worn bowlder of the Vermont quartzite, and one of an epidotic quartz-diorite (tonalite), which may have come across the valley from Hatfield, but is more probably derived from the outcrop of the same rock half a mile north. All the fragments, with the exception of the far-traveled bowlder of quartzite, are quite angular and unworn, and the gneiss ledges upon which the deposit rests is jagged and serrate, the rock dipping $25^{\circ}$ west and being jointed at right angles to the bedding. It is manifest that the ice was here not polishing but rudely tearing up the ledge and moving onward the fragments, and in several cases great masses could be seen, 3 or 4 feet in diameter, which had been moved but small distances from the ledge and could be fitted back into the places from which they had come. A coarse sand fills the interstices of the larger fragments and here and there constitutes the greater portion of the mass. The whole is reddish for 2 feet down, then bluish or whitish to the bottom. In one place it is blackened with carbonaceous material for a rod to a depth of 4 feet, and below this blackened area and for several feet on either side it is blue. Here a swale crossed the line of the ditch and the decomposing carbonaceous material deprived the infiltrating waters of the oxygen, which has over the rest of the section peroxidized the iron to a depth of about 2 feet in most places, though sometimes the reddening extends below the bottom of the ditch 5 feet. It is clear that this locality, placed high upon the eastern rim of the basin and facing westward into the valley, received the full impact of the ice, while the waters moving beneath the latter, produced in part, perhaps, by the very friction of the work whose effects we see here so plainly, washed out all the finer material into the valley below.

The above section may be taken as a typical illustration of a deposit spread in a broad, irregular, interrupted sheet on the rock over much of the elevated country bordering the basin. It is irregular in thickness, distribution, and internal structure. Upon broad surfaces of naked rock the ice rested and depositerl nothing, or in later times atmospheric agencies have removed what was laid down. In sheltered places it was heaped up in great thickness; in other places it is represented only by scattered bowlders resting upon the bare ledges. And when examined as to its internal structure it is found to vary greatly in the size of the stones constituting the mass and in the proportion of far-traveled bowlders entering into its composition. All around the valley the line of the lighest lake terrace is 
quite distinctly traceable as the lower limit of contimons forest growth. The Florence plain on the west, the Long plain in Leverett on the east, and the Bay road on the sonth mark this level in Hanpshire Comty, the Springfield and Hampden plains in Hampden County, and the Montague and Nortlfield plains in Franklin Comnty. Above this line the surface is almost everywhere formed by this deposit, the only exceptions being where the bare ledges appear or where it is covered by the heavy sand of the Glacial lake beds described further on. It is interesting to see how generally around the whole border of the basin the upper limit of the cultivated fields coincides with this purely geological line which I have drawn as the upper limit of the later lake deposits of the valley. Above that, especially if we make exception of the broad sand reaches in Pelham, Shutesbury, and farther south, most of the region is a rocky waste suitable only for growing wood or pasturage, although where the deposit is fine enough to furnish any earth at all it is a soil of very considerable fertility and one not easily exhausted. It is an especially good grass land.

\section{THE FINE VALLEY DRIFT OF THE EAST SIDE OF THE VALLEY.}

Very unlike the coarse incoherent drift of the uplands is the stratum of the same age spread over the bottom of the valley. It has been called by various names, as "drift," "unmodified drift," "till," "lower till," "bowlder clay," "hardpan;" and the last, the common name of the deposit over New England, is most characteristic. It is an excessively compact, wholly unstratified clay of a somber gray color, always more or less sandy, and stuck full of glaciated bowlders, those from 5 to 8 inches in length predominating greatly, while of those above a foot in diameter very fer occur in the many sections of the true lower till which I have examined in this basin.

When examined under the microscope it is found to contain only a very small quantity of true clay or kaolin, the usual product of the decomposition of feldspar. It is more properly described as an extremely fine rock flour, the sharply angular grains of which are mostly quartz and feldspar. And this is easily explicable when we consider its origin-that it is produced not by the slow decomposition of the rocks and the sorting out of the finer clayey portion by running water, but that it represents the finer portion of material produced by the grinding up of rocks largely 
undecomposed and also largely siliceous. Small pockets of water-washed sand occur somewhat rarely, generally as broad sheets less than a foot in thickness and dipping often at a high angle. They merge, often with various contortions of their layers, into the normal till, and are plainly remnants of deposits made by subglacial water seams, which were not wholly molded into the common mass by the later work of the glacier.

The exceeding compactness of the mass is a factor of prime importance in any consideration of the origin of the deposit, since it can be explained only by assuming it to have been caused by the great weight of the ice which rested upon it. For a long time I thought it possible to explain this as due to the slow compacting of a mass of loose material of various sizes aided by the percolation of water, but when once dug up and thrown in heaps it becomes compact again only when dry, as does also the Champlain clay, which lies above it. When water-soaked, however, it sinks readily into fine mud. When both are in their original position and have not been disturbed and are still permeated with water, one can easily push a cane several feet into the clay, but could scarcely penetrate the till more easily than the sandstone. Where this till is well developed a workman will often not remove more than a yard of it in a day. In digging the cellar of the Amlierst Honse the attempt was made to split it off in blocks by means of large wedges and sledges, but the best steel was rapidly blunted, and these were abandoned in favor of powder, and the mass was blasted out as if it had been a rock. In digging a well at the residence of the late President Clark it was also necessary to blast in the same deposit. Masses of the till brought up from a deptl of 55 feet from the well sunk at the first house south of the Amherst College grounds, where the whole excavation was in the typical bowlder clay, could be trimmed into hand specimens with the hammer while still fresh, and broke with a smooth, broad conchoidal fracture, like flint, and projecting pebbles would be broken by a blow without being dislodged from their places. Near the bridge in Leeds an excavation made several years ago exposed a vertical wall 30 to 40 feet high, and it has since scarcely crumbled at all. The deep railroad cutting south of Leeds and the steep eastern bank of the river at that place are also good examples of its durability. It is characteristic of the valley drift no less than of the upland drift already described that it is a wholly amorphous and unstrati- 
fied deposit, and one needs only to examine a firesl exposure of it and see hew all its parts are thrown together in confusion, without any assorting. ancording to the weight and size of the stones--here a large bowlder projecting, there many small mes grouped, and again over broak surfaces the dark-graly compacted clay oecurring almost fiee from stones of considerable size and lacking all signs either in the color or the grain of a lamination or an assortment into parallel layers-one needs only to make these observations and then for comparison examine the clay banks or sant and gravel beds so well exposed in the river banks, remembering that they are instructive only in a somerwhat fresh exposure, to be convinced that all the characteristics of water action-the delicate sorting and arranging, like with like, according to size and weight-are here markedly absent, and that it is quite impossible to explain the bed as formed in this way.

If one has reached this conclusion by carefully comparing the two formations and has the opportunity to examine many sections of the drift where it is a fine sandy elay, he will be almost startled to find isolated patches which seem to show a true and delicate lamination-a series of fine, horizontal, parallel fissures, a few millimeters apart, usually gently undulating. At times the undulations of adjoining lines meet at equidistant points like a flat-meshed net, or like the cleavage of hornblende, so that the clay is separated into a bundle of flat, slarp-edged blades. These lines fade away, however, in all directions into the general formless mass, and constitute not a Iamination in the technical sense-a result of deposition in water-but a pressure cleavage caused by the same force which had compacted the whole stratum. The effect of considerable pressure in producing cleavage, or a tendency to split at right angles to the direction of the force applied, may be seen in a variety of instances, and its recognition has thrown light upon important problems of geology, snch as the delicate banding of glacier ice and the smooth splitting of roofing slates. Gun-cotton pressed into cakes, or thick pasteboard calendered under heavy pressure, may be separated easily into thin layers, and even the splitting of a common cracker or the flaking of pastry is a structure produced by the pressure of rolling ont the dough and developed afterwards in the baking. This structure was well seen in the waterworks ditch opposite Phœnix Row in Amherst, and in the canyon of Deerfield River through the divide range, described in the first section of Chapter XV, p. 509. 
In another way, though rarely, the till may simulate the bedding of sedimentary deposits, where it is thickened into dome-shaped drumlins, and it will be seen later on that these are common in the valley. I have once or twice seen a rude separation into thick, irregnlar layers molded into each other and distinguishable only in a view of a broad surface at a distance. This occurs at the section mentioned at the bridge in Leeds. It would seem that the ice pushed one layer after another into the accumulating mass and so gradually built it up.

In the foregoing discussion of the various phenomena of the valley drift I have assumed its subglacial origin, though many of the details perhaps would fit equally well with the idea that the mass was pushed out from the front of the ice as it retreated northward with various oscillations. The great compactness of the whole and the pressure cleavage wonld hardly

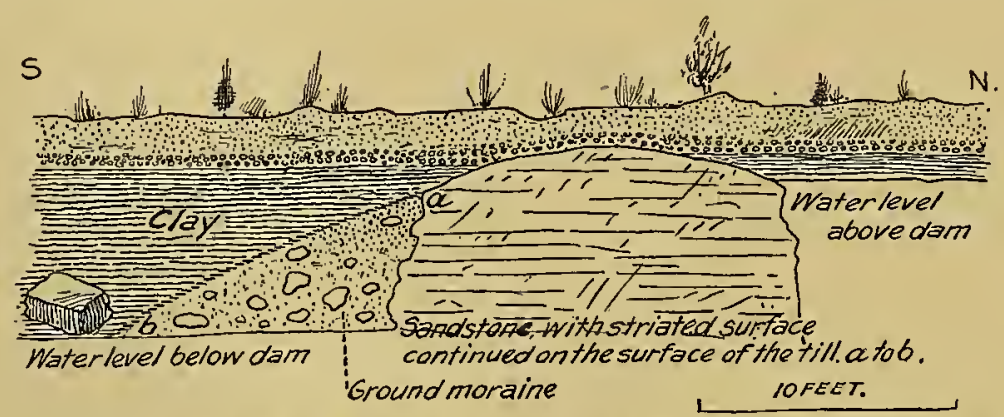

G. 31.-Section on the left bank of the Mill River at the hoe factory, Northampton, taken after the washout of 1878, which carried the dam away, showing the strixe on the surface of sandstone continued on the surface of the till below.

be explicable upon this assumption, and I have now to describe two sections which render it certain that the whole mass is of subglacial formation.

On the night of December 10, 1878, the Mill River, flooded by the very abundant rains and by the breaking away of several dams on its headwaters, rose in Northampton to a height greater than on the occasion of the flood of May 16, 1874, which caused so great a loss of property and life, and was less destructive only because the earlier flood had done its work so thoroughly. It carried away the western part of the dam at the hoe factory in Northampton and wore deeply into the western bank, exposing the section seen in fig. 31 .

The dam had been built on a reef of coarse red sandstone which ran diagonally across the stream from north west to southeast, the stream flowing here from north to south, and the section runs in the latter direction. The 
surfice of the sandstone is rounded and retains everywhere the glacial scratches perfectly. These are broad, deep grooves, miformly directed S. $30-40^{\circ}$ E. On the soutl side the sandstone was uneven and ended abruptly in a mearly vertical wall, against which rested a mass of dark-gray till of stony compactness, the surface of which was an exact continuation of the broal, convex, striated surface of the sandstone, showing that the ice had passed over them both together and planed them down to a common level.

Again, in changing the grade of the Canal Railroad, near the South street bridge in Northampton, a section was exposed where the compact stony clay abutted on the east against the red sandstone, continuing the curvature of the convex roche moutonnese surface of the sandstone in the same way. In each case the drift and the sandstone were covered by the Champlain clays in such a way as to show that the exact surface of the drift upon which the ice rested had been covered with the clays immediately after the disappearance of the latter, a point I have developed more fully in discussing the clays and their relation to the valley drift at the beginning of Chapter XX.

\section{THE COARSE VALLEY DRIFT.}

On the west side of the river in Northampton the bay formed by the retreat westward of the crystalline rocks is much deeper, the drift accumulated there is more abundant, and the drumlins are on a larger scale. The deposit is, however, much more masked by the later accumulation of sand in the flood period, by which the whole surface is brought up to the level of the highest terrace. While the deposit is probably the exact equivalent of the valley drift already described from the east side of the river, I have thought it best to describe it separately, both because it occurs in a separate portion of the basin and because it presents several points of difference when compared with that.

While the paste is clayey and well compacted, it is generally much coarser, bowlders above a foot in length often making up three-fourths of the mass, and masses above 3 or 4 feet in length being in places very abundant. The three outcrops already described in the preceding section from the west side of the river agree in their fineness and exceeding compactness with the fine valley drift with which they are associated, and, like it, certainly rest directly upon the older rocks. I have not been able to ascertain if this was the case with regard to the coarse valley drift here 
under discussion. The latter differs from the former also in the origin of its material. On the east the bowlders, except the abundant far-traveled quartzites, are mostly from Mount Toby and the granite soutl of it. I have rarely found a piece of the spangled mica-schist of the great western range, although the bowlders of psilomelane and yellow cavernous jasper found across Amberst seem certainly to have come from the locality in Conway on the northwest. On the west all the rocks to the north and west are abundantly represented by large bowlders, and very large masses of the Vermont quartzites are also abundant; one taken from near D. Denniston's now adorns the old Whitney homestead, on King street, in Northampton, and is about 6 feet in diameter. ${ }^{1}$ I have been inclined to connect the exceptional coarseness and abundance of the subglacial débris gathered here with the peculiar direction of motion impressed upon the lower portion of the ice by the trend of the great valley. As the ice moved toward the valley from the northwest it came upon its westeru rim well charged with bowlders from the area it had crossed, and was below deflected southward by the trend of the valley, and still farther deflected to the west of south and obstructed by the transverse Holyoke range, and its morainic material was gathered in a sort of eddy under the western cliffs or swept southward in the valley, and so failed to reach the eastern side of the basin.

DISTRIBUTION OF THE COARSE VALLEY TILL WEST OF THE RIVER.

The most northerly exposure of the bowlder clay in the river side is at the westernmost point of the great Hadley bend, where the river has worn into it, and the bowlders, accumulating upon the shore, have formed a natural "riprap" and thrown the current across against the Hadley side, where it will in time cut off the point of the bend and leave its present channel.

This exposure seems to be the northern end of a long ridge or series of drumlins which runs in a general way southward across Northampton, mostly covered by the later sands. It is exposed on Slough Hill, west of the north end of King street, and deeply cut into by the Canal Railroad at the Black Pole bridge. Its further prolongation, Round Hill, is a massive drumlin. Under the Forbes Library, Smith College, and the asylum the bowlder clay rises to the surface and reaches just the same level as the surrounding sands which form the level surface of Elm street. These two

${ }^{1}$ It has been placed over the grave of Prof. Josiah D. Whitney, late professor of geology in Harvard University. 
litls of drift are separated to the depth of the present bed of Mill River, as is shown by the leeight of the bowlder clay in the section at the hoe finctory, already described. West of the asylum Sunset Hill and the long wooded hills between which runs the road to Loudville form the most elevated and extensive accumulation of drift in the valley. The first of these hills, starting from the northwest corner of the asylum grounds, rums sonthwesterly and is continued across the Loudville road by the higher and more missive hill which is conspicuous at a distance fiom the number of great bowlders of whitened quartz-diorite (tonalite) that cover the broad benches on its southeastern side. The road to Easthampton skirts this hill for a long distance on its southern side, and the sands of the high terrace abut upon its other slopes.

This completes the chain of ridges, and a glance at the map will show how they are swung in a broad curve, from Elizabeth Rock to the Westhampton Hills, across the mouth of the deep bay formed by the recession of the crystalline rocks. Within this bay two other prominent drumlins take the same west-of-south direction-the wooded hill east of Florence and the long steep elevation above Bay State on the north. And finally, all the broad wooded area west of Mill River opposite Bay State is a continuous undulating area of bowlder clay, and from a point below Florence nearly all the way to the asylum Mill River is wearing into it, and its westem bank is covered with abundant bowlders from which the stream has washed ont the finer material, and here are the best permanent sections in the bowlder clay to be found in the valley.

Farther south, across Southampton and Westfield, the Champlain sands occupy the greater portion of the valley bottom, and where the till appears it is usually with an undulating surface and is made up of rather fine-grained, reddish material, derived mainly from the red sandstone, very compact, with bowlders nearly all under 1 foot in greatest length, and thus is very different from the upland till. This is notably the case in all the west half of Southwick.

DRUMLINS.

Perhaps the inost notable contribution to science made by the Second Geological Survey of New Hampshire was the recognition of this interesting and peculiar form of drift hills, coupled as it was with a careful mapping of their distribution and a satisfactory explanation of their origin. 
The credit due for this piece of excellent original work is certainly not impaired by the fact announced by Prof. W. M. Davis, in his historical résumé of the literature of the subject, ${ }^{1}$ that the same forms had been observed, mapped, and correctly explained by $\mathrm{Mr}$. M. H. Close, ${ }^{2}$ in Ireland, at an earlier date. As, moreover, the name "lenticular hills," proposed by Messis. Hitcheock and Upham, is certainly not a very satisfactory one, and seemed, indeed, not wholly satisfactory to its authors, it is a matter of congratulation that the earlier paper proposes a name from the Irish, which, with the Scotch, is so much richer in names for the varieties of surface form of the land than is our own dialect. Indeed, if the word could come into general use it would be a valuable addition to our synonyms for hill forms, while its more precise use follows a custom already set in this department of study.

The comparison of drumlins with the sand banks formed beneath flowing water seems quite satisfactory. I have also been interested to compare them with roches moutonnées, with which they are associated in origin beneath the ice.

Fig. 31 , p. 540, is a representation of a vertical bank of clay and till resting against red sandstone. A broad roche moutomnée of the red sandstone, beautifully striated, was exposed, and abutting against the southeru vertical and unstriated wall of the rock was a till of almost equal compactness with the rock itself, bounded above by a curved surface, which was the exact continuation of that of the sandstone. The curve sank under the water above and below. This may with some propriety be called half roche moutonnee and half drumlin, and illustrates the close similarity of the cause originating the two rock forms-the differential pressure of the ice upon its substratum. In several other cases rock takes part in the formation of the drumlin, at times as a nucleus with steeper slopes than those of the drumlin itself, but appearing along its crest; yet this is the exception here as elsewhere.

The distribution of these hills along the valley, as shown in Pl. $\mathrm{XXXV}$, is interesting, and may throw some light upon the question of the north-south motion of the ice in the valley as compared with the northwestsoutheast motion on the higher ground on either side.

${ }^{1}$ Am. Jour. Sci., 3d series, Vol. XXVIII, 1884, p. 407.

'Jour. Royal Geol. Soc., Ireland, 1886, p. 1207. 
If one could remove all the newer deposits-sands and clays-which still await our discussion, and then raise this great stratum of stony clay which overspreats the valley, as one lifts a plaster mask from the face, it would be found that its under surface had been exactly molded to every line and curve of the rocky substratum; but its upper surface would have the effect of a comic mask, swelling with unequal thickness over every prominent feature, distorting and concealing its true form, and sending up great protuberances due wholly to a thickening of its own mass and not molded on any projecting ledge below. The protuberances formed thus by the local thickening of the drift sheet appear now as drumlins-massive domed hills, in shape like an inverted canoe, with the long axis pointing in the direction of the glacial motion, from north to south. Where they are most symmetrical they slope away rapidly and equally toward the east and west, more gradually but equally north and south, and very naturally suggest the name "hogbacks," by which they are often known inland, or "whalebacks," as they are called near the sea. They rise like islands out of the sands, which wrap around their bases to a maximum height of 150 to 200 feet above the present low ground of the valley, and often the thickness of the till composing them seems to be greater than that.

The two hills just north and south of the village of South Amberstnamed Castor and Pollux by President Hitchcock, from their close similarity-another to the east of the former, and two others farther south and west, are all cast in the same mold. Farther north the hill south of College Grove-named the Occident by President Hitchcock-the College Hill, and, finally, all the group of hills occupying the space between Amherst, East Street, and North Amherst villages are of the same origin and preserve in varying degrees the common form.

In the case of all the hills around South Amherst, except Castor, there are no neighboring outcrops by which one can judge of the elevation of the subjacent ledges and so fix the thickness of the drift stratum forming the hill. The surface of the rock may be concave beneath them and the thickmess of the till much greater than their height above the valley bottom. In Castor the gneiss and granite appear high up on the shoulder of the hill on the east and the west, and if it runs under the drift at the same level the thickness of the latter would be about 30 feet, which is probably more than the real thickness.

MON XXIX- 35 
The ledge seems to me to be very deep below the surface of the Occident, the hill south of College Grove, but no certain data are attainable. The well on the east slope of this hill at R. W. Greene's was sunk in "hardpan" 46 feet, as he informed me. In the College Hill the Octagon cellar showed that the surface was the true till The college well is 25 feet deep, and about 45 feet below this the well already mentioned was sunk 55 feet, and another on the southwest slope of the hill, at the east end of Short street, was sunk to the same deptll, giving the till an ascertained thickness of 100 feet, and the whole thickness is certainly much greater.

The high hill north or northwest of East Street has in perfection the form of a drumlin, and is doubtless of common origin with those already described. There is, however, at its top a broad expanse of red sandstone, which appears nowhere upon its slopes, either at the surface or in wells. It has, therefore, a nucleus of rock of different configuration and with sharper slopes than the present hill. Between the Center and North villages, finally, and bounded on the west by the road and on the east by the railroad between these places, is a group of these hills, so blended that the symmetry is somervhat lessened, in which different summits resemble the several hills already described. Under the hill on which Professor Tyler's house is built, and its prolongation eastward, the red sandstone is everywhere near the surface and the till is thin.

West of Mount Pleasant the gneiss is near the surface; it is 50 feet below the surface under the honse at the south end of Mount Pleasant, and rises to the surface a few rods north of the site of the residence of the late President Clark. An examination of the map will make it plain that these hills rest upon a concealed ridge of older rocks running sonth and a few degrees west of south from North Amherst City to South Amherst, and that they lie in the lee of the high ground consisting of crystalline rocks which projects westward north of the former village, and, finally, that there is a close similarity in the arrangement of the drumlins on both sides of the river, those on the west lying in a line curving to the westward and in the shadow of the projecting heights of Elizabeth Rock, as described in the preceding section.

The most striking series of drumlins in the valley is found in Bernardston and Gill. They are of the largest size and of most symmetrical form. A fine view of them may be had from the railway in Northfield village, 
across the river to the west. They cover the first range of hills above the highest terrice and rise one belind the other, their long, curving lines (verlipping repeatedly and forming an ideal drumlin landscape. Standing on top of the tillest of these hills east of the village of Bernardston and looking southward, one cum see the train of drumlins crossing the plain, where they are in part subnerged in the Champlain sands, and then rising high upon the great nass of Triassic sandstone which forms the town of Gill, though not reaching its top. The surface of the sandstone beyond and higher up is molded into drumlin-like forms. Descending the southward slopes of the sandstone mass, or following the eastward side of the valley southward, one finds no drumlins except a single small but wellformed one beside the railroad just north of the station in Whately. Nor is any trace of them to be seen north of or up the north slope of Mount Toby, which holds a sitnation in the valley quite similar to the Gill mass.

It is a peculiarity of these hills in Bernardston that while they in many places obscure the geology of the region fatally, the interspaces are over considerable areas almost driftless, so that, outside the regnlar oval base of the hill, fragments on the surface are quite safe indications of the ledges which lie but a little distance below.

As indicated upon the map the boundary of the crystalline rocks which form the western border of the valley follows the east line of Bernardston near the river and then turns west along the south line of that town and Leyden, and again south along the west line of Greenfield, Deerfield, and Whately, to Northampton, where it is again set back by the width of the latter town, and runs thence southerly to the sonth line of the State. Along this sloping border of the valley between Greenfield and Northampton runs a train of drumlins, some having their bases nearly 100 feet above the level of the high terrace sands (Northampton high terrace 305 feet, Greenfield 357 feet, above sea), while others are more or less submerged in these sands; indeed, in several cases wholly submerged and beautifully regular drumlins have been exposed in the extensive railroad cuttings up this side of the valley. In one most interesting case at the Camp Meeting cutting on the north line of Northampton (see Pl. XV), what seemed to be a broad terrace of coarse sand contained, to the dismay of the contractors, a fine drumlin of rocky hardness which had to be blasted away in front of the steam shovel, and was capped by 
three later glacial deposits with as many intervening sands, which could be followed for 3,350 feet in the open cutting.

Several of these hills of most regular shape are so built up on the steeply sloping rocky valley side (the valley runs here north and sonth) that looking up from below one seems to have before one a drumlin of the largest size, while looking down from higher up the hillside one sees only a small ridge interrupting the eastward slope. These hills are directed southerly, as are the neighboring striæ, but they lie near the western bonndary, between the areas of southeast and of southern motion of the ice, like a line of bars between two currents meeting from different directions; and in Northampton, where the ice was deflected in the valley southwestward, the drumlins have the same direction and swing in a great curve across the reentrant angle in the rocky border.

In the town of Amherst nearly every hill is a drumlin, and in several cases they are laid side by side in pairs and coalesce laterally. It is further interesting that this group of drumlins in Amherst runs right up to the steep northern base of the Holyoke range, which here traverses both the valley and the direction of the ice, and whose crest of trap is finely covered with north-south striæ.

I have mentioned above that the drumlin exposed in the Camp Meeting cutting, a little higher in the valley, is covered by three separate glacial beds, representing, doubtless, as many oscillations in the ice at the time of its retreat, which shows-what, indeed, hardly admitted of doubt-that the drumlins were formed beneath the thick ice of the general glaciation; and the position of this last group, carried with northsouth axes right up to the foot of the steep Holyoke range, which itself is striated in the same direction, bears strong evidence against the existence of a separate Connecticut River glacier which should explain the north-south striation of this valley. Indeed, these north-south drumlins are carried up so high on the sides of the valley that when one imagines ice of the smallest thickness needful to build them and compress them to their present rock-like density, one sees that the ice would have risen above the boundaries of the valley and have overflowed fan-like, as in the great lobes found in the Western States. The facts seem, then, to accord better with the theory proposed by Professor Dana of a differential motion of the lower portion of the ice in the valley, and the long line 
of drunlins carried down the western border of the valley mark the line along which the ice was deflected sontluwardly into its new direction. Sonth of the Holyoke range and east of the Mount Tom range the drumlins are broader, flatter, and fewer in number than farther nortl.

On the hills east and west of the valley drumlins are rare or wanting. I have noted only one train-this of hills of the largest size-which enters the northwest corner of Blandford from Becket, with direction S. $35^{\circ}$ E. A very fine one is situated a little southwest of the center of Granville.

MORAINES AND BOWLDER TRAINS.

The great ridge of bowlders of tonalite which passes the Catholic chureh in Thorndike and extends sonthwardly, going to the west of the group of ligh hills southwest of this village and appearing in exceptional force near E. Brown's liouse, just west of Palmer village, and crossing the river to mount the high hill just south (Bald Peak, in Monson), is a portion of a true terminal moraine of a lobe of the ice which shut up the gorge through which the Quabang River passes northwestward from Palmer village, and furnished the barrier for the Palmer Lake (see Pl. XXXV and Chapter XVII). In the latter part of its course its bowlders are exclusively of Monson gneiss and of very large size, one 26 by 16 by 7 feet.

From the large dike of granite in the center of Middlefield a wellmarked bowlder train is carried across Chester, passing through the center of the town and traceable for a distance of 5 miles.

Just west of the road running north from the village of Leverett a prominent hill of granite is continued for a long distance southward by a mass of bowlders so densely packed that it seems like the continuation of the hill itself, and in the northern part of Worthington is a similar crag-and-tail arrangement of colossal bowlders of mica-schist carried sontheast from a prominent hill, so closely packed that one can jump from one to another for a long distance.

Stretching southeast from the great band of fine-grained granite west of Burnell's pond in Chesterfield is an immense accumulation of large, often immense, bowlders. It continnes to the southeast corner of Chesterfield and on into Westhampton.

A marked bowlder train starts from the dike of peculiar porphyritic granite northwest of Leyden and extends past the center of the town and on a little east of south into Greenfield. 
Bowlders of the peculiar brown, porous, and drusy chalcedony and pyrohsite from Conway are so abundant across Amherst and Granby as to deserve mention. One mass on the eastern peak of the Holyoke range measures 6 by 6 by 4 feet.

THE INTERGLACIAL SANDS.

An elderly lady in Amherst says that when she first visited the town of Amherst there was a remarkable spring, never failing, near H. M. Burt's residence, opposite the $A \Delta \Phi$ house, the water from which flowed down eastward across the common and into a quagmire overgrown with alders, in which several pigs were drowned during her visit. Since then Mr. Burt's well occupies the position of the spring, and is remarkable for its volume of water, which often rises to within 2 feet of the surface at the very crest of the ridge.

Farther north on the same ridge the well at J. L. Lovell's house is also remarkable for its abundant flow of water, it being almost impossible to empty the rell. Again, in lowering the Northampton road opposite College Hall in 1878 a layer of yellow stratified sands, the finest 0.3 to $0.6^{\mathrm{mm}}$, the coarsest 0.5 to $1^{\mathrm{mm}}$ in grain, from 6 inches to a foot and a half thick, much contorted, was exposed, which was covered by a thin layer (from 6 inches to a foot and a half in' the section, but rising to a greater thickness farther north) of a hard, blue till and underlain by an ashy till carrying many striated bowlders, one mass of conglomerate being 3 feet long. The sand layer continned to both ends of the section, about 5 rods. The same section occurred at two excavations farther north on the same ridge, on the grounds of Mrs. Davis and William W. Hunt. I did not connect these facts or find suitable explanation for them until I had stndied the exceptionally interesting section furnished by the digging of the Amherst House cellar.

In digging the cellar a block of earth 92 by 104 feet and 12 feet deep was removed, and at the same time the ditches of the Amherst waterworks were opened, having a depth of from 5 to 8 feet and extending from a point just in front of the cellar eastward to the dam in Pelham, a distance of nearly $3 \frac{1}{2}$ miles, a mile north to the Plant House, 1,400 feet south to the railway station, and 1,200 feet west to the brow of the hill on Amity street.

The cellar section is illustrated by the figures of Pl. XII, drawn carefully to true scale. Fig. 1 is taken from the northeast corner of the cellar, 
12 



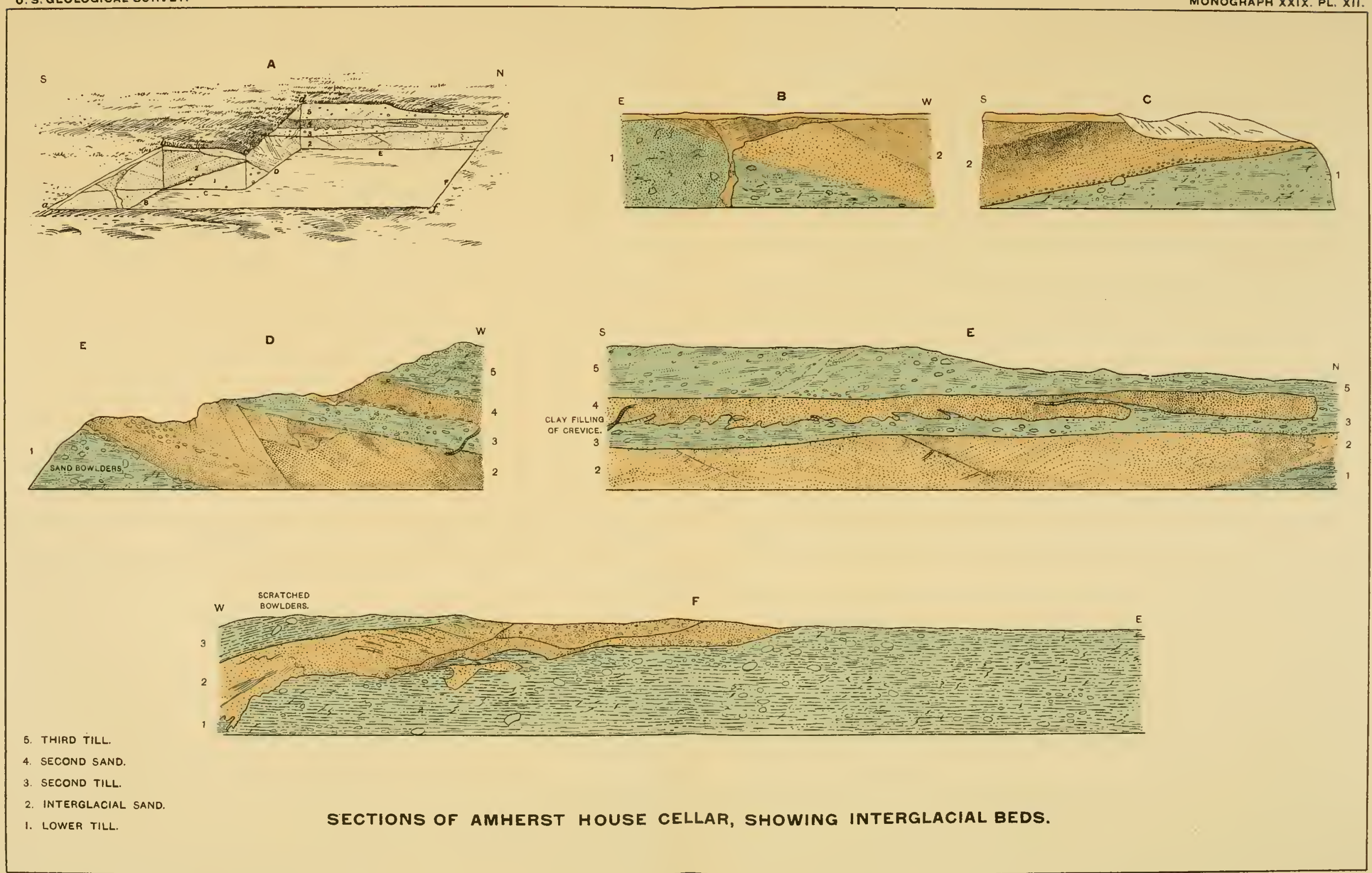



lonking sonthwestward The lowest stratum (1) present is the lowest till or valley dritt, which forms the floor of the cellar and is seen rising to the surfirce in the south wall (fig. 2). It forms all the remainder of the south, all the east, and nearly all the nortl wall (fig. 6); and in the waterworks ditches which radliated from this point it occupied the whole depth for a thousand feet nortl, south, and east; and to the west, where the ditch ran parrallel to the north side of the cellar, it repeated exactly the section developed in the latter (fig. 6). The ground here is 311 feet above tide, and slopes away in all directions, so that the till soon sank under the highest stratified deposits of the subsequent flood period, which reached here nearly 300 feet above tide. Above this level it had never been covered, and the boundary of the till traced upon the map represents only the uncovered part. The bottom of the deposit is liere nowhere exposed, but farther east, opposite the old Amherst Bank building, the New Red sandstone comes to the surface and has this till on its back, and farther north the gneiss does the same at the entrance to the Agricultural College farm, and in both cases the stratum has shrunk to a foot in thickness. The cellar deposit has already been made the type of the detailed description of the valley drift (page 537). Upon this base rests a layer of stratified sand (2) 5 feet thick, upon this a bed of compact till (3) 1 to $1 \frac{1}{2}$ feet thick, next 1 foot of sand (4), and the whole is capped with a 7 -foot bed of till (5).

The lower sands (2) were deposited immediately upon the irregular, hummocky, apparently eroded surface of the till, the lowest layers, sometimes gravelly, folding over smaller irregularities and projecting bowlders and gradually obliterating the depression. The upper and larger portion was cross-stratified on a large scale, the laminæ dipping west from $5^{\circ}$ to $40^{\circ}$, and where the structure was least disturbed a high dip, about $30^{\circ}$, predominated. Here and there a delicate flow-and-plunge structure could be seen. The whole stratum consists of clean, well-washed sand, whitish where not colored by a later infiltration of iron, varying from a fine sand which retains water and has an average grain of $0.09^{\mathrm{mm}}$ to a coarse granitic sand having a grain of 0.5 to $1^{\mathrm{mm}}$. Thin seams of gravel separate the layers of sand here and there. Comparing many samples with the ordinary sands which compose the higher terraces of the valley, I found them to agree quite well under the microscope, but the glacial sands had been more rounded by attrition in water and were better sorted than the later flood 
sands. The bed was, however, everywhere disturbed by the pressure and thrust of the ice which had moved over it from north to south.

On the western face (fig. 5) the laminæ, which, being exposed in the direction of the strike, had run nearly horizontally, have been squeezed into wavy folds, and often show beautiful illustrations of reversed faults, the upthrow overlying the downthrow, the faults always dipping to the north. On the southern face these faults were much more numerous, and as the work of removing the earth progressed they were constantly changing. On oue face of 10 feet I counted twenty. On the surface represented in the figure they are present in great number, and two are especially marked, one faulting the bed 3 feet; these dip $60^{\circ} \mathrm{W}$. In other portions the bed was thrown into entire confusion. Over a large portion of the section a beautifully delicate incipient cleavage has been superinduced in the sands by the pressure, and its existence is made manifest only by the concentration of iron rust in sharply distinct layers $1 \frac{1}{2}$ inches apart, which run parallel to the level base of the till above, passing across the laminæ of the sands and distinguishable instantly from the ordinary lines which inark the lower limit of infiltrating water. Their position in the upper portion of a thick permeable layer and beneath an impervions one would make them difficult of explanation in that way. It seems to me that the pressure has prodnced in the sands distinct traces of a plane-parallel structure, which has favored the movement of the percolating waters in a definite plane, and with this also the deposition of the iron from the water. This structure, I liave no donbt, was produced within the sands when frozen.

At its base the stratum of sand is closely blended with the till, and although the transition is effected in the space of an inch, there is no sharp line of separation. Above, the stratum is planed down to a horizontal line, the laminx being cut sharply across, and the middle layer of till rests upon the surface thus produced like a plank, with a clearly defined line of demarcation between it and the sands it covers. It is a horizontal fault.

It seems to me certain that when the ice moved over this mass of sand, now so yielding and incoherent, the latter was frozen into a solid and rocky mass, and that it was thus eroded and faulted and cleaved, and where the freezing was less entire was swept into the common chaos of the till above. In many cases the upper layers of the till contain well-rounded sand 
lowlders if inches in greatest dianeter, which can be explained only as above indicatted. They are now pockets of a much flattener ellipwidal form, tilled with a buff sand like that forming the layer below.

This sand stratum was again finely exposed in the water-1uain ditch on Anity street (a few rods north), on a line ruming east and west, and thus with the dip of the lamine of the sands. It rested, as before, upon the irregular surface of the till below, and was covered here and there by fragments of the second till, partly removed in grading the road. The sands were exposed for a distance of 350 feet, commencing at a point opposite the northwest corner of the cellar. Here they began as a thin, gravelly bed, and, the till beneath dipping westward, they soon reached a thickness of more than 6 feet, and their whole depth was not exposed for 60 feet. Then the till rose nearly to the surface for 60 feet, and for the rest of the distance the till appeared only here and there in low hummocks in the bottom of the ditch, until at last the sands ran out to the surface on the slope of the hill between the first and second layers of the till, opposite Professor Crowell's house.

The sands agreed in all particulars with those already described in the cellar section, presenting the same gradation from a fine, whitish, clayey sand through buff sands to fine gravel, the same flow-and-plunge structure, and false bedding with westerly dips, all in places more or less obliterated in the contortions produced in connection with the deposition of the second till.

Again, the ditch almost continuously cut across the same sands, overlain and underlain by till and in places confusedly intermixed with the second till, as it continued north on the North Amherst road up to the western base of Mount Pleasant and 80 rods north of the cellar, where the road goes down a small slope, at the gate of the Mount Pleasant grounds. These sands agree exactly with those before described, and are doubtless a continuation northward of the same stratum which I have traced from College Hall and which here crosses the road and runs eastward into Mount Pleasant. What course it takes from here on is uncertain, as it conforms itself to the irregular surface of the underlying till. It seems to me probable that it rises high enough toward the north or to the east to produce the head and strong flow of water in the wells on the ridge mentioned above. That this water sets from the north to the south was shown very clearly by the fact that for 40 feet south of an old well which had been sunk 
under the former Amherst House through the sand stratum (2) and into which the sewage of the house had been directed for many years, the buff color of the sands was wholly discharged and the sands were clotted into a greenish mass, and that this effect extended southward without diminution as far as the excavation continued. On the north the sands retained their buff color up to the well itself. This well was located in the middle of section 5, Pl. XII, and went below the bottom of the section. It was clear that the decomposing organic matter had reduced and removed the iron from the sands for a long distance south, and that the sands had thus lost their power of purifying the water which set southward. A colleague who had had abundant opportunity for judging remarked to me that he never liked the flavor of the water in Mr. Burt's well, located a few rods south.

I have now traced these sand strata along the western slope of the ridge which joins College Hill and Mount Pleasant from the first section northward more than a mile, with a width of 50 to 350 feet and a thickness which for a considerable distance was fully 6 feet. They run farther north and south-how much farther can not be said. They appear with undiminished thickness in the northern exposure and may be seen in the Central Railroad cut on the south. They crop out in a slope produced by later erosion, and the position of these sand strata between layers of till seems to me to have in part determined the position of the Lincoln avenue plain from the Nortlampton roarl to the Agricultural College and northward. Vertically one can see in every section how the sand has been scalped by the ice, and when one considers how exceptional a grouping of favorable circumstances must have been required to shield these incoherent and exposed sand beds beneath the ice and retain any portion of them intact, one will, I thiuk, be inclined to consider what remains as but a feeble remnant of the beds as originally deposited. Again, the texture of the beds, the large scale of the cross-bedding, the flow-and-plunge structure, and the close resemblance to the flood deposits of the valley in later times, make it probable that they were of similar origin, the one being deposited in the flood waters subsequent to the first retreat of the glacier, while the other and later beds were laid down by the floods which accompanied the final melting of the ice.

The sands then furnish strong evidence, if not conclusive proof, of an interruption in the continuity of the presence of the ice in the valley and of 
its retreat from the seaboarl to a point north of Amherst, while the abundant information concerning the character of the glacial deposits in Mane and New IIampshire, published by Prof. C. H. Hitcheock, incline me to the opinion that the recession continned at least to the foot of the White Mountains.

The middle layer of the till (3) in the cellar section is a compact, stony chay, showing no distinction in color, compactness, or texture from either the upper or the lower layer when exposed in fresh section. When frozen it showed itself a little more sandy toward the north end of the section, evidently because it had borrowed part of its material from the sands upon which it rests. Its sharp horizontal line of demarcation from the sands below I have already described. Its upper surface is, on the contrary, most inregular. It sends many long, tortuous projections into the sands above, which are bent over and spun out southward as the smoke of a chimney is by strong wind, and indicate clearly the direction of the motion of the ice. This structure is more manifest in the section itself than it can be made in the drawing, and recalls the "fluidal" structure of many voleanic rocks. Oftentimes filaments of the drift lie wholly inclosed in the sand, strung along in the direction and in the prolongation of one of the projections, from which they have manifestly been separated.

The upper layer of sand (4) is about 1 foot thick, and is somewhat finer than the average of the lower stratum-about one-fourth inch-but agrees with it under the microscope in degree of rounding of the grains. It shows nowhere distinct traces of its former texture, this having apparently been wholly replaced by a fine horizontal lamination, which seems to me rather a pressure cleavage superinduced by the weight of the ice upon the mass when frozen, while below it is confusedly interwoven with the till on which it rests. Above it joins the third layer of till along a line nearly horizontal, although the sand and the till are thoroughly molded together. This is a second horizontal fault. Toward the north end of the section it ends abruptly, being cut off at right angles to its length, and the layers of till above and below it come together, separated only by a thin seam of sand, which in places disappears entirely.

Distinct traces of a second stratum of sand were to be seen in some of the other sections I have described, and while the sand and second till were often so confusedly interwoven that all indications of a second sand 
bed might well have been obliterated, I am inclined to think that such a second layer was deposited on a second till. At the same time I explain this second layer in the cellar section as a sheet of sand which originally formed a part of the lower stratum (2), and which, when frozen, was moved as an immense bowlder into its present position. Thns it would be classed with the true sand bowlders-regular flattened elipsoidal sand pockets with their longer and shorter diameters averaging about 8 and 4 inches, respectively, which occur not rarely in both the upper layers of the till, and which can be explained only by supposing them rounded to their present form when compactly frozen.

Another curious phenomenon which points in the same direction was observed near the south end of the west wall of the cellar. A fissure had opened an inch and a half, commencing at the upper surface of the sand layer and running down through the middle drift layer and for a little way into the lower sand stratum, and this fissure had been filled witl alternating layers of clay and sand, about seven in all, which correspond on each side of the center and present a curious imitation of a mineral vein. (See figs. 4, 5 of Pl. XII.) This would seem also to find its explanation most naturally in the assumption that the sand layers ( 2 and 4 ) were frozen when the fissure was formed and that the latter was kept open so long that successive layers of muddy water trickled down through it. The sand bed abounds in small masses, 1 to $2^{\text {mm }}$ in size, formed of a few grains of sand cemented with limonite.

The upper layer of the till (5) differs in no respect from the lower, and, like it, was removed with chisels and heavy sledges. It had a thickness of 5 feet in the section, but the ground had been lowered here by the same amount, so its whole thickness was more than 10 feet as it appears a few feet west of the cellar. The massive and compact character of the stratum was shown by the effect upon it of the extreme cold of the winter of 1879 . The mass above the sand expanded with the freezing so energetically that it projected like a cornice 10 inches in the west wall of the cellar, which had been cut away vertically.

I am thus inclined to explain the phenomena I have described by assuming that after the deposition of the first till there was a retreat of the ice, during which heavy sand beds were deposited in the valley, followed by a second advance of the ice, which then plowed up and destroyed the 
greater portion of these beds, even moving and partially molding into the till beneath it great sheets of the sand, as in the case of the ber (4) just describerl, more commonly destroying its identity entirely. Nevertheless, I think one would be strongly inclined, from a study of the cellar section alone, to assimne a second retreat of the ice for the formation of the second sand bed, and a third and final advance, during which the third layer of the till was deposited.

Or, finally, one has an alternative; namely, to explain all these sand beds intercalated in the till as deposited by subglacial streams during the progress of a single glaciation of the country. The fact of a retreat and second advance of the ice seems abundantly proved for western Europe, and many observations in this country point in the same direction, especially those made toward the borders of the ice sheet, since traces of a double glaciation would naturally be more abundantly preserved there than farther nortl, where the ice a second time occupied the country in such force as to obliterate most traces of the incoherent deposits made in the interim. Again, the compact, unsorted, and clayey character of the till above and below the sands shows that for the most part there was here no free circulation of the waters below the ice, and we should expect the waters to have eseaped along the bottom of the valley and not along its side 300 feet above the bottom. On the other hand, the sand beds occupy just the same position fringing the valley and have just the same structure as the flood beds which attended the final disappearance of the ice, and seem to me to bear the same relation to the retreating ice of the earlier epoch. ${ }^{1}$

In 1881 the deep railroad cutting south of College Hill exposed the same sand beds at a distance of 1,463 feet south of the first locality cited above on the Northampton road, displaying the following section:

Section in railroad cutting south of College Hill.

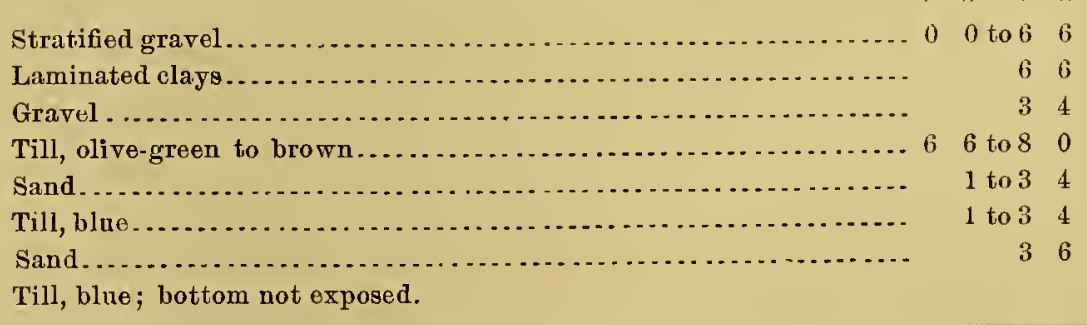

'I prefer to leave this section as it was written in 1879, although now the case in favor of a second Glacial epoch seems to me less strong than then. 
The lower' sand bed maintained a constant thickness for 450 feet east and west, going below the surface at the east end of its exposure and disappearing at the end of the cutting (opposite the northeast corner of College Grove) with the same thickness. It agreed in all particulars with the lower sand in the cellar section above.

The upper layer of sand was exposed for 325 feet east and west, measured back from the end of the cutting. It is greatly contorted and twisted in every conceivable way into the upper layer of till, and in one place it is wholly interrupted for 65 feet and appears in long patches and filaments of sand, one above the other, in the mass of the upper layer of till.

At one place also a third layer of sand is intercalated in the mass of the till halfway between the two more extended layers of sand, with a thickness of 31 feet and a length of 80 feet, and ending abruptly. This seems also to have been a great slab of frozen sand from the lower bed, while the extent of the upper bed here makes it possible that there were two independent sand beds deposited, which it did not seem necessary to assume from the former sections.

\section{THE UPPER TILL.}

I have called the stratum below the interglacial sands the first till, as the product of the first glaciation, and that above the second till, it having been formed during the second advance of the ice, reserving the name upper till for a deposit to which Prof. C. H. Hitcheock has called special attention and to which he has given this name. It is conceived by him to have been derived from the material taken up into the mass of the ice itself, and to have sunk down, when the ice melted, in a coarse, uncompacted, and unstratified sheet upon the lower till, which had been compacted beneath the ice. While the lower till is compact, with few small bowlders, well scratched and not far-traveled, and is bluish in color, having been protected from the air by the thick ice, the upper till is loose, contains many large bowlders, angular and far-traveled, and is reddish from oxidation. I have been able to recognize this distinction only partially in the valley. The immediate deposition of the Champlain clays upon the surface of the lower till proper at several places in the valley shows that the upper till was not uniformly spread upon the latter, and where, as along the northern part of High street in Amherst, an upper loose buff layer from 1 to 6 feet thick covers the blue compact till, I do not find the bowlders to be more angular or far-traveled than below, and am inclined to explain the peculiarities of the surface layer 
at due to the surface oxidation and disintegration by frost. The same was true at the Central Rialiroal cutting south of the college, where beneath the (lays the till was in its upper part clive-green to brown, and blue green below, but with no further distinction in matter of compactness, coarseness, or derivation of bowlders. I have seen several cases where the npper layer was blue and the lower reddish.

\section{REMARKABLE BOWLDERS}

President Hitchcock has described ${ }^{1}$ and named six of the most rotable traveled bowlders to be found on the east of the river in the valley and on its border, remarking that bowlders of the largest size do not occur in this vicinity. Those named are:

\section{THE NORTHERNER.}

An irregular mass of the coarse conglomerate of Metarampe (Mount Tom), weighing nearly 100 tons, $* * *$ lodged on the gneiss rock of Pelham Hill in the bed of a large brook close by a small cascade, where it was pointed out to me by Mr. Newall.

ROCK OREB.

Near the top of Mount Warner, a little east of the summit and in the cleared pasture, lies a large bowlder of imperfectly prismatic trap or greenstone. Its weight we estimated at 78 tons. The rock of the monntain is granite and mica-schist, and no trap in place is found to the north till we reach the north part of Sunderland and the south part of Deerfield, say some 10 miles distant. From that rauge this bowlder undoubtedly came.

\section{ROCK ETAM.}

Northwest of Rock Oreb, say a quarter of a mile in the woods, and far down the northwest slope of the mountain, is another and larger bowlder of the same variety of trap. We estimated the weight of the Hadley Etam to be 385 tons.

Another bowlder of the same columnar trap projects from the ground on a lower bench of the mountain southeast of Rock Oreb. Its exposed portion is half as large as the latter.

\section{THE MAGNET.}

At the western foot of the steep part of Holyoke, and a little south of the place where the railroad goes up the hill, lies a large bowlder of trap precisely like those just described on Mount Warner. It is 15 feet high, and, by a loose estimate, I think it must weigh 300 tons. It is remarkable for exhibiting on its north face a vast number of magnetic poles sufficiently strong to completely invert a common magnetic needle, forming in fact several continuous lines of poles. I spent some days several years ago in tracing them out. These facts furnish a reason for the name which I venture to propose for it, viz, The Maguet. I formerly supposed that 
it had been broken off from the trap ledges immediately above it, bnt its exact correspondence with Oreb and Etam in eharacters, and want of resemblance to the trap of Holyoke, make it more probable that it was bronght into its present position by drift ageney and originated in the same region as those on Warner.

\section{THE SENTINEL.}

As we ascend Mount Boreas, looking northerly up the valley on its east side, * * * we see a prominent bowlder lying near the base. We find it to be composecl of gneiss and lying on gneiss, although the stratification on both is very indistinct. It weighs something less perhaps than 200 tons, although not accurately measured.

THE ROCKING STONE.

Some years ago a bowlder of several tons weight, capable of being rocked a little by one man, lay on a farm then owned by Mr. Grout, about a mile north of Pelham Center, on the road to Shutesbury.

OTHER BOWLDERS.

The finest bowlder ever found in the valley is the one now lying in front of the Woods cabinet, where it was brought by the class of 1857 , as the inscription upon it indicates. Its former north end now faces south. (See Pl. XXXIII.) It was nncovered in lowering the road in front of the residence of the late Edward Dickinson, and, judging from the excavations here for the waterworks, it was derived from the lower till. It is a large, coarse, red sandstone, in size 78 by 66 by 33 inches, the four sides planed down to a flat convex surface and striated longitudinally, the ends for the most part still rough and irregular. It exhibits exactly, on a large scale, the form of the most perfectly polished glacial stones. The strix of the upper surface when it was first exposed ran north-south, as do the striæ in the valley, and it may be that the ice passed over it after it was fixed in the till, thus polishing its fourth side, which was naturally at first mistaken for a ledge. A full description of it was published by President Hitchcock. ${ }^{1}$

The largest specimen of the buff quartzite, which is so abundant in smaller masses throughont the valley, is the one mentioned on page 542, in the yard of the Whitney homestead, on King street, in Northampton, which came from the Denniston place, near Florence. This quartzite, I think, came into the valley farther north from Vermont and then drifted down in the valley with the altered direction of the ice. 
A single bowlder of compact, pure magnetite, alont a foot in diameter, was found hy Mr. W. Newall, of Pelham, in the brook above the Orient House. A portion of it is preserved in the collection of bowlders in the Amberst College cabinet. It came probably from Bernardston.

The bowlders of green lornblendic quartzite which have furnished so many mineral specinens under the name of Shay's flint, praze, homstone, ete., the origin of which was unknown, I have traced to a band of tonalite, from which this rock has been formed as an aphanitic and siliceous product, by crushing along the great eastern fault. It appears capping the Pelham gneiss in a thin band along its western exposure in Pelham, and is now mostly concealed by drift. It is best exposed in the bluffs 50 rods west of the road ruming south from the house of Mr. S. Jewett, in the west part of Pelham, where this road crosses the town line.

Just at the west border of the village of Amherst, on the brow of the hill and along a north-south line, the large conglomerate bowlders were accumulated in unusual abundance. As the land has been long under cul. tivation, many have been removed, but many still project from the surface. In building my house, on Northampton road, I had to remove three, which contained about 300 cubic feet. It may be assumed with great probability that they came from the rock-cut benches on the west of Mount Toby.

President Hitchcock notes" "about 1 mile northeast of the college, in a field, numerous bowlders of chalcedony and lornstone, resembling almost exactly a great vein in the southeast part of Conway," with which much pyrolusite is associated. These bowlder's continue to be found, and one of my former students, Mr. Horace B. Patton, found a great mass of the same rock, about 6 feet on a side, on the eastern spur of Mount Holyoke. I have little doubt they all came from Conway.

Perched bowlders, often poised so that they can be easily moved, occur in several places in the region. Such a one is the "Hanging Rock," on the farm of Jonathan Buddington, in Leyden, which is estimated to weigh 20 tons, and has been known since 1800 . It can be moved with one hand. On the old Atwood farm near the Winchester line, in Warwick, is another, estimated weight 100 tons, which can also be moved with one hand; also two specimens on the Blackmer farm, in Greentwich. The above three are noted in History of Comecticut Valley, Vol. II, page 754. 


\section{H A P T E R X V I I. \\ THE CHAMPLAIN PERIOD.}

GLACIAL LAKES EAST OF THE CONNECTICUT RIVER.

INTRODUCTION.

It is very remarkable that while the heavy sand and gravel deposits of a complex series of glacial rivers and lakes extend over the whole eastern half of the three connties east of the Comnecticut River, such deposits are almost wholly wanting on the, western side. Amherst, in the middle of the area, is about 80 miles from the sea and the same distance from the Sound, and it has come to be very plain to me that the ice front during the retreat of the inland ice was, over this territory, a northeast-southwest line; not a straight line, but one projecting south in a loop in the broad Comnecticut Valley. The effect of this would be that the country to the east would be set free on any given parallel earlier than that on the west; and that in the east the headwaters and gradually nearly the whole of the drainage area of each tributary would be set free before the southward-projecting tongue of ice in the main valley would permit its unobstructed passage to join the waters of the Connecticut; while on the western side the ice melted back up the streams to their heads, leaving their lower portions first and using their channels for the passage of their abundant waters, and thus delivering through them to the main valley an abundant supply of "gletchermilch" (the fine silt from beneath the glacier), but, except in a few cases where a north-south side valley sloped northward, leaving the valleys open and not clogged by the great accumulations of sand found so commonly on the eastern side.

From this it follows that our history of the stratified deposits which accompanied the melting of the ice must begin at the sontheast of the region and proceed northwesterly, ending in the northwest, and we shall find a gradual change in this direction and a remarkable difference on the two sides of the river. 
We have first to discuss lakes at elevations of 800 to 1,000 feet above sea, held back in basins on the eastern border of the region, high up on the Western slope of the great platean of central Massachusetts, which were set frec by the tirst melting of the ice over the area. We must then study how the continued retreat of the ice meovered gradually a more and more complex network of longitudinal and transverse valleys in which successive series of lakes and rivers found temporary place and were drained over passes now abaudoned, as these passes were one after the other, and at lower and lower levels, opened by the ice. We shall see how this melting process went on until at last the space between the eastern rocky border slope of the main valley and the tongue of ice still extending sonthward in the valley from the main mass became a channel by which for a time the waters escaped into the open valley below, and in which they lodged a great mass of coarse, tumultuously irregular, kame-like sands. These sands were afterwards in greater or less measure planed down to the level of the high terrace formed by the flood waters which occupied the Connecticut Valley, and as they often covered masses of the retreating ice, are now deeply pitted here and there at the surface by kettle-holes, or have sunk down into a system of reticulate ridges, due to the melting of the ice.

While the bottom of the valley on a given latitude was still covered by the ice and kept free from the deposits of the melting, it is everywhere indicated, for the central portion of the valley at least, that the tongue of ice was thrust at its southern end into deep water, buoyed up and floated off, and was immediately succeeded by the laminated clays. All along the western border a complex and interesting series of beds show clearly the alternate advance and retreat of the ice, at least three times repeated, and the high terrace on this side is comparatively narrow, and in many places remote from the mouths of streams is represented only by a narrow shelf in the rock or by a notch in the heavy deposits of till. The ligh terrace is not, as is often the case on the eastern side, represented by a broad area of kame-like sand which is planed down to its level, but is of earlier date of deposition than the time of the highest level of the flooded Comecticut. On both sides the high terrace or bench which marks the highest stage of the Connecticut lakes may be defined as a series of deltas, but those on the west are proportionately much less extended and of finer material than those on the east. Horeover, in the northwest comer of the 
basin, in Greenfield, the ice was thrust into the valley and lingered there until the period of flooding had passed its climax and the waters had begun to recede.

Finally, from the shoreward (western) edge of the high sand terrace on the western side one passes immediately onto the bare ledges of rock or onto the coarse till of the uplands, and not, as one often may on the east side, onto sands which stretch continuously many hundred feet above the level of the former Connecticut Lake. Only in exceptional cases, as noted above, where a valley dips northward, has the ice clogged its mouth and aided in the accumulation of glacial lake deposits on this side also. These are here of limited extent and importance.

On the east side of the great longitudinal valley of the Connecticut the land rises rapidly to a height of 860 or 900 feet and then slowly merges into the platean of Worcester County. It is a hilly conntry, and as the rocks strike north and south, it is cut into a series of parallel ranges by north-south valleys; only two transverse valleys, occupied by the Chicopee and Millers rivers, cut back beyond the front range of hills. The tributaries of both these extend back far beyond the limits of the county and branch ont over the western half of the Worcester County highland. From the sonthern line to the iniddle of the State, in the latitude of Amherst, the front range is broken only by the long gorge of the Chicopee.

Pelhain Brook in Amherst and Locks Pond Brook in Montague break through the front range, but no other stream does this except Millers River, already mentioned, before we reach the north line of the State. Just over this line Perchee Brook sets back through the front range and drains the broad valley east of it in Warwick.

The order of the formation of these lakes must have been from southeast to northwest, as already stated, and we have thus to discuss the deposits found in the sontheast portion of the area first, and then proceed north and west. Where the Chicopee River extends eastward beyond the limits of the county the longitudinal valleys are less pronounced, the whole area is elevated and flat, and the conditions were less favorable for the formation of glacial lakes, and for some distance eastward no trace of them is to be found, so far as I have seen. It is a broad, high area of undisturbed till, not covered by any later deposit. Farther east distinct and extensive kame ridges run north and sonth across the area and seem to replace the lake sands discnssed below. 
As the ice melted back across Worcester County the water ran off across it into more eastem drainage systems and has left its esker ridges belind it to makk the place of the ice streams, but as the ground began to slope toward the Comecticut and became grooved by deep valleys, at once the retreat of the ice became more irregular and the escape of the water more interrupted.

ICE BARRIERS.

Upon the map the position of the ice barriers which completed the shore line of glacial lakes and watercourses is marked by a series of red circles. This position is, in the nature of the case, only an approximate one, often an average of many shifting positions. At times a later erosion has removed the beds left at the line of contact, and a series of later terraces occupies its place. In this case it seemed in several instances necessary for the clearness of the map to represent as closely as possible the fact and the approximate position of the ice boundary, and since to represent it in its true position would confuse the expression of these later terraces with which it lad no relation, it was found necessary to draw this boundary upon the color representing the lake area and along that edge of the area nearest to its true position. Whenever possible it is drawn just outside this area across the till. On the map these ice barriers are numbered from sontheast across the State to northwest No. 1 is applied to the oldest series of barriers, approximately contemporaneous and representing portions of a single ice front which retained the Brimfield lakes and tumed their drainage awar east of the Monson Valley and across Brimfield and Wales; No. 2 is applied to the next clearly recognizable series, which diverted the waters into the Monson Valley; and so with the others. The evidence upon which these barriers have been located is given in detail in the description of the separate basins. Arrows are also used on the map to indicate the direction of flow of the waters, and especially the passes by which the lakes were drained.

\section{THE BRIMFIELD LAKE.}

This, the oldest and highest of the lakes, occurs on the eastern border of Hampden County, in the northwest corner of Brimfield, at a height of 830 feet above sea (Pl. XXXV, D, l b). It is a square basin, the north and south sides of which are rock; on the east the waters bathed an enormous "felsenmeer" of great bowlders of gneiss, a rock which always furnishes the 
most abundant and the largest woolsack-like bowlders; on the west its heavy sands and clays overhang the valley of the Quaboag (as the Chicopee River is called above Palmer) and the station of Brimfield, which is 390 feet above the sea. When it was formed the ice must have occupied the whole of Hampden County west of this point, and must have filled the valley of the Quaboag, here running north and south, to furnish the western wall of the basin. One standing at the railroad station and looking east can see that the horizon, almost over one's head, is the horizontal line of the front of the high, level sands of this lake, which extend north and south for nearly 2 miles and stretch back east for a mile and a quarter. Just in front of the station, at a large brickyard, a fresh vertical section of 20 feet of horizontal, perfectly sorted yellow sand is exposed.

In many places a vast number of the great bowlders of porphyritic gneiss have been dropped into the sand from icebergs which separated from the ice front and floated on the lake, and at a distance many slopes produced by erosion look like the coarsest till. They have, however, everywhere the contour of sand slopes, and are very heavy masses of well-bedded sand. Beneath these sands is the following peculiar section of till:

\section{Section of clay at Brimfield station.}

Till with great bowlders on its surface .................. 6.5

Brown laminated clay with few bowlders. . . . . . . . . . . . . 12

Blue laminated clay without bowlders, very fine and tenacious; exposed. $\quad 6.5$

These clays seem to be subglacial deposits, or to have been deepwater deposits overridden by a readvance of the ice. The section was taken at the kiln.

South of this lake are two others belonging in the same series, which may be called the Parksville and the East Monson lakes. The former was half filled from the north by heavy sands thrust forward into its basin as a great delta, whose front scarp is still well preserved as a steep south slope, crevasserl at one point by the stream that emptied the lake nortliwardly. Around the south half of the basin its shore line is hardly traceable.

THE MONSON ESKER.

It was perhaps but little later than the time of the formation of Brimfield Lake, while the ice was thrust down the deep, straight valley which 
oprens sonthwardly from the Quaboag at P'almer and runs south across Junsun (orempied by the New London Northern liailroard) ats far as Sonth In mom, that the waters, confined by the high grome which borders the ralley, ran down orer the ice and formed the Monson esker (k). This now stretches as a marked ridge south from a point west of the second bridge orer the Mlonson Brook at W. Leach's, crosses the brook at North Monson, and rmus down its east side to Monson village. From this point the whole valley, grown broader, is filled with an enormons accumulation of sands, mostly finely sorted and of great thickness, at times containing great sheets of coarse, indeed of the coarsest, gravel, all of well-rounded pebbles intercalated in the most irregular and indescribable manner, the surface being also pitted by deep kettle-holes. These sands rise to a height of 660 to 680 feet, and as the greatest height of the divide at the State line, where the valley narrows to a canyon and where the sources of the Monson Brook flowing north and the Willimansett flowing south now approach closely, is 620 feet, the waters must have passed through this gorge with great depth and velocity.

I have marked an ice front $\left(b^{2}, \mathrm{Pl}\right.$. XXXV, D) across the deep Monson Valley at a point where at its sonth end the esker meets the high gravels, which here expand suddenly to fill the whole valley, as this represents the point where the esker-forming stream flower off from or out from under the front of the ice lobe, whose irregular advances have thrown the sand beds into so great confusion.

\section{THE MONSON DRAINAGE.}

THE EASIIERN PALIIER AND IIONSON LAKE.

In order to understand the complex series of transient lakes and river courses $(1 \mathrm{~m})$ which followed upon the gradual recession of the ice from the point where it held back the waters of the Brimfield Lake, we must study with some detail the configmration of the region abont the point of confluence of the four branches of the Chicopee River, which can best be done with the large topographic map on the mile scale (Palmer sheet).

The Quaboag (the east branch of the Chicopee), where it enters the county, leaves its transverse valley to flow south along the east side of Palmer in a deep longitudinal valley to the sontheast corner of the town at Fentonville, where it tums west again in a transverse valley. Just 
before reaching Palmer village the deep, narrow Monson Valley opens ont southwardly from this Palmer Valley and runs south across the town, bounded by contintous high ground. This Monson Valley becomes a narrow canyon, which is at the State line a low watershed with a height of 620 feet above the sea. A brook gathering here runs north into the Quaboag, and a little farther south are the sources of the Willmansett, which flows south into the Sound. The Quaboag flows west past Palmer, and immediately tums north. Its valley is continued, however, at a higher level (380 feet) westward to the Comecticut basin, and is now occupied by the Boston aud Albany Railroad. This continuation I have called the Ellis Mills Valley. The Quaboag turns north in a narrow gorge between the hill south of Three Rivers and Mount Dumpling, and soon turns west to Three Rivers. On the north of Mount Dumpling the Ware River, coming down from the north, bends west also in the narrow Thorndyke gorge, and joins with the Swift River and the Quaboag to form the Chicopee River at Three Rivers.

The present gorge of the Chicopee River west of Three Rivers is the last and most northern outlet of the waters of the drainage areas of these three streams, and it was opened only after the ice had receded from the Belchertown platean to the north. The Ellis Mills Valley was an earlier outlet at a higher level, and the Monson Valley was a still earlier outlet farther southeast and at a still higher level. This latter outlet determined the level of the lake here, around Palmer, whose waters rose to the height of 620 feet. The ice then occupied the Belchertown platean and the Swift and Ware river valleys and approached Pattaquattic Hill on the north and west, and the ice front extended south past Palmer to Chicopee Mountain $\left(b^{3}\right.$, Pl. XXXV, D).

The best remmant of this lake is seen by mounting to the top of the great level sand plain east of Palmer Center and following it sontheast past Calkins Pond for a distance of nearly 3 miles. It has well-marked shore lines against the rocks on either side, is nearly a mile wide, and where, on the south, it overhangs the Quaboag at Blanchardsville its sands are above 200 feet thick and its broad, flat surface is 610 feet above sea level. Approaching Palmer, its sands swing round the rocky spurs which have bounded it on the west, on the east extending up the Quaboag Valley, and end on the south in a great lunate delta scarp, at the foot of which the river runs. The Monson Valley is its almost direct continuation southward, 
and the chatracter of the bottom of this ralley, with the great esker, only half covered, winding down its middle at a much lower level, shows that the valley can mot have been filled to the 620 -font level and then reexcavaterl, but that the work of filling the lake was arrested at this point by the further recession of the ice that openerl at a lower level the gorge which forms the continnation of the Palmer Yalley eastward, and which I have called above the Ellis Mills Valley. During the continnation of this lake its waters escaped through the Monson Valley to the sonth and did not quite plane the sands accumnlated there down to the level of the pass across the whole ralley, as a central cliannel cut in the sands passes beyond the headwaters of Monson Brook at the State line and is occupied farther sonth, beyond the divide, by the headwaters of the Willimantic.

\section{THE ELLIS MILLS DRAINAGE.}

THE PALIIER LAKE.

As the ice retreated westward a next important halting place $\left(b^{4}\right.$, Pl. XXXY, D) is suggested by the configuration of the country and by heary morainic accumulations. Here the ice abutted against the high hills east of Bonds village, against Hog Hill, surrounded Mount Dumpling, and for a time still closed the passage between Mount Dumpling and Bald Peak. During this time the Ware River Valley was freed from ice and filled with a great volume of sand, and the beds at the 530 -foot level ( $1 \mathrm{p}$ a), extending north from Palmer east of Thorndyke and Bonds village, were laid down, the latter by waters coming from the lower Swift River Valley.

The establishment of this level for so loug, a distance may mean only that the time did not suffice to fill to the 620 -foot level the area newly left by the ice, and that the drainage was still south across Monson. I have assumed that the outlet was south across Palmer and then west, by the breaching of the sonth end of the barrier $\left(b^{4}\right)$, and around the north foot of Bald Peak into the Ellis Mills Valley, perhaps carried along the north slope of Bald Peak and held up to 530 feet by the ice.

THE WARE AND SWIFT RIVER LAIES.

It seems quite plain, however, that a more effective washont occurred when the ice barrier $\left(b^{4}\right)$ yielded just south of Mount Dumpling and all the waters of the Ware River Valley swept west of Wapples station and past 
Palmer Center and then along south of Mount Dumpling, directly into the Ellis Vills Pass, forming the deep channel cut in the sands along this line, which is in places worn down to the till. This channel remains practically intact for a long distance north and south of Palmer Center.

With the melting of the ice back to $b^{6}$, the lower reaches of the Swift River Valley were set free, the Ware River passed out through the gorge at Thorndyke instead of by way of Palmer Center, and the Ellis Mills drainage was fully established. That portion of $b^{6}$ abutting on Mount Dumpling is a massive moraine, but the ice front seems soon to have extended more nearly north and south, between the portion represented east of Bonds village and the part south of Three Rivers. The new level thus established by the Ellis Mills Pass of 390 to 400 feet is manifest in terraces ( 1 s) rising from that level as one goes east up the Quaboag or the Mouson Brook. The broad sands of Ware Valley hardly rise above 500 feet, as they are followed northeast far beyond the limits of the map, and from them a lobe extends northward up Beaver Brook and past its headwaters, to connect with the broad Orange-Enfield sands.

A striking proof of the contention on page 569, that the earlier East Pahner-Monson lake beds aid not fill the northern half of the Monson Valley and that the waters were at this later time held up'to the 400 -foot level in the empty valley, is found in the perfectly formed sand spit at the 400-foot level which projects westward halfway across the mouth of the ILonson Valley just south of Quaboag. This has just the form which would result from the passage of the main current west past the slack water still standing in the Monson Valley to the south.

The Swift River, for a long way above Bonds village, runs now in a deep and narrow valley cut in the till, but high up on its side are the broad sands rising to 400 feet which belong to the series under consideration. On following these sands eastward to the point where the Central Railroad crosses the ice barrier $\left(b^{6}\right)$, one sees that they sink by a sudden irregular slope 30 feet, down to the level of the Belchertown sands, along the line where they. were supported by the ice of this barrier. These sands may be traced a long way north, following, at a level high above the present stream, the West Branch of the Swift River, and branching with the stream at Enfield to blend with the extensive Orange-Enfield sands. The main strean of Swift River here passes throngh a remarkable gorge cut 
obliquely atcross the high ridge that separates the narrow West Branch Valley on the west from the broal flat-bottomed Orange-Enfield basin on the enst.

'The effect of the ice front as it rested liere is seen clearly in the filling of the Bearer Brook channel (in the northeast comer of the Palmer (quatrangle and crossing the middle of Ware), which extends south into the Ware River Valley. An inspection of the malp will show that this channel is the direct contimuation of the Orange-Enfield valley, and it is probable that this longitudinal valley was deeply excavated in pre-Glacial times along the course of Beaver Brook, the north-south portion of the Ware River, and southward past Calkins Pond and the Monson Valley into the Willimansett Valley.

The effect of the ice in this position is further seen in the filling of the high-lying valley which rums south along the east slope of Quabin Hill, which rises south of Enfield.

The sands that pass up the West Branch of Swift River go beyond its head waters and end at Wendell Center, on the divide between the Chicopee and Millers river drainages, in an instructive way. (See p. 574.) The broader sands of the Enfield basin go across Hampshire County into Franklin County and end at Orange, as far north as, but much lower than, the West Branch sands.

On the map I have given a single color $(1 \mathrm{~s})$ to all the sands here discussed, because they form a continuous series with uniform slopes and because they were plainly formed by a continuous series of events which ean not in mapping be conveniently subdivided. It is, however, probable that these two valleys-the West Branch and the Orange-Enfield-remained main drainage arteries until Millers River, fir in the north, was set free of ice, and thus long after the Ellis Mills outlet was exchanged for the permanent Chicopee River outlet.

It seems, however, that the broad basin was in a sense filled stepwise from south to north, so that when the outlet was transferred from the Ellis Vills Valley to the Chicopee River Valley the Swift River began to cut through the sands already deposited and the upper portion of the basin remained still a catchment area for the flood waters. I deduce this from the fact that the sands of the Belchertorn plains, which have clear relation to the present drainage outlet at Three Rivers, are derived entirely from 
Jabish Brook, next west, and Swift River seems to have joined this brook from out its gorge in the till, with its waters clarified in an upper catchment basin. The Orange-Enfield basin has thus in a sense an independent history.

It is, of course, true that the waters swept sands down this broad basin during all the time the ice was melting up it. It is further probable that the final body of sand was swept into the basin and the final molding and forming of its surface, especially in its northern part, was effected when the ice had abandoned it and still clogged Millers River lower down than the head of the basin, so as to allow the drainage of the upper part of the river to enter this basin at its mortheast corner and also to turn back the lower drainage of the river into the northwest corner of the same broad ralley.

The village of Orange stands at the northwest corner of this area of flat sands and gravels, of which thie railroad, thence east nearly to Athol, 4 miles, is closely the northern boundary, and which extends south, with an average widtl of nearly 2 miles, across New Salem, Greenwich, Prescott, and Enfield, to the gorge already described (see p 570), by which its waters escaped sonthwestward. We find the indication of a large and simultaneous influx of water's from the northeast and northwest corners very clear.

The sands are 494 feet above the sea at the railroad station at Orange-about their lowest level. They continne east for a long distance as level, fine sands, and north to the foot of the rocky slopes, where there was no drainage to bring in material. East, within a mile of the Narrows, below Athol, one comes on the face of a great delta (occupied by Millers River) sent out into the plain, terraced on its front at a lieight of about 30 feet above the plain below, but reaching a height of 60 feet at the delta front and rising slightly to the Narrows. On the north the delta extended across the mouth of a small valley, ponding the waters back and forming extensive clay beds, in which the following section was exposed.

Section in brickyard at the Narrovos, in Athol.

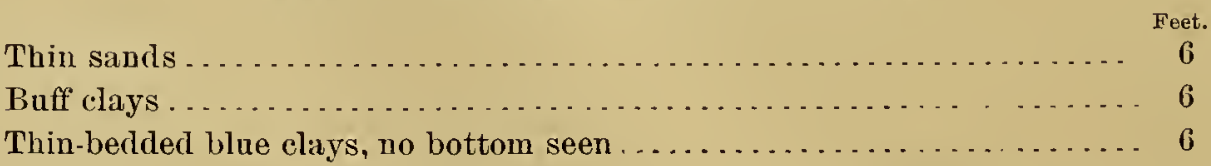

On the west the indication of the influx of the waters is equally clear. 
From Wentell depot up (b), PI. XXXV, (C), the high level sands were formerly plainly continum across the valley. Their inner structure indicates a flow to the east and their upper surface slopes in this direction. They are about 90 feet ligh at the Moss Brook delta. At the Scotts or Orcutts Brolk deltal, next east and opposite this latter, they extend down the Holshire lioad Valley, the next valley on the sonth parallel to and west of the main chamel, at a height of 75 feet above the plain, filling this valley with a great body of sands and gravels, which are beautifully kettle-holerl sonth of North Pond, and which extend sonth to join the main OrangeEnfield chamel in New Salem.

The high sands which thus fill the Holshire Road Valley extend round the north spur of Walnut Hill, which separates this valley from the main Orange Valley, and project out freely into the latter in a delta which matches that at the other corner and which along the north side of the river is confluent with the delta of Fall Hill Brook, on which the cemetery is built.

A section of the sands east of Orange showed a great thickness of fine sands with the cross-bedding dipping eastward; above this a bed, about 2 feet thick, of very fine sauds. This was covered in tum with coarse sands of about the same thickness, the boundary between the two beds being very irregular and the structure indicating a delta front advancing from the west.

The last halting place of the ice in the Swift River drainage area.-The position of the ice on Millers River at the time of this last effective flooding of this portion of the area can be closely fixed at Wendell station $\left(b^{12}\right)$, and the coincident ice front can be traced across from the Connecticut to the northeast corner of Warwick by the following considerations:

Going up Tannery Brook (a branch of Goddard Brook) from Montague village, one comes at the "height of land" on a broad area $\left(1 p^{2}\right)$ of heavy sands and gravels southwest of Dry Hill, bedded and with irregular surface. They extend down to where ice filling the Comecticut Valley would have stopped them, and there end abruptly. Off to the south a col west of Chestnut Hill determined their height and provided for their outflow; to the north they end at a schoolhouse $\left(b^{11}, \mathrm{Pl} . \mathrm{XXXV}, \mathrm{C}\right)$, and here one can look north down an open bowlder-covered valley, wholly free from sand, which must have been filled with ice when the sand beds just passed 
over were deposited. Farther east Osgood Brook, in Wendell, has heavy sands at its south end, while, as before, the open valley to the north extending to the Millers River Valley is bowlder-covered and free from sands. These sands terminate a little farther. north than those last mentioned.

Next east one may follow up the deep V-shaped valley of Wickett Brook from where it joins Millers River south and find it, althongh well fitted to retain sediments and although continned north of Millers River in a deep valley, to be bowlder-covered to the water's edge. At a point a little north of the one reached in the last brook, the high-level bowldery gravels $(1 \mathrm{~s})$ begin and increase and accompany the brook south to its headwaters west of Wendell Center and beyond, and, passing over the col in the deep continuous valley, they continne south to join the heavy sand beds worth of Locks Pond.

On the next brook east-a second Osgood Brook-the brook bed is till covered to a point nearly as far sonth, and then sands commence which run up the valley, increasing as the brook lessens, and, passing its col in the valley, as before, they are continued down the valley of Swift River. The streams which enter Millers River from the north, across Erving, opposite those described above, have inconsiderable sand deposits. Furthermore, the Millers River Valley up to Wendell station has small deposits of high-level sands. With the next brook east, however, this is changed. The brooks thrust extensive deltas into the valley, and from this point on east the drainage was plainly eastward into the Orange basin, as will be detailed below.

Examining the upper waters of the first brook east (Moss Brook) coming down from the north, we see the sands begin on its western tributary a half mile above Harris Pond, and on the main stream at the mill pond (Lake Moore) southwest of Warwick Center, while the valleys above are empty of sands. Below these points the stream is bordered by heavy gravels and sands $(1 \mathrm{~s})$, flat topped, with a width for a long distance of 150 rods, expanding in the southwest of Warwick to a triangular sand plain more than a mile on a side before it enters its narrow gorge to reach the main valley.

Following the brook still farther north through the narrow valley south of Mount Grace, we soon find it again bordered by broad sands, which expand to an extended sand plain that continues north of Warwick beyoud the headwaters of this brook and that is soon trenched by the 
"lpere waters of Mountrin Brook, flowing north. Following this brook for a Long distance with the sands, the latter end abruptly and overhang Sumny Valler, which wats plainly filled with ice when these sands were hitid down The bottom of Sunny Valley, fin below, is also covered with the finegrained, flat siunds of a still later lake.

On 'Tully liver, the last of the series, the sands begin where, in the ealst of Warwick, the Royalston road crosses the river (b ${ }^{13}$, Pl. XXXV, C). Above, the deep, open valley is continuous a long way north in two hranches, farorably shaped and situated to receive and retain sands, but now covered with coarse bowlders. Drawing a line through the points thus fixed in the preceding paragraphs from Tannery Brook in Montague (1. 573) to Tully River (see Pl. XXXV, C), and assuming-which admits of little doubt-that they represent points along a continuous ice front, we see that,while the ice still projected in a lobe down the Comecticut Valley the ice front extended toward the northeast from Montagne and pressed forward in a blunt lobe between Mount Grace in Warwick and Bear Hill in Wendell. See also page 604 for the continuation of this barrier on the west of the Connecticut Valley.

THE CHICOPEE RIVER DRAINAGE.

THE BELCHERTOWN LAKE.

With the breaking down of the barriers $\left(b^{6}, \mathrm{Pl} . \mathrm{XXX} T, \mathrm{D}\right)$ described above, the Quaboag, Ware, and Swift rivers were admitted to the Belchertown platean and became tributaries of the Belchertown Lake. Standing in the middle of the broad, square plain of fine sands which stretches east from Three Rivers, we are shut in on the east and south by high, rocky lills notched for the passage of the three streams mentioned above, and on the west by a broad, low ridge which on its west side slopes down to the valley of the Connecticut. At the sontluwest corner the westem ridge sinks down, and the lake was ultimately drained at this point, the Chicopee River cutting a deep, canyon in till and rock to join the Connecticut, and its three branches dissecting the old lake bottom and showing how great was the volume of sand gathered there. It was so great, indeed, that they nowhere cut through it. The lake extended up the valleys of each of these three rivers in the form of broad erosion plains on each side of the streams, commencing at the same level with the lake sands and rising slowly with the streams. 
If we look north we see the sands divide on the ridge on which the village of Belchertown is built, an eastern lobe passing up the broad valley in which Jabish Brook now flows, the other ruming north at the western foot of the ridge. While the three southern streams were now normal tributaries of the lake, disturbed by ice only in their upper reaches or not at all, these two northern lobes were the place of entrance of two tributary streams which came down in courses largely supplied by the ice itself.

Following up the east of these lobes we find it continuing east of Belchertown village with a width of above half a mile, and northeast of the village widening into a still more extensive area of coarse sands of great thickness-a filled-up lake at a high level-and then contimuing northward in the narrow, deep valley of Jabish Brook as a broad sand flat, on either side of and much higher than the brook and rising rapidly until, coming out on the higher ground, it widens and makes a broad curve to the west and again to the north, in the extreme north of Belchertown, and continues north in Pelham, through the high valley east of the asbestos mine, to join the high terrace in the Pelham basin described later (p. 578). When it makes the second curve to the north it sends down a lobe to the south, and it is here unsupported upon the west by any rocky shore line, but dips westward in a great terrace $\left(b^{9}, \mathrm{Pl}\right.$. XXXV, D). It was here plainly supported for a time by the ice which still filled the Connecticut Valley to the west, and on the breaching of this support the waters ran down along the west side of the ridge, instead of the east, as before, cutting a terrace in the sands already deposited, and, walled on the west by ice, joined the Belchertown Lake by the western lobe as detailed below, running south across the ice which filled the notch at the east end of the Holyoke range.

Starting at its south end, one can follow the western lobe north past Belchertown village for nearly 3 miles, and at the railroad station it is 471 feet above the sea. The low range then forming its western boundary sinks down to the level of the platean, and the plateau itself comes to a sudden termination on a line $\left(\mathrm{b}^{8}, \mathrm{Pl}\right.$. XXXV, D) which runs northeast from the end of this range to join the Belchertown range. Standing anywhere on this line, one is at the north end of the sands, and looks down, across a broad, sloping area of till and rock, quite free from any covering of sands, upon a billowy surface of "reticulated ridges" at 337 feet above sea, which contain the Belchertown ponds, and lower, beyond these, to the west, upon the eastern edge of the highest terrace flat of the Connecticut at about 290 feet. 
We have been following up a tributary of the Belchertown Lake to this plince, and we find here that the ground drops away more than 150 feet below its level. Looking north through the pass formed by the east end of the Holyoke range and the eontinuation of the Belchertown ridge on our right, we see that the latter ridge, just north of the pass and above Dwight's station, runs behind (east of) a new ridge (the ridges stand, en échelon in reference to the valley of the Connecticut, having, as they run nortl, a little more easting than it). Between these ridges is a high valley, in which is the continuation northward of the stream bottom we are following, the two parts facing each other across the low pass of the Belchertown ponds like the broken ends of a Roman aqueduet. A mountain brook has now cut a deep gorge in this valley in till, which is almost as compact as rock, but this is only a central notch in a flat-bottomed valley which ends southwardly quite abruptly above Dwight's station, and which is, in fact, the point in the eastern lobe just described (p. 576), where the breaching of the chamnel deflected the outflow down the west of the ridge to our place of observation. This channel is water-molded and covered with bars and sand flats, exactly as is its southerm portion in Belehertown, and one may follow it up past the asbestos mine, east of which the rocky ridges are smoothed into reefs and eovered by gravel bars, until it merges into the second great terrace (I p, Pl. XXXV, C) of the Pelham basin. Standing here, or, better, on the east end of the Holyoke range, one can see that the ice must have still filled the valley of the Connecticut both north and south of the Holyoke range, and must have rested with a depth of above 150 feet in the low pass of the Belchertown ponds, so that the stream draining the Pelham basin ran between the point where its bed breaks down suddenly above Dwight's station to where it begins again in Belchertown, with its eastern bank the Belchertown ridge, its bottom and western bank of ice.

It is clear, finally, that the melting of the ice back across the low western ranges which bounded the lake in Belchertown at last gave this body of water a new way of exit through the course of Broad Brook, which runs down through the middle of these ranges and joins the Chicopee where it turns south in the same longitudinal valley as that of the brook itself, and that the further retreat of the ice let the waters pass outside (west of) these ranges entirely

MON $\mathrm{xxIx}-37$ 
THE PELHAM LAKE AND ESKER.

Opposite Amherst the frontal range of gneiss which bounds the valley is partly broken down, and a narrow portal opens into a great, rounded upland valley or clongh, about conterminous with the boundaries of the town of Pelham. (See l p, l p 2 Pl. XXXV, C, and fig. 32.) North and south the high level is continuous and is grooved by shallow valleys. The two on the north admitted the glacial waters to the lake, the one on the south gave them egress to the Belchertown Lake, as detailed a few paragraphs back (p. 576).

The rocky bottom of the basin is about 560 to 580 feet above sea, and it is filled up with coarse till to a quite level surface at 640 to 650 feet, and

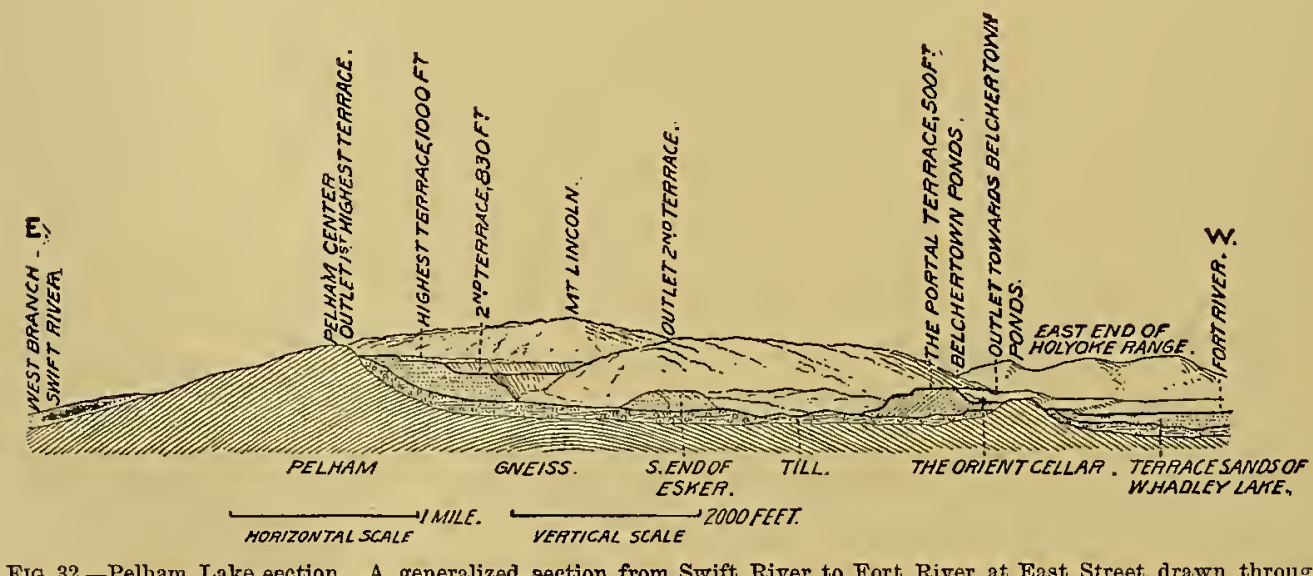

FIG. 32.-Pelham Lake ection. A generalized section from Swift River to Fort River at East Street, drawn through Pellum, showing the different outlets of the Pelham lakes.

this heavy deposit covers the whole southem slope of the basin. From any point high up on this slope, as on the road to the well-known mineral locality, the asbestos mine, one sees massive accumulations of sand, much of it very fine and all well sorted, which rise in a series of terraces of great regularity, with broad, flat surfaces and flat scarps, to a height of 1,000 feet on the east side and 830 feet on the north and west sides of the basin, and are almost wholly wanting on the south side. Westward, the highest terraces end abruptly when they come to the entrance of the basin. At a lower level, 500 feet above sea, they seem to stretch, in the portal terrace, right across this entrance, like a great earthen dan-the narrow notch which the brook has cut being scarcely visible-and they dip steeply 


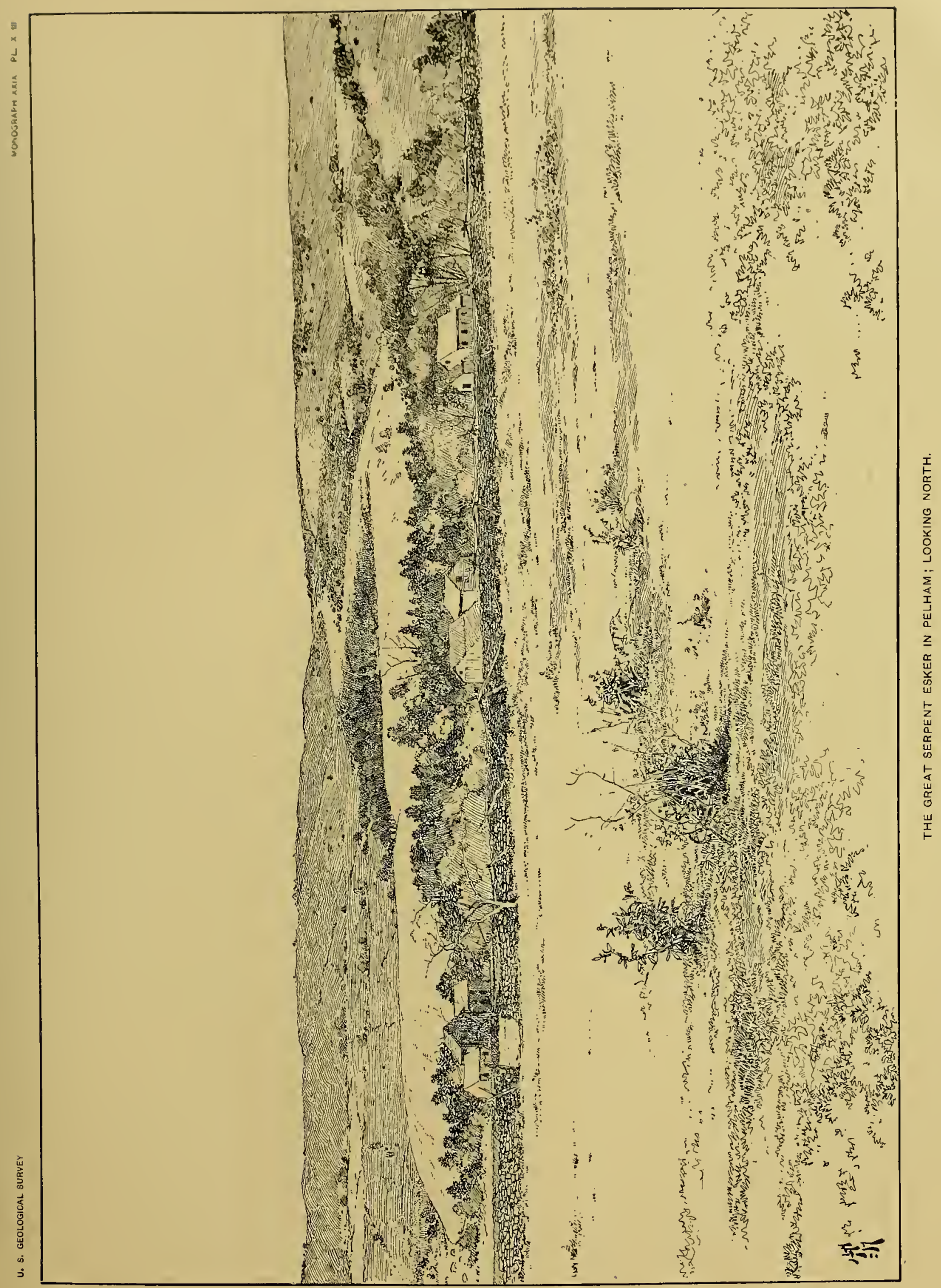



down into the basin toward the east in a series of beautiful terraces, and on the opposite side descent in a series of terrace scarps and irregular slopes to the level of the normal high terrace of the Connecticut River, at 290 to 295 feet. Looking across to the northern liorizon, one sees two slight, broad depressions in the line which joins the eastern and western bounding ridges-by which the two roads pass north from Pelham to Shntesbury-and these mark the southern termini of two valleys by which the waters which deposited the sands entered the basin. Their elevation at the southern end, where they open into the basin and whence the terrace sands extend southwardly, is 820 feet above sea, and they run far north, rising slowly and showing abundant traces of the passage of the waters in their shape and in the tails of sand which lie in the lee of projecting rocks.

But the most remarkable deposit of all is a great ridge (k) of yellow sand (see Pl. XIII), 40 to 50 feet high, which starts from the mouth of the eastern of these channels and stretches down the slope of the basin southward with sinuous course, bending at last westward and skirting the brook and rumning for a long distance out upon the till of the valley bottom, from which it is as sharply demarcated as a new railway embankment thrown across a grassy field. This ridge has sharp slopes on either side, and ends abruptly far in advance of the remaining terrace sands. Much of it is a rather coarse sand, or rather a sand with many pebbles, and rarely a great bowlder is embedded in it. It drops by great steps, so that one is at first uncertain whether to consider it an esker in the sense now current, or to think it a section of the ordinary terrace sands, from which streams cutting back into the mass on either side-their waters being held up to the sand level by the subjacent till-have removed so much of the loose material that this long ridge remains as an index of the former greater extension of the sands toward the center of the valley.

The entire freedom of the broad bottom of the basin from sand or clay, and the great improbability that any such deposit has ever been present and been so entirely removed that no trace or indication of its presence or of any erosion by which it can have been removed is discernible, make it far more probable that the first explanation is the true one, and that it is a deposit in a temporary ice channel, dropped by the melting of the ice on the steep slope down which it now winds like a great snake. 
Indeed, its uniform size for so long a distance scarcely admits of any other explanation. This is represented on $\mathrm{Pl}$. XXXV, C, and its end appears in the section, fig. 32 , p. 578 .

The next striking peculiarity is that, while the grand terraces are heaped high on the east, north, and west of the basin, and across its westem portal, the flat bottom is, and has always been, bare till, and scarcely a trace of sand can be seen upon the south slopes-nowhere enough to mark the water stand. Finally, the highest terrace on the east, at 1,000 feet, has no counterpart on the other side.

I have expressed upon the map (Pl. XXXV, C) the explanation which seems to me most plausible, so far as this was possible. In the first place, the highest sands on the east of the basin, at 1,000 feet, seem to have been deposited by waters coming down the eastern of the two northern valleys when the basin was still nearly filled with ice, and, as these sands are on the same level as the lowest portion of the ridge to the east, the waters would seem to have escaped east into the West Branch Valley. This lowest ground is just north of the section line. The ice barrier (b 8, Pl. $\mathrm{XXXV}, \mathrm{C})$ placed on these lake beds $\left(1 \mathrm{p}^{2}, \mathrm{Pl} . \mathrm{XXXV}, \mathrm{C}\right)$ may well have been somewhat farther west, as the lower-level waters have worn into and terraced these sands on the west.

Some temporary posture of the ice turned the waters of this eastern stream out across its surface in a course directed toward the portal, and the sand filling this chamnel sank to form the great esker as the ice melted. With the retreat of the ice from the basin the asbestos mine valley on its south rim was set free at a level of 830 feet above the sea, furnishing a permanent waste weir for its waters south into the Belchertown Lake, along the course described on page 576, and as the ice still filled the whole Connecticut Valley opposite, it completed the barrier across the portal on the west. The lake basin was then rapidly filled by sands pushed south as great deltas from the two northern valleys, and the waters coming down from the north between the ice and the west slope of Hygeia entered the basin at the portal and sent a third delta into the basin, thus completing the terrace on the westem side. The life of the lake at this stage was a very brief one, and when the deltas had advanced halfway across the bottom the ice barrier $\left(b^{8}\right)$ failed at the portal and the waters escaped, breaching the portal terrace and moving south by a channel, still well marked, which rums 
soutl from the Orient House cellar. The duration of the waters was so brief that little or notling was deposited upon the till over the center of the batsin, or so little that it lias been removed by wind and rain. Yet, starting from this flat bowlder-covered bottom of the basin, one toils up more than a mile orer the slope of fine sand of the Shutesbury road to the top of the deltal at the month of the western valley, and on the other side one can step from an ice-bowlder onto the steep sand slope of the esker, so sharp is the boundary.

If one stands on the south slope of the valley and examines the great sand rampart already described, which is thrown across the portal, it seems still intact as when the ice left it. The narrow notch which the brook has cut deeply through it is barely visible. The terrace surfaces slope $5^{\circ}$ eastward into the basin across the portal, as they do in their northward prolongation where they abut on the ridge of Hygeia to the west.

Fortunately the ditch for the main of the Amherst waterworks ran from the west across the flat where the ice rested at the entrance of the portal (Pelham City), giving a complete section of the semimorainic beds that rested on the ice with all their irregularity. It continued past the Orient, exposing the passage beds to the fine delta sands, and, passing high up above the brook into the notch which this brook has cut into the portal or entrance terrace, it continned along its southern slope through the whole delta deposit and far out into the central portion of the basin. At first, and nearest the ice, the beds dipped west, and these may be "backset" beds, as Prof. W. M. Davis would say, ${ }^{1}$ or may have taken this postnre as a result of the melting of the ice beneath and their sinking westwardly. For the most part the beds dip strongly east into the basin and show that the current came from the west-that is, from the ice.

I append a detailed description of the beds, written when I had no clear view of the meaning of the whole. $A$ describes the till-covered flat outside the portal; $B$, the sands and gravels deposited against and on the retaining wall of ice and confused by its melting, which occmr in decreasing amount eastward; $C$, the finer eastward-dipping delta sands to their ending in the center of the lake. The section runs parallel to and a little north of the section given (fig. 32, p. 578) where the gneiss ridge southwest of the

${ }^{3}$ Beds taking this western dip becanse they were cleposited by waters escaping from beneath the ice with eastward and upward direction. 
Orient cellar has dropped down and is covered with till, while the sands at the Orient cellar drop by a sharp slope to those of the highest terrace of the Hadley Lake.

A.-At the first house in the west village of Pelham, about 320 feet above the sea level, the last trace of the highest bench of the Amherst basin (the Hadley Lake) disappeared, and through the village, eastward into the notch, the coarse till made the surface to the point where the Shutesbury road branches off, as has been described on page 581 .

B.-Here the till goes under sands and continnes about horizontal or rising slightly for a long distance eastward, so that the increased elevation of the surface is to be referred wholly to the thickening of the overlying sands.

Beginning at the Shutesbury road the sands are, for a distance, thin, and contain here and there a large stone-the largest, 1 foot in diameter. They then thicken to 70 feet (fig. 32), and hold this thickness past the Orient House cellar. Where they begin to thicken-at the house west of the Orient-clean-washed, dry, whitish sand appears in layers from 6 to 12 inches thick, dipping $10^{\circ} \mathrm{W}$., alternating with layers of washed gravel 2 feet thick containing many pebbles up to 6 inches, and rarely one a foot, in diameter. The sand layers are evenly stratified and show no finer structure. Sometimes a sand layer waves up and down, and the gravel layer above thickens to fill the depression. A little farther east one layer of fine, well-washed gravel-the pebbles averaging 1 inch-grades westward into sand and eastward into 6-inch gravel. All along in front of the Orient Horse the cutting was mostly in sand, showing most beautiful and contorted flow-and-plunge structure, the dip of the laminæ being 20 to $30^{\circ} \mathrm{E}$., as if urged by a rapid current from the west.

Mnch of the way, however, the whole is thrown into great confusion. Layers of sand a foot thick, with fine false bedding, stand directly on their heads or are varionsly twisted in the gravel, or the sand cuts off vertically. against the gravel, and vice versa. In one case a band of gravel 2 feet wide was intruded into the sand like a dike; in another a mass of sand 8 feet wide occupied the same position in the gravel, as if the water had worn a channel in the frozen gravel and filled it with its own sands.

Leaving the road at the Orient House the ditch passed across the flat field in front of the house, the beds growing finer in grain and the disturbances gradually diminishing. 
$\mathrm{U}_{p}$ to this point the section, after reatching the sand, has crossed the plain of the Orient House (shown in fig. 32, p. 578), a plain whose surface has been produced by at later erosion. The sands exposed in the cutting, however, are a part of the entrance terrace, and their irregularity seems due to their deposition against or upon a shifting barrier of ice.

C.-From here the section contimues at the level of this plain along the north slope of the notch ent by the brook in the portal terrace, about 40 feet below the surface and 60 feet above the brook, and for a long distance runs in clean-rvashed, very fine white sand, laid horizontally in broad, flat lenticular masses, 1 to 6 inches thick and many feet long, with clayey bountaries which projected on slight weathering. It preserves everywhere . its original delicate structure undisturbed.

Eastward the hill is cnt down by erosion and the ditch sinks on its side, showing these fine sands to be in great force and to rest upon till, through which the ditch passes a short distance and rises along the side of a second hill and continues in the sands. There was exposed the following section:

1. Below, a very fine white sand, in layers 4 to 6 inches thick, which ran with very slight undulations for 20 feet or more, and, thinning ont, were replaced by others. This was exposed in a thickness of 1 to 2 feet.

2. Above, for 2 feet, was the same fine sand, but showing a most delicate and beantiful flow-and-plunge structure, the laminæ dipping $20^{\circ} \mathrm{E}$. Above, this sind is limited by an undulating surface of erosion upon which rests-

3. Two feet of coarser sand, slightly reddish, with sharp regular cross bedding, which dips $30^{\circ} \mathrm{E}$. By the weight of the sliding bank above, this has been compressed into curious corrugations.

The ditch rises and sinks in the steep hillside, and the lower horizontal sands (1) can be traced for 40 rods eastivard and are present in considerable thickness. The coarser sands (2) extend probably to the top of the hill, about 30 feet.

A specimen of the sand taken from the lorvest bed (1) was, when dried, like the finest cortundum flour, and consisted of sharp, transparent quartz grains 0.03 to $0.04^{\mathrm{mm}}$ in diameter, with here and there a scale of wine-yellow biotite.

The flow-and-plunge structure of the npper portion of the fine sand, dipping to the east, indicates a current coming from the west, and to this current we may attribute the erosion which prepared the surface upon 
which the coarser sands (3) were deposited, and the eastern dip in these indicates also that the current continued to flow eastward, or toward the center of the lake.

THE HADLEY LAKE DRAINAGE.

THE LEVERETT LAKE AND THE NOTCH EAST OF MOUNT TOBY.

The last of the considerable deposits $(\mathrm{m} \mathrm{t}$ ) at high level on the eastern side of the valley dependent npon the obstructed drainage which attended the retreat of the ice occupies the long, narrow valley along the west border of the Belchertown quadrangle, which runs north by the village of Leverett, along Pond Brook, and past the entrance to "Rattlesnake Gutter," and extends south across the town line into Shutesbury, skirting Mount Boreas on the east and ending just south of this mountain, where, south of $42^{\circ} 25^{\prime}$, the north branch of Fort River, which occupies the lake's former outlet, passes into a canyon to reach the open valley above East Street village, in Amherst. This lake was early filled with sands, and the waters carried their surplus into the valley, contributing to form the abnormally abundant sands of the high terrace of the main valley a mile north of East Street village. One follows the heavy sands from Boreas northward, filling the valley clear across, until, just on the Leverett line, they are carried away entirely by Roaring Brook, which comes out of the mountains on the east and has worn out a deep circular basin in the lake deposits, cutting them clear across, and escapes through a deep, nairow transverse valley into the valley of the Connecticut. The high lake beds extend a little way down this valley and stop abruptly, and it is clear that the lake could have existed only so long as the ice remained to dam this outlet. Two miles north of Leverett Center and opposite Rattlesnake Gutter, there is a passage connecting it with the deep valley which runs down the east side of Mount Toby, and by which the waters which entered this latter valley were diverted into the Leverett Lake.

The lay of the beds in this Mount Toby Valley is rery peculiar and interesting; a deep water-cut canyon runs the whole length of the valley between the conglomerate and the crystalline rocks, and as a brook runs south in its southern part and another north in its northern portion, while its center is without flowing water, it is clear that it was not formed by the present streams. 
In the portion of the valley south of the entrance of the side valley from the Leverett Lake this canyon is bordered by rought ledges and till. North of this the sands coming out of the side valley fill the main valley from side to side with a great volume of coanse sands, cut only by the northward prolongation of the canyon already noted. These sands preserve for a long waly a flat surface, but as they approach the north end of the Mount 'Toby Valley they become gradually kettle-holed on a grand scale, and as the valley widens the sands widen also and preserve their height, 400 feet above sea, until they rest against the northermmost spur of Mount Toby on the west and extend up along the momintain side on the east, above the noteh by which Locks Brook comes out of the mountains, and a remuant still runs up into this noteh. They end abruptly along a broad curve (b" $\mathrm{b}^{11}, \mathrm{Pl}$. XXXV, C), concave to northward, and sink down by a slope as steep as sand will take to the level of the high terrace (336 feet above tide) which formed the shore flats of the Montague Lake (see p. 615).

It seems to me clear that the ice that filled the Montagne basin pressed into the north end of the Mount Toby Valley, compelling the waters of Locks Brook (or Sawmill Brook) to find their way southwardly down this valley and clogging the northem portion of the valley with heavy sands; and so far south as the kettle-holes extend, so far south the snout of the ice was projected into the valley and heavily covered by the sands-the kettle-holes being a measure of the portion which still remained ummelted beneath the sands when the further recession of the ice allowed Locks Brook to run directly westward into the Connecticut, while the great concave slope which bounds these sands $\left(b^{11}, \mathrm{Pl}\right.$ XXXV, C) on the north marks the shore line of the thicker ice, against which the sands were piled.

The waters rumning southward through the canyon already described cut a deep and narrow channel in the jointed quartzite, where they seem to have formed rapids, and at one place a distinct waterfall. They left no deposits in this narrow part, but found it in flood time an insufficient outlet and turned eastward through the side valley into the Leverett Lake, clogging this with abundant sands. At the south end of this Mount Toby canyon there remains on either side of its widened mouth a delta deposit of rounded bowlders, 6 to 8 inches in size, from which all finer material is removed, as a witness of the violence of the current, and farther south the broad, level South Leverett plain $(l \mathrm{~s} h)$, west of Leverett railway station, 
gives evidence of the volume of the sands which were carried through this narrow gorge to form the massive delta thrust into the main valley which now remains as a most important portion of the shore beuch of the Connecticut Lake (see p. 639).

\section{THE LOCKS POND LAKE.}

Following up Locks Brook into the mountains, we find high sands bordering it with every widening of the narrow valley at all levels until we reach the top of the bills and come upon the broad basin of finely sorted sands surrounding Locks Pond. These I have already connected with the line of sands which can be traced southward through Pelham to Palmer. It is clear, thus, that the ice retreated down this valley, but that its shape did not favor the formation of extended deposits, and its position as a deep transverse gorge extending quite across the block of hills between the Connecticut and Swift River valleys was sueh that it intercepted all southward currents so soon as it was free from ice, and it is curious to see how by devious ways it deposited its burden, now in the Leverett Lake, now in the broad delta at the south end of the Mount Toby Valley, now clogging up the northern end of the latter, while at the last it has contributed very little to the filling up of the Montague basin, into which it now enters from the mountains.

Locks Pond now lies in the midst of a broad accumulation of fine sands $\left(1 p^{2}\right)$ which, followed eastward by the road to the Mineral Springs Honse, ends abruptly on the verge of the steep descent to the Swift River Valley, and this seems to have been at one time an outlet for the lake and to have controlled the height of its waters.

\section{NOTCHES THROUGH THE HOLYOKE RANGE AND THE LAKE NORTH OF MOODY CORNERS.}

The manner in which the Belchertown notch was occupied by the Pelham River, and in which, by the expansion of this river into the Dwight's station lake, its waters came to occupy also the next pass westthe Bay Road Pass-is detailed in the section on p. 577. 'These events were the prelude to the complete occupancy of the valley by the lake waters, but at earlier times, immediately following the emergence of the range from the ice, the passes were used as transient watercourses, though no line of esker ridges extends north or south from any one of them. 
THE GRANBY ROAD LAKE.

At the second pass west of the Belchertown ponds, occupied by the little-used road from Amlerst to Granby, there expands in the center of the pass a broad, flat plain of stratified sands ( $m$ t) at a level of 410 feet above sea. The western half is well preserved. The eastern half has been deeply notehed by the waters of a spring-fed brook which escape toward the north. North and south the road goes down over till to the lower and later sands, but toward the south the watercourse by which the overtlow passed into the basin to the south is well marked by thin layers of sand and gi’avel.

THE NOTCH.

In the middle of the east-west portion of the range a pass 463 feet above sea level has traces of coarse-bedded sands in its bottom, and is continued south in a deep canyon cht in the sandstones and underlying diabase, down the side of which the road goes. This canyon I imagine to have been cut by a torrent coming off the ice to the north and through the notch, or at least to have been occupied and enlarged by such a stream. (See p. 510 and Pl. XI, p. 510.)

\section{THE LOW PLACE AND MOODY CORNERS LAKE.}

Farther west and just east of the Holyoke House is another pass, which is, however, turned east by the great mass of the Black Rocks diabase, and the waters coming throngh this pass in the same way seem to have supplied the sands which filled up a small lake $(\mathrm{m} \mathrm{t})$ that extended east and west between the two diabase ridges north of Moody Corners. This lake stood at the height of 314 feet and drained from its west end southwardly across the eastern tongue of the Black Rock dike where it is narrowest, and it was filled with sands to great depth, the earlier sandstone having been very deeply scooped out here by the ice.

THE HOLYOKE NOTCH.

The same flood waters continued farther west, and passed at this high level between the ice and Mount Holyoke into the Springfield Lake, forming the gorge terrace of Dry Brook Hill described on page 661. 
THE PELHAM RIVER AND THE "MORAINE TERRACE" SANDS ALONG THE EASTERN VALLEY SIDE, JUST ABOVE THE LEVEL OF THE HIGH TERRACE.

The continued melting of the ice at last restricted it to the Connecticut Valley, and melting back from the steep rim of the valley on the east it formed a great waterway all along the eastern side of the Amlerst basin, which continued south through the Belchertown notch along the eastern edge of the Springfield basin. In it was deposited a great body of sand and gravel ( $\mathrm{m} \mathrm{t}$ ), occupying the position of a lateral moraine of the Connecticut Valley glacier, but having rather the origin and structure of an esker. ${ }^{1}$ It was a great temporary river bed, its eastern bank being the mountain side, its western in part the low front ranges of the gueiss, ridges of till, and the eastern end of the Holyoke range, but for the most part the eastern rim of the great ice mass which still filled the valley and formed for much of the way the bottom as well as the western bank of the stream. The heavy sands deposited by this stream, where they rested upon a rock bottom, are still flat-topped and rest against the rock on the east, with all the peculiarities of a river-bottom deposit, at a height of 50 to 60 feet above the highest terrace of the Comnecticut Lake which followed. This is true on the West Pellam plain, and southward along the eastern part of the deposit, while its western portion seems to have rested on the ice, and as the ice melted this was dropped to lower and lower levels, its bedding being much shifted and confused by the process until it came to rest in a great series of kettle-loled sands stretching down to and below the level of the highest normal terrace of the Connecticut. 'This latter also has abundant kettle-holes, from which I conclude that the deeply buried remnants of the ice had not wholly disappeared when the great lake assumed its place and entered upon its work of carving out its terrace flat in these kame deposits.

The normal terrace or bench of the Connecticut Lake is determined by its agreement in level with the highest terrace on the other side of the valley, where great deltas of the finest material, most delicately stratified, mark the highest level of the waters, and where ond passes from these directly onto rock or till without crossing the complicated series of bedded deposits on the eastern side which I have described.

1 It is the "moraine terrace" of President Hitchcock, an extremely apposite name, showing that he had very clearly grasperl the peculiarities of its formation. Surface Geology, page 33, 1860. 
The excavations of the Central Railroad on either side of Dwight's station and through the Belchertown notch gave me abundant opportunity to stuly the anatomy of these sands, and especially the peculiarities of the ketfle-lioles, and this material, with matter derived from other portions of the valley, 1 have brought together in Chapter XIX, page 665.

I have given the same color to all the kame-like sands (1) which stretch sonthward at the foot of the eastern rim of the valley just above the highest normal terrace, (2) which extend along the north and west slope of the Holyoke range, and (3) which rise in the central parts of the valley above the level of the terrace flat. The first and most interesting series, to which I have given for convenience of reference the name of the Pelham River, from the place where its remnants are best preserved, is continnously traceable from North Amherst through the Belchertown notch, and from this point great discomnected patches of entirely similar sands and gravels occur at the foot of the eastern valley rim south across the State; and while one can not assert that they were laid down exactly contemporaneously in the bed of a single glacial river, the fact that they maintain just the same slope as the high terrace makes that the most simple supposition. At all events, their common origin-for they were all deposited between the ice and the valley rim-is sufficiently probable to justify a common color for them all.

The deposits of the Pelham River begin just south of North Amherst and swing round east with the curvature of the rocky slope to the point where the stream received the waters of the Leverett Lake (p. 584). The Pelham Lake drained into this strean, breaching the last great terrace which had stretcherl across the mouth of the basin, and the stream itself wore deeply eastward into the soft material of this terrace, forming the flat on which the Orient House stood (fig. 32, p. 578), and ran south from here, bounded for a long way on the west by the gneiss ridge which extends south from the west village of Pelham, and washed the side of the mountain on the east to a height of 400 feet. It is a perfect water course, which farther sonth lacks a western boundary, it having here rested against the ice $\left(\mathrm{b}^{10}, \mathrm{Pl} . \mathrm{XXXV}, \mathrm{C}, \mathrm{D}\right)$, and where it passes into Belchertown a massive drumlin forms its western rim, and it now ends in a great delta thrust out into the depression in which Dwight's station lies. As one stands on the eastern end of the Holyoke range and looks north, one sees this delta resting against the mountain on the east and against the low dam of the 
drift hill on the west, while at a much lower level the high terrace of the Connecticut Lake swings round the drift hill on the west and south. This was the last chapter in the history of the stream. This delta was caused by a breaching of the stream at this point by the melting back of the ice to leave a small temporary lake in its course, in the angle in which Dwight's station now lies, for the stream during its earlier stage seems to have flowed across this depression upon the surface of the ice, and its heavy sands are continuous at the proper level along the flank of the Pelham Hills east of Dwight's station, across from the delta to the sands of the Belchertown Pass, and a section of them is figured and described in the section on kettle-holes (p. 665). Through the Belchertown Pass it threw down the abundant sands and gravels which stretch from wall to wall of the pass and extend through its entire length. Their greatest height is 337 feet, though many kettle-holes, some of the largest size, disguise the original level of the sands. The three Belchertown ponds occupy three of these depressions.

The railroad cuttings showed most confused and tortuous stratification, abrupt alternation from fine sand in great mass to the coarsest gravel, great bodies of fine sand standing with the bedding almost vertical, as if they had been undermined when frozen, and kettle-holes, some partly and some wholly filled up by later sands, as if the ice beneath had melted away while the floods were still in progress.

We may at this point imagine, for the sake of clearness, the following stages in the retreat of the ice from the Springfield Lake basin, or the Granby basin, which is a part of the former, premising that the ice would disappear south of the mountain much earlier than north: (1) When the ice had only melted away from the eastern rim, so as to make a waterway continuous south from the Belchertown notch along the foot of the eastern valley rim; (2) when the ice had melted away from the south face of the Holyoke range; (3) when the ice had melted back from the north face of the same range for a small distance. We imagine the ice to still fill the whole valley of the Connecticut and to prevail over the western hills, but to have disappeared from the eastern.

1. In the first case the waters passing through the Belchertown notch would have continued southward, and we find, after a brief interruption, coarse kettle-holed sands, which commence at P. Chandler's, opposite the lower pond, at 326 feet above sea, and are quite continuous across Granby, 
often developed as lines of kame ridges or as reticulated ridges, in part bounded on the west by a line of drumlins, as opposite the lielchertown poorhouse, in part sloping down directly to the light lake terrace.

On passing the north line of Ludlow a great area of till, leaning on the hight rock borch on the east, projects west across the path of the watercourse we are following. Across this area there is a channel of proper height to have been the continuation of the same, but I found here only indistinct traces of water action. South of this, however, before one reaches the village of Ludlow, is a broad area, which extends southward beneath the village and to the Chicopee River, of the same high sands, which have come for the most part down Broad Brook, and partly also down the Chicopee River from the Belchertowu Lake. The same sands appear south of the Chicopee and extend in less amount across Wilbraham.

2. With the melting back of the ice from the southern slope of the Holyoke range the waters passing through the Belchertown notch would be deflected westward and southwestward, along the south foot of the range, to fill up the deeply eroded area that extends past Moody Corners clear to the Connecticut, which has since been partly reexcavated by Bachelors and Elmers brooks; and as the ice retreated still more the waters would carry their load of sand and gravel directly into the wide Granby basin to build up the broad plain surrounding Forge Poud. The present condition of the gravels extending soutl from the notch makes it certain that this was the last course of the waters. The coarse gravels extending through the notch where they surround the third pond are still very coarse, pebbles 6 inches in diameter being abundant. Here the gorge expands and the gravels extend across the widening basin, growing gradually finer. Halfway to the east line of the town (Granby) they are 4-nch gravels; at the town line, 2-inch gravels; where the wood road cuts deeply into them north of Moody Corners and in South Hadley they are exposed for 35 feet as fine, well-bedded sands.

3. By the melting back of the ice from the north side of the Holyoke range the river expanded lake-like along its northern foot and, aided by waters coming directly across the ice, a great body of sand was rapidly carried in here. This extends west just beyond the "notch road" to South Hadley and stretches through the much lower notch near the east end of the range, and is continuons with the sands in the Belchertown notel. 
4. Finally the waters expanded so considerably that the Pelham River emptied into the lake thus formed, building the delta already described above Dwight's station, and soon disappearing.

THE SUNNY VALLEY LAKE.

The only other large accumulation of glacial sands on the eastern side of the river occupied the Sunny Valley in the northern part of Warwick, and extended across into Winchester, New Hampshire, and was drained by the Valley Brook into the Perchee Brook and thus into the Connecticut. This lies for the most part outside the limits set in this work.

THE SANDS ALONG THE WEST SIDE OF THE MOUNT TOM RANGE AND IN THE WESTFIELD BASIN ABOVE THE LEVEL OF THE HIGH TERRACE.

The sands which rest against the northern slope of the Holyoke range extend west to a point a little beyond the notch road, and are conspicuously absent from the rest of the north face of the range farther west. This may indicate the distance west to which the waters penetrated from the Dwight's station lake, or enlargement of the Pelham River (see p. 589), or these sands may have extended farther west and have been swept away by the later lake waters. Sands at the same level above the high terrace begin again on the west side of the river, just east of the old road to the Nonotuck Mountain House, and extend thence along the whole face of the Mount Tom range in Northampton and Easthampton, in a great mass of ridgy sands and gravels, in which the high terrace flat of the lake is cut. Similar sands at the same level also cover White Loaf, in Southampton, and the ridge east, which rise as islands in the broad sand flats of the Hampden plains. They are not given on the map. They had clearly a common origin, having been swept in between the mountain and the ice, or off the ice onto these islands after the ice had uncovered them, and they stood out like nunataks above it. They have served a common purpose in the later economy of the valley, as they furnished, I have no doubt, a large portion of the material carried south by the two channels on either side of White Loaf, and spread as coarse gravels around Hampden ponds, which dwindle farther south in the broad plain to the fine sands of "Poverty Plain," here, of course, reenforced by the abundant contributions of the Westfield rivers. 


\section{O H A P T E R X I I. \\ THE CHAMPLAIN PERIOD (CoNTINUED).}

GLACIAL LAKES WEST OF THE CONNECTICUT RIVER.

THE GRANVILLE LAKE.

As the ice retreated northwesterly, still sending great lobes down the Connecticut and down the Westfield River, it abandoned the high valley which occupies the whole middle of the town of Granville, while its Connecticut lobe still closed the outlet of this valley at the northeast corner of the town and the gap of Munns Brook, which is cut so curiously through the middle of the eastern rim of the valley. This rim is cansed by the greater durability of the vertical schists of which it is made, which strike north and sonth and form an impassable barrier along the whole eastern side of the town, except that it is cut asunder by this deep notch in its middle, down which a road ouce ran.

This broad valley, which extends across the whole length of the town and a long way into Connecticut, was filled by a great body of sands, now finely terraced down by brooks which run out of the basin on the north, east, and sonth ( $\mathrm{gl}^{2}, \mathrm{Pl}$. XXXV, B). Its height is plainly determined by its southern ontlet, where the brook has a rocky bottom, and it is clear that when the sands filled the basin the northeast and the east outlets $\left(b^{9}\right)$ must have been closed, since, on being opened, the brooks which occupy them cut down deeply through the sands before they reached the rocky bottom of these outlets, proving that the latter were preexistent and deep enough to have kept the waters at a much lower level if they had been open.

\section{THE NORTH GRANVILLE LAKE.}

Another lake of great extent stretches from Granville into Blandford, surrounding Cobble Mountain $\left(\mathrm{gl}^{2}\right)$. Its coarse sands reach a great depth. It was drained by the setting free of the South Branch of the MION $\mathrm{x} \times 1 \mathrm{x}-38$ 
Westfield River through the wildest gorge in Massachusetts, deeply rock cut, and abounding in very large potholes. One is inclined to surmise that some portion of this erosion may date from Glacial or early post-Glacial time.

THE WESTHAMPTON LAKE.

A much more extensive and interesting lake than the one mentioned in the last paragraph occupied, at a much lower level, all the eastern part of Westhampton, about the headwaters of the Manhan River ( $g l^{1}$, Pl.XXXV, B). It wound sinuously among great islands of granite, and extended south into Easthampton, where it passed over a rocky sluiceway, which fixed its level, into the headwaters of the South Branch of the Manhan. From Loudville south into Southampton, around the east flank of Great Mountain, the sands of this lake extend out freely into the Connecticut Valley, without rocky support on the east, and end in a terrace scarp, below which a broad slope of till extends down 170 feet to the normal high terrace of the Connecticut Lake. It is plain that the ice of the Connecticut River glacier furnished the bank of the lake within these limits $\left(b^{9}\right)$. This was at its greatest size. Subsequently it seems to have persisted, with diminished boundaries, and to have received the overflow from the Williansburg. Lake, farther north, when the ice had retreated north so as to set this free, and so to have for a long time retained connection with a long and complicated series of watercourses, which extended back north to the valley of the Deerfield River, and ceased to be occupied when this valley was abandoned by the ice.

So soon, however, as the ice set free the gorge at Loudville the lake was tapped in its upper portion, and the greater part of its area is now drained through this chamel. Two watersheds, however, developed in this area, one at the south, setting off a portion to be drained by the South Branch of the Manhan, and another at the north, which drains through the Roberts Meadow Brook into the Mill River. These streams, especially the middle ones, have cut a fine set of upland terraces in the sands of the ancient lake, and as one sees these brooks leave their upland meadows and plunge into deep gorges on their way to the valley below, one is inclined to ask how far these gorges were preexistent and how far they have been cut by the streams since the time of the lake. In some cases the disappearance of the lake may have been due to such a cutting down rather than to the removal of an ice barrier or the sudden sealing up of the sources of the glacial waters. I have 
for the most fart used the latter as a working hypothesis. In several places, as in the Commecticut gorge above the month of Millers River, much erosion of the rocks has taken place since the time of the lakes.

\section{THE WILLIAMSBURG LAKE.}

The Mill River at Williamsburg village has ent its terraces in a great borly of coarse sand, whose flat surface is 33 feet above the stream. Tntil the ice had so fir melted back that the Deerfield River was open, the overflow of the Ashfield and Conway lakes, described below, reached this lake by way of Mill River and Joe Wright's brook, respectively, though, as the waters left in their passage through these narrow gorges no deposits to attest their former presence, there is on the map an apparent break in the continuity of the deposits between them, of considerable extent in the case of Mill River. The proof of this former continuity is given in the description of the other lakes.

The sands of this lake $\left(\mathrm{g} \mathrm{l}^{1}, \mathrm{Pl}\right.$. XXXV, A) can be followed down South street to the south line of the town, where they divide, one band going south to join the Westhampton Lake, the other sontheast in Northampton to where it widened into the Roberts Meadow Lake, whose water's regained the valley of the Mill River at Leeds, and also passed south into the valley of the Connecticut, down the deep, empty gorge west of Roberts Hills. This gorge has, as in so many other cases, a brook heading in its bottom and r'muning north, and another brook heading farther south and running south, while the gorge is continuous and of uniform size and depth from the Roberts Meadow basin to the open Commecticut Valley. It seems to me a product of subglacial drainage or of the obstructed post-Glacial drainage I am here tracing.

THE BEAVER BROOK LAKE ABOVE LEEDS.

This small lake lay encircled by high hills in the east part of Williamsburg and was drained by a deep gorge through which the brook above named now flows to join the Mill River at Leeds.

THE DEERFIELD RIVER LAKES.

The obstructed drainage south of the Deerfield River (Pl. XXXV, A) was most curious and complex. 'That it was, mutatis mutandis, the counterpart of the drainage south from the Millers River (p. 573) comes ont very clearly. The ice melted back across the high, irregular area south of the 


\section{6}

GEOLOGY OF OLD HAMPSHIRE COUNTY, MASS.

river with a front rudely east and west, or a little north of east and south of west, and the deep transverse valley of the river runs northwest, while deep longitudinal valleys extend sonth from it. The ice thins set free the lower portions of the Deerfield Valley first, but the Connecticut River glacier dammed its month for a long time, thus turning the waters sonth across Conway to form the Conway Lake, south of Bardwells Ferry, whose waters escaped sonth across Hampshire County to enter the valley of the Connecticut by way of the southward ramifications of the Williamsburg Lake.

At the same time the ice had set free the Deerfield np nearly to the month of Bear River in Conway, and still sent a lobe up this valley for some distance, from the sonth end of which the waters escaped that formed the broad Bear River Lake, seen in the middle of Pl. XXXV, A, which drained into the Ashfield Lake. This latter was supplied by a lobe of the glacier which, west of Shelburne Falls, followed up Clessons Brook to beyond Buckland Center $\left(b^{14}\right)$. This lake drained east into the Conway Lake and sonth by way of the headwaters of the Mill River into the Williamsburg Lake. Still farther west the waters gathering from the ice which filled the Deerfield Valley below escaped sontheastwardly from the extreme northeastern corner of Hawley and followed Clessons Brook down as the preceding current followed it up, and the two currents met at the sharp bend of the stream at Buckland Four Corners and joined to form the Ashfield Lake mentioned above. Another current from the ice going south np the valley of Chickley River formed the lake which occupied the middle of Hawley. For this lake I could discover no sonthward outlet, but no doubt one existed.

Three points will be noticed in regard to this drainage: (1) The waters moved up old valleys and filled them to a level determined by passes far to the south, over which the waters continued into another drainage basin; (2) after the retreat of the ice, brooks heading up near these divides ran north, carrying back north a good portion of the gravels which had been carried south; (3) it is only near the month of the Deerfield River that the deposits of these lakes extend north to the river itself; farther west they begin some distance south and the valleys between their beginnings and the river are empty and bowlder strewn, while on the east side of the Connecticut the opposite order holds, viz: at the head of Millers River the corresponding deposits extend up to the river and beyond it to the north, in its middle course up to the river and in its lower parts not quite up to 
the stream. In the following more minute description of these lakes more stress is laid upon the shiftings of the ice front during the formation of each lake and on the character of its deposits.

THE DEERFIELD RIVER AND ITS TRIBUTARIES ON THE NORTH.

This stream lies so nearly in the direction of the melting of the ice that it wals a main chamnel for the exit of its waters, and was not itself encumbered, except that once the readvance of the ice in the Connecticut Valley threw at dam across its mouth. The same is true in the main of its northem branches.

The deep, tortuous, and most picturesque valley of the Deerfield widens slightly in Charlemont and Shelburne, and here a considerable body of sand was gathered, and in several places pretty series of intermediate terraces have been cut in this deposit of the flood period and above the present flood plain of the river. Exactly as in Russell the Westfield River encircled a great hill in midstream, so the flooded Deerfield surrounded a great hill in Shelburne, and the railroad makes a short cut through the abandoned waterway.

Below Shelburne Falls the river runs in a deep canyon till it reaches the Comecticut, and it is hard to say whether the great height of the Charlemont-Shelburne beds is due entirely to the setting back of the waters above this deep, narrow gorge or partly to possible ice dams. In all this distance there are only traces of terraces referable to the flood period or to any subsequent time, but the stream runs deep in a rocky gorge.

It is characteristic also of the streams that enter the Deerfield from the north that either they were open waterways during the melting of the iceand they are therefore now deeply sunk in empty valleys with traces of their high flood terraces in coarse gravel beds left as remnants in sheltered places and with narrow and interrupted flood plains-or they seem to have been occupied by the ice during the height of the flood, at least in their upper reaches, and so are wholly empty of anything except till above the low level of recent flooding. This seems to have been the case with the Deerfield itself above the tunnel entrance, and fine terminal moraines $(1 \mathrm{~m})$ have been thrown across the stream at several places during the recession of this last lobe of the ice.

The curious "delta terraces" which appear where the tributaries on the north side meet the main stream are discussed elsewhere (see p. 605). 
The tributaries on the south side have for the most part cut their way through heary glacial lake deposits, and their facies is thus extremely different from the north-side tributaries, as the former are bordered in their upper courses by broad, heavy deposits of high-level sands and gravels in which they have cut their terraces, while on the north the streams come down in narrow gorges, and only in Coleraine does one widen to form any considerable meadow. This in part explains why Conway and Ashfield are more flourishing villages than the northern tier of towns from Leyden to Monroe.

THE CONWAY LAKE.

Just at the Conway station the train crosses at a dizzy height the South River where it enters the Deerfield. The station is about at the level at which the waters stood at their highest flood after they had obtained free passage to the Comnecticut. The Deerfield now runs in its rocky bed nearly 200 feet below, and the road from the station toils up over heavy sands another hundred feet to a broad, level area of sand, bounded on the south, east, and north by the South and Deerfield rivers, which, when the ice obstruction $\left(b^{13}, \mathrm{Pl}\right.$. XXXV, A) below was removed, cut down through these sands into the rock so quickly that they did not wear back at all into the sands. A great triangle between the rivers, bounded on the west by the road from the South River to the Deerfield, and a mile on a side, is occupied by this great body of sands $\left(\mathrm{gl}^{1}\right)$; in its eastern and larger part it is quite horizontal, at about 460 feet above sea, while in its western part the sand rises nearly 100 feet higher and is covered by till, as if, at an earlier stage of the lake, the waters had stood above this higher level and brought up the sands to that level, and then oscillations of the ice brought in a covering of till over part of the area and determined then or later a lower level for the lake, down to which its sands were terraced. The area requires more study than I could give it. The sands at this lower level are continuous as a broad band south, up the valley of the South River, widening over the area of the village of Conway and receiving there a body of sands which extend up the South River through Burkville, in that part of its valley which runs northwest.

The South River enters the town running east, and holds this direction a mile (the latter part is an empty valley); then it bends south a mile to Conway, and in this part it was occupied by a glacial current which moved south to meet at Conway village the current moving south up the 
valley of South River from the station. It seems to me probable that when the ice first melted out of the great triangle at the station it still filled the decp ralley at and north of Conway village, while the Comnecticut glacier dammerl up the month of the Deerfield and held the waters up to a height of prorhily 550 feet. After this the ice abandoned the South River Valley as fir west as the first bend in the river mentioned, above a mile from the west line of the town. Then the waters, passing down the two lobes of this valley and joining where the village now is, filled the valley to the height of the gromind where the academy stands, and all the area to the sontl (now recmptied by erosion), and escaped sonthwardly by the narrow pass by which the main road goes soutl into Whately. As one goes south from Conway he sees the broad, level gravel plains, 100 feet above the village, which surround the town and extend south, passing continuonsly and at the same level into the flat, plainly waterworn bottom of the narrow canyon, and it is clear that this canyon has fixed the level of the lake. We follow this watercourse sonthward easily and find it expanding into a lake around the headwaters of Roaring Brook, and branching to follow this valley down a mile sontheast, ending abruptly. The Connecticut glacier would seem to have still clogged this valley, and I have so represented it $\left(b^{11}, \mathrm{Pl}\right.$. XXXV, A). The main stream channel continues south into Whately and, reaching the headwaters of West Brook, widens considerably and then contracts at West Whately, where it bends sharply west into Williamsburg. It is quite remarkable that it should thus bend, for the open West Brook Valley turns here toward the east, and, after 50 rods of empty valley way, expands on either side of the brook's bed; and 200 feet below the sands of the above watercourse a great area of heavy sorted gravels begins, which continues southeast with the brook for a mile, widening to above a half mile and ending abruptly with a great scarp which overlooks a broad, sandless valley. Remnants of ice on the east of the main-valley watercourse must have kept it out of the Roaring Brook Valley, as above, and also deflected it at West Whately $\left(\mathrm{b}^{11}\right)$, and the ice, being breached, let the waters through in a flood, which dropped this great volnme of gravel as it expanded into the open valley after the mamner discussed under the section concerning high-level deltas (p. 605), or the ice may have erected a later barrier lower down the valley $\left(b^{12}\right)$. In Williamsburg the stream expanded into another basin, now a broad sand plain, and escaped south 
through a curious narrow canyon, in the bottom of which Wright's brook now rises from a large spring. Down the course of this brook the waters passed to join those of the Williamsburg Lake.

\section{THE BEAR RIVER LAKE.}

The fullness with which all the evidence concerning the formation of the deposits in this basin can be traced leaves little to be desired. The basin is a broad one, extending, with its greatest dimension east and west, across the line between Ashfield and Conway (middle of Pl. XXXV, A). It is surrounded on all sides by high ground, except a narrow passage at the northeast corner, and sends three great lobes northward among the hills. In its southern part it is filled to a great height by an enormous volume of coarse sand, especially in the area around the cemetery at School No. 2. The height to which these sands were brought up was determined by the height of the col at the southwest portion of the basin by which the waters escaped into the Ashfield Lake along the road which runs south to Ashfield Plains. These sands were brought in while the ice was retreating from the valley and still filled its northern parts, as in all the northern portions of the basin the sands occupy a lower level, and it is plain that they were never heaped up to the height of the soutli-side sands and then eroded. It is therefore probable that the north side of the basin was still filled with ice when the latter were brought in, as they must have come from the north.

When the ice had completely left this basin it marked its next halting place with beautiful clearness. The water maintained its former level after this retreat, this being conditioned by the col in the sonthwest corner. It carved a broad bench in the till around the north border of the lake and brought in great bodies of sand over its bottom, but not enough to fill it. If these sands are followed to the northeast corner of the basin, they are found to extend a distance along a narrow rock-bottomed valley, scarcely covering the rocky floor. The rock bottom of the valley then sinks rapidly, while the sands widen somewhat and continue at the old level, thus filling the deepened valley with beds of very great thickness. At a certain point in this valley they end abruptly $\left(b^{3}\right)$, and one goes down by a great lobed scarp to the deep valley bottom, and for 100 rods downstream (northwardly) the steep valley sides are strewn with glacial bowlders to the water's edge. These sands are grooved in the middle by the Bear 
River, which has cut a deep passageway through them. The small river fores on for a mile north in il deep, simclless, bowlder-strewn valley to join the Deerfichll.

It is plain that the ice dammed this valley and that the sands were heaped up against it, and that it then retreated and left the sands to eave into the grreat nurthward-fincing scarp after the changes in the ice farther up the loerfield liver had opened up other channels of eseape for the waters.

THE ASHFIELD LAKE.

The great bodies of flat sands in the middle of Ashfield (middle of PI. $\mathrm{XXXV}, A)$ have naturally, in this extremely liilly country, given the village the name of Aslifield Plains. The Ashfield Lake is represented by a peculiar body of sand surrounding a great rocky hill which overlooks the rillage. At South Aslifield it turned west and drained down a long valley to the east into Conway, and from this point I was uncertain as to its course. The valley it has followed to this point (South River Valley) runs east into the Conway Lake. It is empty of sands for a mile, and then begin deposits which are continuous into the Conway Lake.

The Ashfield beds seem to turn sonth just at the town line, up a branch of the South River, whose valley they fill for a long way south, to the southwest corner of the Greenfield quadrangle, and then repeat the operation already described at the north end of Bear River Lake (p. 600). The valley in which we are following up the deposits euds in a cul-desac, but is continued southward at a much higher level by two valleys, one of which rums through a corner of Plainfield and along the east of Hoores Hill, in Goshen, in a narrow canyon, and thence down the steep slope into Williamsburg Lake, and the other more directly south, by City Pond, into the valley of Mill River, and into the same lake. I have represented the deposits in disconnected patches in both these conrses, because much of the way the valleys are so narrow that all traces of these earlier occupants have been swept ont by the wild floods of the present brooks. It is, of course, probable that the Williamsburg Lake came into existence as soon as the ice melted back from it, and that, as the ice retreated, the two courses I have last traced were long nsed by waters at various stages of this retreat. I am here, however, following out the last occupation before the opening of the Deerfield River. 
It is also quite possible that the Ashfield Lake did drain into the Conway Lake, flowing back south to fill the cul-de-sac described above withont overflowing to the south, and that for a mile east along the South River Valley it left no deposits. My attention was not closely directed to the point when on the ground, and my opinion was formed from a view of the entire area from the top of the highest hill after I had gone carefully over the whole region.

\section{THE BUCKLAND LAKE.}

If we follow the outer contours of the Ashfield Lake where the sands border on the rocks, we shall find them converging just north of Great Pond upon a narrow, rocky canyon, and it is plain that the waters came through this passage for a long time and with great force, bringing the sands which extend sonth from its mouth. The drainage of Great Pond is sonthward, but a small rise of its waters would send it north throngh this gorge. On entering this gorge one expects it to rise among the hills and terminate as a mountain glen, and expects to find the brook which has bronght down the great volume of sand, but a short distance north the valley widens somewhat and sinks 300 feet with great suddenness, so that it has been very difficult to earry the road down to its bottom. One sees immediately that the ice must have filled this deep valley $\left(\mathrm{b}^{13}, \mathrm{Pl}\right.$ XXXV, A) when the waters swept across its back and through the narrow gorge bearing the great volume of sands which now form the Ashfield Plains, for otherwise the deep valley to the north must have been filled first. That it was not filled and then reeroded is certain from its bare, rocky, and bowldercovered sides and from the abundant openings made by the new road carried down to the valley bottom. Taking this road, we go down sharply to the valley bottom over till, and along the bottom for a short way also over till, when we come suddenly upon a great bank of fine, well-bedded sands, about 33 feet high, with a slope as regular as an earthwork, facing us (i. e., facing sonth), and extending right across the valley and resting against its walls. It is like a dam, only breached at the center by a brook which runs north, and we seem to be in the bottom of an abandoned mill pond. Climbing to the top of the slope, we find it is the sonthem termination of a great body of sand which once filled the valley from this point north across Buckland to Buckland Center, and which, though now largely eroded, can be 
easily followed to this point and not farther. It maintains a level abont 200 fier below the Ashfield Lake and 100 feet above the Deerfield River terraces.

It is clear that after filling this lower valley for a long time and allowing the waters to transport the great body of sand into the Ashfield Lake the ice retreated north to Buckland Center and stood there for a time $\left(b^{14}\right)$, maintaining a lake of great depth, which still drained through the narrow canyon and across the sands of the Ashfield Plains, producing the exceptioually large amount of erosion of these sands, while the sands advancing along its own botton were checked when the waters passed into the narrow gorge, and were dropped so suddenly that a steep, subinerged delta front was formed. Exactly this has been happening now for several years at Miller's Falls, where, to improve the railroad, the river above has been turned into a new course for a distance through deep sands, and has thus a great amount of material at its disposal, and a broad, flat bar extending across stream is creeping down into the deep water above the dam, presenting a sharply sloping delta front to the obstrueting dam, as do the sands here to the obsirncting gorge.

At their south end these lower sands are at first fine grained, well sorted, cross bedded, and undisturbed; northward they are soon changed to coarser sand, the surface becomes pitted with kettle-holes, and the sands grow coarser and become coarse gravel. At last glacial bowlders are intermixed and the sand is twisted and tortuous in stratification, and it seems almost to grade into till, as if bowlders were carried sonth with masses of ice by the waters and mingled with the sands, or as if the ice itself had advanced with many oscillations and disturbed the sands $\left(b^{1 t}\right)$.

The ice here postulated $\left(b^{14}\right)$ was a lobe sent southward from ice which then filled the Deerfield River Valley and much of the high gronnd north of the river. Another lobe projecting southward in a much shorter valley, and one rising very rapidly to the high level, produced another considerable accumulation of sand in the extreme northeast corner of Hawley, at the headwaters of Ruddock Brook, which passes down the valley of Clessons Brook to join the sand described already as extending south from Buckland Center up the same brook. They join at the sonth line of the town (at Buckland Four Corners), and run across Ashfield to the delta front described above. 
THE LAST IMPORTANT HALTING PLACE OF THE ICE FRONT ACROSS THE BASIN OF THE DEERFIELD RIVER.

On page $573 \mathrm{I}$ have traced the southern boundary of the ice at its last marked halt across the eastern half of Franklin County, and a similar line may be drawn across the westem half of the county by connecting the ice barriers which formed the northern limit of the glacial lakes south of the Deerfield and kept the deep valleys tributary to this river empty in their lower (northern) reaches across from Coleraine to Mouroe.

Directly opposite the barrier on Dry Hill, in Montague, on the east of the Connecticut River, is the great barrier above Bardwells Ferry $\left(b^{13}\right)$ on the west, and these may be looked upon as two synchronous halting places of the ice front. Between these the lobe of the ice, which at the same time extended down the Connecticut Valley, may have been thrust into the clays south of Deerfield to produce the disturbances at the Wapping cutting figured on Pl. XVIII (p. 694). West of Bardwells are the Bear River barrier $\left(b^{13}\right)$, that at Buckland Four Corners $\left(b^{14}\right)$, that on Ruddock Brook $\left(b^{15}\right)$, and that above West Hawley $\left(b^{15}\right)$.

The moraine across the valley of the Deerfield above the mouth of Hoosac Tumnel (d) lies in the continuation of the curved line which joins these ice barriers, and as these barriers on both sides of the river represent a time when the ice halted for an unusual time, and as they lie along a single curved line, one may assume that they represent a single and exceptionally long halting place of the ice.

\section{GLACIAL LAKES NORTH OF THE DEERFIELD.}

The Hawley Lake requires no special mention (see Pl. XXXV, A), and the high-level sands at the month of the tributaries of the Deerfield on the north are described below. Besides these there is an interesting lake of small dimensions west of Shelburne Center, extending to the river and formed when the Deerfield Valley glacial lobe projected beyond the present mouth of Sluice Brook, throwing back its waters into a lake which drained over a rocky sluice running east from near the cemetery toward the sawmill south of Shelburne Center.

Also in Charlemont, when the Deerfield Valley glacier extended just beyond the village, the waters of Mill Brook were thrown east at a high 
level round the north of Bald Momitain and down the valley of Hartwells lirook.

One finds few other traces of obstructed drainage marked by stratified deposits of any extent across the high ground to the north line of the State.

HIGH-LEVEL DELTAS.

When the reservoir of Mill River broke through the dam at Williamsburg, in 1874, the waters spread out fan-like after their first plunge in the are:i, a few rods below the dam, and, rapidly losing momentum, they were in effect suddenly overloaded and deposited immediately a portion of the sand they were transporting, in an extended flat-topped layer 1 to 3 feet thick, pushed forward in broad lobe-like projections and bordered downstream by a sharp terrace slope of $30^{\circ}$.

All the streams which come down from the high grounds on the west side of the basin in Westhampton, Northampton, Goshen, Williamsburg, and Whately have here and there in their course torrent deposits of a size all out of proportion to their present dimensions, especially where the streans, after rumning through narrow channels, debouch into broad, level portions of their valleys.

I am inclined to refer all these deposits to occasional violent floods when the ice was melting in the upper part of the drainage area of the brooks where they are found, and think they may have been made much as were the smaller terraces described above by the flooded Mill River in modern times. At the same time, each one of them may have been formed while a barrier of ice still filled the main valley and blocked up the mouths of these east-west valleys, forming glacial lakes like those described above.

There is one of these deltas on the upper portion of the Sawmill Brook, on the road from West Farms to Westhampton. It hangs in a remarkable way over the broad valley, into which the stream passes here from between the hills, its downstream slope being $40^{\circ}$, and its broad, flat surface 40 to 50 feet above the brook. It is brought out flush with the surface of the hills on either side of the brook, as if it had been built up against a wall of ice resting against these hills and filling the valleys below.

Two other deltas are found in the upper waters of the Mill River in Goshen, one at the first road crossing above the reservoir, where the brook comes out of a narrow gorge in granitic rocks. This is pushed out into the 
valley, with broad, flat surface and steep downstream slope, and the stream has now cut a deep channel in it to its base. The other occurs about a mile below the reservoir on the same brook and east of Hubbard's ledge. This is much larger than the one higher up, and its surface will include several bundred acres.

It is a very curious circumstance that every brook coming into either of the transverse valleys of the Deerfield and Westfield rivers from the north is flanked at its mouth by a distinct terrace, generally triangular from the flaring of the valley, 65 to 100 feet above the stream, and now divided down its center by the deep cutting of the brook. At the villages of Charlemont, Zoar, Orange, and Huntington are fine examples. The explanation that they were caused by the ice lobe coming down the valley and being thrown across the mouth of the side stream is nowhere excluded by anything I have seen, but it seemed to me possible that they might owe their origin to sudden floods of overladen waters into the open valley in the manner described above.

The features at Charlemont admit of an easy interpretation upon this supposition; opposite the entrance of the tributary, and on the sonth side of the Deerfield River, the high rocky border of the river is set back in a large semicircle, and the south half of this semicircle is still occupied by a great body of sand and gravel, whose level surface slopes south as if in contiunation of the slope of the delta terrace on the other side of the main stream and flanking the tributary. Indeed, if one could restore in imagination what must, on this hypothesis, have been removed by the main stream and by the tributary itself, the great body of sand would form an alluvial fan extending right across the valley of the Deerfield into the great cirque described above, the southem portion of which fan has since been separated from the rest by the erosion of the Deerfield. However, a southward-sloping terrace on the south side of the Deerfield would not be an impossibility, and the rock of the region is so monotonous that it gives no clew to the source of the sand. These terraces were called delta terraces by President Hitchcock. ${ }^{1}$

In order not to multiply colors, I have colored these delta terraces with the same shade as that which would be applied to them if they were "glacial lakes"- that is, sands deposited by the obstructed drainage during the retreat of the ice. 


\section{CHARACTER OF THE TERRACED FLOOD DEPOSITS OF THE WESTFIELD RIVER.}

From the point where it leaves the gates of the momntain on the west line of $\mathrm{W}^{\mathrm{T}}$ estfield, the Westfield River is bordered by ligh-level, coarse beds along the narow valley sides, which widen somewhat where lateral valleys conc in, as at Russell, Huntington, and Chester. The valley narrows above

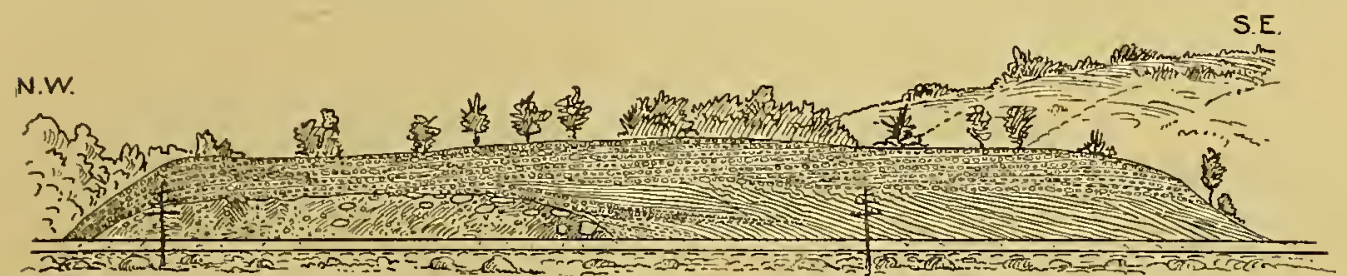

Fra. 33.-Section of terminal moraine covered by high-level flood gravels of the Westfield River. The north slope is caused by caving from the erosion of the river. Russell, juat below station.

Chester, becomes a canyon between Becket and Washington, widens broadly across Hinsdale, and joins the Housatonic Valley in Dalton with increased width. The canyon is a low water-parting. The whole central part of Hinsdale is deeply covered by the stratified beds of a glacial lake which received its waters from the Housatonic Valley while the ice clogged the lower portion of that valley, and discharged them through the canyon of the Westfield. It thus follows that the Westfield Valley was for a time the recipient of the deflected drainage of the upper Housatonic after the ice had disappeared from its own headwaters, and the many bowlders and pebbles of Cheshire quartz-

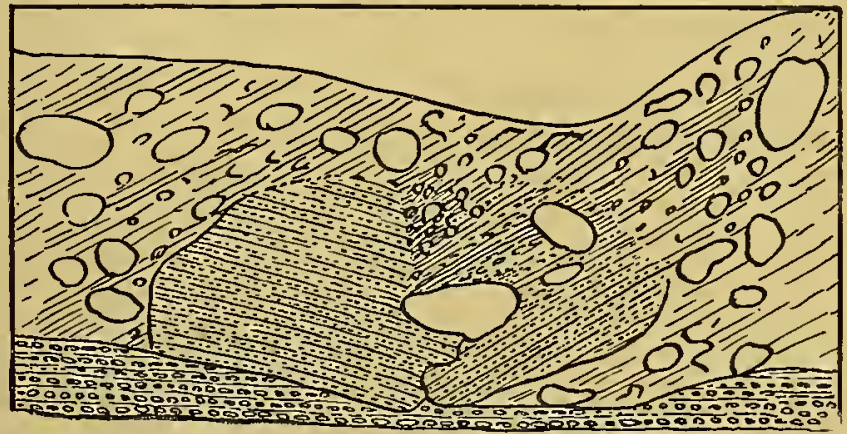
ite found down the valley Frg. 34._Sand bowlders crushed hy the ice while frozen, from just south of confirm this deduction.

the telegraph pole seen at the left in fig. 33 .

An extremely interesting section was opened by the Boston and Albany Railroad, in 1895, just east of Russell, which throws light on the way in which the terraced beds in the valley of the Westfield were built up, as shown in fig. 33 .

In the upstream portion of the section the lower half is a complete 
terminal moraine, the large angular bowlders being abundant. In the upper portion of this moraine are curious separate areas of stratified sand, discontinnous and much twisted in the unstratified mass of the moraine. One of these is shown in fig. 34. These seem to be plainly parts of a stratum of sand washed upon the broad, flat moraine and then, while frozen, broken into blocks by the farther advance of the ice and mixed with the other bowlders of the till. This shows the presence of a lobe of the ice, moving as a valley glacier down the Westfield Valley and halting at this point.

The second matter which is well illustrated is the long-continued, steady, torrential flow, and the high level of the Westfield River during the time immediately following, while the stream was receiving the waters from the melting ice.

On the downstream side (the right of fig. 33) the current quickly filled up the area in the lee of the moraine with strongly cross-bedded sands of medium grain, and above this extends for many rods a bed, 20 feet thick, of well-sorted and well-rounded 6-inch gravel, in perfectly horizontal beds. There is rarely a pebble above 8 inches across, and almost everything below 2 inches across is washed ont of the bed. One gets here another side of the activity of the strong stream which brought the great volume of sands to build up the broad plains of Westfield and Southwick. 


\section{CHA P TER XIX. \\ THF, CHAMPLAIN PERIOD (CONTINUED). \\ THE CONNECTICUT RIVER LAKES. \\ INTRODUCTION.}

"About 4 miles above South Hadley the Connecticut passes between the two large mountains, Tom and Holyoke, having apparently made here in ancient times a breach in this range and forced its passage. By the old people in Northampton I was informed many years since of an Indian tradition that the great valley north of these mountains was once a lake. The story is certainly not improbable. From an attentive survey of the country along this river, I have no difficulty in believing that a chain of lakes occnpied the several expansions at some distant period of time. Here certainly the general geography of the country and the particular appearance of the scenery near the river are favorable to this opinion." "This is the earliest geological discussion of the subject. Still more interesting is the earliest discussion by President Hitcheock of the ancient lakes of the Connecticut, ${ }^{2}$ which he believed to have been drained by the cutting down of the gorge below Middletown, Connecticut, and their lessened remnants drained in turn by the cutting of the notches in the trap ridges.

The abundant deposits of the glacial lakes of the region east of the river in the main antedate those of the valley itself; those of the lakes to the west are more strictly synchronous with, or perhaps a little later than, the valley deposits.

That the ice was thrust forward as a valley glacier beyond the front of the inland ice appears clear from the disposition of the lower of these lake and stream deposits (mt, Pl. XXXV, C, D) along the eastem border (see p. 588). That it was thrust forward into deep water in the valley, in its

1 President Timothy Dwight's Travels in New England, Vol. I, 1822, p. 325.

${ }^{2}$ Am. Jour. Sci., lst series, Vol. VII, 1824, p. 16.

MON XXIX -39 
oscillations overriding beds already deposited, and that it "calved" and sent icebergs down the valley, will appear in the description of the valley beds here given. Because of the peculiar configuration of the valley, this is most plainly discernible in the Hadley basin, less so in the Springfield basin to the soutl, and in the Montague basin, though in the last it can be clearly proved.

One must recall briefly the shape of the Connecticut Valley, as already defined (p. 9), while occupied by the Triassic sandstones, and as now reoccupied by the Commecticut lakes. The eastern rocky bluff runs south one point west from Northfield to Mount Toby, turns on this and runs southwest by sonth, but more irregnlarly, to the Belchertown Ponds at the east end of Mount Holyoke, and then south to the south line of the State.

The western line runs from near the river in Vernon south through West Northfield, turns west across Bernardston and aloug the north line of Greenfield to its northwest corner, where, near the mouth of Leyden Glen, Mrs. Williams was killed by the Indians iu 1718. It turns southward again along the west border of the town. Greenfield was laid out so as to include all the flat country, and the barren hills were left for Shelburne and Leyden. The line goes south to Elizabeth Rock, in Northampton, at the apex of the "big bend" of the Commecticut. Here it is set back west again, as before, to include Northampton, and goes on one point west of south to the sonth line of the State in Southwick.

The r-shaped Holyoke range cut off the Springfield basin, and the L-shaped Deerfield-Toby range cut off the Montague basin on the south and north, respectively, from the Hadley basin. So that, south of the Holyoke range, the area was greatly sheltered from the ice so soon as it sank below the crest of the range, and the ice in the Hadley basin was projected into the southern continuation of the latter along the western foot of this range, as the southwesterly striæ there indicate.

On the other hand, a separate lobe of the ice occupied the main valley of the Connecticut in the Montague basin, and another lobe occupied the northwestern lateral extension of the Hadley basin in Deerfield and Greenfield, the latter lingering longest in Greenfield-indeed, till after" the maximum of the flood had passed.

The waters occupied the basin while it was still largely encumbered with the remnants of the glacial ice, and during all the time of the deposition of the central clays floating ice was abuudant. The occurrence of arctic 
plants in the upper portion of the clays is in larmony with this state of thing's, and the many kettle-lioles in the high terrace of this age are in part due to masses of ice covered deeply by the sands of musual floods and remaining for long periods in the frozen soil. We may be reasonably sure also that no time elapserl between the disappearance of the ice and the full occupancy of the valley by the flood waters. The frontal lobe of the ice was buoyed up and floated away in the advancing water's.

From the first disappearance of the ice the waters were never lower than 180 feet above sea level in the central part of the State until after the culmination of the flood period, when the waters began to settle to their present level, because over the broad area where the clays have been left undisturbed they are continuous from this level downward, and show no intercalation of pebble or sand beds and no interruption of their regular lamination, and they extend clear across the valley from the Pelham range to Northampton.

While these "Champlain" clays were being laid down over the broad bottom of the valley its swollen tributaries were bringing in coarse material along its borders, and the waters of the lake itself were eating into its banks, sweeping off the loose glacial débris and wearing narrow shelves in the rocks themselves, and especially cutting deep into the sides of the great drumlins which are so abundant on both sides of the valley, and carrying the material so gained out into deeper water. It is quite certain that but a small portion of these shoreward deposits have been carried far sonth by the flooded river itself. They are the confluent deltas of its tributaries. Where we can trace the layers of the clay and their delicate sand partings shoreward, we find the latter growing coarser and thicker, and passing continuously into the thick sand and gravel layers which form the "front set" beds of the deltas and bars. The fine flat clay layers continue on unthickened up the delta fronts, more and more separated by the thickened sand layers, and grade into fine sand or are prolonged only as the partings between the thick sand or gravel beds. Hence we may be sure that the great body of the central clays is strictly contemporaneous with the great body of the shoreward gravels, and that the whole has the character of a lake deposit.

We shall need all the light we can obtain in our attempt to reproduce the history of the valley from the reestablishment of the drainage to the subsidence of the waters. The stream may have been at first like the body 
of water which flows out from under one of the Greenland glaciers; then, like the great river Yukon, with its vast volume and lakelike expansions, and finally, like the Rhone, heading in a glacier among our smaller New England Alps. As we trace around the valley the great bench which represents the completed work of the chain of lakes, we must imagine the waters up to and over its level, the tributaries entering at its outer border, ${ }^{1}$ and the deep notches they have cut in the bench, as in later time they followed the lessening waters toward the center of the basin, again filled to its level. We must restore also many smaller gulches cut in the bench where there are now no ruming streams. We must be on our guard for places where, from want of material or the rapid flow of the waters in contracted places, the bench, was not built up to the full level, and, most difficult, must try to form some estimate of the amount carried away or rearranged by the river itself as it sank from its greatest height to its present level. We must inquire also whether kame material-stratified beds formed while the ice still held the waters above their normal leveldoes not blend with and disguise the true terrace of later time, and from a stndy of the imner structure of the beds must seek to learn whether it rose gradually to, or asserted from the first, its highest level.

In no part does the map need more to be supplemented by sections than here, for it can show only those portions of the lake-shore deposit which have escaped degradation and of the lake-bottom beds which have not been molded anew by the river into terraces of a later time and covered by the layers of river-bottom sands and loess $\left(\mathrm{t}^{\frac{1}{2}}-\mathrm{t}^{4}, \mathrm{Pl}\right.$. XXXV), which have for the most part thinly concealed rather than replaced the more massive deposits ${ }^{2}$ of this age. 'The word "terrace"-which we employ in geological discussions with a latitude of meaning for the most part. useful but sometimes liable to be misleading or indefinite, and which from the great development of this structural form along the Connecticut always suggests here the ordinary river-erosion terraces-I am inclined to replace by the word "bench" in the following descriptions, to emphasize the many points of distinction between the highest level as compared with the remaining levels we pass over in going down from the high ground to the river.

If we take a single terrace lower in the series for examination, we shall find it a plain sloping with the river and bordered on the side away from

\footnotetext{
' Outside ls h on Pl. XXXV.

${ }^{2}$ Seo G. K. Gilbert, Outlet of Lake Bonneville: Am. Jonr. Sci., 3d series, Vol. XIX, 1880, p. 341.
} 
the latter hy at searly rising up from the terrace (the bank of the river when the teriace wals part of its bottom), and limited toward the river by a descending scarp) which wals the river bank at a later time, generally when the terrace mate part of its flood plain. Corresponding to this, we shall fiml the plin covered with the meadow loam laid down in the floods of the river, and under this loam the strong river-bottom sands of an earlier date, the last underlain meonformably by older deposits which the river had not reachert and eroded while it flowed above them.

On the other hand, we shall find the highest terrace or bench bounded outwardly by a slope which, as to its material and structure, has no relation to the river. At most, the river has undermined this more or less extensively at the water level, and, by caving, an escarpment of till, sandstone, or gneiss has resulted. The terrace itself, widening into extensive sand or gravel plains where the alluvial cones or deltas of the side streams were thrust ont into the lake, narrows in places remote from these, and its level is often represented by shelves in the sandstone scarcely covered by sands, $o r$ in the till deeply concealed by gravels concentrated from the till itself. Pursuing the same level, we soon come upon the continuation of the normal sand beds which make the bulk of the bench.

Inwardly, however-that is, toward the center of the lake-especially around all the Hadley basin and its prolongation in the Deerfield and Easthampton valleys, the terrace is for the most part bounded, not by an escarpment of steep and constant pitch-an abandoned river bank-but by the slope of passage from shallow to deep water. This is sharpest and most constant on the face of the large deltas (but here of less angle than in the former case, as the highest angle at which sands come to rest under water is less than that assumed in air), less and less marked in other places, until at last the case occurs where from the rocky bank the sands pass with gentle and contimous slope to the deepest central line, where was the thread of the current, and rise in the same way to the opposite bank.

This slope of passage I have called a scarp of deposition, or, as locally synonymons therewith, the delta front, in contradistinction from the ordinary scarp of erosion. On the map the normal high terrace or bench $(1 \mathrm{~s} \mathrm{~h}, \mathrm{Pl} . \mathrm{XXXV})$ and its widening into great delta flats are not separately indicated. One passes by a scarp of deposition to the broad area of the old lake bottom ( $\mathrm{b} \mathrm{t}$ ), which was synchronous with the bench itself. 
The three great water areas indicated already were sufficiently broad and sufficiently separated to justify one in calling them lakes, and these two terraces would then be called the lake-shore and the lake-bottom deposits $(1 \mathrm{sh}$ and $\mathrm{l} \mathrm{b} \mathrm{t})$. This is further justified by the lakelike mode of accumulation of the sediments in these areas, and allows me to use the term "old river bottoms" for the abandoned beds of streams in old oxbows.

The second terrace or the old lake bottom, unlike the other terraces, is a surface depending, not upon the level of the water at the time of its formation, but upon the water level and the amount of material. The valley widens sonthwardly, which lias the same effect as if the supply of material decreased in this direction. As a result, the lake-bottom level sinks gradually as one proceeds toward the south relatively to the lake bench, $o$ the deposition scarp which separates the two increases in height. The third terrace, counting from the shore line, is generally the uppermost flood plain of the normal Connecticut River.

This brings about the curious result that the second and third terraces change places as we go south, the change taking place between the Mrontague and the Hadley lakes; that is, the Montagne Lake was a filled-up lake, and as we go inward from its shore line we pass by a slight scarp of deposition to the remnant of the lake bottom at a level but little lower than that of the bench itself. We descend next by a scarp of erosion to a marked terrace $\left(t^{t}\right)$ that crosses the northern line of the State with a height of 310 feet, which I lave often called the intermediate terrace or the Lily Pond terrace, formed during the early decline of the flood by the rocky barrier at the Lily Pond in Gill (see Pl. XXII, p. 724). This is at times broken into two or more terraces. We descend then finally by an erosion scarp to the group of terraces but little above the present flood plain of the river, and still lower to the incomplete terraces which lie below that level, both which groups have been formed by the river in its present size and condition. The intermediate terrace $\left(t^{4}\right)$ was thus excavated in the lake-bottom beds-that is, inside the lake bottom.

Farther south, in the broader Hadley Lake, the filling had not progressed far enough to obliterate the lake, and the equivalent of this third terrace $\left(\mathrm{t}^{4}\right)$ is found as the first terrace below the bench, generally slightly marked and excavated in the upper portion of the deposition scarp which had connected the shore and deep-water deposits of the highest floods-that 
is, outsite the like-bottom cleposit. In the first case the order is, (1) lake bench, (: $)$ lake botton, (3) 310-foot terrace $\left(t^{4}\right)$; in the second, (1) lake bench, (2) the continuation sonth of $t^{4},(3)$ lake bottom.

In other words, the Hadley Lake continned through the whole period, and its lake-lyottom beds are, strictly speaking, a little later in age than those of the northern basin. It seems by far best to represent all the lakebottom deposits by one color, as I have done.

DETAILED DESCRIPTION OF THE FLOOD DEPOSITS IN THE MONTAGUE BASIN.

This description is in continuation of the interesting account of the terraces of the Connecticut in New Hampshire given by Mr. Warren Upham in the Geology of New Hampshire, Vol. III, page 19. I may mention that I accept the criticism of Professor Dana ${ }^{1}$ of the view taken by Mr. Upham, that the deltas thrust out into the main valley are often above the highest "normal" terrace of the flood time, and consider these deltas as marking by their levels the true height of the flood waters, and look upon the lower level of the highest terrace which connects these deltas as explained by a lack of material in the intermediate spaces. I can not, however, accept the other criticism of Professor Dana that the esker traced down the valley by Mr. Upham has no existence as an earlier structure antedating the flood gravels of the open valley.

The Montague basin is narrow-about a mile wide-where it enters the Warwick quadrangle in Vernon (Pl.XXXV, C), and it retains this width across the area, connecting at the highest water stand westward around Mount Hermon with the northern or Greenfield lobe of the Hadley Lake. As it enters the Greenfield quadrangle at Millers Falls it widens to above 6 miles, and is connected again at flood level by several narrow passes in the trap ridge with the northern lobe of the Hadley Lake at Greenfield. It connects by the narrows at Sunderland with the main Hadley basin. It was a nearly filled-up lake. The main stream quite filled its rather narrow valley down to Millers Falls, where it widens, and here the heavy contributions of the Millers River filled the whole widened valley. The distinction between the shore flats $(\mathrm{s} \mathrm{h})$ filled to the highest effective level of the

'Am. Jour. Sci., 3d series, Vol. XXII, p. 451. 
waters and the unfilled portions $(1 \mathrm{~b} \mathrm{t}), 10$ to 50 feet lower, can be clearly made ont. Kames rise out of the shore flats, which are often kettle-holed and plainly deposited in the presence of remnants of the ice; but there are no continnons and important "moraine terrace" beds fringing the eastern rocky slope and raised above the flood level of the waters. These shoreward plains sink by easy construction scarps to the bottom flats in which the erosion terraces $\left(t^{4}\right.$ to $\left.t^{\frac{1}{2}}\right)$ have been cut.

THE NORTHERN LOBE OF THE LAKE.

From the hill which overlooks the hotel in Sonth Vernon, Vermont, just on the State line, one sees the river for a long way northward flowing in a narrow channel bounded on both sides by high lands which slope rapidly to the stream and leave place for only narrow terraces. Nearer, the sand flats spread westward from the river around the base of a prominent hill (t) which rises to the north, and bending north surround this hill. The sands are very thick, and seem to rise a little above the highest probable flood level for this latitude, about 400 feet, which would indicate that they were bronght in behind this hill while the ice filled the main valley and were not wholly planed down by the later stream. Around the south spur of the hill east into the open valley the sands sink rapidly to the lake bottom at 322 feet, as they failed to receive further protection in the lee of the hill, and the plain of fine sand sinks riverward to 307 feet, and is continued in a remnant which lies just north of the station with a height of 297 feet, cut off from the rest by an old channel of the river.

The old lake bottom commences again just opposite the hotel in South Vernon, it having been cut away by erosion at the State line, and extends southward as a broad, level plain, down the center of which the road to Bernardston passes. On its ontside it rests for more than a mile against the rocks, which rise first abruptly and then more gradually, and present a rugged and irregular surface, thinly covered by loose till. On this surface the river has deposited nothing. Where the Bernardston road monnts from $t^{4}$ to the top of this terrace a section showed-

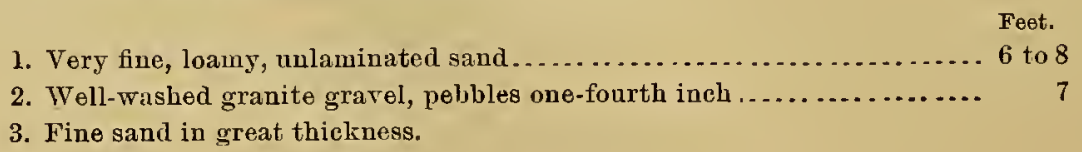


The upper stratum extenterl over the whole surfice of the plain and seems to have been depositerl when the river reached this level only in its Hoods. Following down this plain $(\mathrm{l} h \mathrm{t}$ ) for more than a mile one is confirnted by an great escarpment which stretches obliquely across the road from the rock hillside to the river bluff, and rises 80 feet above the lower 1hin, or 380 feet above the sea, and reaches 400 feet when it rests against the roeks. Seen from the hills across the river, its upper edge is sharply preserverl and its horizontally fluted slope is clearly a portion, preserved intact, of the riverward face of a great submerged bank and not a streamcut scarly. The road rises to the surface of this high plain next to be described.

THE BENNETT'S BROOK PLAIN, OR MORAINE TERRACE.

The plain stretches far southward into Bernardston and Gill, expanding rapidly to more than a mile in width. It is the true high terrace or bench $(1 s \mathrm{~h})$ of the Montagne Lake. The surface is as level as any river terrace for more than a half mile back from the edge overhanging the river, and for a long way sonth. A small reef of rock projects above the general surface near its northern end, and the gravel is scooped out in front and along the sides, the grooves running out sonthward into the common level of the plain exactly as the sands are hollowed out around the pier of a bridge. Shallow, empty watercourses run over its surface and toward the river.

With these exceptions the plain shows a true level as one rides along the road or crosses it at any point going east toward the river, a distance in many places more than a half mile. If, however, one goes westward to the mountain, taking, for instance, the field road to A. Whitehead's, north of the Lily Pond, in about 100 rods flat hollows begin to appear, at first only 5 to 6 feet deep and 20 to 30 feet in radius, but growing deeper and closer together until the whole surface is covered by regular kettle-holes about 20 feet deep and separated only by narrow ridges which rise everywhere jnst to the level of the plain, and the road goes up and down as if it were built along the edge of a saw. Farther on the cols between these hollows grow lower, and by degrees the kettle-holes merge into broad, irregular depressions, several of which are occupied by ponds 50 to 75 rods long and about 40 to 50 feet below the general surface. These ponds were almost wholly dried up in the dry time when I examined them, and showed 
flat sand bottoms out over which peat meadow was spreading. The road we have followed ends in a depression, elongated in the direction of the old shore line and extending to the mountain, which has been further hollowed out by the brook that now runs in it.

The striking peculiarity in comnection with the appearance and gradnal development of this system of kettle-holes is that they are excavated in a quite level plain, and from a distance one would have no suspicion of their existence. At first they do not interfere with the manifest levelness of the surface, and as they grow deeper the ridges between them are flattopped and of the common level, and only as the depressions are crowded together do the ridges become at first sharp-edged and then sink into passes between the hollows, until, against and running southward parallel with the mountain, there is a broad space where almost everything has sunk irregularly below the common level. Along this line the surface of the plain is made up of finely rounded gravel, with cobblestones 6 to 12 inches across, and the exposures in the roadside where the highway descends on the north are of the same material for perhaps 20 feet downward from the surface. Farther south Bemmetts Brook rums across the plain to the river, at the bottom of a gorge 140 feet deep, bounded by a single steep sand slope on either side, without as yet cutting down to the ledge.

Following the northern road down the slope to the ferry, one finds that the great plain is here, on its fiont edge, also made up above of finely rounded gravel of great thickness, consisting of cobblestones 6 to 12 inches in lengtl. Below a point 80 feet above the river, or 280 feet above the sea, fine, horizontally laminated sands underlie the gravels, and similar fine laminated claylike sands appear at the same height in the road going southwest up from the same meadow. The surface of the bench remains unchanged to and beyond the railroad crossing. Here, just on the south line of West Northfield, the configuration of the surface was originally much modified by the great quadrangular mass of Mount Hermon, which rises in the midst of the plain. The surface of the latter was depressed by the sweep of the waters around this obstruction, especially on the west, where they entered the narrow passagervay between this hill and the border of the basin, a passage through which the road and the railroad now go, and this is expressed by the sinking of the plain eastward from 375 feet at the raihroad crossing to about 330 feet at the eastern brow of the terrace. 
Yearer the obstruting lill a brook hats taken advantage of the depression and, as hapjens very often in similar circumstances-so often, indeed, as to make it the rule-lats worn down between the hill and the terrace gravels, shjping down, as it were, upon the northward-sloping side of the sandcovered drumlin and eroding for the most part in the sands of the terrace. The plain is, however, elearly continuous through this pass around the west side of the hill; on the east side it has been removed or terraced down to lower levels by the river. "A distinet esker ridge, elevated about 20 feet above the level of the plain, and older than it, runs along sontheastwardly through the pass and near the momtain side, ending opposite the second crossing.

Sonth of the village of Gill for a long distance lower terraces abut directly upon the steep rocks, and only traces of the high terrace bench oceur where the road comes down from the hill to the Northfield Farms ferry. A section in the latter showed abont 20 feet of clay, its surface about 70 feet above the river and 150 above the sea Above this are sands. From this point the vertical rock wall of the canyon bounds the river, and the high terrace disappears, except in traces, until one reaches Turners Falls.

THE EXTENSION OF THE FLOOD GRAVELS WESTWARD THROUGH TIIE BERNARDSTON PASS TO JOIN THE HEAD OF THE HADLEY LAKE IN THE NORTH OF GREENFIELD.

North of Mount Hermon the mountain side, against which on the west the great bench we are following has rested, swings abruptly westward and continnes-maintaining its height_-westward to Bernardston. Between this lillside and Mount Hermon the gravels of the Bennetts Brook plain extend westward through a narrow pass, 200 rods wide, which I have for convenience caller the Bernardston Pass. This is occupied by the highway and the railroad ruming past Bernardston. The gravels are naturally lowered in the narrow portion of the pass, but rapidly regain their high level of 392 feet as the pass widens soutliwestwardly and the sands expand into a broad, very level plain which widens north up the fiord valley of Dry Brook. It donbtless owes its abundant sands largely to the great stream which flowed down this valley, and its freedom from kettle-holes is due to the fact that this stream continued to flow after the main current had censed to flow westward through the pass and the ice had completely melted away beneath the sands. 
On the south the plain ends very abruptly over the basin in which lies the village of Gill, and Dry Brook has been kept up to the level of the plain by a reef of schist which rises in its front edge and over which the brook falls rapidly into the rounded valley below. The latter is a high basin, with sides and bottom of till, and how far it has been filled up to the flood-plain level and then cleared out again by Dry Brook and its many tributaries it is hard to decide.

Westward across Dry Brook the high plain is soon again supported on the south side by high ground, as well as on the north, and soon begins to develop kettle-holes and merges into a kame area exactly as described in the last section. Its surface dips very slightly westward, it being 396 feet high at its eastern side, 392 feet at its western border, where it begins to break up into kettle-lroles, and 389 feet farther west in the middle of the kane area.

To one looking down on this broad area of intricately reticulated gravel ridges, short kames, and interrupted plains, the whole forming a typical "kame landscape," it seems clear, from the configuration of the surface and the trend of the broken ridges, that the current flowed west into the Greenfield basin. A restored surface carried through the highest portions of the ridges sags along the middle and cuts the high ground north and south like a shore line.

The material also in the pass consists largely of pebbles-mostly under 6 inches in diameter, but some a foot long, in part quite well worn but in part only battered-of the common gneiss and quartzite which abound in the main valley farther north. Westward beyond the narrows the gravels grow much finer.

In the western part of the kame area in and south of the village of Bermardston the pebbles are almost exclusively of the dark mica-schist and the black argillite which occur wholly northwest of this point. This is notably the case in the "Bernardston picnic grove," sonth of the railroad station, where is the north end of a continuons esker which extends a mile or more southwest into the Greenfield basin. Here the pebbles rarely exceed 4 to 6 inches, and are as finely worn into flattened discoid and ovoid forms as on a sea beach.

A kame ridge where the road branches north, just before it goes down over the bridge to enter Bernardston village (opposite E. M. Slate's), gave 
this section: Coarse sand and gravel, 2 feet; medium buff sand, 4 feet; fine, even-bediled simd, 5 feet. 'The ridge was 20 feet wide and the layers 'resser' it horizontally, as if they had been eroded on either side. A little finther west, down the hill toward the bridge, the gravels were found to be coirse and seareely bedded at all.

Every thing shows that the floods swept west through the Bernardston Pass and, joined by the waters coming down the extensive upper valley of Fall River at Bernardston village, passed into the Greenfield basin.

THE OLD COURSE OF FALL RIVER.

Commencing high up in the valley north of Bernardston, Fall River is bordered by a broad, flat plane $\left(\mathrm{l}^{1}\right)$ that has been cut in a heavy sand deposit which once filled the bottom of the valley, forming the lake bench, and which in part still remains intact on either side of the alluvial bottom of the river. At the bridge in the village of Bernardston this plain leaves the river and skirts the west edge of the kame area, being bounded on the west by West Mountain, and extends southwesterly into Greenfield, where it merges with the lake bottom of the Greenfield basin, above which the esker ridges project for a distance and then are finally submerged. The river, on the other hand, does not follow this lower plain, as would seem natural, but runs from the bridge due south, in a deep, narrow channel, cut in the nuch higher kame area, and then among the drumlins and the sandstone ridges to the Connecticut.

It seems to me certain that when the waters of the Connecticut became confined to the main valley to the east, the stream coming down the Bernardston Valley continued to run southwestward by the now abandoned channel, aud cut down and flattened the kame material into the broad, flat, lakelike watercourse which now remains, and which forms now, near the town line, a low divide from which a small brook runs back into the main stream and another on to join the Leyden Brook, in the rest of Greenfield. The continued melting of the ice beneath the kame area at last dropped the sands so low that the stream suddenly found a new course opened to it directly south into the Connecticut.

It can be clearly proved that the flow of the glacial waters in the Bernardston Valley commenced long before the ice had lowered so far that any connection with the main valley can have existed, for the esker ( $k$ ) 
that starts at the mouth of Fall River Valley, in the Bernardston picnic grove, runs south, rising over a col between two drumlins east of the road to Greenfield, at a much higher level than the plain to the west, here described as the old course of Fall River, which was at that time still filled with ice. It can be seen further from this section that the abundant flow continued after the waters had ceased to flow from the main channel through the Bernardston Pass. An inspection of the map will make it clear that the deep Fall River Valley must for a long time have been a main artery of drainage.

When the waters went through the Bernardston Pass the ice had mostly melted far north up the main valley; but a remnant was submerged beneath the sands along the border of the stream in West Nortlifield, causing the kettle-holes of the western border of the Bennetts Brook plain (see p. 617), and through the pass the waters spread their gravels over a considerable but gradually diminishing body of ice. At the same time the great volume of water which came down the valley of Fall River also flowed over ice, and thus were formed the esker ridges of argillite pebbles which project out from this valley and blend with the gneiss gravel brought through the pass from the main valley. A great mass of ice filled the basin of Gill, and thus completed the walls of the pass and prevented the flood from filling this basin, as they naturally would have done.

When the flood had so far receded that the waters of the nain stream no longer went through the pass, the waters of Fall River continued to flow into the Greenfield basin, carrying a large volume of the kame sands southward into this area and smoothing out the broad plain which still extends between the two, until, by the sinking of the ice, its southeastern border was breached and it found exit across the kame gravels south into the drift region of Gill by way, apparently, of its reopened pre-Glacial bed.

\section{THE BENCH ON THE EAST SIDE OF THE RIVER IN NORTHFIELD AND ERVING.}

The hills are set back on the east side of the valley at about the same place as on the west side, and the high sands expand eastward across Hinsdale and the corner of Winchester, in New Hampshire, up the valley of the large Perchee Brook and continue southward with a width of 200 to 400 rods across Northfield and. Erving. The rock surface is everywhere 
quite high, often up to or above the 300-foot contour, and the layer of till above this is generally thin and not molded into drumlins as on the west side. Hence the bench sinds are generally not of great thickness. They represent mininly the deltas of Perchee and Northfield brooks.

At the head of the deep recess formed by the southwestward trend of the valley's rim in the corner of Winchester, New Hampshire, is the apex of the delta of Perchee Brook ( $\mathrm{s} \mathrm{h}$, Pl. XXXV, C), at 392 feet above sea. It consists of coarse deposits, with many rounded bowlders of porphyritic granite, even up to 2 or 3 feet in diameter. The brook runs at the foot of the rocky ridge nearly to the State line, and all its delta is on its south side. From its apex two roads rm toward Northfield. The eastern runs south at the foot of the cliffs and marks the eastern shore until, at $\mathrm{L}$. Lyman's, it turns into the plains toward Northfield street. The western follows the brook until, just over the State line, it goes down from the bench to the next terrace level $(\mathrm{l} f)$ at 320 feet.

Between these two roads rmus a great island of till in the midst of the delta plain. Just at the foot of this hill, on the side facing the head of the delta, is a triangular pond, 800 feet on a side, depressed 30 feet below the level of the plain, its concave base embracing the island and its apex pointing toward the head of the delta. From the other end of this island a sandy esker ridge (k) extends southwest for a long distance, and just south of Mr. D. L. Moody's main school building a cutting showed about 10 feet of well-sorted sands; but I was informed that a little below coarse bowlder beds occur.

What is most remarkable in the deposits of this delta and its continuation sonth in the high terrace is the great accumulation of fine sand. Soon after leaving the hills the brook has cut deeply into these sands, and all the brook sections in the neighborhood are in like material. Following the brook down to where it descends sharply over the rocks to the river plain, these sands are seen to rest on clay at a height of 290 feet above sea. Here a line of springs marks the base of the sands, and immediately below abandoned clay pits occur; as they do southward at various lower points in a gorge cut by a tributary of this brook and farther south by the roadside, showing the clays to be continuous below the level of 290 feet. Following the terrace sonthward, shallow depressions begin to appear in it, and opposite the village street it has developed abundant well-formed kettle-holes 
and is made up of coarse gravel, containing cobbles up to 6 inches in length. Its front edge has a height of $\mathbf{3} 60$ feet where it sinks down by a steep scarp to the level of the Northfield village plain $(1 \mathrm{~b} \mathrm{t}$ ). At its foot a brook runs northwest into the Connecticut, which has cnt a notch in it, but has made no delta projecting out onto the terrace below, showing that when it was effectively eroding the main stream was also strongly eroding, and carried on all its contributions. This is the case, also, with all the tributaries down to Millers Falls.

South of this brook the high terrace $(1 \mathrm{~s} \mathrm{~h})$ is continuous, but narrows rapidly, and by the side of the road going up to F. Johnson's, just north of the single drumlin marked on the map, a section occurs in coarse gravel much contorted. From this point the great sand masses of the next lower level — the old lake bottom ( $\mathrm{b} \mathrm{t}$ )—which are here nearly a mile wide and extend southward for over 2 miles in the great "Beers Plain," lave been thrown up in a wilderness of sand dunes, thus obliterating almost all trace of the scarp which once connected the two levels.

The plain of Northfield village, at the third level-305 feet $\left(t^{4}\right)$-is thinly covered with sand. Immediately below is till or ledge, but southward the rock lies much lower, while the level of 300 feet is maintained by a great volume of sands. Southward these sands rest upon finer material. Just over the railroad, on the road west from the station, 20 feet of coarse sand, dipping S. $20^{\circ}$, rests upon very fine, horizontally bedded sands with a single layer of fat clay 18 inches thick. The former stratum was laid down while the stream was forming the terrace $\left(t^{4}\right)$; the lower is the umeroded portion of the lake-botton beds. Their present eroded surface is 250 feet above sea, and they are exposed with a thickness of 42 feet, and no bottom is seen; nor do the sands vary.

Just south of the village street, where two brooks come together and run under the railroad, the same sands rest, at a height of 270 feet above sea, upon blue banded clays, the fat layers being one-thind to two-thirds of an inch thick, and the intervening layers of sandy clay 6 inches thick. Four miles farther south, at the ferry at Gill station, the clay layers are one-half of an inch wide and are separated by layers of fine sand 2 feet thick. Farther south, below Northfield Farms, the Four-1nile Brook has cut through heavy clay beds rising about 260 feet above sea.

The above figures show that the basin was filled up with fine bedded 
sands and wings to 290 feet at its north end and 260 feet at its sonth end, a descent of 30 feet in 7 miles, and the surface of the light terrace slows about the same descent. As this slope is wholly inconsistent with the aceumulation of thick beds of fine laminated clays, some part of this difference may be assigned to a post-Glacial elevation increasing northwardly, of which we shall find many other indications.

The order of events in the basin seems to have been, in brief, as follows: The broad shoreward gravels of highest level began to be bronght into the basin before the last remnants of the ice had been melted, those on the west side largely by the main stream, those on the east side by the tributaries. Then far to the south the great delta of Millers River, as detailed below, was thrust across the narrow outlet of the basin, ponding back the waters and allowing the deposition of the great thickness of fine sands and clays. The coarser delta deposits were continued out over the finer, unconformably in a sense, and completed the filling of the valley.

Where the highest floods failed to plane the earlier beds down fully they remain as kame ridges. When the floods ceased to rise over these highest flood plains before the ice had wholly melted beneath them the latter are kettle-holed.

THE MILLERS RIVER DELTA. THE GANTON AND OLD COURSE OF THE CONNECTICUT.

The section of the flooded Connecticut which we have above described might very properly be treated separately as the Northfield Lake. It wonld include just that portion of the valley which is portrayed on the Warwick sheet. The valley expands at the north border of this sheet, and soon contracts again to the north ( $\mathrm{Pl}$ XXXV, C).

The high terrace which we have followed south along the east side of the valley as a narrow bench of sands applied to the high, rocky valley side, widens suddenly south of Northfield Farms, extends entirely across the valley proper, and abuts on the west against a steep ridge, called Mine Hill. The river does not, as heretofore, erode its channel down the middle of this plain, but escapes sonthwestwardly from the corner of the basin through a deep gorge of its own cutting, between the ridge of crystalline rock mentioned above and the Triassic conglomerate.

MON $\operatorname{xxIX} \longrightarrow 40$ 
A "dry brook" has cut its notch part way across this plain, just west of the railroad, trying ineffectually to replace the river, and the contours on the north slope of the plain bend south toward the brook gorge.

Millers River, emerging from its portal in the eastern rock border of the valley, makes almost immediately a remarkable curve, turning first south and then $180^{\circ}$ round through west to north, and then runs north, skirting the Mine Hill ridge, to meet the "dry brook," and then with sharp western turn it cuts through this ridge to join the Connecticut.

This is one of the most beautiful spots in the State. The Connecticut comes down from the north in its rertical-walled canyon, its waters foaming in rapids around the great pudding-stone bowlder amidstream, still called the "French King," from a tradition that in the old French wars an expedition dropped down the river to this point and a venturesome officer pushed his cance to the head of the rapids and broke a bottle of wine on the great rock, claiming the land for the French King. The broad stream then bends sharply northwest and flows strongly in its deep gorge, while just at the bend Millers River comes down over the rocks in a picturesque fall, flanked by a ruined mill. The fall has scarcely worn back at all from the mouth of the stream, and the whole impression is one of recency.

Looking down on this Montague plain from one of the high hills east of Millers Falls, one easily restores the beds eroded by Millers River, and then the plain is seen to be the northern portion of its great delta, expanding northward up the narrower part of the valley of the Connecticut. In following this plain down from its north end, opposite the point where the main stream enters its rocky gorge, a distance of about a mile, one finds that the sands grow coarser and coarser and grade into gravel, and opposite the point where Millers River leaves its rocky canyon in the eastern wall of the valley - that is, at the head of the delta-many of the beds are of very coarse gravel alternating with sand beds, showing the coarsest flow-andplunge structure. Moreover, the plain slopes sonthward quite rapidly, its elevation being 362 feet north of Millers River and 350 feet south, at points 3,000 feet apart.

That the delta deposits of the tributary could have been extended north against the current of the main stream more than a half mile proves that the current of the main stream conld not have been very strong, and the southward slope of the surface of the delta indicates that the land was, there relatively depressed toward the north and has since risen. 
From Northtield Farms the Connecticut River runs in a canyon, with sandstome on the right bank and crystalline rocks on the left, and at the mouth of Millers River it turns west and northwest for about 5 miles to 'l'urners Falls, cutting' off' a corner of the Gill sandstone massif, and then runs south, skirting the diabase ridge of Greenfield. It thus gives place for a great expansion of the delta of Millers River, about 5 miles scluine, a broal elevated sand desert-the Montague plain-which on the sontly sinks by a marked delta front to the low basin in which lies the village of Montague. From Tumers Falls back to the mouth of Millers River one descends from the north edge of this plain by a single great erosion scarp to the level of the river, or to the sandstone ledges into which the stream has cut, thereby preventing any further erosion of the delta beds. In all this latter distance it formerly extended north across where the river now runs and rested against the sandstone, and above Factory rillage a broad remnant of it still remains; and at the mouth of Fall River, opposite Turners Falls, it extended into the basin of Greenfield through the gap in the trap range, and sent a large body of sand by this passage into the Hadley Lake. The river poured with full current through this pass, and it must have been a slight chance which determined it in the direction of its present course and prevented it from choosing a chammel down the west side of the trap ridge through Greenfield.

The Connecticut River was thus driven westward around the great delta and compelled to cut a canyon between the sandstone and the crystalline rocks from Northfield Farms to the mouth of Millers River, and in the sandstone on to and beyond Turners Falls, nearly down to the mouth of the Deerfield River.

The old bed of the Comnecticut runs due south from Northfield Farms past Millers Falls, and thence southwest to join its present bed at the mouth of Sawmill River, in Montague. This course is marked by a line of kettleholes continted in the channel of the dry brook mentioned above along the plain north of Millers River, by the sharp bend of the latter, and by the deep erosion basin that extends south from it. Farther on it is continued by the line of large kettle-holes of which Green Pond and Lake Pleasant are the most important, and by the course of Pond Brook and Sawmill River.

Its eastern rocky border is exposed at the falls which give the name to the village of Millers Falls, in the north of Montague, and at the bottom of the deep cuttings of the railroad just below the Millers Falls station. The 
cuttings for the relocation of the tracks of the railroad running southwest from Millers Falls gave fine sections radiating out from the head of the delta. Besides most instructive sections of kettle-holes, described further on, the opening gave a fine view of the whole structure of the delta (see fig. 41 , p. 668).

At a point near where the two railroads separate, the cutting was 20 feet deep and showed the sands resting on glaciated surfaces of gneiss and diabase, without the intervention of till or clays.

The section showed an extensive body of sands, often exposed 12 to 16 feet in thickness, and cross-bedded in great sheets which dip south away from the head of the delta and represent the advancing frout of the latter. Above this a horizontal layer of gravel, averaging about 3 feet in thickness, and diminishing in thickness and coarseness outwardly, made the surface. This represents the concentration gravel manufactured out of the crossbedded sands of the delta by the floods of the river as they swept over its surface after its fiont had passed farther ontward.

Where kettle-holes had sunk during the flood time, this gravel thickened below to fill the depression, and had plainly been pushed into the depressions from the direction of the head of the delta, the gravels being crossbedded in their thickened portions, with radial dip.

All along the eroded front of the delta overhanging Turners Falls the clays, resting directly on till or sandstone, rise to a height of 250 feet above sea and are capped by the delta sands. The clays have a maximum thickness of 59 feet and are thin-laminated, with the layers 1 to $1 \frac{1}{2}$ inches thick. The clays change upward into the sands by repeated alternations of sand and clay. At the top of one stratum of clay 1 foot thick a single layer was contorted and compressed into acute folds bent over southward and covered by a foot of sand, as if moved by the friction of the waters by which the thick layer of nonlaminated sand was brought in. All above and below was undisturbed.

The illustration, fig. 35 (p. 629), indicates the relation of the beds at the large brick pit south of Turners Falls.

The delta sinks southward into the deep land-locked hollow in which is the village of Montague, and along the bald face of the mountain to the east of the village the terrace is represented only by a narrow bench cut in the till, and farther south cut in the high sands which fill the Mount Toby 
gorge. The high hill of sandstone which rises west of the village is connected sonth with Hount 'Toby by a sandstone ridge at about the height of the high terrace, and it is therefore certain that the old bed of the Connecticut can not have gone, as an inspection of the map would suggest, due sonthwest to join the present bed at the Sunderland line. The Montague depression may have been eroded by the pre-Glacial Connecticut in a great bend directed sonthward. It was more probably ent out of the soft sandstone by the ice dividing on Mount Toby.

Farther soutl, around the west side of Mount Toby, in the narrows which separate the Montagne from the Hadley Lake, as well as along the west side of the river from the entrance of the gorge below Northfield

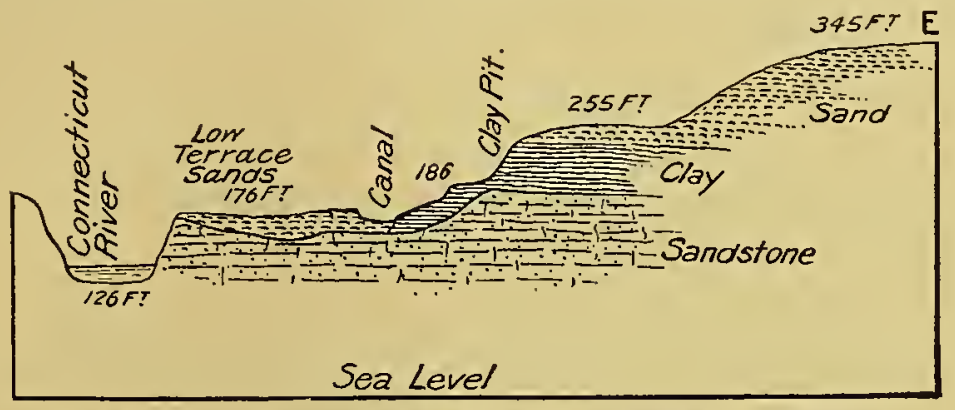

Fia. 35.-Section through the eroded front of the great delta at Montague.

Farms to Sugar Loaf Mountain, the Triassic rocks everywhere approach closely to the present river and the high terrace sands are preserved for the most part only in sheltered recesses.

THE HADLEY LAKE.

THE NORTH END OF THE LAKE IN GREENFIELD AND THE CHANNEL OF CONNECIION WITH THE MAIN VALLEY.

In the last chapter I have traced the waters from the main valley through the Bernardston Pass into the north of Greenfield, where, at the flood time, they widened somewhat into a small temporary lake, whose ontlines, as it extended west across the town, are indicated on the map by the extent of the colors marked $l \mathrm{sh}$ and $1 \mathrm{f}^{1}$, where they are drained by the three branches of Mill Brook.

After the waters had ceased to flow across from the main valley an abundant supply still came down the valley of Fall River and pushed out into this Greenfield Lake a marked delta, and the broad bottom of this 
stream with its delta is marked on the map $\left(\mathrm{f} \mathrm{f}^{1}\right)$ by a color different from that devoted to the lake bottom. The progress of this delta was arrested (as detailed under a preceding heading, p. 621) by the breaching of the high terrace sands and the passage of the Fall River south to the Connecticut. Clay $(\mathrm{lbc}$ ) appears at the surface of the lake bottom at one place, back of the schoolhouse, near the residence of A. Graves. It is abundant and is the only occurrence in this area.

\section{THE GREEN RIVER GLACIER.}

High ground borders Greenfield north and west. In the eastern half of the town all depressions are filled with flood sands, which we have traced into the area through the Bernardston and the Fall River passes. The western half is a deeply sunken area. The two bodies of sand noted above expand westwardly, wrapping around French $\mathrm{Hill}^{1}$ on the north and south, and end very strangely on the west in a high bluff which overlooks the broad, low basin of Green River and Glen Brook.

One goes down from the edge of this bluff by a steep scarp 60 feet to the bottom of the basin, and neither the scarp nor this broad bottom seem to me to be the work of Mill River, which now flows in it, bounded on either side by its own alluvial bottom and terraces.

This valley, which I believe to have been filled with ice while the lake deposits were gathering, stretches along the whole west side of Greenfield. Not only is the mass of sand which must have been removed, if this basin had been filled up at the flood time, out of all proportion to the amount of work done by the other streams in the terrace period, but the bottom of the basin and its eastern scarp is an irregular, kamy, kettle-holed surface, entirely unlike the surface of the erosion terraces of this and the other tributaries of the Connecticut; and the true terraces which border the stream, cut at and below the level of this broad, irregular bottom, correspond in number and extent with those of the other streams.

Again, on the west the rocky and till-covered border of this basin slopes rapidly to its bottom, and opposite each valley notch a great delta heading at a level but little below that of the high terrace, and with its semicircular front untouched by erosion, is thrust far out into the basin, showing conclusively 
that the bottom of the hasin and these high deltas were formed at the same time, which must have becu near the end of the time of the high water stand, when the ice har finally melted after having prevented the filling of the villey. The dissected delta of the Green River itself where it leaves its rocky worge and enters the basin is shown in fig. 36 .

But one traces with great clearness the broad watercourse, with its abundant sands, from Bernardston across the north of Greenfield to where the extended sand flats end suddenly and sink by a great, irregular searp into this basin, and a little farther south the similar watercourse from Finctory Village, near Turners Falls, passes across the middle of Greenfield, and stands in the same relation to the southern part of this deep elongate depression. It must thus have been filled had it stood empty in the way

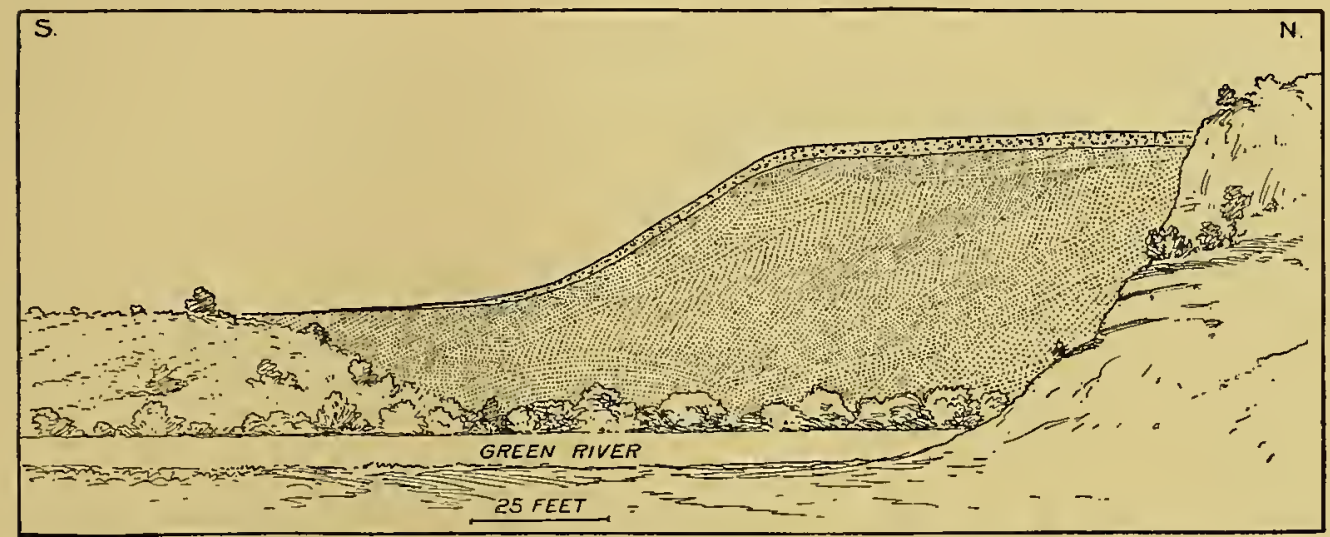

FIG. 36,-Section of the Green River delta at the north end of the Green River basin, where the stream comes out of its rocky canyon, showing that the delta was sent but little into the lake, and its front not eroded.

of these two abundant streams, and I can therefore only suppose that here, in the northwest corner of the valley of the Connecticut, and in this long depression between the mica-schist mass of Charlemont and the red sandstone, a lobe of the ice, sent down the Green River Valley from the ligh ground in Leyden across the whole length of Greenfield, lingered till after the floods had ceased to come through the two passes mentioned above, and after Fall River had ceased to flow west into the Greenfield Lake.

I do not think that the ice stood high above the level of the flood waters in the flood time; but, like the great bodies of ice described by Dall in Alaska, it was submerged beneath the sands as a great continuous body filling the valley and, on melting, allowing its load of sands to drop about 50 feet to their present position. 
THE FACTORY VHLLAGE CHANNEL.

The map shows very clearly the broad watercourse which bends north from Turners Falls and then turns sharply sonthwest and runs, its banks and bottoms well preserved and zneroded, to where it widens out into the broader sand plain of the south part of Greenfield.

This passageway was set free by the ice earlier and was occupied by the Connecticut longer than the passage farther north throngh the Bernardston Pass, and a vastly greater body of material was brought into the Deerfield side valley by this way than by the northern one.

THE HIGH TERRACE PLAINS IN THE SOUTH OF GREENFIELD AND NORTH OF DEERFIELD.

At the end of the Champlain period a broad mbroken plain extended from the south part of Greenfield southward through Deerfield, out of which the channel of Green River and the great basin of the Deerfield River have been eroded. Through the southern part of Greenfield and the north of Deerfield, to near the point where the Deerfield River leaves its rocky gorge, the deposits forming this plain are laminated clays, often 20 to 33 feet thick, overlain by sands reaching a thickness of 80 feet, often horizontally laminated in their lower portions and cross-bedded on a grand scale above.

The section exposed on the south side of the road from Greenfield to Franklin Park, ${ }^{1}$ in the hillside immediately beyond the bridge, is very striking. In the bed of the brook the reefs of bright-red saudstone rise above the water and run under the bank. On this, in the vertical wall facing the stream, is exposed 20 feet of till, dull red and made almost entirely of comminuted sandstone. This is covered by 20 feet of horizontally bedded clay, in layers 1 inch thick on an average, and as one goes up the hillside the clays are seen to be capped by a great thickness of fine sands, horizontally and distinctly laminated, at least 55 feet thick. The upper 20 feet is made up of sands with flow-and-plunge structure and cross-bedding on a grand scale. The section is exposed for 200 feet, and the sands dip with varying and suddenly-changing angle $0-30^{\circ}$, always toward the east. These latter sands vary from fine to coarse.

${ }_{1}$ The broad, perfect plain ( 1 s $\mathrm{b}$ ) southwest of Greenfield and extending to the Deerfield River. 
West aleross the high plain (Franklin Park), from the top of this section to where the railuokd again cuts into it, the sands rise in heavy beds ly a long and slightly curved sweep from north to south. These two sections lie just south of the south end of the great Green River depression mentioned abore. 'T'o the west the wall rises umbroken, and there is no channel down which a considerable stream could have come.

It seems to me that the sands have here been built up to this high level by the water from the Bernardston Pass and Factory village channel coming down over the ice which filled the Green River basin. It is diffieult to see how they can have come from any other direction, and equally difficult to see how they can have been built up here to a broad plain of the height of the high terrace while the above basin remained open and unfilled to the north.

The clays appear abundantly in the south half of Greenfield, where they are used for brick making, and rest on sandstone or till. Farther south, in the southwest corner of the Deerfield River basin, where a brook has cut back in the rim of the basin, is a great exposure of these clays, which for a distance of about 12 feet down from the surface and about the same in from the basset edges of the horizontal beds, have weathered to fine buff clays, while the interior is the ordinary blue clay.

Farther south the upper surface of the clays is marked for a long distance by a line of springs in the bluffs along the west side of the basin. Before reaching the mouth of the gorge of the Deerfield River, however, the clays change into fine sands, and the upper sands also grow finer, and in the southern bluffs of the erosion basin the whole thickness of the old delta of the Deerfield River is made up as illustrated in the Wapping cutting (see Pl. XVIII, p. 694) by 50 feet of the very finest sands, and this continues to be the character of the great body of sands which fill the Deerfield Valley south through Deerfield and Hatfield.

It seems probable that the delta of Deerfield River was thrust across the valley to abut against Deerfield Mountain upon the east, and was elevated more rapidly than the deposits to the north in Cheapside and Greenfield, so that a quiet area of deeper waters existed here, in which the clays were laid down; and later, the current increasing, the horizontal sands were carried in over them, probably through the pass from Turners Falls; and at last the heary floods of the hightest water stand through the 
Beruardston Pass and across the north of Greenfield brought the coarser sands down over the Green River glacier and spread them to build up the broad plain of Franklin Park

THE LAKE BENCH FROM DEERFIELD RIVER SOUTH.

THE DEERFIELIJ DELTA.

South of the erasion basin of Deerfield River the bench ( $1 \mathrm{sh}$ ) consists of the sonthern half of the great delta of the Deerfield-that portion which has escaped the later erosion of the river itself. It spreads out, fanlike, as a broad, flat alluvial cone from the mouth of the rocky canyon of the Deerfield, where it has an elevation of 320 feet, and slopes very gradually to its front edge, which is about 30 feet above the lake bottom, and then drops by a steeper grade to the level of the latter. Its onter boundary is in places not sharply marked, as broad bars molded by the current of the main valley from the abundant detritus furnished by the Deerfield are spread in front of it and render the lake bottom unusually irregular. A cutting of the Canal Railroad, 18 feet deep, passing from the outer border directly to the apex of the cone above Stillwater bridge, showed in beantiful detail the whole structure of the broad delta. It is made up entirely of well-washed sands, everywhere coarser above and finer below. The upper layer varies from 3 to 7 feet, and is made up of coarse sand and fine gravel, well washed and rounded, laid down in broad, lenticular layers, as a whole horizontal or conforming to the slight slope of the surface. Below are fine, whitish, perfectly sorted sands in two grades, fine and very fine. The former are thrown down in layers 1 to 2 feet thick, with delicate flow-and-plunge structure, and dipping at all angles up to $30^{\circ} \mathrm{SE}$. - that is, radially from the old mouth of the river. These layers are separated by other layers, from 2 to 8 inches thick, of the very fine, moist, compact, almost clayey sand, which are thrown down upon rippled surfaces of the coarser, and show a flow-and-plunge structure of extreme delicacy.

In an exceptional case a layer of the very fine sand occurs a mile out in the valley, dipping $15^{\circ}$ SE., which, although bounded for a long distance above and below by horizontal surfaces and contained in undisturbed layers of the coarser sand, is contorted in a very complex way, and 
thin layer's of a coarser sand included within it are so twisted into the mass that they can be followed for only a short distance.

A mile sonth, in the Northimpton quadrangle, in the delta at the road south firom Mill liver village, where Bloody Brook joins Hill River, I found in the same position a layer identical with this in all respects, and it mily be continnous between the two places, and represent a time when the river was clogged with ice, so that its current was stopped and an unwonted thickness of the very fine sands deposited and thrown into confusion by the stranded ice. The layer resembles so exactly the thicker one described from the Wapping cutting (PI. XVIII, p. 694) that one diagram would serve for both.

Farther out, near the outer edge of the bar, the coarse sand and gravel layers thicken downward and pitch sharply southeast in broad, cross-laminated layers, and the finer sands have disappeared or gone below the level of the cutting. It is plain that these latter, which lie below and continue everywhere below the level of the railroad certainly for many feet, represent the front of the delta as it was pushed out into deep water Their varying dip corresponds to the varying slope of the face of the delta, and I am inclined to believe that the thick layers of fine sand ( 1 to 2 feet) represent the product of a single flood, upon whose rippled surface rests in each case the finer deposit of the succeeding winter.

The front of the delta narrows southwarr and is continuous, at the same level, with the delta, also very large, of Mill River, upon which is the rillage of the same name. This is more complete, though Mill River escapes through it in a broad, low plain of erosion, and skirts the hill for a long distance south. Then, for a still longer distance south, across the line into Whately, the bench is wholly wanting. At present the broad lakebottom plain stretching across from South Deerfield abuts against the steep eliffs with no change of level.

TIIE WEST BROOK DELTA.

From Roaring Brook down through Whately the hills have an easier slope and were covered with much drift material, out of which the waters have formed an irregular bench, which is only in part built up to true level. This continues almost to the south line of Whately, where, near West Brook, the bench $\left(l_{\mathrm{s}}\right)$ is again well developed and is very complicated and 
interesting. Long before reaching the brook it rises to the height of 318 feet and widens rapidly into a broad sand plain, across which the brook, emerging from the high lands at the road crossing near a magnificent drumlin (called Belmont) that rises on the north a hundred feet above the plain, runs, over a bed of coarse gravel which is very little lower than the surrounding level, and at the front of the plain falls rapidly over a reef of compact hornblendic granite (tonalite) into the valley below. Just sonth this reef rises in a narrow ridge and runs parallel to and about half a mile distant from the western rim of the valley, southward through Hatfield, to end in Elizabeth Rock in Northampton. At the highest water stand it was a long island in the lake, or rather two islands, as it is broken through at a point in the middle of its length, through which the "Running Gutter" enters the main valley. Into this lateral valley the waters of West Brook carried the greater part of the detritus they were bringing down, and the plain we are following continues at the same high level, quite even and sandy, for a mile farther sonth, bounded on the west by the steep, rocky rim of the valley and on the east by this island; and from the south the sands of the high bench in Northampton enter the side valley west of Elizabeth Rock and pass up it for almost the same distance, while outside, on the east of the rocky island which is called "The Rocks," in Hatfield, the fine sands of the broad lake bottom $(\mathrm{lbt})$ abut at a much lower level directly against the bare cliffs.

On the shrinking of the flood waters West Brook found its way, not down the western side trough into which nearly all its sands had been carried, but, like so many other streams in the valley, by a detour to the north around the north end of the granite ridge. In a similar way Broad Brook, which heads in the broad sand plain north of Florence, runs a long way north up the trough we have just followed south, and breaks through "The Rocks" in the center of the ridge to join the main valley, searching out for itself the most northerly outlet possible.

This is sufficiently explained by supposing that the current of the stream, combined with that of the main stream, kept the sands at a slightly lower level opposite its month than lower down, where they were spread in the long trough of quieter waters, so that on the lowering of the water in the main valley the tributary found its way through lower ground around to the north of the bar; still, the many times this occurs in the valley, under 
rallous circumstances, points to a common cause, and is, I think, commected with the lowering of the mper portion of the valley, thus lessening the pitch to the southward. Brooks firom the north and sonth now join and break through the barrier near the sonth line of Hatfield, and have carried cut much of the sand, so that one can not decide whether the high sands formerly filled it entirely. It is certain that the sands of West Brook spead very slowly sonthward, and that the waters entering by the central break in the ridge spread north and south, throwing down clays up to high level, and that the high delta sands encroached upon them from the north as the growth of the delta went on.

THE MILL RIVER DELTA IN NORTHAMPTON.

Farther south, on the north line of Northampton, the western rim of the valley, which has come down southward from the northwest corner of Greenfield, swing's sonthwestward and runs back of Florence, by the bridge at Leeds, to Loudville, where it turns at right angles and runs for two miles southeast before it regains its southward course. The bay thus formed was studded with a great number of islands, all of till, for the rocky floor lies everywhere deep below the surface. They are the drumlins already described. Into this bay flowed the waters of four large streams, two of which are dignified by the name of river, and they, together, filled the bay and sent great quantities of detritus out into the valley, to be carried southward by the main stream.

Their common delta has been greatly cut away by the streams themselves in their subsequent oscillations as they followed the margin of the great river downward during the period of shrinkage, and one must know the comntry well and draw much on the imagination to reconstruct the broad plain as it formerly spread across from Elizabeth Rock to Loudville and out from Leeds to the border of the Meadows. Mill River has been especially destructive, and, as its mouth advanced from Leeds to its present place, it has worn out all the broad basin in which it flows, and its tributaries have cut out the peculiar depression of the "Bay State." One must think of all this area raised to the level of and merged into the Florence plain in order to reconstruct this, by far the largest delta deposit of the high bench upon the west side of the river.

Along the road from Florence to West Farms, and then to Londville, one rides for several miles over a sand plain ( 1 s h) about 305 feet above sea, 
abutting against the cliffs on the northrwest. Its border against the granite bluffs is exceptionally well preserved, but in places is deeply kettle-holed in the portions adjoining the rocks. It stretches, except where interrupted by drift islands, with gentle slope southward for a long distance, to descend at last more abruptly to the village of Easthampton, its scarp being terraced, but apparently not much cut back, while in Northampton it has suffered much more serious erosion during the formation of the lower terraces.

The apex of the delta of Mill River in Northampton is where the bridge crosses the rocky bed of the stream before entering Leeds. It widens suddenly at Florence. Its extent, apparently out of proportion to the drainage area of Mill River and the other streams that formed it, is due largely to the fact that its sands are spread out among the lenticular drift hills by which the great bay in the crystalline rocks was filled. (See p. 543.)

The cutting along the New Haven and Northampton Railroad made to obtain material for raising the railroads through Northampton gave repeated sections nortl of the railroad, extending from the brook crossing east of Florence to the crossroads next east, a distance of a quarter of a mile. In all the western part of this section (which runs east and west) the sands are cross-bedded on the grandest scale, the layers in the long cut, which was 15 feet high, having a uniform and high westerly dip. In two cases the material suddenly grew fine, and heavy clayey layers are intercalated in the coarse buff to reddish sands. In the eastern portion of the sectionthe part south of the cemetery-the beds bend over and dip east, and are here greatly disturbed and mixed with glacial material by stranded glacial ice.

An inspection of the map will show that the long drumlin called Strawberry Hill, just north of Florence, and the prominent drumlin north of the Bay State, nearly cut off this area from direct communication with the waters coming out of the Mill River gorge, and that these cross-bedded sands must have grown as a broad sand spit extending south from Fortification Hill to the north and made up of material swept south across the Camp Meeting grounds and around the east side of this hill, so that they were thrown down with strong westward dip on the inner (western) and sheltered side of this bar, along the outer side of which the icebergs stranded. 
The southern portion of the delta is composed of the confluent deposits of Mill River and the north branch of the Mamhan. The great glacial lake in Westhimpton (p. 594) served as a catchment basin for sinnds which were carried ultimately by Roberts Meadow Brook and the Mranlan to angment the high terrace at this point. While the sands in Northanpton are in many beds clear gray, showing under the microscope many rounded grains of black mica-schists like those of Goshen and Chesterfield, in others they are reddish from the abundance of garnet grains in them, both peculiarities indicating their origin from the garnetiferous mica-schists in the drainage area of Mill River. The sands of the southern portion of the plain are more largely granitic and are derived from the great granitic area of Westhampton. This may be taken as one of the proofs of the assertion that the high terrace was mainly brought in from the sides of the basin. The great sand plain is continued across to the North Branch, is in all this distance more than a mile wide, and sinks in several great terraces to the clayey lake bottom at Easthampton, and as it nears the south line of Southampton it enters the western of the three passages by which the waters passed out upon the Westfield plain, and just on the town line it received the abundant deposits of the southwest brancls of the Manhan at Russellville, and across the basin since eroded by this stream it was plainly continuous with the north end of the Westfield plain.

Just where the western channel widens by the dropping down of the hill east of East Farms into this broad, open plain the abundant contributions of the branch of the Manhau last mentioned were received and spread clear across the channel, up nearly to the normal high terrace level-the deep water of the lake bottom sliallowing southward in the channel and coming to an end just opposite the mouth of the branch, and marking out thus the channel whereby, on the recession of the waters, the Manhan was compelled to take a course north across Southampton and Easthamptou to join the Connecticut at the head of the oxbow.

LAKE BENCH ON THE EAST SIDE OF THE FADLEY LAKE IN LEVERETT AND AMHERST.

Through the Narrows in Sunderland the bench $(1 \mathrm{sh})$ is well marked. along the west slope of Mount Toby, and turning the corner of the mountain it rests against its south side. It is characterized by fine sands in great quantity, dependent upon the fact that the region is far from the mouth of 
any river, the sands having been carried a great distance by the main stream. Against the north end of Sunderland street it is represented by a horizontal shelf cut in the sandstone. The terrace then widens in the extensive plain of South Leverett which rests against the sandstone mountain on the west and against the crystalline rocks on the east, and runs up into the gorge on the east side of Mount Toby. At its liead, near the railroad-crossing north of the station, it is a coarse gravel with pebbles 6 inches in diameter, and it has a height here of 310 feet above sea. It slopes gently to its front, where it has a height of 290 feet above sea, and is made up of coarse sand.

By recurring to the description of the old course of the Locks Pond Brook down through the Mount Toby gorge to empty into the Hadley Lake at this point (see p. 584) when the ice still filled the Montague basin to the north, the reader will understand my conclusion that the main portion of the great mass of gravel gathered here was swept into its place by the Locks Pond Brook, deflected southward, and only smoothed down to its present level by the waters of the Hadley Lake. I imagine that this deflection of the brook by ice filling the Montague basin may have taken place when the ice had abandoned ail the Hadley Lake except its northern lobe in Greenfield.

Southward, the high terrace is only indistinctly marked against the till for a long distance, as no brooks brought in material here.

THE DELTA OF CUSHMANS BROOK AT NORTH AMHERST AND THE ISOLATION OF THE EAST STREET BASIN IN AMHERST.

On reaching North Amherst we find the high terrace ( 1 s h) developed in great force and, because of the rising of the block of hills north of Amherst Center as a great island in the lake, with considerable complexity.

A great depression, closed on all sides, extends along the eastern line of Amherst, ending on the south at Dwight's station, having the village of East Street in its center and being bounded on the north by the delta of Cushmans Brook.

It is plain that when Cushmans Brook began to flow into the lake there was free communication between this depression and the main area of the lake to the west, across the space now occupied by the delta, and that for a time the sands brought in by the brook were swept southward 
alung the west slope of the Pellam Hills, forming the extensive sand deposits which diank these lills for a long way south. At last, however, the deltir extended across to the rocky hill north of the North Amherst cemetery and exchuder the main current from this eastern basin, and from this time on the sands of Cushmans Brook were swept around west of the Mount Plensint block of hills, bnilding up a great terrace, or rather sand bar, which extends south to the Agricnltural College. The college buildings stind on it, and it ends at the south border of the college farm.

THE BENCH SURROUNDING THE EAST STREET BASIN.

By the extension of the delta of Cushmans Brook across the north end of this basin a separate body of water resulted, connected with the main lake only by narrow channels among the drift hills south of Amberst Center.

The high terrace, continuous sonthward from the extended delta flat at North Amherst City along the flank of the Pelham Hills, is a marked object from College Hill. It appears here, as around much of the valley, as the highest line of cultivation, and above this horizontal line the hillside is heavily wooded. It is a broad sand flat, its material derived partly from the sands brought down from the Leverett Lake deposits (see p. 584) and partly from cutting into the kettle-holed sands carried along the side of the Pelham Hills before the departure of the ice and left at a level higher than that of the lake (m t, Pl. XXXV, C). Fort River, opposite Amherst, coming out of the Pelham basin, adds somewhat to its width, but less than one would expect, the main portion of the sands brought down by this stream having been at an earlier period carried southward, as detailed on page 578 .

South of this stream the terrace is a marked bench cut in the sands thus carried along the slope at a higher level than its own $(\mathrm{m} t)$, and it swings round the west side of the great drift hill north of Dwight's station and continues east as a horizontal bench notched in the south face of the delta of the earlier and higher stream (see p. 589). It was thence continued south and west as a bench cut in the older sands across the entrance of the Belchertown Pass, for at this time the waters certainly did not go through this pass, as the lowest point in the sands across north of the Belchertown ponds is about 30 feet above the high terrace in this latitude. It is continued MON XXIX- 41 
westward along the north foot of the Holyoke range, still as a bench cut in the irregular sands which are heaped so high along its flanks.

SMORE NOTCHES IN THE SIDES OF DRUMLINS.

Along its westeru side the East Street basin is bounded by a continuous line of drumlins, and the high terrace is marked by a horizontal fluting cut in these drift hills. As all the hills south of Amherst village stood as islands in the lake, while narrow channels connected the East Street basin with the rest of the lake to the west, this fluting surrounds them on all sides, and the same was true of the great block of hills north of the village until, by the extension of the delta of Mill River, or Cushmans Brook, it was joined to the mainlaud and made a peninsula.

This horizontal fluting is well shown in the drumlin which rises north of the Methodist Church in Amherst. Starting from the top of the hill, one follows down on either side its regular curved slope for a distance, when it suddenly grows much steeper, and then, at the 300-foot contour, begins a much easier slope. One comes down to this contour line on till, but here begins a shore gravel bed, at first thin, but thickening outward, as its surface has a lesser slope than the old surface of the drumlin upon which it rests.

So long as this East Street basin was open to the north, the water moved through here with considerable velocity in flood time and swept such material as it could erode from the drift hills themselves southward along their slopes (there were no brooks in these isolated hills to bring down material and build up deltas), and so the bench along this side is scantily represented by sloping sheets of gravel concentrated from the till.

Just north of the New London Northern Railroad station, for several hundred feet west of and above the railroad, the bench widens into a considerable sand plain, recently built over. The sands dip south in great sheets, which were pushed over the south front of a deltalike bar and carried south through the notch in which the railroad runs.

Across the village of Amherst the waters of the two basins were continuous. Farther south the fluting is carried along College Hill below the church and the gymnasium. It surrounds the long isolated drumlin southeast of College Hill, and the section through the south end of this hill made by the Central Railroad showed that a great hooked bar of gravel was 
carried out south from the nuclens of till with an anticlinal structure like a nest of inverted cances, a type repeated in connection with all the other isolated drumlins finther south.

At first the axis of the bar seems to have been shifted now to the right and nuw to the left, only part of the deposit of each position being retained permanently. Then the layers are continuous, flat on the top for 30 to 50 feet, and dip east and west. On the west side it was built up with easier slope and finer material, as the bar was being carried south across the somewhat land-locked bay south of College Hill, where it opened eastward into the East Street lake, and the main current, sweeping down the East Street channel, not yet closed on the north, wore a deep fluting into the east side of the drumlin and carried the material south in great sheets of coarse gravel, often 3 to 8 feet thick, to form the eastern slopes of the canoeshaped layers, while, if we follow these sheets over to their western slopes, we find them made up of much finer sand, at times slightly gravelly. At the bottom of the western slopes the sheets run west horizontally for a little distance and then mount up gradually onto fine clays, which latter in turn sink with slight dip eastwardly beneath the sands and below the level of the cutting. This shows that the water stood at this high level for a long time, allowing the fine clays to accumulate (which happened at a ligher level in this sheltered bay than in the deep East Street basin), before the bar was pushed south over them.

The village of South Amberst is built on such a bar carried as a ridge from one drumlin to another, and the road running sonth from the village keeps on the bench around the east side of the great drumlin south of the village, and follows the bar that projects sonthwardly from it to join the high terrace at the "Bay road" along the northern flank of Holyoke.

South of College Hill is a deep depression, just mentioned, sheltered on all sides by drift hills, and never filled up, and another, much more extensive, lies west of the village of South Amherst.

On the decline of the waters a stream draining the East Street lake found its way between drift hills into the first, and from this into the second, of these partially isolated bodies of water, and throngh the western line of drift hills into the main basin, and cut its way down through the drift so slowly that separate terraces were formed around the East Street lake, where the streams entered it from the Pelham Hills. Ultimately these 
streams, uniting in the bottom of the drained lake, completed the erosion of the present sinuous conrse of Fort River, across the drift area south of the college, apparently to a level somewhat lower than the present bed of the river, without striking rock, for the stream now flows over a muddy bottom, and there is no trace of the sheet of bowlders which it mnst have concentrated out of the till. It has, however, sufficient slope for a water power, and the ponding back may have caused it to cover this up, as below the dam it flows over a bottom of coarse bowlders.

THE HIGH TERRACE OR BENCH ALONG THE WEST SIDE OF AMHERST PIDGE.

So long as the water passage from the main basin into the north end of the East Street basin was open, and the sands of Cushmans Brook (or Mill River) were carried down along the flank of the Pelham Hills, the work of the lake waters along the west side of the Mount Pleasant block of hills, and along the west side of College Hill, and its prolongation northward to the head of Prospect street, and of Mount Doma farther south, consisted mainly in the concentration of a coarse, well-washed and wellrounded beach gravel out of the till, of which all these hills are composed.

Becanse of the narrowing of the channel by the hills named above, and by Mount Warner, farther west in mid-channel, the current was here somewhat accelerated, and, aided also by the prevailing west winds, wore with exceptional force into the hillsides along the line we are now tracing, cutting deep into the till along the 300 -foot contour, or a little lower, as the effective erosion level was often somewhat below the highest water stand, and forming thus a broad horizontal or outwardly sloping bench in the till, over which sheets of the concentration gravel spread in bars and low ridges.

The exceptionally steep slope above the 300 -foot contour, often, indeed, slightly concave, which I have called the horizontal fluting, is best developed along the west flank of Mount Pleasant and its continuation north past the Plant House and through the chestnut woods farther north. All the plain south of the Plant Honse has been formed thus by erosion, and the hill formerly extended here as far west as the new road to North Amherst across the College farm.

The gravel spread over this plain in great sheets has been largely used for sidewalks, taken mostly from the pits just south of the Plant Honse. 
where at tew feet of digging exposes the till below. 'This plain sinks away to the next lower level on the west, that on which the Agricultural College buildings are placed, because the old surfice of the till had this configuration and was not fillod up, the onter (western) portion of this latter plain being, however, made up of thick sands through which the brook has cut between the college buildings. This sand is the southern tongue of the delta of Cushmans Brook, carried along the western flank of the Mount Pleasant hill alter this delta had grown across so as to abut against the north end of this hill, and had thus built out the great sand plain which stretches north therefrom, and the main current of the brook, ronnding the hill itself, carried the sand south along its western flank, at a level much below that of the high-water stand of the lake.

Farther south, Mount Pleasant breaks down suddenly, and a short distance to the west a rocky projection at the head of North Prospect street rises 30 to 40 feet above the old high-water stand. This mass of rock, which has now been mostly covered up, used to be called Pikes Peak, and for convenience I will continue to employ that name. Between Mount Pleasant and Pikes Peak the water had free commmication with the East Street basin across the village of Amherst. The water line followed the 300foot contour around the south spur of Mount Pleasant, extended as a rounded bay up its eastern side, skirted on the south the hill on which Professor Tyler's house stands, and so swing around northeast to join the broader terrace above the railroad. (See p. 642.) From Pikes Peak the water line extended south just west of and at the next level below Prospect street for the whole length of this street, turned southeast through the grounds of the president's house, crossed South Pleasant street and ran at the foot of the sharp slope south of the Octagon, skirted the College Hill on the south and east, and on the north ran just north of the Lucius Boltwood house, now Hitchcock Hall, and along the south border of the common, and bending north and crossing Pleasant street it ran north just west of this main street of the village, past the hotel front, to the point of beginning at Pikes Peak. Thus an L-shaped island, with the College Hill as its horizontal and the Prospect street ridge as its vertical portion, rose above the level of the flood waters, which came up almost exactly to the level of the post-office steps. It must be remembered that the level of the college chapel was once contimuous under the Octagon, the library, and the $X \Psi$ house, and that the deep notches 
of the roadways are the result of subsequent excavation, and that the surface is changed by grading north of Walker Hall and the Octagon.

Through this passage between Mount Pleasant and Pikes Peak there was a steady set of the current which has built up the broad area of finely washed and sorted gravels which stretch across and down through the pass and which are well exposed all round the Catholic Church. Southeastward they stretch as a flat of finer sands, with a layer of concentration gravel capping it, across from Professor Tyler's hill to College Hill. The two stone churches and the high-school building are on this sand plain. College street lies so near its border that the houses on the north side have cellars in sand; those on the south side have wet cellars, as they cut through the thin border of the sand and get the drainage which comes down from the College Hill on the surface of the impervious till beneath.

The current swept the sands across in a line from the Catholic Church to the high-school building and the common. An area in the recess of the

N

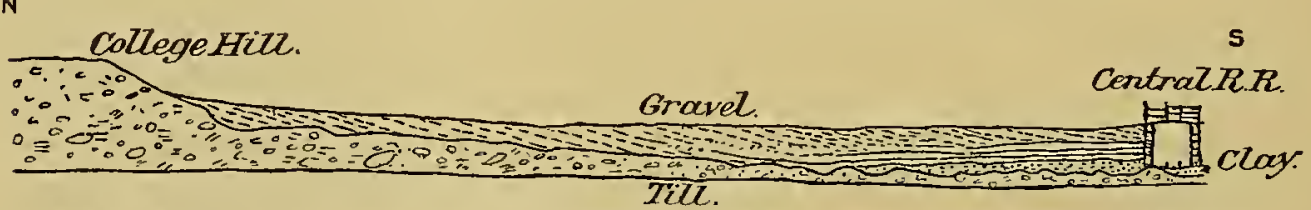

Fig. 37.-Section of shore beds of Hadley Lake south of College Hill, at Amherst. The cutting was 18 feet deep.

L-shaped island, the south half of the common, was not filled up quite to the true level and was underlain by till at no great depth, and so was originally a very swampy place. It has been filled in considerably, and along most of the street to the east and the whole of the street to the west of it the artificial filling has been so great that the waterworks ditches did not reach the undisturbed sands.

Along the whole west side of the L-shaped island the level of Lincoln street is the level of the high terrace. It is a bench cut in the till, very broad, and but little covered by sands, since all that the main stream obtained from the delta of Cnshmans Brook was swept in across the village to the East Street basin.

Thin cappings and bars of sand are applierl to its surface and to the slope down to the lake bottom, and can be well studied from the side of Mount Warner. Along Lincoln street the cuttings of the waterworks struck till for more than half the distance, and along every street which crosses this 
shore line I have at whe time or another had opportunity, in cuttings of the Watter or gals companies, to locate exactly this old shore line and plain.

College Hill breaks down like Mount Pleasant, and sontluwest, at Professor Harris's house, begins another drumlin, named Momnt l)oma (by President Hitcherek), from its regular shape. Between the two the waters passed sontleast into the depression south of College Hill, and a broad, thin sleet of gravel stretches through the pass, and is well exposed in the cutting of the Central Railroad. Everywhere through this pass the till is but a little distance-at most 6 feet-below the surface, as at the bridge over this cutting on Woodside avenne.

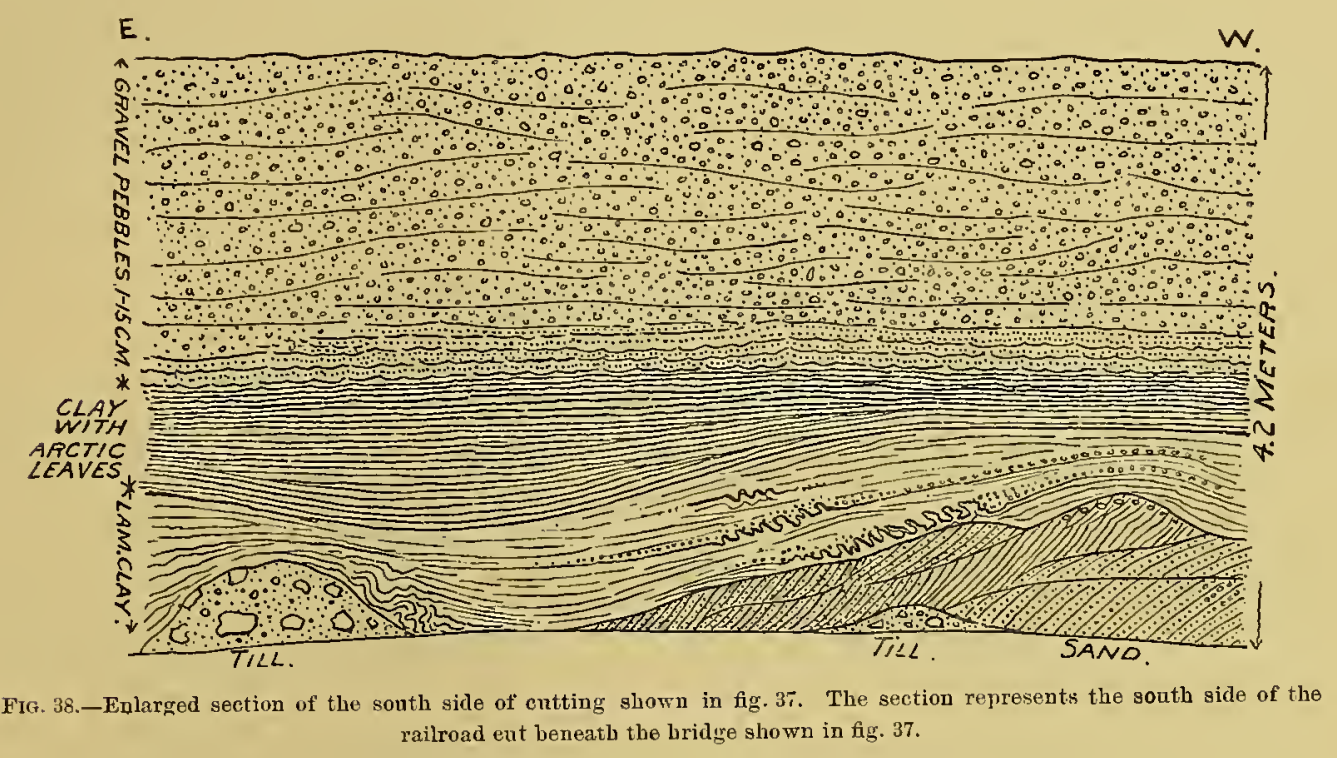

Fig. 37 shows a section south from the Octagon, on College Hill, through the cutting of the Central Railroad, at the point where the highway crosses it. It is interesting as showing sands under the clays and separating them from the till. This is the only instance of the kind I have seen in the valley. The clays thicken off into the deep water south and sontheast, and northward grade to sand layers, and these to the beach gravels which make this broad flat and which are spread over the bench cut back in the till, by which cutting the sharp slope south of the Octagon was produced. The varying currents from the west are finely shown by the detailed sections figs. 38,39 . The quiet water allowed the clay layers to form, and then the strong current crumpled them. 
Farther south, the terrace swinging round either side of Mount Doma is continued in an exceptionally long spit of gravel which bends round southwest and continues to Fort River, and beyond the river a peculiar ridge of sand, sloping down gradnally to the depression west of South Amherst and westerly to the main basin, is carried south to the high terrace skirting the north flank of Mount Holyoke. This seems to me a bar thrown across the mouth of the deep bay which occupied the second depression, mentioned above (p. 643), by the current of the main stream coming down through the channel between Mount Warner and the Amherst ridge.

THE DENCH AROUND MOUNT WARNER.

As one looks at this isolated rocky hill from Amherst a northern portion, horizontal and at the level of the high terrace, attracts attention, and investigation shows this to be a broad, rndely horizontal rocky bench but slightly covered with loose material. To assume that this perfectly terrace-

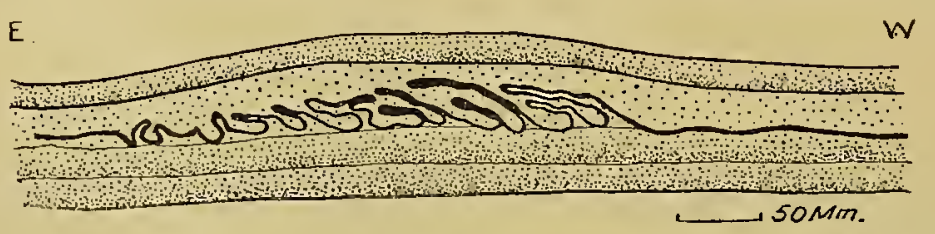

Fig. 39.-Detail of elay layer crumpled by the current, from fig. 38 , to show how the layer was carried along by the friction of a current from the west.

like portion of the mountain was planed down to the level of the high terrace by the flood waters wonld be to assume that this flood period was immensely longer than we have been accustomed to think it, and longer than the other phenomena connected with it would seem to warrant.

An inspection of the map will show that south of the mountain a great tail of sand extends sontheast to the Northampton road. Just under the sonth end of the monntain a pond occupies the place where the waters meeting from both sides around the mountain stagnated and thus prevented the sands from building up quite to the highest level, but farther south a broad, perfectly level sand plain projects at the level of the high terrace southeastward, indicating the direction of the current. (See map, Pl. XXXV, C.) I imagine it to have been deflected somewhat by the prevailing west wind. This tail sinks like a delta southward and runs out on the clay bottom of the lake, reaching nearly the Northampton road. On the west side it flanks the mountain for a long way north, but is so blended with dines carried up from below that its original relations can not be clearly made out. 
This broind, flat, sand-covered platenu in continuation of the sonth end of Ifount Waner has the exilct height of the old Madley Lake. Its direction (sonthenst) was a great puzzle to me, and I tried to explain it by supposing that the sonth (mrent and the west wind produced a resultant sontheast direction in the goreat sand spit. Recently (1888) exeavations along the road south fiom the Catholic cemetery have shown that all along the southeast firont of the platean the till lies almost at the surface and makes the explanation more probable that the whole mass of the deposit is dne to ice, and that the north-south valley movement of the ice is here, where the valley is musually wide and open, replaced by the usual upland (N. $30^{\circ}$ E.) movement, and this agrees with the strong pressure of the ice along the west face of Deerfield Mountain. Only the sunface and slopes of the platean were then molded later by the water and covered and flanked by sand bars.

THE LAKE BENCH ALONG THE NORTH SLOPE OF THE MOUNT HOLYOKE AND MOUNT TOM RANGE.

I have already (p. 586) called attention to the fact that great masses of irregular sands are in places heaped up against the flanks of these ranges at heights much above the highest water level of the Hadley Lake. Where, as along south of Amherst, the high terrace is a bench cut in these sands it sinks gradually, and often without any marked change of slope, into the lake bottom, as if there had been here no marked current, but an undertow had drawn the sands in large quantity down into the deeper water.

Farther west, south of Hadley and in the Holyoke notch, the current was more marked; but the material at the disposal of the stream was less in amount and the terrace is a narrow bench, often of till, and from the entrance of the notch down to Titans Pier the waters cut back the till in a broad bench and then wore into the trap and sandstone, producing a vertical wall which the talus of fallen trap has not yet obliterated.

Across the river the same conditions hold. Above the highest terrace level, as determined by its coincidence with the Florence plain, higher levels of coarse sand occur and the lake bench slopes inward to where it is cut off by the later erosion of the Connecticut, or when we get beyond this, as in Easthampton, it continues its gradual slope to the middle of the basin, or to the line of the deepest water of the broad stream which flowed down 
across the Hampton plain. Along this portion of its course, between Nonatuck and Mount Tom, fine bowlder beaches mark the outer boundary of the ligh terrace.

\section{THE WESTFIELD PLAIN.}

I have followed the high terraces on either side of the broad Hadley Lake and found them much more intimately comnected with the Southampton Valley than throngh the gorge of Mount Holyoke with the Springfield basin. They are confluent with the broad Westfield plain, one of the most interesting deposits of the river.

The broad, unfilled lake, 15 miles wide opposite Northampton, narrowed across Southampton to a width of 3 miles, and on the south line of this town two long ridges, White Loaf and the high hill to the west of it, East Farms Hill, rose as islands in its course, and the waters passed on south by three narrow channels-respectively 180 rods, 120 rods, and 360 rods wide, counting from west to east-into the Westfield plain, the filled-up portion of its ancient bed. These passes formed a waste gate through which the overflow of the river went with velocity accelerated by the narrowing of its passagervay. It swept the abundant kame sands $(\mathrm{m} t$ ) which had been spread at the western foot of the Momnt Tom range and over White Loaf through the eastern and middle channels, and this is the proximate source of the trap pebbles traced far south across the plain by Mr. Diller. ${ }^{1}$ The sands of the Manhan were spread by it over the western portion of the plain. As a result, we have coarse gravels concentrated from the kame gravels in the eastern gorge, stretching far south across Hampden plain and growing gradually finer, and in the same latitudes on the western side of the plain the sands are much finer, being derived from the sands of the Manhan.

That the sand here had this origin in local kame deposits is manifest from the fact that along the whole course of the Holyoke-Tom divide there are no streans florving into the river to bring sediment, and through all this length the high terrace is for long distances wanting or marked only by a narrow shelf eut into older deposits, and certainly nothing was brought from the upper waters of the river across the broad, low clay bottom of the lake in Easthampton.

The delta deposits of the Londville branch, swept along the west side of the basin, had, south of Southampton village, shrunk to a narrow shelf, 
and yet, immediately after passing the two obstructing hills, the waters latre filled the broad valley (which is over $3 \frac{1}{2}$ miles across at its narrowest point) wrll-nigh to the height of the highest terrace, everywhere from side to side, and for 10 miles south. Where the waters swept around the two hills mentioned above, broad grooves appear in the plain, hugging the sides of each hill $\left(1 \mathrm{f}^{1}\right)$, and joining and running out southward on the plain for a long distnnec, with a tail of higher sands between them; and from the southeast corner of White Loaf a heavy bar of coarse gravel (ls h) runs out sontheast, and east of this was left the great depression of the Hampden ponds.

White Loaf ends near the north line of Westfield, but the East Farms Hill is continued in a low, broad reach of till down halfway to Westfield village, dividing the plain, but in all its southern portion hardly rising above the surface of the highest waters, and bounded by a marked bowlder beach.

On the west side was the real thread of the current of the broad river, and this was early utilized for the Farmington Canal. Just on the north line of Westfield the main stream received the waters of the Manhan, and the increased eroding power derived from their junction is seen in the lowering of the plain for a mile south of the town line. This was aided, also, by the narrowing of the channel through this distance. Then the valley quite suddenly doubles in wilth and the low thread continnes along its eastern side, hugging the East Farms Hill, and the plain is gradually built up to a much greater height along its western half, and for a long distance south the height of its western edge is 300 feet, and it slopes east very gradually 40 feet and then quite rapidly 25 feet more to the bottom of the deep-water chamnel. Southward, the highest point in this channel is a mile south of East Farms, where the south end of the East Farms Hill drops down and the two valleys come together. North of this all the brooks which come from the hills of West Farms and East Farms gather in this deep-water current bed and run north.

The terracelike slope which borders this deep-water channel on the west bends round (north of F. W. Griswold's) to the west and runs west to the slope of Pochassic Mountain. The corresponding slope which bounds the chanmel on the east bends east at the same point, and the westward-running last-mentioned slope, if prolonged eastward, would just meet and be continued 
by this similar slope, which stretches east from the Catholic cemetery across the Hampden plain.

The highest sands $(1 \mathrm{sh})$ on the east and west sides of the plain rum south with regular slope and then drop quite abruptly in this terracelike construction scarp. The deep cuttings of the Westfield and Holyoke Railroad and the many openings on the north edge of the Westfield basin do not give any sign that the Westfield ever wore up to the foot of this scarp. Everything indicates rather that the whole plain north and south of the later-eroded basin of the Westfield was the result of one continuous operation, and that this scarp was formed east and west across the channel of the main stream just where the waters of the Westfield River joined its waters, and the outlet through the Divide Range gave a means of communication with the eastern lake, and thus the carrying power of the main stream was suddenly lessened along this line, and the scarp was the index of that lessening. The diminished current carried finer material, and in the steep erosion scarp by which one descends from the sonth edge of the plain to the Westfield River basin, a mile south of the Catholic cemetery, we have many deep sections showing a great thickness of sands so fine that the owners have often attempted to ntilize them for brick making, but without success. On the south of this broad original depression which guided the Westfield rivers finally back to the gorge in the Divide Range and to the Connecticnt, the fine sands continue in "Poverty plain," west of Little River, rising from 229 feet on the edge north of the Westfield basin to 264 feet on the south of the basin of the Little River, in the center of Poverty plain-an enormous waste of desolate sands whose increased height comes from the sands of the Westfield rivers swept down aromnd the high drift hills of the "Fox district."

The broad "Avenue plain" between the two Westfield rivers is a very interesting portion of the original plain of the flooded river. It is now about a mile wide and 4 miles long, and stretches from where it rests against the drift border of the valley between the two Westfield rivers, at a beight of 290 feet, eastward to the cemetery in Westfield, descending 16 feet per mile (Diller), and bounded north, south, and east by the deep erosion basins of the two rivers. It is made up very largely of quite coarse and well-washed gravels, even out at its eastern end, which are exposed in many natural sections and gravel pits, notably just east of the cemetery, where the well-sorted and rounded gravel is 12 to 14 feet thick and rests 
upon sauls. These shoets of gravel stretched, I have no doubt, right across the areal now oreupied by the basin of the Westfield River, and were comtinnous with the fine gravels just northwest of and above the railroad station. Here there is a thoronghly classified bed of 4 to 6 inch pebbles, all well romded and male up very largely of the peculiar hard Lanrentian gneiss of Waslington and Hinsdale and of the Berkshire quartzites, both brought down from the headwaters of the Westfield River.

Mrr. Diller calls attention to the depression of the east end of this Aveme plain 17 feet below the adjacent plains. I believe this plain to have been formed as it now is during the flood time of the main river, and to owe its slope to the heary flood of the Westfield River, which kept this passage between Pochassic Mountain and the West Parish Hills scoured out, and carried ont over its bottom the broad sheets of coarse gravel which reach east to the village of Westfield. The position of these gravels over the underlying sands is the normal one all up and down the valley wherever a delta is advanced into deeper water, and the two beds are parts of the result of a single operation. The flood of the Westfield then, as now, preceded that of the main stream, and thus annually swept its channel clear and gradually built up its heavy gravel beds.

Poverty plain is continuous across Westfield and into Southwick. It begins to contract in width on the town line, and from Southwick Hill southward has a width of little more than a mile and a half. The confinement of the waters in these narrow limits, by increasing their eroding power, seems responsible for the long, shallow depression of the Congamuck or Southwick Pond, and for the curious course of Great Brook, which, starting from the middle of the pond on its west side, runs north anong the drift hills, and, leaving them, takes a diagonal course across Poverty plain, passing within 100 rods of the head of the pond, and finding what I imagine was the thread of the current of the main stream and following it back until it joined the Westfield near the divide gorge.

The thread of the current passed out of the deep water over Southampton village and by the west pass down to and across the place where Westfield village now stands, and then, on receiving the waters of the Westfield rivers, bent east to near the gorge, whence it followed the present course of Great Brook to and across the whole length of Southwick Pond, and so southward across the Farmington basin and by the course of Mill River into the sound at New Haven. 
An inspection of this Westfield-Sonthwick plain as represented on the map will, I think, convince one that it was constructed by a broad, very shallow body of water, often broken into separate threads meandering across the plain, which were separated from one another by long intervening bars and spits, bounded by construction scarps, at times quite steep and fluted on the convex side of the curving channels, but often of long and easy slope.

THE GREATER ELEVATION OF THE T'ERRACES IN THE WESTFIELD THAN IN THE SPRINGF1ELD LAKE. POSSIBLE WESTERN ELEVATION.

Professor Dana has noted that the highest normal terraces in the western valley are 50 feet higher than in the eastern. Mr. J. S Diller has discussed the matter in an interesting article which was published in the Westfield Times and News Letter, September 19, 1877, and which is here reproduced:

THE GEOLOGY OF WESTFIELD AND VICINITY.

Bj J. S. Diller.

Professor Dana has shown that at Tariffville, Connecticnt, where the Farmington River flows through the Divide range, the terraces upon the west side of the range are about 50 feet higher than those upon the east side. At the Westfield gap, through the Divide range, the upper terrace on the west side of the range is $264 \frac{1}{2}$ feet above sea level, but on the east side the highest terrace is 50 feet lower. It has been shown by Professor Dana that during the Champlain period the highest flood level over Springfield was $\mathbf{2 4 0}$ feet above the sea level. We have shown in a previous article that during the same period the highest flood level on the west side of the Divide range was 280 feet above sea level. The flood at Westfield was at least 48 feet higher than that at Springfield.

The question at once arises, Why was the water so much higher on the west side of the range? The answer most frequently given is that the gaps through the Divide range were closed, thus damming the water back aud raising it to a greater height west of the range. In the Westfield River gap, npon the south side of the river, there are two terraces. The lower one extends directly through the gap, at a height of 199 feet above the sea. This terrace is made up of stratified deposits, containing a large portion of clay. The beds extend, with the terrace, directly through the gap. The continuity of the beds is evidence that the gap was open when the deposits were made. These lower deposits, we have reason to believe, were made during the early part of the Champlain period. It therefore appears that during the early part of the Champlain period the gap was not completely closed by either drift or trap rock. It should here be remarked that there is, on the right bauk of the river, just east of Morley's bridge, in the gap, a ledge of trap whose top is 21 feet 
above the highest modern flood level at that place. The ledge breaks the continuity of the lowest beds of the terrace, and may lave once formed a considerable dam in the gap. A bove the ledge the beds are contimons throngh the gap, and are evidence that there the galp was open.

If the gips in the Divide range were not closed during the Champlain period, the leeiglit of the water must have been dne to some other conditions. There were two conditions on which the height of the water seems to have depended, viz: (1) The nalrowness of the gaps through the Divide range, and (2) the difference in slope of the valleys east aud west of the range.

Dr. Davis, in his History of Westfield, says that the Westfield River at Westfield, during tloods in 1819 and 1826, rose 14 feet. Mr. L. F. Root, civil engineer of this place and of the Canal Railroad, has recorded a rise of 12 feet during the great flood of 1869. Mr. Anstin Williams made marks npon a tree near the north end of Morley's bridge, showing the height of the water there dnring an iee flood in 185̃5, and also during the flood of 1869 . In 1855 the water rose $27 \frac{1}{2}$ feet, and in 1869 it rose 26 feet. It thins appears that when the river rose 12 feet at the village it rose 26 feet in the gap. Some of the excess in height was dne to the inflowing water from Little River, but by far the greater part is due to the smallness of the gap through the range.

By measuring the gap it has been determined that a flood niueteen and one-half times as great as the highest modern flood wonld flow through the gap at such height as to cover the top of the highest terrace.

The overflow from the Connecticut and Manhan rivers entered the Westfield Valley by two large streams, neither of which were less than three-fourths of a mile in width, and one having a depth of 40 feet in its most shallow portion. Add to the water poured into the Westfield Valley by these two streams the immense floods of the Westfield rivers and it will be seen that for such floods the gap throngh the Divide range was a small outlet. The smallness of the gap evidently had mueh to do with increasing the height of the water west of the Divide range.

Supposing the stratified drift were removed from the valleys on both sides of the Divide range, we would see that the northern portion of the valley on the west side has much less slope than the corresponding portion of the Connecticut Valley on the opposite side of the ridge. The valley west of the range is crossed by the red sandstone divides which separate the Westfield River Valley from the Manhan River Valley on the north and the Farmington Valley on the sontl. Such divides are not found in the Connecticut Valley on the opposite side of the ridge.

The lowest parts of the valley west of the Divide range are those across which the Westfield and Farmington rivers flow. These lowest portions are considerably higher than the lowest parts of the Connecticnt Valley directly opposite, else the Westfield and Farmington rivers wonld not flow into. the Connecticut.

It is evident that at the close of the Glacial period the average slope of the valley west of the Divide range was much less than that of the opposite portion of the Connecticut Valley. The tro valleys filled, during the Champlain period, with water from the Connecticnt Valley, in the region of Northampton, acted much like two parallel 
troughs having their source in the same place and at the same level, but having different slopes. The water in the one having the least slope must be above the level of the water in the other at all points directly opposite.

The difference in slope of the two valleys, together with the narrowness of the gap in the Divide range, seen to be the cause of the greater height of the water in this vicinity.

It seems that the following considerations should be weighed in seeking for an explanation of this curious difference of level:

(1) The Springfield basin is about four times as wide as the Westfield, and thus much more material would be required to fill it up to the same level.

(2) Because of the northwestern recession of the ice the eastern floods sent the mass of their sands down through the Monson-Willimantic Valley or lodged them in the great series of catchment basins I have described above as the easteru series of glacial lakes.

(3) The same recession of the ice, continued northwestwardly, caused the heaviest floods to pour into the lateral or Westfield Valley by all the transverse valleys coming in from the west, and of these the Westfield River was the most important, because it runs back northwest across the whole plateau of the Berkshire Hills and at Dalton opens broadly into the great Housatonic Valley, and because it remained the main trunk of the ice drainage until the ice had receded from those hills; and while the ice front was in the region of Pittsfield the drainage of a portion of the Upper Honsatonic was deflected into this valley, producing the interesting sand plains in the upper valley at Hinsdale and bringing down bowlders from this region to spread over the Westfield plain.

The combined effect of these three conditions seems sufficient to explain the lower level of the eastern plain, and instead of saying that "the flood at Westfield was at least 48 feet higher than that at Springfield," I should say that the waters were 48 feet shallower in the Westfield basin than over Springfield.

Where kame sands were heaped up in the Springfield basin the high terrace is notched in them at nearly the same height as in the Westfield basin; as, for example, on the extreme east of the basin in Wilbraham or north in Holyoke. At the notch in the Divide Range occupied by the Westfield River the exact surface of the lake bottom has, of course, been removed by the later erosion of the river; but at the next notch sonth, at Risings, just on the State line, the surface is well preserved and is very instructive. It is what might be expected on the assumption of a narrow 


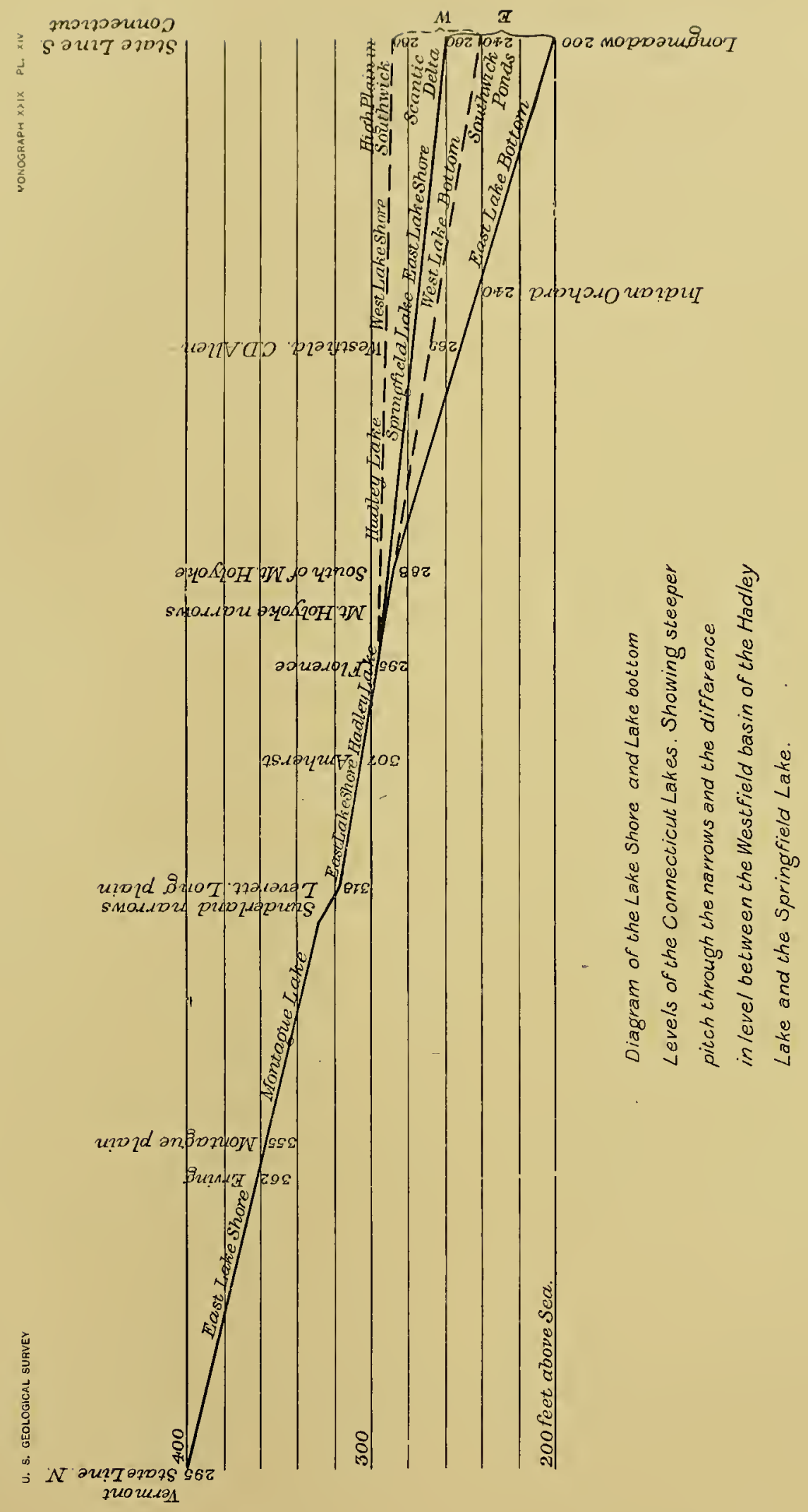



channel between the two extensive bodies of water and a larger influx into the western bisin, and thus a current through into the eastern. 'There was an eroding current which cut a nirrow channel back westward from the galp and trinsported little material into the eastern basin, as the sands of the western basin were delivered into it on the other (western) side.

In the Springfield basin the broad Agawam plain, 220 to 230 feet high, is composed of fine sand and extends right up into this niarow gorge, which passes throngh the gap and bends north and ends abruptly. This channel is not occupied by a brook, and after passing through the gap in the trap range it extends into the Westfield plain, being there worn in till and high terrace gravels.

Mounting to its rim, we find the coarse gravels of the Westfield plain at 280 feet stretching westward, sinking slightly, and growing finer, and forming the broad sand plain that extends across to Congamuck ponds. A brook which flows north to the Westfield River has cut its way back nearly to this dry gorge; but the latter remains still intact, though a high, narrow ridge is all that now separates them. This dry gorge was the erosion channel caused by the escape of part of the surplus waters from the western into the eastern basin. 'The waters stood at practically the same level, but the coarse sands that drifted sonth in the western basin stood at 280 feet, and the fine sands drifting south in the eastern basin stood at 220 feet.

An examination of the diagram, Pl. XIV, will show the relations of the two basins. There remains a distinct possibility that part of this difference, say about 20 feet, may prove to be due to a post-Glacial elevation of the western portion of the area under consideration. The evidence of this is that the broad, flat delta plains in front of the Chicopee River outlet at Collins Mills, on the east of the basin, and of the Scantic Brook, at Scantic, in Longmeadow, are 260 to 265 feet above sea, while the corresponding levels at the head of the delta of the Westfield are 285 to 290 feet above sea. The eastern streams cut through glacial lake beds in their upper waters, and, it would seem, should have built out their deltas in the lake up to flood level.

\section{THE SPRINGFIELD LAKE.}

The Holyoke range, lying in the midst of the Connecticut Valley like an inverted $L$, or like a blowpipe, its tip approaching the crystalline border of the valley at the Belchertown ponds, broken at its bend and in the MON XXIX- 42 
middle of its length for the passage of the Connecticut and Westfield rivers, bounds on the north and west the bed of a third lake, which exteuded south across the borders of the State to the point where the river enters the narrows at Middletown. Its eastern boundary was the high rocky border of the valley across the towns of Belchertown, Granby, Ludlow, and Wilbraham.

The two notches mentioned above were narrow straits connecting this lake with the Hadley Lake, and only a very small portion of the sands and gravels which now fill the latter came through these notches from the northern lake. This was especially true of the northern passage, for over a broad area in front of it the bottom of the Hadley Lake was filled up only a ferv feet above the present level of the meadows, and that with laminated clays capped by fine sands, while immediately south of the gorge the sands are coarse and are built up to a plane 100 feet higher.

Of course, the narrow Holyoke range on the north and west never furnished any considerable tributary to the lake after the ice had disappeared from its north and west slope, but the ice melted away sonth of the mountain much more rapidly then it did north, and there was a long time when bodies of water gathered upon the ice in the northern area and swept through the notches in the Holyoke range, carrying much sand and gravel into the southern basin. I have already traced the watercourse south from the Pelham basin through the passagervay between the east end of the range and the crystalline rocks, and through the notch next west, occupied by the "Bay road." (See p. 588.)

The position of the Holyoke diabase ridges detailed above had great influence on the action of the ice. It plowed very deeply into the sandstones north of the main ridge in the Hadley Lake, but to the south it left the sandstones over much of the basin above the level afterward maintained by the lake. It seemed also to plow in long grooves, leaving several parallel ridges of sandstone, which stretch south across Granby and South Hadley. These ridges may be in part the uptilted western rims of the great fault blocks of the sandstone. It deposited also many great drumlins on and in prolongation of these ridges. Farther south also, across Hampden County, a broad marginal portion of the basin is occupied by low ridges of sandstone and till, which rise, for the most part, but little above the level of the lake sands. This had two results of importance in the history of the lake: (1) So much of the lake was from the beginning shallow that its filling 
up did not require nearly so much material as dirl the much deeper Hadley Lake; (2) the great multitude of elevations make the border of the lake on the east very complicated.

The steep eastem border of the valley is notched for the entrance of only one tributary which heads back of the first series of ridges. This is the Chicopee River, which at the village of Three Rivers gathers all the drainage of eastem Hampshire and Hampden counties. In the time of the lake it carried certainly a much greater volume of water than at present, and as the ramifications of this drainage cover the whole broad area of highlevel glacial lakes already described, their abundant sands furnished an enonnous volnme of already sorted detritus, which is now spread in the broad sand flats of South Hadley, Chicopee, Springfield, and Longmeadow.

The study of the basin brought to iny attention several most interesting problems, and it has been difficult to express upon the map the results reached. An inspection of the map will show that I have there represented the lake, in contradistinction to the two northern lakes, as a nearly filled-up lake. In the former, passing across the high terrace flat toward the center of the valley, one comes upon a well-marked scarp of deposition, or delta front, which descends to the lower plane of the lake bottom. Here one goes out from the head of the Chicopee River delta, 264 feet above sea, and crosses the broad, gradually sloping sand plains to their inner edge overlooking the river meadows at 240 feet, or going south across Chicopee, Springfield, and Longmeadow, finds the level sinking from 255 feet in the nortl to 180 feet in the south; and yet the whole great sand body, the largest on the river, covering a large portion of four towns, expands as a great, extremely flat "alluvial cone" or delta, with imperceptible slope from the mouth of the gorge of the Chicopee at Collins depot to where it is cut off by the later erosion of the river, and shows nowhere any scarp which could justify one in separating the central and lower portion as lake bottom from the higher and shoreward portion as lake shore.

A further inspection of the map will show that in the northern portion of the lake basin the deposits referred to the high terrace $(\mathrm{l} \mathrm{s} \mathrm{h}, \mathrm{Pl}$. XXXV, D) or filled-up portion of the lake are shaped rudely like a comb, with its back stretching along south of the Holyoke range and its teeth extending south between the long ridges of sandstone and till across 
Granby and South Hadley to blend with the extensive delta of the Chicopee River last described.. Starting at the northeast corner of the area, one can trace the coarse gravels of the Belchertown notch (307 feet above sea) southwest continuously to the Granby line, in a band about 50 rods wide, resting against sandstone on the north and till on the south, like a river course, the coarse gravels of the notch (6 inches) becoming gradually finer, at the town line consisting of a 1- to 2-inch gravel. Just here the band expands westward and southward in the broad, perfectly horizontal Granby plain of fine sand, which extends south with nearly half the full width of the town, and west as a much narrower band, sending off a long lobe south on the east side of Granby Hill, and another broader lobe west of the same hill, which starts south with a bottom of 6 -inch gravel (at 266 feet above sea) but grows finer as it goes south.

The deposits extend still farther west and grow still narrower just sonth of the notch of the Holyoke range, where the waters seem for a little way to have passed over the bare sandstones, and they then expand into the broad sand plain of Moody Corners (in the wood road running north from the Corners fine cross-bedded sands are exposed, above 30 feet thick), which extends west across the north of South Hadley, sending several other lobes southward. We have here two elements, diverse in character and origin, which together form, I believe, the bottom deposits of the lake: to the north are the coarse gravels which have plainly come through the Belchertown notch and been swept southward by a strong current in the many lobes just described, and to the south is the enormous body of the sands of the Chicopee River delta described above.

Southward the lobes of the northern deposits blend with the sands of the southern deposit at a common level without the intervention of any scarp which could indicate difference of age between the two deposits; and this is the basis of the decision indicated above-that they are strictly synchronous and together form the flood deposit of the Springfield Lake.

A further and most interesting conclusion is that the floods of the northern basin continued for a long time to pass across the Belchertown notch into the southern basin after the latter was fully abandoned by the ice, although (1) the level of the sands in the Belchertown notch is about 40 feet above the level of the high terrace of the lake to the north, and (2) the abundant kettle-holes show that the water ceased to pass through the notch before the ice had melted out from below the sands spread there. 
In commetion with the second point, we may call to mind (see p. 718) that arctic plants are found in the clays of the Ifaclley Lake to their top; this inlicates a coll climate at an even later time than the one contemplated here, which would permit the ice to remain buried almost indefinitely.

As to the first point, the area covered by the gravels in question, except towind the west, beyond Moody Corners, was left filled nearly to the present level by the ice, and a great body of gravel was swept into this area through the notches of the Holyoke range, and last of all, the last floods passing through the Belchertown noteh spread these gravels and carried them sonth and blended them with the finer contributions of the Chicopee River. It does not seem improbable that floods rising 40 feet above the level of the confluent deltas of the Hadley Lake may have occurred many times, eren after the ice had retreated wholly from this lake basin; but it seems more probable that the southern basin was set free from the ice so long before the northern that the operations here under consideration had been in the main completed before the ice finally retreated from the greater portion of the Hadley basin. I may refer, also, to the proofs of a readvance of the ice in this basin given below.

A further consideration, to which we now turn, will show that the floods through the Belehertown noteh continued until after the ice had set free the Holyoke notch, through which the river now runs.

THE "GORGE TERRACE" OF DRY BROOK HILL, SOUTH OF HOLYOKE NO'FCH, IN THE NORTH PART OF SOUTH HADLEY.

The terrace of Dry Brook Hill, in South Hadley, is the most remarkable terrace in the valley, and was the type of a class in President Hitchcock's classification of terraces. ${ }^{1}$ If the deposits removed by the erosion of the brooks in the north of Granby and South Hadley be restored in imagination, what seems an old river course may be followed through the Belchertown noteh and along south of the Holyoke range-and it was held to be an old river bed by President Hitcheock ${ }^{2}$ - until just south of the Mountain House it bends south on a great drumlin southwest of Moody Cormers and then runs south as a well-defined river channel, skirting this hill on the east and bounded on the west by the marked construction escarpment of a long flat-topped hill of coarse stratified sand, the Dry Brook Hill, which, abutting

'Surface Geology, p. 5.

${ }^{2}$ teminiscences of Amherst College, p. 279, and map. 
on the north against the shoulder of the mountain, runs south nearly a mile. Going up 35 feet to the top of this hill, one is surprised to see that on the west it slopes suddenly down 190 feet to the river which is wearing at its foot. The escarpment on the east which borders the channel is plainly a scarp of deposition, and the whole terrace was possibly built by the rapid current through the Holyoke notch, meeting the current we have traced

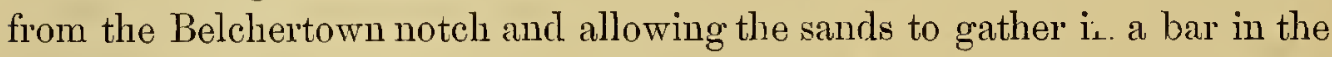
slack water between the two. Perhaps it should be assigned to a slightly earlier period, when the ice, still abutting on the Holyoke range to the north, projected through the notch and allowed the sands to gather against its eastem flank aud on melting let them cave to form the passage for the river. The preseuce of the ice on the north spanning the Holyoke notch is essential to the formation of this great terrace of coarse material, becanse since the ice disappeared nothing but fine clay has been bronght by the waters into the gorge from the nortl, while the section which treats of the glacial gravels carried through the notches in this range (p. 586) furnishes a clear' explanation for this abnormal deposit.

HIGH TERRACE OR BENCH OF THE WEST SIDE OF THE LAKE FROM THE HOLYOKE NOTCH SOUTHWARD.

From the notch to the north line of the town of Holyoke the ground rises rapidly from the narrow, low terrace up a rocky slope to the crest of the eastern trap ridge, and there is scarcely trace of any high terrace upon its flank, because there was deep water in the Hadley Lake opposite the mouth of the notch and little sand was brought through here. What was brought stretched south in a great bar which is almost intact on the other side of the river, in Dry Hill, in the north part of South Hadley, just described, as can be beantifully seen from the imner trap ridge mentioned above. All that passed through the notch on its west side was swept in between the two trap ridges and filled a bay north of the burnt stone mill above Smiths Ferry. All along the riverward flank of the east trap ridge high sands were not laid down becanse, for this portion of the basin, the supply came from the far-off east side, mainly from the Chicopee River, and as the deposit expanded westward its level lowered, so that no high terrace sands were brought against the till-covered trap slope, and the small indentation made by the waters at this level has left no trace of its presence. 
Just at the nurth line of Holyoke the eastern trap ridge sinks below the level of the lake, and over most of the town a great body of till rises much above its level, and in this the lake cut back a broad terrace flat, and where these drift deposits sank below the level of the lake the latter spread its sinds hroadly across Holyoke and West Springfield. From the north line of IIolyoke the influence of the great body of sand sent clear across the basin from the Chicopee River becomes apparent, and although there was 110 drainage down the trap slope on the west, and the till beneath was very largely made up of Triassic shale, the gneissic sands from the east of the basin extend out over the till along the line indicated. They bring a broad area nearly up to the level of the high terrace, because it was quite near that level before; and south of the Westfield River, in Agawam, the terrace expands to nearly the width of the town, largely for the same reason. It was here, of course, somewhat reenforced by material brought through the notch of the Westfield River, but I question if much came that way, as the source of the supply in the Westfield basin was across on the west side, and the sands were in the main swept south. I think more came south over Ashley's pond and west from the Chicopee River, and that the difference of level of the high terrace here and in the Westfield basin is almost wholly owing to a deficit of material in Agawam and West Springfield. Toward the river in Agawam the sands come to be of great volume, and they once extended across to meet those of Longmeadow, and the lake was in this part well filled up when the recession of its waters began.

THE SIMLARITY OF THE BELUHERTOWN NOTCH TO THE NOTCH EAST OF MOUNT TOBY.

I lave already shown (p. 584) how the ice in the Montague basin, abutting against the eastern margin of the basin and against the northeast shoulder of Mount Toby, turned the waters of the Locks Pond Brook south into the gorge between Mount Toby and the high ridge of crystalline rocks in the west portion of Leverett, and how these waters cut a watercourse, still well defined, through the gorge and sent out a broad delta - the present South Leverett plain-into the Hadley basin. Just so the waters of the Pelham brooks flowed south from the Hadley basin into the Springfield basin through the Belchertown notch and spread the long reaches of sand westward down the present course of Bachelors Brook and south to Ludlow Mills. 
THE MORAINE ACROSS THE SOUTHERN PART OF THE GRANBY PLAIN.

North of Ludlow, in the south part of Granby, is a plain about a mile square. It is the sonth end of the great Granby plain, and is bounded on the east by the valley rim and on the west and south by elevated ridges of till, which at the sonthwest corner leave open a narrow passage by which one passes from this plain out onto the broader plain of finer sand that extends down to the Chicopee and across west to the Connecticut River. A brook has occupied this narrow gateway, and its flood plain is just wide enongh to render it slightly uncertain whether the larger plain formerly extended continnously throngh and joined the inner plain at a common level. The difference in level, if any exists, is very slight, and the inner plain is at its south end about 260 feet above sea-a level plain of medinmgrained sand. Fifty rods north the sand changes to a 2 -inch gravel, in another 50 rods to a 3 -inch gravel, in the same distance again to a 4-inch gravel; and it has risen in this distance to 298 feet. It preserves its even surface for another 50 rods, and then suddenly drops down into a series of great kettle-holes, which continne a hundred rods and end against a moraine $(\mathrm{t} \mathrm{m})$ that stretches right athwart the plain from east to west, not reaching: its border on either side. It is mlike any other deposit in the valley, and seems exactly like a terminal moraine. The sands swing round it on either side and extend north, with here and there a depression, but much more regular than immediately south of the moraine. I can not quite understand this, or its time relation to the lake sands, but have expressed on the map the most probable solution of the matter.

KETTLE-HOLES AND THE OLD BED OF THE CONNECTICUT.

As a result of the fact that about all the material which went to fill up the lake came from the east side, at the beginming through the Belchertown notch, later from the Chicopee River, the Connecticut found itself pressed, on the shrinkage of the lake, to its western border; and it has excavated its channel so near that border that from Smiths Ferry to Holyoke there is only a trace of the lake deposits left on the west of the present strean; and in all this distance the river has cut a new bed down into the sandstone, while across Chicopee it has cut its bed largely in till. (See PI. XI, p. 510.) Its present bed seems to coincide with the old one nearly down to Smiths 
Firry, since no rock (ropses out in the bank np) to that point. From here I inmaine that the ofl river lan southeast across South Hadley, then across a contere of Chicopee and Ludlow to Indian Orchard, forlowing the band of browk beds and ponts which ean be traced along this line, especially in Lullow, then following the marked line of kettle-holes which extend a little west of sonth from Indian Orchard across Springfield, to join its present course not far from the north line of Longmeadow. This line of kettle-holes can be traced by the line of ponds on the map, and is especially markel in the northern part of the line and for a long distance south across Springfield, where the otherwise unbroken level of the enormous sand wastes is broken by a great number of these depressions, many of the larmest size, and only here and there is one permanently filled with water. I imagine that remnants of ice lingering longer in portious of the old river bottoms were submerged, and remained until the climate ameliorated.

KETTLE-HOLES AND THE STRUCTURE OF THE HIGH TERRACE SANDS; THEIR ORIGIN FROM THE MELTING OF ICE BENEATH THE TERRACE GRAVELS.

The distribution of kettle-loles is given in comnection with the description of the lower glacial lakes and of the high terrace or shore of the Counecticut lakes. The principal areas are (1) along the outer portion of the high terrace in West Northfield and stretching through the Bernardston Pass; (2) in Northampton; (3) across the high Montague plain south of Millers Falls and along the flanks of the Pelham Hills and through the Belchertown Pass, in sands of the lowest glacial lake; (4) across the Chicopee-Springfield basin.

Continuous railroad sections have given me exceptional opportunity to stndy them, and have convinced me that the explanation of their origin accepted by many geologists is the trine one, viz: That they are formed by the sinking of the sands from the melting away of ice which has been buried beneath them. They range from small shallow depressions, grouped together over sand plains elsewhere quite horizontal, to deep sink-holes with sides as steep as sand will lie, and without outlet, isolated, or so crowded that they are separated only by narrow ridges, and merging thus into broad sunken areas with irregular ridgy surface.

The imer structure of the sands in the neighborhood of the kettleholes increases in complexity and irregularity as the holes increase in size 
and approach nearer to each other, and where they merge in "reticulate ridges" this complexity becomes extreme.

In a continuous section through a plain abounding in kettle-holes new ones came to light which are not indicated by any depression on the surface, they having been formed and filled before the completion of the plain. In other cases this filling has been partial, and in every degree, so that a very slight depression upon the surface may indicate an extensive disturbance of the beds below.

In cases where the lamination of the sands is very regular and horizontal the beds sink down on approaching a kettle-hole, with little disturbance where the bending is slight; where it is considerable they dip insward from all sides with a series of small faults; where the subsidence is extreme they are thrown into complete confusion; where they are wholly or partly filled the upper layer's thicken downward to fill the depression, and have

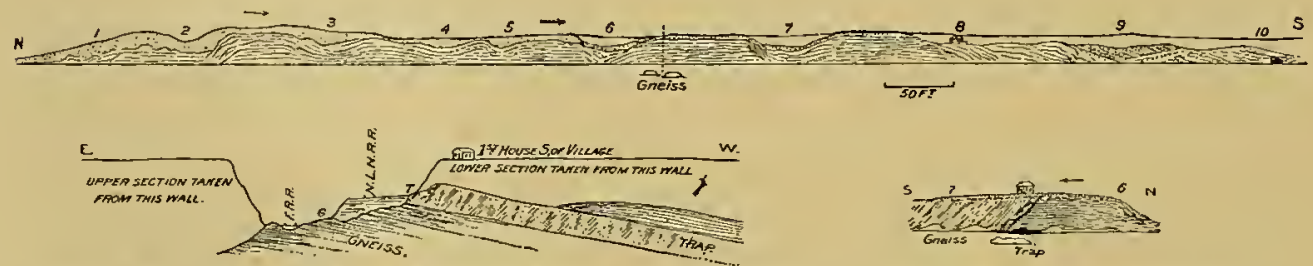

FIG. 40.-Section south of Millers Falls station to show kettle-holes formed by ice melting from beneath the sands.

often a different structure in the depression from that outside, generally a strong cross-bedding dipping in the direction of the current, which shows that the sinking took place somewhat suddenly and the next flood found and filled the depression rapidly. Where the whole thickness of the sand was exposed $I$ found it in one series resting upon a glacial surface of gneiss and trap without the intervention of clay, which might have made place for the sinking in of the sands by lateral flow, as has been suggested; nor is there any indication of a lateral movement of the sands out from under the sunken areas, as I have seen them undisturbed and horizontal on all sides as the broad cutting removed the whole kettle-hole.

These depressions are found only in the lake bench or in the still higher glacial lake beds, and are frequent in places, as in the center of broad sand plains, where local edldies would be supposed to be least effective. Indeed, their great depth, great extent, very steep sides, and irregular distribution would make it clifficult to explain them in this way. On the other 
hand, all their peculiarities seem to me to find abundant explanation in the assmmption that remnants of the ice became covered by the sands, and in the then low temperature remined often for a long time, as in the aretic conntries to-day; and as my knowledge of the region has become more extensive I have found more and more evidence of the presence of ice still in the valley during the building of the high terrace.

The accompanying figures show in detail the facts summarized in the preceding paragraphs. They are selected from a much larger number, and were in part drawn with the thermometer much below zero and are given just as they were made.

In fig. 40, showing the long section on the New London Northern Railroad extending south from the station at Millers Falls and taken from the east wall of the cutting, the upper layer is a coarse gravel 5 to 7 feet thick, coarsest and thickest at the north end of the section, where it is nearest the source of supply at the head of the delta. Beneath this are fine white sands which run in thick sheets horizontally for long distances, the sheets showing the finest false bedding. It is perfectly plain that the gravels were laid down on a horizontal surface of the fine sands, and that these were thrown down in horizontal sheets, and that the sink-holes are of later origin.

At 1 in the figure is the beginning of the cutting just below the station. It is the southern border of an irregular sunken area that sends lobes east nearly to the rocks. The fine sands sink gradually below the surface, and the great thickening of the gravels may be due in whole or part to a sinking of the sands before the whole of the gravels were thrown down.

At 2 the sinking of the under sands is accompanied by a series of small parallel fanlts, dipping inwardly from the irregular sinking, and the gravel thickens downward, partly filling the depression. At 3 is a wholly submerged sink-hole, the sands bending down and the gravels thickening down to fill the space, showing that the ice melted away before the deposition of the upper beds. At 4 and 5 this is repeated. At 6 is a fine kettlehole, and marked faults dipping inward from botl sides, accompanied by a great number of smaller faults with throw in the same direction. At 7 the faults are complicated, as if by gradual melting a new substratum had several times been produced during the building up of the sands.

In the lower figure is shown the other side of the cutting, so that the two views face each other, as shown by the cross section. Here the kettle- 
hole (7) was much wider and only the northern border is drawn, showing the horizontal sands breaking off abruptly and sands with steep southward dip carried in to fill the cavity. The outcrops of trap and gueiss covered with glacial strix, at the base of this section, show that the sands extend down to the rock, and that no clay exists below them which might by lateral flow have allowed the subjacent sands to sink down. Indeed, as the section is cut in the center of a great sand plain, such a supposition is plainly excluded.

At 8 begins a general sinking of a broad area; at 9 an earlier and more rapid sinking of a limited area, which was filled with gravels that are finely cross-bedded with southerly dip, showing that they were carried into the depression by a current from the north. Just below this point the New Loudon Northern and the Fitchburg railroads separate, and at the first cutting below the point of separation on the Fitchburg road the depression

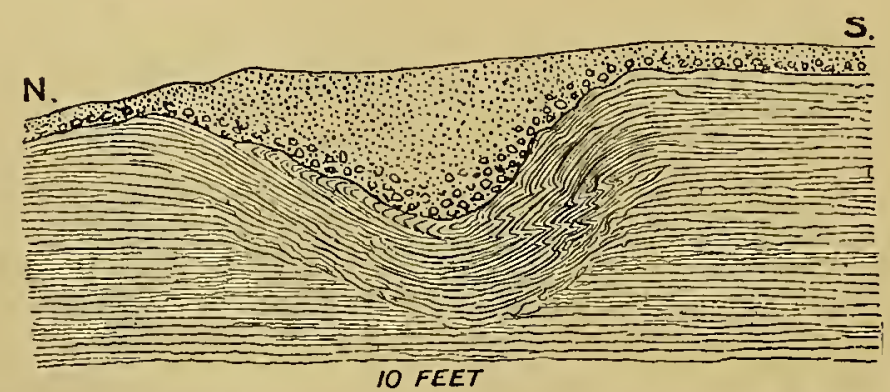

FIG. 41.-Section south of Millers Falls to show kettle.hole formed by ice stranded on the surface of the sands.

represented in fig. 41 was cut across, which is here given in order to contrast a cavity produced plainly by the stranding of floating ice with the sink-holes under discussion.

The horizontal sands come toward the cavity undisturbed from either side, and at a certain distance below retain their horizontality beneath it.

Down the slope on the north side the sands are bent down and the layers are combed over and disarranged, ending abruptly at the surface of the cavity. Below the south side they are squeezed together and finely corrugated. $\Lambda$ thin layer of gravel appears thickened and irregular in the bottom of the cavity and discontinuous on its sonthern side. The whole was filled with a fine unstratified loess, whether wind- or water-brought is uncertain.

Farther west, across the middle of the great Montague plain, runs the line of large water-filled kettle-holes already mentioned as indicating the 
probible position of the old bed of the Comecticut. The great southward bent of Millers River extends into this line for a distance, and the stream wore freely in this direction, becanse from the depth of the old channel it fouml here 110 rock to obstruct it, while all around the rock rises to a much greater level.

$\Lambda$ depression in the plain eonnects this basin with the great kidneyshaped Green Pond, with banks 30 feet high, as steep as sand will lie, and with about 25 feet depth of water. On the sonth the bank breaks down and a low col comnects it with the much larger pond, Lake Pleasant, with sinilar banks and a depth of water of 37 feet, as measured for me by Mr. F. A. Rugg, a former pupil. From its south end rums a depression whose contours have been changed by the brook which runs in it and drains the lake.

In Belehertown the sections made by the Central Railroad cut throngh

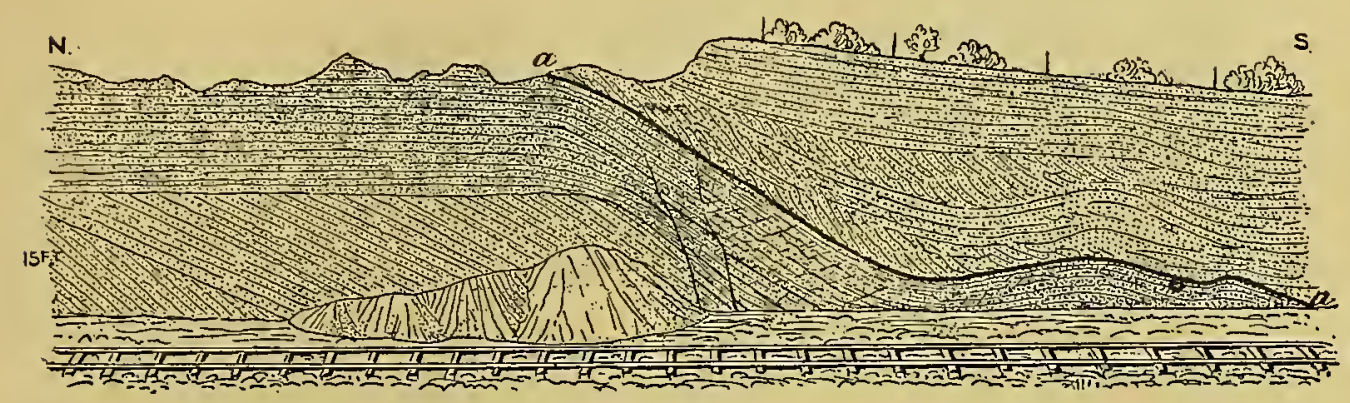

Fig. 42.-Section of north half of a kettle-hole below Dwight's station on the Central Railroad, Belchertown.

many interesting kettle-holes north and south of the Belchertown ponds, which ponds themselves belong to the same class of sink-holes. They belong to the deposits of the Pelham River (see p. 588), and are thins of slightly greater age than the foregoing.

Fig. 42 gives a sketch of a portion of the second cutting below Dwight's station at the "Big Fill." It is carried along the slope of the terrace, and the jagged line in the middle of the figure is explained by the fact that the cut of the New London Northern Railroad is just east of and parallel to this and the crest caved between them, so that only a few of the telegraph poles remained.

The cutting showed the cross section of two submerged kettle-holes. The heavy line commencing at $a$ is the surface of the sink-hole, and it is 
strongly marked by iron rust. From the north the heavy horizontal pinkish sands, underlain by equally heavy cross-bedded sands, both of -medium grain, come for a long distance, and at $a$ they commence to sink down, and seem to have sunk so evenly and on so smooth and regular' a substratum that they were stretched, and a great number of minute fissures, all about normal to the bedding, were formed-fissures so minute that they would have escaped attention if they had not been colored by infiltrated iron rust. A few slight faults dipping inwardly were also formed. They are unduly emphasized from their coloring with rust. Finer, pale-buff, loamy sands rest in this depression and gradually fill it, the sheets being poured orer its northern edge and thickened below and separately cross-bedded.

Farther south, at the soutli end of North Pond, the whole of a goodsized kettle-hole was removed, and fig. 43 would, with small modification,

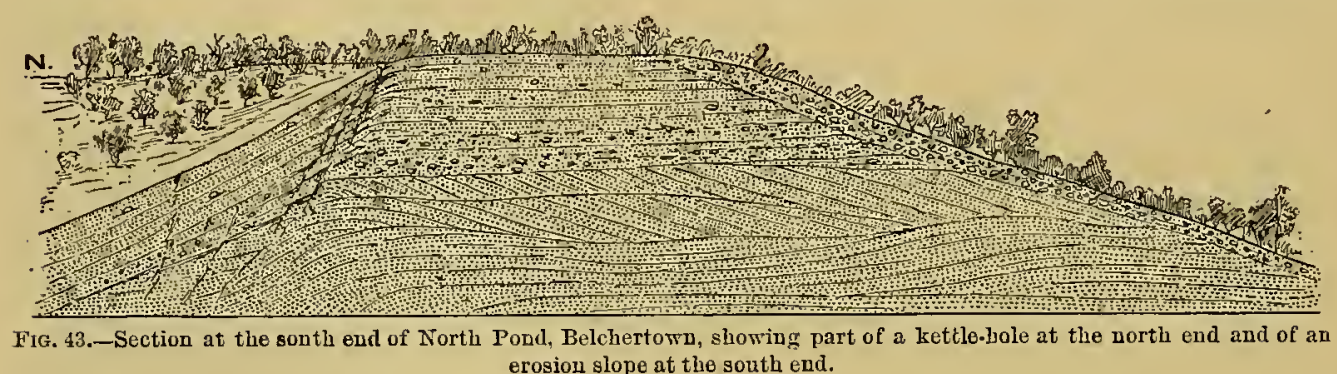

represent any radial section through it. At the north end is seen the quarter of the kettle-hole, with coarse sand and gravel beds above and fine cross-bedded sands below, and both sink with a series of small faults from their normal position down to form the regular bowl-shaped depression. On the south the beds are cut off by erosion. An old torrent bed runs across the plain at this point, and the contrast between the two slopes is striking.

Interesting sections were exposed in the great cutting of fine sand at the north end of the filling of the Central Railroad south of Dwight's station (called the "Big Fill" by the engineers). This cutting was in the terrace connecting the sands spread through the Belchertown Pass with the great delta sent out by Pellam River just north of Dwight's station. (See p. 588.) When this terrace was deposited the ice formed the western bank against which it rested, and when the ice had melted back a little the delta just mentioned was sent out into the temporary lake thus formed, which occupied the corner of the basin in which Dwight's station now lies. The surface of this 
terlace is alout 40 feet alwo the high terace or benely of the Comnecticut Like. In the enstern wall fine, pinkish sands, with regular structure, indicating a steady sonthward ement, form the lower and larger portion of the section. Fig. 44 is drawn from the west wall of this centing, aljout $46^{\circ}$ feet fintler west than the other, and it is interesting to see the marker contust between the two. Except for two small kettle-holes, the eastem section is rery regular, while the western is extremely disturbed. 'The sands below the line a are the fine, pinkish, granitic sands of the lower portion of the opposite section, and these have sunk down irregularly and have been much eroded, and in all the sonthern portion of the section have gone entirely below its level. They are covered by the finer, loamy sands, with much more irregular and shifting (flow-and-plunge) structure, and are tortuous and contorted throughout the whole extent of the exposure, 295 feet (only a small portion drawn), in a manner which would harmonize well with

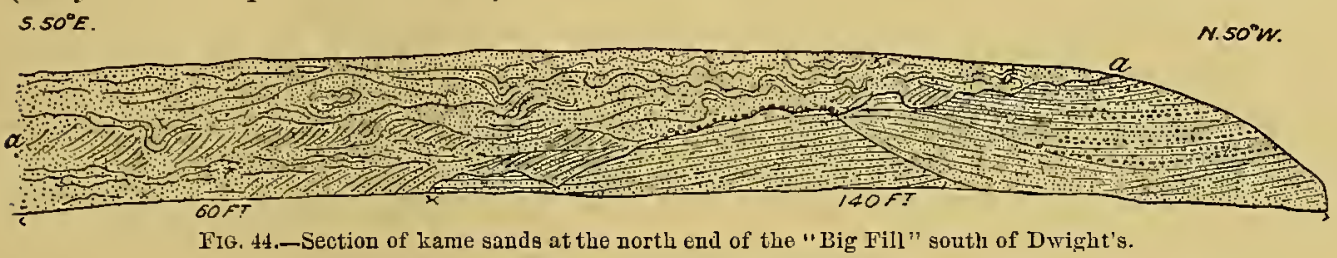

the proposed explanation that they were deposited against and upon a shifting and inconstant wall of ice.

The west and south walls of the "borrow" south of the "Big Fill," at the entrance of the Belchertown Pass, from which material was "borrowed" for the latter, was an example of a region where the kettle-holes are closely approximated, and represent the work of the violent current of the Pelham River in the presence of shifting ice. The whole south wall showed the finest flow-and-plunge structure, whose direction made it seem most probable that the current came over the ice from the northwest. The other walls showed the most rapid alteruations of coarse and fine beds, of cross-bedding, and of shifting and confusion from the repeated sinking of the ice beneath beds already formed.

Finally, an example may be taken from a "borrow" along the east side of the New London Northern Railroad south of the overhead bridge south of North Amherst station, showing the extreme of complexity of an area of "reticulated ridges," where, although the action of water is manifest throughout, the deposit might almost be called a moraine, as the 
action of ice is almost as clear as that of water. It is a "moraine terrace," as these kettle-holed plains were called, with wonderful acuteness, by President Hitchcock. ${ }^{1}$ I subjoin my notes of the section as taken July 30, 1880:

A perfectly though very rudely and confusedly stratified bank makes the upper stratum, commencing at the surface as coarse sands in rapid alternations of grade and pretty regularly horizontally bedded, but below filling up hollows in the next lower bed, and in places there is quite fine sand in the bottom of the hollows. The whole is about 10 feet thick at maximum.

Next below is a single stratum of coarse gravel about $3 \frac{1}{3}$ feet thick, pebbles mostly between three-fourths and 1 inch, but going np to $1 \frac{1}{4}$ inches. This has certainly been pushed in all at once in an overloaded flood current, and has gouged into the stratum of sand below, gathering it up here and there in folds and in other places blending it with its own material.

Next below are the remains of a sand stratum, in its upper portion fine sand, in places well washed, and 1 to 3 feet thick, or in alternations of fine and coarse sands, the latter also well sorted, the whole stratum nearly 7 feet. This graduates below into a coarse gravel, made up for the most part of pebbles three-fourths of an inch long, of which 10 feet are exposed.

It is noticeable that the great majority of the largest bowlders are thoronghly rounded, especially, the quartz bowlders, and many are hard, far-traveled rocks, while side by side with these are many not worn at all, and in one case I found a well-scratched glacial bowlder.

The great angnlar masses of the coarse Mount Toby conglomerate are more than 3 feet on a side. South of the cutting a bowlder of conglomerate 9 feet across lies on the surface of the "moraine terrace," and a peculiar mound rises above its general surface 12 to 16 feet.

LAKE BOTTOMS.

THE BOTTOM OF THE MONTAGUE LAKE.

From the high terrace or lake bench ( $1 \mathrm{~s} h, \mathrm{Pl}$. XXXV) one passes down over a scarp of deposition, not of erosion, to the corresponding and synchronoūs lake bottom $(1 \mathrm{bt})$. This scarp is quite generally well marked, 
especially opposite the entrance of streans. At times, however, especially where the water stood against older sand deposits and where there was little ('urent, al very gradual slope goes down to the lake botton from the old water surlice notcherl in these sands, and no sharp line of demareation exists.

In the northern part of the Montague Lake the filling was nearly complete and the lake bottom is at a high level, and the deejest portion of it, the thread of the old stream, has been removed by the later erosion of the river. Beer's plain, in Northfield, is the principal area of the old lake bottom (or here, rather, river bottom) in this northern portion. It is separated by the great delta of Millers River from the deep, unfilled depression in. which lies the village of Montague. The latter is a deep 'hollow, surrounderl on three sides by rock, while on the north the great scarp of the above delta forms its boundary. The many streams which join and run across the bottom of this small basin have obliterated most of the old surface of the lake bottom.

There is a certain curious parallelism in many orographic features between this basin and the much larger Amherst basin. The village of Plainville, in this latter basin, has the same relative position as Montague village. To the west of each rises a great hill, which stood as an island in the lake, and around the north side of which runs a stream draining the basin. To the southeast a sharp notch between the Trias and the crystalline rocks passes into the next basin south. To the south the Connecticut cuts through the Trias in a narrow gorge, and to the southwest, in each case extends the broad lateral valley once occupied by the flooded river.

THE HADLEY LAKE BOTTON.

Here, as compared with the preceding basin, the conditions are wholly reversed, and the space occupied by the high terrace is, especially along the east side of the basin, very small as compared with that covered by the lake bottom. The real disproportion will appear more clearly if one imagines the color of the lake bottom ( $(\mathrm{bt})$ on the map extended across the succession of shades ( $1-4)$ which represent the later erosion terraces cut in this lake bottom by the Connecticut and its tributaries. This disproportion is as striking in a vertical as in a horizontal sense, since the undulating lake bottom is over broad areas raised only a few feet above the present flood plain of the Comnecticut.

MON XXIX- 43 
In the northern part, in Greenfield, the lake bottom is elevated nearly to the level of the shore bench, as the lake was here shallow from the beginning, and narrow, and it is covered mainly by quite coarse material. Farther south, in the south of this town and in the north of Deerfield, the original depth was greater, and a great thickness of clays gathered, over which the flood sands were swept, as detailed in the section. (See p. 634.)

South of the delta of Deerfield River, throngh the sonthern portion of Deerfield and through Hatfield, the lake bottom is a broad, almost perfectly horizontal sand plain; chosen for the base line of the Borden survey as the most perfect plain in western Massachusetts. It is underlain by fine white sands, with delicate cross stratification dipping very commonly about $15^{\circ}$ S., changing downward pretty suddenly into fine, horizontal clays. This plain extends from the foot of "The Rocks" across Hatfield with a height of only about 13 feet above the lighest flood plain of the Connecticut, and is continuous across the river in the extensive plain of exactly similar character and elevation which extends from the south of Sunderland down through North Hadley and the west of Amherst, and, dividing on Mount Warner, sends one lobe down past its eastern base, between it and the Amherst ridge, while the other entirely similar lobe, which formerly skirted its western base, has been largely removed by the oscillations of the river and disguised by the abundant dunes which have formed over the remaining portion.

One can not well cross the Amity street meadow, west of Amherst, and study the lower slopes of Mount Warner and its southern prolongation without feeling that the meadow was the bottom of a stream whose current molded the sides of Warner. This hill stood like a pier in the midst of the broad water, but nearer its western side, and the currents dividing on it wore deepest around its northern base; and the groores thus formed extended south, widening and shallowing, being best developed at Amity street - a little higher and less marked where it crosses the Northampton road, but traceable like a distinct river bed for a long way south through the woods, until it rises and blends with the broad plain in the southwest part of Hadley, after the obstructing hill had been passed.

It is plain that the western branch of this groove, occupying a narrower passageway and directed toward the Holyoke notch, was the deeper, and so determined the course of the main stream on the recession of the waters. 
Becanse the eistern branch was deepest toward the north and rises and widens to the south, it hat griven rise to a curions little drainage area, whose smaller streams head in its southern higher portion and gather and rum north around the north end of Hount Warner.

An inspection of the map will show that the tail of the high terrace carried out from Mount Warner is curionsly directed southeast, another indiation of the greater force of the current through the passage to the west of the hill. This tail is carried sonth across the Northampton road. Extending across this road and much farther sonth to the base of the Holyoke range, is a broal, very flat plain, underlain by clays of great thickness, which for a long way south are covered by only a thin layer of sand, so that the whole rainfall over the area is kept very near the surface, and the brooks are large and run in very shallow beds.

The groove mentioned above, worn by the waters parting on Mount Warner, seems to have been cut into the clays which had been previously deposited to a higher level than the bottom of the groove over the area where the latter was formed. This is especially clear where the Northampton road crosses the groove just west of Amherst and rises upon the plain south of Mount Warner just mentioned. It goes up over the edges of the horizontal clays to reach this plain. Also, on the west side, the clays rise at the south line of Hatfield 72 feet above the river level. This falls in with many other indications that in the latter portion of the highest water stand the eroding and carrying activity of the stream was considerably increased. Another similar indication is that over the lake bottom and in the high terrace everywhere, and under every variety of circumstances, a coarser stratum overlies finer beds as the last deposit of the flood time, as if the final melting of the ice from this drainage area had come with some suddenness.

At the foot of Amity street another interesting observation and deduction may be made. Along the side of Monnt Warner and its southern prolongation, as well as along the slope of the Amherst ridge east of us, the long sand bars are carried south just as they were left by the flood, and they merge below with the broad, flat thread of the channel, it also being just as it was left by the same current (barring, of course, the small erosion of the brooks); and down both the slopes there is no intermediate terrace or line of erosion to indicate any intermediate water stand between 
the high-water stand of the flood time and the present flood plain of the river; and this observation may be made over all the area $I$ have been describing in this section south of the old waterfall at the Lily Pond in Gill. (See Pl. XXII, p. 725.) This indicates a very sudden shrinkage of the waters from their maximum to nearly their present volume.

I have had occasion already to speak of the depression south of College Hill, among the drumlins, and of the more extended and much deeper depressions west of South Amherst, and to some extent, also, of the still larger depression of the East Street basin. (See p. 641.)

The best point from which to study this basin is at the highest part of the road going north from East Street village. One looks across to the massive terrace which flanks the Pelham Hills and sees at his feet the heavy sand bars which had been carried south at the base of the hill on which he stands before the current was cut off by the delta of Cushmans Brook, which stretches in plain sight across the north end of the basin. The face of the high terrace opposite is cut by a series of finely preserved terraces, which seem to have been formed while the East Street Lake was being slowly drained by the gradual lowering of its ontlet, Fort River, in its conrse throngh the tangle of drumlins sonth of College Hill by which it reaches the main valley. These terraces are figured by President Hitchcock. $^{1} \quad$ The sands were carried out in force over the lake bottom nearly as far south as the village, and from this point south the lake bottom is made up of clay, with often less than 3 feet of fine sand covering it, and this forms the lake bottom south across the low extensive Lawrence Swamp, which is, as it were, the remnant of the old lake imperfectly drained by the single outlet of the basin, Fort River.

In its southern portion the abundant sands around Dwight's station and along the northern flank of Mount Holyoke have been carried down and spread out over the clays by undertow, and slope gradually from the highwater line out into the basin, and this is the case along the whole north flank of Holyoke.

Beyond the great oxbow region of the Northampton Meadows, the lake bottom across Southampton, Westfield, and Sonthwick, except where it has been removed by the basin of Westfield River, is well preserved, and is in effect the deep-water channel, or channels, of the broad arm of the flood

${ }^{1}$ Surface Geology, Pl. IX, fig. 2. 
stream which occupied this lobe of the valley, and which left lake bottom and borker alike intact on the recession of the waters. Over this region it se'med more convenient to disenss them together, as has been done above. (S.e p. 650.)

THE SPRINGFIELD LAKE BOTTON.

On the east side of the river, at Smiths Ferry, sonth of the great Dry Hill bar, and again much farther sonth, across West Springfield and Agawam, are limited areas occupying a level considerably below that of the high terrace or filled portion of the lake, connected with it by a plainly marked scarp of deposition, and on the other side separated from the later terraces by an equally well-narked searp of erosion. To these I have assigned on the map the same color as that given to the lake bottom in the northern lakes. They are, however, of so limited extent that the lake may be fairly contrasted with the more northern ones as a filled-up lake, in so far as its northern half in Massachusetts is concerned.

\section{DETAILED SECTIONS OF THE TERRACES AND LAKE BOTTOMS, SHOWING} SEVERAL ADVANCES OF THE ICE FRONT.

\section{THE CAMP-MEETING CUTTING.}

The cutting of the Canal Raihroad, made in December, 1880, throngh the plain on the north line of Northampton, at the northern edge of which the Methodist camp-meeting grounds, called Laurel Park, are sitnated, ${ }^{1}$ was at once the most complicated and, for the information it gave concerning the oscillations of the ice, the most instructive of all those opened in the valley of late years. It extended, with an average depth of 20 feet, for 3,250 feet. I studied it with great care during the progress of the work and took many sketches of all parts of it. I found the winter time in one respect very favorable for the study of these walls of incoherent sands and clays, as in the steady cold they remained vertical for a long time and "weathered" like banks of sandstone and shale, bringing out many refinements of texture which would otherwise have been overlooked. It was like an anatomist's "frozen section." The cutting afforded two sections 50 feet apart, and after its completion the steam shovel was put into the bank both to the right and

${ }_{1}^{1}$ This cutting is just west of the apex of the great Hadley bend of the Connecticut, where the first road crosses the railroad. 
to the left, and worked back north from the brook to be mentioned to the oldest till, giving two more sections, 2 rods farther from the center on either side, and in the most difficult part of the line. (See Pl. XV, and Pl. XVIII, figs. 2,3 , at p. 694.)

POSITION AND CONTOUR OF THE TERRACE.

Coming down from Deerfield, the great plain of the Borden base line $(1 \mathrm{~b} t)$ sinks across Whately and Hatfield from 220 feet to 170 feet and abuts npon "The Rocks," a low, jagged reef of exposed ledges, back of and above which the lake bench flanks the higher hills to the west. At the north line of Northampton this plain $(1 \mathrm{~b} \mathrm{t}$ ) rises by a gradual slope to the height of 203 feet, and still flanks the sonthern prolongation of the ridge for nearly a mile south and merges around the south end of Elizabeth Rock with the delta sands ( $1 \mathrm{sh}$ ) which fill the great Northampton Bay and rise gradually to 295 feet in Florence. Resting thus on the west against the rocks, the plain on the east overhangs the westernmost portion of the great Hadley bend of the Connecticut, which has here eaten into and destroyed a large portion of it. At its southern end, also, brooks have cut down into the clays and obscured its connection with the delta sand farther south. In all directions between north, east, and south the valley is open and many miles wide. Mount Toby rises in the plain $3 \frac{1}{2}$ miles to the northeast, and it is a point whence one gets a rare view of the beautiful valley. The plain lay thus in the open waters of the Hadley Lake, and it was formed more than 100 feet below the surface of the lake waters.

From the clay pit at the southeastern corner of the plain one goes down the steep slope 70 feet to the river, at the extreme western point of the great bend, over an unbroken succession of laminated clays, which rise to within 6 feet of the surface, being capped by sand, and as I could trace them some way north in the old cutting of the Connecticut River Railroad, to which the new cutting runs nearly parallel, and found traces of the same clays at the north end, I assumed the upward snccession here to be rock, till, heavy clays, and sand, and that this gave the greatest height of the clays for this portion of the valley, and I had no conception of the exceedingly complex anatomy of what seemed a very simple and normal section. 

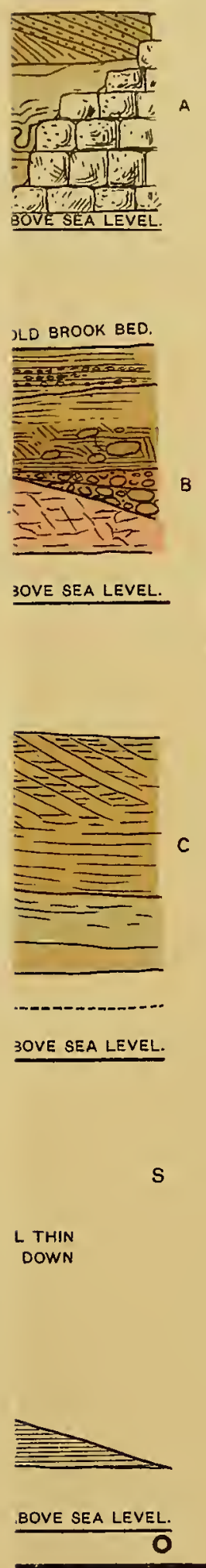



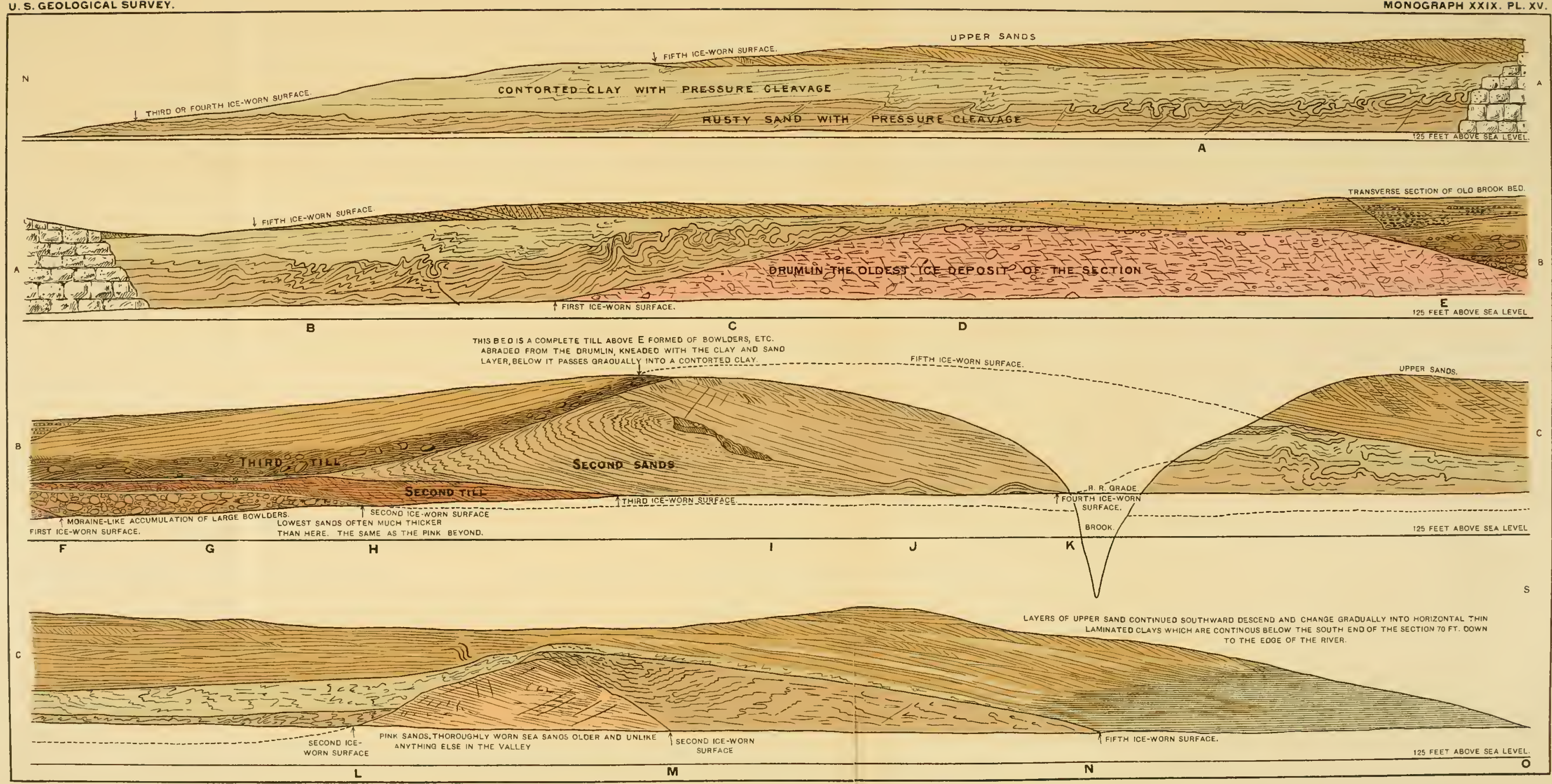

SECTION AT THE CAMP MEETING CUTTING ON THE NORTH LINE OF NORTHAMPTON, SHOWING THREE READVANCES OF THE GLACIAL ICE.

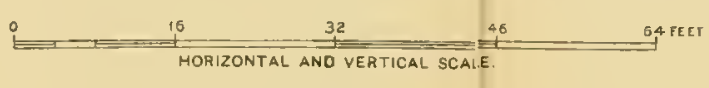



DESCRIPTION GF THE SECTION.

The cutting enters the hill at the north end, near the station of the camp-meeting grounds, and deepens to 18 feet in the first quarter, at the werhead bridge of the road to Hatfield. It soon rises to 24 feet and contimnes with this depth to the end. Exactly in the middle it is cut in two by the narrow sand gulch of a brook which runs east to the Commecticut.

The drumlin.-(Pl. XV, C F.) The central and the oldest member of the series exposed here is a drumlin of the "lower till"-indeed, the lowest till-which rises with easy slope just south of the overhead bridge to a height of 18 feet, and continues about 300 feet before it dips, with the same easy slope, below the level of the raihoad. Excluding for the moment an upper layer of 2 to $3 \frac{1}{2}$ feet, the whole mass is a stony clay of extreme compactness, in which the steam shovel could make but little progress, and which, six months after the work was done, still retained the marks of the shovel teeth. Most of the pebbles were about or under 6 inches in diameter, of well-marked glacial forms, and often scratched, mostly of black argillite and mica-schist, which borders the valley from the middle of Whately north. The mass, when freshly cut, was of a dark-gray color, nearly black, but with a faint shade of brown and green. It showed no trace of stratification at first, but after months of weathering a rude horizontal bedding made its appearance. Lines from 3 to 6 inches apart could in places be traced for a distance across the mass, and the pebbles lay parallel to these planes more often than in other directions.

In the upper 2 or 3 feet of this mass, excepted above from the foregoing description, occurred a great number of bowlders, up to 4 or 5 feet on a side, almost entirely of the tonalite which skirts the valley from the middle of Whately sonth past the section. This upper portion is not separated by any line of demarcation from the portion below. Nor does the stony clay in which these large bowlders are embedded present any difference in texture or color, whether one examines a fresh or a weathered surface, when it is wet, dry, or frozen. This seems to me to represent the portion of the ground moraine which was brought into its present position toward the close of the activity of the main ice, when the ice which passed over this spot was deflected into the valley from the west over the ledges of 
tonalite, instead of, as earlier, over the slate area farther nortl. The original surface of this drumlin represents the oldest surface over which the ice moved.

The bowtder bed.-(Pl. XV, D F.) The drumlin slopes easily southward below the level of the cutting; and resting against this slope, though not rising quite to the level of the top of the drumlin, is a mass of bowlders, from 6 inches to 2 feet in size, with very little admixture of finer material, the bowlders largely tonalite, like those in the upper portion of the drumlin, quite well rounded and showing no traces of scratching. This slopes off very gradually at top and descends below the level of exposure at a distance of 120 feet from the till. That this bowlder bed was concentrated by water action from the bowlder-crowded upper layer of the till below it seems to me probable. Whether this was done in a violent current beneath the ice, or whether it is the oldest shore deposit of the lake which occupied the Hadley basin on the recession of the ice, can not be made quite clear, though I incline strongly to the latter view, which will, I think, be seen in the sequel to be best supported by all the facts. It is also possible that it is a terminal moraine of the retreating ice, and its surface may represent the second surface over which the ice moved.

The pink beach sands.-(Pl. XV, H and L M.) Resting upon this bowlder bed, and separating it from a second till above, is a thin layer of well-washed pink sand, disconnecteả and only a few inches thick on the east wall of the cutting, but nearly 2 feet thick on the west wall, which is plainly the remnant of a much thicker deposit that has been planed away by ice which deposited the till above it. This sand layer disappears here below the level, but if we follow the heavy sands which cover the second till southward we find them resting in marked unconformity upon the same pink sand, which is easily identified with the thin layer already described by its color, size of grains, and well-worn and sorted state, and distinguished from the upper sands by the absence of the clay partings which characterize the latter. Here the pink sands rise in the midst of the newer sands on the east side to the height of 14 feet, in a dome with easy slope northward and more rapid southward, while in the west wall they appear in much greater force, the distance from the point where they first rise above the level of the road to where they sink again below it being 250 feet. The gradual southward rise of the surface of the sands soon brings them to the top of the 
cutting, and they make its whole thickness, being, indeed, somewhat eroded above for over 50 feet, and then sink and rise again in a smaller momd betore they finally disappear. The botton of the sand was nowhere exposed. These sands dip southward $15^{\circ}$ on the east side and are nearly horizontal on the west; they are marked by delieate cross-bedding, and here and there layers of pebbles up to an inch in size occur. When first uncovererl they were of a delicate pink color, so that I was in the habit of calling them peachblow sands. They differ from every other sand in the valley in being perfect beach sands. The sand is more completely sorted and rounded, and the pebbles show the symmetrically rounded forms and satiny surface of beach pebbles. These pebbles are often cemented by calcite, a thing never seen in the Champlain gravels.

The whole is now broken up by a multitude of faults and slips and in places thrown into sharp zigzags like a flight of stairs. It is not, however, molded into the complex curves seen in the more clayey sands above, which we shall see to have been independently and at a later time subjected to a similar crushing. The surface of the sands rises with an easy even slope Fra. 45.-Block of frozen "pink eand," ehowing fine s56. and sinks with the same smooth lines the of joints. The liorizontal lines are the bedding of and sinks with the same snooth lines below one's sight. A curious appear-

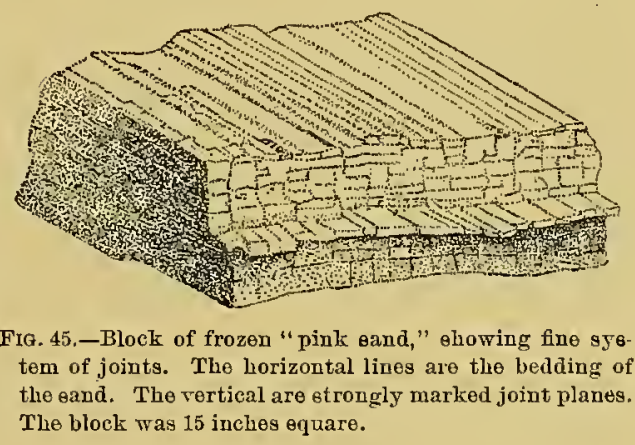
ance shown (fig. 45) by a frozen block of the sand may even be due to the development by the weight of the ice mass, or by torsion in connection with its thrust, of a latent pressure cleavage. A frozen block from the north end of the east opening of the sands had carved out upon it by the wind a series of perfectly parallel cracks, 3 to $4^{\mathrm{mm}}$ apart and about at right angles to the bedding, and these, together with the bedding, had been very beautifully dissected out by the wind.

The sands here dip southward, and the ice coming from the north had ridden over the upturned edges of the lamine, so that the plane of these fissures was at right angles to the direction of the thrust of the ice. I have little doubt that the ice moved over this sand bed while it was frozen, and that this is the reason why the sands are so often and so sharply faulted and broken and not thrown into twisted, contorted folds; as happened later to 
the upper sands when the ice was plainly thrust ont into the waters of the lake-then risen higher-and plowed up its bottom.

While I was studying the sands the workmen were breaking off masses of the frozen sand with wedges and heavy harmers to make way for the stean shovel, and the rock thus formed was one of great hardness. The depression which separates the two parts of the sand on the west side is lined by a thick layer of unstratified pebbles concentrated from the pink sands, and seems to me a "pot-hole" in the sand, cansed by the waters of a moulin of the glacier, though it may be an old brook bed. The eroded surface of these sands is the third erosion plane occupied by the ice.

The second till.-(Pl. XV, E to T.) Returning now to the south end of the great drumlin, we find the second till, which rests upon the pink sands, to have a thickuess of 2 to 3 feet, and to be sharply demarcated on the east from the pink sand and the bowlder bed below, the boundary being a straight line, and separated above from a third layer of till by the thin, disconnected remnants of a second sand, which thickens rapidly sonthward, so that where the second till goes out of sight below, it is separated from the third till above by 15 feet of sand. This second till is the hardest stony clay, wholly indistinguishable from the oldest till of the drumlin, against which it seems to rest in a wedge-shaped end, although no distinct line of demarcation can be seen between them. The ice seems still to have rested upon the surface of the older till, or to have eroded down to it, and a train of large bowlders appears in the second till a little way from the great till, quite plainly derived from it, as farther on they are wanting in the second till. Farther south, where the ice rode up over the pink beach sands as already described, there is but slight trace of tilla few large bowlders resting on the sands-that which we have followed from the oldest till seeming to have been derived from the erosion of the drumlin; and here the material has failed or been removed at a later time by water, as has much of the pink sand, which one can follow by its color as it is swept southward and now lies between the layers of clay of later deposition, showing that ice and water worked together here.

The second sands.-(Pl. XV, H to L.) At the south slope of the drumlin the sands which cover the second till and separate it from the third appear only as a thin, disconnected film, rising to a thickness of 8 to 10 inches on the east side, while on the west they are continuous and 
nearly 2 feet thick and rise up onto the back of the drumlin northwardly, where they atre sheared off abruptly by the third till, which here blends with the second.

Southwarl, the third till, which passes down the south slope of the drumlin, sinking deeply into these sands, rises with an easy gradient up to the surfice of the sands on the east side of the cutting, its further extent being now cut off' by erosion; and on the west side rising in the same way to within a foot of the surface and then extending 50 feet over the sands, and finally thickening downward to 6 feet and ending abruptly in the sands in a club-shaped mass, the sands that rest against its south face being continuous with those beneath it and like them in every way. From this point the sands make the whole thickness of the wall, 24 feet, for a distance of 224 feet to the ravine, and crossing this (25 feet wide), the sands, with the bottom nowhere exposed, run under a bed of clay, the same as that north of the dimunlin, and go on with a slight dip southward and fold over the pink sands already described. They are here much thinned, and dip beneath the surface near the south end of the cutting. These are, for the most part, coarse to very coarse, reddish sands, laid down by a strong and steady southward current in layers which are horizontal for long distances or slightly inclined southward. Only for a few rods on the west side and just south of where the third till rises upon them are they clean, white, better-sorted sands, the cross-bedding dipping sharply north for a time and then as sharply south, ${ }^{1}$ and their eroded surfaces are covered by a layer of well-worn beach pebbles. The bedding is everywhere, except in the white sands, sharply marked by thin layers of very fine sand 2 to 6 inches apart, which are persistent for long distances, and which farther south, where the sands have run beneath the clay, become layers of true clay, and toward the top of the sands approach nearer by the thinning out of the intervening sand layers, and so effect a transition into the clays.

For a long distance south of the brook this arrangement is well developed. Layers of sand, beautifully rippled at surface and about 6 inches thick, are capped by layers of clay, one-fourth of an inch thick, which takes an accurate cast of the ripples below and makes the upper surface more or less nearly horizontal.

${ }_{1}^{1}$ These are back-set and front-set sands, in the terminology of Professor Davis. Bull, Geol. Soc. America, 1890 p. 195. 
In the frozen wall the sand layers were deeply worked out by the wind, and the clay layers projected one above another like the eares of a fluted iron roof. By the thinning of the sand layers the whole deposit loses in thickness and the superineumbent clay sinks lower. This plainly indicates a strong current in the summer floods, a quiet one during the winter, and a depth of water sufficient to so far remove the banks of the stream to the west that the floods brought only thin layers of sand out over the clay to this point, layer's which have mostly dwindled to nothing before we reach the south end of the cutting.

The sands, as indicated above, run up on the south slope of the drumlin in a thin film, and could in one section be traced almost or quite continuously across it, to join a thick bed of similar sand, which extends to the north end of the section, where it is cut off by erosion. It is capped, as in the layer south of the drumlin, by the same thick deposit of clay. These sands are finer than those already described, especially near the drumlin, manifestly because they were laid down in the sheltered area behind it. Northward they grow coarser, and at the extreme north are gravelly, and iron-shot where the water circulated below the clays, with coarse crossbedding dipping south. Through most of the distance the beds are (or were) horizontal, and show repeated oscillations of coarser and finer layers, and everywhere most delicate cross-bedding. Upward, the whole gradually becomes finer, clay layers making their appearance, which at the end effect a somewhat sudden transition into the clay above; in short, the sands agree in all points with the corresponding sands south of the drumlin.

The third till.- - It will make clearer the complex series we are studying if I call attention to the four surfaces on which the ice has rested. The first is the surface of the drumlin. The second is the surface of the second till, which has eroded the pink sands; and as the till layer seems largely derived from the broad surface of the drumlin, this layer lessens and the ice rests almost directly on the sands in the continuation of the surface sonthward. Consideration of the third till, which is the subject of discussion here, may be omitted for a moment. The fourth and last surface occupied by the ice is very clearly defined along the whole length of the section. It is the horizontal upper surface of the clays above the second sands from the north end of the section to the drumlin, and is continued along the eroded surface of the drumlin, and is the surface of the fourth till from the beginning of the 
sime at the sonth end of the drumlin or southward. This fourth till is made up of material derived fiom the drumlin and molded with the clay and sand bekw, and so grades southwardly into the contorted clays uncontanimated with ghlacial débris, whose planed-off npper surface is the contimnation of the fourtly surface occupied by the ice in the whole distance south of the cential gorge to the place where this ice-wom surface sinks below the level of the section.

Bec'anse of this blending of the clays with the second sands beneath them by the fourth ice, the relative importance of the third surface occupied by the ice in the midst of the second sands can not be clearly made ont. It is seen in the sloping layer of till that extends down through the second sands, ending at the north edge of the brook gorge, and is marked "third ice-worn surface" on the main section. Some part of the deep erosion of the second sands between this point and the south end of the drumlin seems due to this third ice advance.

In the opposite side of the cutting, 50 feet 'west of and parallel with the above, the third layer of till ends abruptly in the sands, soon after thickening to 7 feet and rising nearly to the surface in a way peculiar and difficult to explain. It is here a compact, stony clay, in which, near the end, I counted twenty bowlders 12 to 16 inches long, all of glacial shapes and many striated. As seen in the wall of the cutting, it ends in three long, sharp teeth projected sonthward, receiving between themselves corresponding projections of the sands; and these projections are made up of laminæ, which begin against the till and extend from it with perfect regularity, exactly as if it were the fluted face of a sea cliff and the sands had been laid down against it. There seems to be no question here of a thrusting of the ice into the sands after their accumnlation, but it would seem that the third till represents a second advance of the ice after a slight retrogression, and that here it pushed itself over the sands of the lake or estuary as before, with the difference that now the water stand was higher and the snont of the glacier was thrust out into the lake, gouging and crumpling the beds at its bottom. It ended here for a time and then retreated, leaving the till, which it had gathered mainly from the drumlin, covering the sands to this point. The deposition of the sand continued uninterruptedly except so far as the space was occupied by the ice, and the sand increased around and over the till as soon as the ice disappeared. 
Turning to the second cut on the east side, which was 50 feet farther out in the lake and parallel to the two last described, we find the till homogeneous in the lower 2 feet of its thickness. Then it runs up over the sands and thins to a foot in thickness, and is then prolonged in a stratified bed of the same dark greenish-black sandy clay, which ends abruptly (thickening slightly before its ending:) in a sharp point, the last portion being beantifully cross-bedded and apparently the product of a single plunging wave from beneath the ice. This is inclosed above and below in the light-yellow coarse sands, which beneath are undisturbed so far back as traces of lamination occur in the stony clay above, and are conspicuously contorted farther back beneath the amorphous and ice-carried portion of the same bed.

At the fourth cutting parallel to those last discussed (the most westerly), where the till runs up on the sand, it splits into three or four layers, each successive one rumning rup with sharper angle and being separated by thickening sheets of flood sands; and the till reaches here its greatest height. Some layers of the till bend irregularly and sink deeper into the sands and extend farther south, but are cut off by the brook erosion before the connection soutliward is made. (Pl. XVIII, fig. 2, p. 694.)

The transition of the sands to clays beneath this till indicates a deepening of the water's southwardly, by which the ice was more or less buoyed up, allowing a portion of the sands described above to accumulate beneath it, after which the ice dropped again upon the sands. This was repeated several times, and at one of these times a mass of water from beneath the ice swept into the sands the curious point of remanié drift described above, and finally the ice was floated away to the south as icebergs, allowing the sands to continne their accumulation over the till it had left.

The clays above the second sands.-These are, from one end of the cutting to the other, the common Champlain clays of the valley, formed from the wash of till, and where not disturbed are thin-laminated in layers 8 to $12^{\mathrm{mm}}$ thick, each layer buff colored and sandy in the upper third, and composed of fine fat clay in the lower two-thirds.

The fourth till and its effects upon the clays and sands below.-Starting. from the north end of the opening, the surface of the clays is an almost perfectly level surface of erosion on to the drumlin. The ice has passed over it, planing it down to this level, twisting and contorting it and the 
sands bencath it into the greatest confusion, kneading them together, pressing the day in great lowses down into the sands, in some places destroying the lamination of the riay entirely; in others, where the alternation of fine sand and fat clay was more clearly marked, producing in each layer masses where a smoothed surface resembled marlled paper. This contortion increased to its maximmm where the two beds, here inextricably mixed, momited up the north slope of the drumlin and were sheared off on a plane which is almost coincident with the surface of the drumlin and which is enntinued south as the upper surface of the fourth till.

It would seem that the ice pushed out into water of considerable depth, and so, partly buoyed up, was able to move over the plastic clays, producing a minimum of erosion and depositing no till on the clay; but the drumlin acted as a resistant substratum, and between the two the stratified beds were sheared off entirely, the hill itself was scalped, and the combined material was trailed along over the remnant of the sands down the slope (a train of great bowlders occupying its lower portion) for a distance sonthward from the drumlin and plainly derived from it. Masses ranging from filaments to large sheets of the sands or clays, or beds containing alternations of these trvo, are contained in a formless mass of till of great compactness, which rests with a flat under surface upon the sands below.

I lave figured a surface of this bed (Pl. XVIII, fig. 3, p. 694) where it is just beginning to mount again upon the sand (above D, Pl. XV). The upper layer of till is crushed into the sand layer, its bowlders plowing into it and producing folds and faults; while below, a thick bed which once consisted of clay with thin sand partings is as a whole kneaded into such a confused mass that, over the broad, smooth surface sculptured by the wind, wherever the sand layers come to the surface they were eaten out into intricate convolutions, like the interior of the ear.

That portion of the sands caught between the second and fourth layers of till has all structure crushed out of it; but as the upper till layer rides up onto the thick mass of the sands, the line between them is sharply defined, being gently convex below; and as the sands thicken, signs of bedding gradually disengage themselves from the confusion of the mass, and one sees the effect and direction of the thrust of the ice marked with wonderful clearness in the contorted layers of the sand. Within the sands the layers are quite horizontal and undisturbed, and as one follows each back toward 
the till, it is after a few undulations thrown into a series of sharp zigzags or short distinct faults, and the layers thus brought into a vertical position together or bent over southward are then dragged along beneath the ice, rumning a few feet parallel to it and blending together into a confused layer a foot or two thick, in which no structure is visible. On the opposite side, after the last cutting, the appearance was very similar, except that the layers were thrown into still greater confusion, and for 4 rods all the upper half of the sand, 13 feet in thickness, had been pushed 15 or 20 feet southward, the layers now standing on their heads and thrown into folds as complex as the sutures of an ammonite; and farther on the whole mass has been wedged in between the layers of the sands in advance, heaving them up and occupying in a contorted mass a great triangular space beneath them. The till rides over the whole, and every layer of the contorted mass as it comes up from below, as well as of that thrown up by the underthrust portion, bends over southward beneath it as the smoke curls over the chimney edge in a strong wind. As the till continnes sonthward over the sands it moves parallel with their lamination and disturbs them very little, and at last, as it thickens downward, it cuts across them at a low angle, and the layers just below run on continuously and show no signs of any effect from the ice.

Where the fourth till rising over the sands is cut off by erosion it is already largely composed of the contorted clays.

Southward, across the ravine, the surface occupied by the ice sinks into a gentle depression and rises over the pink sands and goes down below the level of the cutting near its south end. It is a surface and nothing more, and in this long distance south of the brook ravine, as well as in the equally long distance north of the drumlin, no trace of till is found upon it. Only in the remaining space, from the drumlin south, the stratum of till is carried forward along this plane, and it is unfortunate that its ending is not to be observed in a satisfactory way, owing to erosion. It is, therefore, not strictly proved that this plane is contimous, but the identity of the beds north and south of the drumlin makes this highly probable, and an inspection of the section will show it to be the only simple supposition, any other requiring an additional recession and advance of the ice.

Everywhere below this plane the clays are variously contorted, as in the reach north of the drumlin; often clay and sand are curiously molded. 
together, and immediately abore it the newer day or sand is wholly molisturbed to the surface of the terrace. Also, in many masses of the laminated clay's a beantiful pressure elearage has been developed, a serjes of fine, closely approximated slip fiults making a large angle with the lamination, and lipping sharply northward in the direction toward which the pressure canc. The section shown in Pl. XVII (p. 692), taken from a similar locality, might have been many times exactly duplicated in the first 300 feet south of the brook.

I assume this work to have been done by the advance of a glacier into the water, and not by icebergs, becanse only a single great boly of ice moving over the soft mass of clays could have planed them down to so true a level except when the protuberance of the drumlin eaused an irregularity in its action, and the great disturbance of the clay and subjacent sands for a depth of above 20 feet over so large a space would indicate a nass of rery considerable thickness which was pushed over the surface and not simply carried forward by the current. Except for these reasons, I do not see why a continnous mass of floe ice might not have done the work, for the scratched bowlders in the till layer seem to have been derived from the earlier till of the drumlin.

The upper sands and clays.-Above the line of disturbance a heavy layer of coarse sands, grading southwardly into laminated clays, smoothes orer the irregularities of this surface and builds up the terrace to its completion. Commencing at the north end, the sands dip sharply southward and represent plainly an advancing delta front or growing sand bank, the sands having been pushed over its surface and deposited upon its southern slope.

In the central portion, over the more irregular surface of the fourth till, these sands-which, where the till ends abruptly, I have already described as deposited continuously against the southern termination of the latter, and as thus being eontinuous with the sands below the till-are carried on in broad, more nearly horizontal sheets, with finely developed flow-and-plunge structure.

Southward, beyond the brook ravine, these horizontal sands are capped by a thick upper layer of cross-bedded sands which dips sharply south and which probably represents the further advance of the delta or bank from the north, the intermediate connecting portion having been removed by MON XXIX- 44 
erosion. In this lower horizontal bed the alternation of coarser and finer layers is very marked, and sonthward the finer layers gradually change to clay, while the coarser grow thinner and finer and at last rum out or blend with the clay layer forming its lower and sandier third. At the same time the boundary between the horizontal and cross-bedded portions of the bed lises slowly southward, since each layer of the latter coming to the bottom of its slope bends sharply to a horizontal position, and, gradually dwindling to become the sandy portion of a clay layer, runs on between layers of the clay, which, coming from the south, bend at the foot of the slope, rise up for a distance upon it, and grade into a layer of finer sand which forms the upper part of the sloping sand layer. Thus, going south, the horizontal layers gain at the expense of the cross-bedded layers above, and the clays gain at the expense of the coarse delta sands, and one has the clearest illustration of the blending of the shore sands and the deep-water clays of the Champlain epoch, and evidence of their synchronism with the later erents of the Glacial epoch.

Rห́SUME์.

The facts detailed in the above section enable us to construct the following pictures of the succession of events over this area:

1. The formation of a drumlin as a part of the ground moraine of the first or great glacier.

2. The recession of the ice to allow of the formation of the bowlder berl which lies at the foot of the drumlin and may be a terminal moraine, or may be due to water action concentrating it from the drumlin itself.

3. The formation of a true sea beach of great extent-the pink sands.

4. A second advance of the ice, rising over the drumlin and eroding the frozen beacli sands.

5 . The second recession of the ice, and the deposition by the flood waters, from its melting, of a great body of sands.

6. The rise of these waters so that an equally great body of clays was deposited upon the sands.

7. A third minor advance of the ice over these clays, molding them into the sands below, removing them entirely over the drumlin, and south of it for a long distance gouging deeply into the sands and covering them with a layer of till derived largely from the drumlin, finally riding up onto 


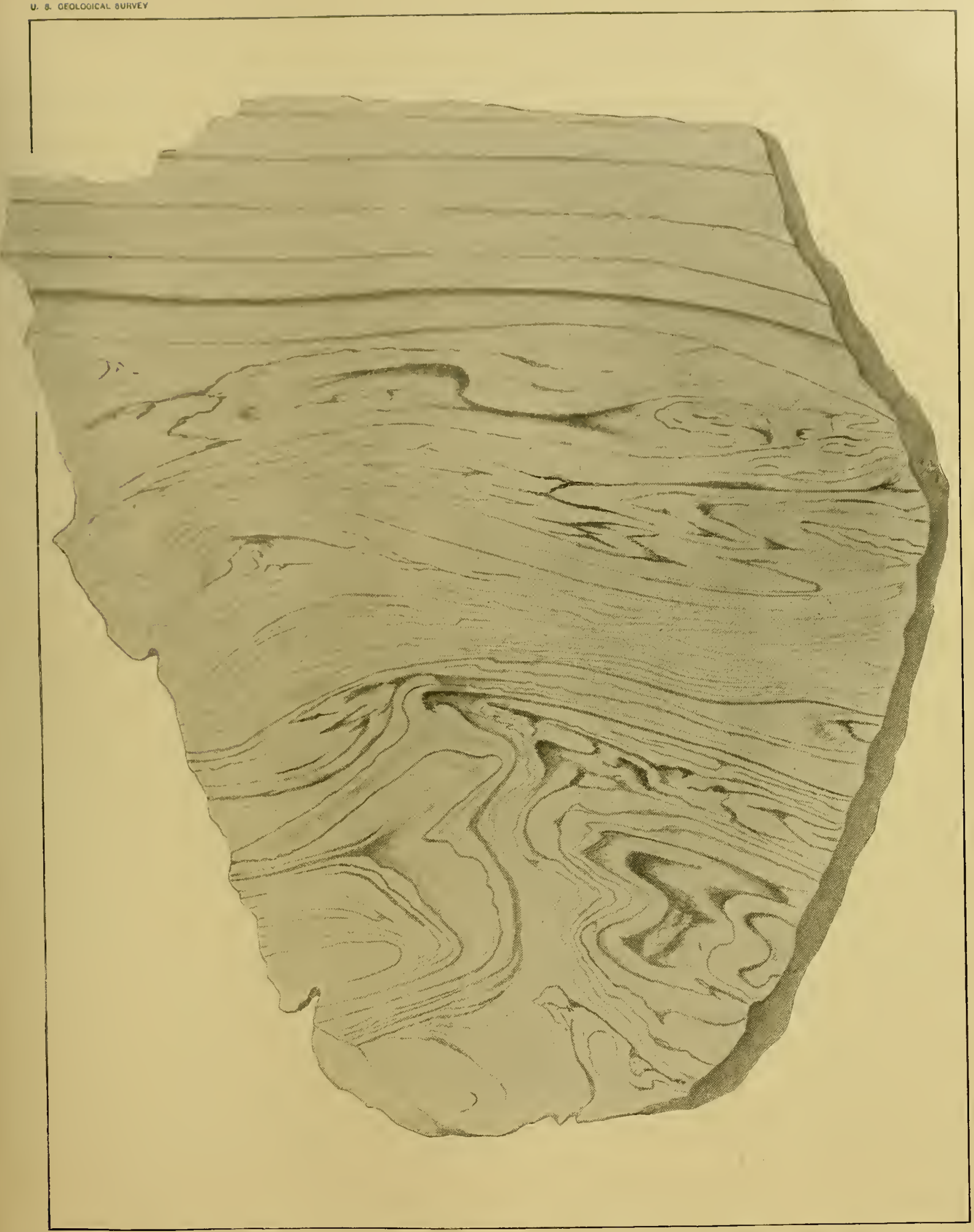



the clays again, and being buoyed up and carrien off southward by the flood waters, which still covered the clays in considerable depth.

8 . The continued deposition of the flood sands in water's somewhat lowered on the recession of the ice, so that coarse sands, with flow-andplunge structure, are laid down, obliterating the irregularities of the surface and completing a terrace of apparently simple structure.

The drumlin (1) must represent the work of the general glaciation. The bowlder bed and the pink sands (2 and 3) must represent an interglacial period of sufficient length to allow of the long-continued and minterrupted presence of a large lake or estuary, and to make this possible the ice must have receded far north of this point in the valley. The erents of 4 to 7 indicate a second advance of the ice, with minor ascillations, during the last of which the end of the valley lobe of the glacier was thrust out into the waters which then filled the valley and by which the laminated clays were being deposited, while at the same time the high terrace gravels were gathering along the shores, a work which on the disappearance of the ice continued to the completion of the terrace.

'The discovery of isolated pockets of glacial débris and disturbed patches at various places in the clays farther south, which must be referred to icebergs or ice floes (described in the following section on the Champlain clays of the Hadley Lake), and of arctic plants also in the same clays, completes the picture of the erents of this time, and indicates that the Champlain clays and sands were here in part synchronous with the Glacial period.

SECTION OF CLAYS IN HATFIELD SHOWING GREAT DISTURBANCE AND PRESSURE CLEAVAGE.

About 3 miles northeast of the section last described (within the same portion of the Connecticut Valley, bounded on the west by the crystalline rocks and on the east by the long ridge of Mount Warner, so that it is in a sense a continuation of the Deerfield Valley), at the southern foot of the red sandstone hill which rises north of the village of Hatfield, a small opening was made in the clays, which reproduced exactly the upper level of disturbance of the Camp Meeting section. The section was 33 feet east of the first house westward from the hotel on the first road south from the ferry. 
Above a horizontal line the clays were horizontal and normal in every respect; below this they were extremely contorted, as indicated in Pl. XVI, showing a smoothed surface about $4 \frac{1}{2}$ inches square. Where the contortion was less pronounced, about 2 feet below the plane of disturbance, in a layer with a thickness of 1 foot and a length of 15 feet, a beantiful pressure cleavage was developed, superinduced upon the original lamination (Pl. XVII) in the whole mass of the clays along parallel planes 2 to $4^{\mathrm{mm}}$ apart and dipping $32^{\circ} \mathrm{N}$. Every stage in the series, from a slight, sharp monoclinal fold affecting all the laminæ along a single plane to the shearing off of the laminæ by small parallel slip faults, could be followed, and the clays, parting easily along the lamination and cleavage planes, broke up into a mass of long pencils.

The more marked fissures are about 6 to the inch; between these again are finer ones, making the whole number about 18 to the incls. Along these the clay is very often slightly faulted; in one case the slip amounts to an inch. The newly formed cleavage layers have undergone decided compression and distortion, which is brought out clearly by the difference in color of the upper and under portion of the original laminæ, so that in tracing the dark bands across the several cleavage planes we find them more or less separated into parts placed slightly en échelon by the contimued faulting in one direction, and these parts variously elongated and flattened out parallel to the plane of cleavage. We may assume the plane of this incipient cleavage to be normal to the direction of pressure. A second system of distant fault planes occurs at right angles to the first, which are more distant from each other and have greater throw, showing that the parts of the bed slipped slightly on each other in the direction of the pressure.

The locality is 125 feet above sea, and thus somewhat lower than the preceding section, but it lies out in the valley, where the clays did not reach so great a lieight as on its borders, and the disturbance must have been very nearly-I think it may be assumed to have been exactly-synchronous with the last disturbance of the previous section. Its position under the lee of a prominent hill, protected from icebergs and floe ice, would also point to a continuous mass of glacial ice as the agent of its formation. 


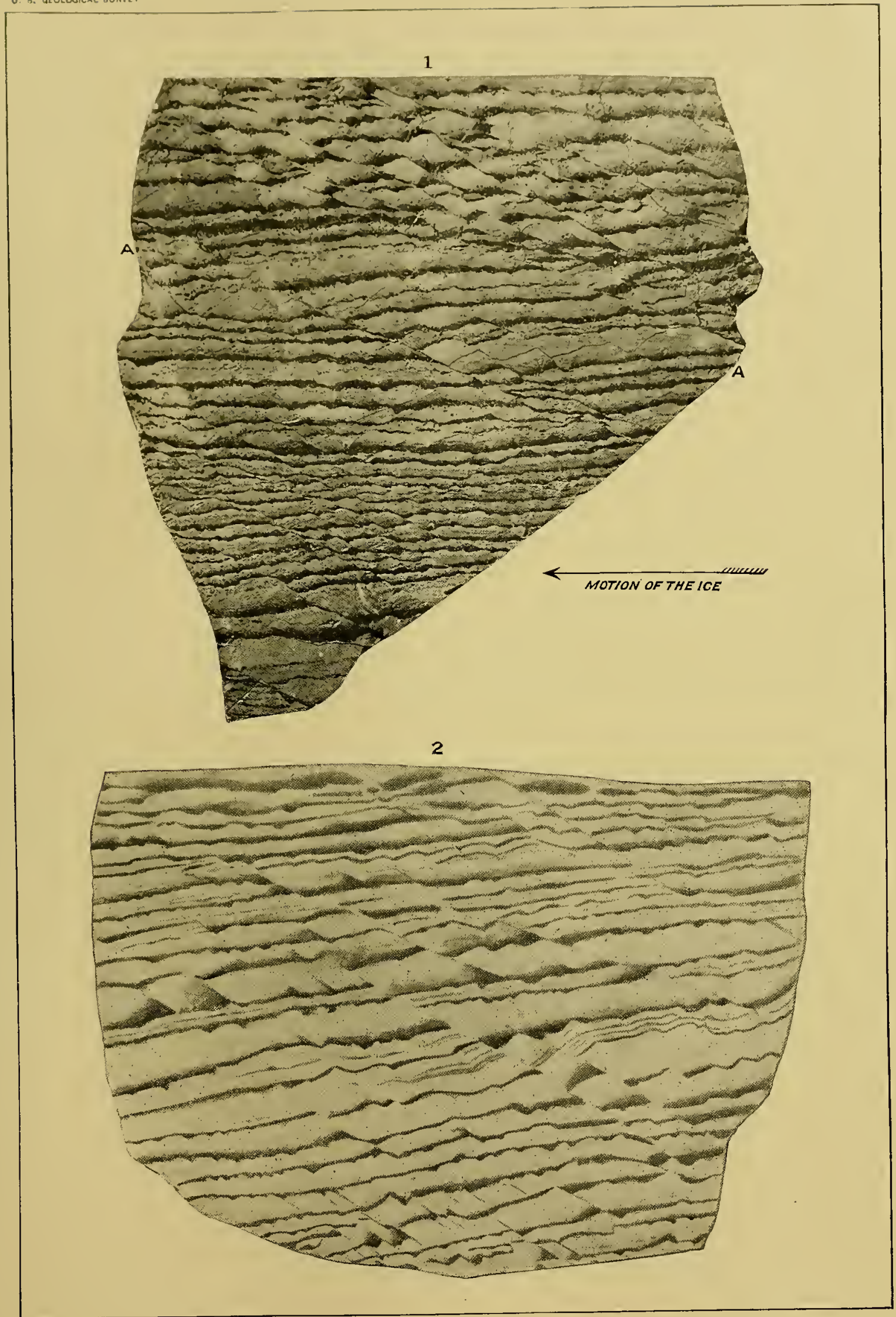

JOINTS AND FAULTS IN LAMINATED CLAY, PRODUCED BY THE WEIGHT OF THE ICE. 

PLATE XVIII. 


\section{P L A T E X VIII.}

\section{THE WAPPING AND CAMP-MEETING CUTTINGS.}

Fig. 1. - Seetion of the fine-grained, contorted sands at the Wapping eutting on the Canal Railroad, in Deerfield.

Fig. 2.- Section on the west side of the Camp Meeting cutting, between the south end of the drumlin and the brook, showing the fourth advance of the ice into the second sands. It is opposite to the portions $G$ and $I$ ou the east section, 3 rods distant from it. It is represented by the disconnected mass of till above $I$.

FIG. 3.-Enlargement of part of Pl. XV (p. 678) at a point halfway between G and H, and above the second sauds, where two large bowlders appear. It shows the passage of the fourth ice over the older elays, here nearly all eroded, and the thrust of the bowlders into the clays, and the kneading together of the elays and subjacent sands. The wind erosion of the sand has produced deep, ear-like depressions in the lower part of the frozen wall.

694 
18 

v. S. GEOLOGICAL GURVEY

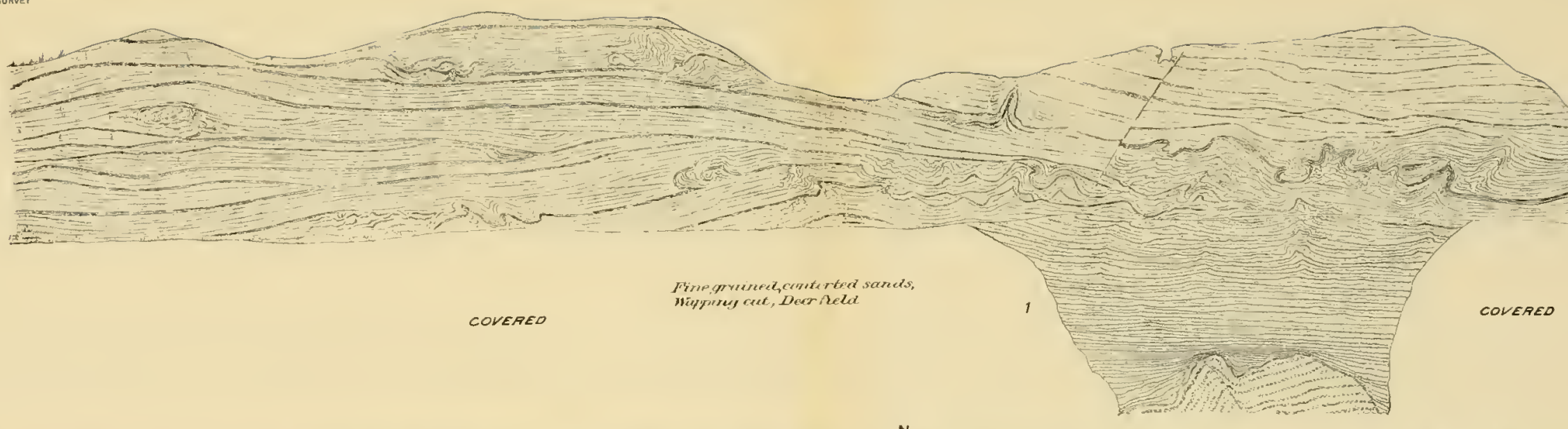

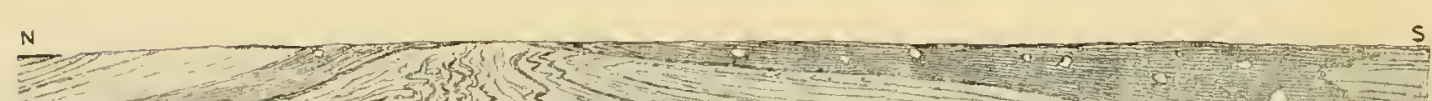

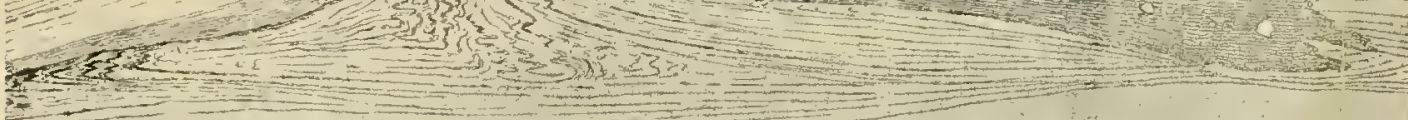

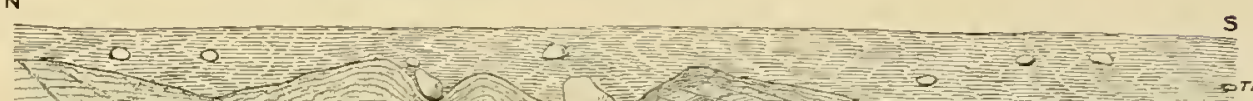

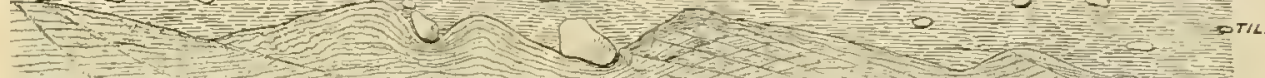

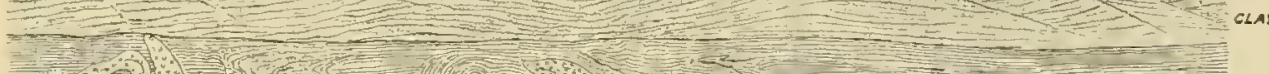

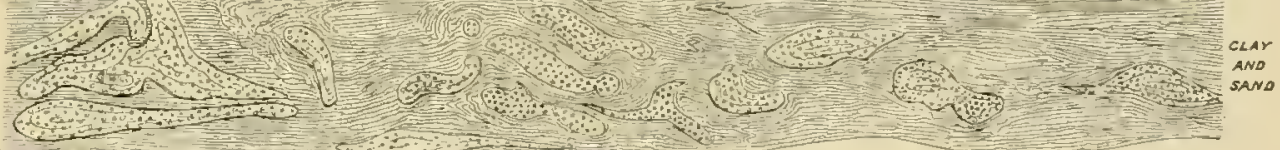





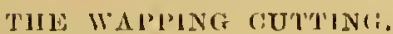

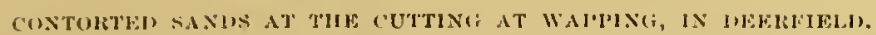

This section, figmed on Pl. XVIIl, fig. 1, was exposed in the works for the extension of the New Haven and Northampton Railuad northward, 2 miles sonth of Deerfield Station, at the same time with the Camp Meeting "utting described above." The delta of the Deerfield River in the Comecticut Lake (1. 634) extended out as a broad, flat allurial fan from the month of the river gorge in the erystalline rocks at West Deerfield, reaching clear ilcross the lateral Deerfield Valley to the foot of the trap ridge. The northern half of this delta has been removed by the later erosion of the Deerfield River, and from the northem rim of the remainder one looks down north into the deep basin thus formed. As the railroad approached this from the south its grade was lowered and a deep cut was made, so that it could pass across this basin by a high embankment. The section given was taken from the west wall, and is thus the north-south section through the middle of the delta, and just opposite the mouth of the gorge of the river. It is made up of fine to very fine, well-sorted sands, in layers $1^{\mathrm{mm}}$ thick and made more distinct by the infiltration of iron. Coarser layers, drying white, and thus standing out prominently, occur 3 to 4 inches apart, and still coarser and thicker ones of the same character about one-half inch apart; these are represented by the heavy lines in the drawing, and they render the contortions visible for a long distance.

The length of the section is 278 feet, the greatest height 45 feet above the railroad. Toward the north end the whole thickness of the sands in the section is crumpled, manifestly by a strong force coming from the north, the disturbance of the sands being greatest in the northern half of the section and in the lower portion of this half, and appearing more in detached patches in the southem part. The cutting was carried along the west side of a brook valley rumning north, and the rain washed a gulch from the cutting down to the level of this brook, exposing the fine sands for 20 to 25 feet below the base of the section. The disturbance lessens downward and the base of the sand is more clayey and rests unconformably upon coarse, reddish, cross-stratified sands derived manifestly from the sandstone, while the upper sands are as plainly derived from the crystalline rocks of the west.

The line of junction of the two sands is extremely irregular, the lower beds having been much eroded before the deposition of the upper, but the

${ }^{1}$ See E. Hitchcock, Geol. Mass., 1841, p. 363. 
junction is such as can have been formed only by the forcible kneading together of the beds. A little farther sonth, on the border of the delta at the house of Captain Briggs, the red sands come to tlie surface in a long knoll. They are finely cross-stratified and dip south with an angle as high as $35^{\circ}$. At the cutting these under sands are much jointed and faulterl, as if they had been subjected to pressure before the deposition of the upper sands. I identify these lower sands with the pink sands of the Camp Meeting cutting (p. 680), and believe them to be a remnant of beds deposited after the first recession of the glacier, while the Deerfield Valley was still sealed up by the ice, which escaped the erosion of the second advance of the ice and on its recession were covered by the sands of the Deerfield delta.

It is not clear to me what could have cansed the extensive disturbance of the upper sands. This disturbance is to be seen in the upper side of the road running parallel to the cutting, several hundred yards to the east. It is at its maximum at the north end of the opening, where the sands have been removed by the erosion of the river and extended an unknown distance to the north in the beds before their removal.

On the north side of the Deerfield River basin, a mile west of Cheapside, a complete section of the sands from the surface down to the till was quite normal and nndisturbed, as also on its northwest border and on the island of the terrace sands which rises in the middle of the basin. Small detached areas of disturbance in the delta sands are common from the head of the latter south to the sonth line of Deerfield, plainly caused by stranded ice, but here a foree of much greater magnitude was certainly concerned.

I have described on page 630 the deep, long depression along the west line of Greenfield in which Green River flows and which was occupied by the west lobe of the ice that found place in the valley while the flood sands brought in across Greenfield through the Bernardston strait were building up the high terrace in Greenfield, and this lobe of ice, extended south, would have come in contact with the delta of the Deerfield from the right direction to have plowed up the sands as we now find them. The high terrace sands are, however, undisturbed right across its supposed track west of Cheapside, and though these sands may have been swept in a little later, their presence renders this explanation only remotely probable. Another possible explanation is that the axis of the delta of which these beds form a part lay to the north of this spot, and along this axis the greater thickness of the beds cansed, by their weight, a flowing of their fine sands. 


\section{H A P T E R X X. \\ THE CHAMPLAIN PERIOD (Conttinued). \\ TIIE CILAMPTAIN CLAYS. \\ INTRODUCTION.}

On the retreat of the ice and on the occupancy of the basin by the flood waters clays began to be deposited over all the botton, far from the shores, where the current was not too strong, and sands and gravels accumulated off the mouths of all the tributaries, and were moved along the shore lines by the shore currents and out into the deeper water by the undertow. The two deposits are therefore strictly contemporaneous, and their laminæ are intercalated with each other at their point of junction (see p. 690). The sands were pushed in deltas rapidly out over the clays, so that their place of junction is a plane with small shoreward dip. It is strictly synchronons with this earlier portion of the flood sands, since, as detailed in the last section, the increased velocity of the flood carried sands out over the clays in every portion of the lake bottoms, even in the most sheltered, like the East Street basin in Amherst.

The scanty outcrops of the clay, mostly along river gorges, are marked by a line of purple dots $(1 \mathrm{~b} \mathrm{c}, \mathrm{Pl}$. XXXV), this color having thus a lithological value, while the other post-Tertiary colors on the map have rather an orographic value.

The great importance and magnitude of this terrane can be seen best in vertical sections, as upon the map it is represented only by thin lines along the river courses and road cuttings and on the steep slopes of terraces; elsewhere it is covered by the succeeding beds of sand.

\section{CLAYS IN THE MONTAGUE LAKE.}

The clays appear in great force above and below Northfield village, where the brooks cut back in the lake-bottom beds, and here they rise 233 feet above sea level. Southward they appear frequently in brook cuttings in the bottom beds, and at Northfield Farms they rise to 270 feet 
above the sea. The fat layers are one-fourth to one-half inch thick and 6 inches apart. This great height was due to the rapid advance of the Millers River delta across the channel farther south, which checked the current to the north. How rapid this was is seen by the section, fig. 41 (p. 688), where far out in the delta the sands rest directly upon the rock. As the delta was extended westward its sands were doubtless carried up grapdually over the clays, for in the long erosion scarp cut in the western face of this delta from Turners Falls around nearly to Montague village, only a small thickness of sand rests upon the clays, which rise to a height of abont 213 feet above the sea and rest upon till or sandstone with a thickness of about 34 feet. The layers average abont 1 inch, one-half fat clay, twothirds fine sand. (See fig. 35, p. 629.)

\section{CLAYS IN THE HADLEY LAKE.}

I have mentioned an isolated occurrence of clay poorly exposed at a schoolhouse in the north of Greenfield. Around Greenfield village the clays are in great force and rest upon till, as seen at the clay pit in the village and on Fall River where the road to Franklin Park crosses it. These clays were continuous through the notch of the Deerfield River, and perhaps also comect farther north, through the passage at the mouth of Fall River, with the Turners Falls clays. Southward they crop out abundantly around the erosion basin of the Deerfield River, to near its south end, opposite the month of the river gorge, where, from the increased current and the increased material brought in by the river, the clays are replaced by a great thickness of sand, which, in the center of the basin, becomes exceedingly fine, with distant clayey partings, as seen in the Wapping eutting (Pl. XVIII, p. 694), where these fine sands rest discordantly on the problematical reddish sands which are there described.

Farther south, through Deerfield and Hatfield, the sand plains are nowhere cut thrcugh to the clays below until the region of complex oxbows of the Connecticut west of Hatfield village, described later (p. 734), is reached, where, in the terrace scarp, the clays appear in great force; only at one place, at a clay pit near the pistol factory, is the substratnm-here coarse till-exposed.

Southward, beyond the influence of the Deerfield, the whole broad bottom of the lake is underlain by a continuous stratum of clay of unknown, 
but in places rentainly of rery great, thickness, and the clay has done more than all the other beds to olliterate the vertical irregularities impressed upon the basin by the ice. It still underlies the whole flood plain of the Connecticut, and although the river in its oscillations has cut in the clay a bronl and deep chlimmel, it has not cut througl to the base of the clay stratum, except opposite North Hadley, where a reef of sandstone projects through, and at the knee of the great bend, where the river has worn into a submerged drumlin. This great bed of clay continues sonthward to the Westlield River, where the conditions of the Deerfield are exactly repeated, and the clays are replaced by the fine delta sands.

It extends everywhere under, and sometimes very far under, the sliore terrace, notably in the case of the Mill River delta in Northampton, where the clays spread under the delta deposits clear up to the "Bay State," near Florence, where they are worked in large brick pits and rest on till with a thickness of 23 feet. There are also large pits near the asylum. It reaches apparently its greatest thickness under the Northampton and Hadley meadows and in the East Street basin in Amherst. At the Belden silk mill, near the station in Northampton, the clay was reached beneath a few feet of sand, and its bottom was 140 feet below the surface-that is, about 12 feet below sea level. Beneath the clay was 10 feet of red sand. The clay was pierced 112 feet at the piers of the overhead bridge at the Northampton station.

The trial piles at the Northampton bridge over the Connecticut, heavy timbers well jointed and hooped, were driven 113 feet below low waterthat is, about 13 feet below sea level-without finding bottom, and after the pile had rester in its place for the night the first blow in the morning advanced it as much as the last of the night before, which would have hardly been possible in any material except a very plastic clay. The piles for all the piers of the bridge were driven 30 feet below the river bottom in the same clays after passing through the river gravels.

About 1,500 feet north of the bridge the clays rise in the high western bank of the river about 72 feet above low water. This is just opposite and only a few yards from the south end of the Camp Meeting entting (see p. 677), and the clays between are continuons. Thus their maximum thickness may be about 218 feet. About the same distance south of the bridge they are exposed for a long way in the river bank, at the south end of Hadley street, a locality furnishing fossil leaves (see p. 738) and an 
abundance of concretions. They have been extensively worked near the asylum in Northampton, at Rich's brickyards east of Southampton, and at Pomeroy's yards west of that town.

They extend east from the river with the full width of the space between Mount Holyoke and Mount Toby, rounding Mount Warner, and being very near the surface in all the area south of Mount Wamer to near the foot of Mount Holyoke, where wells 81 feet deep ( $\mathrm{Mr}$. Shipman, Lawrence plain, south of Hadley) and 40 feet deep (A. Losey, Nuttinsville, Amherst) were sunk in sand and fine gravel without reaching the base of the sands.

Over the bottom of the central depression the clays, being near the surface, are often sandy. The clay is worked for bricks at Plainville (north of Hadley); and in the bottom of the depression, where Amity street crosses the brook, it was formerly worked. Near by, at Mr. Stebbins's barn, a well went through the following:

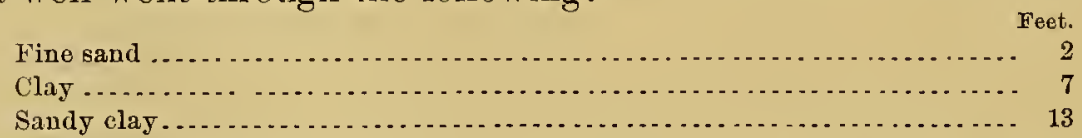

At Mr. S. Harrington's, in North Amherst, a well 90 feet deep did not reach the bottom of the clay.

The clays rise high up on the slope of the Amherst ridge and thin out under the shore gravels. They are cut through by all wells along the slope below, 246 feet above the sea, and reached their greatest observed height in the col between the central depression and the basin south of College Hill, where they were exposed by the Central Railroad cutting from the bridge at Main street east to the end of the cutting, with a maximum height of 260 feet above sea. (See p. 645.) These clays thicken out east into the land-locked basin south of College Hill, where in Champlain time they accumulated to great thickness, with little covering of sand.

In the East Street basin the clays were also developed to great thickness, and over all the area south of the road to Pelham lie very near the surface. At the third house east of the bridge on this road (Mr. Hubbard's) a well was bored 50 feet in clay covered by 8 feet of sand, and the water rises to within 2 feet of the surface. In a well on the south side of the same road near the middle of East Street (Mr. Clutia's) this section was exposed:

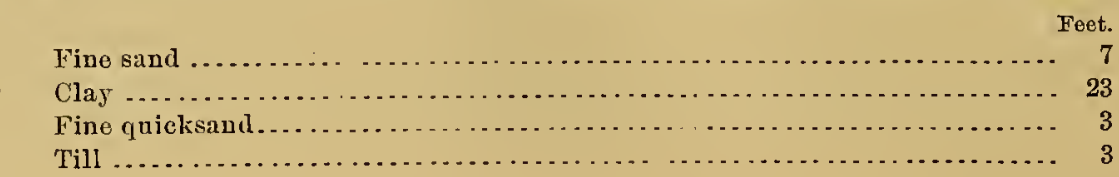


Farther soutl, where the roul from the village crosses Fort River at the brick pits, the following section was taken from the exposture in the pit and firon a well adjacent:

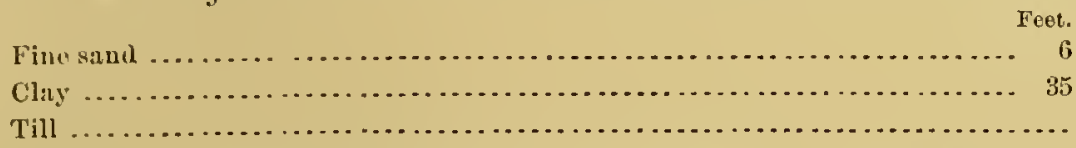

Pockets of pebbles were found in the clay, and the water, very sulphurous and irony, cane to within 5 feet of the surface. Fossil leaves occur here.

\section{CLAYS IN THE SPRINGFIELD LAKE.}

There are no brickyards in Agawam and West Springfield, though the clay crops out at Riverside. There are extensive brickyards along the east side of the river at the following points: Above the Holyoke bridge; at Willimansett; in the northern part of Springfield; and especially beside the Boston and Albany Railroad in the southern part of Springfield, and across the line in Longmeadow.

Eastwardly the clays are deeply covered by the thick sands of the Chicopee River delta, which extend across Wilbraham and Springfield.

\section{CONTACT OF THE CLAYS UPON THE TILL.}

The section exposed at the hoe factory in Northampton, and illustrated in fig. 31 , p. 540, not only shows the contact of the till upon the sandstone and the upper surface of the former, upon which the ice rested, but also demonstrates that the deposition of the clay followed immediately upon the disappearance of the ice, under circumstances which indicate that the ice could not have melted in place upon the till; nor could the till have been exposed to subaerial erosion before the clay began to be deposited. In the former case a loose deposit of upper till must have intervened over the till and sandstone alike; in the latter, the till would have been eroded below the level of the sandstone, and the common uniformly curved surface would not have been preserved.

It seems to me probable that at this time-the end of the Glacial period for this basin-the waters stood over this place, which is about 135 feet above the sea-and of course over the whole basin-at a height so great that the ice was at last buoyed up and floated away, and the clays began immediately to be deposited upon the surface thus abandoned. 
The clays were grayish-blue, very fine, "fat" clays, agreeing exactly with those worked in the large brickyards a few rods south.

When both the clay and the till were wet the sharp, curved line of junction was inconspicuous at a little distance, the whole surface presenting a uniform dark bluish-gray color, but above the line a cane could be easily thrust into the clays for its full length, while the blow of a hammer would not make much more impression upon the till than upon the neighboring sandstone.

The section is situated far within the limits of the high terrace and is exposed by the deep erosion of this terrace by the Mill River, which, in cutting down to this level, has carried its gravel beds over the whole, making the upper horizontal stratum in the diagram. If we restore the terrace here to its condition before it was affected by the erosion of the river, we shall need 25 to 30 feet of clay resting on the till and covered by 35 to 40 feet of sand to bring the level up to 200 feet above the sea, which is the height of the terrace over this area. The clays are exposed with this thickness in the face of the high terrace on both sides of the stream. When the ice disappeared, however, and the deposition of the clay began, this was a deep depression between the "rlrumlins" of till upon which the hospital and Smith College stand, opening southward into the main basin.

In another section, from the Canal Railroad, exposed just west of the South Street bridge in Northampton, the clays rest also directly upon the stony till, and although greatly disturbed by stranded ice and mixed with material dropped from it, there is everywhere at least a foot of the fine clay, undisturbed, intervening between the till and the horizon where coarser iceberg material appears. In many of the clay pits the base of the clay is reached, and it is always in contact with the till.

In the Central Railroad cutting south of College Hill, in Amherst, the following section was exposed beneath the bridge (figs. 37, 38, and 39, p. 645): On the till, which appeared just above the bottom of the cutting, but arose westwardly to occupy nearly its whole thickness, rested coarse, cross-bedded sands, which had been swept from the west over its surface, and which reached a thickness of 3 feet; upon these rested clay, reaching a thickness of about 7 feet, in the lower half banded in layers 1 inch thick, with fine sand partings; many layers resting below between undisturbed 
laver's were conterted for it short distance in a most complex way, as iuclinated in tig. 38 , and on al larger scale in fig. 39.

It seems cleatr that the firiction of the current was sufficient to slicle the laver of tenacions clay upon its substratum of fine sand for a short distance and "rmupte it np, for each of these crmpled lityers is covered by an munually thick aml somewhat coarser film of sand. The layers grow thinner towald the surfice, and the upper 3 feet is an unctuous, uonlaninated chay. It is capped by the coarse beach gravel, which rises to the surface. This is the only occurrence of sand beneath the clay I have seen in the basin, thougl the fine sands of the Wapping cutting (see p. 695) are so exactly equivalent to the clays that the red sands upon which they rest nucouformably may come in the same category. It is also the highest point reached by the clays ( 251 feet), and here the till was for a short time swept by a strong current from the main valley into the East Street basin before the deposition of the clays began.

\section{THE STRUCTURE OF THE CLAYS.}

The upper horizontal laminæ in Pl. XVI (p. 690), from Hatfield, illustrate the minute structure of the Champlain elays. Over all the central portion of the basin they are uniformly thin, even bedded, and horizontal, show a regular alternation of fat and lean portions, and on drying separate easily into layers, each of which consists of a sandy part below and a fat part above, which grade into each other. The brickmakers call the "fat" portion clay and the "lean" portion sand, distinguishing more closely than the geologist.

On the river bank at Hadley the lower and much the larger portion of each layer is an extremely fine sandy clay, drab colored when wet, pale buff when dry, composed of a fine, sharp, quartz sand, 0.15 to $0.24^{\mathrm{mm}}$ in size, and of kaolin in irregular elongated particles, affecting reniform and sausagelike shapes from flocculation. This passes rather abruptly, by the lessening of the percentage of quartz grains, into an upper and finer portion, which is generally one-fourth to one-fifth the thickness of the lower portion, of dark bluish-gray color when wet and olive green when dry. It contains a small proportion of kaolin, the rest being very fine quartz grains. Its average grain is 0.0008 to $0.0016^{\mathrm{mm}}$ for the kaolin.

In a specimen taken from the bank of Fort River, below Mill Valley, in Amlerst, where the olive-green upper portion was $0.7^{\mathrm{mm}}$ thick, the coarser 
lower part $0.3^{\mathrm{mm}}$, measurements of grains from the top of the layer gave 0.0018 to $0.00735^{\mathrm{mm}}$, from the middle of the lower portion 0.00735 to $0.0294^{\text {max }}$, and from the bottom 0.0735 to $0.147^{\mathrm{mm}}$.

At the Hatfield locality (Pl. XVI, p. 690) in each layer the lower twothirds is much coarser than the upper third, and is in reality an exceedingly fine sand, under the microscope appearing like a quartz sandstone, the grains angular, 0.0037 to $0.0075^{\mathrm{mm}}$ in diameter. Besides quartz, there occur feldspar, mica, and a few acicular microlites. The lower portion was olive green when wet, drab when dry. The upper portion showed, both wet and dry, a darker shade of the same color, but the difference was much more marked when it was wet. Under the microscope it appeared like the other portion, except that it was much finer; but there were present many minute opaque particles of koalin, oblong or sausage-shaped, which showed the Brownian movement finely. The size of the quartz grains was 0.0011 to $0.002^{\mathrm{mm}}$.

\section{THE SURFACE OF THE LAYERS.}

In some cases the layers are joined so closely that one can hardly distinguish the line separating two lamine from that dividing the finer and coarser portions of a single one. Generally there is at least a thin film of rust, showing that the waters have sought out the planes of separation between the layers, as affording them easier passage, and the clays on drying split readily along these planes.

On these delicate surfaces one detects rarely the undulating tracks of worms or the small coriaceous leaves of arctic plants. On other surfaces a delicate ripple marking appeared, regularly arranged-broadly elliptical depressions several inches long and of so slight depth that their presence might easily have been overlooked if they had not been brought out by a film of reddish sand, which filled the hollows and was mostly wanting upon the surrounding ridges. The depth of the depressions was often only equal to the thickness of a single grain of the fine sand. This surface sand preserved, also, the delicate water-drift structure impressed upon it by the current. The ripple marks and these drifted sands together register, in each case where they occur, a flood so considerable as to give the whole body of water in the lake a current strong enough to enable it to drift along the bottom sheets of the red sands from the border beds farther north out to this point in the very middle of the lake. 
THE LATERAL PASSAGE OF THE CLAYS INTO THE HIGH TERRACE SANDS.

At the south end of the Camp Meeting cutting (Pl. XV, p. 678) the whole thickness of the cutting was in clay and the plane of junction dipped north with a low angle, so that the clays ran far under the sands and disappeared helow the level of the cut. The sands were part of a delta or bar frout, advancing sonthward and dipping sharply in this direction in quite thick layers which at the bottom of the slope became horizontal, thinuing rapidly and ruming out between the clay layers, becoming finer grained and disappearing or merging with the coarser portion of a layer of the clay. On the other land, some layers of the clay ran up the slope between the sand layers for a distance, becoming coarser and merging with an upper and finer portion of the sand layer.

THE PASSAGE OF THE CLAYS INTO THE SANDS ABOVE.

The delicate partings of sand described above (p. 704) increase in number and in thickness as one approaches the upper surface of the clay, and finally effect the passage of the one into the other.

In the river bank below Hadley, the locality which for the most part furnished the type of the preceding descriptions, the upper portion of the clays has been carried away by the river, and its sands rest mconformably upon the eroded surface of the clays. The true passage beds are best exposed at the extreme south end of the Camp Meeting cutting (Pl. XV, p. 678).

Nine feet below the upper surface of the clay these partings are onesixteenth of an inch thick, of coarse red sand, and are very frequent, so as to give the blue clay a reddish tinge. This continnes upward for 3 feet, when a 4-inch layer of coarse red sand intervenes, which is followed by a band 5 feet thick, where the red sand and clay, alternating in fine but regular layers, are in about equal quantity. The whole is capped by another thick layer of red sand, which grades into the ordinary buff flood sands, here only 4 feet thick.

Opposite the Hatfield Hotel begins a long, narrow remnant of the old lake bottom, which, by a curious freak of the river, has been left intact, while the river has cut away on all sides of it. This preserves the old surface of the clays and the passage beds into the sands above. There is here, within 4 feet, a very gradual passage from the fine clays into fine, white MON XXIX- 45 
sands, locally reddened with iron in the lower part, where the waters have stood on the surface of the clays.

Over all the broad plain south of Mount Warner, over which the road from Amherst to Northampton runs, the passage beds. seem to me to be present, and the clays seem still to retain their full height.

EXPLANATION OF THE STRUCTURE OF THE CLAYS.

In introduction of this explanation a further peculiarity of the clays may be here considered.

While the "fat" portions of the clay layers are very uniform in thickness and grain, the variation in the thickness of the layers depends upon a thickening or thinning of the sandy portions of these layers, which may or may not be accompanied by a corresponding change in the grain of the latter. At times the fat laminæ separate and take in between them 12 to 16 inches of a sand but little coarser than that of the coarse portion of the layers at the Hadley locality, as is the case in a large portion of the Wapping cutting. At other times the grain increases to medium or coarse.

The fat lamine seem to be purely a sediment of matter held in suspension when there was scarcely a trace of current, the lean laminæ to contain in gradually increasing proportion the fine material carried over the bottom by the friction of a slow eurrent, which was regularly intensified for the formation of the thin films of sand which separate the layers. One finds these clays as regular as a pile of thin deals over all the basin, and I imagine that each layer represents a year's work of the flooded river. The fat layers were thrown down in the winter impartially over every portion of the lake bottom, and with the breaking up of the ice in spring the flood swept it off those portions where it had strong current, at times just crumpling it, as show1 in figs. 39 and 40, p. 647 , but over the deep lake bottom only rippling its surface, the fat tenacious clay resisting erosion slightly, while the coarse material brought in by the tributaries was pushed in sheets out over the delta flats and dumped over their fronts, and in small quantity carried out over the clays. In exceptional floods thin films of these sands were earried down across the very middle of the lake, as at the Hadley locality, and came at the beginning of the spring, for the coarse sand rests directly in rippled hollows of the surface of the finest clay. In this sand are found the twigs and reeds and leaves brought down by thie tributaries, and the 
sands grade uprard into the lean portion of the layer, which represents the miform high water of the glacial river during the summer and which is a true "gletchermilch," and this in its tum grades upward into the fat deposits prodnced by the elanifying of the waters during the succeeding winter. This would conspire with the fact that the mass of the coarse material of these deposits has been brought in from the sides and moved but little downstream, to indicate a low pitch for the valley during the time of the glacial stream.

\section{THE TIME OCCUPIED IN THE DEPOSITION OF THE CLAYS.}

The considerations of the preceding section afford data for a calculation of the time occupied by the deposition of the clays, which is presented as interesting rather than specially valuable. If we take the clays exposed in the soutl of the Camp Meeting cutting and in the river bank adjacent, a thickness of 72 feet is exposed down to the water level, which would give, at an average of two-fifths of an inch per layer, 2,155 years. If we take the boring at the Northampton bridge, 113 feet, we have 3,390 years. As these two neighboring sections are measured, the one up and the other down, from the river level, we may add these two numbers to obtain a maximum time for the deposition of the clays $-5,545$ years. The erosion of the Deerfield and Westfield basins and the wearing back of Turners Falls in the red sandstone a distance of 3 miles, with a width of about 60 rods and a depth of about 40 feet, and of South Hadley Falls in the same sandstone for a mile, with somewhat greater width and depth, will each give a measure of the time that has elapsed since.

\section{ACTION OF ICEBERGS OR FLOES UPON THE CLAYS.}

Contorted clays.-At a railroad cutting just west of the South Street bridge in Northampton, already noted (p. 541) as showing sandstone and till planed down together into a drumlin, the clays rest normally on both, and a short distance eastward there begins a peculiar distorting, crumpling, and comminuting of the latter. At its worst the clays are thoroughly chopped up into small pieces, which are mingled in entire confusion. This was exposed for a distance of about 33 feet, with a thickness of 2 feet. Eastward about 50 feet, across a space where the exposure was ouly sufficient to show that the clays were continuous and much disturbed, they 
were again well exposed in a fresh cutting, and here the clay is kneaded into fantastic shapes, squeezed into holes in the drift below, and a large mass of coarse, reddish drift has been dumped into it, and the two are in places well molded together. Twenty feet farther on the clays were perfectly normal and horizontal. The intervening space was well exposed, and one could see how the clay disentangled itself from the mass of coarse material and gradually reassumed its horizontal lamination. Below and above the disturbed portion the clays are quite horizontal and undisturbed.

This locality is at the base of a promontory in the ancient lake, around which the thread of the current bent as it swept southwestward over Easthampton; and the ice floes from the north, stranding here, have plowed up the clays and mingled them with the coarse material with which they were themselves loaded.

In the curve by which the current bent around the projecting drumlins in Northampton several similar disturbed patches isolated in the otherwise horizontal clays have been exposed, as in the digging of the sewer at the sonth end of King street, where they were so distorted that they were mistaken for till by a good observer. They were described as being thoroughly puddled. A mile farther northwest, at the great cut on the railroad to Williamsburg extending from the Bay State Brook east to the crossroads north of the railroad, the same thing is shown for many rods in the eastern portion of the cutting. The sands are irregularly disturbed, and at several places disconnected pockets of bowlders and glacial clay appear, wholly inclosed in the distorted sands.

In the same area of disturbance a mile farther southwest, the fine exposures in the great clay pits south of the Insane Asylum are illustratious of the same action. A horizontal line is marked for many lundred feet in the vertical walls of the excavations at the same level with the plane of disturbance farther north. Above this line the clays are undisturbed and about 12 feet thick before they merge into sand; below they are kneaded into the most tortuous forms, and at times all trace of structure is gone. As in the block above the watch seen in the accompanying plate (XIX), traces of more than one passage of the ice are manifest, and in the largest of the blocks shown in the figure the extreme convolution of the plastic layers on the one side, and the faulting and incipient slaty cleavage on the other, are well shown. The convoluted layer in the block to the right is com- 


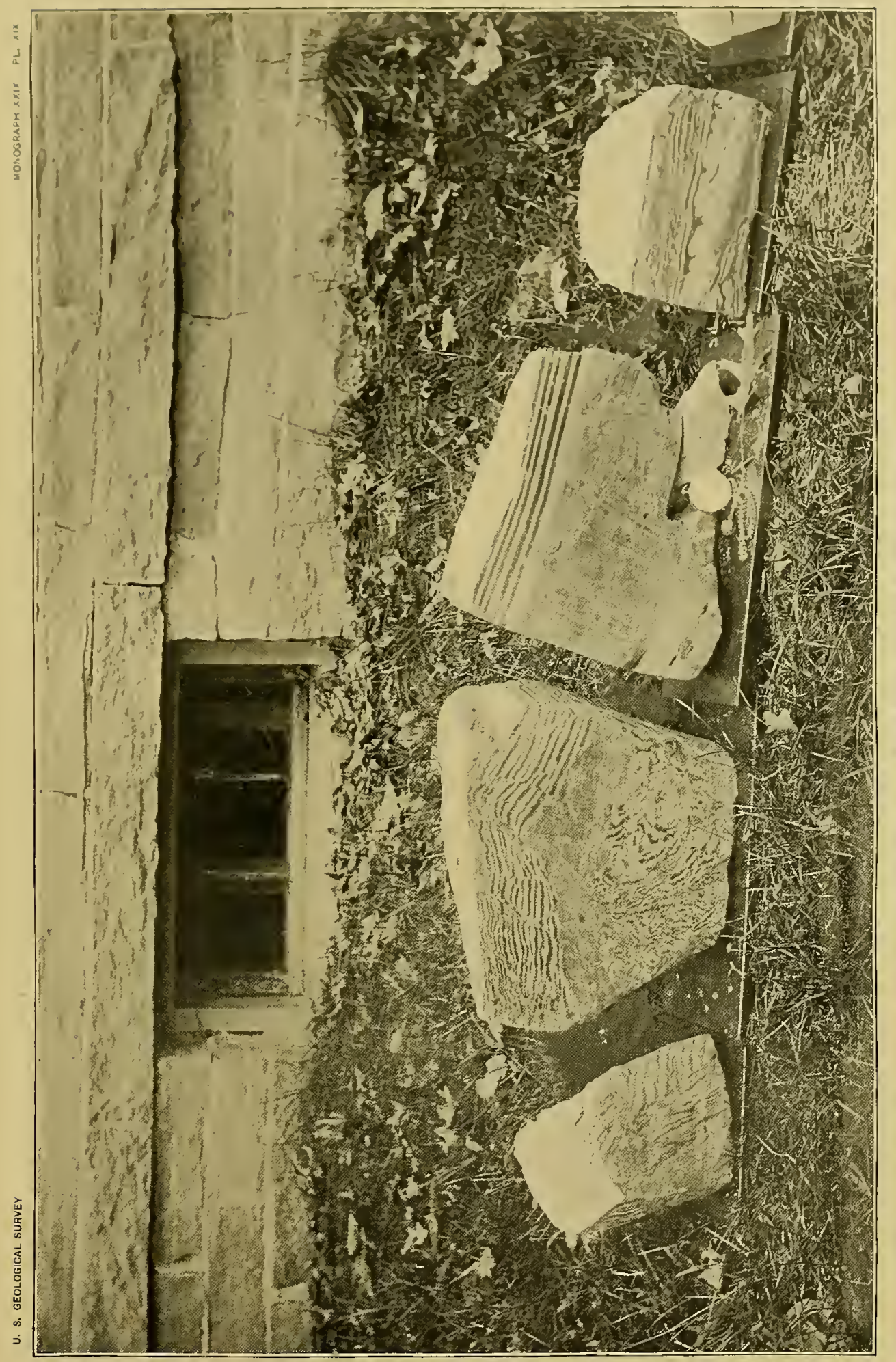



pressed to one-fifth of its former length. Going northwest, we soon come, at Sumset Lill, on the great drumlins that formed the shore of the ancient lake, and it is elear that the disturbanee could not have been cansed by ice coming down the valley of Mill River, which lies behind these.

\section{SECONDARY STRUCTURES IN THE CLAYS.}

.Joints.- Where the clay stands in vertical walls in the river banks it is in time rudely. fissured parallel and at right angles to the exposed surface, and as the horizontal seams of sand weaken the cohesion of the mass in the third plane the river in the spring flood often moves off bodily great cubical masses of the clay and heaps them up lower down. Several years ago, on visiting the bank of the river below Hadley, I found a broad, horizontal surface thus exposed at about low-water level, which was jointed with extreme regularity and beanty. The principal lines ran parallel to the elge of the bank, perfectly straight and parallel to each other and an inch apart.

The second set, also parallel to each other, were an inch and a half apart, and made an angle of $60^{\circ}$ with the first set. The lines of the second set were not always continuous, sometimes failing between two contiguous lines of the first set, but continued beyond in the same direction. These lines represented fissures which extended through one layer of the clay one-third of an inch thick, dividing the clay into blocks of mathematical regularity. Toward the edge the blocks had been moved by the current a short distance from their original position, manifestly very soon after the superincumbent block of clay had been lifted off, for they were, when I examined them, so soft that they could not be toucherd without destroying their form, and yet as they lay they retained their perfect regularity. One could not help thinking that in olden time it would have been called a fairies' pavement, as still in Scotland the claystones are called fairy stones.

Below, where the large massses of clay had lodged, I found the small blocks piled in considerable abundance, but all softened and fused together, and in subsequent years $I$ have always found them in abundance under the same circumstances. Later I found the same jointing in the large clay pit at the Bay State in Northampton, where surfaces 3 and 4 feet square were regularly jointed, exactly as on the river bank. When a vertical surface had been left for some time and the workmen then attacked that portion of 
the pit again, the large blocks of clay when dislodged would slip apart easily along the planes of bedding, where the films of sand lessened the cohesion, and expose broad surfaces of the tessellated pavement.

It was very plain that the greater ease with which the moisture could escape along these sand layers was the determining cause of the appearance of the structure along these planes. The moisture escaped so gradually and the clay was so nearly homogenous that the shrinkage tension could distribute itself equally throughout the mass and finally relieve itself by a system of fissures at angles of $60^{\circ}$ and $120^{\circ}$, of great mathematical regularity.

President Hitcheock mentions ${ }^{1}$ three localities, one on the Agawam and two near the Deerfield River, where these joints also occurred in the same clays, and considers them to be due to a crystallization of the clay and "to be a more simple operation of the same general cause which produced the concretions."

In an elaborate paper entitled "On the structure of rocks called jointing," 2 Prof. W. King says:

Hitcheock states that "mneonsolidated clay beds in West Springfield and Deerfield, in Massaichnsetts, are intersected by numerous and distinct joints, while those above and below are unaffected. This clay has certainly never been snbjected to any great degree of heat, being of very recent origin." ${ }^{3}$ It is to be apprehended that there is some oversight in this statement.

This seems to be a wholly groundless assumption on the part of the author, made in support of the theory advanced in the paper cited. I may add that the fissures extend vertically downward through the fat laminæ as if cut with a knife, and pass down through the sandy laminæe with a curved surface.

The torsion theory of Daubrée will hardly apply, as the joints are found in limited areas having relation to recent erosions, or in bluffs produced by digging. I have searched the clays for many years for fossils and concretions, and these joints have been wanting in so great a number of cases where all the conditions were favorable that they can not well be referred to any such general cause. All the cases occurred in bluffs where the wall below was strong and well supported-and there would seem to

${ }^{1}$ Geology of Massachusetts, 1841, p. 418.

${ }^{2}$ Trans. Royal Irish Acad., Dublin, vol. 25, p. 606.

${ }^{3}$ Elementary Geology, p. 22. 
be suill place for any influence of torsion. Yet from the removal of the clay to produce the bluff, and from the quite sudden drying of the surface of the bhuti, there might be a slight creeping of the clays still below the level of the streams, or the wet floor of the clay pit might produce torsion, which would be influential in producing the forms observed.

Concretions.-In the Journal Book of the Royal Society for 1734 is a minuscript catalogne of objects of natural history found in New England, by John Wintlurop, magistrate of the Connecticut colony and great-grandson of the first governor of Massachusetts. It mentions "clay generated in the form of horse shoes from the bottom of Connecticut River." ${ }^{1}$ It would be difficult to find a boy brought up near the Connecticut who had not in the early summer gathered claystones on the bank of the river which had been washed ont of the clay in the spring floods, and wondered at their abundance, their smooth and apparently artificial surface, and their regular form-spherical, spheroidal, ellipsoidal, or flattened into disks, sometimes variously elongated, lobed, or grotesquely imitating animals and works of art. And he would be hardly satisfied with the common explanation that they were formed from hardened pieces of clay by the wearing of the water. This was Dr. Hitchcock's first opinion, and in $1823^{2}$ he gave a full mineralogical description of them. They thus very early attracted the attention of the geologist, and in 1835 President Hitcheock describes them with care, and asks the questions: "But are concretions the result of crystallographic laws? If so, why are not crystals produced?" The tubular ferruginous form he describes as a fossil of uncertain character. ${ }^{3}$ In the report of 1841 he devotes 16 pages and 5 plates to a discussion of concretions, and presents a classification of them according to form; and though he no longer looks upon any of them as fossils, he considers them exceedingly difficult of explanation and thinks one must assume them to be the result of the action of galvanic electricity, and associates with them, as a result of the same general causes, the prismatic blocks of clay produced by shrinkage joints which I have described on page 709 .

President Hitchoock returns to the subject in 1861, in the report on the Geology of Vermont, and devotes 8 pages and 3 plates to clay-

${ }^{1}$ Am. Jour. Sci., 1st series, Vol. XLVII, p. 282.

${ }^{2}$ Geology of the Connecticut River: Am. Jour. Sci., Ist series, Vol. VI, 1823, p. 229.

${ }^{3}$ Geol. Mass., p. 182. 
stones, and still expects someone to develop the fundamental principles of their formation and "do for them what Abbé Hany did for crystallography." He quotes several pages fiom Prof. C. B. Adams's second report of the Geology of Vermont on the same subject, among other things: "It is obvious that the description and theory of concretions constitute a subject which, although perhaps less extensive than crystallography, is as properly entitled to rank as a distinct science." He quotes, also, from Professor Adams, a new classification of these forms, much more complex than his own, and containing several Greek words newly coined for the purpose. These elaborate classifications seem worthless, and remind one of Rafinesque's paper describing and naming nine new species of thunder and lightning, for all the variety in the forms depends solely upon causes wholly external to the concretion itself, namely, to the constantly varying permeability of the clay in its different parts and the decomposition of its constituents. In tracing the history of these forms one must notice, first, that the clay beds in which they occur differ materially from those beds of clay formed by the decomposition of massive feldspar in situ, which are often quite pure kaolin-a hydrated silicate of almunina. These Champlain clays, on the contrary, contain only a small portion of true kaolin, and are, in the main, an exceedingly fine, largely feldspathic sand, resembling somewhat the finest silt washed from a stamping mill; they are, in fact, the finest portion of the material ground up by the glacier, and the waters which bore it southward may have been in part a veritable gletchermilch, issuing directly from beneath the ice. It may have been carried a long way southward in the valley, and thus have been derived by the ice partly from the Vermont rocks, among which limestone is prominent.

It is certain, also, that the clays contain abundantly particles of minerals, as lime feldspars, which, by their decomposition, afford calcic carbonate. And the waters with which the clays are saturated would, by virtue of the carbonic dioxid they contain, dissolve and carry in solution the carbonate derived from one or both these sources. The waters are constantly percolating, with a slow, capillary motion, through the clays, especially after the beds have been cut through here and there by streams and the edges of the laminx have been exposed, moving always from the moister toward the drier portions; and as the conditions in this respect often change, the direction of their motion wonld also change. 
Anain, since, as 1 have described aloove, every layer is, as a rule, calped by a thin lamina muld finer and more impervions than the rest, while the seams between the lannine are often quite coarse sand, at least at base, the water would move most freely in the lower and coarser portion of the layer, ant least freely in the finer clay lamine above and below. Thlis would tend to confine the water within the limits of single layers. Its motion would vary, also, by infinitesinal gradations with every variation in the permeability of the layer through which it was passing and with every difference in the force by which it was moved.

If we suppose, now, that from any cause a precipitation of the calcic carbonate is commenced at a given point or in a limited area within the coarser layer-a precipitation, that is, taking place in the interstices between and among the grains, cementing them together without greatly moving them from their places-the waters deprived of the carbonate held in solntion would move away and be in turn replaced by other water, still containing in minute quantity the same salt; or, by diffusion, a new portion of the salt would replace what had been precipitated, and, the same canse contimning to act, there would thus follow a continuous slow crystallization within the limits and during the continuation of its effective action. Nor would the process of necessity cease with the exhanstion of the supposed canse by which it was initiated. As a crystal already started grows in an undersaturated solution, the calcite already crystallized out among the grains of the clay would form a group of centers around which more and more new portions of the same would crystallize until a compact mass had been formed, but little permeable to water, which would then continue to increase by superficial accretion, envoloping in its growth the fine sand, as a fog spreads among the trees of a forest.

If the above considerations be founded on fact, it follows that we have only thus far to seek for a cause which may start the growth of a concretion around a given spot in the clay, its continued increase being adequately explained by a reference to the laws of diffusion and crystallization. So far as all the claystones of the valley are concerned, this initiating cause entirely eludes our observation. Very rarely a pebble or a few grains of sand are inclosed wholly or partly by the concretion, but I have never seen one occupying the exact center, and they do not seem to have been the exciting canse of its growth, but rather seem to show that a regular 
form was sometimes assumed in spite of a marked want of homogenousness in the stratum in which the growth took place.

In a great number of exactly similar concretions, however, from other localities, one finds as a nuclens some portion of organic matter-a fish, shell, or leaf-whose shape determines the form of the concretion, except so far as the same may be influenced by the texture of the bed in which it is formed. Here the organic matter inclosed in the bed of clay or fine sand gradually surrounds itself with an atmosphere of the products of its own decomposition, which slowly expands ontwardly-in a massive bed extending equally in all directions; in a laminated one, most widely in the plane of lamination-and among these products of decomposition are some which readily precipitate the carbonates when by the ordinary capillary circulation the latter are brought within their range. Thus as the waters move to and fro in the bed they come from every direction into the area of precipitation, and a solid dependent for its shape upon the contour of this area is formed around the organic nucleus, oftentimes hermetically sealing it and arresting its further decomposition; while, on the other hand, it can not be doubted that many times the organic matter which formed the nucleus and determined the deposition was wholly dissipated into liquid or gaseous compounds before the process was far advancerl.

Such a nucleus, now wholly vanished, may have determined the beginning of the concretions we are discussing, and the fact that President Hitcheock found always a distinct residue of inflammable organic matter in his analyses of claystones goes far to show that such was really the case.

We can see several sources from which organic material may have been, and was, introduced into the clays during and after their formation. The country was without doubt heavily wooded before the advent of the ice, and all the growth and surface soil were ground up together in the till from which the clays are derived, and afterwards, while the latter were forming, an arctic growth had again overspread the hills and worms burrowed in the lake bottom, as I shall show further on (p. 718); and finally, rootlets pierce even such mnpromising beds as these to great depths-25 and 30 feet in the till of the Westem States, for instance, and similar instances are given below. I have found them several feet deep in the clays, with a concretionary accumulation of ferric hydroxid already commenced around 
them. When we consider, however, the extreme farility with which calcic carbonate is brought into solution and again precipitated, it would seem that even a slightere canse might start the growth of a concretion; the decomposition of a grain of feldspar setting fiee an alkali which would appropriate the carbonic dioxid, or even the slight difference of specific heat of different nincrals starting feeble theino-electric cmrents between different ginins, causing them to become points around which crystallization would commence, somewhat as a crystalline precipitate forms along the seratches of a heaker when it is rubbed with a glass rod.

By cutting down a smooth surface at right angles to the lamine in a mass of the clay one can sometimes find early stages in the formation of concretions which illustrate what has been said. There are small spaces confined between two layers of the finer clay, rudely spherical in ontline, thongh not sharply defined, which cut with somerwhat greater difficulty than the clay around, are lighter in color, and effervesce abundantly with acid, while the clay around shows but slight signs of effervescence. In this case the continued accumulation of carbonate within the limits already marked out wonld produce the small sphere which may be looked upon as the normal form. The subsequent growth would be by additions to the outside of this, determined by the varying permeability of the clay, producing forms fluted on the edges where the concretion spread through several layers - the constrictions answering to the denser layers, the convex projections to the coarser-and flat disks where the increase was confined to a single lamina. Finally, the coalescence in varions ways and various degrees of two or more separate spheres or disks would form all the variety of compound and imitative forms.

In another case I discerned, on cutting across the clay, that ferric hydroxid had been precipitated in a regular hollow shell $\frac{1}{2}{ }^{\text {nm }}$. thick, flat spheroidal in shape, $14^{\mathrm{mm}}$ in greatest diameter; and within and concentric with the first shell was a second, similar in shape and thickness, $8^{\mathrm{mm}}$ in diameter. Here the influence of an atmosphere of decomposition surrounding a central body, which precipitated the iron salt as the latter came from all sides within the sphere, seems to be more apparent. Finally, the annular claystones-perfect rings of varions sizes up to 10 inches-may be explained in the same way by supposing the emanation from a decomposing center to be confined within a single layer, and thus to assume a discoid 
form, and to precipitate carbonate everywhere along its border, preventing its penetration inward toward the center. The latter forms are not found in this region, but occur in clays of the same age and origin at Rutland, Vermont.

The common pipestem concretions-small, hollow tubes made of clay or fine sand cemented by limonite, about the size of a clay pipestem-wlich stand verticle in the clay, are plainly due to the passage of water through holes made by small rootlets, and the latter can at times be still found in the holes. At the Wapping cutting (see p. 695) I was able to lift up and bring away broad, frozen sheets of the fine loesslike sand, one-half inch thick, from 30 to 40 feet below the top of the cutting, which showed the early stages of this growth very beautifully. The wind had delicately sculptured the surface and left the incipient concretions projecting above the surface, as a knot projects above the surface of a worn board, but of regular shape, like very large checker-men, each with a small, central root bole, and each about $1 \frac{1}{2}$ inches in diameter and concentrically fluted with beautiful regular grooves, between which rise the deeper yellow ridges where the iron rust was concentrated. When thawed, the whole berl could be blown off the surface of the board upon which it had been placed for preservation.

These ferruginons forms have been produced by decomposing organic matter's at the surface, changing iron rust to ferrous carbonate, which has been carried down the root holes and precipitated around them and then slowly changed to limonite.

The simplest and commonest form of the calcareous concretions is a sphere, like that making the center of the largest specimen shown in the figure, which expands regularly to form perfect disks. (See PI. XX.) That the slow translation of the fluids in the clay has to do with the growth is indicated by the common occurrence of spectacle-like forms, as shown in the plate, where two neighboring disks, as they approximate by growth, mutnally shield each other and so become connected only by a narrow isthmus. That a foreign body may cause the growth, perhaps simply by halting "the solutions, is shown by the fact that the limonite pipestem concretions become the centers around which the regular discoid calcareous concretions have grown.

The folded concretion figured $(\mathrm{Pl} . \mathrm{XX})$ is most interesting as showing that the regular growth could take place in the contorted clays, and this 
U. S, GFological sURVEY

MONOGRAPH $X X I X$ PL, $X X$

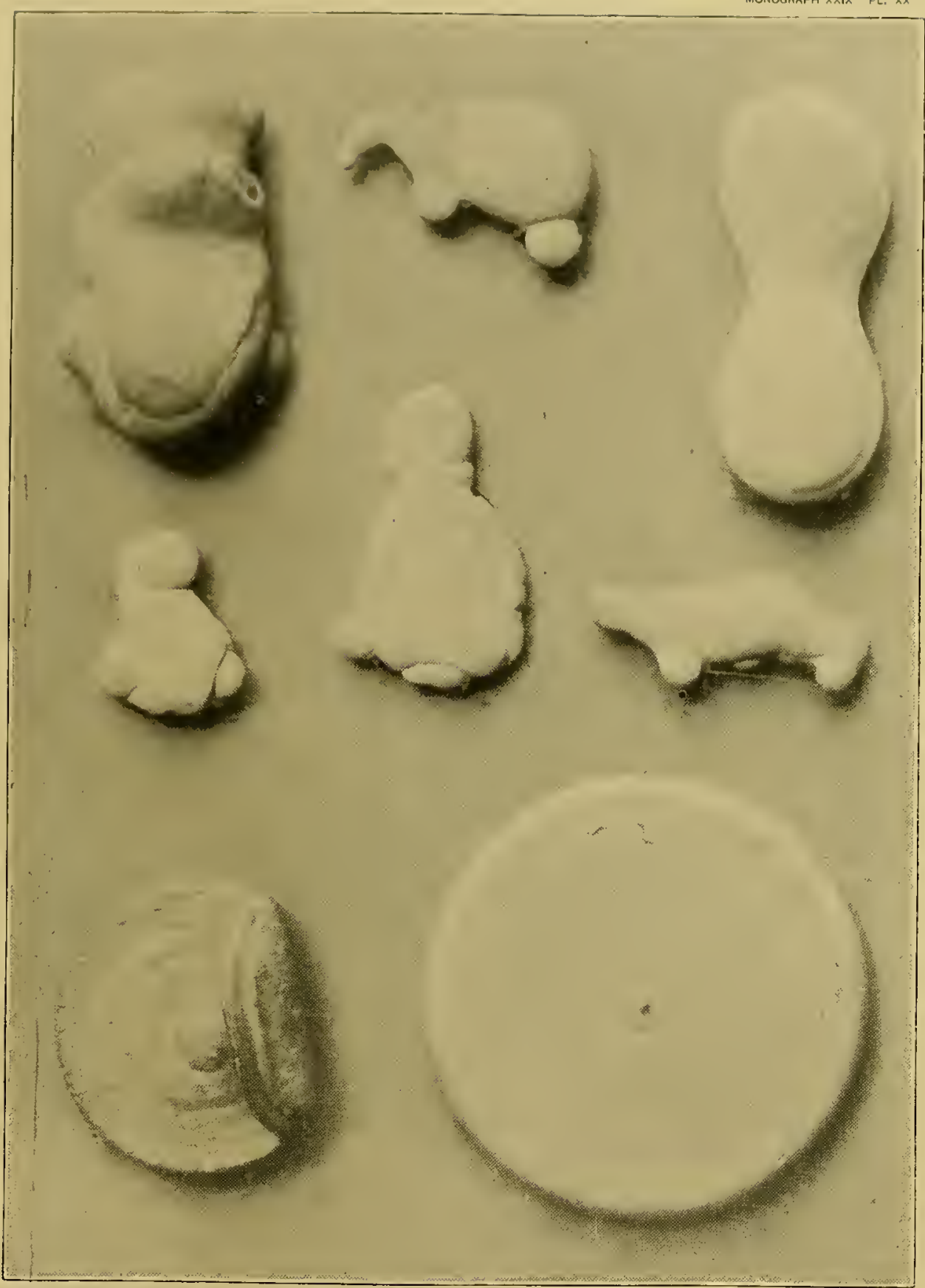

CALCAREOUS CONCRETIONS WITH WORM TRACKS, IN THE CHAMPLAIN CLAYS ; HADLEY AND NORTHAMPTON. 

and the largent concretion figured show beatifully that they took an exact cast of the full thickness of a layer, since they are covered by raised undulating ridges-the worm tracks mentioned on page 719.

ln the table below I have given: (1) an average of 18 analyses of claystomes from Massachusetts and Vermont, 5 from Geology of Massachusutts (p. 408), and 13 from Geology of Verniont (p. 700); (2) the proportion of carbonates to the other constituents; (3) excluding the carbonates, the remainder, reckoned to 100 per cent; and (4) the silica, alumina, and water, reckoned to 100 per cent.

Analyses of elaystones from Massachusetts and Vermont, proportion of eonstituents, ete.

\begin{tabular}{|c|c|c|c|c|}
\hline & 1. & 2. & 3. & 4. \\
\hline $\mathrm{CaCo}_{2} \ldots . . .$. & 47.4 & & & \\
\hline $\mathrm{MgCo}_{1}, \ldots \ldots$ & 4.3 & 01.7 & & \\
\hline $\mathrm{SiO}_{2}$ & 19.1 & & 39.6 & 45.6 \\
\hline $\mathrm{Al}_{2} \mathrm{O}_{3} \ldots$ & 16.9 & & 35.0 & 43.6 \\
\hline $\mathrm{Fe}_{2} \mathrm{O}_{3} \ldots \ldots \ldots \ldots$ & 6.1 & 48.3 & 12.7 & $\ldots$ \\
\hline $\mathrm{MnO}_{2} \ldots \ldots$ & 1.9 & & 4.0 & …... \\
\hline \multirow[t]{2}{*}{$\mathrm{H}_{2} \mathrm{O} \ldots \ldots \ldots \ldots \ldots \ldots$} & 4.3 & & 8.7 & 10.8 \\
\hline & 100 & 100 & 100 & 100 \\
\hline
\end{tabular}

Column No. 2 indicates that a little more than half the mass of the claystones is made up of carbonates, and these have been wholly or in large part infiltrated, and this may be true also of much of the iron and manganese. Column No. 4 would indicate that the original clays in which the concretions used for analysis were formed were wholly kaolin; indeed, there is less silica and water than is needed for the formation of kaolin; which does not agree with the results of examinations with the microscope. The analyses are mostly old, and, I have no doubt, give the quantity of the $\mathrm{Al}_{2} \mathrm{O}_{3}$ too large, and that of the $\mathrm{SiO}_{2}$ correspondingly small.

Thin sections of the small, round and obovate claystones show no trace of a continuous calcite cement binding the grains and needles of the clay together, but present a very fine and uniform mass of needles and grains, not in any marked way distinguishable from the ordinary clay. When treated with acids, effervescence appears from spots covering the whole surface, and the decalcified slide is made up almost wholly of kaolin needles, mostly about $0.008^{\mathrm{mm}}$ long and $0.002^{\mathrm{mm}}$ wide, quartz grains $0.003^{\mathrm{mm}}$ across, 
and coal grains about $0.004^{\mathrm{mm}}$ across. On examining a new slide carefully with high porvers the larger grains, which disappear with acid, are found to have cores of quartz and a warty coating of calcite.

FOSSILS OF THE CHAMPLAIN CLAYS.

REMAINS OF PLANTS.

So far as I can learn, no fossils have been described from the clays of the basin, nor, indeed, from those of the valley of the Connecticut above and below. As early as 1852 Dr. James Eights wrote as fellows of the Hudson River clays:

In one of those thin seams of fine sand that separate the strata of clay, abont 15 feet below the surface of the soil [in a plain 260 feet above sea level], are to be found the remains of a vegetable much resembling in appearanee the leaves and stems of the Mitchella repens. . . . These leaves have undergone but a slight change in their nature, still retaining all the flexibility of the more reent plant. ${ }^{t}$

These were very probably leaves of Vaccinium oxycoccus, which are the most abundant in the clays of the Connecticut.

In the summer of 1878 , while on an excursion with the senior class of Amherst College, I detected a few very small leaves in the river bank below Hadley, at the morth end of the clay exposure, opposite the house nearest the bridge over Fort River; and on a similar excursion in $1879 \mathrm{I}$ found that the floods of the preceding spring had cut deeply into the clays at that place and piled great masses near the south end of the exposure above low-water mark. From these blocks I obtained a better supply, though they were far from abundant. They were confined within narrow limits, both vertically and horizontally, and were generally scattered singly in the laminæ. In two cases layers were separated containing twenty or more leaves of several species and preserving delicately the impression of both the upper and under surface. They were uniformly very small-10 to $20^{\mathrm{mm}}$ in lengthgenerally thick and coriaceous. From their occurring scattered singly in the beds and associated with ripe seed vessels, I assume them to have been blown off the land by the autumu winds; and their position at or just above the base of the upper fine portion of the layer confirms the supposition already expressed-that this fine portion was deposited in the winter.

During the same year my colleague, Mr. J. M. Clarke, obtained leaves

I Observations ou the geological features of the post-Tertiary formation of the city of Albany and its vicinity: 'Trans. Albany Inst., Vol. II, p. 346. 
of the same species from the chay bank near Fort River and east of the Fair Gromuls in Amberst. Here they were matted together, leaves and twigs, in a liyer several millineters thick over a small surface. Later I obtained the sime leaves in some abundance from the clay bels at the cutting south of College Hill, opposite the Central station, where the clays rise to their greatest height. I have also found them at the brick pits beyond the asylum at Northampton.

Besides the aboundant trails of minute dipterous larve, nine plants have been identified with arctic and subaretic species by comparison with White Ifountain and aretic plants in the Amherst Herbariun; these are enumerated below.

Violu palustris L. Very small leaves, round heart-shaped, crenate, with four principal veins, agreeing well with the smallest leaves from the White MLomtains. Two or three leaves at Hadley. Several at the Hampshire Park locality, Amlerst.

Vaccinium oxycoccus L.-Leaves punctate above, rolled up mnderneatl, heart-shaped posteriorly; stem short and broad. While they agree in shape and size closely with the species to which I have referred them, the venation, which is indistinct in the herbarium specimens I have examined, is well marked in the fossil specimens. I have assumed this to be the result of maceration in the latter, since, so far as I could compare them, the venation was alike in both. Twigs occur carrying several leaves and several nicely preserved seed vessels. Very abundant both at Hadley and at Hampshire Park south of College Hill, Amherst.

Vaccinium uliginosum L.-Very rare; Hadley.

Rhododendron lapponicum Wahl.-Single leaves; referred with some doubt to this species. Hadley.

Arctostaphylos alpina Spr.-Several leaves agreeing exactly with those from the White Mountains. Hadley.

Arctostaphylos wva-ursi Spr.-Single leaves; referred with some doubt to this species. Hadley.

Oxyria digyna Campd.-The single impression of a small lenticular seed vessel, which agrees very closely with the impression made by the opened achenium of the mountain sorrel. Hadley.

Salix cutleri Tuck-Leaves agreeing exactly with this species are found oftener than any other. They are often folded together along the 
midrib, which I found to be the case also in the dried specimens studied. Small sessile seed vessels, several on one stalk, also occur in several cases. Hadley, and Hampshire Park, Amherst.

Lycopodium selago L.- I have referred to this species a single specimen agreeing with it in habit and in shape of leaf, but much smaller. Hampshire Park, Amherst.

In 1835 Dr. Hitcheock described fossils from Deerfield, Greenfield, and South Hadley, of a single genus in an imperfect state, resembling Ovulites margantula Goldfuss or Scyphia, which the full description shows to have been ferruginous pipestem concretions. ${ }^{1}$

\section{BURROWS OF DIPTEROUS LARVI.}

Over many surfaces of the laminæ which were free from the delicate rippling I have described above (p. 703), and were exceptionally smooth and fine-grained, run delicate raised threads in regular undnlations, each curve being $4^{\mathrm{mm}}$ long and $3^{\mathrm{mm}}$ deep. At times the raised thread is replaced by a groove of corresponding size, 1 to $1 \frac{1 \mathrm{~mm}}{2}$ in width. These may have been formed by minute worms burrowing just below the surface and raising a ridge, which sometimes sank in to form the corresponding groove. They occur 30 to $40^{\mathrm{mm}}$ in length. It is also interesting that the claystones have taken the cast of the partings between the clay layers so accurately that in the large disk-shaped stone figured in PI. XX, p. 716, both sides are covered by the grooves and ridges, and these show distinctly in the photograph. The claystone came from a point 30 ) feet below the level of the Connecticut at the west pier of the railroad bridge. The same trails appear abundantly on the surface of the folded claystone figured on the same plate; the exact locality from which this stone came is not known, but it is probably in Northampton, or Hatfield. These tracks were first figured by Högbom ${ }^{2}$ from interglacial clays in Jemtland, Sweden. They were later described by Dr. Gunnar Anderson ${ }^{3}$ from Jemtland and Finland. They were identified by him with the traces made by the larva of the dipterous insect Chironomus motilator.

These traces have been found from the strandzone to 300 fathoms in depth, in salt and fresh water, and in both temperate and arctic climates. ${ }^{4}$

${ }^{1}$ Geology of Massachusetts, p. 182.

2 Geol. Föreningens Stoekholm Förhandl., Vol. XV, 1893, p. 29.

${ }^{3}$ Sveriges Geol. Undersölnning, Series C, No. 1b6, 1897, p. 22 (60).

${ }_{4}^{4}$ Fr. Meinert, De eucephale Myggelarver: Kjöbenhavu. Vidensk. Selsk. Skrifter, 6 Raekke, Vol. III, 4, 1886, pl. 441-444. 
REMIINS OF FISIIES.

In 1845 one of my class found half of the pharyngeal bone of a fish in the Champlain clay 20 rods above the old oxbow of the Fort River below Hadley street. It was given to me on the spot and was lost by me throngh excess of care. It was about an inch long, and the principal pecnliarity was that the teeth,

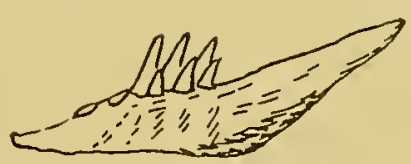

Fia.46.-Pharyngeal bone of a fish, from the Champlain elay, Holjoke. which were rounded and slightly bent cones about the size and proportion of a rather long lead-pencil point, were in a double row, pointing outward. The outer surface below the teeth curved outward and was quite deeply excavated vertically in several grooves, so that the rounded ridges, radiating a little, resembled the base of a tree trunk. The annexed cut, drawn from memory soon after the loss, represents the teeth quite accurately, though making them a little too large for proportion. Profs. E. D. Cope and Bashford Dean, to whom I submitted my drawing, agreed that it was the pharyngeal bone of a carniverous dacelike fish near Leuciscus or Rhodus. MON XXIX- 46 


\section{H A P T E R XI. \\ TERRACES AND MODERN DEPOSITS. \\ INTRODUCTION.}

An inspection of the profile of the river (Pl. XXI) shows in a striking way the ineffectiveness of the stream at low water and its effectiveness at high water. At low water it enters the State 181 feet above sea level and leaves it 39 feet above, but of this descent of 142 feet a fall of 132 is expended at the two dams and the French King Rapids, and 10 feet only in the intermediate spaces, less than 2 inches to the mile, as this portion of the river is about 70 miles long. At high water it crosses the State line at 218 feet $^{1}$ above sea level and leaves the State 57 feet above sea level, a difference of 161 feet, and of this only 83 feet is lost at its falls and rapids; 78 feet is divided over the long stretches of the stream, a little less than 14 inches to the mile on an average, though in reality the stream is divided into segments having velocities which oscillate widely about this mean.

This is the time of active work for the flooded stream, and much work goes on beneath its turbid waters, which is immediately visible when these waters subside, and much which has been unsuspected and which is not readily recognized. The visible effects are the erosion of its banks, the increase of its bars, and the spreading of a fine loam layer over its flood plain. The invisible work is the scouring out of the channel and the transportation through it of an unknown mass of sands, and then the building up of the old bars and shallows again in the old places so perfectly that one does not suspect that they have been removed at all.

1 This high-water datum was taken from the Northfield ferry house. The following notices of years of especially high water are taken from the Supplement of the Hampshire Gazette, November, 1895: "1801, great flood of Connecticut River, called 'Jefferson flood;' 1843, April 15 to 18, great flood; 1862, highest water ever known in the Connecticut, known as the Lincoln flood; all the houses on Maple and Fruit streets submerged." 


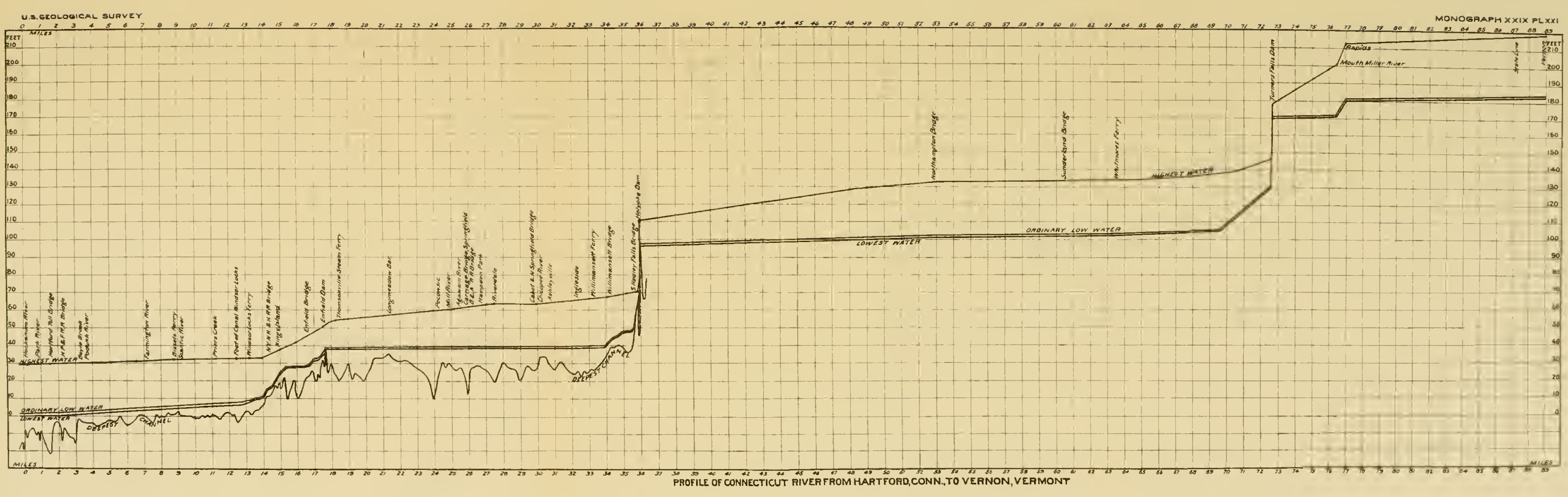



A strean tends to increase its meanderings nutil friction on bank and bottom of its increased length uses up all the force derived from its descent during flood time. But when this happy equilibrium is reached the river goes beyond it and grows too long. It then, for relief, cuts off an oxbow in a sluggish stretch, as the Connecticut las often done between Sugar Loaf and Holyoke. 'This gives the section of the stream new life and eroding' power by as much as it is shortened; and hence, since the great oxbow was cut off at the Northampton Meadow there has been more complaint of the loss of land by erosion across the Hadley and Northampton meadows than anywhere else on the river. The erosion has been especially severe at the upper and lower ends of Hadley street, and the location of the two bridges at Northampton has done much to direct and deflect the stream, especially promoting the erosion above those bridges on the east side and the growth of the islands on the west. At the extreme western apex of the great bend . the stream has worn into a hill of coarse drift, out of which it has constructed a natural riprap, which is restored as often as broken, and a period is put to the stream's wear in that direction, so that everything points to its cutting across parallel to Hadley street unless careful precantions are takenmore careful, it seems to me, than have been thought necessary.

By the continued work of the agents here briefly mentioned, some of which are more fully discussed in the section on incomplete terraces (p. 731), the Comecticut has swung to and fro across the abandoned lake bottom as a cable swings through the water. The sands have melted away before it and filled in behind it, holding it to a constant width. In the Springfield Lake it has cut down very deeply into the lake sands, especially below Holyoke, forming many and complicated terraces.

In the Hadley Lake it has lowered only very little since it began to flow as a river, forming ferv and broad terraces. At the Northampton bridge the track runs off the bridge at the west end and cuts the lake bottom, and from the east end one looks down on the lowest complete terrace, less than 20 feet below the level of the bridge. In the Montague Lake the downward erosion was arrested by the waters striking the Lily Pond sandstone reef, in Gill, and after they had rounded this reef they cut down rapidly to present level, forming an extra terrace not marked farther south. 


\section{THE INTERMEDIATE TERRACE AND THE BARRIER AT THE LILY} POND IN GILL, AN ABANDONED WATERFALL.

Mr. Warren Upham, in his Survey of the Terraces of the Connecticut River in New Hampshire, ${ }^{1}$ described a "second apparently connected series of terraces which mark one of the principal flood plains formed by the river during its work of erosion." It is "most clearly continuous below the south line of Brattleboro, but seems to be traceable from White River Falls."

In the center of the State I was not able to trace any well-marked series corresponding with that described by Mr. Upham, but commencing at the north line it runs down the river, well marked and continuous, to the beginning of the canyon below Northfield Farms, and it had long been a problem to me why the terrace so broadly worn into the older sands in the north was so faintly represented farther south.

A study of the sandstone ridge at the Lily Pond ${ }^{2}$ quarry of Triassic "bird tracks" in the summer of $\mathbf{1 8 8 2}$ made it clear to me that here had been the site of a waterfall of the Connecticut which had worn back two short canyons about 100 feet long, in the northern and deepest of which the Lily Pond lies, and that the two had included a rocky island between them, just as is the case at present with Tumers Falls, and on a larger scale with Niagara. This held up the waters to the level of the 300 -foot terrace above this point.

After an amount of erosion which must have represented a considerable lapse of time, the stream, wearing into the sands of the great delta on the south, cut round the edge of the ridge to the left and sunk suddenly to nearly its present level, abandoning (a) its course through the Lily Pond and Bartons Cove, and (b) the other branch starting from the other notch in the ridge and running parallel with the first, and, like it, still represented by a "cove" extending back some distance along the abandoned channel. The river took thus a more circuitous course through the "narrows," and had still to cut down somewhat to reach its present level, as the prolongation of the sandstone ridge appears just above the water level on the other side of the stream, coming out from under the thick delta sands. This is doubtless the reason why the width of the stream is so small at this point.

\footnotetext{
1 Geology of Now Hampshire, Hitcheock, Vol. III, p. 58.

${ }^{2}$ This is the third Lily Pond mentioned in this chapter; one is in South Vernon, Vermont, the other in West Northfield, and this is just east of the Factory village, in the town of Gill.
} 


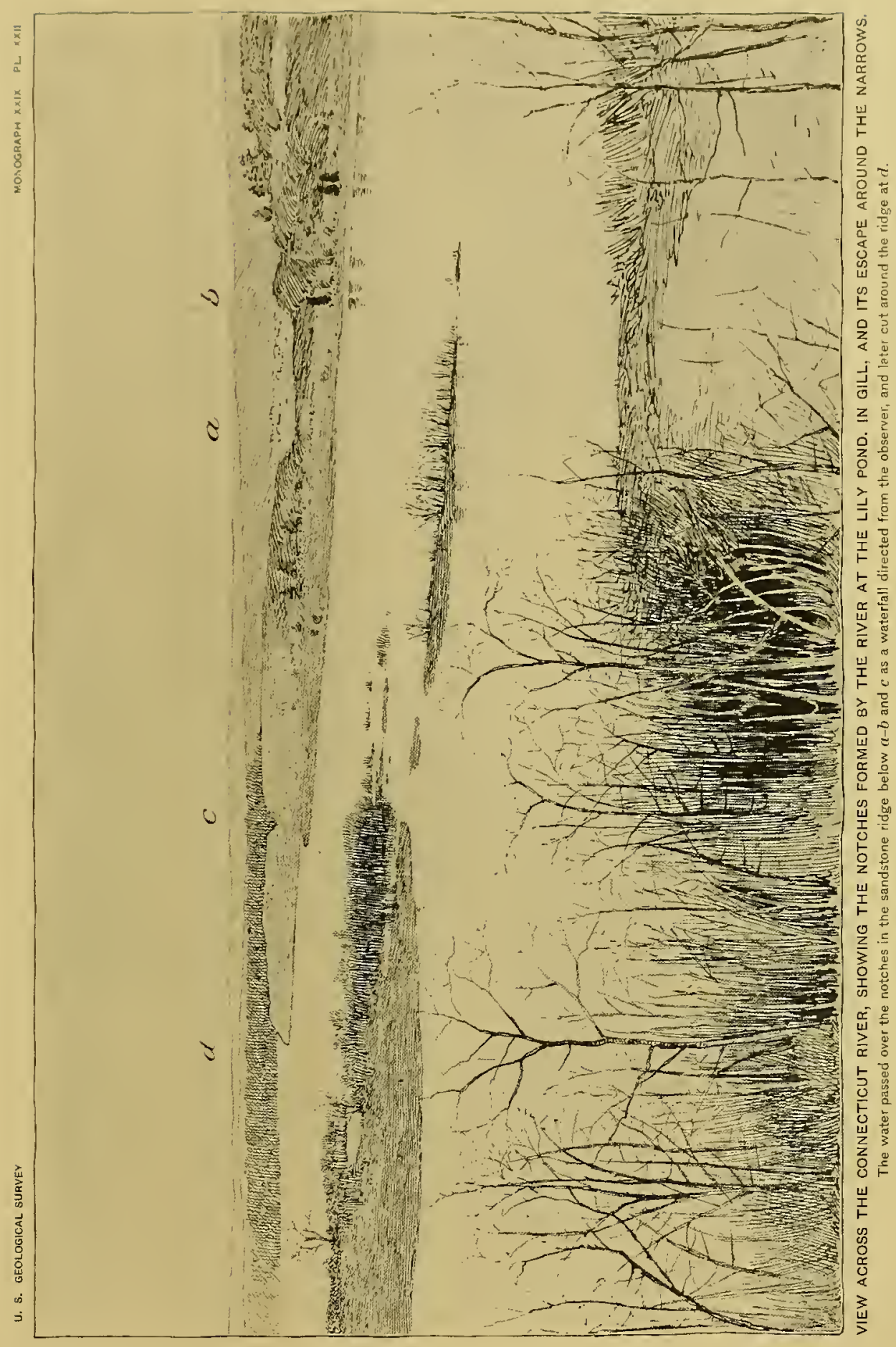



'The view given in Pl. XXIl is taken from the edge of the ligh terrace a mile nurth of Willis Hill, in Montague, looking north across the Conneeticut during the spring flood. The stretch of the river between the "natrows" and the "horsentee" is double the usnal width, and it extends south covering the broad flats shown on the map. The broad notch (a b) in the sandstone ridge to the north, across the river, is the notch by which the waters formerly passed to fall deeply into the canyon concealed to the north. The small southward projection on the map, of the crescent-shaped pond, which is the Lily Pond, represents this canyon. The contours on the mal) are here incorrect, for the ground rises along the ridge to the east. The second notch (c) is opposite the next pond to the left; the place where the river turned the obstacle (d) and cut down to the point of the sandstone ridge is the narrows on the map.

THE JOW-LETEL TERRACES AND FLOOD PLAIN OE THE CONNECTICUT IN THE BASIN OF THE MONTAGUE IAKE.

The subsidence of the waters of the Connecticut lakes to the present Connecticut River was very rapid, interrupted above the Lily Pond falls during their existence (see Pl. XXII), 'bnt completed perhaps still more snddenly here by the turning of the Lily Pond reef by the waters, as described on the preceding page.

As a result, one goes down-through the whole length of the Montagne Lake, which was well filled up in the flood time, except in its sonthem portion-by a great scarp to the series of erosion terraces of the modern river, the highest of which rise but a few feet above the level of the flood plain. I have colored these on the map with different shades of yellow, the darkest for the highest and oldest terrace, farthest from the river $\left(\mathrm{t}^{4}\right)$, the lightest shade but one for the present flood plain $\left(t^{1}\right)$, and a very light yellow for well-marked but incomplete terraces below the completed flood plain $\left(t^{1}\right)$. Abandoned oxbows ( $\left.\mathrm{x} x\right)$ and old river courses $(\mathrm{o} b)$ now play an important part and are colored by lines of the same shade as the terrace coeval with them.

These later terraces form the "meadows" of the Connecticut. The Northfield Meadows and the romantic recess opposite, and the beautiful Pine Meadow above Northfield Farms, are the only ones of considerable extent carved in the northern lake, for from the latter place the river 
any evidence of an intermediate water stand, the rapidity of the decline of flows between rocky banks to the mouth of the Deerfield River and is bordered only by narrow terraces until it reaches the Hadley Lake basin at Sunderland.

\section{THE LATER TERRACES OR MEADOWS OF THE CONNECTICUT IN THE HADLEY LAKE.}

The Sunderland, Hatfield, Hadley, and Northampton meadows, the most famous farming lands and the earliest-settled portion of old Hampshire

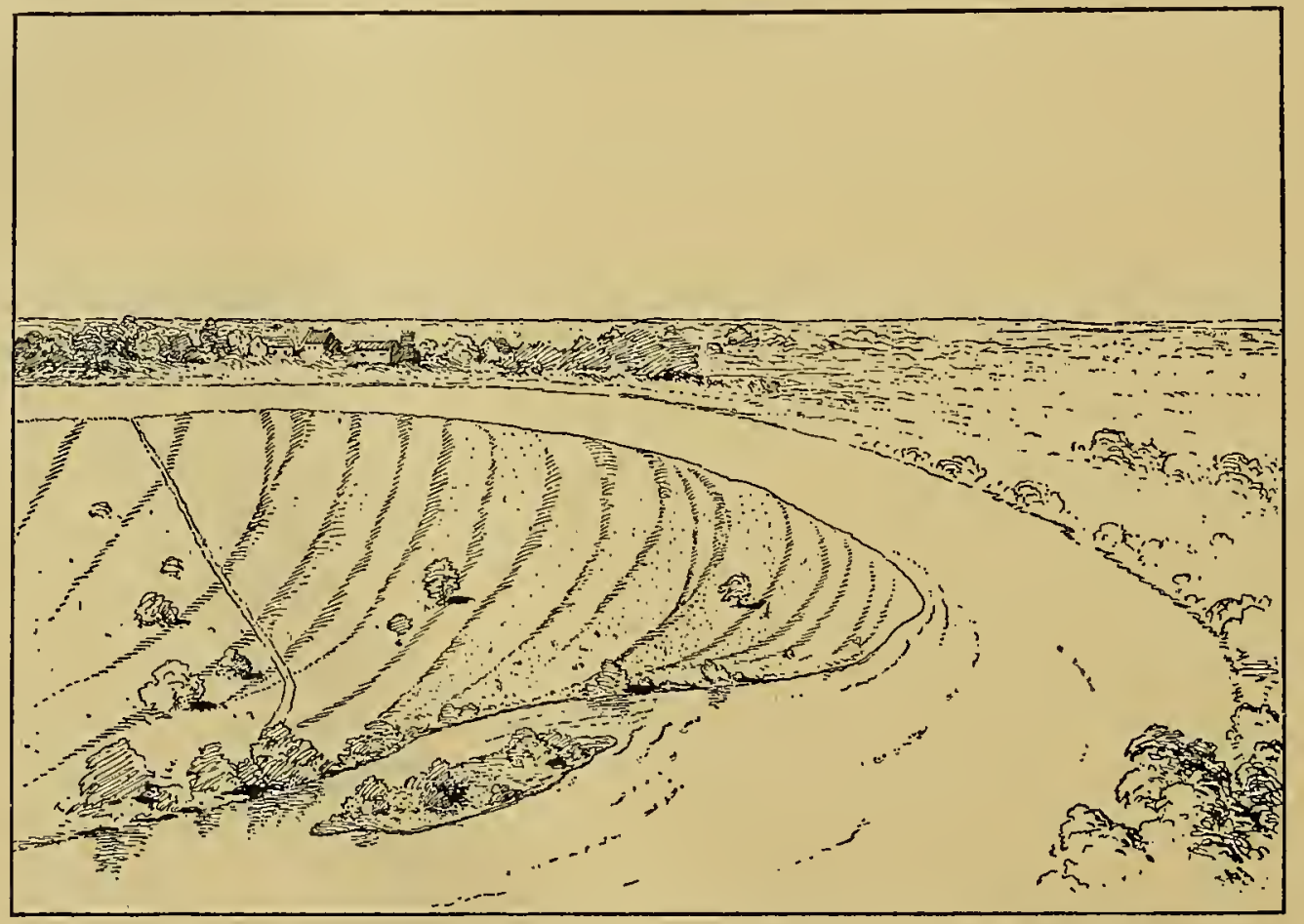

FIG. 47.-Sketch of the point of the Northampton Meadow from Mount Holyoke, to show that the meadow is a composite of many islands. Except when seen just before sunset, the meadow seems an almost perfect plain.

County, make up the area built by the Connecticut since its shrinkage to near its present dimensions, in its passage from Sugar Loaf to Mount Holyoke.

The old lake bottom lay so low, especially in all the area north of Mount Warner, in Hatfield and North Hadley, that after one has followed down the slope from the high lake bench to and across ths bottom to the scarp, a few feet in height, above the oldest of these later terraces (a scarp which registers the farthest outward swing of the river), and has failed to find 
the water to essentially its present rolume becomes quite manifest. The meatows are broal prairies of the richest soil, the gift of the river, and seen from Mount Holyoke or Sugar Loaf when the erops are on, as they are farmed without fencing, they spread in a carpet of wonderful beanty at one's feet and take their place in a landscape which owes much of its charm to the immediate proximity of the prairie and the mountain.

The plain that seems so perfeetly level when seen from above proves on closer inspection to be made up of a series of broad, low ridges (fig. 47), like the long, low swell that comes in on the coast after a distant storm, and the curved grooves which separate these ridges run approximately parallel to the bank of the stream, but with greater or less curve. This is due to the composite nature of the terrace itself, as explained in a general way on page 722 and ilhustrated in its details in the discussion of incomplete terraces on page 731. Each of these low bars represents one of the elements ont of which the terrace is built, and has passed through the stages of bar, island, and "glacis terrace," ${ }^{1}$ as it has added itself to the previously formed plain, while the groove on the outside of each ridge (out from the river) is the unfilled remnant of the waterway which separated the island from the former shore.

The surface of the broad terrace plain north of North Hadley and extending up to Sunderland shows this most strikingly, and when seen from the hill just north of Hatfield each separate island of which the terrace was built by the westward swing of the river can be picked out.

\section{THE STRUCTURE OF THE TERRACES.}

The river sands.-The two scarps which form the riverward limit of the old lake bottom and the outer boundary of the terrace system on either side of the river, and represent the outermost limits of the oscillations of the stream, afford the best natural sections of the lake-bottom berls and commonly expose at least the upper portion of the clays and their junction with the sands above, a junetion very often marked by a line of springs. Between these scarps the river-bottom sands rest in the trough cut in the clays by the river, and the stream rarely runs directly on the subjacent clays. These sands are of medium grain, well washed, straticulate, with southward dip, and often, in addition, cross bedded with sharp southward or more moderate 
northward, eastward, or westward dips, according to their position upon the bar of which they form part.

The muck sands.-In 1838 President Hitchcock wrote: ${ }^{1}$

Luther Root, in digging a well in Sunderland, 80 rods from Connecticut River, at bottom ent through a thick stratum of quicksand smelling of sulphuretted hydrogen. This sand proved to be very fertile. The same happened from a well in South Deerfield, on land of Mr. Rufus Rice. The bed was 6 feet from the surface. On searching, the bed was found on the bank of the river in Sunderland. It is the first stratum that retains water.

President Hitcheock traced it through the Connecticnt, Deerfield, and Westfield river valleys. It is, when wet, slightly green and soapy, but is a fine sand. It contains non oxide and vegetable fiber, and many analyses are given showing "soluble and insoluble geine" (as the substances that may be extracted from vegetable mold were then called), sulphate and phosphate of iron, and silica. In his final report $\mathrm{t}^{2}$ he returns to the subject at great length, compares the fertilizing part to the slime deposit of the river and expects much from its use upon lands. He calls it "muck sand," but notes that it is commonly called quicksand.

Where I have been able to study this it has proved to be the finer deposit thrown down in the channels between islands and the shore to which they were in process of joining themselves, which channels are generally silted up at the upstream ends first and remain then long filled with stagnant water. They are called "intervals" on many New England rivers.

Peat deposits, plant remains.-In his first article on the geology of the valley ${ }^{3}$ President Hitchcock writes:

In the meadows, logs, leaves, butternuts, and walnuts are found undecayed $\mathbf{1 5}$ feet below the surface, and stumps of trees have been observed at that depth standing yet firmly where they once grew. In the same meadows a few years since several toads were dug up from 15 feet below the surface, and 3 feet in gravel, which soou recovered from a torpid state and hopped away.

From the plain east of the south end of Sunderland street, beneath 7 feet of sand, hemlock logs with bark and leaves, beech nuts, and pine burs, have been very frequently dug up, as reported to me by Dr. Trow, of that town. These remains occur sparingly in the river sands everywhere as water-logged fragments, and more abundantly in old stream beds and in the

\footnotetext{
${ }^{1}$ Economie Geology of Massachusetts, p. 93.

${ }^{2}$ Geology of Massachusetts, 1841, p. 107.

${ }^{3}$ Geology of Deertield: Am. Jour. Sci., 1st series, Vol. I, 1819, p. 108; also Final Report, 1841, p. 366.
} 
sheltererd grooves describerl above in connertion with the "muck sand." ln digning wells in the lower part of Northanuton alomg Maple street, on the north side of Mill hiver, and nome the road learling to Hockanum Ferry from Pleasant street, the deposit. las been fomd 16 to 20 feet below the river-a fine, bluish loam, with leaves, branchos, and roots, butternuts, buttomballs, hemlock knots, and a prece of coal. The same deposit was exposed at the foot of King street in Northampton.

Loess.-The most important stratum which goes to make up the terraces is the wholly unstratified loess which everywhere caps them. It is most important economically as giving the meadows their fertility, and deserves attention as a true water-formed river loess. Except for the lack of any-large per cent of calcic carbonate, which, as there is almost no limestone in the clrainage area of the Connecticut, is not surprising, and for the resultant rarity of land shells in the bed, its agreement with the Rhine loess is complete. It caps the river sands, and up and down the river presents a cornice, often 8 feet thick, of a fine, dark, wholly unstratified loam, pierced full of vertical root looles and breaking with vertical walls. It is the accumulated silt of the annual floods of the river, each layer being worked over by wind and frost and by the boring of worms and roots until the whole becomes entirely massive; and a rudely columnar structure is produced by the multitude of root holes, which become passages for water after the rotting of the roots, and so lessen the cohesion in this direction that a vertical cleavage results. This loess layer appears capping the surface in the section (fig. 48, p. 737). It is fincly shown in the curving bank above Northampton bridge, where the river is wearing witl great rapidity into the Hadley Meadow and is forming already a great semicircle. Here the loess forms a perpendicular wall below which the sand slope is cut into great steps by the river as it sinks from high water, so that the whole resembles a Roman circus. The loess is here 5 feet thick. Over the Hatfield lower meadow it is 6 feet thick; over the upper meadow about $2 \frac{1}{2}$ feet. Over the Northfield Meadows the loess is 6 to 8 feet thick, and is especially strongly developed in the West Northfield Meadows.

THE TERRACES OF THE CONNECTICUT IN THE SPRINGFIELD BASIN.

The fact that the basin was left by the ice so nearly filled up to the level of the later lake, and the fact that the contributions to the lake were almost wholly from the east side, caused the thread of the current through 
the lake to hug the western shore; and as the river took the place of the lake, it occupied the same position and cut very'soon down into till or sandstone, and so was unable to swing in broad oscillations, as in the deeper clay-filled Hadley basin. From the notch to Smiths Ferry a narrow terrace, or, for a distance, two narrow terraces, border the river on the west. On the east the river is wearing into the great gorge terrace of Dry Brook Hill, and a single sand slope of 188 feet tonches the water's edge. From the south end of this hill to Holyoke the first position of the river was much farther east, and it has swung west to its present place and built on the east side an early flood plain, long since abandoned, and the river has now cut its bed deep in the sandstones and is thus prevented from oscillating. Doubtless if the dam below were removed the water would run in rapids over this ground, as it does over the rocks above Turners Falls. There is in all this distance scarcely a trace of any low terrace on the west side of the river.

Across Chicopee there is a fine, low terrace bounded on the east by a high scarp of the high terrace, which everywhere shows till in great force beneath the sands of the old lake. From the Chicopee River south to the south line of the town the high terrace scarp comes forward to the river. Across Springfield there is developed a complicated series of river terraces. An incomplete terrace borders the stream opposite and above. Hampden Park. The business portion of the city is built upon the normal flood plain of the river. Above this are two well-marked terraces, which send back deep lobes to the north and south of the armory grounds, up old water courses, and a remnant of one of these intermediate terraces is preserved in the hill north of the Memorial Church, cut off possibly by an oxbow, the only one found in this basin upon the main stream. The low terrace contracts to nothing on the sonth line of the town and widens again in Longmeadow.

On the west side of the river the low terraces expand south of Holyoke into the broader meadows of West Springfield and Agawam.

The series in all this distance is quite complicated, matching the opposite side of the river. There is across West Springfield an early flood plain raised well above the river, and around the entrance of the Westfield River the incomplete terrace occupies broad areas from which the water is largely kept out by artificial embankments. South of this tributary, across Agawam, the system of later terraces is developed with a beanty not exceeded in the 
whole length of the State. Wo lave, beginning back at the mountain, the broat streteh of the light lake flats (lf), sinking into a more limited area of lake bottom $(1 \mathrm{~b} t)$, and cut into this is a series of later terraces, four in number $\left(t^{\frac{b}{3}} t^{3}\right)$, much broader than the corresponding ones north of the Westfield River, and combining with the terraces of this latter stream to form a most beautiful succession of broad meadows, bounded back from the river by sharp slopes, which swing in great curves-representing former curves of the stream-up which one mounts to reach ligher terrace flats as well characterized as those below.

THE INCOMPLETE TERRACES AS ILLUSTRATIONS OF TIIE STAGES IN THE GROWTH OE TERRACES.

All up and down the river broad sand flats may be seen extending out into the stream at a level but little above low water and on the concave side of bends, as north of the knee of the Hadley bend and at the first concavity below the Northampton bridge.

Generally only one bank of the river is wooded at a given section of the stream. Going up or down stream, one comes to a stretch where the growth ceases and is replaced by a caving bank, beyond which the bushes begin again. From the bushy banks the shallows extend far out, and the conditions are favorable for the formation of islands. Against the caving bank lies the thread of the stream. Each set of these sand flats and shallows is connected diagonally across the stream with a corresponding set on the other side, and at low water a series of disconnected deep water-pockets lies in the line of the thread of the current, alternating against the right and left banks of the stream, and so much of the water seeps through the sands of the shallows between the pockets that the bed is not scoured out at all between these long, curved deep-water stretches.

It was a remarkable and interesting discovery of Gen. Theo. G. Ellis, of Hartford, ${ }^{1}$ that at high water a large portion or the whole of this system of bars is scoured out, and on the recession of the flood is replaced exactly in its old place and with its old dimensions, as a curtain held up by the wind sinks to its old place as the wind falls. This is true, of course, in so far as the banks of the stream above and below are unchanged, for these bars are the mechanical solution of a complex equation in hydraulics and change with any change of the factors. 
If bushes or turf strand on the bar and take root, it is protected and its increase is accelerated, and it grows in flood time above the low-water level and rises as an island or promontory, and the tendency of the stream to scour out everything at high water generally keeps open a channel between it and the mainland. This is the condition of Ellwells Island, just north of the west end of Northampton bridge. In the time of canal navigation, sixty years ago, the channel, $\mathbf{3 3}$ feet deep, ran right under the present island, and in digging for the pier of the new bridge old boat hooks were found under its south end.

The island generally joins the mainland by the silting up of the upstream end of the side chamel, and a deep, stagnant inlet runs up from its south end. This is the condition of two broad peninsulas opposite the "oxbow" below Hockanum which have formed since 1840.

The continued growth of the new addition to the flood plain takes place by material brought in over it during floods, and this decreases in rapidity as the ground rises, and soon the checking of the current as it rises over the flat makes itself manifest in the increased deposition along the outer border of the flat, and a "glacis terrace" "results, sloping sharply to the water and gradually backward. The "glacis terrace" is thus. a case of arrested development of a terrace. The groove which separates the new from the old remains preserved for a long time and often permanently.

Again, as the waters rise over the growing terrace, they are arrested first over its upstream portion and thus build up this end most rapidly. 'This is most beautifully illustrated in the terrace which begins at the Northampton bridge and extends sonth to the south end of Hadley street, and is bounded by the road which leaves the main road at the bridge and joins Hadley street at its sonth end. This road runs along the edge of the former bank of the river, and at its south end one looks down upon the lower plain, still separated by a shallow inlet which runs up from the south. Northward, the lower plain gradually rises, the inlet shallows and disappears, and the lower terrace is a complete "glacis terrace." Still farther north the lower plain contimnes to rise, and the scarp which separates the two becomes less in height until at the bridge the two have come so nearly to the same level that one might easily overlook the fact that the newer terrace extends 
for some little distance above the bridge. I have already had occasion to deseribe the meandows an formed by a continued repetition of this process. (Seer fig. 47,1$) .726$. .)

ON TIH: WNCLLATIONS OF TIIE CONNECTICUT TROM ITS EARLAEST POSITION.

From the north line of the State to the Sunderland bridge the river everywhere cut down rapidly to rock and has not swung widely to east and west, but has been condemned from the begimning to rock cutting.

The river at the begiming took its course across the Hadley Lake bottom along the deepest line, which it lais obliterated. I imagine that this line was very near its present position. It probably swung first eastwardly to its eastern limit, at the "halfway house" on the Hadley road. It is more certain that from this eastem limit of its oscillation it has moved west regularly and silted up its bed behind quite rapidly and completely; this is shown by the fact that the Hadley and North Hadley-Sunderland meadows are composed of series of elongate and coalescing islands, as detailed on page 726. It has swung, then, west across the Hatfield and very far west across the Northampton meadows, and regained again a more central position by cutting off its oxbows. During its swing westward, across the Northampton Meadow and back, it has lowered itself by about 7 feet more than its own depth, since at the foot of Hadley street its old bottom sands rest upon the eroded surface of the Champlain clays at a height of 7 feet above the low water of the river. This height may be somewhat increased if we allow for the influence of the Holyoke dam.

From the Holyoke notch south to the Holyoke dam the river early became entangled in rock and has cut only vertically. From the dam south the earliest position, or, more accurately, the earliest restorable position, may be found by following down the outside edge (counting from the river) of the oldest terrace of erosion $\left(t^{3}\right)$. This, the highest terrace of this later series, is found only on the west side of the stream from Holyoke south, and then is for a long way present on the east side, across Springfield, then being transferred to the west side, across Agawam. This represents the sinuous position of the stream from the Holyoke Falls southward at a time when it had first established its course across the lake bottom, and from which it has swung to form its later and lower terraces, ending in its present temporary position. 
THE OXBOW' OF THE CONNECTICUT.

In the Montagne Lake the valley was too narrow, the rock comes too near the surface, and the earlier deposits were too thick to allow of broad bends and cut-offs. Several old river beds there seem rather to have been formed by the building up of an island in midstream and the after limitation of the current to one side of it without filling up the abandoned portion.

Over the broad bottom of the Hadley Lake the stream had more freedom, and in the Hatfield and Northampton meadows are two most interesting series, containing in one case fom and in the other three old cut-off oxbows, and between is the great Hadley bend, where the river runs about 6 miles to advance sonthward 1 mile, and threatens to take a straight course down through Hadley street. (See map, PI. XXXV, in pocket.)

In Hatfield the oldest oxbow runs down west of the village. A part of the unfilled bed of the second is the Great Pond. The third is represented by a sickle-shaped pond east of the road going north from the village, and the completion of the fourth has in very recent years transferred a fragment of Hadley to the west side of the river.

In Northampton a sickle-shaped pond, at the western edge of the meadow, represents the oldest cut-off. The second remains in a smaller pond near the western curve of the third-the oxbow par excellencewhich is still a ring-shaped pond, in communication with the main stream beneath the bridge of the Connecticnt River Railroad. This was cut off during the flood of 1840 . Figures of the river, as seen from Mount Holyoke before 1840, with the fine curve of the stream from 1840 to 1845 , after the cut-off and before the silting up of the months of the oxbow, are given in the publication, Northampton, Meadow and City. ${ }^{1}$

ON THE DEFLECTION OF' STREAMS TO THE RIGHT BANK.

The Connecticut River between Mount Toby and Mount Holyoke, abont 8 miles in a straight line, flows across the broad, level bottom of the ancient lake through thick, very fine-grained, and very homogenous deposits. It is thus, together with its tributaries, farorably situated to give evidence concerning the possible influence of the earth's rotation upon the erosion of streams according to Ferrell's law, that a stream under the influence of the 
carth's rotation always tends to wear its right bank. Aecordingly, it is interesting that the river has constantly made and cut off oxbows on the west-that is, the right side-and never on the east side. It has successively 'unt off four bends in Iatfield and three in the soutl part of Northampton, anI has also male the great Hadley bend, which it has long threatened to change, into an oxbow, and it has never made great bends out to the eastward.

The same testimony also comes in a striking way from the tributaries I have for several years given, as practical work for advanced students, the mappling of portions of these tributaries of the Connecticnt, which rum for long distances out over the old lake bottom, and on counting up the sharp bends and oxbows on the right-hand side of the stream the proportion was as great as 30 to $1 \mathrm{in}$ favor of this side as against the opposite.

\section{RIVER TERRACES AROUND A RECEDING WATERFALL.}

The flood plain of a river tends to reach the full height of highest flood, and on approaching a fall this height diminishes greatly, as the waters as they go over the fall, because of their increased rapidity, rise to only a small fraction of their nolmal height. At the foot of the fall or at the mouth of the canyon below the fall the flood plain begins again at a level as much below that above the fall as the descent of the water's demands.

Thus at Turners Falls the flood plain above the falls is only 7 feet above the level of the waters, and the height above the waters before the erection of the dam was probably not many times greater, while the flood height of the river here is 30 feet. If now the falls recede, leaving remnants of this low flood plain, it will hang over the canyon with a height above the river equal to its original height plus the height of the fall; and this is the case at Turners Falls and at Holyoke, where the old flood plain is continuous from above the falls south along the sides of the gorge formed by the recession of the falls.

If, further, the stream by its oscillations below the falls builds a flood plain at the lower and newer level, we have the curious result that the flood plain above the falls will extend downstream above the flood plain below the falls, the two thus overlapping at two different levels. Distinct traces of this appear at both of the falls on the river, especially at South Hadley Falls, where the flood plain of the river is continued out over the lower one for a long distance. This makes a difficulty in coloring 
the terraces, and I have on the map continued the low-terrace color down the canyon side in dots to distinguish it.

\section{THE TERRACES OF TRIBUTARIES.}

The deep, land-locked basins eut in the lake beds by the tributaries of the Connecticut are among the most remarkable orographic features of the valley. Each stream has first built out the great delta plain and then excavated its basin on the sinking of the main strean. They have this peculiarity in common. Each stream emerges from its gorge in the crystalline rocks, runs across its former delta, and passes through a short rocky gorge just above its mouth, and the stream has thus been fastened at two points like the string of a musical instrument, and has vibrated between these two points to form its closed basin. It lias eroded with great violence because it has had the rapid fall across the crystalline rocks.

The Deerfield and Westfield River basins are the most extensive and interesting examples, the one occupied by the most romantic and sleepy old town in the valley, the other by a typical, unattractive, manufacturing town. These rivers have reoccupied their old gorges in the trap ridges, as already explained (p. 512). The others, Green River, Millers River, IFill River in Northampton, and Cushmans Brook at the Golden Gate in Amherst, have by chance struck rock bottom as they cut down through their deltas, and thus the mouths of their basins are closed below, as are the first two.

The basins are bounded on all sides by high scarps, and over the low meadow bottoms are many abandoned chanuels caused by ice obstruction in spring, which in the Deerfield bottom are developed into a most complieated network.

A prominent, flat-topped hill, called Pine Hill or Pine Nook, its surface on a level with the adjacent high terrace, rises in the midst of the Deerfield Meadow and has doubtless been cut off by an old oxbow of the river, and a smaller but similar one, which has been called an Indian mound, but has the structure of the surrounding delta sands, stands in the basin of Mill River above Florence. 


\section{AT OLD OXHOW OW FOR'L RIVER.}

From the south ent of Hadley street one may follow the Chumplain chlys continuously for a loug distance south in the river bank. Near where they sink below the water a terrace scup belonging to Fort River is eut off in the bank of the Comnecticut. The last louse passed in going south from Undley and before crossing the bridge over Fort River stands on the edce of the completed flood plain of the Comnecticut and looks down over this surp to a lower plain, formerly part of the flood plain of Fort River, which here runs parallel to and just enst of the Connecticut. In fig. 48, a represents the southern termination of the Champlain clays, which a few feet north furnished the leaves described on page 718 , and still farther north abound in claystones; $b$, the bottom sands of the Comecticut when it flowed at a level higher than at present by an amount somewhat greater

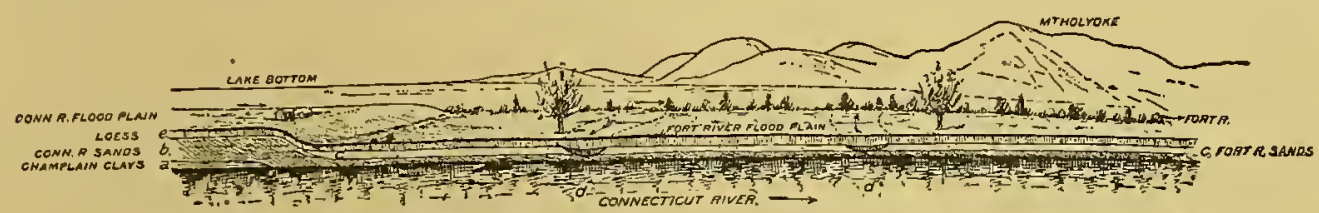

FIG. 48.-An old oxbow of Fort River cut by tbe Connecticut below Hadley. $d, d^{\prime}$, old bed of Fort River.

than its own depth. These are coarse to medium grained straticulate sands, which rest unconformably upon the clay and extend with a thickmess of 20 feet to the point where the old Fort River terrace scarp is cut off in the present river bank. Here these sands end, their horizontal beds abutting unconformably against $c$ and $e$, except that at lowest water their lower beds can be traced beneath $c$ for the whole length of the exposure.

The scarp, partly exposed and partly submerged, against which these sands end, registers the farthest northward swing of Fort River in throwing out an oxbow here on its west side; $c$, which is a fine, horizontally bedded and straticulate sand, is the bottom sand of Fort River as it swung across its flood plain; $d$ and $d^{\prime}$ are two cross-sections of the old oxbow of the tributary, now cut into by the main stream. At $d$ the stream plainly flowed toward the west-that is, toward the reader; at $d^{\prime}$, toward the east; and the Connecticut has cut across this old oxbow, as indicated by the dotted lines. These old river beds are the exact equivalents of the present bed of Fort River - a stratified deposit of leaves, twigs, logs, and seeds in fine MON $\mathrm{xx} 1 \mathrm{x}-47$ 
whitish clay, abundantly pierced by the vertical pipestem concretions, especially in its upper portion, where it grades into $e$, a thick stratum of loess, which is $\mathbf{1 0}$ feet thick over all the lower plain, and still thicker where it projects downward to fill the old river beds. It rises up the terrace scarp with a thickness of 3 feet, and is continuous over the upper plain with a thickness of 6 feet. This represents the accumulated deposits of the Connecticut in flood time, laid down since Fort River abandoned its bed at $d$ and $d^{\prime}$. This stream now runs immediately adjacent, with its surface coincident with that of the Connecticut. When it occupied this old oxbow it flowed at a level $\mathbf{1 3}$ feet higher, and this represents certainly more than half of the amount by which the Connecticut has lowered its bed in the bottom of Hadley Lake since it shrunk to its present size. This would assign to the fossils found here an age about intermediate between those of the Champlain clays below and the present time, or somewhat nearer to the present flora than to the older; and the habits of the fossils themselves agree with this, and indicate a climate like that of northern Vermont or Canada. It is interesting that a fragment of charcoal from some light, opengrained wood was found in the midst of the matted leaves of the leaf bed and was certainly of the same age with them. It was about as large as a walnut.

FOSSILS OF THE TERRACE PERIOD.

VERTEBRATES.

Mastodon americanus.-In 1872 Dr. Edward Hitchcock, jr., writes: "I have seen and identified a mastodon's molar which was found in the town of Coleraine, Massachusetts. It was shoveled out of a muck bed on the farm of Elias Bardwell." ${ }^{1}$ The tooth is still in Mr. Bardwell's possession. MOLLUSKS.

In digging in a marl pit which has formed by the filling of a small pond on the surface of the till on the farm of Fred Conant, at East Shelburne, large quantities of white fresh-water shells are at times thrown out. They are very well preserved, and consist of the following species:

Lymnea elodes Say.-Lengtli, $30 \mathrm{~mm}$. Common.

Planorbis trivolvis Say.-Large diameter, $25^{\mathrm{mm}}$; small diameter, $18^{\mathrm{mm}}$. Common. 
Planorbis parvus Say.-Abundant. Diameter; $6.5^{\mathrm{m}}$.

P'isidium vuriabile Prime.-Abundant. Length, $2{ }^{\mathrm{mm}}$; width, $2 \frac{1}{2} \mathrm{~mm}$.

PLANTS.

Ranunculus aquatilis L.-A single well-preserved plant. This and the following, with one exception, are from the old oxbow in Hadley, described on page 737 .

Acer succharinum Wang.-Leaves. Rare.

T'rumus virginiana L.-Seeds very abundant; leaves abundant. "River" banks. Common, especially northward" (Gray).

Platamus occidentalis L.-Leaves, large branches, and balls found in great abundance.

Matted masses several inches thick and many feet broad consist almost entirely of leaves, many of the largest size. Large branches, often very much flattened and still covered with the characteristic bark, occur fiequently.

In several cases delicate hollow globes of sand, like globes of lace or Chinese hollow ivory balls, have been formed by the penetration of the fine sand to the surface of the central ball, and its spreading in the regular interstices which surround each point of attaclment of a seed, where the grains have been slightly agghtinated and left as a globe of lace on the rotting of the seed ball. The extreme northern range of the species is Lake Champlain and Montreal. ${ }^{1}$

Juglans cinerea L.-Dwarf nuts, $1 \frac{1}{4}$ to $1 \frac{3}{8}$ inches long, $\frac{6}{8}$ to $\frac{7}{8}$ inch wide; less deeply sculptured than the form now common here. In one case nine specially prominent ridges are present. In another the ridges are more rounded, broad, and irregular than now. The species now extend south to Georgia, and north through Canada, but this dwarf form would seem to indicate a station near its south border.

Carya amara, Nutt.-At the old oxbow occurred an impression of an exterior inclosing a cast of the interior of a single specimen in rusty clay. Also well-preserved nuts in abundance were given me by Dr. Edward Hitchcock, as found at extreme low water below the mouth of Fort River, opposite the fourth pile of McIndoes's boom, counting from the northrounded, thin-shelled nuts, averaging somewhat larger than nuts of the same 
species from Burlington, Vermont. Sizes: Burlington, 17.5 to $19^{\mathrm{mru}}$; Connecticut River, smallest, 19 to $20.5^{\mathrm{mm}}$; largest, 22 to $27^{\mathrm{mm}}$. "Barely 1 inch $\left(25.5^{\mathrm{mm}}\right)$ long, thin walled" (Gray). "Northern boundary, Vermont" (Michanx). I am informed that but a single tree of the species is now found in the county, and this upon the Hatfield Meadow.

Quercus alba L.-A few well-preserved leaves.

Quercus coccinea Wang., var. ambigua.-Leaves and abundant acorns in all stages of growth. "The gray oak appears, by my father's notes, to be found farther north than any other species in America." (Michanx, Sylva, vol. 1 , p. 98.)

"Along the northern borders to Lake Champlain and northward." (Gray, Manual, 1872, p. 434.)

Fagus ferruginea Ait.-Next to the sycamore, the most abundant plant represented. Leaves of full size, large fragments of the wood and bark and nuts alike abundant, the latter very large and surpassing in size those now found in the vicinity.

"Common, especially northward." (Gray's Manual, p. 455.)

"Almost exclusively confined to the northeastern United States and to the provinces of Canada." (Michaux, Sylva, vol. 5, p. 22.)

Betula alba L.-Large branches with bark marked exactly as in the common white birch.

Besides these many other indeterminate plants were studied-willow leaves, grape vines, grasses, liliacea, lycopodium, lichens, various seeds, and even a flower.

\section{THF PLEISTOCENE BEETLES OF FORT RIVER, MLASSACHUSETTS.}

By Samuel H. Scudder.

The insects found by Prof. B. K. Emerson in the old bed of Fort River in Hadley, Massachusetts, near its entrance into the Connecticut, have no special interest beyond the fact that they are the first insects found in such deposits in New England. They cousist wholly of Coleoptera, and represent five species and four families, viz: Carabidæ, Dytiscidæ, Elateridæ, and Chrysomelidæ, the latter having two species. At least three of the insects, perhaps all, belong to species not now known to exist, but so far as can be told with any certainty, all belong to existing genera, though some doubt may reasonably be claimed for the single species of 
PLATE XXIII. 


\section{PLATE XXIII. \\ PLEISTOCENE BEETLES OF FORT RIVER, MASSACHUSETTS.}

(The original drawings are by J. Henry Blake.)

FrG. 1. Cymindis extorpescens; elytron $\frac{6}{1}$.

2. Corymbites rethiops (Herbst)?; prothorax ${ }_{1}^{6}$.

3. Dytiscida sp., perhaps a Matus; metasternum $\frac{*}{1}$.

4. The same; a portion further enlarged to show the surface sculpture $\frac{50}{10}$.

5. Donacia elongatula; elytron $\frac{6}{1}$.

6. Saxinis regularis; portion of the right ely tron highly magnified to show the surface sculpture $\frac{50}{1}$.

7. The same; dorsal viow of the beotle $\frac{6}{1}$. 


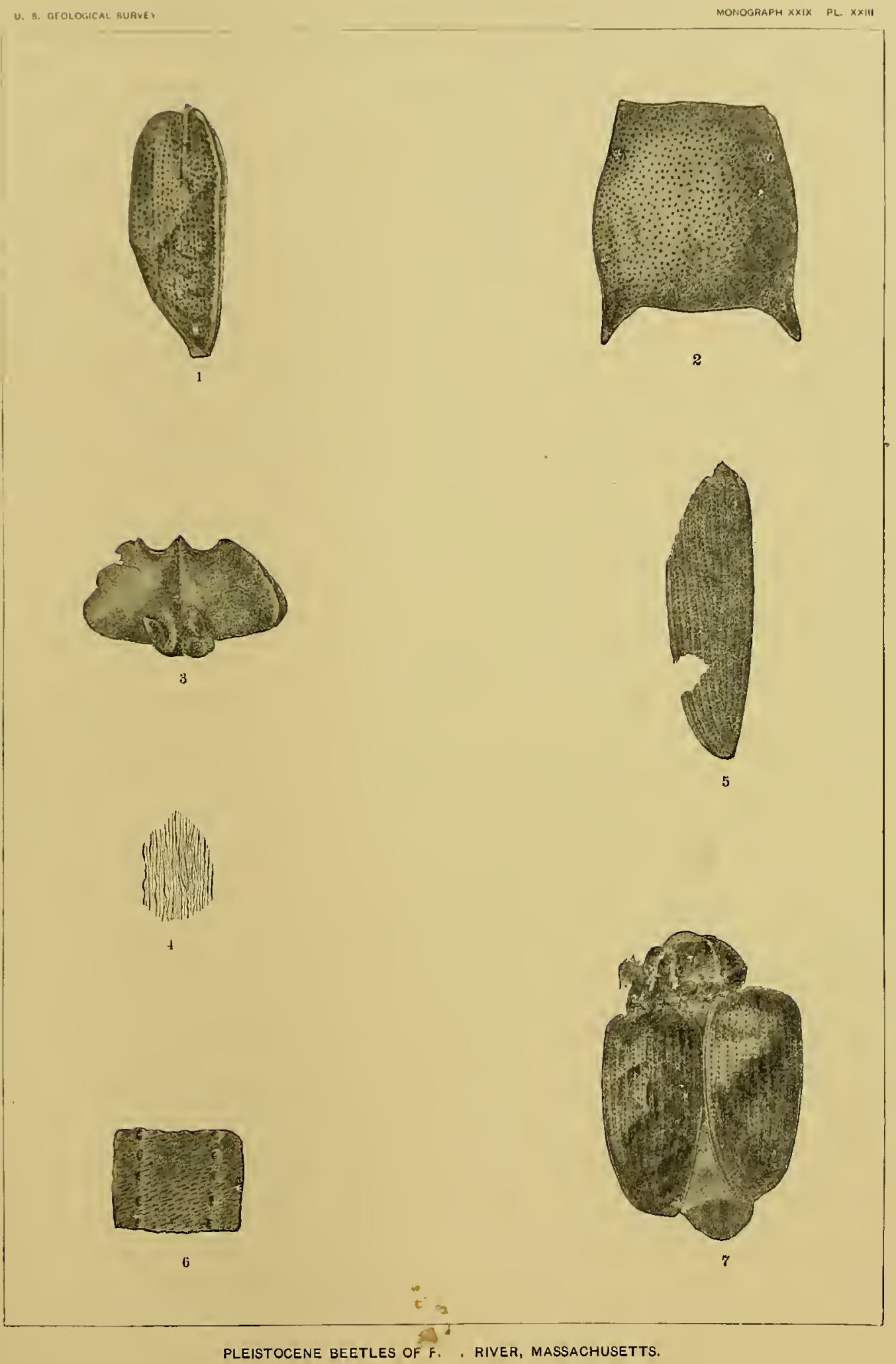



I) stiscidic and one of the two species of Chrysomelide. This is rather surprising, but is what has been found to some degree in American Pleistocene deposits, the insects of which appear to show less close relations to their successors on the spot than is commonly the case in Europe, and in consequence relatively little light can be shed upon the climatic conditions of the time by their remains. In the present case the information is meager and gives no certain clie. The existing species most nearly allied to the Pleistocene Cymindis (Carabidæ) occurs from Massachusetts to Florida, and is more common in the Sonth than in the North; our single species of Matus (Dytiscidæ) is found in Canada and in the Northern States from Massachnsetts to Iowa, but also in Missouri and Florida; Corymbites athiops (Elateridæ) oceurs from Massachusetts to Pennsylvania and Ohio; the Donacia (Chrysomelidæ) most nearly allied to the fossil species described below appears to be one known from the Pleistocene of Italy; while the species of Saxinis (Chrysomelidæ) most closely related to the Pleistocene form here figured is a northwestern species, coming from Vancouver, Oregon, and California, and also from Utah, Colorado, and Wyoming. It is plain, then, that a considerably larger assemblage of forms must be obtained to give any evidence of valne. The following are the species found:

\section{Family CARABIDÆ.}

\section{Cymindis extorpescens.}

\section{Pl. XXIII, fig. 1.}

A single elytron, representing a species about as large as C. cribricollis Dej., but more nearly allied to C. elegans Lec. in the reduction of the interstitial punctures to a single row, seems to be entirely distinct from any of our species of that genus in the reduction of the striæ to a series of short longitudinal dashes separated from one another by their own length, while the interstitial punctures are more lightly impressed, arranged in single straight rows, and separated by twice their own length. The elytron is piceous, with a very faint bluish reflection.

Length of elytron, $6.35^{\mathrm{mm}}$; width, $2.5^{\mathrm{mm}}$.

${ }^{1}$ For information on the distribution of American Coleoptera I always rely upon the ready and efficient aid of my friend, Mr. Samuel Henshaw, of Cambridge. 


\section{Family DYTISCID在.}

\section{Dytiscida sp.}

Pl. XXIII, figs. 3,4 .

The metasternum of a species of Dytiscidre is among the fragments obtained. It is nearly complete, and, of all with which I have been able to compare it, most resembles that of Matus, particularly on account of the depth of the median groove, the form and relative abbreviation of the rounded intercoxal prolongations, and the shape of the coxæ, and it agrees very well in size with our single species, $M$. licarinatus. As, however, it is not nearly so long in proportion to its breadth as in that species, and narrows remarkably from behind forward, it hardly seems possible to refer it to that genus, and I find no other with which I can so well compare it. Instearl, also, of being faintly and rather sparsely punctulate, as in $M$. bicarinatus, the surface is feebly, longitudinally, and undulately striate, and of a dull piceous color. In the general form of the metasternum it more nearly resembles an Agabus.

Length of metasternum, $3^{\mathrm{mm}}$; breadth posteriorly, $5^{\mathrm{mm}}$.

Family ELATERIDA.

Corymbites athiops (Herbst)?

Pl. XXIII, fig. 2.

The prothorax of an elaterid of a piceous color is referred here with some doubt. There are but two or three of our species which have a prothorax large enough to compare with it, but the size and general proportions, and especially the punctation of the surface, agree perfectly with C. ethiops. It differs from that, however, in the greater slenderness of the produced posterior outer angles, the sides are more strongly convex on the posterior half, and it is not narrowed to nearly the same extent anteriorly. This last point makes its reference here very doubtful, but until further remains are found it seems best to place it here with a mark of doubt.

Length of prothorax along the median line, $5.35^{\mathrm{mm}}$; greatest breadth, $5.25^{\mathrm{mm}}$. 


\section{Fimily CHRYSONELIDE.}

Tribe Jonacinn.

Donacia elonyatula.

Pl. XXIII, fig. 5.

A single neirly perfect left elytron appears to represent a species not hitherto known, but apparently most nearly allied to D. lignitum Sord., from the Italiau Pleistocene. It is somewhat more than three times as long as broad, tapering from the middle to the nontruncated apex, before which the outer margin is more strongly but very regularly curved, with no sudden change of direction. Besides the marginal groove, there are in the basal half ten parallel strix with delicate longitudinal punctures, but in passing from the base to the apex the two middle unite just before the middle to form a single stria, and just beyond the middle they are joined by the fourth from the inner margin. No others unite until shortly before the apex, when the third and fourth from the inner margin unite and terminate, and halfway from here to the apex all but the outer ones approach and terminate, the outer ones acting similarly at the very apex. The surface is shining piceous.

Leugth of the fragment, $7.25^{\mathrm{mm}}$; probable length of elytron, $7.6^{\mathrm{mm}}$; breadth in middle, $2.2^{\mathrm{mm}}$.

Tribe Clythrini.

Saxinis regularis.

Pl. XXIII, figs. 6, 7 .

The most complete specimen found in these beds is a chrysomelid, with the last abdominal segment exposed and callous, which with its form indicates one of the Clythrini. It is slightly larger than and of a similar form with S. saucia Lec., though it differs decidedly from it in the details of the form and structure of the elytra. The prothorax is crushed and misshapen, so that nothing more can be said of it than that it differs from that of Saxinis in its lesser breadth, being decidedly narrower at base than the elytra, and on this account it is exceedingly doubtful if it should be placed 
at all in that genus, or, in fact, in any other of the American Clythrini. The elytra differ from those of $S$. sauciu mainly in having the abbreviated apex less rounded and more squarely truncate, the inuer apical angle especially being far more angulate; as there, both outer and sutural borders are delicately margined, and the general proportions of the elytra are much the same (in this respect resembling it rather than our other species of Saxinis), but they are a little and gradually narrowed on the apical half, while nearly equal in S. sancia; besides the punctures which adjoin the outer margined border, the elytra liave ten very straight and regular equidistant series of delicate punctures, which are short oval, those in each row separated from their neighbors by more than, usually about twice, their own length, and the general surface is sparsely covered with excessively delicate hairs scarcely longer than the punctures. The general color is a uniform shining piceous with a slight greenish, metallic tinge, the metallic green being decided in the punctures. The last abdominal segment shows a slight dull median ridge.

Length of body, $8^{\mathrm{mm}}$; of elytra, $6.5^{\mathrm{mm}}$; breadth of base of prothorax, $3.1^{\mathrm{mm}}$; of each elytron, $2.5^{\mathrm{mm}}$.

\section{THE REPULSION OF TRIBUTARIES. ${ }^{1}$}

Oscar Peschel, ${ }^{2}$ from his orographic studies, notes the tendency of a tributary to run a long distance near and nearly parallel to its primary. In all the tributaries which enter the Connecticut across the broad lake deposits between Mount Toby and Mount Holyoke this is very marked. They all I'un out throngh the old bordering bench $(\mathrm{s} \mathrm{h})$ in deep gorges, then take a straight course down over the old lake bottom $(1 \mathrm{~b} t)$, following its slope, but when they reach the oldest terrace flat formed by the river in its oscillations after the shrinking of the lake, they bend abruptly south and continue as far as possible to run nearly parallel to the main stream, and when they enter the latter it is by a sudden bend at right angles. This will be clearly seen by an inspection of the map (Pl. XXXV, in pocket), or of the Northampton and Belchertown sheets.

First, the brooks north of Sunderland village, on the east side of the

${ }^{1}$ See Pl. XXXV, in pocket at end of volume.

${ }^{2}$ Vergleichende Erdkunde, 1878, p. 141. 
river, do not show the peculiarity, since the erosion terraces are there narrow or wanting, but the fivo brooks south show it most clearly. Cushmans Brook (called Ifill River on the new map) runs down west of Mount Warner. The next two brooks sonth do the same, and then Fort River, the last of the series, illustrates the rule in the most striking manner, and indeed formerly ran much farther south than now, parallel with the Connecticut, and entered the latter above Hockanum at the boat landing of the Mount Holyoke House. This has here plainly the following explanation: The water sank very suddenly in the lake, and the oldest position of the present river of which any trace remains was the eastern edge of the terrace system. On this sinking of the lake water the streams followed it by the shortest course, cutting gorges in their old deltas, and at one time each one joined the main stream at the point where it at present cuts the boundary between the lake bottom $(1 \mathrm{bt})$ and the terrace system $\left(\mathrm{t}^{1}-\mathrm{t}^{3}\right)$. As the Connecticut swung west and built up its ternace behind it the tributary elongated and kept its course across this newly formed terrace, and since this terrace flat or flood plain was built up as a series of bars which grew to be islands, behind each of which there is for a long time a long groove opening south (see p. 726), the brook occupied this and entered the main stream round its south end, and at last this operation, many times repeated, gave the streams their present course.

It was the observation and study of this law several years ago which causerl me to doubt the then prevalent idea held by those most competent to judge, that the Comnecticut Valley had been filled up to the height of its high terrace-the lake bench-and then excavated, and led me to map the terraces, as I have done, into ( $a$ ) a high bench or string of deltas bordering the valley; $(b)$ a succession of lake bottoms sloping from the above centerward and broadening in each of the wider stretches of the valley, and $(c)$ a comparatively small area occupied by the "oscillation terraces" of the river proper-the "meadows." 


\section{DUNES AND WIND LOESS.'}

President Hitchcock notes ${ }^{2}$ the dunes in Montague and Hadley, and in the east part of Hadley south of the road, and their motion southeastwardly. ${ }^{3}$ The lake bottom in Northfield is strikingly cut up by great dunes over the whole of the Beers plain, and farther sonth in Montague one can see where they have crept upon the west slopes of the islands which rose in the midst of the old delta of Millers River, the broad Montague plain.

The low lake bottom in Hatfield, made up as it is of very fine sands, is also greatly affected by old dunes, and many of the scattered farm buildings are here built upon dunes, while a liue of still moving sand drifts runs up through the center of the plain, and is indicated on the map.

But the most remarkable exhibition of dunes in the valley is where the prevalent westerly winds strike the scarp which, on the east side of the river, separates the flood plain of the Connecticut from the lake bottom. This sharp, westward-facing scarp has been longest exposed to the winds, and is made up of very fine sands, and taking the eastern of the roads which runs from Sunderland to North Hadley, one crosses an almost contimuous line of great sand drifts until this road joins the next westerly one, and the line of dunes is continued southward, and along the west side of Mount Warner has pushed high up the side of the hill. Farther south the scarp is notched in many places by old or still active dunes, one of which is in sight on the soutl side of the road from Amherst to Northampton, just before it enters Hadley.

Wind loess.-All along the west slope of the Amherst ridge, especially opposite the lower openings in the ridge, as across the old cemetery or south of College Hill, a layer of fine unstratified loam or loess has been brought by the prevailing westerly winds from the broad lake bottom of fine sand which extends west from the bottom of the ridge. This layer is from 2 to $2 \frac{1}{2}$ feet thick, and extends over the whole ridge, resting on the shore sands and gravels, and higher up on the till, and extends for a long distance down over the east slope. I have traced it everywhere over the ridge in the network of cuttings for the gas and water pipes, the sewer's, and the

${ }^{\prime}$ See $\mathrm{Pl}$. XXXV, in pocket at end of volume.

${ }^{2}$ Geology of Massachusetts, p. 130; Jour. Boston Soc. Nat. Hist., Vol. I, p. 80.

${ }^{3}$ Geology of Massachusetts, Final Report, p. 326. 
raihoal, and found it present in every undisturber opening. It was especially well marked in the ditches dug across the Agricultural College farm in 1 sigh for laving water pipes.

\section{MINEIAT SPRINGS.}

The noteworthy springs in the region may be classified as follows:

1. Syrings from the gneiss. In Shutesbury, just west of the village, is a spring which was discovered about 1808 , and a hotel was built at the place, which is still called the Pool Tavern, although it las long been used as a private house and the well dug over the spring has caved in."

More celebrated are the "Orient Springs," in Pelham, so named by President Hitchcock. These springs rise on the strong transverse fanlt which crosses Pelham and Prescott. The large building built at the spring in 1861 was never a success, and it was burned in 1883. It is a quite strong* sulphur spring.

2. Springs from the mica-schist. The abundant pyrite in these sclists has everywhere produced springs which are strongly mineralized. In Amherst, especially along the west of the ridge, where the schists come near the surface, many wells contain so much copperas that the waters blacken tea and curdle milk.

In Hawley the Moody Spring, in the sonthwest part of the town, is said to possess strong medicinal properties and to be a specific for saltrheum and other cutaneous diseases A similar chalybeate spring in the southern part of Ashfield has a local reputation.

The Mount Mineral Spring, Shutesbury, was known as a chalybeate spring as early as $1828 .^{2}$ The Mount Mineral Spring Company was incorporated in 1867. A fine hotel was sustained for some years, but burned in 1876, and the property has since been abandoned. Appended is an analysis of the water, furnished me by the present owner of the property. It is a pure alkaline chalybeate water containing manganese in solution.

${ }^{1}$ Evert's History of Connecticut.Valley in Massachusetts, Vol. II, p. 758.

${ }^{2}$ E. Hitchcock, Am. Jour. Sci., 1st series, vol. 13, I828, p. 217. 
Analysis by S. Dana Hayes of xater of Mount Mineral Spring; in one United States gallon of 231 cubic inches; June 14, 1878.

\begin{tabular}{|c|c|c|}
\hline & $\begin{array}{c}\text { Parts per } \\
100,000 .\end{array}$ & Gralns. \\
\hline Sulph. pot ...... & 1,476 & 0.868 \\
\hline Sulph. lime ......................... & 301 & .175 \\
\hline 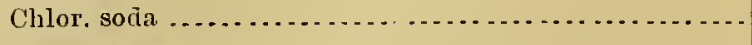 & 3,360 & 1.949 \\
\hline 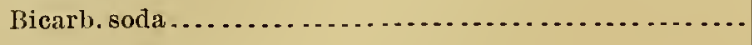 & 1,398 & .811 \\
\hline Bicarb. lime............................. & 2,351 & 1. 364 \\
\hline 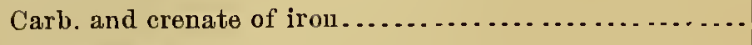 & 5,537 & 3.108 \\
\hline 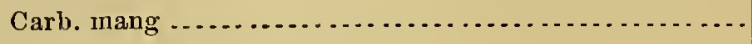 & 364 & .223 \\
\hline Alumina ................. & $\cdots \cdots \cdot$ & trace \\
\hline Silicic acid in solution ................ & 701 & .407 \\
\hline Total. & 15,488 & 8.905 \\
\hline
\end{tabular}

3. Water of artesian wells in the Triassic. All the artesian wells dug in the valley have much saline matter in solution. I was informed by Prof. C. U. Shepard, as the result of his analysis of the water of the South Hadley well, that common salt was present in large amount, and the abmndance of the salt psendomorphs in the sandstones in which the well was bored indicates that this comes from the sea water entangled in the sandstones at the time of their deposition. The appended analysis of a sample from the more northern well shows that the water has nearly the constitution of a bittern. One United States gallon of water contained in solution 102.54 grains of saline matter, which consisted of the substances named below.

Analysis by Prof. C. A. Goessmann of one gallon of water from the artesian well at the Montague Paper Company's mills at Turners Falls, Massachusetts; made at Amherst, November 2, 1874.

\begin{tabular}{|c|c|}
\hline & Grains. \\
\hline Potassa ............. & 0.352 \\
\hline 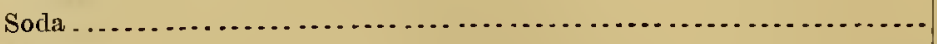 & 2.994 \\
\hline 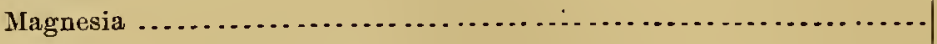 & 3.690 \\
\hline 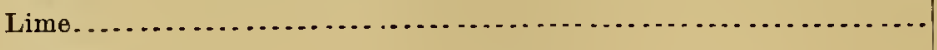 & 36.951 \\
\hline 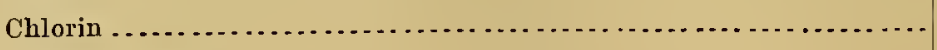 & .363 \\
\hline 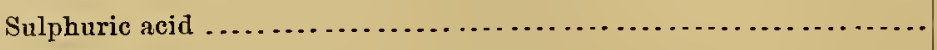 & 58.191 \\
\hline 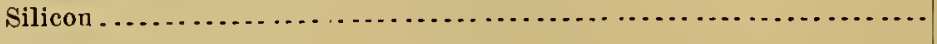 & $\operatorname{trace}$ \\
\hline 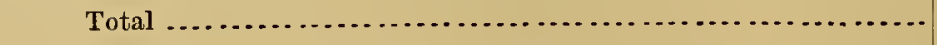 & 102.541 \\
\hline
\end{tabular}


4. Springs of the glarial lalie's in the uplands. - Spring's rising from the base of the heavy sands of glacial lakes in the uplands rest on the till, and those from the bise of similar sands of the Connecticut Lake rest on the Champlain diys. These are hardly to be called mineral springs. The former furnish the somrees of many of our mountain brooks. 'The latter, lying nearer the villages, are better known. Of these are the slightly chalybeate spring at South Hadley Falls, the fine, strong spring which gushes out of the bluff west of Hatfield village, and several issuing from the bluffis that surround Deerfield. In Springfield the Wesson Spring, which supplies the water of Court Square and a fountain at the corner of Willow and Stockbridge streets; the Walker Spring, at the comer of Maple and Stockbridge streets, and the Ingersoll Grove Spring, a hundred feet south of Dartmouth terrace, the water of which is sold largely in the city, are of this character. The rain waters which have fallen upon the surface of the ligh terrace on which the higher portion of the eity is built sink through these sands to the horizontal and impervious surface of the clays beneatli and emerge at the edge of the bluff.

The Ingersoll Grove Spring was reported upon by the State board of health, ${ }^{1}$ and the result of its analysis is given below (I) in connection with the analysis (II) in the same pamphlet of the Massasoit Spring, described below. The Massasoit Spring is of ideal purity; the other gives plain indication of the presence of the barn, sewer, and streets, which are reported in the immediate vicinity of the spring.

Analyses of raters of Ingersoll Grove and Massasoit springs. [Parts in 100,000.]

\begin{tabular}{|c|c|c|}
\hline & I. Ingersoll Grove. & II. Massasoit. \\
\hline Residue on evaporation .............. & 8.70 & 5.50 \\
\hline Ammonia: & & \\
\hline Free ......... & .000 & .000 \\
\hline Albuminoid . . . . . & .0008 & .000 \\
\hline 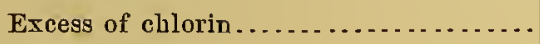 & .43 & .09 \\
\hline Nitrogen as- & & \\
\hline Nitrates...... . & .5000 & .0600 \\
\hline Nitrites........... & .0002 & .0001 \\
\hline 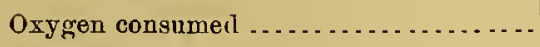 & .0275 & .0160 \\
\hline 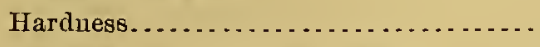 & 2.73 & 2.86 \\
\hline Bacteria per cubic centimeter. . . . . . . & .0 & .0 \\
\hline
\end{tabular}

1 Examination of spring waters offered for sale in Massachusetts : Twents-third Ann. Rept. State board of health, pub. doc. 34, 1891 (also separate publication), pp. 356, 362, 364. 
The Massasoit Spring on the "Bear Hole" farm, in the western part of West Springfield, issmes from the base of a very high bluff of sand that forms the east wall of the deep channel which the Black Brook has cut in the broad sand plain. The spring is said to show the uniform temperature of $45^{\circ} \mathrm{F}$. thronghout the year. An analysis by Prof. Charles Mayr, published in the pamphlet advertisement of the spring, is here given:

Analysis of water of Massasoit Spring.

\begin{tabular}{|c|c|c|}
\hline & $\begin{array}{l}\text { Grains in } \\
1,000,000 .\end{array}$ & $\begin{array}{c}\text { Grains in } \\
1 \text { gallon. }\end{array}$ \\
\hline Sodium chloride (salt) ............... & 6.0 & 0.360 \\
\hline 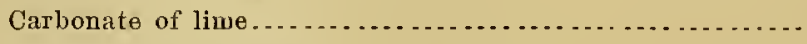 & 23.0 & 1.380 \\
\hline 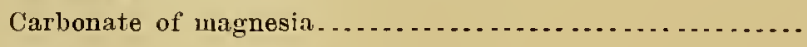 & 8.0 & .480 \\
\hline 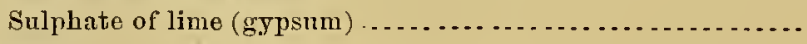 & 4.2 & .252 \\
\hline 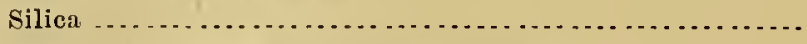 & 4.0 & 9.240 \\
\hline 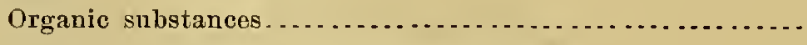 & 12.0 & .720 \\
\hline Potash, iron, alumiua, phosphates, nitrates .............. & trace & trace \\
\hline Total. & 57.2 & 3.432 \\
\hline
\end{tabular}

Althongh the spring was discovered only in 1886, very attractive buildings have been erected and it has become a well-known place of summer resort, and the water has been put on sale in Springfield for table use. The brook just to the west ruus over the surface of the trap, which dips with great thickness beneath the sands from which the springs flow, but it is not probable that a deep-seated water coming up through the sandstone and trap would be so pure. It is probable that the waters come wholly from the sand itself, and that the exceptional purity comes from the fact that they have been filtered through a hundred feet of this sand.

\section{THICK MODERN FISSURE DEPOSITS OF QUARTZ SURROUNDING ROOTS IN THE BASE OF THE HOLYOKE TRAP SHEET.}

In 1891 a great block of the trap fell from the vertical wall at the point on the river above Titans Pier, where the trap contains limestone, and disclosed a mass of translucent chalcedonic quartz nearly as large as a man's head, which was pierced with tubular openings 0.5 to $1 \mathrm{~mm}$ in diameter and at least 4 inches in length, generally nearly but not rigidly parallel, and so 
clesely grouped that the separating walls of siliea were quite thin or partly wanting. At times they were quite widle apart or in sinall gronus. These tubes are lined with limonite and sometimes nearly filled with it. At times a separate "ylinder or open tube of limonite is found free in the cavities. The limonite can not be wholly removed from the cavity, but impregnates the silica for a small but definite distance in from the surface of the cavity.

The most striking cirenmstance is that the silica in one portion of the mass grades with imperceptible boundary into a mass of distinctly banded, siliceous, dove-colored limestone, or ankerite, as it oxidizes into a porons oclier.

It seems tolerably elear that the general explanation of this must be that a mass of rootlets penetrating a fissure of the trap became coated with limonite and that then a deposit of silica, at first impregnating the limonite there, went on to fill the whole fissure, while in part of the latter a mixture of calcite and silica completed the work. Where the delicate cylinders and tubes of limonite rest free in the eavity we may suppose that limonite was deposited within the bark of the rootlet, replacing or surrounding the slurunken pith. Indeed, a portion of this bark remained in the tube at one place and was in part removed and burned.

MON XXIX- 48 


\section{H A P T E R X X I .}

\section{SUPPLEMENT TO THE AUTHOR'S MINERAL LEXICON OF FRANKLIN, HAMPSHIRE, AND HAMPDEN COUNTIES. ${ }^{1}$}

1895. Albi're. Blandford; Osborn's soapstone quarry.

Fir.e, fresh, white-translucent crystals an inch across. In flat plates from growth in fissnres and large development of basal plane, which is deeply striate parallel to the intersection edges with the primary prism.

Twinned by the pericline law and with few plates interposed according to the albite law.

Forms present, $b(010), c(001), m(110), \mu(450), f(130), \zeta(150), M(110), v(450)$, $\approx(1 \overrightarrow{3} 0), x(\overline{1} 01), y(\overline{1} 12), e(021), p(\overline{1} 11), o(\overline{1} 11)$. (See p. 85.)

1896. Albite. Chester.

At the adit of the new mine opened north of the road opposite the old Emery mine. The mineral occurs in perfect simple white crystals an inch in leugth. They inclose titanite and are coated with prochlorite.

1892. Allanite. Belchertown.

Cited from Belchertown. E. S. Dania. Sys. Min., p. $105 \mathrm{~s}$.

1892. Ankerite. Middlefield.

E. S. Dana. Sys. Min. Localities, p. 1059.

Donbtless from the steatite bed. All the specimens I have examined from these beds were dolomite.

1892. Anthophyllite. Blandford.

E. S. Dana. Sys. Min., p. 1058.

This is the brown actinolite from Osborn's soapstone quarry.

1892. Anthophyluite. Chesterfield.

E. S. Dana. Sys. Min., p. 1058.

This is the hair-brown, coarsely fibrous mineral from the bluff above Burnell's pond, which is identical with the cummingtonite or amphibole-anthophyllite occurring in Cummington, a little way farther north, in the Conway schists. 
1892 Axthophrutte. Cliesterfielel.

k. S. Dana. Sys, Min. Localities, p. 1058.

l have never loumd this mineral in Chesterfield, nor any of the minerals with which it is associated; nor do I recall any other eitation of the mineral from this town. 1 suppose it to be the brown cummingtonite from the bluff's west of burnell's pond.

1858. Anthophyllite. Enfield.

Specinens labeled "anthophyllite gneiss" in the State collection.

E. Ifitch cock, Nos.96, 97, under gneiss. Cat. State Col. Mass. Agr. Rept., p. 15.

A dark-brown, bladed mineral. The powdered fragments all extinguish longitudinally, as it it were a rhombic mineral.

1895. AnT'hracite. Holyoke.

In Chicopee shale of Triassic age below the Holyoke dam. In thick masses coating siderite. It has rounded surfaces, showing that it was introduced into the fissure as a bitumen. It is in very brittle layers, which give a yellow flame for an instant and then glow without further flame. (See p. 370.)

1895. Aратite. Blandford.

Occurs in the Osborn soapstone quarry, in rich, deep oil-green crystals an inch long, intercrystallized with ehlorite. (See p. 85.)

1895. Apatite. Chester.

Crystals 1 to $3^{\mathrm{mm}}$ in length occur on and in the diaspore. (See p. 143.)

1895. Aragonite. Chester.

A beautiful fibrous satin spar occurs in the serpentine at the old mine, in sheets a foot square and $1 \frac{1}{2}$ inches thick. (See p. 143.)

1895. Barite. Holyoke.

Cavities 4 inches long and one-third inch wide and an inch deep, with rectangular ends or ends beveled like barite crystals, occur in the Chicopee shale below the Holyoke dam. (See p. 370.)

1892. Bastite. Westfield.

E. S. Dana. Sys. Min. Localities, p. 1060. Cited as Schiller Spar (Diallage). This is a bastite derived from enstatite, from Munns Brook.

1818. Beryl. Emerald. Chesterfield, Goshen, Northampton.

Chesterfield furnishes them in great abundance, from the weight of an ounce, or less, to six pounds. Hexagonal prisms; diameter sometimes twelve inches; light green (Waterhouse). Northampton and Goshen (Hunt). All coarse granitic beryl.

Samuel L. Mitchill. Phillips Mineralogy, with additions on American Minerals. 
1892. Beryl. Russell, Warwick.

E. S. Dana. Sys. Min. Localities, p. 1059.

1841. CaLcite. Iceland Spar. Wales.

In gneiss. E. Hitchcock. Final Rept. Geol. Mass., p. 638.

1897. Cerusite. Hatfield.

At the lead mine the mineral occurs in small globular forms, with drusy surfaces, and some of the globules are hollow.

1896. Chinochlor. Blandford.

Broad encrusting masses, 3 inches thick, of a mniaxial chlorite, which is granular at the base but grows coarser npward, and grades into stont crystals one-half inch across, which project freely from the surface. From the Blandford soapstone quarry, formerly Osborn's quarry. (See p. 85.)

1896. Corundum. Emery. Middlefield.

Found one-half mile morth of the soapstone quarry at C. Smiths's. Traced north from bowlders by Dr. H. S. Lncas. Shows quite large veins of blue corundum. (See p. 81.) Springfield Republican, December 12, 1896.

1897. Corundum. Pelham.

Crystals with perfect polished $O$ face. Heating developed $O$ cleavage. Others with polished prism faces deeply fluted horizontally by the oscillation of the unit pyramid face. (See p. 47.)

1853. Cummingtonite. Hornblende. Cummington.

Fibrons, resembling anthophyllite; color, ash-gray; in mica-slate.

Analyses of cummingtonite.

\begin{tabular}{|c|c|c|}
\hline & Per cent. & Per cent. \\
\hline $\mathrm{SiO}_{2} \ldots \ldots \ldots \ldots$ & 51.09 & 50.74 \\
\hline 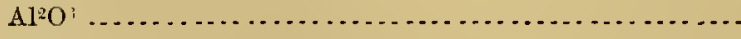 & trace & .89 \\
\hline 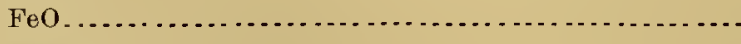 & .95 & 33.14 \\
\hline 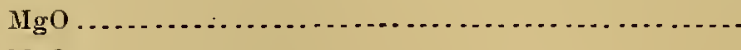 & 32.07 & 10.31 \\
\hline 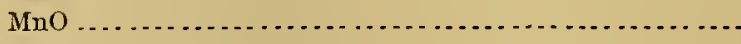 & 10.29 & 1.77 \\
\hline $\mathrm{CaO} \ldots \ldots \ldots \ldots . . . . . . . . . . .$. & 1.50 & trace \\
\hline 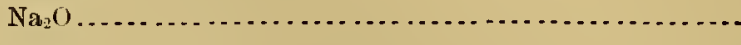 & .75 & .54 \\
\hline 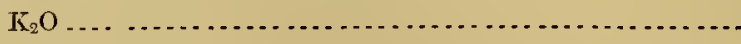 & trace & $\ldots \ldots . .$. \\
\hline \multirow[t]{2}{*}{ 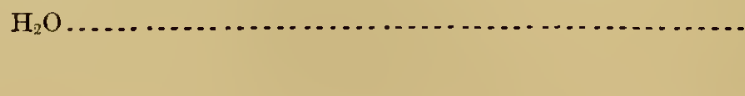 } & 3.04 & 3.04 \\
\hline & 99.69 & 100.43 \\
\hline
\end{tabular}

J. L. Snith and G. J. Brush, Reexamination of American minerals: Am. Jour. Sci., 1st series, Vol. XVI, 1829, p. 48. 
1892. Cummngtonite. Amphibole-Anthophyllite, Iron-Hagnesium, Amphibole. Cummington. Sp. gr. $=3.1$ to 3.32 .

L. S. Dana. Sys. Min., pp. 390, 395. Cites above analyses.

1895. Datolite. Northampton.

Delaney's quarry, on railroad near north line of Holyoke, in Triassic diabase. Discovered by hev. J. Prevost. In a crushed zone in the diabase embedded in calcite. Very tine crystals of most brilliaut luster, the largest nearly a half inch across, and with the slightly green tiut which is commou in the Bergen erystals, but liere a little more yellow than there. The forms are of a type vew in the valley, resembling fig. 1 , with the addition of the base, or fig. 4 , page 503, of Dana's Sys. Miu., 1892, but with $\varepsilon$ and $\mu$ greatly increased at the expense of $m$ and $n_{x} ; c$ is a large composite face. The forms present are os $\mathrm{P}(110), \frac{1}{2} \mathrm{P}(\overline{1} 12)$,

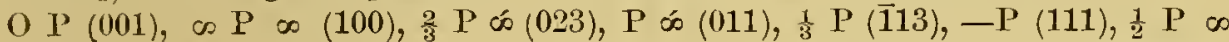

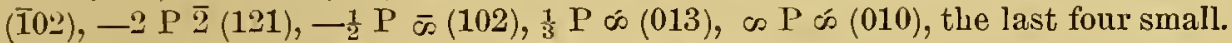
Specimens in the Smith and Amberst College cabinets. (See p. 470.)

1895. Datolite var. Botryolite. Greenfield.

At Cheapside, in a new road cut through the trap; in white globular masses in steam holes iu red trap. (See p. 443.)

1895. Enstatite. Granville.

The mineral, in large, square, colorless prisms from the large bed at Downey's (see p. 90), has been analyzed by Mr. W. F. Hillebrand, with the following result:

Analysis of enstatite from Granville.

\begin{tabular}{|c|c|}
\hline & Per cent. \\
\hline $\mathrm{SiO}_{2} \ldots \ldots \ldots$ & 54.04 \\
\hline $\mathrm{TiO}_{2} \ldots \ldots \ldots \ldots .$. & none \\
\hline $\mathrm{AI}_{2} \mathrm{O}_{3} \ldots \ldots \ldots$ & .52 \\
\hline $\mathrm{Cr}_{2} \mathrm{O}_{3} \ldots \ldots \ldots$ & .14 \\
\hline $\mathrm{Fe}_{2} \mathrm{O}_{3} \ldots \ldots \ldots . .$. & 1.51 \\
\hline $\mathrm{FeO} \ldots \ldots \ldots \ldots$ & 3.90 \\
\hline NiO ............... & .23 \\
\hline $\mathrm{MnO} \ldots \ldots \ldots \ldots$ & .11 \\
\hline $\mathrm{CaO} \ldots \ldots . . . . . . . .$. & none \\
\hline SrO $\ldots \ldots \ldots \ldots . . . .$. & none \\
\hline $\mathrm{BaO} \ldots . . . . . . .$. & none \\
\hline MIgO $\ldots . . . . . . . .$. & 34.40 \\
\hline $\mathrm{K}_{2} \mathrm{O} \ldots \ldots \ldots \ldots \ldots$ & \\
\hline $\mathrm{Na}_{2} \mathrm{O} \ldots \ldots \ldots \ldots$ & .08 \\
\hline $\mathrm{Li}_{2} \mathrm{O}$ & \\
\hline $\mathrm{H}_{2} \mathrm{O}$ below $110^{\circ} \mathrm{C} \ldots \ldots \ldots$ & .70 \\
\hline $\mathrm{H}_{2} \mathrm{O}$ above $110^{\circ} \mathrm{C} \ldots \ldots \ldots \ldots$ & 3.07 \\
\hline $\mathrm{P}_{2} \mathrm{O}_{1}$ & none \\
\hline \multirow{2}{*}{ 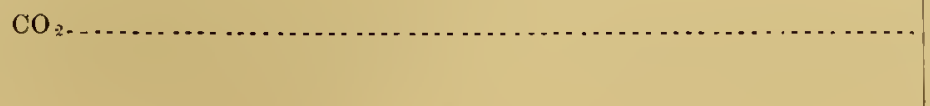 } & 1.32 \\
\hline & 106.02 \\
\hline
\end{tabular}


1892. Enstatite. Westfield.

E. S. Dana. Sys. Min. Localities, p. 1060. Cited as Scapolite. This is the enstatite, or the compact feldspar associated with it, from the serpentine locality on Munns Brook. (See p. 90.)

1896. Epidote. Huntington, on farm of W. L. Angell.

In a fissure in gneiss associated with quartz, biotite, albite, and calcite. (Penfield and Pirsson.) Lighter-colored crystals bent and broken.

$\mathrm{SiO}_{2}=37.99 . \quad \mathrm{Al}_{2} \mathrm{O}_{3}=29.59 . \quad \mathrm{FeO}_{3}=5.67 . \quad \mathrm{FeO}=0.53 . \quad \mathrm{MnO}=0.21$. $\mathrm{CaO}=23.87 . \quad \mathrm{H}_{2} \mathrm{O}=2.04$. $\frac{2}{2}$ sp. gr. 3.367. Contains minimum Fe.

Faces: $\mathrm{u}(100), \mathrm{c}(001), \mathrm{m}(110), \mathrm{w}(210), \mathrm{e}(101), \mathrm{i}(\overline{1} 02), \mathrm{r}(\overline{101}), \mathrm{k}(012), \mathrm{o}(011)$, $\mathbf{n}(\overline{1} 11), \mathbf{g}(\overline{2} 21), \mathrm{g}(\overline{2} 11)$. Twins (100). Optical constants given. Double refraction diminishes with the iron. E. H. Forbes, Zeit. Krys. u. Min., Vol. XXVI, p. 138.

1859. Fibrolite. Palmer.

Citer as cyanite under mica-schist in catalogue of State collection, Nos. 216 and 218. E. Hitchcock. Sixth Ann. Rept. Dept. Agr., p. 14. This is the coarse fibrolite from bowlders which are in place in the schist area included in the Belchertown tonalite. (See p. 243.)

1892. Galena. Westhampton.

E. S. Dana. Sys. Miu. Localities, p. 1060. Not elsewhere cited.

1892. GEDRITE. Orange; east of North Orange, on the west slope of Big Tully Mountain

Wrongly cited from Warwick in Mineral Lexicon (Bull. U. S. Geol. Survey No. 126), p. 86.

1892. Heulandite. Chester.

Dana. Sys. Min. Localities, p. 1058. Cited as Stilbite. This is cited from E. Emmons, Mineral localities: Am. Jour. Sci., 1st series, Vol. VII, 1824, p. 254. Was recognized to be heulandite by Prof. C. U. Shepard from the specimens in Emmons's cabinet. Boston Jour. Phil., Vol. III, p. 608.

1896. Lazulite. Chittenden, Vermont.

In quartz-muscovite rock. There is a specimen in the collection of Harvard University from the above locality, where it was found by Mr. C. H. Whittle. This is probably the locality from which the unique specimen found in Greenfield came. See under Lazulite, in Bull. U. S. Geol. Survey No. 126.

1895. Olivine var. Villarsite. Blandford.

At the base of the upper (eastern) serpentine bed at the Osborn soapstone quarry, in lenticular remnants in the serpentine associated with some still unchanged olivine. (See p. 85.) 
1896. Prochlorite. Chester.

On albite in druses at adit north of road at old mine, in fine, large masses. (See 1). 143.)

1734. Prrite. Northampton? "Marcasites," Pyrites.

"Fragments of greenish sulphurous marcasite from Mount Tom and Eolyoke, each side Connectient River:"-John Winthrop, F. R. S., Ex. Vol. XV, Journal Book of lioyal Soc. Am. Jour. Sci., 1st series, Vol. XLVII, 1844, p. 289.

1892. Pyrolusite. Williamsburg.

E. S. Dana. Sys. Min. Localities, p. 1060.

1897. Pyroxene. Diopside. Bald Mountain, Shelburne Falls, Massachusetts.

In a dark, impure limestone. The crystals are themselves full of inclosed limestone and effervesce strongly. They are in stout prisms up to au inch and a half in length and a balf inch across, greenish-white in color, strongly lustrous on the prism faces and glossy; color, pale green. They are nearly square prisms and recall the Canaan white pyroxenes. This mineral shows under the microscope the brilliant colors and the strong prismatic cleavage of pyroxene, and a basal parting with many interposed twiu laminæ. The extinction reaches 330. The specimen probably comes from a limestone bed of the Conway schist, which has been strongly and peculiarly metamorphosed by contact with granite.

1888. Quarcz. Rose quartz. Blandford.

Abundant by roadside near E. H. Osburn's.

1892. Quar'z. Amethyst. Greenfield.

The cavities iu the red diopside-diabase, described on page 443 , from the cut through the trap ridge made for the electric railroad, contain small amethysts of great beauty, which are interpenetration twins of model-like perfection. The twinuing plane is $\mathrm{O}(0001)$.

1897. Rhodonite. "Cunningham" (for Cummington.)

G. P. Merrill. Stones for building and decoration, p. 174. Cites Kunz, Min. Rec., 1887. 
1895. Salt. Holyoke.

Small cavities, which seem to be flatteued and slightly distorted from the cubical form, occur below the Holyoke dam in the Triassic Chicopee shale. (See p. 370.)

\section{Siderite. Holyoke.}

In trench below Holyoke dam, on fissure surfaces of Chicopee shale of Tri. assic age; broad surfaces, coated with drusy crystallization, crystals one-fourth to one-half of an inch across, yellow-gray to warm reddish-yellow, with brilliant luster. Forms $\mathrm{R}, \infty \mathrm{R} 2$, in equal development, which makes the attached crystals simulate dodecahedrons, so that they can almost be taken for garnet. Followed by gypsum (?), barite, calcite, anthracite, pyrite. (See p. 370.)

1879. Serpentine. Picrolite. Florida.

Specimen in collection of Harvard University.

Analysis by W. H. Melville.

Anclyses of serpentine.

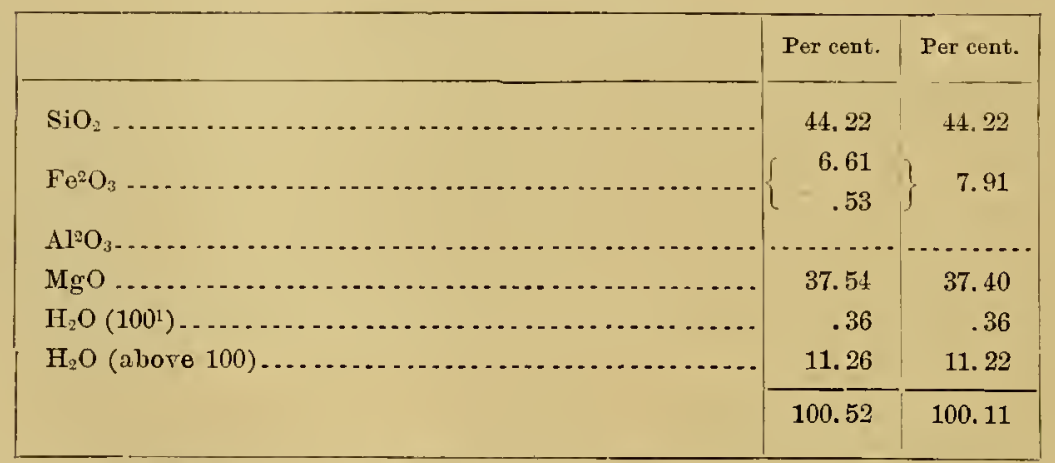

M. E. Wadsworth, Proc. Boston Soc. Nat. His., Vol. XX, p. $286 . \quad$ (See p. 73.)

1897. Serpentine. Variety picrolite.

Pelham; asbestos mine at the bottom of the large digging and in the midst of the unchanged olivine rock. A thick seam of a leek-green columnar and polished serpentine, plainly prodnced by pressure and slipping. A thick layer of slickensided columnar serpentine. (See p. 47.)

1825. Spodumene. Vicinity of Deerfield. (Goshen or Chesterfield.)

Light green, brittle, exfoliates with blowpipe. Yields prism of $100^{\circ}$; contains 8 per cent lithia. Found in a collection of minerals, but precise locality not known. George Bowen, Proc. Phil. Acad. Sci., Vol. III, p. 285.

1825. Spodumene.

S. Robinson. Cat. Am. Min. Citation of above.

1892. Spodumene. Chester.

E. S. Dana. Sys. Min. Localities, p. 1058. This citation depends on the doubtful report of the species iu Chester, in small quantity in granite, by C. Dewey. Geology of Berkshire: Am. Jour. Sci., 1st series, Vol.VIII, 1824, p. 243. 
18.66. SPOH) MLNe. (ioshen.

Mr. Alvan liarus writes me as follows concerning the sporlumeno localities in the north part of Goshon, near 'Taylor's mill, and at Mlanings:

Nuw York parties have ben at work on the spoulumen. mattex for lithia for the past eight yours, oll' and on. 'They had no dificulty in gatting' it into a solntion, lut had tronble in making the seplaration. Thuy wroto mo a fow diags ago that they had succedod in doing it all right and would som report results, for whieh I am still waiting. Wo find the spodnmene in plane at two points, as indicated on the map, meleading worth and south and the other half is milo to the onst, rinning oast and west. Thero seems to bo an abundance of it.

1596. 'Talc. Soapstone. Blandford.

Reported from the north end of Blair's pond. (S. A. Bartholemew.) Also as an inclosure in hornblende-schist on the road going worth from North Blandford past Bartholemew's quarry, 100 rods east of the road on the west side of liound Hill.

1896. 'T'itanite. Chester.

At the new adit north of the roarl at the old mine, in druses in and on albite, and covered by prochlorite; wine-yellow; common flat forms, often twinned; fine crystals, $3-6^{\mathrm{mm}}$ long. (See p. 143.)

1852. Tourmaline. Chesterfield.

The colored tourmalines are rarely terminated. A fine crystal is figurer having the faces $\infty \mathbf{R} 2, \infty \mathbf{R}, \mathrm{O} R$, $\mathbf{R}$, with the basal plane making nearly the whole termination of the crystal. C. U. Shepard. Treatise on Mineralogy, p. 220 .

1896. Tourmaline. Huntington.

A mile north of Knightsville, at the 700-foot contour, on the east side of the river.-A. Barrus (private communication).

1896. Tourmaline. Huntington.

Beantiful flattened tonrmalines occur in muscovite at the quarry in pegma. tite, near Knightsville.

1896. Tourmaline. Dendritic Tourmaline. Northampton.

In fissures in the fine-grained muscovite-biotite-granite from the village of Haydenville; an exquisite, delicately traced dendritic growth of tourmaline. The surfaces of the fissures are perfectly flat, wholly fresh, and the rock for 1 or 2 millimeters in is whiter from the absence of biotite, while the surface on which the dendrite is has also a slight excess of biotite in larger crystals than in the rest of the rock, and a few brown-red garnets. (See Pl. VIr, p. 316.)

1896. Zorsite. Chesterfield.

The locality is found by following the brook which enters East Branch a mile south of Bisbee will, five-eights of a mile east, and then going 30 rods sonth into a spur of the hill narked 1455.-A. Barrus (private communication.) 


\section{H A P T E R X X I I.}

\section{CHRONOLOGICAL LIST OF PUBLICATIONS UPON THE MIN- ERALOGY AND GEOLOGY OF FRANKLIN, HAMPSHIRE, AND HAMPDEN COUNTIES.}

1734. Selections from an ancient catalogue of objects of natural history formed in New England more than one huudred years ago, by John Winthrop, F. R. S. Journal Book of Royal Society, vol. 15, p. 451; Am. Jour. Sci., vol. 47, 1844, p. 282. The paper was copied from an ancient manuscript. (See under Claystones.)

1796. J. Morse. The American universal geography, $3 d$ ed., Boston, p. 410 ; copper ore, Leverett; black lead, Brimfield.

1810. J. Morse. The American gazetteer, 2 vols., Boston.

1810. B. Sillinan. Particulars relative to the lead mine near Northampton (Mass.). Bruce's Journal, vol. 1, p. 63.

1811. William Meade, M. D. A description of several combinations of lead lately discovered at Northampton. Addressed to the editor. Bruce's Jourual, vol. 1, p. 149.

1815. E. Hitchcock. Southampton lead mine; Basaltick columus ou IIount Iolyoke. North American Review, vol. 1, p. 334.

1816. Parker Cleaveland. Mineralogy and geology. Bostou, $8^{\circ}$.

1817. J. F. L. Hansmann. Kieselspath von Chesterfield, Mass. Götting Gelehrte Anzeigen, p. 1401.

1818. E. Hitchcock. Description of Turners Falls ou Connecticut River; with sketch by Mrs. Hitchcock. Portfolio. Philadelphia.

1818. E. Hitchcock. Remarks on the geology and mineralogy of a section of Massachusetts on Connecticut River, with a part of New Hampshire and Vermont; 12 pages; dated October, 1817 ; map in 1 st and $2 d$ editions omitted in reprint; contains list of minerals. Am. Jour. Sci., 1st series, vol. 1, p. 105.

1818. Samuel L. Mitchill. An elementary introduction to miveralogy, by William Phillips, with notes and additions on American minerals, by Samuel L. Mitchill, Professor of Mineralogy, etc., in the University of New York. Cyanite and beryl, from Hampshire County.

1819. Amos Eaton. Account of the strata perforated by, and of the minerals found in, the great adit to the Southampton lead mine; 4 pages. Am. Jour. Sci., 1st series, vol. 1, p. 136 .

1819. B. Silliman. Localities of minerals, etc.; "Molybdena is found in Shutesbury * * * on land of William Eaton;" 1 page. Ibid., p. 238. 
1819. Goorge Gibbs. On the toumalines and other minerals fonnd at Chesterfield and Goshen, Hass.; (i pages. Am. Jour. Sei., 1st series, vol. 1, p. 346.

181\%. li. Hitchcock. Supplement to the remarks on geology, etc., of a sectiou of Massichusetts; 3 pages. Ibid., p. 436.

18:0. Amos Waton. Index to geology of Northern States. 120. Troy, N. Y.

18:0. Chester Dewey. Localities of minerals; 3 pages. Am. Jonr. Sei., 1st series, vol. :2, p. 236.

1821. Stromeyer. Chemische Untersuchungen. Göttingen. Aalysis of Chesterfield albite, p. 307.

1821. Dr. William Atwater. Extract of letter; Hill of serpentine iu Westfield; 1 page. Am. Jour. Sci., 1st series, vol. 3, p. 238.

1821. Editor's note. On fossil fish (Sunderland), with catalogne of specimens sent by E. Hitclicock; 2 pages. Am. Jour. Sei., 1st series, vol. 3, p. 365.

1821. T. Dwight. Travels in New England and New York. 8०. Vol. 1, pp. 34-35.

1822. Editor's note. Micaceous iron; Northampton and Hawley. Am. Jour. Sci., 1st series, vol. 4 , p. 53 .

1822. Editor's note. "This fluor spar is of a grass or emerald greeu, a rare color in this country; not found except near Northampton, by Dr. David Hunt." Ibid., p. 188.

1S22. Prof. O. Dewey. Miscellaneous notices relating to American mineralogy and geology; Crystallized steatite in Middlefield; 3 pages. Ibid., p. 274.

1822. Parker Cleaveland. An elementary treatise on mineralogy and geology; 2d edition; 2 vols.

1822. Editor's note. Miscellaneous uotices on mineralogy; Allularia, Brimfield, Mass. (Prof. Amos Eaton). Am. Jour. Sci., 1st series, vol. 5, p. 41.

1822. Prof. Amos Eaton. Geologieal and agrienltural report of the region adjoining the Erie Canal (with profile of the rocks across Massachusetts from Boston to Northfield, by E. Hitchcoek).

1822. Prof. C. Dewey. Notice of crystallized steatite (Middlefield); 1 page. Am. Jour. Sci., 1st series, vol. 5, p. 249. See Hampshirite in Mineral Lexicon, Bull. U. S. Geol. Survey No. 126, p. 91.

1822. E. Hitchcock. Fluate of lime and noble agates in Deèrfield. Ibid., p. 407.

1823. H. J. Brook. Cleavelandite. Annals of Philosophy, p. 381.

1823. E. Hitchcock. A sketch of the geology, mineralogy, and scenery of the regions contiguous to the River Connecticnt; with a geological map and drawings of organic remains, and occasional botanical notices. (Read before the American Geological Society at their sittiug, September 11, 1822. Part I, 86 pages; section, Mount Toby, pl. 8; fossils, pl. 9; map, pl. 10.) Am. Jour. Sci., 1st series, vol. 6, p. 1.

1823. E. Hitcheock. Same. Part II, Simple minerals; 35 pages. Ibid., p. 201.

1824. E. Hitchcock. Same. Part III, Scenery. Ibid., vol. 7, p.1.

1824. E. Hitchcock. Same. Part IV, Miscellanies; 1 plate. Ibid., p. 16.

[The same published separately. New Haven. S. Converse, publisher, 1823.] 
1824. Anon. Hogtooth spar from Williamsburg. Hampshire Gazette, July 14.

1824. Prof. Chester Dewrey. A sketch of the geology and mineralogy of the western part of Massachusetts and a small part of the adjoining States; with geological map; 60 pages [contains many notes from Emmons]. Ibid., 1) 1.

1824. E. Emmons. Article ou minerals of Chester, etc., in Lycenm of Nat. Hist. of Berkshire Medical Institute; published (?). See Am. Jour. Sci., 1st series, vol. 8, p. 32.

1824. Dr. William Mearle. Localities of minerals; Siliceous oxide of manganese, Chesterfield. Ibid., p. 54.

1824. Dr. Jacob Porter. Localities of minerals; Red oxide of titaninm, Cummington; Sulphuret of molybdena, Chesterfieid. Ibid., p. 58.

1824. George T. Bowen. Analysis of spodumene from the viciuity of Conway, Mass. Jour. Acad. Nat. Sci., Phila., vol. 3, p. 284; Am. Jonr. Sci., 1st series, vol. 8, p. 121.

1824. J. Porter. Localities of minerals; 1 page. Am. Jour. Sci., 1st series, vol. 8 , p. 233.

1824. C. U. Shepard. Localities of minerals; Pelham, etc. [First notice of Shay's fliut.] Ibid., p. 235.

1824. Prof. Chester Dewey. Additional remarks on the geology of a part of Massachusetts, etc.; 5 pages. [First notice of spodumene, before called white augite.] Ibid., p. 240.

1824. E. Emmons. Notice of the granite veins and beds in Chester; 3 pages, 1 plate. Ibid., p. 250.

1824. Professor Dewey. Additional notice of argentine [iu Williamsburg]. Ibid., p. 248.

1824. C. U. Shepard. Green feldspar associated with sappare and siliceous oxide of manganese, in Chesterfield. Ibid., p. 251.

1824. Jacob Porter. Localities of minerals. Ibid., p. 252.

1824. Dr. Eben Emmons. Miscellaueous localities. Ibid., p. 254.

1825. S. Robinson, M. D. Catalogue of American minerals, with their localities, Boston, 8 .

1825. E. Hitchcock. Notice of several localities of minerals in Massachusetts; spodnmene corrected; pyrophysalite in Goshen; 3 pages. Am. Jour. Sci., 1st series, vol. 9, p. 20.

1825. O. U. Shepard. Localities of minerals. Ibid., p. 47.

1825. J. Porter. Localities of minerals. Ibid., p. 54.

1825. A. O. Hubbard. Remarks on the lead veins of Massachusetts and glacial lakes; 2 pages. Ibid., p. 166.

1825. B. Silliman. Notice of a mineral supposed to be phosphate of lime from Williamsburg aud of the localities of several other minerals. Ibid., p. 174.

1825. J. W. Webster. Determination of chlorophæite from Turners Falls, from specimens sent by Dr. E. Hitcheock. Boston Jour. of Phil. and Arts, vol. 2, p. 610.

1825. E. Hitcheock. Mineral localities. Ibid., p. 610. 
18:5. U. U. Shepard. Nineral localities, with description of anthophyllite (=actinolite), inlite (=heryl). lioston Jomr. of Phil. and Arts, vol. "2, 1).39.5.

182.j. C. U. Shepard. Mincral localities, with description of sporhmene, beryl, schillerspan, houlandite, hematite, anthophyllite, and \%oisite from the Berkshire Ltills. Ibicl., 1) (607.

18... Is. Ilitcheock. Geological sketch of the comntry on the Comecticut River; malp ant engravings. Noticed. Am. Jour. Sci., vol. 9, p. 179.

18ะ5. 13. Hitchuck. Topaz? (in Goshen); 1 page. Ibid., 1) 180.

18... C. U. Shepard. Localities of minerals. Ibid., p. 248 .

15:5. F. Mohs. Mineralogy. English edition; W. Haidinger, Edinburgh. Oites American localities fully.

18:5. E. Emmons. Carbonate of manganese, Cummington, Mass. Am. Jour. Sei., 1st series, rol. 9, p. 249.

1825. Emerson Davis. Localities of minerals (West Springfield). Ibid., p. 252.

18:6. E. Limmons. Localities of minerals (Ohester and vicinity). Ibid., vol. 10, p. 11.

1826. Simeon Colton. Localities of minerals (Mouson and vicinity). Ibid., p. 12.

18:26. J. Porter. Localities of minerals (Plainfield and vicinity); correction of Dwight's Travels; house on Ronud Hill of soapstone from Middlefiald, not Plainfield. Ibicl., p. 18.

1826. J. Fincl. Nemoir of the new or variegated sandstone of the United States. [First suggestion that the Connecticut River sandstone was the New Red.] Ibid., p. 209.

1826. Emerson Davis. Notice of rocks and minerals in Westfield. Ibid., p. 213.

1826. Prof. J. W. Webster. On chlorophaite from Gill, Mass. Boston Jonr. of Phil. and Arts, vol. 4.

1826. E. Hitcheock. Chlorophrite (Gill). Am. Jour. Sci., 1st series, vol. 10, p. 393.

1826. Anon. Tabular quartz at Palmer, Mass. The Chemist aud Meteorological Journal, John R. Cutting, editor, Amherst Mass., vol. 1, p. 78.

1526. Report of the commissioners of the State of Massachusetts on the rontes of canals from Bostou Harbor to Connecticut and Hudson rivers. Letters from Prof. Edward Hitcheock and others, with geological details; 248 pages; large folding map. $8^{\circ}$.

1827. Alanson Nash. Notices of the lead mines and veins of Hampshire County, Mass., and of the geology and mineralogy of that region; figures in text and engraved map; 33 pages. Am. Jour. Sci., 1st series, vol. 12, p. 238.

1827. Jacob Porter. Localities of minerals. Ibid., p. 378.

1828. E. Hitchcock. Miscellaneous notices of minerals, with geological remarks; 16 pages. Am. Jour. Sci., 1st series, vol. 14, p. 215.

1828. Editor's note. Chesterfield tourmalines. "Mr. Clark designs to explore his locality and will be better prepared to furuish collectors of cabinets who may visit him." Ibid., p. 400.

1829. Editor's notice. Analysis of tourmaline (green, Chesterfield), by Gmelin. Ibid., vol. 15, p. 389.

1S29. E. Hitchcock. Tin at Goshen. Ibid., vol. 16, p. 188. 
1829. C. U. Shepard. Discovery of stanniferous columbite in Massachusetts (Chesterfield); S pages. Am. Jour. Sci., 1st series, vol. 16, p. 218.

1829. A History of Berkshire, Mass. ; in two parts. By "Gentlemen in the county." Pittsfield, Samuel W. Bush.

1830. A. Eaton. All primitive general strata below granular quartz are contemporaneous and schistose; 2 pages. Am. Jour. Sci., 1st series, vol. 17, p. 334 .

1831. J. Porter. Localities of minerals. Ibid., vol. 20, p. 170.

1831. John G. Hales. Plan of the town of Northampton, in the county of Hampshire, surveyed wuder direction, of the selectmen, January, 1831. Pendleton's Lithography, Boston.

1832. E. Hitchcock. Report on the Geology of Massachusetts, examined under the direction of the Government of that State during the years 1830 and 1831; Part I, The economic geology of the State, with a geological map; 70 pages. Am. Jour. Sci., 1st series, vol. 22, p. 1.

1832. Alfred Sunith. On the water courses and the alluvial and rock formations of the Connecticut River Valley. Ibid., p. 204.

1832. E. Emmons. Manual of mineralogy and geology. 2d editiou; Albany; $12^{\circ}$; 299 pages. Am. Jour. Sci., 1st series, vol. 24, p. 397.

1833. Editor's note. Professor Hitchcock's report of the geology of Massachusetts (chromate iron, Blandford; rotten stone, West Springfield). Ibid., p. 396.

1833. E. Hitchcock. Report on the geology, zoology, and botany of Massachusetts; 692 pages; atlas, 19 plates. (See 1832 above.)

1835. C. U. Shepard. Microlite, a new mineral species; 2 pages. Am. Jour. Sci., 1st series, vol. 27, p. 361 .

1835. C. U. Shepard. Treatise on mineralogy; (Part I, containing terminology and characteristics, 1832, 256 pages); Part II, in 2 vols., Description of species, 1835; vol. 1, 300 pages; vol. 2, 331 pages; $12 \circ$; New Haven.

1835. E. Hitchcock. Report on geology, etc.; 2 d edition; 702 pages, 18 plates, 60 cuts. (See 1833 above.)

1835. Editor's note. Soapstone or steatite of Middlefield. Am. Jour. Sci., 1st series, vol. 27, p. 382.

1835. Editor's note. Uranite at Chesterfield, Mass., described by Professor Shepard. Jbid., vol. 28, p. 382.

1836. E. Hitchcock. Ornithichnology, or description of the footmarks of birds (oruithichnites) on New Red sandstone iu Massachusetts; 34 pages, 3 plates. Ibid., vol. 29, p. 307. January, 1836.

1836. E. Hitchcock. Controversy with Rev. Mr. Chapin, of Connecticut, on footmarks. Knickerbocker, vol. 8, p. 289. September, 1836.

1836. J. H. Redfield. Fossil fishes of Counecticut and Massachusetts, with a notice of an unclescribed genus. Annals of the Lyceum of Nat. Hist., N. Y., vol. 4, p. 35 .

1836. Editor's note. Albite of Chesterfield. Analysis by MM. Aug. Laurent and Ch. Holms. Am. Jour. Sei., 1st series, vol. 30, p. 381. 
18:37. W. IIteheock. Fossil footsteps in sandstone and graywacke; 3 pages. Am. Jour. Sei., 1st series, vol. :32, 1\% 17 t.

1837. U. U. Shepard. Chemical exmination of microlite. Ibir., p. 338.

183s. J. W. Foster. New locality of iolite, with other minerals associated (Brimfield); 2 pages. Ibirl., vol. 33 , p. 399.

1833. C. U. Sheprurl. Yotice of a second locality of topaz in Connecticut, and of the phenalite in Massuchusetts; 3 pages. Ibid., vol. 34, p. 329 .

183S. L. Hitchenck. Report on a reexamination of the economical geology of Massachusetts; 139 pages; Boston, Dutton \& Wentworth, State printers.

1839. Editor's notc. Solid impressions and easts of drops of rain. Am. Jour. Sci., 1 st series, vol. 37,1 1. 371.

15.0. E. Hitchcock. Elementary geology. Amherst. J. S. \& C. Adams; $12^{\circ} ; 329$ pages.

1841. W. C. Redfield. Short notices of American fossil fishes; 5 pages. Am. Jour. Sci., 1st series, vol. 41, p. 24.

1S11. Mr. Teschemacher. On the occurrence of phosphate of uranium in the tourmaline in Chesterfield; abstract. Proc. Boston Soc. Nat. Hist., April, 1841, vol. 1, p. 15 .

1841. E. Hitchcock. Final report on the geology of Massachusetts; in four parts: 1, Economical geology; 2, Scenographical geology; 3, Scientific geology; 4 , Elementary geology, with an appended catalogue of the minerals and rocks in the State collection; by E. Hitchcock, LL. D.; $4^{\circ}$; 831 pages, 55 plates, geological map.

1S41. H. D. Rogers, L. Vanuxem, R. C. Taylor, E. Emmons, T. A. Conrad. Report on the ornithichnites or footmarks of extinct birds in the New Red sandstone of Massachusetts and Connecticut, observed and described by Professor Hitchcock, of Amherst. Am. Jour. Sci., October, 1S4l, 1st series, vol. 41, p. 165. The report of a committee appointed by the Association of American Geologists to determine if the tracks described by Hitchcock were really tracks and not imitative forms.

1841. S. Borden. Account of a trigonometrical survey of Massachusetts. Trans. Am. Philos. Soc., Phila., new series, vol. 9, p. 33.

1842. J. E. Teschemacher and A. A. Hayes. On the identity of pyrochlore with the microlite of Professor Shepard; 3 pages. Am. Jour. Sci., 1st series, vol. 43, p. 33 .

1842. C. U. Shepard. On the want of ideutity between microlite and pyrochlore; 6 pages. Ibid., p. 116.

1842. C. U. Shepard. Washingtonite and phenacite (Goshen). Additional notices of the supposed phenacite of Goshen; 2 pages. Ibid., p. 364.

1S42. F. Hitchcock. On a new species of ornithichnite from the valley of the Connecticut River, and on the raindrop impressions from the same locality (title only). Trans. Assoc. Am. Geol. Nat., vol. 1, p. 63.

1842. William C. Redfield, Remarks on Sunderland Triassic fishes. Ibid., p. 65. 
1842. James G. Percival. Report on the geology of the State of Connecticut; map. New Haven. $8^{\circ}$.

1843. C. Lyell. On the fossil footprints of birds and impressions of raindrops in the valley of the Connecticut (abstract); 4 pages. Proc. Geol. Soc. London, vol. 3, p. 274; also Am. Jour. Sci., 1st series, vol. 45, p. 394 .

1843. B. Silliman. Ornithichnites of the Connecticut River sandstones and the dinornis of New Zealand (correspondence of Dr. Deane, Dr. Mantell, and R. Owen); 12 pages. Am. Jour. Sci., 1st series, vol. 45, p. 177.

1843. F. Alger. Identity of lincolnite and heulandite; abstract. Proc. Boston Soc. Nat. Hist., vol. 1, p. 145 .

1843. J. E. Teschemacher. On the occurrence of the phosphate of uranium in the tourmaline locality at Chesterfield. Jour. Boston Soc. Nat. Hist., vol. 4, 1844, p. 35.

1843. J. E. Teschemacher. Description of the oxide of tin at the tourmaline locality, Chesterfield. Trans. Assoc. Am. Geol. Nat., vol. 1, p. 296.

1843. E. Hitchcock. Description of five new species of fossil footmarks; $10 \mathrm{pp.} \mathrm{Ibid.,}$ p. 254.

1844. James Deane. On the fossil footmarks of Turners Falls, Mass., with 2 plates; 6 pages. Am. Jour. Sci., 1st series, vol. 46, 1). 73 .

1844. A. A. Hayes. Reexamination of microlite and pyrochlore; 8 pages. Ibid., p. 158.

1844. Francis Alger. Beaumontite and lincolnite identical with heulandite; 4 pages. Ibid., 1). 233; also in Jour. Boston Soc. Nat. Hist., vol. 4, p. 422.

1844. J. E. Teschemacher. Mineralogical notices; Pyrochlore(microlite). Jour. Boston Soc. Nat. Hist., vol. 4, p. 501. Lon. Edin. and Dub. Philos. Mag., 1844.

1844. Simeon Borden. Topographical map of Massachusetts, compiled from astronomical, trigonometrical, and varions local surveys, made by order of the legislature.

1844. E. Hitchcock. Geological map of Massachusetts, made by order of the legislature; scale 5 miles to the inch (on same sheet with map above).

1844. E. Hitchcock. Geological map of Massachusetts. Explanation of the newly colored geological map of Massachusets; 22 pages; $12^{\circ}$.

1844. E. Hitchcock. Report on ichnolithology or fossil footmarks, with a description of several new species, and the coprolites of birds from the valley of Connecticnt River, and of a supposed footmark from the valley of Hudson River; 31 pages, 2 plates (read before the Association of American Geologists and Naturalists at Washington, May 11, 1844). Am. Jour. Sci., 1st series, vol. 47, p. 292.

1844. C. U. Shepard. A treatise on mineralogy; 2 d edition; $12^{\circ} ; \mathrm{pp} .168$. New Haven. (See first edition, 1835.)

1844. E. Hitchcock. Discovery of more native copper in the town of Whately, in Massachusets, in the valley of the Connecticut River, with remarks upon its origin; 2 pages. Am. Jour. Sci., 1st series, vol. 47, p. 322. 
181. J. 1)eine. On the discovery of fossil footmarks; 9 pages. Am. Jorr. Sei., 1st series, vol. 47, p. 381.

184. L. Ilitelicock. licjoinder to the preceding article of Dr. Denne; 10 pages. lbill., 1. 390.

1841. J. Deane. Answer to the "Rejoinder" of Professor Hiteheock; 2 pages. Ibid., 1. 399.

15.4. 1\%. Ilitehcock. Extract from letter respecting the lincolnite. Ibid., p. 416.

184t. Francis Alger. An elementary treatise on mineralogy. By William Phillips; 5 th ed.; 662 pages; Boston.

1845. 1. Hitchicock?. Mount Holyoke. Report on celebration of the opening of a road on to the mountain. Franklin Express, Vol. I, Mar'ch, 1845.

1St5. S. L. Dina, M. D. Analysis of coprolites from the New Red sandstone formation of New England, with remarks by Professor Hitchcock. Am. Jour. Sci., 1st series, vol. $4 \mathrm{~S}, \mathrm{p} .46$.

1845. E. Hiteheock. Extract from a letter *** * on fossil footmarks, lineolnite, and letter from R. Owen on great birds' nests of New Holland. Ibid., p. 61.

1845. J. Deane. Description of fossil footprints in the New lied sandstone of the Connecticut Valley; plate. Ibid., 13. $15 \mathrm{~s}$.

1845. C. U. Shepard. Reply to notice of mineralogy with notice of microlite, goshenite, urauite. Tbid., p. 168.

1845. J. E. Teschemacher: Remarks on uraninm and pysochlore; reply to above on microlite and uranite. Ibid., p. 395.

1845. J. Deane. Notice of new species of batrachian footmarks; 3 pages and cut. Ibid., vol. 49, p. 79.

1845. J. Deane. Fossil footmarks and rainclrops (letter). Ibid., p. 213.

1845. J. Deaue. Illustrations of fossil footmarks; S pages, 1 cut. Jour. Boston Soc. Nat. Hist., vol. 5, p. 277.

1545. J. Barratt. On fossil footmarks in the red sandstone of the Counecticnt Valley. Proc. Assoc. Am. Geol. Nat., p. 23.

1845. J. Barratt. On the evidences of congelation in the New Rerl sandstone. Ibid., p. 26.

1845. C. Lyell. On fossil footsteps of birds on Connecticut River. Hist. Travels in U. S., vol. 1, p. 200.

1S46. Note. Washingtonite of Shepard=ilmenite; analysis. Am. Jour. Sci., 2d series, vol. 1, p. 122.

1846. F. Alger. Reaffirms his opinion that lincoluite is henlandite (abstract). Proc. Boston Soc. Nat. Hist., vol. 2, p. 89.

1846. F. Alger. Notices of new localities of rare minerals aud reasons for uniting several supposed distinct species; lincolnite is heulandite. Washingtonite analysis. Jour. Boston Soc. Nat. Hist., vol. 5, p. 297.

1S46. J. Barratt. Sentinel and Witness extra; Middletown, Conn., July 3, 1846. Geology of Middletown and vicinity (reprint of). On the tracks of large birds found at Middletown, Conn.; by Joseph Barratt, M. D.

MON YXIX- 49 
1846. J. E. Tesehemacher. Damonrite in Chesterfield. Proc. Boston Soc. Nat. Hist., vol. 2, p. 107; Am. Jour. Sci., 2d series, vol. 2, p. 119.

1847. James Deane. Notice of new fossil footprints. Am. Jour. Sci., 2d series, vol. 3 , p. 74 .

1847. E. Hitcheock. Elementary geology; Sth edition, enlarged; 361 pages.

1847. Editor's note. Ornithichnites. Am. Jour. Sci., $2 d$ series, vol. 3, p. 276.

1847. E. Hitchcock. Description of two new species of fossil footmarks found in Massachusetts and Connecticut, or of the animals that made them; cuts. Ibid., vol. 4, p. 46.

1847. J. Deane. Fossil footprints. Ibid., vol. 4, p. 448.

1847. E. Hitcheock. On the trap tuff or volcanic grit of the Connecticut Valley, with bearings of its history upon the age of the trap rock and sandstone generally in the valley. Ibid., p. 199.

1848. J. Deane. Fossil footprints of a new species of quadruped. Ibid., vol. 5, p. 40.

1848. X. Hitchcock. Fossil footmarks of United States; 128 pages, 24 plates. Mem. Am. Acad. Arts Sci., new series, vol. 3, p. 129.

1848. Dexter Marsh. Fossil footprints; 3 pages, cut. Am. Jour. Sci., 2d series, vol. 6, p. 252 .

1849. J. Deane. Illustrations of fossil footprints of the valley of the Connecticut; 16 pages, 9 plates. Mem. Am. Acad. Arts Sci., new series, vol. 4, p. 209.

1850. J. D. Dana. Spodumene, Norwich; monoclinic. Am. Jonr. Sci., 21 series, vol. 10, p. 119.

1850. J. D. Dana. Staurotide, Norwich. Ibid., p.121. Was triphylite.

1850. J. G. Brush. On American spodnmene. Ibid., p. 370.

1850. E. Hitch cock. On the river terraces of the Counecticut River, and on the erosions of the earth's surface. Proc. Am. Assoc. Adv. Sci., vol. 2, p. 148.

1850. C. Hartwell and E. Hitchcock, jr. Description of certain mineral localities, chiefly in the northern part of Worcester and Franklin comnties in Massachusetts (title). Ibid., p. 159.

1850. J. Deane. Fossil footprints of Connecticnt River. Jour. Acad. Nat. Sci. Phila., 2 d series, vol. 2, p. 71.

1850. E. Hitchcock. On terraces and ancient sea beaches, especially those of the Connecticut River and its tributaries. Rep. Brit. Assoc., 1850, p. 87 . Communications.

1850. E. Hitchcock. On the erosions of the earth's surface, especially by rivers. Ibid., p. 85.

1850. William H. Gibbs. An address delivered before the literary association, Blandford, Mass., September 21, 1850. Springfield, George O. Wilson. Contaius notes on minerals in Blandford, furnished by Dr. Shurtleff, of Westfield.

1851. W. J. Craw. Chemical examination of a phosphate of iron, manganese, and lithia from Norwich, Mass.; 2 pages. Am. Jour. Sci., $2 \mathrm{~d}$ series, vol. 11, p. 99.

1851. J. D. Dana. Physical and crystallographical characters of the plosphate of iron, manganese, and lithia of Norwich, Mass.; 2 pages. Ibid., p. 100. 
1851. J. 1. Dana (?). Mineralogical notices No. IlI. Mineral species deseribed by Prot: O. U. Shepard, New Haven. Proc. An. Assoc. Adv. Sei., New Haven. Enumate. Am. Jour. Sei., 2d series, vol. 12, p. 211.

1851. J. D. Dana (?). On the erystallographic identity of eumanite and brookite. Am. Jour. Sci., 2d series, vol. 12, 1) 397.

1851. Willian C. Redtield. On the post-Permian date of the red sandstone rocks of Now , Iersey and the Connecticut Valley, as shown by their organic remains. Proc. Am. Assoc. Adv. Sci., vol. 5, p. 45.

185:. J. E. Teschemacher. On the angles of eumanite. Am. Jour. Sci., ad series, vol. 13, p. 117.

185:. E. Hitchcock. On the terraces and sea beaches that have been formed since the drift period, especially those along the Connecticut River. Proc. Am. Assoc. Adv. Sci., vol. 6 (1851), p. 264.

1852. C. U. Shepard. On the triplite (allandite) of Norwich, Mass. Ibid., p. 234.

185̃. C. U. Shepard. A treatise on mineralogy; 30 edition; 451 pages, 488 illus. trations.

1852. E. Hitchcock. On the geological age of the clay slate of the Connecticut Valley in Massachusetts and Vermont. Proc. Am. Assoc. Adv. Sci., vol. 6 (1851), p. 299.

1853. Jnles Marcon. Geological map of the United States and the British Provinces of North America. Text and profiles.

1853. J. L. Smith and G.T. Brush. Reexamination of Anerican minerals; Spodumene; Norwich. Am. Jour. Sci., 2d series, vol. 16, p. 471.

1853. E. Hitehcock. Report on certain points in the geology of Massachusetts; Coals, ancient glaciers. 44 pages, 3 plates.

1853. E. Hitchcock. Report on soapstone of Middlefield, Mass.. to Metropolitan Soapstone Co., of New York; 4 pp.

1853. E. Hitchcock. Renarks on saulstones and fossil footmarks (abstract). Proc. Boston Soc. Nat. Hist., vol. 4, p. 378.

1853. Seientific intelligence; Tryphyline, Norwich. Am. Jonr. Sci., 2 d series, vol. 15, p. 445.

1853. Scientific intelligence. Triplite of Norwich, Mass.: reference to Shepard and editor's note. Ibid., p. 445.

1853. C. U. Shepard. Triplite, Norwich. Proc. Am. Assoc. Adv. Sci., vol. 6, p. 234.

1854. J. C. Warren, M. D. Remarks on fossil impressions in the sandstone rocks of Connecticut River; 54 pages, 1 plate. Boston.

1854. J. W. Mallet. Analysis of beryl from Goshen. Am. Jour. Sci., $2 d$ series, vol. 17, ?. 180.

1854. J. W. Mallet. On phosphate of iron and manganese, from Norwich, Mass. Ibid., vol. 18, p. 33.

1854. W. B. Rogers. Fossils of the New Red sandstone and its relations to the rocks of Virginia and North Carolina. Proc. Boston Soc. Nat. Hist., vol. 5, p. 18; also Am. Jour. Sci., 2 d series, vol. 19, p. 123. 
1854. T. T. Bonvé. Note on Portland society's fossil footprints. Am. Jour. Sci., $2 d$ series, vol. 19, p. 37 .

1854. J. Wyman. On impressions of a donbtful sixth toe in some batrachian footpriuts. Proc. Boston Soc. Nat. Hist., vol. 5, p. 84.

1854. J. C. Warren. Note on ripple-marked slabs from Turners Falls. Ibid., p. 84.

1854. J. C. Warren. Note on slabs with impressions from Conuecticut River sandstone. Ilvid., p. 209.

1854. W. B. Rogers. Note on Clathropteris. Ibid., 212.

1854. C. T. Jackson. Note on tail traces in Connecticut River sandstone. Ibid., p. 309 .

1854t. T. T. Bouvé and W. B. Rogers. Note on plates prepared by Mr. J. Deane for a proposed work on the fossil impressions of the Connecticut Valley. Ibid., p. 348.

1855. C. H. Hitchcock. Impressions (chiefly tracks) ou alluvial clay in Hadley, Mass. Am. Jour. Sci., 2d series, vol. 19, p. 391.

1855. E. Hitchcock, jr. Description of a new species of Clathropteris discovered in the Connecticnt Valley sandstone. Ibid., vol. 20, p. 22.

1855. J. Wyman. Notice of fossil bones from the red sandstone of the Connecticut River Valley, from East Windsor, Conn.; Reptilian sanroid, but with hollow bones. Ibid., p. 394 .

1855. E. Hitcheock. Bones and tracks from Connecticnt River sandstone. Ibid., p. 416.

1855. W. B. Rogers. On the age of the so-called Now Red sandstones of the United States. Proc. Am. Assoc. Adv. Sci., vol. 8, p. 290.

1855. James Hall. Red sandstone of the Connecticut River Valley and the proofs of its Oolitic or Liassic age. Ibid., p. 290.

18̄̃5. E. Hitchcock. Description of several sections measured across the sandstone aud trap of the Connecticut River Valley in Massachusetts. Ibid., vol. 9, p. 225.

1855. E. Hitchcock. Additional facts respectiug the tracks of Otozoum moodii on the Liassic sandstone of the Connecticut Valley. Ibid., p. 228.

1856. E. Hitchcock. Discovery of a new species of fossil fish and fossil footmarks from the sandstone of Turners Falls. Am. Jour. Sci., 2d series, vol. 21, p. 97.

1856. E. Hitchcock, jr. A new fossil shell in Connecticut River sandstone. Ibid., vol. 22, p. 239.

1856. W. C. Redfield. On the relatious of the fossil fishes of the sandstone of Connecticut and other Atlantic States to the Liassic and Oolite periods (name "Newark Group" proposed for the Triassic sandstones of Alleghany slope). Ibid., p. 357; also Proc. Am. Assoc. Adv. Sci., Part II, vol. 10, p. 180.

1856. E. Hitchcock. Description of a large bowlder in the drift of Amherst, Mass., with parallel strix on four sides. Am. Jour. Sci., 2d series, vol. 22, p. 397.

1856. E. Hitchcock. Illustrations of surface geology; 155 pages, 12 plates. Smithsonian Contributions, vol. 9. Secoud edition published in 1860. 
18in. Roswell Field. Note on the new web-footed rpecies of track. Froc. Boston Soc. Xat. llist, vol. 6, 1) 10.

1856. I. (. Warren, Mr. 1). On now and remarkable gigantic fossils and footmarks (real before lioston Soriety of Natural History; vol. 5, p. 298). Daily Traveller, Jannary 24.

185̃. 12. 1 Iit cheock. Additional facts concerning tracks of Otozonm moodii on Liassic sandstone of Comnecticut Talley. Proc. Am. Assoc. Adv. Sci., vol. 9, p. 228.

1856. J. 1)ane. On sandstone fossils of Connecticut River; 6 pages, 3 plates. Jour. Acal. Nat. Sci. Philia., 2d series, vol 3, p. 173.

1857. I. W. Mallet. On the rose-colored mica of Goshen. Am. Jour. Sci., 2d series, vol. 23,1 . 180.

1557. L. Hitchcock. Tadpoles' nests; argument from number of phalanges as to bird nature of Triassic animals. Proc. Boston Soc. Nat. Hist., vol. 6, p. 111.

1857. H. F. Walling. Map of Hampden County, Mass., based npon the trigonometrical survey of the State; 240 rods to the inch.

1857. E. Hitchcock. Geological maly of Hampden County (with the above).

1858. E. Hitchcock. Ichnology of New England (list of works on ichnology to date); 232 pages, 60 plates; 4 .

185̃. U. H. Hitchcock. Geological section from Greenfield to Charlemont, Mass. Proc. Boston Soc. Nat. Hist., vol. 6, p. 330.

1858. H. F. Walling. Map of Franklin County, Mass., based upon the trigonometrical survey of the State; 240 rods to the inch.

1858. E. Hitchcock. Geological map of Franklin Connty (with the above map).

1859. Dr. Henry T. Bowditch. Life and character of Dr. J. Deane. Boston Medical and Surgical Journal, February 7, 1859.

1859. Who described the bird tracks? Controversy between Dr. Deane and Professor Hitcheock. Four-column article from life and character of Dr. Deane, of Greenfield, by Dr. Henry T. Bowditch. Springfield Republican, May 7, 1859.

1859. E. Hitchcock. A half-column letter of Mr. W. W. Draper, of Greenfield, who claims to be the first discoverer of footmarks. Ibid., May $21,1859$.

1859. E. Hitchcock. Reply to Mr. Bowditch and defense of claims to priority in discovery of footmarks. Four columns, Springfield Republican, May 14, 1859; 6 pages; $8^{\circ}$. See Reminiscences of Amherst College, p. 388.

1859. E. Hitcheock. Catalogue of geological specimens in the State House; 69 pages, Appendix to Sixth Annual Report of the State Board of Agrienlture.

1860. Roswell Field. Ornithichnites, or tracks resembling those of birds. Am. Jour. Sci., 2 d series, vol. 29 , p. 361 .

1860. E. Hitchcock. Illnstrations of surface geology. 155 pages, 14 plates; $4^{\circ} ; 2 d$ edition, Amherst, J. S. \& C. Adams; 1st edition in Smithsonian Contributions, vol. 9,1856 .

1860. E. Hitchcock and C. H. Hitchcock. Elementary geology; 31st edition; rewritten; 430 pages. 
1860. Roswell Field. Note on reptilian natnre of tracks. Proc. Boston Soc. Nat. Hist., vol. 7, p. 316.

1860. Roswell Field. Ornithichnites. Proc. Am. Assoc. Adv. Sci., vol, 13, p. 337.

1860. Henry F. Walling. Map of Hampshire County, Mass., based upon the trigonometrical survey of the State, the details from actual surveys; 240 rods to the inch.

1860. E. Hitchcock. Geological map of Hampshire County (with above map). (I doubt if President Hitchcock prepared this map. See page 408.)

1861. J. Deane. Ichnographs from the sandstone of Connecticut River. Boston: Little, Brown \& Co.

1861. E. Hitchcock, C. H. Hitchcock, etc. Report on geology of Vermont; 2 vols., $4^{\circ}$. (Connecticnt River terraces, Bernardston, Shelburne Falls section.)

1861. E. Hitcheock. Remarks upon certain points in ichnology. Proc. Am. Assoc. Adv. Sci., vol. 14, p. 144.

1861. E. Hitchcock. Additional facts respecting the Clathropteris of Easthampton, Mass. Ibid., p. 158.

1862. J. D. Dana. Fossil larve in Connecticut River sandstone. Am. Jour. Sci., $2 d$ series, vol. 33, p. 451.

1862. G. J. Brush. On the ocenrrence of tryphyline at Norwich, Mass. Ibid., vol. 34, p. 402.

1862. E. Hitcheock. Supplement to the ichnology of New England. Proc. Am. Acad. Arts and Sci., vol. 6, p. 85.

1862. E. Hitchcock. Postscript to above. Ibid., p. 104.

1863. E. Hitchcock. New facts and conclusions respecting the fossil footmarks in the Connecticut River Valley. Am. Jour. Sci., 2d series, vol. 36, p. 46.

1863. E. Hitcheock. Reminiscences of Amherst College; 412 pages; $8{ }^{\circ}$. Geological map of Amherst and vicinity.

1863. C. T. Jackson and Charles S. Richardson. Manhan Silver-Lead Mining Company, Hampshire County, Mass. *** Geological surveys and reports, March, 1863. Boston: Alfred Mudge \& Co., printers, 34 School street; with map. The copy in the library of Amherst College came from Dr. Jacksou's library, and has his notes in pencil.

1864. C. U. Shepard. Mineralogical notices; Tungsten in Chesterfield. Am. Jour. Sci., $2 \mathrm{~d}$ series, vol. 37, p. 407 .

1864. C. T. Jackson. Discovery of emery in Chester, Mass. Proc. Boston Soc. Nat. Hist., vol, 10, p. 84.

186. Conncil of American Acarlemy of Arts and Scieuces. Obituary of President E. Hitchcock. Proc. Am. Acad. Arts and Sci., vol. 6, p. 291.

1865. C. T. Jackson. Discovery of emery in Chester. Am. Jour. Sci., 2d series, vol. $39, \mathrm{p} .87$.

1865. C. U. Shepard. Mineralogical notices (Chester, Whately). Ibid., vol. 40, p. 112.

1865. C. U. Shepard. Mineralogical notices (addition to Chester, Whately). Ibid., p. 123. 
18ti5. E. Hitcheock and C. II. Hitcheock. Supplement to the ichnology of New Vinglund; 96 pages, 20 plates; 40.

1865. C. U. Shepart. Liat Whately mine of yellow ocher and sienna; 8 pages; 120 ; Amlerst, Mass., Jamualy 18, 1865.

IS65. U. U. Shepart. $\Lambda$ description of the emery mine of Chester, Hamplen County, Mass., U. S. A.; 16 panges; London.

1860. C. U. Shepard. Scheelctine at Sonthampton lead mine. Am. Jour. Sci., 2d serics, vol. $41,1.215$.

1866. F. P'isini. Corundophilite of Shepard. Ibid., p. 394. (Analysis.)

1866. J. Lawrence Smith. On the emery mine of Chester. Ibid., vol. 42 , p. 83.

1S66. C. T. Jacksolr. Analysis of some minerals from Chester. Ibid., p. 107.

1866. C. U. Shepard. Mineralogical notices; Cotunnite in Southampton lead mine; Colnubite, Northfield, Mass. Ibid., p. 246.

1866. J. D. Dana. Corundophilite of C. U. Shepard. Ibid., p. 269.

1866. C. U. Shepard. Note concerning the minerals of the emery mine of Chester. Ibid., p. 421.

1866. C. T. Jackson. Chemical analyses of minerals associated with the emery of Chester. Proc. Boston Soc. Nat. Hist., vol. 10, p. 320.

1866. C. H. Hitchcock. Description of a new reptilian bird fiom the Trias of Massachusetts. Annals New York Lyceum, vol. 8, p. 301. (Tarsodactylus expansus.)

1867. T. H. Leavitt. Facts about peat as an article of fuel (cites Hitcheock and Dr. H. N. Lucas's experiments on mixing coal and peat). Private publication.

1867. C. U. Shepard. On the supposed tadpole nests or imprints made by the Batrachoides nidificans (Hitchcock) in the red shale of the New Red sandstone of Sonth Hadley. Am. Jour. Sci., $2 d$ series, vol. 43, p. 99.

1867. J. P. Cooke, jr. Clinochlore from Chester, Mass. Ibid., vol. 44, p. 206

1867. J. D. Dana. Note on the corundophilite of Chester. Ibid., pp. 258 and 283.

1868. C. U. Shepard. Corundophilite (analysis by Eaton). Ibid., vol. 46, p. 256.

1868. J. D. Dana. A system of mineralogy; Descriptive mineralogy.

1570. J. H. Adams (a member of the class of 1870, Amherst College). Notice of asbestos and cormulum with other minerals at PelLam. Am. Jour. Sci., 2d series, vol. 49, p. 271.

1570. E. D. Cope. On the Megadactylus polyzelus of Hitchcock; abstract from memoir in Transactions of American Philosophical Society. Ibid., p. 390.

1870. C. U. Shepard. Mineralogical contributions (microlite, vermiculite). Ibid., vol. 50, p. 91.

1870. C. H. Hitchcock. The geology of Vermont; 5 pages; $4^{\circ}$; privately printed as part of a proposed geological atlas, but without map.

1871. J. D. Dana. On the Connecticut River Valley glacier. Am. Jour. Sci., 3d series, vol. 2, p. 233.

1871. W. H. Niles. Peculiar phenomena observed in quarrying (Monson, Mass.). Proc. Boston Soc. Nat. Hist., vol. 14, p. 80; also separate publication. 
1871. A. A. Julieu. Analysis of cymatolite. Am. Chemist, vol. 1, p. 300.

1871. H. F. Walling and $O$. W. Grey. Official topographical atlas of Massachusetts. Stedman, Brown \& Lyon, Boston.

1871. C. H. Hitchcock. "Geological description" and geological map of Massachusetts, in above atlas, p.17. The map was so incorrectly colored by the publishers that it was publicly repudiated by Professor Hitcheock at the Boston meeting of the American Association for the Advancement of Science.

1872. E. Hitchcock. Discovery of the tooth of a mastodon in Massachusetts (Coleraine). Am. Jour. Sci., 3d series, vol. 3, p. 146.

1873. J. D. Uana. On rocks of the Helderberg era in the valley of the Connecticut, the kinds including staurolitic slate, hornblendic rocks, gneiss, mica-schist, etc., besides fossiliferous limestone. Ibid., vol. 6, p. 339.

1873. J. J. Dana. On the Glacial and Champlain eras in New England. Ibid., vol. 5, p. 198.

1873. J. D. Dana. Additional note to above. Ibid., p. 217.

1873. W. H. Niles. Note on movements of rocks in Monson. Proc. Bostou Soc. Nat. Hist., vol. 16, p. 41.

1873. H. F. Walling. List of lakes, ponds, and reservoirs in Massachusetts. Appendix B, Report Massachnsetts State Board of Health.

1873. Adolph Knop. Studien iiber Stoffwandlungen in Mineralreiche. Leipzig. Serpentine, p. 50.

1874. W. H. Niles. On some expansions, movements, and fractures of rocks observed at Monson, Mass. Proc. Am. Assoc. Adv. Sci., vol. 22, Part II B, p. 156.

1875. E. S. Dana. Trap rocks of Connecticut Valley. Ibid., vol. 23, Part II B, p. 45; also Am. Jour. Sci., 3d series, vol. 8, p. 390.

1875. G. W. Hawes. Trap rocks of Connecticut Valley (analysis of Holyoke trap). Am. Jour. Sci., 3d series, vol. 9, p. 185.

1875. J. D. Dana. Ou southern New England during the melting of the great glacier; No. 1, ibid., vol. 10, 1. 168; No. 2, ibid., p. 280; No. 3, ibid., p. 353; Sup., ibid., p. 497.

1875. J. P. Cooke, jr. On two new varieties of vermiculites (pelhamite). Proc. Am. Acad. Arts Sci., vol. 10, p. 453.

1875. Report of the water commissioners of the town of Westfield on the construction of the waterworks, including engineer's (L. F. Root) report; 50 pages; Westfield, Mass.

1875. J. Hall, T. Sterry Hunt, Thromas Doane. Reports upon Hoosac Tunnel, with profile, in report of the corporators of the tunnel. House docnment No. 9, Mass. legislature.

1876. C. U. Shepard. Hermannolite, a new species of the columbium group. Am. Jour. Sci., 3d series, vol. 11, p. 140.

1876. J. D. Dana. On southern New England during the melting of the great glacier. Appendix Am. Jour. Sci., 3d series, vol. 12, p. 125.

1876. W. O. Crosby. Report on geological map of Massachusetts prepared for Centennial Exposition; 52 pages; $8 \circ$; Boston. Map not published. 
187i. Review of above. Am. Jour. Sci., 3il series, vol. 12, p. 459.

1876. C. U. Shliepart. Contributions to mineralogy (private pnblication.) Amherst Collexe, May 11 ; j) plyes. Clester and Pelham minerals.

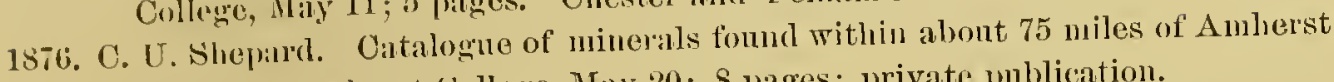
College. Amherst College, May $20 ; 8$ pages; private publication.

1876. W. H. Niles. 'The geologieal agency of literal pressure exhibited by certain movements of rocks. P'roc. Boston Soc. Nat. Hist., vol. 18, ]. 272.

187i. C. H. Ilitcheock. Lentienlar hills of glacial (trift. Tbicl., vol. 19, p. 63.

1876. F. Pisini. Notices minéralogiqnes (amesite, enchlorite). Comptes Rendus Acall. Sei. Paris, vol. 83 , p. 166.

1877. J. 1). Dana. Note on the Helderberg formation of Bernarlston. Am. Jour. Sci., 3il series, vol. 14, p. 379.

1877. I. S. 1)iller. Westfield during the Champlain period. Ibid., vol. 13, p. 262; see mal.

1877. A. A. Julien. On aglaite. Eng. and Min. Journ., New Yor'k.

1877. C. U. Shepard. Contributions to mineralogy. Amherst; 8 pages; private publication.

1877. O. H. Hitchcock. Note upon the Connectient Valley Helclerberg. Am. Jour. Sei., 3d series, vol. 13, p. 313.

1877. O. H. Hitchcock. The geology of New Hampshire, vol. 2; 428 pages; Concord, N. H.

1877. J. S. Diller. Geology of Westfield and vicinity. Westfield Times and NewsLetter, vol. 36, February 21, 28; vol. 37, March 7, 14, 21, 28, September 19.

1878. I. C. Russell. The physical history of the Triassic formation of New Jersey and the Comnecticut Valley. Annals New York Acad. Sci., vol. 1, pp. 220-254; published separately.

187S. C. Doelter. Ueber Spodumen und Petalit. Teschermaks Min. Mit., n. s., vol. 1, p. 517 .

1879. A. A. Julien. On spodumene and its alterations, from the granite veins of Hampshire Connty, Mass. Annals New York Acad. Sci., vol. 1, p. 31S; 1 plate.

1879. Above reviewed. Am. Jour. Sci., 3d series, vol. 19, p. 237.

1879. A. A. Julien. Composition of cymatolite from Goshen. lbid., vol. 17, p. 398.

1879. S. L. Penfield. Chemical composition of triphylite. Ibid., p. 226.

1879. H. F. Walling. Some indieations of recent sensitiveness to nnequal pressures in the earth's crust. (Contour map of Mount Toby and Sugar Loaf.) Proc. Am. Assor. Adv. Sei., vol. 27, p. 190.

1879. Majority and minority reports of committee on permanent protection of town from future floods, with report of Hiram F. Mills, civil engineer. Westfield, Mass.; 30 pages.

1879. Louis H. Everts. History of the Connecticut Vailey in Massachusetts. 2 vols; Philadelphia. Many geological notes under the town histories.

1880. G. J. Brush and E. S. Dana. Spodumene and the results of its alteration. Am. Jour. Sci., 3d series, vol. 20, p. 257. 
1881. C. H. Hitchcock. Geological map of the United States, with pamphlet; map 13 by $S$ feet. J. Bien, New York.

1831. G. W. Hawes. On the miveralogical composition of the normal Mesozoic diabase upon the Atlantic border. Proc. U. S. Nat. Mns., vol. 4, p. 129.

18ś1. Chauncey Stephenson. Local geology, West Worthington. Hampshire Gazette, November 2:, 1881.

1851. Chauncey Stephenson. Local geology No. 2 (emery and iron), West Worthington. Hampshire Gazette, November 29, 1881.

1882. J. D. Dana. The flood of the Connecticut River Valley from the melting of the Quaternary glacier. Am. Jour. Sci., 3d series, vol. 23, pp. 87 and 179.

1882. B. K. Emerson. The Deerfield dike and its minerals. Ibid., vol. 24, pp. 195, 270,349 .

1882. W. M. Davis. Triassic trap rocks of Massachusetts, Connecticnt, and New Jersey. Ibid., p. 345.

1882. W. M. Davis. The struetural value of the trap ridges of the Connecticnt Valley. Proc. Boston Soc. Nat. Hist., vol. 22, p. 116.

1883. Albert Williams, jr. Mineral resources of the United States, vol. 1. U.S. Geol. Survey.

1883. G. F. Kunz. American gems and precious stones. Separate publication from above work. (Mineral resources, vol. 1.)

1883. W. M. Davis. On the relation of the Triassic traps and sandstones of the eastern United States. Bull. Mus. Comp. Zool. Harvard Coll., vol. 7 (Geol. Series 1), p. 251; 3 plates of sections.

1883. R. P. Whitfield. Observations on the fossils of the metamorphic rocks of Bermardston, Mass. Am. Jour. Sci., 3 d series, vol. 25, p. 368.

1883. G. H. Cook. Anumal Report of the State Geologist of New Jersey for 1882. Trenton, N. J.

1883. J. D. Dana. Revier of above, including notes on "The origin of the Jura. Trias of eastern North America." Am. Jour. Sci., 3d series, vol. 25, p. 383.

1883. J. D. Dana. Western discharge of the flooded Connecticut. Ibid., p. 440.

18s3. J. D. Dana. Phenomena of the Glacial and Champlain periods about the month of the Connecticut Valley; that is, in the New Haven region. Ibid., vol. 26, p. 341 .

18S4. J.D. Dana. Drift and terraces. Papers on the Quaternary of New England, from Am. Jour. Sci., 1871 to 1884, and Mem. Conn. Acad., 1870. (A small edition of the papers cited above, bound in a single volume.)

1884. M. E. Wadsworth. Lithological studies. Mem. Mus. Comp. Zool. Harvard Coll., vol. 11, p. $1 ; 4^{\circ} ; 8$ plates; serpentine, Westfield, Mass. (pl. 7, fig. 3).

1885. Albert Williams. jr. Mineral resources of the United States, vol. 2. U. S. Geol. Survey.

1885. G. F. Kunz. Precious stones. Separate publication from above work (Mineral resources, vol. 2).

1885. A. G. Dana. On the gahnite of Rowe, Mass. Am. Jour. Sci., 3d series, vol. 29, p. 455 . 
1855. G. P. Herrill. 'The collection of building and ornamental stones in the United States National Museum; a handbook and catalogue. Report Smith. sonian Institution, 1855-6, Part II, pp. 277-648; Plates I-1X.

1855. Dwight Porter. Report on the water power of the region tributary to Long Islind Sound. Tenth Census U. S., vol. 16.

1856. A. Willians, jl. Mineral resources of the Uniterl States, vol. 3. U. S. Geol. Survey.

1856. G. F. Kun\%. Precious stones. Separate publication from above work (Mineral resoluces, vol. 3).

1886. Channcey Stephenson. The talcose slate ledge in western Hampshire (native gold on farm of Austin Geer, in West Worthington). Hampshire Gazette, February 22, 1886.

1856. Samuel H. Scudier. The oldest kuown insect larva, Mormolucoides articulatus, from the Connecticnt River rocks. Mem. Boston Soc. Nat. Hist., vol. 3, No. 13, p. $431 ; 4^{\circ}$.

18s6. W. M. Davis. The structure of the Triassic formation of the Counecticut Valley. Am. Jour. Sci., $3 d$ series, vol. 32 , p. 342.

1856. E. S. Dana. Mineralogical notes; Columbite, Northfield; Diaspore, Chester. Ibid., p. 386.

1886. David T. Day. Mineral resonrees of the United States for 1885; vol. 3. U. S. Geol. Survey.

18s6. Raphael Pumpelly. Mining industries of the United States; Corundum, mica, feldspar, quartz. Teuth Census U. S., vol. 15.

1857. B. K. Emerson. Preliminary notes on the succession of the crystalline rocks and their various degrees of metamorphism in the Connecticut River region (abstract). Proc. Am. Assoc. Adv. Sci., 35th meeting, Buffalo, p. 231; also Am. Jour. Sci., 3d scries, vol. 32, pp. 323 and 324.

1857. B. K. Emerson. The age and canse of the gorges cut through the trap ridges by the Connecticut and its tributaries; Prelim. Notes. Proc. Am. Assoc. Adv. Sci., p. 232.

1587. B. K. Emerson. The Holyoke range of the Comecticut. Ibid., p. 233.

1887. B. K. Emerson. The geology of Hampshire County. W. B. Gay, Syracuse, N. Y. Chapter II in Gazetteer of Hampshire County; also Am. Jour. Sci., $3 d$ series, vol. 32, p. 223 . Section on the Glacial lake copied. Am. Jour. Sci., $3 d$ series, vol. 34, p. 404.

1887. N. S. Shaler. Flnviatile swamps of New England. Ibid., vol. 33, p. 210.

1887. J. D. Dana. Taconic rocks and stratigraphy, with a geological map of the Taconic region. Ibid., p. 393.

1857. David T. Day. Mineral resources of the United States, vol. 4. U. S. Geol. Survey.

1857. G. F. Kunz. Precious stones. Separate publication from above work (Mineral resources, vol. 4). 
1887. W. O. Crosby. The elevated potholes near Shelburne Falls, Mass. Technology Quarterly, Boston, vol. 1, p. 36.

1888. J. D. Whitney. Names and places, studies in geological and topographical nomenclature (100 copies printed), p. 117. Sugar Loaf an "Eddy-Peak," of Triassic sandstone.

1S8s. J. D. Dana. On the crystalline limestone and the conformably associated Taconic aud other sehists of the Green Monntains region. A separate publication of the author's papers upon this subject dated 1873-1882, with separato title and preface.

1388. J. S. Newberry. Fanna and flora of the Trias of New Jersey and the Connecticut Valley. Trans. N. Y. Acad. Adv. Sci., vol. 6; Review, Am. Jour. Sci., $3 d$ series, vol. 36, p. 70 .

1888. W. O. Crosby and Charles L. Browu. Gahnite from Rowe, Mass. Technology Qnarterly, vol. 1, pp. 407, 408; also Am. Jour. Sci., 3d series, vol. 36, p. 157.

1888. John S. Newberry. Fossil fishes and fossil plants of New Jersey and the Connecticut Valley. Mon. U. S. Geol. Survey, vol. 14, 1888; 4०; 96 pages, 26 plates.

1888. O. Lnedecke. Ueber Datholit. Zeitschrift für Naturwissenschaften, vol. 61, p. 235. Halle.

1889. I. C. Russell. The Newark system. Am. Geol., vol. 3, p. 178.

1889. C. H. Hitchcock. Recent progress in ichnology. Proc. Boston Soc. Nat. Hist., vol. 24, p. 117.

1889. W. M. Davis. The structure of the Triassic formation of the Connecticut Valley. Seventh Ann. Rept. U. S. Geol. Survey, p. 461.

1889. W. M. Davis. Topographic development of the Triassic formation of the Connecticnt Valley. Am. Jour. Sci., 3d series, vol. 37, p. 423.

1889. W. M. Davis and Chas. L. Whittle. The intrusive and extrusive Triassic trap sheets of the Connecticut Valley. Bull. Mus. Comp. Zool. Harvard Coll., vol. 16, p. 99.

1890. B. K. Emerson. Porphyritic and gneissoid granites iu Massachusetts (abstract). Bull. Geol. Soc. Am., vol. 1, p. 599.

1890. G. F. Kunz. Gems and precious stones of the United States. New York, Screntific Pub. Co.

1890. B. K. Emerson. A description of the "Bernardston Series" of metamorphic Upper Devonian rocks. Am. Jonr. Sci., 3d series, vol. 40, pp. 263 and 362; map and sections. Review in N. Y. Iudependent, December 4.

1890. E. Nason and G. F. Varney. A Gazetteer of the State of Massachusetts. - Boston. 1890. David T. Day. Mineral resources of the United States for 1888; vol. 6. U. S. Geol. Survey.

1890. W. O. Crosby. The kaolin in Blandford, Mass.; 9 pages. Technology Quarterly, vol. 3, p. 228.

1890. Samnel $\Pi$. Sendder. The fossil insects of North America, with notes ou some Europeau species. 2 vols; $4^{\circ}$; illustrated. Macmillan \& Co., New York. 
18!) Jules Marcon. Biographical notiee of Ebenezer Emmons. American Geologist, Vul. 7, l. I.

1591. 13. K. limerson. On the Trims of Massachusetts, with map; 6 pages. I3nll. Geol. Soc. Am., vol. 2, p. 4 isl.

1891. G. P. Merrill. Rocks in building and decoration. New York: J. Wiley \& Sols.

1891. H. S. Williums. Correlation papers. Devonian and Carboniferous. Bull. So, U. S. lieol. Survey.

18!2. B. K. Enterson. Proofs that the Holyoke and Deerfield trap sheets are con temporaneous flows and not later intrusions. Am. Jonr. Sci., 3d series, vol. 43, p. 146 .

1892. R. s. Tarr. Central Massachusetts moraine. Ibid., p. 141.

189:. I. C. Russell. Correlation papers. The Newark system. Bull. 85, U. S. Geol. Survey.

1592. C. R. Van Hise. Correlation papers; Archean and Algonkian. Bull. 86, U. S. Geol. Survey.

1892. David T. Day. Mineral resources of the United States for 1889 and 1890; vol. 7. U. S. Geol. Survey.

1892. Lester F. Ward. The plant-bearing deposits of the American Trias. Bull. Geol. Soc. Am., vol. 3, p. 21.

1892. J. D. Dana. Additional observations on the Jura-Trias trap of the New Haven region. Am. Jour. Sci., 3d series, vol. 44, p. 165.

1892. M. M. Mitivier. New footprints from the Connecticnt Valley. Proc. Am. Assoc. Adv. Sci. for 1891, p. 286.

1892. J. F. Kemp. Notes on a granite from Chester, Mass. [shonld be Becket]. Trans. N. Y. Acarl. Sci., vol. 11, p. 129.

1593. C. H. Hitchcock. The Green Mountains anticlinal. Seience, vol. 20, p. 328.

1594. B. S. Lyman. Some New Red horizons. Proc. Am. Phil. Soc. Phila., vol. 33, p. 19:. Contains an extremely incorrect geological map of the Massachusetts Trias.

1894. R. Pumpelly, J. E. Wolff, and T. Nelson Dale. Geology of the Green Monntains in Massachusetts. Mon. U. S. Geol. Survey, vol. 23; 203 pp., 4, 23 plates.

1895. C. H. Hitchcock. The Connecticut sandstone group. Sustaining the above name for the Triassic sandstones of the Atlantic coast. Science, n. s., vol. 1, p. 74 .

1895. W. O. Crosby. Report on serpentinic or verd antique marble in Westfield. Cited in correspondence of Springfield Republican, Feb. 3, 1895.

1595. B. K. Emerson. Serpentine pseudomorphs after olivine, formerly called salt psendomorphs (from Middlefield). Bull. Geol. Soc. Am., vol. 6, p. 473.

1895. B. K. Emerson. Calcite psendomorphs after salt in Triassic shale. Ibid., p. 473.

1895. B. K. Emerson. Puckering of corundum crystals around allanite (from Pelham). Ibid., p. 47. 
1895. B. K. Emerson. The geology of Old Hampshire in Massachnsetts. Abstract. Bull. Geol. Soc. Am., vol. 6, p. 473; American Geologist, vol. 16, p. 238.

1895. B. K. Emerson. The Archean and Cambrian rocks of the Green Mountain range in sontheru Massachusetts. Title, Proc. Am. Assoc. Adv. Sci., vol. 44, p. 149; abstract, Americau Geologist, vol. 16, p. 247.

1595. Anon. Another vein of corundum discovered by a Chester mau. Announces the discovery of corundum by Dr. H. S. Lucas a mile east of Middlefield, and repeats the history of the original discovery at Chester. Springfield Republican, December 12, 1895.

1595. J. Volney Lewis. Coruudum of the Appalachian crystalline belt. Trans. Am. Inst. Mining Eng., A tlanta meeting, October, 1895.

1896. E. H. Forbes. On the epidote from Huntington, Mass., and the optical properties of epidote. Am. Jour. Sci., 4th series, vol. 1, p. 26.

1596. Dwight Porter. The flow of the Commecticut River. Science, n. s., vol. 3, p. 579.

1896. C. H. Hitcheock. The geology of New Hampshire. Journal of Geology, vol. 4, p. 44. Review of the report of the Second Geological Survey of New Hampshire, aud statement of the ehanges in the classificatiou of the rocks there made, dependent on later study of New England geology; with reference to the Bernardston series, Leyden argillite, etc.

1896. New topograplical atlas of Hampden County; 33 maps; J. Richards \& Co., Main street, Springfield, Mass.

1896. The building stones of Pennsylvania. Appendix Anu. Rept. Penusylvauia State College. Reports building stones of Massachusetts.

1597. B. K. Emerson. Diabase pitchstoue and mud inclosures of the Triassic trap of New England. Bull. Geol. Soc. Am., vol. S, pp. 59-\$6, pls. 3-9.

1897. Gilbert H. Montagne. Fossil bird-track discoveries in the Connecticut Valley. Springfield Republican, November 14, 1897.

1897. Anou. Further filds of tracks at Mount Tom. Ibid., November 15, 1897.

1897. William Orr, jr. Studies in local geology. 1. The trap ridges of Holyoke. Ibid., November $28,1897$.

1897. J. C. Rand. Minerals of Massachusetts. The Mineral Collector, vol. 4, p. $161 \mathrm{ff}$. 
24 



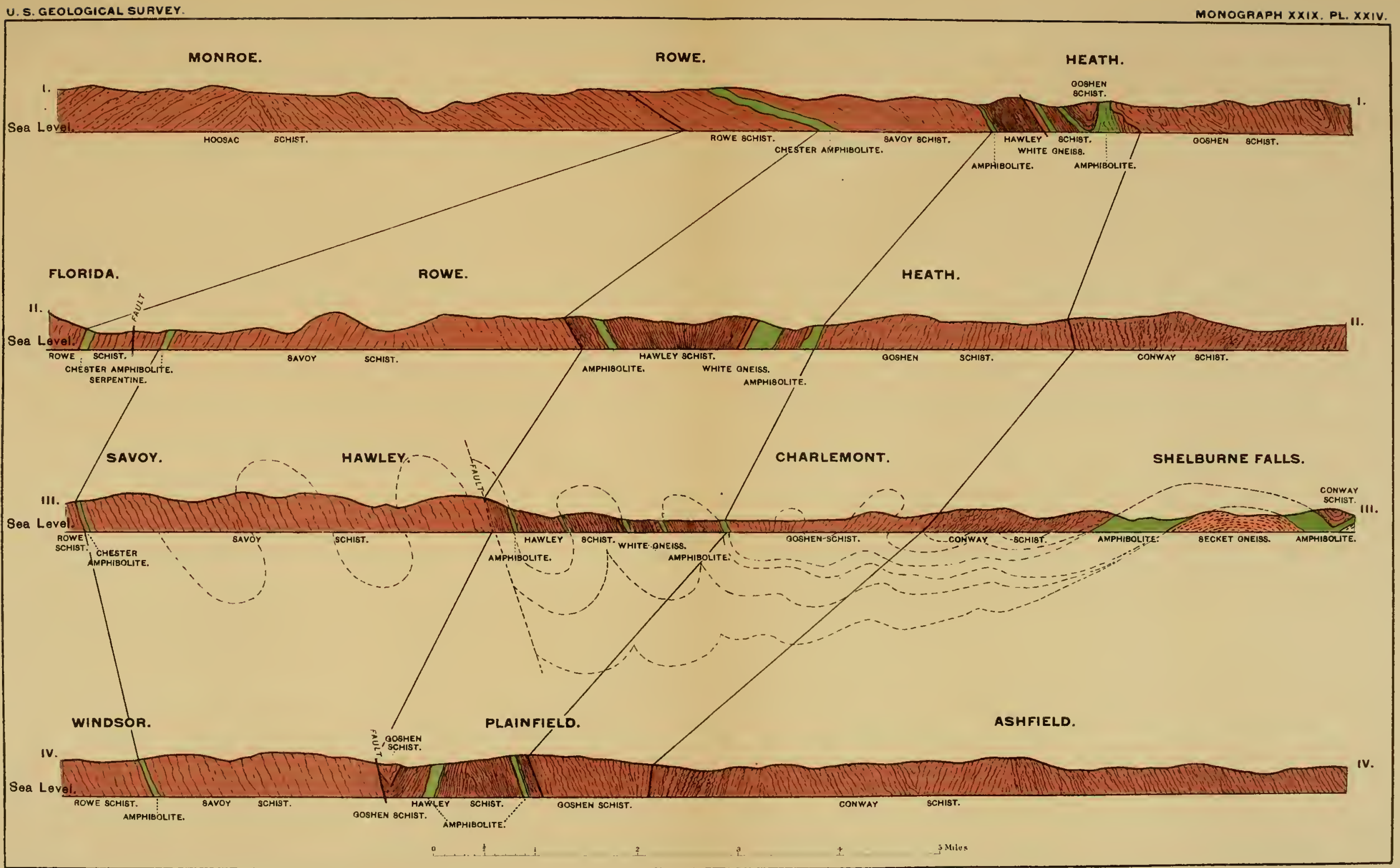

SECTIONS ALONG LINES I TO IV ON GEOLOGIC MAP. 

25 



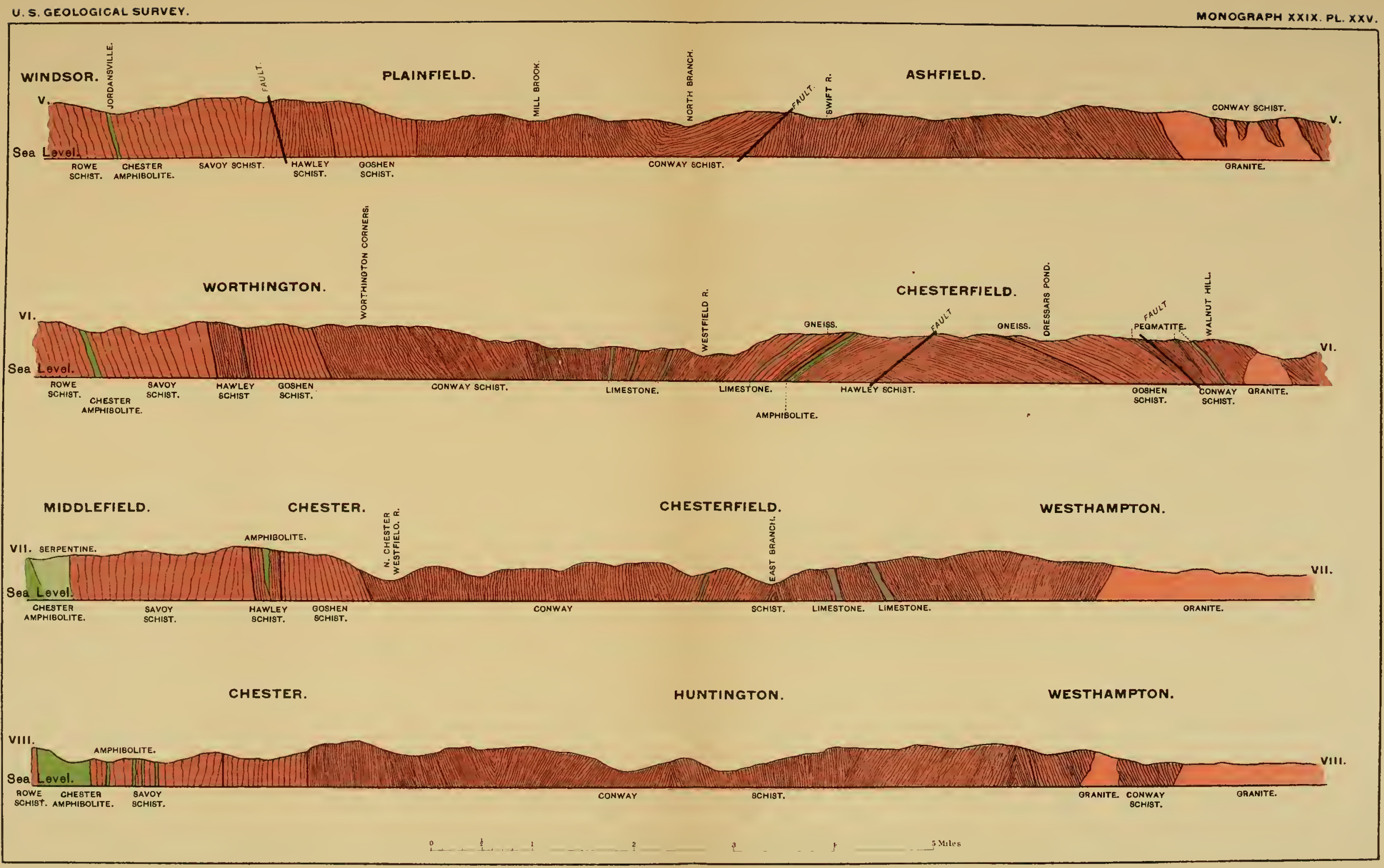

SECTIONS ALONG LINES V TO VIII ON GEOLOGIC MAP. 

26 


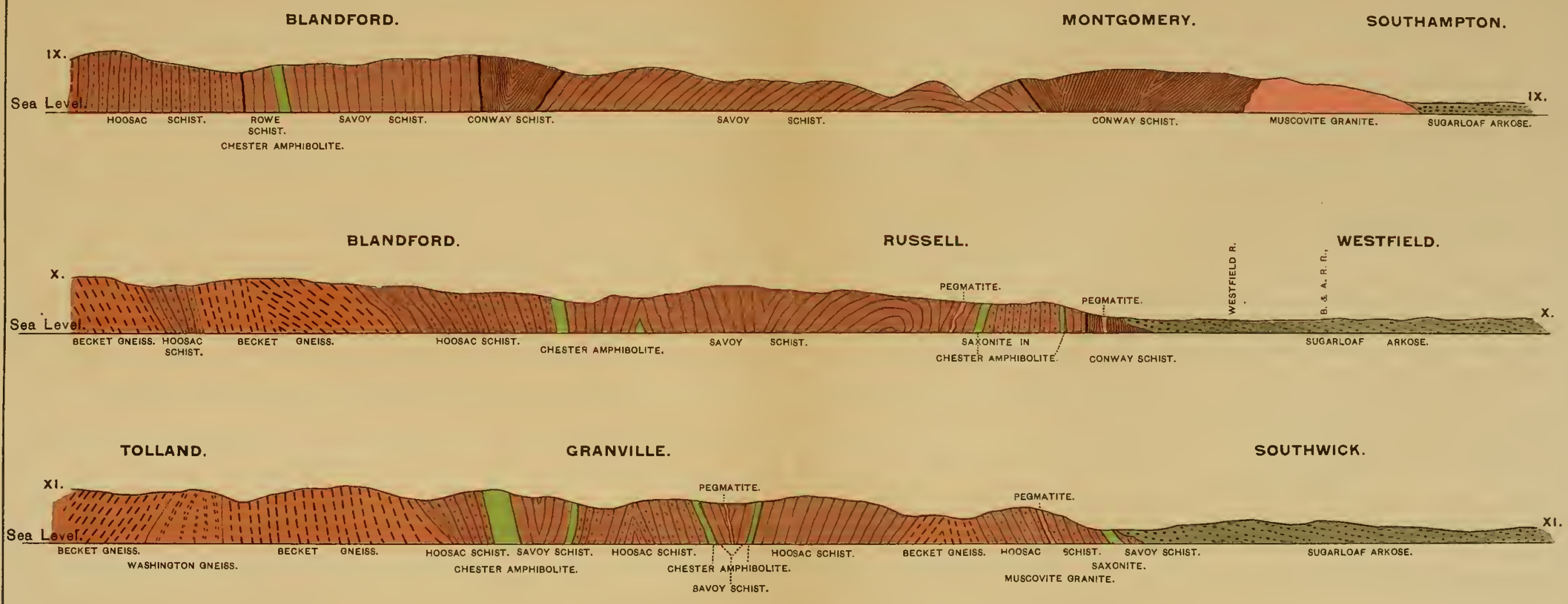

TOLLAND.

GRANVILLE.

SOUTHWICK.

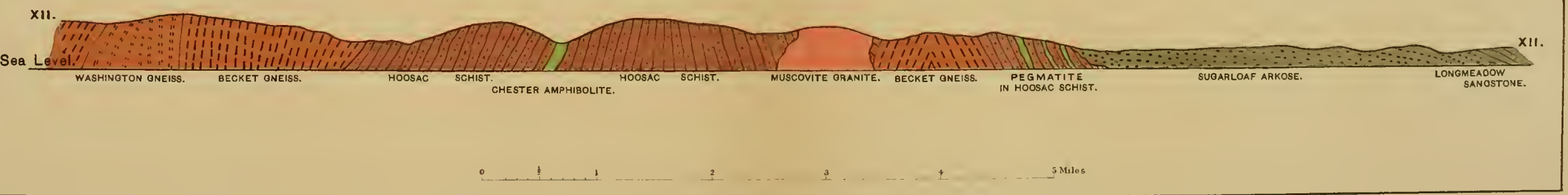



27 



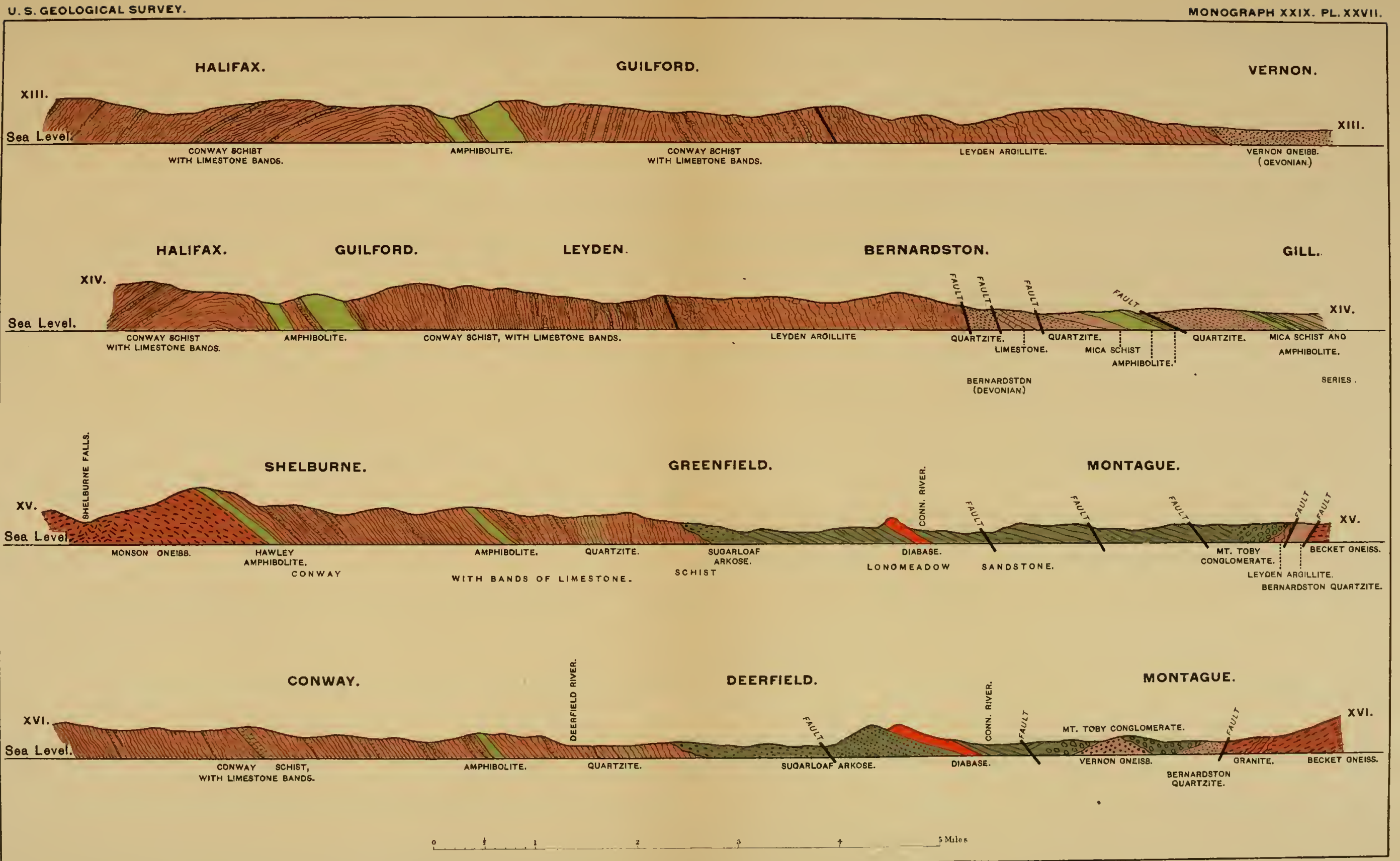

SECTIONS ALONG LINES XIII TO XVI ON GEOLOGICAL MAP. 

28 



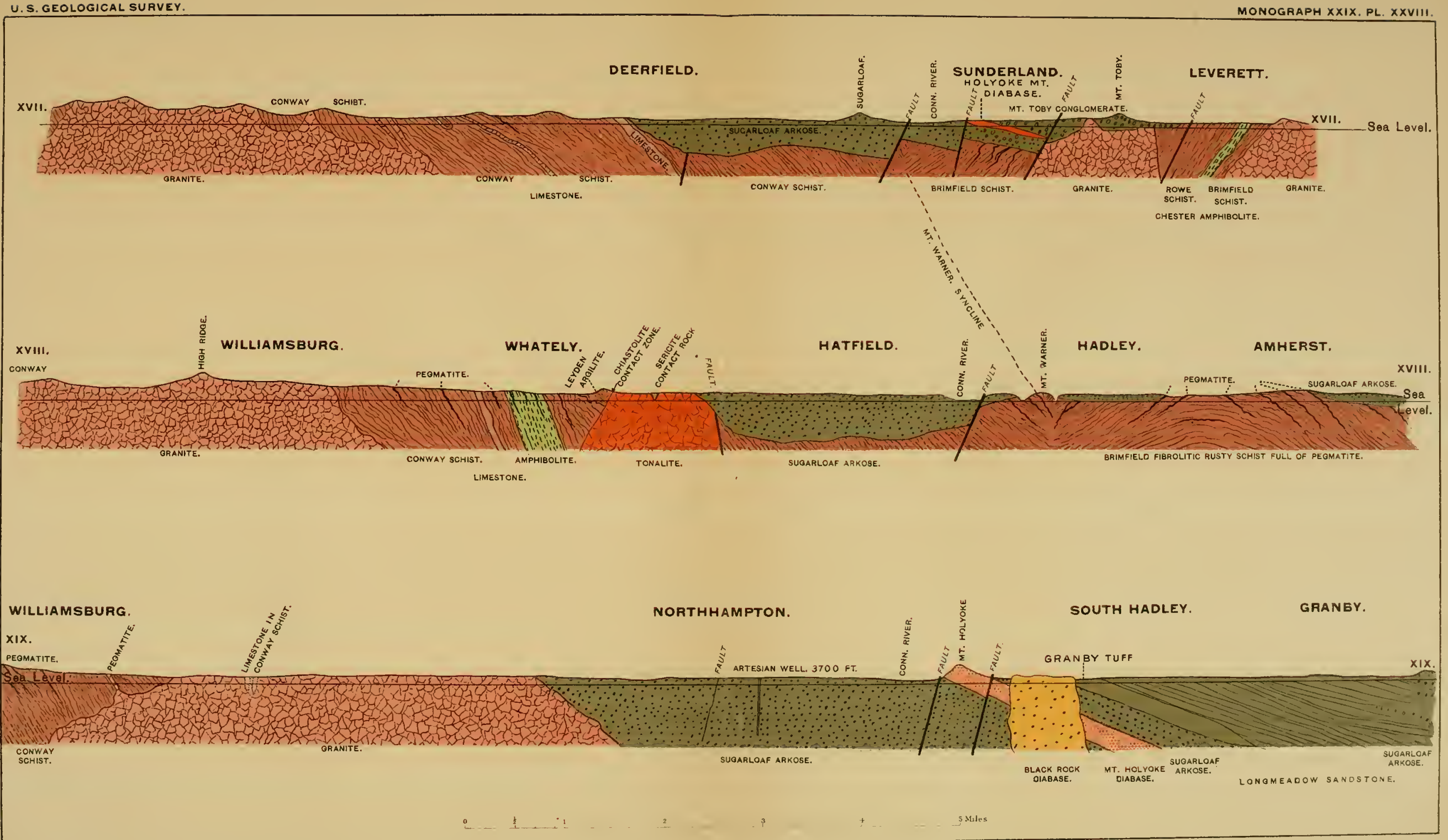

SECTIONS ALONG LINES XVIITO XIX̃ ON GEOLOGICAL MAP 

29 



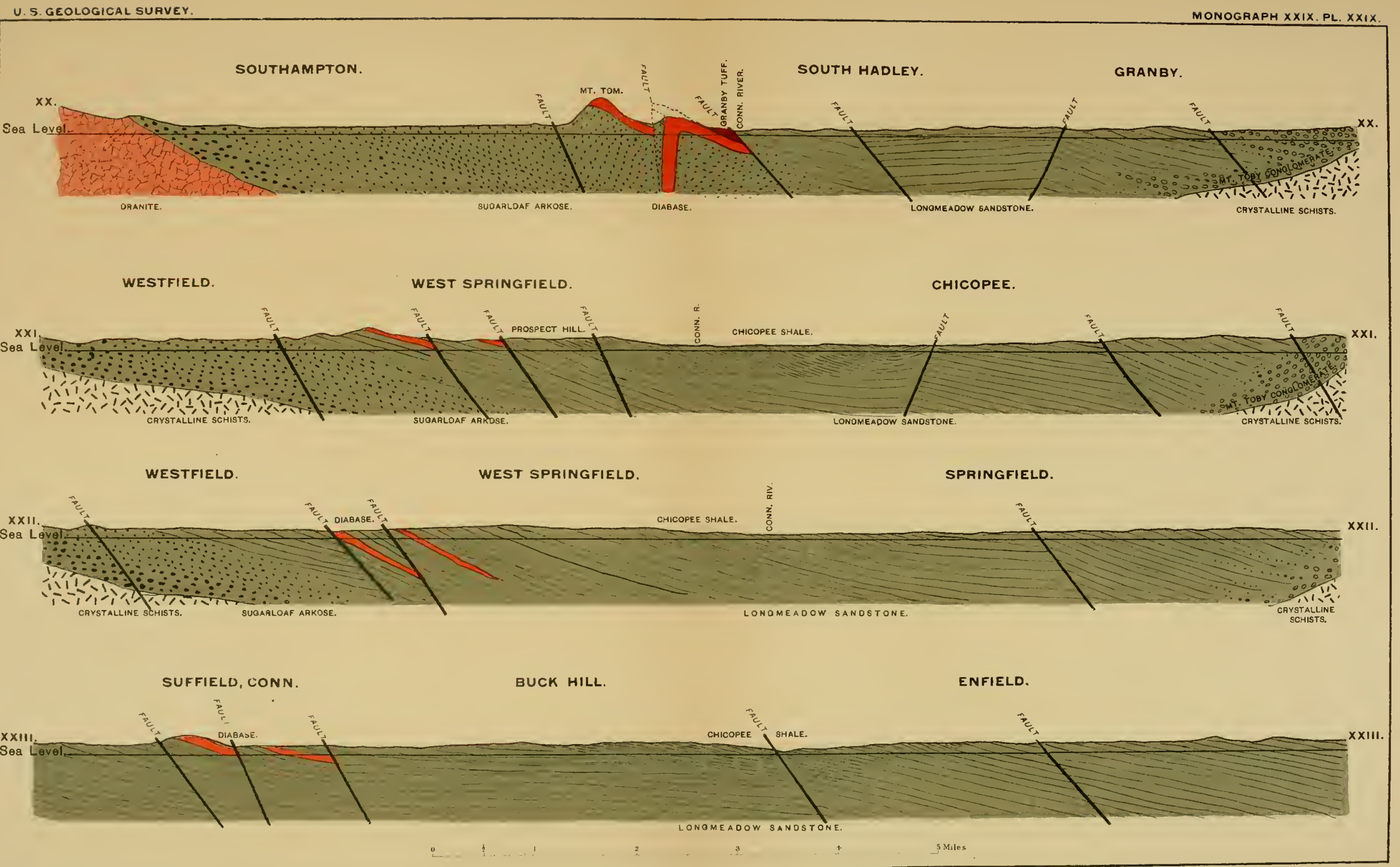

SECTIONS ALONG LINES XX TO XXIII ON GEOLOGIC MAP. 

30 



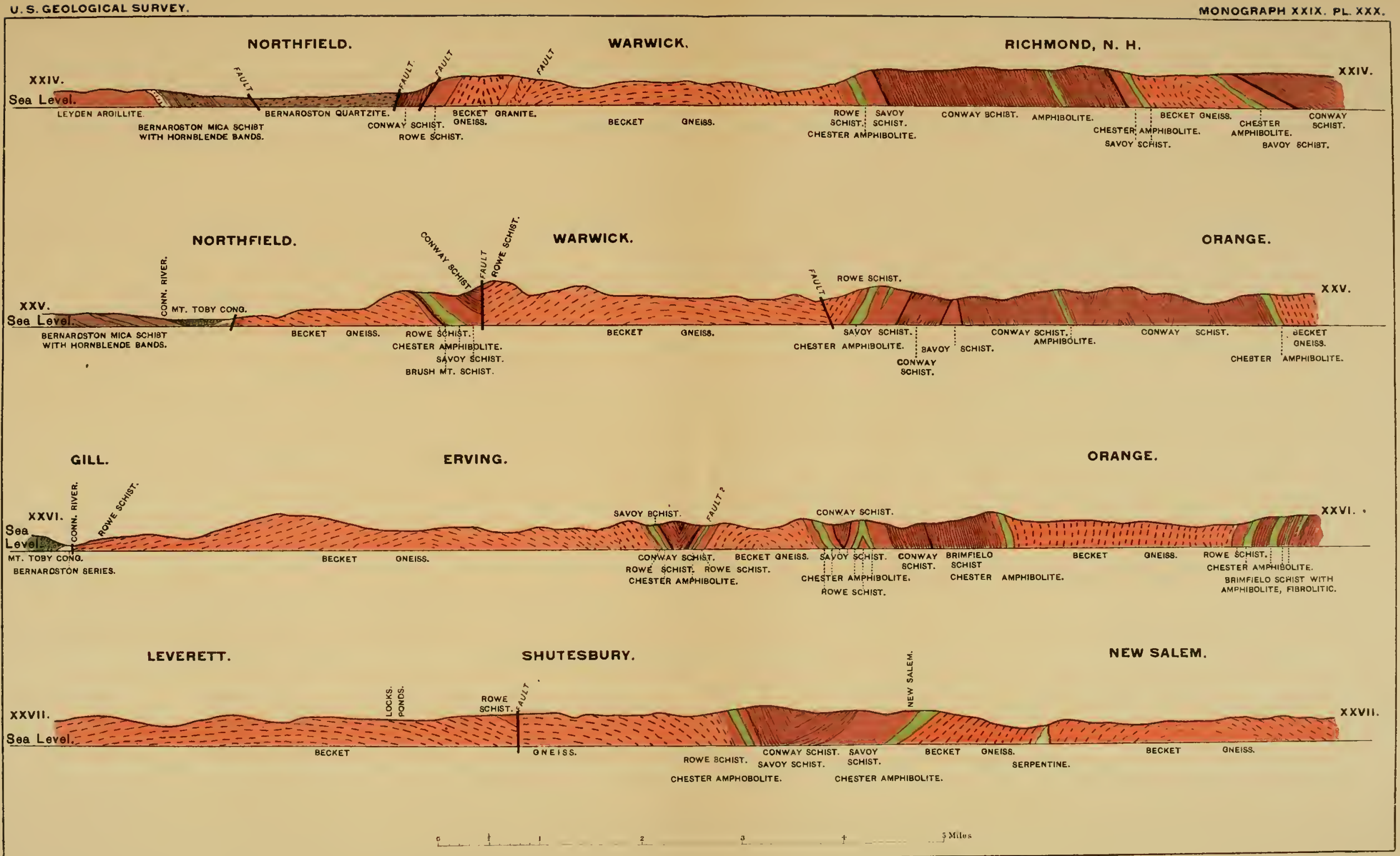



31 


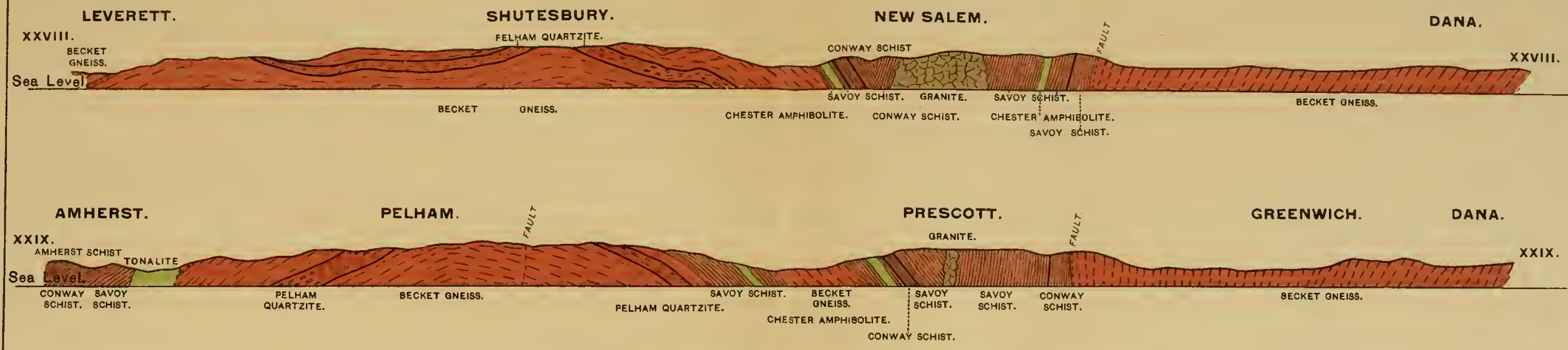

AMHERST. PELHAM. EREENWICH.

$x \times x$

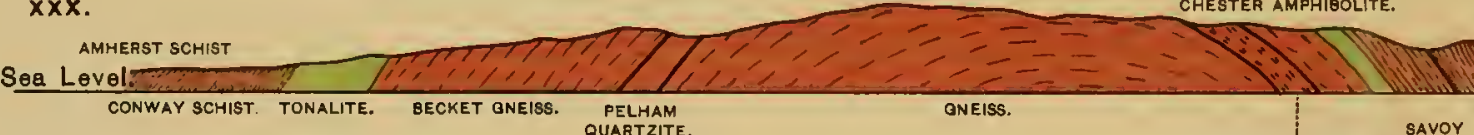

CONWAY SCHIST. TONALITE. BECKET GNEISS. PELLHAM

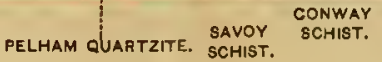

LUDLOW.

BELCHERTOWN.

PALMER.

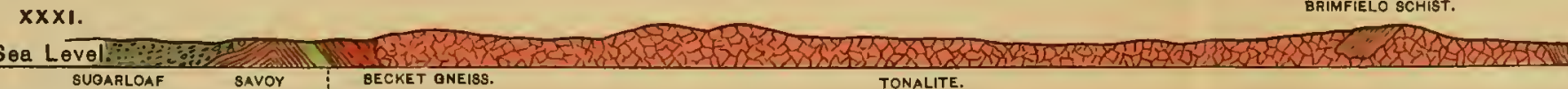

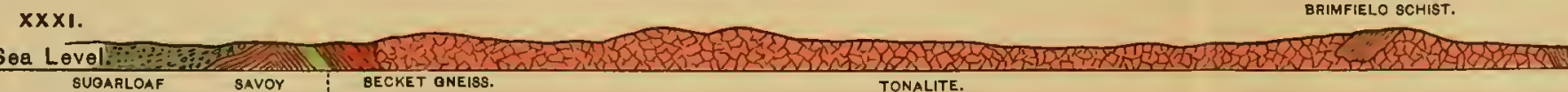

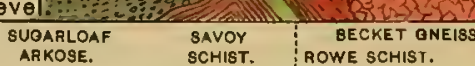
SCHIST. ROWE SCHIS.
CHESTER AMPHIOOLITE.

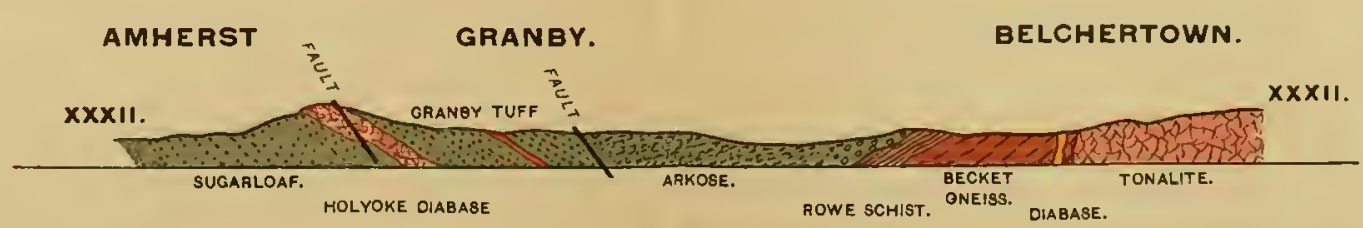

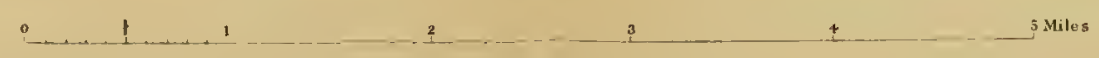



32 



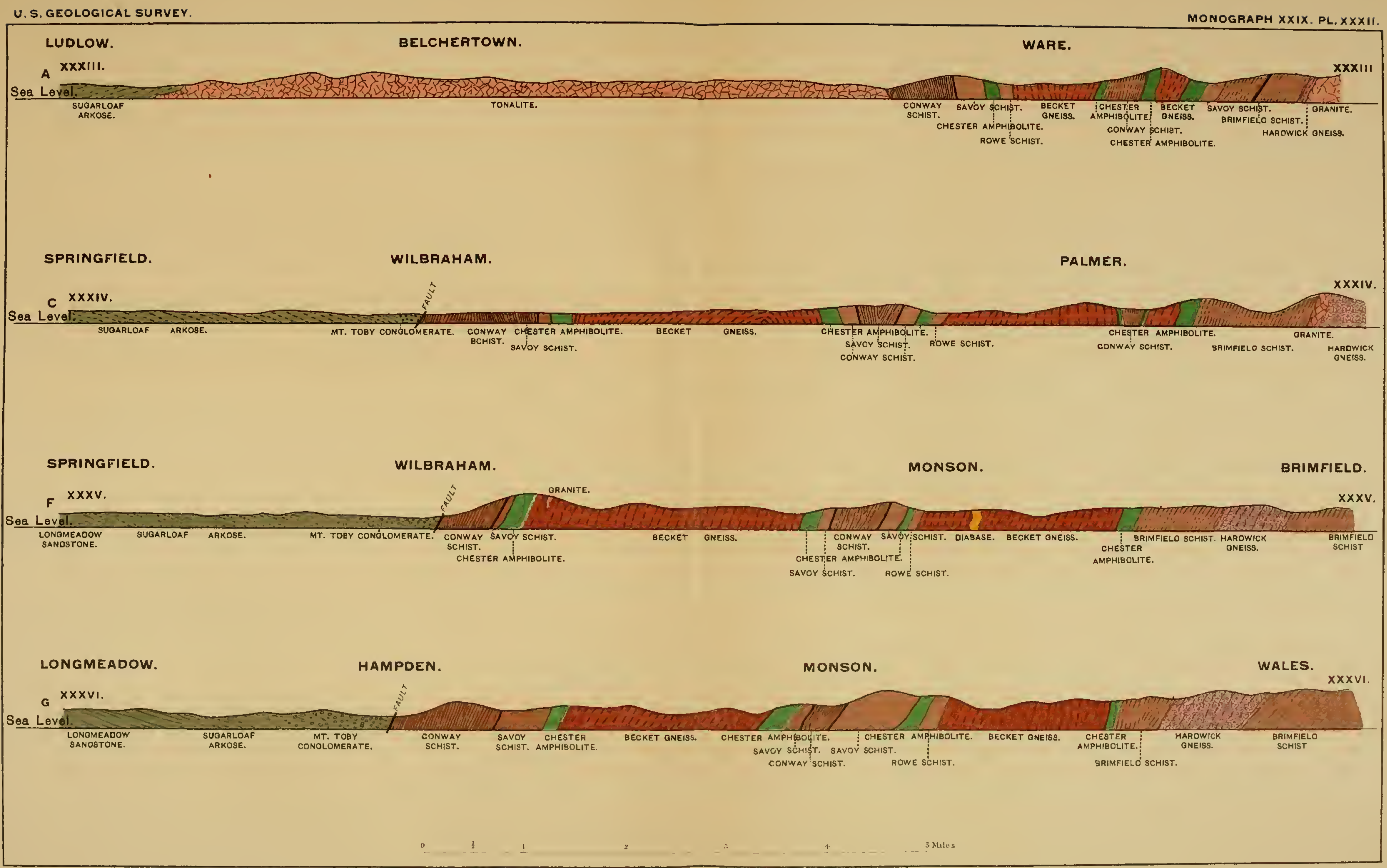

SECTIONS ALONG LINES XXIII TO XXXVI ON GEOLOGICAL MAP. 



\section{N I) EX.}

A.

Artinolit"quartzite, 1'elham and Wilbraham ....... Actiublite-tremolite.gneiss, oceurrence of .......... Adams, C. 13., cited on Green Monntain gneigs .....

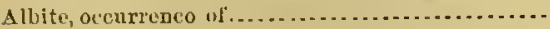
Aluitic nranite, occurrence and character of . . ..... 323-331 crushing of minerals in ...................... $\quad 329$ lydrothermal charges in reins of ............ 329-330 Altitic mica-schist, arens of ...................... $66-76$ bornbleudic bands in....................... $\quad 75$

Algonkian rocks, description of................. 19-30

Allanite, occurrence of .......................... 754

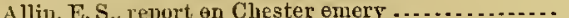

Ames, James T., mineralogic work of .............. report ou Clsester emery by .....................

Anlherst, analyses of hornblende schist from ....... Conway schist in. . . . . . . . . . . . . . . . . . . . . . . . 222-225

Amherst Ridge, terrace along................... 644-649

Amherst schist, correlation of . ................... 224 minerals in . . . . . .......................... 224-225

A mplibolites, occurrence of..................... 66-177

descriptions of . . . . . . . . . . . Chester serieg............................. 147-155 derivation from limestones . . . . . . . . . . . . . . . . . 153, 154 analyses and eections of ........ 167, 168, 195-196,300-306 Coaway schist .............................. 189-196 Wlıately ................................... 192-194

Leverett and Amlierst ........................ 218-220

Warwick ................................ 227-228

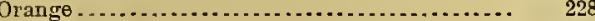

metamorphism of .......................... 236-237

pyroxenic . . . . . . . . . . . . . . . .

Bernardston series . . ......................... 293-294

porplryritic character of

Amygdaloidal eandstone, description of ............ $435-436$

Analyses, amphibolite ................ 167, 168, 195-196, 303 andesine. ................................ $\quad 140$

claystones................................ 717

Coles Brook limestone ......................

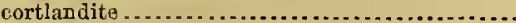

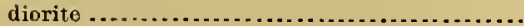

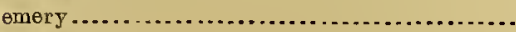

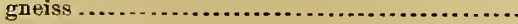

granite......................................

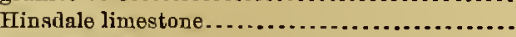

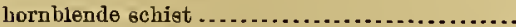

indianite ...................................

Longmeadow sandetone.

mineral spring waters ...................... 750-752

Mlonson gueiss .............................

pitchstone..................................

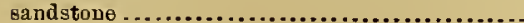

Analyes, Page. tonalito................................ 336 trap rock................................ 464 waters of mineral springs.................. 750,752 Andesine, analyses........................... 140 Inkerite, occurreuce of . . . ..................... 754 Anorthite, South Hadley .......................... 485 Anthophy llite, deseription of .................... 52

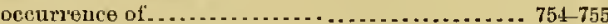

Anthracite, occurrence of ...................... 755

Antigorite-serpentine ......................... 98

A patite, occurrence of ......................... 755

Aplite, occurrence of .......................... 331

Aragonite, occurrence of..................... 755

A rgillite, degcription of . . . . . . . . . 2............... 201-210 quartzite in . ............................... 202 Bernardston series ......................... 261-262 arens of . . . . . . . . . . . . . pseulu-glacial stria on ...................... . 531-532 Artesian wells, records of ...................... . 380-389

Asbestiform authophyllite ....................... 52

Asbestos quarry at Pelhdm, description of......... 47-54 figures of walls of .......................... 48,49

Ashfield lake, fleposits of ......................... 601-602

Atbol, eastern ayncline in ........................ 234-236 metamorphism of amplibolite at. .............. 236-237 hiotite-muscoviti-granite from .... . . . . . . . . . . 316-317 section in ................................ 572 Angite, South Hadiey ......................... $\quad 486$ B.

Barite, occurrence of.......................... 755 Bastite, occurrerice of .......................... 755

Bastite-gerpentine, occurrence of.................. 98

Batterson's quarry, South Hadley, dike at......... 189

Bear River lake, deposits of . . . . . . . . . . . . . . . . . 600-601

Becket, conglomerate-gueiss at.................. 31-38 granitoid gneiss from ..................... 36 crusting tests of granite from ................ $36-38$ Becket gneiss, contact with Washington gneiss..... 31-32 Belchertown, contact zon $\theta$ in .................. 243-248 sectidn of sehists near...................... 244 record of artesian- $\pi$ e]l boring in.............. 245 degcripties of rocke from................... 246-248 corflaaditu at................................. $346-347$ dikes in .................................. 481-482 de scription of former lake in................. 575-577 sraction :n................................. 670 Belchertowu tonalite, contact zone around.......... 243-248 Ber aardstou, table slrowiag encceesion of rocks near. $\quad 258$ Upper Devonian fossils of . . . . ................ 259-260 degcription of range from South Vernon to..... 272-282 P. ernardeson gneiss, MIontague ................. 362-363 
Page.

Rernardsi $\mathrm{n}$ series of Deronian rocks, diecussion of . 253-300 descri $i_{\perp}$ tion of regiou of ....................... 260-261 relatiou to argillite........................ 261-262

fault in . . . . . . . . . . . . . . limestone ot ................................ 265-267

magnetito bed in . . . . . . . . . . . . . . . . . . . . . . . 267-268 quartzite bed in ............ . . . . . . . . . . 268-269 mica-schjst and holmblendie beds in .... . 270-271, 276-282 feldspat]ic quartzite of....................... . 282-283 beds of ...................................... 285 original character and metamorphism of....... 285-287 petrographical lescription of . . . . . . .......... 287-295

Beryl, occurrence of ........................... $755-756$

Biotite-gneiss, description of. . . . . . . . . . . . . 44 45, 182-183

Biotite-granite, Chesterfield . ................... 318-322

Biotite-muscovite-gran'te, occurrence and character of ...

Biotite-quartz-schist, Be nardston series........... 289-290 Black Rock core, Hount Holyoke, description of ... . 489-491 contact with diabase (figured)............. 490

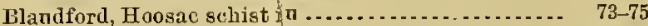
pyroxenite in ................................ $85-90$

Blandford, serpentines in......... 85-90, 102-104, 104-108, 111 a ruphibolites at............................ $96-97$ Sатоу schist iu... ....................... 159 descriptiou of biotite-gnetss from ............ 182-183 dikes iu .................................. 327

Blue-qnartz gneiss .......................... 28

Boltou limestone, metamorphism of .............. 155

Boston and Albany Failroad, section along........ $71-72$

Buwlders, description of . . . .................... 559-561

Bowlder trains . . ............................... 549-550

Brimfield, cordierite granitite at . ................ 321-322 garnet-biotite-norite at. . . . . . . . .............. $315-346$ description of former lake in . . .............. 565-56

Brimfield station, section at ..................... 566

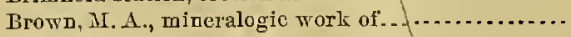

Brookite, occurrence of...........................

Buctland lake, deposits of .

\section{C.}

Calcite, occurrence of ........................ $\quad 756$

Calcite and dolonite, pseudomorphs of............. 389-391

Cambrian (Lower) gueisses.......................... 31-65

Camp Meeting cutting, sections at. . . . . . ...... 677-691, 69 \& junction of elays and sands at................. 705

Cerussite, occurrence of....................... $\quad 756$

Chalcopyrite, occurrence of .................... 131

Chamberlain, W. G., report on Chester emery b5 ... . 133-134

Champlain clays, description of . . ................ 697-721 jnnction of sands with ...................... 705-706

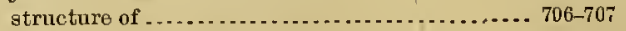
time occupied in deposition of .............. 707 action of ice on . . joints iu ............................. concretions in............................. $711-718$ fossils of ................................ 718-721

Cbamplain period, phenomeno of................. . 562-592

Chaudler, C. F., analyses by ..................... 369

Charlemont, mica-schist from ................... 163 dikes in quartz veins in ........................ 169

Chemical analyses. (See Aualyses.)

Chester, amplibolite aud serpentine in .......... 78 - 156 sections at emery mine in ...................... 85, 141 history and description of emery bed in ........ 117-d $t 7$ Savoy schist in .......................... 159,1 150
Page.

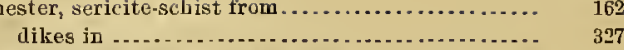
Chester amphibolite and serpentine, occarrence aud character of ............................. $78-156$ Chester amplibolite serios, description and correla-

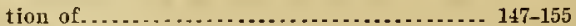

sedimentary origiu of ...................... - 155 Chester emers, morle of formation of............. 154-155 Chester emery hed, history and description of. . . . . . 117-147 Chester Emery Company, orgaujation and work of. 121 Chester emery mine, association and paragenesis of minerals at ................................ 143-147

Chester Granite Company, quarry stones of........ 36 Chester series, extent aud character of ............ 149 Chesterfield, biotite gneiss from................... 183 copper mine at............................ 504 Chiastolite-schist ............................. 209-210 Chicopes shale, occurrence and ebaracter of........ $\quad 370$ Chlorite-schist, dikes and quartz veins in .......... 169 Cbloritoid, description of ........................ 129 Clapp, O. MI., mioeralogic work of............... 7 Clark, J. D., mineralogic work of..................

Clark Hill quarries, Middlefield, granitoid gneiss

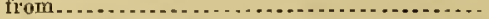

Clarke, John Mason, cited ou character and age of fossis from Bernardston . . . . . . . . . . . . ..... 259-260

Clay and marl deposits, origin of................ $459-460$

Clays and till, contacts of ..................... 701-703

Claystones, analyses ot . . ........................... 717

Clinochlor, occurrence of ........................ 756

Coles Brook, sections at ........................ 22,23

Coles Brook anticlioe, description of ............. 21-24

Goles Brook limestone, analysis of................ 27 occurreuce and character of ................ 27,28

College Hill, Ainher'st, section at............. 557 Counecticnt, origin of name...................... ${ }^{\text {n. }} 2$

Connecticut River, old conrse of . . . ........... 513-515, 627 terraces of ........................... $722-738$ ogcillatious of ............................... 733 axbors of deflection of............................... 734-735 Connecticut River lakes, description of ........... 609-696

Connecticut Rirer sandstone, area of . . ........... 351-351 summary of history of ...................... 495-500

Counecticut River tributaries, deflection of ........ 735 terraces of ............................... 736 repalsiou of ................................... $746-747$

Connecticnt River Tallej, general geology of...... 13-14 general description of ......................... 9 9-10

Conglomerate-gneiss, Becket.................. 31-38

Couway, mineral vein at ........................ 504 deposits of old lake in........................ 598-600

Conway schists, occurrence and character of ....... 183-201 gneiss berls in ................................. 185 suhordinate beds in . . . . . . . . . . . . . . . . . . . 185-199 limestoue beds in . . . . . . . . . . . . . . . . . . . . . . . 188, 189 amplibolites in . . . . . . . . . . . . . . . . . . . . . . . . . . 189-196 protrusion throngh Leyden argillite in Wbately 196-197 cleavage in ................................... 199-200 fossils of . . . . . . . . . . . . . . . . . . . . . . . . . . 200-201

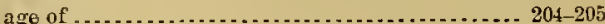
Leverett .................................... 222

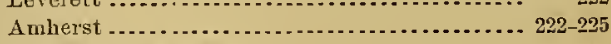
Cook, Helon P., analyses by ................... 8 Copper ores, Hawley schist. .................... 171 Cordierite, figured ........................... 208 
l'age.

Cordiorite grmits, l3rimutield ................. 321-32

Currolation of rucks, section showing........... 16-18

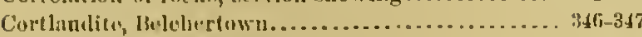

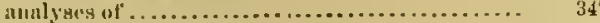

Cmualophititu, doseription of . ................. 130

C'orımlum, ocostren'v of..................... 128, 750

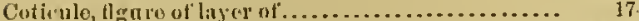

Coys 1 till porplyzritic granile................. $319-320$

Coucretions, Champlain colays.................. 711-i18

Crosby, W. O., citol ou mululu of Westfield......... 92-93

oited on mica-granites.................... 812,314

Crushing tust, granito..................... $36-38$

Cummingteuile (rhorlonite), ocourrence of .. 171, 172, 756, 757

Cushuraus Brook, delta of .................. 640,6 641

\section{D.}

Dama, E. S., citul on Triassic diabases............ 408-409

Dana, J. D., cited on origin of limestone fragments in trup.

Dana, J. D., tities and ahstracts of papers on Upper

Duronian rocks .............. 253, 254, 256, 257, 259

Dana, J. D., titles of paper's on Pleistocone ......... 508

Distolite, occurrence of. ........................ 757

Davis, W. MI, citer on Cretaceous degradation........ cited on trap rocks....................... $409-410$

Deerfield bed, description of

l)eertield River and tributaries, description of...... 597-598

Deerfield River, delta of ....................... 634-635

Deertield River lakes, deposits of................. 595-597

Deerfield sheet of ermptive rock, description of ..... 418-416 normal disbase of . ......................... 411-443

diopside-diabase of .......................... 443-414

Delaney's quarry, Northampton, section at......... $\quad 470$ rocks at ............................... 470-473

hollow bomb from ......................... $\quad 480$

Deltas at high level, trace of .................... 605-606

Deunis, L. M., analysis of granite by ............. $36-37$

Devonian argillites, pyendo-glacial stria on....... 531, 532

Deronian rocks, Williams Farm, map and sections. 263-26

Dewey, C., cited on mica-granites ............... 312,313

Diaspore, nature of.......................... 129

Diabase, Deerfield anil Holyoke................. $\quad 372$ dikes of ................................. 411-418

alteration of ................................ 419-439 contact of sandstono with..............439,452,455-450 deseription of ....................... 441-443,461-464

Deerfield sheet........................... 441-443

limestone inclusions in . . . . . . . . . . . . . . . . . . . $452-455$

granitic inelnsions in ....................... 483-488

Diabase anygdaloid, contact with clayey limestone (figured)

208

Diabase-pitchstone, deseription of .............. 432-433

Diahase-tuff, occurrence and character of ......... . 369

Dike recks, description of . .................... 324-328

Dikes, Charlemont ........................... 169

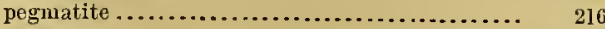

diabase........................................... $411-418$

Diller, J.S., titles of paper's on Pleistocene.......... 508 quoted on geology of Testfield and vicinity... 65 4656

Diorite, Prescott (figured) ..................... 208 North Prescott and New Salem ............... 342-345 Leverett Center............................. 344-345 apalyses of

Diopside-rliabaee, Deerfield eheet................. 443-444

Dolomite changing to serpentine, (figured)......... $100^{3}$

Dolomite and calcite, pseudomorphs of.............. 389-391 MON XXIX -50
Irift, rplauel ...................... I'ago.

valliy .............................. 537-54

I)ry Brook 11ill, gorge terrace of .............. 661-602

1) rumline, leseription of . . . . . . . . . . . . . . . . . . . . . . 54:3-549

Hunes and wind loess, occurrence of............. 748-749

Dwight, Timotlyy, (noted....................... 60.69

Dright station, eections near ................. 669,671

E.

Eakins, L. G., analyses by .................... 167, $168,196,221,303,316,336,345,347$

Eastern eyncline, description of .............. 231-242

East Greenwich-Enfieh вyncline .................. 251

Eaton, Amos, eited on occurrence of serpentinc at Loudville

cited on mica-granites. .

Eights, James, eited on plants of Champlain clays.. $\quad 718$

Emery; analyses of ............................ 125

varieties of............................... 126-127

map of veins of . . . . . . . . . . . . . .

wode of formation..... . . . . . . .

Emery bed, Chester, description of.............. 117-147 eection ................................. $14 \mathrm{I}$

association and paragenesis of minerals at ...... 143-147

Emmons, Jibenezer, early inineralogic work ........

citerl ou mica.granites ..................... $\quad 312$

Enfield, rocks in . . . . . . . . . . . . . . . . . . . . . 232-233

Enfield-Greenwich basin . ....................... 9

Enstatite, formation of. . . ...................... 148-153 altered to serpentine (figured) ............... 106 occurrence of................................. $757-758$

Enstatite-serpentines, Granville and Ruseell....... 90 90-92 Russell................................... 111-112 Enetatite-6erpentine and limestone complex at Westfield warble quarry........................ 147-155

Enstatite-serpentine psendomorphs in white marble

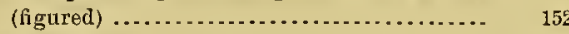

Epidote, description of........................ 130 occurrence of ............................. $\quad 758$ Epidate-fibrolite, Northfielı................... 328

Epidote-gneiss, Pelham....................... 54

Erratics, description of ........................ 559-561

Eruptive rocks, ennmeration of ................. 14 description of . ..................... 307-350,407-501 contact effects of ........................... $349-350$ Eruptions, epociss of ......................410,411

\section{F.}

Fall River, finlt at mouth of .................. 439, 440 olri course of ................................ 621,622 Faults, descriptions of....................... $95-96$ Feldspatbic quartzite, Bernardston series......... . 282-283 Fihrolite, occurrence of.......................... 229-758 Fibrolite-scbist, Belchertown ................. 246-218 Field, Roswell, oarly geologie work ............... Fishes, Triassic............................... 398 400

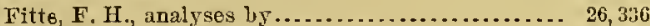
Florenee, aualyses of granite from............. 316 Flynt's quarry, Monson, gneiss at................ 59-65 Foot tracks and trap sheets, possible connection between............................... $\quad 379$ Fort River, old oxbow of........................... $737-738$ Pleistocene beetles of . . ..................... 740-746 Fossils of the Terrace period.................... 738-740 Fox Brook, Triassic sandstone outcrop along...... 271 
Franklin County, Rowe schist in................. $\begin{array}{r}\text { Page. } \\ 76\end{array}$ Rowe serpentine in ..................... $79-80$

G.

Gadrite, occurrence of $\ldots . . . . . . . . . . . . . . . . . .$. Galena, occurrence of............................

Garnet, Northfield ............................. 106, 328 Garast-biotite-norite, Brimfield................. 345-346 Garnetiferous quartzite, figure of................ 174

Glacial action in Triassic time .................. 363-364

Glacial grooves and striw...................... 522-531

Glacial notcbes.................................. 529-531

Glacial period, erosion during . ................... 515-517 topography during ........................ 518-521

Glacial and Triassic periods, interval between ...... 508-517

Glass in trap, origia of ........................... 437-439

Glass-breccia, description of.................... 433-435

Gneies, Monson .......................... 15,41-45, 56-65

Hiosdale . . . . . . . . . . . .................... 20, 24-25

Lee.................................... 20, 29-30

Washington ............................. 20

blue-quartz.................................. 28

Low er Cambrian .......................... $31-65$

Mirldlefield............................... $34-36$

Becket ................................... $\quad 36$

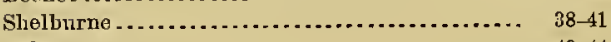

Pelluam................................... $13-44$

Orangs................................... 56-65

Goessmann, C. A., analysis by .................. $\quad 750$

Goshen, limestone at ........................... 191

dikes in ..................................... $326-327$

galena at ................................. 504

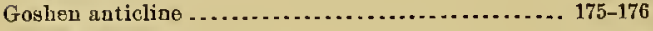

Goshen schists ................................. 177-183

Granby, cores and dikes in ...................... $482-483$

Granby Plain, moraine across................... 664

Granby Road Lake, description of deposits of ....... 587

Granby tuff, occurrence and character of........... 369

Granby tuff bed, description of................. 476-479 source of material of ....................... $\quad 480$

Granito, Becket, crushing tests of ............. $36-38$ analyeis of ............................... 37,316

Hard wick . . . . . . . . . . . . . . . . . . . . . . . . . 317-318

Huntington, crushing of minerals in.......... 329

age of .................................. $\quad 348$

genetic relations of ........................... 348-349

included in diabase......................... 483-488

Gra aitite, occurrsuce of ....................... 317-322

Granitoid gaeiss, Middlofield................... 34-36

Beket................................. 36

Pelham.................................... 43-44

Granville, Hoosac schist in ............... 73-75

enstatite-serpentines inl................... 90-92

eerpentinss at............................. 108-111

deposits of former lake io ..................

Graphitic mica-schist series.................. 177-210

Greenfield, altered diahase in .................. 419-439

exposures in quarry at..................... $421-\$ 31$

details of trap ridge east of ................. 426

thin sections from "ash bed" at .............. 430

mineral vein at............................ 505

terrace in................................ 632-634

Greenwich-Enfield basin ........................ g

Green River glacier, deposite of . . . . . . . . . . . . . . 630-631

Gulf road, sections on.......................... 213-215
H.

Page.

Hadley Lake, deposits of . . . . . . . . . . . . . 629-657, 673-677 drainage of ............................ 584-586 sections of heds of . . . ........................ 646,647

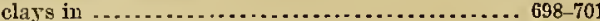

Hadley Lako basin, terraces in.................. $726-729$ Eampden Emery Compans, organization and work

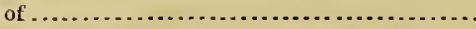

Hampden County, ampliholite aod serpeatine ia.... Rowo schist in .......................... 76-78

Hampshire County, Ruwe seliet in .............. $76-77$ former area of............................. 1 serpentine in .......................... $81-85$

Hardwick gneiss ................................ 239-241

Hardwick gneissoid granite and grauitite ......... 317-318

Hassam Brothers, report on Chester emery ........ 133

Hatfield, mineral vein at........................ 505-506 section of clays i11.......................... 691-692

Hausmano, early description of kieselspath (albite)

by ................................... 5

Hawes, G. T., eited on Triassic diabases.......... 408-409

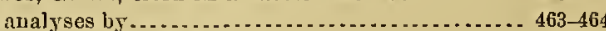

Hawley, great fault in .......................... 172

Hawley gcbist, occurrence and character of....... 163-171 possible igneous origin of . .................. 169 miceral deposits in .......................... 170-171 copper ores in ............................. 171

Hayes, S. D., analysis by ..................... $\quad 750$

Heath, pyroxene-schist from.................... 163 amphibolite from . .......................... 168

Hematite, South Hadley ....................... 486, 487

Hillelırand, W. F., aoalyses by ................... 88

Hinsdale, rocks in ........................... 19-24

Hinsdale gneiss, occurrence and character of ..... 25. 21-25

Hinsdalo limestons, oceurrence and character of . . . 20, 25-27 analysis of .......

Hitchcock, C. H., titleo and abstracts of papers on

Upper Jevoniau rocks, by .......... 253, 254, 255-257 cited on relation of limestone to quartzite in Berbardeton series.......................... 286 cited on recsnt progress in ichnology ......... . . 400-404

Hitchcock, Edward, oarly geological work of ....... 3-6 cited on metamorphism of uica-schist.......... 67-68 analyses by $\ldots \ldots \ldots \ldots \ldots \ldots \ldots \ldots \ldots \ldots . . .188-189,463,464$ titles a do ahstracts of papers on Upper Devonian rocks by. ............................... 253-255 cited on mica-granites . ...................... 312-313 cited on occurrence of syenite................. 331-334 cited on Triassic fossils ........................ 394-398 cited on trap rocks ........................... 407-408 titles of papers on Pleistocene................. 508 cited on topography of Connecticut Valley ...... 510-511 cited on glacial notches...................... $\quad 530$ cited on notable bowlders.................... 559-560 cited on nuck sand of Sunderland ............ 728

Holyoke, record of artesian well at................ 383-385 high terrace near............................ 662-663

Holyoke dam, crushed hand at.................. 370-372 section of.................................. $\quad 371$

Holyole Range, description of................. 10-11 trap rocks in ............................... $365-367$

Holy oke trap sheet............................... 446-460 diahase of ................................. 461-464 fiesured quartz deposit in . . .................. 752-753

Hoosac fault, notes on........................ 95-96 Hoosac schist, occurrence and cbaracter of .......... $66-76$ 
INDEX.

Paga

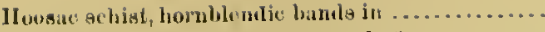

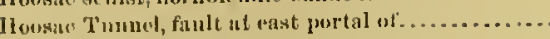

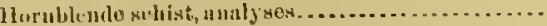

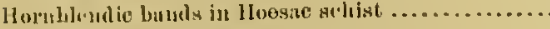

IInafionl, B., mineralogis work el'.................

Hlubbard, A. (1., cltod ..........................

Ilulson and Chester liratuite Compuny, locket, tests of granite of ..............................

I[unt, Thivil, early minuralegie work of ...........

Iluntingtum, mineral ve:u at ......................

Ifyelromica-schis

I.

I $\left(\theta_{1}\right.$, 'Triassi : . .............................. 363-361

Ico barriers, jusitions of ....................... 565

I.lymolugy: Triassie rocks ...................... $400-404$

Indiunite, leguription of...................... 130

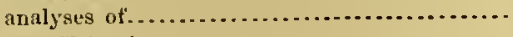

Insects, Triassic.

Iutrusive rocks in Siaroy schist..................

Irving station, section near

J.

Jackson, C. T., cited on Chester emery bed.......... 119-120 cited en cliaracter of emery at North Mountain. 138 cited on occurrence of emery at Sonth Moun-

tain .................................. 138-139 cited on eccurrence of andesine at Seuth Moun-

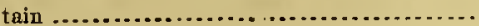

analyses by ...................................

cited on width of emery bed at South Mountain.

Julien, A A cited on mica-granites -......... 312314 cit ed on tourmaline-spedumene dikes....... 324, 325, 326 cited en meteoric alteration of recks........... $\quad 330$

K.

Kemp, J.F., cited on Becket granite

Kettle-heles, occurrence of

King, W. cited on jeints in claye...

L.

Labradorite, South Hadley

Laidley, T. T.S., repert on Chester emery ............

Lake botfome and terraces, descriptiens and ssc. tiens of..................................

Lazulite, eccurrence of......................... 758

Lee gneiss, eccurrence and character of........... . 20, 29-30

Loverett, Con way schist in.

mineral vein at. ........... 580

description of former lake in.................. 584-586

Lerorett Center, amplibelite and mica-schist series

in ................................... 220

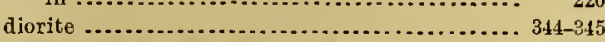

Leverett-Amherst area, description of ............ 218-225

Ley'den argillite, pretrnsion ot limestene of Conway schist through ......................... 196-197 description of ............................. 201-210

stratigraphy of.............................

boundary on Conway schiste................... 203-204

a gre of ................. 204-205

contact metamerpbism of ..................... 205-210

change to chiastelite-sclist................... 208

Lily Pond, Gill, terrace at..................... 724-725
Limestene, Ifinstalis ........................ 20, 25-27

analyses of ...........................26,27, 180

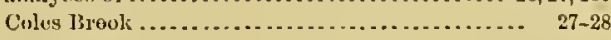

pyrexuni" ................................ 163

Conway schists.............................. 188-189

Whately . . . . . . . . . . . . . . . 191

motamorplosed liv granitito ................. 197-199

fussiliforous, description .................. 362-271

Beruardston series................... 265-267, 289-290

lutruardston ................................. 294-295

inclucled in diabase............................ 452-455

included in trap......................... $456-459$

Litliophyse, eccurrence of ...................... 436

Little Mountain, Nerthampten, trap sheet at ....... $\quad 466$

Locks Pond Lake, description of................. 556

Loess, eccurrence of.............................. 748-749

Lengmeadow sandstone, oceurrence and character of 364-369 analyses ................................. 369

Loud ville, mineral rein at . . . . . . . . . . . . . . . . . 502-50

Lewer Cambrian gneisses....................... 31-65

Lower Silurian sericite schists and amplibolites, disenssion of . .......................... 66-177

Lueas, H. S., mineralogic work of ................. cited en Chester elncry bed ............... 118,120-121

Lyman, Benjamin Smith, cited on New Red horizens. 446

M.

Magnet (The), a notable bewlder, description....... 559560

Magnetite, eccurrence of ....................... 127-128

deposits of ............................ 172-174, 175

Bernardsten series ........................ 267-268

South Hadley .............................. 487

Magnetits-emery bed, Cbester................... 117-1

1 Carble, Westfisld ............................. $92-95$ stellate (igured) ............................ 159

MTargarite, description of . ....................... 129

Mrarl and elay depesite, origin of ................ $459-460$

Masonite, description of .......................... 129

Maynard quarry, analyses of rock from ............ 369

Mrayr, Charlss, analysis by ...................... 752

Meads, William, early mineralegic paper by .........

Meriden, thin sections of "asb bed" at............ 430 analysis of pitchstene frem .................. $\$ 37$

Merrill, George P., cited on cost and strength of Triassic sandstone ............................. 394

Iresezeic time, eresion in ......................... 515-517 Metamorphism, Bernardsten series ................ 285-287

Meteric alteration of rocks.................... 330

Mica and amphibolite, Bernardston series ......... 291-293

Micaceons quartzite, descrjption of............... 46

Mica-granites, historical noteo on .................. . 312-314

Mica-Bcbist, relation of Becket gneiss to .......... $72-73$ description of .............................. 162 South Orange and New Salen. ................ 231-232 IVare.................................... 238-239 Bernardston series .............. 270-271, 276-282, 291-293 Northfield................................ 285

Mica-schjst series, descriptien of.......... 177-210, 218-220

Yiddlefiold, Heөөac schist in ................... $70-73$ serpentine in ............................ 81-85 perphyritic granitite in .................... 318-319 Mill River, Nortbampton, section of drift at........ 540 delta of ................................. 637-639

Millers Falls, dikes near....................... 412,413

Millers Falls statien, section near. . ................ 666-668

Tiller Piver, rock at mouth of................. 285-399 
Page.

Millers River delta, deseription .................... 625-629 Mineral deposits, Hawley schiet. .................. 170,171

Hiueral lexicon of Franklin, Hampshire, and Hampden counties, supplement to.............. 754-761

Mineral springs, locations of ....................... 749-752 analyses of waters of . . . . . . . . . . . . . . . . . 750-752

Mineral veias, deseription of ................... 502-507

Monroe, Hoosac schist in . . .................... 67-70

Ionson, goeiss in ....................... 15,41-45,56-65 granite quarries at........................ $60-65$

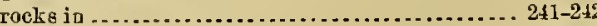

analyses of gneies from ...................... $\quad 316$

dikes in .................................... $414-415$

glass-bearing dikes in..................... 616-418

description of esker in . .................... 566-567

lake deposits in ............................. 567-569

Honson gneiss, description of.................. 15,41-15

analyses of ............................... 62

strength of . . ............................... 63

expansion inquarrying...................... 63-65

couglomerate etructure in.................. 63-65

mioeral veit in............................ 65

Mronson syncline ................................ 249-250

Monta ${ }^{2}$, Beroarlston gneiss at................. 362-363

lake deposits in ............................ 615-629

clays in ..... . . . .

terraces in ................................ 725-726

Moore's quarry, Florence, analyses of rock from.... 316

Moraines and bowlder trains..................... 549,550

Mouut Holyoke, analyses of trap from ............. $\quad 46$

lake bench on . . . . . . . . . . . . . . . . . . . . . . . . 649-650

Mount Toly conglomerate, occurrence and character

of . . ................................... 358-363

Mount Tom, faults at ........................ . $449-451$

lake beweh on . .......................... . . . 649-650

Mount Waroer, bench around .................... 648-649

Muscovite-grauite, ocenrreace and character of. .... 322-323

M nscovite-schist, description of ................. 181-18?

N.

Nash, A., mineralogic work of

citud on mica-grauites. ...................... 312, 313

Newberry, J. S., cited on Triassic fishes........... 398-399

Newell, Willian, mineralogic work of ............

New Salem, serpentine in great central syocline in . . . . ................ diorite

55,56

Niles, W. H., cited on expansion of Monson gaeiss.. 64-65

North Amberst, granite at ...................... 323 breccia at................................... 363

Northampton, record of artesiau well at .......... . 385-388 trap sheet in .............. 466 dikes in ................................. $494-49$

mineral voin at............................ 506-507 section of drift at ......................... 540

Northfield, description of se1ni-9y ucline in......... 212-216 quartzite in ............................. 28 jmica-sehist in . ........................... 285

North Granville lake, deposits of ............... 593-594

North Lererett, rocks in . ...................... 219-220

Nortb Prescott, diorite......................... 342-345

Northermer (a notable bowlder), deseription of...... $\quad 559$

$$
\text { o. }
$$

Olivine, occurrence of.......................

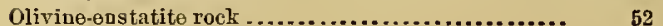

Page

Orange, gneiss in .......................... $\quad \mathbf{5 6} 6 \mathbf{6 5}$ great central sy ucline in . .................... 227-230 eastern syucline in . . . . . . . . . . . . . . . . . . . . . . 234-236 Ordway, John M., letter or Monson granite........ 62-63 Orr, William, jr., analyses by.................... 336 Osborn soapstone quarry, Blandford, section at..... $\quad 87$ analysis of serpentine from.................... 88 rocks at. .............................. 102-104 Ottrelite, description of ....................... 129 Owen, Richard, cited on Triassic reptiles............ 405

P.

Paleontology, Triassic rocks................... 391-406

Palmer. rocks in .............................

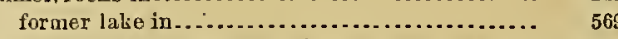
Paragenesis, secondary minerale, Deerfield sheet.... 444445 Peaked Mountain, section near . . .... . . . . . . . . . . . . . 249-25u Pegmatite, occurrence and character of.......... 322-323, 328 Pegmatite dikes and minerals ................ 216, 323-331

Pelham, gueiss in ............................. 42-45 asbestos quarry at...................... $47-5$ figures of walls of asbestós quarry at......... $\quad 48,49$ eerpentine from .......................... $\quad 55$ diabase in.............................. 413 microscopic diabase dike from............... $\$ 16-417$ section in.................................. 578 Pelham and Wilbraham, actinolite-quartzite of.... $\quad 45-47$ Pelham lake and esker, description of............ 578-584 Pelham-Shntesbury syncline, deseriptiou of........ 225-227 Peru, blue quartz of............................ 28 Pitchstone, analysie of........................ 437 Pitchstone breccia, alteration of diabase to........ $410-439$ Plagioclase-feldspars . . . . . . . . . . I'lainficld, limeston $\theta$ at........................ 192

Plant renains, Champlain clays................. 718-720 Plants, Triassic .............................. 394-398 Pleistocene period, phenomena of ................. 508-517 Pleistocene beetles of Fort River, description of . ... 740-740 Porphyritic granite, ocenrrence of ............... . . 319-320 Porphyritic granitite, ocenrrence of................ 318-319 Posterior trap sheet, deseription of. ................ $464-476$ Pot.holes, occurrence of ......................... 532-533 Proseatt, rocks in ............................... 232-233 Prochlorite, occurrence of Publications on geology and mineralogy of Franklin,

Hampsbire, and Hampden counties, list of .. 762-782 Pyrite, occurrence of . . ..................... 170-171, 759 Pyrolnsite, occurrence of....................... 75 Pyroxede, occurreace of....................... $\quad 759$ Pyroxene-schist, description of.................. 163 I'yroxene-serpentioe, Blandford .................. 104-108 Pyroxenic limestone, description of ................ 163 Pyroxenic amphibolites. . . . . . . . ................. 243-245 Pyroxenite, Blandford......................... 85-90

\section{Q.}

Quartz, nceurrence of...................... 169, 752-753,759 Quartz-diorite, occurrence and character of. . . . . . . . 331-342 Quartz-grabbro, oecurrence of..................... 331-342 Quartz-garmet rock, figare of..................... 174 Quartz veins, Charlemont ........................ 169 Quartzite, Shnteslonry.......................... 46 Warwick....................................... 227-228 Orange.................................. 228 Bermardston series .................. 268-269, 287-290 areas of.................................... 273-276 Northfiold............................... 28 
INDEX.

R.

... $405-400$

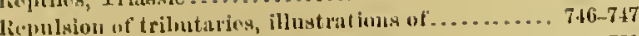

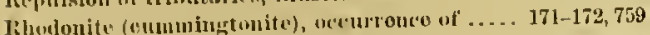
lioal untorlal, use of tral as................... $5010-501$ liosring lovok, lault at ......................... 475- 174 liock Etsu (a notulle buwkler), deacription of.....

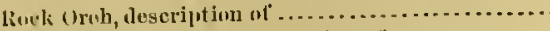
likekin stone ('l'lo), description of ............... liowe, serpreutines at...........................

liowe sehist, vecurrence and clarater of ........... section.

compured with Savoy schist .................. Rowo serpentine, section of .

Rugsell, I. C cited on action of ite in Triassis time.

Rusmell, enstatite-ser]entines in ..................

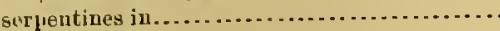

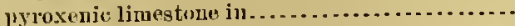
uinerul vein at

S.

Sablite changing to tremolite, figured ............ Salt, nceurrence of .

Siands, interglacial

Sandstoue, Connectic $435-436$ $439,452,455-456$ contret of diahase with .............. 439,452,455-456
gills intruded in . .......................... $469-470$

Savoy schist, occurrence and eharaeter of .. 156-163, 220-221 intrusive racks in ......................... 163

Saxonite, Mronson gneiss....................... 47-50

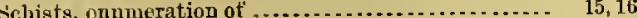
siluritn .................................. 211-252

Schliorengänge, E. Hitelacock's suggestion of the.

(t)

Sindler, s.

Sentinel (The) (a notable bowlier), description of.

Sericite-gneiss, Whately...................... 206-209

Soricite-schists and amplibolites, degcription of .... 66-177

Sericite-schist, description of.................... 103

Serpentive, Monson gneiss.................... 47-56

Pelham................................. 54,55

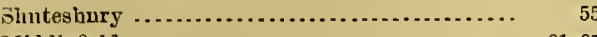

Iriddlefield ............................... 81-85

analysis.......................... 84, 88, 116-117

Chester ................................. 85

Blandford ................................ 85-90

petrographic descriptions of ................. 97-117

Westfield ............................ 92-95, 113-114

derivation o1 .............................. 115

occurrence of ................................ 760

Serpentinization, exampleg of .............. 95-96, 147-148

Shearing, Westfield uarlle quarry ............... 148

Shepard, C. U., mineralogie work of............. 5,7

cited on Chester emery mine................ 122-135 cited on occurrence of indianite at Soutl MIom

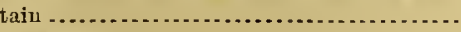

Shellourne, gneiss at........................... rocks of anticline in.........................

mineral vein at.............................

Shelburne Falls anticline, rocks of ..............

Shntesbury, serpentine from .

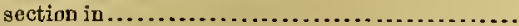

Siderite, occurreuce of.

Silliman, Benjamin, roport by, on Sonthampton leal mine
Silliman'e Journal, cited on lead mines and voins.... Page. Sills intruled in eaudetorto..................... 469-470 Silurian (Low $\cdot$ r) sericite schista and smphibolites.. 66-177 Silur iur kehiste, enst eidlo ol' valloy ............... 211-252 Sunth, J. Istwence, citerl on minerals accumpanying emery .............................. $\quad 131$ Smiths Ferty, dike at......................... 495 Sudom Mountaiu, serpentiue from .............. 114 Suvoy schiot at........................... 159 pyroxenic limestone from ................... $\quad 163$ Sontl Hadley, recorl of artesian well at............ 381-382

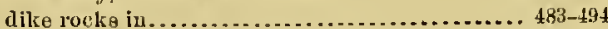
South Orauge, great central oyncline jn ........... 230-232 South Vernon, description of yange from Bernards-

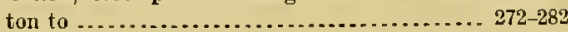
Spodumene, occurrence of ..................... 760 Springs (miveral), occurrence of................. $749-752$ analyses.............................. 750-752 Siringfield basin, terraces in.................. 729-731 Springfield lake, deposits of .................... 657-665 Springfteld lake bottom, description of............ 677 clays in ................................. 701 Springfield Republican, cited on Monson granite ituarry ............................ $60-62$ cited on Chester emery bed ..................... 120 quoted on ose of Triassic sandstone for building purposes ................................. 391-394 State Line fault, Holyoke dam ................... 370-372 Steatization, Westfield marble quarry............ $\quad 147$ Stellate marble, figure of ..................... 152 Stokes, H. N., analysis by ..................... $\quad 437$ Strix, glacial ................................. 522-531 Suess, E., cited . ........................... 13 Sugarloaf arkose, occnrrence and cbaracter of ....... 354-358 Sunny Valley lake, lescription of ................ $\quad 592$ Swift River lake, description of............... 569-575 T.

Talc, occurrence of ............................ 760 Taft, John B., reports on Chester emery made to... . 193-134 Terraces, Connecticut River ..................... 722-738 Terraces and lake botioms, detailed sections of ..... 677-696 Terrace period, Connecticut Rirer, fossils of. ...... . 738-740 "Tho Crater," North Blanford, rocks at ....... 86, 101-102 Thomas, Judson, acknowledgments to ............ 141 Till, description of ........................... $533-543$ contacts of clays and......................... 701-703

Titanite, occurrence of ........................ 761

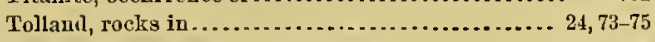
Tonalite, ocenrrence and character of ............. 331-342 analyses of ............................. 336 crushing and alteration of.................. 339-342 Topography of the region...................... 8 $8-11$

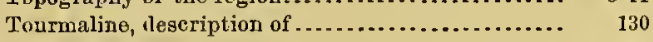

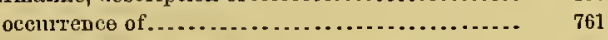

Tourmaline dendrite, Leeds..................... 316 Tonrmaline-spodumene dikes, Chesterfield........ 324-326 Trap, limestone fragments in ................... 456-459 nuderrolling of ............................. $460-461$

Trap rocks, Holyoke range . . . . . . . . . . . . . . . . . . . . 365-367 origin of glass in .......................... $437-439$

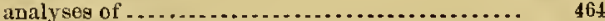
road-making use of . . . . . . . . . . . . . . . Trap sheets and foot track, possible connection between -

Tremolite ehanging to aerpentine, figured ......... 100 


\begin{tabular}{|c|c|}
\hline Tremolite rock, oceurrence of $\ldots \ldots \ldots \ldots \ldots \ldots \ldots \ldots . .108-110$ & $\begin{array}{r}\text { Page. } \\
\text { Westfield, serpentine and marble in......... 92-95, 113-114 }\end{array}$ \\
\hline Trenolitization, Westfield marble quarry .......... & Westfield, sections in ............................ 92-94 \\
\hline Triassic basin, mode of formation of . . ............. 373-379 & Westfield Little River, artesian well on........... \\
\hline Triassic beds, summary of bistory of ............. 495-500 & Westficld plain, deposits of . . . . . . . . . . $650-65 t$ \\
\hline Triassic eruptions, three epochs of. . .............. $410-411$ & Westfield River. deposits of...................... 607-608 \\
\hline Triassic eruptives, occurrenco and character of ..... 407-501 & Westfield marble quarry, enstatite-serpentine and \\
\hline Triassie glaeiers .............................. 363-364 & limestone complex nt................... 147-155 \\
\hline 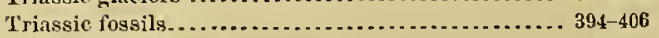 & Westfield marble quarr \\
\hline Triassic jocks, description of ............ & Westhampton, inineral reins at................ 502-504 \\
\hline gencral section of ................... & 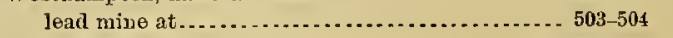 \\
\hline of & deposits of former lake in ................... $594-595$ \\
\hline Triassic sandstones, thicknesses of ................. & 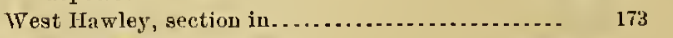 \\
\hline architectural uso of . . . . . . . . . . & Whately, amphibolite bed at . . . . . . . . . . . . 190, 198-194 \\
\hline Triassic and Glacial periods, interval between ...... 508-517 & carbonaceous limestone at . . . . . . . . . . . . . . . . \\
\hline Tuif, occurrence of .............................. 476-481 & protrnsion of Conway schist through Lejden \\
\hline Tuttaceous agglomerate, occurrence of $\ldots \ldots \ldots \ldots \ldots .476-481$ & 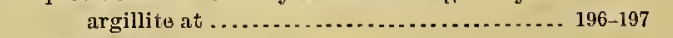 \\
\hline Turners Falls, record of artesian well at........... $380-381$ & 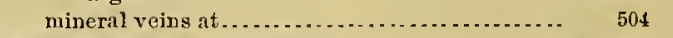 \\
\hline $\begin{array}{c}\text { mineral ruin at............................ } \\
\text { V. }\end{array}$ & $\begin{array}{r}\text { Whetstone schist, occurrence and character of .... } \begin{array}{r}186-187, \\
220-221\end{array}\end{array}$ \\
\hline Vernon limestone, areas of ...................... & Whitfield, R. P., titles and austracts of paper on \\
\hline 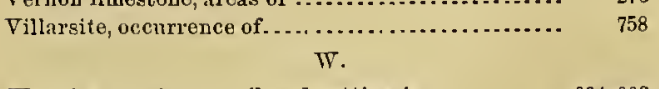 & 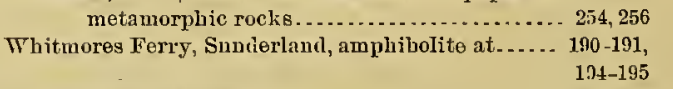 \\
\hline Wapping, section at railroad cutting in .......... & hormblende-schists at . ....................... 361-362 \\
\hline $237-239$ & Wilbraham, gneiss in ... \\
\hline 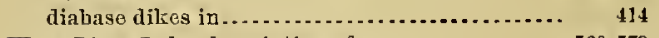 & , lescription of . $248-249$ \\
\hline Ware River Lake, description of .................. 50ิ9-573 & Wilbraham and Pelhan, actinolite-quartzite of..... \\
\hline Warwick, great central syncline in ............... 227-230 & Williansbner, mineral reins at $\ldots . . . . . . . . .$. \\
\hline ear. . . . . . . . . & 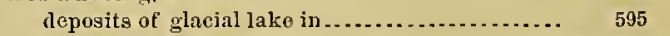 \\
\hline currence and character of.... & Williams farm, map and soctions of rocks at. .. . 263, 264, 260 \\
\hline Washington gneiss, contact with Becket gneiss..... & Williams farm section, description of . . . . . . . . 262-271 \\
\hline Washingtonite, occurrence of ................... $\quad 131$ & Worthington, amphilıolite fionı.................. \\
\hline 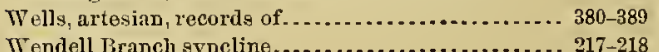 & 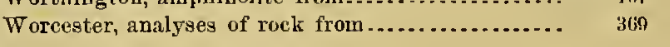 \\
\hline 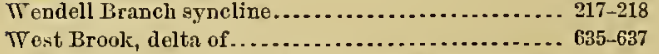 & \\
\hline $\begin{array}{l}\text { Westfield-Holjolie Railroad, trap filled with lime- } \\
\text { stone fragments along ..................... }\end{array}$ & 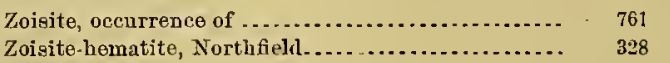 \\
\hline
\end{tabular}




\title{
ADVERTISEMENT.
}

\author{
[Nonograph $\mathrm{XXlX.]}$
}

The statute approved Mareh 3, 1879, establishing the Uniterl States Geological Survey, contains the following provisions:

"The publications of the Geologieal Survey shall consist of the aunual report of operations, geological and oconomic maj's illustrating the reson'ces and classification of the lands, and reports upon renoral and economic geology and paleontology. The amnal report of operations of the Geological Survoy shall accompany the anmual report of the Secretary of the Interior. All special memoirs and Survey shall survey shall be issned in uniform quarto series if deemed necessary by the Director, but retherts of said survey shardinary octavos. Three thousand copies of each shall be pullished for scientific exchanges and for sale at the price of publication; aud all literary and eartographic materials received in exchange shall he the property of the United States and form a part of the library of the organization: And the money resulting from the sale of such pablications shall be covered into the Treasury of the United States."

Except in those cases in which an extra number of any special memoir or report has been supplied to the Survey by special resolution of Congress or has been ordered by the Secretary of the Interior, this office has no copies for gratuitons distribution.

\section{ANNUAL REPORTS.}

I. First Annual Report of the United States Geological Survey, by Clarence King. 1880. $8^{\circ}$. 79 pp. 1 map.-A preliminary report describiug plau of organization and publications.

II. Second Anuual Report of the United States Geological Survey, 1880-'81, by J. W. Powell. 1882. $8^{\circ}$. $1 \mathrm{v}, 588 \mathrm{pp} .62 \mathrm{pl}$. 1 map.

III. Third Annnal Report of the United States Geological Survey, 1881-'82, hy J. W. Powell. 1883. $8^{\circ}$. xviii, 564 pp. $67 \mathrm{pl}$. and maps.

IV. Fourth Annual Report of the United States Geological Snrvey, 1882-'83, by J. W. Powell.

1884. $8^{\circ}$. xxxii, $473 \mathrm{pp} .85 \mathrm{pl}$. and maps.

1884. Fifth Annual Report of the United States Geological Survey, 1883-'84, by J. W. Powell. 1885. $8^{\circ}$. xxxvi, $469 \mathrm{pp}$. $58 \mathrm{pl}$. and nuaps.

VI. Sixth Annual Report of the United States Geological Survey, 1884-'85, by J. W. Powell.

1885. $8^{\circ}$. xxix, $570 \mathrm{pp} .65 \mathrm{pl}$. and maps.

VII. Seventl Anunal Report of the United States Geological Surrey, 1885-'86, by J. W. Powell.

1888. $8^{\circ}$. xx, $656 \mathrm{pp} .71 \mathrm{pl}$. and maps.

VIiI. Eighth Annnal Roport of the United States Geological Survey, 1886-'87, by J. W. Powell.

1889. $8^{\circ}$. 2 pt. xix, 474 , xii pp., 53 pl. and maps; 1 p. $1 ., 475-1063$ pp., $54-76$ pl. and maps.

IX. Ninth Aunnal Report of the United States Geological Survey, 1887-'88, by J. W. Powell.

1889. $8^{\circ}$. xiii, $717 \mathrm{pp} .88 \mathrm{pl}$ and maps.

X. Tenth Annual Report of the United States Geological Snrvey, 1888-'89, by J. W. Powell.

1890. $8^{\circ} .2$ pt. xv, 774 pp., 98 pl. and maps; riii, $123 \mathrm{pp}$.

XI. Eleventh Annual Report of the United States Geological Survey, 1889-90, by J. IV. Powell.

1891. $88^{\circ} 2 \mathrm{pt} . \mathrm{xv}, 757 \mathrm{pp.,} 66 \mathrm{pl}$. and maps; ix, $351 \mathrm{pp}$., $30 \mathrm{pl}$. and maps.

XII. Twelfth Annual Report of the United States Geological Survey, 1890-'91, by J. W. Powell.

1891. $8^{\circ} .2 \mathrm{pt.}$, xiii, $675 \mathrm{pp} ., 53 \mathrm{pl}$. and maps; x viii, $576 \mathrm{pp} ., 146 \mathrm{pl}$. and maps.

XIII. Thirteenth Annual Report of the United States Geological Survey, 1891-92, ly J. W.

Powell. 1893. $8^{\circ} .3$ pt. vii, 240 pp., 2 maps; x, 372 pp., 105 pl. and maps; xi, 486 pp., 77 pl. and maps.

XIV. Fourteenth Annual Report of the United States Geolngical Survey, 1892-93, by J. W. Powell. 1893. $8^{\circ} .2 \mathrm{pt} . \quad$ vi, $321 \mathrm{pp} ., 1 \mathrm{pl}$; $\mathrm{xx}, 597 \mathrm{pp}$., $74 \mathrm{pl}$. and maps.

XV. Fifteenth Annual Report of the United States Geological Survey, 1893-94, loy J. W. Powell.

1895. $8^{\circ}$. xiv, $755 \mathrm{pp} ., 48 \mathrm{pl}$. and maps.

XVI. Sixteenth Annual Report of the United States Geological Survey, 1894-95, Charles D. Walcott, Director. 1895. (Part I, 1896.) 80. 4 pt. xxii, 910 pp., 117 pl. and maps; xix, 598 pp., 43 pl. and maps ; xv, 646 pp., 23 pl.; xix, 735 pp., 6 pl.

XVII. Seventeenth Annual Report of the United States Geological Survey, 1895-96, Charles

D. Walcott, Director. 1896. $8^{\circ}$. 3 pt. in 4 vol. xxii, $1076 \mathrm{pp}, 67 \mathrm{pl}$. and maps; xxv, $864 \mathrm{pp} ., 113 \mathrm{pl}$ and maps; xxiii, $542 \mathrm{pp}$., 8 pl. and maps; iii, $543-1058$ pp., 9-13 pl.

XVIII. Eighteenth Annual Report of the United States Geological Survey, 1896-97, Charles D. 
Walcett, Director. 1897. (Parts II and III, 1898.) 8०. 5 pt. in 6 rol. 1-440 pp., 4 pl. and maps; i-v, 1-653 pp., $105 \mathrm{pl}$. and maps; $i-v, 1-861 \mathrm{pp}$., $118 \mathrm{pl}$. and maps; $i-x, 1-756 \mathrm{pp}$., $102 \mathrm{pl}$. ancl maps; $i-x i i$, 1-642 pp., 1 pl, ; 643-1400 pp.

\section{MONOGRAPHS.}

I. Lake Bonneville, by Grove Karl Gilbert. $1890.44^{\circ}, \quad \mathrm{xx}, 438 \mathrm{pp} .51 \mathrm{pl} . \quad 1$ map. Price \$1.50. 1I. Tertiary History of the Grand Cañon District, with Atlas, by Clarence E. Dutton, Capt., U. S. A. 1882. 4. xiv, $264 \mathrm{pl}$. $42 \mathrm{pl}$. and atlas of 24 sheets folso. Priee $\$ 10.00$.

1II. Geology of the Comstock Locle and the Washoe Distriet, with Atlas, by George F. Becker.

1882. 4. $x v, 422 \mathrm{pp} .7 \mathrm{pl}$. and atlas of 21 sheets folio. Price $\$ 11.00$.

IV. Comstock Mining and Miners, by Eliot Lord. $1883.44^{\circ}$ xiv, $451 \mathrm{pp} .3 \mathrm{pl}$. Price $\$ 1.50$. V. The Copper-liearing Rocks of Lake Superior, by Roland Duer Irving. 1883. 4०. xvi, 464 pp. $151.29 \mathrm{pl}$, and maps. Price $\$ 1.85$.

VI. Contributions to the Knowledge of the Oleler Mesozoic Flora of Virginia, by William Morris Fontaine. $1883.4^{\circ}$. xi, $144 \mathrm{pp} .541 .54 \mathrm{pl}$. Price $\$ 1.05$.

VIi. Silver-Lead Deposits of Eureka, Nevada, by Joseph Story Curtis. 1884. 40. xiii, 200 pp. $16 \mathrm{pl}$. Price $\$ 1.20$.

VIII. Paleontology of the Enreka District, by Charles Doolittle Walcott. 1884. 4. xiii, 298 pp. 24l. 24 pl. Price \$1.10.

IX. Brachiopoda and Lamellibranchiata of the Raritan Clays and Greensand Marls of New Jersey, by Robert P. Whitfield. 1885. 4․ xx, $338 \mathrm{pp} .35$ pl. 1 map. Price $\$ 1.15$.

X. Dinocerata. A Monograph of an Extinet Orier of Gigantic Mammals, by Othniel Charles Marsh. 1886. 4. xviii, 243 pp. 56 l. $56 \mathrm{pl}$. Price $\$ 2.70$.

XI. Geological History of Lake Lahoutan, a Quaternary Lake of Northwestern Nerada, by

Israel Cook Russell. 1885. 40. xiv, $288 \mathrm{pp}$. 46 pl. and maps. Price $\$ 1.75$.

XII. Geology and Mining Indnstry of Leadville, Colorado, with Atlas, by Samnel Franklin

Emmons. 1886. $4^{\circ}$. xxix, 770 pp. 45 pl. and atlas of 35 sheets folio. Price $\$ 8.40$.

XIII. Geology of the Quicksilver Deposits of the Pacific Slope, with Atlas, by George F. Becker.

1888. 40. xix, $486 \mathrm{pp} .7 \mathrm{ul}$. and atlas of 14 sheets folio. Price $\$ 2.00$.

XIV. Fossil Fishes and Fossil Plants of the Triassic Rocks of New Jersey and the Connecticut Valley, by John S. Newberry. 1888. 40. xiv, $152 \mathrm{pp} .26 \mathrm{pl}$. Price $\$ 1.00$.

XV. The Potomac or Younger Mesozoic Flora, by William Morris Fontaine. 1889. 40. xiv, $377 \mathrm{pl} .180 \mathrm{pl}$. Text and plates bound scparately. Price $\$ 2.50$.

XVI. The Paleozoic Fishes of North America, by John Strong Newberry. 1889. 40. 340 pp. 53 pl. Price $\$ \mathbf{I} .00$.

XVII. The Flora of the Dakota Gronp, a Posthumons Work, by Leo Lesquereux. Edited by

F. H. Knowlton. $1891.40 .400 \mathrm{pp} .66 \mathrm{pl}$. Price $\$ 1.10$.

XVIII. Gasteropoda and Cephalopoda of the Raritan Clays and Greeusand Marls of New Jersey, by Robert P. Whitfield. $1891.4^{\circ} .402 \mathrm{pp} .50 \mathrm{pl}$. Price $\$ 1.00$.

XIX. The Penokee Iron-Bearing Series of Northeru Wisconsin and Michigan, by Roland D. Irving and $\mathrm{C}$. R. Van Hise. 1892.40 . xix, $534 \mathrm{pp}$. Price $\$ 1.70$.

$\mathrm{XX}$. Geology of the Eurekn District, Nevada, with an Atlas, by Arnold Hague. 1892. $4^{\circ}$ xvii, $419 \mathrm{pp} .8 \mathrm{pl}$. Price $\$ 5.25$.

XXI. The Tertiarr Rhynchophorous Coleoptera of the United States, by Samuel Hubbard Scudder. 1893. $4^{\circ}$. xi, $206 \mathrm{pp}$. $12 \mathrm{pl}$. Price 90 cents.

XXII. A Manual of Topographic Methods, by Henry Gannett, Chief Topographer. 1893. $4^{\circ}$. xiv, 300 pp. 18 pl. Price $\$ 1.00$.

XXiic. Geology of the Green Monntains in Nlassachnsetts, by Raphael Pumpelly, T. Nelson Dale, and J. E. Wolff. 1894. $4^{\circ}$. xiv, $206 \mathrm{pp} .23 \mathrm{pl}$. Price $\$ 1.30$.

XXIV. Mollusca and Crustacea of the Miocene Formations of New Jersey, by Robert Parr Whitfield. 1894. 40. $193 \mathrm{pp} .24 \mathrm{pl}$. Price 90 cents.

XXV. The Glacial Lake Agassiz, by Warren Upham. $1895.4^{\circ}$. xxir, $658 \mathrm{pp} .38 \mathrm{pl}$. Price $\$ 1.70$.

XXVI. Flora of the Amboy Clays, by John Strong Newberry; a Pisthumous Work, edited by Arthur Hollick. $1895.40 .260 \mathrm{pp} .58 \mathrm{pl}$. Price $\$ 1.00$.

XXVII. Geology of the Dewver Basin in Colorndo, by Sanuel Franklin Emmons, Wrhitman Cross, and George Homans Eldridge. 1896.4 . $556 \mathrm{pp} .31 \mathrm{pl}$. Price $\$ 1.50$.

XXVlII. The Marquette Iron-Bearing District of Michigan, with Atlas, by C. R. Vall Hise and W. S. Bayley, including a Chapter on the Republic 'Trough, by H. L. Smyth. 1895. 4०. 608 pp. 35 pl. Price $\$ 5.75$

XXIX. Geology of Old Hampshire County, Hassachusetts, comprising Franklin, Hampshire, ant Hampden Connties, by Benjamin Kíendall Emerson. 1898. $4^{\circ}$. xxi, $790 \mathrm{pp} .35 \mathrm{pl}$. Price $\$ 1.90$. XXX. Fossil Meduse, by Charles Doolittle Walcott. 1898. 40. ix, $201 \mathrm{pp} .47 \mathrm{pl}$. Price $\$ 1.50$.

In preparation:

XXXI. Geology of the Aspen Mining District, Colorado, with Atlas, by Josiah Edward Spurr.

XXX1I. Geology of the Yellowstone National Park, Part II, Descriptive Geology, Petrograpliy. and Paleontology, by Arnold Hague, J. P. Iddings, W. Harvey Weed, Charles D. Walcott, G. M. Girty; T. IV. Stanton, and F. H. Knowlton. Foerste.

XXXIll. Geology of the Narragausett Basin, by N. S. Shaler, J, B. Woodworth, and Angust F. 
XXXIV. 'I'ho Glacial fravols of Maino and their Associated Deposits, ly Georgo H. Stone. llollirk

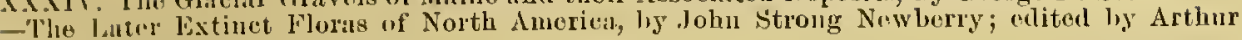
- Hora of Hu Lower Coal Mlasuros of Missouri, by David Whito.

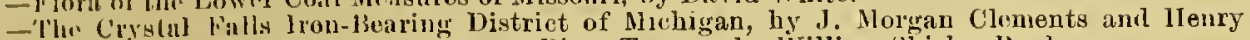
lolon Suyth; with i Chapter on tho Sturgeon River Tongue, liy Villiam shirley Bayley.

- Vianropurala, Joy O. C. Mlitsh.

-iteremantia, by O. C. Narsh.

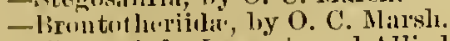

- Fora of the Laramie and Alliod Foruations, by l'rauk Hall Knowlton.

BULLITINS.

1. On IIfpersthene-Andesite and on Triclinie Pyroxene in Augitic Rocks, by Whitman Cross, with il Coulugicil Sketch of Bnftalo Peaks, Colorado, by S. F. Emmons. 1883. 80. 42 pp. 2 pl.' price 10 cents.

2. Gold and Silver Conversion Tables, giving the Coining Values of Troy Onnces of Fine Metal, etr., computerl ly Albert Willians, jr. I883. $8^{\circ}$. $8 \mathrm{pl}$. Price 5 cents.

3. On the Fossil launas of the Upper Devonian, along the lleridian of $76^{\circ} 30^{\prime}$, from 'Tompkius

Count, N. Y. to Bradford Connty, Pa., by Henry S. Williams. 1884. 80. 36 pp. Price 5 cents.

4. On Mlesozvic Fossils, by Charles A. White. 1884. 8\%. 36 pl. 9 pl. Price 5 cents.

5. A Dietionary of Altitudes in the Uuited States, compilerl by IIenry Gannett. 1884. 8०. 325 pl). Prico 20 cents.

6. Elevations in the Dominion of Cnnada, by J. W. Spencer. 1884. 8०. $43 \mathrm{pp.}$ Price 5 cents.

7. Mapoteca Geologica Amcricana. A Catalogue of Geolegical Maps of Anerica (North and South), 1752-1881, in Geographic and Chronologic Order, by Jnles Marcou and John Belknap Mareou. 1884. 8\%. 184 pN. Price 10 cents.

8. On Seconilary Enlargenlents of Mineral Fragments in Certain Rocks, by R. D. Irving and C. R. Van Hise, $1884.8^{\circ} .56 \mathrm{pp} .6 \mathrm{pl}$. Price 10 cents.

9. A Report of Work done in the Washington Laboratory duriug the Fiscal Year 1883-'84. F. W. Clarke, Chief Chemist; T. M. Chatarl, Assistant Chenist. $\quad$ I884. $8^{\circ} .40 \mathrm{pl}$. Price 5 cents.

10. On the Cambrian Fannas of North America. Preliminary Studies, by Charles Doolittle Walcott. $1881.88^{\circ} .74 \mathrm{pp}$. $10 \mathrm{pl}$. Price 5 cents.

II. On the Qnatemary and Recent Mollusea of the Great Basin; with Description of New Forms, by R. Ellsworth Call. Introduced by a Sketch of the Quaternary Lakes of the Great Basin, ly G. K. Gilbert. $1884 . \quad 8^{\circ} .66$ p). 6 pl. Price 5 cents.

12. A Crystallographic Study of the Thinolite of Lake Lahontan, by Elward S. Dana. 1884. $\overline{8}^{\circ}$. $34 \mathrm{pp} .3 \mathrm{pl}$. Price 5 cents.

13. Bonndaries of tho United States and of the Several States and Territories, with a Historieal Sketch of the Territorial Chances, by Henry Ganuett. 1885. 8०. I35 pp. Price 10 cents.

14. The Electrical aud Magnetic Properties of the Iron-Carburets, by Carl Barns and Vincent Strouhal. 1885. $8^{\circ} .238 \mathrm{pp}$. Price 15 cents.

15. On the Mesozoic and Cenozoic Paleontology of California, by Charles A. White. $1885.8^{\circ}$. 33 pp. Price 5 cents.

16. On the Higher Deronian Fannas of Ontario County, New York, by J ehn M. Clarke. $1885.8^{\circ}$. 86 pp. 3 pl. Price 5 cents.

17. On the Development of Crystallization in the Isneous Rocks of Washoe, Nevada, with Notes on the Geology of the District, by Arnold Hagne and Joseph P. Iddings. I885. 8०. 44 pp. Price 5 cents.

18. On Marine Eocene, Fresh-Water Miocene, and other Fossil Mollnsca of Western North America, br charles A. White. I885. 8०. $26 \mathrm{pp}$. 3 pl. Price 5 ecuts.

19. Netes on the Stratigrapliy of Calilornia, by George F. Becker. 1885. $8^{\circ}$. $28 \mathrm{pp}$. Price 5 cents.

20. Contributions to the Mineralogy of the Rocky Monntains, by Whitman Cross and W. F. Hillebraud. 1885. $8^{\mathrm{C}}$. $114 \mathrm{pp} .1 \mathrm{pl}$. Price 10 cents.

2I. The Lignites of the Great Sionx Reservation; a Report on the Region between the Granc and Moreau Rivers, Dakota, hy Bailey Willis. 1885. 80. 16 pl. 5 pl. I'rice 5 cents.

22. On New Ćretaceous Fossils from California, by Charles A. White. I885. 8०. 25 pp. 5 pl. Price 5 cents.

23. Observations on the Jnnetiou between the Eastern Sandstone aud the Keweenaw Series on Keweenaw Point, Lake Snperior, by R. D. Irving and T. C. Chamberlin. I885. 8. I24 pp. $17 \mathrm{pl}$. Price 15 cents.

24. List of Marine Mollusea, comprising the Quaternary Fossils and Recent Forms from American Localities between Cape Hatteras and Cape Roque, including the Bermudas, by Williau Healey Dall. 1885. $8^{\circ} .336 \mathrm{pp}$. Priee 25 cents.

25. The Present Technical Condition of the Steel Indnstry of the United States, by l'hineas

Barues. 1885. $80.85 \mathrm{pp}$. Price 10 cents.

26. Copper Smelting, by Flenry 11. Howe. 1885. $8^{\circ}$. $107 \mathrm{pp}$. Price 10 cents.
27. Report of Work done in the Division of Chemistry and Physics, mainly during the Fiscal Year I884-'85. 1886. $8^{\circ}$. $80 \mathrm{pl}$. Price 10 cents.

28. The Gabbros and Associaterl Hernlilencle Roeks occurring in the Neighborhood of Baltimore, Maryland, by George Huntington Williums. 1886. 80. 78 pl. 4 pl. Price 10 cents. 
29. On the Fresh-water Invertebrates of the North American Jurassic, by Charles A. White. 1886. 8. $41 \mathrm{pp} .4 \mathrm{pl}$. Price 5 cents.

30. Second Contribution to the Studies on the Cambrian Faunas of North America, by Charles Doolittle Walcott. $1886 . \quad 8^{\circ} .369 \mathrm{pp} .33 \mathrm{pl}$. Price 25 cents.

31. Systematic Review of onr Present Knowledge of Fossil Insects, including Myriapods and Arachnids, by Samnel IHubbard Scudder. 1886. $8^{\circ} .128$ jp. Price 15 cents.

32. Lists and Analyses of the Mineral Springs of the United States; a Preliminary Study, by Albert C. Peale. $1886.8 \circ .235 \mathrm{pp}$. Price 20 cents.

33. Notes on the Geology of Northern Califormia, by J. S. Diller. 1886. $8^{\circ}$. $23 \mathrm{pp}$. Price 5 cents. 34. On the Relation of the Laramie Molluscan Fauna to that of the Succeeding Fresh-Water Eocene and Other Groups, by Charles A. White. 1886. $8^{\circ} .54 \mathrm{pp}$. 5 pl. Price 10 cents.

35. Physical Properties of the Iron-Carburets, by Carl Barus aud Vincent Stroubal. 1886. $8^{\circ}$. 62 pp. Price 10 cents.

36. Subsidence of Fine Solid Particles in Liquids, by Carl Barus. 1886 . $8^{\circ}$. $58 \mathrm{pp}$. Price 10 cents. 37. Types of the Laramie Flora, by Lester F. Ward. $1887 . \quad 8^{\circ} .354 \mathrm{pp} .57 \mathrm{pl}$. Price 25 cents. 38. Peridotite of Elliott Connty, Kentucky, by J. S. Diller. $1887.80 .31 \mathrm{pp}$. $1 \mathrm{pl}$. Price 5 cents. 39. The Upper Beaches and Deltas of the Glacial Lake Agassiz, by Warren Upham. $1887.8^{\circ}$. 84 pp. 1 pl. Price 10 cents.

40. Changes in River Courses in Washington Territory dne to Glaciation, by Bailey Willis. 1887.

8. 10 pp. 4 pl. Price 5 cents.

41. On the Fossil Faunas of the Upper Devonian-the Genesee Section, New York, by Henry S. Williams. 1887. $8^{\circ} .121$ pp. 4 pl. Price 15 cents.

42. Report of Work done iu the Division of Chemistry and Physics, mainly during the Fiscal Year 1885-86. F. W. Clarke, Chief Chemist. 1887. $8^{\circ} .152 \mathrm{pp} .1 \mathrm{pl}$. Price 15 cents.

43. Tertiary and Cretaceons Strata of the Tuscaloosa, Tombigbee, and Alabana Rivers, by Eugene A. Smith and Lawrence C. Johnson. 1887. $8^{\circ} .189 \mathrm{pp} .21 \mathrm{pl}$. Price 15 cents.

44. Bibliography of North American Geology for 1886, by Nelson H. Darton. $1887 . \quad 8^{\circ} .35$ pp.

Price 5 cents.

45. The Present Condition of Knowledge of the Geology of Texas, by Robert T. Hill. 1887. $8^{\circ}$. 94 pp. Price 10 cents.

46. Nature and Origin of Deposits of Phosphate of Lime, by R. A. F. Penrose, jr., with an Introduction l.y N. S. Shaler. 1888. $8^{\circ} .143 \mathrm{pp}$. Price 15 cents.

47. Analyses of Waters of the Yellowstone National Park, with an Acconnt of the Methods of Analysis employed, by Frank Austin Gooch and James Edward Whitfield. 1888. 8०. 84 pp. Price 10 cents.

48. On the Form and Position of the Sea Level, by Robert Simpson Woodward. 1888. $8^{\circ} .88$ pp. Price 10 cents.

49. Latitudes and Lougitudes of Certain Points in Missonri, Kansas, and Now Mexico, by Robert

Simpson Woorlward. 1889. $8^{\circ} .133 \mathrm{pp}$. Price 15 cents.

50. Formulas and Tables to Facilitate the Construction and Use of Maps, by Robert Simpson Woodward. $1889.8^{\circ}$. 124 pp. Price 15 cents.

51. On Invertebrate Fossils from the Pacific Coast, by Charles Abiathar White. 1889. $8^{\circ} .102$

pp. $14 \mathrm{pl}$. Price 15 cents.

52. Subaërial Decay of Rocks and Origin of the Red Color of Certain Formations, by Israel

Cook Russell. $1889.88^{\circ} 65 \mathrm{pp} .5 \mathrm{pl}$. Price 10 cents.

53. The Geology of Nantucket, by Nathaniel Southgate Shaler. 1889. $8^{\circ}$. 55 pp. 10 pl. Price 10 cents.

54. On the Thermo-Electric Measnrement of High Temperatures, by Carl Barus. 1889. $8^{\circ}$. $313 \mathrm{pp}$., incl. $1 \mathrm{pl}$. $11 \mathrm{pl}$. Price 25 cents.

55. Report of Work done in the Division of Chemistry and Physics, mainly during the Fiscal

Year 1886-'87. Frank Wigglesw orth Clarke, Chief Chemist. $1889.88^{\circ} .96 \mathrm{pp}$. Price 10 cents.

56. Fossil Woorl aud Lignite of the Potomac Formation, by Frank Hall Knowlton. $1889.8^{\circ}$. $72 \mathrm{pp} .7 \mathrm{pl}$. Price 10 cents.

57. A Geological Reconnoissance in Southwestern Kansas, by Robert Hay. $1890 . \quad 8^{\circ} .49$ pp.

2 pl. Price 5 cents.

58. The Glacial Boundary in Western Pennsylvania, Ohio, Kentucky, Indiana, and Illinois, by George Frederick Wright, with an Introdnction by Thomas Chrowder Chamberlin. $1890.8^{\circ} .112$ pp., incl. $1 \mathrm{pl} .8 \mathrm{pl}$. Price 15 cents.

59. The Gabbros and Associated Rocks in Delaware, by Frederick D. Chester. 1890. $8^{\circ} .45$ pp. 1 pl. Price 10 cents.

60. Report of Work done in the Division of Chemistry and Physics, mainly during the Fiscal

Year 1887-'88. F. W. Clarke, Chief Chemist. 1890. 8०. $174 \mathrm{pp.} \mathrm{Price} 15$ cents.

61. Contributions to the Mineralogy of the Pacific Coast, by William Harlow Melville and Waldemar Lindgren. $1890.8^{\circ} .40 \mathrm{pp} .3 \mathrm{pl}$. Price 5 cents.

62. The Greenstone Schist Areas of the Menominee and Marquette Regions of Michigan, a Contribution to the Subject of Dynamic Metamorphism in Eruptive Rocks, by George Huntington Williams, with an Introduction ly Roland Duer Irving. 1890. $8^{\circ}$. $241 \mathrm{pp}$. $16 \mathrm{pl}$. Price 30 cents.

63. A Bibliography of Paleozoic Crustacea from 1698 to 1889 , including a List of North American Species and a Systematic Arrangement of Genera, by Anthony W. Vogdes. $1890.8^{\circ} .177 \mathrm{pp}$. Price 15 cents. 
61. A Report of Work done in the Division of Chemistry and Physirs, mainly inring the Fiscal

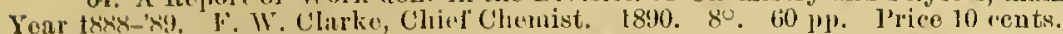

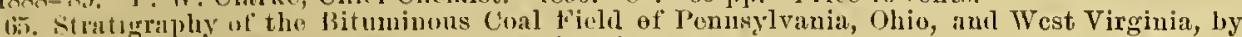

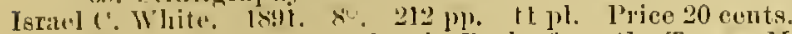

dit. On a Cirmp of Volcanic Rocks from the Tewan Mountains, New Mexico, and on the Ocourrence of l'rimary (Yuirtz in Certain Basalts, by Joseph Paxson lddings. 1890. 80. 3.t pp. Price 5 cents.

67. The lielations of the Traps of the Newark System in the New Jersey Region, by Nelson Iloratio Dat'ton. isyo. 8 . 82 l'p'. l'rico 10 cents. cents.

68. Eurthinulies in California in 1889, by James Edward Keeler. 1890. $8^{\circ} .25$ pp. Price 5

69. A Classed and Annotated Biograplyy of Fossil Insects, Jy Samuel Howard Scudder. 1890 8०. 101 pp. Price 15 cents.

70. A Rejurt on Astronomical Work of 1889 and 1890, by Rolvert Simpson Woodward. 1890. $8^{\circ}$. 79 1'p. l'rieo 10 cents.

7t. Index to tho known Fossil Insects of the World, including Myriapods and Arachnils, by

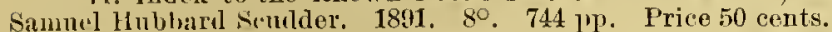

72. Altitude's between Lako Superior and the Rocky Mountains, by Warren Upham. 1891. $8^{\circ}$. 229 plp. prive 20 cents.

73. The Viseosity of Solids, by Carl Barus. 1891. 80. xii, 139 pp. 6 pl. Price 15 cents. 15 cents.

74. The Mlinerals of North Carolina, by Frederick Augustus Genth. $1891 . \quad 8^{\circ} .119 \mathrm{pp}$. Price

5. Recorl of North American Geology for 1887 to 1889, inclusive, by Nelson Horatio Darton.

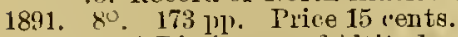

76. A Dictionary of Altitudes in the United States (Second Edition), compiled by Henry Gannett,

Chief 'toplographer. 1891. $8^{\circ}$. 393 pp. Price 25 cents.

77. The Texan Permian and its Mesozoic Types of Fossils, by Charles A. White. 1891. $8^{\circ} .51$

pp. 4 pl. Price 10 cents.

78. A Report of Work done in the Division of Chemistry and Physics, mainly during the Fiscal

Year 1889-90. F. W. Clarke, Chiet' Chemist. 1891. 80. 131 pl. Price 15 cents.

79. A Late Volcanic Eruption in Northern California and its Peculiar Lava, by . S. S. Diller.

80. Correlation Papers-Devonian and Carboniferons, ly Henry Shaler Williams. $1891.8^{\circ}$.

279 pl. Price 20 cents.

81. Correlation Papers-Cambrian, by Charles Doolittle Waleott. 1891. 8०. 547 pp. 3 pl. Price 25 cents.

cents.

82. Correlation Papers-Cretaceous, by Charles A. White. 1891. 8०. 273 pp. 3 pl. Price 20

83. Correlation Papers-Eocene, by William Bnllock Clark. 1891. 8․ 173 pp. 2 pl. Price

15 cents. Correlation Papers-Neocene, by W. H. Dall and G. D. Harris. 1892. 8. 349 pp. 3 pl.

Price 25 cents.

85. Correlation Papers-The Newark System, by Israel Cook Russell. 1892. $8^{\circ}$. 344 pp. 13 pl.

Price 25 cents.

86. Correlation Papers-Archean and Algonkian, by C. R. Van Hise. $1892 . \quad 8^{\circ}$. 549 pp. $12 \mathrm{pl}$.

Price 25 cents.

87. A Synopsis of American Fossil. Brachiopoda, including Bibliography and Synonymy, by

Charles Schuchert. 1897. $8^{\circ} .464 \mathrm{pp}$. Price 30 cents.

88. The Cretaceons Foraminifera of New Jersey, by Rufus Mather Bagg, Jr. $\quad$ 1898. $8 \circ .88$ pp.

$6 \mathrm{pl}$. Price 10 cents.

89. Some Lava Flows of the Testern Slope of the Sierra Nevarla, California, by F. Leslie

Ransome. 1898. $8^{\circ} .74 \mathrm{pp} .11 \mathrm{pl}$. Price 15 cents.

90. A Report of Work done in the Division of Chemistry and Physies, mainly during the Fiscal

Year 1890-91. F. W. Clarke, Chief Chemist. 1892. 80. $77 \mathrm{pp}$. Price 10 cents.

91. Record of North American Geology for 1890, by Nolson Horatio Dartun. 1891. $8^{\circ} .88 \mathrm{pp}$.

Price 10 cents.

92. The Compressibility of Lirmirls, by Carl Barns. 1892. 8०. $96 \mathrm{pp} .29 \mathrm{pl}$. Price 10 cents. 93. Some Insects of Special Interest trom Florissant, Colorado, and Otlier l'oin ts in the Tertiaries

of Colorado and Utah, by Sammel Hubbard Scudder. 1892. 8. 35 pp. 3 pl. Price 5 cents. 94. The Mechanism of Solicl Viscosity, by Carl Bartus. 1892. 80. 138 pl. Price 15 cents.

95. Earthquakes in California in 1890 and 1891, by EdwarJ Singleton Holden. 1892. $8^{\circ} .31 \mathrm{pp.}$

Price 5 cents.

96. The Volume Thermodynanics of Liquicls, hy Carl Barns. 1892. 8. $100 \mathrm{pp}$. Price 10 cents. 97. The Mesozoic Echinoilermata of the United States, by W. B. Clark. 1893. 8०. 207 pp. $50 \mathrm{pl}$.

Price 20 cents.

98. Flora of the Outlying Carboniferous Basins of Sonthwestern Missouri, by David White.

1893. 8०. $139 \mathrm{pp}$. 5 pl. Price 15 cents.

99. Record of North American Geology for 1891, by Nelson Horatio Darton. 1892. $8^{\circ} .73 \mathrm{pp}$.

Price 10 cents.

100. Bibliography and Index of the Publications of the U. S. Geological Survey, 1879-1892, by

Philip Creveling Wrarman. 1893. 80.495 pp. Price 25 cents.

101. Insect Fauna of the Rhode Islind Coal Field, by Samuel Hubbart Scudder. 1893. $8^{\circ}$

$27 \mathrm{pp} .2 \mathrm{pl}$. Price 5 cents. 
102. A Catalogue and Bibliography of North American Mesozoic Invertebrata, hy Cornelius Breckinridge Boyle. 1892. $8^{\circ}$. 315 pp. Prise 25 cents.

103. High Temperature Work in Igueous Fusion and Elullition, chiefly in Relation to Pressure, hy Carl Barus. $1893.8^{\circ} .57 \mathrm{pp} .9 \mathrm{pl}$. Price 10 cents.

104. Glaciation of the Yellowstone Valley north of the Park, lyy Walter Harvey Weed. 1893. $8^{\circ}$. 41 pp. 4 pl. Price 5 cents.

105. The Laramie and the Overlying Livingstone Formation in Montana, hy Walter Harvey

Weecl, with Report on Flora, hy Franl Hall Knowlton. $1893.8^{\circ} 68 \mathrm{pp} .6 \mathrm{pl}$. Price 10 cents. 106. The Colorado Formation and its lnvertebrate Fauna, by T. W. Stanton. 1893. 8०. 288

pp. 45 pl. Price 20 cents.

107. The Trap Dikes of the Lake Champlain Region, hy James Furman Kemp and Vernon

Freeman Mausters. 1893. 8 . 62 pp. 4 pl. Price 10 cents.

108. A Geological Reconnoissance in Central Washington, hy Israel Cook Russell. 1893. $8^{\cup}$. $108 \mathrm{pp} .12 \mathrm{pl}$. Price 15 cents.

109. The Eruptivo and Sedimentary Rocks on Pigeon Point, Minnesota, and their Contact Phenomena, hy Williaw Slirley Bayley. 1893. $8^{\circ} .121 \mathrm{pp} .16 \mathrm{pl}$. Price 15 cents.

110. The Paleozoie Section in the Vicinity of Three Forks, Montana, by Albert Charles Peale. 893. $8^{\circ} .56 \mathrm{pp} .6 \mathrm{pl}$. Price 10 cents.

111. Geology of the Big Stone Gap Coal Fields of Virginia and Kentucky, by Marius R. Camp-

bell. $1893.8^{\circ} .106 \mathrm{pp} .6 \mathrm{pl}$. Price 15 cents.

112. Earthquakes in California in 1892, by Charles D. Perrine. 1893. $8^{\circ}$. 57 pp. Price 10 cents.

113. A Report of Work done in the Division of Chemistry during the Fiscal Years $1891-92$ and

1892-93. F. W. Clarke, Chief Chemist. 1893. $8^{\circ}$. 115 pp. Price 15 cents.

114. Earthquakes in California in 1893, by Char]es D. Perrine. 1894. $8^{\circ} .23$ pp. Price 5 cents. 5 cents.

115. A Geographic Dictionary of Rhode Island, hy Henry Gannett. 1894. 80. 31 pp. Price

116. A Geographic Dictionary of Massachusetts, hy Henry Gannett. 1894. $8^{\circ}$. 126 pp. Price 15 cents.

117. A Geographic Dictionary of Connectient, by Henry Gannett. 1894. $8^{\circ}$. 57 pp. Price 10 cents.

118. A Geographic Dictionary of New Jersey, by Henry Gannett. 1894. $8^{\circ}$. 131 pp. Price 15 cents.

119. A Geological Reconnoissance in Northwest Wyoming, by George Homans Fldridge. 1894. 8. $72 \mathrm{pp}$. Price 10 cents.

120. The Devonian System of Eastern Pennyslvania and New York, hy Charles S. Prosser. 1894.

8. 81 p. 2 pl. Price 10 cents.

121. A Bibliography of North American Paleontology, hy Charles Rollin Keyes. 1894. 80. 251

pp. Price 20 cents.

122. Results of Primary Triangulation, by Henry Gannett. 1894. $8^{\circ} .412$ pp. 17 pl. Price 25 cents.

15 cents.

23. A Dictionary of Geographic Positions, by Henry Gannett. $1895 . \quad 8^{\circ}$. 183 pp. 1 pl. Price

124. Revision of North American Fossil Cockroaches, by Samuel Hubhard Scudder. $1895 . \quad 8^{\circ}$.

$176 \mathrm{pp} .12 \mathrm{pl}$. Price 15 cents.

125. The Constitution of the Silicates, by Frank Wigglesworth Clarke. 1895. $8^{\circ}$. 109 pp.

Price 15 cents.

126. A Mineralogical Lexicon of Franklin, Hampshire, and Hampden connties, Massachusetts, by Benjamin Kendall Emerson. $1895.8^{\circ} .180 \mathrm{pp}$. 1 pl. Price 15 cents.

127. Catalogue and Index of Contributions to North American Geology, 1732-1891, by Nelson

Horatio Darton. $1896.8 \circ .1045$ pp. Price 60 cents.

128. The Bear River Formation and its Characteristic Fauna, by Charles A. White. $1895.8^{\circ}$.

$108 \mathrm{pp}$. $11 \mathrm{pl}$. Price 15 cents.

129. Earthquakes in California in 1894, by Charles D. Perrine. $1895.8^{\circ} .25$ pp. Price 5 cents. 130. BibJiography and Index of North American Geology, Paleontology, Petrology, and Mineralogy for 1892 and 1893 , by Fred Boughton Weeks. 1896. $8^{\circ} .210 \mathrm{pp}$. Price 20 cents.

131. Report of Progress of the Division of Hydrography for the Calendar Years 1893 and 1894,

by Frederick Haynes Newell, 'Topographer iu Charge. 1895. 8c. 126 pp. Price 15 cents. 132. The Disseminated Lead Ores of Sontheastern Missouri, by Arthur Winslow. $1896.8^{\circ}$.

$31 \mathrm{pp}$. Price 5 cents.

133. Contrihutions to the Cretaceous Paleontology of the Pacific Coast: The Fanna of the

Knoxville Beds, by T. W. Stanton. $1895,80.132 \mathrm{pp} .20 \mathrm{pl}$. Price 15 cents.

134. The Cambrian Rocks of Pennsylvania, by Charles Doolittle Walcott. $1896.8^{\circ} .43$ pp.

$15 \mathrm{pl}$. Price 5 cents.

135. Bibliography and Index of North American Geology, Paleontology, Petrology, and Mineralogy for the Year 1894, by F. B. Weeks. 1896. $8^{\circ}$. $141 \mathrm{pp}$. Price 15 cents.

136. Volcanic Rocks of South Mountain, Pennsylvania, by Florence Bascom. 1896. 80. 124 pp.

$28 \mathrm{pl}$. Price 15 cents.

137. 'The Geology of the Fort Riley Military Reservation and Vicinity, Kansas, by Robert Hay.

1896. $8^{\circ}$. $35 \mathrm{pp} .8 \mathrm{pl}$. Price 5 cents.

138. Artesian-well Prospects in the Atlantic Coastal Plain Region, by N. H. Darton. $1896.8^{\circ}$.

$228 \mathrm{pp} .19 \mathrm{pl}$. Price 20 cents.

139. Geology of the Castle Monntain Mining District, Montana, hy W. I. Weed and L. V. Pirs-

son. 1896. $8 \circ .164 \mathrm{pp} .17 \mathrm{pl}$. Price 15 cents. 
110. Report of Progress of the Division of Hycirography for the Calendar Year 1895, by Fredlerick

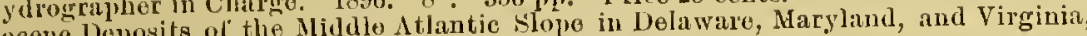
111. Tho lioceno boposits of the Midale $40 \mathrm{pl}$. P'rice 15 ronts.

by Willimu Bullock Clark. 1896. 8 . 167 pl. 40 pl. Paleontology of North western Lonisiani, hy 1.12. A Briel Contribution to the Goology and Paleontols.

T. Wayland Vaughan. 1896.80 .65 p 4 pl. Price 10 cents. 143. A 13 ith

Price 15 conts.

1896. $80.71 \mathrm{pp} .21 \mathrm{pl}$. Price 10 cents. 145 . The Potomac lormation in Virginia, by W. M. lontaine. 1896. $8^{\circ} .149 \mathrm{pp} .2 \mathrm{pl}$. Price 15 cents.

1t6. Bibliography and Index of North American Geology, Paleontology, Petrology, and Mineralow for the Yoar 1895 , by F. B. Weelss. 1896. $8^{\circ}$. 130 pp. Price 15 cents.

147. Vartheuakes in Calitornia in 1895 , by Charles D). Perrine, $\Lambda$ ssistant Astronomer in Charge

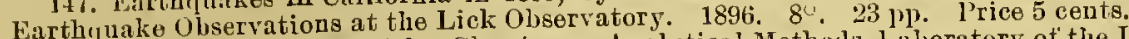

18 Lulyses of Locks, with a Chapter on Analytical Methods, Laboratory of the United States Geological survey, 1880 to 1896, by F. W. Clarks and W. F. Hillelnand. 1897. 80. 306 pl. Price 20 c'ents.

19. Bibliography and Index of North Ameriean Geology, Paleontology, Petrology, and Miner-

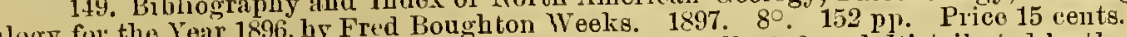

150. The Elucationil Series of Rock Specimens Collected aud Distributed by the United States Geologrical Survey, by Joseph Silas Diller. 1898. $8^{\circ}$. $398 \mathrm{pp} .47 \mathrm{pl}$. Price 25 cents.

In pres8: The Lower Cretaceons Gryphinas of the Texas Region, by R. T. Hill and T. Waylancl 151. The Lower Crotaceons

Vatughan. 1898. 152. A Cataloginol cents.

1898. 8. A Bibliomraphic Index of North American Carboniferous Invertebrates, by Stuart IVeller. 1898. $8^{\circ}$. pp. Price cents.

\section{IVATER-SUPPLY AND IRRIGATION PAPERS.}

By act of Congress approved June 11, 1896, the followinc provision was made:

"Prot streams and to the methods of ntilizing the water resources may be prin'ed in octavo form, not to

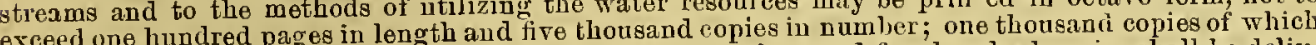
exceed one hundred pages in length and five thotsand copies in number; one thotisand copies of which shall be for the otficial use of the Gcological snrvey, one shall be delivered to the House of Representatives, for distribution."

Under this law the following papers have been issued:

1. Pumping Water for Irrigation, by Herbert M. "ilson. $1896 . \quad 8 \circ .57$ pp. 9 pl.

1. Prrigation near Phœnix, Arizona, by Arthur P. Davis. 1897. 8. $97 \mathrm{pp} .31 \mathrm{pl}$.

3. Sewage Irrigation, by George W. Rafter. 1897. 8. 100 pp. 4 pl.

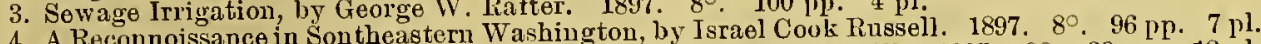

4. A Reconnoissance in Sontheastern Washiugton, by Israel Cook Russell. $1897.80 .96 \mathrm{pp} .7 \mathrm{pl}$.

5. Irrigation Practice on the Great Plains, by Elias 3ranson Cowgill. 1897. 8 . $39 \mathrm{pp} .12 \mathrm{pl}$.

7. Seepage Waters of Northern Utab, by Samuel lortier. $1897.8^{\circ} .50 \mathrm{pp} .3 \mathrm{pl}$.

7. Seepage Waters of Northern Ut, IVindmills tor Irrigation, by Edward Charles Murphy. $1897.80^{\circ} .49 \mathrm{pp} .8 \mathrm{pl}$

8. Windmills tor Irrigation, by Edward Charies Burphy. 189.890 . 90 pp. $21 \mathrm{pl}$.

10. Irriotion in Mesilla Valley, New Mexico, by F. C. Barker. 1898. 8. 51 pp. 11 pl.

11. River Heights for 1896, by Arthur P. Davis. $1897.8 \% 100 \mathrm{pp}$.

In press:

12. Water Resources of Southeastern Nebraska, by Nelson H. Darton. $1898 . \quad 8^{\circ} .55 \mathrm{pp} .21 \mathrm{p}$.

13. Irrigation Systems in 'Texas, by William Ferguson Hutson. $1898.80 .67 \mathrm{pl}$. $10 \mathrm{pl}$

14. Nem Tests of Certain Pumps and Vater-Lifts used in Irrigation, ly Ozm P. Hood. $1889.88^{\circ}$.

pp. 1 pl.

15. Operations at River Stations, 1897, Part I. 1898. $8^{\circ} .100 \mathrm{pp}$.

16. Operations at River Statious, 1897, Part II. 1898. $8^{\circ}$. 101-200 pp.

\section{TOPOGRAPHIC MAP OF THE UNITED STATES.}

When, in 1882, the Geological Survey was directed by law to make a geologic map of the United States there was in existence no suitablo topographic map to serve as a base for the geologic map. The preparation of such a topographic map was therefore immediately begun. A bout one-fith of the The preparation of such a topographic map was therefore immediately ocgun. A sout onsed in atlas area of the conntry, excluding Alaska, has now heen thus mapped. The map is published in atlas sheets, each sheet representing a small quadrangular district, as explinned under the following heading. The separate sheets are sold at 5 cents each when fewer than 100 copies are purchased, but whell they are ordered in lots of 100 or more copies, whether of the same sheet or of different sheets, the they are ordered in lots of 100 or more copies, whether of the searly every State being representecl. price is 2 cents each. The mapped areas are widely scattered, nearly every State being representeds "List of Publications," a pamphlet which may be had ou application. 


\section{GEOLOGIC ATLAS OF THE UNITED STATES.}

The Geologic Atlas of whe United States is the final form of publication of the topographic and geologic maps. The atlas is issued in parts, progressively as the surveys are extended, and is designed ultimately to cover the entire country.

Under the plan adopted the entire area of the country is divided into small rectangular districts (designated quadrangles), bounded by certain meridians and parallels. The unit of survey is also the unit of publication, and the maps and descriptions of each rectangular district are issued as a folio of the Geologic Atlas.

Each folio contains topographic, geologic, economic, and structural maps, together with textual descriptious and explanations, and is designated by the name of a principal town or of a prominent natural feature within the district.

Two forms of issue have been adopted, a "library edition" and a "field edition." In both the sheets are bound between heavy paper covers, but the library copies are permanently bound, while the sheets and covers of the field copies are only temporarily wired together.

Under the law a copy of each folio is sent to certain pnblic libraries and educational institutions. The remainder are sold at 25 cents each, except such as contain an unusual amount of matter which are priced accordingly. Prepayment is obligatory. The folios ready for distribution are listed helow.

\begin{tabular}{|c|c|c|c|c|c|c|}
\hline No.! & Name of sheet. & State. & Limiting meridians. & Limiting parallels. & $\begin{array}{l}\text { Area, in } \\
\text { square } \\
\text { miles. }\end{array}$ & $\begin{array}{l}\text { Price, } \\
\text { in } \\
\text { cents. }\end{array}$ \\
\hline 1 & Livingston .. & Montana.. & $110^{\circ}-111^{\circ}$ & $45^{\circ}-46^{\circ}$ & 3,354 & 25 \\
\hline 2 & Ringgold & $\left\{\begin{array}{l}\text { Georgia..... } \\
\text { Tennessee. }\end{array}\right.$ & $85^{\circ}-85^{\circ} 30^{\prime}$ & $34^{\circ} 20^{\prime}-35^{\circ}$ & 980 & 25 \\
\hline 3 & Placerrille.... & $\begin{array}{l}\text { California. } \\
\text { Tennessee . . . . }\end{array}$ & $\begin{array}{r}120^{\circ} 30^{\prime}-121^{\circ} \\
80^{\circ} 3 m^{\prime}-85^{\circ}\end{array}$ & $\begin{array}{l}38^{\circ} 30^{\prime}-39^{\circ} \\
35^{\circ} 30^{\prime}-36^{\circ}\end{array}$ & $\begin{array}{l}932 \\
969\end{array}$ & $\begin{array}{l}25 \\
25\end{array}$ \\
\hline $\begin{array}{l}4 \\
5\end{array}$ & Sneramento & California . . ..... & $121^{\circ}-121^{\circ} 30^{\prime}$ & $38^{\circ} 30^{\prime}-39^{\circ}$ & 932 & 25 \\
\hline 6 & Chattanooga. & Tennessee. & $85^{\circ}-85^{\circ} \quad 30^{\prime}$ & $35^{\circ}-35^{\circ} 30^{\prime}$ & 975 & 25 \\
\hline 7 & Pikes Peak rout & Colorado.. & $105^{\circ}-105^{\circ} 30^{\prime}$ & $38^{\circ} 30^{\prime}-39^{\circ}$ & 932 & 25 \\
\hline 8 & Sewanee........ & Tennessee ....... & $\begin{array}{r}85^{\circ} 30^{\prime}-86^{\circ} \\
1066^{\circ}-105^{\circ} \quad 15^{\prime}\end{array}$ & $\begin{array}{l}35^{\circ}-35^{\circ} 30^{\prime} \\
38^{\prime}-45^{\prime}-39^{\circ}\end{array}$ & 975 & 25 \\
\hline 9 & Anthracite-Crest & $\begin{array}{l}\text { Colorado } \\
\text { Virginia }\end{array}$ & $106^{\circ} 45^{\prime}-107^{(12} 15^{\prime}$ & $38-4 b^{\prime}-3 y^{\circ}$ & & 50 \\
\hline 10 & Harpers Ferr & $\left\{\begin{array}{l}\text { West Virginia .. } \\
\text { SIaryland........ }\end{array}\right.$ & $77^{\circ} 30^{\prime}-78^{\circ}$ & $39^{\circ}-39^{\circ} 30^{\prime}$ & 925 & 25 \\
\hline 11 & Jackson .. & $\begin{array}{l}\text { California...... } \\
\text { Virginia }\end{array}$ & $120^{\circ} 30^{\prime}-121^{\circ}$ & $38^{\circ}-38^{\circ} 30^{\prime}$ & 938 & $2 \overline{5}$ \\
\hline 12 & Estillville & $\left\{\begin{array}{l}\text { Kentncky } . . . . . . \\
\text { T'ennesseo ..... }\end{array}\right.$ & $82^{\circ} 30^{\prime}-83^{\circ}$ & $366^{\circ} 30^{\prime}-37^{\circ}$ & 957 & $\therefore 5$ \\
\hline 13 & Fredericksbu & $\left\{\begin{array}{l}\text { Mrarglañd . . . . . } \\
\text { Virginia ...... }\end{array}\right.$ & $77^{\circ}-77^{\circ} 30^{\prime}$ & $38^{\circ}-38^{\circ} 30^{\prime}$ & 938 & 25 \\
\hline 14 & Staunton ... & $\left\{\begin{array}{l}\text { Virginia .......... } \\
\text { W est Virginia.. }\end{array}\right.$ & $79^{\circ}-79^{\circ} 30^{\prime}$ & $38^{\circ}-38^{\circ} 30^{\prime}$ & 938 & 25 \\
\hline 15 & Lassen Peak.. & California...... & $121^{\circ}-122^{\circ}$ & $40^{\circ}-41^{\circ}$ & 3,634 & 25 \\
\hline 16 & Knoxville.. & $\left\{\begin{array}{l}\text { Tennessee } \\
\text { North Carolina. }\end{array}\right.$ & $83^{\circ} 30^{\prime}-84^{\circ}$ & $35^{\circ} 30^{t}-36^{\circ}$ & 925 & 25 \\
\hline 17 & Marysville. & California....... & $121^{\circ} 30^{\prime}-122^{\circ}$ & $39^{\circ}-39^{\circ} 30^{\prime}$ & 925 & 25 \\
\hline 18 & Smartsville. & $\begin{array}{l}\text { California....... } \\
\text { Alabama........ }\end{array}$ & $121^{\circ}-121^{\circ} 30^{\prime}$ & $39^{\circ}-39^{\circ} 30^{\prime}$ & 925 & 25 \\
\hline 19 & Stevenoon & $\left\{\begin{array}{l}\text { Georgia..... } \\
\text { Tennessee .. }\end{array}\right.$ & $85^{\circ} 30^{\prime}-86^{\circ}$ & $34^{\circ} 30^{\prime}-35^{\circ}$ & 980 & 25 \\
\hline 20 & Cleveland. & Tennessee. & $84^{\circ} 30^{\prime}-85^{\circ}$ & $35^{\circ}-35^{\circ} 30^{\prime}$ & 975 & 25 \\
\hline 21 & Pike & $8 s 8 e 8$. & $85^{\circ}-85^{\circ} 30^{\prime}$ & $35^{\circ} 30^{\prime}-36^{\circ}$ & 969 & 25 \\
\hline 22 & McMinnville & Tennessee & $85^{\circ} 30^{\prime}-86^{\circ}$ & $35^{\circ} 30^{\prime}-36^{\circ}$ & 969 & 25 \\
\hline 23 & Nomini.... & $\left\{\begin{array}{l}\text { Marsland . } \\
\text { Virginia... }\end{array}\right.$ & $76^{\circ} 30^{\prime}-77^{\circ}$ & $38^{\circ}-38^{\circ} 30^{\prime}$ & 938 & 25 \\
\hline $\begin{array}{l}24 \\
25\end{array}$ & $\begin{array}{l}\text { Three Forks. } \\
\text { Loudon...... }\end{array}$ & $\begin{array}{l}\text { Montana........ } \\
\text { Tennessee ...... }\end{array}$ & $\begin{array}{r}111^{\circ}-112^{\circ} \\
84^{\circ}-81^{\circ} 30^{\prime}\end{array}$ & $35^{\circ} \begin{array}{r}45^{\circ}-46^{\circ} \\
30^{\prime}-36^{\circ}\end{array}$ & $\begin{array}{r}3,354 \\
969\end{array}$ & $\begin{array}{l}50 \\
25\end{array}$ \\
\hline 26 & Pocahontas.. & 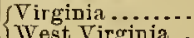 & $81^{\circ}-81^{\circ} 30^{\prime}$ & $37^{\circ}-37^{\circ} 30^{\prime}$ & 951 & 25 \\
\hline 27 & Morriatown.. & Tennessee...... & $83^{\circ}-83^{\circ} 30^{\prime}$ & $36^{\circ}-36^{\circ} 30^{\prime}$ & 963 & 25 \\
\hline 28 & Piedmont & $\left\{\begin{array}{l}\text { Maryland } \\
\text { West Viro }\end{array}\right.$ & $79^{\circ}-79^{\circ} \quad 30^{\prime}$ & $39^{\circ}-39^{\circ} 30^{\prime}$ & 925 & 25 \\
\hline 29 & Nevada City... $\left\{\begin{array}{l}\text { Nerada City } \\
\text { Grass Valley } \\
\text { Banner Hill }\end{array}\right\}$ & California & $\left\{\begin{array}{lllll}121^{\circ} & 00^{\prime} & 25^{\prime \prime}-121^{\circ} & 03^{\prime} & 45^{\prime \prime} \\
121^{\circ} & 01^{\prime} & 35^{\prime \prime}-121^{\circ} & 05^{\prime} & 04^{\prime \prime} \\
120^{\circ} & 57^{\prime} & 05^{\prime \prime}-121^{\circ} & 00^{\prime} & 25^{\prime \prime}\end{array}\right.$ & $\begin{array}{lllll}39^{\circ} & 13^{\prime} & 50^{\prime \prime}-39^{\circ} & 17 & 16^{\prime \prime} \\
39^{\circ} & 10^{\prime \prime} & 22^{\prime \prime}-39^{\circ} & 13^{\prime} & 50^{\prime \prime} \\
39^{\circ} & 13^{\prime} & 50^{\prime \prime}-39^{\circ} & 17^{\prime} & 16^{\prime \prime}\end{array}$ & $\begin{array}{l}11.65 \\
12.09 \\
11.65\end{array}$ & 50 \\
\hline 30 & $\left\{\begin{array}{c}\text { Yellowstone } \\
\text { tional Park. }\end{array}\right.$ Na- $\left\{\begin{array}{l}\text { Callatin } \\
\text { Canyon... } \\
\text { Shoshone. } \\
\text { Lake...... }\end{array}\right\}$ & Wjoming & $110^{\circ}-111^{10}$ & 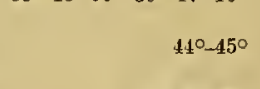 & 3,412 & 75 \\
\hline 31 & Pyramid Peak ................. & California .... & $120^{\circ}-120^{\circ} 30^{\prime}$ & $38^{\circ} 30^{\prime}-39^{\prime}$ & 932 & 25 \\
\hline 32 & Franklin .... & $\left\{\begin{array}{l}\text { Virginia .......... } \\
\text { West Virginia.. }\end{array}\right.$ & $79^{\circ}-79^{\circ} 30^{\prime}$ & $38^{\circ} 30^{\prime}-39^{\circ}$ & 932 & $2 \overline{5}$ \\
\hline 33 & Briceville... & T'ennessee...... & $84^{\circ}-84^{\circ} 30^{\prime}$ & $36^{\circ}-3$ & 963 & 25 \\
\hline 34 & & ginia & $30^{\prime}$ & $-39^{\circ}$ & 932 & 25 \\
\hline 35 & Gadsden ............................... & Alabama & $86^{\circ}-86^{\circ} 30^{\prime \prime}$ & $34^{\circ}-34^{\circ} 30^{\prime}$ & 986 & 25 \\
\hline 36 & Pueblo & Colorado & $104^{\circ} 30^{\prime}-105^{\circ}$ & $38^{\circ}-38^{\circ} 30^{\prime}$ & 938 & 50 \\
\hline 37 & Downierille . & $\begin{array}{l}\text { California........ } \\
\text { California..... }\end{array}$ & $\begin{array}{l}120^{\circ} 30^{\prime}-121^{\circ} \\
120^{\circ}-120^{\circ} 30^{\prime}\end{array}$ & $\begin{array}{l}39^{\circ} 30^{\prime}-40^{\circ} \\
39^{\circ}-39^{\circ} \quad 30^{\prime}\end{array}$ & $\begin{array}{l}919 \\
925\end{array}$ & $\begin{array}{l}25 \\
25\end{array}$ \\
\hline 39 & Trucke & & & & & \\
\hline
\end{tabular}




\section{STATISTICAL PAPERS.}

Miveral Resources of the United States [1882], hy Mllert Williams, jr. 1883. $8^{\circ}$. xvii, $813 \mathrm{pp}$. Price 5n cents.

Mineral Resunrees of tho United States, 1883 and 1884, by Alhert Williams, jr. 1885. 80. xiv, 1016 pl. l'rice 60 cents.

Minemal Resonren's of the United States, 18×5. Division of Mining Statistics aud Technolegy. 1886. 80. vii, 576 pl. P'rice 40 cents.

Miner:ul Resonrces of the Uniterl States, I886, by David 'l' 1)ay. 1887. 8०. viii, 813 jp. l'rice 60 conts.

Minoral hesoureos of the United States, 1887, by David 'T. Day. 1888. 8०. vii, 832 pl. Price 50 conts.

Mineral Resonrces of the Unitel States, 1888, by David 7'. Day. 1890. $8^{\circ}$. vii,652 pl. 1'rice 50 conts.

Nineral Resources of the United States, 1889 and 1890, by David T. Day. 1892. $8^{\circ}$. viii, $671 \mathrm{pp}$.

Price 50 c.ents.

Mlineral Resources of the Initerl States, 1891, by David T. Day. 1893. $8^{\circ}$. vii, 630 pp. Price 50 cenits.

Mineral Resources of the United States, 1892, lyy David T. Day. 1893. 8०. vii, 850 pp. Price 50 cents. 50 conts.

Mineral Resonrces of the United States, 1893, by David T. Day. 1894. $8^{\circ}$. viii, 810 pp. Price

On March 2,1895, the following provision was included in an act of Cengress:

"Provided, That hereafter the report of the mineral resources of the United States shall be issued as a part of the report of the Directer of the Geological Survey."

In compliance with this legislation the following reports have been published:

Mineral Resonrces of the Inited States, 1894, David T. Day, Chief of Division. 1895. $8^{\circ} . \quad \mathrm{xV}$, 616 pp., 23 pl.; xix, 735 pp., 6 pl. Being Parts III and iV of the Sixteenth Aunual Report.

Mineral Resonrces of the United States, 1895, David T. Day, Chief of Division. 1896. $8^{\circ}$ xxiii, $5+2$ pp., 8 pl. and maps; iii, 543-1058 pp., 9-13 pl. Being Part III (in 2 vols.) of the Seventeenth Annual Report.

Mineral Resources of the United States, 1896, David T. Day, Chief of Division. 1897. $8^{\circ}$. xii, 642 pp., 1 pl.; 643-1400 pp. Being Part V (in 2 vols.) of the Eighteenth Annual Report.

The report on the mineral resources for the calendar year 1897 will form a part of the Nineteenth Annual Report of the Survey.

The meney received from the sale of the Survey publications is depesited in the Treasury, and the Secretary of that Department declines to receive bank checks, drafts, or pestage stamps; all remit. tances, therefore, must be by MONEY ORDER, made payable to the Director of the United States Geolegical Survey, or in curlency - the exact amount. Correspondence relating to the publications of the Survey should be addressed to

WASHINGTON, D. C., May, 1898. The Dinector,

United States Geological Survey,

WASHINGTON, D. C. 

[Take this leaf out and pasto the soparated titlos upon throo of your catalogno cards. The first and socond fitlos need no addition; ovor the third write that subject under whioh you would place the book in your library.]

\section{LIBRARY CATALOGUE SLIPS.}

Onited States. Department of the interior. (U. S. geological survey.)

Department of the interior | - | Monographs | of the | United
States geological survey | Volume XXIX | [Seal of the departmeut] | Washington | government printing office | 1898

Second title: United States geological survey | Charles D. Walcott, director | - | Geology | of | Old Hampshire County, Massachusetts | comprising | Franklin, Hampshire, and Hampden counties | by | Benjamin Kendall Emerson | [Vignette] |

Washington | goverument printing office | 1898

4. $\mathrm{xxi}, 790 \mathrm{pp} .35 \mathrm{pl}$.

\& Emerson (Benjamin Kendall).

United States geological survey I Charles D. Walcott, director | - Geology | of | Old Hampshire County, Massachusetts | comprising | Franklin, Hampshire, and Hampden counties | by | Benjamin Kendall Emerson | [Vignette] |

Washington | government printing office | 1898

$4^{\circ} . \quad x x i, 790 \mathrm{pp} .35 \mathrm{pl}$.

[United States. Department of the interior. (U. S. geological survey.) Monograph XXIX.]

这

United States geological survey | Charles D. Walcott, director | - | Geology | of | Old Hampshire County, Massachusetts | comprising | Franklin, Hampshire, and Hampden counties | by | Benjamin Kendall Emerson | [Vignette] |

Washingtou | goverument printing office | 1898

$4^{\circ} . \quad \times x i, 790 \mathrm{pp} .35 \mathrm{pl}$.

[United States. Department of the interior. ( $U$. S. geological survey.) Monograph XXIX.] 



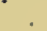







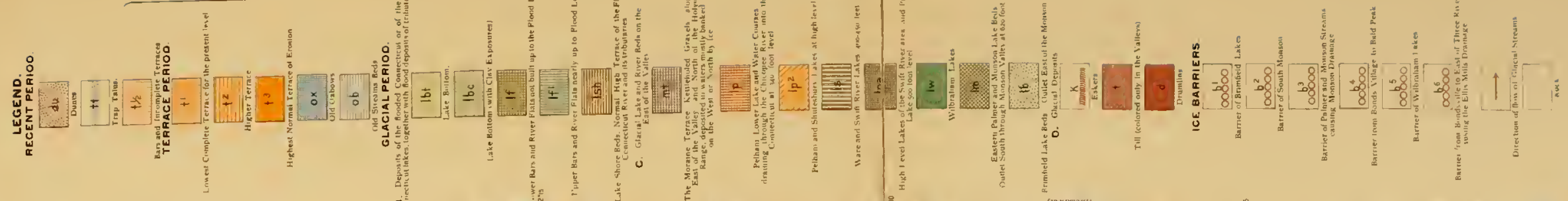

年 年 年

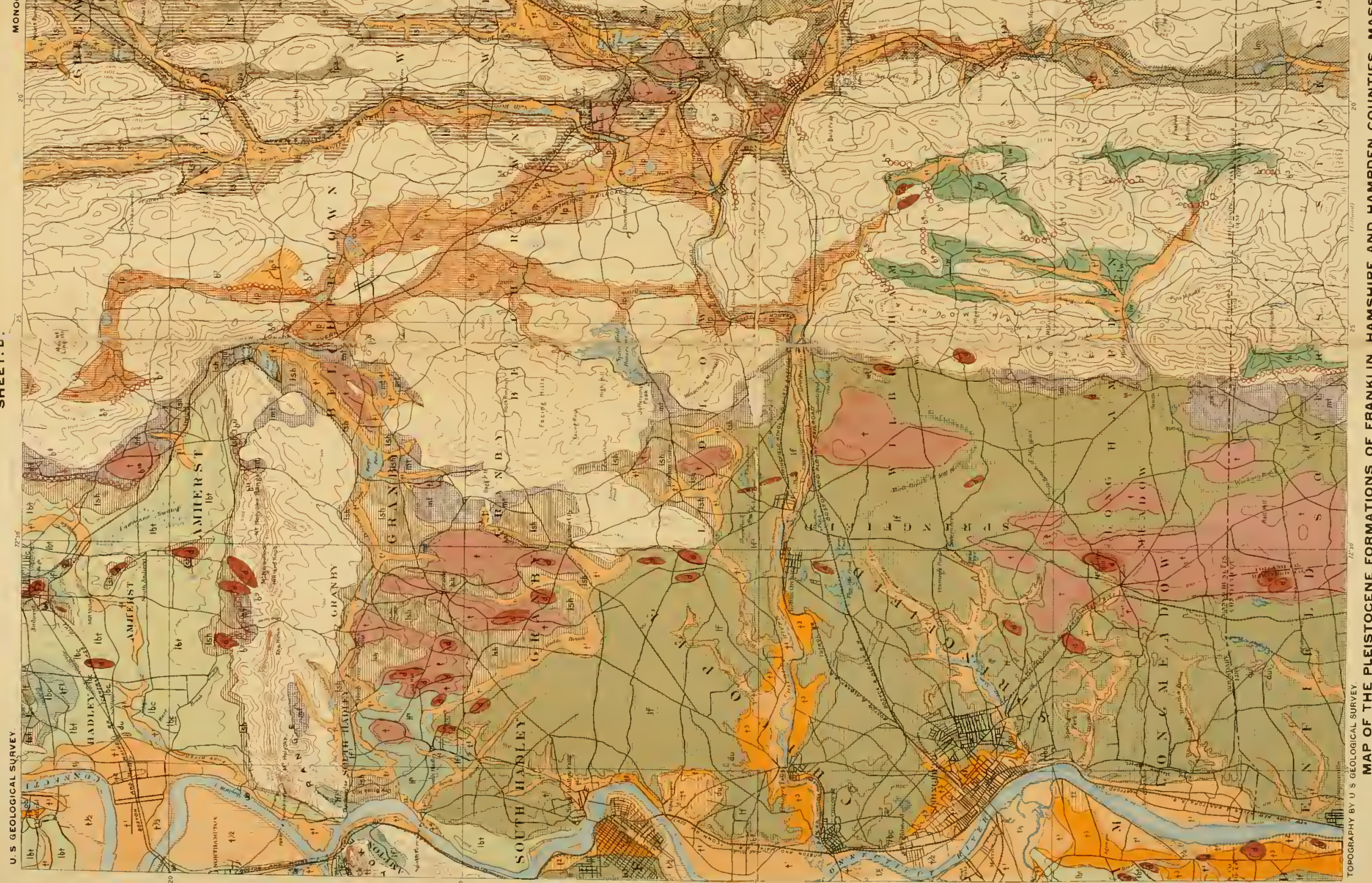



Pat

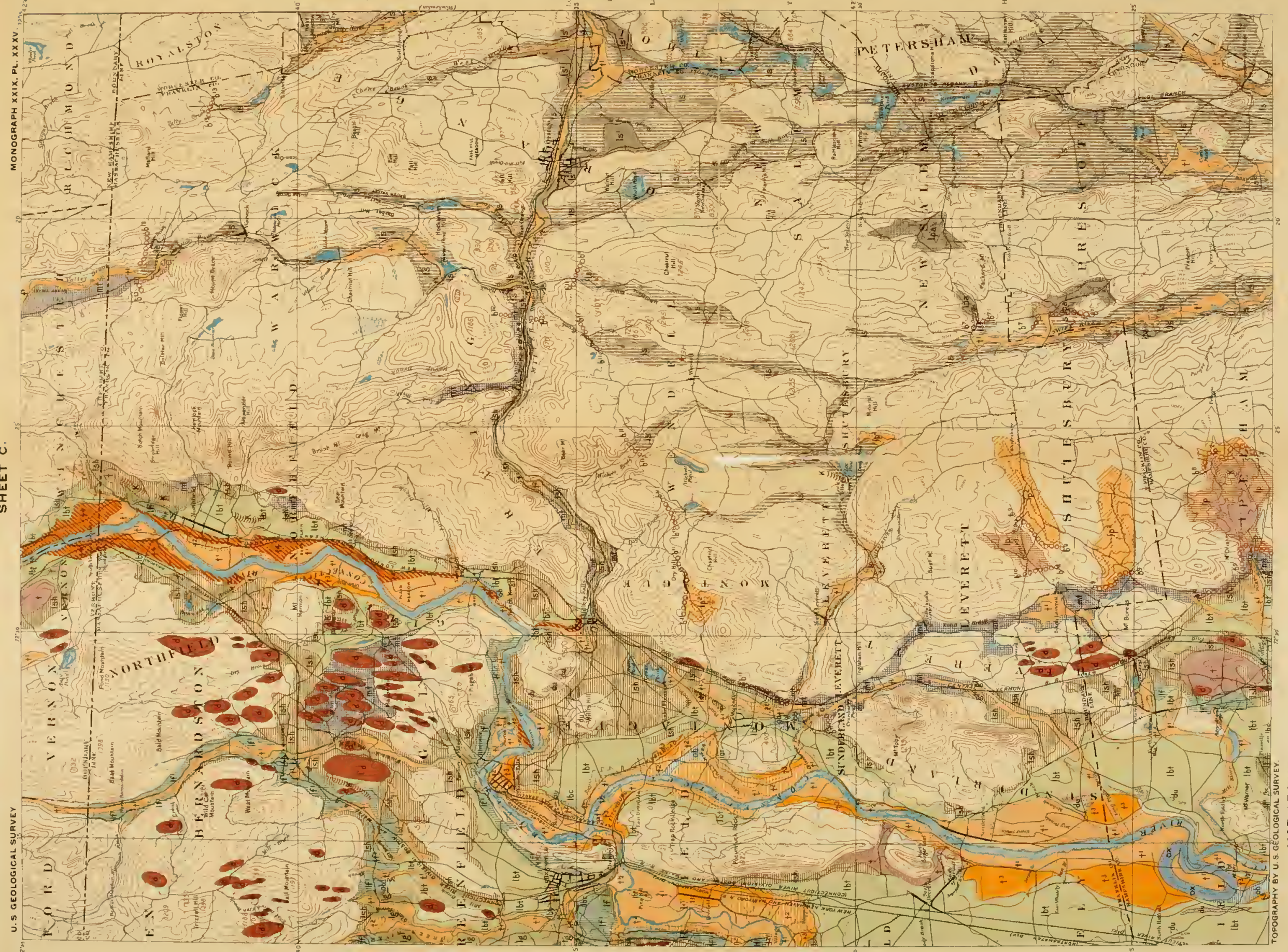





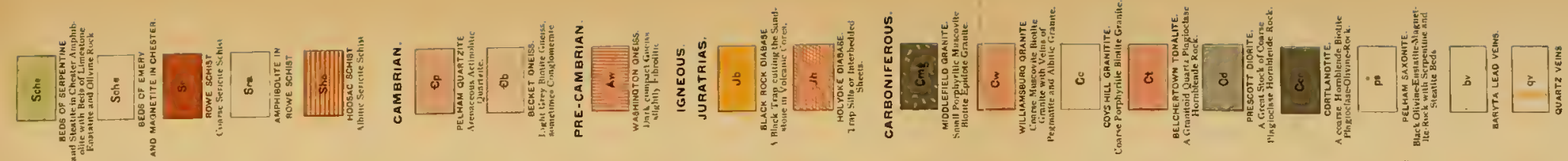

IfH

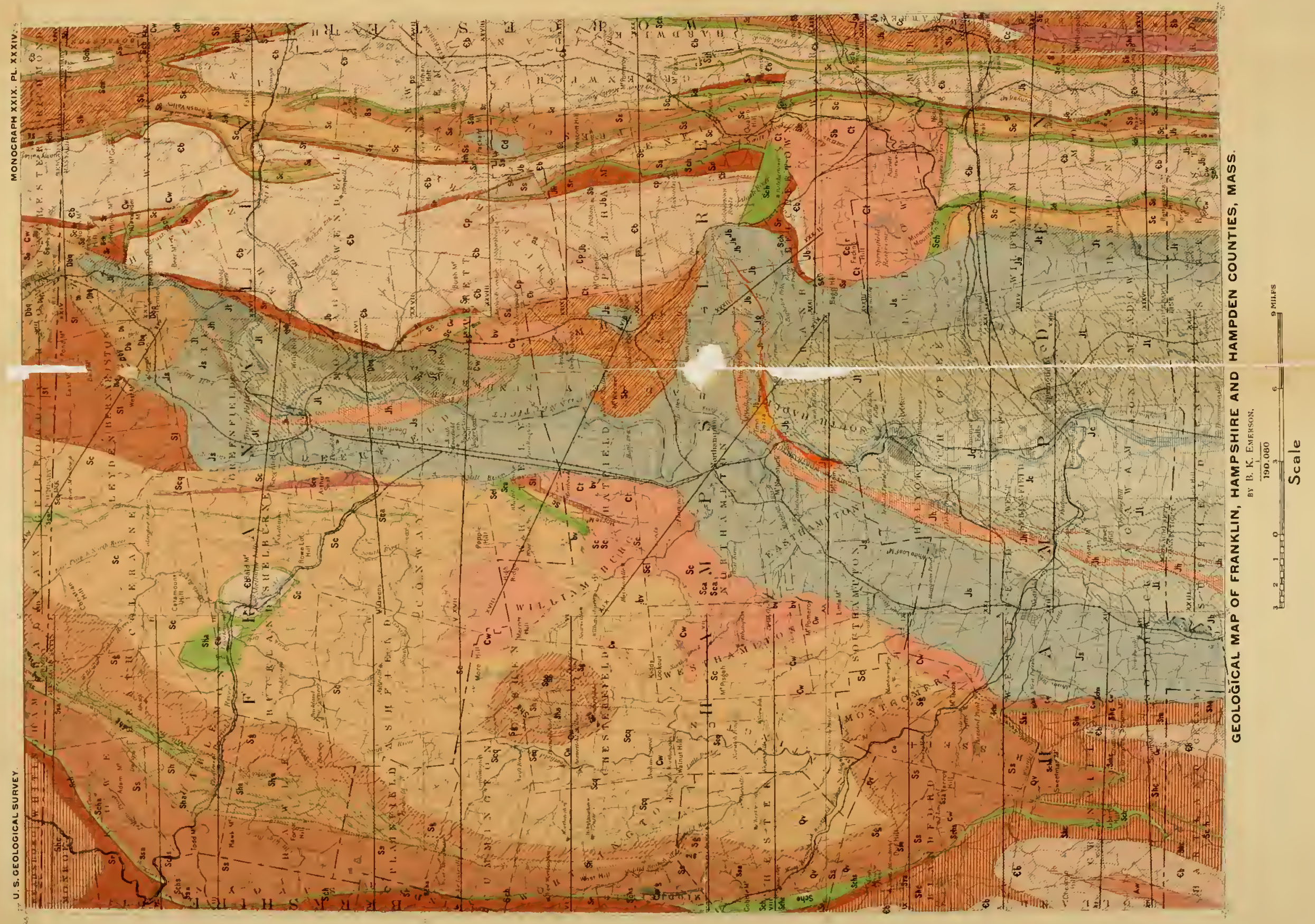





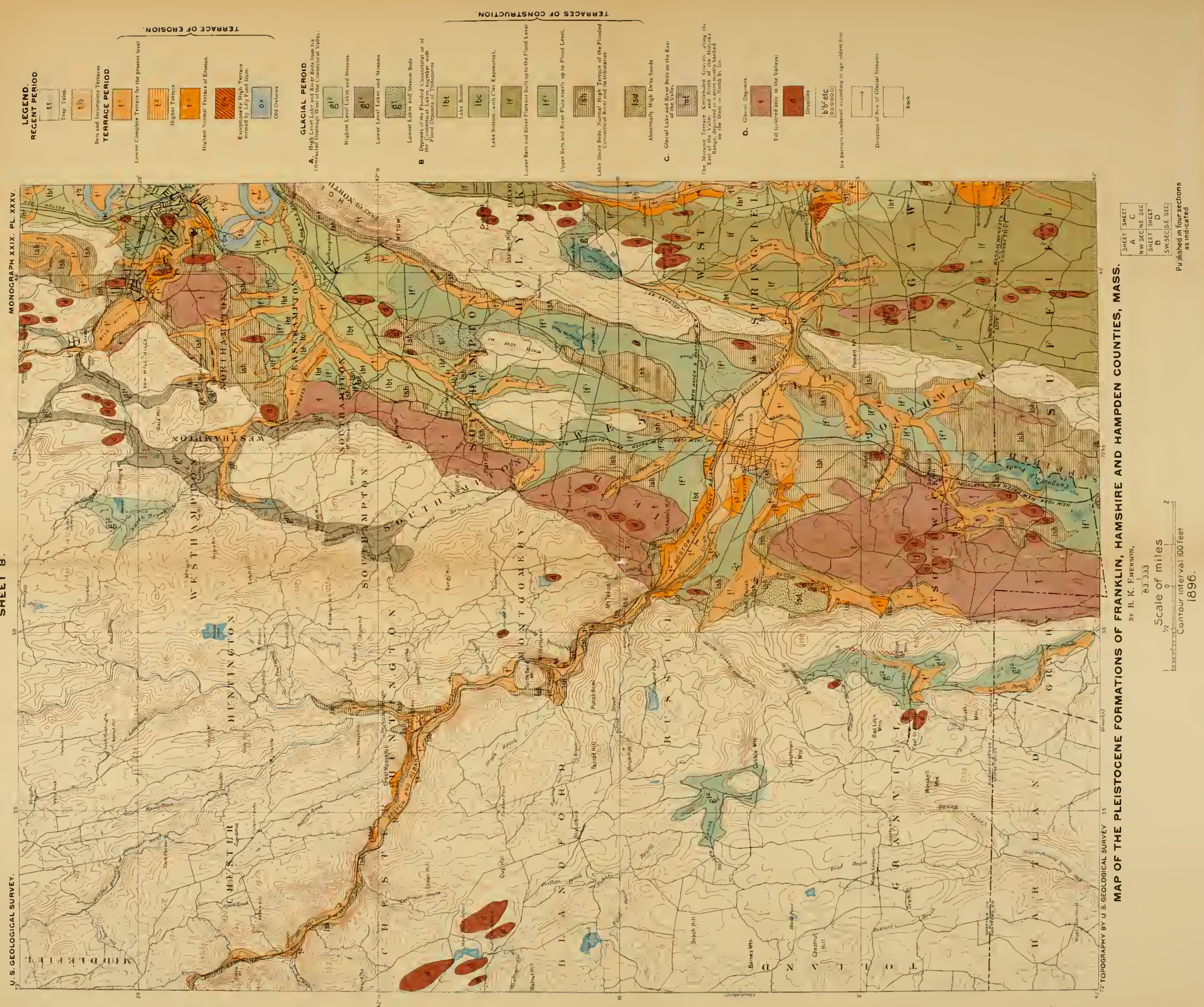




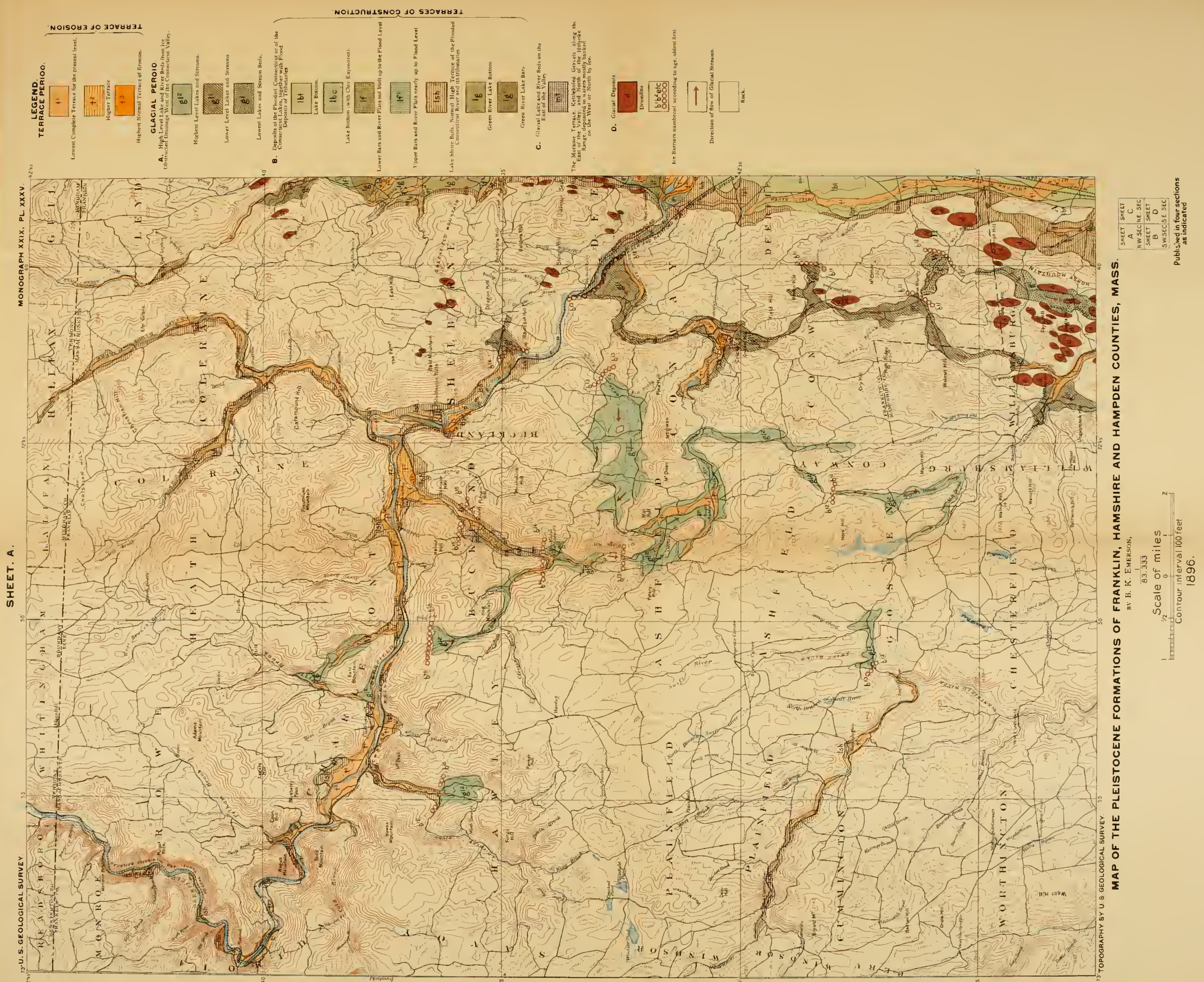

MUNUR GNG GPRE

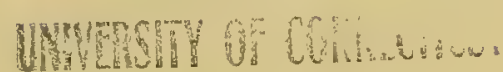

Mounetis 
